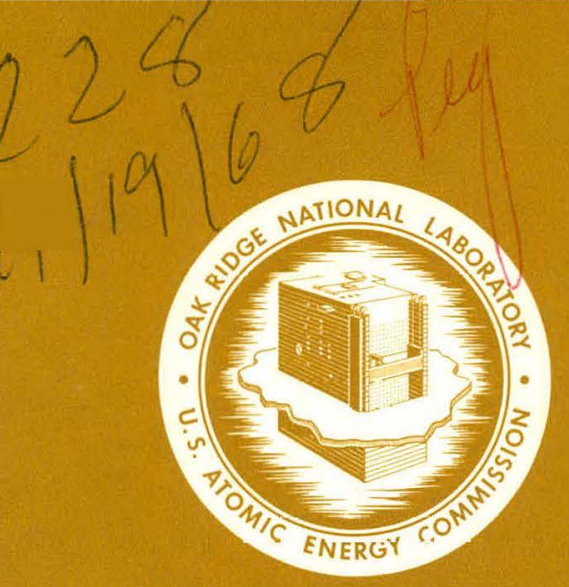

OAK RIDGE NATIONAL LABORATORY

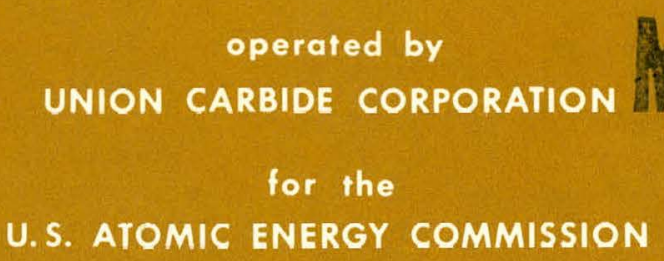

ORNL-NSIC-52

UC-80 - Reactor Technology

\title{
INDEXED BIBLIOGRAPHY OF CURRENT
}

NUCLEAR SAFETY LITERATURE - 15

NSIC STAFF 


\section{DISCLAIMER}

This report was prepared as an account of work sponsored by an agency of the United States Government. Neither the United States Government nor any agency Thereof, nor any of their employees, makes any warranty, express or implied, or assumes any legal liability or responsibility for the accuracy, completeness, or usefulness of any information, apparatus, product, or process disclosed, or represents that its use would not infringe privately owned rights. Reference herein to any specific commercial product, process, or service by trade name, trademark, manufacturer, or otherwise does not necessarily constitute or imply its endorsement, recommendation, or favoring by the United States Government or any agency thereof. The views and opinions of authors expressed herein do not necessarily state or reflect those of the United States Government or any agency thereof. 


\section{DISCLAIMER}

Portions of this document may be illegible in electronic image products. Images are produced from the best available original document. 


\title{
A BIMONTHLY REVIEW JOURNAL PREPARED BY NSIC
}

\author{
safety. \\ Nuclear Safety covers significant developments in the field of nuclear
}

The scope is limited to topics relevant to the analysis and control of hazards associated with nuclear reactors, operations involving fissionable materials, and the products of nuclear fission.

Primary emphasis is on safety in reactor design, construction, and operation; however, safety considerations in reactor fuel fabrication, spent-fuel processing, nuclear waste disposal, handling of radioisotopes, and related operations are also treated.

Qualified authors are invited to submit interpretive articles, which will be reviewed for technical accuracy and pertinency. Authors will be advised as soon as possible of acceptance or suggested changes. Send inquiries or 3 copies of manuscripts (with the draftsman's original line drawings plus 2 copies, and with continuous-tone glossy prints of photographs plus 2 copies) to J. P. Blakely, Oak Ridge National Laboratory, P. O. Box Y, Oak Ridge, Tennessee 37830 .

Nuclear Safety is prepared by the Nuclear Safety Information Center at Oak Ridge National Laboratory for the U.S. Atomic Energy Commission, Division of Technical Information. For subscriptions, address Superintendent of Documents, U.S. Government Printing Office, Washington, D. C. 20402. The subscription rate is $\$ 3.50$ per year. Below is an order blank for your convenience.

U.S. GOVERNMENT PRINTING OFFICE DIVISION OF PUBLIC DOCUMENTS WASHINGTON, D.C. 20402

OFFICIAL BUSINESS RETURN AFTER 5 DAYS

Name
Address_ State___ Zip _ _ _ _ _ _ _ _

POSTAGE AND FEES PAID U.S. GOVERNMENT PRINTING OFFICE

TO INSURE PROMPT, ACCURATE SHIPMENT, PLEASE PRINT OR TYPE CORRECT ADDRESS ON MAILING LABEL ABOVE

MAIL ORDER FORM TO:

Superintendent of Documents, Government Printing Office, Washington, D.C. 20402

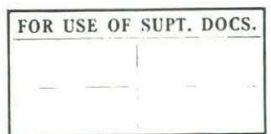

Enclosed find $\mathrm{S}$ (check, money order, or Supt. of Documents coupons). Please enter my subscription to NUCLLAR SAFETY for one $\square$, two $\square$, or three $\square$ years, at $\$ 3.50$ a year; $\$ 1.00$ additional for foreign mailing.

Please charge this order to my Deposit Account No.
Name

Address

City and State
ZIP Code 
CONTRACT NO. W-7405-ENG-2t

NUCLEAR SAFETY INFORMATION CENTER

INDEXED ÖIBLICGRAPHY OF CURRENT NUCLEAR SAFETY LITER.ATURE - 15

NSIC STAFF

NOVEMBER 1968

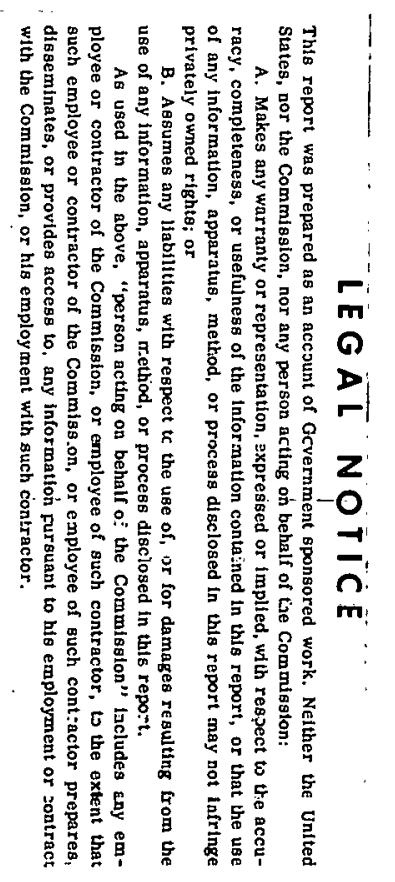

\footnotetext{
OAK RIDGE NATIONAL LABORATORY

OAK RIDGE, TENNESSEE OPERATED BY UNION CARBIDE CORPORATION FCR THE

U.S. ATOMIC ENERGY COMNISSION
} 
Printed in the United States of America. Available from Cleoringhouse for Federal Scientific and Technical Informotion, Notional Bureau of Standards,

U.S. Deportment of Commerce, Springfield, Virginio 22151

Price: Printed Copy $\$ 3.00$; Microfiche $\$ 0.65$

\section{LEGAL NOTICE}

This report was prepared as on account of Government sponsored work. Neither the United States, nor the Commission, nor any person acting on behalf of the Commission:

A. Makes any warranty or representation, expressed or implied, with respect to the occuracy, completeness, or usefulness of the information contained in this report, or that the use of any information, apparatus, method, or process disclosed in this report may not infringe privately owned rights; or

B. Assumes any liabilities with respect to the use of, or for damages resulting from the use of any information, opparatus, method, or process disclosed in this report.

As used in the above, "person acting on behalf of the Commission" includes any employee or contractor of the Commission, or employee of such contractor, to the extent that such employee

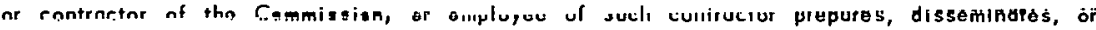
provides occess to, any information pureuant to his omploynent ur contruct with the Commission, or his employmont with such contractor. 
FOREWORD

THE INDEXED BIBLIOGR APHY OF CURRENT NUCLEAR SAFETY LITERATURE IS PUBLISHED FOUR TIMES ANNUALLY UNDER THE AUSPICES OF THE NUCLEAR SAFETY INFORMATION CENTER. THE C.ENTER WAS ESTABLISHEC IN MARCH 1963 AT THE OAK RIDGE NATIONAL LABORATORY UNDER THE SPONSORSHIP OF THE U.S. ATOMIC ENERGY COMMISSION AND SERVES AS A FOCAL POINT FOR THE COLLECTICN, STORAGE, EVALUATION, AND DISSEMINATION OF NUCLEAR SAFETY INFORMATION. THE CENTEPS EXTENSIVE REFERFNCE FILES ARE STORED ON MAGNETIC TAPE AT THE CAK RIDGE COMPUTING TECHNOLOGY CENTER (CTC) AND ARE READILY AVAILABLE FOR USE BY THE NSIC STAFF IN GIVING GUIDANCE ON PROBLEMS THAT ARISE IN THE FIELD OF NUCLEAR SAFETY. THE PRODUCTION DF THIS BIBLIOGRAPHY WAS MADE POSSIBLE THROUGH I BM-709O COMPUTER PROGRAMS OEVELOPED BY THE INFORMATION SYSTEMS DEPARTMENT OF CTC.

BIBL IOGRAPHIC ITEMS HAVE BEEN SOP.TED INTO $1 \%$ CATEGORIES OF NUCLEAR SAFETY INFORMATION. ITEMS MAY APPEAR IN AS MANY AS THREE CATEGORIES. A SELECTOR INDEX AND AN AUTHOR INDEX ARE PRQVIDED FCR THE CONVENIENCE OF THE USER.

EACH BIBL IOGRAPHIC ITEM CONSISTS OF $\triangle U T H O R(S)$, TITLE, CORPORATE AUTHOR(S), NUMBER DF PAGES, TABLES, FIGURES, REFERENCES, DATE, DOCUMENT NUMBER (S), $\triangle V A I L-$ $\triangle B I L I T Y$ (IF NOT OBVIOUS), AN INFORMATIVE ABSTRACT OF LESS THAN IOC WORDS, AND SEVERAL SELECTOR TERMS. THE SELECTOR TERMS CR KEYWOROS ARE ASSIGNEC BY NSIC PERSONNEL TO SERVE AS COORDINATE INDEXING TERMS FOR STOP.AGE AND FUTURE RETRIEVAL OF INFORMATION. THE MOST SIGNIFICANT SELECTOR TERMS FOR EACH BIBLIOGRAPHIC ENTRY ARE ASTERISKED AS WEIGHTING FACTORS. SELECTOR TERMS ARE INCLUDED WITH THIS BIBL IOGRAPHY SINCE THEY CAN, THROUGH THE SELECTOR. INDEX, BE OF AID TO THE READER IN LOCATING ITEMS OF INTEREST. MANY READERS, HOWEVER, WTLL PREFER TO SCAN THE CATEgORIES MOST RELATED TO THEIR FIELD OF INTEREST.

NSIC STAFF MEMBERS SELECTED, EXTRACTED, AND KEYWORDED THE VARIQUS ENTRIES IN THE BIBLIOGRAPHY. THE ASSIGNMENTS OF THE STAFF MEMBERS, MOST OF WHOM WORK HALF TIME FOR THE CENTER, ARE AS FOLLOWS

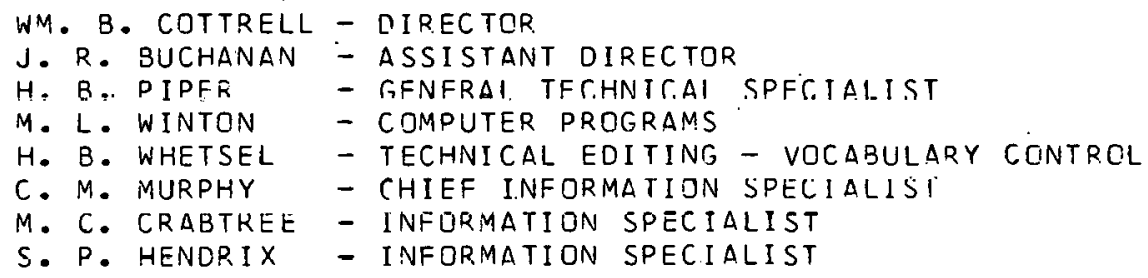

CATEGORY

$\begin{array}{ll}1 . & \text { J. P. BLAKELY } \\ 2 & \text { H. B. PIPER } \\ 3 & \text { L. B. SHAPPERT } \\ 4 & \text { S. P. HENDRIX } \\ 5 & \text { M. H. FONTANA, C. G. LAWSON } \\ 6 & \text { J. V. WILSON, H. F. BAUMAN, } \\ & \text { B. E. PRINCE, J. O. SHITH } \\ 7 & \text { G. W. KEILHOLTZ } \\ 8 & \text { H. A. MCLAIN } \\ 9 & \text { C. S. WALKER, E. W. HAGEN } \\ 10 & \text { C. S. WALKEF, E. W. HAGEN }\end{array}$

\section{CATEGRRY}

$\begin{array}{ll}11 & \text { J. R. RUCHANAN, J. G. MERKLE } \\ 12 & \text { W. G. STOCKOALE } \\ 13 & \text { W. G. STOCKDALE } \\ 14 & \text { F. M. EMPSON, B. L. HOUSER } \\ 15 & \text { F. M. EMPSON, B. L. HOUSER } \\ 16 & \text { S. D. SWISHER } \\ 17 & \text { E. N. CRAMER, R. L. SCOTT, } \\ & \text { W. F. IIIRICH } \\ 18 & \text { E. N. CRAMER, R. L. SCOTT, } \\ & \text { W. C. ULPICH }\end{array}$


THE SERVICES OF THE CENTER INCLUDE PRINCIPALLY (I) PREPAFATION OF STATE-OF-THE-ART REPORTS IISSUED WI TH ORNL-NSIC REPORT NUMBERS) IN THE SÜBJECT AREAS LISTED ABOVE WITH STAFF ASSIGNMENTS, (2) PREPARATION OF THE BIMONTHLY TECHNICAL PROGRESS REVIEW, NUCLEAR SAFETY, (3) ANSWERING TECHNICAL INQUIRIES AS TIME IS AVAILABLE, AND (4) CCUNSEL AND GUIDANCE ON NUCLEAR SAFETY PROBLEMS IN THE ABOVE SUBJECT AREAS. THE COMPUTER CODE USED IN THE PREPARATION OF THIS BIBLIOGRAPHY IS ALSO USED FOR SELECTIVE DISSEMINATION OF INFORMATION AND SPECIAL LITERATURE SEARCHES.

SERVICES OF THE NSIC ARE AVAILABLE WITHOUT CHARGE TO GCVERNMENT $\triangle$ GENCIES, RESEARCH AND EDUCATIONAL INSTITUTIONS, AND THE NUCLEAR INDUSTRY. THE NSIC SERVICES ARE AS LISTED $\triangle B O V E$ BUT UNDER NO CIRCUMSTANCES DO THEY INCLUDE FURNISHING COPIES OF ANY DOCUMENTS (EXCEPT NSIC REPORTS) ALTHOUGH ALL DOCUMENTS MAY BE EXAMINED AT THE CENTER BY QUALIFIED PERSONNEL. INQUIRIES CONCERNING THE CAPABILITIES AND OPERATION OF THE CENTER MAY BE ADDRESSED TO

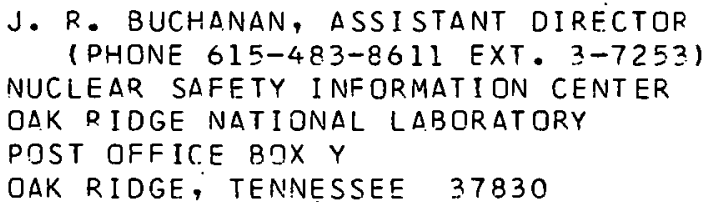

THE PUBLICATIONS CONTAINED IN THIS REPORT WERE PROCESSED $8 Y$ THE NSIC STAFF DURING MARCH, APRIL, AND MAY, 1968.

PREVIOUS NUCLEAR SAFETY INFORMATION CENTER RIBLIOGRAPHIC REPORTS, NDNE OF WHICH ARE CUMULATIVE, ARE AS FOLLOWS

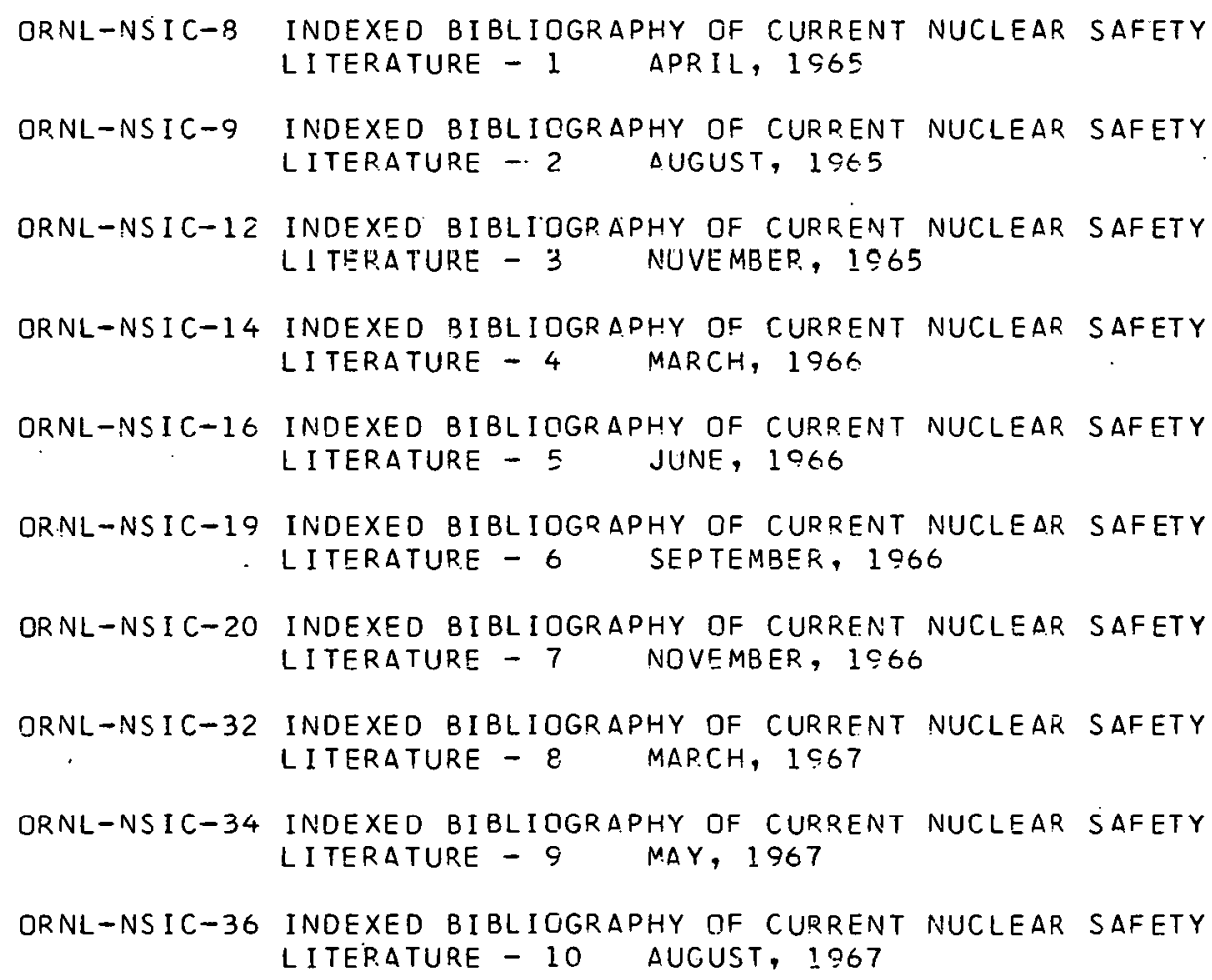


ORNL-NSIC-40 INDEXED BIBLIOGRAPHY OF CURRENT NUCLEAR SAFETY LITERATURE - 11 NOVEMEER, 1967

ORNL-NSIC-42 INDEXED BIBLICGRAPHY OF CURRENT NUCLEAR SAFETY LITERATURE - 12 FEBRUARY, 1968

ORNL-NSIC-44 INDEXED-BIBLIOGRAPHY OF CURRENT NUCLEAR SAFETY LITERATURE - 13 MAY, 1968

ORNL-NSIC-45 INDEXED BIBLIOGRAPHY OF CURRENT NUCLEAR SAFETY LITERATURE - 14 JULY, 1968 
THIS PAGE

\section{WAS INTENTIONALLY LEFT BLANK}




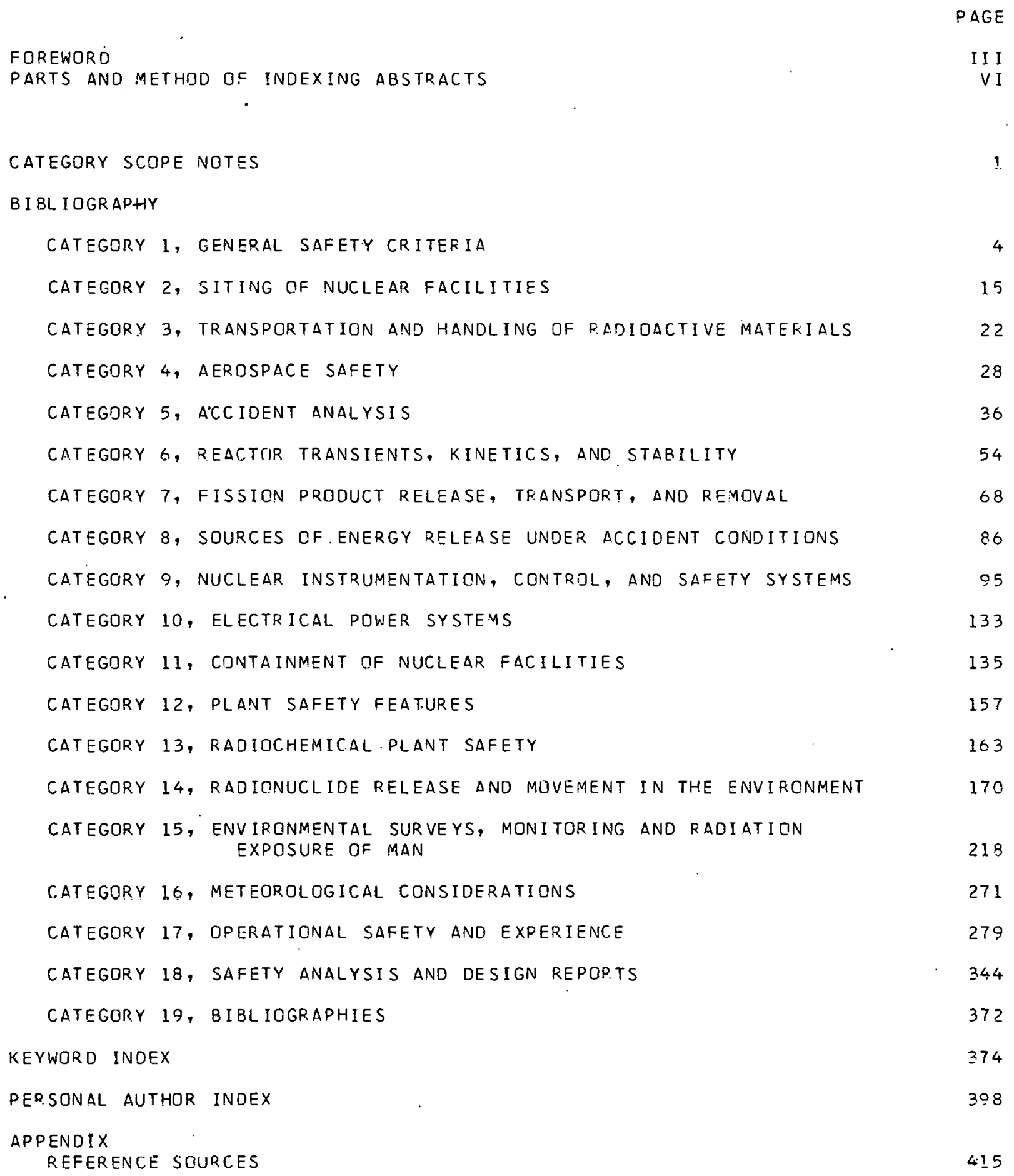




\section{CATEGORY SCOPE NOTES}

A BR IEF EXPLANATION OF THE COMPOSITION OF EACH CATEGQRY WITHIN THE SCOPE OF THE NUCLEAR SAFETY INFORMATION CENTER FOLLOWS

\section{GENERAL SAFETY CRITERIA}

THIS CATEGORY LNCOMPASSES ALL SAFETY ASPECTS OF RADIATION PHILOSOPHY, ST ANNDAROS, CODES, COST, FINANCIAL LIABILITY AND INSURANCE. OTHER ITEMS OF INTEREST ARE THE COMPARATIVE RISK TO THE PUBLIC HEALTH AND SAFETY FROM NUCLEAR AND NONNUCLEAR HAZARDS.

\section{SITING OF NUCLEAR FACILITIES}

THIS CATEGORY DEALS WITH DOCUMENTS RELATED TO THE FACTORS USED IN EVALUATING SITES SUCH AS CHARACTERISTICS OF. THE FACILITY DESIGN, PRCPOSED OPERATION, POPULATION DENSITY, USE CHARACTERISTICS OF THE SITE ENVIP.ONS, PHYSICAL CHARACTERISTICS OF THE SITE, EARTHQUAKE CONSIDERATIONS, AND THE RËLATIONSHIP OF ENGINEERED SAFEGUARDS TO NUCLEAR FACILITY SITING.

\section{TRANSPORTATION AND HANOLING OF. RAOIOACTIVE MATERIALS}

THIS CATEGORY CONTAINS ARTICLES DEALING WITH SHIPPING CONTAINERS, SHIPPING REGULATIONS, CRITICALITY SAFETY AS RELATED TO SHIPPING AND HANDLING, TRANSPORTATION ACCIDENTS, AND ALL OTHER ITEMS DEALING WITH SAFETY DURING THE TRANSPORTATION ANDIOR HANOLING OF RAUIOACTIVE MATERIALS.

\section{AEROSPACE SAFETY}

THIS CATEGORY COVERS SAFETY CONSIDERATIONS SUCH AS LAUNCH AND REENTRY PROBLEMS THAT ARE UNIQUE TO NUCLEAR SYSTEMS USED IN AEROSPACE VEHICLES.

\section{ACCIDENT ANALYSIS}

ALL FACETS OF THE ANALYSIS DF POSTULATED ACCIDENTS ARE CONSIDERED IN THIS CATEGORY. INCLUDED ARE BURNOUT HEAT FLUX, CRITICAL HEAT TRANSFER, RELIABILITY ANALYSIS, IN PILE EXPER IMENTS, COOLANT ACTIVITY BUILDUP, PIPE RUPTURE, AND EXPERIMENTS, I.E. LOFT. EXPERIMENTS RELATED TO REACTOR KINETICS ARE. CATALOGED IN CATEGURY 6 .

6. REACTOR TRANSIENTS, KINETICS, AND STABILITY

THIS CATEGORY INCLUDES THE VARIOUS STUDIES, POTH ANALYTICAL AND EXPERIMENTAL, SUCH AS TREAT AND SPERT IN WHICH THE TRANSIENT BEHAVIOR OF REACTOORS AND CRITICALITY ACCIDENTS ARE EXAMINED.

\section{FISSION PRODUCT RELEAGE, TRANSPORT, AND REMOVAL}

THE RELEASE OF FISSION PRODUCTS FROM VARIOUS MATERIALS AND THEIR MOVEMENT WITHIN A NUCLEAR FACILITY CONTAINMENT SYSTEM $\triangle R E$ INCLUDED IN THIS CATEGORY. TRANSPORT OF THE FISSION PRODUCT INVOLVES THE PHYSICAL AND CHEMICAL CHARACTERIZATION OF THE RELEASED RADIOACTIVE MATERIALS, AS WELL AS THE VARIUUS MECHANISMS SUCH AS DEPOSITION, ADSORPTION, FILTRATION, FALLOUT, ETC., THAT WOULD ATTENUATE THEIR CONCENTRATION WITHIN THE CONTAINMENT SYSTEM.

\section{SOURCES OF ENERGY RELEASE UNDER ACCIDENT CONOITIONS}

SOURCES OF ENERGY CONSIDERED IN THIS CATEGORY INCLUDE NUCLEAR, WIGNER, AND GAMMA ENERGIES, AS WELL AS CHEMICAL REACTIONS, METAL-WATER REACTIONS, AND ANY OTHER TYPES DF ENERGY THAT MIGHT BE RELEASEO AS THE RESULT OF A NUCLEAR ACC I DENT.

9. NUCLEAR INSTRUMENTATION, CONTROL, AND SAFETY SYSTEMS

THE DESIGN OF CONTRCL AND SAFETY SYSTEMS FOR VARIOUS NUCLEAR PROCESSES, AS WELL AS THE REQIIRED INSTRIIMENTATION ANO HARDWARE, ARF INCIIIMFD IN THIS CATEGORY. THE PROBLEMS INVOLVED ARE THE PERFORMANCE REQUIRED CF SAFETY SYSTEMS THE SPECIFICATION OF INSTRUMENTATION THE CONCEPTS OF COINCIDENCE, REDUNDANCE, FAILURE MODES, AND RELIABILITY THE ADEQUACY OF SHUTDOWN MARGINS THE DESIGN FEATURES OF DIFFERENT MECHANICAL DEVICES AND RELATED SUBJECTS. 
10. ELECTRICAL POWER SYSTEMS

INFORMATION RELATED TO ROUTINE AND EMERGENCY MEANS OF SUPPLYING ELECTRICAL POWER TO NUCLEAR FACILITIES IS COVERED IN THIS CATEGORY.

ii. CONTAINMENT OF NUCLEAR FACILITIES

THIS CATEGORY ENCOMPASSES ALL ASPECTS OF PRESSURE CONTAINMENT, PRESSURE RELEASE CONTAINMENT, AND MULTIPLE BARRIER CONTAINMENT FOR REACTORS, RAOIOCHEMICAL PLANTS, HOT CELLS, SOURCES, ETC., AND WILL INCLUCE SUCH ASPECTS AS DESIGN CONSIDERATIONS, LEAKAGE, PENETRATIONS, STRUCTURAL INTEGRITY, AND LEAK TESTING.

12.- Plant SAFETY '̈́̈EATURES

THE SAFETY ASPECTS. GF MAINTENANCE, DECONTAMINATICN, REACTOR SYSTEMS, URANIUM MINING AND MILLING, AND FUEL FABRICATION AND STORAGE ARE COVERED IN THIIS CATEGORY. ENGINEER.ING DEVICES SUCH AS PRESSURE ANO TEMPERATURE REDUCING SYSTEMS, AIR CLEANING SYSTEMS, AND CORE SPRAY AND SAFETY INJECTION SYSTEMS THAT ARE DESIGNED TO MINIMIZE THE CONSEQUENCES OF NUCLEAR ACCIDENTS ARE INCLUDED.

13. RADIOCHEMICAL PLANT SAFETY

NUCLEAR SAFETY INFORMATION RELATED SPECIFICALLY TO RADIOCHEMICAL PLANTS IS COVERED IN THIS CATEGORY.

14. RAOIONUClide RElease AND MOVEMENT IN THE ENVIRONMENT.

ALL ASPECTS OF THE INTENTIONAL OR ACCIDENTAL RELEASE OF RADIOACTIVITY TO T.HE ENVIRONMENT ARE INCLUDED IN THIS CATEGORY. RACI OACTIVE WASTE MANAGEMENT, INCLUDING WASTE TRANSPORTATION, TREATMENT, DISPOSAL AND EFFLUENT CONTROL IS OF PRIMARY IMPORTANCE AS IS RADIONUCLIDE OCCURRENCE AND MOVEMENT. THE LATTER INCLUOES FALLOUT, GEOLOGICAL CONSIDERATIONS, COUNTERMEASURES, ANALYTICAL TECHNIQUES, HYDROLOGIC CONSIDERATIONS; AND RADIONUCLIDE MOVEMENT IN SOIL AND WATER.

15." ENVIRONMENTAL SURVEYS, MONITORING, AND RADIATION EXPOSURE OF MAN

THIS CATEGOP.Y INCLUDES ITEMS RELATED TO (1) ENVIRONMENTAL AND PERSONNEL MONITORING DUR ING ROUTINE AND ACCIDENTAL RADIONUCLIDE RELEASE, (2) MONITORING METHOOS AND TECHNIQUES, 13 ) DOSE MEASUREMENT AND CALCULATION, (4) DETERMINATION OF MAXIMUM PERMISSIBLE DOSE AND CONCENTRATION, $\triangle N D$ (5) INTERNAL AND EXTERNAL EXPOSURE TO RADIONUCLIDES.

16. METEOROLOGICAL CONSIDERATIONS

THIS CATEGORY CONSIDERS NOT ONLY DIFFUSION AND DEPOSITION OF RADIOACTIVE MATERIAL NEAR THE EARTHS SURFACE IN CONNECTION WITH REACTOR OPERATIONS BUT ALSO THE ATMOSPHERIC TRANSPORT AND FALLOUT IN THE TROPCSPHERE AND STRATOSPHERE AS A RESULT OF NUCLEAR. WEAPONS TESTS.

17. OPERATIONAL SAFETY AND EXPERIENCE

THIS CATEGORY INCLUDES COVERAGE OF THE SAFETY ASPECTS OF ROUTINE REACTOR OPERATION AND OF INCIDENTS OR UNUSUAL OPERATING OCCURRENCES, LARGE OR SMALL. POWER, RESEARCH, ANO TEST REACTORS AND FUEL REPROCESSING PLANTS WILL BE COVERED. ALL AVAILABLE OPERATING, INCIDENTS, SAFEGUARDS, AND INSPECTION REPORTS WILL BE COLLECTED AND INDEXED.

18. SAFETY ANALYSIS AND DESIGN REPORTS

ROUTINE LISTINGS OF THE LATEST NUCLEAR FACILITY SAFETY ANALYSIS AND DESIGN REPORTS ARE TO BE FOUND IN THIS CATEGORY. INCLUCED ARE BOTH ANALYSES AND REPORTS BY FACILITY DESIGNERS AND SY THE AEC REGULATCRY STAFF.

\section{BI BLIOGRAPHIES}

THIS CATEGORY CATALOGUES DOCUMENTS ON NUCLEAR SAFETY TOPICS THAT ARE EXCLUSIVELY BIBLIOGRAPHIES AS WELL AS THOSE THAT INCLUDE EXTENSIVE BIBLIOGRAPHIES WITH OTHER MATERIAL. 
CATEGORY
GENERAL SAFETY CRITERIA

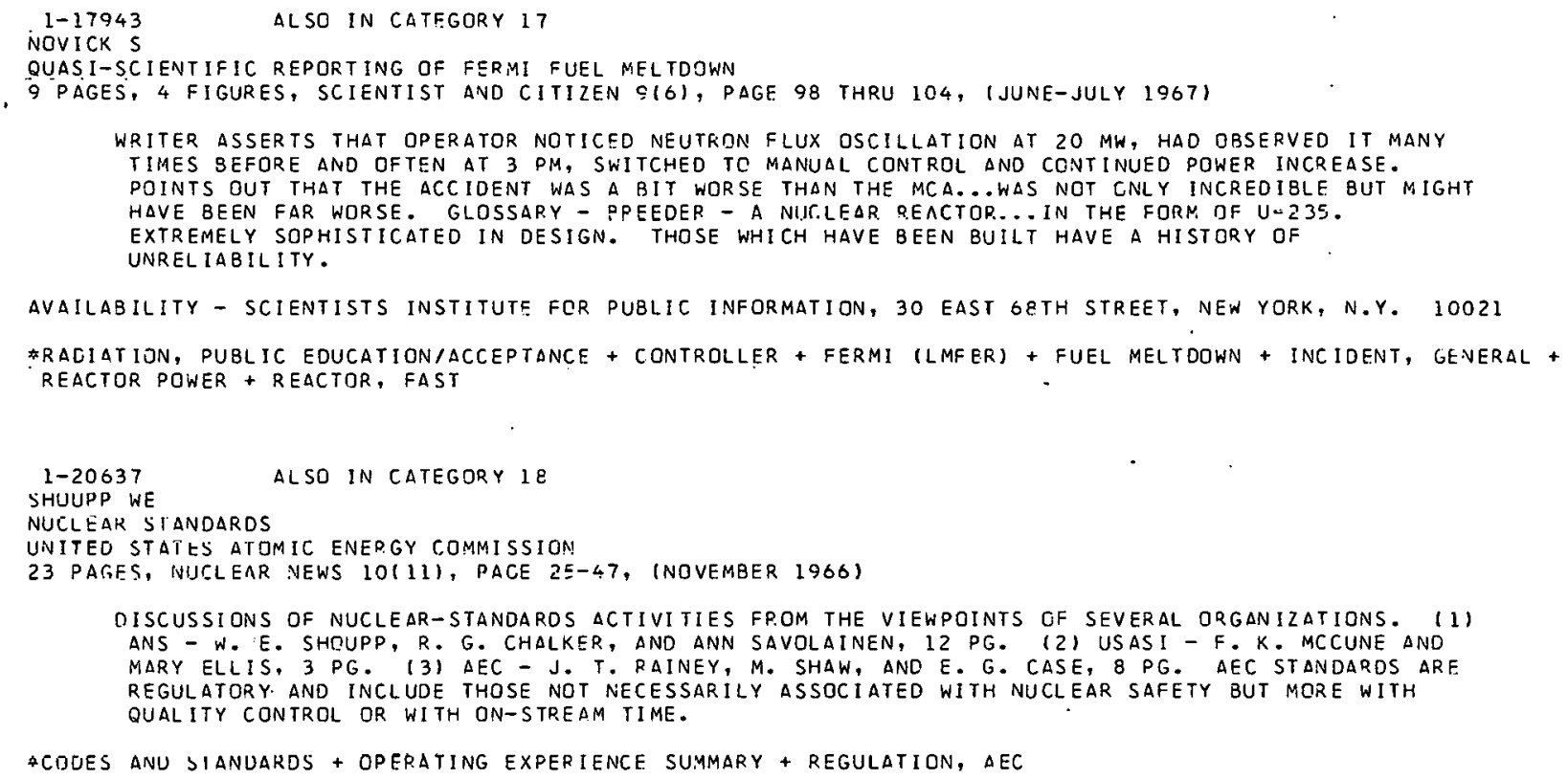

OISCUSSIONS OF NUCLEAR-STANOAROS ACTIVITIES FPOM THE VIEWPOINTS GF SEVERAL ORgANIZATIONS. (1) ANS - W. E. SHRUPP, R. G. CHALKER, AND ANN SAVOLAINEN, 12 PG. (2) USASI - F. K. MCCUNE AND MARY ELLIS, 3 PG. (3) $\triangle E C$ - J. T. RAINEY, M. SHAW, ANOE. G. CASE, 8 PG. AEC ST ANDARDS ARE REGULATORY. AND INCLUDE THOSE NOT NECESSARILY ASSOCIATED WITH NUCLEAR SAFETY BUT MORE WITH QUAL ITY CONTROL OR WITH ON-STREAM TIME.

FCOUES ANu bIANUARDS + OPEPATING EXPERIENCE SUMMARY + REgulation, AEC

1-21271 ALSO IN CATEGORY 15

PROPOSED STANDARD. PQOGRAM FOR TESTING RICLOGICAL SHIELDING IN NUCLEAR REACTOR PLANTS AMERICAN NUCLEAR SOCIETY

8 PAGES, 7 REFERENCES, NUCLEAR ENGINEERING BULLETIN, $5(1)$, (JULY 1967 ) ANS 6.1

THIS STANDARD DESCR IBES AN OPEPATIONAL SHIELD-TESTING PROGRAM TO BE USED IN EVAL, UATING THE INSTALLED BIOLCGICAL SHIELDING IN NUCLEAR PLANTS. A GENERAL TESTING PROCEDURE IS JUTLINED; AND THE NECESSARY RADIATION MEASUREMENTS AND TYPES OF INSTRUMENTS ARE PRESCRIBED.

*SHIELDING + CODES AND STANMAROS + REACTOR, SAFETY SYSTEM + TESTING

1-21291 ALSO IN CATEGOR'I 10

DIABLD CANYON CONFTRMANCE WITH PROPOSED GENERAL DESIGN CRITTERIA

PACIFIC GAS AND ELECTRIC COMPANY, SAN FRANCISCO, CALIF.

R PAGES, SEPTEMBEP. 8, 1967, DOCKET NO. 50-275, TYPE--PWR, MFG--WESI., At--PG+E

LISTS SIGNIFICANT PSAR (AND SUPPLEMENTS) CHAPTERS WHICH DEAL WITH EACH CRITERION OF JULY ISG7.

aVAILABILITY - USACC PUBLIC DOCUMENT FOOM, WASHINGION, D. C.

*aec design CRITeria + oiablo canYun (PWR) + PEACTOR, PWR + RePORT, PSAR

$1-21389$

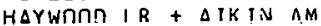

COSTS AND ECONOMICS CF HICAVY WATER MODERATED NUCLEAR PLANTS

ATOMIC ENERGY OF CANADA LIMITED, CHALK PIVER, ONTARIO

AECL-2946+5M-99/36+ CONF-670919-5+.13 PAGES, 5 TABLES, 13 REFERENCES, SEPT. 1967, PRESENTED AT THE IAEA SYMPOSIU:M ON HEAVY WATER PONEP. REACTORS, VIENNA, SEPT. $11-15,1967$

THE DEVELOPHENT OF HEAVY-WATER-MODFRATEC POWER P.EACTORS IN CANADA HAS INCLUDED STUDIES OF THREE COOLANT SYSTEMS - HEAVY WATER, LIGHT WATER, AND ORGANIC. ECONOMIC COMPAR ISONS DO NOT SHOW LARGE ADVANTAGES OF ONE SYSTEM. OVFR THE DTHER, BUT EACH OFFERS ITS OWN TLCHNICAL AND OPERATIONAL ADVANTAGE. AS THE HEAVY-WATER-COOLED CONCEPT IS THE MOST ADVANCED TECHNICALLY, WITH PLANTS IN OPERATION, IHIS SYSTEM IS USED TO SHOW DETAILS OF CAPITAL, FUEL, AND OPERATING COSTS. THE ECONOMIC ADVANTARFS AND DISADVANTAGES OF THE ALTERNATIVE COOL ING SYSTEMS ARE DISCUSSED.

AVAILABILITY - CLEARINGHOUSE FOR FEDERAL SCIENTIFIC AND TECHNICAL INFORMATION, SPRINGFIELD, VIRGINIA, $\$ 3.00$ COPY, \$0.65 MICROF ICHE

\#CCONOMIC STUDY + \#REACTOR, HWR + \#REACTOR, NRGANIC COCLED + \#REACTCR, WATER + CANADA 
CATEGQRY I
GENERAL SAFETY CRITEPIA

$1-21390$

HOSTETLER DR + STENART JE + HOLLAND CL + WODOS JJ

THE EFFECTS OF SAFETY ON ECONOMICS IN A 1000 -MW(E) LIQUID-METAL-CCOLEO FAST-BREEDER REACTOR (LMFBF) BABCOX AND WILCOX CO.

1 PAGE, ANS TRANSACTIONS $10(2)$, PATE 694, (JUNE 1967), PRESENTED AT THE 1967 WINTER MEET ING OF THE

AMERICAN NUCLEAR SOC IETY, CHICAGO, ILLINO!S, NOV. 5-9, 1967

IN A LIQUID-METAL-COOLEO FAST-BREEDER REACTOR THERE EXISTS A TPADE-OFF BETWEEN CORE SAFETY AND ECONOMICS. RESULTS INOICATE THAT THE PRICF DAID FOR SPOILING IANY FEATURE OF A CORE THAT IS INTRODUCED SPECIFICALLY TO IMPPOVVE CORE-SAFETY CHARACTERISTICS AAT THE EXPENSE OF BREEDING RATIO, DOUBLING TIME, AND ECCNDMICSI IS HIGH, AND THAT NEITHER THE PANCAKE NOP. aNNULUS HAS A CLEAR-CUT ADVANTAGE FROM EITHER A FUEL-COST OR SAFETY STANDPNINT. A STRONG INCENTIVE THEREFORE EXISTS TO DEVELOP ENGINEERED SAFEGUARDS THAT WILL PERMIT RECUCED EMPHASIS ON SOOIUM VOIDING IN CORE DESIGN.

* ECONONIC STUDY + \#REACTOR, BREEDER + \#REACTOP, FAST + \#REACTOR, LMCR + \#SAFETY PROGRAM + DESIGN STUDY

$1-21391$

ROJAHN W + JACQUOT A

THE OTTO HAHN, THE NUCLEAR POWER RESEARCH SHIP AND ITS IMPORTANCE FOR THE EUROPEAN COMMUNITY EUROPEAN ATOMIC ENERGY COMMUNITY

8 PAGES, 6 FIGURES, ENERG. NUCL: (PARIS), 9, PAGE 173-180, (MAY 1967), IN.FRENCH

DISCUSSES THE SIGNIFICANT PARTICIPATION OF EURATOM IIN THE DEVELOPMENT OF MERCHANT MARITIME REACTORS, AS WELL AS THE JOINT FIELDS OF RESEARCH AND THEIR HARMONIOUS EXECUTION WITHIN YHE EUROPEAN FRAMEWORK. THE NUCLEAR RESEAFCH AND ORE-SHIP OTTO HAHN IS DESCRIBED IN DETAIL. IT WOULD APPEAR THAT COAMERCIALLY COMPETITIVE NUCLEAR SHIPS COULD BE ATTAINED BY USE OF AN ADVANCED DESIGN REACTOR GENERATING 60,000 HP. EVEN THOUGH A MARKET FOR SHIP REACTORS CAN BE FORESEEN, DEVELDPMENT STILL DEPENDS ON PUBLIC FUNDS. THESE CONTRIBUT IONS COULD BE REDUCED, HOWEVER, BY JOINT ACTION OF INTERESTED SEGMENTS OF THE EUROPEAN COMMUNITY.

*EURATOM + \#OTTO HAHN (PWR) + *REACTOR, MARITIME + ELUNOMICS

$1-2 i 392$

USA STANDARD. QUALITY CONTROL FOR THE PLATE TYPE URANIUM ALUMINIJM FUEL ELEMENTS

AMER ICAN NUCLEAR SDCIETY

USAS N8.1-1967+. 7 PAGES, 1 FIGURE, JANUARY 1967

THIS STANDARD DUTLINES THE MINIMUM QUALITY CONTROL (INCLUDING INSPECTION) REOUIREMENTS FOR THE MANUFACTURE OF THE PLATE-TYPE URANIUM-ALUMINUM FUEL ELEMENTS GENERALLY USED IN RESEARCH AND TEST REACTORS. THE FUEL ELEMFNTS CONSIST OF FLAT OR CURVED PLATES OF A URANIUM-ALUMINUM ALLOY THAT IS CLAD WITH ALUMINUM. THIS STANDARD IS APPLICABLE TO FUEL ELEMENTS IN WHICH THE FUEL PLATES ARE MECHANICALLY FASTENED OR WELDED TO SIDE PLATES FOR STRUCTURAL RIGIDITY, BUTT IT DOES NOT APPLY TO ELEMENTS IN WHICH THE FUEL PLATES ARE BRAZED TO THE SIDE PLATES.

AVAILABILITY - AMERICAN NUCLEAR SOCIETY, 244 E. OGOEN AVENUE, HINSOALE, ILLINOIS 6OS21, \$1.5O CQPY

*ALUMINUM + \#CODES. AND STANDARDS + \#CORE, PLATE TYPE + \#FUEL ELEMENT + \#URANIUM + ALLOY + CLAD + QUALITY CONTROL + REACTOR, RESEARCH + PEACTUR, IESI

$1-21393$

CRITICAL

1 PAGE, NUCLEAR. ENGINEER ING 12(138), PAGE 807, (NOV. 1967 ).

A SMALL UTR-10 TEACHING REACTOP, SITUATED WITHIN FIVE MILES OF THE CENTER OF. THE CITY OF I, ONDON AT THE GUEEN MARY COLLEGES MARSHGATE LANE SITE, WENT CRITICAL ON SEPTEMBER $26,1967$. THIS FACILITY, WITH A MAXIMUM POWER OF $50 \mathrm{KW}$ FOR LIMITED PERIOUS, WAS DESIGNED FOR REACTOR PHYSICS STUDIES. AND WILL ALSO BE USED IN ASSOCIATION WITH THE FIRST BRITISH DEGREE COURSE IN NUCLEAR ENGINEERING.

\#REACTOR PHYSICS + \#PEACTOR, RESEARCH + \#REACTOF, TRAINING + \#SITING, URBAN + \#UNITEO KINGDOM

$1-21405$

SEVENTH REPORT ON THE ACTIVITIES OF THE AGENCY

EUROPEAN NUCLEAR ENERGY AGENCY, PARIS (FRANCE)

NP-15919+. 125 PAGES, DECEMBER 1965

REPORTS PROGRESS ANO DEVELOPMENT OF COMPUTER-PROGRAM LI BRARY, INFORMAT ION AND DATA CENTERS, AND ESTABLISHMENT OF A' COMMITTFE TG COLLATE AND OISSEMINATE INFORMAT ION ON REACTOR SAFETY OTHER TOPICS INCLUDE REGULATION AND CONTROL IN FIELDS OF TRANSPORT OF RAOIOACTIVE MATERIALS, WASTE DISPOSAL, ANO RADIATION PROTECTION. PREDICTS INSTALLEO NUCLEAR CAPACITY WILL EXPAND FROM PRESENT 4,400 MW(E) TO 12,000 BY 1970.

ÄVAILABILITY - MICROCARD EDITIONS, INC. (FOR SALE) ACCOUNTING AND SHIPPING OEPARTMENT, WEST SALEM, 
CATEGORY
GENERAL SAFTY CRITERIA

$1-21405$ \#CONTINUEOF
WISCONSIN 54669

ADMINISTRATIVE CONTROL + COMPUTER PROGRAM + ENEA + INFORMATION RETRIEVAL + RADIATION SAFETY ANO CONTROL + RFGULATION, GENERAL + TRANSPORTATION AND HANOLING + WASTE DISPOSAL, GENERAL

1-21669 ALSO IN CATEGORY 18

PUBRLIC ATTITUDES AFFECTING THE GROWTH UF ATOMIC POWER PLANTS IN CALIFGRNIA

OFFICE OF ATDMIC ENERGY DEVELOPMENT AND RADIATION PROTECTION, STATE OF CALIF., SACRAMENTC

I4 PAGES, DECEMBER 1967

A SUMMARY OF A SURVEY BY OPINION RESEARCH CORP. FOR CALIFORNIA OFFICE CF ATOMIC ENERGY DEVELOPMENT AND R.ADIATION PROTECTION. PAMPHLET COVERS OPINICN IN SANTA MONICA, SAN LUIS CBISPO, AND SACRAMENTO, $\triangle S$ WELL AS A STATE-WIDE OPINION SAMPLE. THF MAIN RESULTS APE - (I) THE GENERAL PUBLIC KNOWS LITTLE ABOUT THE NUCLEAR POWER INCUSTRY AND WANTS TO KNOW MDRE, (2) ABOUT 3 TO 1 FOR NUCLEAR PLANTS NFAR THEM (SANTA MONICA, LESS THAN 2 TO 1 ), (3) IN ANSWER TO - ARE THERE ANY NUCLEAR POWER. PLANTS IN CALIFORNIA NOW - 3]\%-YES, 23\%-NO, ANO 46\%-DONT KNOW, (4) SUPPORT FER POWER PLANT IN GFNFRAL AREA VARIFD FROM 75\% IN FAVOR, I3\% OM NDT CARE, AND $7 \%$ IPPOSED AT SAN LUIS OBISPO, TO 37, 24, ANU 24, RESPECTIVELY, AT SANTA MONICA, AND (5) MORE THAN 7 TO 1 FELT NUCLEAR PLANTS WEPE LESS LIKELY TO CAUSE POWER FAILURE. GREATEST FEAR WAS RADIATION (17\%), LESS THAN $1 \%$ WOPRIED ABOUT EARTHQUAKE DAMAGE TO PLANTS.

AVAILABILITY - OFFICE DF ATOMIC ENERGY OEVELOPMENT AND RADIATION PRETECTION, SACRAMENTE, CALIFORNIA RADIATION, PUBLIC EDUCATION/ACCEPTANCE + REACTOR, POWER

1-21773 ALSO IN CATEGORIES 4 AND 19

PUSLICATIONS MF IASL RESEÁC.CH, IDE6

LOS ALAMOS SCIENTIFIC LAB, LOS $\triangle L A M O S$, NEW MEXICO

TID-24041+MM-1144+. I38 OAGES, SFPTEMBER $19 E 7$

PAPERS, REPJRTS, BOOKS, JOURNAL ARTICLES, ETC., OF LASL PUBLISHED IN ICGG $\triangle P E$ LISTED

ALPHABETICALLY BY AUTHCR UNDER 36 SUBJCCT AREAS. INCLUDES DOCUMENTS ON AEROSDACE SAFETY,

BIOLOGY ANO MEDICINE, CHEMICAL KINETICS, HEALTH AND SAFETY, INSTRUMENTS, METALLURGY AND

CERAMICS, REACTCR TECHNDLOGY, AND WASTE DISPDSAL.

* RIBLIOGRAPHY + ACCIDENT, GENERAL + AERUSHACE SAFETY + BIOMEDICAL + DECONTAMINATION + DOSIMETRY, GENERAL + INSTRUMENTATION, GENERAL + WASTE DISPOSAL, GENERAL

$1-21791$

ALSO IN CATEGUKY 14

THERMAL POLLUTION CAUSED BY NUCLEAR POWER. PLANTS

4 PAGES, WATER RESJURCES NEWSLETTER 2(8), NOVEMBER 1967

HEARINGS ON THE THERMAL POLLUTION CAUSED GY NUCLEAR POWER PLANTS WERE ANNOUNCED BY THE SENATE PUBLIC WORKS SUBCOMMITTEE ON AIR ANC WATER POLLUTION. THE HEARINGS WILL PE HELD IN NEW ENGLAND BECAUSE OF NUCLEAR POWER PLANTS PLANNFN IN VERMONT AND IN MAINR. THE VERMUNI HLANT AS PRESENILY PLANNED WILL DAISE TEMPERATURE OF CONNECTICUT RIVFR 15 TO 20 OEG AS IT FLOWS INTR MASSACHUSETTS.

*HEAT SINK + \#THERMAL POLLUTION + \#WASTE UISPOSAL, GENERAL + REACTOR, PONER + RIVER, GENERAL + VERMONT YANKEE (BWR) + WASTE DISPOSAL, RIVER

$1-21814 \quad \dot{A}$ SO IN CATEGORY 17

NUCLEONICS WEEK REPORTS RESULTS OF SUPVEY COMPARING NUCLEAR AND NONNUCLFAR PLANIS

2 PAGES, NUCLEONICS WEEK, PAGES 4-5 (JUNE 2 , I GG )

I CONSUMERS POWER CO.) COVERS SHIPPINGPORT, DRESDEN, YANKEE, INDIAN POINT, RIG ROCK POINT, HUMGOLDT BAY, HALLAM, PIAIIA, CVTR, AND FERMI TROM THE START GF UYLRAT IONS TO PRESENT, AND ALL THE CONVENT IONAL POWER STATIONS OF THE SAME COMPANIES. ACCIOENT RATES PEP MILLION MAN-HOURS ARE LOST-TIME ACCIDENTS (NUCLFAR-2.06, NONNUCLEAR-4.14), MEOICAL CASES (5E.4 VS 61.29), $\triangle N D$ SEVERITY RATE IN DAYS LDST PER MILLION MAN HOURS $(917.4$ VS 738.9$)$. WALKE SAYS THAT THE NUMBER OF EMPLOYES RADIATION EXPOSUPSS ABOVE THE STATUTORY LIMIT CAN BE COUNTED ON ONE HAND.

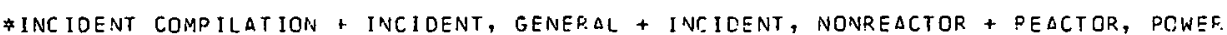

- 1-2IYUO ALSO IN CÁTEGORY C

PROPOSED STANDARD - CRITICALITY ACC IOENT ALAPM SYSTEM

AMERICAN NUCLEAR SOCIETY

7 PAGES, NUCLEAR FNGINEER.ING BULLETIN $5(2)$, NOVEMBEP 1907

THE USEFULNESS ANO PROTECTIVE FFATUFES OE CPITICALITY ALARM SYSTEMS HAVE BEEN DEMONSTPATED IN INSTANCES OF ACCIDENTAL CRITICALITY THAT HAVE OCCURRED DURING THE PROCESSIVG OF FISSIONABLE MATERIALS. THIS STANDARD PROVIDES GUIDANCE FOR THE ESTABLISHMENT AND MAINTENANCE OF AN ALARM SYSTEM TO INITIATE PERSONNEL EVACUATION IN! THE EVENT OF ACCIDCNTAL CRITICALITY. IHIS STANDARD WAS PREPARED BY WORK-GROUF 5 DF SUBCOMMITTEE ANS-8 OF THE STANDARDS CIOMMITTFF RE THE 
CATEGOPY TI
GENERAL SAFETY CRITERIA

$1-21900 *$ *ONTINUED*

AMERICAN NUCLEAR SOCIETY.

AVAILABILITY - AMERICAN NUCLEAR SOCIETY, hINSOALE, ILLINOIS, \$1.50 COPY

ACCIDENT, CRITICALITY + CODES ANO STANDARDS + CFITICALITY SAFETY + ENGINEERED SAFETY FEATURE + PROCEOURES AND MANUALS + RADIATION SAFETY AND CONTRCL + REGULATION, GENERAL + SAFETY PRINCIPLES AND PHILOSOPHY

$1-21985$

LASURTEGUI A

SPANISH NUCLEAR LEGISLATION

10 PAGES, ENERG. NUCL. (MADRID) 10, PAGE 509-518, (NOVEMBER-DECEMPER 1966), IN SPANISH

DESCRIBES CHRONOLOGICALLY THE SPANISH LEgISLATION ON NUCLEAR ENERGY WHICH REgAN IN 1945. ALL ASPECTS OF THE LEGISLATION ARE DFSCRIBED, E.G., REGULATION ON URANIUM MINING AND DROCESSING, LIABILITY REGAPDING ACCIDENTS AT NUCLEAR PLANTS AND NUCLEAR"POWERED VESSELS, SHIPMENT OF RADIDACTIVE MATERIAL, ETC. THE INTERNATI ONAL AGREEMENTS REGAROING NUCLEAR ENERGY SIGNED BY SPAIN, AND MEMEERSHIP IN INTERNATIONAL ORGANIZATIONS, ARE ALSO GIVEN. A BRIEF DESCRIDTION OF THE ORgANIZATION OF THE JUNTA DE ENERgIA NUCLEAP. AND OF NUCLEAR. ENEPGY TEACHING FACILITIES IN SPAIN ARE LISTED.

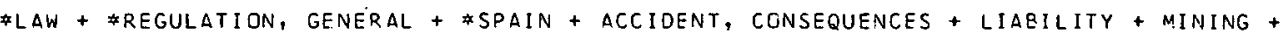

TRANSPORTATION ANO HANOLING

$1-22143$ ALSO IN CATEGORY 17

DRL SAFETY EVALUATION OF NATIONAL BUREAU OF STANDARDS REACTOR

USAEC DIVISION OF REACTOR LICENSING

57 PAGES, DOCKET 50-184, AUGUST 14,1967

CONCERNS THE 1C-MWT CP-5 TYPE OF REACTOR ISINGLE LOOP, HEAVY WATERI AT GAITHERSBURG, MO.

ITEMS OF INTEREST ARE - (A) ON-SITE METEGROLOGICAL TEST SHOWED THAT SITE DOES NCT DIFFER GREATLY FROM THAT AT WASHINGTON NATIONAL AIRPORT, WHERE THE CATA FOR METECRROLOGICAL EVALUATION WAS OETAINED. (B) THE POSSIBILITY OF A SIGNIFICANT SPILL IS REMOTE, AND SOIL CONDITIONS ALLOW TIME FOR EMERGENCY MEASURES. (C) POPULATION INCREASE WAS LARGER THAN EXPECTED IN 1964. (D) ANALYSIS OF THE MAXIMUM POTENTIAL EARTHOUAKE $10.01 \mathrm{G})$ SHEWS THAT REINFORCED-CONCRETE CONFINEMENT BUILDING WOULO CRACK CONSIDERABLY BUT WOULD REMAIN INTACT AND RETAIN ITS CONFINEMENT CAPABILITY.

AVAILABILITY - USAEC PUELIC DOCUMENT ROOM, WASHINGTON, D. C.

*CONTAINMENT, LOW PRESSURE + \#METEORDLOGY + \#POPULATION DISTRIGUTION + EARTHQUAKE ENGINEER ING + REACTOR, FLUX TRAP + REACTOR, HWR + REACTOR, RESEARCH + SAFETY EVALUATION + SITING, REACTOR + SOIL

$1+22334$

JASKE. RT

AN EVALUATION OF THE USE OF SELECTIVE OISCHARGES FROM LAKE ROOSEVELT TO COOL THE COLUMBIA RIVER BATTELLE-NORTHWEST, RICHL AND, WASHING TON

BNWL-208 +. 87 PAGES; FIGURES, TABLES, 17 REFERENCES, FEBRUARY 1966

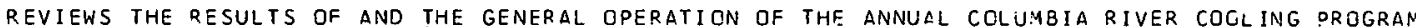
FOR 1953, 64, AND 65. VARIATIONS OF TEMPERATURE INTRODUCED BY UPSTREAM MANIPULATION OR ALTERATION OF THE NATURAL WATERCOURSE PERSIST AS FAR OOWNSTREAM AS THE HANFORD FLANT. ABOUT 85\% OF THE TEMPERATURE ALTERATION, EITHER POSITIVE OP NEGAIIVE, IS RETAINED, WIT!I A TENDENCY TOWARD VALUES OF 65\% TO 75\%. AT LOWER FLOWS (LESS THAN 100,000 CU. FT/SEC). RESULTS REPQRTED FOR PREVIOUS EFFECTS OF THE ANNUAL RIVER COOLING PROGRAM MAY HAVE BEEN OVERSTATED. A HIGH DEGREE OF INTEGRATION AMONG FLOOD CONTRCL, POWER, AND COOLING-WATER USER INTERESTS IS REQUIRED TO MINIMIZE EFFECTS ON FISHERIES.

AVAILABILITY - CLEARINGHOUSE FOR FEDERAL SCIENTIFIC AND TECHNICAL INFORMATION, SPRINGFIELD, VA., S3. OO COPY, \$0.65 MICROF ICHE

\#HANFORD SITE + \#THEPMAL POLLUTION + BATTELLE NORTHWEST + ECOLOGICAL CONSIDERATICN + REACTQP, PEGDUCTION + RIVER, COLUMBIA

$1-22458$

JASKE RT

THE USE OF DIGITAL SYSTEMS MODELING IN THE EVALUATION OF REGIONAL WATER QUALITY INVDLVING SINGLE OR

MULTIPLE RELEASES

PACIFIC NORTHWEST LABOPATORY

BNWL-SA-1372 +. 22 PAGES, 10 FIGURES, 1 TABLE, AUGUST 1967 , PRESENTED AT PROCEEDINGS OF AMERICAN

INSTITUTE OF CHEMICAL ENGINEERS MEETING CN WATER POLLUTION $\triangle B A T E M E N T$, NEN YORK, NOVEMBER 26-30, IOG7

THE DEVELOPMENT OF A DIGITAL SIMULATION SYSTEM BASED ON THEORETICAL CHANNEL FLON WAS

SUCCESSFULLY ACCOMPLISHED AND USED IN A VARIETY OF CASES INVOLVING WIDELY DIVERGENT INPUT

VARTABLES. THE RESULTING ACCURACY WAS WITHIN THE NORMAL CONFIDENCE BASED ON STAT ISTICAL

TREATMENT OF EXTENDED DATA RECORDS. RIVER TEMPERATURES IN EXISTING SYSTEMS WERE SUCCESSFULLY

MODELED TO WITHIN 0.25 C OVER A SIX-MONTH PERIOO. 
GENERAL STEGORY TPEYY CP.ITERIA

$1-22458$ \#CONTINUEC*

AVAILABILITY - R. T. JASKE, PACIFIC NOPTHWEST LAB.

*THERMAL POLLUTION + BATTELLE NORTHWSST + COMPUTER PFOGRAM + CCMPUTEK, DIGITAL + 2IVER, COLUMBIA + RIVER, GENERAL

$1-22450$

JASKE RT

HEAT AS $\triangle$ POLLUTANT

GENERAL ELECTRIC, RICHLAND, WASH.

22 PAGES, 10 FIGURES, NOV. 11,1964 , PRESENTED AT SEMINAR PROCEEDINGS WATER QUALITY CCNTPJL FALL GUARTER -

1964, CONDUCTED BY CREGON STATE UNIVEOSITY, WATER RESOURCES FESEARCH INSTITUTE, NOV. II, ISE4

DISCUSSES FOUR POINTS - 11 ) EFFECTS OF HEAT ON THE PLANNING $\triangle N D$ JUSTIFICATION OF INDUSTDIAL PLANTS AND PROCESS CONDITIONS, 121 EFEECT OF TEMPERATURE ON THF C.TST, C.HEMICAL TASTE AND ODOR, ANO ESTHETIC FACTORS ON MUNICIPAL WATER SUPPLIES, (3) LSGAL ASPECTS JF STFEAM REGULATION RELATED TO. INCREASED THERMALISM, AND (4) IMPROVEO DEFINITICN OF TENPERATURE AS A PARAMETER IN RESFAQCH STUDIES OF EVERY NATURE.

* HHERMAL POLLUTION + BATTELLE NORTHWEST + RIVED, GENERAL + WATER, DPINKING + WATER, GENEPAL

$1-22500$

GROUP SHELTER

U.S. DEPARTMENT OF AGR ICULTUPE

THIS IS A 10 MINUTE FILM REFERENCED ON PAGE O2 OF THE USAEC IE MM FILM CATALOG CRR 1 CGG-G7, PPOUUCED FOR

THE USAECS CIVIL EFFECTS BRANCH BY THE U.S. DEPARTMENT OF AGEICULTURE, MOTION DICTIJEE SERVICE. FOR SALE BY THE PRODUCER, AT \$40.00 PER PQINT, INCLUDING SHIPPING CASE

A IU-MIN LULUK MUVIE UESCLIBING AN UNDERGROUND CORRUGATED-MET LL AFCH SHELTER DESIGN FGP PROTECTION OF 100 DFRSONS FOR TWR KEEKS OR MORE. DESIGN WAS RASED NN EXPEDIENCE GAINED DURING 1957. EFFECTS TESTS AT NTS AND ON SURSEQUENT STULIES, IS DESCDIBEC IV DETAIL IN CIVIL-EFFECTS TEST DPERATIONS REPORT CEX-58.7 - $\triangle E C$ GROUP SHELTER.

AVAILABILITY - AVAILABLE FCO. LDAN (FREF) FPOM USAEC HEADQUARTEFS ANC FIELD LIBRAPIFS. CLEAPED FDF TELEVISION

FALLOUT + SHIELOING

$1-22571$

JASKE RT

THE USE OF A DIGITAL SIMULATION SYSTEM FOR THE MODELING AND PREOICTIDN OF WATER QUALITY BATTELLE NORTHWEST

BNWL-SA-1141 A +. IC PAGES, 4 IGURES, PREPARED FDR PRESENTATION AT THE FOURTH INTEFNATIONAL CCNFERENCE

ON HATER POLLUTIOM RESEARCH, MRAGUE, CZCCIOOLOVAKIA, AUOUST IOUE

SPECIAL RELEASES OE COCL NATER FRGM LOWER LEVELS OF LAKE FOOSEVELT ARE MAOE TO 5 ERUCE THE

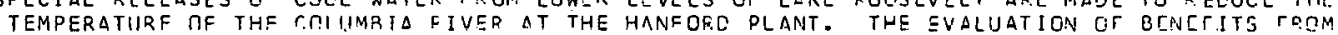
THESE RELEASES HAS BEEN RENDERED INCREASINGLY DIFFICULT BY AODITIONAL IMPOUNDMENTS ON THE RIVER BETWEEN GKONU COULEE DAM AND THE HANFORD PLANT. THE USE CF ELECTRONIC DATA DROCESSING AND OF A DIGITAL-COMPUTER SIMULATION SYSTEM PERMITTEO OPEPATIONS RESEAOCH SIIPPNRTIVG THF PURPOSE OF OPTIMIZING THE USE DF SELECTIVE DISCHARGE FPOM LAKE DOOSEVELT FOR

REACTOR-PRODUCTICN ENHANCEMENT ANC PRCTECTION OF FISHERIES.

AVAILABILITY - R. T. JASKE, BATTELLE MEMGEIAL INSTITUTE, PACIFIC NOFTHWFST LABCRATDRY, RICHLAND, KASHINGTON

* COMPUTER, DIGITAL + \#DATA PE.QCESSING + \#THERMAL POLLUTION + BATTELLE NORTHWEST +

ECOLOGICNL CONSIDEDATION + HANFQR. SITE, RIVIR, COLUMOIA + SIMULATION

$1-22706$

JASKE RT + GUEBEL JB

EFFECTS OF DAM CONSTPUCTION ON TEMPEEATUFES CIF COLUMBIA RIVER

BATTELLE NORTHWEST

7 PAGES, 4 TABLES, 3 FIGURES, 5 PEFERENCES, J. AMFPICAN WATER WORKS ASSC. 591E), PAGES $935-942$ (AUGUST

19671

SINCE 1958, THE RICHLAND TPECATIDNS OFFICE OF THE USAEC, WITH THE COGPERAT ION OF QTHER FEDEFAL AGENCIES, HAS SPONSORED AN ANNUAL POOGRAM TO REDUCE THE TEMPERATURE OF THE COLUMBIA RIVER DUF.ING LATE SUAMER. TO EVALUATE THE T:C SULTS OF TIIIS PRDGFAM, A SYSTEM OP DATA COLLECTIONN POINTS WERE INSTALLED, WITH PARTICULAR EMPHASIS DN MEASUPEMENT ACCURACY. THE FFFC.TION DF LOW-HEAD RESERVGIRS ON THE MAIN STEM OF THE CCLUMBIA RIVER HAS NOT PRGDUCEO A SIGNIFICANT CHANGE IN THE AVERAGE RIVER TEMPFRATUFE. THE EFECTIDN OF GRAND COULEE DAN CREATED A 3O-DAY DELAY IN THE TRANSUURT UF WAIEK IHRGIUGH THE RESERVIIE. SYSTEM. THS ERECTION DF C:AMS AND RESERVOIRS DECREASES EXPECTEO VARIANCE IN WATER TEMPERATURE.

*HANFORD SITE + "\#THERMAL POLLUTION + BATTELLE NOPTHWEST + ECOLQgICAL CONSIOERATION + REACTOR, PRODUCTION + RIVER, COLUMBIA 
CATEGORY CRE ITERIA
GENER SAFTY CRITERIA

$1-22799$

KAROLY R

FUTURF PROBLEMS IN THF CONVFRSION, TRANSPORTATION, AND STORAGE OF ENERGY. ELECTRICITY. NEW SYSTEM OF

POWER GENERATION. NUCLEAR

6 PAGES, 2 TABLES, ENFRgiA ES ATOMTECHNILSA 20 , PAGF $249-254$, (JUNE I967), IN HUNGARIAN

DETAILED PAPERS DISCUSSING (IN HUNGARIANI THE SAFETY AND ECONOMY OF NUCLEAR ENERGY ARE PRESENTED, INCLUDING A DETAILEO REVIEW OF SOME FEACTOR TYPES, THEIR SIZES, ANE SEVERAL PRCPERTIES. THE DEVELOPMENT OF BREEDEPS FOR COUNTRIES WITH NO URANIUM SOURCES IS DISCUSSED. DTHER TOPICS PDESENTED ARE - REACTCE COSTS, SELECTION OF REACTOR TYPE IFUEL SUPPLY, EXPERIENCE JF COUNTRY, GEOLOGICAL WEALTH OF COUNTRY, DEMANC OF CAPITAL, COSTS OF ENERGY GENERATION, CONDITIONS OF PAYMENT, AND IMPGFT DEMAND), SITING, HYDROLOGICAL CIRCUMSTANCES ICOOLING WATER SUPPLY, AND WASTE PEMOVALI, AND TRANSMISSION LINES IDISTANCE OF NETWORKS ANO SECURITY ASPECTSI. POWER, GENERATION RY MAGNETOHYOROOYNAMIC GENERATORS IS ALSO OISCUSSEO.

ECONOMICS + SITING, FEACTOR

$1-22819$

WIRTZ CB + RENN CE

WATER TEMPERATURES ANG, $\triangle Q U A T I C$ LIFE

JOHN HOPKINS UNIVERSITY, EALTIMORE, MD.

EEI-65-901 +. 99 PAGES, 262 REFERENCFS, JUNE 1, 1965

QUICK REFERENCE AND GUIOE FOP. THOSE RESPONSIBLE FOR MAINTAINING FAVORABLE WATER GUALITY AS PART OF INDUSTRIAL OPFRATIONS. DESIGNED TO EXAMINE EFFECTS CF CHANGES IN WATER TEMPEPATURE UPON FISH LIFE AND UPON SMALL BOTTOM-LIVING ORGANISMS THAT ARE IMPORTANT IN THE FOOD ECONOMY CF FISH. DATA FPOM THE REVIEW OF PERTINENT PAPERS IS ARRANGED, FOR VARIOUS TEMPERATURE RANGES, UNDER - EFFECTS JF EXPOSURF, COMPOUND STRESS EFFECTS, EFFECTS ON FEEDING ANO GROWTH, EFFECTS ON REPRODUCTION. AND [IEVELCPMENT, EFFECTS ON MOVEMENT AND ACTIVITY, AND ENVIRONMENTAL CONDITIONS.

AVAILABILITY - EOISON ELECTRIC INSTITUTE, 750 THIRD AVENUE, NEW YORK, NEW YORK 10017 , \$2.00 COPY * HeAT SINK + THERMAL POLLUTION + ESTUARY + oCEAN ANC SEA + RIVER, genERAL

$1-228 \geq 0$

EOINGER JE + GEYER JC

HEAT EXCHANGE IN THE ENVIRONMENT

JOHN HOPKINS UNIVERSITY, BALTIMORE, MN.

EEI-65-902 +. 259 PAGES, TABLES, FIGURES, REFERENCES, JUNE 1, 1965

DEALS WITH THE PHYSICS OF HEAT-TRANSFER PHFNOMFNA OCCURRING IN SUPFACE WATERS. IT IS DESIGNED TO ASSIST ENGINEERS AND SCIENTISTS IN CARRYING OUT TEMPERATURE COMPUTATIONS RELATED TO THE HEATING AND COOLING OF NATURAL WATERS. KNOWN PRINCIPLES OF METEOROLOGY, HYDRODYNAMICS, AND HEAT .TRANSFER ARE USED TO DEVELOP GENERAL FORMULATIONS USEFUL IN THE PREDICTION DF

TEMPERATURES CF INTEREST TO THE POWER INOUSTRY. SUBJECTS INCLUDE.- THE STUDY OF HEATED WATER RISTHARRFS. THF FXS.HANGF DF HFAT RETWEEN WATER AND THE ATMOSPHERE, THE EQUILIGR IUM TEMPERATURE AND THE EXCHANGE COEFFICIENT, PROPERTIE ÉS OF THE HEAT-EXCHANGE HURMULA, ANALYSIS JF HEAT OISTRIGUTIONS, APPLILAIIUNS TO COOLING PONDS, APPLICATIONS TO RIVERS ANO STREAMS, LAKES, AND RESERVOIRS, A STUCY OF A POWER PLANT DISCHARGE, AIR ANALYSIS DF A FOWER PLANT DISCHARGE.

AVAILABILITY - EOISON ELECTRIC INSTITUTE, 750 THIRD AVENUE, NEW YGRK, NEN YORK 10017 , \$2.5O COPY

* HeAT SINK + \#THERMAL POLLUTION + ESTUARY + CCEAN AND SEA + rIVER, GENERAL

$1-22841 \quad \triangle L S E$ IN CATEGIRY 17

HADDAM NECK APPLIES FCP EXEMPTION FFOM 10 CFR 20. 203(C)(2)--PHYSICAL CONTROL OF HIGH RADIATION AREAS CONNECTICUT YANKEE ATCMIC POWER. COMPANY

3 PAGES, JANUARY 3, 1968 , DOCKET 50-213, TYPF--PWR, MFG--WEST., AE--STONE + WEBSTER

REQUESTS SUBSTITUTION OF DRDCELURAL ANC PHYSICAL-ACCESS-CONTROL MEASURES $\triangle T$ T ENTRANCES TO HIGH RADIATION $\triangle R E A S$ IN LIEU OF VISIBLE OF AUDIBLE ALARMS. PHYSICAL CONTRGLS INCLUOE BARRICAOES AND SIGNS AT AREAS WITH RADIATION LEVELS IN EXCESS OF 0.1 R/HR, AND LOCKEO WIRE MESH DOORS TO AREAS OF 1.0 R/HP. DETAILEC PROCERURAL CONTROLS ARE LISTEO.

AVAILABILITY - USAEC PUBLIC DOCUMENT POOM, WASHINGTON, D. C.

* AOMINISTRATIVE CONTRQL + *PADIATION SAFETY AND CONTROL + HAODAM NECK (PNR) + HIGH RADIATION + REACTOR, PWR + REGULATION, $\triangle E C$

$1-22919$

JASKE RT

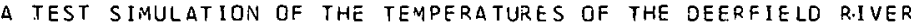




\section{CATEGORY
GENERAL SAFETY CR.ITEPIA}

$1-22919$ *CONTINUED*

BATTELLE NORTHWEST, RICHLAND, WASH.

BNWL-628+. 41 PAGES, P FIGURES, 3 TABLES, G REFERENCES, DECEMBEF 1967

SUMMARIZES THE FESULTS OF A DIGITAL SIMIILATION OF TEMPERATURES IN THE DEERFIELD RIVER DRAINAGE BASIN IN THE AREA OF THE YANKEE REACTOR FROJECT. STATISTICAL U TESTS PEP.FORMED FOR EACH SIMULATION RUN INOICATE THAT COMPUTEO VALUES FOE MOST OF THE TIME PERIDD UNOER CONS IDERATIGIN WERE LESS THAN ONE STANDARD DEVIATION OF THE DBSERVED VALUES, INDICATING A MINIMUM OF 68\% CONFIDENCE IN THE ACCURACY OF THE CCRRELATICN.

AVAILABILITY - CLEARINGHOUSE FOR FEDERAL SCIENTIFIC AND TECHNICAL INFORMATION, SPRINGFIELD, VIRGINIA, $\$ 3.00 \mathrm{COPY}, \$ 0.65$ MICROF ICHE

*thermal pollution + battelle northwest + Reactor, POWER + River, Genefal + yankee (PWF)

$1-22926$

CHRISTIAN SCIENCE MONITOR COMMENT ON PROPCSED AEC RULE CHANGES

1 PAGE, CHR ISTIAN SCIENCE MONITOR 6O191, PAGE 1, COLUMN 1, (DEC. $5,196.7$ )

(FIVE SHORT FARAGPAPIIS IN FOCUS, ON NOV. 22, 1907 , RESPECTING CHANGES TO 10 CFF. 2, 50, 115 ) CHANGES MAY GE FOUGH ON PEOPLE WHO DO NOT WANT ATOMIC POWER. PLANTS IN THEIR VICINITY. PROTESTS ABOUT NASTE-HEAT POLLUTION OF WATER WOULO NO LONGER BE HEARD BY AEC. OFPONENTS WOULD HAVE TO TAKE THEIR CASES ELSEWHERE, MOST LIKELY TO POLLUTION-CONTROL AUTHCR ITIES. PREHEARING CONEERENCES TO BE HELD IN WASHINGTON ARE EXPECTED TO MAKE IT MURE DIFFICULT FCR POORLY FINANCFD. LOCAL GROUPS TO ATTEND HEARINGS BECAUSE COSTS OF TRAVEL AND HOTEL MIGHT BE PROH I BITIVE.

*RAOIATION, PUBLIC EOUCATION/ACCEPTANCE + \#REGULATION, AEC + CONSTRUCTION PERMIT PROCESS + SITING, REACTOF + THERMAL POLLUTION

$1-22927$

PROPOSEO RULE :MAK ING FOR $10 \mathrm{CFR}, 2,50,115$

6 PAGES, FEDERAL REGISTER 32(226), PAGE 16050-16053, (NOV. 22, 1967)

ISSUED FOR PUBLIC COMMENT ARE CERTAIN AMENOMENTS TO PFESENT RULES OF PRACTICE (BASED ON REGULATORY REVIEW PANEL RECOMMENOATIONS) INCLUDING - $(2)$ INTERVENTIOON PET ITIONS TO BE FEASONABLY SPECIFIC ANO TO BE CENIED IF NOT ON TIME OR OUTSIDE AEC JURISOICTION. (3) ASLB ALTERNATE MEMSERS. (4) PREHEARING CONFERENCE (TO EXC.HANGE PREPAREO TESTIMONY IN CONTESTED CASES) WILL BE HELD IN WASHINGTON, D. C. COMMISSION POL ICY AND PRACTICE IS TO HOLD THE EVIOENTIAZY HEARING IN THE VICINITY OF THE SITE OF THE PROPOSED FACILITY, TO GIVE 30 DAYS FEDERAL-REGISTER NOTICE, AND MAKE PUBLIC ANNOUNCEMENT OF (A) DATF AND PLACE FOR THE HQUCEUURES IO APPEAR, (B) THE LOCATION NEAR THE SITE WHERE REPORTS ARE FILEO. (5-13) DETAILS OF HEAR ING PROCEDURES. $(1,14,15)$ NOTICE WILL BE ISSUED AT LEAST 30 DAYS BEFORE A PUBLIC HEAR ING.

*RADIATION, PUBL IC EDUCATION/ACCEPTANCE + \#REGULATION, AEC + CONSTRUCTION PERMIT PROCESS + SITING, REACTDR + THERMAL POLLUTION

1-22941 ALSO IN CATEGORIES 3 ANO 17

EABCOCK ANO WILCOX REPORTS OLUTONIUM NI IPATE LEAKAGE FROM POLYETHYLENE BOTTLES BABCOX AND WILCEX COMPANY

1 POGE, $\triangle T$ OMIC ENERGY CLEARING HOLSE $14(6)$, PAGE 8, (FF.B. 5,1968 )

(LETTER, JAN, 17) ALTHOHÊH NOT RFPMRTAFIF UNDER 10 CFR 20, THIS IS AN EXANPLE OF LEAKAGE AS IN YOUR HEALTH AND SAFETY BULLETIN $25 \%$, DEC. 21,1067 . ON JAN. 8, I968, ROUTINE INSPECTION REVEALEO A LEAK FROM A SMALL CPACK IN A I-GAL POLYETHYLENE BCTTLE THAT PENETRATED THRQUGH THRE 4-MIL-THICK POL YE THYLENE BAGS (TWO WITH POOR HEAT SEALS), DISSOLVED A 3-IN.-DIAM HOLE IN THE CARBON-STEEL SHELF, ANO DRIPPED THROUGH TWU OIHER STEEL SHELVES. THE BOTTLE WAS QUITE STIFF, AND CRACK MAY HAVE BEEN CAUSED BY RADIOLYTIC GAS PRESSURE, RADIATION DAMAGE, OR OXIDATION. STAINLFSS-STFFI. SHFI.VING ANO ACID-RESISTANT ORIP PANS ARE BEING CONSIDERED.

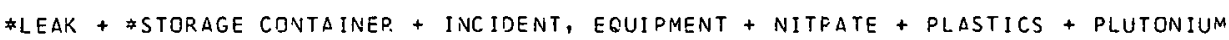

$1-22342$

RUNYON D

COULO WASHINGTON SURVIVE AN ATOMIC PLANT ELOWUP

2 PAGES, HIGURES, THE WASHINGTON D.C. FXAMINFR 11141 , PAGF 1 ANח 16, (NECEMBEF 7-10, 1967)

(FIRST PART.) PRIEF OISCUSSIUN UF THE OCY. GE FERMI-PLANT FUEL MELTDOWN, THEN A REMINDER THAT THE PLANT CDNTA INEE ENOUGH U-235 TC MAKE 40 HIROSHIMA-SIZE ATOM BOMES. REFERENCES TO LEO COODMAN AND SCIENTISTS INSTITUTE FCR PUBLIC INFORHATION STATEMENTS - D IOBT AEC REPORT GUESSEO THAT THE WORST RESULT OF A CRITICAL ACCIDENT WOULD BE THOUSANDS KILLED AND INJURED 45 MILES AWAY, (QUTTE) - THE ACCIDENT WAS A EIT WCRSE FHAN THE MCA ... IT WAS $\triangle L S O$ UNFORSEEN, DESPITE ALL THE AECS HIGHLY TCUTEO STUO!ES ON THE PRCRABILITY OF SUCH ACCIDENTS. OFFICIALS HAVE SINCE PITT OUT A STORY THAT THE FERMI PLANT WENT HAYWIRE - DESPITE ALL THE AUTJMATIC CONTROLS ANO ERAKES - BECAUSE A WOPKEP DROPPFD A BFFR. CAN IN THE WORKS (UNQUOTE).

FERMI (LIMFBR) + FUEL MELTOOWN + PROBABILITY + RADIATION, PUBLIC EDUCATION/ACCEPTANCE 
CATEGCEY
GENERAL SAFETY CRITERIA

$1-22943$

ALSO IN' CATEGORY 17

RUNYON 0

INVISIBLE DEATH - POLLUTION OF THE ATOMIC AGE

2 PAGES, FIGURES, THE WASHINGTON D. C. EXAMINEF 1(15), PAGES l ANO 8 (DECEMBER 14-17, 19G7)

(SECOND OF. THREE PARTS.) (QUOTE) ATOMIC POWER PLANTS GENERATE MORE CONTROVERSY THAN ELECTRICITY. THE OISPUTE OVER SAFETY IN ITSELF IS A MEASURE OF THE LACK GF KINOWLEDGF. ABCUT THE INHERENT DANGERS (UNQUOTE). ARTICLE DISCUSSES FERMI AND WINOSCALE INCIDENTS, SHOWS PICTURE OF IRRADIATED AND UNIRPADIATEO CHICKEN EMBROYOS. (QUOTE) THE FEDERAL GOVERNMENT QUICKLY WASHES ITS HANDS OF RESPONSIBILITY. FOR INSTANCE, RESPONSIBILITY FOR KEEPING NUCLEAR GARBAGE WAS FOISTED DN THE STATE OF NEW YOFK (UNQUOTE). LEO GOODMAN HAS COMPILED A WEALTH OF ACTUAL MATERIAL - ATOMIC REACTOR ACCIOENTS (210), ATOMIC FATALITIES (129), AND ACCIDENTS INVOLVING RADIATION $(9 \in 8)$.

INCIDENT COMPILATION + RADIATION, PUBLIC EDUCATION/ACCEPT.ANCE.

$1-22944$

RUNYON D

2 PAGES, FIGURES, THE WASHINGTON D.C. EXAMINER 1(15), PAGES 8 AND 1E, (DECEMBER 21-24, 1967)

(THIRD OF 3 PARTS.) ASSERTS THAT A NATIONAL FORTUNE OF' BILLIONS WAS SPENT FOR IE PLANTS THAT ARE SHAKY AT BEST OR TOTAL FAILURES. A \$120 MILLION PLANT PRODUCEO ONLY \$33O,OOO WORTH LIF ELECTRICITY BEFORE A MINOR ACCIDENT SHUT IT DOWN COMPLETELY. PIQUA CONTRACT WAS ENDED LAST WEONESDAY AFTER. TWO YEARS OF SHUTDOWN DUE TO TECHNICAL DIFFICULTIES IN THE REACTOR CORE. GOVERNMENT LOSS - \$24 MILLION. UMW AITRIBUTED WIRTZ URANIUM-MINER LUNG-CANCER ACTION TO THIS SERIES IN THE EXAMINER. ILLUSTRATES EFFECTS OF RADIOACTIVITY WITH AEC PHOTO TF PGNE DAMAGE TO RADIUM-WATCH-DIAL PAINTER, WHO TOUCHED BRUSH TO TIP OF TONGUE.

RADIATION, PUBL. IC EDUCATIONIACCEPTANCE + RADIUM

$1-22959$

TOMS $J$

NEW D. C. PAPER CRUSADES AGAINST NUCLEAR SCOURGE

2 PAGES, 1 FIGURE, THE OAK RIOGEP, $20(12)$, PAGES 1 AND 4 (FEBRUARY 6, 1969)

(MEDILL NEWS SERVICE) DISCUSSES DEC. 7, 14, AND 21, 1067, ARTICLES IN D. C. EXAMINER BY LAMUN RINYYON, JR., WHO ASSERTS THAT 200 U.S. REACTORS ARE POTENTIAL BOMBS. CITES. WINDSCALE. AND FERMI ACCIDENTS, AND CITES LEO GOODMAN AS COMPILING MUCH OF THE INFORMATION FROM AEC SOURCES. * DISCUSSES AEC REPLY CITING THAT PUBLISHERS IGNDRED FACTUAL. ERRORS POINTED OUT AFTER FIPST ARTICLE, ANO PROTESTIING INACCURACIES AND DISTORTIONS. \# REP. JOHN $\triangle N D E R S O N$, ON THE HOUSE FLOOR, STATES - (QUOTE) RARELY, IF EVER, HAVE I SEEN A MORE IFRESPONSIBLE PIECE OF JOURNALISM THAN THIS ARTICLE... PURE AND UNADUL TERATED SENSATIONALISM. (UNQUOTE)

\#RADIATION, PUBLIC EDUCATION/ACCEPTANCE + FERMI (LMFBR) + INCIOENT, WINDSCALE

$1-23145$ ALSO IN CATEGORY 17

ELK RIVER QUERIES AEC ON ITS RESPONSIBILITY FOR NUCLEAR SAFETY

RURAL CCOPERATIVE POWER ASSOCIATION

3 PAGES, FEBRUARY 6, 1968, DOCKET 115-1, TYPE--BWR, MFG--A.C., AE--SGT + LUNDY

$\triangle E C-C O O$ PROPOSES TO SUESTITUTE A NEW CONTRACTOR (OVER THE OBJECTIONS OF RCPA) FOF NUS TO PERFORM TECHNICAL-SUPPORT CONSULTATION SURVEILLANCE IN THE AREA OF NUCLEAR REACTOR SAFETY. RCPA ASKS $\triangle E C$ TWC QUESTIONS - $(1)$ DOES RCPA HAVE COMPLETE AND UNRESTRICTED RESPONSIBILITY TO CARRY OUT THE LICENSING AGENCYS PEQUIREMENTS FDR NUCLEAR REACTOR OPERATING SAFETY. I $2 I$ IF YOU DETERMINE THAT THE AUTHORIZED OPERATOR DOES NOT HAVE THIS RESPONSIBILITY, SHOULD NOT

OPERATING AUTHORIZATION, TECH. SPECS., ETC., BE AMENDED TO ASSIGN THIS RESPONSIRILITY TO THE PARTIES WHOM YOU DETERMINE HAVE THIS AUTHORITY.

AVAILABILITY - USAEC PUBLIC DOCUMENT ROOM, WASHINGTON, D. C.

AOMINISTRATIVE CONTROL + ELK RIVER (BWR) + REACTOR, BWR + SAFETY REVIEW + TECHNICAL SPECIFICATIONS

$1-23166$

MIRONE M + SANTASILIA F + COLLING F

EXPERIMENTAL ASSESSMENT OF. CORE PERFGRMANCE UNDER NORMAL OPERATING CONDITIONS AND VERIFICATION OF SAFETY MARGINS AT INCREAS.ED OUTPUT IN THE GARIGLIANO BWR POWER STATION.

ENEL, IT ALY

1 PAGE, ENEA-(MISC), 5/902 (MAY 1966)

DESCRIBES THE O8JECTIVES OF A LONG-RANGE PHYSICS MEASUREMENT PROGRAM SET UP AT THE LATINA NUCLEAR POWER STATION. IMMEDIATE OBJECTIVE IS TO DETERMINE THE EVALUATION OF THE CORE REACTIVITY WITH IRRADIATION. PERIODIC MEASUREMENTS WILL BE. MADE OF THE PARAMETERS WHICH EFFECT REACTDR SAFETY. THESE INCLUDE TEMPERATURE COEFFICIENTS OF FUEL AND MODERATOR, 
GENERAL SATEGORY "CRITEP.IA

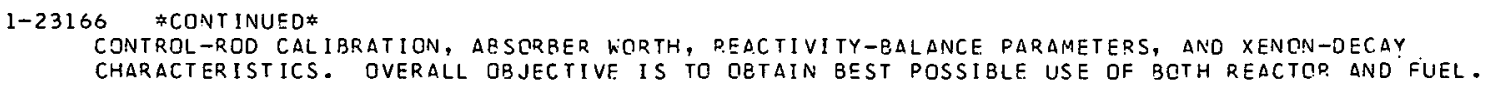

A DESCRIPTION OF THE RESULTS AND APPLICATIONS OF A SERIES OF CRITICAL EXPERIMENTS PERFORMED ON A MOCKUP OF SEFOR AI ZPR-3. CRITICAL MASS VALUES WERE OFTERMINED FOR 1-, 2-, ANO 3-SEGMENT FUEL DESIGNS. EFFECTIVENESS GT SEGMENTED FUEL IN REDUCING AXIAL EXPANSIUN KEACIIVITY WAS DEMONSTRATED, AND RESULTS NERE AN IMPORTANT FACTOR IN SELECTION OF THE 2-SEGMENT NFSIGN FOF, $S=$ F'R. MEASUREMENTS OF THE R.EACTIVITY WOFTH OF THE RADIAL REFLECTOR. ESTABL.ISHEC THE ADEGUACY OF THE SEFJP DEFLECTOR CONTRCL SYSTEM. DOPPLEP. COEFFICIENTS NAS YEASURED. THE CALCULATED U-238 DOPPLER COEFFICIENT WAS IN AGREEMENT WITH EXPERIMENT. THE MEASURED PU-23S CONTRIRUTION TO THE SFFAR DOPPLER COEFFICIENT WAS NEAP. ZEP.C. MAXIMUM POSITIVE REACTIVITY CAUSED BY LE.SS OF SODIUM NAS MEASUREO. THE MEASURED REACTIVITY WAS SMALL ANO CLOSE TO THE CALCULATED VALUE. OTHER MEASUREMENTS MADE INCLUOEO THE RATIO OF 1/BETA-EFFECTIVE, FISSION PATIOS, FISSION ANC SORON TRAVERSES, AND PLUTONIUM WORTH OISTRIBUTION.

AVAILABILITY - CLEARINGHOUSE FOR FEDERAL SCIENTIEIC ANO TECHNICAL INFOPMATICN, SPFINGFIELD, VA., \$3. OO COPY; \$0.65 MICROEICHE

*CRITICALITY EXPER IHENT + \#MEASUREMENT, REACTIVITY + \#SEFOR (RE) + COMFARISON, THEORY AND EXPERIENCE + CRITICAL ASSEMBLY FACILITY + DOOPLER COEFFICIENT + REACT.IVITY EFFECT, EXPANSION + REACTOP, BREEDER + REACTOR, FAST + REACTOR. IMCR + SOMIIIM COEFFICIENT + ZDP. 3 (CAE)

1-23308 ALSO IN CATEGORY 11

NEW CONTAINHENT DESIGN LOWERS NUCLEAR PLANT CAPITAL COSTS WEST INGHOUSE COR PORATION

2 PAGES, FIGURES, NESTINGHCUSE ENG. , 27, PAGES 82-83 (MAY 1967)

$\triangle$ NEW CONCEPT IS CIESCRIBED WHICH WILL ORASTICALLY REOUCE THE SIZE DF A NUCLEAR PLANT CONTAINMENT STRUCTURE. IT USES AN ICE BED TO SERVE AS A HEAT ABSORBER IN THE EVENT OF ACCIDENTAL RELEASE OC STEAM WITHIN THE CONTAINMENT STRUCTURE. ITS ADVANTAGES ARE - A SMALLER CONTAINMENT STKUCTUPE, DESIGN FCP LOWEP PPESSURES, WITH RESULTANT REDUCTION IN CADITAL CCSTS, RAPID ABSORPTION OF HEAT, AND A VIRTUALLY STATIC SYSTEM, WHICH CONTRIQUTES TO RELIABILITY. TESTS HAVE DEMONSTRATCD THE EFFECTIVENESS OF THIS NEW CONTAINMENI CUNCEPT AND HAVE CONFIRMEO ENGINECRING ESTIIMATES OF THE PERFORMANCE. THE ICE CONDENSER PERFORMS EQUALLY WELL OVFR A WIDE RANGE DF CONOITIONS, INCLUDING A VARIETY OF ICE CONFIGURATIONS AND STEAM BLOWDOWN TIMES RANGING FROM IO SEC TO 45 MIN.

\#CONTAINIENT OESIGN + \#CONTAINMENT, ICE CONDENSEE + \#MODEL TESTING + ECONOMICS + MOCKUD

$1-23376$

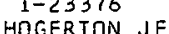

THE ARRIVAL OF NUCLEAF PONER

11 PAGES, FIGURES, SCIENTIFIC AMERICAN: 21R(2). PAGES 21-31 (FEBRIIARY 1CAB)

EXCELLENT BACKGF OUND ARTICLE THAT OISCUSSES THE ECONOMIC AND PHILGSUPHICAL HISTOPY RF THE SUCCESS OF VUCLEAR DOWER IN THE US. PQ⿱NSENTS STEP-WISE PROGFESS CROM 1042 TO IOGE, INCLUOING THE FIRST PILES, PWPS, BWRS, THE HTGR, AND BREEDERS. ACTIVITIES OF THE CE:AL INTEFESTS $\triangle F E$ BROUGHT OUT, TOGETHË WITH THE GROWING POPULAR INTEREST IN CLEAN AIR ANO THE INCIPIENT FROBL FMG DF THEPMAL PELLUTION.

\#ECONOMIC STUDY + \#REACTOR, POWER + \#PEVIEW + PEACTOR, BREEDER + REACTOF, BWR + FEACTOR, GCR + FEACTOR, PWO

$1-23391$

MCALEVY RF + MAGEE RS

A CRITFRINA FOR SPACF TAPSIULF FIRE HAZMRO MIMIIMIZATION

STEVENS INSTITUTE OF TECHNOLOGY, HOROKEN, N. J.

I PAGE, JOURNAL OF SPACECQAFT ROCKETS 4(10), PAGE 1390 (OCTOBER 1967)

STEVENS INSIIIUIE IS ENGAGEO IN A FUNDAMENTAL STUDY OF THE MECHANISM OF FLAME SPREADING OVER THE SURFACE OF IGNITING SOLIO HATEF.IALS. RESULTS HAVE DEEN FGODUCED THAT HAVE IMPLICATIGNS CONCERNING THE FIRE HAZARD ASSCCIATED WITH OXYGEN-RICH FNVIRCNMENTS. AS A CONSEQUENCE OF THE SUBJECT PROGRAM, A FATIONAL BASIS FOR THF. SFIFCTTINN MF MANNEO CAPSULE ENVIDONMENTS HAS EMERGED FOR VINIMIZATION OF THE RATE CF FLAME SPREAOING AFTER ACCIDENTAL IGNITION.

\#FIRE + \#IGNITION + \#OXYGEN + AEROSPACE SLFETY + SPACECRAFT 
$1-23443 \quad \Delta L S O$ IN CATEGORY 6 JUBOVSKII $B G+K A M A E V A V+K U Z N E T S O V F M$ CRITICAL PARAMETERS CF FISSIONABLE MATERIALS SYSTEMS ANO NUCLEAR SAFETY (A HANDBOOK) JPRS 42,322 + TT-67-32951 +: 173 PAGES, $\triangle$ UGUST 23, 1067, TPANSLATED FRCM PP 1-226 OF KPITICHESKIE PARAMETRY SISTEM S DELYASHCHIMISYA VE SHCHESTVAMI I YADERNAYA EEZOPASNOST, ATOMIC PUBL ISHING HOUSE, MOSCON, 1066

ARTICLES IN THIS HANDẼOOK ARF - 11 B BASIC CONCEPTS OF NUCLEAR SAFETY, (2) METHEDS OF DESIGNING HJMOGENEOUS RFACTOP.S, (3) CRITICALITY OF SYSTEMS OF INTERACTING SUBCRITICAL ASSEMBLIES DF FISSIONABLE MATEKIALS, AND (4) BASIC NORMS FOP. FNSURING NUCLEAR SAFETY.

CRITICALITY SAFETY + DESIGN CRITERIL + REACTCR SAFETY SYSTEM + SAFETY ANALYSIS

1-23695 ALSO IN CATEGMRY 11

LIBEP. T + BARNETT QL

FINAL REPORT. AN EXDEK IMENTAL INVESTIGATION OF FRANGIBLE PLATE FRAGMENTATION

I IT RESEARCH INSTITUTE, TECHNCLOGY CENTER, CHICAGO, ILLINOIS

IITRI-M-6095 +. 99 PAGES, FIGURES, TABLES, ¿ REFERENCES, DCT. 1966

DISCUSSES THF EFFECTS OF BLASTS (POSSIBLY FRेOM NUCLEAR DETONATIONS) ON PLATES. OF CONCERN ARE STRUCTURAL DEBR IS AND PERSONNEL PROTECTION. EMPHASIS IS ON DYNAMIC LDADING AND TESTING FOR PREDICTABLE CRACK PATTERNS.

AVAILABILITY - DEFEVSE COCUMENTATION CENTER, CAMERON STATION, ALEXANDRIA, VIRGINIA

CIVIL DEFENSE + MISSILE GENERATION AND PROTECTION + SHIELOING + STRESS ANALYSIS

$1-23921$

MORRISON DI

RESEARCH ON THE SAFETY GF NUCLEAR POWER REACTORS

BATTELLE MEMOR I AL INST ITUTE

7 PAGES, 4 FIGURES, 7 FEFERENCES, BATTELLE TECH. REV., 16, PAGE 3-9, (SEPT. 1967 )

RESEARCH IN AREAS PELATIVE TO POWER-REACTOR SAFETY PROVIDED CONSIDERABLE INSIGHT INTG IHE PROBLEMS THAT MAY EE FNCOUNTERED IN THE UNLIKELY EVENT OF A MAJUR ACCIDENT. WITHIV CURPENT UNDERSTANDINS OF THE PROBLEMS, EFFECTIVE MEANS FOR COUNTERACTING THE ACCIDENT HAVF BEEN DEVISED, AVD APDRGACHES THAT SHOULO LEAD TO A REDUCTION IN THE PROBABILITY OF OCCURRENCF OF THE ACCIDENT ARE BEING FOLLOWED. HOWEVER, IN VIEW OF THE FOTENTIAL CONSEQUENCES, ADOITIONAL UNDERSTANDING OF THE POSSIBLE ACCIDENT IS BEING SOUGHT THROUGH CONTINUING RESEARCH EFFORTS.

* SAFETY ANALYSIS + \#SAFETY ORINCIPLES AND PHILOSOPHY + \#SAFETY PRCGFAM + BMI + REACTOR, BWR + REACTOR, PWR

$1-23923$

MIALKI Vin

35 YFARS DF RFACTIR SAFFTY

5 PAGES, 5 FIGURES, 3 TABLES, S REFERENCES, ATOMWIRTSCHAFT (12), PAGE 573-5777, (DECEMBER 1967j İN GERMAN̈

PROTECTION IROM. QADIATION IS THE MAIN ASPECT OF REACTOR SAFETY. SUT THERE ARE ALSO ECONOMIC INTTERESTS, WHICH PARTICULARLY CONCERN MANUFACTURERS, OPERATORS, AND INSURERS OF NUCLEAR ENERGY INSTALLATIONS, WHOSE SIGNIFICANCE IS CONSIDERABLY INCREASING WITH THE RAPID GROWTH IN THE UTILIZATION CE NUCLEAR ENERGY. ATTEMPTS HAVE BEEN MADE TO DERIVE JUSTIFIABLE PREDICTIGNS OF THE RELIABILITY OF NUCLEAR POWER STATIONS AND THEIR COMPONENTS BY MODEL CONCEPTIONS AND SYSTEA ANALYSES. IT IS NECESSARY FOR THIS PURPOSE TO FIND OUT THE CAUSES OF FAILURES, I.E., TO UNDERTAKE AN EVALUATION DF PAR.TICULAR CASES OF DAMAGE AND THEIK REACIIUN ON THE UPERATILN OF THE INSTALLATION.

* SAFETY PRINCIPLES ANO PHILOSOPHY + \#SAFETY REVIEW + GERMANY

1-23926 ALSC IN CATEGOSIES 7 AND 11

COTTRELL WB

FETY RESEAQCH AND DEVELOPMENT PROGRAM BIMONTHLY REPORT FOR NOVEMBER-DECEMBER 1967 ORNL NUCLEAR SAFETY RESEARCH AND

DAK RIDGE NATIJNAL LAB., TENN.

INCLUDED IN THIS PROGRESS PEPOPT IS WORK ON VARIOUS CHEMICAL REACTIONS, AS WELL AS THE QELEASE, CHARACTERIZATICN, AND TRANSPORT OF FISSION PROOUCTS IN CONTAINMENT SYSTEMS UNDER VARIOUS ACCIDENT CONOITIONS AND ON PROBLEMS ASSOCIATED WITH THE REMOVAL OF. THESE FISSION PRODUCTS FROM GAS STRCAMS. ALTHOUGH MOST OF THE WORK HAS BEEN AND CONT INUES TO BE IN GENEFAL SUPPORT DF WATER POWER-REACTOR TECHNOLOGY, INCLUDING SCME IN DIRECT SUPPORT OF THE LOFT AND CSE PRGGRAMS, SEVERAL PROJECTS WERE STARTED THE FIRST OF THE CALENDER YEAR IN SUPPORT OF THE HIGH-TEMPERATURE GAS-COOLED PEACTOP (HTGR) PROGRAM. THESE PFOJECTS INCLUDE BOTH IN-PILE AND OUT-PILE STUDIES OF REACTION RATES AND FISSION-PRODUCT RELEASE AND TRANSPORT PHENOMENA RELEVANT TO PCTENTIAL HTGR ACCIDENT SITUATIONS. OTHER MAJOR PROJECTS INCLUDE FUEL-TRANSPORT SAFETY INVESTIGATIONS, A SERIES OF OISCUSSION PAPERS ON VARIDUS ASPECTS OF WATER-PEACTOR 
CATEGORY
GENERAL SAFETY CRITERIA

$1-23926$ *CONTINUED*

TECHNOLOGY, AND THE STUDIES ON PRESSURE-VESSEL TECHNOLOGY. FXPERIMENTAL WORK RELATIVE TO PRESSURE-VESSEL TECHNOLOGY. EXPERIMENTAL WORK RELATIVE TO PRESSURE-VESSEL TECHNOLOGY

INCLUDES INVESTIGATIONS OF THE ATTACHMENT OF NOZZLES TO SHELLS AND THE VARIABILITY DF IMPACT DATA ON LOW-ALLOY STEELS.

AVAILABILITY - CLEARINGHOUSE FOR FECERAL SCIENTIFIC AND TECHNICAL INFORMATION, SPRIVGFIELD, VIRGINIA $22151, \$ 3.00$ COPY, $\$ 0.65$ MICROFICHE

*CHEMICAL KINETICS + \#CONTAINMENT, GeNERAL + \#CSF + \#FISSION PRODUCT PETENTION + * FISSION PRODUCT TRANSPORT + \#FISSIIN PROCUCT, AIRBORNE + \#IMPACT PROPERTY + \#IN PILE EXPERIMENT + *LOFT $(S-R P)+$ *NOZZLE + *DUT DF PILE LOOPS ANO EXPERIMENTS + *REACTOR, HTGR + *STEEL + CONTAINMENT SPRAY + FISSION PRODUCT RELEASE, GENERAL + PRESSUP.E VESSEL 


\section{CATEGQRY
SITING OF ONUCLEAP. FACILITIES}

$2-20627$

SCHEIDEGGER AE

TECTONICS OF THE ARTIC SEISMIC BELT IN THF HEIGHT OF FAULT-PLANE SOLUTIONS OF EARTHQUAKES

5 PAGES, BULLETIN O? THE SEISMOLOGICAL SOCIETY CF AMERICA 56(1), PAGE 241-245, (FEBRUARY 1966)

A STATISTICAL METHOD DEVISED EARLIEP BY THE WRITER FOR.THE TECTONIC INTERPRETATION OF FAULT-PLANE SOLUTIONS OF EARTHQUAKES IS APPLIED TO FAULT-PLANE SOLIJTIONS OF ARCTIC EARTHQUAKES WHICH WERE RECENTLY PUBLISHED IN RUSSTA. IT IS SHOWN TIHAT THE FARTHOUAKES ON THE GREENLAND SIDE OF THE ARCTIC SEISMIC BELT REPRESENT THE SAME TECTONIC PATTERN AS SEEN ON THE MID-ATLANTIC RIDGE, WHEREAS THE EAFTHQUAKES CIN THE SIBERIAN SIDE ARE TECTONICALLY CONNECTED WITH THE VERK HOGAN RANGE.

*TECTONICS + EARTHQUAKE PREDICTION + EARTHQUAKE RECOROS + EARTHQUAKE, GENERAL + SEISMIC ZONE + SOUR CE MECHAN ISM

$2-20634$

KASAHARA K + OKADA A

ELECTRO-OPTICAL MEASUREMENT OF HORIZONTAL STRAINS ACCUMULATING IN THE SWARM EARTHQUAKE AREA

EARTHQUAKE RESEARCH INSTITUTE

16 PAGES, BULLETIN OF THE EARTHQUAKE RESEARCH INSTITUTE 44, PAGE 335-350, (1066).

SINCE OCTOBER 1965, THE AUTHGRS REPEATED GEOOIMETER SURVEYS FOR A BASE-L INE NET IN MATSUSHIRO ANO OBSERVED HORIZONTAL STRAIN ACCUMULATION SUCCESSFULLY. THE FOLLOWING CONCLUSIOVS WERF. DRAWN - 111 STRAIN, WHICH PREDCMINATES IN THE NS-DIRECTION, ACCUMULATED MOST ACTIVELY DUFING THE PER IOD OF NOVEMBEP-DECEMEER 19E5. MODE OF THE STRAINS AS REPRESENTED BY THE PRINCIPAL AXES HARMONIZES SUPPRISINGLY WELL WITH THE SEISMIC FGRCE SYSTEM THERE. (2) ACCUMULATED STRAIN ENERGY REACHED AN AMOUNT COMPARABLE TO THAT OF SEISMIC ENERGY. THESE SORTS OF INFORMATION SEEM TO SUGGEST AN INSEPARABLE RELATIONSHIP OF THE EARTHS STRAIN TO THE SFISMIC ACTIVITY.

* TECTONICS + EARTHQUAKE PREDICTION + EARTHQUAKE, GENEPAL + INSTRUMENTATION, EARTHLUAKE + SEISMIC ZONE + SOURCE MECHANISM

2-20635

RIKITAKE T + YAMAZAKI Y + HAGIWARA Y + KAWADA K + SAWADA M + SASAI Y + WATANABE T + MOMOSEK + YCSHINO T + OTANI K + OZAWAK + SANZAI, Y

GEOMAGNETIC AND GEOELECTRIC' STUDIES OF THE MATSUSHIRO EARTHQUAKE SWARM

EARTHQUAKE RESEARCH INSTITUTE

46 PAGES, BULLETIN OF THE EARTHQUAKE RESEARCH INSTITUTE 44, PAGE 363-408, 11966

OBSERVATIONS OF CHANGES IN THE GEOMAGNETIC FIELO BY A PRGTON PRECESSIDN MAGNETOMETER AND A SECOND-ORDER G.S.I. MAGNETOMETER WERE CARPIED OUT AT STATIONS IN THE MATSUSHIRO EARTHQUAKE AREA WHERE WE HAD AN EARTHQUAKE SWARM IN 1965. TWD SERIES OF MAGNETIC SURVEY AS WELL AS AN EARTH-CURRENT OSSERVATION WEFE ALSO CONDUCTED THERE. A STRONG MAGNETIC ANOMALY ASSOCIATEO WITH A VOLCANIC DOME CALLED MT. MINAKAMIYAMA WAS FDUND. COMPARISJNS BETWEEN THE RESULTS OF MAGNETIC OBSERVATION THERE ANO THOSE AT THE KANOZAN GEODETIC ORSERVATORY ANU AT THE OSHIMA MAGNETIC OBSERVÁTORY SEEM TO SUGGEST OCCURRENCES OF LOCAL ANCMALOUS CHANGES IN THE

- GEOMAGNETIC FIELD OF THE ORDER OF 10 GAMMA THAT MIGHT BE ASSGCIATED WITH SEISMIC ACTIVITIES, ALTHOUGH ELIMINATION OF GENERAL MAGNETIC CHANGES SUCH AS MAGNETIC STORM, DAILY VARIATION, ANO THE LIKE. WAS NOT QUITE COMPLETE. AN ANOMALOUS CHANGE IN EARTH-CURRENTS WAS ALSO OBSERVED AT THE TIME OF A RELATIVELY LARGE EARTHQUAKE.

* instrumentation, earthouake + earthouake prediction + earthquake, general + Seismic zone + tectonics

2-20636

RIKITAKE T + YAMAZAKI Y + HAGIWARA Y + KAWADA K + SAWAOAM + SASAI Y + YOSHINO T

GEOMAGNETIC AND GEOELECTRIC STUDIES OF THE MATSUSHIF.O EARTHQUAKE SWARM

EARTHQUAKE RESEARCH INSTITUTE

10 PP., BULLET IN OF THE EARTHQUAKE RESEAPCH INSTITITUE 44, P. 409-418, (1966)

CHANGES IN THE GEOMAGNETIC TOTAL INTENSITY AT A STATION IN THF MATSUSHIRC EARTHQUAKE AREA WERE EXAMINED. THE OESERVATION SY A PROTDN PRECESSION MAGNETOMETER MAAKES IT CLEAR THAT THE TOTAL INTENSITY THERE DECREASED BY A FEW GAMMAS DURING A PERIOD FRCM NOV. 1965 TO FEB. 1966 . A NUMBER OF SHORT-TERM FLUCTUATIONS IN THE TOTAL INTENSITY THAT MIGHT BE RELATED TO SEISMIC ACTIVITY ARE ALSC OBSERVED.

EARTHQUAKE PREDICTION + EARTHQUAKE, GENERAL + INSTRUMENTATION, EAPTHQUAKE + SEISMIC ZONE + TECTONICS

$2-20661$

WYSS M + BRUNE JN

THE ALASKA EARTHQUAKE TIF 29 MAP.CH 1964. A COMPLEX MULTIPLE RUPTURE

7 PAGES, BULLETIN DF THE SEISMOLOGICAL SOCIETY OF AMERICA 57(5), PAGE 1017-1023, 10CTOEER 1967)

THE SEISMOGRAMS OF THE ALASKAN EARTHOUAKE OF 28 MARCH 1964 ARE CHARACTER IZED BY MULTIPLE 
SITING OF NUCLEAR FACILITIES

\begin{abstract}
2-20661 *CONT INUED*
P-PHASES NOT PREDICTED BY THE TRAVEL-TIME CURVES. SEISMOGRAMS WITH LOW MAGNIFICATIONS FPOM 80 STATIONS COVER ING DISTANCES FROM 40 TO 90 DEG AND A hIIOE RANGE OF AZIMUTHS WERE ANALYZEC. THE CHARACTER OF THE P-WAVE PORTION OF THE SEISMOGRAMS IS INTERPRETED IN TERMS CF AN APDROXIMATE MULTIPLE-EVENT SOURCF MECHANISM WHEFE THE PROPAGATING RUPTURE TRIGGERS LARGER DISTINCT EVENTS. SIX EVENTS WERE LOCATED USING THE GUTENBERG SINE-CURVE METHCO. THE TIMES AFTER THE INITIAL ORIGIN TIME WERE $\because, 1 \%, 28,2 \circ, 44, \triangle N D 72$ SEC, RESPECT IVELY, AND THE EVENTS WEPE LCCATED $35,66,89,93,165$, ANO $250 \mathrm{kM}$ AWAY FROM THE I.NITIAL. EPICENTER. DIVIDING THE DISTANCE BY THE DELAY-TIME GIVES AN AVERAGE RUPTUPE VELOCITY OF3.5 KM/SEC.
\end{abstract}

EARTHQUAKE RECORDS + EARTHQUAKE, GENERAL + FAULT + SEISMOLOGY + SOURCE MECHANISM + TECTONICS

$2-20729$

ULLMANN $W+$ MAAT R

A QUANTITATIVE INTERPRETATION OF SEISMICITY AND SEISMIC ACTIVITY

4 PAGES, 16 REFER ENCES, GEOPHYSICAL J. 13 (1-3) PAGE 363-366, (JULY 1967)

A NEW METHOD FRR COMPUTING SEISMICITY WAS WORKEO UUT, ANO THE CONCEPT SEISMIC ACTIVITY WAS MATHEMATICALLY FORMULATEO $\Lambda$ S AN ENLARGEMENT OF SEISMICITY. FOR COMPUTATION OF SEISMIC ACTIVITY, A MATHEMATICAL REPRESENTATION OF THE ENERGY DENSITY FUNCTION OF AN EAFTHOUAKE IS NEEDED. FOR THIS UNDEF THE SIMPLEST SUPPOSITIONS, A HEURISTIC FUNCTION WAS CONSTRUCTEO. THE MODIFICATION CF THE TEEINITION OF SEISMICITY BY USING THIS FUNCTION CAUSES AN INCREASE IN THE OEGREE OF PHYSICAL INFORMATION OF SEISMICITY.

* EARThQUAKE PREDICTION + EARTHQUAKE, general + ENERgY LEVEL + MATHEMATICAL STUDY + SEISMIC ZONE

2-20863 ALSC. IN CATEGCRY 1.8

SECIIUN I. ADOITIONAL INFORMATIGN ON TSUNAMIS

PACIFIC GAS AND ELECTRIC COMPANY

55 PAGES, 18 FIGUPES, 5 TARLFS, 4 REFERENCES, DAGE 1-20 OF AMENDMENT 5 , TO THE LICENSE ADPLICATION, (FOURTH SUPPLEMENT TO CIABLO CANYON PRELIMINARY SAFETY ANALYSIS REPOKT), SECTION 4 , DCTCBER IO, I 967, DOCKET NO. 50-275, TYPE--PWR, MFG--WEST., $\triangle E--P G+E$

SECTION I INCLUOES - (A) SUPPLEMENTAPYY REPGRT ON TSUNAMI STUOIES, BY MAP. INE ADVISEPS, INC. GIVES RESULTS CF A STUEY (IN PESPONSE TO AEC OUESTI:ONS) AN TSUNAMIS RECENTI. Y RECCPDED IN TI:E PACIFIC, AND DISCUSSES POSSIEILITY OF A LARGE TSUNAMI ANO WAVE RUNUP AT DIABLO CANYON. (D) 2 BULLETINS ( $\triangle$ CEEP OFF THE COAST OF MEXICO ANO CENTRAL AMERICA, ANO, SEISMIC ACTIVITY IN MEXICO DUPING JUNE 1932). (C) REPOPT BY P. E. HOUTZ ON THE 1O53 SUVA TSUNAMI. (D) REPORT ON $1918^{\circ}$ RUSSIAN TSUNAMI. (E) ZND SUPPLEMENT TO REPORT ON TSIUNAMI POTENTIAL AT DIABLD CANYON (REFRACTION DF APPRAACHING TSUNAMI).

AVAILABILITY - USAEC PUELIC DOCUMENT ROOM, WASHINGTON, D. C.

\# TSUNAMI + DIABLO CANYON (PWR) + EARTHQUAKE + REACTMR, PWR + PEPOPT, TJAR I IITING, REDLIIJH

2-20954 ALSO IN CATEGGRY 1 \&

APPENDIX A. PLANT SITE GEDLBGY

IACIFIC GAS AND ELECTPIC COMPANY

14 PAGES, I FIGURE, PAGES $1-13$ OF AMLNDMENT 3 TO THE LICENSE APPLICAT ION ITHIRD SUPPLEMENT TO DIAELO

CANYON PRELIMINARY SAFETY ANALYSIS DEPQRT), JULY 31,1967 , DOCKET 50-275, TYPE--PWR, MFG--WEST., AE--PG+F

GEOLOGY UH THE OIABLO CANYON PCWEP PLANT SITE, SAN LUIS RBISPO CGUINTY, CAL IFORNIA

ISUPPLEMENTARY REPORT II, BY RICHARD H, JOHNSTN, IILY R; IFET). AFPENOIN A WRESENIS DETAILS

ON RELATIONBHIPS UT LAULTS LND SHEARS AT THE SITE.

AVAILABILITY - USAEC PUELIC OUCUMENT ROOM, WASHINGTON, D. C. ?ח43?

AEC QUESTION + EARTHQUAKE + GEOLOGICAL CONSIDERATION, GENERAL + REACTOR, PWR + REPORT, PSAR + SITING, REACTOF

2-21917 ALSO IN CATEGQRY $1 E$

REPQRT UPON FOUNDATION CYNAMICS FOR THE PFRPOSED NUCLEAR POWER PLANT $\triangle T$ SURRY, VIRGINIA MASSACHUSETTS INSTITUTE DF TECHNOLOGY

52 PAGES, 23 - IGURES, 6 REFERENCES, $\triangle M E N O M E N T$ 4 (SUPPLEMENT VQLUME 1 ) CF THE $\triangle P P L I C A T I C N$ FQR LICENSE IOR

SURRY 1 AND 2, OCTOBEF 6, 1967; DOCKETS 50-2801281, TYDE--PWR, MFG.--WEST, AF--STONE + WSBSTEP

(INCORPORATEO IN SUKKY 1 AND 2 PSAR, AMENDMENT 4.) ANALYTICAL MOOEL AND CALCIIIATIONS OF EARTHQUAKE RFSPONSE GIVEN IN OCTAIL FOR SURPY AN:? FOP. NIGATA. ALTHCUGH WATER TABLE IS $\triangle T$ ELEVATION ZERO, HATER STOOD IN DRILL HOLE FROM 2 TO $20 \mathrm{FT}$ ELEV. DUE TO PERCHED AND SEASONAI WATER TABLES. RELATIVE DISPI AREMENT OF STRUCTURES IS LESS THAN 3 IN. ERO MAXIMUM HYPOTHETICAL EARTHQUAKE. SOILS UNCER CONTAINMENT SUILOING AFE MOR E FAVORABLE IDETAILED CTMPARISON MADE) THAN AT NIGATA, JAPAN, KHERE A SET OF SEVERE EAPTHQUAKES IN 1064 DRODUCED ND LIQUEFACT ION OP SETTLEMENT. SITE ALSO COMPARED WITH THAT AT MALIBU. \#\# VERY CONSERVATIVE ESTIMATES INDICATED THAT LIQUEFACTION MIGHT OCCUR IN THF SANC UNDER THE FUEL BUILDING. REPORT SUGGESTS THAT PLANNED USE OF PILES BE REVIEWEO, AND, IF PILES APE USED, STEDS BE TAKEN TO PPEVENT LIOUEFACTION.

AVAILABILITY - USAEC PUBLIC DOCUMENT ROCM, WASHINGTON, D. C. 


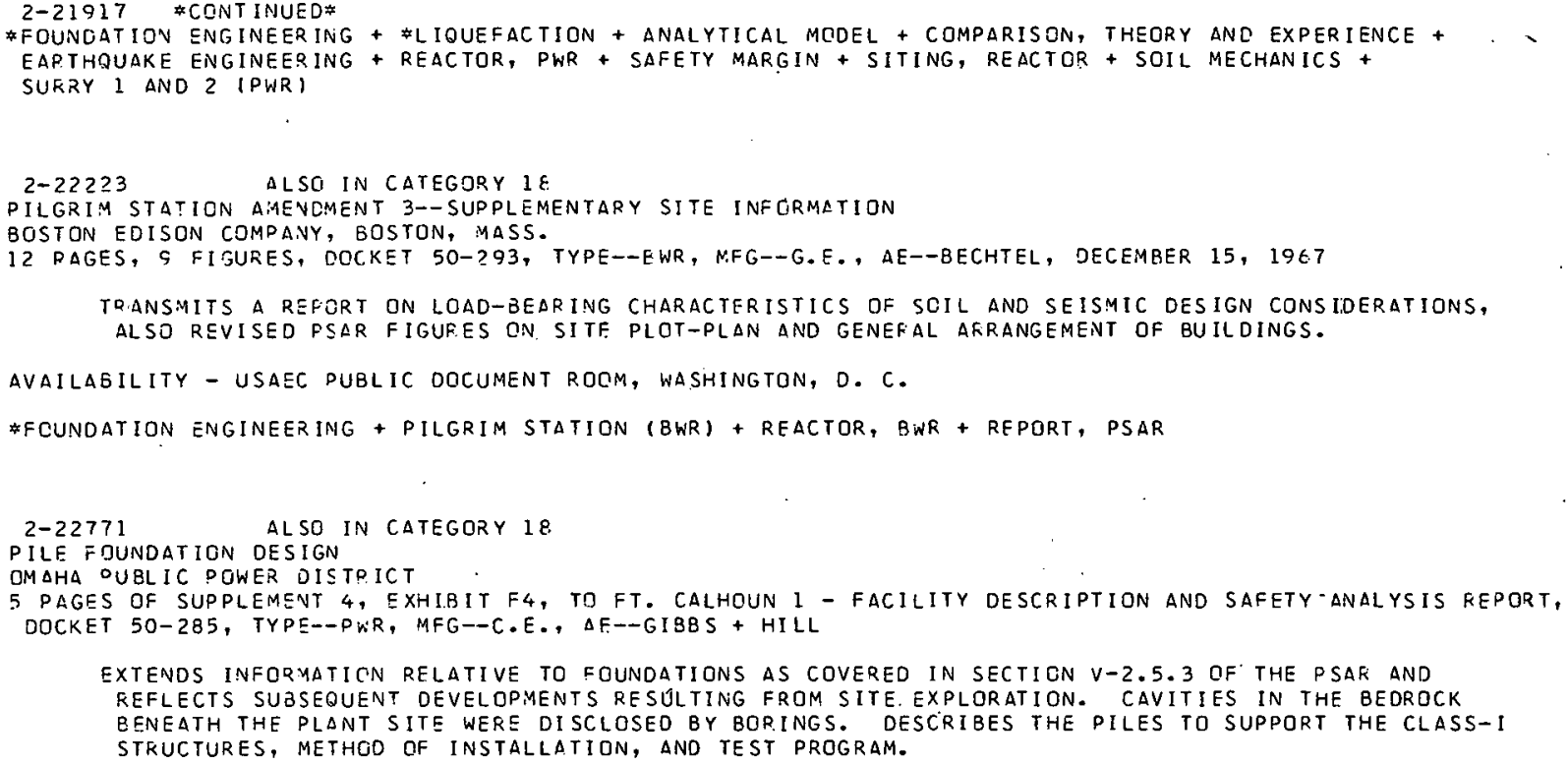


2-23187 \#CONTINUED*

THEM. SECOND, THERE IS AN ASEISMIC LAYER BETWEEN THE COULOMB L-AYER AND THE RALEIGH-PATEFSON REGION WHICH IS TOO SOFT TO PERMIT FRICTIONAL ERACTURE AND DOES NOT CONTAIN MATEK IALS OF LCW FRACTURE STRENGTH SUCH AS DECOMPOSING SERPENTINE. CALCULATIONS ON THIS BASIS GIVE CONSISTENT VALUES BOTH OF THE GAULT DISPLACEMENT AND THE ENERGY RELEASE.

AVAILABILITY - CLEARINGHOUSE FOR FEDERAL SCIENTIFIC AND TECHNICAL INFORMATION, SPRINGFIELD, VA., \$3.OO COPY, SO.65 MICROFICHE

\#FAUlt + displacement, genfral + eapthquake, general + roCk meChanics + source mechanism + tectonics

$2-23188$

SHJBATA H

REGENT DEVELOPMENT IN EARTIIDUAKE PESISTANT DESIGNS FOR NULLEAR POWER PLANTS IN JAPAN

JAPAN ATOMIC POWER COMPANY

3 DAGES, NIPPON GENSHIRYCKU GAKKAISHI 8 , PAGES 614-616 (NOVEMBER 19E6) IN JAPANESE

RECENT DEVELOPMENTS IN EARTHQUAKL-RESISTANT DESIGNS FOR NUCLEAR PUWER PLANTS IN JAPAN ARE REVIEWFO TO COVEF THE DERIOD SINCE PREVIOUS REPQRT ON THE SAME SUBJELI. IHE FIPST DART IS OEVDTED TO A COMPARISON OF THE DESIGN CONCEPTS AND PROCEDURES PETWEEN THOSE OF THE DLANTS CONSTRUCTED, UINDER CONSTRUCTION, AND BEING DESIGNED IN JAPAN. THE SECOND PART CF THE REVIEW COVERS THE DAOGRESS MAOE IN STUDIES IN. THIS FIELD, AND THE MOVES SEEN IN GOVERNMENT OUARTERS TO UTILIZE THE FESULTS OF THESE STUDIES IN SETTING THE REGULATIONS PERTAINING TO NUCLEAR SAF ETY.

*EARTHOUAKE ENGINEERING + DESIGN CRITERIA + EARTHQUAKE, GENERAL + VIBRATION ANALYSIS

$2-23139$

ANDERSON DL

A SEISMIC EQUATION OF STATE

SEISMOLOGI CAL LABQRATORY, PASADENA, CALIF.

21 PAGES, FIGURES, TAPLES, REFERENCES, gECPHYS. JOURNAL oF THE ROYAL ASTRO. SOC. 13, PAGES O-3O (1S67)

THE BIRCH HYPOTHESIS GF A CLOSE P.FLATIONSHIP BETWEEN SEISMIC VELOCITY AND DENSITY IS EXTENDED ANO MOOIFIEO SO AS TO RE IN ACCORO WITH THEORETICAL PREDICTIONS CONCERNING THE FORM OF THE EOUATION OF STATE. ALTHOUGH DEVELCPED AS A SIMPLE METHOD TO ENSURE CONSISTENCY BETWEEN THE SEISMIC VELOCITIES ANO. DENSITIES IN FREE OSCILLATION CALCULATIONS, THE RFSULTING EQUATION OF STATE IS OF JUITE GENERAL UTILITY IN GEOPHYSICAL STUDIES WHERE THE SEISMIC VELOCITIES, RATHER THAN HYDRCSTATIC PRESSURE AND TEMPERATURE, ARE THE DIRECTLY MEASURED VARIABLES.

\#SEISMQLOGY * EARTH YATERIAL, DYNAMIC DRIPEKTY + EARTHQUAKE, GENERAL + ROCK MECHANICS + TECTINISS

$2-23190$

TAJIMI H + ICHINC: I

A SEISMIC DESIGN DF REACTQP. ENCLOSURE OF THE JAPAN POWER DEMONSTRATION REACTMR IJPRR) AND ITS ACTUAL

BEHAVIOR FUR EAKIHUUAKE

NIHON IINIVERSITY, JAPIN

6 PAGES, 7 FIGURES, 3 TABLES, 5 REFERENCES, EULL. JAP. SOC. MECH. ENG. 9, PAGES $294-9$ (MAY 1966 )

BEING SITUATED IN A FREQUENT SEISMIC AREA, A SEISMIC DESIGN ANALYSIS OF NUCLEAR REACTORS TO BS CONSTRUCTED IN THIS COUNTRY IS RFQUIRED FOR SAFETY. FOR THE JPDR THE VIBRATICN

CHARACTEFISTISS OF RFACTOR CONTAINMENT STPUCTURE, FOR FACTORS SUCH AS NATURAL PERIJD $\triangle N D$ DAMPING ACCELERATION WERE ANALYZEC TQ CHECK THF VAI TMITY RF ST ATIG DESICN EARTIIGUAKL

LIEF-ICIENF. AFTER COMPLETION OF THE PLANT, MANY SEISMIC SENSORS WERF MOUNTED ON VAPIOUS PARTS OF THE ENCLOSURE STRUCTUFE TO OESERVE ITS VIBRATION CHARACTERISTICS DURING EARTHQUAKE. USING THE DATA OETAINCD FROM AN ACTUAL EARTHQUAKE, THE NATURAL. PEPIOD, LOCATIMN IFF ROCKING CENTERS, ETC., WEFE CALCULATED. THE CALCULATEO VAlutS SHUW gOOD AGREEMENT WITH THE ABOVE MENTIONED ANALYTICAL RE SULTS.

*EARTHQUAKF FNGINEERING + DESIGN CPITEPIA + EARTIIOUAKE RECORDS + EARTHLUAKE, GENERAL + JAPAN + STRUCTUQAL INTEGR ITY

$?-2 \times 191$

SHEPHEROR + DONALD DA

SEISHIC RESPJNSE DF TGRTIONALLY UNSALANCED BUILDINGS

UNIVERSITY OF CANTERBURY, CHRISTCHUPC.H, NEW ZEALANO + DXFMRO IINIVFBSITY, OXFOED, ENGLAND

18 PAGES, FIGURES, 4 TAQLES, J. SOUND VIR. 6(1), PAGES ?0-37 (1967)

THE POOBLEM OF $\triangle P P L Y I N G$ THE P.ESPONSE-SPECTRA TECHNIQUE TC THE DETERYINATION OF THE SEISMIC GESPONSE OF TRPSIONAIL Y UNBALANCED BUILDINCS IS COMPLICATED BY TWO FACTURS. RECOENITION OF ASYAMETRY INVCLVES AN INEREASE IN THE NUMEEF OE DEGQEES OF FPEEDOM DF THE SYSTEM WHICH HAVE TO TO TAKEN INTO ACCOUNT. SECONDLY, THE COMPINATION OF INDIVIDUAL MODAL RESPONSES TO OBTAIN THE TOTAL RESPONSE GF A BUILCING MAY BE DIFFICULT SINCE THE VALIDITY OF METHODS WHICH RELY DN THE MODES HAVIMG SIGNIFICANTLY DIFFERENT PERIODS IS CLEARLY OPEN TO QUESTION IN CASES WHERE THE MAXIMUIA RESPCNSE OF THE TRANSLATIONAL DND TORSIONAL MOOES OF VIBRATION OCCUR AT SIMILAR FREQUENCIES. IN THIS PAPER, THE FIPST DF THF PROBLEMS REFERRED TO ABOVE IS EXAMINED. A METHOD OF MODAL $\triangle N A L Y S I S$ SUI TARLE FDF TOPSIONALLY UNBALANCED BUILDINGS IS DRESENTED AND FXAMPLES OF ITS APPLICATION TO TYPICAL MULTISTOPEY STRUCTURES ARE INCLUDED. 
$2-23191 *$ CONTINUED*

* EARTHQUAKE ENGINEERING + ACCELERATION + EAPTHQUAKE, GENERAL + MATHEMATICAL STUDY + RESPCNSE SPECTRUM + VIBRATION

2-23192

HUDSON DE

INSTRUMENTAL DATA ON STPONG EARTHQUAKE GROUNO MCTIONS

CAL IFORNIA INSTITUTE UF TECHNOLOGY, PASADFNA, CALIF.

11 PAGES, 3 FIGURES, PEFERENCES, ENGINEERING GECLOGY $4(2)$, PAGES $31-41$ (JULY 1967 )

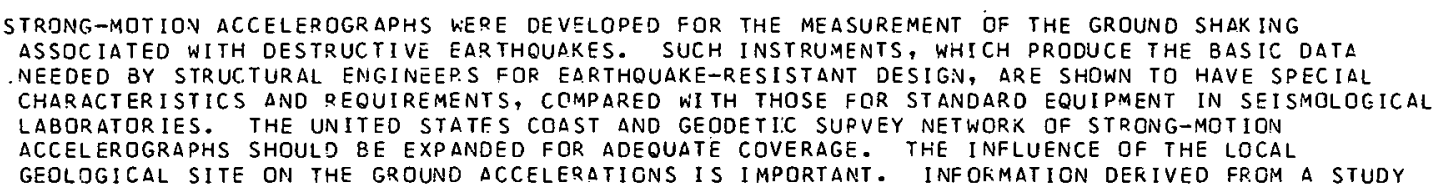

* ACCELERATION + EARTHQUAKE RECOROS + EARTHQUAKF, GENERAL + INSTRUMENTATIUN, EARTHQUAKE + RESPQNSE SPECTRUM

2-23195

STUDY OF ECONOMIC FEASIBILITY OF FAST BREEDER REACTOR PROTOTYPE IN NEW ENGLAND AFEA. VOLUME II. GENERAL SITE SURVEY FOR NUCLEAR PLANTS IN THE NEW FNGLAND AREA JACKSON AND MORELANO, BOSTON, MASS.

NYO-3530-2 +. 128 PAGES, FIGURES, TAELES, REFEPENCES, AUGUST 18,1957

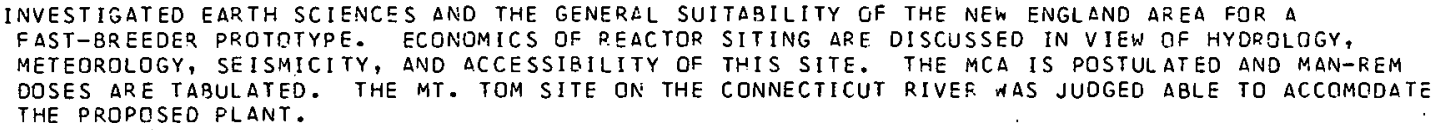

AVAILABILITY - CLEARINGHOUSE FOR FELERAL SCIENTIFIC AND TECHNICAL INFORMATION, SPRINGFIELD, VA., \$3. OO - COPY, \$0.65 MICROFICHE

\#REACTOR, BREEDER + \#EEACTOR, FAST + *SITING, REACTOR + ACCIDENT, MAXIMUM CREDIBLE (MCA) + ECONCMICS + HYDROLOGI CAL CONSIDERATION, GENERAL + METEOROLOGY + THERMAL POLLUTION

$2-23196$

$\triangle D A M S C A$

REMOTE SITING OF NUCLFAF POWER NO LONGFR A NECESSITY

CENTRAL ELECTR ICITY GENERATING BOARD

3 PAGES, ELECTRICAL REVIEW 180, PAGES 588-90 (APRIL 21,1967 )

PAPERS PRESENTED AT THE SYMPOSIUM ON CONTAINMENT AND SITING OF' NUCLEAR POWER PLANTS IIAEA, VIENNA) ARE DISCUSSED IN A GENERAL WAY. EACH COUNTRY SEEMS TO HAVE A DIFFERENT APPROACH TO THE SITING PRCBLEM, BUT IN ALL CASES IT APPEARS THAT A COMPREHENSIVE LOOK HAS BEEN TAKEN AT REACTOR SAFETY. WHATEVER THE FUTURE MAY HOLD IN THIS RESPECT, THE SYMPOSIUM HAS SHOWN THAT NUCLEAR SAFETY HAS RECEIVED SUCH COMPRE HENSIVE CONSIDERATION THAT URBAN SITING CAN BE REGARDED AS A REALISTIC PROPOSAL CAPABLE OF JUSTIFICATION FOR SUITABLY DESIGNED AND TESTED PLANTS ON ANY PEASONABLE BASIS OF JUDGMENT.

* IAEA + \#SITING, REACTOF. + REVIEW + SAFETY PROCRAM

2-23197 ALSO IN CATEGORY 10

COOPER RE + RUSCHE BC

SITE FVALUATION USING MEASURED METEOROLOGY DATA

SAVANNAH RIVER LABORATOFY

DP-MS-67-69+CONF-670931-3+. I6 PAGES, FROM USAEC METEOROLOGICAL INFORMAT ION MEETING, CHALK RIVER, ONTARIO, CANADA, SEPTEMBER 1967

DETAILED MEASUREMENTS OF THE WIND SPEED, WIND OIRECTION, AND TEMPERATURE AT HEIGHTS UP TS I2OO FT AT THE SAVANNAH RIVER PLANT FORM THE BASIS FOR A COMPREHENSIVE ANALYSIS OF THE FREQUENCY DF OCCURRENCE OF POTENTIAL OFF-SITE DOSES. THE RESULTS WERE EXPRESSED ON CURVES IN DOSE PER UNIT RELEASE OF ACTIVITY VS DISTANCE FROM THE REACTOR, WITH PROBABILITY OF OCCURRENCE $\triangle S$ S PARAMETER. CURVES WERE DEVELOPED TO SHOW OOSE AS A FUNCTION OF DIRECTION AND PROBABILITY OF OCCURRENCE.

AVAILABILITY - CLEARINGHOUSE FOR FEDERAL SCIENTIFIC AND TECHNIICAL INFORMATION, SPRINGFIELD, VA., \$3.OO COPY, \$0.65 MICROFICHE

* METEOROLOGY + \#ITE CLIMATOLOGY + \#SITING, GENERAL + ATMOSPHERIC DIFFUSION + DISPERSION +

MEASUREMENT, GENERAL + STACK 
CATEGDPY
SITING CF NUCLEAR FACILITIES

2-23198
CARLBOM L + OBRADOVIC J + MOJOVIC L

ESTIMATE OF THE PRDPCSED NUCLEAR POWER DLANT SITES IN YUGOSLAVIA

AKTIEBOLAGET ATOMENERGI, STOCKHOLM

3 PAGES, I FIGURE, I TABLE, NUKL. ENERG. 3, PAGES 10-12 (1966), IN SIOVAK

SITES FOR NUCLEAR POWER STATIONS IN YUGOSLQVIA APE ANALYZED. ECONIMIC COMPARISONS ARE MACE, TAKING INTO ACCOUNT ELECTRIC POWER TRANSMISSION COSTS, COSTS DF MAKING SITE ACCESSIBLE TL. NORMAL MEANS GF TRANSPORTATION, LAND INVESTMENT, HUILUING COSTS IESPECIALLY THOSE ASSOCIATEO WITH SEISMICITYI, EFFECT OF COOLANT WATER ON PLANT EFFICIENCY, COSTS OF WASTE OISPOSAL. THESE ANALYSES MAKE POSSIBLE THE CHCICE OF A SITE WITH SUBSTANTIALLY CLEAP INSIGHT IVTO CONSEQU ENCES.

* SITING, REACTOR + *yUgOSLAVIA + EARTHQUAKE ENGINEERING + SEISMOLOGY + WASTE DISPOSAL, GeNERAL

$2-23199$

PRICE HL

SITING OE ROHER REACTGRS

US ATOMIC ENEPCY COHMISSION

4 PAGES, NUCLEAR SAFETY $9(1)$, OAGES 1-4 (JAN. FEE. 1968)

DISCUSSES AEC REGULATIONS PEGARDING REACTOR SITING AND SETS FGRTH THE AEC POSITION ON THE SUBJECT AT THIS TIME. THERE $\triangle R E$ TWO MAJOR AREAS RELATED TO POWER REACTRR SITING THAT HAVE PROVED TO $8 E$ THE MOST TROUBLESOME - METROPOLITAN SITING AND THE LOCATION OF REACTORS IN AREAS OF HIGH SEISMICITY. THE FOLLOWING ARE PROVIDING HELP IN RESOLVING THE SAFETY QUESTICNS INVOLVED - CODES AND SPECIFICATIONS ARE BEING IMPROVED, MORE RELIABLE ENGINECRED SAFETY FEATURES ARE SEING DESIGNFO, RESEAR.CH AND DEVELOPMENT WORK IS UNDER WAY, EXPERIENCE IN THE OPERATION OF POWER REACTORS IS BEING GAINED, AND THE DEVELOPMENT gE MORE DEFINITIVE CQITEFIA IS PL ANNED OR QEINC CONSIDERED.

\#SITING, REACTOR + PQPULATION DISTRIBUTION + SAFETY FRINCIPLES AND PHILOSOPHY + SEISMOLOGY, GENERAL

2-23326 ALSO IN CATEGQRIES 18 AND 12

PLANT PROTECTION AGAINST HURRICANE WAVE ACTION

FLORIDA POWER CORPJRATION, ST. PETERSRURG, FLORIDA

GAI-REPDRT-1650+.92 PAGES, FIGURES, TABLES, OCTOBER 26, 1967, CRYSTAL RIVER UNITS 3 AND 4, ADPENOIX 2C, SECTION I OF PRELIYINARY SAFETY ANALYSIS REPORT, AMENDMENT 1, DOCKET NO. 50-302/303, TYPE--PWF, NFG--9+W, $A E--G I L S E R T$ ASSOC.

AFTER REVIE!NING 12 YEARS JF USWE $\triangle N E$ CORPS OF ENGINEERS EFFCRT ON ANALYZING HYDRODYNAMIC ECFECTS OF HURRICANES, THE OREOICIEL MAX. PROBABLE HURRICANE (WATER LEVEL GN SITE OF II, 4 FT WITH 9-FT WAVES) PROTECTION WAS VEFIFIED WITH MODEL TESTS AT U OF FLA. (MOVIE AVAILARLEI. CIRCULATING-OUMDS WILL BE INUNDATEO, QUT NUCLEAR SERVICE WATER PUMDS ADE INSIDE BUILDING. APPENDIX - (1) SEIL CEMENT SLOPE PRGTECTION (4 PG), (2) A MODEL. INVESTIGATICN OF FXTREME RIJNUP ( 15 PG), (इ) NORMAL ANC EXTREME LOW TIDE CONSIOERATIONS.

AVAILABILITY - USASC DUELIC DOCUMEVT ROOM, WASHINFTON, D. C.

* DESTRUCTIVE WIND + \#FLCOD + \#SITINC, FEACTOF I \#WEATHER, SEVERE + CRYSTAL. RIVER 3 AND 4 (PWR) + ENGINEERED SAFCTY FEATUDE + HYDRAULIC ANALYSIS + MCDEL TESTING + REACTOR, PWR + REPCRT, PSAP

2-23812 ALSO IN CATEGORY 18

MORRIS PA

DRL RECOMMENOS EARTHQUAKE $\triangle$ CCELERATION FOR. ZION

AEC, DIVISION OF REACTOR LICENSING, WASHINGTON, D. C.

LETTER TO A. B. BEHNKE, COMMONWEALTH EOISON CO., CHICAGO, ILLINOIS, 1 PAGE, FEBRUARY 21 , 1968, DOCKET NO. SU-295/304, TYPE-LWR, MFG- KEST., $A E--S G T+$ LUNDY

U.S. COAST AND GEOOETIC. SURVEY RECOMMENDS, WITH RRL AND USGS CONCURRING, THAT AN ACCELERATICN DE 0.08 G IS DQEQUATS FQR LIKELY EARTIQUAKES, AND 0.17 G IS THE MAXIMUM GROUND ACCELERATIDIV FOR DESIGN FOR SAFE SHUTDOWN. DRL UNCEPSTANDS THAT AN AMENDMCNT WILL BE FILED CN THIS RASIS.

AVAILABILITY - USAEC DUELIC DOCUMENT RDOM, WASHINGTON, D. C.

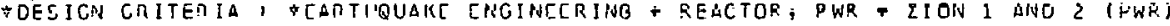

2-24269 ALSO IN CDTEGDPY IE

HUDSON RIVER VALLEY CCMMISSION RECOMYENOS RELOCATION OF CASION SIAIIUN

NIAGARA MOHAWK PJIER CDFPORATION

2 DAGES, ATZYIC EYEQGY CLENDING HOUSE, 11(1\%), PACES $22-24$ (AFRIL 1,1960 )

(FINDINGS, MARCH 22.) A PURLIT, HEAFING WAS HELD IN $\triangle L G A N Y, N$. Y., FEB. 28 . IN THE OPINION OF THE COMMISSION, AN CFFICIAL $\triangle D V I S O Q Y$ OGENCY OF N.Y. STATE, FOUND THAT THE BENEFITS OF THE REACTOR AT EASTON SITE WERE OUTWFIGHED BY THE ALVERSE EFFFCTS GN THE SCENIC, HISTOR.ICAL, 


\title{
SITING OF NUELLEAR FACILITIES
}

\begin{abstract}
2-2426\% \#CONT I NUEC *
KECREATIMNAL, ANC NATURAL RESTURCES OF THE R.IVER. FINDINGS (B) - NO PUBLIC CONCERN ON PADIOLOGICAL SAFETY IF AEC CRITERIL MET. (C,D) - PROOF THAT THERMAL-POLLUTION EFFECTS ON ECOLOGY ARE NCT RETFIMENTAL IS LACKING. LOWW RIVER FLOW MAY REQUCE' POWER LEVEL. (E,H) COOLING TONERS MAY ADVERSELY AFEECT SCENIC VALUES, NHICH THE PLANT ITSELF MAY aLSO DO.

*REgulation, STATE + \#SITING, kEACTTOR + \#THERMAL PCLLUTION + EASTON IGH:RI + REACTOR, BWR
\end{abstract}


CATEGORY TRANSPORTATION ANO HANOLING OF RADIOACTIVE MATERIALS
THONG

3-20628

THOMPSON JT + MORGAN JM

NUCLEAR TRANSPOPTATION

JOHN HOPKINS UNIVERSITY + VIRGINIA MILITARY INSTITUTE

12 PAGES, 2 FIGURES, 1 TABLE, 29 REFERENCES, NUCLEAR SAFETY 2(5), PAGE 443-454, (DCTO6ER 1967)

A REVIEW OF NUCLEAR TRANSPORTATION RESEARCH PERFORMED UNDER THE COGNIZANCE OF THE USAEC WAS ACCOMPL ISHED IN 1964 AND REPORTED IN 1965 . THIS PAFER SUMMARIZES T.HE STRENGTHS AND WEAKNESSFS OF THE RESEARCH PPOORAM UNDER SUCII ACCOMPLISHMENTS AS SYMPOSIA, CRITICALITY EXPER IMENTATION ANO ANALYSIS, AND MGOEL TESTING. IT ALSO POINTS OUT GAPS IN KNOWLEDGE, NEGLECTED AREAS, ANO $\triangle R E A S$ OF DUPLICATIDN, AS WELL AS THE EFFECTS OF CLASSIFICATION, LACK OF INOUSTRIAL PAETICIPATION ANO COORDINATION, ETC. ALSO DISCUSSED ARE SOME OF THE PROBLEMS THAT CALL FOR RESEAFCH. THESE ARE SUMMARIZEO UNDER SUCH HEADINGS AS COMPARISON OF TRANSPRRTATICN MODES; SAFETY $\triangle N D$ ITS COST, CP. I ITCLITY CONTROL, INSURANCE, WE IGHT-COST RELATIONS, INTERCHANGEABILITY, SPECIALIZEO SERVICES, RELATIONS WITH TRANSPORTATION GFOUPS, AND REGIIT. ATIDNS. ENCOUF, AGEMENTS FOR THE FUTURE ARE NOTEO.

COOES ANO' STANOARUS + FLUNUMICS + R AND D PREGRAM + SAFETY PRINCIPLES ANO PHILOSOPHY + TRANSPCRTAT IUN AND HANOLING

$3-20620$

$3-20629$
SCHABERT HO

CASK FOR TRANSDORTING IROPLDIATSD EXPERIMENTAL FUEL ELFMENTS

SLEMENS-SCHUCKERTNERKE AG, ERLANGEN, GER.

5 PAGES, 4 FIGURES, I TABLE, 7 REFEPFNCES, ATOMPRAXIS 13, PAGE 78-22, (FEBRUARY 1OG7), IN GERMAN

$\triangle$ DRY CASK USEC TCR TRANSPORTING IRRADIATEO FUEL ELEMENTS HAVING A WEIGHT OF 4 .3 METRIC TONS IS DESCRIBED. ONE EXPERIMENTAL FUEL ASSEMBLY PRODUCING $0.38 \mathrm{KW}$ OF DECAY HEAT MAY BE SHIPPED IN THE CASK. THE LEAD SHIELO CF THE CASK REMAINS SOLID AFTEF. $\triangle$ 9-METER FREE DROP AND A SUSSEQUENT 1-HJUF. FIRE, DUF TO THE USF OF A SPECIAL OUTSIDE INSULAT ION WHICH IS EQUIPPED WITH METALLIC STRAPS FOR DECAY-HEAT DIVERSION. THIS DESIGN CONCEPT SHDULD PROVE ADVANTAGEDUS IF APDLIED TO LAKGE FUEL CASKS.

EQUIPMENT DESIGN + FIPE + HEAT TRANSFEF + SHIPPING CONTAINER + THERMAL INSULAT ION

$3-20630$

ALSO IN CATEGORY 13

LLOYDRC + CLAYTON ED

INTERACTING ARRAYS OF CONTAINERS WITH U-2:3 SOLUTICN

BATTELLE NORTHWEST LAB.

CONF-67C-602 +. 12 PAGES, 8 FIGIJRES, $\triangle B S T F A C T$ IN ANS TRANSACTIONS 10(1), PAGE 188 AND 189, (JUNE 1967), PAPER DRESENTED AT THE 196,7 ANNUAL MEETING OF THE AMEFICAN NUCLEAR SOCIETY, SAN DIEGO, CALIF.., JUNE $11-15,1967$

\begin{abstract}
SUBCRITICAL VEUTRON INTERACTION EXPERIMENTS WERE RUN WITH BARE AND LUCITE-REFLFCTED ARRAYS OF BITTLES OF U-233 SOLUTION. THE FFFECT ON CRITICALITY OF AOOING LJCITE MOOERATOR BETWEEN THE SOTTLES WAS ALSO STUDIED. THCSE EXPEPIMENTS PROVIOE DATA FOR NUCLEAR-SAFETY GUIDANCE IN HANDLING, STOFAGE, AND SHIOMENT OF THIS MATERIAL, AND FOR CHECKING INTERACTION CALCULATIONS. THE EFFECT OF MODFRATION WAS LETFEN.INEC BY PLACING LUCITE PLATES OF DIFFERENT THICKNESS BETWEEN BOTTLES DF THE ARRAYS. THIS WAS DONE FOR THE $2 \times 2$ BOTTLE REFLECTED ARRAY ANO FLIR THE $3 \times 3$ AND $4 \times 4$ POTTLE $5 \Delta R E$ AFFAYS. THE THICKNESS OF LUCITE BETWEEN BOTTLES GIVING THE LARGEST REACTIVITY INCPEASE IN THE PEFLECTCD $\triangle R R A Y$ WAS $\triangle B C U T$ ONE INCH, AND IN THE BARE $\triangle R R A Y$ $\triangle B C U T$ T'NO INCHES.
\end{abstract}

CFITICALITY SAFETY + FUEL HANDLING + FUEL STOCAGE + LIQUIO FUEL + NEUTRON INTERACTION + URANIUM

$3-20631$

DELL TK, MCKITTRIBK N

SHIELOED CONTAINER FOR CARPYING AND DISPENSING DOSES OF RADIOISOTOPES FOR INTRAVENOUS USE

ST. FRANCIS HOSPITAL

2 PAGES, I FIGURE, J, MED. LAP. TER.HNIL., 22, PAGE 226 AND 227 , (OCT. 1965)

$\triangle$ LEAD POT (2-3/4 IN. OD, WITH WALLS $1 / 2$ IN. THICK) WHICH SURROUNDS COLUMNS OF TE-132 RECEIVED IN THE LAB FRIM THE SUPPLISP, FORMS THE PASIC PART OF THE CONTAINER WHICH IS DESIGNED TO ACCOMMODATE BIJOU BOTTLES OF G-ML CAPACITY. THE CONTAINER, WHICH MAY BE USED FOP CARRYING

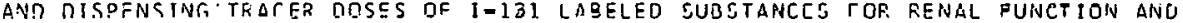
CERERRAL-BLODD-FLOW STUDISS, ATTENUATES THE GAMMA RIADIATION EMITTED BY THIS ISOTOPE BY DVER 5\%. UNUSED DC;SES MAY BE RESTEPILIZED BY PLACING THE WHOLE CONTAINER. IN AN AUTOCLAVE WITHCUT QEMOVING THE ECTTLE.

TMOINE + R.ADIJISOTDPE + STOPAGE CONTAINEP + UNITTO KINGDOM

3-20633

RAOIOACTIVE CRASH CLOSES RRITISH DOAD $101 / 2$ HOURS

1 PAGE, THE NEW YORK TIMFS; THUR SOAY, SEPTEMBEP 28,1967 


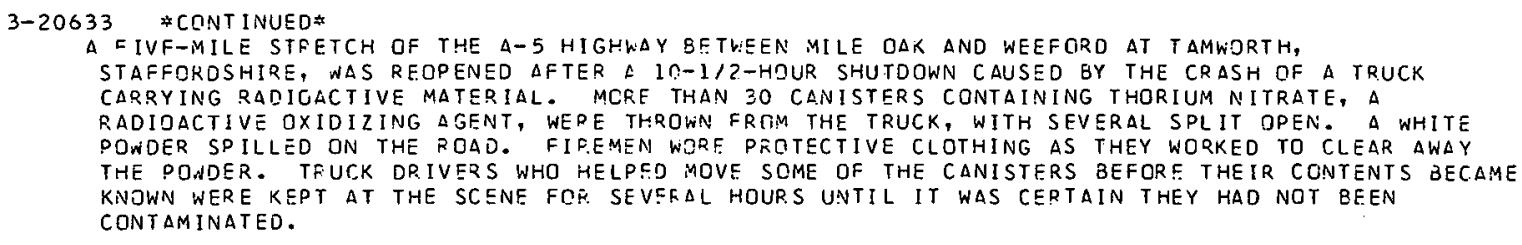

ACCIDENT, RADIOISOTOPE + ACCIDENT, TRANSFQRTATICN + CONTAMINATION + OPERATING EXPERIENCE SUMMARY + THORIUM

3-22155 ALSC IN CATERORIES 11 AND 12

LEFRANCOIS J

MECHANICAL GAP TRANSFEP. PUMP

COMMISSARIAT A L-ENERGIE $\triangle$ TOMIQUE

BRITISH PATENT $1,068,709+5$ PAGES, 2 FIGURES, MAY 10,1967

A MECHANICAL TRANSFER PUMP PAPTICULERLY ADAPTED TO THE TRANSFER OF RADIOACTIVE GASES COMPRISES A LIQUID PISTON MOVING IN A COMPRESSION CHAMBER. THE CHAMBER HAS INTAKE ANO DELIVERY VALVES WHOSE OPENINGS AND CLOSINGS ARE SYNCHRONIZEO WITH THE MOVEMENT OF THE PISTON, WITH THE INTAKE VALVE LOCATED ON THE AXIS OF THE DELIVERY VALVE. THE DELIVERY VALVE IS MADE UP OF A FLDATING MEMBER, WHICH IS RAISED DIRECTLY FROM ITS SEATING AS A RESULT OF COMPRESSION OF THE VOLUME OF GAS PRJDUCED SY THE MOVEMENT OF THE LIQUID PISTON. A PORTION OF THE COMPRESSION CHAMBER CONTAINING THE LIOUID PISTON IS FORMED BY A PAIF OF BELLOWS THAT ARE OPERASLE BCTH TO CONTRACT OR BOTH TO EXPAND TOGETHEP SO AS TO ENSURE MAXIMUM LIOUID DISPLACEMENT IN THE CHAMBER .

AVAILABILITY - THE PDTENT OFEICE, 25 SOUTHAMPTON BLDG., LONDON, W. C. 2, ENGLAND, \$O.4C PER COPY \#PATENT + \#PUMP + TPACE?, RAS

3-22156 ALSO IN CATEGORY 11

BAUDIFFER G + ROSSETTIL

DEVICE FOR HAVDLING AND OBSEFVIVG SLONGATED BODIES WHICH EMIT RADIATION

EUROPEAN ATOMIC ENERGY COMMUNITY

BRITISH PATENT $1,058,140+4$ PAGES, 1 FIGURE, FEBRUARY 9, 1967

DESCRIBES A DEVICE USED IN HANCLING AND OBSEP.VING ELONGATED EODIES WHICH EMIT RACIATION, SUCH AS IRRADIATED FUEL RODS FROM A REACTOR. THE DFVICE CONSISTS OF A SEALED ENCLOSURE OF VERTICAL ELONGATED SHAPE SURROUNDEC BY AN ADEQUATE RADIATION SHIELD WITH QNE OR MREE VIEKING PORTS. IN THE ENCLOSURE ARE GUIOES AND SUPPORT MECHANISMS FOR SUPPQRTING AND HANDL ING THE IRRADIATED BODY OR POD.

AVAILABILITY - THE PATENT OFEICE, 25 SOUTHAMPTON BLDG., LONDON, W. C. 2, ENGLAND, \$O.49 PER COPY \#FUel haNDL ING MACHINE + \#PATENT + CONTAINMENT DESIGN

3-22158

BREEANT $C$

TRANSIT FLASK FOR RAQIOACTIVE OBJECTS

COMMISSARIAT A L ENEFGIE DTOMIQUE

BRITISH PATENT $1,055,91 \varepsilon+3$ PAGES, 1 FIGURE, JANUARY 18,1967

DESCRIBES AN AIR-TIGHT SHIELDEO CONTAINEF USEO TO PROTECT AND TRANSPORT RADIOACTIVE OBJECTS SUCH AS IRRADIATED FUEL ELEMENTS. IT CONSISTS OF A HIGH-DENSITY METAL CASING, FCRMING $\triangle N$ OUTER COVER FOR THE SHIELDING MATEFIAL. THE CASING HAS AT LEAST ONE POCKET BOUNDED BY A DE CORMABLE FUSIBLS PB-SB ALLGY SHEET WHICH LIQUIFIES AT A PREOETERMINED TEMPERATURE AND

ESCAPES THROUGH A PP-SI PLUG, FORMING AN EXPANSION VOLUME FOR THE SHIELDING MATERIAL.

AVAILABILITY - THE PLTENT OFFICE, 25 SOUTHAMPTON BLOG., LONDON, W. C. 2, ENGLAND, \$O.4S PER COPY

\#PATENT + FIRE + LEAD + SHIELOING + SHIPPING CONTAINER

$3-22150$

BERNARD H

MECHANICAL OROBLEMS ENCOUNTERED IN RESEARCH ON PACKAGING

FRANCE. COMMISSARIAT A L-ENERGIE ATOMIQUE

13 PAGES, 11 FIGUPES, 3 REFERENCES, QULLETIN D-INFOFMATIONS SCIENTIFIQUES ET TECHNIQUES 114, PAGE 39-51, ( $\triangle P R I L$ 1967) IN FRENCH

THE FIRST PART OF THIS PAPER DESCRIEES THE PROELEHS IN MAKING MECHANICAL TESTS ON TYPE B PACKAGING, IF CONCLUSIONS OF GENERALLY VALID NATURE ARE TO DRAWN FRUM THE RESULTS. THE SECOND PART ANALYSES THE EFFECTS DUE TO KINETIC ENERGY STORED AT THE MOMENT OF IMPACT, PART I CULARLY ON THE CLOSING SYSTEMS, WHICH MUST GUARANTEE AIRTIGHTNESS.

REGULATION, IAEA + SHIPPING CONTAINER + TEST, DESTRUCTIVE + TEST, DROP 
TRANSPORTATION AND HANTEGING DF RADIOACTIVE MATERIALS

$3-22160$

BDUILLET J + MOREAU J

PACKAGING SAFETY CRITERIA

FRANCE. COMMISSARIAT A L-ENERGIE ATOMIOUE

2 PAGES, BULLETIN D-INFOPMATIONS SCIENTIFIQUES ET TECHNIQUES 114, PAGE II ANO 12, (APRIL 1967 ). IN FRENCH

IN 1961, THE INTERNATIONAL ATOMIC FNERGY AGENCY LAID DOUN SAFETY RECGMMENDATIONS FOR THE TRANSPORT OF RADIOACTIVE MATERIALS, THESE HAVE DECENTLY BEEN REVISED. THEY ARE EEING ADCPTEO THRQUGHOUT THE WGRLD IN THE FORM OF INTEPNATIONAL AND NATIONAL REGULATIONS. THE RASIC IOEA IS TO CONCENTRATE TO A MAXIMUM ON THE SAFETY OF THE PACKAGING. WITH REGARD TO IRRAOIATION R.ISKS, THE PACKAGING SAFETY CRITFRIA ARE EXPRESSED IN $\triangle$ CERTAIN EFFICIENCY RANGE TO WHICH THE PACKAGES MUST RESPOND, ACCORDING TO THE. ACTIVITY THEY $\triangle R E$ CALLED ON TO CONTAIN. AS TO CRITICALITY QISKS, THESE CRITERIA ARE EXPRESSED BY A PRECISE SET OF RULES ANO HYPGTHESES TL BE RESOECTED IN THE CALCULATIONS. THE REGULATIONS THROUGHCUT SHCW AN ATTEMPT TO STRIKE A BALANCE RETWEEN THF ADMISSIBLE LEVEL OF RISK CHOSEN BY SOCIETY, AND THE PRACTICAL NEEDS OF THE LABDPATORY AND OF INDUSTSY.

\#RFGIJLATION, IAEA + \#SAFETY PR INCIPLES ANO PHILOSOPHY + CUULS AND STANDARDS + CRITICALITY SAFETY + SAFETY QEVIEN + SHIPPING CONTAINFR + TRANSPQRTATION AND HANDLING

$3-22161$

CAPETH + BDUILLET J

HISTORY OF THE TRANSPCRT OF RADIOACTIVE MATEFIALS IN FRANCE

FRANCE. COMMISSARIAT A L-EVERGIE ATOMIOUE

4 PAGES, BULLETIN D-INFGRMLTIONS SCIENTIFIQUES ET TECHNIQUES I14, PAGE 7-10, (APRIL 19E7). IN FRENCH

THE PROBLEM OF TRANSPORTING RADIOACTIVE MATERIALS BEGAN TO TAKE SHAPE SERICUSLY IN FRANCE IN 1956-57. THE FIPST STAGE OF ITS CEVELDOMENT IS THE ORAKING UP OF REGULATIONS, hHICH ENDS AROUND ISEO. COMMISSARIAT TRANSPQRTS, WHICH THEN REPRESTNTED ALMOST ALL NATIONAL RACIOACTIVE FREIGHT, ARE HANDLSD DIRECTLY, AND THE CASES DO NOT YET SEAR THE STAMP OF THE RULING WHICH IS IN THE PR.CCESS OF TAKING SHAPE. THE SECOND STAGE IS THAT OF THE INDUSTRIALIZATICN DF TRANSPORTS. THEIR NUMBER HAS GROWN CONSIDERABLY, AND THE CALL ON THE TRANSPORT INDUSTRY IS INCREASINGLY WIDE, TO BECOME ALMOST TOTAL IN 1963. THE THIRD STAGE IN DEVELOPMENT, WHICH IS STILL IN OPERATION AT PRESENT, IS THAT OF TECHNICAL RESEARCH INTD PACKAGING METHODS, BASEO ON A SET OF REGULATIONS REVISED IN THE MEANTIME AND NOW MUCH MORE PRECISE TECHNICALLY. THE PHASE A.SQUT TO BEGIN IS THAT CF FCONOMIC DPTIMIZATION.

OPERATING EXPERIEVCE SUMMARY + REPQRT, OPEFATIONS + SAFETY PROGRAM + TEANSPORTATION AND HANOLING

$3-22162$

SALTIEL L

RESOLUTION GY OROIVATOR OE THE PROBLEM POSED DY THE STATUTORY HEAT TEST

FRANCE. COMAISSARIAT A L-ENERGIE ATOMIQUE

19 PAGES, 11 FIGURES, SULLETIN D-INFOPMATIONS SCIENTIFIQUES ET TECHNIGUES 114, PAGE 73-E0, (APOIL 1967 ). IN FRENT.H

THE TQANSPORT REGULATICNS DEMAND DRGOF FPRM THE SENOERS THAT THE TRANSPQRT CASTLFS CAN

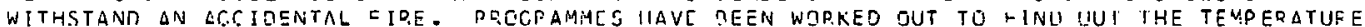
CHANGE IN A CCMDCSITS CYLINDER EXPCSED TO A FIRE DADIATING ACCORNIVG TO STEFANS LAH. THE ORÜGKAMME RESTLVES THE PAPTIAL DIFFERENTIAL FOURIEQ EQUATITN BY THE CRANK-NICHOLSTIN METHGO, USING A RECURSIVE PROCESS OF LINEAFIZATICN CF THE STRESSES AS A FUNCTION OF TL $L T$ TWO PQINTS OF THE REGION CF INTEGFATION (THE EXTERNAL SUPFACE AND INTEPFACE). THE DPOGRAMME HAS A SELF-GENERATING TIME CUT-OFF OF VARIAELE INTERVAL, WHICH AFFORDS MAXIMUM CALCULETION SPEFO WHILC PREVENTING THE RELATIVE TRKLIH UN THE TFMPEDATUEE FROM EXCEEDING A DREDSTERMINED VALUE.

HHFAT TRANSFER, + EIPE + FRANCE I REGULATION, GENERAL + SHIHHING LUNIAINER

$3-22163$

LENAIL B + LUCASH + MERLE JP

HEAT DROBLEMS ENCOUNTERED IN DESEARCH ON PACKAGING

FRANCE. CUMMISSARIAT A L-ENERGIE ATOMIQUE

8 PAGES, BULLETIN D-INFCPMATIONS SCIENTIFIQUES ET TECHNIQUES 114, PAGE 53-71, (APRIL 1067). IN FRENCH

THE STATUTORY RECCMMENDATIONS REQUIRE THAT PACKAGING DESIGNED FOR TRANSPDRTING RACIOACTIVE MATERIALS SHOULD QESPECT CERTAIN SAFETY CONDITIONS UNOER BOTH NORMAL TRANSPORT CONDITIONS AND ACCIDENTAL CONDITIONS. AFTER A BRIEF OUTLINE OF THE STATUTOFY OBLIGATIONS AND A REVIEW GF THE QISKS, THE METHCN OF CONDUCTING THE CALCULATIONS IS DESCRIBED FOR THE TWD QUITE DIFFERENT SETS OF CIRCUMSTANCES MENTIONED ARTVF. UNDER NORMAL CONDITIONS, TIIE MAIN SOURCE OF HFAT

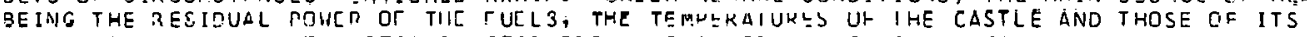
CONTENTS ARE CALCULATED STEP EY STFP FROM THE EXTERNAL TEMFEDATURES. THE METHDOS USES TO LOWER THE TEMDERATURES ARE MENTIONED ERIEFLY. UNDER TEMPORAPY CONDITIONS IACCIDENTAL

CONDITIONS DF $\bar{F} I K E)$ THE PROSLEMS ENCOUNTERED AND THE METHODS USED TO SIIVF THEM MFE DESCPIBED.

\$HEAT TRANSFER + \#HIGH TEMPERATURE + FIRE + FRANCE + REgULATION, GENERAL 
CATEGORY
TRANSPORTATION ANO HANDLING OF RADIOACTIVE MATERIALS

3-22164

MICHEL C + PIROVANJ A + MCRDCHESSES-RECNIER G

HEAT IRANSFER IN IRZAOIATED FUEL TRANSPORT CASKS

FRANCE. CDMYISSARIAT A L-ENEPGIE ATOMIQUF

13 PASES, 12 FIGUPES, 2 FEFEPENCES, QULLETIN D-INFORMATIONS SCIENTIFIQUES ET TECHNIQUES 114 , PAGE 81-93, (APRIL 1067). I.V FRENCH

THE TFAISPORT GF NUCLFAP FUEL ELEMENTS IN CASKS FROM THE NUCLEAR REACTOR WHERE THEY ARE IRRADIATED TO THE PFOCESSING PLANT POSES HEAT PROSLEMS AS A FESULT OF THE RESIDUAL POWEP OUE TJ FISSION PRRDUCTS CONTAINED IN THESE FLENENTS. THIS ARTICLE DESCRIEES THE THEOPETICAL AND EXPERIMENTAL WIIRK WHICH LED TO THE DEVELCPMENT AND VERIFICATION OF OROINATOR PROGRAMS

ENASLING THE TEMPEPATUHE DISTRIBUTION INSIDE ANR OUTSIDE PARALLELEPIPEDIC CASKS, CONTAINING

FUEL CLADDINGS OF THF E.D.F. $\angle$ TYPE, TO RE CALCULATEO.

\#HEAT TRANSFEP + FiANCE + FUEl ElEMENT + SHIPPING CONTAINER

$3-22441$

TRANSPOF.T $3 F$ THE RAN MOTERIALS OE THE URANIUM INDUSTRY -- ORES, CONCFNTRATES, URANIUM METAL

FRANCE. COMAMISSAEIAT A L-ENERGIE ATOMIQUE

12 PAGSS, 8 FIGURES, 3ULLETIN D-INFGRMATICNS SCIENTIFIOUES ET TECHNIQUES 115, PAGE 45-56, (MAY 1967), IN FRENCH

THF ESSENTIAL ESPECT DF THE PRORLEM GF TRANSPORT OF RAW MATERIALS IN THE URANIUM INDUSTRY IS THE ECJNOM,IC CNE. THIS ARTICLE DESCRIBES THE TFANSPORTATION NECESSARY TO CARRY OUT THE PRESFNT FRENTH PROGRAMME OF ANNUAL URANIUM ORE PRODUCTION. THE TECHNICAL MEANS EMPLOYED TO TRANSPGCT JRES, URANIFERTUS PPECONCENTRATES PPODUCED OVERSEAS, CONCENTRATES AND URANIUM IVGOTS ARE DSSCQIBED. THE QUANTITIES IN METRIC TONS REPRESENTEO BY THIS PROGRAM ARE

INDICATED, AND AN IOEA IS GIVEN OF THE EXTENT TO WHICH THE TRANSPORTATION PRICE CONTRIBUTES

TO THE COST PFICF OF NUCLEAR FUELS. THIS IS OBSERVED TO BE FAR FRJM NEGL IGIBLE.

ECONOMIC STUDY + FRANCE + FAW MATSRIAL + FAW MATERIAL + THANSPORTATION ANO HANDLING

$3-22.44$

LABRCUSSE

STATISTICAL AND ECONGMIC DATA CF́ RADIOACTIVE MATEFIALS TRANSPRRTATION

FRANCE. COMMISSARIAT A LEFNFRGIF ATOMIQUE

14 PAGES, 4 FIGURES, 5 TABLES, BULLETIN D-INFORMATIONS SCIENTIFIQUSS ET TECHNIQUES I15, PAGE $57-7 C$, IHAY $1967)$, IN FRENCH

\begin{abstract}
THE ESTABLISHYENT OF A COST PRICE WHICH WCULD MFAN ANYTHING OTHER THAN A SIMPLE WRITTEN ACCOUNT YADE CUT AFTFRWARDS, AND WHICH WOULO BE VALID LS A REFERENCE FCR ECONOMIC

CALCULATION, VEETS WITH MANY DIFFICULTIES IN THE MATTER OF THE TRANSPORT OF RADIOACTIVE MATEEIALS. HEVEEVE STATISTICS SHCW THAT THE VOLUME OF THESE TRANSPORTS, WHICH HAS GROWN VERY WUICKLY SINCE jOES, HAS SEGUN TO TAKF ON A MORE UNIFORM ASPECT SINCE 1SE5. WWE HAVE SEEN MOREOVEP. THAT THE TECHMICAL LND STATUTORY PRCBLEMS ARE WELL DEFINED, EVEN IF THEY ARE NOT ALL SOLVED. THE TIME HAS COHE THEHEHEHE WHEN EVALUATIONS AND ESTIMATES OR A VALID ORDEP OF MAGNITUDE CAN BE HADE. NE SHALL GIVE IN TURN THF IINIT COSTS RELATIVE TO THE VARIOUS MEANS OF TSANSPORT, TO THE TYDES TF PACKING USEU ANO TO THE NUCLEAR RISK INSURANCE. A SYNTHESIS OF THE COST PRICE. IS MADE FTP. $\triangle$ FEW TFANSPOP.TS.
\end{abstract}

FECGNIMIC STUDY + FRANCF + INSURANCE + STLTISTICAL CORRELATION + TRANSPORTATION AND HANDLING

$3-22443$

BUUURCIEO F

TRANSPORTATION OROCEDURES OF THE CEA

FRANCE. COMYISSAEIAT A L-ENERGIE ATOMIOUF

7 PAGES, 2 FIGURES, EULLETIN D-I VFORMATIONS SCIFNTIEIQUES ET TECHNIQUES 115, PAGE 37-43, (MAY 1967), IN

FRENCH

IN VIEW JF THE PISKS INVOLVED IN THE TRANSPORT OF RADIOACTIVE MATERIALS, IT HAS EEEN NECESSARY TO DECEEE A CEFTAIN NUMBER OF SAFETY REGULATIONS TO CUT DOWN THE PROBABILITY OF AN ACCIDENT AND, IF DNE SHCULD OCCUR, TO LIMIT THF CONSEQUENCES. THE AUTHOP. EXAMINES IN TURN THE PQACTICAL PRJCEDURES OF A GENERAL WAIUKE WHICH THE USER CAN NOW FIND IN THE DECREE OF JULY IST $1 S E 6$ (RJAE AND R.AIL) THEN THF PROCEDURES SPECIFIC TO COMMISSARJAT TRANSPORTS. IN CONCLUSIDN, THE POJCEDURE IS SHOWN TO SE WELL FOUNDED SINCE OF ZI, OOO TRANSPORTS CAPPIED OUT IN 9 YEARS, NCT ONE ACCIDENT CAUSER EY RACIOACTIVITY HAS BEEN PECORDED.

\#FPANCE + \#REGULATION, GENFEAL + COMPARISCN, THEORY AND EXPERIENCE + TRANSPORTATION AND HANDLING

3-22444

$\checkmark$ INAR.VICK L

TECHNICAL AND PRACTICAL DESITN DE EXPENDASLF PACKAGING FOR RADIOISOTOPES

FRANCE. COMMISSARIAT A L-ENEPGIE ATOMIQUE 
TRANSPORTATION ANO HANDEIING OF RADIOACTIVE MATERIALS

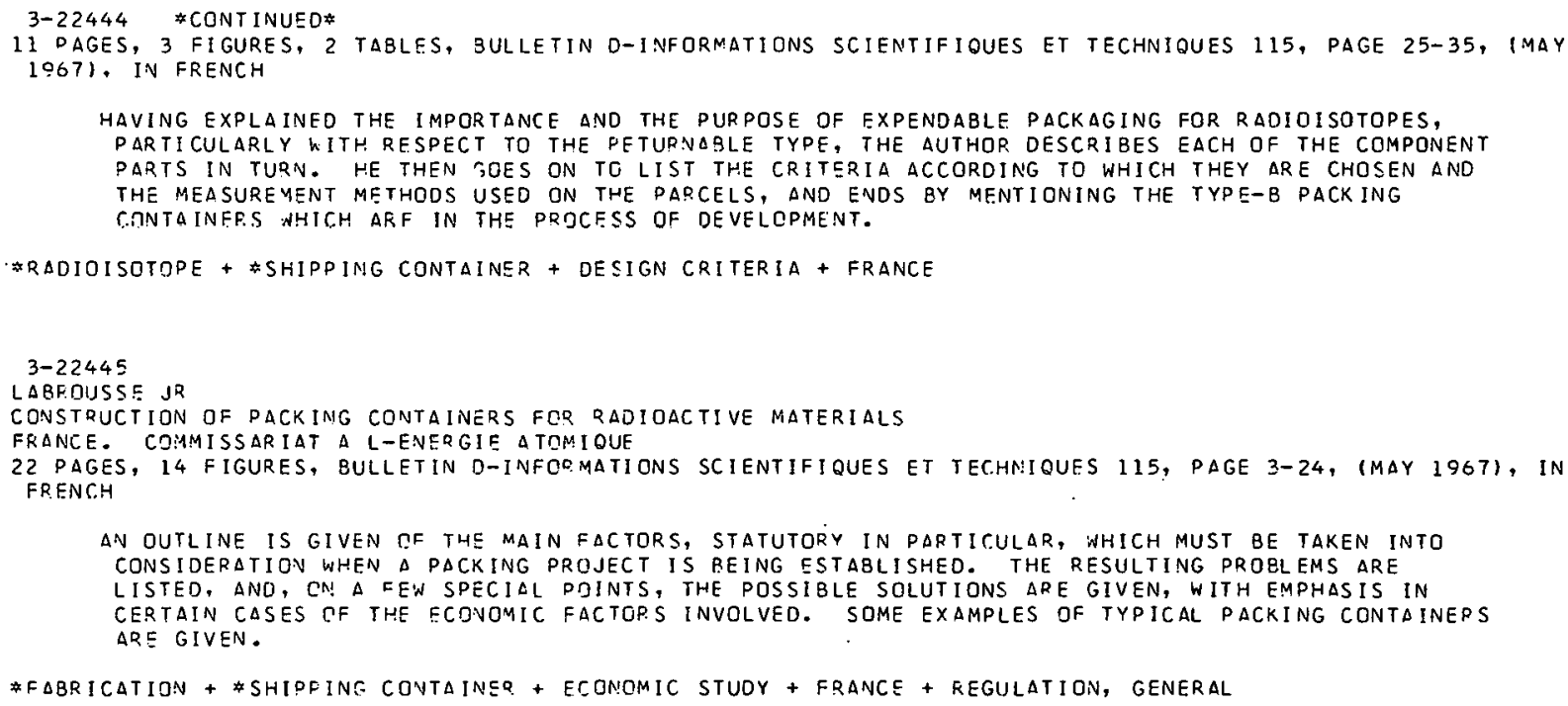

AVAILABILITY - US ATCMIC ENCRGY COMMISSION, CIVISION OF OPEFATIONAL SAFETY

\& PERSONNEL PROTECTIVE DFVICE + CONTAMINATION

3-22441 ALSU IN LAIEGIKIES I ANLL 17 BABCOCK AND WILCOX REPOFTS PLUTONIUM NITRATE LEAKAGE FROM POLYETHYLENE BOTTLES BABCOX AND WILCOX COMPANY

1 PAGE, ATOMIC ENERGY Cleafing HOUSL 14(6), FAGE 8 , (FEB. 5, 1068 )

(LETTER, JAN. 17) ALTHDUGH IOT PEPORTABLE UNOER 10 CFR 20, THIS IS AN EXAMPLE OF LEAKAGE AS IN YOUR HEALTH AND SAFETY 9IJLI.ETIN 2ES, EEC, 21, 1967. ON JAN. 3, 1968, ROUTINE INSPECTION REVEALED A LEAK FROM A SMALL CPACK IN A I-GAL POLYETHYLENE EOTTLE THAT PENETRATED THPOUGH THREE 4-MIL-THICK PQL YT THYLENE PAGS (TWO WITH POOR HEAT SEALS), DISSOLVED A 3-IN.-DIAM HOLE IN THE CARSON-STEEL SHELE, AND DRIPPED THROUGH TWO OTHER STEEL SHELVES. THE BOTTLE WAS QUITE STIFF, AND CRACK MAY HAVE BEEN CAUSED RY RAOIGLYTIC GAS PRESSURE, RADIATION DAMAGE, OR

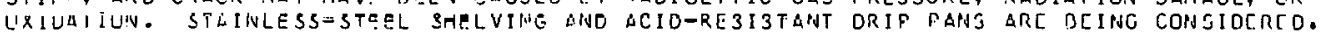

\#LEAK + \#STORAGE CONTAINEF + INCIDENT, FQUIPMENT + NITPATE + PLASTICS + PLUTONIUM

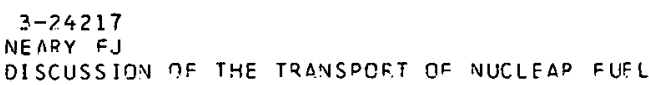


$3-24219$ *CONTINUEO*

REPROCESSING PLANT 1000 AILCS SWAY. THE FUEL WAS ASSUMED TO BE SHIPPED IN ONE OF FOUR DIFFERENT SIZE CASKS (49-, 21-, 7-, OF 3-FLEMENT CAPACITY). THE LOWEST COST DF SHIPFING THE SPENT FUEL IS REALIZED BY SHIPPINEE IT IN THE CCOELEMENT CAPACITY CAST IABOUT 22 DOLLARS PEP. KILOGRAM GF HEAVY METALS). THF HIGHEST COST IS REALIZED BY SHIPPING THE FUEL IN THE 7-ELEMENT CAPACITY CASK 3Y TRUCK (ABOLT SES PED KILGGRAM DF HEAVY METALSI. THE COST OF SHIPPING THE FUEL QY TRUCK IS LESS THAN RY RAIL ONLY IF SHIPMENTS ARE LIMITED TE THE 3-ELEMENT CAPACITY CASK. THE SHIPPING CISTS FOP THIS CASK ARE \$7I BY TRUCK, ANC \$78 BY FAIL PSR KILOGRAM CF HEAVY METALS. THESF FIGURES GO NOT INCLUDE COSTS OF SHIPPING REFLECTOP. ELEMENTS.

AVAILABILITY - CLEAR INGHOUSE FOR FEDERAL SCIENTIFIC ANC TECHNICAL INFORMATION, SPRINGFIELO, VIRGINIA S3.OO COPY, \$0.65 MICRCFICHE

ECONOMIC STUDY + FUEL HANDLING + REACTOR, GCF + SHIPPING ANALYSIS + TRANSPORTATION AND HANDLING

$3-24220$

SEOEN WH

DLSO IN CATEGURTYS 13 AND 17

WH-TERM SPENT FUEL STORAGE COSTS

GENERAL ATOMIC DIVISION, GENEPAL DYNAMICS CORO, SAN DIEGD, CALIF.

GAMD-7994 +. 27 PAGES, FIGURES, TAELES, SFPTEMBER 1,1967

PRELIMINARY DESIGNS HAVE BEEN PREPARED, AND PRESENT-DAY COSTS HAVE BEEN ESTIMATED FOR SPENT FUEL STORAGE VAULTS CONSTRUCTED AS A PART OF A 1000 MW(E) HIGH-TEMPERATUPE GAS CGOLED REACTOR (HTGP) PLANT. TWO SPENT FUEL STORAGE CONCEPTS WERE DEVELOPED. IN ONE CONCEPT, THE FUEL ELEMENTS ARE STORED IN DPEN CYLINDERS AND GASECUS NITROGEN IS CIPCULATED ACRDSS THE FUEL ELEMENTS TO REMOVE THE OECAY HEAT. IN THE OTHER CONCEPT, THE FUEL ELEMENTS APE STORED IN SEALSD CONTAINEPS FROM WHICH NG CONTAMINATEO GRAPHITE DUST CAN ESCAPE. THEREFORE, A OVCE-THROUGH AIR COOLING SYSTEM IS USED IN WHICH THE AIR IS PASSED AROUND THE OUTSIOE WALLS OF THE CONTAINERS. THE FUEL STORAGE VAULTS FGP BOTH CONCEPTS HAVE THE SAME CAPACITY - THE AMOUNT JF FUCL DISCHARGED FRCM A IOCO IAWIEI REACTIRR NVEF $\triangle$ 5-YR PERIOD. AMORTIZING VAULT CAPITAL COSTS OVER A 5-YR PE?IOD, THE TOTAL ANNUAL COST OF STORING THE FUEL ELEMENTS WOULD GE APPROXIMATELY \$6O PER KILOGREM DF HEAVY METALS STOREE FQR BOTH THE OPEN CYLINDEF: CONCEPT (UNCANNED) AND THE SEALFD CTNTAINEP CONCEPT (CANNED).

AVAILABILITY - CLEARINGHOUSE FOR FEDERAL SCIENTIFIC $\triangle N O$ TECHNICAL INFOPMATION, SPRINGFIELD, VIPGINIA F3. OO COPY, \$0.65 MICROFICHF

\#ECONOMIC STUOY + FUEL STORAGF + zEACTOR, GCR + STORAGE CONTAINER + WASTE HANDL ING

$3-24221$

EVANS JH

STRUCTURAL ANALYSIS GF THE BROOKHAVEN NATIONGL LABGRATIRY SHIPBOARD IRFADIATCR

OAK RIDGE NATIONAL LAROFATORY, OAK FIDFE, TENN.

ORNL-TM-2064 +. 82 PAGES, FIGURES, TABLES, JANUARY 1068

THE METHOOS D̄F E EALUATTING THE STR.UCTURAL INTEGFITY OF A CONTAINEF IN WHICH RADIOACTIVE MATERIAL IS SHIPPED TO SHOW COMPLIANCE WITH THE LUUVFNING REGIIITIONS ARE ILLUSTQATED IN THIS P.EPORT OF THE STRUCTURAL ANALYSIS PERFORMED ON THE BROOKHAVEN NATIONAL LABOFATOPY SHIPBOARD IRRADIATOR. TFSTING METHOJS, CALCULATORY PROCEDURES, ANO CPERATING EXPERIENCE WEFE ADPLIED IN THE ANALYSIS OF THE CASK WITH RESPECT TO THE REGULATICNS COVERING THE GENERAL STANDARDS FOR PACKAGING, THE STRUCTURAL REQUIREMENTS, THE NORMAL CONDITIONS OF TRANSPORT, AND THE HYPOTHETICAL ACCIDENT CONOITIONS. STRUCTUFAL MODIF ICAT IONS WERE PROPOSEO TO EL IMINATE DEFICIENCIES IN THE EXISTING CASK, AND THIS ANALYSIS DEMONSTRATED THAT WITH THE PROPOSEO CASK LID, LIFTING DEVICES, ANO CEASH FRAME, THE IRPACIIATOR COMPLIES WITH ALL THE $\triangle P P L I C A B L E$ REGULATIONS.

AVAILABILITY - CLEAP.INGHOUSE FOR FEDER.AL CCIFVTIFIR. AND TEC.HNICAL INFORMATION, SPRINCFIELO, VIRGINIA \$3. OO COPY, \$0.65 MICROFICHE

ACCIDENT ANALYSIS + CONTAINMENT INTEGOITY + IMPACT SHOCK + REGULATICN, GENERAL + SHIPPING CONTAINER + STRUCTURAL INTEGR ITY 


\section{CATEGORY LAL
DEFOSPACE SAEETY}

$4-21398$

BL $\triangle K E$ VE

AERCSPACE NUCLEAR SAFETY

SANDI A CORP., AL BUQUERQUE, N. MEX.

SC-DC-67-1900+COVF-67C614-6 +. 14 PAGFS, FIGURES, JLLY JCA7, PRESENTED AT 2ND INTERMATIONAL SYMPJSIUM DN NUCLEONICS IN AERCSPACE, COLUMZUS, OHIO

OUR FUTURE IN SEACE WILL BE GOVERNED LARGELY BY THE AMOUNT CF DONEP. WE TAN CAREY THERE. CONE DF THE MOST PROMISING SUUUREES OF PCWER IS FRCM THE OECAY OF RADIOACTIVF ISOTOPES. ALTHGUGH POWER LEVELS ARE NOT HIGH ITHAT IS, GENEPALLY P.ELOW ICOC WATTS ELECTRICAL), THE FEL IARILITY AND LOVG LJEE QF THESE SYSTEMS ARE INDSED ATTFACTIVE. THE CHALLENGE IS TO INCREASE THE SOECIFIC POWER OF THESE SYSTEMS AND AT THE SAME TIME TO INCPEASE THE OVERALL SAFETY. THIS PAPER DISCUSSES THF PROBLSM. CONCFRNED WITH INCREASING AEROSPACE NUCLEAR SYSTEM SAFETY.

AVAILABILITY - CLEARINGHOUSE FQR FEDERAL SCIENTIFIC AND TECHNICAL INEDRMATION, SPRINGFIELD, VIPGINIA, $\$ 3.00$ COPY, \$0.65 MICRCFICHE

* $\triangle E R O S P A C E$ SAFETY + FSAFETY PPINCIPLES ANC PHILOSOPHY + DOSE + isOTCPIC GENEPATOR + REACTOR, SPACE + SAFETY PROGRAM

4-21773 ALSO IN CATEGCSIES 1 AND 1 C

FUDL ICATIOHS JT LASL OEEEARTH, IOKK

LOS ALAMOS SCIENTIFIC LAB., LOS ALAMOS, NEW, MEXICO

TIC-24041+MM-1144+。138 DAGES, SEPTEMEER 1067

PAPERS, REPJRTS, QOOKS, JDURNAL ARTICLES, ETC., OF LASL PUBLISHEC IN IOOC ARE LISTED

ALPHABETICALLY FY AUTHOR UNDER ZE SUBJECT $\triangle F E A S$. INCLUCES DCCUMFNTS CN AERDSPACE SAFETY,

BIDLOGY AND MEOICINE, CHEMICAL KINETICS, HEALTH AND SAFETY, INSTEUMENTS, NETALLURTY ANO

CERAMICS, REACTOF TECHNDLOGY, AND WASTE DISPOSAL.

\#9IBLIOGRAPHY + ACCIDENT, GENERAL + AEPDSPACF SAFETY + BIOMEDICAL + TECONTAMINAT ICN + OCSIMETRY, GENERAL + INSTRUMENTATION, GENEFAL + WASTE OISPOSAL, GENEAAL

4-22331 ALSO IN CATEGORY

MOHLER RR + DRICE HJ

OPTIMAL NUCLEAR REACTOQ CONIYUL

NEW MEXICO UNIVER'SITY, ALEUQUERQUE

$S C-C R-67-2746+.16 \%$ PAGES, AUGUST 1967

THE COMPUTATIONAL ASPECTS OF GPTIMUM CONTROL OF NUCLEAR-ROCKET DEACTORS WAS STUDIED FOO VARIOUS CONSTDAINTS IN CONTROL ANO STATE. THE CONCLUSION WISS THAT THE OPTIMAL STARTIJP OFF A NUCLEAR-ROCKET REACTOR IS GENERALLY A MAXIMAL-EFFORT PROCESS, CGNSISTENT WITH THE VAPIOUS CONSTRAINTS NHICH ARE IMPOSED ON THE VARIABLES. IN ADDITION, THE OPTIMAL SOLUTIONS REQUIRING MINIMUM EIJEL CONSIIMPTION ARE THE SAME AS THOSE WITH MINIMAL TIME AS FHE CPTIMALITY CPITER IC.N.

AVAILABILITY - CLEARINGHOUSE FOR. CEDER.AL SCIENTIFIC AND TECHNICAL INFORMATION, SPRINGFIELD, VA., \$3. OO COPY, \$O. AS MICROCICHE

\#NUCLEAR ROCKEI + \#REACTOD CONTRQL I \#REACTOR, SOACE + THERRFTICAL INVESTIGATION

4-22333 ALSO IN CATEGORY

FRICE HJ + MOHLER RR

COMPUTATION OF ORTIMAL CANTROLLS FRF $\triangle$ NUCLFAR RCCKET REACTOR

NEW MEXICO UNIVERSITY

SC-CR-67-2723+. 32 FACFS, SEPTEYAER 1967

VARIOUS CPTIMAL KEOCTOF CONTRCL PROBLEMS WITH COMOLICATED CONSTRAINTS ARE SOLVED FOR A NUCLEAR ROCKET ENGINE. THE TECHVIDUE UTILIZES A DIGITAL COMPUTER, WITH THE NUMEFICAL $\triangle L G O R I T H M$ FCRMED BY A SUCCESSION OE I INFAR PROGRAMNING PROBLEMS. EACH PROGRAMHING PROSLEN HAS A SOLUIIION WHICH IS USFD TO RELINEAR.IZE THE SYSTEMS DYNAMICAL EQUATIONS.

AVAILABILITY - CLEARINGHOUSE FOR FERERAL SCIENTIFIC AND TECHNICAL INFOPMATION, SPRINGFIELO, VA., \$3. OD COPY, \$O.65 MICROFICHE

*NUCLEAR ROCKET + \#UECCTÖL CONTQOL + \#REACTOR, SPACE \& COMPITER PRMGRAM + MATHEMATICAL TREATHFNT + THEORETICAL INVESTIGATION

ENGEL FC + $81 S H D^{\circ} \triangle A$

TEST AND ANALYSIS OF A MANIFOLO AND RE-ENTDANT THEE ASSEMRLY. TEASIBILITY OF A CHEMICAL DOISON LCEO SYSTEM WESTINGHOUSE ELECTRIC CORP., PITTSBURGH, DA.

WCAP-2870 + NASA-CR-549C4 +. 80 PAGES, FIGURES, TABLES, REFERENCES, JULY 1960

AN ANALYTICAL AND EXPEPIMENTAL MQDEL STUDY WAS PERFORMED GE A MANIFGLD AND RE-ENTFANT TUEE 
CATEGCRY
AEROSPACE SAEETY

4-22338 \#CDNTIVUE[

CHEAICAL-PIISÜIY DISTP IBUTION SYSTEM WHICH ARE PART OF A ROCKET REACTOR CTNTROL LOQP. THE SYSTE DPEAATCS DY CHANGING THF CONCENTFATIÜN GF THE POISON ICADMIJM SULFATEI IN A WATFR STLUTION CIRCLLATING THRDUGH IOQ PARALLEL TUDES WHICH PRDJECT FROM A MANIFOLD INTO THE CORE. A SPECIAL MAVIFGLD AND RE-ENTRANT TUBE ASSEMLLY WAS DESIGNED, AND A FULL-SIZE FLOW MOOEL WAS MADE JF PLEXIGLAS, A SCRIES OF TESTS WERE THEN PERFORMED TO PRGVE THE DESIGN.

AVAILABILITY - CLEARINGHOUSE FOR FEDERAL SCIENTIFIC ANL TECHNICAL INFOFNATION, SPRINGFIELD, VA., \$3. OO COPY, \$0.55 MICRJFICHE

*FLOW DISTRIBUTION + \#FLDW THEOPY AND EXPEPIMENTS + \#TEST, SYSTEM OPERABILITY + CONTPOL SYSTEM + NUCLEAR RICKET + PISON, SOLUELE + REACTCR, SPACF + REACTOR, WATER

4-22463

HOLCOMB NE

ALSL IN CATEGORIES 11 ANE 12

EXPER I ENCE WITH GLOVEZCX INERT ATMOSPHERE CONTROL SYSTEM

ARGONNE NATIDNILL LAB., IOAHO OIVISION, ICAHO FALLS, IDAHO

4 PAGES, 2 FIGURES, NUCLEAP ENOINEEFING AND DESIGN 6(3), PAGE $213-216,10(1.1967)$

THE HANOLING AND PREPARATION OF SODIUM FOR FUEL ELEMENTS AT THE FUEL CYCLE FACILITY FOR THE $S E C D N D$ EXPERINENTLL 3REEDER FEACTOF REOUIRES THE USE OF A GLOVEBOX EQUIPPED WITH A

RECIRCULATIIVG INERT ATMOSPHERE OF HIGH PURITY. THE ARGON GAS PUEIFICATION SYSTEM CONSISTS OF A PALLAOIUM CATALYST FOR, KEMUVING OXYGEN, MOLECULAR SIEVE ORYER FOR REMOVING WATER, AND A CANNED BLOWER FOP CIRCULATING THE GAS. THE PURIFICATION SYSTEM SERVES A 250 CU. FT GLOVEBOX COMPLEX AND NITH CONTINUOUS GPERATION CAN MAINTAIN AN DTMOSPHERE WITH OXYGEN IMPURITIES OF 2 PPM AND WATER IIAPURITIES OF $E$ PPM AT AN INLEAKAGE RATE OF 0.COZ CU. FT/HR OF AIR WHILE ZPERATING THE GLOVEBOX CDMPLEX AT A NEGATIVE PRESSURE OF 1 IN. OF WATEK.

*AFGON + \#DECDNTAMIVATICN + \#GLOVE FOX + \#ODIUM + OPERATING EXPERIENCE

$4-22464$

CASEY DF

FINAL DESIGN OF SODIUM-HEATED, MOOULAF STEAM GENERATORS FOR THE SODIUM COMPONENT TEST INSTALLATION (SCTI) ATOMICS INTERVATIONAL, A DIVISITV OF NORTH AMEPICAN AVIATION, INC., CANCGA PARK, CALIFCRNIA

13 PAGES, $\rightarrow$ FIGURSS, 2 TABLES, 19 REFERENCES, NUCLEAR ENGINEERING AND DESIGN G(3), PAGE 223-235, (LCTOSER $1967)$

DESCRIPTION OF DESIGN AND OPEFATION CRITERIA FOR A 37-TUBE, MODULAR-TYPE, LOW-TEMPERATUPE FVAPJRATJÉ ANO HIGH-TEMPERATURE SUPERHEATER FOR TESTING IN THE SODIUM COMPONENT TEST INSTALLATION (SCTI.). DISCUSSION OF MECHANICAL DESIGN DETAILS AND. OUTLINE OF PERFORMANCE ANALYSIS. THE SVADORATDR ANE SUPERHEATER MODULES, WHEN COMBINED, NOULD BE CAPAELE OF FEINERATING STELM AT 2400 PSI ANN $1050 \mathrm{~F}$.

* DES IGN CRITERIA + \#HCLT FXCHANGER + *SODIUM + EVAPOPATION + CUT DF PILE LOOPS AND EXPEF IMENTS + THERMAL ANALYSIS + THEPMAL EXPERIMENT

$4-22465$

HJLCOMB $\mathrm{NF}$

CARBURIZATION OF TYPE 304 STAINLESS STEEL IN LIQUIO SODIUM

ARGGNNE NATIONAL LAB., IDAHO FACILITIES, IDAHO FALLS, IDAHO

9 PAGES, $S$ FIGURES, 1 TABLE, 9 REFEF CNCES, NUCLEAR ENGINEERING AND DESIGN 613), PAGE 264-272, (DCTOBER 10671

MICROHALUNESS SCANS ACROSS TEST SPECIMENS WERE USED AS A SUITAZLE METALLURGICAL TECHNIQUE FCP DETERMINING JUANTITATIVELY THE CAREURIZATION POTENTIAL OF MOLTEN SODIUM IN CONTACT WITH TYPF 304 STAINLESS STFEL. THF ADVANTAGE OF USING HARDNESS DAIA IN THIS MANNER IS THAT IT COULD BE USED AS A METHCD UE ANALYSIS CF CARBURIZATICN SPECIMENS WHEN CHEMICAL ANALYSES ARE NOT

FEASIBLE. RESULTS INDICATED THAT MICROHARDNESS VALUES AT TEMPERATURES OF 565 , 605, AND G5O C CJULD SE FITTED TO CUFVES COHRELATING THE HARONESS TO CARBON CONTENT OF LIQUID SODIUM. IT WAS FOUND THAT CADBONACEOUS COMPOUNDS INTENTIONALLY MIXED IN LIOUID SODIUM. GAVE A CARBON SJURCE NHICH PFOQUCED CARBURIZATIGN IN THE STAINLESS STEEL TIST SPECIMENS. IHE CADSULE METHOOS USE? FOP PREVIDING AND CONTROLLING A MOLTEN SOCIUM ENVIRONMENT FOR THE STAINLESS STEEL TEST SPECIMENS TNOT CATED A NEED FOR FURTHER STUDY IN THE USE OF VARIDUS CAPSULE-LINER MATERIALS WHICH ARE INERT TO CAPSUEIZATION.

\#CARBON + \#PRJPERTY, FHYSICAL + \#SOCIIUM + \#STEEL, STAINLESS + MASS TRANSFER

4-22466 DLSO IN CATEGODY 7

KEIL H

FISSION DRJDUCT TRANSFEF IN THE SYSTEY. VOZ/LIOUID SODIUM/STAINLFSS STEEL

EUC.OPEAN ATQMIC ENERGY COMMUNITY, CHEMISTRY DEPAFTMENT, ISPRA (ITALY)

5 PAGES, 8 FIGURES, 2 TA 9LES, 14 RTFEPENCES, ATGMKERNENERG 12(3-4), PAGE 96-100, (MARCH-APRIL 1967)

FISSION-PRONUCT TRANSFER FROM UO? POWDER THROUGH LIQUID SODIUM TOWARDS STAINLESS STEEL WAS INVESTIGATED, AND THE DIFFUSION OF FP, U, $A N D$ PU IN STAINLESS STEEL WAS MEASURED IN THE TEMPERATURE RANGE 700 TO $1000 \mathrm{C}$. DIFFUSION COEFFICIENTS AND ACTIVATION ENERGIES ARE STATED.

\#DIFFUSIJN COEFFICIENT + *FISSION PFODUCT RETENTION + \#SODIUM + *STEEL, STAINLESS + 
4-22466 \#CONTINUEO*

IISSION PRODUCT RELEASE, GENERAL + FISSION PRODUCT TRANSPORT + PLUTONIUM + URANIUM DIOXIDE

4-22468. ALSO IN CATEGORY 7

CASTLEMAN AW + TANG IN

THERMOCYNAMICS OF FISSION PRDOUCT SOOIUM SOLUTICNS

BROCKHAVEN NAT IONAL LAB.

BNL-11611 +. 3 PAGES, 1 FIGURE, 1 TABLE, 2 REFERENCES, NOV. 19E7, $\triangle B S T R A C T$ IN $\triangle N S$ TRANSACTIONS IOI2),

PRESENTED AT THE 19E7 WINTEQ MECTING OF THE AMEPICAN NUCLEAR SOCIETY, CHICAGO, ILLINOIS, NOV. 5-S, 1967

gIVES THE RESULTS OF AN INVESTIGATION OF THE REQUIDED THERMODYNAMIC PROPERTIES AND THE ADPLICATION OF THESE RESULTS IN CALCULATING FISSION PQOCUCT PAPTIAL PRESSURES AND THE EXTENT OF THEIR VAPORIZATION. WE MEASUREC THE THERMODYNAMIC PROPERTIES OF SODIUM IODIDE-SODIUM SOLUTIONS USING A CONTINUOUS VAPORIZATION TECHNIQUE. EXPERIMENTS WEFE MACE OVEP THE TEMPERATURE RANGE 700 TO $1100 \mathrm{~K}$. THE RESULTS, WHICH ARE REPRESENTED BY IHE EQUATION DELTAIAVE.) F-SUPERSCRIPT-E EQUALS $15,000-6.8 \mathrm{~T}$, ARE IN EXCELLENT AGREEMENT WITH OUP. ESTIMATES EAPLOYING TWO METHOCS, ONE BASEO ON PHASE-DI AGRAM CALCULATIONS AND THE OTHER ON STATISTICAL MECHANICAL CONSIDEPATIONS. THE PARTIAL PRESSURES PER MOLE FRACTION OF FISSICN PRTDUCTS IN SOLUTION ARE PLOTTED AS A FUNCTION CF RECIPROCAL ABSCLUTE TEMPERATURE.

*FISSION PROOUCT RETENTION + \#SQOIUM + \#THERMODYNAMICS + ANTIMONY + BARIUM + CESIUM + PROPERTY, PHYSICAL + RUBIDIUM + STRONTIUM + TELLURIUM

$4-22469$

$\triangle L$ SG IN CATEGORY 7

SALZANO FJ + ARCNSONS

THRESHOLD PRESSURES FCP. THE REACTION DF SCIOIUM AND OTHER ALKALI METALS WITH GRAPHITE

BRDOKHAVEN NAT IONAL LLS.. UPTON, N. Y.

BNL-11554 + CONF-671102-11 +. 8 PAGES, FIGURES, TABLES, REFERENCES, 1967, PRESENTED AT 15TH CDNFERENCE ON REMOTE SYSTEMS TECHNOLOGY AND ATOH FAIR, CHICAGO, ILLINOIS

THIS PAPEP DRESENTS THE RESULTS CF A CALCULATION OF THE THRESHOLD PRESSURES FOR THE SODIUM-GRAPHITE SYSTEM SASEO ON AN IONIC MECHANISM OF BONDING OF THE ALKALI-METAL TO THE GRAOHITIC LAYEFS. THF THRESHOLD PRESSUPE INCREASES IN THE ORDER CESIUM, RUBIDIUM, POTASSIUM, AND SODIUM. THUS, THE INITIATION CF THE REACTION BETWEEN SOOIUM AND GRAPHITE REQUIRES PRESSURES WHICH APE MORE THAN THREE DRDERS OF MAGNITUDE HIGHER THAN FOF THE OTHER ALKALI METALS.

AVAILABILITY - CLEARINGHOUSE FOR FEDERAL SCIENTIFIC AND TECHNICAL INFORMATION, SPRINGFIELD, VIRGINIA, $\$ 3.00$ COPY, \$0.65 MICROFICHE

*CHEMICAL REACTION + \#GEAPHITE + \#SOOIUM + CESIUM + POTASSIUM + RUBIDIUM + THEORETICAL INVESTIGATION + THERMOUYNAMICS

$4-22471$

CUMMINCS RL

EVALUATION OF FERRITIC STEEL IN THE SECONOAPY SODIUM SYSTEM

ATCMICS INTERNAT IONAL, CANOGA PARK, CALIF.

NAA-SR-MEMO-11996(P,EV,) +, 21 PAGES, TABLES, REFECENCES, OCTOBER 25, 10\%6

THE MECHANICAL ANO METALLURGICAL PROPERTIES OF FERRITIC STEELS WERE REVIEWED FQR APPLICABILITY TO CONSTRUCTILN OF THE IFTF SECONDAFY SODIUM SYSTEM AS REPLACEMENT FOP THE MORE COSTLY AUSTENITIC STAINLESS STEELS. MATERIALS SELECTED FOR EVALUATION UPON THE BASIS OF THEIR COST, RESISTANCE TO COPROSION IN SCOIUM, ANC GENERALLY GOOO MECHANICAL PROPERTIES WERE ASTM $\triangle$ IOG, GRADE B; MEOIUM CARBON STEEL, AND 2 1/4-CHPOMIUM/1-MOLYBOENUM STEEL. THE PROPEPT IES OF THESE MATERIALS WER COMPARED WITH TYOE-304 5S. THE RECOMMENDATIONS FOR THE FFTF SECONOARY SODIUM SYSTEM CONSTRUCTION ARE - (1) MAKE PIPING FROM SCHEDULE-10 TYPE-304 SS, (2) MAKE THE AIR-COOLED HEAT DUMP EXCHANGER WITH 2 ? / $\angle T H$ POME/1 MOLYBDENUM STEEL TUBING HAVING CARBON STEEL FINS, (3) MAKE THF PURIFICATION COLO-TPAP FROM ASTM A 106 , GRADE B CARBCN STEEL.

AVAILABILITY - CLEAR INGHOUSE FOR FEDERAL SCIENTIFIC AND TECHNICAL INF ORMATION, SPRINGFIELD, VIRGINIA, $\$ 3.00$ COPY, \$0.65 i1!CROF ICHE

\#FFTF (TR) + \#SODIUM + \#STEEL + \#STEEL, STAINLESS + CORROSION + MASS TRAVSFER + PROPERTY, PHYSICAL + REACTOR, FAST + FEACTOR, LMCP.

$4-22474$

EICHELBERGER QL + MCKISSON RL

THE SOLUBILITY OF COPPER IN LIQUIO SODIUM

ATOMICS INTERNATIUNAL

2 PAGES, ANS TRANSACTIONS 10(2), PAGE 405 AND LGE, (NOV. 1967 ), PPESENTED AT THE. 1967 WINTER MEETING OF THE AMERICAN NUCLSAR SCCIETY, CHICAGO, ILLINJIS, NOV. 5-9, 1967

THE SDLUEILITY CF COPPEP IN SCDIUM WAS MEASURED IN THE TEMPERATURE RANGE 250 TO 725 C. TWO TECHNIOUES WEFE USER. THE CGPPER SQUPCE IN POTH TECHNIQUES IS OFHC COPPER. IN CNE CASE, THE SOLUTE WAS IN THE FORM OE A CPUCIPLE, SO THE SODIUM WAS NOT IN CONTACT WITH ANY OTHER METAL DIIRING THE EQUILIBRATIGN.

* COPPER + \#PROPERTY, OHYSICAL + \#SODIUM + CHEMICAL DFACTION 
CATEGORY
AER CSPACE SAFETY

$4-22476$

FAUSKE HK + QUINN DJ + JEANS WC

SODIUM FLASHING EXPER IMFNT

ARGONNE NATIONAL LAB.

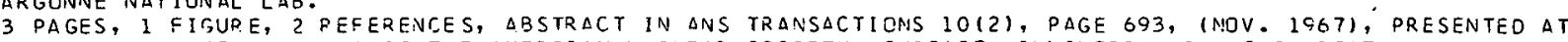

THE 1967 WINTER MEETING OF THE AMERICAN NUCLEAF SRCIETY, CHICAGO, ILLINJIS, NOV. 5-9, 1967

\begin{abstract}
BECAUSE OF THE LARGE INHERENT COMPPESSIRILITY ASSOCIATEO WITH FLASHING LIQUIO METALS, SUCH PHENOMENA AS CPITICAL FLOA ANO THE VELOCITY GF SOUND PECCME IMPCRTANT WHEN ATTEMPTING TO DESCRIBE THE COOLANT DYNAMICS FCLLOWING A SUDOEN LOSS OF COOLING CAPAEILITY IN A FAST-BREEDER REACTOR. TD ORTAIN DATA ON CFITICAL FLON CE MAXIMUM EXPULSION RATES CF LIQUIO-SODIUM-VAPOR MIXTURES, A SODIUM-FLASHING EXPERIMENTAL ASSEMSLY WAS BUILT. THE FLASHING OF LIQUID SODIUM. WAS ACHIFVED RY GECREASING THE SYSTEM PPESSUPE BELTIN THE SATURATION PRESSURE CORRESPONOING TO THE STAGNATION TEMPERATURE.
\end{abstract}

* SOOIUM + *THERMAL EXOEPIMENT + EVAPORATION + PROPERTY, PHYSICAL + FEACTOR; LMCP + STEAM + THERMAL PROPERTY

$4-22479 \quad \Delta L S O$ IN CATEGORY 7

KOONTZRL + NELSON CT + BAURMASH L

CHARACTERISTICS OF AEROSOLS GENERATED DURING SODIUM FIRES

ATOMICS INTFRNATIONAL

2 PAGES, I TABLE, I REFERENCE, ANS TRANSACTIONS 10121, PAGE 690 AND 690, (NOV. 1965), PRESENTEO AT THE

1067 WINTER MEETING OF THE AMERICAN NUCLEAR SOCIETY, CHICAGO, ILLINOIS, NOV. 5-0, 1967

STUDIES ARE 3EING CONDUC TED TO DEVELOP EXPERIMENTAL INFORMATION AND ANALYTICAL METHODS THAT

CHARACTERIZE THE RELEASE. AND TRANSPORT OF EFFLUENTS GENERATED DURING A SODIUA FIRE IN A

LIQUID-METAL FAST-BREEDER. (LMFAR). EXPER IMENTS HAVE BEEN CONDUCTED TO STUOY THE RELEASE OF

OXIOIZED SODIUM AND A SIMULATED FISSION PROOUCT CONSISTING CF NA-131-I INVOLVING VARIDUS

QUANTITIES OF SODIUM IN DICFERENT SIZED CONTAINERS AND IN VARIOUS OXYGEN ENVIRONMENTS.

\#AEROSOL + \#FIRE + \#PARTICLE SIZE + \#SODIUM + IODINE + OXYGEN + REACTOR, LMCR

$4-22480$ ALSO IN CATEGORY 7 .

HAUSKNECHT DF + GREENFIELD MA

A MODEL DESCRIBING THE REHAVIOR OF THE $\triangle E P O S O L$ PRODUCED BY A SODIUM FIRE

ATOMICS INTERNATIDNAL + UCLA, SCHOOL OF MEDICINF

1 PAGE, 8 REFERENCES, $\triangle N S$ TRANSACTICNS $10(2)$, PAGE 690, (NOV. 1967), PRESENTED AT THE 1967 WINTEP. MEETING OF THE AMERICAN NUCLELR SOCIETY, CHICAGO, ILLINOIS, NOV. 5-9, 1967

PREDICTION OF THE BEHAVIOR DF AED.GSOLS GENFRLTEO DURING A LARGE SOOIUM FIRE IS REgUIP.ED IN THE SAFETY ANALYSIS OF SODIUM-COOLED FAST REACTORS. TI AID IN UNDERSTANDING AND EXTENDING THE RESULTS OF THE EXPERIMENTAL PPOGRAM, A THEORETICAL EFFOKT WAS UNDERTAKEN TO DEVELOP A MATHEMATICAL MODEL THAT WOULD PREDICT THE AGGLOMERATION ANO DEPOSITION HISTORY CF AEROSOL

PARTICLES. THE MATHEMATICAL MOOEL IS BASED ON THE CLASSICAL APPROACH OF SMOLUCHCWSKI AS GENERALIZED BY MULLFR AND GOLDMAN, FOR A OISTRIBUTION OF PAFTICLE SIZES. NUMER ICAL INTEGRATION OF THE BASIC EQUATION WAS ACCOMPLISHED FIRST BY FRIEDMAN AND SHIFFMAN, AND MURE RECENTLY BY ZEBEL, USING AN IBM-650 COMPUTER. NUMERICAL EVALUATIONS WERE PERFORMEO WITH THE IMPROVED MODEL AND GOOD AGREEMENT WAS OBTAINED WITH EXPER.IMENTAL RESULTS FOR MASS DISPOSITION ANO PARTICLE SIZE. IT ILLUSTRATTS THE IMPORTANCE OF THE ADDITICNAL AGgLOMERATION MECHANISMS IN ACHIEVING AGREEMENT WITH EXPEPIMENT.

\#analytical model + \#COMputer program + \#Fire + \#SODIUM + MOdel testing

4- 22493

ALSO IN CATEGORY 7

MUKBACH EW + GOOINE JE

DISPENSING $\triangle N D$ SAMPL ING SODIUM FOR THE LMFRR CLADDING PROJECT

ATOMICS INTERNAT IONAL

1 PAGES, ANS TRANSACTIONS 1012 ), PAGF 493, (NOV, 1967), PRESENTED AT THE 1967 WINTER MEETING OF THE

AMERICAN NUCLEAR SOCIETY, CHICAGO, ILLINCIS, NOV. 5-9, 1967

GNE OF THE TASKS ON THE LMFBR CLADDING PROGRAM AT ATOMICS INTERNATIONAL INVGLVES THE

MAINTENANCE OF A SUPPLY OF SYSTEMS-QUALITY SODIUM, THE DISPENSING DF THIS SODIUM, AND

SAMPLING OF SOOIUM TEST UNITS. A SUPPLY LOOP OF OVEP ISO-GAL CAPACITY WAS CONSTFUCTED FER

MAINTAININS SUFFIC IENT SODIUM GF CONSTANT COMPOSITI ON FOR THE DURATION OF THE PRCGRAM. THE

LOOP, WHICH OPERATES AT $500 \mathrm{~F}$, IS COLD-TRAPPED AT $260 \mathrm{~F}$ FOR CONTROL OF OXYGEN, AND

HOT-TRAPPEO AT $1200 \mathrm{~F}$ USING A STAINLESS-STEEL FOIL TRAP FOR CONTROL OF CARBON. THE IMPURITY

LEVELS IN THE SODIUM ARE LESS THAN 15 PPM CARBON. LESS THAN 10 PPM OXYGEN, AND LESS THAN 5

PPM EACH OF IP.ON, CHROMIUM, AND NICKEL. EXPERIENCE TO DATE HAS SHONN THAT HIGH-PUPITY SCOIUM

CAN BE DISPENSED AND SAMPLED WITHGUT EXCESSIVE CONTAMINATICN.

\#CARBON + \#SODIUM + CHROMIUM + CONTAMINATION + DECONTAMINATION + IRON + NICKEL

$4-22484 \quad \triangle L S O$ IN CATEGORY 7

PLUMLEE DE + NOVAK PE 
CATEGORY
AEROSPACE SAFETY

4-22484 \#CONTINUED*

DIRECT IN-PILE MEASUREMENT OF THE CENTRAL TEMPERATURE OF A SODIUM-BONDEC MIXED-DXIDE FUEL PIN GENERAL ELECTRIC

1 PAGE, I FIGURE, 5 PEFERENCES, ANS TRANSACTIONS 1012), PAGE G39, (NOV. 1967), PDESENTED $\triangle$ T THE I967

WINTER MEETING OF THE AMERICAN NUCLEAR STCIETY, CHICAGO, ILLINOIS, NOV. 5-9, 19E?

- IN PREVIQUS EXFER IMENTS, SODIUM-BONCED MIXED-OXIDE FUEL SPECIMENS INDICATED GOCD SHORT-TERM PERFOR:AANCE UP TO LINEAR POWER GFNERATICN RATES CF $30 \mathrm{KWIFT.} \mathrm{SATISFACTOPYY}$ MIXED-OXIDE/SODIUM/CLADDING CCMPATIPILITY WAS OESERVED IN FUEL IFRADIATED TO 14 , LCO MWO/T AT POWERS UP TO $21 \mathrm{KW/FT.} \mathrm{BECAUSE} \mathrm{OF} \mathrm{THESE} \mathrm{PROMISING} \mathrm{R.SULTS,} \mathrm{AND} \mathrm{THE} \mathrm{LACK} \mathrm{OF} \mathrm{OATA} \mathrm{CONCERNING}$ THE EFFECT JF SODIUM ON THE THERMAL CONDUCTIVITY OF MIXED-OXIDE FIJEL, THIS EXPEFIMENT KAS DESIGNED AS PART OF THE FAST CEPAMIC REACTOR DEVELOPMENT PRJGRAM TO PERMIT THE CIPSCT MEASUREMENT JF THE CENTRAL FUEL TEMPERATURE OF A SOOIUM-BDNCED FUEL SPECIMEN WITH $\triangle$ HIGH-TEMPERATURE THERMCCJUPLE. THE RESULTS OF THIS EXPERIMENT SUPPORT THEORCTICAL CALCULATIONS CF IMPROVED THERMAL CONDUCTIVITY OF SODIUM-BONCED CUEL MAOE IN THE LITEDATUFE AND POINT TO THE POSSIBILITY OF ATTAINING SURSTANTIALLY HIGHER POWER DENSITIES IN

SODIUM-BJNDED MIXED-OXIDE FUEL COMPARED TC GAS-BONOED FUEL.

* DES IGN CRITERIA + \#FUEL BLIRNUP + \#FUEL ELEMENT + \#THERMAL EXPERIMENT + SODIUM

4-22486 $\quad A L S O$ IN CATEGQRY 7

HORN FL

SOME AEROSOL PROPERTIES DF VAPORIZED FAST-REACTOR FUELS

BROCKHAVEN NAT IONAL LAB.

3 PAGES, 1 TABLE, ABSTRACT IN ANS TFANSACTIONS 10(2), PAGE 609, (NCV. 1967), PRESENTED AT THE 1967 NINTER MEETING DF THE AMER ICAN NUCLEAR SOCIETY, CHICAGO, ILLINOIS, NOV. 5-9, 1967

THE NATURE AND COAGULATION BEHAVIOF CF AEROSOLS FORMED DURING THE HIGH-TEMPERATURE VAPORIZATION OF FAST-REACTOP. FUEL MATERIALS WERE INVESTIGATED. THE FUEL: MATERIALS, PUOZ AND UD2, WERE RAISED PAPIDLY ABOVE THEIR MELTING POINTS TO SIMULATE AN ACCIDENTAL RELEASE OF FUEL DURING A RFACTOP. POWER EXCURSICN. INOIVIDUAL STUDIES WERE MADF. WITH PUO2 VAPCRIZED $\triangle T$ TEOO C AND UO2 VAPORIZEO AT 3000 C INTO FOTH ARGON AND NITIROGEN GASES. IN ADDITION, CGMBINATIONS OF VAPORIZED PUOZ-UO2, AND NA VAPORIZEC INTO MOIST AIR ANO MIXED WITH VAPORIZING UOZ WEPE ALSC STUDIED. THE MAXIMUM PARTICLE SIZF, WHICH WAS REACHED AT ABCJT 24 H, WAS DEPENDENT UDON THE INITIAL MASS CCNCENTRATION. THE STANDARD DEVIATION GENERALLY REMAINED CONSTANT FCR $A$ PARTICULAR RUN, PUT INCREASED AS THE MASS CONCENTRATION DF THE RUNS WAS INCREASED. THERE WAS NO APPARENT CORRELATION DE COAGULATION CONSTANT WITH TIME, SURFACE-TO-VOLUME RATIO, CR MASS CONCENTRATION IN THE RANGE OF VALUES INVESTIGATED.

*AEROSOL PRODUCTION + \#FUEL MELTOOWN + \#PAPTICLE SIZE + \#PLUTONIUM + \#SODIUM + AEROSGL + AEROSOL PROPERTIES + ARGON + EVAPORATION + PLUTONIUM DIOXIDE + URANIUM DIOXIDE

4-22489 ALSO IN CATEGORY 7

IIUPIK LL HT, DERGLR 5

FISSION-PROOUCT DEPOSITION IN A FAST-BREEDFR REACTOR SYSTEM CONTAINING FAILED FUEL ELEMENTS ATOMICS INTERNATIONAL

15 PAGES, TABLES, FIGUPES, REFERENCES, NOVEMEER 3, 1967, ABSTRACT IN ANS TRANSACTIONS 10(2), PAGE 496, PRESENTED AT AMER ICAN NUCLEAR, SOCIETY WINTER MEETING, NOVEMBER 5-9, 1967, CHICAGO, ILLINOIS

A DESIGV OBJECTIVE FOR THE LIOUID-METAL FAST-BREEDER REACTCR (LMFBR) IS TO ALLOW FOR POSSIBLE JPERATION WITH SCME FAILED FUEL ELEMENTS, ANO IN ADOITION, TO PERMIT ACCESS TO THE HEAT-EXCHANGER CELLS $\triangle F T S R$ REACTOR SHUTDOWN. THE CONCEPT OF A SYSTEM-OEPLETION FACTOP PROVIDES AN INTERIM METHOD OF ESTIMATING THE FISSION-PPODUCT DEPOSITION RESULTING FROM FAILEO-FUEL-ELEMENT OPERATION. THE SYSTEM-DEPLETION CONCEPT IS PROPOSEO AS AN INTERIM METHOD OF MORE CLOSELY APPDOXXIMATING THE ACTUAL EXTENT OF DEPOSITION AND THE CONSEQUENT MAINTENANCE PROBLEM.

\#CESIUM + \#DEPOSITION + \#EISSION PRODUCT P.ETENTION + \#FISSION PRODUCT TRANSPOFT + \#REACTOR , LMCF + * SODIUM + CERIUM + IQOINE + REACTOR, FAST + RUTHENIUM + ZIRCONIUM

4-22514 ALSO I.N CATEGORY 7

ETTINGER HJ + MOSS ND + BUSEY H

CHARACTEQISTICS OF THE AEROSOL PRODUCED FPCM BUFNING SODIUM AND PLUTONIUM

LOS ALAMOS SCIENTIFIC LABORATORY, LOS ALAMCS, NEW MEXICO

14 PAGES, 6 TASLES, 15 FIGURES, NUGLEAF SCIENCE AND ENGINEERING 30, PAGES 1-13, 10CTDSER 1967)

SAFETY ANALYSIS OF SODIUM-COOLED PLUTONIUM-FUELEE FAST REACTGR PLANTS MUST BE CONCERNEO WITH THE POSSIBILITY GF FIRCS INVULVING THISS MATERIALS. DESIGN OF AN AIR CLEANING SYSTEM FOP SIJCH A FACILITY REQUIRES BASIC DATA DEFINING THE AEROSGL CHARACTERISTICS OF SCEIUM ANO PLUTONIUM RELEASED DURING A FIPE. WHEN PLUTCNIUM ALLOY WAS BURNED UNDER REDUCED CXYGEN CONOITIONS, THE FP.ACTION AIRBORNE RANGEO FROM $2 \times 10(-7 T H)$ TO $4 \times 10(-6 T H)$. FIFES INVOLVING PLUTONIUM ALLOY AND SODIUM TOGETHEP PPODUCEO AIKBORNE FLUTCNIUM-SODIUM RATIOS RANGING FROM 0.34 TO $0.008 \%$

\# AFROSOL PRODUCTION + \#FIRE + \#PARTICLE SIZE + \#PLUTONIUM + \#SCOIUM + AERJSOL PROPERTIES + METAL, LIQUIO + PARTICLE SIZE DISTRIBUTION + REACTOP, FAST + REACTOR, LMCR

$4-22515 \quad$ ALSO IN CATEGORY 7 
$4-22515 *$ CONTINUED*

NICHOLSRW + GITTIJS JH

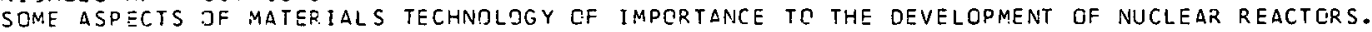

UNITED KINGDOM ATOMIC ENERGY AUTHORITY, RISLEY, ENGLAND

TRG-REPORT-1516 + . 30 PAGES, 19 FIGURES, 10 REFERENCES, MAY 26,1967

DESCRIBES THE EFFECTS OF IRRADIATION ANO CORROSION ON STRUCTURAL MATERIALS IN THE ADVANCED GAS-COOLED REACTOR AND THE HIGH TEMPEFATUFE GAS-CODLED REACTOR, WITH PARTICULAR MENTION OF THE INFLUENCE OF RESISTANCE TO CURKOSION GN THE SELECTION GF MATERIALS FOR HEAT EXCHANGEF TUSING AND FOF THERMAL INSULATION FOILS. A MAJOR PRGGRAM CF EXPERIMENTS INVOLVING A

STATISTICAL EXAIIINATION OF THIS PRCRLEM HAS HIGHLIGHTED THE ADVANTAGES ACCRUING FROM USE OF A FINE METALLURGICAL GRAIN SIZE. WITH F.ESPECT TO THE STEAM GENERATING HEAVY WATER REACTOR, MENTION IS MADE OF THE ASSFSSMENT CF ZIKCGNIUM ALLOY PRFSSURE TUBES FOR HYDROGEN AND IPRADIATIUV EMRRITTLEMENT AND A TECHNIQUF BASED ON MEASUPING THE CRITICAL CPACK OPENING DISPLACEMENT IS DESCRIISED WHICH MAY BE OF GENERAL VALUE FOR ASSESSING FRACTURE TOUGHNESS IN REL $\triangle T I O N$ TJ ENGINEFRING DESIGNS. MENTION IS MAOE OF SEVERAL ASPECTS OF THE CORROSION ANC MASS TRANSEER CF METALS IN LIUUID SCDIUM.

AVAILABILITY - UNITED KINGDOM ATOMIC ENERGY AUTHORITY

\#ALLGY + \#CORRISIJN + \#PADIATION EFFECT + \#STEEL + \#ZIRCONIUM + CARBON + MASS TRANSFER + METAL, LIQUID + REACTOR, GCR + REACTOR, POWEP.

4-22516 ALSO IN CATEGORY 7

THOMPSTN R + EVETTS MA + MOTT BW

A SODIIJM PURIFICATIUN ANO GENERAL HANDLING FACILITY

ATCMIC ENERGY RESSARCH ESTARLISHMENT, MFTALLURGY DIV., HARWELL

AERE-Q- $502+.12$ PAGES, 3 FIGURES, 2 TABLES, JULY 1967

GIVES AN ACCJUNT CF THE DESIGN AND PERFORMANCE OF A MOLECULAR SOOIUM STILL, TOGETHER HITH A VACUUM/GLDVE EOX FOR GENERAL HLNCLING OF THE PURIFIED METAL. ANALYSIS OF SODIUM BOTH BEFORE AND AFTER DISTILLATION HAS SEEN MADE ANO THE RESULTS REPORTED. IT IS CONCLUDED THAT IN GENERAL THE SYSTEM WORKS WELL, RUT, FOR THE PFODUCTICN OF MATERIAL OF GREATER PURITY, PARTICULARLY WITH RESPECT TO CARPCA, SOME MODIFICATIONS TO THE VACUUM SYSTEMS ARE REQUIRED.

AVAILABILITY - UNITEO KINGDOM ATOMIC ENERGY AUTHORITY, METALLURGY OIVISIJN, ATOMIC ENERGY RESEARCH ESTABL-ISHMENT, HAR NELL, SEOKSHTRF

\#COOLAVT CHEMISTPY + \#ECONTAMINATICN + \#METAL, LIQUID + \#RECOVERY PROCESS + \#SODIUM + CARBON + REACTOR. COOLANT

$4-22547$

WILLIAMSTN KO+ $3 \triangle P T L I T J R+$ THUKSTGN RS

STUDIES JF FORCED CONVECTION REAT TFANSFER TO CRYCGENIC FLUIDS

LOS ALAMOS SCIENTIFIC LAB', NEW MEXICC

LA-DC-871E + CONF-67110?-3+. 30 PAGES, 1.67 , FROM 6OTH ANNUAL MEETING UF THE AMERICAN INSTITUTE OF CHEMICAL ENGINEERS, NEM YORK

RECENT FORCED-CONVECTION HEAT-TRANSFER STUOIES FOR LIQUIO H2 AND LIQUID N2 WFRE DIRECTED AT STEADY AND OSCILLATING FLOW, CORP.ELATION OF DATA FROM MANY AUTHORS, AND INSTRUMENTATION

PRO3LEMS. DATA WERT OBTAINED IN PIPES FANGING IN SIZE FRCM $1 / 4$ TO 4.5 IN. IN INNER DIAMETER.

AVAILAPILITY - CLEARINGHOUSE FOR EEDEPAL SCIENTIFIC ANC TECHNICAL INFORMATION, SPRINGFIELO, VIRGINIA \$3. OO CGPY, \$O.65 YICROFICHE

CRYOGENICS + HEAT TRANSFEP. EXPERIMFNT + PIPING + THERMAL EXPERIMENT

4-22549 ALSO IN CATEGORY 7

KELLER DL

PROGRESS RELATING TO CIVILIAN ADPLICATIONS DURING OCTORER THROUGH DECEMBER 1 O66

BATTELLE AAEMGR IAL INST. COLUMBUS, GHIO

QMI-1701 + G6 PAGES, FIGURES, TABLES, JANUARY 1,1967

THIS PROGRESS FEPORT PRESENTS INFOFMATION ON THE FOLLOWING - URANIUM-PLUTONIUM MONONITRIDE FUEL MATERIALS, IRRADIATION EFFECTS IN REACTOR CLADOING MATERIALS, COATED-PARTICLE FUEL MATERIALS, CEFAMIC-COATED PLUTONIUM-EASE PAPTICLE FUELS, PYROLYTIC-CARBON-COATED URANIUM NITRIDE, GRAPHITE COATINGS ON FUEL PARTICLES, UOZ-PUO2 FUEL DEVELOPMENT; AND EFFECTS OF HIGH SURNUF CV UOZ-CEOZ AND UOZ-ZRO FUELS.

AVAILABILITY - CLEARI,JGHOUSE FJP FEDEPAL SCIENTIFIC AND TECHNICAL INFORMATION, SPRINGFIELD, VIRGINIA $\$ 3.00$ COPY, $\$ 0.65$ MICRCFICHE

*FUEL FLEMENT + \#PLUTGNIUM + \#TESTING + \#URANIUM + CAFEIDE + CARBON + CERAMICS + COATED PARTICLE + GIRRJSION + FUEL REPFICCESING + GRAPHITE + NITPIDE + OXIDE + STEFL, STAINLESS

4-22555 ALSC: IN CATEGORY 7

$A D W I C K A G+W A R M E R R J$

THE INFLUENCE OF PARTICLE SIZE DISTPIBUTICN ON THE SINTERING OF CERAMIC POWDERS 
ONE DF THE FACTCRS THAT CAN AFFECT THE SINTERED DENSITY OF A CERAMIC IS THE PRESSING BEHAVIGR. - THIS IN TURN IS INFLUENCED BY THE PAPTICLE-SIZE DISTRIBUTION. FROM AN ANALYSIS OF DATA GN THE DACKING OF DENSE SPHERES AND PACKING EXPEPIMENTS ON IRREGULAR SHAPED, COARSE CERAMIC PARTICLES A SER IES CF CURVES HAVE BESN DEF.IVED. IT IS CLAIMED THAT THESE CURVES CAN BE USEO TO RELATE THE INFLUENCE OF PAR.TICLE SIZE DISTRIBUTION CF THE PACKINC EFFICIENCY AND ULTIMATELY ON THE SINTERING BEHAVIOR. OF CERAMIC POWDERS. THE PARTICLE-SIZE DISTRIBUTIONS OF (U, PUIO2 POWDERS WERE MEASURED USING THE OPTICAL MICROSCOPE. THESE OISTR IBUTIONS HAVE BEEN CORRELATED WITH SUSSEQUENT PRESSING AND SINTERING BY MEANS OF THIS ANALYSIS. GQOD AGREEMENT HAS BEEN FOUND.

AVAILABILITY - PUBLIC RELATIONS BRANCH, UKAEA, RISLEY, WARRINGTON, LANCASHIRE

\#CERAMICS + \#PARIICLE SIZE UISTRIBUTION + \#PLUTONIUM OXIDE + \#URANIUM DIOXIDE + FUEL, POWDER TYPE + PARTICLE SIZE + DLUTLNIUM

$4-22557$

HASKIN WL

CRYOGENIC HEAT PIPE

AIK FURCS FLIGHT DYNAMICS LAB., WRIGHT-PATTERSON AFB, OHIO

$A D-657,025+A F F D L-T R-66-228+.49$ PAGES, 20 FIGURES, 5 TARLES, 24 REFERENCES, JUNE 1 O67

A HEAT PIPE IS A METAL TUSE CONTAINING A TWO-PHASE FLUID TO TRANSPORT HEAT OVER SEVERAL FEET BY EVAPORATING LIQUID AT THE WARM END AND CONOENSING THE VAPGR AT THE COLD END. AN EXPERIMENTAL HEAT PIDE WAS CONSTRUCTED AND INSTRUMENTEC TO PERMIT MEASUREMENTS OF THE HEAT TRAINSOCRT IN A NITROGEN VAPOR TURE WHEREIN THE VAPOR PRESSURE AND BOUNDAPY TEMPERATIJRES COULO BE MONITCRED. NO MAJOR FEFORT WAS MADE TO OPTIMIZE THE PERFORMANCE OF THE TUEE TESTED, EUT VARIOUS DESIGNS AND OPERATING PARAMETERS WERE INVESTIGATED EXPERIMENTALLY TO DETERMINE THEIF ECFECTS ON THE THERMAL IYPEDANCE OF THE TUBE. HEAT LOAOS OF UP TO 130 WATTS WEPE TPANSFERFED AXIALLY IN IHIS 3/4-IN.-0.D., 3-IN.-LONG HEAT PIPE WITH LESS THAN HALF THE TOTAL TEMPERATURE DROP REQUIPED SY A COPPEQ POD OF COMPARABLE SIZE. THE MAIN TEMPERATURE DROPS IN THE HEAT PIPE ARE DUE TO HEAT CONDUCTION THR OUGH THE TUBE WALL AND THE FLUID FILLFD WICK LINER OF THE EVAPRRATOR AND CCNDENSER SECTIONS. WHEN THE TUBE SUPFACE TEMPERATURES WERE NEAP. THE CRITICAL TEMPERATURF OF NITROGEN, VAPOR. FILM FOPMATION CAUSED A LARGE TEMPERATURE DROP.

AVAILABILITY - CLEARINGHOUSF, FGP, FEDEPAL SCIENTIFIC AND TECHNICAL INFORMATION, SPRINGFIELD, VA., \$3. OO COPY, \$O.65 MICROFICHE

\#CRYOGENICS + \#HEAT PIPE + \#HEAT TRANSFER EXPERIMENT + \#HEAT TRANSFER, CONDUCTION + AEROSPACE SAFETY + PIPING + THERMAL EXPERIMSNT

$4-\angle \angle S 68$

MCKEE JM

REMOVAL OF OXYGEN FROM SDOIUM

UNITED NUCLEAR CORP., ELMSFORC, N. Y.

AD-64824Z + UNC-5143+ AFAPI-TR-66-?7+. 63 PAGES, 12 FIGIJRES, 2 TABLES, REFERENCES, APRIL 1966

ANODIC ELECTROLYSIS OF OXIDE-COATED GETTERING ALLOYS IN SODIUM WAS EVALUATED AS A MEANS OF INCREASING THEIR OXYGEN-REMOVAL RATE. TWENTY-TWO ZIRCONIUM- ANC THORIUM-BASE ALLQYS WERE TESTED IN SODIUM THEPMAL CONVECTION LOOPS. DETECTABLE INCPEASES IN GETTERING RATE WEPE OBSERVED FOR UNALLOYED $2 I$ I CCONIUM ANC A FEW OTHER ALLOYS WHICH FORMED ADHERENT, DENSE, BLACK FILMS. THE GAINS WERE NOT LARGE ENOURH TO WARRANT DRACTICAL APPLICATION, APPARENTLY DUE TO HLLIKLNIL SHLIT I-CIFCUI IIMI; THROULH SMALL FILM DEFECTS SOME OF THE ALLOYS WHICH FORMED NONADHERENT, PCRGUS, WHITE FILMS ACHIEVEO HIGHER. REMOVAL RATES THAN HAD BEEN HOPED FCR FROM ELECTYULYSIS. ZR-13 A/D TI WAS THE EEST OF THESE. THIS ALLOY PRODUCED AN OXYGEN CONTENT CF LESS THAN 1 PPM IN SOOIUM AND MAINTAINED SIGNIFICANTLY HIGHEP. REMOVAL RATES THAN PUIKL

ZIRCONIUM AT ALL TEMPERATURES AND EXYGEN LEVELS.

AVAILABILITY - CLEARINGHOUSE FOP. FEDERAL SCIENTIFIC AND TECHNICAL INFCRMATION, SPRINGFIELD, VA., \$3. OO COPY, \$9.65 MICROFICHE

*FILM, GENERAL + \#DUT OF PILC LOOPS ANO EXPERIMENTS + \#OXYGEN + \#SODIUM + ALLOY + OXIDE + REACTOR, LMCR + THERMAL EXPER IMENT + ZIRCONIUM

$4-22698$

SCHAEFEK H + SULLIVAN,

RAOIATION MONITOE ING WITH NUCLEAR, EMULSIONS ON PROJECT CEMINI II. RESULTS ON THE I4-DAY MISSION GEMINI

VII.

NAVAL AERJSDACE MEDICAL INST, PENSACOLA, FLA

$A D-649335+N A M I-990+.21$ PAGES, 4 REFEPENCES, JAN. 11,1967

ON THE 14-DAY MISSION OF GEMINI VII, RADIATION MONITORING WITH SMALL PACKS OF NUCLEAR EMULSIONS WITHIN THE SPACE SUITS WAS CARQIED CUT IN THE SAME WAY AS ON MISSIONS GT-IV AND $V$ DESCRIBED EARLIEF. IT WAS A SINGULAR AOVANTAGE OF GT-VII THAT THE BACKGROUND OF THE NUCLEONIC COAPÜNENT. IN THE SEA-LEVEL/CONTROLS, WHICH THE EMULSIONS INEVITABLY ACCUMULATE DURING THE TIME BETWEFN MANUFACTUPF ANO DEVELOPMENT, WAS LESS THAN $4 \%$ OF THE FLIGHT EXPOSURE. 3Y TPACK EVALLATION OF THE GT-VII EMULSIONS, THEREFORE, A UNIQUE OPPORTUNITY AROSE TO OBTAIN STATISTICALLY SIGNIFICANT COUNTS IN SMALL FMULSION AREAS, THUS ALLOWING ANALYSIS CF LOCAL 
4-22698 *CONTINUED*

VARIATIONS JF THE LOW-ENERGY PROTON FLUX EVEN WITHIN THE SAME FILM SHEET.

AVAILABILITY - CLEARINGHOUSE FOR FEOERAL SCIENTIFIC AND TECHNICAL INFORMATION, SPRINGFIELD, VIRGINIA \$3.0O COPY, \$O.65 MICROFICHE

* AEROSPACE SAFETY + \#MONITOR, RADIATION, PERSONNEL + \#MONITORING SYSTEM, RADIATION + \#SPACECRAF

$4-22699$

SCHNEIDER MF + JANVI JF + BRENTNALL B

PROGRAM 631A. VOLUAE VI. EXPERIIAENT D8. RADIATION IN SPACECP.AFT.

AIR FORCE WEAPONS LAR., KIRTLAND AFB, N. MEXICO

$A D-646555+$ SSD-TR-66-115+. 272 PAGES, MAY 1966

DESCRIBES IN TECHNICAL DETAIL THE AIP. FORCE RADIAT ION EXPERIMENT DB, CARRIED DUT AS PART GF THE 63IA PRUGRAM ON THE VASA GEMINI FLIGHTS. THIS EXPERIMENT WAS CONCERNED WITH GATHER ING DOSE DATA LND DEVELCPING TECHNIQUES FURTHERING THE ART OF MANNED SPACECRAFT RADIATION DOSIMETRY SYSTEMS. INFORMATION FROM OS SHOULD BE OF SIGNIFICANT VALUE IN ENSUR ING MANNED MISSION SAFETY AND SUCCESS IN THE FUTURE. FROM THIS EFFORT, NFW AND INTRICATE

SPACEFL IGHT-WORTHY RADIAC SYSTEMS HAVE EVOLVED. THIS RADIATION EXPERIMENT CONS ISTED OF THE LATEST AVAILAELE PASSIVE DFVICES COMPLEMENTARY TO (AND CORRELATFD WITH) ACTIVE IONIZATIDN CHAMEERS, GIVING INSTANTANEQUS DOSE DATA.

AVAILABILITY - CLEARINGHOUSE FOR CEDEPAL SCIENTIFIC AND TECHNICAL \#AERDSPACE SAFETY + \#SPACECRAFT + RADIATIDN EFFECT + DOSE + DOSIMEINFORMATION, SPRINGFIELD, VIRGINIAA \$3.00 COPY,\$0.65 MICROF ICHE TRY, GENERAL + EXPERIMENT, GENERAL

$4-22700$

BENDER MA + GOOCHPC + KONDO S

THE GEMINI-3 S-4 SPACFFLIGHT-KADIATION INTERACTION EXPERIMENT

OAK RIDGE NATIONAL LAGORATORY, OAK RIDGF, TENNESSEE

22 PAGES, 6 FIGURES, 4 TABLES, 19 REFERENCES, PADIAT, RES, , 31 , PAGES 91-111 (MAY 1967)

TO TEST THE SUGGESTION THAT UNUSUAL RADIOBIOLOGICAL EFFECTS ARE ASSOCIATED WITH SPACEFLIGHT, THE S-4 EXPER IMENT WAS CARPIED OUT DURING THE GEMINI-3 MANNED SPACEFLIGHT. THE EXPER IMENT CONSISTED IN THE IRRADIATION OF DUPLICATE SERIES OF WHOLE-HUMAN-BLOOD SAMPLES SIMULTANEOUSLY ON THE GROUND AND $\triangle B O A R D$ THE SPACECRAFT DURING THE ORBITAL PHASE OF THE FLIGHT. AFTER THE MISSION, A CYTOGENETIC ANALYSIS WAS MADE TO DETERMINE THE FREQUENCIES OF CHROMOSOME ABERRATIONS. COMPARISON OF THE GRCUNO AND FLIGHT RESULTS SHOWED THAT, ALTHOUGH THERE WAS NO SIGNIFI CANT DIFFERENCE BETWEEN THE YIELDS OF MULTIPLE-BREAK ABERRATIONS, THE YIELD OF SINGLE-BREAK ARERRATIONS WAS SIGNIFICANTLY HIGHER IN THE FLIGHT SAMPLES.

* $\triangle E R O S P A C E$ SAFETY + \#IGMEDICAL + \#RADIOBIOLOGY + EXPERIMENT, GENERAL + RADIATION DAMAGE + RADIATION EFFECT + SPACECRAFT

4-23332 ALSO IN CATEITURLES Y ANO 17

STRAHL H

ITENTATION

SNAP SYSTEM INSTRUMENTATION

ANL-7380 $\rightarrow 3$ PAGES, 2 TABLES, 1 REFEPENCE, PAGES $37-39$ OF PROCEEDINGS OF THE SYMPOSIUM ON LIOUID METAL INSTRUMENTATION AND CONTROL, MARCH 2,1967

THE EXPERIENCE GAINED DURING OPERATION OF SNAP REACTORS WITH LIQUID-METAL PROCESS INSTRUMENTATION IS PRESENTED. THIS EXPERIENCE IS BASEO ON THE OPERATION CF SEVERAL SNAP REACTOR SYSTEMS AT TEYPERATUPES UP TO 1300 F FOR PERIOCS OF UP TO 10,000 HR. SEVERAL TYPES OF TEMPERATURE AND PRESSURE DEVICES WERE INSTALLED IN A LOOP, AND THEIR PERFORMANCES WERE COMPARED AND EVALUATCD PRIOR TO SELECTION DF INSTRUMENTATION FOR THE SEDR TESTS.

AVAILABILITY - CLEARINGHOUSE FOR FEDERAL SCIENTIFIC AND TECHNICAL INFGRMATION, SPRINGFIELD; VA. , \$3. OO COPY, \$0.65 MICROFICHE

* INSTRUMENTATION, PRCCESS + \#QPERATING EXPERIENCE SUMMARY + *SNAP, GENERAL (SR) + HIGH TEMPERATURE + INSTRUMENTATION, FLCh + INSTRUMENTATION, LIOUID LEVEL DETECTION + IINSTRUMENTATION, PRESSURE +

INSTRUMENTATION, TEMPERATURE + INSTRUMENTATION, TESTING + REACTOR, LMCR + REACTOR, SPACE

4-23391 $\triangle L S O$ IN CATEGORY I

MCALEVY RF + MAGEE RS

A CRITERION FOR SPACE CAPSULE FIRE HAZARO MINIMIZATION

STEVENS INSTITUTE OF TECHNOLOGY, HOBOKEN, N. J.

1 PAGE, JOURNAL OF SPACECKAFT ROCKETS 4(10), PAGE 1390 (OCTOBER 1967)

STEVENS INSTITUTE IS ENGAGED IN A FUNDAMENTAL STUDY OF THE MECHANISM OF FLAME SPREADING OVER THE SURFACE OF IGNITING SOLIO MATERIALS. P.ESULTS HAVE BEEN PRODUCED THAT HAVE IMPLICATICNS CONCERNING THE FIRE HAZARD ASSOCIATED WITH OXYGEN-RICH ENVIRONMENTS. AS A CONSEQUENCE OF THE SUBJECT PROGRAM, A RATIONAL BASIS FOR THE SELECTION OF MANNED CAPSULE ENVIRONMENTS HAS EMERGED FOR MINIMIZATION OF THE PATE OF FLAME SPREADING AFTER ACCIDENTAL IGNITIGN.

\#FIRE + \#IGNITIDN + \#OXYGEN + AEROSPACE SAFETY + SPACECRAFY 


\section{CATEGOPY
AEPOSPACE SAFETY}

4-23855

JOHNS RH + KAUFMAN A

FILAMENT-OVFRWRAPPED METALLIC CYLINDRICAL PPESSURE VESSELS

NASA LEWIS RESEARCH CENTER, CLEVELAND, OHIC

6 PAGES, 8 FIGURES, 2 TABLES, 8 REPERENCES, J. SPECFCRAET ROCKETS 4(7), PAGE 8.72-877, (JULY 1967)

THE INFLUENCE OF MATERIAL PROPERTIES OF A WRAPPER PRESSURE VESSEL IS DETERMINED THEORETICALLY. QVERCOMING THE DIFFERENCE IN YIELD STRAINS OF NRAPDING AND EASE MATERIALS BY WINDING POETSNSIDN AVD PLASTIC FLOW OURING RRFSSURIZATICN ISS CCNSIDEFED. RESIDUAL STIESSES IN THE WRAPPING AND IN THE AETAL CYLINDEF ARE DISCUSSES. P. V. EFFICIENCY IS DFTER: INED AS A FUNCTION OF ALLOKASLE COMPRESSIVE STRESS IN THE METAL. BUCKLING TESTS INDICATE THAT RUCKLING OF THE SHELL CUE TO DRETENSION IN THE WINDING PROBABLY WILL NOT RE A PRTELEM IN SPACE APPLICATIONS. FAILURE OF THE METAL SHELL OFTEN IS DUE TO TENSILE INSTABILITY AT HIGH PRESSURSS IN THE 1.1 STFESS FIELD IMPCSED. A DEFORMATION THEOFY ANALYSIS $\triangle G R E E D$ WELL WITH THE RESULTS OF 19 OF 20 TESTS OF $5.6-I N$. -DIAM AL CYLINDEF.S WPADPED WITH GLASS IMPE.EGNATED WITH EROXY RESIN. THE WRARRED VESSELS WERE UR TO 50 \% MOFE EFFICIENT. FACTORS OF SAFETY (EURST PRESSUPE) MAY BE $40 \%$ HIGHER THAN THOSE BASED CN STRESS IN THE METAL.

*MODEL TESTING + \#PRESSURE VESSEL + SPACECRAFT + STPESS ANALYSIS 


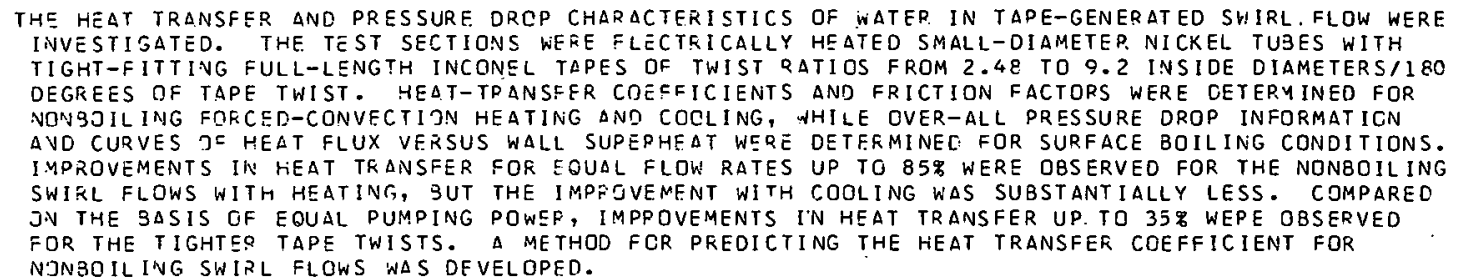
NONBOIL ING SWIRL FLOWS WAS DEVELOPED.

AVA ILAEILITY - R.F. LGPINA AND A.E. BERGLFS, MASSACHUSETTS INSTITUTE GF TECHNOLDGY, NATIONAL MAGNET LABORATJRY, CAMBR IDEE, MASS.

FLOW, TNO PHASE + FLGN, VDFTEX + FUEL ELEMENT + HEAT TRANSFER AUGMENTAT ION + HEAT TRANSFER, BOILING

$5-10543$

EDFSKUTY CJ + THURSTON RS

SIMILARITY OF FLOW OSCILLATIONS INDUCED BY HEAT TRANSFER IN CRYOGENIC SYSTEMS

LOS ALAMOS SCIENTIFIC LAR., NEW MEXICQ

$L A-D C-8505+C O N F-57 C$ IL-1 $1+22$ PAGES, 1967

FLOW OSCILLATICNS AT ACCUSTIC FREQUENCIES ARE OFTEN ORSERVED DURING FORCED-CONVECTION HEAT TRANSFER TO CFYOGENIC LIQUIDS. THIS PHENOMENON OCCURS IN TWO-PHASE FLOW AND AT SUPERCRITICAL PRESSURES NHEN THE FLUID UNDEPGOES A LARGE CHANGE IN DENSITY SIMILAR TO A PHASE CHANGE. IT HAS BEEN PJSTULATED THAT THE USCILLATIONS ARE GENERATED .DURING FILM BUILING BY THE THERMAL RESPONSE OF THE VAPOR FILM TO FLOW OISTRUBANCES. THFOUGH THE USE OF DIMENSIONLESS SIMILARITY NUMBERS, A COREELATION IS SHGWN TO APPLY TO NEW DATA ON LIOUIO NITROGEN AND LIQUID HYDROGEN IN 1/4-IN. I.D. ANO 0.0. SYSTEMS. THE 16-FOLD GEOMETRICAL SCALING VERIFIED THE SUITABILITY DF APPLYING THE CSCILLATION INCEPTICN CRITERION TO $\triangle V O I D$ OSCILLATIONS IN A WATER-TJ-LIJUIE-HYDROGEN HEAT EXCHANGER, WHICH SERVES AS AN ENERGY SOURCE FOR A TURBO-PUMP USED DURING VUCLEAR GOCKET ENGINE TESTS.

AVAILABILITY - CLEAPINGHOUSE FOR FEDERAL SCIENTIFIC AND TECHIICAL INFORMATION, SPRINGFIELD, VIRGINIA \$3. OO COPY, $\$ 0.65$ MICROFICHE

CQYOGEVICS + FLOW STAPILITY + FLDN, PULSATING + HEAT TRANSFER, ROILING + HEAT TRANSFER, CONVECTION

$5-19544$

IUNG LS

LOCAL SOIL ING VOID FOP CALCULATING MODERATOR COEFFICIENT

WESTINGHOUSE ELECTRIS CL̈., PITTSBURGH, PA.

CONF-S7OGO2 +. ABSTF ACT IN ANS TRANSACTIONS 1O(1), PAGE 357, PRESENTED AT AMERICAN NUCLEAR SOCIETY ANNUAL MEETIVG, JUVE $11-15,1$ I T, SAN DIEGO, CALIFORNIA

PRESENTS A IMETHCO FOF CALCULATING THE LOCAL BOILING VOID CONCENTRATION FOR PWRS. THE VOIO CONCENTRATIONS SC. CALCULATED MAY EF USED WITH THE COMPUTER COOE REVO PROPOSED BY WCAP.

FLOri, TWJ PHASE + HEAT TRANSFER ANALYSIS + REACTOR, PWR + VGIO COEFFICIENT

5-2131C ALSC IN CATSGORIES 6 ANC \&

WALTER C + GEVCO JU

NURLOC-1.0 A OIGITAL COMPUTSO PROGZAM FOR THERMAL ANALYSIS OF A NUCLEAR-REACTOR LOSS-OF-COOLANT ACCIOENT BATTELLE MEMJRIAL INSTITUTE, COLUMSUS, OHIC

BMI-1907 +. 319 PAGES, FIGURE5, TAELES, REFERENCES, JULY 6,1967

NURLOC-1.0 CONTAINS MATHE:1ATICAL MODELS FRP MOST OF THE FROCESSES OCCURP. ING IN A PEACTOR ACCIDENT WHICH AFFECT THE SOLID ANO FLUIO TEMPEPATURE DISTRIBUTIONS. MODELS WERE DEVELOPEO AVO PROGRAHMEO FGR HFAT CONDUCTION, HEAT GENERATION, THERMAL RADIAT ION, BOIL-OFF, MELTDOWN, POSTBLOWDO:N HEAT AND MASS-TFANSEER COEFFICIENTS, $\triangle N O$ METAL-WATER REACTION. TEST CASES DF ACCIDENT HEAT TQANSFER IN THE LDFT REACTCR WERE CALCULATED FGR TIMES UP TO 400 SEC.

CALCULATIONS VIEPE ALSO PERFORMEO FQR A TYPICAL GDO-MLIT) BWR FOR A SIMILAR PERIOD OF TIME. A TYPICAL 100 O-M.WI (E) PWR GAVE TEMPEPATURE AND METAL-WATEP REACTIONS MUCH DIFFERENT FROM THCSE FOP. LOFT. THE PFRCENTAGE JF CLADEING D.EACTED WAS LESS BY MGRE THAN A FACTOR OF TWD FOR THE 10OO-MW(E) PEACTCR THAN FOR LOFT FER SIMILAR PERIODS OF TIME.

AVAILAOILITY - CLEAQINGHOUSE FOR FFDFEAL SCIENTIFIC AND TECHNICAL INFGRMATION, SPRINGFIELO, VA., \$3. OO COPY, SO.SS MICROEICHE

ACCIDFYT, LOSS OF GOOLANT + ACCIDENT, MAXIMUM CREDIRLE (MCA) + COMPUTER PROGRAM + REACTOR, GENEPAL + 


\section{ACC COTERTORY 5 ANALYSIS}

5-21319 *CONTINUEO*

REACTOR, WATEA

5-21320 ALSO IN CATEGORY 12

EIBER RJ + MAXEY WA + DUFFY AR + ATTERBURY TJ

INVESTIGATION OF THE INITIATION ANO EXTENT OF DUCTILE OIPE RUPTURE. QUARTERLY PROGRESS REPORT FOR JULY-SEPTEMBER, 1767.

BATTELLE MEMORIAL IVSTITUTE

BMI-1817 +. 15 PAGES, 12 FIGURES, 2 TABLES, 3 PEFERENCES, OCTOBER 1, 1067

RUPTURES TESTS WERE MADE ON SIX PIPES, 24 IN. $00 \times 1.5$ IN. WALL THICKNESS, MADE CF AIOGB MATERIAL. ALL TESTS WITH SURCOOLED WATEF SHOWED RELATIVELY SHORT DUCTILE FRACTLRE. TESTS WITH WET VAPTQ PRMPRGATFD AN END-TO-END FPACTURE AT A PRGPOCATION SPEED OF 750 FT/SEC.

AVAILABILITY - CLEARINGHOUSE FDR FEDERAL SCIENTIFIC AND TECHNICAL INFORMATION, SPRINGFIELD, VA., \$3.00 COPY, \$O.65 MICRDFICHE

ACCIDENT, LOSS OF CDOLANT + ACCIDENT, LOSS OF PRESSURE + FAILURE, PIPE

$5-21321$

TABIC 5

DIGITAL COMPIJTER. BLOWDOWN ANALYSIS FQP. LOSS-GF-FLUID TEST FACILITY. PART I ENGINEER ING

KAISER ENGINEERS, OAKLAND, CALIF.

TID-24031 +. 73 PAGES, PEFERENCES, MAY 1965

THIS COMDUTER PRUGRAM ADPLIES TO BLOWDOWN CF THE PRESSURIZED-WATER REACTOR PRIMARY CQGLANT

LJOPS. THE LEOPP CONTAINS A PEACTOK, PUMF, CHECK VALVE, HEAT SXCHANGER, ANO PRESSURIZER. ONE-DIYENSI JVAL AND TRANSIENT MASS BALANCE, FORCE BALANCE, AND ENERGY BALANCE EQUATICNS, FOR BOTH THE FLUID AND THE WETTED WALLS, ARE SOLVED NUMERICALLY, USING THE FIRST-ORDER

DIFCERENCES IN BOTH TIME AND SPACE. THE COMPRESSIBILITY OF THE FLUID, DUE TO A CHANGE IN

PHASE (FGOM LIDUID TO STEAM), IS INCLUDED, AS WELL AS THE LOCAL HEAT TRANSFER FRCM THE WALLS.

FAUSKES CRITICAL FLCW OELATION IS MADF TO APPLY AT THE RUPTURE, AND SCHROCK AND GPOSSMANS TWO-PHASE PRESSURE DROP CORRELATION IS INCORPORATED IN THE FERCE BALANCE EQUATION. STEAM

TABLES, CODEJ IN FUNCTION FOFM, PKCVIDE THE EQUATIONS OF STATE FOR THE TWO-PHASE-

THEQMIODYNAMIC EDI.'ILIRPTIIM IS ASSUMED TO APPLY OUPING BLOWDCWN.

AVAILABILITY - CLEARINGHOUSE FOR FEDERAL SCIENTIFIC ANC TECHNICAL INFORMATION, SPRINGFIELO, VA., \$3. OO COPY, SO.65 MICRNIEICHE

ACCIDEVT, LOSS OF COCLANT + COMPUTEF, DROGRAM + COMPIITFF, OIGITAL + LOFT (S-RR) + REACTOR, PWR + REACTIR, SARLTY DESEARCM

$5-21322$ - ALSO IN CATEGCPIES G AND 2

KINETIC STUDIES DF HETERTGENEOUS WATER PEACTCRS. ANNUAL SUMMARY FEPDRT, 1966

TRW SYSTEMS GROUP, REDONDO BLACH, CALIF.

STL-372-50+. 129 DAGES, 57 FIGURES, 3 TABLES, 44 FEFERENCES, DECEMBEF 1966

ANVIIAL SIMYARY P.FPORT-1965. SUMMARIZED WORK ON - I1) THE PPOCESS OF THERMAL PRESSURE

GENERATION, (2) SHOCK-TIJPE EXPERIMENTS, (3) POSSIBILITY OF DESTRUCTIVE IN-CORE PPESSURE IN MELTDONN ACCIOENT, (4) IN-PILE CAPSULE MEASUREMENTS OF STEAM-VOID FORMATION, AND (5) POWER PCACTOR INSTAEILITY ANO TWO-PHASE FLUK.

AVAILASILITY - CLEARINGHOUSE FOR FECIEFAL SCIENTIFIC AND TECHNICAL INFORMATION, SPRINGFIELD', VA., \$3. OO COPY, \$0.55 AICRCF ICHE

ACCIDENT, PFACTIVITY + EXPLOSION + FLGW, TWO PHASE + REACTOR TRANSIENT + REACTOR, WATEF. + TRANSFEF FUNCTION

$5-21323$

SNOW AL

DETERMINATION OF LOADS TO CREATF A FULLY PLASTIC PIPE CROSS SECTION

BETTIS ATOMIC POWER LABORATORY, PITTSBURGH, PA.

WAPח-TM-KG +. 43 PASES, REFERENCEES, JUNE 1057

ONE OF THE FAILURE MODES OF PIPING SYSTEMS IS GROSS YIELOING. IF PIPE LOAOINGS $\triangle R . E$ RESTRICTEO

TO VNLUES WHICH EXCLLIIDE FIII I Y PLASTIC CRCSS SECTIONS, GROSS YISLDING OF THE PIPE WILL NOT

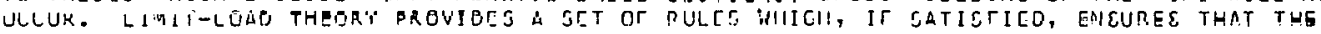

P.ESULTING LDAOS ARE AT TR RELOW THE VALUES WHICH INITIATE GROSS YIELOING. A PRCCEDURE HAS

PREVIDUSLY SEEN OEVELOPED WHICH ESTIMATES THE LIMIT LOADS INEGLECTING THE SHEAR LOADI OF AN

CLASTIC-PERFECTLY PLASTIC PIPE WHICH CBEYS THE TRESCA YIELD CRITERION. THIS REPOPT OETAILS

THE EXTENSION OF THAT ANALYSIS TO INCLUDE SHEAR EEFECTS AND GIVES LIMIT LOAOS FCF BOTH TRESCA ,
AND VON MISES CRITERIA.

AVAILABILITY - CLEARINGHOUSF FOR EEDERAL SCIENTIFIC ANO TECHNICAL INFORMATION, SPEINGFIELD, VA., \$3. OO COPY, $\$ 0.65$ MICRDFICHE

PIPING + PIASTIGITY + STRESS ANALYSIS 
CDTEGORY 5
ACCIDENT ANALYSIS

5-21475 ALSO IN CATEGORIFS O $\triangle N I 17$

TECHNOLOGY OF ROILING WATER REACTOR STABILITY ANALYSIS

GENERAL ELECTR IC COMPANY

75 PAGES, 49 FIGURES, 16 REFERENCES, 4 TABLES, MEMORANDUM SCER-60, DOCKET 50-277 AND 278 , TYPE--BWR, MFG--G.E., AE--BECHTEL, JULY 1967

(INCORPORATED IN PEACH POTTOM PSAR SUPPLFMFNT 2.) ASSERTED GQOD AGREEMENT BETWEEN FABLE-II PRDGRAM AND KRR/GARIGLIANO ROD-OSCILLATOR DATA. APED HYDROEYNAMIC LOUP ENSURES SUCCESSFUL USE IN EXAMINING INTERCHANNEL HYOFODYNAMIC STABILITY. MODEL SUMIAARIZED, BUT DATA (4O GPAPHS) IS POORLY DISCUSSED TO SUPPORT THE ASSERTION.

AVAILABILITY - USAEC PUBLIC DOCUMENT ROOM, WASHINGTON, D. C.

\#COMPARISON, THEORY AND EXPERIENCE + \#COMPUTER PROGRAM + \#FLOW STABILITY + PEACH BOTTOM 2 AND 3 (BWR) + REACTOP. STABILITY + REACTCR, BWR

$5-21810 \quad \Delta L S O$ IN CATEGORY 17

BIG ROCK POINT SUPPLIES ADDITION INFCPMATION ON PROPOSFD CHANGE IB--RESULT OF TWD-PUMP TRIP ANALYSIS

CONSUMERS POWER COMPANY

2 PAGES, DOCKET 50-15E, TYPE--BWR, MEG--G.E., $\triangle E--B E C H T E L$, DECEMBER, 14,1967

ANALYSIS OF 2-PUMF TRIP FOR END OF LIFE AND BEGINNING OF LIFE, AND FOR $7 \times 7,8 \times 8, \quad A N D$

TYPE-C $(11 \times 11)$ FUFL. TABLE GIVES POWER, CORE FLOW, AND MCHFPS VS TIME 0 , 1--

TRIP. MCHFR IN ALL CASES INCREASES WITH TIME (MINIMUM IS AT T EQUALS ZERO).

aVAILABILITY - USAEC PUBLIC DOCUMENT ROOM, WASHINGTON, D. C.

* ACCIDENT, LOSS OF FLOW + \#BURNOUT HEAT FLUX + \#CENTERLINE MELTING + RIG ROCK POINT (BWF) + REACTCR, BWR + TECHNICAL SPECIFICATIONS

5-22116 ALSO IN CATEGORIES 7 AND 14

KRESS TS + NELSONP

NUMERICAL SOLUTION JF THE ISOTHERMAL'FISSION-PRODUCT DEPOSITION EQUATIONS. THE PROGRAM PREOEP-II

OAK RIDGE NATIONAL LAE., TENN.

ORNL-TM-1970+. 28 PAGES, 3 FIGURES, 2 REFERENCES, OCT, 1967

THE HEAT-MASS AIVALOGY WAS PREVIOUSLY USED TO DEVELOP A SEMILINELR SYSTEM OF PAPTIAL DIFFERENTIAL EQUATIONS TO DESCRIEE THE ISOTHEPMAL DEPOSITION OF FISSION PRODUCTS. IN THIS REPORT, THIS SYSTEM IS TRANSFORMED INTO A SYSTEM OF INTEGRAL EQUATIONS IN COMPUTATIONALLY CONVENIENT VARIAELES, AND A FINI TF-DIFFERENCE METHOD FOR THE SCLUTION OF THE INTEGRAL EQUATION SYSTEM IS DESCRIBED. $\triangle$ RRIEF DESCRIPTION IS GIVEN CF THE COMPUTER PROGRAM PREDEP-II, WHICH ACCEPTS DATA IN TEPMS OF PHYSICALLY CONVENIENT DIMENSIONLESS VARIABLES, TRANSFORMS THESE TO THE COMPUTATIONAL VAPIABLES FOR MEANS OF SCLVING THE FINITE-DIFFEPENCE EQUATIONS, AND FINALLY REPORTS THE RESULTS IN TERMS OF THE PHYSICAL VARIAELES.

AVAILABILITY - CLEARINGHGUSE FOR FEDERAL SCIENTIFIC AND TECHNICAL INFORMATION, SPRINGFIELD, VIRGINIA,

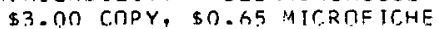

COMPUTER PROGRAM + DEPOSITION + FISSION PROOUCT TRANSPORT + FISSION PRODUCT, NONVOLATILE

5-22140 ALSO IN CATEGORIES 6 ANO 17

MANHATTAN COLLEGE ZPR MODEPATOR COEFFICIENT MEASUREMENTS

MANHATTAN COLLEGE, BPONX, NEW YORK

45 PAGES, 5 TABLES, DQCKET 50-199, DECEMRER 24,1967

AT DRL DIRECTION (NOV. 2, 1060) MZPR MEASURED THE EXCESS REACTIVITY AT THE TEMPERATURE AT WHICH THE MODERATOR COECFICIENT CHANGES FROM POSITIVE TO NEGATIVE. A HEAT EXCHANGER, A MIXER, AND 12 T.HERMISTORS WERE BOUGHT, THE MIXER C AUSEO VORTEXING AND MOVEMENT OF

INSTRUMENTATION AND LIGHTS IN THE CORE AND HAD TO BE MODIFIED. WITH IO THERMISTORS IN THE

. CORE AND CONTROL ROOS FULLY WITHOFAWN, THE REACTOR WAS SUBCRITICAL DUE TO THE POISON EFFECT OF THE COPPER LEAD WIRES. RESULTS OF THE EXPERIMENT WERE - TURNAROUND TEMPERATURE - IIO F, EXCESS REACTIVITY $\triangle T 110 \mathrm{~F}$ - $0.44 \%$, WORTH OF 5 PAIRS OF THERMISTOR LEADS - $0.10 \%$, LEAST-SQUARES TEMPERATURE/REACTIVITY RELATIONSHIP - (OELTA K/K) $\%$ IS EQUAL TO- $35.83 \times$ $10(-2 N D)$ PLUS $100.67 \times 10(-4$ THI TIMES T MINUS $45.53 \times 10(-6 T H)$ TIMES T SOUARED. PROBAELE ERROR IS $2.1 \times 101-4 T H$ ) $\%$. (INCLUGES 25-PAGE TABLE OF THERMOCOUPLE CALIBRATION.)

AVAILABILITY - USAEC PUBLIC DOCUMENT ROOM, WASHINGTON, D. C.

*MODERATOR COSFFICIENT + *REACTIVITY, EXCESS + *TEMPERATURE COEFFICIENT + CRITICAL ASSEMELY FACILITY + IN CORE MEASUREMENT + MEASUREMENT, GENERAL + REACTIVITY EFFECT, ANOMALOUS + TECHNICAL SPECIFICATIONS

5-22142 $\quad$ ALSO IN CATEGORIES 17 ANO 12

STATUS OF ORESDEN I CORE SPRAY SYSTEM

COMMONWEALTH EDISON COMPANY, CHICAGG, ILL. 
5-22142 *CONTINUED*

1 PAGE, DOCKET 5O-10. TYPE--9WR, MFG--G.E., AE--BECHTEL, DECEMEER 19, 1967

GE RE-EVALUATED THE DESIGN-BASIS ACCIDENT ANC IS DESIGNING AN EMERGENCY CORE-SPRAY SYSTEM. DRESDEN REPORTS THAT THE DESIGN AND ANALYSIS WORK DN THIS SYSTEM IS $25 \%$ COMPLETE, EXPECTED TO BE COMPLETE BY MARCH 1, 1968 .

aVAILABILITY - USAEC PUPLIC DOCUMENT ROOM, WASHINGTON, D. C.

\#CQRE SPRAY + \#MODIFICATION, SYSTEM OR EGUIPMENT + DRESOEN I (BWR) + EMERGENCY COOLING CONSIDERATIONS + REACTOR, BWR

5-22225 ALSO IN CATEGRRY 17

PATHFINDER ATOMIC POWER PLANT SAFEGUAROS ANALYSIS FOR SECOND CGRE LGAOING

ALLIS-CHALMERS, BETHESDA, MAPYLAND

ACNP-S7525 +. 108 DAGES, 15 FIGURES, 33 TABLES, REFERENCES, DCCKET 50-130, TYPE--BWR, M.FG--A.C., AE-DIONEER SERV., JUNE 30,1967

DSSCRIBES AND EVALUATES COPE-I I COMPCNENT CHANGES - 11 LOW-ENR. ICHMENT QXIDE SUPERHEATER FUEL IIN PLACE DF FULLY ENRI CHED CERMET FUEL) FOP LONGER FUEL LIFETIME AND ECONOMY. (2) B 4C PELLET IN INCUNEL TLIBE IN SAME CRIICIFIRM PATTERN TO REPLACE PRESENT SCL ID BORCN-SS ROILEP. CONTROL BLADES. (3) BOILER FUEL RGDS ARE THE SAME DIAMETEP IN THE UPPER AND LOWER CORE HALVES (COP.E-I FUEL HAS STEPPER-DIAMETER RODSI, BUT WATER-TUEES WILL REPLACE SOME FUEL IN THE UPDER HALF TO COMPENSATE FOP STEAM VOIDING. COMPLETE CHANGES WILL TAKE DLACE OVER SEVERAL REFUELING. REACTOD DYNAMICS, THERMAL ANALYSIS, AND ACCIDENT ANALYSIS REPEATED.

EXPERIMENTAL JUSTIFICATION MADE FOP, REVISEO ANALYSIS METHODS.

AVAILABILITY - USAEC PUELIC DOCUMENT ROOM, WESHINGTON, D. C.

\#REFUELING + CONTROL ROD BURNUP + FUEL ELEMENT + MODIFICATION, SYSTEM OR EQUIPMENT + PATHFINDER (ISR) + P.EACTOR, BWR + PEACTOR, INTERNAL SUPEPHEAT + PEPCRT, OPERATIONS ANALYSIS + SAFETY ANALYSIS +

TECHNICAL SPECIFICATIONS

5-22236 ALSO IN CATEGORIES 18 ANC 9

ACES REPORT ON DIABLO CANYON

U.S. ATOMIC ENERGY COMMISSION, WASHINGTON, D. C.

5 PAGFS, 11 REFERENCES, DOCKET 50-275, TYPE--PWR, MFG--WEST, AE--PG+E, DECEMBER 20,1967

ACRS BELIEVES THAT THE FOLLDWING o ITEMS PERTAIN TO ALL LARGE WATER-COOLED POWER P.EACTORS (1) THERMAL. SHOCK EFFECT OF COLD WATER INJECTION IN LOSS-OF-COOLANT ACCIDENT,. (2) SFFECT OF BLOWDCWN FORCES ON CDRE AND PRIMAPY SYSTEM COMPONENTS, (3) EFFECT OF FUEL FAILURES ON

EMEDGENCY COOL ING ABILITY. (4) INDEPENDENCE OF CONTROL ANE PROTECTICN

INSTRUMENTATION--PRESENT DESIGN INADEOUATE, (5) PROMPT OETECTION OF GROSS FUEL FAILURE, (6) PRIMARY -SYSTEM QUALITY CONTP.CL AND IN-SERVICE INSPECTION. \#\# FIXFD PRISON IBDROSILICATE GLASSI DURING FIRST CYCLE TO ENSURE NEGATIVE MOCERATOR COEFFICIENT NEEOS MORE PERFORMANCE DATA.

AVAILABILITY - USAEC DUBLIC DOCUMENTT ROOM, WASHINGTON, D. C.

\#BLOWDOWN + \#RESSURE VESSEL + \#THERMLL MECHANICAL EFFECT + ACCIOENT, LOSS OF COOLANT + ACFS + CONTROL ROD PROGRAM + CDRE RFFLOODING SYSTEM + DIAPLO CANYON (PWRI + EMERGENCY COOLING CONSIDERATIONS + FAILURE, FUEL ELEMENT + FAILURE, FUEL CLEMENT + INCEPENDENCE +

INSTRUMENTATION, DETSCTION FAILED FUEL ELEMENT + MOOERATOR COEFFICIENT + PLANT PROTECTIVE SYSTEM + POISON, FIXED + REACTOR, PWR

$5-22257$

MOORE JQ

SAN ONOFRE INVESTIGATES HIGH DELTA-T ACROSS B STFAM GENERATOR

SOUTHERN CALIFDRNIA EOISON CO., LOS ANGELES, CALIF.

3 PAGES, ATOMIC EVERGY CLEARING HOUSE 14(3), DAGES 18-20 (JANUARY 15, 1968), DOCKET 5C-206, TYPE--PWR, MFG--WEST., AE--9ECHTEL

(LETTER, JANUACY 5) SINCE POWER TESTING IN JULY, CALORIMETRIC MEASIJREMENTS OF PRIMARY AND SECONDARY DIFFER BY 4 TO 1O\%. SIX ERRATIC RESISTANCE TEMPERATURE-DETECTORS IN THE PEACTCR LOOP WERE REPLACED IN NOVEMPER. IN UECEMHER, AT 405 MWE ICOQ LCADI, THE SG DELTA-T WAS 40/48/44 F FTR A/B/C STEAM GENERATCRS, GIVING THE AVERAGE PREDICTED FOR 450 MWE (100\%). ACCOROING TO RESLLTS OF ANALYSIS SINCE THEN, RTDS ARE DCCURATE, BUT PIPE LOCATION AFFECTS INDICATED TEMTERATURE 5 TO $10 \mathrm{~F}$. PUMP FLOWS DRF DIFFFRFNT (B. PUMP LOWEST). THE RANGE BLING FROM 112 TO QL\%, DEPENDING ON METHCD. UNIT IS BEING HELO AT 3 RD-VALVE POINT (4OS MWE), WITH ALARMS SET ACCCRDINGLY. FOR FURTHER STUDY.

*REACTOR POWER + COMPARISUN, IHEUKY ANO EXPERIENCE + FLOW ORIFICE + FLDW, GLNLRAL ; INSTRUMENTATION, ABNORNAL INDICATION + INSTRUMENTATION, TEMPERATURE + OPERATING EXPERIENCE SUMMARY + PUMP + REACTOR, PWR + SAN ONOFRE (PWR) + STEAM GENERATCR

5-22456 ALSG IN CATEGORY 17

EBR. II MEASUREMENTS QPF FROMPT POWER COEFFICIENT FOILED

ARGONNE NATIONAL LAS., ARGOVNE, ILL. 
$5-22456$. $\quad$ CONT INUEO*

ANL-7399+. 7 PAGES, 5 FIGUPES, 2 TABLES, PAGE $48-54$ OF ARGONNE NATIONAL LABORATORY. REACTOR DEVELOPMENT PROGRAM PROGRESS REPQRT, NOVEMBER 1967

TRANSFER FUNCTIONS WERE MEASURED. THE WORTH OF THF ROD USEO IN ROD-DROP EXPERIMENTS CHANGES ABOVE THE 0.5-MW CALIBRATIDN LEVEL. DURING THE DROPPING OF THE ROD, IT SEEMS THAT ROO WCRTH INCREASES ENTUGH TO CANCEL THE EFFECT OF PROMPT NEGATIVE FEEDSACK FOR O.3 SEC. TOTAL FEEDEACK IS ABOUT 0.33 CENT. REACTIVITY DIFFERENCES BETNEEN FULL-POWER FLOW AND REDUCED-POWEP. FLOW CONDITIONS SEEN TO BE STEADILY INCREASING WITH CUEL BURNUP.

AVAILABILITY - CLEARINGHOUSE FOR FEDERAL SCIENTIFIC AND TECHNICAL INFORMATION, SPRINGFIELD, VIRGINIA, $\$ 3: 00$ COPY, \$0.65 MICROF ICHE

*CONTROL FOO WORTH + \#POWEP COEFFICIENT + \#TFST, PHYSICS + CONTROL ROD CALIBRATION + EER I $\triangle N D$ IRE) + FUEL BURNUD + P.EACTOP, LMCR + REPOFT, DPERATIONS ANALYSIS + RESPCNSE TIME + TRANSFER. FUNCTION

5-22500 ALSO IN CATEGORY 17

SPERT DESTRUCT IVE TEST, PART-I

PHILLIPS PETROLEUIM COMPANY

THIS IS 4 IS 1 INUTE FIL Y REFERENCFD ON PAGE 60 OF THE USAEC IO MM FILM CATALOG (PROFESSIONAL LEVEL) 1960-67, PRODUCEO BY PHILLIPS PETRQLFUM COMPANY AS CONTRACTOR THE USAEC AT THE NATIONAL REACTOP. TESTING STATION, IDAHO, FOR SALE BY TELEFILM INDUSTRIES, AT \$75.62 PER PFINT, INCLUDING SHIPPING CASE, F.O.B. HOLLYWOOD, CAL I FORVIA

15-MIN COLOR MOIVIE: TECHNICAL FILM. DOCUMENTS THE DESTRUCTIVE TEST PRDGRAM OF A HIGHLY EVRICHED AI PLATE-TYPE CORE AT NRTS, SHOWING SPECIAL FACILITY MODIFICATIONS, TRANSIENT TESTING WITH LIMITEC CORE DAMAGE. SHEWS VIEWS OF FAILED, BOWED, AND MELTED PLATES. SLOW-MOTION STUDIES SHOW FINAL CORE-DESTRUCTION TEST.

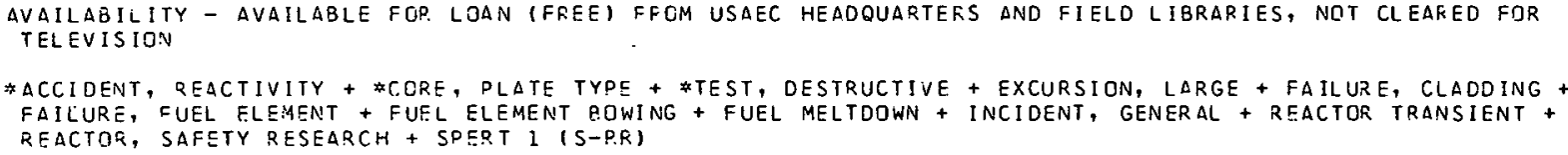


ACCIDENT ARY ANALYS IS

5-22704 \#CONTINUED*

KERNENERGIEANL AGEN, ALLGEMEINE ELEKTRICITAETS-GESELLSCHACT, FPANKFURT AM MAIN, WEST GERMANY EURAEC-1699 + EUR-28EE +. 46 PAGES, FIGURES, JUNE 1966

THE PERIOO UNOER REVIEW WAS MAINLY CONCERNED WITH TWO DRJECTIVES - (1) PREPAPATION OF DATA FOR TRANSFERRING THE RESULTS OF AIR/WATER EXPERIMENTS TO THE BEHAVIOR OF THE SEPARATOR IN REACTOR OPERATING COVDITIONS. (2) FURTHER DFVELOPMENT OF THE DROP-TYPE CYCLONE WHICH PREVIOUS EXPERIMENTS PROVED TO BE APPLICAELE TO MEDIUM PEACTOR QUTPUTS, FOR USE IN LARGE REACTORS. A COMPARISON OF THE RESULTS OE STEAM TESTS CARRICO OUT UNOER R.CACTOR CONDITIONS WITH THOSE OF AIR/WATER EXPERIMENTS SHOWS THAT THE SEPAEATION IS ALWAYS BETTER WITH THE LATTER. IT HAS NOT BEEN POSSIBLE SO FAR TO GIVE ANY QUANTITATIVE INOICATIONS ON THE SEPARAT ING EFFICIENCY IN THE PERMISSIBLE JPERATING RANGE OF THE SEPARATORS, BUT, ON ACCOUNT OF THE OUALITATIVE AGREEMENT OF THE LOAD CURVES, THE PERMISSIBLE LOAD LIMIT OF A SEPARATRF CAN BE ESTIMATED FROM AIR/WATER EXPER IMENTS.

AVAILABILITY - CLEARINGHOUSE FOR FEDFRAL SCIENTIFIC AND TECHNICAL INFORMATION, SPRINGFIELD, VIRGINIA \$3. OO COPY, \$0.65 MICEJFICHE

\#FLOW, TWO PHASE + *HEAT TRANSFER, BOILING + \#REACTOR, BWR + HEAT TRANSFER + STEAM

$5-22705$

FAJEAU H + SAUNIER JP

NUMERICAL PRIOGRAM FOF TWO-DIMENSIONAL ANALYSIS OF THE THERMODYNAMIC BEHAVIDUR DF A BOILING LIQUID CENTRE D ETUDES NUCLEAIRES, CCMMISSARIAT A L ENERGIE ATOMIQUE, SACLAY, FRANCE

CEA-R-3141+. 60 PAGES, TABLES, FIGURES, JANUARY 1067 , IN FRENCH

THIS TWO-DIMENSIONAL CODE HANDLES THE FOLLOWING PROBLEMS - 11 ANALYSIS OF THERMAL EXPED. IMENTS EN A WATER-LDOP AT HIGH OR LCW PRESSURE, STEADY-STATF OR TPANSIENT BEHAVICUR. (2) ANALYSIS OC THERMAL ANC HYDRCDYNAMIC BEHAVIOUR OF A LIGHT WATER P.EACTOR HOT CHANNEL. THE FUEL ELEMENTS ARE ASSUMED TO BE CLAT PLATES. THE POWER AND PRESSURE-DROP VARIATIONS DUR ING TRANSIENT CONDITIONS ARE DBTAINED FROM THE COMPLEMENTARY ONE-DIMENSIONAL CODE CACTUS ICEA REPORT R-3039).

AVAILABILITY - MICROCARD EDITIONS, IFOR SALEI, ACCOUNTING AND SHIPPING DEPARTMENT, WEST SALEM, WISCONSIN *FlOW, TWO PHASE + \#HEAT TRANSFER, EOILING + HEAT TRANSEER + ThERMODYNAMICS

$5-22708$

GENCD JM + RAINES GE

METAL-WATER REACTIONS DURING A LOSS-OF-COOLANT ACCIDENT. THE ZIRCONIUM-STEAM REACTION BATT ELLE-MEMOR IAL IVSTITUTE, COLUMBUS, OHIO

20 PAGES, 8 FIGURES, 1 TABLE, 18 REFERENCES, OCTOBER 21, 1966 , ABSTFACT IN ANS TRANSACTIONS $9(2)$, PAGE 555, (WINTER 1966), PAPER DRESENTED AT THE AMERICAN NUCLEAP SOCIETY WINTER MEET ING, OCTOBER 30, NCVEMBER 3. 1966, PITTSBURGH, PENNSYLVANIA

DEVELOPED A CALCULATIONAL TECHNIQUE FOR DESCRIBING ANALYTICALLY THE EXTENT OF METAL-WATER F.EACT ION THAT WOULO OCCUR IN A REACTOR CORE DURING A LCSS-OF-COCLANT ACCIDENT. ALTHOUGH THE 2IRCONIUM-STEAM FEACTION WAS CONSIDEPED, THIS MCDEL MAY BE APPLIEU. IU ANY HUEL-CLAUDING MATERIAL, TROVIDED THE APPROPQIATE OXIDATION KINETICS AFE NVAILAGLE. THE MODEL IS PREDICTED DN THE ASSUMPTION THAT TWO BRDAD TYPES OF RATE-LIMITING PHENCHENA CAN REPRESENT THE MECHANISM FOR THE CXIDATION OF ZIRCONIUM UNDER ACCIDENT CONDITIONS - (1) THE GAS-PHASE DIFFUSION OF STEAM FROM THE EULK STREAM TOWARD THE CLADDING SURFACE ANO $(2)$ THE SOLID-STATE DIFFUSION OF VARIOUS IONIC SPECIES THROUGH THE ZIRCONIUM OIOXIDE PRODUCT INTO THE BASE METAL QUANTITATIVELY EXPRESSED AS THE PARABOLIC RATE LAW. THE APPLICABILITY OF THIS TECHNIQUE IS DEMONSTRATED USING THE LOFT DFACTOF.

* ACCIDENT, LOSS OF COOLANT + \#ANALYTICAL MODEL + \#CHEMICAL KINETICS + FMASS TRANSEER + \# METAL WATER REACTICN + \#IRCALOY + COMPUTER PROGRAM + HEAT TPANSFEF ANALYSIS + LOFT (S-RR) + REACTOR, SAFETY RESEARCH + STLAM

5-22723 ALSG IN C.ATEGORY \&

ARGONVE NATIONAL LABCRATORY. CHEMICAL ENGINEERING DIVISION RESEARCH HIGHLIGHTS. MAY ICEG - APRIL I967 ARGONNE NATIONAL LABORATORY, $\triangle R G O N N E$, ILLINOIS

$\triangle N L=7350+111$ PAGES, TABLES, FIGURES, P.FFERENCES, $\triangle P R I L 1967$

SUMIAARY OF ANL PEACTOR. SAFETY PROGRAM FOR THE PERIOD MAY 1966 THROUGH APRIL 1967 . THIS PRDGRAM IS NOW CONCENTRATED TO 11 ) STUDIES RELATING TO THERMAL (WATER-COOLED) REACTORS, AND (2) STUOIES RELATING TO FAST (SODIUM-CDOLED) REACTORS. ITEM-) EFFORTS ARE DIFECTFD TO ANALYTICAL STUDIES CONSIDERING THE METAL-WATER REACTION, CORE HEATUP, AND FUEL FAILURE IN LOSS-OF-COOLANT ACCIDENTS, AND TO EXPERIMENTAL STUDIES CONSIDERING THE HEATUP AND MELTOOHN OF ALUMINUM-CLAD FUEL PLATES ANC ZIRCALOY-2-CLAD UG? FUEL RODS IN LOSS-OF-CCOLANT $A N D$ NUCLEAR-EXCURSION ACC IOENTS. ITEM-2 EFFOFTS APE DIRECTED TO STUDIES OF THE HIGH-TEMPERATUFE PHYSICAL ANO TPAASPORT PROPERTIES OF FAST REACTCR FUEL MATERIALS, ENERGY TFANSFER FROM HIGH-TSMPERATUFE FUEL MATERIALS TC LIQUIO SOOIUM. DND THE SCDIUM-AIR P.EACTION.

AVAILABILITY - CLEAOINGHOUSE FOR FEDEP.AL SCIENTIFIC AND TECHNICAL INFORMATION, SPRINGFIELO, VIFEINIA \$3. OO COPY, DO.65 MICRDFICHE

\#ACCIDENT, LOSS DF CROLANT + \#ACCIDFNT, REACTIVIIY + \# \#FUEL MELTDONN + \#HEAT TRANSFER EXPERIMENT + \#PROPERTY, PHYSICAL + \#SODIUM + \#TEMPERATURE TRANSIENT + \# URANIUM DIOXIDE + ZIFCALCY + ACCIDENT MODEL + AIP + ANL + COMPUTER PROGRAM + HEAT TRANSFEP ANALYSIS + 
CATEGORY 5
ACCIDENT ANALYSIS

5-22723 *CONTINUTD*

HEAT TRANSFER, BOILING + IN PILE EXPERIMENT + OXIDATION + STEAM + TREAT (PRR)

5-22775 ALSO IN CATEGORY 17

DRESDEN 1 SUPPLEMENT A TO PROPOSED CHANGE 14 - CYCLE 6 DESCRIPTION $\triangle$ ND SAFETY EVALUATICN REPORT COMMONWEALTH EOISOV COMPANY

6 PAGES, TABLES, FIGURES, JanuarY 17, 1968, DOCKET 50-10, TYPE--BWR, MFG.--G.E., AE--BECHTEL

ANSWERS 5 QUESTIONS (AEC LETTER OF 22 NOV. 67) ON PROPOSED CHANGE 14. QUESTION 1 COVERS EXPER IMENTAL FUEL ASSEMBLIES. QUESTIDN 2 - REFUELING ACCICENT ANALYSIS. QUESTICN 3 INSTRUMENTED FUEL-ELEMENT POSITIONS. QUESTION 4 - FUEL-ELEMENT ORIENTATION. GUESTICN 5 TSCH. - SPEC. CLAKIFICATION.

AVAILABILITY - USAEC PUBLIC DOCUMENT ROOM, WASHINGTON, D. C.

*AEC QUESTION + \#REFUELING + ORESOEN 1 (RWR) + REACTOR, BWR + TECHNICAL SPECIFICATIONS

5-22785 ALSO IN CATEGORY 17

N. CARQL INA STATE (RALEIGH) PROPCSED AMENDMENT 4-REVISED MCA ANALYSIS

NORTH CAROLINA STATE UNIVEPSITY

8 PAGES, 7 REFER SNCES, JAN. 10, 1968, DOCKET NO. 50-111

8

MCA IS A STEP-FEACTIVITY INSERTION. NEW ANALYSIS ASSUMES THAT TOTAL EXCESS REACTIVITY (I.5\%) IS HELD COWI BY A LONG CADMIUM TUBE PLACED IN THE VERTICAL EXPOSURE PORT, THAT THE REACTGR IS BROJGHT CRITICAL WITH THE CONTROL ROOS FULL OUT, THEN THE TURE IS PULLED FROM THE CORE.

BASED CN BORAX AND SPEPT DATA, MAXIMUM FUEL-PLATE-SURFACE TEMPERATURE WOULD BE 230 C, WITH AN ENERGY RELEASE TO PEAK POWER OF $10 \mathrm{KW}$-SEC AND RESULTS TO NC CLAD MELT OR FUEL-ELEMENT RUFTURE.

AVAILABILITY - USAEC PUBLIC DOCUMENT ROOM, WASHINGTON, D.C.

ACCIDENT ANALYSIS + ACCIDENT, MAXIMUM CREDIBLE (MCA) + ACCIDENT, REACTIVITY + REACTOR, POOL TYPE + -REACTOR, RESEARCH + REPORT, SAR + TECHNICAL SPECIFICATIONS

5-22788 ALSO IN CATEGORY 17

ASSESSMENT OF LACRWR CARRY-UNDER SEPARATORS

ALL IS-CHAL.YERS MANUFACTURERS

16 PAGES, FIGURES, JAN. 9, 1968, DOCKET NG. 115-5, TYPE--BWR, MFG--A.C., AE--SGT + LUNDY

EVEN THOUGH EXACT CAUSE OF FAILUPE OF THE SIMILIAR PATHFINDER FAILURE HAS NOT BEEN DETERMINED, DESIGN HAS LAFGEF. MARGIN OF SAFETY AGAINST STRUCTURAL FAILURE. OUTLET VELOCITY AND PRESSURE DIFFERENCE ARE LESS, GIVING $1 / 4$ THE HYDRAULIC FORCE, WHILE THE RIB STRENGTH IS 3 TIMES, GIVING A FACTCR-OF-12 ADVANTAGE.

AVAILABILITY - USAEC PUELIC DOCUMENT RDOM, WASHINGTON, D. C.

* SAFETY YARGIN + \#SEPARATOR + \#STRUCTURAL INTEGRITY + :4YDRAULIC ANALYSIS + LACROSSE (BWR) + RFACTOR, BWR + STRESS ANALYSIS

$5-22874 \quad$ ALSE IN CATEGORY 17

EXPERIMENTAL DETERMINATIJN OF THE DEPARTURE FROM NUCLEATE BOILING IN LARGE ROD BUNDLES AT HIGH PRESSURES WESTINGHOUSE ELECTRIC CORP., ATOMIC POWER DIVISION

WCAP-7045 +. 33 PAGES, 7 FIGURES, 11 REFERENCES, AMENDMENT 5 TO THE LICENSE APPLICATIGN, IFIFTH

SUPPLEMENT TO DIABLO CANYON PRELIMINARY SAFETY ANALYSIS REPORT,, NOVEMBER 6, 1967 , DOCKET NO. 50-275,

TYPE--PWR, MFG--WEST., AE-PG+E

(SUBMITTED AS DIABLO CANYON APPENDIX B TO FIFTH PSAR SUPPLEMENT). TESTS MADE AT I600-23OO PSIG ON A $5 \times 5$ ARRAY OF 7-FT-LONG INTERNALLY HEATED RCDS SHOWED TONGS (W-3) CORP.ELATION DERIVED FOR FLOW INSIOE TUBES (J. NUCL. ENERGY, VOL. 21 ) AN AVERAGE $8 \%$ CONSERVATIVE. THIS IS GELIEVED DUE TO SPECIAL MIXING WAVES IN SPACER GRID. CRUD WHICH FLAKED DFF ELEMENTS AND CAUGHT ON GRID RAISED THE PRESSURE DROP AND DNB FLUXES. CRUD FDULING OF RODS INCREASED FOD TEMPFRATURE 100- $200 \mathrm{~F}$, DOUBLED THE PRESSURE DROP, BUT DID NOT HAVE A SIGNIFICANT EFFECT ON ONB HEAT FLUX FOR 3 POINTS RECHECKED. BUT, AT DNB, THE SLOPE CHANGE OF HEAT FLUX VS TEMP. WAS NOT SO LARGE. DESPITE OESERVATION OF TRANSITION FROM BUBBLY TO SLUG FLOW AT $30 \%$ VOID IN CLOSED CHANNELS, THE OPEN GEOMETRY TESTED SHOWED NO FLOW INSTABILITY (AND THUS PREMATURE DNB), WITH EXIT VOIDS (CALCULATED WITH THINC) OF 23-68\%.

AVAILABILITY - USAEC PUBLIC DOCUMENT ROOM, WASHINGTON, D. C.

* COMPARISON, THEORY AND EXPERIENCE + \#HEAT TRANSFER CORRELATION + \#HEAT TRANSFER EXPERIMENT + DIABLO CANYON (PWR) + DNB + FLOW BLOCKAGE + FLOW STABILITY + FUEL ELEMENT + REACTOR, PWR + REPQRT, PSAR + SURFACE FILM DEPOSIT

5-22884 ALSO IN CATEGORY 17

SELECTED FERMI OPERATING EXDERIENCE - OCT 1966

POWER REACTOR DEVELOPMENT COMPANY 
5-22884 *CONT INUED*

EF-38 +. I7 PAGES, TARLES, OCTOBER 1966

BRIEF REVIEW OF THE OCT. 5 MELTDOWN. AT 0345, CRITICAL ROD POSITIONS DURING HEATUP CORRELATED WELL WITH PREVIOUS MEASUREMENTS WITH IHE FEACTOP AT I MWTH AT 345 , POWER RISE WAS STAFTEO, HELD TWICE FOF BOILER FEED-PUMP STAFT. AT ISCO, DURING POWER RISE, VARIATIONS IN AUTO-PQWEF, CONTROL DUE TC ERRATIC DN/DT, SIMILAR TO PAST NOISE PICKUP. REACTOR WAS PUT IN MANUAL AND POWEP. RISE HALTED. NOISE DISAPPEARED UNTIL 1505 , WHEN FEECWATEF. CONTROLLEP. PUT IN AUTOMATIC. * \# ASST. REACTOR ENGR. NDTED CONTROL YOUS HIGHEK THAN NORMAL, CHECKED CORE OUTLET TEMPS PECORDED BEHIND CONTROL PANEL AND FOUND 2 SUBASSEMBLIES IOO F HIGHER THAN BULK TO: HIGH D.ADIATION ALAFMS STARTED, AND POWEF WAS PEDUCED MANUALLY.

AVAILABILITY - USAEC PUBLIC DOCUMENT ROOM, WASHINGTON, D. C.

*FUEL MELTONNN + *INCIDENT, GENERAL + FERMI (LMFBR) + FLOW BLQCKAGE + INSTRUMENTATION, TEMPERATUFE + REACTIVITY EFFECT, ANOMALOUS + REACTOR, FAST + REYORT, UUERATIONS

5-22887 ALSO IN CATEGORY IT

MCCARTHY JF

SELECTED FERMI OPERATING EXPERIENCES

ATOMIC. POWER DFVELOPMENT ASSOC., INC., DETPOIT, MICH. + POWER REACTOR. DEVELOPMENT CO., CETROIT, MICH. + DETROIT EDISON CO., MICH.

APOA-CFE-4 +. 37 PAGES, MAY 1967

CORE-HOLDDOWN MECHANISM REMOVED, CORE SWEEP FOUND NO DEBRIS ABOVE FUEL, NOP PROJECTING

ELEMENTS. REVISED FUEL-HANDLING MACHINE FOUND 2 ROWS OF FUEL THAT NEEDED EXCESSIVE FOPCE TO

LIFT. FCUR ADJACENT ELEMENTS, INCLUDING THE TWO THAT RAN HOT OCT. 5 , CDULD NOT EE LIFTEL.

\#* BRIEF DISCUSSION SUMYARZING ANALYSIS OF JULY/AUGUST STEAM-GENERATOR INSTABILITIES. A

DRESSURE AND A TEMPERATURE RAMP CAUSED BCILING IN THE DOWNCOMER AND EVENTUAL FLOK STARVATION.

PRESSURE RAMPS WILL RE ELIMINATEO, AND SOOIUM/STEAM CONOITIONS SET TO MAINTAIN A REQUIRER

DOWVCGMER HEAT-TRANSFER AREA.

AVAILABILITY - CLEAP.INGHOUSE FOR FEDERAL SCIENTICIC AND TECHNICAL INFORMATION, SPRINGFIELD, VIRGINIA \$3. OO COPY, \$O.S5 MICROFICHE

\#FLOW STABILITY + FCRMI (LMFBR) + FUEL HANDLING MACHINE + FUEL MELTDOWN + REACTOF, FAST +

REPDRT, OPERATIONS SUMMARY + STEAM GENERATOR

$5-23804$

MCCARTHY JF + NASH CR

C.MMPILATION OF CURRENT TECHNICAL EXPERIENCE AT FNRICO FERMI ATOMIC POWER PLANT. MENTHLY F.EPORT NO. 12, JULY 1967

ATOMIC POWER DEVELOPMENT ASSOCIATES, INC, DETROIT, MICHIGAN + POWER REACTOR DEVELOPMENT COMPANY + DETROIT

EDISON CO, NICHIGAN

APDA-CFE-12+. 33 DAGES, FIGURES, AUGUST 1967

(PAGFS 7-1 I) SFPAKATION DF THE THO STUCK ASSEMBLIES BY A SPECIAL CHISEL SAVED 2 MCNTHS. NO FOREIGN MATERIAL WAS FOUND ON THE SUPPORT PLATE. (PAGE 14) RELEASE OF GAS IN LUADING A FUEL ELEMENT $\triangle N D$ TRANSPORT BY BUILDING VENTILATION SYSTEM CONTAMINATED THE AREA WITH ZE-NE-95 AND SR-90. AN ADDITIONAL CHANGE HOUSE WAS CONNECTED TO TH'E AIPLOCK. (PAGE IE-25) PICTURES $\triangle N D$ EXAMINATION P.ESULTS DF DAMAGED ELEMENTS MI27 AND MO98 GIVEN. (PAGE 27-28) A COMPINATION ELON RESTRICTOR AND CHECK VALVE WILL BF INSERTED IN EACH STEAM-GENERATOR TUBE. THIS WILL INCREASE THE PART-LOAD PPESSURF DROP (PREVENTING FLOW IMBALANCES ANO TUBE-SHEET FAILURESI, YET ON A

WATER DUMP WILL ALLOW NORMAL BACKFLOW.

AVAILABILITY - PUBLIC DCCUMENT ROOM, WASHINGTON, D. C.

WFISSION GAS RFIFASE + FFI.OW QRIFICE + \#REMOTE MANIPULATING AND VIEWING + CONTAMINATICN + FEPMI (LMFBR) + FLOW DISTRIBUTION + FLOW STASILITY + FUEL MEL WLUWN + REACTOR, FAST + REPORT, OPERATIONS SUMMARY + STEAM GENERATOF + VENTILATION SYSTEM.

5-22898 ALSO IN CATEGORIES 9 AND 17

COMPILATION OF CURRENT TECHNICAL EXPERIENCE AT ENRICC FERMI ATOMIC POWER PLANT. MONTHLY REPORT Ne. O, CPRIL 1067

ATOMIC POWER DEVELOPMENT ASSRCIATES, INC., DETROIT, MICH + POWER PEACTGR DEVELOPMENT CEMOANY + DETROIT

EOISTN COMPANY, MICHIGAN

$\triangle P D A-C F E-D+. \quad 31$ DAGES, JUNE 1967

(PAGE 23) A LOW-FREQUENCY CDIL TO NCNDESTRUCTIVELY IEST FUEL PINS HAS A THRESHOLD OF IOOO PFM HYDF IDE, TESTEG ON DELI QERATELY HYCRIDED (250-5000 PPM) PINS. (PAGE 24) BYPASS FLJW ANALYSIS OF SUBASSEMBLY LEWER NOZZLE EEING CAUGHT ON TGP OF THE SUPPORT PLATE SHDWS FLOW REDUCED BY 7 , INSUFFICIENT TO CAUSE FUEL OAMAGE. (PAGE 27 ) FAILURE OF A SOLENOIO VALVE ALLOWED DRIMARY-SHIELC-TANK PRESSURE TO TAKE POSITIVF PRESSURE SWINGS. FAILURE BLEW A FUSE IN THE C JMMON POWER SUPFLY, PREVENTING SWITCHOVER TG AN ALTERNATE SENSING LINE. 'MANUAL VALVES REDLACE THE SCLENOID VALVES (IN A LESS COMPLICATEO ARRAY).

AVAILABILITY - CLEARINGHOUSE FOR FEDERAL SCIENTICIC ANO TECHNICAL INFORMATION, SPRINGFIELD, VA., \$3. OO COPY, \$O.65 MICROFICHE

\#FAILURE, COMPONENT + \#AILURE, SEQUENTIAL + \#FLOW DISTRIBUTION + \#TEST, NONDESTRUCTIVE + CLAO + 
ACATEGORY
ACCIDENT ANALYSIS

5-22898 \#CONTINUED*

ELECTRIC PONER, NORMAL + FERMI (LMFBR) + FUEL ELEMENT + HYORIDE + HYOROOYNAMIC ANALYSIS + INDEPENDENCE + REACTOR, FAST + REPORT, OPERATIONS SUMMARY + VALVE

$5-22976 \quad$ ALSO IN CATEGORY 17

ROSUEL A + ROUVILLOIS X

TWISTED TAPES FOR INCREASED DOWER. DENSITY

SNECMA

3 PAGES, 7 FIGURES, 7 REFERENCES, NUCLEAR ENGINEERING 13(140), PAEES 43-45 (JANUARY 1968)

ASSEMBLY WAS IFEADIATEO FROM NOV. SE TO MAY 67, EXAMINED, AND REINSERTED IN A HIGHEP. FLUX DISITIOV. ARTICLE DISCUSSES EXPERIMENTAL STUDIES IHYORODYNAMIC LOOP WITH AIR-WATER MI.XTURE AND A 4-ROD ASSEMIBLY, AND LATER WITH A 4-ROD CLUSTER AT BWP CONDITIONSI, CRITICAL HEAT FLUX ESTIMATES (CENTRIFUGAL ACTION P.EDUCES WATER FNTRAINMENT, GIVING DOUBLE THE HEAT FLUXX BEFCRE DRYJUT OCCURS) AND GOO-MWE OESIGN ECONOMICS (ECONOMY WOULD REPFESENT 4-5\% OF THE GENERATING COST).

*HEAT TRANSFER AUG IENTATION + \$ IN PILE EXPERIMENT + ONB + FLOW, VORTEX + FUEL ELEMENT + HEAT FLUX, DRYOUT + OUT OF PILE LOOPS ANO EXPERIMENTS + REACTOR, BWR

5-22978 ALSO IH CATEGORY 17

ROSEN3AUY HS + EDVIES JH + PON JO

INTERACTION OF IOOINE WITH ZIRCALJY-2

GENERAL ELECTRIC CO., SAN JOSE, CALIF.

GEAF-5100-5+ 43 PAGES, 27 FIGURES, 2. TABLES, 12 R.FFERENCFS, JANUAFY 1966

FAILURES DUE TO PINHOLES IN THE 7.IRCALOY-2 CLADOING OF TWO RODS IOPERATED WITH CENTERL INE MELTING) REVEALEO THAT IODINE HAD CONCENTRATED AT PELLET INTERFACES AT THE UPPER ENDS OF FUEL POOS (NEAR DINHOLES). IN GUT-OF-PILE STUDY, GENERAL ATTACK, PITTING, ANO STRESS-CORROSION CRACK ING OCCURPEC. HOWEVER, THE FRACTURE MORPHOLOGY OF TEST CLADDING ANO FAILED CLADDING SHOWED SIMILARITIES. (VERDICT) NO CONFIDENT CONCLUSION CAN BE DRAWN REGARDING THE ASSOCIATION OF THE IN-DILE FAILURES WITH ZIRCALOY-2/IODINE ATTACK MECHANISM.

AVAILABILITY - CLEARINGHOUSE FOR FEOERAL SCIENTIFIC AND TECHNICAL INFOFMATION, SPRINGFIELD, VA., \$3. OO COPY, \$0.S5 MICPOFICHE

\#CHEMICAL REACTION + \#FAILURE, CLADOING + \#FISSION PROCUCT, IGDINE + \#ZIRCALOY + CENTEPLINE MELTING + CORROSIJN + GETR (TF) + IN PILF LOOP + REACTOR, BWR + STRESS COPROSION

5-23160 $\quad A L S G$ IN CATEGORY $t$

DIFTZ KA

QUARTERLY TECHNICAL REPORT - STEP PP.JECT, APRIL $1967--J U N E 1967$

PHILLIOS PETROLEUM COMPANY

IDO-17240+.73 PAGES, 50 FIGURES, 11 TAQLES, 41 REFERENCES, SEPT. 1967

PPOGRESS IS REPRRTEO UNDER SIX HFADINGS - LOFT REACTOR PHYSTCS CALCULATIONS, LGFT BLOWDOWN ANALYSIS, LOFT RADIOLOGICAL STUDIES, SEMISCALE BLOWDOWN TEST PROGRAM, MEASUREMENT EVALUATICN 14IGH-TEMDERATUEE THEPMOMETRY STUDIFSI, AND LCFT FM MULTIPLEX SYSTEM.

AVAILABILITY - CLEARINGHOUSE FOR FEDERAL SCIENTIFIC AND TECHNICAL INFORMATION, SPRINGFIELD, VA., \$3. OO COPY, \$0.65 AICROFICHE

\#LGFT $(S-\hat{R} R)+$ BLOWDCWN + HIGH TEMPERATURE + RADIOLOGY + REACTOR PHYSICS + REACTOR, BWR +

REACTOK, SAFETY RESEARCH + REACTOR, TEST

$5-23314$

ALSO IN CATEGORY 11

AN ANALYSIS OF TURBINE MISSILES RESULTING FROM LAST-STAGF WHEEL FAILURE

GENERAL ELECTRIC CO., SCHENECTADY, N. Y.

TR-67SL211 +. 73 PAGES, 15 FIGURES, 3 TARLES, 7 REFERENCES, OCT. 3,1967

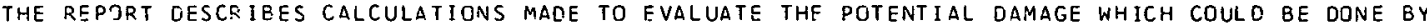
HYPOTHETICAL TUREINE MISSILES IN THE UNLIKELY EVENT OF THE FAILURE OF THE LAST-STAGE WHEEL OF A NUCLEAR MACHINE. IT IS CONCLUDED THAT THE MISSILE KINETIC ENERGY ABSOREED BY THE TURBINE CASING IS AS LARGE DR LARGER THAN PREVIOUSLY ASSUMED AND THAT A $120-D E G$ WHEEL FRAGMENT IS POTENTIALLY MGP.E DAMAGING THAN EITHER A 9O- OR I IOO-DEG FRAGMENT. THE POTENTIAL DAMAGE INCREASES SLIGHTLY WITH LAST-STAGE WHEEL SIZE. THE CONCRETE-SLAB. THICKNESSES PENETRATED FOP. THE 38-, 43-, ANC 52-IN. WHEELS $\triangle R F$ IN THE APPROXIMATE RATIOS 1, 1.01, 1.08.

AVAILABILITY - USAEC PUELIC DOCUMENT ROOM, WASHINGTON, D, C.

\#FILURE, EQUIPMENT + \#MISSILE GENERATION AND PFOTECTICN + \#TURBINE + ACCIDENT ANALYSIS + IMPACT PROPERTY

$5-23390 \quad$ ALSO IN CATEGORY 17

HADOAM NECK AMENDMEVT 17 . RE-ANALYSIS GF STFAM LINE RUPTURE 
CATEGORY 55

5-23390 \#CONT INUED*

CONNECTICUT YANKEE ATOMIC POWER COMPANY

7 PAGES, JANUARY 8, 1968 , DOCKET 50-213, TYPE--PWR, MFG.--WFST., AE--STONE + WEBSTER

REANALYSIS USES 10-SEC VALVE-CLOSUPE TIME INSTEAD OF I SEC (5EE PROPOSED CHANGE 5, 1/9/168). 36-IV. DOUBLE STEAM-HEADER BREAK RESULTS IN AN OFF-SITE THYROID DOSE OF 0.05 REM. MAXIMUM REACTIVITY GAINS LESS THAN 19. 24-IN. DOUELE BREAK UPSTREAM FROM THE ISOLATION VALVES RESULTS IN A MAXIMUM RFACTIVITY GAIN OF 1.01\%. SHUTDOWN MARGIN IN BOTH CASES IS 3.4\%, WITH MUS! REACTIVE EOO STUCK OUT GF THE CORT. MAXIMUM REACTIVITY GNIN WITH NO BORON INJECTION IS $1.9 \%$.

AVAILABILITY - USAEC PUBLIC DOCUMENT RODM, WASHINGTON, D. C.

* ACCIDENT, STEAM LiNe RUPTURE + \#RESPONSE TIME + \#VALVE + CONTAINMENT PENETRATION, Closure of + HADOAM NECK (PWR) + REACTIVITY EEFECT + REACTOR, PWR + REPORT, SAR + SAFETY ANALYSIS

$5-23395$

KUN11 O SUZUKI H

PARTICLE-TO-FLUID HEAT AND MASS TRANSFEP IN PACKED BEOS. OF FINF PARTICLES

UNIVERSITY DF TOKYO, TOKYO, JAPAN

8 DAGES, 6 FIGURES, 27 FEFERENCES, INT. J. HEAT MASS TRANSFER 10(7), PAGES $845-52$ (JULY 10E7)

BY APPLICATION OF A SIMPLE MOOEL OF HEAT OR MASS TRANSFER BETWEEN SOLIDS $\triangle N O$ FLOKING FLUID IN PACKEO BEDS, EXPERIMENTAL DATA OF EGTH NUSSELT AND SHERWDOD NJMBERS REPORTED IN THE PREVIOUS LITERATURES ARE INTERPRETED THEORETICALLY IN THE RANGE OF LOW PECLET NUMBER (LESS THAN IO). THEN IT IS SUGGESTEO THAT CHANNELLING OR LOCAL UNEVEN CONTACTING OF FLUIDS WITH SOL IDS IS RESPONSIBLE FOP. THE FURTHER DECREASE OF APPARENT HEAT- AND MASS-TRANSFER COEFFICIENTS IN THE ABOVE SYSTEM.

\#DARTICULATE + DROPLET + FLUIDIZEO GED + HEAT TRANSFER + MASS TRANSFER

$5-23396$

NOROON P + DAVID HG

COUPLED DIFFUSION DF MOISTURE AND HEAT IN HYGROSCOPIC TEXTILE MATERIALS

CSIRO WOOL RESEARCH LABORATORIES, RYDF, SYONEY, AUSTRALIA

14 PAGES, 1! FIGURES, 15 TABLES, INT. J. HEAT MASS TPANSFER 10(7), PAGES 853-66 1JULY 1067)

A EINITE-DIFFEPENCE SOLUTION, BASED ON THE DOUBLE-SWEEP METHOD, WAS FOUND FOR SOLVING THE NONL INEAR JIFFERENTIAL EQUATIONS THAT DESCFIRE COUDLED DIFFUSION OF HEAT AND MASS (MOISTLRE) IN HYGROSCOPIC TEXTILE MATERIALS. IN ADOITION TO THE DIFFUSION EQUATIONS, A PATE SQUATICN WAS INTROCUEED, DESCLIBING THE RATE OF EXCHANGE OF MOISTURE BETWEEN THE SOL ID TTEXT ILE FIBRES) $\triangle N D$ THE GAS PHASE (PCRE SPACE). A NUMEPICAL $\triangle P P L I C A T I O N$ OF THE THEORY WAS MAOE, USIING WOOL $\triangle S$ SN EXAMPLE FOR THE HYGROSCOPIC MATERIAL, $\triangle N O$, IT IS SHOWN THAT, SIMILAR TO FOR G,FN R.MNVECTIVE TRANSFER, TRANSFER OF MOISTURE FROM AIR TO THE WOOL ANO FROM THF WOCL TO AIR ARE NOT SYMMETRICAL PRDCESSES.

\#PORQUS MEDIA + HEAT TRANSFER + MASS TRANSFER

$5-23397$

GLOUCHKOTV LK + MIKHAILOV MD

THE VARIATION OF HEATING MEOIUM TEMPEPATIIRF TO RAISE A BODY AT A GIVEN TEMPEPATURE IN A MINIMUM TIME

O PAGES, I FIGURE, 3 TABLES, 6 REFERENCES, INT. J. HEAT MASS TRANSFEF 10 (7), PAGES 8E7-E75 (JULY 1967)

THE VARIATICN OF HEATING MEDIUM TEMPERATURE NFCESSARY TO RAISE A BODY AT A GIVEN IEMPEPATURE

IN $\triangle$ MINIMUM TIME WAS DETERMINCD. THE RESULTS ARE GIVEN FCP A PLATE, A CYLINDEF, AND A

SDHERE.

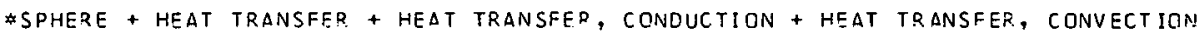

$5-23398$

LASSAU G + LE FUR 3

PROFILS DE CONCENTRATIONS DANS UNE COUCHE LIMITE LAMINAIRE FIGEE AVEC UNE REPARTITION CONTINIJE ET

DISCIJVI INUE UE CATAL'TSEUR SUR LA PARCI

33 PAGES, 14 FIGURES, 1 REFEPENCES, [NT. J. HEAT MASS TRANSFER 10 17 , PAGES 877-909 $1 J U L Y$ 1967!

A METHOO FOR INTEGRATING THE LAMINAF BOUNDAFY-LAYER EQUATIONG IS PRESENTEO FOR A FLUID WITH CONSTANT PRDOERTIES, WITH EMPHASIS ON THE FESCLUTION DF THE DIFFUSION EQUAI IUN. THE METHOO IS BASED ON AN IIERATIVE PROCESS. THE INTEREST OF THE METHOD LIES IN THE FACT THAT IT C.AN BE USED IN CASES WHEDE SIMILARITY DOES NOT ADPLY. THE CORPFSPCNDING NUMERICAL CALCULATIONS ARE MUCH SIMPLER TIIAN THE CALCULATION BY FINITE DJFFFRENCF MFTHCES. (IN FRENCH.)

* BOUNDARY LAYER + FlON, LAMINAR + HEAT TRANSFER + MASS TRANSFER

$5-23309$

RUCKENSTEIN E 


\section{ACCIDENTERY ANALYSIS}

$5-23399 \%$ CONTINUED*

FILM BDILING ON A HORIZONTAL SURFACE

POLYTECHNICAL INSTITUTE, BUCHAREST, RUMANI

9 PAGES, 1 FIGURE, 14 REFERENCES, INT. J. HEAT MASS TRANSFER 10 (7), PACES 911-19 (JULY 1967)

AN ANALYSIS JF THE HEAT-TRANSFER PROCESS IN THE CASE OF FILM EOILING IS MAOE BY TAKING INTO ACCOUNT THE TAYLOR INSTABILITY AND THE GRCWTH GF THE PRCMINENCES UP TO THE BUBBLE DEPARTURE. THE INITIAL RADIUM GF THE PROMINENCES IS DETERMINED BY THE TAYLCR INSTABILITY, THE FINAL RADIUS BY THE SUCYANT AND SUR.FACE TENSION FCRCES. THE GRGVTHi OF THE PROMINENCES IS OUE EOTH TO THE TAYLOR. INSTAEILITY AND TO A PART OF THE VAPOUR GENEKATED AT THE LIGUID-VAPOUR

INTERFACE BY THE HEAT FLUX. THE REST OF THE VAPOUR GENERATED BY THE HEAT FLUX CCMPENSATES THE DECREASE OF THE FILM THICKNESS CAUSED BY INSTABILITY ANO MAINTAINS A STABLE FILM OF VAPOUR. THE APPENDIX CONTAINS EQUATIONS FOR THE DIAMETEF DF THE DEPARTING BUBBLE WHICH TAKE INTO ACCOUNT ALSO THE FRICTION AND INERTIAL GORCES.

*FILM BOILING + *HEAT TRANSFEP, BOILING + BOUNDARY LAYER + FLCW STABILITY + HEAT TRANSFEP. + POOL EOILING

$5-23400$

FROST $W+K I P P E N H A N C J$

BUBBLE GROWTH AND HEAT-TRANSFER MECHANISMS IN THE FORCFD CONVECTION BGILING OF WATER CONTAINING A SURFACE $\triangle C T$ IVE $\triangle G E N T$

THE UNIVERSITY OF TENNESSEE SPACE INSTITUTE, TULLAHOMA, TENN. + UNIVERSITY OF WASHINGTCN

19 PAGES, 16 FIGURES, 3 TABLES, 12 REFFRENCES, INT. J. HEAT MASS TRANSFER 10 (7), PAGES O11-19 (JULY 1967)

REPORTS AN EXOERIMENTAL INVESTIGATION OF FRRCED-CJNVECTIGN ROILING IN A VERTICAL ANNULUS. THE BOILING FLUID WAS WATER BOTH PURE AND WITH VARICUS AMUUNTS OF SURFACE ACT IVE AGENT ADDED TC REDUCE SURFACE TENSION. IN ADNITION TO SURFACE TENSION, THE VELOCITY ANO SUBCOQL ING WERE ALSO VARIEO. IT IS CONCLIJDED THAT LATENT ENERGY TR.ANSPORT CONTRIBUTES ABOUT $50 \%$ GF THE MEASURED HEAT FLUX IN WATER WI THOUT A SURFACE ACTIVE ADCITIVE AND SIGNIFICANTLY MORE IN WATER CONTAINING AN $\triangle D D I T I V F$.

* heat transfer, boIling + eubBle + heat transfer + heat transfer, convection + water, general

$5-23401$

LEVY $S$

FORCED CONVECTION SUBCOOLED BOILING-PREDICTION OF VAPOR VQLUMETRIC FRACTION

GENERAL ELECTRIC COMPANY, SAN JOSE

15 PAGES, 14 FIGURES, 4 TABLES, 18 FEFERENCES, INT. J. HEAT MASS TRANSFER 10(7), PASES 951-E5 (JULY 1967)

A MODEL WAS DEVELOPCD TO PREDICT THE VAPOK VOLUMETRIC FRACTION DURING FORCED-CONVECT ION

SUBCOOLED 30 ILING. THE ITFTHOD WAS APPLIEO TQ A VARIETY OF TEST OATA, ANO THE AGFEEMENT WAS

SATISFACTORY FOR A MULTITUDE OF FLOW, HEDT FLUX, AND FLUID PPOPERTY CONDITIONS.

*HEAT TRANSFER, BOILING + FLOW, TUBE + FLGW, TURPULENT + HEAT TRANSFER +. HEAT TRANSFER, CONVECTION

S-TS4II? ALSO IAI CATECORY 19

LUIKOV AV

HEAT TRANSFER BIBL IOGRAPHY--TUUSSIAV WOPKS

B.S.S.R. ACAOEMY JF SCIENCES, MINSK, U.S.S.R.

18 PAGES, INT. J. HEAT MASS TRANSFER IO(7), PAGES 9SO-1014 (JULY 1967)

BIBLIOGRAPHY JF THE RUSSIAN LITERATIIRE.

* BI BL IOGRAPHY + \#HEAT TKANSFER

$5-23403$

RDTEM 2

THE EFFECT OF THERMAL CONOURTION OF THE WALL UPON CCNVECTION FROM A SURFACE IN A LAMINAR BOUNOARY LAYER THE UNIVERSITY OF BRITISH COL UMBIA, VANCOUVER

6 PAGES, 2 FIGURES, 1 TASLE, E REFERENCES, INT. J. HEAT MASS TRANSFER 10(4), PAGES 4E1-t, (APRIL 1SG7)

THIS PAPER CONSIOEPS THF INFLUENCE GF WALL THERMAL CONDUCTION UPCN THE INTERFACE TEMPERATURE PROFILE FOR THE CASE OE A THIN HEAT-DISSIPATING WALL COOLED PY FORCED LAMINAR CGNVECTION. A METHOD FCR THE RAPID $\triangle P P R O X I M A T E$ CALCLLATION DF BOTH THE TEMPERATURE AND THE FILM COEFFICIENT IS GIVEN FDR THE TWO CASES OF AN ALMOST I SOTHERMAL WALL AND A WALL OF ALMOST CONSTANT FLUX.

* BOUNOARY LAYER + *HEAT TPANSFER, CGNOUCTICN + HEAT TRANSFER + HEAT TRANSFER ANALYSIS

$5-23404$

MALLING GF + THODOS G

ANALOGY BETWEEN MASS AND HEAT TRANSFER IN BEDS OF SPHERES--CONTRIBUTIONS DUE TO END EFFECTS

NORTHWESTERN UNIVERSITY, EVANSTON, ILLINOIS

10 PAGES, 8 FIGURES, I TABLE, 12 REFERENCES, INT. J. HEAT MASS TRANSFER 10(4), PAGES 489-498 (APRIL 1967)

MASS- AND HEAT-TRANSFER DATA OBTAINED BY THE VAPORIZATION OF WATER FRCM POROUS SPHERES WEFE 
CATEEQRY
ACCIDENT
AMALYSIS

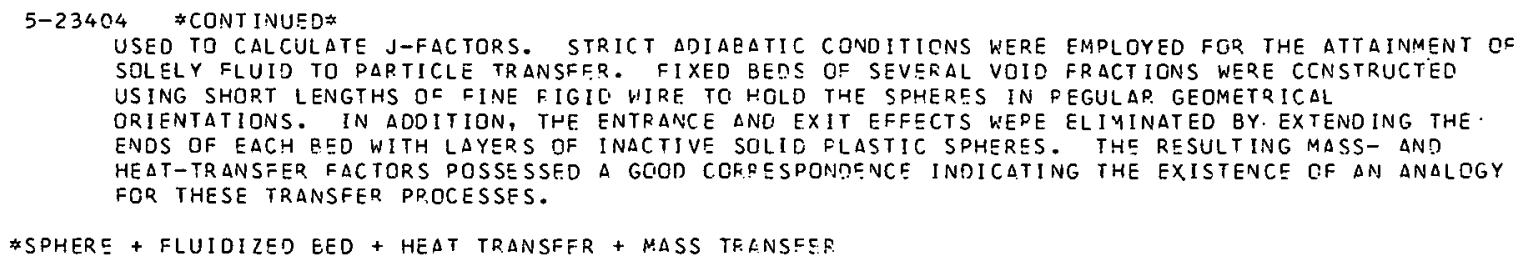

A MONTE CARLO METHDO FOF. THF NUMERICAL SOLUTION OF NONLINEAR, FPGQUENCY-DFPENDENT, RADIATIVE TRANSFER PROBLEMS IS DESCRIBLO. THE ACCUPACY OF TIIE METHDO IS INVESTIGATED WITH RESPECT TO THE NUMBEF OF OARTICLES REQUIRED, PPOPAGATICN OF STATISTICAL ERROR, TFUNCATION EOROR, AND CONVERGENCE TO A KNOWN SOLUTION. THE SOLUTION OF A SIMPLE FFEQUENCY-DEPENDENT KADIATIVE HEATING FROBLEM IS ILLUSTRATEO. GFAY-BODY CALCULATIONS USING GOTH THE PL ANCK IMEAM ABSORPTIEN COEFFICIENT AND THE ROSSELAND MEAN FREE PATH APE COMPAPEO WITH THE FREQUENCY-DEPENDENT CALCULATION.

\#HEAT TRANSFER, RADIANT + \#MONTE CARLO + HEAT TRANSFER

$5-23406$

LAVENDER WJ + DEI DC

THE EFFECT IF FLUID TURBULENCE ON THE RATE OF HEAT TPANSFER FROM SPHERES

DELMAR CHEMICALS LIMITEO, MONTREAL + UNIVERSITY OF WATERLOO, WATERLCO, ONTARIO

11 PAGES, 6 FIGURES, 5 TAGLES, ?O REFERENCES, INT. J. HEAT MASS TFANSEER 10(4), PAGES 52O-539 (APFIL 1967)

THE RATE OF HEAT TPANSFER FROM A 1.25-IN-OIAM SPHERE WAS STURIED IN A VERTICAL WINO TUNNEL RESULTS IN SOTH HEAT TP.ANSFER AND DRAG JNDICATE THAT THE PPOOUCT JF REYNDLDS NLIMEER AND TURBULENCE INTENSITY (DEFINED AS THE TUREULENT P.EYNOLDS NUMBER) IS $\triangle N$ I YPCRTANT PARAIIETEF $\triangle N D$ THAT THE SCALE OF TURBULENCE IS OF MINOR SIGNIFIC.ANCE.

* SPHERE + FLON, TURBBUENT + HEAT TRANSFER + HEAT TRANSFER CORPELATION

$5-23407$

WURSIIE-SCHIVIOT P:A

HEAT TRAVSFER IN THE THERMAL ENTRANCE REGION CF CIRCULAR TUPES AND ANNULAR PASSAGES WITH FULLY ULVELUHEO LAMINAR FLOW

TECHINICAL UNIVERSITY OF OENMARK, TONPFNHAGEN

11 PAGES, 9 TABLES, 12 REFERENCES, INT. J. HEAT MASS TRANSFER 10(4), PAGES 541-5:1 (APFIL OT)

SERIES SOLUTIONS OF THE TYPE-FIRST PROPOSEO BY MERCER. ARE PPESENTED FOR LAMINAE. FLOW IN TUBES AND ANNULAR OASSAGES (INCLUOING THE PLANF OUCT) WITH A STEP-CHANGE IN EITHER THE TEMPERATUFE OR THE HEAT FLUX AT ONE WALL. THIS TYPE OF SOLUTION-WHICH MAY BE REGARDED $\triangle S$ SN EXTENSION OF THE WELL-KNOWN LEVEQUE-5OLUTION-CONSTITUTES A CONVENTFNT AITERNAT IVE TO THE EIGFNVALUE SOLUTIONS IN THE FIRST PART OF THE THERMAL ENTRANCE PEGION, WHERE A LAOGE NUMBEF CF TERMS IS QEUUIRED IN TIIE CIGEAFUNCTION EYPAMISIONS.

\#FLOW, $A N N U L A R+$ *LGW, TUBE + FLOW, LAMTNAD + HEAT TRANSFER

5-23409

PRESSER KH + PIETRALLA G + HARTH K

HEAT TRANSFER AND PRESSURE DROP IN INSIDE HEATEC ANNULI BY HIGH PEESSIJRE GAS CDCLING

INSTITUT FUR RFAKTORBAUEL EMENTE DER KERNFCRSCHUNGSANLAGE JULICH DES LANDES NORDRHEIN-WESTFALEN E.V.

12 PAGES, 18 FIGURES, 8 TABLES, 25 REFERENCES, DTCMKERNENERGIE $12(1-2)$, OAGES 43-54 (JANUAFY 1067)

HEAT TRANSFER AND PRESSURE DRQP UL IHKEE OIFFERENT ANNULI WITH DIAMETEE. CATIOS OHF

(D-SUB-A/D-SIJB-I) CQUAL TO 1.5, 2, $\triangle N O 2.67$ WEFE INVESTIGATEC WITH TURSULENT FLGW JF CO2 TG

N2. THESE YEASUREMENTS WERE CONDUCTED AT PRESSUEES FROM 10 TO $80 \mathrm{KPISO.} \mathrm{CM} \mathrm{AND} \mathrm{GAS}$

TEMPERATURES TROH ?OO TO 400 C FFYNII RS NUMPERS ARE IN THE UP TO NOW NOT INVESTIGATED RANGE

FROM 70,000 TO E, 000,000. THE HYDFAULIC SQUIVALENT CIAMETER. WAS USED. ABSULUI W WLL ANO

BULK TEMPERATURE DATIOS FROM 1.02 TO 2 . I WEKE STUOIEC.

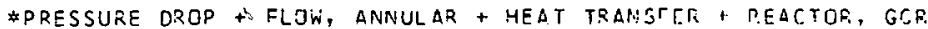

$5-23410$

HORI M + OUCHIY

EFFECT OF ORIFICE PRESSURE DROP ON BUPNOUT HEAT FLUX IN PARALLEL CHANNELS

JAPAN $\triangle T O M I C$ ENERGY D.ESEARCH INST., TOKYO 
CATEGORY 5
ACCIDENT ANALYSIS

T-23410 \#LUNTINUED*

4 PAGES, 7 FIGURES, 2 REFERENCES, NIPPON GENSHIRYOKU GAKKAISHI 8, PAGES 536-9 10CT. 196.6)

AS EXEMPLIFIED IN THE CASE OF BCILING-WATER FEACTORS, OFIFICING AT THE INLET DF EACH CHANNEL IS CONSIDEREO TO SE EFFECTIVE IN SUPPRESSING FLOW INSTABILITY IN PARALLEL CHANNELS. IT IS ALSO EXPECTED THAT SUCH ORIFICING SHOULS AFFECT THE BURN-OUT HEAT FLUX IN PARALLEL CHANNELS. IN THIS EXPER IMENT, THE BURNOUT HEAT FLUX IN PARALLEL CHANNELS WAS MEASUREO BY VARYING THE SINGLE PHASE IOR IFICE) PRESSLIRF DOCP AND OTHFR CONDITICINS (FIOW RATE AND INLET TEMPERATURE)

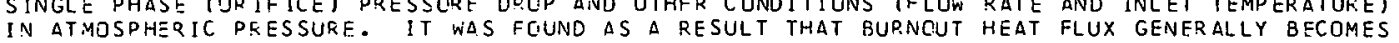
HIGHER AS THE SINGLE PHASE PRESSURE DROO IS INCPEASED UNDER FIXED CONDITIONS OF FLOW RATE ANO IINLET TEMPERATURE. IN ONE CERTAIN CASE HCWEVER, THE BURNOUT HEAT FLUX BECAME HIGHER WITH DECREASE OF THE SINGLE PHASE PRESSURE DROP. THIS WAS PROBABLY DUE TO THE LARGE EFFECT OF NATURAL CIRCULATION CAUSED BY THE LOW FLCW KATE DF THAT PARTICULAR CASE.

F SURNOUT HEAT FLUX + \#FLOW STABILITY + \#REACTOR, OHR + FUEL ELEMENT + PRESSURE DROP

$5-23411$

HAMMITT FG + RUBINSON MJ + LAFFERTY JF

CHOKED-FLOW ANALOGY FOR VFRY LOW QUALITY TWO-PHASE FLOWS

UNIVERSITY OF MICHIGAN, ANN AR BOP, MICHIGAN

12 PAGES, 14 FIGURES, 1 TABLE, NUCLEAR SCIENCE AND ENGINEERING 29 (1), PAGES 131-142 (JULY 1967)

TWJ THEORETICAL MOOCLS TO PREDICT AXIAL PRESSURE DISTRIBUTION, VOIO FRACTICIN, ANE VELOCITY IN A CAVITATING VENTURI APE APPLIED. THF THEORETICAL PREDICTIONS ARE COMPARED WITH EXPERIMENTAL DATA FROM COLC-WATEO AND MERCUPY TESTS, ANC GOOC AGREEMENT FGR THE PRESSUF.E PROFILES IS FJUVD. THE OREDICTED VOID FRACTIONS AKF FOUND TO BE TOO HIGH, PROBABLY BECAUSE THE MODELS ASSUME ZERO SLIP OR NEGATIVE SLIP BETWEEN THE VAPOR AND LIGUID PHASES. THE ANALOGY BETWEEN THE CAVITATIVG VENTUR I ANO JTHEP CHOKED-FLOW REGIMES IS EXPLGREC. THE CAVITATING VENTURI IS AV EXAMPLE OF AY EXTREMELY LCW QUALITY TWO-PHASE CHOKED FLOW DEVICE. THE PRESENT STUDY IS THUS SOMEWHAT APPLICASLE TO THE STUCY OF LIOUID-COOLED NUCLEAR REACTOR PRESSURE VESSEL OR PIPINS, RUPTURES, WHICH HAVE RECFIVEO CONSIDERABLE ATTENTION! IN RECENT YEARS.

\#FLGN, AXJAL + \#FLOW, TwO PHASE + FLOW THEQRY AND EXPERIMENTS + HEAT TRANSFER

$5-23412$

LSITNAKER JM + GODFREY TG

THERMOOYNAMIC PROPERTIES TIF UFANIUM CAPPIDES

OAK RIDGE NATIONAL LDZORATCRY

15 PAGES, 7 FIGURES, 3 TABLES, 38 REFERENCFS, JOUPNAL GF NUCLEAR MATERIALS 21 , PAGES I75-I89 IFEBRUARY 19671

THERMOOYNAMIC' AND PHASE INFORMATIOM PELATIVE TO THE URANIUM-CAREON SYSTEM WERE ANALYZED AND SHUWN TO BE SONS ISTENT. THE ANOMALOUSLY HIGH HEAT CAPACITY CF UCZ IS JUSTIFIEO IN THE ANALYSIS. THEDMAL FUNCTIONS AKE CALCULATED FGR UC AND UC2.

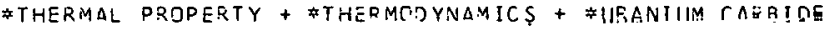

$5-23413$

FEPER RC + HERRICK EC

IDEAL GAS THERMOOYNAMIC FUNCTIONS OF TERRIUM, EREIUM, THULIUM, ANO PLUTONIUM

LOS ALAIOSS SCIENTIFIC LABORATORY, LOS ALAMCS, NEW MEXICO

5 DAGSS, 5 TAZLES, 15 REFERENCES, J. CHEMICAL ENGINEERING AND DATA 12(1), PAGES R5-8S (JANUARY 1967)

IMPROVEO IOEAL GAS THERMUDYNAMIC FUNCTIONS ARE CALCULATEO FOR MONATOMIC TERBIUM, ERBIUM,

THUL IUM, ANO PLUTONIUM, USING R.ECENT ENERGY-LEVEL DATA. THE FUNCTIONS ARE TABULATFR FRCM IOO

TO $6000 \mathrm{~K}$ AT 1 DO-DEG INTERVAIS.

\#PROPERTY, PHYSICAL + \#THERMAL PROPERTY + \#THERMODYNAMICS + ERBIUM + PLUTONIUM

$5-23414$

HAFRIJTT P + BAFNSTONE LA

HEAT TRANSHER IN ELUIDIZED BEDS

C.OFNELL UNIVERSITY + ESSC RESEARCH LND ENGINEERING COMPANY

4 PAGES, : REFERENCES, IND. ENG. CHEM. 50141, PAGES 55-58 (APKIL 1967 )

DISCUSSES THE INCCNSISTENCIES IN PUBLISHEO DATA AND METHODS OF ESTIMAT ING THE ACTUAL COEFFICIENTS FOR PARTICLE-TO-GAS HEAT TRANSFFR IN FLUID BEDS. CALCULATIONS FOR TWD

FLUIDIZEO-BED REACTIONS SHON THAT THE PARTICLE-TO-GAS TEMPERATURE DIFFERENCE WILL NEARLY ALWAYS BE VEGLIGIBLE, BUT SIGNIFICANT TEMPERATUPE DIFFERENCES MAY EXIST BETWEEN GAS BUBBLES AVD THE DENSE BED.

\#FLUIDIZED BED + FLOW THEORY AND EXPERIMENTS + HEAT TRLNSFER + HEAT TRANSFER ANALYSIS

$5-23415$
$K U M A Q R+J \Delta I N$
$\vdots$
$\vdots$

ACCESSICN NUMBER $5-23410$ TO $5-23415$ 
$5-23415$ *CONT INUED*

HEAT TRANSFER IN COUETTE FLOW CF BINGHAM MATERIAL WITH LINEARLY VARYING WALL TEMPERATUPE

INDIAN INSTITUTE OF TECHNOLDGY, NEW DELHI, INDIA

9 PAGES, 3 FIGUFES, 1 TABLE, 14 REFERENCES, JOURNAL CF THE FRANKLIN INSTITUTE 28313 ), PAGES $250-5 \varepsilon$ (MARCH 19671

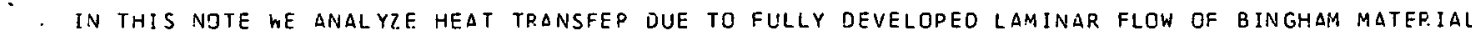
BETWEEN TWO PARALLEL INEINITE PLATES WITH LINEARLY VARYING WALL TEMPERATURE. A NUMBER, CHI, DEF INED AS THE NONDI:MENSIONAL LONCITUDINAL TEMPERATUPE GPADIENT ALONG THE PLATE, IS INTRODUCED. DE SHOW THAT THE TEMPERATURE AT A PLACE IN THE CHANNEL IS HIGHER WHEN THE PLATES ARE MAINTAINEO AT A LINEARLY DECREASING TEMPERATURE THAN WHEN THS PLATES ARE MAINTAINED AT A LINEARLY INCREASING TEMPERATUFE IN THE OIRECTION OF FLOW. THE EFEECT OF OISSIPATION IS TO INCREASE THE TEMPERATUFE AND THIS EFFECT IS MORE SIGNIFICANT WHEN THE FLOW REGION IS NARRCWER.

$5-23416$

NIJSINGR + EIFLER H + DSLFAU B + CAMPOSILVAN

STUDIES ON FLUID MIXING BETWEEN SUBCHANNFLS IN A BUNOLE OF FINNED TUEES

EUPATOM, ISDRA, ITALY

25 PAGES, 29 FIGUPES, 6 TABLES, NUCLEAR. ENGINEERING AND DESIGN, 5(3), PAGES 229-253 (MAY 1967)

STUDIES THE FLUID FLOW BeHAVICUR IN A BUNDLE OF FINNEG TUBES, SIMULATING THE CHARACTEP ISTIC PARTS OF AN OFGEL CLUSTER FUEL ELEMENT. RESULTS OBTAINED CDNCEFN FLOW DISTPISUTION AND INTER SUBCHANNEL MIXING RATES. THE EXPER.IMENTAL DATA NERE IN GOOD AGREEMENT WITH THE PREDICTIONS OF RFLATIVELY SIMPLE HYORCOYNAMICAL MODELS.

\#FIN + \#LLWW, CROSS + FLOW THCORY AND EXPEPIMENTS + FUEL ELEMENT + HEAT TRANSFER +

HEAT TRANSFER AUGMENTATION

$5-23417$

MILLS WJ + PDREH M

HEAT TRANSFER FROM AN ISOTHERMAL SPHEDE TG A LOW PR.ANDTL NUMBEF FLUID IN POTENTIAL FLOW

PENNSYLVANIA STATE IJNIVFRSITY + ISRAEL INSTITUTE OF TECHNOLCGY, HAIFA, ISRAEL

6 PAGES, 6 FIGURES, 2 REFERENCES, I SRAEL JOURNAL OF TECHNOLOGY, 4(3), PAGES $224-229$ (1966)

THE PROSLEM OF HEAT TRANSFER FROM AN ISOTHERMAL SPHERE TO A LGW-PRANOTL-NUMBER FLUID IN STSADY ANO NONSTEAOY DOTSNTIAL FLCW WAS TOEATEO ANALYTICALLY. THE SOLUTICN TO THE PROBLEM IS GIVEN EY A PJKER SERIES IN THE PECLET NUMBER OF WHICH THE FIP.ST THREE TEPMS ARE CALCULATED. THE INSTANTANEOUS AND AVERAGE NUSSELT NUMRERS WERE COMPUTED AND COMPARFD WITH A SIMILAR SOLUTION FOR HEAT TRANSFER FROM A SPHERE IN A STOKES FLOW.

H METAL, LIOUID + FSPHEQE + FLOW, LAMINAP + HEAT TRANSFER

$5-23418$

ZORAVKOVIC VM

ANALYTICAL ADPROACH TO $\triangle C C I D E N T A L$ LGSS OF COOLANT IN BWR

4 PAGES, 3 FIGURES, 2. TABLES, 3 REFERENCES, DTOMKERNENEP.GIE 12(1-2), DAGES 25-28 (JANUAFY-FEBRUARY 1967)

IN GER.MAN

IN THE CASE DF FEEO PIPF OR OUTLET STEAM PIPE RUPTURE, IT COMES TO SUDDEN OISCHAFGE OF SUPERHELTEO HEAVY WATER OR STEAM INTO THE DRY WELL WHERE THE REACTOR IS LOCATED. THIS IS ACCOMPANIED SY SUDOEN AND HIGH BUILC UP CF PRESSURE, WHICH WOULD CAUSE FURTHER DAMAGE. TO SUPDOESS PR SSSURE INCREASE $\triangle N D$ TO PREVENT RADIOACTIVE CONTAMINATION OF ENVIRONMENT, THE DRY WELL IS CONNECTEC RY SPECIAL VENTING PIPES TO THE WET WELL. IN THIS PAPER, THE METHOD OF CALCULATICN IS OISOLAYED IN WHICH THE UNSTATIONARY REGIME OF PRESSURE CALL IS THECRETICALLY PERFORME?. DISCHARGE TIME OF LIQUID IS DFSCRIRED BY TWO NEW DIMENSIONLESS NUMBEPS WHICH CONTAIN ALL SECYETRICAL AND THERMOPHYSICAL PARAMETERS OF THE REACTOQ VESSEL.

\#BLOWDOWN + \#PIPING + PRESSURE TRANSIENT + REACTOR, BWR

$5-23419$

MIXON FO + WHIT $\triangle K E R$ CF + ORCUTT JC

AXIAL DISPERSION AND HEAT TQANSFEF IN LIOUID-LIQUID SPPAY TOWERS

REECAMCH THIANCLE INSTITUTE, DURHAM, NOPTH CAROLINA

8 PAGES, 5 FIGURES, 3 TASLES, A.I.CH.E. JOURNAL, 1311 ), PAGES $21-28$ (JANUARY I967)

A ZADIOTRACFR TFC.HNIOUE WAS USED TO MEASUFE AXIAL OISPEPSION IN EOTH PHASES IN SPRAY TOWERS TOERATED AT $\triangle N C$ NEAR FLODDING. A NEW METHOD THAT EXHIBITS CERTAIN ADVANTAGES OVER METHOUS USED I IN THE DAST IS PRE SENTED FOR RCDUCING SUCH DATA. IT IS DEMONSTRATED THAT AXIAL DISDERSICN IN ELCOODED AND NEAR-FLOODEC SPRAY TOWERS IS SUFFICIENTLY SEVERE TO CONTRDL COMDLETSLY THEIR, PERFQRMANC.E AS HFLT FXT.HANGFRS.

\# SPRAY, GENERAL + FLGW, TWO PHASE + HEAT TRANSFFo + MASS TRANSFER

$5-23420$

DISCHINGEF $2 \mathrm{H}$ 
$5-23420 *$ CONT INUEC:*

PERFORMANCE EVALUATION GF HFAT EXCHANGERS FOP SODIUM-COOLED P.EACTCRS. QUARTERLY TECHNICAL PROGFESS REPORT NO. 6, JCTOBER 1, 1066-DECEMEER 31,1968

UNITED NUCLEAR CORPOFATION, ELMSFORD, N. Y.

UNC-5166 +. 33 PAGES, JANUARY 20,1967

EARLY DATA FRTM THE RISE-TO-POWER TESTS OF THE SCTI WERE USED TO SHAKE DOWN THE EVALUATIGN PRDCEDURES FOR THE ALCU HEAT FXCHANGEPS. SOME TINTIATIVE OBSERVATIONS REGARDING THERMAL PERFORMANCE WEKE MADE. A LITERATUFE SEARCH WAS UNDERTAKEN TO FSTIMATE THE EFFECTS OF GAS ENTRAINMENT IN THE SODIU:A ON HFAT TPANSFER. BECAUSE OF THE POSSIBILITY OF ADVEPSE EFFECTS, IT WAS RECOMMENDE! THAT STEPS BE TAKFN TC REDUCE THE GAS ENTRAINMENT IN THE STEAM GENERATORS, QR, PERFERABLY, TO ELIMINATE IT ALTOGETHEF.

AVAILABILITY - CLEARINGHOUSE FOR FEDERAL SCIENTIFIC AND TECHNICAL INFORMATION, SPRINGFIELD, VIRGINIA, $\$ 3.00$ COPY, \$0.65 YICROFICHE.

*HEAT EXCHANGER + *METAL, LIQUID + \#SDOIUM + HEAT TRANSFER

$5-23421$

POPPENDIEK HF + FEISENGUTZ LV + GREENE ND + MORTON WA + SABIN CM + CONNELLY DJ

INVESTIGATION OF FUNCAMENTAL MECHANISMS AND PARAMETERS THAT INFLUENCE STEAOY STATE AND TRANSIENT

PERFOR:A ANCE OF RAIKINE CYCLE LIOUIO METAL SYSTEMS. QUARTERLY REPORT OCTDBER 1-DECEMBEF. 31,1966 GEOSCIENCE LTD., SOLANA BEACH, CALIF.

SAN-677-6 + GLR-49+. 21 PAGES, DECEMBER 1966

A HEAT-TRANSEEF ANALYSIS OF THE VAPCFIZATION OF A DROPLET ON A HCT ROUGH SURFACE IS PRESENTED. HEAT IS TRANSFEQRED TO THE LIQUID DROP SY CONOUCTION THROUGH THE ISSUING VAPOR FILM UNOER THE DROP AND BY CONDUCTION THROUGH SURFACE ASPERITIES THAT ARE IN CONTACT WITH THE DROP.

PREDICTED VAPCFIZATION LIFE-TIMES APE COMPARED WITH RESULTS FOR S:10OTH SURFACES IFILM

BOILING) AND WITH EXPERIMENTAL BEHAVIOR.

AVAILABILITY - CLEA? INGHOUSE FOR FEDERAL SCIENTIFIC AND TECHNICAL INFORMATION, SPRINGFIELO, VIRGINIA, $\$ 3.00$ COPY, \$0.65 MICRGFICHE

\#DROPLET + \#MERCURY + HFAT TRANSFER + METAL, LIQUIO

$5-23422$

ROGERS JT

HEAT TRANSFER LIMITATIONS ON NUCLEAR REACTOR FUEL ELEMENTS

CANADIAN GENERAL ELECTPIC, PETERBORDUGH, ONT.

10 PAGES, 14 FIGURES, 8L REFEPENCES, THE CANADIAN JOURNAL OF CHEMICAL ENGINEERING, $44(5)$, PAGES 28 S-298 (OCTORER 1066$)$

LIMITATIONS DN MFAT TP.ANSFER RATES ON FUEL ELEMENTS IN CANADIAN HEAVY-WATEP-MODERATED REACTOFS ARE EXAMINED. WITH ORGANIC COOLANT IN SIMPLE FLOW GEOMETRIES, HEAT FLUXES ARE LIMITED BY DEPARTURE FRIM NUCLEATE BOILING (DNB), IN SIMULATEO FUEL BUNDLES THE FAILURE MECHANISM CAN BE EITHER LOCALIZEO DNB, DR COKE-OUT (THE FCRMATION, DEPOSITIGN ANR RAPIO GRCWTH OF COOLANT DECOMPOSITION PRCDUCTS ON HEATED SUPFACESI. WITH BOILING LIGHT-WATER COOLANT, CRITICAL HEAT FLUX (CHF) IS CAUSED BY DNB AT LOW QUALITIES AND BY DRY-OUT AT HIGHER OUALITIES. PARAMETERS GDVERNING CHF IN TUPES AND ANNULI ARE FAIRLY WELL ESTABLISHED. DATA FOR FUFL BUNDLES ARE BECOMING AVAILASLE. METHODS OF INCREASING CHF DND OF RATIONALLY SETTING MARGINS OF SAFETY ON CHF ARE BEING DEVELOPED.

\#DNE + \#HEAT FLUX, CEITICAL + \#HEAT FLUX, DRYOUT + \#REACTOR COOLANT + HEAT TRANSFER + REACTOR, BWR + REACTOR, ORGANIC CJOLED + REACTOR, PWR

$5-23423$

MORGAN RP + YERAZUNIS S

HEAT ANO MASS TRANSFER EETWEEN AN EVAPORATIVE INTERFACE INN A POROUS MEDIUM AND AN! EXTEFNAL GAS STREAM RENSSELAER POLYTECHNIC INSTITUTE, TROY, NEW YORK

9 PAGES, 6 FIGURES, 24 FEFERENCES, A.I.CH.E. JOURNAL, $13(1)$, PAGES 132-140 (JANUARY 19E7)

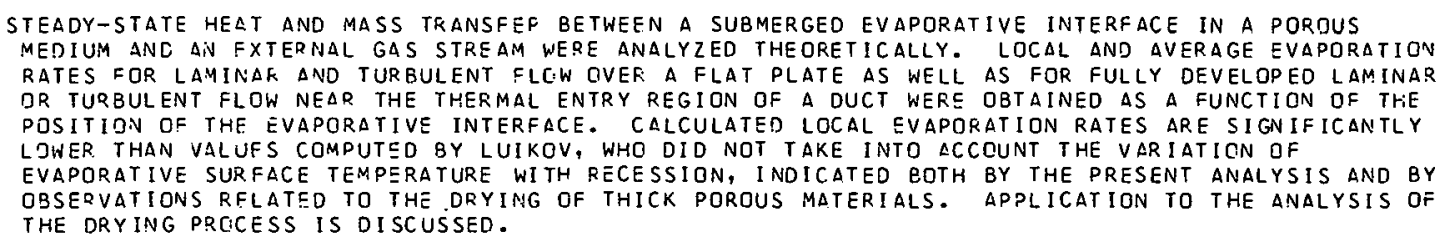
THE DRYING PRCCESS IS DISCUSSED.

\# POROUS DIFFUSION + HEAT TRANSFER + MASS TRANSFER

$5-23424$

REIDRC + BRIANPL + WEGER ME

HEAT TRANSFER AND FROST FORMATION INSIDE A LIQUID NITROGEN-COOLED TURF

MASSACHUSETTS INSTITUTE OF TECHNOLOGY, CAMRRIOGE, MASS. 
CATEGGRY 5
ACCIDENT ANALYSIS

$5-23424$ \#CONTINUED*

6 PAGES, 10 FIGURES, 24 REFERENCES, AICHE JOURNAL $12(6)$, PAGES 1190 -g5 (NOVEMBER 1066)

AN EXPER IMENTAL STUDY WAS UNDERTAKEN OF SIMULTANEQUS HEAT TRANSFER AND FROST DEPGSITION INSIOE A LIQUID-NITROGFN-COOLED TUBE FRR A RANGE OF HUMIDITICS ANO FEYNOLDS NUMBERS. THE DATA INDICATE THAT OIFFUSION OF HATEP VAPOR WI THIN THE FROST LAYEF CAUSEC THE FROST DENSITY AND THERMAL CONDUCTIVITY TO INCREASE WITH TIME. THE INCREASE WAS SO GREAT THAT THE HEAT-TRANSFER RATE BECAME CCNSTANT EVEN WHILE FROST CONTINUEO TO ACCUMULATE. IN A SEPAPATE STUDY, THE THERMAL CONDUCTIVITIES OF FQOSTS FORMED ON A VEKY COLD SURFACE hERE MEASUPED AND FOUND TE BE LOWER THAN VALUES NEAR THE FREEZING PGINT OF WATER.

\#CRYOGENICS + FLOW, TUBE + HEAT TRANSFER + NITROGEN

$5-23425$

CHRISTIANSEN EB + JENSEN GE + TACFS

LAMINAR FLOW HEAT TRANSFEF.

UNIVERSITY OF UTAH, SALT LAKE CITY, UTAH

7 PAGES, 5 EIGURES, 21 FEFERENCES, A.I.CH.E JOUFNAL, $12(6)$, PAGES 1196-1202 (NOVEMBEP 1066)

NUMER ICAL SOLJTIONS DE THE EQUATIONS OF MCTION AND ENERGY FCR THE HEATING OF NON-NEWTONIAN FLUIDS IN P.ECTILINEAR, AXISYMMETRIC LAMINAF FLOW IN TUBES OF CIOCULAR C.ROSS SECTIOV $\triangle P E$ EXTENDED TO THE CASE DF CODLING AT CONSTANT TUBE-WALL TEMPEPATURE. THE FLUID DENSITY, HEAT CAPACITY, AND THERMAL CONDUCTIVITY ARE ASSUMED CONSTANT, BUTT THE FLOW PRCPERTIES ARE REDRESENTED BY A TEMPERATURE-DEPENDENT EQUATION. THE RESULTS $\triangle G E$ PRESENTED AS GR APHS. THE MEAN DEVIATION OF EXPEPIMEVTAL DATA FOR THE CCOLING OF AQUEGUS CHC AND CARBOPCL DISPERSICNS FROM THE NUMERICAL SOLUTIONS IS PLUS C.R MINUS $8 \%$.

FLOW THEORY AND EXPERIMENTS + FLOW, $\triangle X I A L$ + FLOH, LAMINAR + FLOW, NONNEWTONIAN + HEAT TRANSFER.

$5-23426$

HEACHN + HELLUMS JD

HEAT TR ANSPDRT AND TEMPERATURE DISTPIPUTIONS IN LAFGE SINGLE DFCPS AT LOW REYNOLDS INUMEERS--A NEW

EXPER IMENTAL TECHNIOUE

RICE UNIVERSITY, HOUSTON, TEXAS

7 PAGES, 6 FIGURES, I TABLE, 10 REFERENCFS, $\triangle$ ICHE JOURNAL 12(3), PAGES 553-59 (1966)

A NEW EXPERIMENTAL TECHNIQUE WAS DEVELCPEO FOR STUDY OF TRANSPQFT FRGM DRQPS. LLRGE SINGLE DROPS WERE HEATED DIELECTRICALLY WHILE SUSPENDED MOTIONLESS IN AN UNHEATED CONTINUDUS PHASE. DIRECT MEASUREMENTS CFF TEMPERATURE DISTRIBUTICNS WITHIN DRCPS $A F E$ PRESENTEO BOTH FIR CIRCULATING DPOPS AND FOR DROPS IN WHICH SURFACE-ACTIVE MATEPIALS RETARD CIRCULATION. THE RESULTS OF THE MEASUPEMENTS WILL BE USEFUL IN ASSESSING THE VALIDITY OF THE VARIOUS PPOPOSED MDDELS.

*DROPLET + HEAT TRANSFER + HEAT TRANSFER COPRELATION + SPRAY, GENERAL

$5-23427$

WACHTERS LH + BONNE H + VAN NOUHUIS HIJ

THE HEAT TRANSFEP FREM A HOT HORIZONTAL PLATE TO SESSILE WATER DROPS IN THE SPHERODIAL STATE LARORATORIUM VOOR FYSISCHE TEC,HNOLOGIE, THE NETHERLANDS

14 PAGES, 14 FIGURES, 3 TABLES, 24 P.EFERENCES, CHEM. ENG. SCI $21(10)$, PAGES $923-36$ (CCT. 66)

THE HEAT TRANSFER FROM A HOT METAL SURFACE TO A WATER DROP FFSTING UPON IT WAS INVESTIGATED. THE EXPEC IMENTALLY DETERMINED EVAPORATION RATE IN A SATURATED $\triangle T M O S P H E R E$ AGREED RATHER WELL WITUI THE PREDICTIOHS OF A SIMPLF THEOF', IN WHICH THE BOTTCM OP THE OROP WAS ASSUNED TU EE FLAT. AGREEMENT WITH A MORE FEFINED THEQEY IN WHICH THE CURVATUPE OF THE BOTTOM IDUE TO THE PQESSURE ORDO ALCNG THE BOTTOM) WAS ALSO CONSIDERED, WAS NCT SO GOOD, PROQABLY BECAUSE OF THE SIMAL OSE ILLATOP.Y MOTIONS OF THF BOTTCM GF THE DROP.

\#DRQPLET + \#HEAT TRANSFEF. CORP.ELATION + HEAT TRANSFER + SPRAY, GENERAL + WDTER, GENERAL

5-23439 $\triangle L S C I N$ CATECORIES 6 AND 7

KIET

QUARTERLY TECHNICAL FEPGRT STEP PROJECT JANUARY 1-MARCH 31, 1967

PHILLIPS PETROLEUM COMPANY

IOO-17230 +. 156 PAGES, 81 FIGURES, 15 TABLES, 5C REFERENCES, AUGUST 1967

TIIIS RLFORT IS ONE OT A SERIES ON TI:C FOLLOKI ING TOPICS - LOPT OE3IGIN AINALISIS, LOPT BLOWCUNIV ANALYSIS, DIRECT RADIATION LEVELS CURING LOFT OPERATION, FISSION DROOUCT BEHAVICR STUDIES, LOFT RAOIOLOGICAL STUDIES, MOOEL FGIRULATION FOR THE SUBCOOLEO GECOMPRESSION DUPATION IN A PAR SYSTEM FOLLJWING A PRIMARY-COOLANT-LOOP SREAK, AND SEMISCALE BLOWDOWN TEST PROGRAM.

AVAILABILITY - CLEARINGHOUSE FOR FECEQAL SCIENTIFIC AND TECHNICAL INFOPMATION, SPRINGFIELD, VA., \$3. OO COPY, $\$ 0.65$ MICROFICHE

ACCIDENT, LOSS OF COGLANT + CONTAINMENT DESIGN + CQPE NELTOOWN + CDRE SPRAY +

FISSION PROOUCT RELEASE, GENERAL + LOFT (S-RR) + REACTOR TPANSIENT + REACTOR, SAFETY FESEARCH 


\section{ATEGORY
IENT ANALYSIS}

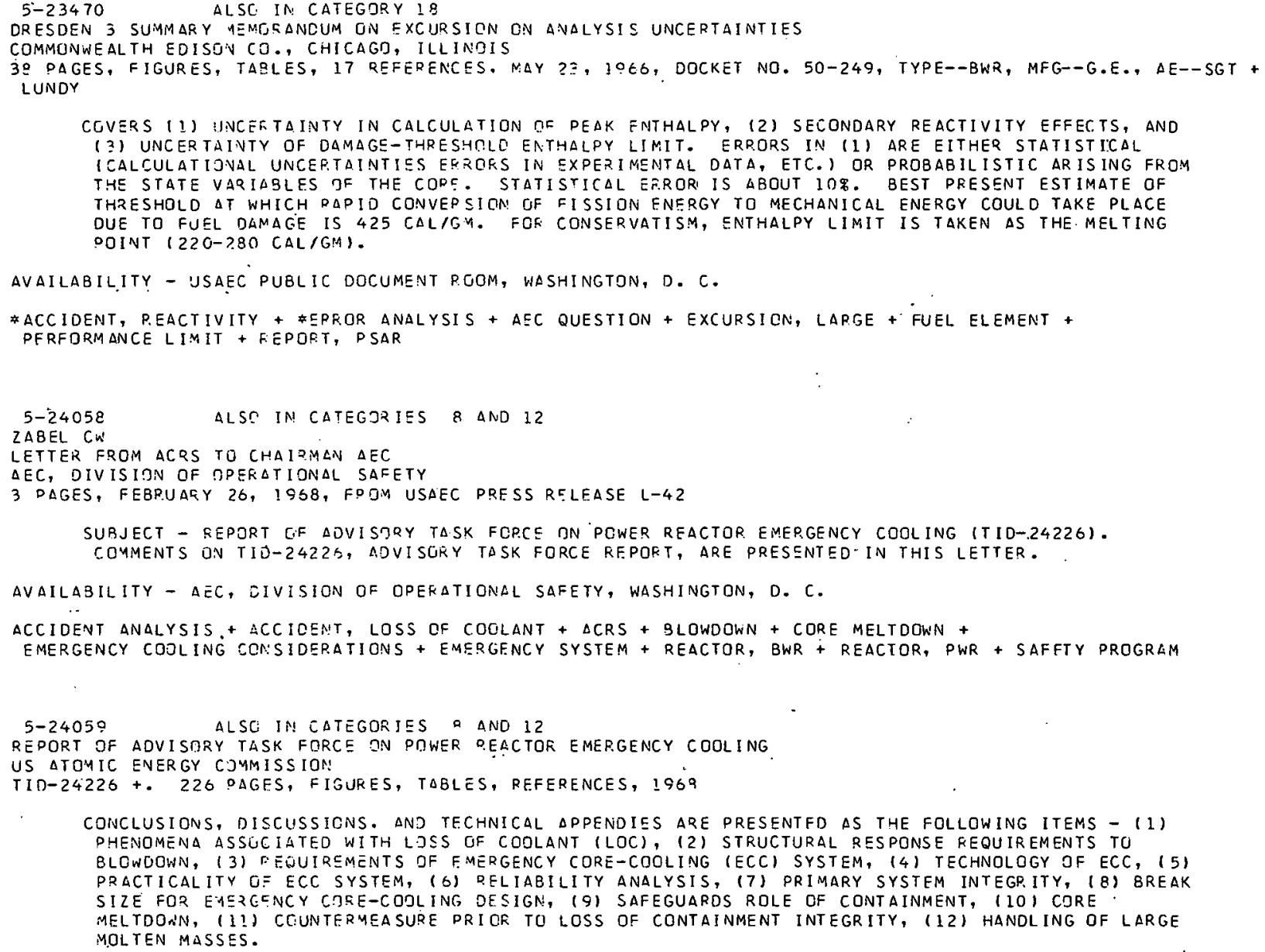


REACTOR TRANSIENTS, KINETICS, AND STABILITY

$6-20587$

DOFRNER RC + KNAPD WE + KARAM RA + RUTLER DK

ZPR-9 ASSEMBLIES NO. $6-O$ CRITICAL EXPERIMENTS

ARGONNE NATIONAL. LAB., ILL.

$A N L-7208+104$. PAGES, 86 FIGURES, TABLES, FEFEFENCES, MARCH 1967

A SERIES DF FAST CPITICAL ASSEMRLIFS WAS STUDIED IN THE ARGONNE ZPR-9 FACILITY IN SUPPORT OF THE DESIGN ECFRRT IN THE FAST-REACTOR NUCLEAP-PROPULSION PPOGRAM. AN ATTEMPT WAS MADE PQIMARILY TO PROVIDE INTEGRAL MEASUPEMINTS AS CIICCKPOINTS FOF CROSS-SECTICN SETS THAT WERE GENERATED FOR THE PROGRAM AND, SECCNDARILY, TO PROVIDE DATA TO TEST THE UTILITY OF SIMPLE, JNE-DIMENSIOVAL, MULTIGROUP DIFFUSION THEOFY IN THE PROGRAM. $\triangle$ MAJOR OBJECTIVE OF THE PRESENT REPDRT IS TO PRESENT THE RESULTS OF A SER.IES OF CRITICAL EXPERIMENTS, EMPHASIZING THE I YPORTANT DIFFERENCES BETWEEN MEASUREMENTS MADE IN METAL-ANO OXIDE-FUELED CDRES AND BETWEEN ALUMINUM, AL203, AND BEO AS REFLECTOR MATERIALS.

AVAILABILITY - CLEARINGHDUSF FOR FELEP.AL SCIENTIFIC AND. TECHNICAL INFORMATION, SPRINGFIELD, VIRGINIA \$3. OO CQPY, \$O.S5 MICROEICHE

CONTROL ROD WORTH + CRITICALITY EXPERIMENT + DELAYED NEUTRON + FLUX DISTRIBUTION +

PROMOT NEUTRON LIFCTIME + REACTIVITY COEFFICIENT + REACTIVITY EFTECT I RETLCCTOR I ROSSI ALPHA

$0-21124$

BARS B

STOCHASTIC FLUCTUATIONS IN THE POWER PULSES OF TRIGA REACTORS

TECHNICAL UNIVERSITY IF HELSINKI, OTANIEMI, FINLAND

1 PAGE, 4 REFERENCES, NUKLEONIK $9(6$ ), PAGE 301 (APRIL 1967 )

THE STATISTICAL FLUCTUATIONS IN THE PEAK POWER AND THE RELEASED ENERGY DUR ING A TR. IGA REACTOR POWER PULSE NERE CALCULATED ANO COMDARED WITH EXPERIMENTAL OBSERVATIONS. THE THEORY DEVELDPED FOR THE FLUCTUATIONS IN THE POWER BURSTS OF PULSING REACTORS SHOWED THAT THE CHAIN REACTION HAS A MINOR INFLUENCE DN THE FLUCTUATIONS IN THE POWER PULSES PROVIDED THAT THE PRE-PULSE STEACY-STATE POWER IS SUFFICIENTLY HIGH. THE STATISTICAL FLUCTUATIONS IN THE POWER PULSES OF THE TRIGA MARK II PIEACTCR (FIR-I) ARISE MAINLY FROM THE VARIATICNS IN THE INJECTED REACT IVITY.

NOISE ANALYSIS + REACTOF DYNAMICS + REACTOR TRANSIENT + THEORETICAL INVESTIGATION

6- 21125

NISHTHARA H

SPACE-DEPENDENT BEHAVIOF DF' 4 SOILING WA'TER REACTOR BY AN ADIABATIC MCDEL.

KOYOTO UNIV.

6 PAGES, 6 FIgURES, 1 TABLE, 11 REFEQENCES, J. NUCL. SCI. TECHNOL. (TOKYO) 3 , PAGES 528-533 (ODEC. 1966)

USING AN ANALYTICAL MODEL FOR SPACE-DEPENDENT BOILING-WATER-REACTOR KINETICS BASED ON THE CONVENTIONAL $\triangle D I A B A T I C$ APPROXIMATION, SOME NUMERICAL SIMULATIONS ARE PQESENTED FOR A SAMPLE 3OILING-NATER REACTOR AT $200 \mathrm{MW}(T H)$, TOGETHER WITH $\triangle N$ ANALYSIS OF ITS SPACE-TIME EEHAVIDR. RESULTS OF THE SIMULATION STUDY INCICATE THAT SPACE-DEPENDENCE IS SIGNIFICANT WHEN THE REACTOR IS UNOERGOING A LARGE TRANSIENT, WHILE, FOR SMALL DISTURBANCES, THE REACTOR BEHAVES WITH LITTLE VUCLEAR SPACE-DERENDENCE.

OYNAMICS, NONLINEAR + FLUX DISTRIBUTION + REACTOR DYNAMICS + REACTOR TRANSIENT + SPACE DEPENDENT DYNAMICS + THEORETICAL INVESTIGATION

$6-21126$

VON HANS-JURGEN H + WOLFGANG D

RESULTS OF ZERO-PIWEK EXPEPIMENTS OF THE AVR REACTOR

BROWH BOVERI/KRUPP REAKTCPBAU GHBH, JUELICH, GERMANY

3 PAGES, TABLES, FiguFES, AT. STROM., 13 , PAGES 24-26 (FEB. MAR. 1067) IV GERMAN

REPORTS THE RESULTS OF ZERD-POWER EXPERIMENTS CONDUCTCD ON THE AVR PEBELE-BED REACTOR. THE REACTOR FIRST ACHIEVED CRITICALITY ON AUGUST 26, 1966. THE REACTIVITY WORTH OF THE SHUTOOWN RODS WAS OETERMINED TO BE $-2 \%$, AND THE AVERAGE VALUE OF THE TEMPERATURE COEFFICIENT OF REACTIVITY SETWEEN 25 AND 11 I C WAS MEASURED TO BE -1.3 X $10(-4 T H) / D E G C$.

CONTROL ROD CALIBRATION I RTACTOR GTARTUP TESTINE + REACTOR, PEBBLE BED + SHUTDOWIN MARGIN + TEMPERATURE COEFFIC IENT

$6-21130$

LITTLE WN + HARDIERW

FCC-IV. $\Lambda$ D.EVISEO VEOSION DF THE FCC FUNDAMENTAL MODE FAST REACTOR CODE.

BATTELLE-NORTHWEST, PICHLAND, WASH., PACIFIC NGRTHWEST LAB.

BNWL $-450+134$ PAGES, AUGUST $196 ?$

FCC-IV IS A MULTIPURPOSE EUNOAMFNTAL-MOOF COOE FOR USF IN FAST REACTOR NEUTRONICS ANALYSIS. 
6-21130 \#CONTINUED*

THE CODE CAV QE USED TO - (1) COMPUTE RESTINAVCE SHIELDED CROSS SECTIONS USING DATA IN THE RUSSIAN FORMAT, (2) COMPUTE THE FUNCAMENTAL-MODE FLUX AND ADJOINT FLUX, (3) COMPUTE AND FUNCH COLLAPSED MICRCSCOPIC, MACROSCOPIC, AND PERTUREATION CROSS SECTIDNS, (4) COMPUTE FUEL BUPNUP AT CONSTANT FLIJX OR POWER DENSITY. IN $\triangle$ E5-K MEMORY, THE CODE CAN HANDLF 14 ISOTOPES WITH 40 ENERGY GROUPS AND 10 DOWNSCATTERING TERMS. PUNNING TIME ON A UNIVAC IIO8 IS $\triangle B O U T$ IS SEC.

AVAILABILITY - CLEARINGHOUSE FOR FEDERAL SCIENTIFIC AND TECHNICAL INFORMATION, SFRINGFIELD, VIRGINIA S3. OO COPY, \$O.65 MICROFICHE

COMPUTER PROGRAM + CROSS SECTION + FUEL BUPNUP + REACTOR DYNAMICS

6-21235 ALSO IN CATEGQRY :

DRAGT J9

THREEFOLD CORRELATIONS ANO THIRD ORDER MOMENTS IN RFACTOR NOISE

REACTOR CENTRUM NEDEFLAND, PETTEN, NETHERLANOS

7 PAGES, 2 FIGURES, NUKLEONIK, 10, PAGES 7-12 (JUNE 1967)

PRESENTS A. THEOEY COR THE FVALUATION OF THIRD-CROER MOMENTS CF NEUTRON COUNTS IN A REACTOF OUE TO THRESFOLD CORRELATION OF THE DETECTEO NEUTRDNS. POINT REACTOR THEORY IS USED THPOUGHOUT. THE PROBABILITY FOR DETECTION OFF THREE NEUTRONS IN SUCCESSION IS FOUNC, AND FROM THAT THE CENTRAL MOMENTS CF THE NUMBEPS OF NEUTRON COUNTS IN SPECIFIED TIME INTERVALS ARE CALCULATED, AS WELL AS THE TRIPLE DUTOCORRELATION FUNCTION FOR THE COUNT RATE. THE THREEFOLD CORRELATIONS AFE SHOWN TO BE DUS TC TWO BRANCHING PROCESSES IN THE FISSION CHAINS IN THE REACTOR. IN THE DOMINATING AND FASILY MEASURABLE PPOCESS ONLY SPLITTING OF THE FISSION CHALNS INTO TWO BRANCHES IS DETECTED. A VARIANT OF THE FEYNMAN ALPHA TECHNIQUE IS PROPOSEO FOR THE MFASIJREMENT OF THIS EFFECT. IN THE OTHER PROCESS, TRIPLE SPLITTING OF THE FISSICN CHAIN IS INVOLVED. THIS PROCESS CAN PROVIDE NEW PHYSICAL INFORMATION. IN PARTICULAR, REACTOR PONER AND EFFECTIVE DELAYED NEUTRON FRACTION CAN BE OBTAINED WITHOUT THE NEED FOR ANY OTHER STATIC MEA.SUREMENT. AN EXPERIMENT FOR THE MEASUREMENT OF THIS EFFECT IS PROPOSED, WHICH IS SHOWN TO PE MOST FEASIBLE FOR A FAST REACTOR.

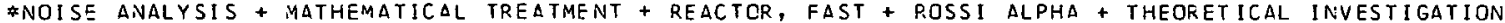

$6-21241$

FOX JK

COMPARISON OF ORNL CLEAN CRITICAL EXPERIMENTS WITH CALCULATIONS

IDAHO NUCLEAR CORP. IDAHO FALLS

IN-1120+. 23 PAGES, 4 FIGURES, 8 TAPLES, 25 REFERFNCES, SEPTEMBER 10 T

THE ACCURACY OF SEVERAL REACTOR CODES WAS DFTERMINED EY COMPARISONS DF CALCULATIONS WITH OATA ON CLEAN CRITICAL EXDFFIMENTS PEPFORMED AT GRNL. ALL THE SYSTEMS STUDIED WERE MODERATED TO SOME DEGREE BY HYOROGEN. MIST OF THE COMPARI SONS WERE WITH DATA ON HIGHLY ENRICHED URANIUM FUELED CORES, ALTHOUGH A FEW WERF WITH 2 TO $5 \%$ ENRICHED FUELS. A FOUR-GROUP STRUCTUPE WAS USED IN ALL CASES. TRANSPURT THEOFY WAS USED ONLY FOR OBTAINING FLUX-WEIGHTED CROSS SECTIRMS. THF TARII ATFA RF GIII TS INIIR.ATF THAT WITH PRMPFRIY WFIGHTED CONSTANTS EIGENYALUE CALCULATIONS USING DIFFUSION THEDRY AGREE WELL. WITH EXPERIMENTS.

AVAILABILITY - CLEARINGHOUSE FO? FEOERAL SCIENTIFIC AND TECHNICAL INFORMATION, SPRINGFIELD, VA., \$3. OO CCPY, \$O.65 MICKONFICHE

\#COMPARISON, THEORY AND EXPERIENCE + \#CRITICALITY EXPEPIMENT + COMPUTER PROGRAM + REACTOR PHYSICS + REACTOP, GENERAL + TRANSPOPT THEOKY

$6-21242$

FRUHAUF CL

TER4 - PEACTOR TRAVSIFNT ANALYSIS PFDGRAM

KNOLLS ATOMIC POWEZ LAB. SCHENECTADY, N.Y.

KAPL $-M-6713(R E \dot{V}$. A) +. G1 PAGES, REFERENCES, MAY 1967

TER4 IS A FORTFAN-IV COMPUTCR PRORRAM FOR ANALYZING POWER AND TEMPERATURE TRANSIENTS IN AN OPEN-LOOP REACTOR. REACTIVITY MAY BE VARIED BY CONTPOLLROD MGTION OR BY TEMPERATURE CHANGES COMBINED WITH THE TEMPERATURE COFFFICIENT EFFECT. THE SPACE-INDEPENDENT ONE-ENERGY-GRCUF REACTOR-K INETICS EQUATIONS WITH SIX DELAYED NEUTRON GROUPS ARE SOLVED FOR THE NOMINAL CHANNEL ONLY. A ONE-CIMENSIONDL HEAT-TRANSFER MODEL OF A ONE-PASS REACTOR IS USEO. REPORT INCLUDES INPUT/OUTPUT DESCRIPTION AND SAMPLE PROBLENS.

AVAILABILITY - CLEARINGHOUSE FOR FEDERAL SCIENTIFIC AND TECHNICAL INFORMATION, SPRINGFIELD, VA., \$3. OO COPY, $\$ 0.65$ MICROFICHE

* COMPUTER PROGRAM + \#REACTOR TRANSIENT + REACTOR DYNAMICS + REACTLR KINETICS + TEMPERATURE TPANSIENT

$6-21243$

ADALIOGLU U + OZEMRE AY

REACTOR KINETICS ACCORDING TO PI APPROXIMATION

ISTANBUL TEKNIK UNIVEP SITESI NUKLEEP. ENEPJI ENSTITUSU, TURKEY + FEN FAKULTESI TEORIK FIZIK KURSUSU,

INSTANBUL, TURKEY

6 PAGES, 3 FIGURES, 4 TABLES, 8 REFERENCES, NUKLEONIK O(8), PAGES 367-372 (MAY 1967) 
CATEGORY
REACTOR TRANSIENTS, KINETICS, AND STABILITY

6-21243 \#CONTINUEC*

DERIVED THE REACTOP KINETICS EQUATIONS ACCCREING TO THE PI APPROXIMATICNS. SPECIAL CASES WERE

STUDIED FOP THE TRI RESEARCH RFACTCR, USING ONE GROUP OF DELAYED NEUTFCNS. THE PI

APPRDXIMATION GAVE HIGHER FLUXES THAN SIMPLE DIFFUSION THEORY AFTER SOME SIMALL INTERVAL

FOLLOWING A PCSITIVE PEACTIVITY INSFRTION, ANO $\triangle$ GOUT EQUAL FLUXES FOLLOWING $\triangle$ NEGATIVE

REACTIVITY INSERTION.

\#REACTOR TRANSIENT + EQUATION, IN HOUR + REACTOP. PHYSICS + REACTOR, RESEARCH

$6-21244$

GANDINI A + SALVATORES M

COMPARISON BETWEEN THE ELMOE AND THE ITERATIVE METHODS TO GENERATE TRANSPORT AND ELASTIC REMOVAL CF.OSS

SECTIDNS FOR FAST REACTOP. EVALUATIONS

COMITATO NAZ IONALE PER L [ENCRGIA NUCLEARE, R.OME, ITALY

RT-FIYA- $(66)-3+.12$ PAGES, TABLES, REFERENCES, 1966

ELASTIC REMDVAL AND TRANSPORT CROSS SECTIONS WERE CALCULATED COR THE CASE CF

DILUTE-PUD2-TUCLCD, NA-COOLED FAST REACTOR IISING THE ELMOE CODE AND AN ITERATIVE METHOD.

COMPARISON OE THE RESULTS OBTAINED BY THF TWD METHODS INDICATES THAT, THE ITERATIVE METHOC IS

ARPLICABLE TO TYPICAL PROBLEMS OF INTEREST.

AVAILASILITY - MICROCARD EDITIONS, INC., ACCQUNTING AND SHIPPING DEPT., WEST SALEM, WISCCNSIN 54GES

CROSS SECTION + MATHEMATICAL STUDY + PLUTONIUM DIOXIDE + REACTOR, LMCF + SEDIUM + TRANSPORT THECRY

6-21245 ALSO IN CATEGJRIES 7 AND 12

REPGRT OT WORK IN THE 4 TH OUNRTER OF 1066

COMMISSARIAL A L-ENEQGIE ATOMIQUE, CADAQACHE, FRANCE

EURFNR-267+. 89 PAGFS, 1966

THIS REPORT IS ONE OF A SERIES OF REPORTS ON WORK PERFQRMED UNDFR THE UNITED STATES-ELIPATCM FAST REACTOR EXCHANGE PRTGRAM. TOPICS CCVERED ARE - CRITICALITY STUOIES, METALLUP.SY, RADIATION EREECTS, RADIATION SHIELDING AND PROTECTION, FEACTOR CONTROL, P.EACTOP, ENGINEEPING, RADIATION EFEECTS, RADIATION SHIELOI
REACTOR FUELS, AND REACTOR SAFETY.

AVAILASILITY - MICROCARD EDITIONS, INC., ACCCUNTING AND SHIPPING RFPT. INEST SALEM, WISCRNSIN E4EGO

ACCIDENT, REACTIVITY + CRITICAL!TY EXPERIMENT + FISSION PROCUCT RETENTION + REACTOP. CONTROL + DEACTOR DYNAMICS + REACTOR. IMCR + SOOIUM

$6-21247$

RI ACKRIIRN D + SHERWIN J + TYROR JG

REACTOR CALCULATIONS FOR AGR

UNITED KINGOOM ATOAIC ENERGY AUTHORITY, WINFRITH

11 PAGES, 6 FIGURES, 9 TARLCS, 18 REFERENCES, J. BRIT. NUCL. ENERG. SOC S(?), PAGES 14L-54 (AORIL 1967)

DESCFIDLS THE METHODS FOR CALCULATING FNRICHMENT REQUIREMENTS, FOWER DISTRIBUTIONS, FUEL-MANAGFMENT STRATEGISS, ETC., FOR AGR-TYPE SYSTEMS. THE VARIOUS COMPUTER CCLFS USEU IN AGR REACTOR-CORE PIIYSICS STUDISS IN TERMS OF THE HOMORENEOUS $\triangle N D$ HETEROGENEOJS MODELS OF THE REACTOR ARE DISCUSSED WITH PESPECT TO THEIR RELATIVE ACCURACY AND SOLUT ION TIMES. THE AUTHOQS CONGLIIIFF THAT FEW-GROUP COARSE-MESH HOMOGENFOUS CODES $\triangle R E$ GENERALLY $\triangle D E Q U A T E$ FOR THE STUDY OF AGR CORE PERFORMANCF, EXCEPT FOR ESTIMATION OF PFAK FUEL RATINGS ADJACENT TO PFRTURBATIJVS IN THE LATTICE.

AGR (ADVANCED GASCOOLED REACTER, WINCSCALE, UK) + ANALYTICAL MODEL + CCMPARISCN, THEORY AND EXPERIENCE + COMPUTER PROGRAM + MATHEMATICAL TREATMENT + DOWFR CISTRIRUTICN + REACTOR, GCR + PEACTCR, THERMEL + UNITED KINGOOM

$6-21245$

DURAND-SMET RA

POSSIBILITIES FOR ZONING A 1700 LITER, SOEIUM-COCLER FAST REACTOR FCD. MEASURING THE SOUIUM VOID

COEFFICIENTS

KERINFORSCHUNGSZENTRIJA, KATILSPUHE

$N P-16853+P S B-243+.72$ PAGES, 1965

PREBLEMS ASSOCIATED WITH A LOW-ENERCY CDITICAL ASSEMBLY FOR MFASURING SODIUM-VOIC COEFFICIENTS WERE EXAMIVED. TO AVOIO REQUIRING AN EXCESSIVE OIJANTITY OF PIUTONIUM, THF ASSEMELY IS ZONED.

THIS, HOWEVER, INTRODUCES ERROSS IN THE MEASUREMENTS, WHICH MUST SE EVALUAT ED. THIS REPCIRT

DESCRISES STUOIES MAOE TO DETEE,HINE THE CONSEQUENCES OF DIFFEPENT REACTOR ZONING ON THE

[XPERIMENTAL SODIUVIVIIN RIFFETSIENTS.

AVAILABILITY - MICRJCARD EDITIONS, INC., DCCOUNTING AND SHIPPING DEPT., WEST SALEM, WISCONSIN 5LGEO

CRITICALITY EXPERIMENT + REACTOR, FAST + SCOIUM + SCOIUM COEFFICIFNT + VOIO COEFFICIENT

$\therefore$

ACCESSION NUMPER 6-21243 TO 6-21240 
REACTOP. TPANSIENTS, KINFTICS, AND STABILITY

$6-21250$

CARVER JG

PLUTONIUM SUPCRITICAL EXPEPIMFNT PRCGFAM. QUARTEFLY FEPORT NO. I1, JANUARY I-MAFCH 21, 1967.

GENERAL ELECTRIC CJ., PLEASANTTN, CALIF.

GEAP-5486 + EURAEC-18?7+12. PAGES, $\triangle P R I L 3,1967$

THE THO MAJDR DOJFCTIVES JF THE PROGPAM ARE TO PROVIDE EASIC REACTOR PHYSICS DATA FDR P.LUTONIUA-ENRICHED UO? FUEL LATTICES IN LIGHT WATER ANO TO OEVELGP A THEORETICAL MODEL CAPABLE UF AECURATELY PREDICTING ALL THE EXPERIMENTAL RESULTS. MAJOR EMPHASIS IS BEING GIVEN TO EVALUATING TECHNIOUES FOK CALCULATING SLOW-NEUTRON SPECTRA AND COMPUTING REACTION RATES ONCE THE SPECTPUN IS ESTARLISHED. THE REPORT SUMMARIZES WORK ACCOMPLISHED TO DATE. FINAL EXDER IMENTAL RESULTS AND CONCLUSIONS AWAIT A MORE COMPLETE DATA REOUCTION AND ANALYSIS.

AVAILABILITY - CLEARINGHOUSE FOR FEDEFAL SCIENTIFIC AND TECHNICAL INFORMATION, SPRINGFIELD, VA., \$3. OO COPY, \$O.55 MICROFICHE

CRITICALITY EXDERIISNT + PLUTONIUM DIOXIDE + REACTCP, WATER

E-21319 ALSE IA CATEGCROISS 5 AND

NURLOC-1 . O A DIGITAL COMPUTE? DRGGFAM FOR THERMAL ANALYSIS OF A NUCLEAR-REACTOR LOSS-OF-COOLANT ACCIDENT BATTELLE MEMOZ IAL IVSTITUTF, COLUMEUS, DHIO

BMI-1807+ 319 PAGES. FIGIJRES, TARLFS, EEFERENCES, JULY 6,1967

NURLOC-1.0 CONTAINS MATHEYATICAL MCDELS FOF. MOST OF THE PROCESSES OCCURR ING IN A REACTOR ACCIDENT WHICH AFFECT THE SÜLID ANE FLUID TEMPERATURE OISTRIEUTIONS. MODELS WEFE DEVELOFED AND PRIGRAMMED FUR HEAT CJNDUCTION, HEAT GENERATI ON, THERMAL RADIATION, BOIL-OFF, MELTDOWN, DISTBLOWDONN HEAT AND MASS-TRANSFEF CEEFFICIENTS, ANE METAL-WIATER REACTION. TEST CASES OF ACCIDENT HEAT TRANSEFR IV THF LOFT PEACTOK WERE CALCULATED FOR TIMES UP TC 400 SEC.

CALCULATIONS WERE $\triangle L S O$ PSRFORMED FGP A TYDICAL 6OO-MWIT) BWR FCF A SIMILAR. PEDICD OF TIME. A

TYPICAL 1OOO-N,NIE) BWR GAVE TEMPERLTURF AND METAL-WATER REACTIONS MUCH DIFFERENT FẼOM THCSE

TUR LUFI. THF PERCENTAGE GF CLADCING REACTED WAS LESS BY MORE THAN A FACTDR OF TWO FOR THE

10OO-MWIE) REACTCP THAN FOR LCFT FOF. SIMILAR PEFIODS OF TIME.

AVAILASILITY - CLEARINGHOUSE FOR FECERAL SCIENTIFIC AND TECHNICAL INFORMATION, SFRINGFIELD, VA., \$3. OO COPY, \$0.5.5 MICRDFICHE

ACCIOENT, LOSS DF COCLANT + ACCIDENT, MAXIMUM CREDIBLE (MCA) + COMPUTER PROGFAM + REACTOR, GENEPAL + REACTOR, WATER

6-21322 ALSO IN CATEGTPIES 5 AND 8

KINETIC STUDIES OF HETEF JGENEOUS HATER. REACTORS. ANNUAL SUMMARY PEPDRT, 1966

TRW SYSTEMS GRDUP, REDONDO BEACH, CALIF.

STL-372-50+. 129 DAGES, 57 FIGUPES, 3 TAELES, 44 REFERENCES, DECEMBER 1966

ANNUAL SUMMAZY REPQRT-196́6. SUMMAFIZED WORK ON - 11 THE PRMCESS JF THERMAL PRESSURE

GENERATICN, (2) SHDCK-TUBE EXPEFIMENTS, 1 3 ) POSSIBILITY OF DESTFUCT IVE IN-CORE PRESSURE IN

MEITDOMN ACCIDENT, (4) IVTILE CAFSULF MEASUREMENTS GF STFAM-VMIO FORMATICN, AND (5) POWER

AEACTOR INSTAFILITY AND TWO-PHASE FLOW.

AVAILASILITY - CLEARINGHOUSE FOR EECERAL SCIENTIFIC AND TECHNICAL INFORMATION, SPRINGFIELO, VA., S3. OO

COPY, $\$ O .65$ MICROFICHE

ACCIDENT, REACTIVITY + EXDLOSION + FLOW, TWD PHASE + REACTOP. TRANSIENT + REACTOR, WATEF + TPANSFER FUNCTION

$6-21435$

POONEY AN + SMITL HP

PQOMPT-VEUTRTNN KIVETICS OF A SPHERICAL-CEVITY REACTOR

UIVIVERSITY GF CAL I FORNIA, BERKELEY, CALIF.

\& DAGES, 4 FIGURES, NUCLEAF SCIENCE AND ENGINEERING 29 13) PAGES 373-380 (SEPT 1967 )

$\triangle$ SIMPLE KINETICS MOOEL IS PROPOSFC THAT DESCRIBES TIME DEPENDENCE OF THE PROMPT-NEUTRON PJPULATION IN A CAVITY REACTOF IN TERMS OF A LINCAR FIRST-ORCER DIFFERENTIAL EQUATION FOR THE NET THERMAL-NEUTPON CURRENT AT THE CAVITY WALL. THE MODEL IS APPLICABLE IF THE CAVITY ALBEDO CHANGES SLJWLY DURING 4 NEUTRGN LIFETIME AND DOES NOT EXCEED A SPECIFIED MAXIMUM VALUE. THIS RANGE OF APPLICABILITY IS DEFINED EY CERIVING THE KINETICS EQUATIDN ON THE BASIS OF AN $\triangle G E-D I F F U S I O N$ THEORY APFZOXIMATION THAT DESCRIBES THE TIME OEPENDENCE DF THE THERMAL-NEUTRON FLUX AT THE CAVITY WALL IN TERMS OF A VOLTERRA INTEGRAL EQUATION DF THE SECOND KIND. THE METHOD OF DERIVING THE KINETICS EQUATION SUGGESTS A MEANS OF EXPERIMENTALLY DETERMINING THE EFFECTIVE INUTIPLICATION FACTOP. ANE AVERAGE NEUTRON LIFE-TIME-TO-FISSION FOR MORE COMPLEX CAVITY GEOMETRIES EY MCASURING THERMAL-NEUTRON ASSORPTION RATE IN A NONMULTIPLYING GAS IN THE CAVITY.

PROMPT CZITICALITY + PRCMPT NFUTRON LIFFTIME + DEACTOR KINETICS + THEORETICAL INVESTIGATION 


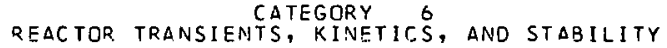

$6-21436$

VIGIL JC

SOLUTIION OF THE REACTOR KINFTICS EQUATIONS BY ANALYTIC CONTINUATIO

LOS ALAMOS SCIENTIFIC LABORATOPY, LCS ALAMCS, NEW MFXICD

10 PAGES, 10 FIGURES, 1 TABLE, NUCLEAP, SCIENCE AND ENGINEERING 29 (3) PAGES 392-401 (SEPT. 1967)

A METHOD BASED ON ANALYTIC CONTINUATION, WHICH IS WELL SUITED FOF FAST OIGITAL COMPUTER $\triangle P P L I C A T I O N$, HAS REEN APPLIED TO THE POINT REACTOR KINETICS EQUATIONS. THE MOST IMPCPTANT CHARACTERISTIS RF THE METHOD IS THAT IT YIELOS AN ANALYTIC CPITERION FOR THE MAGNITUDE DF THE TIME STEP. THIS CKITERION IS SUCH THAT THE TIME STEP AUTOMATICALLY EXPANUS UK CONTRACTS, DEPENIING DN THE SEHAVIDR OE. THE FUNCTION WITHIN EACH INTERVAL. THE USE OF THIS CRITERICN TO DETERMINE THE TIME STED GUARANTEES THAT THE FRACTIONAL ERROP IN THE PESULTS INCREASES, AT MDST, LINEARLY WITH THE NUMBEP OF TIME STEPS. FURTHERMORE, THE MAGNITUDE OF THE TIME STEP DETERMINED CROM THIS CRITERION CAN EE MUCH LARGER THAN THE PROMPT-NEUTRON GENERATION TIME.

DYNAMICS, WONL INEAQ + REACTRR OYNAMICS + FEACTOR KINETICS + PEACTCF TRANSIENT + THEORETICAL INVESTIGATION

$6-21437$

SMILFY JW

STREAK--A NUMERICAL SOLUTION FOR SPACE TIME NEUTRON OIFFUSION EQUATIONS. COMPUTER PROGRAM FOR ANALYSIS OF PROMPT NONLINEAR TRGNSIENTS IN REACTDRS

PENNSYLVANIA STATE UINIVERSITY

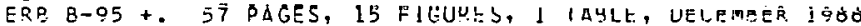

STREAK IS A COMPUTER PROGRAM CESIGNED FOR ANALYZING PROMPT NEUTPON FLUX TRANSIENTS SUCH AS THOSE OF DULSED FESEART.H REACTORS, FOR HAZARD ANALYSIS OF POWER P.EACTORS, AND FOR. ANALYZINE PIJLSED NEUTRON EXPEPIMENTS IN MULTIPLYING OR NONMULTIPLYING MEDIA. STREAK SOLVES THE NONL INEAR, JVE-DIMENSIONAL, TIME-DFPENDENT NEUTRON DIFFUSION EQUATIONS IN TWO ENERGY GPOUPS. SEPARASILITY CF SPACE AND TIMF IS NOT ASSUMED. UP TO SIX GROIJPS OF OELAYEO NEUTRONS APE ALLOWEO, $\triangle N D$ LLMOST ANY FESDBACK MECHANISM CAN BE INCORPORATEO. A NEW METHOD OF OIRECT NUMERICAL INTEGRATION CF THE KINETICS EQUATICNS IS EMPLOYED, WHICH ALLGWS INTEGRATION TINE STEOS CONSIDEEABLY LARGER THAN THOSE NORMALLY ALLOWED IN FINITE-OIFFERENCING INTEGRATICN SCHEMES.

AVAILABILITY - PENNSYLVANIA STATE UNIVERSITY, ENGINEERING PUBLICATICNS, 227 HAMMOND BUILDING, UNIVERSITY PARK, PA. 1S:02

CQMPUTER PROGRAM + DYNAMICS, NDIVLINEAR + FLUX DISTRIBUTION + PULSED NEUTRON TECHNIDIJE + FEACTOR OYNAMICS + REACTOP KINETICS + FEACTOS TFAVSIENT + SFACE DEPENDENT DYNAMICS

$6-21438$

PROCEFDINGS OF THE CONFEPENCE ON REACTDF PHYSICS, CASACCIA CENTER OF CNEN, ITALY, SEPT. $15-16,1$ SE5 COMITATI NAZIINALS DEF L ENERGIA NUCLEAKE, RCME, ITALY

RT $-F I-(65)-13+$ CONE-650902+. II3 PAGES, 1966, IN ITALIAN

COLLECTION JF PADERS DESCRIPING THE ACTIVITIES OF ORGANIZATIONS THAT DEAL IN ITALY WITH R.ACTRR-PHYSICS PDOPLEMS.

AVAILAGILIFY - MITROCAROS EDITIJNS, INC., ACCOUNTING AND SHIPPING OEPT., WEST SALEM, WISCONSIN 5LES9 CRITICALITY EXPERIMEN!T + FLUX OISTRIPITION + THEORETICAL INVESTIGATION

$6-21439$

CARLSMITH RS + BEVNEII LL + EUISUN TE + GIFT EH T THOMAS WE I WLLTARE FC

REVIEN OF MOLTEN SALT REACTOR PHYSICS CALCULATIONS

OAK RIDGE NATIONAL LAL., IENN.

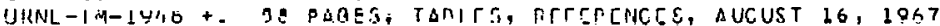

A SET OF CALCULATIONS WAS MADE TO CHECK THE REACTIVITY AND RREECING RATIO OF THE REFERENCE OESIGV OF THF MSSR. INSOFAR AS POSSIBLE, THE CROSS SECTIONS AND CALCULAT IONAL METHODS WERE MADE INDEPSNDENT OF THOSE IISFO PREVIOUSLY. THE REFERENCE COMPOSITITJN GAVE A K-EFF OF O.C5. WHEN THE REACTOR WAS MADE CFITICAL EY THE $\triangle D D I T I O N$ OF $14 \%$ MOFE U-233, THE EREEDING P.ATIO WAS 1.062, COMPADEO WITH 1.054 IN THE PFEVIOUS CALCULATIONS. FEOPTIMIZATION OF THE COMPOSITION WJUL P POBABLY OECREASE THIS DIFFEDENCE IN BREEOING RATIC.

AVAILABILITY - CLEARINSHJUSE FOR FEDEPAL SCIENTIFIC AND TECHNICAL INFDRMATION, SPRINGFILLU, VIHG INIA, $\$ 3.00$ COPY, \$O. ES MICROFICHE

FUEL BURNUP + MSBR(RE) + KEALIIVITY EFPECT + THEDFETICAL INVESTICATION

$6-21440$

GREENSDAV

EFFECT OF G̈POUP-CJNSTANTS AVERAGING PPNCFEURE ON FEW-GPOUP PEACTIVITY CALCULATIGNS

RENSSEL $\triangle$ ER POLYTECHVIC INST., TROV, N. Y. 
INVESTIGATED THE EXTENT TO HHICH A VARIETY OF REACTIVITY COEFFICIENTS ARE AFFECTEO SY THE PROCFDURES USED TO GENERATE THE FNEFGYGF.CUP AVERAGEU CONSTANTS FOR CALCULATING THE

COEFFICIENTS. THAEE GROUP-AVERAGING SCHFMES ARE COMPAPED - 111 THE CONVENTIJNAL PROCEDUFE WHICH EMPLOYS FLUX AVEPAGE CONSTANTS, 12) THE BILINEAR PRGCEDURE, (3) THF CONSISTENT PRDCEDURE, NHICH USES FLUX AND IMPCPTANCE-FUNCTION AVERAGED CONSTANTS FOR THE FLUX AND ADJOINT SQUATIGNS RESOECTIVELY.

AVAILABILITY - CLEARINGHOUSE FOR FEDERAL SCIENTIFIC AND TECHNICAL INFORMATION, SFKINGFIELD, VA., \$3. OO COPY, \$0.65 MICROFICHE

CROSS SECTION + FLUX DISTFISUTIJN + PFFTURBATIDN METHOD + REACTIVITY CCEFFICIENT

6-21475 ALSE IN CATEGORISS 5 AND 17

TECHNOLOGY OF BOILING WATER, REACTOR STABILITY ANALYSIS

GENERAL ELECTR. IC COMPANY

75 PAGES, 49 FIGURES, 16 REFEPENCES, 4 TARLES, MEMDRANCUM SCER-50, DOCKET 50-277 AND 278, TYPE--BWR, MFG--G.S., AE--BECHTEL, JULY 1967

(INCORPORATED IN PEACH BOTTOM PSAP. SUPPLEMENT 2.) ASSERTED GOOO AGREEMENT BETWEEN FABLE-II PROGRAM AND KFE/GARIGLIANO F.OD-DSCILLATOR DATA. APED HYDROCYNAMIC LOOP SNSURES SUCCESSFUL USE IN EXAMINING INTEPCHANNEL HYDRCDYNAMIC STABILITY. MODEL SUMMARIZED, PUT DATA (L9 GRAPHS) IS PGOPLY DISCUSSED TO SUPPORT THE $\triangle$ SSERTION.

AVAILABILITY - USAEC FUSLIC DCCUMENT PDOM, WASHINGTON, D. C.

*COMPARISON, THEORY AND EXPERIENCE + \#COMPUTER PROGRAM + *FLOW STABILITY + PEACH BOTTOM 2 ANO 3 (EWP.) + REACTOR STABILITY + PEACTCR, BWR

6-21735 ALSO IN CATEGORIES P AND 18

FRENCH RJ + GALLAGHER. JM + MOQRE JS + SALVATORI R

INDIAN POINT UNIT NJ. 2 ROOD EJECTIUN ANALYSIS

WESTINGHJUSE ELECTRIC CLRP., PITTSBURGH, PA.

WCAP-2940 +. 108 PAGES, 45 FIGURES, 7 TABLES, 25 REFERENCES, OF SECOND SUPPLEMENT TO INOIAN POINT 2 PRELIMINARY SAFETY ANALYSIS REPOFY (EXHIBIT B-?), MAY 1966 , DOCKET 5G-247, TYPE-PWR, MFG--WEST, $\triangle E--U N I T D$ ENGR

(INCLUDED IN PSAR SUPDLEMENT 2,) ANALYSIS USES CHIC-KIN FOR KIVETICS, AND HAS 1.5 OR I.O REACTIVITY $\ddot{6}$ FOK EJECTED ROD IC OR $102 \%$ POWER) AND $1.5 \%$ FOR POSITIVE MODEPATOR EFFECT WITH A SCRAM AFTER 1.5 SEC. ALTHO SOME FUEL MELTING WOULD OCCUR, PEAK SYSTEM PRESSURE IS LESS THAN 6000 PSIA. A SHOCK-WAVE ANALYSIS FGR REACTOR VESSEL INDICATES THAT I/3 OF CSRE MUST BECOME MOLTEN AND DISPERSED TC DILATE VESSEL WALL UP TO $50 \%$ ULTIMATE ELONGATION IBASED CNN. TNT EXPEQ IMENTS AT NRL-WISEI.

AVAILABILIT̈Y - USAEC PUELIC DOCUMENT FOOM, WASHINGTON, D. C. .

\# $\triangle C C I D E N T$ ANALYSIS + \#ACCIDENT, CONTROL ROC EJECTION + EXPLOSION + FUEL MELTDCWN + INTEGRITY + PRESSURE VESSEL

6-21833 ALSO IN CATEGORY O

WILLIAMS MIM IN HETERRGENEOUS SYSTEMS. 1. PLATE-TYPE ELEMENTS

UNIVERSITY OF LONDON, FNGLAND

11 PAGES, 2 FIGURES, NUCLEAR SCIEINCE AND ENGINEERING 30(2), PAGE 188-198 (NOVEMBER 1967)

A FORMAL ISM BASED UPON THE SOURCE-SINK METHOD OF HORNING, FEINBERG, AND GALANIN hAS DEVELC.PEO WHICH PREDICTS THE NEUTRON NIISE SFECTRUM AND TIME-DE PENDENT CORRELATION FUNCTICIN IN HETEROGENEOUS PEACTOR SYSTEMS. THE METHOD IS APPLIED TO TWO PRCBLEMS IN INFINITE-PLANE GEOMETRY - THE INFINITS LATTICE AND DETECTOR PEPTURBATIONS. IN THE LATTICE PROELEM, IT IS SHOWN THAT THE SIMPLF, HOMOGENEOUS THEQRY WILL BE VALID ONLY WHEN THE LATTICE SPACING IS VEPY MUCH LESS THAN THE $\triangle T T E N U A T I G N$ LENGTH OF A NEUTRON WAVE IN THE PURE MODERATOR. THE FLUX DEPRESSION IN THE NEIGHBORHOOD OF A NEUTRON DETECTOR IS FOUND TO INTRCDUCE SIGNIFICANT CORRECTIONS TO THE NOISE SPECTRUM.

\#NCISE + \#NOISE ANALYSIS + \#REACTOG KINETICS + MATHEMATICAL TREATMENT + NOISE CROSS COFRELATION + THEORET ICAL INVESTIGATION

6-21997 ALSG IN CATEGORY 17

SAXTON PLUTONIUM PROGPAM SEMIANNUAL PPOGRESS REFORT FOR THE PERIOD ENDING JUNE 30 , 1967 WESTINGHIUSE ELECTRIC CGRP., PITTSBURGH, PA. ATOMIC POWER DIV.

WCAP-3385 + EURAEC-1 $1877+.36$ PAGES, 20 FIGURES, 3 TAELSS, 4 REFERENCES, JUNE 30,1967

REACTOR WAS SHUT OOWN 5 MONTHS TO IN:STALL SUPERCRITICAL LOOP. (PAGES 5-16) THE LAST

JUST-CR ITICAL RORON CONCENTRATION CALCULATION BEING $10 \%$ HIGH WAS ATTRIBUTED TO EITHER (A) NONUNIFORM AXIAL FUEL-BURNUP DEPLETION IN POQ-XY, WORTH 700 HR DUT GF A PREDICTED SSOO, OR, 
CATEGOPY
REACTOR TRANSIENTS, KINETICS, AND STABILITY

\section{6-21987 \#CONT INUED*}

(B) LEOPARD CFOSS SECTIONS INADEQUATE FOP. PLUTONIUM, WORTH 250 HR. IPAGES 22-35) TWO FUFL

ROOS WERE GAMMA-SCANNED AND METALLCGRAPHIC SPECIMENS PREPAREO. VIPAC FUCL HAD NORE

CLAD-HYDRIDE IMOFE MOISTURE IN FUEL) AND A REACTION LAYER (APPARENTLY FROM REDUCTION OF HYPERSTDICHIMETRIC FUELI.

AVAILAGILITY - CLEARINGHOUSE FOR FEDERAL SCIENTIFIC AND TECHNICAL INFORMATICN, SPRINGFIELD, VIPGINIA, $\$ 3.00$ COPY, \$N.65 MICREIEICHE

\#FUEL FI FMENT + \#IRZADIATION TESTINE + \#PLUTONIUM DIDXIDE + FUEL, POWDER TYPE + HYDRIDE + R AND D PROGRAM + REACTIVITY EFFECT, ANOMALOUS + REACTCF, PWR + SAXTON (PWR) + STOICHIGMETRY +.ZIFCALGY

6-22140 $\quad \triangle L S O$ IN CATEGORIES E AND 17

MANHATTAN COLLEGE ZPF MODERATOR COEFFICIENT MEASUREMENTS

MANHATTAN COLLECE, BRECNX, NEW YORK

45 PAGES, 5 TABLES, DOCKET 50-195, DECEMPER 24, 1967

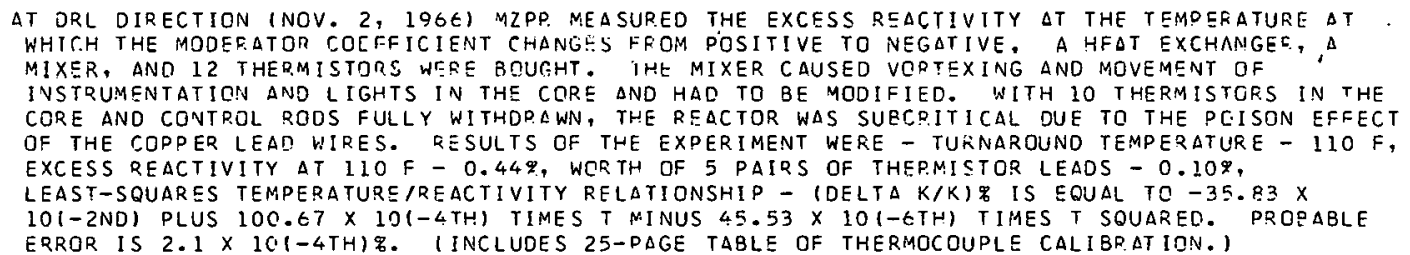

AVAILABILITY - USAEC PUBLIC DOCUMENT ROOM, WASHINGTON, D. C.

* MCDERATOR CDEFFICIENT + \#PEACTIVITY, EXCESS + \#TEMPERATURE COEFFICIENT + CRITICAL ASSEMBLY FACILITY + IN CORE MEASUREMENT + MEASUFEHENT. GENERAL + REACTIVITY EFFECT, ANOMALOUS + TECHNICAL SPECIFICATIONS

6-22782 ALSO IN CATEGORY 17

U OF WISCONSIN REPORTS ON OPERATION WITH NEWLY INSTALLED CORE

METROPOLITAN EDISIN CE.

1 PAGE, JAN. 4, 1968, DCCKET NO. 50-156

INITIAL CRITICALITY WITH THE MOOIFIED TRIGA CORE WAS REACHED ON 14 NOV. 67. THE ONLY SIGNIFICANT VARIATIDN IN OERFORMANCE CONCERNS THE PULSING PERFOKMANCE DF THE CORE. CORE IS DIFFERENT FROM PROTCTYPE CORE IN THAT IT IS ALMOST ENTIRELY GRAPHITE REFLECTED, INCDEASING THE EFFECTIVE NEUTRON CYCLE TIME FEOM $39 \times 10(-6 T H)$ SEC TO $42 \times 10(-6 T H)$. THIS FFSULTS IN LONGER PROMPT DEFIOCS FOQP. A GIVEN REACTIVITY INSERTION. THE POWER COEFFICIENT CF FEACTIVITY IS MORE NEGATIVE THAN EXPECTED.

AVAILÁSILIIY - USAEC PUELIC DOCUMENT DOOM, WASHINGTON, D. C.

* GDAPHITE + \#PROMPT NEUTRDN LIFETIME + *RFFLECTCF + PNWER COEFFICIENT I R[ACTOR KINETILS + IEACTOR, PULSEO + KLUURT, DPERATIONS ANALYSIS + TRIGA (RR).

6-22787 ALSC IN CATEGORY 17

POSITIVE GRAPHITE-REFLECTUP. TFMP COEFF AT U GF WASHINGTON REACTUK

UNIVERSITY OF WASHINGTON, SFATILE, WASH.

2 PAGES, JAN. 4, 196 , DOCKET NO. $50-139$

SINCE RAISING THF POWER FROM $10 \mathrm{~kW}$ TO 100 , WE OBSERVE THAT THE REG. ROD MUST BE LONERED TC MAINTAIN CRITICALITY WITH EXTENDFD 100-KW FIINS. R.ECORDS SHOH THAT D TYPICAL LUN $\triangle D D S$ O.C42 DK/K., A TES $I$ SHDWS THE COEFFICIENT IU BE ABOUT PLUS 0.0014\% DK/K PER DEG F, ASSOCIATFD h.ITH THE COOLANT WATEE TEMPERATURE. THE EXCESS REACTIVITY IS TO RE COMPUTED HOURLY. IF POWEF IS LESS THAN $10 \mathrm{KW}$, THE $0.595 \%$ I IMIT IS UNCHANCEO. IF DOWER IS TU EXCEEO IO KW, ANE INITIAL RFACTIVITY EXCEEDS $0.5 \%$, THE OPSRATGR IS NUI TO PROCEED UNTIL NOTIFYING REACTGR SUPEFVISOR.

AVAILABILITY - USAEC PUELIC DOCUMENT ROQM, WASHINGTON, D. C.

*GRAPHITE + \#REACTIVITY EFFECT, ANOMALDUS + \#REFLECTQR + \#TEMPERATURE COFFFIC.IFNT + POWER UPRATINO + PRTCEDIIRES AND MANUALS I REACTOR, GRAPHITE MUUERATER + REACTOR, RESEARCH

O-Z28OOI ALSO IN CATEGORY 17

CONTROL DF XENON INSTABILITIES IN LARGE PWRS. QUARTEGLY PROGFESS REPORT FOR THE PERIOC ENOING JUNE 3O; 1967

WESTINGHOUSE ELECTRIC T.CRP.. PITTSBUPCH, FD.

WCAP-3680-4 + EURAEC-18EO +.72 PAGES, FIGUFSS, JULY 1967

FEPORTS RESULTS OF GROUPS WORKING ON $(1)$ EFFECT CF CORE PARAMETERS ON SPATIAL OSCILLATIONS, (2) REMEOIAL CONTROL PRCCEDURES, ANO (3) 3-OIMENSIONAL ANALYSIS. A SIMPLE CORRELATION WAS DEVELOPED TO CORRECT FOR THE ERRORS CAUSEO BY USING FINITE TIME STEPS IN CIFFUSION-THEORY CALCULATIONS. AN INOEX OF THE INFLUENCE OF VARIOUS CORE PARAMETERS MN STARII ITY HAE DFVFI. TPFD. 
C.ATEGORY
REACTOR TFANSIENTS, KINETICS, ANO STABILITY

6-22801 \#COVTINUED*

AVAILABILITY - CLEARINGHOUSE FOR EECEFAL SCIENTIFIC ANO TECHNICAL INFORMATION, SPRINGFIELD, VIRGINIA \$3.OO COPY, \$O.65 MICRDFICHE

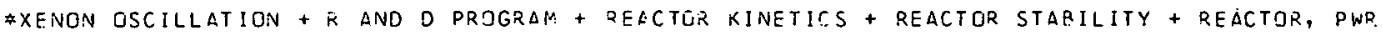

6-22830 ALSG IN CATEGORY 17

WASHINGTON STATE U REPBFTS REACTIVITY EXCESS IN CENVERTED TRIGA

WASHINGTJN STATE UNIVERSITY, DULLMAN, WLSHINGTON

3 PAGES, I FIGURE, JANUARY 10, 1968 , DOCKET 50-57

THE WORTH OF THE CENTPAL FUEL ELEMENT (4-ROD CLUSTER) WAS PREOICTED AS \&3.61 (BASED ON A CYLINDR ICAL COFE) BUT MEASUREC AS $\$ 5.36$ AND $\$ 5.73$ IN THE ACTUAL RECTANGULAR CONFIGURATION. REVISFD ACCIDFNTAL-FUEL-4DDITION ANALYSIS GIVES 1234 C PEAK FUEL TEMP. IA RISE OF 884 CI IVSTEAD OF R5: (LIVIT IS SET AT IOOO C). PRESENT $\triangle$ IOMINISTRATIVE CONTROL CF LOADINGS WILL PREVENT SUCH ACCIDENT. IN ADDITION WE PLAN TO LIMIT FUEL TEMP. TO IOO C WHEN A CORE OPENING EXISTS, SO THAT PEAK FUEL TEMP. IN THE ACCIDENT WOULO NOT EXCEED 984 C. THIS WILL ALLOW LOW-POIER TESTING.

AVAILABILITY - USAEC FUPLIC DCCUMENT RDOH, WASHINGTON, D. C.

*CGMPARISON, THEORY AND EXPERIFNCE + \#RFACTIVITY EFFECT, ANOMALOUS + \#FEACTIVITY, EXCESS + ACCIDENT ANALYSIS + ACCIDENT, REFUELING + REACTOR, RESEARCH + IRIGA (RR)

6-22831 ALSE IN CATEGORY CONTRDL DF XENON INSTABILITIES IN LAKGE PWRS. QUARTERLY PRCGRESS REPCRT FOR THE PERIOD ENDING SEPTEMBER 30,1967

WESTINGHOUSE ELECTRIC CORP., PITTSPURGH, PA. ATOMIC POWER DIVISIDN

WC.AP-3680-5 + EURAEC-19EE +. IO PAGES, OC TOBER 1967

THIS REPORT IS CNE OF A SERIES OF SUCH REPORTS CONCERNED WITH INVESTIGATING THE CHARACTER ISTICS ANO CRNTROL GF SPATIAL INSTABILITIES IN LARGE PRESSURIZED-WATER REACTORS, WITH PARTICULAR EMPHASIS ON AZIMUTHAL XENON INSTABILITIES (X-Y PLANE). THE PROGRAM CONSISTS OF THE FOLLDWING TASKS - 11) EUXE-200 EFFECT OF CORE PARAMETERS ON SPAT IAL OSCILLATIONS, (Z) EUXE-300 P.EMEDIAL CONTROL DRGCEDURES, (3) EUXE-400 THREE-DIMENSIONAL ANALYSIS.

AVAILABILITY - CLEARINGHOUSE FOR FEDEPAL SCIENTIFIC AND TECHNICAL INFORMATION, SPRINGFIELD, VIRGINIA, $\$ 3.00$ COPY, \$0.65 MICRCFICHE

INSTASILITY. + REACTOR, PWR + XENON

6-22920 ALSO IN CATEGORY 17

MOLTEN-SALT REACTOR PRCIGRAM. . SFMIANNLIAL PROGRESS REPORT FOF PERIOD ENDING FEBRUARY 28 , 1967

QAK RIDEE NATIONAL LLE., TFNN.

ORNL-4119+. S HAGES, Z FIOURES, RACR 14-29, IIIY 1967

INCLUSION RF XE-135 POISONING WITH MODIFIEO XENON KEMUUAL IGAS STRIPRINC) RARAMETERS RFIIIFES THE STEADY-STATE RFACTIVITY LNOMALY IU ABOUT $0.03 \%$ DK/K. TESTS ON THE T.IRCULAT ING-BUBBLE EFFECTS (RAISING PRFSSURE, OESERVATION OF REACTIVITY AFTER A STATIONARY FUEL PEFIOD) SHOKED THE EFFECT ABOUT $0.03 \%$ JK/K. THERE $\triangle P P E A R S$ TO HAVE BEEN A PRSITIVE SHIFT OF ABOUT O.05\% DK/K DURING THE FIRST $1000 \mathrm{MW}$ HR. THE SHIFT REMAINS CONSTANT. NG SIGNIFICANT CAUSE HAS BEEN FOUNC. THE CHANGE IS NEAR. THE ESTIMATEO CONFIDENCE LIMIT (PLUS OR MINUS O.O4\%) AND MUCH SHALLER THAN TIIE JPEPATING LIMIT (PLUS OR MINUS $0.5 \%$ DK/K).

AVAILABILITY - CLEARIINGHOUSE FOR FEDEPAL SCIENTIFIC AND TECHNICAL INFURMATION, SPRINGIIELD, VIPGINIA, $\$ 3.0 .0$ COPY, $\$ 0.65$ YICROFICHE

*REACTIVITY EFFECT, ANONALOUS + MSPE (RE) + REACTOR, MOLTEN SALT + RSPORT, OPERATIONS ANALYSIS + VOIO COEFFICIENT

$6-23161$

CANOSA J

RAMP REACTOR EXCURSICNS WITH NONLINEAR FEEQBACK

GENERAL ELECTKIC CJ.. NUCLEAR TECHNOLOGY CEPT. , VALLECITOS ATOMIC LA3., PLEASANTCN, CALIFORNIA

5 PAGFS, 3 TABLES, 6 PEFERENCES, NUKLEONIK 1011), PAGE 41-45, (1967)

THE PROBLEM OF FEACTOR EXCURSIONS CAUSED BY A RAMP REACTIVITY INSERTION IS SOLVED BY APPROXIMATE ANALYTICAL METHOCS IN THE PROMPT APPROXIMATION WHEN THE REACTGR HAS A VERY GENERAL TEMPEFATUF.E-DEPENDENT REACTIVITY FEEDBACK.

OYNAMICS, NONLINEAP + REACTIVITY EFFECT + REACTCR DYNAMICS + REACTOR TRANSIENT + TEMPERATURE COEFFICIENT

$\epsilon-23162$

AN EVALUATION OF THE $\triangle T O M I C S$ INTERNATIONAL 1000 MWE FAST BREEDER REACTOR

CHICAGO OPERATIONS OFFICE, USAEC 
CATEGORY
REACTOR TRANSIENTS, KINETICS, AND STABILITY

6-23162 \#CONTINUED*

COQ-285 +. 58 PAGES, 4 FIGURE 5,17 TABLES, JULY 1966

THE ATOMICS INTERNATIONAL DESIGN FOF AN LMFBF. WIAS EVALUATED AND COMPARED WITH AN EARLIER EVALUATION DF FOUR DESIGNS FROM OTHER FIRMS. THE CORE-REGION SODIUM-VOID EFFECT IS KEPT BELOW \$1.0D IN THIS DESIGN BY THE USE OF COUPLEC MODULAR COFES. THE BLANKET DOPPLER

COEFFICIENT IS HIGH - MINUS 0.016 T DK/DT. THE EVALUATERS CALCULATED SOMEWHAT DIFFERENT

VALUES FOR THE IMPDRTANT NUCLEAR PARAMETERS BECAUSE OF DIFFERENCES IN THE CROSS SECTIONS USFD.

AVAILABILITY - CLEARINGHOUSE FOR FEDERAL SCIENTIFIC ANC TECHNICAL INFOPMATION, SPRINGFIELD, VA., \$3. OO COPY, \$O.65 MICROFICHE

\#COUPLED CORES + \#REACTOR, BREEDER + \#REACTOP, FAST + DESIGN STUDY + DOPPLER COEFFICIENT + REACTOR DYNAMICS + REACTOR, LMCR + VOID COEFFICIENT

6-23163

WILSON B + ENSELMOZ JR + HARTLEY AJ

AXIAL STAGILITY CALCULATIDNS FDP. A.G.R. SYSTEMS

UNITED KINGDOM ATDMIC ENERGY AIITHERITY, PI SLEY

TRG-REPIRT-1138+JNFC-RKWF-P344+.64 PLGES, 25 FIGUFES, REFEFENCES, DEC. 13,1965

THR.EE METHODS GF CALCULATION UF AXIAL STABILITY MODES ARE DESCRIBED - MODAL ANALYSIS, a STEADY-STATE METHDD USING THE FLIPT CODE, AN ANALOGUE METHOD. IN THE MODAL ANALYSIS, CRITERIA FOR AN ASYMMETPIC FLUX, FLATTENED FLUX ANO SINUSOIDAL FLUX HAVE BEEN DERIVED WITH BOTH DNE-TERM ANO THREE-TERM EXPANSIONS FOR THE HARMONIC. THE STEADY-STATE METHOD USING FLIRT YIELDS A CRITERION FOR. TEMPERATURE INSTABILITY WHICH CAN ACCOMODATE ANY FLUX

DISTRIBUTION AND MORE ACCURATE HAPMONIC REPRESENTATION. A PERFORMANCE CRITERION BASED ON THE

TRANSIENT PERFORMANCE OF THE HARMONIC HAS BEEN PROPOSED DND STUDIED USING THE ANALOGUE

METHOD. STARII.ITY THRESHOLDS AND THE- RELATIONSHIP BETWEEN THE PERFORMANCE CRITER ION AND STABILITY MARGINS HAVE BEEN OBTAINED.

AVAILABILITY - CLEARINGHOUSE FOR FEDERAL SCIENTIFIC AND TECHNICAL INFORMATION, SPRINGFIELD, VA., \$3. OO COPY, \$0.65 MICROFICHE

COMPUTER, ANALOG + CCNTPOL ROD INTERATTION + CONTROL SYSTEM + COQLANT CCEFFICIENT + REACTOR CONTRCL + REACTOR. OYNAYICS + REACTOP STABILITY + PEACTOR TPANSIFNT + SPACE DEPENOENT DYNAMICS

$6-23154$

NISHIHAR A H

ACI $\triangle B A T I C$ MDDEL FOR SPACE-DEPENDENT BOILING WATER REACTOR KINETICS

KYOTO UNIVERSITY

5 PAGES, 1 FIGURE, 10 REFERENCES, J. NUCL. SCI. TECH. (TOKYO) 3, PAGES 486-90 (NOV. 1966)

EQUATIONS ARE OERIVEO FOR AXIALLY SPACE-DEPENDENT BWR FEEDSACK KINETICS. THESE EQUATIONS ARE

COUPLEO TO THE NEUTRON EQUATIONS IHKUULH ALIAEAIIL AHPRÜXIMATION. THE REACTOR IS DIVIOCL INTO A VUMBER OF AXIAL REGIONS. ASSUMING A TPAPEZOIDAL DISTRIEUTION OF THE VCID AND THE WATER VELOCITY DI.STRIBUTIONS ALTNG THE AXIS, PALANCE EQUATIONS FOR ENERGY $\triangle N D$ MASS ARE INTEGRATEO TO YIELD THE REGION-EXIT QUANTITIES. WITH OTHER PERTINENT EQUATIONS, A COMPUTER CODE IS WRITTEN.

* REACTOR KINETICS + *EEACTOR, BWP + REACTCF QYNAMICS + SPACE DEPENDENT DYNAMICS + THEOPETICAL INVESTIGATION

$6-23165$

GEETS JM + RAJAGOPAL V

STUDY OF REACTOR TRANSIENTS. FINAL REPORT

WEST INGHDUSE ELECTRIC CORP., PITTSBUKGH, PA., ATOMIC PCWER DIVISION

CVNA-2331. SU WAGES, FITURES, TABLE 3 , JUNE $196 \%$

FQR THE CVTR, THE FESULTS DF A SERIES OF DYNAMIC MEASUREMENTS, TOGETHER WITH AN ANALYSIS OF REACTOD, TRANSIENTS AT R5 MW ARF GIVEN. DYNAMICS MEASUREMENTS WEFE CAFRIED OUT USING NOISE ANALYSIS AND REACTIVITY COMPUTER TECHNIQUFS. ANALYSIS OF REACTOR TRANSIENTS UNDER POSTULATED ACCIDENTAL CONDITIONS WAS PREPARED TO JUSTIFY A REACTOR POWEP INCREASE TO 61.7 MWTH FROM THE PREVIOUS LICENSEC POWEP OF $44.3 \mathrm{MWTH}$.

AVAILABILITY - CLENPINGHOUSE FRR FFRFRAI ST.IFNTIFTR. AND TECHNICAL INFORMATION, SPRINGFIELD, VA., \$3. OO CDPY, \$0.65 MICRDFICHE

\#ACCIDENT ANALYSIS + *CVTR (TWR) + \#REACTOR. TRANSIENT + ACCIDENT, COLD COOLANT + ACCIDENT, CONTROL RCD WITHDRANAL + DLLIUENI:, LUSS UF COOLANT + REACTOR, PWR

$6-23167$

ALSO IN CATERORY IT

BERNANDER O

MEASUREMENTS OF THE REACTIVITY PROPERTIES CF THE AGESTA NUCLEAR POWER REACTOR AT ZERO PCWER AKT IEBOLAGET ATOMENERGI, STOCKHOLM

$A E-289+43$ DAGES, FEFERENCES, JULY 196.7

FOD. THE MOLJTA RLACTIR, MODERATOP LEVEL MNE TFMPFQATIIPF TRIFFFIRIFNTS OF REACTIVITY AND CONTROL $\rightarrow$ ROD DIFFEPENTIAL REACTIVITY WORTHS WEFE DETERMINFD PY PFFIDD MEASUREMENTS. CRITICAL 
REACTOR TRANSIENTS, KINETICS, AND STABILITY

6-23167 \#CONTINUED*

MDDERATOR LEVELS ANO LEVEL COEFFICIENTS WEFE MEASURED FOR 32, 6?, AND 136 FUEL-ASSEMBLY CDRES AT ROOM TEMPERATURE, FOR CORES WI TH AND WITHOUT CONTROL RODS. TEMPERATURE COEFFICIENTS AND DIFFERENTIAL WORTHS WFPE DETERMINED FOR THE FULLY LOADEC CORE WITH FULL TANK BETWEEN 30 AND $210 \mathrm{C}$. CRITICAL POSITIONS FOR RON COMBINATIONS WERE MEASURED AS A FUNCTION OF TEMPERATURE. COMPARISON OF CALCULATIONS WITH EXPERIMENTAL RFSULTS IS DISCUSSED.

AVAILABILITY - MICROCARD EOITIONS, INC., ACCOUNTING ANC: SHIPPING DEPT., WEST SALEM, WISCONSIN 54669

\#AGESTA (PWR) + \#MEASURE MENT, REACTIVITY + COMPAFISON, THEGRY AND EXPERIENCE + CONTROL ROO WORTH + MODERATOR COEFFICIENT + REACTOP, PWR

$6-23169$

ALSO IN CATEGORY 5

DIETZ KA

QUARTERLY TECHNICAL FEPORT - STEP PROJECT, APRIL ICE 7--JUNE $19 E 7$

PHILLIPS PETROLEUM COMPANY

IDO $-17240+.73$ PAGES, 50 figURES, 11 TABLES, 41 REFEFENCES, SEPT . 1967

PROGRESS IS REPORTED UNDER SIX HEAOINGS - LOFT REACTOR. PHYSICS CALCULATIONS, LOFT BLOWDOWN ANALYSIS, LOFT RADIOLOGICAL STUDIES, SEMISCALE BLOWDOWN TEST PROGRAM, MEASUREMENT EVALUATION (HIGH-TEMPERATURE THERMCMETRY STUDIES), AND LOFT FM MULTIPLEX SYSTEM.

AVAILABILITY - CLEARINGHOUSE FOR FEDERAL SCIENTIFIC ANC TECHNICAL INFORMATION, SPRINGFIELO, VA., \$3.0O COPY, \$0.65 MICROFICHE

*LOFT (S-RR) + BLOWDOWN + HIGH TEMPERATUFE + RADIOLOGY + REACTOR PHYSICS + REACTOR, BWR +

REACTOR, SAFETY RESEARCH + REACTOR, TEST

$6-23170$

DRAGT JB + TURKCAN E⿱

SOME REMARKS ON THE PRACTICAL USE OF THE P-METHOD IN REACTOR NOISE ANALYSIS

REACTOR CENTRUM NEOEFLAND, PETTEN

3 PAGES, 9 REFERENCES, NUKLEONIK 10121, PAGES 67-69 (FEBRUARY $t, 1967$ )

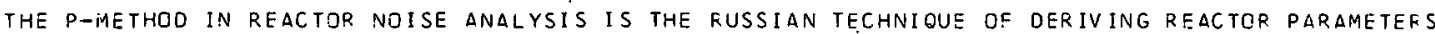
FR.OM THE EXPERIMENT.ALLY DETERMINEO PROBABILITY P-SUB-K FOR DETECTING K NEUTRONS IN $A$ GIVEN TIME INTERVAL. THIS PAPER OESCRIBES SOME APPROXIMATIONS FOF. THE CALCULATION OF THE P-SUE-K. SOME DIFFICULTIES MIET IN THE ANALYSIS OF THE EXPERIMENTAL DATA ARE OISCUSSEO. MOST PRACTICAL WAY OF ANALYSIS SEEMS TO BE A NONLINEAR LEAST-SQUARES ANALYSIS, WHERE SOME PRECAUTIONS HAVE TO BE TAKEN.

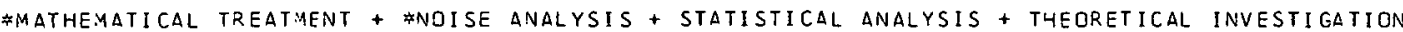

$6-23171$

WDOE DC + RUBIN HH

A NODAL CALCULATIOV OF A SPACE-TIME TRANSIENT USTNG COLIPLING COEFFICIENTS WHICH ACCOUNT TDR. CHANGING

INTERNODAL LEAKAGES

KNOLLS $\triangle T$ TOMIC POWER LAB., GENERAL ELECTRIC

2 PAGES, ANS TRANSACTION 1011), PAGES 250-251 (JULY 1967 )

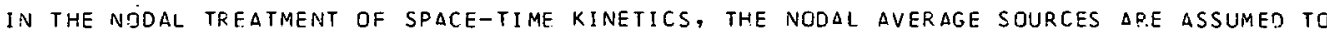
INFLUENCE DNE ANOTHER BY MEANS DF COUPLING COEFFICIENTS WHICH MEASURE THE CONTRIRIITATIOM TO THE INTEGRAL FISSION RATL IN NOOE I OF THE FISSION SOURCE. INTEGRATEO OVFR NMDE I, TO ACCOUNT FOR CHANGING SOURCE UISIRISUTIONS IN A REACTOR TRANSIENT, A METHOD IS PRESENTED IN WHICH THE COUPLING COEFFICIENTS ARE CONSTRUCTEO FRCM A PREVIOUSLY CCMPUTEO SERIES OF STATIC REACTOR CONFIGURATIONS WHICH BRACKET THE CONFIGURATIONS TO BE ENCOUNTERED IN THE TRANSIENT.

DYNAMICS, NONLINEAR + REACTOR DYNAMICS + REACTOR KINETICS + REACTOR. TRANSIENT + SPACE CEPENDENT DYNAMICS

$6-23173$

KEDL RJ + HOUTZEEL A

DEVELOPMENT OF A MODEL FOR COMPUTING XE-135 MIGRATION IN THE MSPE

OAK RIDGE NATIÜNAL LASOF. TTORY

ORNL $-4069+.77$ PAGES, 22 FIGURES, 3 TAELES, 21 REFEPENCES, JUNE 1957

THIS REPORT DEALS PRIMARILY WITH DEVELOPING A MODEL FOR COMPUTING THE MIGRATION OF XE-135 IN THE MSRE AND WITH EXPERIMENTS CONGUCTEO TO ESTAELISH THE MOOEL. A PREOPERATIONAL EXPERIMENT WAS RUN IN THE MSRE WITH KR-85 TRACER, AND MANY OF THE GAS-TRANSPORT CONSTANTS WERE INFEFRED FROM THE RESULTS. EQUIVALENT TRANSPORT CONSTANTS FOR CALCULATING THE XE-I3E MIGRATION GAVE A FROM THE RESULTS. EQUIVALENT TRANSPORT CONSTANTS FOR CALCULATING THE XE-13E MIGR
PDISONING OF ABOUT $1.4 \%$ WITHOUT CIRCULATING BURELES AND WELL SELOW I\% WITH BUBBLES. PRELIMINARY MEASUREMENTS MADE ON THE CRITICAL REACTOR SHOW XENON POISONING OF O.3 TO O.4⿻. SINCE PHYSICAL MEASUREMENTS CONFIRM THAT THERE ARE BUBBLES IN THE SYSTEM, THE CONCLUSION IS DRAWN THAT THE COMPUTATION MODEL, THE KRYPTON EXPERIMENT, AND REACTOR OPERATION AGREE.

AVAILABILITY - CLEARINGHOUSE FOR FEDEPAL SCIENTIFIC AND TECHNICAL INFDRMATION, SPRINGFIELD, VA., \$3. OO COPY, SO.65 MICROFICHE

REACTIVITY EFFECT + REACTOR DYNAMICS + XENON OSCILLATION 
REACTOR TRANSIENTS, KINETICS, AND STAPILITY

6-23348 ALSO IN CATEGORY

DAHL RE + JACKSON JL

MEASUREMENT OF NEUTRON FLUX IN FAST REACTGF EXPERIMENTS

BATTELLE MEMOR IAL INSTITUTE, RICHLAND, WASHINGTON

ANL-7380 +. 7 PAGES, 5 FIGURES, 1 TABLE, 6 REFERENCES, PAGES 132-139 OF PPOCEEOINGS DF THE SYMPOSIUM ON LIOUID METAL INSTRUMENTATION AND CONIROL, MARCH 3,1967

ACCURATE MEASUREMENT OF NEUTRON FLUX AND DFTERMINATION CF SPECTRA ARE CRITICAL IN FAST REACTORS FOR INTERPRETATION ANO APPLICATION OF FUFLS ANO MATERIALS TEST DATA. DELATIVE RESPONSSS OF ACTIVATION MONITORS $\triangle P E$ SUFFICIENTLY OIFFERENT IN FAST REACTCRS TO PEQUIPE THE USE OF ADVANCED ANALYTICAL AND EXPEPIMENTAL METHODS TO CHAFACTERIZE THE NUCLEAR ENVIPONMENT. ACTIVATION MONITORS DISCUSSED IN THIS REPORT ARE MATERIALS CONTAINING SPECIFIC ISOTOPES THAT ARE ACTIVATED BY NEUTRONS. 'STUDIES ARE IN PROGRESS TI DEVELCD DOSIMETDY TECHNIGUES FOR FAST REACTOR APPLICATION.

AVAILABILITY - CLEARINGHOUSE FOR FECFRAL SCIENTIFIC AND TECHNICAL INFORMATION, SPRINGFIELD, VA., D3. OO COPY, \$0.65 MICROFICHE

*FLUX, INTEGRATED + \#MEASUREMENT, GEACTIVITY + \#NEUTRON + DOSINETEY, GENERAL + FXDERIMENT, GENEFAL + - INSTRUMENTATION, NUClEAR I. DEACTOR, FAST

6-23358 ALSO IN CATEGGRY C

ROUX $D P 8 P^{2}$

SUBCRITICALITY MEASUREMENTS BY NEUTRON NOISF ANALYSIS

OAK RIDGE NATIONAL LABORATORY

ANL-7380 +. 3 PAGES, 8 REFERENCES, PAGES $180-182$ OF PROCEEDINGS OF THE SYMPOSIUM ON LIQUIO METAL

INSTRUMENTATION AND CONTPOL, MARCH $2,1 \% 6$

EVALUATES THE NDPLICABILITY OF USING, RENCTGP FLUC.TUATIONS (NOISE) TO MEASURE REACTRF

PAR AMETER.S ON LIQUIO METAL FAST RPEEDER PEACTORS (LMFBR) ANO AS AN ON-LINE SAFETV DEVICE.

REACTOR SUBCRITICALITY MEASURENENT BY NOISE ANALYSIS HAS A FAIR CHANCE TO gE SUCCESSFULLY

APPLIED IF THE MEASUREMENTS ARE LIHITED TO THOSE OF ONLY SMALL SHUTDOWN MARGIN. IN THE RANGE

OF 1 TO 2 DOLLARS SUBCPITICAL, AN ACCURACY OF $10 \%$ CAN BE EXPECTED.

AVAILABILITY - CLEARINGHOUSE FOR FEDERAL SCIENTIFIC AND TECHNICAL INFORMATION, SPRINGFIELD, VA., \$3. OO COPY, \$O.65 MICROFICHE

\#NEUTRON + \#NOISE ANALYSIS + CRITICALITY SAFETY + REACTOR, LMCF + SHUTDOWN MARGIN

6-23408 ALSO IN CATEGORY 17

MOVEMENT OF INSTRUMENTED FUEL ELEMENT BY A CONTPOL F.OD MAGNET

WASHINGTON STATE UNIVERSITY

2 PAGES, ATOMIC ENERGY CLCAR ING HOUSE 14(६), CAGES 22-?3 (FFBPUARY 196\%)

(LETYER, FEB. 7) IN A RECENTLY CONVEPTED TRIGA, THERMCCOUPLE LFAOS FROM A SINGLE UNCLAMPEC FUEL ROD ARE IN A STAINLSSS-STEEL CONCUIT, WHICH HAS A RIGHT ANGLE 7 IN. AROVE THE RCD MAGNETS WHEN THEY ARF IN THE DOWN POSITION. INSERTION OF ANOTHEP EXPEDIMENT DUSHED THE ANGLE OVER NO. 3 MAGNET. RDD 3 POSITION WAS 15.2 IN. AT CRITICALITY, AND THEN WAS EAISED TO IC IN. BEFORE PULSIVG, WHICH GAVE GNLY A 70 C READING. CORE CHECK SHOWED THE BEND NOT OVER THE MAGNET, BUT EXPERIMENTS SHOWED THAT FLEL ROO LIFTED 12 IN. (REMOVEO \$I.BO REACTIVITY). ROO IS NOW CLAMPED.

\#ACCIDENT, REACTIVITY + \#FAILURE, AOMINISTRATIVE CONTRCL + FUEL HANDLING + INSTRUMENTATION, IN CORE + REACTOR, PULSSO + TRIGA (RR)

$6-23434$

MILANIS + WEISS SH

SMALL URANIUM- 233 FUELED SESD-AND-QLANKET CRITICAL EXPERIMENTS (LWBR-LSBR DEVELOPMENT PFOGRAM)

WESTINGHOUSE ELECTDIC CQPP., BETTIS ATOMIC ROWER LAB., PITTSBURCH, PENN.

WAPD-TM-614 +. 167 PAGES, F IGGURES, TARLES, FEFERENCES, NOVEMBER, 1967

TO PROVIDE FUNDAMENTAL DATA FOR URANIUM-233 AND TO VERIFY THE ABILITY TO CALCULATE THE PHYSICS CHARACTERISTICS OF SUCH SYSTEMS, EIGHT SMALL SEED-AND-BLANKET CFITICAL ASSEMBLIES WERE STUDIED. ROD-TYPE SEED FUEL ELEMENTS EITHER URANIUM-233 OP. URANIUM-235 WERE UTILIZED TO PERMIT DIRECT COMDAPISCN OF THEIR LATTICE CHARACTERISTICS. BLANKET REGIONS CONTAINED ROC TYPE ELEMENTS OF EITHER NATURAL THOZ OR I W/O 233UO2-THO2 WERF COMPARED. THE EIGHT ASSEMBLIES WERE EITHEP A RECTANGULAR ARRAY HAVING A CENTFAL SEEO REGIGN SURROUNDEO QY A WET BLANKET WITH $\triangle$ METAL-TO-WATER RATIO CF $\triangle B C U T$ ONE, JR A HEXAGOVAL ARRAY HAVINGA CENTRAL SEEO REGION SURROUNCED GY A TIGHTLY PACKED DRY BLANKET WITH A METAL-TO-WATER R.ATIO OF AEOUT G.2.

AVAILABILITY - CLEARINGHDUSE COR FECEPAL SCIFNTIFIC AND TECHNICAL INFOFMATION, SFRINGFIELD, VIFGINIA \$3.0O COPY, \$O.S5 MICPOFICHE

*CRITICALITY EXPERIAENT + \#URANIUM-233 + FEACTOF PhYSICS + FEACTOR, BREEDEP. + TEST, PHYSICS + THCFIUM 
QCATEGORY
REACTOR TPLNSIENTS. KINETIC.S, AND STABILLITY

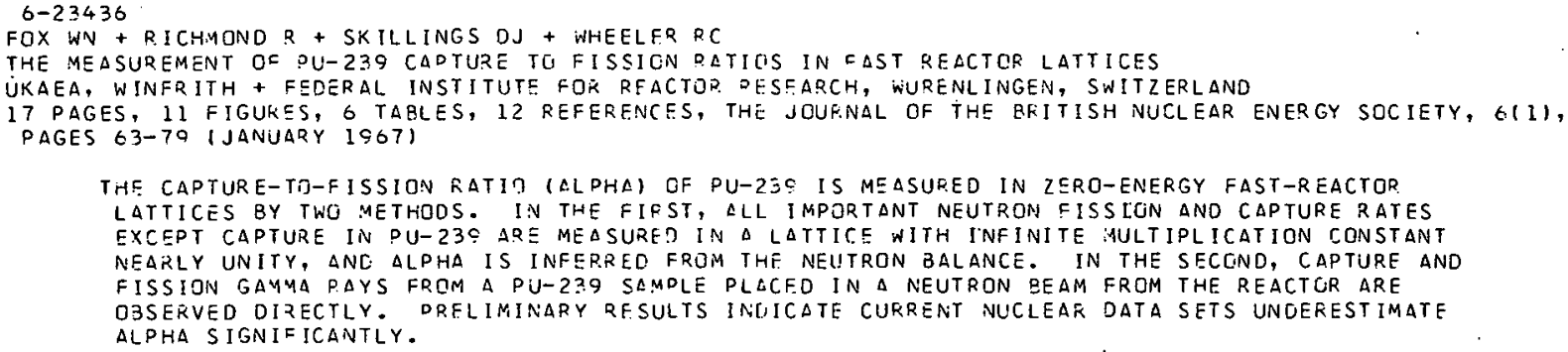

PLUTONIUM + REACTOR FHYSICS + REACTOR, BFFEDER + FEACTOR, FAST

$6-23437$

BARCLAYFR + WILSON PJ

AN ANALYSIS OF GRAPHITE MGDERATED URANIUM AND PLUTGNIUM/URANIUM FUELLED SYSTEMS USING THE LATTICE CODE WIMS ATOMIC FNERGY FSTABL ISHMENT, WINFR I TH

6 PAGES, 5 TABLES, 15 DFFERSNCES, THE JOURNAL OF THE BFITISH NUCLEAR ENERGY SCCIETY, $6(1)$, PAGES 61-85 (JANUARY 1967 )

THE PERFORIAANCE OF THE REACTOF LATTICE CODE WIMS HAS BEEN INIESTIGATED BY THE ANALYSIS OF A SERIES OF GRAPHITE MOOERATEO SYSTEMS CONTAINING REGULAR LATTICES OF SINGLE ROES OF URANIUM OR PLUTCNIUIA/URANIUM METAL. REACTIVITY PREDICTIONS SHOW A MARKFO DEPENDENCE DN RESONANCE CAPTUEES IN J-23\%, A FEDUCTION OF SOME 12\% IN THESE EVENTS EEING REQUIRED TO EL IMINATE THIS EFFECT. GOJD AGT.EEMENT IS SHOWN IN THE COMPARISON OF FISSION REACTION RATES, WHILE TEAPERATURE COEFFICIENTS ANO FINE STRUCTURE ARE REASGNABLY WELL PZEDICTED.

COMPUTER PROGRAM + PLUTLNIUM + REACTOF PHYSICS + REACTOR, GRAPHITE MOCERATED + TEMPERATURE COEFFICIENT + URANIUM

$6-23438$

TAXELIUS TG

QUARTERLY TECHNICAL FEPCET SPERT PROJECT CCTOBER, NOVEMSEP, DECEMRER, 1966

PHILLIPS PETROLEUM COMPANY

IDO-17245+. 40 DAGES, 28 FIGURES, 2 TABLES, 10 REFERENCES, OCTOBER 1967

THIS DEPORT IS ONE OF A SERIES ON THF FOLLOWING TOPICS - SPERT-III OXICE CORE KINETICS

PROGRAM, SPERT-IV CAP SULE-DRIVER-CORE SUPASSEMELY TEST PROGRAM, AND POWER BURST FACILITY

IN-PILE FUEL-TESTING PPIGRAM (TREAT TEST SERIES 11 AND 12$)$

AVAILABILITY - CLEARINGHJUSE FOR FEDEDAL SCIENTIFIC ANC TECHNICAL INFGRMATIDN, SPRINGFIELD, VIRGINIA \$3. OO

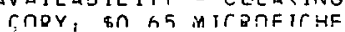

CORE, CAPSULE DPIVER (CDC) + IN PILE EXPEFIMENT + FEACTOR TPANSIENT + SPERTं 3 (S-RR) + SPERT 4 (S-RR) + TREAT (PRR) + URAVIUM OIOXIDE

$6-23439$ ALSO IN CATEGTRIES 5 AND 7

$K I F T 2$

QUARTERLY TECHNICAL PEPERT STEP PROJECT JANUAPY 1-MARCH $31,19 E 7$

PHILLIPS PETROLEUP COMPANY

IDO-17239 +. 156 DAGES, 81 FIGUDES, $15^{\circ}$ TLFLES, 50 REFERENCES, AUGUST 1967

THIS REPORT IS TNE IF A SERIES TM THE FOLLOWING TOPICS - LOFT DESIGN ANALYSIS, LCFT BLOWDOWN ANALYSIS, JIPECT RADIATION LEVELS DURING LOFT OPERATION, FISSION PRODUCT BEHAVIOR STUOIES, LOFT RADIGLOGICAL STUDIES, MLDEL FGRMULATION FOP. THE SUBCOOLED DECOMPRESSION DURATION IN A PWR SYSTEM FJLLOWING A PRI YAFY-CDOLANT-LOOP BREAK, AND SEMISCALE BLOWDOWN TEST PROGRAM.

AVAILABILITY - CLEARINGHOUSE FOR CEOEP.AL SCIENTIFIC AND TECHNICAL INFORMATION, SPRINGFIELD, VA., \$3. OO COPY, \$0.S5 MICROFICHE

ACCIDENT, LOSS OF COOLANT + CONTAINMENT CEESIGN + CORE MELTDCWN + CORE SPRAY +

FISSION PRODUCT RELEASE, GENCRAL + LOFT (S-PR) + REACTOR TRANSIENT + RSACTOR, SAFETY RESEARCH

$6-23440$

KIER PH

ANALYSIS OF THE INITIAL CRITICAL EXPERIMENTS OF THE EBWD. PLUTONIUM RECYCLE PROGRAM

ARGONNE NATIJNAL LABCRATORY, $\triangle Q$ GONNE, ILLINOIS

ANL-7368+. 41 PAGES, 6 . FJGURES, IC TABLES, 27 REFEPENCES, AUGUST 1967

DESCRIBES THE EXPERIMENTAL RESULTS AND THE ANALYSIS OF THE EXPERIMENTAL RESULTS FOR 


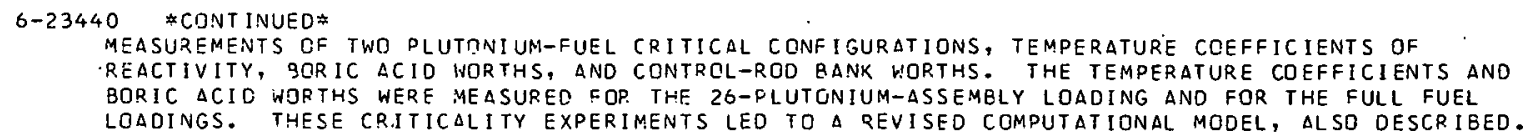

A RELATION IS ESTA ILISHEO RFThFFN THE EFFECTIVE MULTIPLICATION FACTOR OF NEUTRONS IN A REACTOR $\triangle N D$ THE FXPFR IMFNTAI. VALUES OF REACTIVITY COEFFICIENTS, DETEFMINED BY MEASUREMENTS OF OIFEERENTIAL OEACTIVITIES FOP A SERIES OF CRITICAL STATES OF THE REACTOR. CORRECTION TEFMS ALE GIVEN IN INTEGRAL FJRM.

\#REACTOR. PHYSICS + CRITICALITY EXOEFIMENT + REACTIVITY EFFECT + THEORETICAL INVESTIGATICN

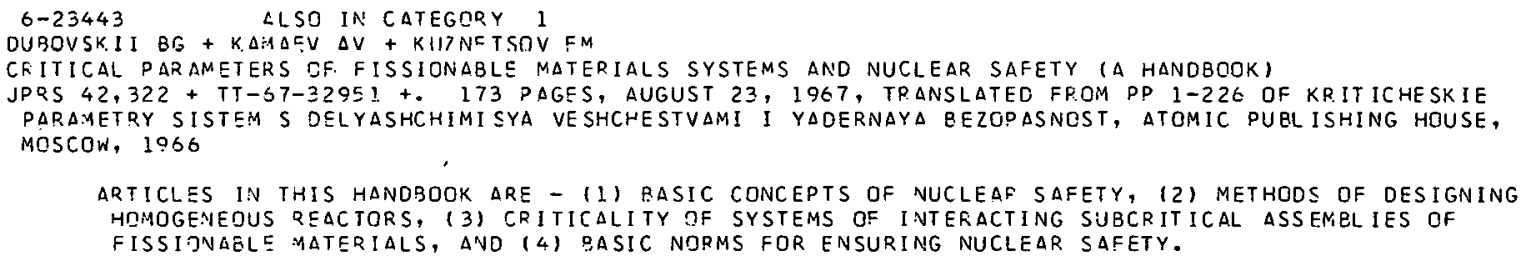

AVAILABILITY - INSTITUTE OF PHYSICS ANU IHE PHYSILAL SULIEIY AIVU IHE L.E.b.E., SEKKELET

\#CCMPARISON, THEQRY AND EXPERIENCE + \#POWER OISTRIBUTION + \#REACTOR, GCR + FLUX DISTRIEUTION + TEST, PHYSILS

6-23446 ALSO IN CATEGORY $1 \varepsilon$

ENGELMANN P + BICKEL W + DAFUNERT U + HAEEPMANN FW + VAN VELZE PL + WLAZE H + WITTEK G CONSTRUCTION AND EXPERIMENTAL EQUIPMENT OF THE KARLSRUHE FAST CRITICAL FACILITY, SNEAK KERNFDRSCHUNGSZENTRUM, KARLSRUHE, WEST GEFMANY

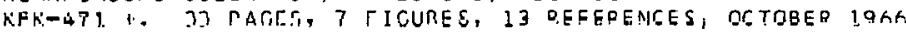

SNEAK IS A FIXED VERTICAL ASSEMBLY WITH FUEL ELEMENTS SUSPENDFD FROA A TOP GRIO. TWO HOP.IZONTAL CHANINELS WILL BE USED IOR. A MATERIAL REPLACEMENT DRAWER WITH AUTOMATIC SAMPLE CHANGER, A DETECTOR DR MATERIAL TFAVEDSt OEVILE, AIVU A PULSEO NEUTRON SOURCE. FCUR VERTICAL CHANNELS CLOSE TO THC CJRE CENTER AFF AVAILAGLE FOR INSTALLATION DF A PILE-OSCIIIATMR. A GAS-HEATED LOOP IS BEING BUILT FOP DOPPLEP EXPEPIMENTS. FDUP METHODS USEO IN SNEAK FOR DRECISE REACTIVITY MEASIREMENTS APE COMPARED - THE ASYMPTOTIC PERIOD METHCO, THE PILE OSCILLATOR METHOD, THE IVVERSE KINETICS METHCD, AND THE AUTOROD METHOD.

AVAILABILITY - MICROCARD EOITIDNS, INC., ACCOUNTING AND SHIPPING DEPT., WEST SALEM, WISCONSIN 546E9

\#CRITICAL ASSEMSLY FACILITY + \#MEASUPEMENT, REACTIVITY + \#REACTOR, FAST + CONTROL ROD + DOPPLER EFFECT + OSCILLATOR, REACTIVITY + PLUTONIUM CXIDE + REACTOR CONTHITL 
6-23493 ALSO IN CATEGORY IE

DRESDEN 2 AND 3 THERMAL LIMITS

COMMONWEALTH EDISJN COMFANY

17 PAGES, 8 FIGURES, PAGES 3.1-1 THRU 3.2-16. OF ORESOEN 1 AND 2 FINAL SAFETY ANALYSIS P.EPORT, VELUME 1, NOVEMBER 17, 1967, DOCKETS 50-237/249, TYPE--BWR, MFG.--G.E., $\triangle E--S G T+$ LUNDY

FUEL-DAMAGE LIMITS ASSUMED ARE DNE AND/OR I\% PLASTIC STRAIN IN THE ZIRC CLADDING. DESIGN MCHFR IS 1.5 AT 2O\% OVERPOWER (APEO-3892). EXPECTED HCHFR IS 1.9 (APED-5286 HEAT-FLUX CORRELATION FCF EWRS). THE LATTICE LIMIT WILL BE THE GOVERNING CRITERION SINCE A PROPERLY CHOSEN LIMIT FOR NORMAL OPERATION CAN ENSURE THE THEFMAL MARGIN AT 2OK OVERPOWEF CONOITIONS. MAXIYUM LINEAF HEAT RATE LIMIT WILL BE $17: 5 \mathrm{KW} / F T$. THE ABCVE CRITERIA DO NDT STATE THE POWER LEVEL DR PEAKING EACTORS. THESE WILL BE CETERMINEO BY THE OPERATJR, SUBJECT TO CONSTRAINTS, INCLUDING THEPMAL LIMITS APOOVE.

AVAILASILITY - USAEC PUELIC DOCUMENT ROOM, WASHINGTON, D. C.

BURNOUT HEAT FLUX + [FESDEN 2 (BWP) + PEFFORMANCE LIMIT + REACTOR, RWR + REPORT, SAR + THEP.MAL CDNSIDERATIGN.

$6-23831$

PENDERGAST MS

REACTOR KINETICS MODEL. TWO MODES, WITH SUGGESTED TEST FOR DETERMINING THE REACTIVITY COUPLING COEFFICIENT

KNOLLS ATOMIC POWER LAB., SC.HENECTACY, NEW YORK

KAPL $-3160+.70$ DAGES, FIGURES, REFERENCES, SEPT. 1966

WITH TWJ-MOOE REACTOP. KINETICS, THE SPATIAL SHAPE OF THE POWEF DENSITY IS ASSUMED TO BE A LINEAR COMBINATIGN OF A SYMIYTTIC MOOE AND A TILT MOOE WITH TIME-VARYING COEFFICIENTS GIVEN SY THE TWO-AOOE PEACTOR KINETICS EQUATIONS. FOR A TIME SOLUTION, THE SEPARATION OF EIGENVALUES (CF THE SYMMETRIC AND TILT MODES) MUST BE KNOWN. THIS REPORT SUGGESTS $A$ TEST FOR DETERMINING THIS QUANTITY. THE SUGGESTED TEST IS DEVISED EY ORTAINING TRANSFER FUNCTIONS FOR A LEET, A RIGHT, AND A CENTRAL ION CHAMBER WITHIN THE REACTOR. BASICALLY, THE TEST CONSISTS OF JSCILLATING THF TILT MODE AT'TWC DIFFERENT FREQUENCIES, WHILE HOLDING THE SYMMETRIC MCDE NIEARLY STATIONARY.

AVAILABILITY - CLEAPINGHOUSE FOR FEDEPAL SCIENTIFIC AND TECHNICAL INFGRMATION, SPRINGFIELD, VIPGINIA, $\$ 3.00$ COPY, \$0.65 MICROFICHE

* REACTOR KINETICS + PQWER DISTEIBUTION + REACTOP PHYSICS + SPACE DEPENDENT OYNAMICS +

THEORETICAL INVESTIGLTION + TRANSFER FUNCTION

$6-23917$

MILLS CB

LOW CRITICAL MASS

LOS ALAMCS SCIENTIFIC LASORATORY, LCS ALAMDS, NEW MEXICO

2 PAGES, 4 FIGURES, 3 REFERENCES, NUCLEAP, APPLICATIONS, 411), PAGES 17-18 (JANUARY 1968)

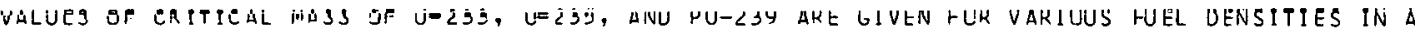
WATER-MODERATED CORE SURROUNCED BY A THICK WATER OR BERYLLIUM REFLECTOR. A THICK BE MODEFATOF: IS SHIWN TO YIELO A MINIMUM CRITICAL MASS OF ONI.Y ONF-THIRO OF THE ENRICHED FISSIONABLE FUEL REQUIRED FOR: A WATER-REFLECTED ASSEMBLY.

\#CRITICAL MASS + \#PLUTONIUM + \#URANIUM-232 + \#URANIUM-235 + BERYLLIUM + CRITICALITY SAFETY + i REACTOR PHYSICS 
$7-18345$

BOCKHOFF KH + MIGNECSE + THEOBALD J + WAPTENA J

A LARGE AREA FISSION FRAGMENT DETECTOP. WITH FAST RESPONSE

CENTTRAL BUREAU FOR NUCLEAR MEA SUREMENTS, EURATOM, GEEL, BELGIUM

5 PAGES, 5 FIGURES, NUCL. INSTR. AND METHCDS 45, PAGE 233 THRU 237,1966$)$

DESCRIBES PERFOKMANCE OF A FISSION-FRAGMENT DETECTOR WHICH CAN BE USED FOR HIGH-RESOLUTION FISSION-CROSS-SECTION MEASUREMFNTS. IT CONSISTS OF TWC VEPY THIN PLASTIC SCINTILLATCR. FOILS DF I.ARGE AREAS SANDWICHING A FISSILE LAYFP. COINCIDENCE TECHNIGUES APPLIED TO THE SIGNALS OF TNO PHOTOMULTIDLIERS WHICH VIFW THESE SCINTILLATORS ALLCW TO DISCRIMINATE FISSICN FRAGMENTS AGAINST ALPHAS AND OTHER BACKGROUNE SOURCES. AMPLITUDE SPECTRA AND THE DEPENCENCE OF FISSION DETECTION EFFICIENCY FR. LM LOCATION ON THE DETECTOR SURFACE WERE STUDIED. AS $\triangle$ FESULT DF AN APPL ICATION OF THE DETECTOR, U-235 FISSION REACTION RATES ARE SHOWN IN FUNCTION OF NEUTRON TIME OF EL IGHT.

*ANAI YTICAL. TFCHNIQIIF, CALIRRATION + \#INSTPUMENTATION, GENERAL + \#INSTRUMENTATION, RADIATION MCNITCQIVI. + ALPHA EMITTER + FISSION RECOIL.

$7-20550$

GETHARD PE + ZUMWALT LE

DIFFUSION OF METALLIC FISSION PRODUCTS IN PYFOLYTIC CARBON

GULT GENERAL ATOMIC

7 PAGES, FIGURES, REFERENCES, NULLEAR APPLICATIONS, 3(11), PP. 679-655, (NOVEMESR 1967)

THE DIFFUSION OF STRONTIUM A.VD CESIUM THROUGH THIN LAYERS (100 MICRONS) OF ISOTRODIC PYPRLYTIE CARBON NAS ACASURED QVER THE TEMPERATURE RANGE 1000 TO $1700 \mathrm{C}$. DIFFUSION COEFFICIENTS OBSEPVED FDR CESIUM ARE ORDERS OF MAGNITUEE LOWER THAN THOSE FOR STRONTIUM. THE DIFFUSICN RATES FOQ SOTH SERIES ARE MUCH LOWEP THAN THOSE. OBSERVED IN POKGUS PQLYCRYSTALLINE GOAPHITE, WHER? LITTLE DIEFERENCE IS SEEN BETWEEN CESIUM AND STRCNTIUM. WHEN CONSTANT CHEMICAL PDTENTIAL STURCES $\triangle R E$ USED, CHEMICAL ANO SELF-DIFFUSION MEASUREMENTS FOR STRONTIUM GIVE IDENTICAL RESULTS IN THE SQ CONCENTRATION RANGE 0.01 TO 0.2 WT CDNCENTRATIOV EFFECT FCQ CESIUM OVER THE FANGE 0.00001 TO C.15 WT\%. THE DIFEER.FNCE PETWEEN STR NNTIUM ANO CESIUM DIFEUSION IN PYROLYTIC CARBDN IS ATTRIBUTED TO THE GFEATER STEFIC FFFECT GF THE PYROLYTIC-CAPBON DEFECT STRUCTURE FELATIVE TO CFSIUM.

*CARBON + \#CIFFUSIJN + \#FISSION PROOUCT PIETENTICN + \#FUEL INTEGRITY + \#PYROLYTIC + CESIUM + FISSIDN PRCDUCT TRANSPORT + GRAPHITE + STRONTIUM

7-21245 ALSE IN CATEGCRIES 6 AND 12

REPORT DF WORK IN THE 4TH GUARTER OF 1066

COMMISSARIAL A L-ENERGIE DTOMIQUE, CADARACHF, FRANC.F

EURFNR-?67 +. 89 PAGES, 1966

THIS REPCRT IS CNE OF A SERIES OF REPORTS ON WORK PERFORMED UNOFR THE UNITED STATES-EURATCM -ASI REALTUR EXLHAIVE PROERAM. TOFICS COVEREO ARE - CRITICALITY JTUDILS+ METALLURGY, RADIATION EFFECTS, RADIATION SHIELDING $\triangle N O$ PROTECTION, REACTOP COVTROL, REACTOR ENGINEERING, R.EACTOR FUELS, AND REACTOR. SAFETY.

AVAILABILITY - MICROCARD EDITIONS, INC., ACCOUNTING AND SHIPPING CEPT. WEST SALEM, WISCONSIN E4EE9

ACCIDENT, RFACTIVITY + CRITICALITY EXPERIMENT + FISSION PRODUCT FETENTION + PEACTOR CCNTPOL +

REACTUH OYNAMICS + FEACTOR, LMER + SOOIUM

$1-212 W 1 \quad \Delta L S O$ IN LATEGORIES 12 ALTE, 17

PI SUA REQUESTS REMTVAL UF HIGH EFFI.CIENCY FILTERS

PI UUA NUCLEAR PDWER FACILITY

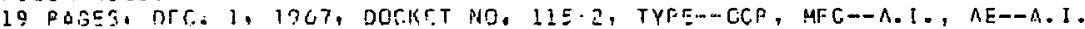

DIOUA REQUESTS EXFMPTION FROM TECH.-SPEC. REQUIREMENT OF VENTILATION FILTERS WHILE THE FUEL IS STQRED AND THE QEACTUP IS INUPCPAIIVE. THE EILTERS COST MOPE THAN \$40OO PER YEAR. PIOUA HAS ALWAYS CONTENCED THAT THE FILTERS WERE UNNECESSARY EVEN UNDEF OPERATING CONOITIONS. ENCLOSED IS A REPORT - HIGH EFFICIENCY PARTICULATE AIP FILTER EVALUATION EOR PIQUA (IT PAGESI.

AVAILABILITY - USAEC PUELIC DOCUMENT ROOM, WASHINGTON, D. C.

FILTER. HIGH EFFICIENCY + PIQUA (OCR) + REACTOR, ORGANIC COCLED + TECHNICAL SPECIFICATIONS + VENTILATION SYSTEM

7-21815 ALSO IN CATEGORY 17

GULF GENERAL ATOMIC PROPOSFO AMENOMENT--FUELED EXPERIMENTS IN TRIGA MARK F

GULF GENERAL ATOMIC, INC.

9 PAGES, 1 figure, 1 TAELE, OOCKET 50-163, NOVEMBER 22,1967

GULF-G.A. WITHQRAWS MAY 21, 1S67, AFPLICATION AND REQUESTS DUTHORITY TC PERFORM FUEL 
7-21815 \#CONT INUEC*

EXPER IMENTS NITH THE LIHITATION THAT THE RELEASABLE IOEINE INVENTJRY NOT EXCEEO I.T/F CURIES, WHERE F IS THE. ACTUAL P.ELEASE FRACTION OF MATERIAL INVCLVED EASEO DN EXISTING DATA, OR I.O IF VI DATA IS AVAILABLE. THIS LIMIT WAS DETERMINEC FROM REACTOF-RGOM EXPOSURES, AND RESULTS IN ND APDRECIABLE GFF-SITF DOSE. ATTACHMENT I IS A HAZAROS ANALYSIS - CONSEQUENCES OF ACTIVITY RELEASE FRGY TH:E TRIGA MARK F REACTCR. GULF-G.A. ASKS FOR A TEMPORARY AUTHORIZATION TO OPERATE EXPERIMENTS WITH 1.5 CURIES OF IOOINE.

AVAILABILITY - USAEC PUELIC DOCUMENT ROOM, WASHINGTON, D. C.

\#FISSION PRODUCT, IOCINE + \#IRRADIATION TESTING + HAZAROS ANALYSIS + REACTOR, PESEARCH + TECHNICAL SPECIFICATIONS + TPIGA (RR)

$7-22110^{\circ} \quad \triangle L S O$ IN CATEGORIES 5 DNG 14

NUMERICAL SOLUTION GF THE ISOTHERMAL FISSION-PRGOUCT DEPOSITION EQUATICNS. THE PRDGRAM PREDEP-II OAK FIDGE NATIONAL LAE., TENA.

DRNL-T.M-IS70+. 28 PLGES, 3 FIGUPES, 2 REFERENCES, OCT, $19 E 7$

THE HCAT-MASS ANALOGY WAS PQEVIOUSLY USEO TO DEVELEP A SEMILINEAR SYSTEM OF PARTIAL OIFFERENTIAL FQUATIONS TO DESCRIBE THE ISOTHERMAL DEPOSITICN OF FISSION PRODUCTS. IN THIS FEP.JFT, THIS SYSTEM IS TQANSFORMED INTO A SYSTEM OF INTEGRAL FQUATIONS IN COMPUTATIONALLY CONVENIENT VARIAPLES, AND A FINITE-DIFFERENCE METHOD FOR. THE SOLUTION OF THE INTEGRAL CRIJATION SYSTEM IS EESCRISEO. A BRIEF DESCRIPTION IS GIVEN OF THE COMPUTER PRCGRAM PQEDEP-II, NHICH ACCFPTS DATA IN TERMS OF PHYSICALLY CONVENIENT DIMENSIONLESS VARIABLES, TRANSFGRMS THESE TO THE CQMPUTATIONAL VARIABLES FOR MEANS OF SOLVING THE FINITE-DIFFERENCE EQUATIONS, ANC FINALLY REPJRTS THE RESULTS IN TERMS CF THE PHYSICAL VARIABLES.

AVAILABILITY - CLEARINGHOUSE FOR FEUERAL SCIENTIFIC ANR TECHNICAL INFORMATION, SPRINGFIELD, VIRGINIA, $\$ 3.00$ COPY, \$0.65, MIC ROF ICHE

COMPUTER PSOGRAM + DEPOSITION + FISSION PRODUCT TRANSPORT + FISSION PRODUCT; NONVOLATILE

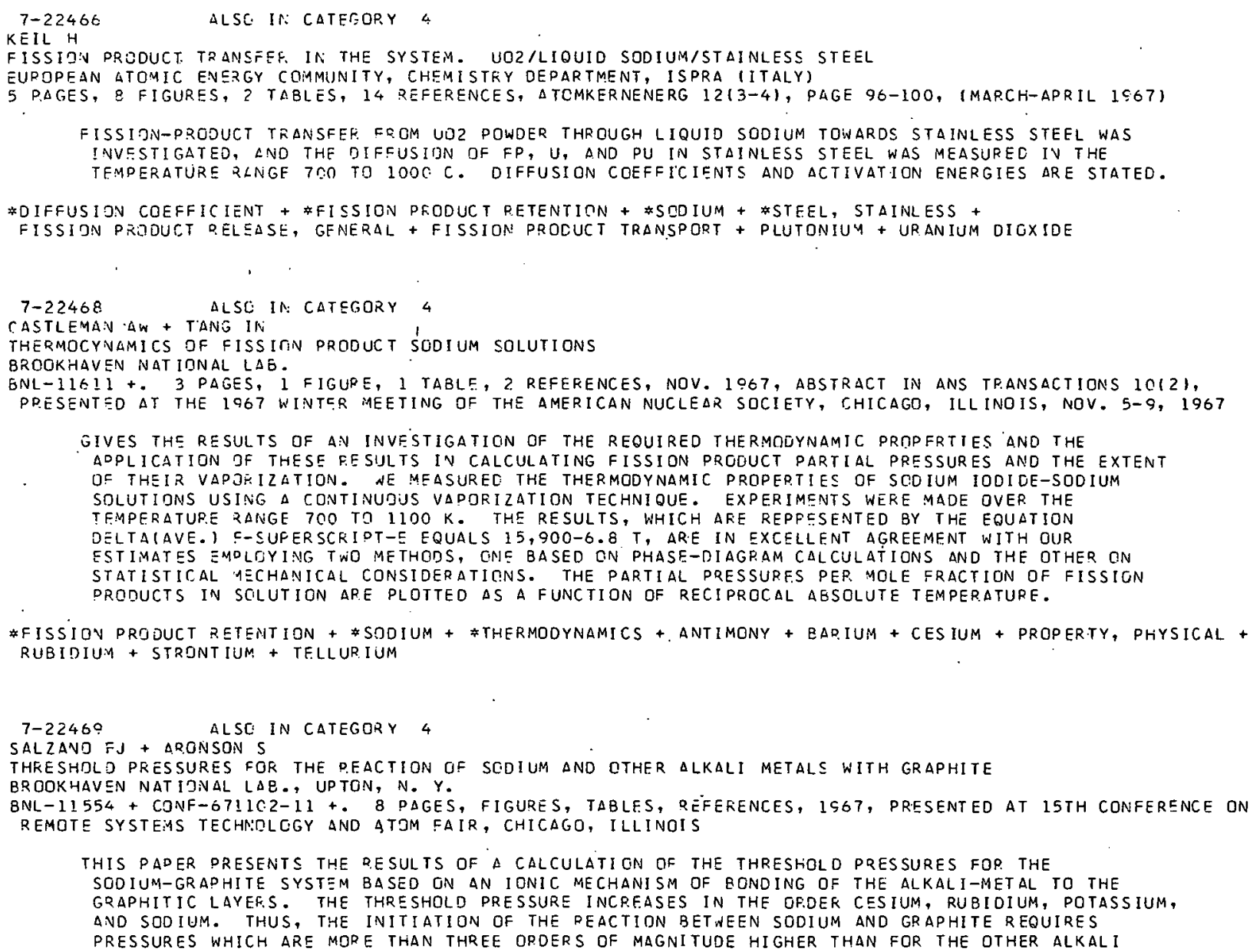


CATEGORY 7
FISSION PRODUCT RELEASE, TRANSPOPT, AND REMOVAL

\section{$7-22450$ \#ONT INUEO}

METALS.

AVAILABILITY - CLEAPINGHOUSE FOR FEDERAL SCIENTIFIC AND TECHNICAL INFORMATION, SPRINGFIELD, VIRGINIA, $\$ 3.00$ COPY, \$0.65 MICROF ICHE

\#CHEMICAL PEACTION + \#GRAPHITE + \#SODIUM + CESIUM + POTASSIUM + RUBIDIUM + THEORETICAL INVESTIGATION + THERMOOYNAMICS

$7-22472$

HILLIARD RK + COLEMAN LF + MCCORMACK JO

AEROSOL BEHAVIOR - SINGLE COMPONENT VS. MIXTURE I

BATTELLE-NORTHWEST, FICHLAND, WASH. PACIFIC NOPTHWFST LAB.

1 PAGE, PAGE 70 OF ENGINEERING DEVELOPMENT DEPARTMENT QUARTERLY REPORT, IANIIARY, FEBPUARY, MARCH IOSE

AN IMPORTANT CONSIOEFATION IN DEVELGPINC A SYNTHETIC FISSION PRODUCT AEROSUL FÜK MASS TRANSPORT STUOIES IS THE NUMEER OF COMPONENTS REQUIRED FOR AN AEROSOL WITH TRANSPQRT PROPFRTIES SIMILAR TO THAT RELEASEC DURING AN ACTUAL ACCIDENT. FIVE CONTAINMFNT TESTS WERE MADE IN THE AOF SIAINLESS STEEL TANK USING SINGLE-COMPONENT $\triangle E R O S O L S$ OF IODINE, CESTIMM TXIOE, TELLURIU:A OXIOE, BAPIUM IJXIDE, AND RUTHENIUM OXIDE. THEN, IN PUN 53, ALL FIVE WERE GTNESATED, MIXEQ, PASSEO ÜVEK MULIEN STAINLESS STEEL CLAD UOZ, AND INJECTED INTE THE CONTAINMENT VESSFL. TEST CONOITIONS FIR THE SIX TESTS WERE SIMILAR EXCEPT FOP THE TYPE CF AEROSOL. THE PRIMARY CONCLUSION IS THAT THE BCHAVIOR OF ANY OF THESE FIVE AEROSCL MATERIALS IS NOT SIGNIFICANTLY AFFECTED BY THF PRESENCE OR ABSENCE OF OTHER AEROSOL MATERIALS. A SECOND CONCLUSION IS THAT TELLURIUM, BARIUM, AND RUTHENIUM BEHAVED SIMILAPLY, BEING LARGELY PARTICULATE, DEPCSITING ON SCLID SURFACES AND NGT NASHING OFF WITH CONTINUED STEAMING. IODINE AND CESIUA, ON THE OTHER HANC, WERE ESSENTIALLY SOLUBLE IN THE STEAM CONDENSATE. AFTER AN INITIAL R.APID DEPDSITION UN SURFACES, THEY WERE REMCVED BY THE CONDENSATE UPON CONTINUED STEAM ING.

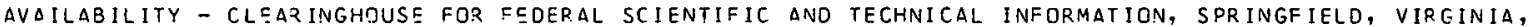
$\$ 3.00$ CJPY, \$0.65 MICROFICHE

*AEROSOL PRODUCTION + *AERCSOL PRGDERTIES + \#TESTING + AEROSOL + EARIUM + CESIUM + IODINE + OXIDE + RUTHENIUM + TELLURIUM

$7-22477$

RITZMAN RL + GIESEKE JA + BLUTREICH JN + MORFISON DL

ANALYTICAL DESCRIPTIGI OF FISSION-PRODUCT TRANSPQRT ANO DEPOSITION IN CONTAINMENT VESSELS

BATTELLE MLMOR IAL INSTITUTE

1 PAGE, 2 FIGURES, 2 FEFEPENCES, ANS TPANSACTIONS 10(2), PAGE 714 , (NOV. 1967), FRESENTED AT THE I967

WINTEQ MEETING OF THE AMEPICAN NUCLEAD SOCIETY, CHICAGD, ILLINOIS, NOV. 5-9, 19,7

A MATHEMATICAL MODEL WAS DEVFLOPEO TO DESCFIBE THE TIME-DEPENCENT BEHAVIOR OF FISSION PRODUCTS WITHIN A TINITAINMENT VESEEL. ALTIIOUGI! IT HAS OCEN LIMITEO IN SUIME KESHELIS IU FISSION-PRODUCT IODINE, THE METHOD CAN BE FEADILY EXTENDED TO INCLUDE OTHER CHEMICAL SPECIES. THE MODEL IS DESIGNATEC COVCOEP. APPLICATICN OF THE MODEL TO LARGE POWER REACTOP CONTAINIAENTS PEVEAIS THAT NITHIN THF PANGE OF EXPECTED MASS TRANSPORT RATES, THE RATE UH FISSION-PRODUCT REMOVAL WILL BE DETEPMINED EY SAFETY-SYSTEMS OPERATION CHARACTFFISTICS RATHER THAN BY DEPOSITIEN PRUCESSES AT VESSEL SURFACES.

* ANALYIICAL MODEL + *COMPUTER DROGRAM + \#FISSION PRCOUCT TRANSPORT + CONTAINMENT, GENERAL + DEPCSITION + MODEL TESTING

$7-22478$

GENCA .IM + RMSENBEQG HS + BERRY WE + MQRRISON DL

FISSION-PRODUCT DEPDSITION STUDIES, PART I : IRTINE ON TRIMARY VLSELL JURTACES

EATTELI.F MFMIIKIAL. INSTITUTE

2 PAGES, 1 FIGURE, 1 TAELE, 5 REFERENCES, ANS TRANSACTIONS $10(21$, PAGE 714 AND 715 , (NOV. 19G7), PRESENTEO

AT THE 1967 WINTER MEETING OE THE AMLRICAN NUCLEAR SOCIETY, CHICAGU, ILLINOIS, NOV. 5-9, 1967

EXPEKIMENIS WERE PERFORMED IN STEAM-AIR AND STEAM-HYOROGEN ATMOSPHERES DEL INEATING THE

DEPOSITION KINETICS OF IODINE AND HI ON PREFILMED ZIRCALCY -4 (ZRC2-X) AND PREFILMED TYPE-304

STAINLESS-STEEL (R304) SURFACES. A STPAIGHT LINE REASONABLY FJTS THE DATA AND P.EVEALS THE

NEGATIVE TEMPERATURE COEFFICIENT OF IODINE DEPOSITION ON PREFILMED STAINIFSS STFEL.

* DEPOSITION + \#IODINE + \#STEAM + EXPERIMENT, GENERAL

$1-22479 \quad$ ALSO IN CATEGORY 4

KOCNTZRL + NELSON CT + BAURMASHL

CIIARACTERISTICS OF AEROSCLS GENERATEU UUKING SOUIUM FIFES

ATOMICS INTFRNATIONAL

2 PAGES, 1 TABLE, I REFERENCE, ANS TRANSLCTIONS 1012), PAGE 680 AND 600, (NOV. I965), PRESENTED AT THE

1967 WINTER MEETIVG GF THE AMER ICAN NUCLEAR SDCIETY, CHICAGO, ILLINOIS, NOV. 5-9, 1967

STUDIES $\triangle R E$ BEING CONDUCTED TO DEVELOP EXPERIMENTAL INFORMATION AND $\triangle N A L Y T I C A L$ METHODS THAT

CHARACTER IZE THE PELEASE AND TRANSPORT OE EFFLUENTS GENFRATEC OUYPING A SRRIIM FIRF IN A

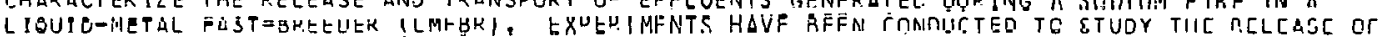


FISSION PRODUCT FFLEASE, TRANSPORT, AND REMOVAL

$7-22479 *$ CONT INUED*

OXIDIZED SJOIUHA AND A SIMULATED FISSION PRODUCT CONSISTING OF NA-131-I INVOLVING VARIOUS

QUANTITIES OF SODIUM IN DIFFERENT SIZFD CCNTAINERS AND IN VARIOUS OXYGEN ENVIRONMENTS.

\#AEROSOL + *FIRE + \#PLRTICLF SIZE + \#SODIUM + IODINE + OXYGEN + REACTOR, LMCR

7-22480 $\quad$ ALSC IN CATEGORY 4

HAUSKNECHT DF + GREENFIFLD MA

A MODEL DESCRIBING THF PEHAVIOR OF THE AFFOSOL PRODUCED BY A SODIUM FIRE

ATOMICS INTERNATIDNAL + UCLA, SCHOOL OF MEDICINE

1 PAGE, 8 REFERENCES, ANS TRANSACTIONS $10(2)$, DAGE 690, (NOV. 1GE7), PRESENTED AT THE 19G7 WINTER MEETING

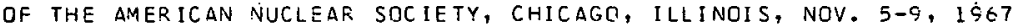

PREDICTION OF THE BEHAVIOR OF AEROSOLS GENERATEO DURING A LARGF SODIUM FIRE IS REQUIRED IN THE SAFETY ANALYSIS OE SODIU:A-CDCLED FAST REACTORS. TO AID IN UNDERSTANDING AND EXTENDING THE RESULTS OF THE EXPERIMENTAL PROGRAM, A THEORETICAL EFFURT WAS UNDERTAKEN TO DEVELDP A MATHEMATICAL MODEL THAT WOULD PREDICT THE AGGLOMERATION AND DEPOSITION HISTORY CF AEPOSOL PAPTICLES. THE MATHEMATICAL MODEL IS BASED ON THE CLASSICAL APPROACH DF SMOLUCHOWSKI AS GENERAL IZED BY MULLER AND GOLDMAN, FOR A DISTRIBUTION OF PARTICLE SIZES. NUMERICAL INTEGRATION OF THE BASIC EQUATION WAS ACCOMPLISHED FIRST BY FRIEOMAN AND SHIFFMAN, AND MUPE RECENTLY BY ZESEL, USING AN $1 B M-650$ COMPUTER. NUMERICAL EVALUATIDNS WERE PERFORMED WITH THE IMPROVED MODEL AND GOOD AGREEMENT WAS OBTAINED WITH EXPERIMENTAL RESULTS FOR MASS DISPOSITION AND PARTICLE SIZE. IT ILLUSTRATES THE IMPORTANCE OF THE ACDITIONAL AGGLOMERATIGN MECHANISMS

IN ACHIEVING AGREEMENT WITH EXPER.IMENT.

* ANALYTICAL MODEL + \#COMPUTER PROGRAM + \#FIRE + \#SODIUM + MODEL TESTING

$7-22481$

KRESS TS + NEILL FH

A SIMPL IFIED APPROACH TO CALCULATING CONVECTIVE PLATEOUT OF FISSION PRODUCTS

DAK RIDGE NATIONAL LAB., TENN.

2 PAGES, 4 REFERENCES, $\triangle N S$ TRANSACTIONS 10(2), PAGE 712 AND 719, (NEV. 1965), PRESENTED AT THE 19E7 WINTER MEETING OF THE AMERICAN NUCLEAR SOCIETY, CHICAGO, ILIINOIS, NCV. 5-9, 1967

MANY ANALYSES OF THE TRANSPORT ANO DEPOSIYION OF FISSION PRGDUCTS IN A REACTOR COOLANT CIRCUIT SHARE COMMON DEFICIENCIES, THE MATHEMATICAL MDDELS ARE CUMBERSOME AND IMPRACTICAL TO APPLY, THE. PHYSICAL MCDELS ARE LIMITED IN THE CHOICE OF SURFACE REACTICNS AND DO NOT READILY DESCRIBE THE SIMULTANEOUS ADSORPTION OF SEVERAL F.ISSION PRODUCTS ONTO A CGMMON SURFACE. A QUASI-EQUILIBRIUM IS ASSUMED TO FXIST AT ALL TIMES BETWEEN THE ADSORBATE ON THE SUIP.FACE AND IN THE GAS STFEAM IN DIRECT CONTACT WITH THE SURFACE. THIS IS EQUIVALFNT TO ASSUMING THAT THE TRANSFER ACROSS THE BOUNDARY LAYER. IS THE CONTROLLING RATE. AXIAL VARIATIONS ARF NOT INCLUDED IN THE DER IVATION OF THE EQUATIONS. THESE CAN BE OETAINED, HOWEVER, BY PROGPESSIVE APPLICATION JF THE EQUATIONS IN DOWNSTREAM FINITE-DIFFERENCE REGIONS USING MASS BALANCES TO ESTABLISH THE RESPECTIVE GAS-STPEAM CONCENTRATIONS. AGREEMENT WAS GOOD UNOER THE CONDITIONS OF THE COMPARISON WHICH SIMULATED CONDICTIONS IN A FISSION-PRODUCT DEPCSITION EXPER IMENTAL SUSTEH AT ONML.

* ANALYTICAL MODEL + \#DEPOSITION + \#MODEL TESTING + FISSION PROUUCT RETENTION + FISJION PRODUCT TRANSPORT

$7-22482$

MISHIMA J + HASTY RA + SCHWENDIMAN LC + BURGER LL + POSTMA AK

REMOVAL OF AIR BNRINF MFTHYL IODIDE FROM SIMULATED REACTOR-CONTAINMENT ATMOSPHERES BYY HYDRAZINE .SPRAYS BATTELLE NORTHWEST LAS.

1 PAGE, ANS TRANSACTIONS $10(2)$, PAGE 719, (NOV, 1967), PRESENTED AT THE 1967 WINIEK MEETING OF THE AMERICAN NUCLEAR SOCIETY, CHICAGO, ILLINCIS, NOV. 5-9, 1967

THE USE OF HYDRAZINE $\triangle S$ A POSSIBLE ADDITIVE TO. PRESSURE-SUPPRESSION SPRAYS IS BEING INVESTIGATED SINCE IT HOLDS SOME PROMISE AS A SCAVENGER FOR BJTH AIRBORNE MOLECULAR IODINE AND METHYL IODIDE. THE GAS-PHASE REACTION BETWEEN HYDRAZINE AND METHYL IODIOE IS SLOW. IN A TYPICAL EXPERIMENT, ONLY IO\& OF THE METHYL IODIDE REACTED IN A LARGE EXCESS OF HYDRAZINE VAPOR. REMOVAL GF TRACE METHYL IODIDE FROM THE GAS PHASE TO A STATIC SOLUTION OF ALKALINE HYORAZINE WAS MEASURED. UNDER A DECAYING TEMPERATURE REGIME WITH AN INITIAL TEMPERATURE OF 75 C, THE REMOVAL HALF-TIMES FOR AN ALKALINE 5 WT' HYDRAZINE SOLUTION RANGED FROM 25 TO 50 MIN. INCREASING THE TEMPERATURE INCREASED THE RATE OF FEMCVAL.

\#ORGANIC IODIDE + \#SPFAY, GENERAL + CHEMICAL REACTION + IODINE

7-22483 ALSCIN IN CATEGQRY 4

MURBACH EW + BODINE JE

DISPENSING AND SAMPLING SODIUM FOP. THE LMFBR CLADDING PROJECT

ATOMICS INTERNAT IONAL

1 PAGES, ANS TRANSACTIONS 10(2), PAGE 493, (NDV. 1967), PRESENTED AT THE 1967 WINTER MEETING OF THE AMERICAN NUCLEAR SOCIETY, CHICAGO, ILLINGIS, NOV. 5-9, 1967

ONE OF THE TASKS GN THE LMFBR CLADDING PRCgRAM AT ATOMICS INTERNATIONAL INVOLVES THE MAINTENANCE OF A SUPPLY OF SYSTEMS-GUALITY SODIUM, THE DISPENSING OF THIS SDDIUM, AND SAMPLING DF SCDIUM TEST UNITS. A SUPPLY LOOP OF OVER I5O-GAL CAPACITY WAS CONSTRUCTED FOR MAINTAINING SUFFICIENT SODIUM OF CCNSTANT COMPOSITION FOR THE DURATION OF THE PROGRAM. THE 
FISSION PROOUCT FELEASE, TRANSPORT, ANO REMOVAL

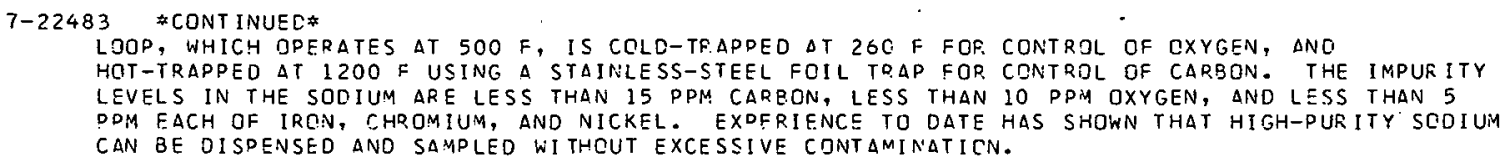

*CARBON + \#SODIUM + CHROMIUM + CONTAMINATION + DECONTAMINATION + IRON + NICKEL

$7-22484$

PLUMLEE DE + NOVAK PE

DIRECT IN-PILE MEASUREMENT OF THE CENTRAL TFMPEFATURE OF A SOCIUM-EONDED MIXED-OXIDE FUEL PIN

GENERAL EL ECTR IC

1 PAGE, I FIGURE, 5 FEFERENCES, NNS TRANSACTIONS 1012), PAGE E39, (NOV. 1967), PRESENTED AT THE 1SE7

WINTER MAESTING OF THE AMERICAN NUCLEA? SCCIETY, CHICAGO, ILLINOIS, NOV, 5-0, 1967

IN PREVIQUS EXPER IMENTS, SODIUM-BONOED MIXED-OXIDE FUEL SPECIMENS INCICATED GOCO SHORT-TEFM PERFDRMANCE UP TD LINEAP. POWER GFNFPATION RATES OF 30 KWIFT. SATISFACTDPY 1 IXED-OXIDE/SOOIUM/CLADDING CCMDATIBILITY WAS ORSERVED IN FUEL IRRADIATED TO 14,400 MWO/T AT POWERS UP TO $2 ! \mathrm{KW} / F T$. SECAUSE CF THESE PROMISING RESULTS, AND THE LACK OF DATA CONCERNING THE EFFECT OF SODIUM ON THE THERMAL CONDUCTIVITY OF MIXED-OXIDE FUEL, THIS EXPEPIMENT WAS DESIGNED AS DART OF THE FAST CEDAMIC. PEACTOR DEVELOPMENT PROGRAM TO PERMIT THE DIPECT MEASUREMENT OF THE CENTRAL FUEL TEMPEPATURE OF A SODIUM-BONDED FUEL SPECIMEN WITH A HIGH-TEMPERATURE THERMOCOUPLE. THE RESULTS OF THIS EXPERIMENT SUPPORT THEORETICAL CALCULATIONS OF IMPRJVED THERMAL CONDUCTIVITY OF SODIUM-BONDED FUEL MADE IN THE LITERATUPE AND PDINT TO THE POSSIBILITY OF ATTAINING SUBSTANTIALLY HIGHER POWER DENSITIES IN SODIUM-BONDED MIXED-OXIDE FUEL COMPARED TO GAS-BONDED FUEL.

\# DESIGN CRITERIA + \#FUEL BURNUP + \#FUEL ELEMENT + \#THEPMAL EXPERIMENT + SODIUM

$7-22485$

SOLDAND BA + WARD WT

UPTAKE OF METHYL IDDIDE FRO!A WIND-TUNNEL GASES BY A SUSPENDED DROP GF WATER

DAK RIDGE NATIONAL LAB., TENN.

1 PAGE, 1 REFERENCE, ANS TRANSACTIONS 10(2), PAGE 720, (NOV. 1967), DFESENTED AT THE ISE7 hINTEF MEFTING OF THE AMER ICAN NUCLEAR SOCIETY, CHICAGO, ILLINOIS. NOV. 5-9, IGG7

A STUDY OF THE TRANSPORT DF METHYL IOOIDE GAS INTO A WATER RPGP SUSPENDED IN A WIND TUNNEL WAS DIRECTED TOWARD LN EXAMIVATION OE THE EFFECT OF SOLUTICN ACDITIVES ON THIS PROCESS.

CONCENTRATION DF CHZI IN THE TUNNEL GASES WAS $\triangle B O U T$ O.0000I MMOLE/CC. THE WATER RROP UNCER STUDY REMAINS SUSPENDED IN THE WIND TUNNEL THROUGH THE UDHARO THIOIST OF THE FLOKING GAS

MIXTURE. IT APPEARS THAT THE PDQCESS OF MASS TRANSFER OF CHZI INTO A WATEP DRCF CONTAINS BOTH ELEMENTS OF A STRICTLY GAS-WATER SUPFACE INTEPACTION AS WELL AS THOSE DIFECTLY RELETED TO THE SOLUTION CHEMISTRY OF THE DROPS INTERIOR.

* ORGANIC IODIDE + \#PPRAY, GENERAL + DIFFUSION + IOOINE + SORPTION

$7-22486^{\circ} \quad$ ALSC IN CATEGQRY 4

HORN FL

SOME AEROSOL PROPERTIES OF VAPORIZEC FAST-REACTOR FUELS

BROOKHAVEN NATICNAL LAS.

3 PAGES, 1 TABLE, ABSTRACT IN ANS TFANSACTIONS 10(2), PAGE 699, (NCV. 1967), PRESENTED AT THE 1C67 WINTER

MEETING OF THE AMER ICAN NUCLEAR SOCIETY, CHICAGO, ILLINAIS, NOV. 5-8, 1067

THE NATURE AND COAGULATION BEHAVIOR COF AEROSOLS FORMED DURING THE HIGH-TEMFERATURE VAPOE IZATION OF FAST-REACTOP FUEL MATERIALS WERE INVESTIGATED. THE FUEL MATERIALS, PUOZ AND UOz, WERE RAISED RAPIDLY ABOVE THEIR MELTING POINTS TO SIMULATF AN ACCIDENTAL RELEASE OF FUEL OUR ING A REACTRP. POWER EXCURSION. INDIVIDUAL STUDIES WERE MADE WITH PUC2 VADORIZED AT $2 E O C$. C AND UO2 VAPORIZED AT 3000 C INTO BCTH $\triangle R G O N$ AND NITROGEN GASES. IN ADDITION, COMEINATICNS OF VAPORIZED DUO2-UC2, $\triangle N D$ VA VAPORIZED INTO MOIST AIR AND MIXED WITH VAPORIZING UO2 WFFE $\triangle L S O$ STUOIED. THE MAXIMUM PARTICLE SIZE, WHICH WAS REACHED $\triangle T$ ABOUT 24 H, WAS DEPENDENT UPON THE INITIAL MASS CONCENTRATION. THE STANDARD DEVIATION GENEPALLY REMAINED CCNSTANT FOR A PARTICULAR RUN, BUT INCRE ND AFPARENT CCRPELATION OF COAGULATION CONSTANT WITH TIME, SURFACE-TO-VOLUME PATIC, OP MASS CONCENTBATIOA IN THE F.NNGE OF VALLES INIVESTIGNTED.

\#AEROSOL PROOUCTION + \#FUEL MELTOOWN + \#PARTICLE SIZE + \#PLUTCNIUM + \#SODIUM + AEROSOL PROPERTIES + APGON + EVAPORATION + FLUTONIUM DIOXIDE + URANIUM DIOXIDE

$7->>487$

TANG IN + CASTLEMAN AW

ON THE TRANSPORT OF FISSION-PRODUCT IODINE FROM MOLTEN URANIUM

BROOKHAVEN NAT IONAL LAB.

3 PAGES, 1 FIGURE, 4 REFEPENCES, $\triangle B S T R A C T$ IN $\triangle N S$ TRANSACTIONS 10 (2), PAGE 720 AND 721 , (NOV. 1SE7),

PRESENTED AT THE 1967 WINTER MEETING OF THE AMEPICAN NUCLEAR SOCIETY, CHICAGO, ILLINOIS, NDV. 5-C, 1967

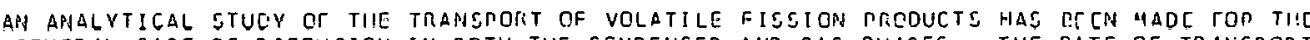

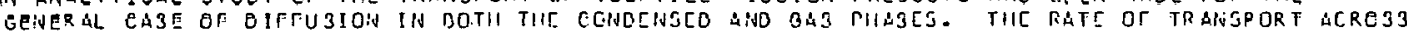


FISSION PRCDUCT FELLEASE, TPANSPORT, AND REMOVAL

\section{$7-22487 \%$ CONT INUEC $*$}

THE VAPOR-LIQUID INTERFACE WAS EXPFESSED BY THE LANGMIIIF EQUATION FOR VAPORIZATION, GENERALIZED FRR. NONIDEAL MULTI-COMPGNENT SOLUTIONS. THE SAME GENERAL MATHEMATICAL EXPRESSION IS ADPL ICABLE FOR THE CASE OF A DESORPTION MECHANISM OF. A RATE CONTROLLEO BY A FIRST-ORDER F.EACTION AT THE INTERFACE. EXPERIMENTAL RESULTS ON THE RELEASE OF FISSION-PRODUCT IOOINE FROA MOLTEN URANIUM ARE PRESENTED IN THIS PAPEP. WITH EMPHASIS ON THE ELUCIDATION OF THE RELEASE MECHANISM. THE EXPSRIMENTAL RE SULTS APE ADEQUATELY CORRELATED WITH AN ANALYTICAL MODEL CONSIDERING ONLY LIQUID-PHASE DIFFUSICN AND AN INTERFACIAL RESISTANCE TERM.

\#ANALYTICAL MODEL + \#FISSION PRODUCT, IODINE + \#FUEL MELTDOWN + \#MOUEL TESTING + URANIUM

$7-2243 \%$

KUNKEL WO + PERGER S

FISSIDN-PRODUCT DEPOSITIOM IN A FAST-BREEOER REACTOR SYSTEM CONTAINING FAILED FUEL ELEMENTS ATOMICS INTERNATIONAL

15 PAGES, TASLES, FIGURES, REFEQENCFS, NOVFMBER 3, $1967, \triangle B S T R A C T$ IN $\triangle N S$ TRANSACTIONS 10(2), PAGE 406, PRESENTED AT AHER ICAN N!UCL $A R$ SOCIETY WINTER MEETING, NOVEMBER 5-9, 1967, CHICAGO, ILLINOIS

A DESIGN OBJECTIVE FI!P. THE LIQUIO-METAL FAST-BREEDEP. FEACTOP (LMFBR) IS TO ALLOW FQR POSSIBLE OPERATIJN WITH SUME FAILED FUEL ELEMENTS, AND IN ADOITION, TC PERMIT ACCESS TO THE HEAT-PXCHANGEP CELLS AFTER REACTOR SHUTOOWN. THE CONCEPT OF A SYSTEM-OEPLETION FLCTQR PROVIDES AN INTER IM MFTHOD OF ESTIMATING THE FISSION-PROOUCT DEPOSITION RESULTING FROM FAILED-FUEL-ELEMENT OPERATION. THE SYSTEM-OEPLETION CONCEPT IS PROPOSED AS AN INTERIM METHCO OF MORE CLOSELY APPPOXIMATING THE ACTUAL EXTENT OF DEDOSITION AND THE CONSEQUENT MAINTENANCE PROBL $=M$.

\#CESIUM + \#DEPOSITION + \#EISSION PROOUCT EETENTION + \#FISSION PROCUCT TRANSPORT + \#REACTQR, LMCR + * SODIUM + CERIUM + IDDINE + PEACTDP, FAST + RUTHENIUM + ZIRCONIUM

7-22497 ALSO IN: CATEGORY 17

$\triangle I R$ ANO GAS CLEANING FOR NIJCLEAR FNERGY

OAK RIDEE NATIJNAL LABOEATCP.Y, OAK FIDGE, TENN.

THIS - IS A 30 MINUTE FILN REFERENCED ON PAGE 60 OF THE USAEC IE MM FILM CATALOG FOR 1966-ET, PRODUCED BY OAK RIDGE NATIGNAL LABGRATORY, FOR SALE QY CALVIN PRODUCTICNS, AT \$8G.23 PER PRINT, INCLUDING SHIPPING $C \cdot \Delta S E$

DISCUSSES USE, DEVELCPMENT, AND MANUFACTURE OF HIGH-EFFICIENCY FILTERS FQR NUCLEAR $\triangle P P L I C A T I O V S$, !NSPECTED BY $\triangle E C, \triangle N D$ CURRENT $R$ AND D FRGGRAMS I $A T$ HARVARD, ORNL, AND EDGEWODD ARSENAL). COVERS IODINE-CULLECTION SYSTEMS, AEROSOL REACTIONS ON FILTERS, RARE-GAS ABSORPTION STUDIES, ETC.

AVAILABILITY - LVAILASLE FOR LJAN (FOEE) FPOM USAEC HEADQUARTERS aNO FIELD LIBRARIES. CLEAREO FOK TELEVISION

\#FILTER, HIGH EFFICIENCY + EILTER INSPECTION + R AND D PROGRAM

7-22514 ALSC IN CATEGORY 4

ETTINGEPHJ + MOSS hiD + BUSEY H

CHAKACTEZISTICS DF THE AEROSOL PRODUCED FRCIM BURNING SODIUM ANO PLUTONIUIA

LOS ALAMOS SCIENTIFIC LABORATORY, LOS ALAMOS, NEW MEXICO

14 DAGES; D TABLES, 15 FIGURES, NUCLEAR SCIENCE AND ENGINEEPING 30, PAGES 1-13, 10CTOBER I967)

SAFETY ANALYSIS OF SODIUM-COOLEO PLUTONI UM-FUELED FAST REACTOR PLANTS MUST BE CONCERNED WITH THE POSSIBILITY OE FIRES INVOLVING THESE MATERIALS. DESIGN OF AN AIR CLEANING SYSTEM FOF. SUCH A FACILITY REQUIRES BASIC DATA DEFINING THE AEROSOL CHAFACTERISTICS OF SDDIUM ANO PLUTONIUM RELEASED DURING A FIRE. WHEN PLUTONIUM ALLOY WAS BURNED UNDER REDUCED OXYGEN CONOITIONS, THE FP.ACTION AIRBOFNE FANGED FROM $2 \times 101-7 T H)$ TO 4 X 1O(-6TH). FIRES INVOLVING PLUTONIUM ALLOY ANO SOOIUH TOEETHER PRODUCED AIPBORNE PLUTCNIUM-SODIUM RATICS RANGING FROM 0.34 TO $0.008 \%$.

* AEROSOL PRODUCTION + \#FIRE + \#PARTICLE SIZE + \#PLUTONIUM + \#SCDIUM + DERDSOL PROPERTIES + METAL, LIQUID + PARTICLE SIZE CISTRIEUTICN + REACTOR, FAST + REACTOR, LMCR

$7-22515$

ALSO IN COTEGORY 4

NICHOLSRH + GITTUS JH

SOME ASPECTS OF MATERIALS TECHNULOGY חTF IMPORTANCE TO THE DEVELOPMENT OF NUCLEAR REACTCRS.

UNITED KINGDOA ATUYIC ENER,GY AUTHORITY, RISLEY, ENGLAND

TRG-REPDRT-1516 +. 30 PAGES, 19 FIGURES, 19 FEFERENCES, MAY 26, 1967

DESCRIEES THE EFFECTS OF IRRADIATICN AND COFFOSION ON STRUCTURAL MATERIALS IN THE ADVANCED GAS-C.DOLED REACTOP. ANO THE HIGH TEMFEPATURE GAS-COOLEO REACTCR, WITH PARTICULAR MENTION CGF THE INFLUENCE UF RESI STANCE TO CORROSION ON THE SELSCTION OF MATERIALS FDR HEAT EXCHANGER TUZING AND FOR THERMAL INSULATION FGILS. A MAJOR PRCGRAM OF EXPERIMENTS INVOLVING A

STATISTICAL EXAMINATION OF THIS PEGBLEM HAS HIGHLIGHTED THE ADVANTAGES ACCEUING FROM USF OF A FINE METALLURGICAL GRAIN SIZE. WITH PESPECT TO THE STEAM GENERATING HEAVY WATER REACTOR, MFNTION IS MADE OF THE ASSESSMENT CF ZIRCONIUM ALLOY PRESSURE TUBES FOR HYORDGEN AND

I RRADIATIION EMOF. ITTLEMFVT AND A TECHNIQUE BASED ON MEASURING THE CRITICAL CRACK OPENING

DISPLACEMENT IS DESCR IBED WHICH MAY BE OF GENERAL VALUE FOR ASSESSING FRACTURE TOUGHNESS IN 
FISSION PROOUCT RELEASE, TPANSPORT, ANO REMOVAL

$7-22515$ FCONTINUED*

RELATION TO EINGINEERING DESIGNS. MENTION IS MADE DF SEVER.AL ASPECTS OF THE CQRROSION ANE MASS TRAANSFER OF METALS IN LIQUID SODIUM.

AVAILABILITY - UNITEO KINGDOM ATOMIC ENERGY AUTHORITY

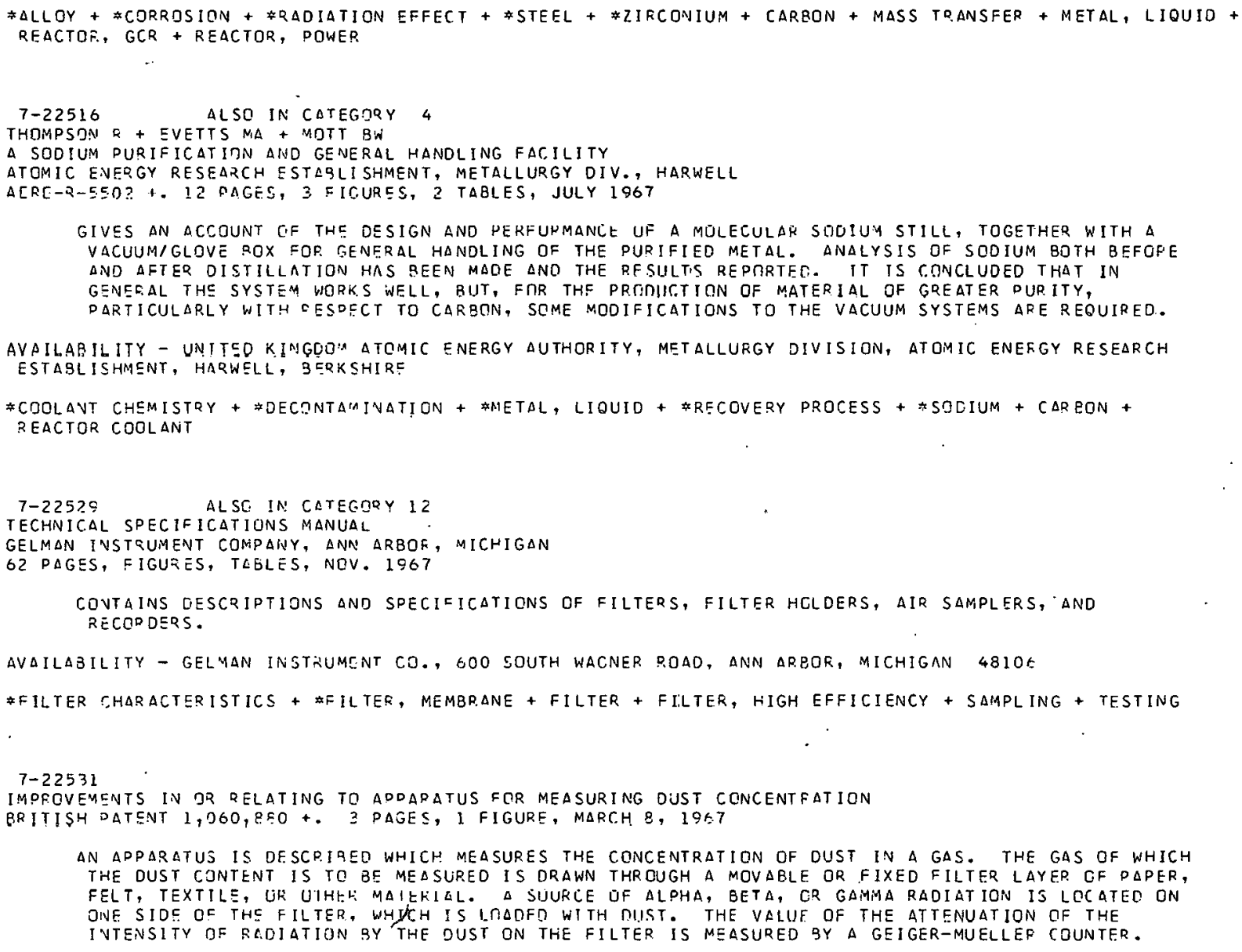


FISSION PRODUCT RELEASE, TRANSPOFT, AND REMOVAL

$7-22533 *$ CONT INUED*

TAKAHASHI K

EXPEPIMENTS ON ADSOPPTION OF RADIOACTIVE IODINE VAPOR. ON SMALL METALLIC FUME PARTICLES

KYOTO UNIVERSITY

3 PAGES, 1 TABLE, 2 FIGURE, 4 REFERENCES, JOURNAL OF NUCLEAF SCIENCE AND TECHNOLOGY, $3(9)$, PAGES 4 OI-4O3

(SEPTEMBER 1966 )

RADIOACT IVE IODINE RELEASTD FROM NUCLEAR SPENT FUEL INTC ATMUSPHERE DUF. ING THE CCURSE DF FUEL REPPJCESSING OR IN THE CASE OF REACTOF ACCIDENT CAN SE CLASSIFIED INTO THE FORMS OF (I)

SLEMENTAL MOLECULE, (2) ADSOREED HN AEROSOL PAPTICLES, AND (3) COMPOUND GASES. SINCE THEY SHOW CONSIDERABLY OIFFERENT PHYSICO-CHEMICAL AND EIOLSGICAL EEHAVIOURS, IT IS IMPORTANT TO DISTINGUISH THE COMPONENTS OF A MIXTURE OF THESE FORMS. IN THIS WORK, MOLECULAR IODINE VAFOR WAS GENERATED $\triangle N D$ MIXED WITH METALLIC FUMES AND THE ADSORPTION OF IODINE VAPOP GN FUME PARTICLES WERE EVALUATED BY HEANS IF A METHOD USING A OIFFUSIJN TUSE. THE MEAN CONCENTRATION GF GAS OR AEROSOL PAPTICLES PASSING THFOUGH A CIRCULAR TURE AS LAYINAR FLOW OECPEASES BY OIFFUSIVE DEPOSITION ON THE TUPE WALL.

* AEROSOL PROPEPTIES + \#FUFL MELTDOWN + \#ICOINE + AEROSOL + DEPGSITION + METAL

$7-22534$

COLE HA

AN ANALOGUE COMPUTCR FOR DARTICLE SIZE ANALYSIS

ATOMIC EVERGY RESEARCH ESTABLI SHIMENT. HARWELL, ENGLAND

AERE-R-5096 + N66-35297+. 22 PAGES, R.EFEFENCES, FFBRUARY 1966

DESCRIBES AN ANALOGUE COMPUTER. THAT OPEPATES IN CONJUNCTION WITH THE KARL ZEISS PARTICLE-SIZE ANALYSER. THE ANALYSER IS USED TO MEASURE THE OIAMETEP DISTRI PUTION CF BUBBLES IN A. PHOTOGRAPH OF A COLUMN OF FJAM, AND THE COMPUTER MAKES USE OF THIS INFORMATIDN TO PROVIDE SIMULTANEOUS ANO SEPARATE INUICATIONS PROPORTIONAL TO TOTAL SURFACE AREA AND VDLUME AS THE ANALYSIS PROCEEDS. THESE INDICATIONS ENARLE AN IMMEDIATE DETERMINATION OF THE MEAN SURFACE AREA OF FOA:M PER UNIT VOLU:ME OF CONTAINED AIR FOR THE SAMPLE. THE COMPUTER MAY ALSO RF IISED WITH THE ANALYSER FOR. THE TOTAL ARFA ANALYSIS OF PARTICLES OF APPROXIMATELY CIRCULAR SHAPE, DR FOR TOTAL AREA ANO VDLUIYE ANALYSIS OF PARTICLES OF APPROXIMATELY SPHERICAL SHAPE.

AVAILABILITY - CLEARINGHOUSE FOR FEDERAL SCIENTIFIC AND TECHNICAL INFORMATION, SPRINGFIELD, VIFGINIA \$3. OO COPY, \$O.65 MICRDFICHE

* ANALYTIEAL TECHNIQUE, CALIBRATIDN + \#COMPUTER PROGRAM + \#FOAM + \#PARTICLE SIZE OISTRIEUTION + AEROSOL PROPERTIES

$7-22535$

DAOILION J

EXPERIMENTAL STUDY OF THE REHAVIOR GF FISSIJN PRODUCTS IN CASE OF ACCIDENT IN A SWIMMING POOL REACTOR

COMMISSARIAT A L ENEPGIE ATOMIQUE, FRANCE

6 PAGES, FIGURES, BULL. INFORM. SCI. TECH. (PARIS), 112, PAGES 13-18 (FEBRUARY I967) IN FRENCH

IN ESTIMATING NUCLEAR RISKS CONNECTED WI TH THE RUNNING OF A RFACTOR, AN ESSENTIAL FACTOR, SOMETIMES NEGLECTED BECAUSE INSUFFICIENTLY KNOWN, I I THE KNOWLEDGE OF THE TYPE, AMGUNT, ANL BEHAVIOUR OF THE CONTAMINATION ACTUALLY RELEASED INSIDE THE CONTAINER IN THE CASE OF AN ACCIDENT. IN THE SPECIAL CASE OF SWIMMING-POOL REACTORS, THE COOLING FLUID PROVES TO BE A VERY EFFICIENT BAPRIER AGAINST CONTAMINATION. THREE EXPERIMENTS WERE CARRIED OUT IN THE REACTOP, CAQRI, DURING WHICH SEVFRAL FUEL ELEMENT PLATES WERE MELTEO INSIDE THE COFE ITSELF.

* FISSION PRODUCT RELEASE, GENERAL + \#FUEL MELTDGWN + FUeL INTEGRITY

7-22537

NELSON RW

FLOW IN HETEROGENEOUS PORUS MEDIA

BATTELLE-MEMOR IAL INSTITUTE

BNWL-SA-207+. OPAGES, I FIGURE, RFFERENCES, WATER RESOURCES RES. $2(3)$, PAGES 487-95 $10 C T O B E R$ 4, 1967 )

THEORETICAL WOFK LEADING TO THE DESCPIPTION OF FLUID FLOW IN A HETEROGENECUS POROUS MEDIUA: HAS DEVELOPED SLOWLY AND SOMEWHAT SPORADICALLY, EVEN THOUGH THE AREAS OF ENGINEERING APPLICATICNS PREDDIIINANTLY INVOLVE FLOW IN A NONHOMOGENEOUS MEDIUM. IN PROVIDING A THEORETICALLY CONSISTENT BASIS FOP ANALYSIS, THE SPECIAL CHARACTERISTICS OF MACROSCOPICALLY HETEDOGENEGUS MATERIALS ARE OISCUSSED TO PROVIDE ACCURATE DEFINITIONS. THE END RESULT OF THE DISCUSSICN AND DER IVATION IS A SET DF RATHER GFNEPAL EULERIAN EQUATIONS DESCRIBING TWO-PHASE FLOW IN A MACROSCOP ICALLY HETEROGENEOUS MEDIUM. THESE EQUATIONS AND THEIR REDUCED FOR:YS INCLUOE DESCEIPTIONS CIF SOME FORTY UI FFERENT FLOW SYSTEMS SUCH A VARIETY OF FLOW CONDITIONS IS CATEGORIZEO THROUGH THE USE OF A SPECIAL TABULAR SCHEME, WHICH MAKES IT POSSIBLE TO WRITE THE APPROPRIATE EQUATICNS EFFICIENTLY.

\#FLOW THEORY AND EXDERIMENTS + \#POROUS MEDIA + \#THEORETICAL INVESTIGATION + CIFFUSION + FLOW, TWO PHASE

$7-22538$

ALLEN J

THE RELEASE OF IODINE FFOM URENIUM DIOXIOE FUEL

UNITED KINGDGM ATOMIC ENERGY AUTHORITY, RISLEY 
FISSION PROOUCT PELEASE, TRANSPORT, AND REMJVAL

$7-22538 *$ *ONTINUED*

7 PAGES, 1 FIGURE, 34 KEFERENCES, J. BRIT. NUCL. ENERGY SOC E(2), PAGES 127-133 (APRIL 1967)

IOOINE-13! IS THE FISSION PRODUCT OF GREATEST IMPORTANCE IN CONSIDERING THE SAFETY AND SITING OF THE AOVANCED GAS-COOLED AND THE STEAM-GENERATING HEAVY-WATEP REACTORS. MUCH INECFMATION IS AVAILABLE.CN THE TRANSPIDRT DF ICOINE IN OXIDE-CUELED REACTOR SYSTEMS, BOTH FC.E NOPMAL. QPSRATION AND FGE FAULT CONDITIONS, ALTHOUGH THFORIES OF THE YECHANISM DF SOME CF THE PROCESSES ARE STILL RATHER SPECULATIVE. IT IS EXPECTED THAT THE CONSIDFRABLE ACTIVITY IV THE FIELO WILL SOCN LEAD TO A MOFE FUNOAMENTAL IINDFESTANDING OF THE PROCESSFS INVRIVER.

*FISSION PRODUCT RELFASE, GENERAL + \#FISSION PRODUCT, IODINF + \#REACTOR, GCR + \#URANIUM DIOXIDF + DIFFUSION + FISSION PECOIL + IOOINE

$7-22539$

QLAKE $A R+B U L L O C K S L+H I L T O N D A$

DEPUSITS FTRMEO INTILE ON MAGNOX FUEL ELEMENT SURFACES

CENTRAL ELECTRICITY GENERATING BOARD, BERKELEY, ENGLAND

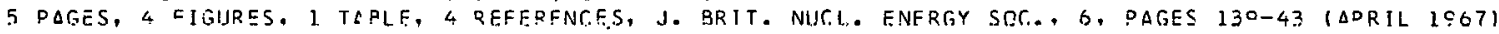

DEPOSITS REMOVEO FRCM SPLITTER CAGES ON FUSL ELEMENTS DISCHARGED FROM THE RERKELEY AND BRADWELL REACTORS WERE EXAMINEC. THE MATERIAL ON THE LOWEP GECKELEY FUEL SLEMENTS WAS IDENTIFICD AS PARTIALLY OXIDIZED AND POLYMERIZED BLOWER-MOTOR GIL, WHILE THE EVIDENCE INOICATES THAT THE FINELY OIVIDED CARBON PRESENT ON UPPER ELEIAENTS IS CERIVED FROM THE RADIOLYSIS JF CO. IT IS CONCLUDED THAT THE DEPOSITION VALUES OETAINEO WEUE EQUILIBSIUN. VALUES. THE 5-35 ACTIVITY PRESENT ON FUEL ELEMENT SURFACES WAS ALSO MEASURED, ANE IT IS SUGGESTED THAT THIS WAS THE RESULT OF S TRANSFER FROM THE MODEFATQR.

* CARBJN + *DEPOSITION + *FUEL ELEMENT + \#SULFUR + FUEL HANDLING

$7-22541$

CABARET J + VALENTIN A

CONNECTION AND CLOSUFC DEVICE FRR A FILTER AND FILTERS INCORPORATING SAME

COMMISARIAT AL ENERGIE ATOMIQUE

BRITISH PATENT 1,058,430+. 3 PAGES, 1 FIGURE, FEBRUARY 8,1967

$\triangle$ DEVICE FOR CONNECTING AND CLCSING A FILTER UNIT TO AVOID PGLLUTIGN OR CONTAMINAT.ION DUR ING REMOVAL OR REPLACEMENT OF THE FILTEP IS DESCRIBED. THE CONNECTING DEVICE IS USED BETWEEA, A FILTER HOUSING AND A FLUID DELIVEPY SLEEVE WHICH ENSURES THAT THE FILTER HDUS INE IS CLOSED REFORE THE HEFMETIC SEAL BETWEEN THE HCUSING AND THE FLUID DELIVERY SLEEVF, WHICH IS USFE TO CARRY THE FLUIOS TO BE FILTERED, IS BROKEN.

AVAILASILITY - THE DATENT OFFICE, 25 SOUTHAMPTON BUILDING, LGNDON, h.C. 2, ENGLAND (49 CENTS DER CCPYI *Filter design + *ilter maintenanCE + Filter.

$1-22342$

REIDEL H.J

RADIOCHEAICAL DETERMINATION OF THE FISSION-PPODUCT RELEASE FROM COATED FUEL PARTICLES IN REACTEF IRRAOIATION

DRNL-TR-1789+EUR-3271.0+. 8 PAGES, NCVEMBES 1.66

AN IMPORTANT QUESTION IN THE USE OF COATED PARTICLES AS A NUCLEAR-FUEL CARFIER IN COERATICN CIE $\triangle$ HIGH-TEHPERATUPE GAS-COOLEC SEACTOP. IS HOW MUCH OF THE GASEOUS A.VD NON-GASECUS FISSION PPODUCTS PENETPATE THF COATING. THE PYRCLYTIC CARBON COATING CAN PREVENT CONTAMINATION CF THE REACTOP COPLING CIRCUIT WITH THE HIGH-ACTIVITY FISSION PRODUCTS. AS PART OF A RESEAFCH PROGRAM ON THE BEHAVIOR OF VAPIOUS TYPES OF PARTICLES AS A FUNCTION OF THE OPERATING

TEHDERATUPE, BURN-UP ETC., WE MAOE A RADIOCHEMICAL STUDY OF THE FISSION PROOUCT DISTOIRIITIRIN WHEN THE COATED FARTICLES WERE SUPRQUNDEO BY GRAPHITE. FOR THE ANALYTICAL SEPAFATION AND OETERMINATION OF THE FISSION ELEMENTS WE USED DISTILLATION, PRECIPITATION, LIGUID EXTPACTICN, $\triangle N O$ IDN EXCHANGE. THF MF THONS APF DFSCRIBED RRIEFIY. TWELVE FISSION NUCLIDES WEPE

DETERMINED. A SURPRISINGLY HIGH MGEILITY WAS FOUND FOR BAFIUM, STRONTIUM, AND YTTRIUM. THE RELEASE OF TTHER FISSION PRODUCTS WITH HIGH FISSION YIELD WAS CONSIDERABLY LOWER. SOME GF THE CONOITIONS AFFECTING THE FISSION PRODUCT YIELD ARE DISCUSSEO.

AVAILABILITY - CLEADINGHOUSE FOR FEDERAL SCIENTIFIC AND TECHNICAL INFOFMATIGN, SPRINGFIELD, VIRGINIA \$3. OO COPY, $\$ 0.65$ MICROFICHE

*COATED PARTICLE + \#CIFFUSION + \#FISSION PFODUCT FETENTION + EAPIUM + STRONTIUM + YTTRIUM

$7-22543$

POSTMA AK

THERMOPHORETIC VELOCITY OF LAPGE AEROSOL PARTICLES

PACIFIC NORTHWEST LAB., BATTELLE-NORTHWFST, FICHLANE, WASHINGTCN

BNWL-163+. 17 DAGES, NOVEMR SR 1965

THE VELOCITY OF THERMAL DEPULSION CF LARGE AEQOSNL PARTICLES HAS BEFN CALCULATFD PY OTHEPS BY CQUATING THF THFRMAL. FORTE DN A STATIONARY PARTICLE TO THE STOKES-CUNNINGHAM VISCGUS FODCE. THIS PRSCEOURE IS THEORETICALLY UHSOUND RECAUSE THT. DOLPDARY COPOIT IONG TMRLOYEC IM THE 
CATECRRY

FISSION PROCUCT RELEASE, TRANSPOFT, ANC REMOVAL

\section{$7-22543$ \#ONTINUED*}

VISCOUS FORCE FQUSTION ARE ERRONECUS WHEN THE PARTICLE MOVES IN A THERMAL GRADIENT. IN THE CURRENT STUDY THESE DICFICULTIES HAVE BEEN CIFCUMVENTEO BY REDEKIVING THF THERMAL FORCE EOUATION, ALLCINING FOR A RELATIVE VELECITY BETWEEN THE PARTICLE AND THE GAS STREAM. THE VELOCITY OF MCTICN IS THEN CALCULATED BY SETTING THE NET FURCE ON THE PARTICLE EOUAL TO ZERO. THE VELOCITY OSTAINED BY THIS MORE REALISTIC APPPOACH AGREES WITH THAT CALCULATEO BY THE FOR MER METHOD, WhICH IS SURPFISING IN VIEW OF TH:F INCORRECT BOUNDARY CONDITIONS EMPLOYEO IN THE FOR:MER METHCL. INVESTIGATION CF THE DRAG FORCE EOLATION.SHOW'S THAT THE THEPMAL FORCE AND THE VISCOUS ECECE ARE FXEFTED INDEPENDENTLY OF EACH OTHER, WHICH EXPLAINS THIS UNEXPECTEL AGF EEMENT. THE SANGF OF APPLICARILITY SF THF ANALYSIS IS EXFLCRED BY COMPARISON WITH AVAILABLE EXPERIMENTAL DATA.

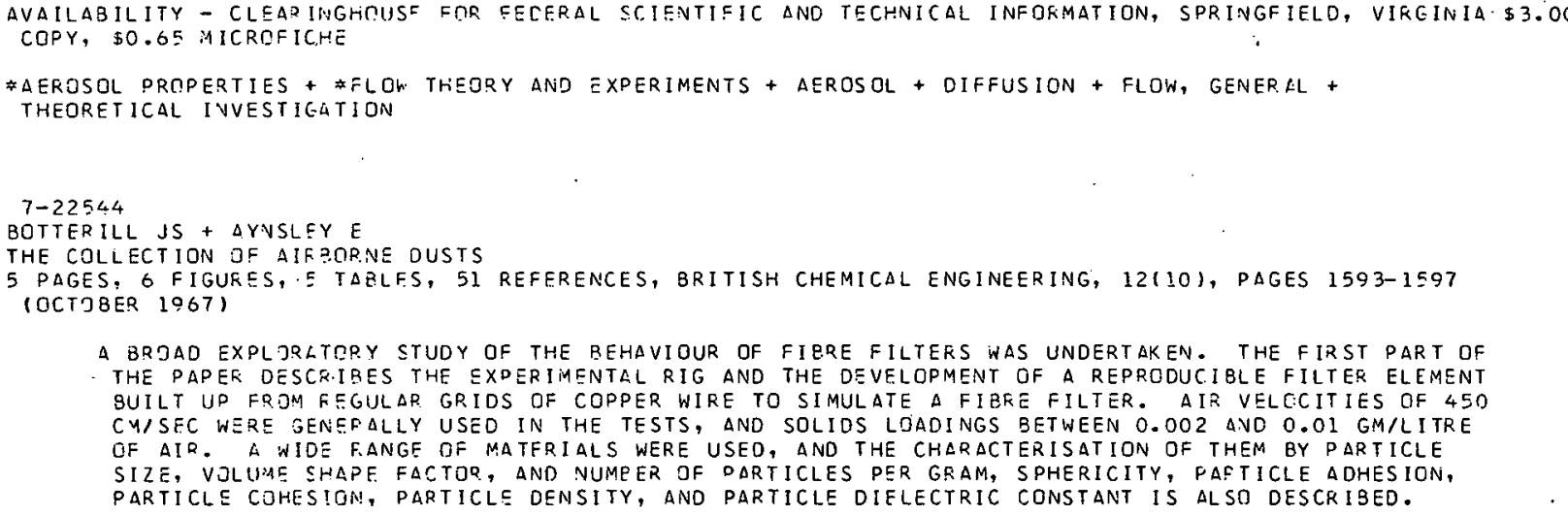

A BRJAD EXPLJRLTRPY STUDY OF THE REHAVIOUR OF FIQRE FILTERS WAS UNDERTAKEN. THE FIRST PART OF THE PAPER DESCR.IBES THE EXPERIMENTAL RIG AND THE DEVELOPMENT OF A REPRODUCIBLE FILTER ELEMENT SUILT UP FROM FEGULAR GRIDS OF COPPER WIRE TO SIMULATE A FIBRE FILTER. AIR VELCCITIES OF $45 O$ CY/SEC WERE GENEFALLY USED IN THE TESTS, AND SOLIOS LOADINGS BETWEEN 0.002 QND 0.01 GM/LITRE OF AIR. A WIOE F.ANGF OF MATFRIALS WERE USEO, AND THE CHARACTERISATION OF THEM BY PARTICLE SIZE, VOLUAE SHAPE FACTOQ, AND NUMEER OF DARTICLES PER GRAM, SPHERICITY, PACTICLE ADHESION, PARTICLE COHESIGN, PARTICLE DENSITY, AND PARTICLE DIELECTRIC CONSTANT IS ALSO DESCRIBED.

* AFF.SDL PROPEPTIES + \#PARTICLE SIZE DISTFIBUTION + \#SAMPLING + AERGSCL + FILTER

$7-22545$

LIESE KH + HILD W

SEPARATION OF IODINE FECM FISSION PFEDUCT SOLUTIONS WITH SILVEP CHLOPIDE ON SILICA GEL

TECHNISCHE HOCHSCHULE, CARISTADT, GERMANY

4 DAGES, I FIGURE, I TARLES, PADIOCHIMICA ACTA 7, PAGES 74-77 (JUNE 1S67) IN GEFMAN

THE IODINE PROCUCED SY FISSIONING UFANIUM WAS SEPARATED IN $\triangle$ CARRIER-FREE FORM FPGM NEARLY ALL OTHER FISSION PRODUCTS BY THF USE OF COLUMNS FILLED WITH SILVER CHLDRIDE ON SIL ICA GEL. THE YIELDS OF CAREIER-FREE IODINE VARIEC ABOUT $90 \%$. BY ADDING VERY SMALL AMOUNTS OF CARR IER, THE YIELD COULD BE INCRFASED TO ABOUT 98 TO $99 \%$ WITH BETTEF REPREDUCIBILITY.

ACSORPTIIJN + FISSION PRCDUCT, IODINE + IOCINE + TESTING

$7-22548$

WHITBY KT + VOMELA $2 A$

RESPONSE DF SINGLE PARTICLE OPTICAL COUNTERS TO NONIDEAL PARTICLES

MECHANICAL ENGINESRING CEPARTMENT, UNIVERSITY OF MINNESOTA, MINNEAPOL IS, MINN.

15 PAGES, 15 FIGURES, 7 TABLES, REFERENCFS, ENVIRONMENTAL SCIENCE AND TECHNOLOGY, I(10), PAGES EOI-814 (TICTOBER 1967)

MEASURED THE RESPONSE OF THE POYCO PC 200, SOUTHERN RESEARCH INSTITUTE ISRII, AND BAUSCH AND LTMB I $\triangle$ ANO L) SINGLC-PARTICLE COUNTERS TO NONIOEAL BUT MONODISPERSED DERGSOLS. AEROSOLS USED WERE POLYSTYRENE LATEX, DIOCTYLPHTHALATE, INOI A INK, ANO POLYSTYRENE. THE INDICATED SIZE OF THE AESCPBING INDIA INK WAS 1/2 TO $1 / 5$ GF THE TRUE SIZE FOR ALL OF THE CCUNTERS. THE ROYCO AND SRI CQUNTEFS, WHICH ACCEPT LIGHT THRCUGH ONLY A SMALL SOLID ANGLE, INDICATED A CONSIDERAPLF SPREAD IN SIZE DISTRIEUTION FOR THE INOIA INK AND POLYSTYRENE PARTICLES IWHICH HAD SOME SURFACE ROUGHNESS). THE RESOLUTION ON ROUGH-SURFACEO AEROSOLS WAS BETTER FOR THE 2 AND L COUNTER, WHICH ACCEPTS LIGHT THROUGH A MUCH LARGER SOLID ANGLE. EXPERIMENTS WERE ALSO PERFJR:AER WHICH SHOWED THAT HIGH CONCENTRATIONS OF SUBCOUNTABLE-SIZED MONODISPEPSED DOP AEROSOLS (E.G., 10, COO PER CC. IF C.2E MICRON) GENERATED A RELATIVELY MONDOISPERSED

DISTRIBUTIOV CE IMPULSFS PULSES WITHIN THE COUNTING RANGE.

- \#AEROSOL PRODUCTION + *AERCSGL PROPERTIES + \#ANALYTICAL TECHNIGUE, CALIBRATION + \#SAMPLING + AEROSOL + PARTICLE SIZE + PARTICLE. SIZE DISTRIBUTICN

7-22549 ALSO IN CATEGDRY 4

KELLER D

PROGRESS RELATING TO CIVILIAIN APPLICATIONS DURING DCTOBER THRUUGH DECEMBER 1966

BATTELLE MEMORIAL INST . COLUMBUS, OHIO

BMI-179] +.96 PAGES, FIGURES, TAGLES, JANUAKY 1,1067

THIS PROGRESS REPORT DRESENTS INFOFMATION ON THE FDLLOWING - URANIUM-PLUTONIUM MUNONITPIDE FUEL MATEKIALS, IRRADIATION EFFECTS IN REACTOR. CLADOING MATEPIALS, COATED-PARTICLE FUEL MATERIALS, CERAMIC-COATED PLUTONIUM-BASE PARTICLE FUELS, PYROLYTIC-CARBGN-COATED URANIUM 
FISSION PROOUCT RELECSE, TRANSPRET, AND PEMOVAL

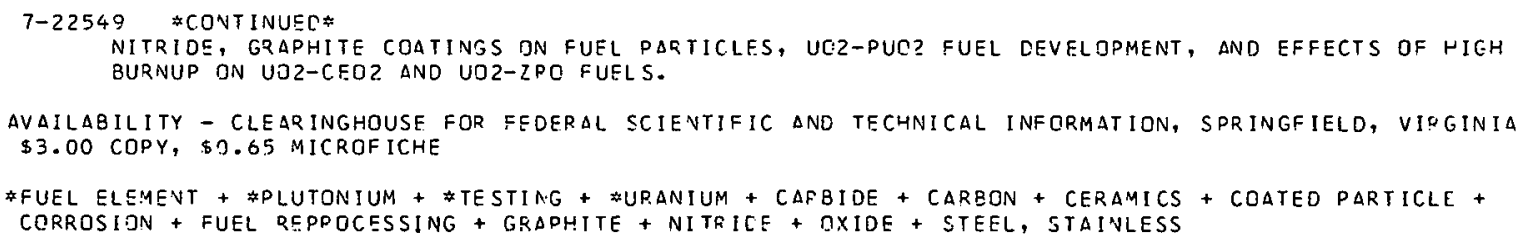

GLASS BEADS, SILICONE-COATED GLASS BEADS, AND FOTASSIUM CARBONATE WERE EVALUATED AND FOUND UNSATISFACTORY FOR GISTINGUISHING RFTWFEN VARIOUS F COMS OF IOCINE. WIILE ANIGN EXCHANGE P.ESINS QUANTITATIVELY PETAINED ROTH ELEMFNTAI ICOINE AND HI, A CATION EXCHANGF RESIN RETAINEO HI NEAPLY QUANTITATIVELY YET RETAINED ONLY ABCUT 3 O OF ELEMENTAL IOOINE IN MOIST AIR AT EO C.

AVAILABILITY - CLEARINGHOUSE FOR FEDEQAL SCIENTIFIC ANC TECHNICAL INFORMATION, SPRINGFIELD, VA., \$3. OO COPY. $\$ 0.65$ MICROFICHE

* ANALYTICAL TECHNIQUE, GAS + \#ION EXCHANGE + \#SAMPLING + FILTER + FISSION PRODUCT, IODINE + IODINE + SIMULATION + SORDTION + STEAM

$7-22355 \quad$ ALSC IN CATEGORY 4

$\triangle D W I C K A G+W A R M E R$ RJ

THE IVFLUENCE OF DARTICLE SIZE DISTRIQUTICN ON THE SINTERING CF CERAMIC PONDERS

UNITED KINGDOM ATOMIC ENERGY $\triangle U T H O R I T Y$, RISLEY

TRG-REPSRT-1188(0) +. IO PAGES, 7 EIGUPES, 4 TARLES, \& PEEERENCES, 1066

ONE OF THE FACTORS THAT CAN AFFECT THE SINTERER CEENSITY OF A CERAMIC IS THE PRESSING REHAVIOR. THIS IN TURN IS INFLUENCED SY THF PARTICLE-SIZS DISTPIBUTION. FPOM AN ANALYSIS DF DATA ON THE PACKING OF DENSE SPHERES $\triangle N O$ PACKING EXPERIMENTS ON IRREGULAR SHAPED, COAFSE CERAMIC DARTICLES A SER IES OF CURVES HAVE SEEN DEPIVEO. IT IS CLAIHED THAT THESE CURVES CAN RE USED TO RELATE THE INFLUENCE OF PARTICLE SIZS DISTPIBUTION OF THE PACKING EFFICIENCY AND ULTIMATELY ON THE SINTERING BEHAVIOR OF CERAMIC POWDERS. THE PARTICLE-SIZE DISTRISUTIONS OF (U,PU) 22 POWDERS WERE MEASURED USING THE OPTICAL MICFOSCOPE. THESE OISTR IBUTIONS HAVE BEEN CORRELATED WITH SUISEQUENT PFESSING AND SINTERING BY MEANS OF THIS ANALYSIS. GGOD AGREEMENT HAS DFFN FOUND.

AVAILABILITY - PUSLIC PELATIONS BOANCH, UKAEA, FISLEY, WARRINGTON, LANCASHIRE

*CEPAIICS + \#PARTICLE SIZE DISTRIRUTION + \#PLUTONIUM OXIDE + \#URANIUM DIOXIDE + FUEL, POWDER TYPE + PARTICLE SIZE + PLUTONIUM

$7-22556$

ACKLEY RD + ADAMS RE

REMOVAL TF RADIOACT IVE METHYL IDDIDE FROM STFAM-AIR SYSTEMS (TEST SERIFS III)

CAK RIDGE NATIONAL LAQUHATORY

GRNL-4180+. 23 PAGES, I FIGUPE, S TABLES, 5 PEFEPFNCES, OCTOBER 1967

TWO TYPES OF CCMMERCIAL IODIZED CHAFCOAL WERE EFFECTIVE FOR CH3-131I TRAPPING AT COMNITIONS AS SEVERE AS $290 \mathrm{~F}$, 60 PSIA, ANO SÖ FELATIVE HUMIDITY. IN THIS SECOND PHASE OE THE WOPK, THRFF AODITIONAL TYRES OF COMHERCIAI IDOILEO CHAFCUHL, TWU VAHIETIES OF LABORATORY-IMHPEGNATED IODIZED CHARCOAL AND TWO CHARCOAL-EASED OXIOIZING CATALYSTS WEFF TESTED WITH KESPECT TO CH3-I-131 REMCVAL FPOM FLOWING STEAM-AIR. THE THPEE TYPES OF COMMFRCTAI. IDOIZEO CHARCOAL $\triangle L S O$ WERE CDUNE TO GE EFFECTIVE FGF CH3-I-13! TPAPPING IN STFAM-AIR SYSTEMS. USEFUL TPAPPING CAPABILITY WAS OESEFVED AT P.FLATIVF HUMIDITIES HIGHER THAN SOS, BUT AT P.ELATIVE HUMIDITIES INDICATER TO GE $\triangle T$ OD NFAR $100 \% \triangle P P F E C I \triangle B L E$ LCSSES IN CH3-I-13I REMCVAL EFFICIFNCY WEPE FREQUENTLY OBSFRVTD. THF TWE LABPFATCRY-IMPPEGNATED IODIZED CHADCOALS WEFE INVESTIGATED TO OETERMINE IE CERTAIN VARIATICNS IN THEIR PREPAPATION MIGHT IMPFOVE THEIF OUALITIES DS TRAPDING AGEVTS AT VERY HIGH RELATIVE HUMIDITY. ACCORDING TC THE RESULTS CRTAINED. NEITHER NF THESE THJ MATERIALS APPEAPED TC FEPRESENT A SOLUTION TO THE PROBLEM ASSOCIATEC WITH JPERATIDNS AT VERY HIGH RELATIVE HUMIDITY. THE TWD CHARCOAL-QASED OXIDIZING CATALYSTS WIEFE FDUND TO BE RELATIVELY INEFFICIENT AS COMPAFFD TO THE PERFODMANCE OF SUITABI.Y IMPPFGNATFD I JOIZ:D CIIARCOAL.

AVAILABILITY - ELEARINGHOUSF FOR FEDFRAL SCIENTIFIC ANE TECHNICAL INEORIATION, SPRINGFIELD, VA., \$3. OO CIPY, SO. 65 YICRJFICHE

*CHARCOAL + \#CHARCJAL ACSORBEP + \#DRGANIC IODIDF + \#TESTI:VG + FILTEF, BED + STEAN

$7-22558$

MERRIMAN JR + PASHLEY JH + SMILEY SH

ENGINEERING DEVELDOMENT OF AN ABSORPTIDN PFOCESS FOE THE CONCFNTRATION AND COLLECTION OF KRYPTON AND XFNON 


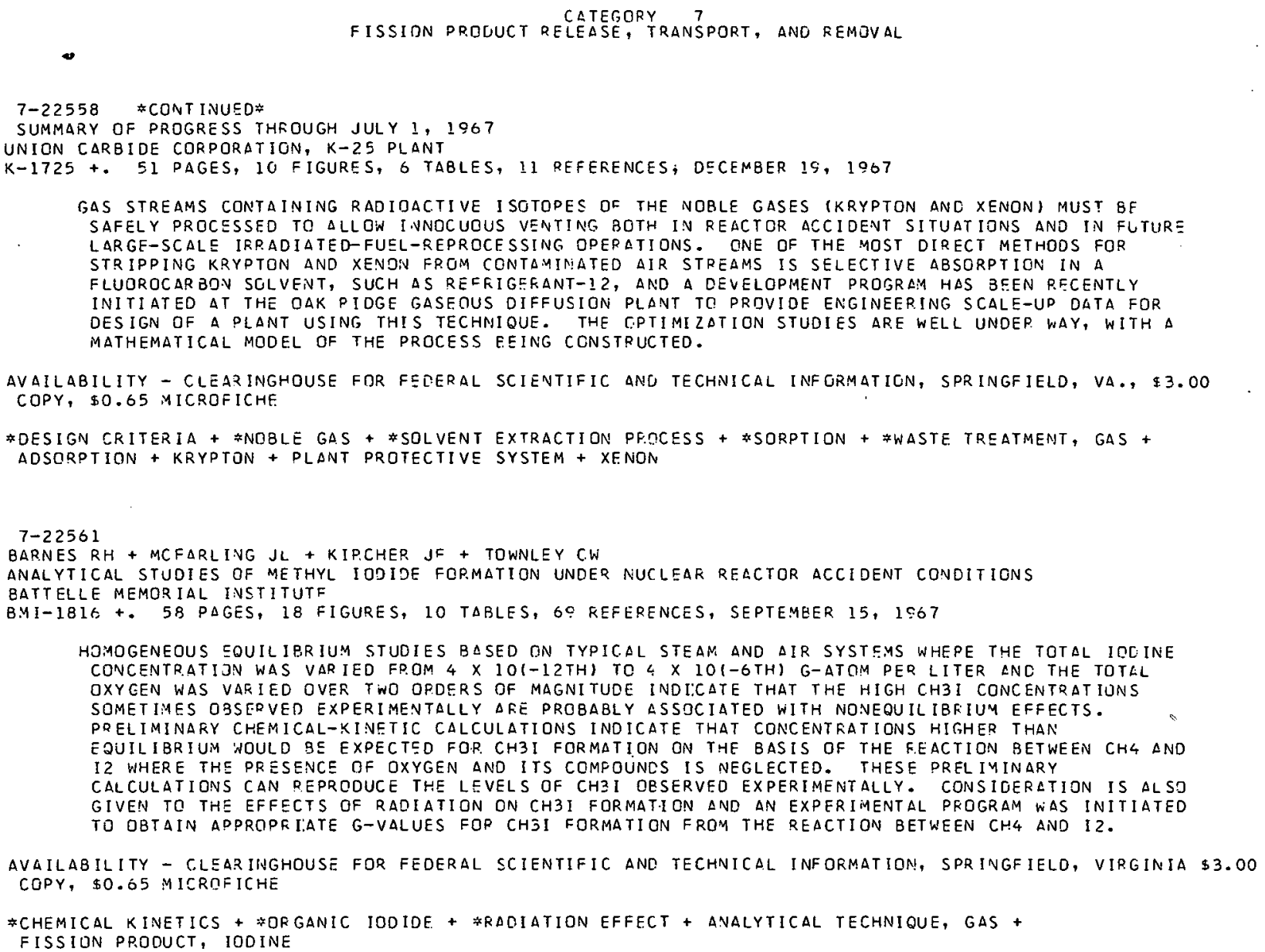

gas STREAMS CONTAINING RADIDACTIVE ISGTOPES OF THE NOBLE GaSES (KRYPTON AND XENON) mUST BE SAFELY PROCESSED TO ALLOW INNOCUOUS VENTING BOTH IN REACTOR ACCIDENT SITUATIONS ANO IN FLTURE LARGF-SCALE IRPADIATED-FUEL-REPROCESSING OPERATIONS. ONE DF THE MOST DIRECT METHODS FOR STRIPPING KRYPTON AND XENON FRUM CONTAMINATED AIR STREAMS IS SELECTIVE ABSORPTION IN A FLUOROCARBOV SOLVENT, SUCH AS REFFIGEKANT-12, AND A DEVELOPMENT PROGRAM HAS BEEN P.FCENTLY INITIATED AT THE OAK PIDGE GASEOUS DIFFUSION PLANT TO PRIVIDE ENGINEER.ING SCALE-UP DATA FOR DES IGN OF A PLANT USING THIS TECHMIQUE. THE C.PIIMIZATION STUDIES ARE WELL UNDEP. WAY, WITH A MATHEMATICAL MODEL OF THE PROCESS FEING CONSTRUCTED.

AVAILABILITY - CLEARINGHOUSE FOR FEQERAL SCIENTIFIC AND TECHNICAL INFGRMATIUN, SPRINGFIELD, VA., 3 . OO COPY, \$0.65 MICROFICHF.

\#DESIGN CRITERIA + FNOBLE GAS + \#SLLVNT EXTRACTION PFOCESS + \#SORPTION + \#WASTE TREATMENT, GAS + ADSORPTION + KRYPTON + PLANT PROTECTIVE SYSTEM + XENON

$7-22561$

BARNES RH + MCFARLING JL + KIPCHER JF + TOWNLEY CW

ANALYTICAL STUDIES OF METHYL IODIDE FOPMATION UNDER NUCLEAR REACTOR ACCIDENT CONDITIONS BATTELLE MEMOR IAL INSTITUTF

B.MI-1816 +. 58 PAGES, 18 FIGURES, 10 TABLES, 69 REFERENCES, SEPTEMEER 15, 1967

HOMOGENEOUS EOUILIBRIUM STUDIES BASED ON TYPICAL STEAM AND AIR SYSTEMS WHEPE THE TOTAL IOCINE CONCENTRATIJN WAS VARIED FPOM $4 \times 10(-12 T H)$ TO $4 \times 10(-6 T H)$ G-ATOM PER LITER ANC THE TOTLL OXYGEN WAS VARIED OVER TWO OPDERS OF MAGNITUDE INDICATE THAT THE HIGH CH3I CONCENTRATIUNS SOMETIMES OSSERVED EXPERIMENTALLY ARE PROBABLY ASSOCIATED WITH NONEQUILIBFIUM EFFECTS. PRELIMINARY CHEMICAL-KINETIC CALCULATIONS INOICATE THAT CONCENTRATIONS HIGHER THAN EQUILIBRIUM NOULD BS EXPECTSD FOR. CH3I FORMATION ON THE BASIS OF THE FEACTION BETWEEN CHA AND I 2 WHERE THS PRESENCE OF OXYGEN AND ITS COMFOUNCS IS NEGLECTED. THESE PREL IYINARY CALCULATIONS CAN REPRODUCE THE LEVELS OF CHZI OBSERVEO EXPERIMENTALLY. CONSIOERATION IS ALSD GIVEN TO THE EFFECTS OF RADIATION ON CH3I FORMATION AND AN EXPERIMENTAL PROGRAM WAS INITIATED TO OBTAIN APPROPEI:ATE G-VALUES FOR CHJI FORMATION FROM THE REACTION BETWEEN CHA AND I2.

AVAILABILITY - CLEARINGHOUSE FOR FEDERAL SCIENTIFIC AND TECHNICAL INFORMATION, SPRINGFIELD, VIRGINIA \$3. OO COPY, \$0.65 MICROFICHE

\#CHEMICAL KINETICS + \#OFGANIC IODIDE + \#RADIATION EFFECT + ANALYTICAL TECHNIQUE, GAS +

FISSIUN PRODUCT, IODINE

$7-22562$

GENCO JM + BERRY DA + BERRY WE + ROSENBERG HS + CREMEANS GE + MORRISON DL

FISSION PRODUCT DEPIOSIIIUN ANO ITS ENHANCEMENT UNDER REACTOP ACCIDENT CONOITIMNS. DUIARTERLY PROGRESS REPORT FOR JULY-SEPTEMBER 1967

BATTELLE MEMORIAL IVSTITUTE

BMI-X-10213 +. 62 PAGES, 20 FIGURES, 28 TABLES, 13 REFERENCES, OCTOSEF 1,1067

PROGRAM OBJECTIVES - (1) THE PERFORMANCE OF EXPERIMENTAL ANC ANALYTICAL WORK DIRECTED TOWAPD OBTAINING DCFINITIVE INFORMATION ON THE CHEMICAL AND PHYSICAL PRGCESSES WHICH AFFECT IODINE TRANSPORT AND OEPOSITION, AND $(2)$ THE DEVELOPMENT OF PFACTICAL COATINGS WHICH WCULD RETAIN SIGNIFICANT TRACTIONS OF FISSION-PRTDUT. T IODINE RELEASED IN THE EVENT OF A SERICUS ACCIDENT IN A WATER-COOLED REACTOR. THE FQLLOWING IS A I IST OF THE MOST PROMISING CANDIDATES, AS DET ERMINED BY THE RESULTS OF THE SCREENING PROGRAM - 1, 10-PHENANTHROL INE, TBAM, DMAM, GENTAC, EPON 1001, GENAMID 2000, VERSAMID 100 , AND VERSAMID 125. SEVERAL AMINE-CGINTAINING SYSTEMS HAVE BEEN FOUND THAT SHOW HIGH PRCIMISE AS REACTIVE IMPREGNANTS CNTO ASBESTOS MATS. THF RESULTING COMPOSITES HAVE HIGH ADSORPTION RATES FOR ELFMENTAL IODIVE, AND ARE FUNCTIONAL IN STEAI AT 115 AND $170 \mathrm{C}$. THESE MATERIALS APE (1) TBAM, (2) 1, IO-PHENANTHRCLINE, I3I DMAM AND (4) GENTAC. CONCLUSIONS FROM THE ELEMENTAL I DDINE SCREENING STUDIES.

AVAILABILITY - CLEARINGHOUSE FOR FEOERAL SCIENTIFIC AND TECHNICAL INFOKMATION, SPRINGFIELD, VA., \$3. OO COPY, \$O.65 MICROFICHE

*COATING, SURFACE + *FISSION PRBDUCT RETENTICN + \#IOOINE + \#OFGANIC IGOIDE + FISSITN PPODUCT TRANSPORT + SURFACE, GENERAL + SURFACE, PAINTED

$7-22563$

MEARS LD + ELLEMAN TS

THE DIFFUSION OF RECCIL FISSION FRAGMENTS FROM SOLIO SURFACES CALCULATED RELEASE CURVES

NORTH CAROLINA STATE IINIVERSITY

ORO-3508-2 +. 28 PAGES, 7 FIGURE, 7 TABLES, 4 FEFERENCES, AUGUST 1067

MEASUREMENT JF FISSION-PRODUCT RELEASE FROM A FISSION-RECOIL-IMPREGNATED SURFACE DUR ING HEATING PROVIDES $\triangle$ USEFUL METHCO FOR STUCYING FISSIDN-PRODUCT MIGRATION IN NONFISSIONABLE SOLIDS. THIS REPORT. CONTAINS TAELES ANO FIGURES GIVING THE PREDICTED FRACTIDN OF RECOIL FISSIDN PRODUCTS RELEASED FROM A SPHERICAL SPECIMEN FOR DIFFERENT DIFFUSION COEFFICIENTS AND HEATING TIMES. THE DATA ARE FOR A POSTIPRADIATION EXPERIMENT IN WHICH THE SAMPLE IS HEATED AT CONSTANT TEMPERATURE AFTER IMPREGNATION WITH FISSION RECCILS. 
FISSION PRODUCT RELEASE. TRANSPORT, AND REMOVAL

$7-22563$ *CONTINUED*

AVAILABILITY - CLEARINGHOUSE FOR FECERAL SCIENTIFIC AND TECHNICAL INFQPMATION, SPQINGFIELD, VA., \$3. OO COPY, \$0.65 MICROFICHE

\#OIFFUSIDN + \#FISSION RECOIL + \#THERMAL EXPERIMENT + FISSICN PRODUCT RELEASE, GENEPAL + XENON

$7-22564$

HILLAKY JJ + GATELF + GUHNEY K

EXPER IEINCE IN TESTIVG INSTALLED FISSION PR.ODUCT TRAPPING PLANT WITH METHYL IODIDE

UNITED KINGDOM $\triangle T O M I C$ ENERGY $\triangle U T H O R I T Y$, SELLAFIELD, ENGLAND

TRG-REPQFT-1548+. 12 PAGES, 3 FIGUPE, 2 TABLES, 4 KEFERENCES, JULY 16,1967

A SIMPLE EXPERIMENTAL PPOCEDUPE WAS DEVELOPED, BASED ON LABELLCO METHYL IODIDE, FOR THE FULL-SCALE IV-SITF. TCSTIVG OF THE CHARCOAL RED CF AN INSTALLED TISSION-PPOOUCT-TFAHHING DLANT. A JECUNTAMINATION FACTOR OF 1000 IS EASILY MEASURABLE FOQ $\triangle 10,000-C U$. FT/MIN PLANT WITH A FEW YC GE IONINE-131 TEST CARRIED OUT TO DATE UN SEVEOAL PLANTS INDICATE THE NECD FOR SUCH TESTS SINCF THE RESULTS HAVE IN SCME CASES SHCWN INAOSQUATE PECFCRYANCE, WHICH HAS USUALLY SEEN ASSOCIATED WITH MECHANICAL LEAKAGE. THE MOST SFFECTIVE METHCO DF ACH!EVING RELIABLE SEALING AHPEARS TO PE TO PASS GAS COWNKAROS THRDUGH $A$ SED OF CHAFCOAL WHICH

COM!LCTCLY FILLS THE DVAILABLF APEA, RATHER. THAN TO ATTEMPT TO SEAL AN ASSEMBLY HGLOING A GED INTC A FLANGE IN THE DUCT OE VFSSEL. PROVISICN SHOULD BE MACE FOR WITHDRAWING REPQESENTATIVE SAMPLES CF CHARCOAL EOR LABOFATORY TESTING.

AVAILASILITY - CLEARINGHOUSE FOR FECEPAL SCIFNTIFIC ANC TECHNICAL INFOFAATION, SPEINGFIELD, VA. S ?. OO COPY, $\$ O .65$ MICROFICHE

\#CHAPCOAL ADSOFBER + \#FILTER OPERATICN + \#FILTEP. TEST PEQUIPEMENT + \#GRGAVIC ICOIDE + \$TESTING + DECONTAMINATION FACTGR + FILTEQ INSTALLATION + FILTER, BED + FISSICN PRODUCT, IOOINE + LEAK

$7-22707$

FIPST MW + VILES FJ + REIST PC + SMITH DG + UNDEP.HILL OW + MOELLER CWd

ANNUAL PROGRESS REPORT HARVARO AIR CLEANING LABORATORY. SEPTEMRER 1, 1960-AUGUST 31 , 1967 HARVARD UNIVERSITY, ECSTDN, MASSACHUSETTS

NYO-841-11 +. 10 DAGES, OCTREER IS67

THIS PRUGRESS FEPORT INCLUDES (1) NINTH AIR CLEANING CONFERENCE, (2) IN-PLACE TESTS, (3) CLEANUP SYSTEMS FCR AIPBDRNE IODINE COMDOUNDS, (4) SODIUM FILTRATION, (5) WATER REMOVAL FR(M SATUPATED ATMOSPHERE, (6) KRYPTON SAMPLING AND ADSORPTICN, (7) UNDERGRCUND DISPOSAL OF GASEOUS WASTES, (B) THE DIFCUSION-BOARD CONCFPT, (9) CONSULTING SER.VICES.

AVAILABILITY - CLEARINGHOUSE FOR FEDERAL SCIFNTIFIC AND TECHNICAL INFOF:ATION, SHRINGFIELD, VIDGINIA \$3.OO COPY, \$O. 65 MICP.OFICHF.

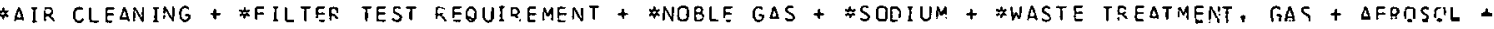
DECONTAMINATION FORTRR \& EILTET I TLSTINO

$7-22810$

ACAMS RE + ACKLEY RO

REMOVAL DF ELEMENTAL PACIOIODINE FROM FLQWING HUMID AIR BY IODIZED CHARCOALS

OAK RIDGE NATIONAL LAEOFATORY, OAK FIDGE, TENV.

ORNL-TY-2040 +. 25 FAGES, 2 FIGURES; 4 TABLES, \& PEFEFENCES. NOVEMEEP. 2,1967

CERTAIN TYPES OF IGDIZEO CHARCDAL HAVE BEEN FOUND TO BE USEFUL FCO TRAPPING RAPITARTIYE METMYL IDOIDE. THF OIIFSTION HAS DEEN OAISCD; HOWEVER, $\triangle$ IL WHETHER OF NOT THE IODI 2 ING DRDCESS REDUCES THE CAPACITY OF THE CHARCOAL FOR ELEMENTAL IODINE (I-2) TO $\triangle N$ UNACCCPTARLF I.EVEL. IVVESTIGATINN CONCERINING THIS ROINT HAS BEEN MAOE LUR THE CGNDITIJNS CF RCOM TEMDERATURF ANR

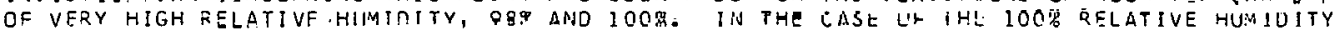
CONDITION, IHE CHARCOAL WAS CAUSED TO CONTAIN BULK PHASE LIOUID WATER, I.E. IT hAS WATERLOGGEO. ACCOROING TO THE RESULTS, THE IODIZEO CHARCOALS THAT WERE TFSTSO FCSSESS AMPLC C.APACITY AT 25 C FOR I* 2 WHEN THE RELATIVE HUMICITY WAS OS\%. THE WATERLOGGED ICCIZEI CHARCOALS EXHIRITEO ERFATIC I-2 DFMOVAL PERFOSMANCE WHICH FANGED FRCM GOOO TO FAIR. THIS SOMSWHAT UNPRECICTABLE BEHAVIOR IS POOBARLY ASSOCIATED WITH SWEEP GAS CHAMNEL ING IN THE CHARCOAL BEO RATHER THAN OVERLOADING OF THE CHARCOAL WITH I-2. COVIDUSLY, DOERATIONAL CONDITIJNS THAT MIGHT RESULT IN WATERLOGGING SHOULO EE AVOIDED IF EFFICISNT TFAPPING OF I- 2 IS REQUIRED.

AVAILABILITY - CLEARINGHOUSE FOR FEDERAL SCIENTIFIC AND TECHNICAL INFQRMATION, SPRINGFIELD, VIRGINIA. $\$ 3.00$ COPY, \$0.65 MICROF ICHE

*CHARCOAL AOSORBER + \#IOOINE + \#WATER VAPOR + CHARCIAL + FILTFP, PED I TISSION PRODUCT, IOCINE + STEAM

$7-22811$

PARSLYLE+ROW TH

BEHAVIOR OF FISSION DRODUCTS RELEASED INTE A STEAM-AIR ATMOSPHERE FRJM CVERHEATED UO-2 PREVIOUSLY

IRRADIATFO TO 20.000 MmD/T

OAK RIDGE VATIMNAL LABOFATODY, DAK FIDGE, TENN.

ORNL-TM-IOCS, PART I +. 44 OAGES, II FIGUPCS, I2 TABLES, 10 FEFERFNCES, SEPTEMBER 27,1067 
$7-22811$ *CONTINUSED*

SIJMMAOIZES THE PESULTS OF THE FIPST RUN MADE IN THE NUCLEAR SAFETY PILOT PLANT USING ZIRCALOY-2-CLAO UO2 IRRADIATED TI 20,000 MWO/T AND REIRRADIATED SHORTLY BEFORE THE RUN TC FEPLENISH THE INVENTORY OF SHOPT-LIVED FISSICN FRODUCTS. THE RUN WAS MADE BY MELTING THE FUEL IN A PLASHA UNCER RFDUCING CONDITICNS (STEAM AND FREE HYDROGEN PRESENT IN THE FURNACE) WITH A STEAM-AIR DTMOSPHERE IN THE MODFL CONTAINMENT VESSEL. IN THE MGDEL CONTAINMENT VESSEL, 80-SO\& DF THE ACTIVITY APPAFENTLY DEPCSITED DURING THE MELTDOWN PHASE WHEN A DRAFT TUBE WAS BEING USED TO MIX THE CONTAINMENT VESSEL CONTENTS. REMOVAL WAS EY CONVECT ION RATHER THAN SEOIMENTATION. A SIGNIFICANT PART GE THE REMAINING MATERIAL APPARENTLY ACTED AS NUCLEI FJF A WATER FCG, WHICH THEN SETTLLE. PROTOTYPES DF REMOTELY ACTUATED SAMPLERS FOP THE LOFT EXPERIMENT WEKE TESTED SUCCESSFULLY.

AVAILABILITY - CLEAPINGHOUSE SOR FEDEPAL SCIENTIFIC ANO TECHNICAL INFORMATION, SPRINGFIELD, VIRGINIA \$3.OO COPY, \$N.65 MICROFICHE

\#FUEL MELTDJWN + \#SPP + \#STFAM + \#URANIUM DIOXIOE + AIR + ALLOY + FISSION PRODUCT TRANSPORT + ZIRCONIUM

7-22917 ALSO IN CATEGORY 18

CONTINUUM DILATATION MODFL FOR CREEP SWELL.ING OF CERAMIC NUCLEAR FUELS WITH APPLICATIONS ILWB-LSBR DEVELTP AENT PROGRAMI

BETTIS $\triangle T O M I C$ POWER LAE., PITTSAURGH, PA

WAPD-TY- 49 +. 44 DAGES, 13 FIGURES, 2 TABLES, 11 REFERENCES, SEPTEMBER 1967

PRESENTS A CREEP MODFL FGR THE CREEP SWFLLING OF CERAMIC FUELS, INCLUDING THE FFFECTS OF FAPR ICATED PJROSITY, FISSION-INDUCED POROSITY, AND SURFACE TENSIOV, USING AS A MACROSCOPIC UILATATIJNAL EL EMENT A HOLLOH! SPHERE WITH THE CENTRAL CAVITY PLAYING THE ROLE OF THE FABEICATED PORE, WITH FISSION GAS PORES IN THE ANNULUS REPRESENTED BY ANALOGOUS MICROSCOPIC HOLLOW SPHERES. APPENDIX DESCRIBES THE COMFUTER PROGRAM FUEL SRELL III FOR FORTPAN II.

AVAILABILITY - CLEARIAJGHOUSE FOR FEDEPAL SCIENTIFIC AND TECHNICAL INFGRMATION, SPRINGFIELD, VIRGINIA \$3. OO COPY, \$O.S5 AICROCICHE

* ANALYTICAL MODEL + \#CREEP + CEPAMICS + COMPUTER PROGRAM + FUEL ELEMENT + R AND D PRGGRAM +

REACTOR, BREEDER + REACTOR, PWD.

7-22945 ALSC IN CATEGOPY 18

CALCULATION OF SPRAY IODINE REMOVAL FACTOF. FOR WESTINGHOUSE 2-, 3-, AND 4-LOOP PWR

PUELIC SERVICE ELECTFIC AND GAS COMPANY

7 PAGES, 7 REFEPENCES. DAGES $6.3-14$ THRU $6.3-20$, VOLUME 2 OF SALEM 1 AND 2 PRELIMINARY SAFETY ANALYSIS

REPOQT, 22 JAN. 1 OEE, DOCKETS 50-272 AND 50-311, TYPE-PWR, MFG.--WEST. AE-PUBLIC SERVICE OF N.J.

gIVES THE TECHNICAL GASIS FOR, THE CALCULATION OF, and THE EXPER IMENTAL VER IFICATICN OF THE IODI'UE-REYJVAL AND COSE-REDUCTION FACTORS, USING NAOH AS SPRAY ADDITIVE. THE REDUCTION IN THE 2-HF GFE-SITE DOSE IS 59 (2 LOOP, 60 PSIG, 286 F), $22(3,42,264)$, AND 64 (4, 47, 270$).$ DISCIJSSES REYOVAL DEF HI, CH3I, ANC FARTICLES.

AVAILABILITY - JSAEC PUELIC DOCUMENT POOM, WASHINGTON, D. C.

* ADCITIVE + \#CONTAINMENT SPRAY + \#FISSIMN PROOUCT, I ODINE + MATHEMATICAL TREATMENT + REACTOR, PWR + REDUCTION + SDOIUA

$7-2 ? 992$

LIPSETT JJ + PALMER JF

LOCATING FUEL FAILURES RY FISSION PRODUCT OEPOSITION IN CANDU-PHW REACTORS

CHALK RIVER NUCLEAR LABS

AECL-27ES + CONF-S71119-1 +. 27 PAGFS, 12 FIGURES, 3 TABLES, 14 REFERENCES, FROM CONFERENCE ON FAILEO

FUEL ELEMENT DETECTION, VIENNA, AUSTRIA

:AANY SYSTEMS FOF LOCATING FUEL-CLADDING FAILURES ARE COSTLY AND DIFFICULT TO MAINTAIN BECAUSE THEY USUALLY EMPLOY A COMPLEX ARRANGEMENT OF SAMPLE FLCWS CONTROLLED IN LONG LENGTHS DF SYALL-DIAMETER TUBING. IN PCWER REACTORS GF THE PRESSURE-TUBE TYPE, THE PROSLEM MAY BE SIMPLIFISD WITH A GE LLI) GAMNA-RAY SPEC. TOMETER MOUNTED NEAR THF END-FACE DF THE RFACTOR AND SET TO SCAN THE GUTLET COOLANT PIPES FOK DEPOSITED FISSION PRODUCTS. EXPERIMENTS IN THE NFX REACTOR LOOPS ANE IN THE NPD POWER REACTCR TESTED THIS CONCEPT, AND THE RESULTS AP.E ENCOURAGING. THE EXPFPIMENTAL RESULTS HAVE BEEN EXTRAPGLATEC TO THE CASE OF CANDU-PHW REACTOR.S. IT APPFAPS THAT THE TECHNIGUE WOULD BE SATISFACTORY IF A MONEL SURFACE WERE IMSTALLED IN THE OUTLET C.OOLANT PIPE FROM EACH FUEL CHANNEL.

AVAILABILITY - CLEARINGHOUSE FOR FEDERAL SCIENTIFIC AND TECHINICAL INFGRMATION, SPRINGFIELD, VA., \$3. OO COPY, \$9.55 MICRTF [CHE

* ANALYTICAL TECHNIQUE, CALIRRATION + \#CLAD + \#FAILURE, FUEL ELEMENT + \#FUEL INTEGRITY +

* INST RUMENT ATION, DETECTION FAILED FUFL SLEMENT + \#REACTOR, PRESSUF.E TUBE + DEPOSITION +

EXPERIMENT, GENERAL + FAILURE, CLADOING + FISSICN PPODUCT TRANSPORT + FUEL ELEMENT

7-229?

MISHIMAT 
FISSION PRODUCT P.ELEASE, TRANSPJPT, AND REMOVAL

$7-22993$ \#CONTINUEO*

METHYL IOOINE BEFAVIOR IN SYSTEMS CONTAINING AIRBORNE RADIOIODINE

BATTELLE-NORTH.NEST LABOPATORY, R ICHLANO, WASHINGTON

8 PAGES, 104 REFERENCES, NUCLEAR SAFETY C(1), PAGES $35-42$ (JAN-FEB 196E)

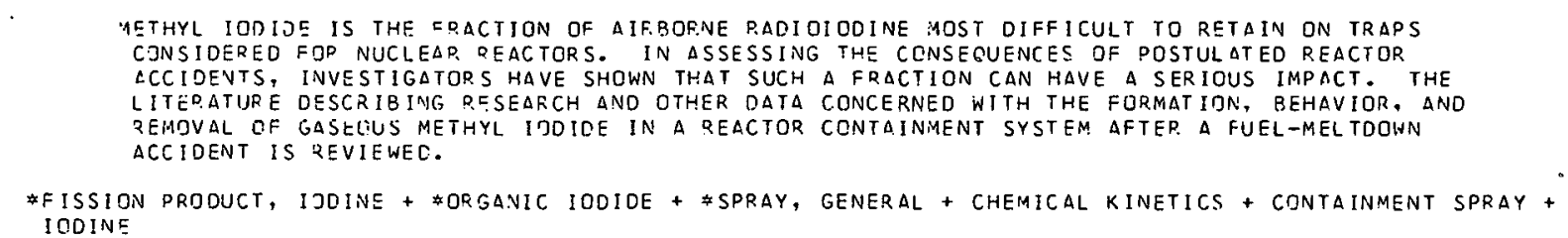

$7-22984$

HAMMER RQ + NEWBY QJ + ROHDE KL

PENETQATION OF IODINE INTC DFOTECTIVE COATINGS

IDAHO NUTLEAR CORD., IDAHU FALLS

IN-1075 +. 9 PAGES, 8 FIGUEES, 2 IABLFS, 5 REFEPENCES, NOVEMEER $19 E 7$

THE PENETRATION OF IGNINE INTO PROTFCTIVE COATINGS CHARACTEPISTIC OF THOSE USED IN REACTOF CONTAINMENT BUILDINGS WAS STUDIED, AND THE FOLIGWING GENEPALIZED FINDINGS RESUL TED - (I) PENETRATION OF IODINE. INTO THE COATING OCCURS WITH THE FOUR TYPES OF PAINT COATINGS TESTED, EPOXY, VINYL, CHLORINATED PUBBER, AND PHENOLIC. (2) THE PENETRATION IS AT LEAST IN PART REVERSIBLE. (3) THE DEGPEE GF PENETRATION IS ASSOCIATED WITH THE TEMPERATURE OF THE COATING AND ITS DHYSICAL STATE. A MCDEL FOR UNIDIRECTIGNAL DIFFUSICN IN A SEMIINFINITE SOL ID, TERIVED FROM FICKS BASIC CIFFUSION CONCEPTS, ADEOUATELY DESCFI QES THE PENETRATION OF IODINE IVTO THESE COATINGS TO THICKNESSES AS GREAT AS 0.25 MM. DIFFUSIVITIES FER IDDINE IGENEPATED $4 S$ I2) IN THE PROTECTIVE COATINSS TFSTEO RANGED FROM IO(-8TH) TO 1O(-10TH.) SQ. CM PER SEC.: ECFECTS TF COATING TYPE, ADDITIVES, $\triangle N D$ EXPOSURE TIME ARE ALSO REPORTED.

AVAILABILITY - CLEAPINGHDUSE FGR FFDEPAL SCIENTIFIC AND TECHNICAL INFCRMATION, SPRINGFIELD, VA., \$3. OO CQPY, \$0.65 MICRCFICHE

\#CONTAINAENT DAINT + \#IOOINE + \#URFACE. PAINTEO + ANALYTICQL MODEL + COATING + DIFFUSICN

$7-22935$

NICKEL H

ON THE USE OF BORON COMPOUNDS [N SAS-CUULEU HIGH-TEMPERATURE FEACTOPS. II. COMPATIRILITY QF COATED PAPTICLES CCNTAIVING PORON ANO SORONATCD GCAPHITE WITH GRAPHITE

INSI IIUT FUR REAKTOP.WERKSTRFFF, OER KERNCOF SCHUNG SANLAGE JULICH

9 PAGES, FIGURES, TAELES, REFERENCES, NUKLEONIK O(8), PAGES 372-380 (1967) IN GERMAN

THE USF OF GRADHTTF FIIIL ELGMEMTS, HIICII CONTAIN DOROIN CUMHLUNUS AS ABSURBER ANOICR QURVABLE-POISOIV MATERIALS, IN GAS-COOLED HIGH-TEMPERATURE PFACTORS IS SUGGESTEO. HERERY THE JMPORTANT OUESTION ARISES AS TO THE STABILITY OF THE BCIRON CCMPGUNDS IN A GRAPHITE MATRIX AT HIGH TEMPERATURES. THE SFCONN PART JF THE FAPER IS ORESENTEO HERE CONCERNEU WIIH THE COMPATABILITY OF COATED PARTICLES CCNTAINING BORON CARBIDE AND BORONATFR GRAPHITE WITH GRAOIITE A.T A TEMPERA TURE UF LOOOC. ON THE APPLICATICN OF COATED PARTICLES CONTAINING RORON IV GPAPHITE FUEL ELFMENTS DE THIS PEACTOR TYPE, IT CAN BE STATEO IN SUMMARY THAT CNLY PADTICLES CINNTAINING A DENSE ISCTRCPIC HIGH-TEMPERATURE PYRULLYIIC-CARBON LAYEP. APE SUITARLE. THIS STATEMENT IS SASEO ON THF PESULTS OF OUR ANNEALING EXPEFIMENTS AT 1000 C ON MIXTIRFS IIF CGATED PAPTICLES AND GRAPHITE AND EADIATION FXUEPIMENTS WITH THE SGAE.

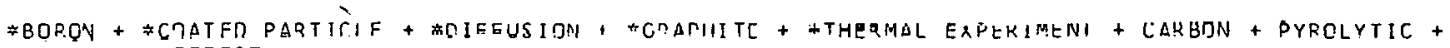
RADIATIDN EFFECT

$7-22986$

MAFKANAT + NISHTZANA, Y + SHISAYAMAT I KAHAGUCHI O

STUOY ON REMQVAL OF IDOINE FRUM AIMUISPHERE QY SPRAY. (1) REMOVAL DF IOOINE BY SPRAY UNDER ATMOSPHER IC

PRESSUPS

NP-TR-1537+. 19 OAEES, TRANSLATED FR OM NIPPON GENSHIPYOKU GAKKAISHI 7, PAGES 563-5E9 (1965)

THE RFMOVAL JF ELEMFNTARY IODINE FR.CM ATMOSPHERE BY SPRAY WAS STUOIED USING A STEEL DRUM II.S iN IN OIAH. $X$ Z M) FITTEO WITH $\triangle N$ IODINE-GENERATING SYSTEM, C SPRAY NOZZLE, AN ELECTRIC HEATER, AND A GAS-SAMPLING SYSTEM. THE EXPERIMENTS WEFE RUN OVER A TEMPERATUPE PANGF OF 25 TO $30 C$ AT ATMSSPHERIC FRESSUPE, AND THE PEMOVAL RATE OF IODINE WAS ESTIMATED BY GAS CHP.DMATOGKADHY. THE PLATEDUT DATE-CONSTANT JNCEEASEO WITH INEREASING TEMPERATUPE, BUT THE WASHOUT QATE-CONSTANT WAS INDEPENOENT OF TEMPEPATURF.

AVAILABILITY - CLEARINGHOUSF FOR FFIERAL SCIENTIFIC ANO TFCHNICAL INFQRMATION, SPRINGFIELD, VIPGINIA \&3. O0 COPY, \$O.GS MICRTFICIE

AIF. CLEANING + ANALYTICAL TECHNIQUE, AIO + CHEMICAL KINETICS + CONTAINMENT SPRAY + IODINE + SPRAY, GENERAL

7-22987 ALSE. IN CATEGOFY II

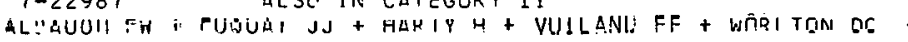


$7-22987$ *CONT INUEE

NUCLEAR SAFETY QUARTEQLY REPORT APRIL, MAY, JUNE, 1967 FOR NUCLEAR SAFETY BRANCH OF USAEC DIVISION OF REACTOR DEVELOPMENT $\triangle N$ NO TECHNOLOGY

QATTELLE-NORTHWEST, RICHLAND, WASHINGTON

BNWL-537 +. 33 PAGES, FIGURES, TABLES, DECEMRER IS67

THE STATUS OF THE FOLLONING PFOJECTS ARE PEPORTED - CONTAINMENT SYSTEMS EXPERIMENTS ICSEI, FISSION-PRODUCT-AERDSOL CCNTROL, CFACK DETECTION IN PRESSUPE PIPING BY ACOUSTICAL EMISSION, COLUMBIA RIVER SEDIMENTATION STUDIFS, DISPOSAL DF REACTOF CFF-GAS INTO SOIL SYSTEMS, AND SIMULATION MOCELING OF THERMAL GENERATION IN SELECTED FIVER SYSTEMS.

AVAILABILITY - CLEARINGHOUSE FOR FEDERAL SCIENTIFIC ANO TECHNICAL INFORMATION, SPRINGFIELD, VIRGINIA S3. OO COPY, $\$ 0.65$ MICROFICHE

* $\triangle E R O S O L$ PRDOUCTION + \#CONTAIN:AENT PAINT + \#CSE + *TEST, NONOESTRUCTIVE + \#WASTE TREATMENT, FIXATION + *WATER POLLUTION + AERCSOL + AEROSCL PROPERTIES + CONTAINMENT LEAKAGE CONTROL + CONTAINMENT SPEAY + FISSION PRODUCT TRANSPORT + FISSION PRCDUCT, IODINE + ORGANIC IODIDE + PIPING + SPRAY, GENERAL + WASTE DISPOSAL, GAS + WASTE DISPOSAL, LIQUID + WASTE DISPOSAL, TEREESTRIAL

7-23311 ALSO IN CATEGOR IES 11 ANO 19 PATENTS IN THE FIELD DF CAN-RUPTURE DETECTION

COMMISSARIAT a L-ENERGIE ATOMIQUE, SACLAY (FRANCE). CENTRE D-ETUDES NuCleAIRES

CEA-BIB-78 . 141 PAGES, FIGURES, OCTOBEF. 1967 , IN FRENCH

THE ABSTRACTS GF PATENTS ISSUED IN THE DRINCIPAL INDUSTFIAL CCUNTRIES APE LISTED ACCOPDING TO SEVERAL CHAPTEP.S PERTAININF, TO THE GENERAL PFINCIPLES OF LEAK DETECTION, DETECTION ITSELF OF FISSION PRODUCTS, APPARATUS USED OIRECTLY OR IN COMBINATION WITH AND FOR THE PURPOSE OF DETECTION, THE INDICATION AND TRFATMENT OF THE DATA GIVEN, THE EXAMINATION BEFORE AND AFTER USE OF CARTRIDGE JACKETS. A CUMULATION LIST IS APPENDED, GIVING IN PP.OGRESSIVE ORDER THE PATENT NUMBERS FOR 18 COUNTRIES TO FACILITATE THE SEARCH OF THE ABSTRACT IN THE CORRESPONOING CHAPTER .

AVAILABILITY - MICRGCARD EDITIONS, INC. (FOR SALE) ACCOUNTING AND SHIPPING DEPARTMENT, WEST SALEM, WISCONSIN 54669

\#FUEL ELEMENT + \# INSTRUMENTATION, DETECTION FAILED FUEL ELEMENT + *TEST, LEAK LOCATICN + MONITOR, RADIATION, GENERAL

$7-23372$

NOTLEY MF+ DESHAIES R + MACEWAN JR

MEASUREMENTS OF" THE FISSION PRODUCT GAS PRESSURES DEVELOPED IN UO-2 FUEL ELEMENTS DURING OPERATION ATOMIC ENERGY OF CANACA LIMITED

$A E C L-2662+.75$ PAGES, 37 FIGURES, 8 TAPLFS, NOVEMBER 1966

DESCR IBES EXPEF IMENT AND PRESENTS RE SULTS OF MEASUREMENTS. TWELVE UOZ FUEL ELEMENTS SHEATHED IN ANNEALED 304-SS WERE IRRADIATED IN THE NRX REACTOR TO A MAXIMUM BURNUP OE 3200 MWDITON U. A SIGNIFICANT AMUUNT OF FISSIDN-PRCDUCT GAS IN THE FUEL WAS RELEASED DURING POWER TRANSIENTS, WITH MOST OF RELEASE NCC.URRING AS ELEMENT POWER WAS LOWERED. ELEMENTS WITH LESSER FUEL DENSITY INCREASED THE AMJUNT OF FP. GAS RELEASED, BUT NOT PROPORTIONALLY SINCE THEHE WAS MORE VOIO VOLUME WITH THE LOW-DENSITY FUEL.

AVAILABILITY - CLEARINGHOUSE FOR FEDERAL SCIENTIFIC AND TECHNICAL INFORMATION, SPRINGFIELD, VIRGINIA \$3. OO COPY, \$O.65 MICROFICHE

*FUEL BURNUP + *FUEL FLEMENT + \#PRESSURE, INTERNAL + CANADA + FISSION GAS RELEASE + FUEL, POWDER TYPE + IRRADIATION TESTING + MEASUREMENT, GENERAL + URANIUM DIOXIDE

7-23439 ALSO IN CATEGORIES 5 AND 6

OUARTERLY TECHNICAL REPORT STEP PROJECT JANUARY 1-MARCH 31,1967

PHILIIPS PETROLEUM COMPANY

IDO-17239 +. 156 PAGES, 81 FIGURES, 15 TABLES, 50 REFERENCES, AUGUST 1967

THIS REPORT IS ONE OF A SERIES ON THE FOLLOWING TOPICS - LOFT DESIGN ANALYSIS, LCFT BLOWDOWN ANALYSIS, DIRECT RADIATION LEVELS DURING LOFT OPERATION, FISSION PRODUCT BEHAVIOR STUDIES, LOFT RADIOLOGICAL STUDIES, MODEL FORMULATION FOR THE SUBCOOLED DECOMPRESSION DURATION IN A PWR SYSTEM FOLLOWING A PRIMARY-COOLANT-LOOP BREAK, AND SEMISCALE BLOWDOWN TEST PROGRAM.

ÁVAILABILITY - CLEARINGHOUSE FOR FEDERAL SCIENTIFIC AND TECHNICAL INFGRMATION, SPRINGFIELD, VA., \$3. OO COPY, \$0.65 MICROFICHE

ACC IDENT, LOSS OF CORLANT + CONTAINMENT DESIGN + CORE MELTDOWN + CORE SPRAY + FISSION PRODUCT RELEASE, GENERAL + LOFT (S-RR) + REACTOR TRANSIENT + REACTOR, SAFETY RESEARCH

7-23438 ALSO IN CATEGORY 18

DRESDEN 2 AND 3 SAFETY ANALYSIS INVOLVING FISSION PRODUCT RELEASE FROM FUEL

COMMONWEALTH EDI SON COMPANY

5 PAGES, 3 TABLES, PAGES 14.2-13 THRU 14.2-17 OF DRFSDEN 2 AND 3 FINAL SAFETY ANALYSIS F.EPORT, NOVEMBER 
CATEGRFY 7
FISSION PRODUCT RELEASE, TRANSPORT, AND FEMOVAL

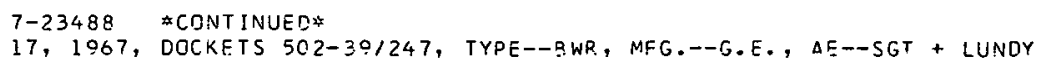

BY USING TIMS MULTIPLEXING TECHNIQUES, THF HIGH DATA PROCESSING CAPABILITIES OF A SINGLE DIGITAL COMPUTEF. CAN BF USED TO REPLACE A MULTIPLE ANALOGUE CONTRDL SYSTEM WITH A CONSERUFNT SAVING IN COSTS ANO SLMEWHAI HE: IEK UPEMAIICN. TO TEST THIS PREMISE, ANC IO GAIN AN INSIGHT INTO THE PROSLEMS, A DIGITAL COMPUTER CONTROLLEP. WAS INCOPPORATEO IN THE CONTFOL SYSTEM FOE. THE DOUGLAS OOINT NUCLEAP. DOWEL ULANT. MUCH USEFUL EXPERIENCE IN THE DESIGN PUASE HAS EFEN GAINCO, AND DRCRATING CXOTRITINCE WHILE STILL LIMIILU HAS ELEN ENLUURAGING.

AVAILABILITY - CLEAR INGHOUSE FQR EECERAL SCIENTIFIC AND TECHNICAL INFORMATION, SPRINGFIELD, VA., S?. OO COPY, SO.65 MICRU! LCHE

* COMPIJTER CONTROL + \#CPEPATING EXPERIENCE + \#REACTOR, HWR + CHALK PIVEP + COMPUTER PROGRAM + IAEA + INSTRUIAENTATION, CONTROL + INSTRUMENTATICN, GENERAL

7-23926 ALSO IN CATEGORIES I ANG 11

FOTTRELL WB CAK RIDGE NATIINAAI. LAPI. TENN.

ORNL-TM-2095 +. I37 PAGES, FIGURES, TABLES, DEFEPENCSS, FFE. ISGE

INCLUDED IN THIS PROGRCSS P.EPORT IS WOSK ON VARIOUS CHEMICAL REACTIONS, AS WELL AS THE RELEASE, CHARACTERIZATION, ANR TRANSPCRT OF FISSION ORCDUCTS IN CONTAINMENT SYSTEMS UNDER VARIOUS ACCIDENT CONDITIJNS AND ON PROELEMS ASSOCIATED WITH THE REMOVAL OF YHFSE FISSION PRODUCTS FRDM GAS STREAMS. ALTHOUGH MOST OF THE WOKK HAS BEEN ANO CONT INUES TO ER IN GENERAL SUPPORT OF NATER POWER-REACTCP. TFCHNOLQGY, INCLUDING SOME IN DIRECT SUPPORT JF THE LOFT ANO CSE PROGRAMS, SEVERAL PRDJECTS WEHE STARTEO THE FIRST OF THE CALENDER YEAR IN SUPPORT OF THE

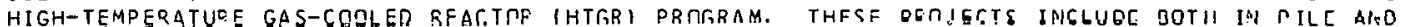
DIT-PILC STUDIES OF PEACTION PATES AND CISSION PRODUCT KELEASE AND TRANSFORT OHENIMENA 
7-23926 *CONT INUED\#

RELEVANT TO PCITENTIAL HTGR. ACCIDENT SITUATIONS. OTHER MAJOR PRDJECTS INCLUDE FUEL-TRANSPORT SAFETY INVESTIGATIONS, A SEPIES OF CISCUSSION PAPERS ON VAR.IOUS ASPECTS OF WATER-R.EACTOR TECHNOLOGY, ANE THE STUDIES CN PRESSURE-VESSEL TECHNCLOGY. EXPERIMENTAL WORK RELATIVE TO PRESSURE-VESSEL TECHNOLOGY. FXPEPIMENTAL WORK RELATIVE TO PFESSURE-VESSEL TECHNOLOGY INCLUDES IINVESTIGATIONS OF THF ATTACHMENT OF NOZZLES TU SHELLS AND THE VARIABILITY OF IMPACT. DATA ON LOW-ALLOY STEELS.

AVAILASILITY - CLEARINGHGUSE FOR FEGEFAL SCIENTIFIC AND TECHNICAL INFORMATION, SPRINGFIELD, VIRGINIA $2 ? 151, \$ 3.00$ COPY, $\$ 0.65$ MICROFICHE

*CHEMICAL KINETICS + \#CONTAINMENT, GENEPAL + \#CSE + \#FISSION PRODUCT RETENTION +

\#FISSION PRODUCT TRANSPCRT + \#ISSION PQQOUUT, AIRBOPNE + \#IMPACT PROPERTY + \#IN PILE EXPERIMENT + \#LOFT (S-RR) + \#NOZZLE + \#OUT OF PILE LOCPS AND EXPERIHENTS + \#REACTOR, HTGR + \#STEEL + CONTAINMENT SPEAY + FISSION PRODUCT R.ELEASE, GENERAL + PRESSURE VESSEL

7-24270 DLSC IN CATEGRRIES I7 AND 13

NORTH ED

FILTER FAILURE ALLOWS HIGHER PARTICULATE RELEASE RATE

NUCLEAK FUEL SË̈VICES, INC., WEST VALLEY, N. Y.

4 PAGES, ATOMIC ENEDGY CLEAPING HJUSE, 14(14), PAGES 25-28 (APFIL 1, 1968), CCCKET 50-201

(LETTER, MARCH 24) ON MAR. 8-10, THE PARTICULATE RELEASE FROM THE STACK ALMOST EQUALED THE MONTHLY ALLJNANC, DUF TO FAILUFE CF THE DISSOLVER OFF-GAS FILTER (PLACED IN SERVICE MAR. 7 ). IT HAD SEFN LCDDED FOR SEVCRAL MONTHS PRICR, READING 5 R/HR. ALTHOUGH IT MET THE DOP TEST MAR. 7, EITHEF. THE MEDIA SECAME PQROUS OR DEVELCPSD A CRACK, OR THE SEALANT HARDENED AND FAILED TO SEAL. MOFE PRIBABLY, THE ORGANIC EINDER EMBRITTLED, FREEING THE GLASS FIBERS AND ALLOWING THEA TO VIBRATE TO THF POINT OF FAILURE, OR TO PERMIT THEM TO MOVE RELATIVE TO EACH UTHER. FILTCKS WILL SE REPLACED WITHIN A SHORT TIME AFTER REMOVAL FROM SERVICE FOR HIGH $\because R E S S U R E$ DROP GR HIGH PADIATION.

\#FILTER, DAMAGED + \#FILTER, FIBERGLASS + \#RADIATION DAMAGE + \#RADIOALTIVITY RELEASE + \#STACK + .

FAILURE, EQUIPMENT + FUEL REPROCESSING + NFS 
NURLOC-1.0 CONTAINS MATHEMATICAL MCDELS FOR MOST OF THE PROCESSES OCCURR ING IN A REACTOR ACCIDENT WHICH.AFFECT THE SOLID AND FLUID TE:APERATURE DISTRIEUTIONS. MODELS WERE DEVELOPED AND PROGRA41EO FOR HEAT CONDUCTICN, HEAT GENEFATION, THEPMAL RADIATION, ROIL-OFF, MELTDOHN, PJSTBLOWOOWV HEAT AND MASS-TRANSFEP CDEFFICISNTS, AND METAL-KATER REACTION. TEST CASES OF ACCIDENT HEAT TPANSFER IN THE LOFT PEACTOR WERE CALCULATED FGR TIMES UP TO 400 SEC. CALCULATIONS WERE ALSO PEPCORMED FOF A TYPICAL GOO-MWIT) BWR FOR A SIMILAR PERIOD OF TIME. A TYPICAL 1OCO-MW(E) BWR GAVE TEMPEPATURE AND METAL- WATSR REACTIONS MUCH DIFFERENT FROM THCSE FOR LOFT. THE PERCENTAGE OF CLADOING QEACTED WAS LESS BY MORE THAN A FACTGR OF TWO FOR THE IOOO-MW(E) REACTCR THAN IOR LDFT FCP SIMILAR PEFIOOS OF TIME.

AVAILABILITY - CLEARINGHCUSE FOR FEDERAL SCIENTIFIC AND TECHNICAL INFOPMATION, SPRINGFIELD, VA., \$3. OO CDPY, \$C.65 HICRTEICHE

ACCIDENT, LISS OF COCLANT + ACCIDENT, MAXIMUM CPFDIBLE (MCA) + CGMPUTER PROGFAM + REACTOR, GENERAL + Y.EACIUK, WATEZ

8-21322 ALSO IN CATERORIES 5 AND 6

KINETIC STUDIES DE HETEPOGENEGUS NATEP. REACTORS. ANNUAL SUMMARY REPORT, 196E

TRW SYSTFMS GROUP, RECONDD BEACH, CALIF

STL-372-50+. 129 PEGES, 57 FIGURES, 3 TABLES, 44 REFERENCES, DECEMBEP, 1966

ANNUAL SUMMAZY PFPOPT-1966. SUMMARIZED WOFK ON - 111 THE PFOCESS OF THERMAL PRESSURE

GENERATION, (2) SHOCK-TUBE EXPER IMENTS, 12) PESSIBILITY OF DESTRUCTIVE IN-CORE PRESSURE IN

MELTDONN ACCIOENT, 141 IN-PILE CAPSULE MEASUREMENTS OF STEAM-VOID FORMATIGN, AND (5) DOWER

F.EACTOR INSTABILITY AND TWO-PHASE FLOW.

AVAILABILITY - CLEAQINGHOUSE FOR FECERAL SCIENTIFIC ANC TECHNICAL INFORMATION, SPRINGFIELD," VA., \$3. OO COPY, \$Q.65 MICROFICHE

ACCIDENT, REACTIVITY + EXPLOSION + ELDW, TWO PHASE + PEACTOF TRANSIENT + REACTOR, WATER + TRANSFER FUNCTION

3-21735 ALSE IN CATEGORIES E $\triangle N O 18$

FRENCH PJ + GALLAGHEE JM + MOORE JS + SALVATCOI E

INOIAN POINT UNIT NO. 2 RDD EJECTION ONALYSIS

WESTINGHOUSE ELECTRIC CORP., PITTSPURGH, PA.

WCAP-2040 +. 108 PAGES, $\angle 5$ FIGURES, 7 TAQLES, 25 REFEPENCES, OF SECOND SUPPLEMENT TO INDIAN POINT 2

PRELIMINARY SAFETY ANALYSIS REOORT IEXHIEIT B-2), MAY 1066, OOCKET 5ח-247, TYPE--PWR, MFG--WEST, AE- -UNITD ENCR

(INCLUDED IN DSAR SUPPLEMENT 2.) ANALYSIS USES CHIC-KIN FOR KINETICS, AND HAS 1.5 QR 1.0

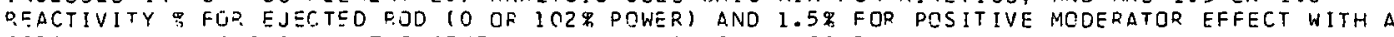
SCRAM AFTER 1.F SFC. ALTHO SOME FUEL MELTING WOULD OCCUR, PEAK SYSTEM PRESSURE IS LESS THAN 6000 PSIA. A SHGCK-WAVE $\triangle N A L Y S I S$ FOR. RFACTOP VESSEL INDICATES THAT 1/3 OF CDRE MUST BECOME MOL.TEN ANO DISFEFSEO TO DILATE VESSEL WALL UP TO 50 O ULTIMATE ELONGATION IBASED ON TNT EXPER IMENTS $\triangle T$ NDLL-WISEI.

aVAILABILITY - USAEE PUELIC DOCUMENT RgOM, WASHINGTON, O. C.

* ACGIDENT ANALYSIS I *ACCIDENT, CONTMOL ROD EJECTION I EXPLOSION I FUTL MELTDOWN I INTEGRITY I PDESSUPE VESSEL

$8-22473$

DAVIS RJ

THE SIGNIFICANCE OF CHAPCOAL IGNITION TEMPEPATUPES

DAK RIDGE NATIONAL LAB., TENN.

2 PAGES, ANS TRANSACTICNS 10(2), DAGE 511 AND 512, (NOV. 1967), PRESENTED AT THE 1SG7 WINTER MEETING OF

THE AMEP.ICAN NUCLEAF SER, IETY, CHICAGC, ILLINOIS, NCV. 5-9, 1967

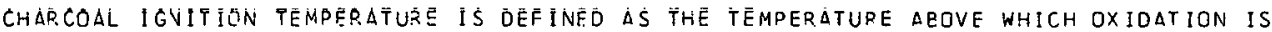

SELF-SUSTAINIIUG. EXPERIMENTALLY, IGNITICN TEMPERATURE IS OBSEPVED BY SLIILY HEATING A

SPECIMEN AVD NOTING THE TEMPERATURE AT WHICH THE HEATING RATE SUDDENLY INCREASES, IGNITION

TEMPERATURS CAM EE QUITE PRECISFLY MEOEURTD AND RERRODUCED. IN THIS TARLR, ICNITIOA

TEMPERATURE IS DEFINED IN TEEMS OF A SIMPLF THECRETICAL MODEL. THE RESULT IS A WORKING

EQIJATIDN THAT FELATES IGNITION TEMPERATUFE TO SEVERAL PARAMETERS. THESE INCLUDE, THE

CHARCOAL ACTIVITY (THE EFFECTS OC PROMOTERS, INHIBITORS, ANC SURFACE AREA), OXYGEN ACTIVITY

(AIP. VELOCITY AND OXYGEN CONCENTRATION). THE STOICHIOMETRY OF THE JVERALL CHEMICAL REACTION, AND THE ACTIVATILN ENCDGY OF THE PATE-DETEFMINING STEP OF THE MECHANISM. THE USE OF THE

WTRKING EQUATIUN IS DEMCNSTRATED. ECFECTS OE SURFACE AFEA, ASH CONTENT, ANO AIR VELOCITY ARE CORRELATED WITH THE WORKING ERUATION AS THE BASIS.

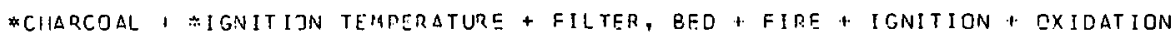


SOURCES OF ENERGY RELEASE UNDER ACCIDENT CONDITIONS

$8-22584$

$8-22584$
JENKS GH + GRIESS JC

WATER CHEMISTRY IN PRESSURIZEO ANO ROILING WATER POWER REACTORS

OAK RIDGE NATIONAL LAGORATORY, DAK RIDGE, TENN.

ORNL-4173 +. 55 PAGES. TABLES, FIGURES, REFERENCES, NOVEMBER 1967

THE CHEYICAL 8FHAVIOR OF NATER IN SMALL, HERMETICALLY SFALED, TFRRESTRIAL LOW-POWER QEACTORS (TLPR) HAS BEEN PREDICTED FRGM INFOFMATION AVAILABLE IN THF LITERATURF. TITANIUM INSTEAC CF STAINLESS STEEL OR INCONEL HAS BEEN SUGGESTEO A STRUCTURAL MATEFIAL FOR THESE REACTOPS. RADICLYTIC GASES POSE NO PKOBLEM IN PPESSURIZED-WATER REACTORS IF THE WATER IS SUFFICIENTLY PURE AND HYDRGGEN IS ADDED TC I T. THFY ARE NC PR.OBLEM IN ROILING-WATER REACTCRS IF. THESE GASES RECIRCULATE IN THESE REACTOF.S AS PREDICTED.

AVAILABILITY - CLEARINGHOUSE FOR FELERAL SCIENTIFIC ANC TECHNICAL INFORMATION, SPRINGFIELD, VIRGINIA, $\$ 3.00$ COPY, \$0.65 MICROF ICHE

\#COOLANT CHEMISTRY + \#CURROSION + \#RADIOLYTIC GAS + CHEMICAL KINETICS + DESIGN STUDY + CPNL + REACTOK, SWR + REACTUR, PWP.

$8-22690$

ISHINATARI N

WATER. CHEMISTRY OF JPDP.

JAPAN AT DIAIC ENERGY RESEARCH INST., TOKYO, JAPAN

JAERI- $1135+.21$ PAGES, TABLES, FIGURES, REFERENCES, CCTOBER 1966

REPORTS RESULTS OF ADDITIONAL WORK ON THE WATER CHEMISTRY OF THE JAPAN POWER DEMONSTRATION FEACTOR (JPDR). MEASUREMENTS OF THE RADIQLYSIS, INDUCEO ACTIVITIES, AND WATER OUALITIES ARE GIVEN. RADIOLYTIC GAS AND INDUCED RADIONUCLIDE CONCFNTPATIONS IN THE REACTOR WATER ARE SIMILAR TO THOSE IN THE OTHER POILING-WATER REACTORS. THE CHEMICAL ASPECTS OF THIS REACTOR, INCLUOING THE SUPPRESSION OF THE RELEASE GF RADIOIODINE FROM THE COOLANT SYSTEM, ARE CONSIDER CD EXCELLENT.

AVAILABILITY - MICROCARD EDITIONS, INC. (FOR SALE), ACCOUNTING ANO SHIPPING DEPARTMENT, WEST SALEM, WISCONSIN

*COOLANT CHEMISTRY + \#RADIOLYTIC GAS + \#RADIONUCLIDE, INDUCED + ACTIVITY BUILDUP +

COOLANT PURIFICATION SYSTEM + CQRROSION + JAPAN + REACTOR, RWR

$8-22691$

HAMMAR L + ALLISON GM + ANDFRSON AR + CARLSON F + FJELLESTAOK + INNVAEP R + ROSER

WATER CHEMISTRY RESEARCH DT THE HALDEN BOILING HEAVY WATER REACTOR (HEWP.)

INSTITUTT FOR ATOMENER.GI, HALDEN, NOPWAY

HPR-55 +. 149 PAGES, FIGURES, TABLES, REFERENCES, JUNE 1967

A WATER CHEMISTFY PROGRAM WAS PERFORMED AT THE HALDEN BOILING WATER REACTOR. TO INVESTIGATE THE RADIOLYSIS OF WATER AND THE N-IE ACTIVITY IN STEAM. RACIOLYTIC GAS FOPMATION WAS CONFINED

LARGELY TO THE BOILING WATER WITHIN THE FUEL CHANNEL AND WAS LOWER THAN THAT FOR THE BOILING

LIGHT-WATER REACTORS. ADOITION OF DEUTERIUM OR AMMONIA TO THE HEAVY WATER SUPPRFSSEO THE

FORMATION OF RADIOLYTIC GAS BUT INCPEASED THE STEAM-WATER DISTRIBUTION RATIO OF THEN-IG.

*COOLANT CHEMISTRY + \#DEUTERIUH + \#HBWR (BWR) + \#NITROGEN + \#RADIOLYTIC GAS + CHEMICAL ANALYSIS + HEAVY WATER + NORWAY + RADICNUCLIDE, INDUCED + REACTOR, SWR

$8-2269.4$

CHAMBERLAIN HV + KOVAC LP + REICKS GH + KOVACIC EC

TUSE WASTAGE IN SOOIUM-WATER REACTION TESTS

ATOMIC POWER DEVELOPMENT $\triangle S S O C I A T E S$, INC.

2 PAGES, 1 TABLE, ANS TRANSACTIONS 10121 , PAGES $601-692$, PRESENTEO AT THE AMERICAN NUCLEAR SOCIETY WINTER MEETING, NOVEMBER 5-9, 1967 , CHICAGO, ILLINOIS

A SERIES OF TESTS WAS PFRFORMED IN A SODIUM.LOOP CONTAINING A WATER-FILLEO TUBE BUNOLE WHERE A JET OF WATER FROM A CAPILLARY TURE WAS ALLOWED TO IMPINGE ON $\triangle$ TARGET AREA LOCATED ON THE DUTSIDE OF THE TUBE BUNDLE. THE TUBE BUNDLE WAS MADE OF 1-IN.-OIAMETER, O.120-IN.-THICK, 2-1/2 CROLOY TUBING. F.ESULTS, INDICATED THAT DECREASING THE TARGET-TO-NOZZLE DISTANCE AND INCREASING THE WATER VELOCITY THROUGH THE CAPILLARY NOZZLE INCREASED THE TARGET WASTAGE RATE SIGNIFICANTLY. THE SODIUIM VELOCITY AND THE DURATION OF THE LEAK HAD NO MEASUPABLE EFFECT ON THE WASTAGE PATE. METALLURGICAL EXAMINATION OF THE WASTED AREA INDICATED THAT THE EFFECT OF THE METAL-WATEF REACTION ON THE TAPGET WASTAGE RATE WAS NEGLIGIBLE.

* FAILURE, TUBING + *METAL WATER REACTION + *SCOIUM + CHEMICAL REACTION + EROSION + HEAT EXCHANGER + METAL, LIQUID 
SDURCES OFF ENFFGY RELFASE UNDER ACCIDENT. CONDITIONS

$8-22695$ \#CONTINUED*

SURFACE TEMPERATURE MEASUREMENTS IN SONIUM-WATER REACTIDNS

ATOMIC POWER DEVEL JPMENT ASSOC, IATES, INC.

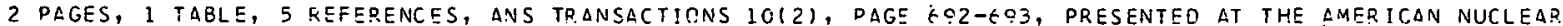
SOCIETY WINTER MEETING, NOVEMBER 5-9, 1967, CHICAGC, ILLINOIS

MADE SER IES OF TESTS WHERE WATEP WAS INJECTED AT A P.ATE OF 0.003 L $9 / S E C$,THQRUGH O.DOB-IN. -DIAM CAPILLAFY TUBE IN A POOL GF SUDIUM TIOWARDS A STAINLESS-STSEL-SHEATHED THERMOCOUPLE TARGET. MAXIMUM MFTAL SUREACF TFMPERATURES WERE MEASUREC AS A FUNCTION OF THE DISTANCE BETWEFN THE WATER INJECTILN PGINT ANO THE TAFGET SURFACE TEMPEPATURES VARIEO FRCM $1538 \mathrm{~F}$ FOR A 1/4-IN. DISTANCE TO 7CC F FOF A 1-1/2-IN. DISTANCE, AND THE ZONE FOR THE METAL-WATER REACTION ADPEARED TO BE VERY LOCALIZED.

\#METAL WATER REACTION + \#QDIUM + \#TENPERATUPE GRADIENT + CHEMICAL FEACTION + FAILURE, TUEING + HEAT EXCHANGER + METAL, LIOUID

$8-226 \div 6$

DUMM K + MAUSBECK + + SCHNITKER iN

EXPERIMFNTAL AND THFGLETICAL INVESTIGATIUNS GF SOOIUM-WATER REACTIONS IN TUEES

INTERATOM GBH, EERMANY

14 PAGES, 9 FIGUF.ES. PAPER DRESENTED DURING CREST MEFTING OF SHCCK STRUCTURE INTERACTIGNS, JUNF $26-2$, ISE6 AT ISPRA, ITALY

5QDIUM-NATER PEACTIONS IN A SITUATIGN SIMULATING A DOUBLE-ENDED TUBE FAILUIFE IN SINGLF-WALL STDIUM-HEATED STEAM GSNERATORS WERE INVESTIGATED EXPCRIMENTALLY AND THEJRETICALLY. THF THEORETITAL MODEL IS RESTRICTED TO ONE OIMENSION AND DOES NOT INCLUDE THE REFLECTED PDESSUPE PULSES. REASONABLE AGRSEMENT BETWESN THEORY AND EXPERIMENT WAS OBTAINED FOR THE INITIAL PRESSURE PULSES. BECAUSE DF THE QUICK MOVEMENT OF THE PEACTION FACE, SATISFACTCEY MLASUREMLNTS LI THE TEMPERATUPES AND THE MATERIAL STRESSES WERE NOT ORTAINED.

AVAILABILITY - K DUMM, INTERATOM, BENSBFRG/KOLN, FRG, GERMANY

*CHEMICAL KINETICS + \#FAILURE, TUBING + \#HEAT EXCHANGER + \#METAL WATER. REACTION + \#PRESSURE PULSE + * SODIUHA + ACCIDENT MGIEL + CHEMICAL REACTION + GERMANY + METAL, LIGUID

$\varepsilon-22702$

PALIMER DJ

R.EACTION DF HYDROGEN WITH GRAPHITE

BRITISH PETROL EUM COMPANY, SUNBURY-ON-THAMES, ENGLAND

2 PAGES, NATUSE (LONOSN), 215 , PAGES $338-28$ ? (JULY. 22,1957 )

EXPERIMENTS $\triangle R E$ DEPOPTED IN KHICH GFAPHITE WAS GROUND IN THE PRESENCE DF HYDPOGEN AND NITROGEN. IT WAS CONCLUDES THAT THE AESOPPTION OF GASES RY THE GRAPHITE KAS DUS TJ A C.HEMICAL ECACTIOR: THAT TOOK PLACE DUP.ING COMMINUT IDN. IT IS SUGGESTFE THAT THFSE Z.FACTICNS GCCUR DUC TO SUSJECTION TO INSTANTANECUS HIGH TEMPERATURES GENEFATED EY FRICTION FETWEEN THE STECL GRINDING EALLS.

\#CHEHISORFTION + \#GRDHITE + \#HYDRDGEN + \#NITPCGEN + $\triangle D S O R P T I O N+C H E M I C A L$ REACTION

$8-22708$

GENCO JM + RAINES GE

METAL-WATEP. REACTIJNS DURING A LOSS-OF-COOLANT ACCIDENT. THE ZIPCONIUM-STEAM REACTION

BATTCLLE.MCHONIAL, INSTITUTE, CCLUMBUE, OHIQ

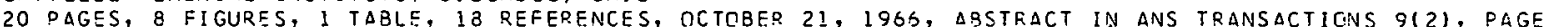
555, (WINTER 1966 ), PAPEF PRESENTEO AT, THE AMERICAN NUCLFAP SOCIETY WINTER MEET INF, CCTOOER 3O, NOVE:ABER 3. IOGK, PITT SRIIRGH, PFNNSYIVANIA

DEVELOPED A CALCULATIONAL TECHNIQUE FOR DESCRIBING ANALYTICALLY THE EXTENT OF METAL-WDTER REACTIJN THAT WOULD OCCUR IN A REACTOP CONF DURINC A LOSS-RF-COOL ANT ACCIDENT. ALTHOUGH THE ZIRCONIUM-STEAM KEACTIUN WAS CLNSIUEYEU, THIS MUDEL MAY BE APDLIEO TO ANY FUFL-CLADOING MATERIAL, DROVIDED THE APDROPRIATE CXIDATION KINETICS ARE AVAILABLE. THE MODEL IS PPEDICTED ON THE ASSUMPTION THAT THO BFCAD TYPES OF RATE-LIMITING PHENCMENA CAN REPRESENT THE MSCHANISM FOR THE OXIDATION OF ZIRCONIUM UNEER ACCIDENT CONDIT.IONS - 11 ) THE GAS-PHASE DIFFUSION OF STEAM FROM THE EULK STREAM TCWARD THE CLADDING SURFACE $\triangle N D$ (2) THE SOLID-STATE DIFFUSION GF VAFIOUS IOIJIC SPECIES THROUGH THE ZIRCON!UM DIIXIOE HRULULI INIU IHL HASL MEIAL, GUANTITATIVELY EXPRESSED AS THE PARABOLIC PATE LAW. THE APPLICABILITY OF THIS TECHNIQUE IS DEMONSTRATED USING THE LOFT FEACTCF.

\# $\triangle C C I D E N T$, LOSS DF COCLANT + *ANALYTICAL MCOEL + \#CHEMICAL KINETICS + \#MASS TRANSFER + \#METAL WATER REACTIGN + \#IRCALOY + COMPLITEP PROGEAM + HEAT TRANSFER DNALYSIS + LOFT (S-RR) + REACTOR, SAFETY EESEARCH + STFAM

$8-22711$

GENCO JM

METAL-WATER REACTIDNS

BATTELLE-MEMOR I AL INST ITUTE

2 PAGES, 5 FIGURES, NUCLEAF. MATERIALS 1011), DAGFS 32-?3 (SPRING 1967) 
SOURCES OF ENEFGY RELEASE UNDER ${ }^{8}$ ACCIDENT CONDITIONS

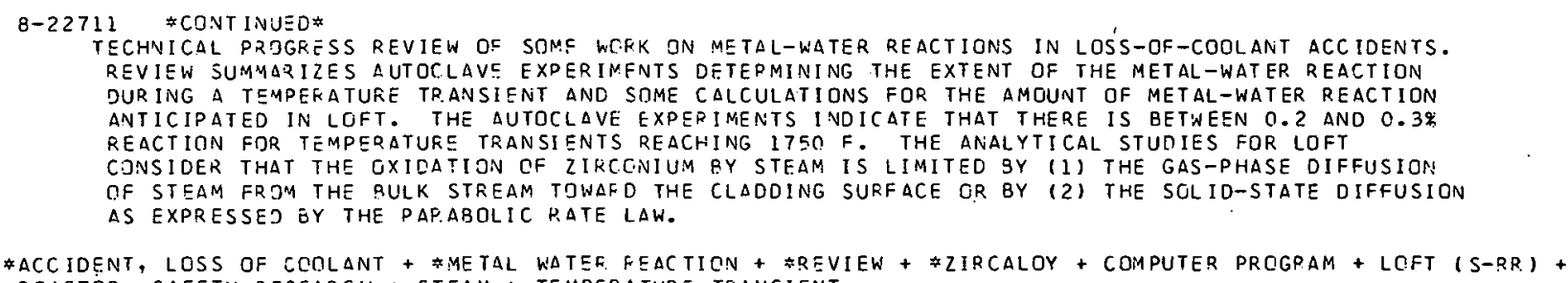




\section{SOURCES CF ENERGY RELEASE UNOER ${ }^{8}$ ACCIDENT CONDITIONS}

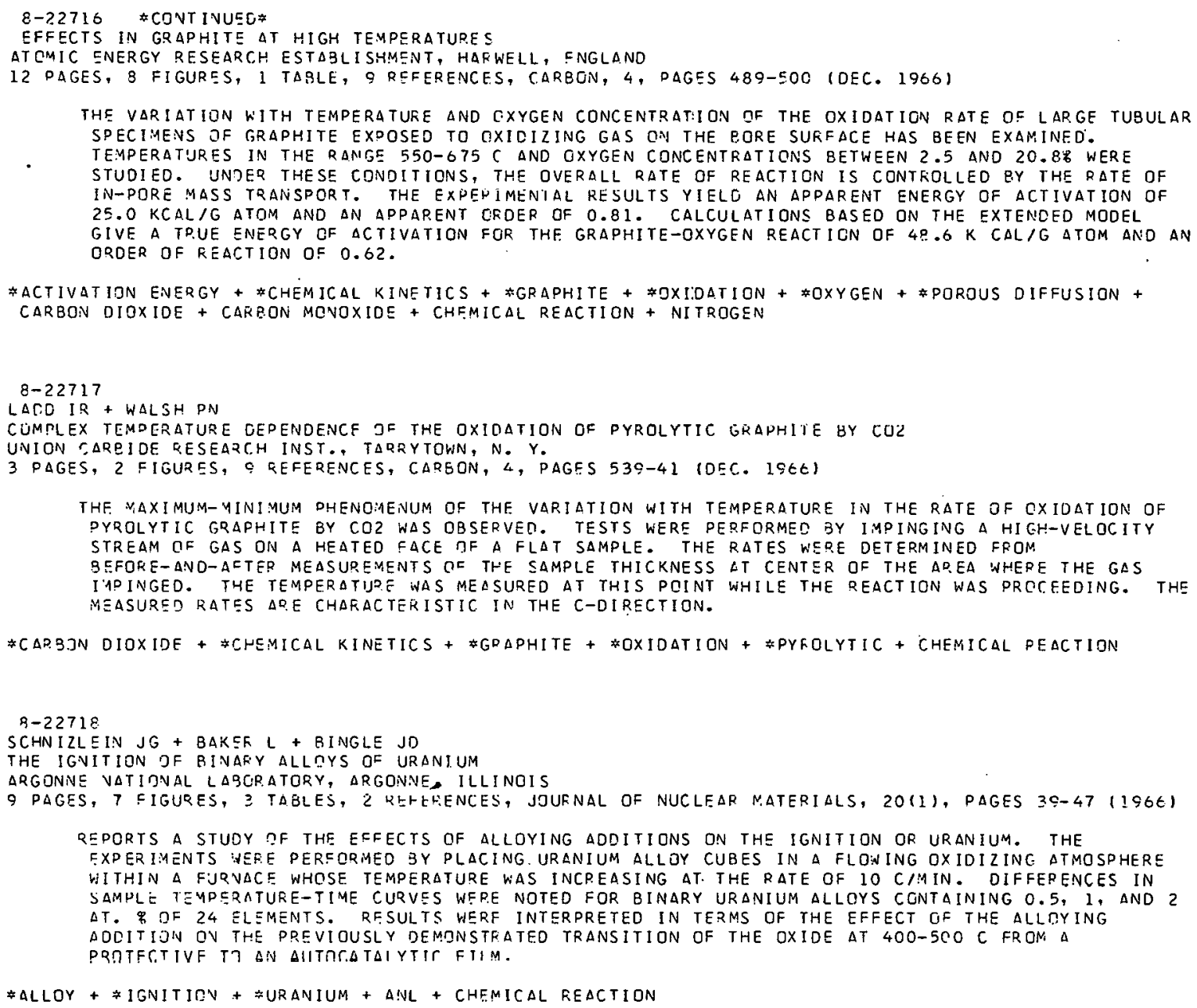

THF NAXIMUM- YINIMUM DHENOMENUM OF THE VARIATION WITH TEMPERATURE IN THE RATE OF CXIDATION OF PYROLYTIC GRAPHITE BY CO2 WAS OBSERVED. TESTS WERE PERFORMED BY IMPINGING A HIGH-VELOCITY STREAM OF GAS ON A HEATED FACE DF A FLAT SAMPLE. THE RATES WERE DETERMINED FROM. BEFORE-AND-AETER MEASUREMENTS GE THE SAMPLE THICKNESS AT CENTER OF THE AP.EA WHERE THE GAS IMPINGED. THE TEMPERATIPE WAS MEASURED aT THIS POINT WHILE THE REACT ION WAS PRCCEEDING. THE MEASURED RATES ARE CHARACTERISTIC IN THE C-DIRECTION.

*CAP. 3.JN DIOXIDE + \#CHEMICAL KINETICS + \#GRAPHITE + \#OXIDATION + \#PYFOLYTIC + CHEMICAL PEACTIDN

*aCtIVATION ENERgY + \#CHEMICAL KIVETISS + \#UFANIUM CARBIDe + \#WATFR, genERAL + CHEMICAL pEACTIGN

$8-22720$

MU FNSTER H

INVESTIGATIONS DF SDOIUM-AIR REACTIONS

ARGINNE NATIONAL. I AR.. III.

ANL-T2ANS-366 +. 8 DAGES, TRANSLATED FROM NUKLEGNIK 7 , PAGES 477-8C (1065)

SODIUM-AIP. REACTIONS (FIPES) IN CLOSEO SPACES WERE INVESTIGATED. A THEORETICAL MODEL WAS DEVELOPED AND COMDARED NITH TWD EXPERIMENTAL INVESTIGATIUNS. THE RESULTS FROM THE CALCULATIONS AGPEE WFLL WITH THE EXPFRIMENTAL DATA.

AVAILABILITY - JOHN CRERAR. LIBRAPY, 35 WEST 33F.D ST. , CHICAGO, ILLINOIS, \$1.10 COPY, \$O.80 MICROFICHE *AIR + *COMBUSTION + *COMPARISON, THEORY ANO EXPEPIENCE + \#FIRE + \#SODIUM + ANALYTICAL MCOEL + CHEMICAL REACTIOV + GEFMANY + METAL, LIGUIO 
SQURCES OF ENERGY RELEASE UNDER ACCIDENT CONDITIONS

$8-22722$

DAVIES RA + BRAY JA + LYONS JM

CORROSION IF STSELS IN THE VICINITY OF A SODIUM WATER FEACTION

UNITEO KINGDOM ATOMIC ENERGY AUTHORITY

SM-85/15 +. 14 PAGES, 2 TABLES, 4 FIGURES, PRESENTED AT IAFA SYMPOSIUM ON ALKALI METAL COOLANTS, CORROSIJN STUDIES AND SYSTEM OPERATING FXPERIENCF, VIENNA, 28 NOVEMBEF - 2 DECEMBER 1966

INVESTIGATED THE THINNING OF WATER TUBES DUF TO SODIUM-WATER REACTIONS IN THE VICINITY OF A LEAKING WATER TUBE IN A SODIUM-WATER HEAT EXCHANGER. TESTS SIMULATING A DOUBLE-ENDED FAILURE AND SMALL LEAKS IN A WATER TUBE WFFE MADE IN A MODEL HEAT EXCHANGER. OTHER SMALL TESTS

SIMULATING S.1ALL TUBE LEAKS WERE PERFURMED. WASTAGE OF THE ADJACENT TUBES.APPEARS TO BE a DIRECT RESULT OF THE CONDITIONS DUF ING THE METAL-WATER REACTION. THESE INCLUDE THE DIPECTIGN OF THE WATER/STEAM JET FROM THE LEAKING TUBE, DISTANCE OF THE $\triangle$ DJACENT TURE FROM THE LEAKING TUBE, AND THE NUMBEP. DF TUBES FAILING AS A RESULT OF THIS LEAK GR BREAK.

- AVAILABILITY - INTERNDTIONAL ATOMIC ENERGY AGENCY

*CORROSION + \#FAILURE, TURING + \#METAL WATEP. REACTION + \#SODIUM + CHEMICAL REACT ION + HEAT EXCHANGER + METAL, LIQUID + STEEL, STAINLESS

$8-22723 \quad$ ALSO IN CATEGORY 5

ARGONNE NATIONAL LABRRATORY. CHEMICAL ENGINEERING DIVISION RESEAPCH HIGHLIGHTS. MAY 1966 - APEIL I967 ARGONNE NATIONAL LABQRATORY, ARGONNE, ILLINOIS

$A N L-7350+111$ PAGES, TABLES, FIGURES, REFERENCES, APRIL $19 \in 7$

SLMMARY OF AIVL REACTOR SAFETY PROGRAM FOE THE PERIOD MAY 1966 THROUGH APRIL 1967 . THIS PPOGRAM IS NOW CONCENTRATED TO (1) STUDIFS RELATING TO THERMAL (WATER-COOLED) REACTORS, AND (2) STUDIES RELATING TO FAST (SDDIUM-CDOLED) REACTORS. ITEM-1 EFFORTS ARE DIRECTED TO ANALYTICAL STULIES CONSIOERING THE METAL-WATER REACTION, COKE HEATUP, AND FUEL FAILURE IN LOSS-OF-COOLANT ACCIDENTS, AND TO EXPEPIMENTAL STUDIES CDNSIDERING THE HEATUP AND. MELTDOWN OF ALUMINUM-CLAD FUEL PLATES ANE ZIRCALOY-2-CLAD UO2 FUEL RODS IN LOSS-OF-COGLANT AND NIJCLEAR-EXCURSION ACCIDENTS. ITFM-2 .EFFORTS ARE DIRECTED TO STUDIES DF THE HIGH-TEMPERATURE PHYSICAL AND TRANSPORT PROPERTIES CF FAST REACTOR FUEL MATERIALS, ENERGY TRANSFER FROM HIGH-TEMPERATURE FUEL MATERIALS TO LIQUID SODIUM AND THE SODIUM-AIR REACTION.

AVAILABILITY - CLEAR INGHOUSE FOR FEDERAL SCIENTIFIC AND TECHNICAL INFORMATION, SPRINGFIELD, VIRGINIA \$3. OO COPY, $\$ 0.65$ MICROFICHE

\#ACCIDENT, LOSS OF COCILANT + \#ACCIDENT, REACTIVITY + \#ALUMINUM + \#ANALYTICAL MODEL + \#CHEMICAL REACTION + * FUEL :MELTOONN + \#HEAT TRANSFER EXPERIMENT + \#PROPERTY, PHYSICAL + \#SGOIUM + \#TEMPERATURE TRANSIENT + *URANIUM OIOXIOE + \#ZIFCALUY + ACCIDENT MODEL + AIR + ANL + COMPUTER PROGRAM + HEAT TRANSFER ANALYSIS + HEAT TRANSFER, BIILING + IN PILE EXPERIMENT + OXIDATION + STEAM + TREAT (PRR)

$8-22821$

GENCO JM

METAL-WATER REACTIONS

BATTFIIF MFMRRIAI INSTITIITF

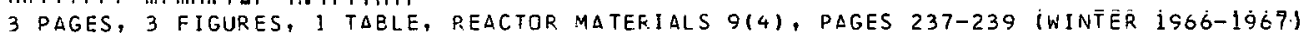

TECHNICAL PROGFESS REVIEN OF WORK ON METAL-WATER REACTIONS. EXPERIMENTS OETERMINING THE RATES OF THE STAINLESS-STEEL/STEAM PEACTION FÜR TEMPERATURES BETWEEN 1000 ANO 1250 C INDI'CATE THAT THE REACTION RATES AFTER AN INDUCTION PERIOD CDULD BE CORRELATED BY THE PARABOL IC LAW. SIMPLIFIED CALCULATIONS OF THE ANTICIPATED METAL-WATER REACTION IN LOFT SHOW THAT.IT IS LESS WHEN STAINLESS-STEEL-CLAD FUEL PINS ARE USED INSTEAD OF ZIRCALOY-CLAD FUEL PINS. TREAT EXPERIMENTS SIMULATING THE LOSS-OF-C.OOLANT ACCIDENT CONDITIONS FQR ZIRCALOY-CLAC UOZ FUEL PRODUCED 40\% METAL-WATER. REACTION. TP.EAT EXPERIMENTS SIMULATING NULLEAR-PUWER-EXCUUSION CONDITIONS FOR VIBRATORILY PACKED ZIRCALOY-CLAD UO2 PRODUCEO THE SAME METAL-WATER REACIIUN AS IN THE PREVIOUS TESTS. FAILURE MECHANISM OF PRESSURIZED AND UNPRESSURIZED FUEL PINS APPEAR TG RE DIFFERENT, HOWEVER.

\#ACCIDENT ANALYSIS + \#CHEMICAL KINETICS + \#MFTAL WATER REACTION + \#REVIEN + *STEEL, STAINLESS + *TREAT (PRR) + \#ZIRCALOY + ANL + LOFT (S-FR) + PEACTOR, PULSEO + REACTOR, SAFETY RESEARCH + URANIUM DIQXIDE

$8-22822$

LEMMON $\triangle W$

METAL-WATER REACTIONS

BATTELLE MEMORIAL INSTITUTE

2 PAGES, Z FIGURES, 1 TABLE, REACTOR MATEFIALS 9(3), PAGE 179-180 (FALL, 1966)

TECHNICAL PROGPESS REVIEW OF ANL WORK ON METAL-WATER REACTIONS. REVIEW SUMMARIZES FURNACE EXPEFIMENTS FOF DETERMINING THE NATURE OF OXIDATION OF STAINLESS STEEL BY STEAM AT HIGH TEMPERATURES. AT $1400 \mathrm{C}$, SWELLING AND FOAMING CF THE SAMPLE PREVENTS A SIMPLE INTERPPETATION OF THE REACTOP. RATE IN TERMS OF DRIGINAL SAMPLE AREAS. THE MAJOR PART OF. THE REACTION PRODUCT APPEARS TD BE FE304, A SPINFL-TYPE CDMPOUND.

*METAL WATER REACTION + \#REVIEW + \#STEEL, STAINLESS + ANL + CHEMICAL KINETICS + STOICHIOMETRY 
CATEEREY
SOURCES CF ENFFGY RELEASE UNDER ACCIDENT CONOITICNS

$8-22923$

LEMMON $\triangle W$

METAL-WATER REACTIJNS

EATTELLE MEMORIAL INSTITUTE

¿ PAGES, 2 FIGURES, 1 TABLE, PEACTOP. MATERIALS $९(2)$, PAGE 110-111 (SUMMER 10G6)

TECHNICAL PROGFESS REVIEW OF ANL WOK ON METAL-WATCR DEACTICNS. REVIEW, SUMMARIZES TREAT EXPERIMENTS USING NINE-PIN CLUSTEPS OF STAINLESS STEEL OR ZIRCALOY-CLAO WO2 FUEL SIIBMERGEO IN WATER. THE EXTENTS OF THE MFTAL-WATER REACTION IN THESE EXPERIMENTS AGREE WITH THDSE OBTAINED IN SIMILA?. EXPERIMENTS USING A SINGLE-FUULL-PIN SPECIMEN.

*METAL WATER REACTION + \#EEVIEW + \#TREAT (PRP) + ANL + STEEL, STAINLESS + URANIUH DIOXIDE + ZIPCALGY

$8-22824$

LEMMON $A W$

METAL-WATER REACTIONS

BATTELLS AEMORIAL INSTITUTE

3 PAGES, I FIGURE, 1. TARLE, REACTOR MATERIALS 911), PAGES 41-43 (SPFING 1966)

TECHVICAL PROGRCSS PEVIEW OF ANL WOPK ON ME TAL-WATER REACTILNS. HEV!EW COVERS (I) FURNACE EXPEFIMENTS INVESTIGATING THE GEHAVIOC CIF STAINLESS-STEEL- AND ZIRCALOY CLAD UOZ FUEL PINS IN LOSS-OF-CCOLANT ACCIDENTS, (2) SIMPLIFIEO CALCULATIONS FOR THE ANTICIPATED METAL-WATEO REACTION IN LCFT HITH ZIQCALCY-CLAD FUEL PINS, SHOWING THE IMPORTANCE OF THE STEAM FLOW THROUGH THE QEACTOR CORE, (3) KINETICS OF THE FEACTION OF STEAM WITH SEVFRAL REFFACTOFY MATFRIALS, (4) SQME WOOK ON THE RFACTION CF STAINLESS STEEL WITH STEAM, ANO (5) FESULTS CF ALUMINUM-NATES PEACTION USING LASEF-BEAM TECHNIQUES.

\#CHEMICAL KINETICS + \#METAL WATEP FEACTION + \#REVIEW + ACCIDENT ANALYSIS + ACCIDENT. LCSS CF COCLANT + ALUMINUIM + ANL + HETAL, REFRACTORY + STEEL, STAINLESS + ZIRCALOY

$8-22834$

POESCHEL $5+$ SKOUTAJAN F.

EXPER IMENTAL INVESTIGATION BF CHEIAICAL DEACTIONS OF URANIUM, URANIUM OIOXIDF, ANO URANIUM CAPRIDE WITH AIR ANO WATER VAPOR IN THE TEMPERATURE RANGE FROY 600 TO $1300 \mathrm{C}$.

BATTELLE INSTITUT. . ., FRANKFURT AM MAIN, WEST GERMANY

BMWF-FBK-67-13 .. 112 PAGES, FERRUARY $19 E 7$, IN GERMAN

THE CHE:AICAL REACTICNS OF UGANIUM, URANIUM DICXIDE, AND URANIUM CARBIDE WITH AIR AND WATEO IN THE TEMPERATURE RANGE OF tOO TO 13 OC C WERE INVESTIGATED EXPEEIMENTALLY. THESE REACTIONS WERE STUDIED THERMOGRAVIMETR. ICALLY AT O2 OR H20 PARTIAL PRESSURES OF O.I TO 1 ATM, RESPECTIVELY, ANO A TOTAL PRESSURE OF I ATM. FOR U/AIR AND UCIAIR, A LINEAR TINE LAH NAS HUUNO, FOR U/HZCIGI A PARAQOLIC LAM, AND FOR UD2/H2OIG) A PAPAPCLIC OG A LINEAR LAW, DEPENDING ON THE TEMPERATURE. NO REACTION WAS OBSERVEO FOF UOZ/HZD(G) DURING BRIEF PER ICOS. THAT OF UC/HZO(G) DEPENDED ON THE STCRAGE TIME. THE ACTIVATION FNEPGY FOR U/AIF AMOIJNTS TG $6.4 \mathrm{KCAL/GP.AM-ETCM,} \mathrm{THAT} \mathrm{OF} \mathrm{UO?/AIF,} \mathrm{TO} 7.0$ AND $23.6 \mathrm{KC.AL/MOLE} \mathrm{IN} \mathrm{THE} \mathrm{VMLICITY} \mathrm{RANGE} \mathrm{OF} \mathrm{THE}$ LINEAR AND THE PARABOLIC TIME LAWS, RESPFCTIVELY, AND TO 15.6 TO 28.9 KCAL/GRAM-ATOM FDK $U / H 2 O(G)$.

AVAILABILITY - MICROCARD EDITIONS, INC, (FDR SALE), ACCOUNTING ANO SHIPOING DEPALTMENT, WEST SALEM, WISCONS IN

\#AIR + \#CHEMICAL DEACTICN + FURANIUM + FULANIUM COREIUE + FURANIUM OICXIDE + ACTIVATION ENERGY + CHEMICAL KINETICS + GERMANY + WATEF VAPCR

$8-22935$

HENZEL N + KLEINE-TSPQE

EXPEPIMENTAL INVESTIGATION QF CHEIIICAL PEACTIONS OF URANIUM, URANIUM DIOXIDE, AND URANIUM CARBICE WITH AIR

AND NATER VADOR IN THE TEMPEDATURE R.ANGE BEISFEN 1000 AND $3200 \mathrm{C}$

PATTELLE INSTITUT E.V., ERANKFURT AM MAIN, WEST GERMANY

BMWF-F SK-67-1? +. I?; PAGES, FESRUARY 1QE7, IN GERMAN

THE INITIAL PHASE OF THE RFACTIONS OF URANIUM, URANIUM DIOXIDE, AND URANIUM CARBIDE hITH AIR AND WATEF VAPED, I SOTHERIAALLY INVESTIEATED TO 2200 C IN THE FRAMEWORK OF A RFACTOR SAFETY PROGRAM, YIELDS U02, UC2 PLUS Y, CP U308 RESPECTIVELY. REACTICN RATE IS PROPCRTIONAL TC THE PAPTI IAL PRESSURE DF THE GAS BUT HAFDLY AFFECTED BY THE ABSOLUTE PRESSURE. AT STANOARD PSESSURE, IT IS A LINEAR FUNCTIDN OF TIME FOK SYSIEM UIAIK, FUP. DTHERS $\triangle$ HIGHER IMAXIMUM, THIRD POWER) FUNCTION. AT O.I ATM PARTIDL PRESSURE IN AEGON, LINEAR TIME CUNCT IONS $\triangle D F$ FJUND, EXCEPT FOF, UC/H2OIG) (HIGHEF, OROEQ) $\triangle N O$ U/H2O(G) (EFPATIC).

AVAILABILITY - MICROCARD EOITIONS INC. (FCR SALF), ACCCUNTING AND SHIPPING DEPAPTMENT, WEST SALEM, WISCONS IN

*AIR + \#CHEMICAL REACTION + *UIANIUM + *URANIUM CAREIDE + \#URANIUM DIOXIDE + FWATER VAPUR +

ACTIVATION ENERGY + CHEMICAL KINETICS + GERMANY + HIGH TEMPFRATURE 
SOURCES OF ENERGY RELEAEG UNDER ACCIDENT CONDITIONS

8-23160

METAL-NATER REACTIONS

BATTELLE IAEMOR IAL INSTITUTF

3 PAGES, 4 FIGURES, 1 TABLE, PEACTOS :AATERIALS 10(4), PAGE 230-232, (WINTER 1967-1968)

REVIEWS PROGR ESS CF WORK ON METAL-WATER RFACTICNS. SUMMARIZES SOME OF THE CHEMICAL KINETIC STUDIES SY ANL ON THE NICKEL-STCAM REACTION ANO BY GF-NMPO ON THE ZIRCONIUM-STEAM ANO THE STAINLESS-STEEL/STEAM FEACTIONS.

*CHEMICAL KINETICS + \#METAL WATER REACTION + \#NICKEL + \#REVIEW + \#STEEL, STAINLESS + \#ZIRCONIUM + ACTIVATIJN ENEPGY + CHEMICAL REACTION + STTAM + ZIRCALOY

8-23174 ALSE IN CATESORY 17

EXPLOSIVES ACCIOENT/INCIDENT ABSTRACTS, SEPTEMBER 19E1-JUNE 1967

ARMED SERVICES EXDLOSIVES SAFETY SOARD, WASHINGTON, D. C

$A D-6 C 0,020+.300$ PAEES, OCTOBER 1907

TO GIVE GUIDANCE TO THE INTERAGENCY CHEMICAL ROCKET PPOPULSION GRDUP IN SOLVING PROBLEMS GN THE SENSITIVITY CIF NEW PROPELLCNT MATERIALS (INITALLY N-F COMPGUNOS) ALL INCIDENTS INVOLVING RAPID SPONTANEOUS DECOMPOSITION, PFESSURE EXPLOSION, OR DETONATION WILL EE RECOROED, REPORTEO, AVD COMDILED. THIS IS APPARENTLY THE SECOND COMPILATION.

AVAILABILITY - CLEARINGHOUSE FOR FEDERAL SCIENTIFIC ANO TECHNICAL INFQRMATION, SPRINGFIELD, VA., \$3. OO COPY, \$O.65 MICROFICHE

\#EXPLOSIVE, CONVENTIGNAL + \#INCIOENT COMPILATION + EXPLOSION + INCIOENT, NONNUCLEAR

3-23340 ALSO IN CATEGDRY O

CHAMBERLAIN HV

LEAK DETECTION--SODIUM-WATER PEACTIONS

ATOMIC POWER DEVELOPMENT ASSOCIATES, INC., DETROIT, MICHIGAN

ANL-7390 + 4 PAGES, 3 FIGURES, I TABLE, I REFERENCE, PAGES 75-78 OF PROCEEDINGS OF THE SYMPOSIUM CN

LIQUID METAL INSTRUMENTATION AND CONTRDL, MARCH 2, 1967

THE PROBLEMS ASSDCIATED WITH LEAK DETECTION GF SGDIUM-WATER ARE REVIEWEO, AND FOUR METHODS FOR DEVICE DES IGN $\triangle R E$ GIVEN.

AVAILASILITY - CLEARIVGHOUSE FOR FEDERAL SCIENTIFIC AND TECHNICAL INFORMATION, SPRINGFIELD, VA., \$3. OO COPY, $\$ 0.65$ MICROFICHE

FINSTRUMENTATIJN, PRECESS + LEAK + LEAK RATE + METAL WATER REACTION

$8-23377$

SAZONOVA YV + KOMARDVA GN

PROTECTION OF BORON CARGIDE AGAINST OXIOATION AND REACTION WITH VARIOUS MATERIALS AT IZOO C IN AIR

ATMOSPHERE

8 PAGES, 4 FIGURES, 3 TABLES, 10 REFERFNCES, ZH. PRIKL. KHIM., 39 PAGES 2662-9 (OEC. 1S66)

a COMPLEX SILICO-SILICIDE-BORIDE-OXIGE COATING WAS DEVELOPED FOR PROTECTION OF 3ORON CARBIDE AGAINST OXIDATION AND CONTACT WITH QUARTZ, CORUNDUM, BEO2, AND MOSIZ AND C-FE ALLOYS IN ATMOSPHERE AT $1200 \mathrm{C}$ FOR OVER $300 \mathrm{HR}$. THE PHYSICOCHEMICAL REACTIONS TAKING PLACE BET NEEN THE SILICO-SILICIOF-BORIDE-OXIDE COATING AND ITS COMPONENTS, THE BACKING MATERIAL, AND GAS MEDIA MIRING FIISING CF THE COATING ON THE BORON C.APBIDE HAD DECISIVE EFFECTS ON THE PROCESS OF FORMATION AND PRCITECTIIN PROFEFTIES OF THE COATING.

* AIR + \#BORON + \#CAREIDE + \#CHEMILAL SEACTION + *COATING, SURFACE + CONTROL ROD + OXIDE + SILICON + USSR

$8-23435$

ANFIMOV NA

COMPUSTION OF GRAPHITE IN AN AIR FLOW AT HIGH TEMPERATURES

8 PAGES, FIGURES, REFERENCES, IZV. ZN SSSF MEKH I MASHINOSTR, 5, PAGES 3-11 (1964)

THE RATES OF REACTION OF GRAPHITE WITH AIR AT TEMPERATURES GREATER THAN 3000 K WEFE DETERMINED BY A MATHEMATICAL ANALYSIS. AT THFSE TEMPERATURES, THE REACTION RATES ARE LIMITEO BY THE RATES OF DIFFUSION OF THE VARIOUS COMPONENTS THROUGH THE BOUNDARY LAYER ADJACENT TO THE SOL ID SURFACE. IN CALCULATIAIG THE RATES, IT WAS FCUNE. THAT APPROXIMATION SCHEMES IN CALCULATING. THF. DIFFUSION CONSTANTS, SUCH AS ASSUMING THAT. THE MILTICOMPONENT GAS MIXTURE IS A BINARY GAS MIXTURE, RESULTED IN A CONSIDERABLE ERROR IN THE RATE GF GRAPHITE CONSUMPTION. HOWEVER THESE APPRIXIMATIONS HAD LITTLE EFFECT ON THE GRAPHITE SURFACE TEMPERATURE.

*AIR + \#ANALYTICAL MGDEL + \#CHEMICAL KINETICS + *CO:4BUSTION + \#GRAPHITE + BOUNDARY LAYER, REACTING + CHEMICAL REACTION + CIFFUSION COEFFICIENT + MASS TRANSEER + MATHEMATICAL STUDY + USSR 
SOURCES OF ENERGY RELEASE UNDER ACCIDENT CONDITIONS

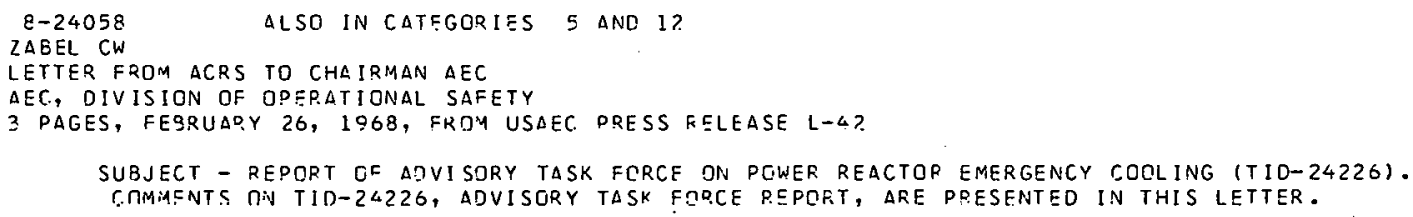


$9-17949$

BLAHO D

ELECTRONIC EQUIPMEVT FOR THE CONTROL OF A REACTOR

CESKOSLOVENSKA AKADEMIE VED, REZ. USTAV JADERNEHO VYZKUMU

UJV-1632 +. 10 PAGES, DECEMPER 1966 , IN CZECH

DEALS WITH ELECTRONIC EQUIPMENT FOR THE AUTOMATIC CONTROL AND PROTECTION OF A REACTOR WITH MOVING DETECTING ELEMENTS. THE. EQUIPMENT PROCESSES THE PULSES FROM THE NEUTRON DETECTOR AND SUPPLIES THE GUTPUT SIGNALS FOR THE CONTFOL OF THE REACTOP AND THE PISITIONS OF THE DETECTING ELEMENTS. THE ELECTRONIC EQUIPMENT CONSISTS OF A LINEAR PULSE AMPLIFIER, A PULSE DISCR IMINATOR, A LINEAR AND A LOGARITHMIC COUNTING PATE METER, A COMPARISON CIRCUIT ANO PROTECTING CIRC.UITS.

AVAILABILITY - MICROCARD EDITIONS, INC. (FOR SALE) ACCOUNTING ANC SHIPPING DEPARTMENT, WEST SALEM, WISCONSIN 54669

INSTRUMENTATION, LINEAR + INSTRUMENTATION, LOGARITHMIC + INSTRUMENTATION, PULSE +

INSTRUMENTATION, RATE OF CHANGE + REACTOR CONTROL + REACTOR SAFETY SYSTEM

$9-20638$

MCCARTHY WJ + JENS WH

ENRICO FERMI FAST BREEDER REACTOR

POWER REACTOR DEVELOPMENT CO. + $\triangle$ TOMIC POWER DEVELOPMENT $\triangle S S O C I A T F S$, INC.

4 PAGES, NUCLEAR NEWS $10(11)$, PAGE 54-57, (NOVEMBER 1966 )

SHORT DISCUSSICN OF CUFPENT STATUS, MOSTLY WHAT HAS BEEN LEARNED. AN INLET STRAINER,

CORE-PLATE STANDOFF PINS, OR PROVISION FOR CROSS FLON WOULD HELP ELIMINATE FUTUFE MELTDOWNS. REACTIVITY RATE-DF-CHANGE INFORMATION AND A FASTSR FISSION-PROOUCT MONITOR IOELAYED NEUTPONS

AT CORE EXIT TO SUPPLEMENT PFESENT SENSITIVE COVER-GAS AS DETECTOR WITH 13-MIN TRANSPORT LAGI

IS NEEDED. FEW PROVISIONS WERE MADE FOR INCIIIENT RECOVERY, E.G., DIFFICULT ACCESS TO WHOLE

CORE, NO PROVISION FOR DRAINING VFSSEL DR FOR ON-SI:TE. INSPECTION OF IRRADIATED FUFL.

*FLOW BLOCKAGE + FUEL MEL TOOWN + \#INCIDENT, GENERAL + FERMI (LMFBR) + FUEL HANDLING MACHINE + INC IDENT, RECOVERY FROM + INSTR UMENTATION, DETECTION FAILED FUEL ELEMENT +

INSTRUMENTATION, OPEPATING REACTIVITY + OPEPATING EXPERIENCE SUMMAPY + REACTOR, LMCF +

REMOTE MANIPULATING AND VIEWING

9-20708

EILLETFR TR + BROWN OP

MICROWAVE TECHNIQUES FOR REACTOR INSTPUMENTATION

BATTELLE NORTHWEST LAS.

16 PAGES, 8 FIGURES, 4 REFERENCES, ABSTRACT IN ANS TPANSACTIONS 10(2), PAGE 637, (NOV. 9, 1967), PRESENTED

AT 1967. WINTER MEET ING OF THE AMERICAN NUCLEAR SOCIETY, CHICAGG, ILLINOIS, NOVEMBER 5-S, I967

THEORETICAL INVESTIGATICNS AND EXPERIMENTAL WORK REGARDING NEH AND PROMISING SENSOFS AND INSTRUMENTATION FOR HIGH-FLUX HIGH-TEMPERATURE REACTORS ARE BEING CONDUCTED. MICROWAVE TECHNIQUES AND IN-CORE SENSORS WHICH MEASIIRF THFRMAL-NEUTRON FLUY DENSITY, REACTOR TEMPERATURE, AND COOLANT-GAS IMPURITIES HAVE EXHIBITEO PROMISING, CHARACTERISTICS. FOR MEASUREIAENI IELHNIQUES, THE DEVIATION OF THE P.ESONANT FREQUENCY OF A MICROWAVE CAVITY IS RELATED TO THE MONITORED QUANTITY.

*COMPARISON, THEORY AND EXPERIENCE + \#INSTRUMENTATION, IN CORE + FLUX, INTEGRATED + HIGH TEMPERATURE + INSTRUMENTATION, COOLANT QUALITY + INSTRUMENTATION, NUCLEAR + INSTRUMENTATION, TEMPERATURE + MEASUREMENT, TEMPERATURE + PADIATIINN EFFEGT + THEPMAL NEUTRON

Q-20709

ALSO IN CATEGORY 17

CALLEN RC + PROUTEAULP + FRIEDLAND AJ

RESPONSE. OF FERMI FUEL SUBASSEMBLY OUTLET THERMOCOUPLES UNDER NORMAL AND FUEL-FAILURE CONDITIONS ATOMIC POWER DEVELOPMENT ASSOCIATES, INC. + ELECTRICITE DE FRANCE

2 DAGES, ANS TRANSACTIONS $10(2)$, PAGE 637 AND 632 , (NOVEMBER 9, 1967), PRESENTED AT THE 1067 WINTER

MEETING OF THE AMERICAN NUCLEAR SOCIETY, CHICAGO, ILLINOIS, NOVEMBER 5-9, 1967

HIGH-POWER TESTS INCLUDED MEASUREMENT OF CORE AND INNER RADIAL BLANKET LOCAL COOLANT OUTLET TEMPERATURES TO DETERMINE STATIC THERMAL RESPONSE. RESPONSE OF THE TEMPERATURE INSTRUMENTATION WAS EXAMINED IN I SOTHERMAL TESTS. REACTOR POWER AND ELECTROMAGNETIC FLOWMETERS WERE CALIBRATED DURING HEAT-BALANCE MEASUREMENTS GN THE STEAM-FEEDWATER SIDE OF THE STEAM GENEPATORS.

* INSTRUMENTATION CALIBRATION + *TEST, INSTRUMENT RESPONSE + COMPARISON, THEORY ANO EXPER IENCE + FERMI (LMFBR) + INSTRUMENTATION, FLOW + INSTRUMENTATION, POWER RANGE + INSTRUMENTATION, TEMPEPATURE + OPERATING EXPERIENCE SUMMARY + REACTOR, FAST + REACTCR, LMCR 
CATEGOPY,
NUCLEAR INSTRUMENTATION, CONTROL, ANO SAFETY SYSTEMS.

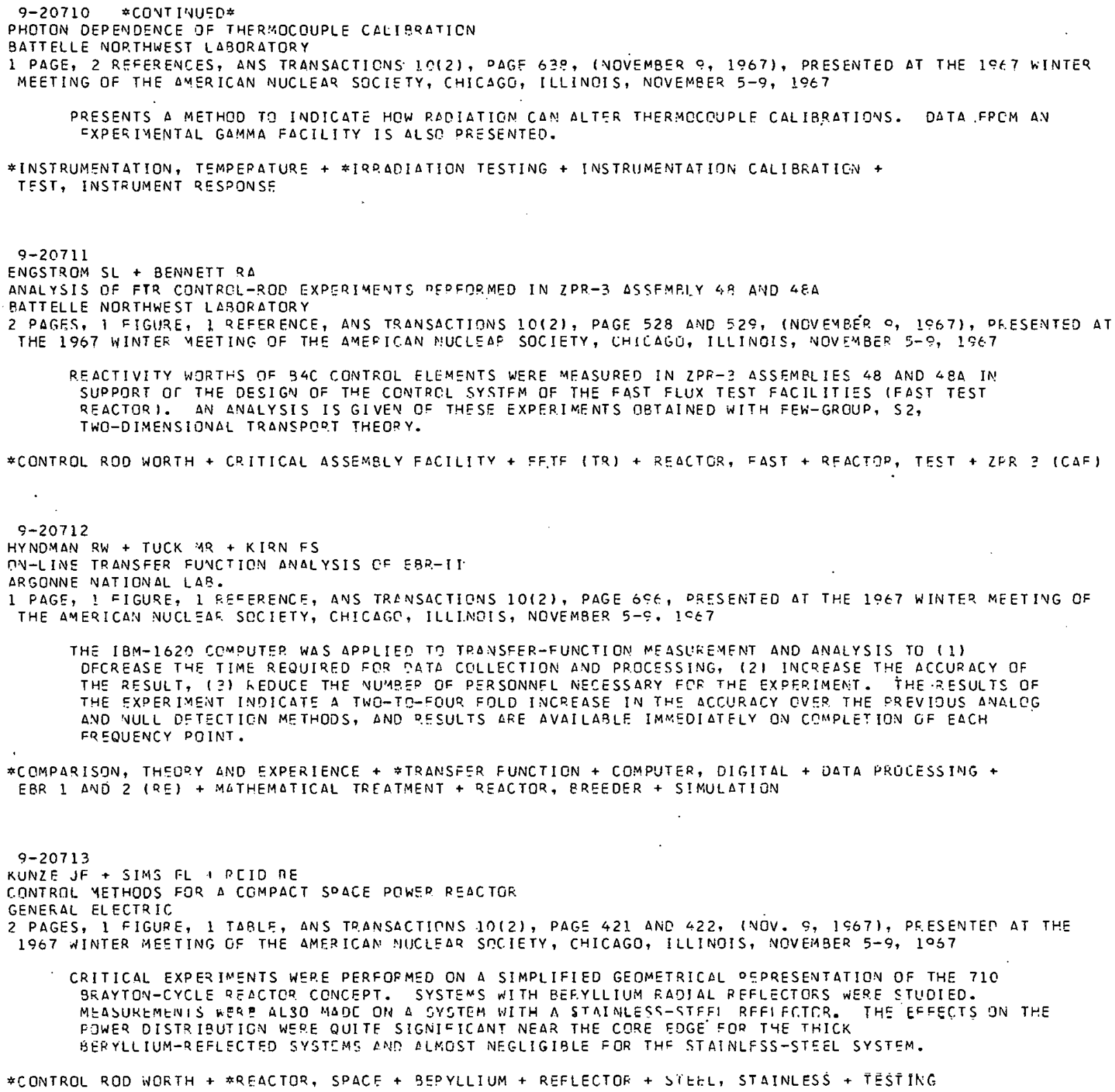

\#CONTROL ROD WORTH + \#REACTOR, SPACE + BEPYLLIUM + REFLECTOF + SIETL, STAINLESS + TESTING

$9-20714$

PEDR.SON CV

DEVFLOPMENTS IN THE ELIMINATION OF GORON LQSS DURING FABRICATIGN CF STAINLESS-STEEL-UQ 2 CERMET FUEL ARGONVE NATIONAL LAB.

2 PAGES, 4 REFERENCES, ANS TFANSACTIONS 1C12), PAGE 481 AND 422, (NCVEMEER 9, 19E7), PEESENTED AT THE 1067 WINTSR MEETING OF THE AMERICAN NUCLEAP, SECIETY, CHICAGO, ILLINOIS, NOVEMBER 5-0, 1967

TWO ILLHNIUUES FOR PPEVENTING LOSS GF EORGH WEFE INVESTIGATFR. THE FIRSI INVÖLVEO THE USE OF A CHROMIUM CAFRIDE AND NICSIUM BAPRIER COATING $\triangle N D$ RESTFICTING FABRICAT ICN TEMPEFATURES TO LESS THAN $1175 \mathrm{C}$. THE SECOND USED BOROSILICATE GLASS BE DDS CISHEKSEU THROUGHOUT THE CERMET. IRRADIATION TESTING OF FUEL-PLATE SAMFLES DEMONSTRATED THAT THESE MATERIALS NOULE PERFODM WELL UNDEQ. AARE CONDITIONS.

\#CONTROL ROD FABRICATIDN + AARR (RR) + BCRON + FUEL ELEMENT + PUISCN, BURNABLE + REACTCF, RESEAPCH 
CATEGORY
NUCLEAR INSTRUMENTATION, CONTROĹ, AND SAFETY SYSTEMS

Q-20715 \#CONTINUSD*

SUPERIOR IRRADIATION PERFORMANCE OF STAINLESS-STEEL CERMET FUFL PLATES THROUGH USE OF LOW-DENSITY UO 2 I DAHO NUCLEAR CORO.

1 PAGE, 2 REFERENCES, ANS TRANSACTICNS $10(2)$, DAGE 482 , (NOV. 9, 1967), PRESENTED AT THE 1967 KINTER

MEETING OF THE AMER ICAN NUCLEAR SOCISTY, CHICAGO, ILLINOIS, NOVEMBER 5-9, 1967

\begin{abstract}
IMPROVEMENT IV CORE LIFETIME OF UO2 STAINLFSS-STEEL CERMET FUEL PLATES WAS PREDICTED THROUGH USE OF AN I DEAL OISPERSION AND ELIMINATING FUEL-PARTICLE STRINGER ING AND FRACTURING. IRRADIATION TESTING IN SUPPOPT OF THE ARGONNE ADVANCE RESEARCH REACTOR HAS SHOWN THAT THE UOZ FUEL-PARTICLE DENSITY IS ALSO DF MAJOR. IMPOFTANCE IN PPOLONGING FUEL OPERATING LIFE. THIS WAS DETERMINCO SY IRRADIATION AND EVALUATION OF CERMET FUEL PLATES MADE FROM A SINGLE BATCH OF UI 2 BY TWO DIFFERENT FUEL FABRICATORS, USING DIFFEPENT PROCEDURES. THE PLATE WITH MOFE STRINGEFING AND PODRER FUEL DISPERSION, BUT WITH LOWER AS-FABRICATED FUEL-PARTICLE DENSITY, EXHIBITEO THE SUPERIOR PERFORMANCE.
\end{abstract}

AAPR (RR) + CONTROL FOO FABRICATION + FUFL ELEMENT + IRRADIATION TESTING + REACTOR, RESEARCH + STEEL, STAINLESS + URANIUM. OXIDE

$\mathrm{S}-20803$

DEVELOPMCNT OF A ETREN CINCENTRATION METES. QUARTERLY PROGRESS REPORT FOR THE PERIOD ENDING JANUARY 3I, $1 \% 67$

WESTINGHOUSE ELECTRIC CORP., PITTSBURGH, PA.

WCAP-3600-2 + EURMEC-1.778+56 PAGES, FIGURES, TABLES, FEBRUARY 1967

THIS DROGRESS REPGRT IS ONE OF A SEPIES. THE OVERALL OBJECTIVE OF THE PROGRAM IS TO DEVELOP, OESIGN, TEST, ANO EVALUATE THE PERFCRMANCE OF A. PROTOTYPE BOFON-CONCENTRATION METER. THE METER SHOULD BE SUITABLE FOR AUTOMATED USE IN DETERMINING BOPON CONCENTRATIONS IN THE COCLANT OF A CLOSED-CYCLE, WATER-MODERATED AND COOLED POWER REACTOR. THE DESIGN OBJECTIVES FGR THE BORON YETER INCLUDF A PRECISION OF PLUS OR MINUS $0.3 \%$ OR 2 PPM (WHICHEVER IS GREATER) ANC A RESPONSE TI AE CF ABOUT I MIN. NO FURTHER REPORTS IN THIS SERIES WILL BE SUMHARIZED UNLESS A . SIGNIFICANT CHANGE. IN THE PROGRAM OP. A SIGNIFICANT ITEM OF INTEREST TO NSIC IS PEPURTED.

AVAILABILITY - CLCARINGHOUSE FOR FEDERAL SCIENTIFIC AND TECHNICAL INFRRMATION, NATIONAL BUREAU CF STANDARDS, U.S. DEPT. GF COMMERCE, SPRINGFIELD, VA., \$3.00 COPY, \$C.65 MICROFICHE

COOLANT JUALITY + INSTRUMENTOTION, COOLANT QUALITY + INSTRUMENTATION, SURVEILLANCE

9-2099? $\quad \triangle L S O$ IN CATEGORY IE

USF OF DART LENGTH AESOFEEP. RODS IN WESTINGHOUSE PRESSURIZED WATER PEACTDRS

PACIFIC GAS AND ELECTEIIC CO.

WCAP-7072 +. 24 PAGFS, 11 FIGURES, AMENDMENT 1 TO $\triangle P P L I C A T I O N$ FOR LICENSE IFIRST SUPPLEMENT TO DIABLO CANYJN DRELIYINARY SAFETY ANALYSIS REPORTI, JUNE 1967, DOCKET 50-275, TYPE--PWR, MFG.--WEST, AE--PG+E

THE PART-LENGTH RODS, PRDVIDED IN ACDITION TG THE NORMAL CONTROL-ROD SYSTEM, ARE FOR SHAPING THE AXIAL DDWER CISTRIBUTIJN AND CONTROLLING AXIAL XENON OSCILLATIONS. 8 RODS ARE TO BE USED.

AVAILABILITY - US̈AEC DUGLIC DGCUMENT ROOM, WASHINGTON, D. C.

*CONTROL ROO + POWER DISTRISUTION + XENON OSCILLATION

$0-21225$

JACKSON CN

REACTOR IN-CORE FEGENERATIVE NEUTRON DETECTORS INTEFIM DEVELOPMFNT REPORT

BATTELLE NORTHWEST, PACIFIC NORTHWEST LAB., RICHLANO, WASHINGTON

BNWL-430 +. 20 PAGSS, 7 FIGUFES, 2 TABLFS, 6 REFERENCES, DCTOBER 1967

DEVELOPMENT DF REGENERATIVE U-234, U-235 NEUTRON FLUX DETECTORS IS BEING CCNDUCTED.

APPROPRIATE COMBINATIONS DE THE ISOTOPES ARE USED SUCH THAT THE FERTILE ATOMS TPANSMUTE, BY ABSORPTION OF THERMAL NEUTRONS, TO FISSILE ATOMS AT ABOUT THE SAME RATE AS THE FISSILE MATERIAL DFPLETES. THUS, LONG-TERM DETECTIGN SENSITIVITY REMAINS RELATIVELY CONSTANT FOR EXTENDED IN-CORE EXPOSURE PERIODS.

AVAILABILITY - CLEARINGHOUSE FOR FEDE?AL SCIENTIFIC AND TECHNICAL INFORMATION, SPRINGFIELD, VIREINIA, $\$ 3.00$ COPY, \$0.65 YICFCFICHE

\#EQUIPMENT DESIGN + \#INSTRUIMENTATION, COMPONENT + \#INSTRUMENTATION, IN CORE + FLUX, INTEGRATED +

IN CORE MEASUREMENT + NEUTRON + TEST, INSTRUMENT RESPONSE

$S-21229$

POPPEQ GF + LIPINSKI WC + HARFER JY

WIDE-RANGE COUNTIIVG-CAMPBELLING NEUTRON-FLUX DETECTION SYSTEM

ARGONNE NATIONAL LABOP. ATORY

ANL-7224+. 45 PAGES, 7 FIGUFES, 2 TABLES, 10 REFERENCES, $\triangle P F I L$ ICE 7

A NEUTRON-DETECTICN SYSTEM THAT USES A SINGL'́ FIXED-POSITION NEUTFON OETECTOR TO CONTINUOUSLY MONITOR UP TO TEN DECADES OF REACTGE PGWER WAS ASSEMBLEO AND TESTED. SUPERIOR GAMMA OISCRIMINATION, COMPARED NITH THAT FGP CONVENTIONAL SYSTEMS, WAS REALIZED OVER THE ENTIRE NEUTRON-FLUX FANGE. 
$9-21229 \#$ CONTINUED*

AVAILABILITY - CLEARINGHOUSE FDR FECERAL SCIENTIFIC AND TECHNICAL INFDRMATION, SPRINGFIELD, VA., \$3. OO COPY, \$C.65 MICROFICHE

COMPARISON, THEOPY AND EXPFRIENCE + COUNTEF + FLUX, INTEGRATED + INSTRUMCNTATION, CAMPBELL ING + INSTRUMENTATION, WIOE PANGE + NEUTRON

$9-21230$

STRINDEHAG

CHERENKDV DETECTORS FOR FISSION PRODUT.T MONITORING IN REACTOR, COOLANT WATER

AKT IEBOLAGET $\triangle T O M E N E R$ T, , STOCKHOLY, SWEDEN

$\triangle E-294+56$ PDGES, PEFERENCES, SEPTEMBEF 1967

THE PRTPERTIES DF CHERENKAV DETFRTORS WHEN USED FOR FISSION-PROCUCT MONITOPING IN WATER COOLED REACTORS $\triangle R E$ DISCUSSED. THE BASIC THEORY FOR CALCULATION C,F THE DETECTOR PESPONSE IS PDESTNTEO, TAKING THE CPTICAL TRANSMISSION IN THE SANPLE CONTAINER AND THE PROPERTIES OF THE DHOTOMULTIPLIER TUBE INTO ACCCUNT. SPFCIAL ATTENTION IS PAID TO THE ENERGY RESOLUTION QF THIS TYDF DF CHEFENKOV OETECTOR. FCR THF DESIGN OF PRACTICAL DETECTORS THE RESULTS FROM SEVEPAL IVVESTIGATIONS OF VARIOUS WINDOW AND REFLECTOR MATERIALS ARE GIVEN. THE SELECTION OF PHOTOMULTIOLIER TUBES IS BRIEFLY OISCUSSED.

AVAILAGILITY - CLEAPINGHOUSE FOP FE IEQAL SCIENTIFIC AND TECHNICAL INFOPMATION, SPRINGFIELD, VA., \&3. OO COPY, SU.GS MICKUFICHE

* INSTRUMENTATION, DETECTION FAILED FUEL ELEMENT + COMPARISON, THEDFY ANO EXPERIENCE + EQUIPMENT DESIGN + FISSION PROOUCT ACTIVITY, GROSS + INSTPUMENTATION, COMPONENT + INSTRUMENTATION. CODLANT QUALITY + INSTRUMENTATION, QADIATION MONITORING

$9-21231$

KRFJCI M + BLAZEK J + ZIKAN

THE DYNAMICS CF TR-O DEACTOR MODERATOP. LEVEL CONTROLLED BY C.IPCULAR OVERFLOW-ANALDGUE SOLUTION CESKOSLOVSNSKA AKADEMIE VED, REZ

UJV-1845 +. 50 PAGES, JULY 1067 , IN CZECH

A CONTREL DEVICE IN THE FORM OF A CIRCULAR VERTICALLY MOVING CVERFLOW WAS DESIGNEO TO CONTRCL THE TR-O REACTDR. BY HEAVY-WATFQ-MODERATOF LEVEL. THE DYNAMICS CF THE REACTOR HYDRAULIC SYSTEM NITH THE CONTROLLING CVERFLOW POSITIONED IN A SPECIAL AUXILIARY VESSEL IS SOLVEO VIITH AN ANALOGUE CCMPUTER. THE ESSENTIAL NONLINEARITIES OF THF SYSTEM ARE CONSIDERED. A NUMEEF OF VARIANTS IS INVESTIGATEO WHICH INVOLVE VARIDUS CHARACTERISTIC VALUES ODF THE CONTROL DEVICE.

AVAILABILITY - MICROCARD EDITIONS, INC., NCCOUNTING AND SHIPDING DFPT., WEST SALEM, WISCONSIN E4EG9

* INSTRUMENTATIJN, CONTROL + *INSTPUMENTATICN, FlOW + \#INSTRUMENTATION, LIQUID LFVEL DETECTION + REACTOR, HWR + SIHULATION

$-21232$

GRISSTM M

SOME FIRST THOUGHTS GN THE SPR-S REACTOP CONTROL SYSTEM

LAWEEVCE RADIATIOV LASOR DTORY, I IVFRMORF

UCID-15204 . 14 DAGES, AUSUS1 2, 1967

A PNEUMATIC SEPVO SYSTEM AND A GENERAL LOGIC-CONTROL SCHEME AFE PRESENTED AS A METHOD FOR CONTROLLING THE SPR-G REACTOP. SOME PNEUMATIC DEVICES UTILIZING THE TECHNIQUES GF FLUIDICS TECHNULULYY AKE EXAMINEU.

AVAILABILITY - CLEARINGHOUSE FOR FEDERAL SCIENTIFIC AND TECHNICAL INFORMATION, SPRINGFIELD, VA., \$3. OO LUHY, SÜ.BQ AICPOFICHE.

* INSTRUMENTATION, CONTRGL + CONTROL SYSTEM + INSTRUMENTATION, FLUIDICS + REACTOR CONTROL + SERVOMECHANIS:M + SPACECRAFT

Q -21233

CLARY. P.H + BAL DEIN YNA

PHYSICS VERIFICATION PROGRAM. PAGT II. GUARTEPLY TECHNICAL PIEFORT, APRIL-JUNE 1967

BAPCOCK AND WILCOX CO., LYNCHBURG, VA.

BAW-3647-5,. 27 PACES, = ICUPES, TABLES, SEPTEMBER 1967

THL BABCOCK AND WILCOX COMOANY--NUCLEAP DEVELDPMENT CENTER, QULARTERLY TECHNICAL REPORT. ONE DF A SERIES OF SIMILAR REPORTS CONCERNED WITH EXPSRIMENTS TO INVESTIGATE AND COMPARE THE FFSPRNSF C.HARACTEPISTICS OF IN-CCRE AND CUT-CF-CORE STARTUP DETECTORS FOR USE WITH LARGE PRESSUR IZEO-WATEP. REACTORS.

AVAILABILITY - CLEARINGHOUSS FOR FEOERAL SCIENTIEIC AND TECHNICAL INFORMATION, SPRINGFIELD, VA., \$3. OO CQPV, \$O.65 MICROFICHE

* INSTRUIGENTATION, STARTUP + IN CRLE MFASUREMENT + INSTRUMENTATION, IN CDRE + REACTDR, PWR + EOL IO STATE NFMITE 
MEASUREMENTS AND ANALYSIS OF REACTIVITY EFFECTS IN EMPTY CHANNELS IN A FAST REACTOR AKTIEBOLAGET ATOMENERGI, STUDSVIK, SWEDEN

5 PAGES, 7 FIGURES, 2 TABLES, 11 REFERENCES, NUKLEONIK, 10, PAGES 14-13 (JUNE 1967)

MEASUREMENTS IF NEUTRON STREAMING IN EMPTY CHANNELS AND INTFRACTION BETWEEN CHANNELS WERE MADE IN THE ZERO-ENERGY FAST REACTOR FR-G. CALCULATIONS OF THE MEASURED EFFECTS WERE MADE USING DIFFUSION THEORY WITH STREAMING-CCRRECTED DIFFUSION CONSTANTS. WHILE EXACT AGREEMENT WITH EXPFR IMENT WAS NDT ACHIEVED, THE CALCULATEO VALUES QUALITATIVELY REPRODUCE THE EXPERIMENTAL RESULTS. THE OBSERVED STREAMING EFFECTS ARE LAFGE ENOUGH TO NARRANT CONSIDERAT IDN IN CURPENT MEASUREMENTS OF COOLANT-VOID REACTIVITIFS PERFCRMED. IN FAST ZERO-ENERGY REACTORS.

* MEASUREMENT, REACTIVITY + COMPARISON, THEORY AND EXPERIENCE + REACTIVITY EFFECT + REACTOR, FAST

9-21235 ALSO IN CATEGORY 6

THREEFOLD CORRELATIONS AND THIRD ORDEP MOMENTS IN REACTOR NOISE

REACTOR CENTRUM NEDFRLAND, PETTEN, NETHERLANDS

7 PAGES, 2 FIGURES, NUKLEONIK, ID, PAGES 7-13 (JUNE 1967)

PRESENTS A THEORY FOR THE EVALUATION OF THIRD-ORDER MOMENTS OF NEUTRON COUNTS IN A REACTOR DUS TO THREEFOLD COREELATION OF THE DETECTED NEUTRONS. POINT REACTOF THEOP.Y IS USED THROUGHOUT. THE PROBABILITY FOR DETECTION OF THREE NEUTRONS IN SUCCESSION IS FOUND, AND FROM THAT THE CENTRAL MOMENTS OF THE NUMBERS DF NEUTRON COUNTS IN SPECIFIFD TIME INTERVALS ARE CALCULATED, AS WELL AS THE TRIPLS AUTOCORRFLATION FUNCTION FOR THE COUNT RATE. THE THREEFOLD CORRELATIONS ARE SHOWN TO BE DUE TO TWO PRANCHING PROCESSES IN THE FISSION CHAINS IN THE REACTOR. IN THE DOMINATING AND EASILY MEASURABLE PROCESS ONLY SPLITTING OF THE FISSION CHAINS INTO TWO BRANCHES IS DETECTEO. A VARIANT OF THE FEYNMAN ALPHA TECHNIQUE IS PROPOSED FOR THE MEASUREMENT OF THIS EFFECT. IN THE OTHER PROCESS, TRIPLE SPLITTING OF THE FISSION CHAIN IS INVOLVED. THIS PROCESS CAN PROVIDE NEW PHYSICAL INFORMATION. IN PARTICULAR, REACTOR POWER AND EFFECTIVE DELAYED NEUTRON FRACTION CAN BE DBTAINED WITHOUT THE NEED FOR ANY OTHER STATIC MEASUREMENT. AN EXPEFIMENT FOR THE MEASUREMENT OF THIS EFFECT IS PROPOSED, WHICH IS SHOWN TO BE MOST FEASIBLE FOF A FAST REACTOR.

*NOISE ANALYSIS + MATHEMATICAL TREATMENT + REACTOR, FAST + ROSSI aLPHA + THEORETICAL INVESTIGATION

$0-21236$

UTSUROM + SHIBATAT

POWER NOISE SPECTRA OF A WATER REACTOK IN LOW-FREQUENCY REGION

KYOTO UNIVERSITY

6 PAGES, 8 FIGURES, t REFERENCES, J. NUCLEAP. SCIENCE TECHNOLOGY (TOKYO), 4, PAGES 267-72 (JUNE I967)

POWER-NOISE MEASUREMENTS WERE CARRIEO CUT ON THE KYOTO UNIVERSITY REACTOR. AT VAR IOUS POWER. LEVELS UNDER NATURAL CONVECTION FOR. TWO KINOS OF CORE CONFIGURATIOIV WITH OIFFERENT

TEMPERATURE COFFFICIENTS OF REACTIVITY. ANALYSIS OF. THE RESULTS REVEALED STRCNG NOISE IN THE LOW-FPEQUENCY REGION AT IIIGHER LEVELS, EVEN WITH A CORE CONHIGURAIION OF ESSENTIALLY ZERO TEMPERATURE COEFFICIENT OF TOTAL REACTIVITY.

*MEASUREASNT, NOISE + FLUCTUATION + JAPAN + NOISE + NOISE ANALYSIS

$9-21237$

KITANO

REACTOR-CONTROL OEVICE WITH CONTROL ELEMENTS WOUND AND UNWOUND

TOKYO ELECTRIC POWER CU., INC.

JAPANESE PATENT 1966-2240+. 4 PAGES, 5 FIGURES, FEBPUARY 15, 1966 , IN JAPANESE

IN THE REACTOR CONTROL DEVICE, CONTRQL ROOS WITH CONTROL ELEMENTS WOUND AND UNWWUND ARE USED. BY MEANS OF THE THIN, WIDE, AND LONG CONTROL ELEMENTS, WHICH CAN BE WOUND AND UNWOUND IN THE CONTROLLED CASE, THE NEUTRON-ABSORBING AREA CAN BE VARIED FREELY. IN AND THROUGH THE CONTPOL RCD CASE IS INSTALLED A ROTARY SHAFT. ONE END OF EACH FLEXIBLE CONTROL ELEMENT LONG PLATE IS FIXED ONTO THIS SHAFT, AND THE OTHFP. END IOR. THE PLATE ITSELF) CAN, BE DRAWN OUT OF THE CASE THROUGH THE SLIT CUT IN THE CASE WALL. THE CONTROL-ELEMENT PLATES CAN BE YAKEN CUT OP. PUT BACK IN THE CONTROLTRDD CASE.

CONTROL ROD + JAPAN + PATENT + REACTOR CONTRQL

$9-21238$

GIANNINI G + LESNONI G + PAOLETTI GM + ZAFFIRO B

THE EFFICIENCY DF THE AESORBERS IN THE LATINA REACTOR

ENTE NAZIONALE PER L ENER.GIA ELETTRICA, POME, ITALY

EUR-3487. I +. 56 PAGES, JUNE 1967, IN ITALIAN

LÓNG-TERM VARIATIONS IN THE REACTIVITY OF THE LATINA REACTOR ARE CONTROLLED EY ALTER ING THE 
$9-21238$ \#ONTINUEO*

WEIGHT AND NUMRCR OF $\triangle B$ SORBER CHANNELS IN THE CORC. THE MEASURES TAKEN AT 1100 AND ISOC MND/T RESPECTIVELY ARE DESCRIBEO. THE METHODS USCD TO ANALYSE THE EXPERIMENTAL DATA $\triangle P F F$ DISCUSSED. THE METHOC QE CALCULATING THE REACTIVITY CONTRQLLEO BY THE ARSORBERS $\triangle N D$ THF DISTR ISUTIONS OF INTEREST COR PURPOSES CF PREPARING THE EXPERIMENTAL DATA, TOGETHER WITH THE RESULTS OF THEGRETICAL AND EXPEP.IMENTAL FINDINGS, IS GIVEN.

AVAILABILITY - MICROCARE. EOITIONS, INC., ACCCUNTING ANE SHIPPING EEPT., WEST SALEM, WISCCNSIN S4EEG ACONTROL ROD + AQEACTIVITY EFFECT + AREACTOP CCNTPCL + COMPARISCN, THEOPY ANC EXPERIENCE + ITLLY

$9-21239$

CONTROL ELEYENTS FOR FAST NUCLEAR REACTORS

HITACHI LTD.

BRITISH PATENT $1,055,050+$. L PAFES, \& FIGUFES, FEQRUARY 1,1967

DESIGN OE CONTOOL ELEMENTS COMPFISING NEUTPON MODERATOR AND AFSOFBER IS OESCRIEEC. THE NEUTRON ABSOREER HAS A LAPSE NEUTRON-LBSORPTION CROSS SECTION IN THE INTEFHEDIATE NEUTRON ENERGY DANGE IN COYRINATION WITH A LIMITED QULNTITY GF MCDEFATOR MATEFIAL FOR SLOWING DOWN FAST NEUTRONS PRGDUCED IN THE CUFL. FaST NEUTRONS ARE THUS MODEFATED AND AESORPER.

AVAILABILITY - THE DATENT OFFICF, 2E SOUTHEMPTON BUILDING, LONDON, h.C. 2, ENGLAND, SO.LC COPY \#CONTROL ROD + \#FAST AISUTPON + \#MODERATOR + JAOAN + PATENT + REACTCE, FAST + UNITED KINGOCM

$0-21240$

WILDE N + BOLAND TJ + ANDERSON SD

INGTRUMENT DEVTLDPMERT RRANCH, ANNUAL REPCFT 1 GQ

PHILLIPS PETROLEUY CC., IDAHO FALLS

IDC-17,234+. 99 PACES, 87 GIGURSS, 5 TAELES, 41 PEFERENCES, JULY 106.7

THIS REPJRT IS DNE OF A SERIES QF SUCH PEPGPTS DESCRIRING SIGNIFICANT OEVELOPIENT $\triangle C T I V I T I E S$ IN INSTRUMENTATION AT THE NATIONAL DEACTCR TESTING STATION. THE BRANCH IS CONDFISED OF THREE SECTIONS WHICH SFECIALIZE I:V CETFCTCR APFLICATIONS, SYSTEMS OEVELODMENT, AND SYSTEVS ANALYSIS. THE EIRST SECTIGN, CETECTOF DFVELOPMENT, DESCRISES THE ACTIVITIES CEGUIRING SPECIALIZEO OETECTRO OF TRANSDUCER LEVELOFMENT. THE SECCND SECTIOV APPLIES MOSE TOWARD COMPLETE MEASUPEMENT SYSTEMS OR SPECIFIC COMPONENT IMPROVEMENTS AND INCLUOES DESCEIDTIONS OF TECHNIQUES DIFECTEO TONAPD A PARTICULAR APPLICATION. THE THIRD SECTION OF THIS FEPOPT IS DIRECTED TOWAFD REDGPTING JN SOLUTIONS $\triangle V A I L A B L E$ THROUGH MATHEMATICAL MODELS $\triangle S$ AFDLIER TO SPECIFIC REACTOR DROBLEMS.

AVAILAQILITY - CLEARINGHOUSE FDR EEDEPAL SCIENTIFIC AND TECHNICAL INFCRMATION, SPRINGFIELD, VA., \$三. OD COPY, \$0.65 MICROFICHE

CONTROL, CCMPUTER + CATA PROCESSING + INSTFUMENTATION, GENERAL + INSTRUMENTATION, IN CCF. + INSTRUYENTATION, NUCLEAD + INSTRUMENTATICN, GAOIATION MONITORING + INSTRUMENTATION, SUOVEILLANCE + INSTRUMENTATION, TEMPERATURE + SIMULATION + TEST, INSTRUMENT RFSOONSE

O-21413 ALSO IN CATEGOPYY 17

INIIISN HIINTI I KHUIRTS STIIIK LONTLIIL EOIT

CONSOL IDATED EDISON COMPANY OF NEW YGRK, INC.

4 PAGES, DOCKET 50-3, TYPE--PWR, MEC--- + +W, AE--CON ED, NOVEMBER 2C, $1 c^{\circ} .7$

DURING TESTING OF THE CCNTPQL RODS DFTEE P.EFUELING, NO. 8 ROD STUCK 16 IN: FRDM FULL INSEFTICN UPPON GRAVITY SCRAM. THE CGINTRL RCO AND ASSOCIATED MECHANISMS WERE REMOVED, THE SVUBRER PISTON RFQUIRING FCPCE. A $1-1 / 2-x-1 / 4-x-1 / 4-I N$. PIECCE OF STAINLESS STEEL WAS FLUSHED FPOM THE CONTRQL-RCE POSITION. METALLEGPAPHIC AND ACTIVITY TESTS INOICATED THAT IT HLD BEEN LEFT IN THE PEACTOF. AT THF TIME OF. CONSTF.UCTICN, 5 YEARS AGO.

AVAILABII ITY - USAFS, PIIRI IC. DOCHMFNT ROMM, WASHINGTON, D. C.

\#FAILURE, SCRAA MECHANISM + \#INCIDENT, EQUIFMENT + CONTROL ROD + INCIAN DOINT I (PWR) + DEACTOR, EWR + TESTING

O-21419 ALSC IN CATEGQRY 17

HTGR CPITICAL FACILITY FEDORTS COMDONENT FAILURF IN SCPAM CIRCUIT

GIII F GFNFRAL. $\triangle T$ TMIC INC.

1 PAGE, COCKET 50-24C, NCVFMBEP. 2?, 1967

ON NEV. 1, 1967, DURING THE MONTHLY SAFETY EQUIPYENT CHECK, IT WAS DISCOVEPEC THAT THE OPTICAL METER RELAY IN THE FUEL-ELCMENT TEMPEPATURE-GFACIENT SCFAM CHANNEL WAS INOPFRATIVE. IT WAS DEPLACED BY A SPARE, ANO A TEST CIECUIT ALLEWING WEEKLY CHECKS WAS INSTALLEO. MALFUNCTISN WAS NOTED IN LOG ROCK BUT NOT Q.EPOF.TED TC AEC UNTIL NOV. $22,1967$.

AVAILABILITY - USAEC PUBLIC DOCUMENT PJCM, WASHINGTJN, D. C.

\#FAILURE, COMPONENT + \#AILUPE, SCRAM MECHANISM + CRITICAL DSSEMELY EACILITY + FUEL ELEMENT + INCIDENT, EQUIPMENT + FFACTOP., HTGP + TEMPERATUFE GRADIENT 
$5-21437 \quad A L S O$ IN CATEGQRY 17

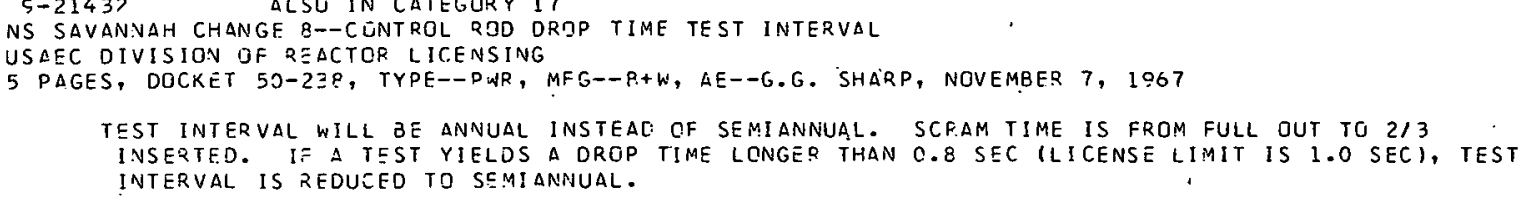

AVAILABILITY - T. LOW, CENTRAL EleCTRICITY LABORATORIES, CLEEVE, ROAD, LeATHEPHEAD, SURFY, ENGLANG EURATOM + INSTRUMEVTATION, GENEPAL + PELIABILITY DNALYSIS + UNITED KINGOOM

$9-21779$

ANDERSON JL

NUCLEAR INSTRUMENT MGOULE MAINTENANGE MANUAL. PART 12, OR GATE. ORNL MODEL Q-2612

OAK RIOGE NATIONAL LAQ., TENN.

ORNL-TM-1638(DT.12) + 13 PAGES, 1 FIGUPE, I TABLE, SEPTEMBEP 19; 1967 
NUCLEAR INSTRUMENTATIDN, CONTROĹ, AND SAFETY SYSTEMS

9-21770 *CONTINUEC*

THE OR GATE IS USED IN FEACTOR SAFETY SYSTEMS TO COMBINE SEVERAL INFOPMATICN SIGNALS OF A

SAFETY CHANNEL INTO A SINGLE-ACTION OUTPUT WHERE IT IS DESIRED TO CAUSE SAFETY ACTION WHERE ANY ONE DR MORE GF THE SEVERAL SIGMALS IS IN THE AQNORMAL OP TRIP STATE. THE CIRCUIT ACCEPTS UP TO EIGHT LCGIC OR BISTATE INPUT SIGNALS. THE CIRCUIT, APPLICATLON, MAINTENANCE

PROCEDURES, AND ACCEPTANCE TESTS ARE DESCRIBED.

AVAILABILITY - CLEARINGHOUSE FDR FEDERAL SCIENTIFIC ANO TECHNICAL INFCRMATION, SPRINGFIELD, VIRGINIA, $\$ 3.00$ COPY, \$0.65 MICROFICHE

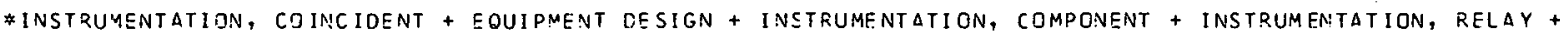
INSTRUMENTATION, SWITCH

TI IMERMANN $P$

ALSC IN CATEGORY 17

ANALYSIS OF FAILURE CATA FCR ELECTRONIC FOUIPMENT AT RISO. PERIOD 1760-1965

DANISH ATOMIC ENERGY CONMISSION, RE SEARCH ESTASLISHMENT, RISO

SUPPLEMENT TO RISO. REPOFT NO. $38+13$ PAGES, 12 TABLES, REFERENCES, APRIL 1967 , PRESENTED AT CREST MEETING, BRUSSELS

THIS SUPDLEMENTARY PADER SUMMARIZES THE FAULT STATISTICS OF FAILURE DATA FOR ELECTRONIC

EQUIPMENT AT RISO FGR THE FIVE-YEAF. PERIOD 19EO-1965. THE DATA $\triangle R E$ PEESENTED CROM A DOINT OF VIEW OF RELIABILITY PREDICTIONS. THE EQUIPMENT CDVERED RY THE REPOFTING SYSTEM CONSISTS OF (1) LABORATDRY INSTRUMENTS DESIGNED IN THE REPARTMENT AND (2) COMMERCIAL PEACTCR INSTRUMENTS BELONGING TO THE TWO RESEARCH P.EACTQP.S DR2 AND DO 3 .

AVAILABILITY - D. TIMMEFMANN, DANISH ATOMIC ENERGY COMMISSION, CENMARK

\#FAILURE, IVSTRUMENT + \#UPERAIING EXPEKIENCF SUMMARY + \#RELIAEILITY ANALYSIS + DENMARK + REACTDR, RESEAPCH + D. ISO

$9-21828 \quad$ ALSE. IN CATEGORY 17

JENSEN A RASMUSSEN + TIMMERMANN P

ANALYSIS OF FAILURE DATA FOR ELECTRONIC EQUIOMENT AT RISO

DANISH ATOMIC ENERGY CCMMISSION, RESEARCH ESTABLISHMENT, RISO

RISO REPJRT NO. $39+23$ PAGES, 13 TABLES, REFERENCES, SEPTEMBER, 1963 , PRESENTED AT CR.EST MEETING, BRUSSELS, ADRIL 1967

A FAILURE-REPOFT ING SYSTEM FOR ELFCTFONIC EQUIPMENT IS DESCRIBCO, AND FAULT DATA FOR SELECTED FI.FC.TRINIT. REACTRR INSTRUMENTS AND PESEARCH EQUIPMENT ARE PRESENTEO. SOME AVERAGE FIGURES ARE SUGGESTED FOP ROUGH PREDICTIDNS OF FAILURES IN LARGER INSTRUMENT SYSTEMS.

AVAILABILITY, JUL. GJELLERUP, 87, SOLVGADE, C.CPENHAGEN K. DENMARK

\#FAILURE, INSTRUMENT + \#OPERATING EXPERIENCE SUMMARY + \#RELIABILITY ANALYSIS + DENMARK +

DEACTOR, RESEARCH + DISD

$9-218 \geq 9$

GI ESELER H

A METHOD FRO CALCULATING RELIABILITY OF SOLID STATE REACTOR SAFETY SYSTE:1S

IECHNISCHE HOCHSCHULE MUNCHEN

EUR/C/2539/67 +. 22 PAGES, 8 FIGURES, MAPCH lSET, PRESENTED AT CREST MEETING, $A P R I L$ ISET

A MATHEMATICAL METHOD OF RFLIABILITY CALCULATIONS DF SOLIO-STATE REACTCR. SAFETY SYSTEMS IS DRESENTED. THE COMPUTATION IS POSSIBLE BY MEANS DE PROBABILITY $\triangle N D$ RELIARILITY THEOPY AND LINEAR PROGRAMMING. THE REHAVIDR OF THE SYSTEMS CAN BE OESCFIEED BY A HOMOGENECUS MARCOVIAN PROCESS.

AVAILABILITY - H. GIESELER, TECHNISCHE hGCHSCHULE MUNCHEN, geRMANY

\#REACTOR SAFETY SYSTEM + \#RELIARILITY ANALYSIS + MATHEMATICAL TREATMENT

$9-21830$

HOHMANN CL + WALSH JM + HONKA EK

LIMITERS IN NFRVA RFACTRR CONTROL

WEST INGHOUSE ASTRONIJCLEAQ LABORATCRY, FITTSBURRIH, PCNA.

6 PAGES, 8 FIGURES, 2 REFERENCES, NUCLEAP. APOLICATIONS $3(11)$, PAGES $650-564$ (NOVEMBER 1967)

LIMITER CIRCUITS, WHICH OVERRIDE SPUFIOUS SIGNALS FRON NORMAL CONTROL CIRCUITS, EPERATE WHEN THEIR INPUTS (E.G. POWEP OP TEMHEKAIURE) EXLEEU HRELEIEKMINEU SEIHUIINIS. INITIDLLY CONCEIVED AS A NECESSITY FOR NUCLEAR ROCKET FLIGHT SYSTEMS, THEY HAVE BEEN DEVELDPED SUCCESSFULLY AND HAVE BEEN SHJWN TR: BE ALVANTAGEOUS FOR GROLND TFST SYSTEMS ALSC. THUS THEY MAINTAIN VITAL SFACTOR PARAMETER.S WITHIN ACCEPTABLS LIMITS, ALLOWING THE REACTOP TO OPERATE WHILE THE DIFFICULTY IS BEING $\triangle T$ TACKED.

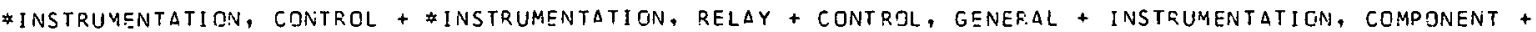
NUCLEAR RDCKET + QEACTOR CCNTROL 


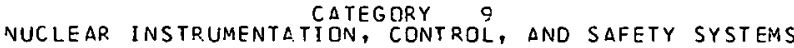

$9-21831$

CREWS RE + HOHMANN GL

NUCLEAR SUBSYSTEM CDNTROLS FOR THE NERVA EXPERIMENTAL ENGINE

WEST INGHOUSE ASTRONUCLEAR LABORATORY, PITTSBURGH, PENN.

6 PAGES, 2 FIGURES, I TABLE, REFERENCES, NUCLEAR APPLICATIONS 3(11), PAGES 653-658 (NOVEMBER 1:G7)

THE NUCLEAR SUBSYSTEM CONTROLS DESCRIBED FOF THE NERVA EXPERIMENTAL ENGINE ARE THE RESULT OF A DESIGN EVOLUTION THAT BEGAN WIITH THE KIWI TEST SERIES. THIS CONTROL-CEVELOPMENT PROGRAM HAS RESULTEO IN A CONTROL SYSTEM FOR ETS-1 IENGINE TEST STAND AT NUCLEAR ROCKET DEVELQPMENT STATIONS, JACKASS FLATS, NEVAOAI, WHICH INCLUDES NEW CGNCEPTS, SUCH AS AN AUTOMATIC STARTUP CONTROLLER ANO OVERRIDE CONTROLLERS, AND IMPROVED PERFORMANCE WHICH W'ILL FACILITATE FUTUFE ENGINE TESTING.

\# INSTRUMENTATION, CONTROL + \#NUCLEAF ROCKET + CONTPOL, GENERAL + CONTRGLLER + REACTOR SAFETY SYSTEM

$9-21832$

SPINKS N

A ELACK-WHITE MODEL FOR INCLUDING EPITHERMAL ABSGRPTION IN CALCULATION OF CONTROL-ROD WORTH AUSTRALIAN ATOMIC ENER.GY COUMISSION, RESEARCH ESTABLISHMENT, LUCAS HEIGHTS, AUSTRALIA

6 PAGES, 1 FIGURE, 4 TABLES, NUCLEAR SCIENCE AND ENGINEERING, 30(2), PAGE 176-181 (NOVEMBER 1967)

EPITHERMAL ABSGRPTION BY CONTROL RODS IN REACTORS IS TAKEN INTO ACCOUNT BY REPLACING THE BLACK-GREY-TRANSPARENT ROD SY A RLACK-TRANSPARENT MODEL. THF LETHARGY BOUNDAPY IN THE MC:DEL IS DETERMINED FOR I/V ABSORBERS BY THE PRESCRIPTION THAT, AT THE BOUNDARY, HALF THE INC IDENT PARTIAL CURRENT IS $\triangle B S O R B E D$ BY THE FOD. APPLICATION OF THE MODEL TO SPACE-INDEPENDENT SPECTRUM CALCULATIONS IMPROVES THE CALCULATION TO T.HE EXTENT THAT, PROVIDED THE BLACK-TRANSPAFENT BDUNDARY IS THE BOUNDARY BETWEEN THE GROUPS, TWO-GROUP METHODS CAN BE USED FOR CONTROL RCDS IN BARE REACTORS. FOR CONTROL RODS IN REFIECTED REACTORS, THREE GROUPS ARE INDICATED. CALCULATIONS ARE PRESENTED TG DEMONSTRATE THE ACCURACIES OF THE BLACK-TRANSPARENT MODEL AND THE SMALL NUMBER OF NIEUTPON ENERGY GROUPS.

\#CONTROL ROD WORTH + ANALYTICAL MODEL + COMPARISON, THEORY AND EXPERIENCE + MATHEMATICAL TREATMENT + THEORET ICAL INVESTIGATION

$9-21833$

ALSO IN CATEGORY 6

WILLIAMS MM

REACTOR NOISE IN HEIEROGENEOUS SYSTEMS. I PLATE-TYPE ELEMENTS

UNIVERSITY OF LONDON, ENGLAND

11 PAGES, 2 FIGURES, NUCLEAR SCIENCE AND ENGINEERING $30(2)$, PAGE 188-198 (NOVEMBER 1967 )

$\triangle$ FORMAL ISM BASED UPON THE SOLR.CE-SINK METHOD OF HORNING, FEINBEFG, AND GALANIN WAS DEVFLCPED WHICH PREDICTS THE NEUTRON NOISE SPECTRUM AND TIME-DEPENDENT COPRELATION FUNCTION IN HETEROGENEOUS PEACTOR SYSTEMS. THE METHOD IS APPLIED TO TWO PRGBLEMS IN INFINITE-PLANE GEOMETRY - THE INFINITE LATTICE AND DETECTOR PERTURBATIONS. IN THE LATTICE PRORLEM, IT IS SHOWIN THAT THE SIMPLE, HOMOGENEOUS THEORY WILL BE VALID ONLY WHEN THE LATTICE SPACING IS VERY MUCH LESS THAN THE ATTENUATION LENGTH OF A NEUTRON NAVE IN THE PURE MODERATDR. THE FLUX DFPRESSION IN THE NEIGHBORHOGD OF A NEUTRON DETECTOR IS FOUNE TO INTRMNIIC.F SIGNTFIC.ANT CORRECTIONS TO THE NOISE SPECTRUM.

\#NOISE + \#NOISE ANALYSIS + \#REACTOR KINETICS + MATHEMATICAL TREATMENT + NOISE CRDSS CORRELATION + THEORETICAL INVESTIGATION

$9-21834$

SPINKS N

AN ANALYSIS OF THE MUTUAL INTERACTION OF CIRCUMFERENTIAL CONTFOL PLATES

AUSTRALIAN ATOMIC ENEP.GY COMMISSION R.ESEARCH ESTABLI SHMENT, LUCAS HEIGHTS, AUSTRALIA

6 PAGES, 4 FIGURES, 2 TABLES, NUCLEAR SCIENCF AND ENGINEERING 30(2), PAGE 182-187 (NOVEMBER 1967)

FROM AN EMPIRICAL CHOICE JF THE SHADOWING OF ONE CONTROL-PLATE ELEMENT BY ANOTHER, EXPRESSIONS ARE OER IVED FOR THE REACTIVITY WOP.TH GF SYSTEMS OF CIRCUMFERENTIAL CONTROL PLATES. THE EXPRESSIONS CONTAIN THREE PAPAMETEPS WHICH ARE' DETERMINED WHEN INOEPENDENT CALCULATIONS GF THREE CONTROL SYSTEMS HAVE BEEN MAOE. THE PARAMETERS CAN BE EXPRESSED IN TERMS OF THE WORTH OF THE COMDLETE CONTROL OLATE, THE INCREASE IN REACTIVITY DUE TO UNSHADOWING OF AN END OF A CONTROL PLATE, AND THE DECAY CONSTANT GF THE ASSUMED EXPONENTIALLY DECAYING SHADOWING FUNCTION. APPLICATION OF THE EXPRESSIONS TO A PARTICULAR PEACTOR DESIGN, WHERE CIRCUMFERENTIAL CONTROL PLATES SEPARATE CORE FROM RADIAL REFLECTOR, SHOWS THAT THE ANALYSIS IS ACCURATE FOP THOSE SITUATIONS WHERE THE NUMBER. OF CONTROL PLATES IS NOT LARGE. THE ANALYSIS NEGLECTS NEUTRON ABSORPTICN EY THE EDGE OF A CONTPOL PLATE SO THAT IT UNDERESTIMATES REACTIVITY WORTH IN SITUATIONS INVOLVING LARGE NUMBEPS OF CONTRGL PLATES WHERE THE SURFACE AREA OF THE PLATE. EDGES BECOMES SIGNIFICANT.

*CONTROL ROD INTERACTION + MATHEMATICAL TREATMENT + THEORETICAL INVESTIGAT ION

9-21900 ALSG IN CATEGORY 1 
NUCLEAR INSTRUMENTLTICN, CONTROL, AND SAFETY SYSTEMS
NOEY,

9-21900 \#CONTINUEO*

PROPOSED STANDARD - CF. ITICALITY ACCIDENT ALAPM SYSTEM

AMERICAN NUCLEAR SOCIETY

7 PAGES, NUCLEAR ENGINEERING BULLETIN 5121 , NDVEMEER 1067

THE USEFULNESS AND PROTECTIVE FEATURFS OF TRITICALITY ALAFM SYSTEMS HAVE REEN DEMONSTRATED IN INSTANCES OF ACCIDSNTAL CRITICALITY THAT HLVE OCSURREU DUPING THE PROCESSING CF FISSIONAELE

MATERIALS. THIS STANDARD PRCVIDES GUIDANCE FCR THE ESTABLISHMENT AND MAINTENANCE OF AN ALARM SYSTEM IO INIIIAIE PEKSUNNFL EVACULTION IN THE EVENT OF ACCIOENTAL CFITICALITY. THIS

STANDARD WAS PREPARED PY WDOK-GROUP E OF SUBCOMMITTEE ANS-O CF THE STANDARDS COMMITTEE CF THE AMER ICAN NUCLEAR SOCIETY.

AVAILABILITY - AMERICAN NUCLEAR SOCIETY, HINSDALE, ILLINCIS, \$1.50 COPY

ACCIDENT, CRITICALITY + CODES ANO STANDADOS + CRITICALITY SAFFTY + ENGINEERFC SAFETY FEATUPE + PROCEDURES AND MANUALS + FADIAIIIN SAFEIY DNI CUNTRGL + TEGULATIEN, GENERAL + SAFFTY DRINC.IPIFS ANO PHIIOSOPHY

$9-21901$

MARCILLAT G

AUTOMATIC CONTROL OF NUCLEAR REACTORS

EURATIM, ISPRA, ITALY

7 PAGES, 10 FIGURES, 1 TARLE, 5 REFERENCES, ONDE ELEC, 46 , FAGFS $1237-43$ (NOVEMEEK 106E) IN EREMCH

AFTER A REVIEW CF THE DYNAMIC PROPEFTIES OF NUCLEAR REACTORS, $\triangle N D$ OFF THE CONSTPAINTS IN THE NEUTRON POWER EVGLUTIONS, A CONTFGL METHOO IS DERIVED WHICH IS VALID WITHEUT MOOIFICATICN GF COMMUTATION FOP EOTH STATIONARY ANE OYNAMICAL STATES. WITH THE AID OF A SPECIFIC CASE IT IS

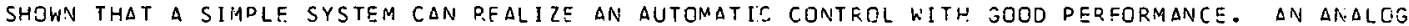
SIMULATION OF THE PLANT AND CONTRQL SYSTEM IS USED TO CEMONSTFATE THE VAL IOITY ÇE THE VAF IOLS ASSUMPTIONS AND SIMPLIFICATIONS.

* INSTRUMENTATION, CONTRGL + \#REACTOR CONTECL + COMPUTER, ANALOG + CONTFOL, GENERAL + FEANCE + SIMULATION + TRANSFER FUNCTION

$9-2 ! 902$

DOIREAU M

NUCLEAR ELECTRONICS AT THE C.E.A. - $\triangle$ CHIEVEMENTS AND PFOSPECTS

CUMMISSARIAT A L-ENERGIS ATOMIQUE

7 PAGES, 7 FIGURES, ఢ REFERENCES, ONEF, ELEC. 47, PAGFS 724-30 (JUNE 19G7) IN FRENCH

THE EXPERIENCE ACOUIGED AT THE CEA MADE POSSIBLF THE INDUSTFIAL CEVELOPMENT OF STANOADO ELECTRONIC EQUIPNIENT WHICH MEFTS THF GENERAL REQUIREMENTS DF NIJCLEAR RESEARCH CENTFPS RENATPAN BASIC PLUG-IN FUNCTICN UNITS, FAST ELECTRDNICS, AND ELECTRGNIC EGUIPMENT FOP. THF CONTROL DF REAT TRRS. AMUNF FIHC Z LCHICVFMFNTS ARE MENTIONEE THE DEVELDPMCNT OF NUELEAR DSTECTJRS, MULTIDIMENSICNAL LNALYZFFS, THE USE GF ON-LINE COMEUTERS IN CONVESTIGN WITH NUCLEAR EXPER INENTS TOP FJO CENTPALIZEG TFEATMENT PF MEASUREMENTS. BESIDES, THE CFA HAS TAKEN DART IN THE DEVTLOPMENT OF NONSPECIFIT. NUCLEAR MEASURINE INSTRUMCNTS SHCH AS CET

CSCILLOSCOPES AND PULSE GFNEFATOES.

* INSTRUMENTATION, GENERAL + \#MEASUREMENT, gENCPAL + EQUIOMENT DESIGN + FRANCE + INSTRUIGNTATION, COMPONENT + URERATING EXHEHIENEE SUMMAHY

$0-31003$

TSAPUK + IFTODE I + DOPDESKUK

NUTOMATIC CONTROL SYSTEM EOP. THF RIIMANTAN VVO-S REACTMR

5 PAGES, 3 FIGUPES, 2 ZEFEPENCES, RFY, PCUN. PHYS. 11 , PAGES $513-17$ (1CG6) IN FUMANIAN

IMPROVEMENTS AND A FURTHER DEVËLOPMENT OF A NEW AUTOMATIC CONTROL SYSTEM EOR A VVE-S $5 E A C T O P$ WERE TESTED DUF ING EXPERIMCNTLL OPELATIONS. AN AUTOMATIC UNIT CQR STANDAFD TIME FUNCTION CF ALL NORMAL REACTCR OPERATIONS PERAITTEO MEDSURING THE FXACT TINE DE MAVUAL STARTUP, THE FATE OF CONTROL-ROD MOTION CONTROLLES FY A EESOSACK CIRCUIT, THE P.SCUCED INFLUENCE OF FAST PARASITIC FLUCTUATIONS ON THE CONTPCL-FOD RATE, QEDUCEO THF NUMPFR CF ELEMENTS, AND SIMPLIFIED DPEOATING CONDITIGNS.

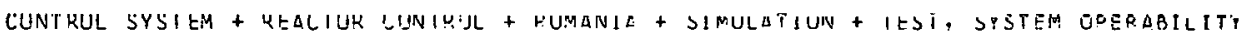

$9-21919$

DL SEN HO

THEORETICAL AND EXPER IMENTAL INVESTIGATICIN OF INPFUANCE VOIO METEFS

INSTITUTT FOR ATOMENERGI, KJCLLER, NDENAY

KR-118+. 157 PAGES, O FIGUPES, REFFPFNCES, $\triangle U G U S T$ 1SA

SURVEYS THE LITERATUFE ON THEOPIES TN THE DIELECTRIC CONSTANT IELECTRIC CONOUCTIVITY OF TWO-PHASE MEDIA). IMPFCANCE VCIS METERS LE DIFFERENT TYPES ANO NUMBEQ OC ELECTFODSS ARE CALIBRATED AGAINST A QUICK-CLOSING VALVFS SYSTEM IV AV AID-WATEF LOZP OF CHANNEL RIAMETEF $2 E$ :AM. THE IVELUENCE OE SEVERAL CAEAMETESS CN THE VOID METER REACINGS IS INVESTIGATED. THE EXPER IMENTAL FESULTS SHCW JEPFNDENCY CE FLOW DATE, ELECTRODE GEUMETRV, DNC ELOW PEGIME. FRCM EXPEQIMENTS ANO THEOESTICAL CONSIEEOATIONS, TWO ALTEGNATIVE VIIO METEF. GEOMETLIES ALE 
NUCLEAR INSTRUMENTATIONEGORY, CONTROQ

$9-21919 *$ CONTINJTO* DESCRIBED.

AVAILABILITY - CLEARINGHOUSE FOR FEDERAL SCISNTIFIC ANO. TECHNICAL INFORMATION, SPRINGFIELD, VA., \$3. OO COPY, \$O.65 MICRDFICHE

*FLOW, TWO PHASE + *INSTRUMENTATION, FLOH + COMPARISON, THEORY AND EXPERIENCE + INSTRUMENTATION CALIBRATION

$9-21920$

MCNALLY JK

GAMMA-INDUCED SENSITIVITY LOSS IN THE PRGPURTICNAL COUNTERS OF A NUCLFAR POWER PLANT

ARYY ENGINEER REACTOKS GPQUP, FORT EELVOIR̈, VA.

$A D-634621$ +. 15 PAGES, TABLES, 7 REFERFNCES, JUNE 1966

SENSITIVITY JF ROTH THE B-IO LINFT AND BFZ FILLEO PROPOPTIONAL COUNTERS DEPENDS STPONGLY UPCN THE GAMMA FLUX INTENSITY IV WHICH THE DETECTOR IS OPEQATING. LOSS OF SENSITIVITY OCCURS RECAUSE OF A C.EDUCTION IN PULSE HEIGHT AS GAMMA FLUX INCREASES. PULSES PRODUCED BY NEUTFONS AND BY GAYYA RAYS ARE EOTH REDUCED IN HEIGHT. THEREFORE, A LDW DISCRIMINATDR BIAS MAY BE USEO TO YINIMIZE SENSITIVITY LOSS WITHOUT COUNTING GAMMA PULSES.

AVAILABILITY - CLEARINGHOUSE FOR FEDEFAL SCIENTIFIC AND TECHNICAL INFORMATION, SPRINGFIELO, VA., S3. OO COPY, \$O.65 MICROFICHE

*FAILURE, INSTRUMENT + *INSTRUMENTATICN, ARNORMAL INDICATION + COUNTER + FLUX, INTEGRATED + GAMMA + INSTRUMENTATIDN, NUCLEAR + NFUTRDN + OPFRATING EXPERIENCE SUMMARY + REACTOR, MILITARY + SM I (PWP)

$9-21021$

BR $\triangle Y D E N R+B D W M A N D+M C S H E R P Y$ L

USE OF MOJS TRANSISTOFS IN SOLID-STATE RAOIATION SURVEY METERS

AR:AY ELECTRONICS COMMANO, FORY MONMCUTH, AEW JERSEY

AO-62970S + ECOM-26SI+. 13 PAGES, 3 FIGUFES, 3 REFERENCES, FEE. 1906

AN ALL SOLID-STATE SURVEY METER USING AN MOS TRANSISTIOR INSTEAD OF AN ELECTROMETER TUBE WAS DESIGNED AND CCNSTRUCTED. THE SUFVEY METER, USING ONE HIGH-MEGOHM RESISTOR, HAD TWD SCALE RANGES - 500 MR/HR AND 50 MK/HP. LCOITIONAL SCALE RANGES COLLD GE OBTAINED BY USING

ADDITIONAL HIGH-MEGOHM RESISTORS. AN $\triangle L L-S O L I D-S T A T F$ SURVEY METER OFFERS DISTINCT ADVANTAGES DVER PRESENT-DAY TUBE MONELS. LOW COST, RELIABILITYY, AND CCMPACTNESS ARE A FEW OF THE MAJOP FEATUFES. IN DDOITION, IT WILL OF POSSIELF TO INTEGPATE THE ENTIRE CIRCUIT ON A SINGLE CHIP AND ENCASE IT IN A SINGLE HEADER FRF $\triangle D D I T I O N A L$ SIZE DECREASE.

AVAILABILITY - CLEARINGHOUSE FDR FEDERAL SCIENTIFIC AND TFCHNICAL INFORMATION, SPRINGEIELD, VA., \$3. OO COPY, \$O.65 MICROFIC.HE

* INSTRUMENTATION, COMDONENT + \#INSTFUMFNTETICN, RAOIATION, MCNITORING + \#INSTRUMENTATION, SURVEILLANCE + FOUIPM: VT DESIGN + SOLID STATE DFVICE

$9-21 \% 22$

WHITE

DR IVE SYSTEM SELECTIUN HTLTQ OSCILLATORS

BATTELLE-NOR THWEST, FICHLAND, NASH.

BNWL-535 +30 PAGES, FIGURES, SEPTEMBER 1066

ELEVEN SYSTEMS WERE EVALUATED. IN THF. SELECTION OF A PONERED DRIVE SYSTEM TO MOVE AND CONTFOL THE MECHANICAL OSCILLATOR MECHANISM ECR THE HIGH TEMPERATURE LATTICE TEST.REACTOR. THE MECHANISM MOVES AND POSITIONS PEACTOR COMPONENTS INSIDE THE GPERATING REACTOR. OBJECTS WEIGHING UP TO T200 LB APE MCVED AT HIGH SPEEDS AND POSITIONED TO WITHIN TOLERANCES OF PLUS GR MINUS 0.010 IN. AN ELECTRCHYORAULIC SERVO DRIVE SYSTEM UTILIZING A SERVO VALVE WAS CHOSEN AS THE OSCILLATOR DPIVF. THARACTEPISTICS, ADVANTAGES, DISADVANTAGES, AND SCHEMATIC DIAGRAMS ARE PRESENTED AND DISCUSSED.

AVAILABILITY - CLEARINGHOUSE FOR FEDEFAL SCIENTIFIC AND TECHNICAL INFORMATION, SPRINGFIELD, VA., \$3̈. OR COPY, \$O.65 MICR.JFICHE

*INSTRUM ENTATIDN, CONTRCL + \#SERVOMECHANISM + ACTUATOR + BATTELLE NCRTHWEST + IN PILE EXPERIMENT + INSTRUMENTATIQN, COMPONENT + REACTOR, TEST

Q-21023 ALSO IN CATEGORY 11

NONDESTRUCTIVE FLAN DETECTION IN NUCLEAR PGWER INSTALLATIONS

PHILLIPS PETROLEU:A COMPANY, IOAHO FALLS, IDAHO

2 PAGES, ANS TRANSACTIONS 1011), PAGES 330-331 (JUNF 1967), SAN DIEGO, CALIF.

INVESTIGATIJNS WERE CONDUCTED INTI THF FFASIBILITY OF APPLYING ACOUSTIC PHENOMENA TO FLOW DIAGNOSTICS. THEY WERE DIRECTED LT DE VELGPING A NONDESTRUCTIVE TECHNIQUE FOR THE DETECTION $\triangle N D$ DEFINITION OF FLAWS IN THE LAFGE COMPLEX PRESSURE VESSELS AND PRIMARY SYSTEM OF NUCLEAR POWER INSTALLATIONS. THEY CONSISTEC IN APPLYING THE TECHNIQUE OF OETECTION AND INTERPRETING ACOUSTIC EMISSIONS EMANATING FROM MATERIALS UNDER APPLIED STRESS. 
9-21923 *CONTINIJED*

\#TEST, NONDESTPUCTIVE + \#TEST, PRESSURE VESSEL + FAILURE, PRESSURE VESSEL + INSTRUMENTATION, TESTING + PRESSURE VESSEL + STRESS STRAIN DATA

$9-21973$

BASTL $W$

EXPERIENCE ON ELECTRONIC AND ELECTRCMECIIANICAL CQUIPMENT IN CERMAN PEACTOR PLANTS

TECHNISCHEN HOSCHSCHULE, DARMSTADT

EUR-C-2540-57 +. 20 PAGES. 11 FIGURES, 4 REFERFNCES, APRIL 1967 , PFESENTED AT THE ENEA COMMITTEE [IN

REACTOR SAFETY TECHNDLOSY MEETING ON RELIARILITY OF ELECTRONIC EQUIPMENT AND SYSTEMS FOR NUCLELR. REACTOR

SAFETY, RP.USSELS, APRIL 1967

PRESENTS $\triangle$ REVIEW OF THE EXPERIENCE GAINED IN GERMAN POWER REACTDR PLANTS REGARDING SAFETY SYSTFMS AND THE ASSOCIATED EQUIPMFNT (CONTROL-ROD ORIVES AND CONTROL-ROD SCRAM SYSTEMS). THE EFFDFT OF SAFETY-SYSTEM OESIGNERS FOUND THEIR PRACTIICAL EXPRESSION MAINLY IN IMPRCVEMENTS OF RELAY SYSTEMS, THE MAIN IDEA EEING TO IMPFOVE OPERABILITY AND RELIABILITY OF THE PLANT WITHOUT DECREASING SAFETY. THE EXAMPLES SHOWED THAT MUCH EXPEP.IFNCE HAD BEEN GAINED FOR FURTHER DESIGN AND OPERATION CF SAFETY SYSTEMS AND CONTRCL-RCD SYSTEMS. FAULT ANALYSIS PROVED VERY USEFUL.

AVAILABILITY - W. BASTL, TECHNISCHF HOCHSCHULE MUCHEN, INSTITUT FUEF MEB- UND REgELUNGSTECHNIK, MUCHEN, $\checkmark$

\#OPERATING EXPER IENCE SUMMARY + \#FEACTOR SAFETY SYSTEM + CONTROL RCD DFIVE + CONTROL RED SCRAM MECHANISM + GERMANY + INSTRUMENTATION, RELAY + REACTOR, POWE?

$9-21974$

KAWAGUCHI C + ITOT+ $T$ TRAK

RELIARILITY OF REACTCR INSTRUMENTATION BY PEOUNDANCY AND OECISION BY MAJDRITY SYSTEM

JAPAN ATOMIC ENERTY PESEAP.CH INSTITUTE, TCKDI-MURA IRARAKI-KEN, JAPAN

JAFR I-MFMO-2630+.19 PAGES, 4 FIGURES, I TABLE, $\triangle P R I L 12,1967$, PFESENTEO AT THE EVEA-COMMITTEE CN

REACTOR SAFETY TECHNDLOGY MEETING ON RELIABILITY OF ELECTRCNIC EGUIPMENT ANO SYSTEMS FOR NUCLEAR REACTORY

SAFETY, BRUSSELS, APRIL $1 \subseteq 67$

ACCORDING TO THE RESULTS OF THE STUDY CN RELIABILITY OF THE INSTRUMENT SYSTEM FOR THE JAPANESS MATFRIAL TESTING FFACTOR, THE OVEFALL RELIABILITY DEPENOS ON THE RELIAEILITY OF THE DEVIATICN DETSCTORS, THE AVEOAGING. U:VIT, AND THE FAILURE-CHANNEL-OECISICN UNIT.

AVAILABILITY - C. KAWAGUCHI, T. ITO, K. ARA, JAPAN ATOMIC ENERGY RESEARCH INST., TOKAI-MURA IBAPAKI-KEN, JAPAN

\# INSTRUMENTATION, GENEPAL + \#REACTSR SAFETY SYSTEM + \#RELIAPILITY ANALYSIS + JAPAN + MATHEMATICAL TREATMENT

$0-21.975$

CHAUVIN

THE CONTROLS ON RAPSCOIE

FRANCE. COMMISSARIAT A LE ENERGIE ATOMIQUE

3 PAGES, I FIGURE, INDUSTPISS ATJII QUES $5(6)$, PAGE $84-86,11067)$, IN FPENCH

DISCUSSES CONTROL WORK ON THE REACTGR RAPSODIE. REFERS TO SOME ASPECTS OF THE CONTROL EQUIPMENT, COMPINENT, AND SYSTFMS FRMM A RRIFF INSPFCTION.

\#CONTROI - GFNFRAL. + \#REACTQR CONTPOL + CONTROL SYSTEM + FRANCE + INSTRUMENTATION, CONTFOL

$0-21570$

TYRRELL JA + ADSHEAD H + TATTEGSALL JO

NUCLEAR R.EACTOR CONTRMI. MFCHANTSM

UNITED KIVGODM ATOYIC ENCQGY AUTHORITY

BP. IT ISH PATENT $1,070,572+.11$ PAGES, FIGUPES, JUNE 1, 1967 , PATENT (ERITISHI)

DESCFIBES A NUCLEAP PEACTOR CONTROL MECHANISM HAVING A FLUID-CPERATED PISTCN AND CYLINOEP DEVICE TO MOVE A CONTROL UNIT P. LATIVE TC A REACTOR CORE. IT PROVIDES A RACK AND ASSOCIATEO CONTROL JNIT LNO AN E3CAPEMENT MECHAINISM TO COOFERATC WITII TIIE RACK TO SLCURT STLFHISE MDVEMENT OF THE CONTROL UNIT.

AVATIABII TTY - THE DAIENI UHFICE, 25 SOUTHAMPTON BUTLDING, LONOON, W.C. 2, ENGLANO, SO.4O PER COPY \#CONTRUL HUL URIVE + DATENT + UNITED KINGOCM

$9-21077$

HIRATSUKA Y

REACTUR CONTROL ROD

HITACHI ITD JAPAN

JAPANESE PATENT 1966-11439+. 4 PAGES, 3 FIGURES, MAY 27 ; 1966 , PATENT (FOREIGN) IN JAPANESE 
$9-21977$ \#CONTINUED*

GIVES A DESIGN FOR A CONTROL ROD THAT MOVES AMONG THE FUEL ELEMENTS AND IN THE DIRECTION CF THE AXIS OF THE FUEL ELEMENTS. IT IS SUPPORTED BY THE LATTICE PLATES. ROD-SHAPED CONTROL ELEMENTS ARE PILED UP HDRIZONTALLY WITHIN THE PLATE, ONE OVER THE OTHER.

AVAILABILITY - PHOTOCOPIES MAY BE OBTAINED FROM THE U.S. PATENT OFFICE, DEPARTMENT OF COMMERCE, WASHINGTON, D. C. \$0.30 PER PAGE

*CONTRDL ROD + CONTRGL ROD INTERACTION + JAPAN + PATENT

9-22131 ALSO IN CATEGURY 17

WNYNRC PULSTAR PROPOSED CHANGE--INSTEUMENT CALIBF:ATION

WESTERN NEW YORK NUCLSAR RESEARCH CENTER, INC. , BUFFALO, NEW YORK

3 PAGES, DOCKET 50-57, CECEMBER 15,1967

STATE UNIVERSITY OF N.Y. ASKS PERMISSION TO CALIBRATE TRANSIENT (PULSING) INSTEUMENTATION BY USE OF NEUTRON-ACTIVATED FOIL INSTEAD OF BY AN INSTRUMENTED FUEL PELLET. IN OLD METHOD, III CHANGES IN PELLET ORIENTATION AND POSITION RESULTED IN INACCURATE MEASUREMENTS, (2) PELLETS FAILED BY RADIAL CRACKING, AND (3) THERMAL INSULATION OF THE PELLET WAS A PROBLEM. FOIL METHOD HAS PROVED RELIAELE. AL SO REQUESTED IS A CHANGE IN PULSE-ROO CALIBRATION PROCEDURE. PREVIOUSLY THE IN-HOUR METHOD WAS USED, WHICH WAS INACCURATE DUE TO XENON CHANGES. ROD WOULD BE CALIBRATED EITHER BY COMPARISON WITH A STANDARD ROD CR BY TWO OR MORE CALIBRATION PULSES SEPARATED BY ENEPGY RELEASES OF NOT LESS THAN 5 MW-SEC.

AVAILABILITY - USAEC PUBLIC DDCUMENT POOM, WASHINGTON, D. C.

* INSTRUMENTATION CALIBRATION + \#INSTRUMENTATION, PULSE + INSTRUMENTATION, NUCLFAR + PULSTAR (RF) + REACTOR, PULSED + REACTOR, RESEARCH + TECHNICAL SPECIFICATIONS

i

9-22236 ALSO IN CATEGORIES 18 ANO 5

ACRS REPORT ON DIABLO CANYON

U.S. ATOMIC ENERGY COMMISSION, WASHINGTON, D. C.

5 PAGES, 11 REFERENCES, DOCKET 50-275, TYPE--PWR, MFG--WEST, AE--PG+F, DECEMBER 20, 19t.7

ACRS BEL IEVES THAT THE FOLLOWING 6 I TEMS PERTAIN TO ALL LARGE NATER-COCLED POWER REACTORS (1) THERMAL SHGCK EFFECT OF COLD WATER. INJECTION IN LOSS-OF-COOLANT ACCIOENT, (2) EFFECT OF BLOWDOWN FORCES ON CORE. AND PRIMARY SYSTEM COMPONENTS, (3) EFFECT OF FUEL FAILURES ON EMERGENCY COOLING ABILITY. (4) INEEPENDENCE OF CONTROL ANO PROTECTION

INSTRUMENTATIGN--PRESENT DESIGN INADEOUATE, (5) PROMPT DETECTION OF GROSS FUEL FAILURE, (6) PRIMARY-SYSTEM QUALITY CONTROL AND IN-SERVICE INSPECTION. \#\# FIXED POISON (BOFOSILICATE GLASS) DURING FIF.ST CYCLE TO ENSURE NESATIVE MODERATOR CDEFFICIENT NEEOS MORE PERFORMANCE DATA.

AVAILABILITY - USAEC PUBLIC DOCUMENT ROOM, WASHINGTON, D. C.

\# BLOWDOWN + \#PRESSURE VESSEL + *THERMAL MECHANICAL EFFECT + ACCIDENT, LOSS OF COOLANT + $\triangle C R S$ + CONTROL ROD PROGRAM + CORE REFLOODING SYSTEM + DIABLO (ANYON (PWR) + EMERGENCY COOLING CDNSIDERATIONS + FAILURE, FUEL ELEMENT + FAILURE, FUEL ELEMENT + INDEPENDENCE +

INSTRUMENTATION, DETECTION FAILED FUEL ELEMENT + MOOERATOR COEFFICIENT + PLANT PROTECTIVE SYSTEM + POISIN, FIXED + REACTOR, PWR

9-22258. ALSD IN CATEGORY 17

BECK' GP

UNIVERSITY OF ILLINOIS REPORTS TRIGA PULSE ROD FAILURE

UNIVERSITY OF ILLINOIS

2 PAGES, ATDMIC ENERGY CLEARING hOUSE 14(3), PAGES 21-22 (JANUARY 15, 1968), D0CKET 50-151

(LETTER, JANUARY 4) (A) A BAD RELAY ALLOWED THE PULSE ROD TO EE PAISED WHEN THE SHIM ROD WAS ASOVE FULLY INSER.TED WITH IOODE SWITCH IN MANUAL. (B) THE PNEJMATIC SOL ENGID VALVE FAILED TO DROP THE PULSE RGD DN SCRAM. THE RUBBER SEATS ON THE SIX-YEAR-OLD-VALVES WERE WORN AND

OCCASIONALLY ALLOWED AIR TO LEAK TO THE TOP POP.TION OF THE OIAPHRAGM, HOLDING AIP. PRESSUFE ON THE PISTON EVEN WHEN THE ELECTRICAL PORTION WORKED PROPERLY. THE AIR PRESSURE WAS REDUCED FROM 75 TO 40 PSI, WHERE THE ROD DIO RELEASE. THE REACTOR OPERATEO SATISFACTORILY. A BACKUP SAFETY SYSTEM (RELEASE OF AIR PRESSUPE AT A VENT ADJACENT TO CONSOLE) WAS AVAILABLE.

* FAILURE, COMPONENT + \#FAILURE, SCRAM MECHANI.SM + CONTROL ROD DRIVE + INCIDENT, EQUIPMENT + INSTRUMENTATION, RELAY + REACTOR; RESEARCH + SHUTOOWN SYSTEM, SECONDARY + TRIGA (RR) + VALVE

9-22281 ALSC IN CATEGORY 17

CASALI F + ZAPPELLINI G

REPORT ON THE RBI REACTCR SAFETY SYSTEM

COMITATO NAZIONALE PER I ENERGIA NUCLEARE, RGME, ITALY

RT/ING-166)27+. 118 PAGES, 56 FIGURES, 16 REFEFFNCES, DECEMBER 27, 1966. IN ITALIAN

(IN ITAL IAN) A 10-W HEAVY-WATER-COOĹED GRAPHITE-R.EFLECTED FLUX-TRAP REACTOR LOCATED IN BOLOGNA. DESCRIBES AREA AND BUILDING (5 PG), FUSL ANO CONTROLS $(20$ PG), ALSO INCLUDES ANALYTIC STUDY OF THE INCIDENT POSSIBILITY $(14$ PG $)$ AND WASTE DISPOSAL $(2$ PG $)$. 
NUCLEAR INSTRUMENTATIOAR, CONTROL, ANO SAFETY SYSTEMS

$9-22281$ \#CONTINUEC*

AVAILABILITY - MICROCARD EDITIONS, INC., ACCCUNTING ANC SHIDPING, DEPT., WEST SALEM, WISCONSIN 5LEGQ

\#REPORT, SAR + CRITICAL ASSEMBLY FACILITY + ITALY + PEACTOR, FLUX TPAP + REACTCD, GQAPHITE MDOFFATEO + REACTOS, HWR

Q-22327 NLSG IN CATEGORYY 17

GARRICK BJ + GEKLER HC + GOLOFISHER L + KARCHER RH + SHJMIZU E + WILSCA JH

RELIABILITY ANALYSIS GF NUCLEAR POWER PLANT PROTECTIVE SYSTEMS

HOLMES $\triangle N D$ NARVER, INC., LOS ANGFLES, CALIF.

HN-190 +. 268 PAGES, FIGUPES, TABLES, MAY 1CE.7

INVESTIGATEO DATA AND ANALYSIS REQUIREMENTS FOR A RELIABILITY MONITORING PEOGRAM IN PDWER PEACTOR SAFETY. THE OQJECTIVES WEPE - II) THE CEFINITION OC A SYSTEM FOR THF CCLLSCTION AND ANALYSIS OF BPERATING, MAINTENANCE, INSPFCTION, AND TESTING CATA ON COMPONENTS CF ENGINEERED SAFETY SYSTEMS, ANO (2) THE INVESTIGATION OF TECHNIQUES FCO THE FVALUATION OF RELIAEILITY ANJ THE APDLICATICN OF THESE TECHNIQUES TO ENGINEERED SAFETY SYSTEMS TYDICAL QF WATER-COGLED AND - 1ODERATEO POHER RFACTORS. TWO METHOCS WEKE SELECTED. AUTOMATIC RELIASILITY MATHEYATIC MODEL 1 A COMPUTERIZED P.ELIABILITY ANALYSIS PROGRAM) AND FAULT-TREE DNALYSIS IA LOGICAL AVALYSIS CONCEPT). ADPLICATIONS OF BOTH TC SAMPLE PROBLEMS, USING AVAILASLE RELIAEILITY DATA, SHCWED THAT THEY PROVIDE USEFUL RELIARILITY ESTIMATES.

AVAILABILITY - CLEAPINGHOUST FOR FEOEPAL SCIENTIFIC AND TECHNICAL INFOFMATICN, SPRINGFIELD, VA., S3. OO COPY, $\$ 0.55$ MICROFICHE

*REACTOQ SAFETY SYSTEM + FPELIABILITY ANALYSIS + CODES DND STANCAEDS + COMPUTEQ PAOGOAM + DPESOEN ? (3WR) + DPERATIVG EXPERIENCE SUMMARY + REACTCR, BWS + DEACTOR, PWR + SAN CNOFEF (PWP) + YANKEE (PWF)

O-22331 ALSE. IN CATEGORY 4

MOHLER R2 + DFI ICE HJ

OPTIMAL NUCLEAR RFACTOR CONTRCL

NEW MEXICD UNIVERSITY. ALBUDUERQUJF

SC-CP-67-2746 +. ISZ PAGES, AUGUST 1967

THE COMPUTATIONAL ASPECTS QF CEPTIMUM CONTROL OF NUCLEAR-ROCKET DELCTOPS WAS STUDIED FRR VARIDUS CONSTFAINTS IN CONTFOL ANO STLTE. THE CONCLUSION WAS THAT THE TQDTIMAL STAQTUP OF A NUCLEAR-ROCKET GEACTOR IS GENERALLY A MAXIMAL-FFFORT PROCESS, CUNSISTENT WITH THE VARIOUS

CONSTRAINTS WHICH ARE IMOOSEO ON THF VARIARLES. IN ADOITION, THE OPTIMAL SOLUTIGNS REOUIPINS

MINIMUM FUEL CONSUHPTION $\triangle R E$ THF SOME AS THOSE WITH MINIMAL TIME AS THE OFTIMALITY CFITEFICN.

AVAILABILITY - CLEARINGHOUSE FQP. FEEERAL SCIENTICIC AND TECHNICAL INECEMATICN, SPRINGFIELD, VA., \$3. OO COPY, \$2.65 MICRDFICHE

\#NUCLEAP, ROCKET + \#REACTOO CONTROL + \#PSACTOR, SDACE + THFORETICAL INVESTIGATION

$0-22332$

C.P

MULTI-PURPOSE REACTOF FUEL CHAVNEL MONITORING SYSTEM

GENEP.AL EL ECTP.IC CO., F. ICHLANO, WOSHINGTON

RL-GEN-O20(R.EV. 1$)+$. 3E PAGES, MAY 1.067

THE PROCESS TUEES GF THE N-REACTOP ARE CORROSION-RESISTANT AND THOROUGHLY TESTED BUT MAY DEE SUBJECT TO DANAGE CR TETERIOCATION. THE FOLLOWING PROBES HAVE BEEV DEVELCOSD TC ASSESS DRDCESS TUBE CCNCITIONS IN THE REACTZR - A TELEVISION PROBE VISUALLY EXAMINES THE INNFU. SURFACE AND MEASURES DIT GR SCRATCH DEDTH, AN ULTRASONIC HYCDIDE PROBE HEASURES HYDRCGEN CDNTENT IN THE TUPE HALL, AN INNEC-OIAMETFE PFOBE MEASURES TURE CD.EEP. PERIPHERAL EQUIDNENT IS DPOVIDED TO CLFAN AND DRY THE TLPES AND TO INSERT THE PROESS INTO THE PROCESS TURES.

AVAILABILITY - CLEARINGHOUSE FOR FEDEQAL SCIENTIFIC AND TECHNICAL INFCFMATICN, SERINGFIELO, VA., \$Z. OO C.CPY, SO.SS MIC.ROFIC.HF

* IN CDRE MEASUREMENT + \# INSTRUMENTATION, IN CODE + \#INSTRUMENTATION, SUOVEILLANCE + EAILURE, TUEINE + MONITOR, RADIATIJN. TELEMETRY + NUCLEATE ROILING + TEST, NONDESTfUCTIVE

S-22333 ALSE IN CATEGORY 4

PRICE HJ + MOIILCR RR

COMPUTATION OF OQTIHAL CONTROLS FOR A NUCLEAP ROCKET FEACTOE.

NEW MEXICO UNIVERSITY

$S C-C R-67-2723+32$ PAGES, SEPTEMQER 1.67

VARIOUS OPTIMAL FEACTOR CONTROL PRORLENS WITH COMPLICATEO CCNSTPAINTS AFE SOLVED FOR $\triangle$ NUUCLEAR ROCKET ENGINE. THE TECHVIQUE UTILIZES A DIGITAL COMPUTER, WITH THE NUMEDICAL ALGOGITHM FORMED BY A SUCCESSION OF LINEAD PPOGRAMMING PRCBLEMS. EACH DRGGRAMMING PROBLEM HAS SOLUTION WHICH IS USED TO RELINFAPIZF THF SYSTEMS DYNAMICAL EQUATIONS.

AVAILAEILITY - CLEARINGHCUSE FOR FEDEQAL SCIENTIFIC AND TECHNICAL INFOPMATION, SPRINGFIELD, VA., S3. OO COPY, $\$ 0.65$ MICROFICHE 
$9-22333 *$ FONT INUEC *

*NIJCLEAR ROCKET + \#REACTOR CONTROL + \#RFACTOR, SPACE + COMPUTER PFGGRAM + MATHEMATICAL TREATMENT + THEORETICAL INVESTIGATION

$0-22334$
FUEETJ+ GUYOT C

CONSIDFRATIONS ON THE RELIABILITY OF SYSTEMS FOR REACTCP SAFETY (IN FRENCH)

COMMISSARIAT A L ENERGIF ATOMIQUE, SACLAY

40 PAGES, 16 FIGURËS, PRESENTED AT ENEA COMMITTTEF ON REACTOR SAFETY TECHNOLOGY MEETING OF RELIAEILITY OF

ELECTRONIC EQUIPMENT AND SYSTETS FUR NUCLEAR REACTOF SAFETY, GRUSSELS, APRIL IOGT

GIVES AN JPERATIONAL SKETCH OF THE ELECTRONIC SYSTEMSS FOR THE CONTROL ANO SURVEILLANCE OF NUCLEAR REACTORS AT CEA. THE DATA IS EVALUATEO. TO DETERMINE THE RELIABIL ITY AND MA INTENANCE DF THE EQUIP:AENT. TWO EXAMPLES ARE GIVEN FOR DETERMINING THE EFFECT OF DIFFERENT TECHNOLOGIES ON RELIA3ILITY. THE PFOVISIONAL OR EXPERIMENTAL FELIABILITY HAS A GPEAT EFFECT ON THE DEFINITION ANO REALIZATION OF MATERIALS COMPOSING THE SAFETY SYSTEMS. OPEPATIONAL RESULTS ARE NECESSARY FOR THESE EVALUATIONS. IT IS ALSO FUNDAMENTAL NOT TO NEgLECT THE CUNDITIONS OF INSTALLATION AND DPERATION DF THIS EQUIPMENT.

\#OPERATING EXPERIENCE SUMMAPY + \#OELCTOR SAFETY SYSTEM + \#RELIABILITY ANALYSIS + COMPAKISON, THEORY LND EXPERIENCE + FRANCE

9-22338 ALSE IN CATEGORY 4

ENGEL FC + BISHOP AA

TEST AND ANALYSIS OF A MANIFOLD AND RE-ENTRANT TUBF ASSEMBLY. FEASIBILITY OF A CHEMICAL PCISON LOCP SYSTEM IUESTINGHOUSE ELECTRIC C.QRP., PITTSBURGH, PA.

WCAP $-2870+$ NASA-CR- $54994+.90$ PAGES, FIGURES, TABLES, REFEPENCES, JULY 1966

AN ANALYTICAL ANO EXPERIMENTAL MONEL STUDY WAS PERFORMED OF A MANIFOLD AND RE-ENTRANT TUBF CHEMICAL-POISCN E.ISTRIBUTION SYSTEM WHICH ARE PART OF A POCKET. REACIUK-CUNIKUL LOUP. THE SYSTEM JPERATES EY CHANGING THE CONCENTRATION OF THE POISON (CADMIUM SULFATE) IN A WATER SOLUTION CIRCULATING THKJUGH $1 \subseteq 8$ PARALLEL TUBES WHICH PPOJECT FFOH A MANIFOLD INTO THE CURE. A SPECIAL MANIFOLD AND RE-ENTRANT TUBE ASSEMBLY WAS DESIGNED, AND A FULL-SIZE FLOW MODEL WAS MADE OJF PLEXIGLAS. A SERIES OF TESTS WERE THEN PERFDRMED TO PROVE THE DESIGN.

AVAILABILITY - CLEARIINGHOUSE FJR FCDEPAL SCIENTIFIC AND TECHNICAL INFORMATION, SPRINGFIELD, VA., \$3. OO CUPY, \$O.S5 MICROFICHE

\#FLOW DISTRIBUTION + \#FLOW THEORY ANO EXPERIMENTS + \#TEST, SYSTEM GPERAPILITY + CONTROL SYSTEM + NUCLEAR RJCKET + POISUTN, SOLUBLE + REACTOK, SPACE + REACTOR, WATER

9-22457 ALSE IN CATEGORY 17

ERR 2 STEAM GENERATOF LËVEL CONTROLLEP MALFUNCTION

$\triangle R$ GUNAE NATIONAL LAB.. AR.GONNE, ILL.

ANL-7399+. I PLGE, PAGE C4 CF ARGGNNE NGTIONAL LABGRATORY. REACTOR DEVELOPMENT PROGFAM PFOGRESS REPQRT, NOVEYBF, 1067 , DECFMBER 1 CA

DN THE NOV. 12, 1967, STARTUD, AT 20 MW THE PRIMARY BULK-SODIUM TEMPERATURE BEGAN INCREASING AND CDULO IDT $3 E$ CONTRCLLED EY ADJUSTING SECONOARY FLOW. A MALFUNCTION OF THE STEAM-DPUM: WATES-LEVFL CONTFOLLSR/ALAF,M ALLOWEO THE DRUM TO BOIL OR.Y.

AVAILAGILITY - CLEARINGHOUSE FOR EEDEPAL SCIENTIFIC AND TECHNICAL INFORMATION, SPRINGFIELD, VIRGINIA, $\$ 3.00$ COPY, $\$ 0.05$ MICRCFICHE

\#CCNTROLLER + \#FAILURE, COMPONENT + \#INSTRUMENTATION, LIQUID LEVEL DETECTION + EBR I AND 2 (RE) + INCIOENT, EQUIPMENT + INDEPENDENEE + REACTOR, LMCR + STEAM GENERATOR

$9-22491$

OPTIMIZATION DF SOLID BURNABLE POISCINS

2 PAGES, $\triangle$ TOMKERNENEFG $12(7-8)$, PAGES $295-6(1967)$, IN GERMAN

SLEMENTAFY CONSIDERATIONS LEO TO AN GPTIMIZATION OF SOLID, PUFNAGLE POISONS. FOR SIMPLICITY IN THE EXAMPLE, GLL QUANTITIES ARF FELATED TO THE iAEAN THERMAL NEUTRON FLUX IN THE ACTIVE CORE BY MEANS UF REACTION RATES AND SELF-SHIELOING FACTOPS. SPECTRAL COUPLING OF POISON AND FUEL IS NEGLECTED IN A FIRST APPROXIMATION EUT CAN BE TAKEN INTO ACCOUNT IN $\triangle$. SECOND CALCULATION. THE SPACE-DEPENDENT WEIGHTING OF THE POISON BY THE IMPORTANCE IS INCLUDEO IN THE SELF-SHIELEING FACTISR.

GERMANY + MATHEMATICAL TRE

S-22493 ALSO IN CATEGORY 18

GEORGIA TECH SUDPLIES AODITIONAL INFORMATION

GECRG IA INSTITUTE DF TECHNOLOGY, ATLANTA, GA.

? PAGES, DECEMSER 14, 1S67, DOCKET 50-276 
CATEGCPY
NUCLEAR INSTRUMENTATION, CONTROL, AND SAFETY SYSTEMS

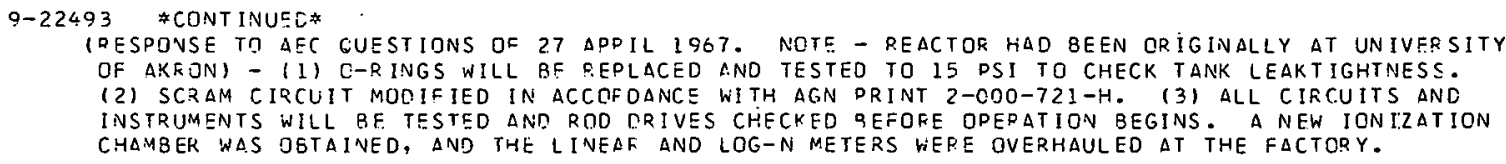

AVAILABILITY - CLEARINGHOUSE FOR FEOEPAL SCIENTIFIC AND TECHNICAL INFGRMATION, SPRINGFIELO, VA., \&3. OO COPY, \$0.65 YICROFICHE

* DESIGV CRITERIA + *OESIGN SIUUY + FINSTRUMENTATION, CENERAL + \#OUALITY CONTROI. + PM 1 (PWR) + REACTDR CONTROL + PSACTOR, MILITAQY + REACTCR, POWER

$9-22513$

KUNZE JF+ SI:ASFL + WCQO RE

PBF CRITICAL EXOEQIMENT CONTROL ROD MEASUREMENTS

GFMFRAL ELECTRIC COYFANY, IDAHO FALLS, IOAHO

GEMP-560+. 37 PASES, FIGURES, TAQLES, REFERENCES, IICTEQER 10,1067

DATA AND OFLATED INFGRMATICN ASSOCIATED WITH CONTROL-ROD MEASURFMENTS CONDUCTED WITH THF POWER BURST FACILITY CFITICAL EXPERIMENT PEACTDO SYSTEM APE PRESENTED. THE DATA INCLUDES THE CRITICAL WATER LEVELS, INCREMENTAL WATER WORTHS, PULSEO-NEUTRON-GENEPATCR RESULTS RELATEO TO THE VARIOUS CCFE GEOMETRIES AND CGNTROL-ROC CONFIGURATIONS. THESE RESULTS DRCVIDE THE MEANS BY VHICH THE CONTROL-ROD WDFTHS ARE DETERMINED. VALUES OF THE REACTIVITY WORTH CF A PARTIC:JLAR CONTF:CL FOD ARE DEDUCED.

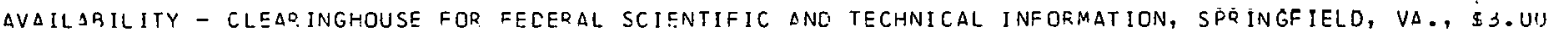
COPY, \$0.65 MICROFICHE

\#CONTROL ROD WJRTH + ACRITICALITY EXPERIMENT + CONTRCL ROD INTERACTION + CRITICAL ASSEMGLY FACILITY + IDAHO FALLS + DGE (S-RR) + PULSEU NEUTRËN TECHNIQUE + REACTOR, SAFETY PESEARCH

$9-22550$

KAMFMOTOY + SHIPAK + HANDA M + YAMAGISHI S + FUKUDA T + TAKAHASHIY + TANIFUJI T + OMORI S

SIUIJES JN CERAMIS TULLS HITH THS USF OF FISSINN GAS RFIFASE LOOP, (III) - NEUTPGN FLUX MONITORING IN SPECIYEN CHAMBER J = FGRL BY COUNTING NITROGEN-16 GENERATEO OXYGEN-1G (N,P) NITRCGEV-1E REACTIIN IN PF.IMAPY COQLING WATEE

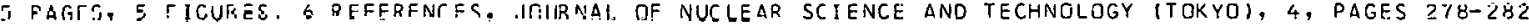
(JUNE 1967 )

HLUX MOVITCOIVG IH THF SPTCIMEN CHAMBEP OF FISSION GAS RELEASE LOOP (FGRLI WAS CARPIEO OUT EY DIFECTLY AND CINT INUOUSLY REAUING WITH A GAMME-RAY SPECTRCMETER THE CONTENT OF N-IG IN THE PRIMARY COOLING WATER PRDDUCCO QY C-I6(N,P)N-1E REACTION WITHIN THE COOLING JACKET OF FGRL. N-16 GENERATIRN IS NDT INFLUENFED EY GAMMA-FAY BUILO-UP IN THE REACTOR NOF BY THE TEMOERLTUPR IN THE SPECIMEN CHAMRES. THF DFTECTOR CAN BE SIMPLY SET DUTSIDE THE PIPE THROUGH WHICH THE COOLING NATER ELCWS, RECAUSE THE HIGH-ENFFGY GAMMA RAYS EMITTED DURING THE N-16 DECAY EASILY PENETHAIE THE PIPE VIALL.

* INSTRUMENTATIDN, RADIATION MONITORING + CHAMBEF, NEUTRON + IFRADIATION TESTING + JAPAN + NITROGEN + THERMAL NEUTRON

9-22781 ALSC IN CAILGUKY 17

U OF ILLINJIS REPORTS INTEPLOCK FAILURF DLLOWING IMPEGPER PLLSE-SAFETY RJD OPERATION

NUCLEAR ENGIVEEF. IVG PPCGRAM, UNIVEPSITY OF ILLINOIS

1 PAGE, JAN. 4, 15:65, DCCKET NC. 50-151

UURING A CHECK DF INTEPLOCKS, A FAILFD INTEFI RICK WAS OISCOVERED WHICH ALLOWED THE PULSE-SAFETY RDD TO BF ZAISED NITH THE SHIM CONTE RL ROE NGT FULLY INSERTED AND IN THE MANUAL MODE. THE MELAY HAS REDI AIF". TMTFRLOCK WILL CONTINUE TO BE CHECKED POUTINELY WITHIN TIMES SPECIFIED BY TLCINICAL SPET. IFICATIONS. 
$9-22781$ \#CONT INUEC * AVAILABILITY - USAEC PUBLIC DOCUMENT RDOM, WASHINGTON, D. C.

* FAILURE, COMPONENT + \#INSTRUMENTATION, INTEPLDCK + \#INSTRUMENTATION, RELAY + CONTROL ROD PROGRAM + OPERATING EXPERIENCE SUMMARY + REACTOR, PULSED + REACTOR, PESEARCH + TECHNICAL SPECIFICATIONS + TEST, CONTROL ROD DRIVE + TRIGA (RR)

9-22784 $\triangle$ LSC IN CATEGRRY 17

CATHOL IC U REPORT JF FACILITY MODIFICATIONS

THE CATHOL IC UNIVERSITY OF AMERICA, WASHINGTON, D. C.

4 PAGES, JAN. 8, 1968 , DOCKET NO. 50-77

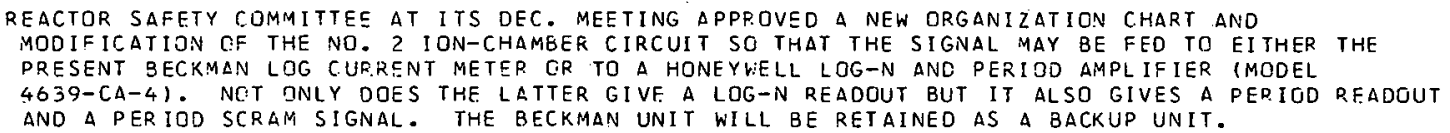

AVAILABILITY - USAEC PUELIC DOCUMENT ROOM, WASHINGTON, D. C.

*INSTRUMENTATION, POWER RANGe + ADMINISTFATIVE CGNTROL + AGN (TNG) + INSTRUMENTATION, PERIOD + MODIFICATION, SYSTEM OR EQUIPMENT + REACTOR, TRAINING + SAFETY REVIFW

9-22831 $\triangle L S O$ IN CATEGORY $t$

CONTROL OF XENON INSTABILITIES IN LARGE PWRS. QUARTERLY PROGRESS REPORT FOR THE PERIDD ENDING SEPTEMBER 30,1967

WESTINGHOUSE ELECTRIC CORP.., PITTSBURGH, PA. ATCMIC POWER OIVISION

WCAP-3690-5 + EURAEC-1925+. 10 PAGES, OCTOBER 1967

THIS REPORT IS ONE OF A SERIES OF SUCH REPRRTS CONCERNED WITH INVESTIGAT INGG THE

CHARACTER ISTICS AND CONTROL OF SPATIAL INSTABILITIES IN LARGE PRESSURIZED-WATER REACTORS, WITH PARTICULAR EMPHASIS ON AZIMUTHAL XENON INSTABILITIES (X-Y PLANE). THE PROGRAM CONSISTS OF THE FOLLJWING TASKS - 11 ) EUXE-20O EFFECT CF CORE PARAMETERS ON SPATIAL OSCILLATIONS, (2) EUXE-300 REMEDIAL CONTRQL PROCEDURES, 131 EUXE-400 THREE-DIMENSIONAL ANALYSIS.

AVAILAPILITY - CLEARINGHOUSE FOR FEDERAL SCIENTIFIC AND TECHNICAL INFCRMATION, SPRINGFIELO, VIRGINIA, $\$ 3.00$ COPY, \$0.65 MICRCF.ICHE

INSTABILITY + REACTOR, PWR + XENON

$9-22832$

APPLICATIONS OF ULTRASGNIC ENEKGY. ULTRASONIC INSTRUMENTATION FOR NUCLEAR APPLICATIONS. BIMONTHLY PROGRESS REPORT NO. 36, AUGUST 1,1 , 1 , 7-SEPTEMBER 30,1067

$\triangle E P O P R O J E C T S$, INC., WEST CHESTER, PA.

NYO-3622-11+. 12 PAGES, FIGURES, OCTOEER 1967

THIS REPJPT IS ONE OF A SERIES OF SUCH REPORTS CGNCERNED WITH THE APPI ICATION OF ULTRASONICS TO MEASUREMENT PROBLEMS IN NUCLEAR REACTORS. DEVELOPMENT OF INSTRUMENTAT ION WAS UNDERTAKEN, BEGINNING WITH THEORY, DESIGNING A PROTOTYPE, THEN DEVELOPING AND TESTING A UNIT. TOPICS COVERED IN THIS P.EPORT AR.E -- $(1)$ ULTRASONIC INSTRUMENTAT ION FOR THE OETECT ION OF INCIPIENT BOILING IN MDLTEN METAL (2) ULTRASONIC FLOWMETER FOR USE IN METAL OR FUSED-SALT SYSTEMS.

AVAILABILITY - CLEARINGHUUSE FOR FEDERAL SCIENTIFIC AND TECHNICAL INFCRMATION, SPR INGFIELO, VIPGINIA, $\$ 3.00$ COPY, \$0.65 MICRLF ICHE

INSTRUMENTATION, CODLANT QUALITY + INSTRUMENTATION, FLOW + INSTRUMENTATION, IN CORE

$9-22833$

HILBORN HS

USAEC-AECL COOPERATIVE PROGRAM. MONTHLY PROGRESS REPORT, SEPTEMGER 1 CET

DU PONT DE NEMOURS (E. I.) AND CO., AIKEN, S. C. SAVANNAH RIVER LAB.

DPST-67-83-9 +. \& PAGES, OC TOBER 10, 1967

THIS REPORT IS ONE OF A SERIES OF SUCH REPORTS CONCERNING THE CCOPERATIVE EFFORTS BETWEEN THE U.S. AND CANADIAN GOVERNMENTS IN THE CEVELOPMENT OF HEAVY-WATER-MODERATED POWER REACTORS. THE TOPICS COVERED ARE - (1.) PHYSICS EXPERIMENTS WITH FUEL ASSEMBLIES (SIMULATEO BURNED-UP FUEL), (2) AECL IN-CORE FLUX MONITCRS, ANO (3) SIEVE-TRAY TESTS.

AVAILABILITY - CLEARINGHOUSE FOR EEDEFAL SCIENTIFIC ANO TECHNICAL INFORMATION, SPRINGFIELO, VIRGINIA, $\$ 3.00$ COPY, $\$ 0.65$ MICROFICHE

CANADA + COMPUTER PRQGRAM + FLUX, INTEGRATED + FUEL BUPNUP + HEAT TRANSFER + INSTRUMENTATION, IN CORE + IRRADIATION TESTING + PEACTOR, HWR + SAVANNAH RIVER PLANT + TESTING + TRANSPORT THEORY + UNITED STATES 
9-22843 *CONT INUEO

MICHIGAN STATE TRIGA FEQUESTS PERMISSICN TO REASSEMRLE 4 FUCL ELEMENTS

MICHIGAN STATE LINIVEPSITY

1 PAGE, JANUARY 18,1068 , DOCKET 50-204

IT IS NECESSARY TC DISASSEMBLE \& INSTRUMENTEO ELFMENTS FOR TRANSFED. FRCM U OF ILLINOIS. THESE AQE TO BE REASSEMPLEO IN THE STOPAGE $\triangle P E A$ EC THE OOCL OR IN A FUEL CASK SUSPENDEC OVER THE POOL. THEY WILL THEN RE TESTFO ETF ELECTPICAL CONTINUITY. CNLY DNE ASSEMBLY WILL BE TESTED IN THE CORE AT A TIME, THEN RETURNEE TO STOFDGE.

AVAILABILITY - USAEC PUBLIC DOCUMENT F.OOM, WASHINGTON, 2 . C.

* FUEL haNDL ING + FUEL ELEMENT + INSTRUMENTATION, IN CORE + INSTFUMENTATION, TEMPEPATUPE +

REACTOR, RESEARCH + TECHNICAL SPECIFICATIONS + TRIGA (RR)

9-22844 ALSO IN CATEGORY 17

MANHATTAN COLLEGE SUPFLIES ADOITITNAL INIFORMATION INN SHUTOOWN SYSTEMS

MANHATTAN COLLEGE, BKONX, NEW YORK

2 PAGES, C.ECEMBER. 29. 1967, DOCKET 50-199

(1) BORON EMERGENCY SHUTOOWN SOLUTICN (WORTH AT LEAST 3\%) IS FJRMED EY OISSULVING MORE THAN

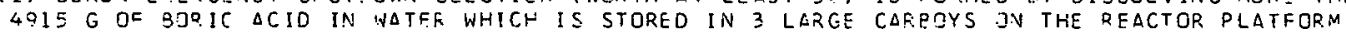
(TECH. SDECS. SPECIFY THAT THEY BF AVAILABLE IN THE VICINITY CF THE CONSOLE). \#\#\#(?) DUMP TANK FIJR DELIVERY OF THE BORON SOLUTION IS RULEO OUT BECAUSE GF DIFFICULTY IN CLEANING CORE AFTED ACCIDENTAL TRIP. \#\#\#(3) SHUTDOWN ROD IS $\triangle N$ IRCN PIPE, TEN FT. LCNG, I3/16 IN. I.D., ANO $15 / 16$ IN. C.D., CONTAINING 1.22 LE OF B4C POWDER.

AVAILABILITY - USAEC PUBLIC DOCUMENT POOM, WASHINGTON, D. C.

* SHUTDOWN SYSTEM, SECONCARY + $\triangle E C$ QUESTION + $\triangle G N$ (TNG) + BORCN + TONITROL ROD + DOISON, SOLUBLE + REACTOP. RESEARCH + TECHNICAL SPECIFICATICNS

S-22982 ALSC IN CATEGORY 17

SELECTED FEPMI EXPERIENCE - JULY 1966

POWES REACTDR DEVELTPMENT ROMMPANY

$E=-35+$ 1! PAGES, JULY 1966

SHUTODNNS BEGAN JULY 1 S TO REPLACE COPDER GASKET ON NO. 2 STELM-GEVERATOR WATEO HEADER, AFTER S.MME TESTS AT 100 MW WERE COMPLETED. MEASURED CORE GUTLET TEMPERATIJRE DIFFERENCES AND R\%. GREATER THAN EXPECTEO. \# OURING A PRESSURE RAMP FROM O5O TO EDO PSIL WITH REACTOR AT ET

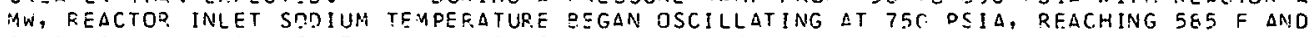
CAUSING A JNE-LOCP SHUTDOWN, WHICH GAVE L LOSS-OC-FLOW SCRAN. THERE MAY RE SIGNIFICANT HELT TRANSFER IN THE CENTRAL REGICN OF THE STFAM GENERATOR, SE ROILING OCCUPS TOO SQON IN THE TUB:, CAUSIVE ELOW INSTASILITY. A SECLND SCRAM CAME SIMILARLY, QUT FROM TOO HIGH

TFMPERATURE, DUE TR ERFATIC TE 301 .

AVAILABILITY USAEC PUELIC DCCUMENT POCM, WASHINGTON, D. C.

\#FLCW STABILITY + \#SCEAM, SPUR IJLS + \#STFAM GENERATDF + FERMI (LMEBE) +

INSTRUMCNTATION, ABNOPMAL INDICATION + INSTRUMENTATICN, TEMPEFATUPE + OPERATING EXOEPIENCF SUANARY + REACTOR, FAST + REPCRT, UHEHAIIUNS + TEST, PLANT RESPONSE

9-22.98 $\quad 4 L 50$ IN CLATEGUKY L?

SELECTED FERMI OPERATING EXPERIENCE - JAN. ICG7

POWER QEACTOR DEVELOPMENT COMPANY

EF.4I 1. I TAGE, PAGF E OF FNRICO FEFMI ATOMIC POWER PLANI KEPUKT HOH JANUAGY 1 GG?

(PAGE S) SOURSE-PANGE COUNTING RATE ON CHANNELS $1 / 2$ ROSE GY FACTEFS OF $2 / 3$ CN JAN. 10, ADPAQENILY TRQM A COAMON INDETCRMINATF NOISE SQURCE. CFOSS CDUCLING BETWEEN VARIOUS EQUIPMENT RAOIDTION MONITORS WAS ELIMINATFO WITH FILTEP CAFACITORS IN THE COMMON DOWER SUPPLIES.

AVAILAPILITY - USAFC PUBLIC DOCUMENT DOOM, WASHINGTON, D. C.

*INSTRUMENTATIDN, ABRIRRMAL INDICATION + ELECTRIC. POWER, VITAL + FFFMI (LMERP) + IVDEPENOEVCE + INSTRUMENTATION, STARTUD PANGE + MONITQR, DAOIATION, AQEA + FEACTCF, FAST + PEPCRT, ODERATIONS

$9-228 \div 0$

MCCARTHY JF

SELECTED FEPMI OPERATING EXOERIENCE - JAN. 1967

ATOMIC POWER DEVELOPMENT ASSOCIATES, INC., DETROIT, MICH. + PGNER REACTOR DEVELOPMENT CO., DETROIT, MICH. + DETROIT EDISON CD., MICHIGAN

APDA-CFE-6 +. I DAGE OF COMPILATION OF CLPRFNT TECHNICAL EXPERIENCE AT EVRICU FERMI ATCMIC POWEP. PLANT, MONTHLY REPORT NO. 6, JANUARY 1967, ZO DLGES, MAY 1967

(PAGE 10) A JAN. 10 DOUBLING OF THE SHUTDCWN COUNTING RATE GN CHANVELS 1 AND 2 , WHICH TOCKK PLACE IN 5 IIIN $\triangle N D$ LASTED ABOUT 15 HQ, NAS $4 P P A R F N T L Y$ NOISE (CRQM $A N$ IC MG $55 T$, STANDBY POWER) ENTERING THE SCALE JF TWO MODULSS. CISCFIMINATISN CURVES SHOWED NO CUANGE. (DG IS) 
$\$-22990 *$ CONTINUEO*

OF THE 191960 SCRAMS TABULATEO, 5 WERE SINGLE ROO DFOPS, 3 WePE LOSS OF COOLANT DUE TO HIGH FEEDWATEP TEMP., TWO WERE UNKNOWN SAFETY-SYSTEM TRANSIENTS, ONE WAS DUE TO FAULTY OETECTORS, AND 4 WERE SCHEDULED. (PG 24) SUBASSEMBLY MO99 SHOWED THAT TWO DF FOUR PINS HAD 2500 PPM OF HYDRIDE IN THE CLAD (VS 150 FOP. OTPEFS, AND 10,000 AS FAILURE THR.ESHGLC).

AVAILABILITY - CLEARINGHOUSF FOR FFCEPAL SCIENTIFIC. AND TECHNICAL INFORMATIGN, SPRINGFIELD, VIRGINIA \$3. OO COPY, SO.

\#EXAMINATION + \#FUEL ELEMENT + \#INSTEUMENTATION, AÖNOPMAL INDICATION + \#INSTRLMENT ATION, STARTUP RANGE + *SCRAM, REAL + EMERGFNCY POWER, ELECTRIC + FERMI (LMFBP. + HYDRIOE + INOEPENDENCE + REACTOR, FAST + RFPORT, OPERATIONS SUMMARY + ZIRCALOY

Q-2?3C? ALSO IN CATEGORY 17

MCT.ARTHY JE + NASH CR

COMPILATION OF CURRENT TECHNICAL EXPERIENCE AT ENRICO FERMI ATOMIC POWER PLANT. MONTHLY REPORT NO. 1I, JUNE. 1067

ATOMIC POWER DEVELJPMENT ASSOCIATES, INC., + POWER FEACTOR DEVELOPMENT CO. + DETROIT ELISON COMPANY,

MICHISAN

APCA-CFE-11+. II DEGES, FIGURES, AUGUST 1967

CONTAINS SUGJECT INDEX FOR CFE PEPQPTS 1-11. (PAGE 8) DURING VESSEL DRAINING OPERATIONS, THE COUINT IN.j-RATE CHANNELS INCRSASED A FACTOR OF 20, AND THE INTERMEDIATE-P.ANGE CHANNELS ROSE A FACTOP. OF 10,000. SAFETY CHANNELS WERE NOT AFFECTED. SIGNALS WERE CONTINUOUS AND LASTED 6 MIN. CAUSE SUPPCSED ELECTRICAL. (PAGE 12) THE STUCK PAIR OF FUEL ELEMENTS WERE VISIBLE THR JUGH BCRESCOPES. (PAGE IE) VARIATION OF PREDICTED FROM MEASURED SODIUM DELTA $T$ INCREASES WITH INCREASINE DISTANCE FROM CORE CENTEF. TWD MODELS WERE CEVELOPED FOR LOCAL FLOW VAR I ATIONS. (PAGE 17 ) VARIOUS CONSTRUCTION MATERIALS WERE IMMERSED IN HOT SODIUM TO SEE IF THFY COULO P.ETAIN THEIR FORM.

AVAILABILITY - CLFARINGHOUSE FQR FEDERAL SCIENTIFIC AND TECHNICAL INFORMATION, SPRINGFIELD, VA., \$3. OO COPY, \$C.S5 MICRTFICHE

*FLOW . BL JCKAGE + *FLO'N DISTRIBUTION + \#INSTRUMENTATION, ABNGRMAL INCICATION + FERMI (LMFER) + INSTRIIMENTATION, INTERNEDIATE RANGE + INSTRUMENTATION, STARTUP RANGE + MATERIAL + REACTOR, FAST + REPORT, OPERATIONS SUMMARY

9-ZZZOQS ALSO IN CATECSORIES 5 AND 17

COMPILATION OF CURRENT TECHNICAL EXPERIICNCE AT ENRICO FERMI ATOMIC POWER PLANT. MONTHLY REPORT NC. 9, APR IL 1057

ATOMIC PDWEQ DEVELOPMENT ASSOCIATES, INC., DETROIT, MICH + POWER REACTOR DEVELOPMENT COMPANY + DETROIT EDISON COMPANY, MICHIGAN

$\triangle D D A-C F E-9+.31$ PAGES, JUNE 1967

(PASE 23) A LOW-FPEQUENCY COIL TO NONCESTFUCTIVELY TEST FUEL PINS HAS A THRESHOLD OF 1 OOOO PPM HYDPIDE, TESTEP DN DELI QERATELY WYERIOCO (250-5000 PPM) PINS. (PACE 24) BYRASS FLOW ANALYSIS DF SUBASSEMBLY LOWEF NDZZLE EEING CDUGHT ON TOP OF THF SUPPORT PLATE SHOWS FLOW FEDUCED BY $7 \%$, INSUFFICIENT TO CAUSE FUEL DAMAGE. (DAGE 27 ) FAILURE OF A SOLENOID VALVE ALLONED PR̃ I YARY-SHIELG-TANK PRESSURE TO TAKE. POSITIVE PFESSURE SWINGS. FAILURE BLEW A FUSE IN THE COMMON PGWER SUPPLY, PREVENTING SWITCHOVER TO AN ALTERNATE SENSING LINE. MANUAL VALVES QEPLACE THE SOLENOID VAĹVES (IN A LESS COMPLICATEO ARRAY).

AVAILAPILITY - CLEARINGHOUSE FOR FEDERAL SCIENTIFIC AND TECHNICAL INFORMATION, SPRINGFIELO, VA., S3. OO COPY, \$0.65 IIICKUF ICHE

\#FILURE, COMPONENT + \#FAILURE, SEQUENTIAL + \#FLOW DISTRIBUTION + \#TEST, NONDESTFUCTIVE + CLAD + ELECTRIC POWER, NOPMAL + FERMI (LMFBR) + FUSL ELEMENT + HYDRIDE + HYDRDOYNAMIC ANALYSIS + INDEPENDENCE + REACTJR, FAST + REPGRT, UPERATIONS SUMMAFY + VALVE

$0-22047 \quad \Delta L S O$ IN CATEGOPY 17

DOESDEN I PROPOSED CHANGE 15-OREFUELING WI THOUT COCKED RODS

COMMONNESLTH EDISON COMPANY, CHICAGL, ILLINOIS

4 PAGES, JANUARY $17,19 E 8$, DOR.KET 50-10, TYPF--8WR, MFG--G.E., $\triangle E--E E C H T E L$

DRESDEN ASKS TO ELIMINATE REQLIPEMENT THAT SOME CDNTROL RCOS PE COCKED DURING REFUELING. SHUTDONN MARGIN AT ALL STAGES, WITH ONE RGO STUCK OUT OF CORE, WOULD HAVE'TO BE AT LEAST IZ.. A CONTROL RDD IN THE VICINITY OF THE REFUELING ACTIVITY WOULD BE WITHCRAWN AND REINSERTED BSFOKE ANO AFTSR FACH FUEL $\triangle D D I T I C N$. ONE-STUCK-ROD REFUELING ACCIDENT RESULTS IN NO CLAC OR FUFL MELTING.

AVAILABILITY - USAEC PUSLIC DOCUMENT ROOM, WASHINGTON, D. C.

\#REFUEL IVG + \#SHUTDDRN MARGIN + ACCIOENT, REFUELING + GDMINISTRATIVE CENTROL + CONTROL POD + DRESDEN I (BWR) + REACTOR, BWR + TECHNICAL SPECIFICATIONS

9-22949 ALSC IN CATESDRY 17

PLUM BRDDK SUPPLIES ADOITIONAL INFORMATION ON CHANGE REPORT 32--CONTROL RODS 
NUCLEAR INSTRUMENTATION, CONTROL, ANC SAFETY SYSTEMS

$9-22948$ \#CONTINUED*

NATIONAL AE?ONAUTICS ANC SPACE $\triangle D M I N I S T O A T I O N$, LEWIS RESEARCH CENTER

3 PAGES, JANUARY 12 , ISEQ, OOCKET 50-30

TESTS WITH CONTPOL-ROD-BEARING MATERIALS 1ZIP.CALCY 32, 17-7PH STAINLESS, 6061-T6 ALUMINUM, TI- 16 ALUMINUM, AND WAUKESHA METAL \&?) SHOWED WAUKESHA BE TG HAVE THE BEST COMBINATION OF PROPERTIES, WITH 6061-TE AI AN ACCEPTABLE SECONO. BEARING PLATE IN ALL CASES WAS 304

STAINLESS. TEST CONDITIONS WERE - (1) VELOCITY, 12 FT/SEC (FOC DR3P VELCCITY), (2) LATEPAL LOADING OF 65 PSI (RREATEP. THAN THAT EXPECTED), AND (3) 10-MIN PUN, EOUIVALENT TO 3 , OOO RDD DRTPS. NEAR OF BEAPINC MATCRIAL, CAHAGE TO STAINLESS-STEEL SURFACE, AND THE INITIAL AND FINAL COEFFICIENT OF FP. ICTION WFRE DETERMINED. \#\# \#OD-DROD TIMES FOR THE REFLFCTCR ROOS WILL SE CHECKED AFTER INSTALLATION OF THE ROLLERLESS GUIDFS (BEFOPE GPERATION) AND ROOS G, 7 , ANO 8 WILL BE CHECKED MONTULY COF E MONTHS.

AVAILAgILITY - USAEC PUELIC DOCUMENT POOM, WASHINGTON, D. C.

* CONTRMI ROD SCRNM IAECHANISM I \#TEST, PROOF + AEC QUESTIUN + CONTPOL ROO ORIVE + PLUM EROOK (TP) + REACTOR, TEST + RESPCNSE TIME + TECHNICAL SPECIFICATIONS

9-22949 IL.ST IN CATEGORY 17

UNIVERSITY OF ILLINOIS REPDRTS SCLENOID FAILURF CAUSES PULSE-SAFETY P.OD TO FAIL TO DROP

UNIVERSITY OF ILL 'NOIS, URBANA, ILLINOIS

2 PAGES, JANUARY 4 , 1968 , [IOCKET 5O-151

DURIVG STARTUP CHECKRUT, THE PULSE-SAFETY ROD FAILED TO DROP. POD WAS THEN DREPPED BY VENTING AIR PRESSURE. RDD THEN OPERATED PPCPERLY IN REPSATED CHECKS. AFTER A SECOND FAILURE TO DRCP OCCURRED DURINS THE CHECKOUT, THE SOLENOID VALVE CONTRCLLING TLE AIR PRESSURE WAS TESTED ANE FMUNO TO RE THE SOUPCE OE TRCURLE. SINCE NO REPLACEMENT WAS AVAILABLE, THE AIR PRESSURE WAS REQUCED FROA 75 PSI TO 40, AT WHICH THE VALVE OPERATED PROPERLY IA REPLACEMENT VALVE WAS OBTAINEDI. THE FIISPER SEATS IN THF S-YIAR-OLD VALVE WERE WOFN, ALLIJWING LEAKAGE. H A QACKUP SAFETY SYSTEM (RFLEASE SF AID PRESSURE WITH THE VENT NEAF THE CONSCLE) WAS AVAILABLE IN EVENT OF FAILURE DURING R.OUTINE SHUTDOWN.

AVAILABILITY - USAEC, DUBLIC DOCUMENT POQN, WASHINGTON, D. C.

\#FAILURE, SCRAM MECHANISM + \#INCIJENT, EQUIPMENT + *VALVE + FAILURE, EQUIPMENT + JDECATING EXPFRIENCE + PRESSURF, INTERNAL + REACTOK, DULSED + SHUTOOWN SYSTEM, SECONDARY + TRIGA (RP)

$0-22050 \quad A L S O$ IN CATEGQRY 17

UNIVERSITY JF ILLIVIS REOTRTS FOILUFE IN PULSE ROO SOLENOIC VALVE

UNIVERSITY OF ILLINDIS

2 DAGES, JANUARY 15,1068 , DOCKET $5 \mathrm{C}-151$

THE PULSE ROD FAILED TO DQDP DUPING A ROUTINE SHUTOOWN, DROPPED WHEN MANUAL VENT OPENED, EUT WITHOREW WHEV VENT CLOSED. MASTFR-KFY SWITTH DR DQPEO FOD, AND ORLRATION THEREAFTER WLS NURMAL. CAUSE APPEAQS TO BF IN A NUMPER OF MICROSWITCHES, AND MECHANICAL MOVEMFNT OF IAND $\triangle$ HOLDING COINTACT IN) THE UP-BUTTON. (TWO YEARS AGO SIMILAR DIFFICULTY WAS RELIEVED BY LURRICATIOV APY SIZE REDUCTICN GF THE BUTTON SLIDE.I SINGLE OCCURRENCE DCES NOT ALLOW THE FINUING THAT A COMPONENT FAILED.

AVAILABILITY - USAEC PUELIC DICIJMENT DOOM, WASHINGTON, D. C.

\#FAILUFE, SCRAM MECHAINISM + CLVTTOL ROD OFIVE + FAILURE, COMPCNENT + INCIDENT, EQUIPMENT + REACTOQ, PULSED + TH IGA (DE) + VALVE

C-22974 ALS? IN CATFGORIFS 10 ANE 18 UKL KEQUESTS ACOIT IONAL DISCUSSICIN ON FOFT CALHOUN

J. S. ATOHIC ENEKG? LUMMI \$SION, WASHINGTON, D. C.

1 PAGE, JAINUARY 27. 1968, DOCKET 50-285, TYPE--PWR, MFG--C.E., $\triangle E--G I R E S+H I L L$

CANFIRMS PHOVF CONVEPSATION OF JARUAFY 17,1 , 68 , THAT ACRS WISHES $\triangle D O I T I O N A L$ INFCRMATION BEFOFE PREOARING THEIR REPORT - (1) ADEQUACY OF OFF-SITE POWER, AND GENERAL DES IGN CF.ITEEION 3\%, (2). ABILITY TO INSERT CONTROL FONS IF A PRIMARY COOLANT LINE LARGER THAN I2 INCHES RUPTURES, AND (3) ACEQUACY OF THE REACTOP. PROTECTION SYSTEM, ESPECIALLY THE SCRAM BUS, TO PROVIOE PROTECTION IF A SINGLE FAILURE WERE TO OCCUR.

USAEC PUBL IC DOCUMENT PEOM, WASHINGTCN, D. C

\#EMERGENCY PONER, ELECTRIC + \#PLANT PROTECTIVE SYSTFM + ACOS * AEC CESICN CRITERIA + AEC DUESIIUN + HAILUKE, SCRAM MECHANISIA + ET. CALHOUN (EVR) + FEACTOF, PWR + SINGLE FAILURE CRITERION

$9-22992$

MCCORO RV

HIGH FLUX ISOTOOE D.FACTUC, OUAPTERLY REDORT, JULY-SEPTEMBER OF 1967

DAK RIDGE NATIONAL LABORATCRY

ORNL-TM-2078 $\because 26$ PAGES, 2 FIGURES, 12 TABLFS, NQVFMRER 12, 1967

SENSITIVITY LOSS GF. THE IONIZATIDN THAMBSRS CONTINUED AS A RESULT JF BURNUP OF BORCN COATING. 
9-22992 \#CONTINUED*

OPERATING INPUT CUPRENT WILL BE LOWERED BY VIITHERAWING CHAMBERS TO LOWER FLUX. SUMMARIZES PPOSLEMS EXPERIENCED WITH CONTTROL-PLATE 'BEARINGS. FIRST FAILURES OCCURRED AT END OF CYCLE 4 (SEPT. 30, 1966) WHEN BEARING BALLS WORE ENOUGH TO COME OUT OF THE RACE. AT ENO OF CYCLF 14, FIVE OF SIXTEEN LUGS (BEARING HOLOEPS) WERE MISSING FROM THE PLATES. POSSIBLE CAUSES ARE GIVEN (LATER TESTS P.EVEALE FAILURES DUE TO WEAK LUGS AND VIBRGTIONAL STRESSES INDUCED EY COOLANT FLOW FORCESI.

AVAILABILITY - CLEARINGHOUSE FOR FEDFRAL SCIENTIFIC AND TECHNICAL INFORMATION, SPRINGFIELO, VA., \$3.0O COPY, \$D.65 MICROFICHE

* CONTROL ROD + *FAILURE, SCRAM MECHANISM + FAILURE, INSTRUMENT + HFIR (FTR) + HYDRAULIC EFFECT + INSTRUMENTATION, POWER RANGE + REACTOR, FLUX TRAF + REPORT, OPERATIONS + STRESS + VIBPATION

9-23143 ALSO IN CATEGORY 17

ANALYSIS OF INNOPERATIVE CONTROL RDD AT SAN ONOFPE

SOUTHERN CAL IFORNIA EDISON COMPANY

6 PAGES, JANUARY 26,1968 , DOCKET 50-260, TYPE--PWR, MFG--WEST., AE--BECHTEL

THE CAUSE OF THE MAY 19, 1967, FAILURE OF RDO G-13 WAS A FAULTY LATCH PIN IN THE MOVAELE

GRIPPER ASSEMBLY, WHICH DID NOT HAVE THE PROPER THICKNESS AT ONE END, LOOSENED, AND JAMMED

THE MEC HANISM AT $80 \%$ WITHDRAWN. THE PIN FAILED WHERE IT WAS FLARED (TO HOLD IT IN PLACE) TO

0.009 IN. INSTEAD OF 0.25. QUALITY-CONTROL CHECKS REVEALEC THAT THIS STEP HAD BEEN $100 \%$

INSPECTED AND THAT TWO PEOPLE HAD INITIALED THE SHEET. THIS IS ATTRIBUTED TO RANDOM

OCCURRENCE. \#\# DEPENDING ON POSITION AND CORE LIFE, 12-15 RODS COULD STICK; AND THE REACTOR

COULO BE SHUT DOWN BY OTHER POOS IF ANOTHER ACCIDENT IS NOT COMPOUNDED.

aVAILABILITy - USAEC PUBLIC DoCUMENT ROOM, WASHINGTON, D. C.

*CONTROL ROD ORIVE + \#FAILURE, SCRAM MECHANISM + \#QUALITY CONTROL + CONTROL ROD FABRICATION + EXAMINATION + REACTOR, PWR + SAN ONOFRE (PWR)

9-23147

ATKINSON H + JAMES PR + TAIT D

DESIGN AND USE OF SIMPLE R.EACTIVITY METERS FOR FAST REACTORS

UNITEO KINGDOM ATOMIC ENERGY AUTHORITY, GGUNREAY (SCOTLAND). REACTGR GROUP

TRG-REPORT-1526(D) +. 28 PAGES, 12 FIGUPES, 7 F.EFERENCES, JUNE 21, 1967

TWO SIMPLE ACCURATE REACTIVITY METFR SYSTEMS COSTING LESS THAN 1000 POUNOS WERE TESTED ON THE DOUNREAY FAST REACTOR. THESE DESIGNS AND A DESCRIPTION OF THE EXPERIMENTAL YEASUREMENTS AND TESTS ARE PRESENTED.

AVAILABILITY - CLEARINGHOUSE FOR FEDERAL SCIENTIFIC AND TECHNICAL INFORMATION, SPRINGFIELD, VIRGINIA, $\$ 3.00$ COPY, \$0.65 MICREF ICHE

* DESIGN STUDY + *INSTRUMENTATION, OPERATING REACTIVITY + DQUNREAY (TR) + EQUIPMENT DESIGN +

P.EACTIVITY EFFECT + REACTUR, FAST + REACTOR, TEST + UNITED KINCDOM

$9-23148$

ANDERSON JL

NUCLEAR INSTRUMENT MEOUL MAINTENANCF MANUAL. PART 13. MAGNET CONTROL AMPLIFIER, ORNL MODEL Q-26I3 DAK RIDGE NATIONAL LAB., TENN.

ORNL-TM-1638(PT.13) +. 1E PAGES, 1 FIGURE, 2 TABLES, NOV. 2,1967

THE AMPL.IFIER IS NORMALLY USED TO CCNTROL THE CURRENT TO A SCRAM-LATCH MAGNET IN A REACTOF SAFETY SYSTEY. WHEN THE BISTATE INPUT SIGNAL IS NORMAL, THE $\triangle M P L I F I E P$. OUTPUT IS $\triangle$ REGULATEO CUPRENT $\triangle D J U S T A B L E$ FROM 0.3 TU 2.2 AMP. WHEN THE I.NPUT SWITCHES TO THE $\triangle B N O R M A L$ STATE, THE DUTPUT CURRENT IS SWITCHED TO ZERD IN LESS THAN 5 MSEC FOR A TYPICAL COMPATIBLE MAGNET

DESIGN. THE CONTROL AMPLIFIER WAS DESIGNED SPECIFICALLY FOR THE HFIR 3-COIL, 2-CUT-DF-3

COINCIDENCE AAGNFT SYSTEM BUT MAY BE USED FOR SINGLE-COIL MAGNETS AS WELL.

AVAILABILITY - CLEARINGHOUSE FOR FEDERAL SCIENTIFIC AND TECHNICAL INFORMATION, SPRINGFIELD, VIRGINIA, $\$ 3.00$ COPY, $\$ 0.65$ MICROFICHE

\#CONTROL ROD SCRAM MECHANISM + \#INSTRUMENTATION, AMPLIFIER + \#INSTRUMENT ATION, CONTRDL + EQUIPMENT DESIGN + HFIR (FTR) + INSTRUMENTATION, SWITCH + FEACTOR, FLUX TRAP + REACTOR, RESEARCH

$9-23149$

ANDERSON JL

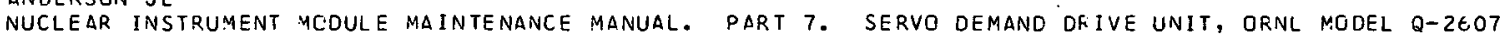

OAK RIDGE NATIONAL LAE., TENN.

ORNL-T:1-1638 (PT.7) †. 13 PAGES, I FIGUFE, 1. TABLE, NOV. 9, 1967

THIS MOOULE PROVIOES A REMOTELY AOJUSTED REFERENCE VOLTAGE WHICH IS USED AS THE POWER-DEMANO SIGNAL IN A REACTOR POWER-LEVFL CONTRLLLER. THE VOLTAGE VS PEPCENT POWEP CALIBRATION AND THE RATE OF CHANGE OF DEMAND SIGNAL APE BOTH FIXED. THE UNIT CONSISTS OF A MOTDR-DRIVEN

DUAL-PRECISION PQTENT IOMETER AND ADJUSTARLE ROTARY LIMIT SWITCHES. ACCURATE EXTERNAL

REFERENCE VOLTAGES ARE APPLIED ACROSS THE POTENTIDMETER SECTIONS, AND THE DEMAND SIGNALS ARE 
9-23149\#CONTINUEO*

TAKEN FROM THE WIPERS DF THE POTENTIOMETERS.

AVAILABILITY - CLEARINGHOUSE FOR CEDERAL SCIENTIEIC ANO TECHNICAL INFOFMATION, SORINGFIELD, VIPGINIA, $\$ 3.00$ COPY, \$0.65 MICRCFICHE

*INSTRUMENTATION, COMPONENT + \#INSTRUMENTATION, CONTROL + \#INSTRUMENTATION, PDNER RANGE +

EQUIDMENT DESIGN + INSTPUMENTATION, POSITION + SERVOMECHANISM

$c-23150$

WHITT RE + DUGGINS RC

DIGITAL COMPUTERS AS PRCCESS INSTRUMENTATIGN

4 PAGES, 12 REFERENCES, NUCLSAQ SAFETY O(!), FAGE 25-28, (FEB, !SGE)

THE ALL-DIGITAL CONTHUL SYSTEM gECOMES ATTRACTIVE ECONOMICALLY AS NUICI FAR PUWEG PLANTS BECOME LARGER AND YJKE COMPLEX. A EECENT STUDY IS P.EVIEWED THAT CENSIOE PEO SATISFYING POWER-PLANT-INSTFUMENTATION ECQUIKEMENTS THROUGH THE USE OF SPFCIAL-PURPOSE DIGITAL SYSTEMS. HOWEVER, PRESENT EXPFRIMENTS INOICATES THAT IT IS ADVISABLE TO COVSIDEF THE PGOVED MFRITS CIF CONVENTIONAL DNALUG METHODS EEFORL MAKINC ANY STPONG COMMITMENTS TD THE USE OF DIGITAL-CONTRCL COMPUTERS.

\#COMPUTED, DIGITAL + \#INSTRUMENTATION, DRCCESS + CONTROL SYSTEM + CCNTFOL, CCMPUTER + CONTROL, GENERAL + INSTRUMENTATION, CONTROL + INSTRUMENTATIGN, GENERAL

$9-23151$

HANAUER SH + NALKER CS

PRINCIPLES DF DESIGN OF REACTOR-PROTECTICN INSTRUMENT SYSTEMS

GAK QIDGE NA'TIUNAL LAE.

7 PAGES, 1 FIGURE, 3 FEFERENCES, NUCLEAP SAFETY $9(1)$, PAGE 28-34, (FER. 1968$)$

DESIGN POLICY OF REACTOP. DROTECTICN INSTPUMENT SYSTEMS IS DISCUSSED FRCM $\triangle$ REVISW! OF PUBLISHED DEEINITIONS TO THE ROLE OF THE HUMAN COPERATCR IN PLANT PPCTECTION. TOPICS CONSIOERED ADE PERFDRMANCE RECUIRED UNDEP ACCIDENT CONDITICNS AND RELIAEILITY OF THE DEVICES INVOLVED, REDUNDANCY ANO CCINCIDENCE, TESTING AND MAINTENANCE, ANO THE RELATION SETWEEN THE DRCTECTICN SYSTEM AND THE OPERATION SYSTFM. REVIEW

$0-23152$

$W \triangle N G C C$

AUTOMATIC CONTPOL SYSTEM FOD DETECTIGN OF NUULLAR MAGNETIC RESONANCE

CALIFOR!NIA UAIVCASITY. FEOKFIFY. I AWFENVGF DADIATION LAB.

UCRL-17715 +. 25 PACES, $\varepsilon$ FIGURES, 1 TAPLE, AUGUST $3,195 \overline{7}$

AN AUTOMATIS TOLTPOL SYSTEM FRP JETECTION OF THE NUCLEAP MAGNETIC RESCNEVCE IS CESCR IBEO. THE SYSTEM IS A CGMEINATION OE THE COMMERCIAL INSTRUMEN IS ANO THE MODJLAR UNITS DEVELODER IN THE LAB. THE HRCOUSNCY JE INTEREST IS ANYWHEPE BETWEEN IOO AND OOS MUZ. THE RANEE OF THE

FREQUENCY SNEEP ING IS DETERAINEO EY THE SAMPLE UNDER DBSERVATION, NHICH IS SELDCMLY OVER IOO

MHZ. THE ACELEACY OF THE RRFGUIENCY REDETITION IS WITHIN $10 O \mathrm{KHZ}$

AVAILABILITY - CLEARINGHDUST EJP GEOEEAL SCIENTIFIC, AND TECHNICAL INFCRVATION, SPRINGFIELO, VIREINIA, $\$ 3.00$ CODY, \$0.65 HICFOF ICHF

CONTREL SYSTEM + EQUIEMENT DESIGN + INSTRUMENTATION, CONTROL + INSIRUMENIAIIUV, MUCLEAF,

RESDNANCL OVERLAO + TEST, PHYSIS.S

$4-23183$

TOSTES D + LESEY J + MAFIINR

DEVICF FOR REGULATING THE POWFR LEVLL DE A NUCLEAK REACTOR

FRANCE. COMMISSARIAT AL ENERGIT ATOMIGUE

SRITISH PATENT I, O76,70E +. 2 DAGES, I FIGUPE, JULY 19, 1967

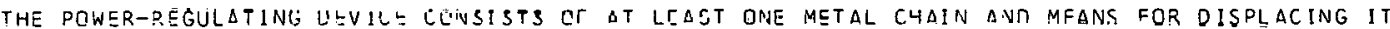

WITHIV A VERTICAL CHANNEL EXTENDING THROUGH THE REACTOR COOE.

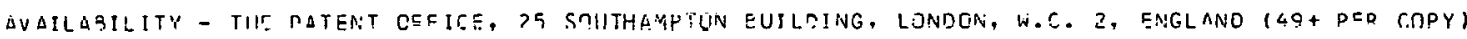

*CONTROL ROD + PATEVT + UNITED KINGCON

$9-23185$

LEJAILLF V.J + DUF.EAU G

INSPECTION, COMTROL GND AUTRMATION RF NUCLFAR REACTORS

\& PAGES, E FIGIJEC5, ATOMPRAXIS $13(11 / 12)$, PAGES 527-5L4 (NOV-DEC 1OE7). IN GERMANI 
CATEGORY
NUCLEAR INSTRUMFNTIION, CONTROL, AND SAFETY SYSTEMS

$9-23195 \%$ CONTINUFD $=$

THE FIRST PART CE THE ARTICLE INCLUDES A DESCF.IPTION BY COMPAGNIE FRANCAISE THOMSGN HOUSTON HOTCHKISS SRANCT OF THE PRINCIDLES ANE TECHNI QUES I MPLEMENTED BY THE COMPANY IN SEVERAL REACTOKS KECENTLY SUILY. THE SECONC FAFT IS A CETAILED DESCRIPTION OF THE AUTOMATIC FIJEL-HANDLING SYSTEMS FITTED BY ALCATFL IN ELECTRICITE DS FRANCE NUCLEAR PLANTS EDF 3 AND EDF 4 .

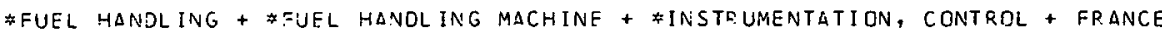

C-23186

DEVELOPMENT OF A RORCN CONCENTRATION METFF. TECHNICAL PROGRESS REPGRT FOR THE PERIDO ENDING SEPTEMBER 3O, 1966 .

WESTINGHOUSE ELECTRIC CORP., PITTSBURGH, PA.

WCAP-36CO-1 + EURAEC-17Z2 +. 25 PAGES, 4 FIGURES, 3 TABLES, OCTORER 1966

THIS MONTHLY PFGGRESS REPORT IS QNE OF A SERIES. THE OVERALL GBJECTIVE OF THE PROGRAM IS TO DEVELOP, DESIGN, TEST, ANO EVALUATE THE PERFORMANCE OF a PP.OTOTYPE BORON-CDNCENTRAT ION METER. THE METER SHJULD BE SUITABLE FOR CUTOMATED USE IN DETERMINING BQRDN CONCFNTRATIONS IN THE CJOLANT OF A CLOSEO-CYCLE, WATER-MODERATED AND -COOLED POWER REACTOR. THE DESIGN OBJECTIVES FOR THE BŨR JN METER. INCLUDE A PRECISIION OF PLUS OR MINUS 0.3 PEFCENT OR 2 PPM IWHICHEVER IS GREATER, ANE A RESPONSE TIME DF $\triangle B C U T$ I MIN.

AVAILABILITY - CLEARINGHOUSE FJR FCDERAL SCIENTIFIC AND TECHNICAL INFORMATION, SPRINGFIELD, VA., \$3.00 CÖPY, \$0.65 MICPDFICHE

BORON + INSTRUIAENTATION, COOLANT QUALITY + INSTRUMENTATION, SURVEILLANCE

$2-23327$

SWANSOV CD + WOOD $12+$ CONE RR

EAST FLUX TEST FACILITY INSTRUMENTATION AND CONTROL PROGRAM

BATTELLE MEMOR IAL INSTITUTE, RICHLAND, WASHINGTON

ANL-733C + 5 PAGES, I FIGURE, REFERENCES, PAGES 4-8 OF PROCEEDINGS OF THE SYMPOSIUM ON LIQUID METAL INSTR!JMENTATION AND CONTRQL, MARCH 2,1967

DESCPIBES THE FCLATION OF THE FFTF INSTRUMENTATION ANO CONTROL PROGRAM TO THE LMFBR PROGRAM. INSTRUMENTATIGN AND CONTZOL TECHNOLOGY NEEDED TO FULFILL FFTF FUNCTIONAL TEST REQUIREMENTS, AND DPERATIONAL ANE SAFETY REQUIREMENTS ARE SUMMARIZED. A BRIEF DESCRIPT ION OF THE MAJOF FFTF QEACTOR CONCEPTS DRESENTLY UNDER STUOY AND THE TYPES OF INSTRUMENTAT ION PP.OBLEMS ASSDCIATED NITH THESE CONCEPTS IS PRESENTEO.

AVAILABILITY - CLEARINGHOUSE FOR FEOERAL SCIENTIFIC AND TECHNICAL INFOFMATION, SPRINGFIELD, VA., \$3. OO COPY, \$C.65 MICROFICHE

* DESIGN T.RITEGI + \#EQUIPMENT DESIGN + \#IN CORE MEASUREMENT + \#INSTRUMENTATION, GENERAL + * INSTRUMENTATION, IN CCRE + FFTF ITRI + FUEL ELFMENT + INSTRUMENTATION, TEMPERATURE +

INSTRUMENTATIOIN, TESTING + REACTOR, FAST + REACTOR, LMCR + REACTOR, TEST + SYSTEM DESCRIPTION +

- TEST, COMPONSNT

$9-23328$

$K N C X A E+P O P P E R$ GE

ANL FARTTICIPATION IN THE FFTF INSTR UMENT EEVELOPMENT EFFORT

AR.GONVE NATIONAL LABORATDRY

ANL-7390 + . O PLGES, 4 FIGURES, 6 REFERFNCFS, PAGES S-14 OF PROCEEDINGS OF THE SYMPOSIUM ON LIQUID METAL INSTRUMENTATION ANJ CCNTROL, MARCH 2, IC67

IN-CORE INSTZUMENT DEVFLOPMENT IS PROCEEDING IN THE FQLLOWING CATEGORIES - $(1)$

FAILED-FIJEL-LCCATION.DETECTION, (2) SIGNAL-LEAD CONNECTORS, (3) FISSION-GAS-PRESSURE

TRANSDUCEFS, (C) IN-COPE FLOWNETERS, AND (5) FUEL-OIN THERMOCOUPLES. ONE OF THE PP.IME

03JECTIVES JE THE PROGRAM IS TO PFGVIDE BOTH THE FFTF AND THE LMFBR PROGRAM WITH THE

SPECIFICATIONS NFCESSARY FOR MATEFIALS AND FABRICATICN PROCEDUPES AS WELL AS THE QUALITY

CONTROL AND INSPECTION METHOOS NEEOED SO THAT RELIABLE COMMERCIAL INSTRUMENTS CAN BE MADE

AVAILAOLLE.

AVAILABILITY - CLEARINGHOUSF FOR FEDERAL SCIENTIFIC ANO TECHNICAL INFORMATION, SPRINGFIELD, VA., \$3. OO COPY, \$2.55 Y ICROFICHE

*EQUIP MENT DESIGN + FINSTFUMENTATION, IN CORE + INSTRUMENTATION, COMPONENT +

INST RUMENTATICN, DETECTIGN FAILSD FUEL ELEMENT + INSTRUMENTATION, FLOW + INSTRUMENTATION, PRESSURE + INSTRUNENTATION, TENPEFATURE + REACTOF, LMCR

$9-23329^{\circ}$

HINESS OP + HOSST KN

SERUF DEVELDPMSNT ACTIVITIES

GENERAL ELECTRIC CO., SUNNYVALE, CALIF.

ANL-7380 + 7 PAGES, 6 FIGURES, 3 REFERENCFS, PAGES $15-21$ DF PROCEEDINGS OF THE SYMPQSIUM ON LIQUID METAL INSTRUMENTATION AND CONTROL, MARCH 2, 1967

DEVELOPED INSTRUMENTATIONS TO MEASURE FUEL-PELLET CENTRAL TEMPERATURE, FUEL-ASSEMBLY COOLANT 
CATEGORY 9
NUCLEAR INSTRUMENTATION, CONTROL, AND SAFETY SYSTEMS

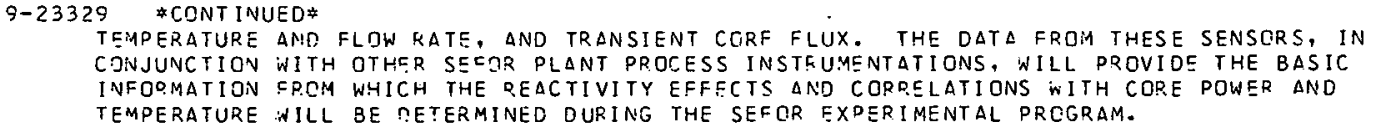

AVAILABILITY - CLEARINGHOUSE FOR FEDERAL SCIENTIFIC ANC TECHNICAL INFORMATION, SPRINGFIELD, VA., S3. OO COPY, \$0.65 MICROFITHE

\#EQUIPMENT DESIGN + \#INSTR UMENTATION, IN COPE + CHAMREF, FISSION + HIGH TLMPERATURE + INSTRUMENTATION, FLOW + INSTRUMENTATION, NUCLEAR + INSTRUMENTATION, TEMDERATURE + REACTOR, LLMCR

9-23330 ALSO IN CATFGORY 17

EBE-II INSTRUMENTATION EXPER. IENCES

EBR-II INSTRUMENTATICN EXPER IR
ARGONNE NATIONAL LASERATORY

ANL-7380 +. 7 PAGES, 3 FIGURES, PAGES 22-2\& CF PROCEEDINGS OF THE SYMPOSIUM ON LIQUID MEIAL

INSTRUMENTATION $\triangle N$ F. ONTRCL, MAP.CH 2,1967

EXPER IENCES WITH THE ERR-II PRESSURE INSTEUMENTATION, BOTH STATIC AND DIFFERENTIAL, THE TEMDERATURE-MEASURIING DEVICES, AND WITH THF LEVEL I'NCICATIONS AKE PRESENTED. THE PROBLEMS ENCOUNTERED ARE CUTLINED, AND THE COPRECTIVE ACTION TAKFN TO RECTIFY A PROBLEM IS GIVEN VHERE POSSIBLE. THE IMHUURTANCE OF FFE-INSTALLATION DATA IS STPESSED. CALIBRATICN ANC R.EPAIR PRCCEOURES USEC FOR FILLED SYSTEMS ARE INCLUDED FOR GENERAL INFORMATION ANO TO POINT OUT THE TYDE OF INFORMATION THAT MUST BE INCLUDEC IN THE PRE-INSTALLATICN CALIBRATION CHECK ON A COMPONENT

AVAILASILITY - CLEARINGHOUSE FOR FEDERAL SCIENTIFIC AND TECHNICAL INFORMATION, SPRINGFIELD, VA., S3. OO COPY, \$O. .5 MIT.ROEICHE

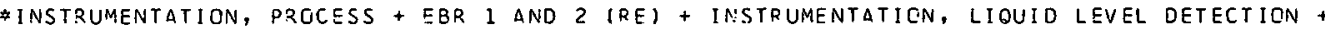
INSTRUMENTATION, DFESSURE + IVSTRUMENTATION, TEMPERATURE + OPERATING EXPERIENCE SUMMARY + REACTOQ, BPEEDEK + REACTOR, LMCR

$-2333$

$\operatorname{SCOTT} C \mathrm{C}$

FEPMI PROCESS INSTRUMENTATION

ATOMIC POWER DEVELOPNENT ASSOCIATES, INC, DETROIT, MICHIGAN

ANL-7380 +. P PAGES, 12 FIGURES, PAGES $20-36$ OF PROCEEDINGS OF THE SYMFOSIUM ON LIOUID METAL

INSTRUMENTATION AVO CONTRCL, MARCH 2,1907

DPERATING EXPERIENCE AND EQUIFMENT DESIGN $\triangle P E$ REVIEWED FOR THREE KINUS OF PRCCESS INSTRUMENTS ON THE FERMI PEACTOR. DROBLEMS $\triangle$ SSOCIATED WITH PLUGGED PROCESS LINES, IN-PLACE CAL IRRATION, AND THE DIFFICULTY OF REMOVING UNITS FOR MAINTENANCE ARE DISCUSSED COMPONENTS

AVAILABILITY - CLEARINGHOUSE FOR FEDERAL SCIENTIFIC AND TECHNICAL INFORMATION, SPRINGFIELO, VA., \$S. UIJ COPY, \$0.65 YICRDFICHE

\&INSTRUMENTATION, DRRCESS + \$OPERATING EXPERIENCE SUMMARY + EQUIPMENT DFSIGN + FEKMI ILMFBR + TINSTRUMENTATION CALIERETION + INSTRUMENTATION, FIUW + INSTPUMENTATION, PRESSUPE +

INSTRUMENTATION, TEMPEFATIIRF, + EEACTOR, FREEDER + DEACTOR, LMCR

$9-23332 \quad$ ALSG IN CATFGORIES 4 AND 17

STPAHL H

SNAP SYSTEM INSTRUMENTATION

ATOMICS INTERNATIONAL, CANOGA PARK, CALIF.

ANL-73UU +. A HAGES, 2 TAMICS, I REFEDTNGE, PAGFS 37-39 OF PROCEEOINGS OF THE SYMPOSIUN ON LIUUIO METAL INSTRUMENTATION AND CONTROL, MARCH $2,1 \subseteq E 7$

THE EXPERIFNCE GAINEU UURING, CPERATION TPR SNAR EEACTORS WTTH I,IOUID-METAL PROCESS

INSTRUMENTATICN IS PRFSENTEO. THIS EXPERIENCE IS BASED ON TIIE GRERATION CF SEVFAAI SNAP REACTOR SYSTEMS AT TCIMPEPATURES UP TO $1300 \mathrm{~F}$ FOR PERIOOS OF UP TO 10,000 HR. SEVERAL TYPES OF TEMDERATURE ANO PRESSURF CIEVICES WERE INSTALLED IN A LOOP, $\triangle N D$ THEIR PER FORMANCES WERE COMPARED AND EVALUATEO DRIOR. TO SELECTION OF INSTRUMENTATION FOK THE SEDD. TESTS.

AVAILASILITY - CLEAQINGHOUSE FOR FEDERAL SCIENTIFIC AND TECHNICAL INFCFMATION, SPRINGFIELD, VA., \$3. OO COPY, \$O.S5 MICEOCICHE

\# INSTRUMENTATION, D2ULESS + \#OPERATING [XRTRICACE SUMMARY + \#SNAP, GLMFEAL (SR) + HIGII TEMPERATURE + INSTRUMENTATION, FLOW + INSTRIIMEVTATION, LIOUIO LEVEL DCTECTION + INSTRUMENTATION, PRESSURE + INSTRUMENTATION, TEMPEPATURE + INSTRUMENTATION, TESTING + FEACTUR, LMCR. + RSACTOR, SRACE

$0-23333$

ALSG IN CATEGDRY I 7

TURNER GE

SCTI SODIUM INSTRUVENT CPERATING EXPEPIENCE

ATDMICS INTERVATINNAL, CANOGA DARK, CALIF.

ANL-7380 +. 3 PAGES, DAGES $40-42$ OF PROCEEDINGS OF THE SYMPOSIUM CN LIQUID METAL INSTRUMENTATION AND

CONTPOL, MARCH $2, \quad 1 \subseteq 67$ 


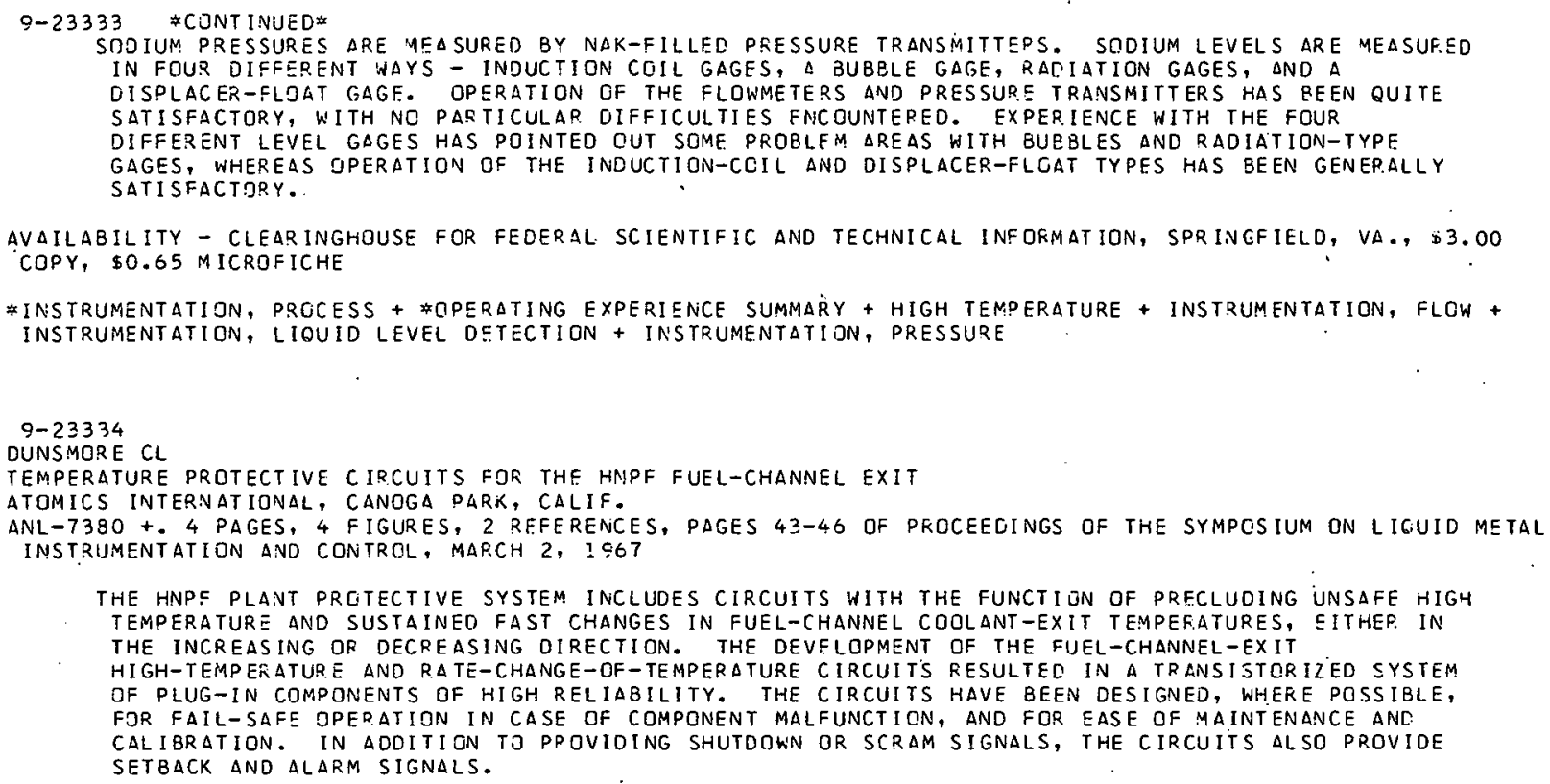


NUCLEAR INSTRUMFNTATION, CONTROL̈, AND SAFETY SYSTEMS

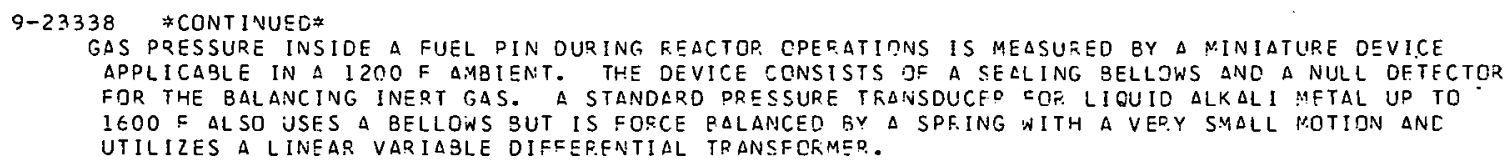

AVAILASILITY - CLEARINGHOUSE FOR FECEOAL SCIENTIFIC AND TECHNICAL INECRMATION, SFEINGFIELD, VA., I X. OO COPY, \$0.65 MICROFICHE

INSTRUMENTATION, LIQUID LEVEL DETECTION + METAL, LIOUIO

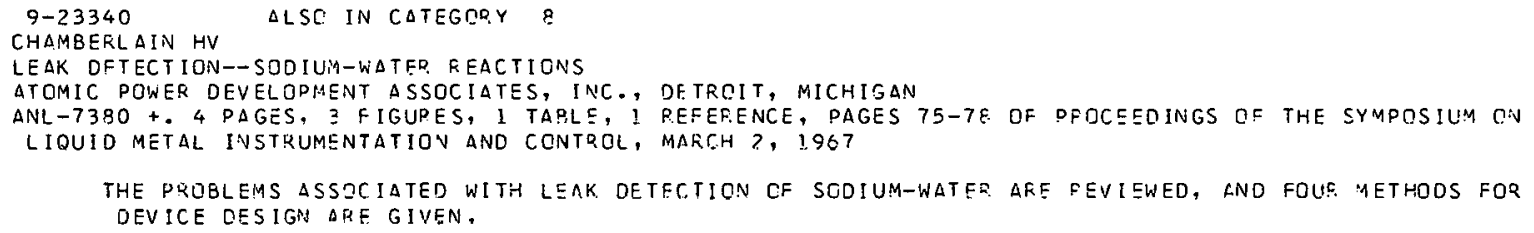




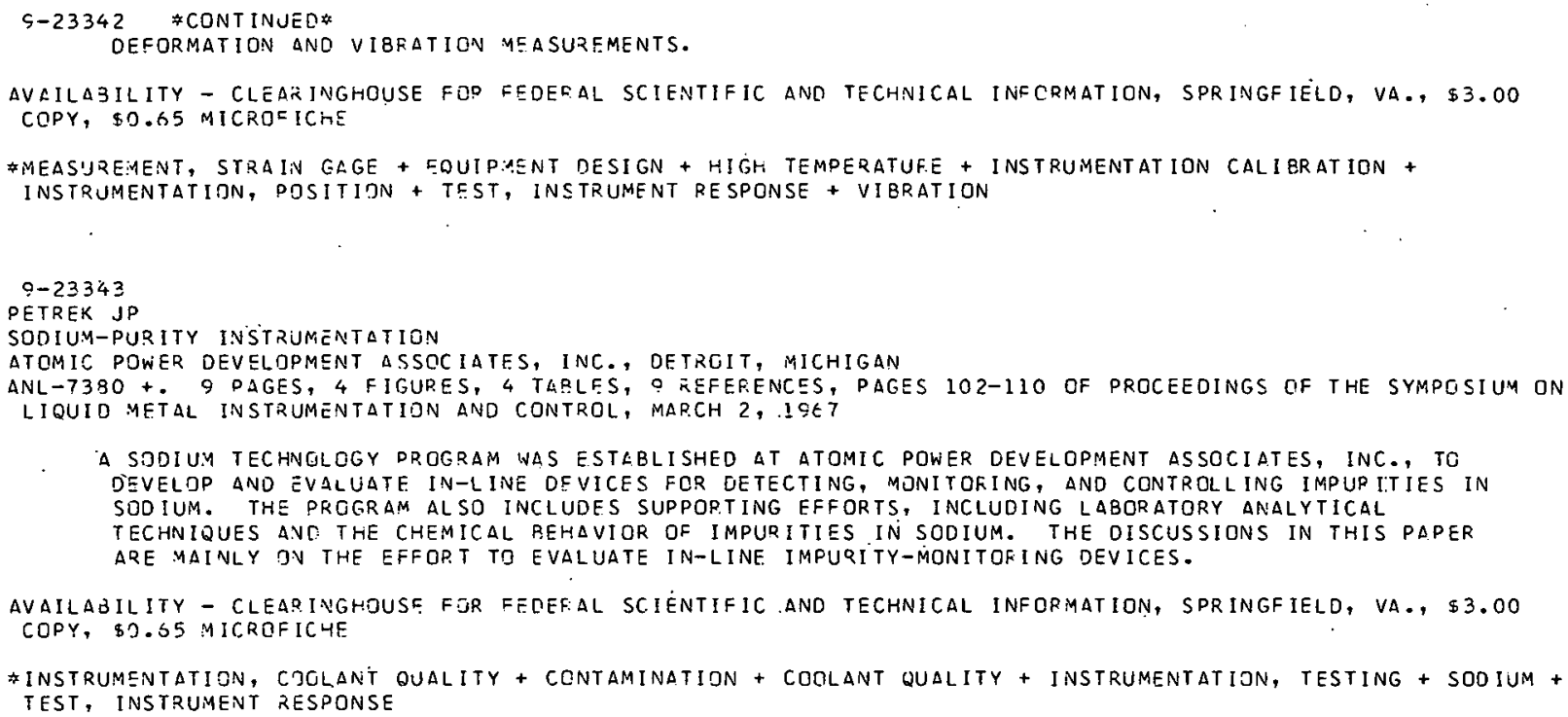

A SODIUM TECHNGLOGY DROGRAM WAS ESTABLISHED AT ATOMIC POWER DEVELOPMENT ASSOCIATES, INC., TO DEVELDP ANO EVALUATE IN-LINE DEVICES FOR DETECTING, MONITOFING, AND CONTROLLING IMPUP I:TIES IN SODIUM. THE PRGGRAM ALSO INCLUDES SUPPOPTING EFFORTS, INCLUDING LABORATORY ANALYTICAL TECHNIQUES ANG THE CHEMICAL REHAVIOR OF IMPURITIES IN SODIUM. THE OISCUSSIONS IN THIS PAPER ARE MAINLY OV THE EFFOP.T TO EVALUATE IN-LINE. IMPUQITY-MONITOFING DEVICES.

AVAILABILITY - CLEARINGHOUSE FOR FEDEFAL SCIENTIFIC AND TECHNICAL INFORMATION, SPRINGFIELD, VA., S3. OO COPY, \$2.55 MICREFICHF

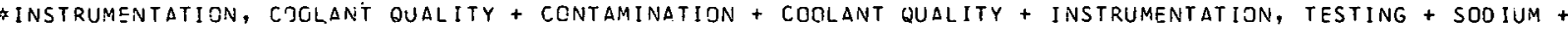
TEST, INSTRUMENT RESPONSE

$0-23344$

$M C K E E J+C A P L I N G E 3$ L

CARSON METER DEVELOPMENT, AN INTERIM PEPOPT

UNITED NUCLEAR CORP., ELMSFORD, NE N YORK

ANL-7380+. 7 PAGES, 10 FIGURES, 5 TABLES, PAGES $111-117$ OF FROCEEDINGS OF THE SYMPOSIUM ON LIQUID METAL INSTRUMENTATION AND CONTRGL, MARCH $2,19 E 7$

PP.OSPECTS APPEAR ENCOURAGING FOR THE SUCCESSFUL DEVELOPMENT OF AN ON-LINE METER. WHICH WILL PROVIDE $\triangle$ CTVTINLIOUS MEASUREMENT OF THE CARBURIZING POTENTIAL IN SODIUM AND OTHER

LIQUIO-METAL SYSTEMS. PROGRESS TO DATE IS PRESENTED HERE FOP COMMENT BY POTENTIAL USERS. THE SENSING ELETAENT IN THE SC:DIUM IS A CAREON PERMEARLE TUBE THFOUGH WHICH DECARBURIZING GAS FLDINS TO A GAS ANALYZEP.

AVAILABILITY - CLEARINGHOUSE FOR FECERAL SCIENTIFIC ANO TECHNICAL INFORMATION, SPRINGFIELD, VA., \$3. OO COPY, \$O.65 MICROFICHE

* INSTRUMENTATION, COOLANT QUALITY + CEPBEN + CONTAMINATION + EQUIPMENT DESIGN + SODIUM +

TEST, INSTRUIANT RESPON:SE

$-23345$

GOLDMANN K

A TECHNIQUE FOK CALIERATION OF ELECTROCHEMICAL OXYGEN METERS

UNITED NUCLEAR CORP , EL MSFORD, NEW YORK

ANL-7380 +. 5 PAGES, \& FIGURES, I TARLE, ? FEFERENCES, PAGES $118-122$ GF PROCEEOINGS OF THE SYMPOSIUM TN LIGUID METAL INSTRUMENTATION AND CONTROL. MARCH 3,1967

DESCRIEES EQUIPMENT AND TECHNIQUES USED FOR CALIBRATING OXYGEN SENSORS IN POTASSIUM.

CAL ISRATION DATA ARE DPESENTED. COMMENTS ARE MADE ON THE HIGH OXYGEN DISSOLUTION AND

GETTERING RATES QRSERVED DURING THE CALIBRATION RUNS WITH POTASSIUM. ATTEMPTS AT USING THIS

TECHNIQUE. FOR THE CALIBRATION AF OXYGFN METERS IN SODIUM ARE DESCRIBED.

AVAILABILITY - CLEARINGHOUSE FOR FEDERAL SCIENTIFIC AND TECHNICAL INFORMATION, SPRINGFIELD, VA., \$3. OO

COPY, \$0.65 MICROFICHE

* INSTRUMENTATION CALIEPATIDN + CONTAMINATION + OXYGEN + SODIUM + TEST, INSTRUMENT RESPONSE

$5-23346$

WOLFSON R

COMPUTER SYSTEMS FOR FAST TEST REACTORS

CURTISS-WRIGHT CORP., EAST PATERSON, N. J.

ANL-73.80 +. 2 PAGES, PAGSS 126 AND 127 OF PROCEEDINGS TF THE SYMPOSIUM ON LIQUID METAL INSTRUMENTATION AND CONTROL, MARCH 3,1967

A FAST TEST REACTUR FACILITY (FFTF) WILL REQUIRE AN INSTRUMENTATION SYSTEM WITH A DIGITAL

COMPUTER AS ITS NEP.VE CENTER. THIS R.DMPUTING 'CFNTER IS GENERALLY DESCRIBED IN TASK 35 IN THE

LMFBR PROGRAY PLAN. THE IMPORTANT SYSTEM CGNSIDERATIONS FOR SUCH A CENTER ARE DESCRIBED IN

THIS PAPER, FROM BQTH COST AND DESIGN VIEWPOINTS.

AVAILABILITY - CLEARINGHOUSE FOR FERERAL SCIENTIFIC AND TECHNICAL INFORMATION, SPRINGFIELD; VA., S3. OO COPY, \$O.S5 MICROFICHE 


\section{CATEGCFY OO
NUCLEAR INSTRUMENTATICN, CONTROL, AND SAFETY SYSTEMS} $9-2.346$ \#CONTINUED*
\#COMPJTER CONTRDL + \#INSTRUMENTATION, CONTROL + COMPUTER, DIGITAL + FFTF ITRI + REACTOR, FAST +
REACTDR, TEST

$9-23.347$

DQIVER GE

THE LMTER COMPUTER CONTPOL CENTER

BATTELLE MEMOF IAL INSTITUTF, RICHLAND, WASHINGTON

ANL-7380 +. 4 PAGES, PAGES $128-13$ ! OF PPCCEEDINGS OF THE SYMPOSIUM DN LIQUID METAL INSTRUMENTATICN AND CONTROL, MARCH 2,1967

IF THE DRESENT TDEND IN INSTR UMENTATION AND CONTROL SYSTEMS CCNTINUES, IT IS "HIGHLY LIKELY THAT LMFBRS WILL USE OIGITAL COMPUTFRS TO HANDLE DATA AND CONTRCL REACTDRS, HEAT EXCHANGERS, AND POWER-CENEFATION FOUIDMENT. WHAT IS NEEDED IS A SINGLE [RGANIZATION WHICH CCMPRISES THE BEST OF KNONLEDGE AND EXPERIENCE IN DLL PHASES OF REACTCR CGNTPDL, IN SHIJKI, A COMPUTER CONTRDL CENTEF. THE CENYERS MAIN JOB WOULD DI TO RROVIDE THE LMFBR PIANT DFSIGNER WITH THE SDECIAL IZED HELP NEEDED TO ACQUIPE, INSTALL, AND OPERATE A CCMPUTER-BASED DATA-HANDLING AND CDNTROL SYSTEM.

AVAILABILITY - CLEARINGHDUSF FOR FECEDAL SCIENTIFIC AND TECHNICAL INFORMATICN, SPRINGFIELO, VA., \$3. OO COPY, \$0.65 MICRJF ICHE

* COMPUTER CONTRCL + *INSTRUMFNTATION, CONTPOL + CONTROL SYSTEM + DATA PROCESSING + REACTOR, LMCF

Q-2334? ALSO IN CATEGDQY 6

DAHL RE + JACKSCN JL

MEASUREMENT OF NEITRCIN CLLIX IN FAST D.EACTTR EXPERIMENTS

BATTELLE YEMDR IAL IVST JTUTE, FICHLANO, WASHINGTON

ANL-7380 +. 7 DAGES, 5 FIGURES, I TABLE, 6 REFERENCES, PAGES 132-139 OF PROCEEDINGS OF THE SYMPOSIUM ON LIQUID HETAL INSTPUMENTATION AND CCNTCOL, MARCH 3,1967

ACCURATE MEASIJPEMENT OF NEUTRON FLUX AND DETERMINATION OF SPECTRA ARE CRITICAL IN FAST PEACTORS FIR INTERDRETATTON AND APPLICATION OF FUELS AND MATERIALS TEST DATA. RELATIVE RESPONSES OF LCTIVATION MONITORS ARE SUFFICIENTLY DIFFERENT IN FAST REACTORS TO R.EQUIDE THE USE OF AOVAVCED ANALYTICAL AND EXPERIMENTAL METHODS TO CHARACTERIZE THE NUCLEAR ENVIRONMENT. ACTIVATICN MONITCRS DISCUSSEQ IN THIS REPCRT ARE MATERI ALS CONTAINING SPECIFIC ISOTOPES THAT ARE ACTIVATED SY NEUTRCNS. STUDIES ARE IN PROGRESS TO DEVELGP DGSIMETRY TECHNIGUES FOR FAST RFACTCR APPLICATION.

AVAILARILITY - CLEARIMIRHOUSF FRR FEOERAL SCIENTIFIC AND TECHNICAL INFORMATION, SPP.INGFIELO, VA., \$3. OO CQPY, \$Ö.65 IICROFICHE

\#FLUX, INTEGPATED + \#MEASUREMENT, REACTIVITY + \#NEUTRON + DCSIMETRY, GENERAL + EXPERIMENT, GENERAL + INSTRUMENTATION, NUCLEAP + REACTDR, FAST

$9-2334 \mathrm{~s}$

JOSL IN CN

SCME CONSIDERATIONS ON SELF-DOWERED DETECTORS FOR LMFBR SERVICE

REUTER-STOKES ELCCTRONIC CCMOCNENTS, INT. . CIFVFLAND, OHIO

ANL-7380 +. 1 PAGE, 2 REFEPENCFS, PAGE 139 OF PP.OCEEDINGS OF THE SYMPOSIUM ON LIGUID MEIAL INSTFUMENTATION AND CONTROI, MARCH 2, 1967

HIGH-TEMPERATUPE SERVICE $1700 \mathrm{CI}$ HAS NOT REEN RECORDED FOR SELF-POWERED DETECTORS. MATEPIALS AND ELECTRICAL LEAKAGE RESLSIANLE SEEM TO BP. THE PROQLCM, BETA-OEGAY DETECTMPS SHIIIRI PROVIDE FAIR SEVSITIVITY TO FAST NEUTRONS, BUT PROMPT-FESPONSE COVVERSION DETECTORS WILL HAVE VER.Y LOW SENSITIVITIFS. RATHER THAN FIGHT LOW NEUTRON SENSITIVITY AND HIGH GAMMA FIELDS, THE OPPOSITL U!-FERS AN ATTRACTIVE ALTRRNATIVE,

AVAILABII ITY - CLEAPINGHDUSE FQR FEQERAL SCIENTIFIC AND TECHNICAL INFOFMATION, SPRINGFIELD, VA., SZ. OO COPY, TO.65 MICDOFICHE

*STLF POWERED FLUX DETECTOR + iNSTRUMENTATION, NUCLEAR

$9-2.350$

LEWIS RH

ALL-5OLID IN-CORE PDWER MONITORS FOF. LIMBFP SEDVICE

THE BASCOCK AND WILCOX COMPANY, LYNLHSUMG, VA.

ANL-7380+. O PAGSS, ? FIGUESS, 1 TABLE, 10 PFFERENCES, PAGES 140-45 OF PROCEEDINGS CF THE SYMPOSIUM ON LIOUID METAL INSTRJMENTATION CDNTRCL, MAGCH 2, 1967

AN ALL-SOLID, SELF-POWEP.D, IN-CORE NEUTRON DETECTOR (RHUUIUM TYPE) FOR MEASURING THE POWER DISTRIBUTITN IN LAPGF THERMAL POWEF PEACTOFS WAS DEVELCPED BY BABCOCK ANO WILCOX. DETECTOPS JF THIS TYOE AFE ALSO NECESSARY TO ENSURE OPTIMUM PEFFORMANCE DF LMFBRS. THUS, AN IN-CORE FLUX-MONITOR DEVELOPMENT PROGRAM WDS INITIATED EASED ON AN EXTFNSION OE THE SAME DETECTION PRINCIDLE USEC IN THE RHODIUM-TYPE DETECTDD.

AVAILABILITY - CLEARINGHOUSE FOR FEDERAL SCIENTIFIC ANE TECHNICAL INFORMATION, SPRINGFIELD, VA., \$3. OO COPY, \$O.S5 IIICRDFICHE 
9-23350 *CONT INUED*

*INSTRUMENTATION, IN CORE + \#SELF POWERED FLUX DETECTOR + HIGH TEMPERATURE + REACTOR, LMCR + REACTDR, THERMAL + RHOCIUM + SOLID STATE DEVICE

$9-23351$

KINZER JE + PARK TA

A MINIATUR IZEO NEUTRON FLUX SENSOR FOR LMEQR ENVIRONMENT

ATOMICS INTERNATIONAL, CANOGA PARK, CALIF.

ANL-7390 +.2 PAGES, 2 FIGURES, 1. REFERENCE, PAGE $146-47$ OF PROCEEDINGS OF THE SYMPOSIUM ON LIOUID METAL

INSTRUMENTATION AND CONTROL, MARCH 2, 1907

THE ADIT (ADVANCED DEVELOPMENT IRRAOIATION TECHNIQUES) FLUX SENSGR WAS DEVELOPED AT ATOMICS INTERNATIONAL TO MEST THE NEED FOR IN-CORE NEUTRON-SENSING DEVICE. THE DEVICE CONSISTS OF A THERMOCOUPLE IN WHICH FISSIONABLE MATERIAL HAS REPLACED THE OXIDE I,NSULAT ION ARDUND THE MEASUR ING JUNCTION. THE TYPE OF FISSIUNARLE MATERIALL USED MAY BE CHOSEN TO MATCH THE NEUTRON-FLUX ENVIRDNMENT OF INTFREST.

AVAILABILITY - CLEARINGHOUSE FOR FEOERAL SCIENTIFIC AND TECHNICAL INFORMATION, SPRINGFIELD, VA., \$3. OO COPY, \$0.65 MICROFICHE

*INSTRUMENTATION, IN CORE + \#INSTRUMFNTATION, NUCLEAR + FLUX, INTEGRATED + NEUTRON + REACTOR, LMCR

$-23352$

SWICKARO EO + BACASTOW JL

HIGH TEMPERATURE NEUTPON DETECTOR TEST

UNIVERSITY OF CALIFORNIA, LOS ALAMOS. NEW MEXICO

ANL-7380 +. 13 PAGES, 12 FIGURES, 2 TABLES, PAGES 148-60 OF PROCEEDINGS OF THE SYMPOSIUM ON LIOUID METAL INSTRUMENTATION AND CONTROL, MARCH 2, 1967

THE TESTING OF TWG HIGH-TEMPERATUPE NFUTRON DETECTORS PROM EACH OF THREE MANUFACTURES WAS STARTED. THRES PARAMETERS WERF VARIED DURING TESTS - (1) SOURCE (NONE, NEUTRON), CHAMBER VOLTAGE (MANUFACTURERS RECOMMENDED, HIGH, LOW), AND TEMPERATURE (10O C INCREMENTS TO 6OO C). ANALYSIS OF DETECTOP PERFORMANCE IS BASED ON 4OO-CHANNEL ANALYZER DATA. AT EACH TEMPERATURE, MEASUREMENTS OF DETECTOR (ANO INTEGPAL LEAD) RESISTANCE AND CAPACITANCE ARE MADE.

AVAILABILITY - CLEARINGHOUSE FOR FEDERAL SCIENTIFIC AND TECHNICAL INFORMATION, SPRINGFIELD, VA., \$3. OO COPY, \$0.65 MICROFICHE

* InStRUMENTATION, NUCLEAP + *TEST, INSTRUMENT RESPONSE + COUNTER + hIGH TEMPERATURE + NEUTRQN

$9-23353$

LUPICA LA

A COMPENSATED IONIZATION CHAMBER FOR THE NERVA REACTOR

WESTINGHOUSE ELECTRIC CORP, ELMIRA, NEW YOPK

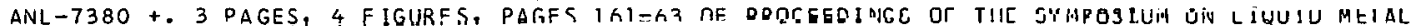

INSTRUMENTA ATION AND CONTROL, MARCH $2,1 \subseteq 67$

A COMPENSATED IONIZATION CHAMEER, THE WX-5362, WAS DEVELOPED FOR USE IN THE NERVA PROGRAM AS A NEUTRON-FLUX DETECTQR FOR REACTOR CONTKOL. THE CHAMBER WAS DESIGNED TO WITHSTAND THE

EXTREMES OF RADIATION, TEMPERATURE, SHOCK, AND. VIBRATION ASSOCIATED WITH THE NERVA REACTOR.

AVAILABILITY - CLEARINGHOUSE FOR FEDERAL SCIENTIFIC AND TECHNICAL INFRRMATION, SPRINGFIELD, VA., \$3. OO COPY, \$O.65 MICROFICHE

*CHAMBER, IUN + \#INSTRUMENTATION, NUCLEAR + COUNTER + FLUX, INTEGRATED + NERVA PROGRAM + NEUTRON + REACTOR CONTROL + REACTOP, AIRCRAFT

$9-23354$

GILMOUR GA

NUCLEAR INSTRUMENTATION

WESTINGHOUSE ELECTRIC CGRP, PITTSBURGH, PA.

ANL-7380 +. 1 PAGE, 3 REFEPENCES, PAGE $164^{\circ}$ OF PROCEEDINGS OF THE SYMPOSIUM ON LIQUID METAL INSTF.UMENTATION AND CONTROL, MARCH 2,1967

THE 'WEST INGHOUSE ASTRONUCLEAR LABORATORY HAS A BROAD INSTRUMENTATION AND CONTROL PROGRAM IN SUPPORT OF NCRVA ONE AREA OF OIAGNOSTIC INSTRUMENTAT ION IS CONCERNED WITH MEASUREMENTS OF GAMMA HEATING IN CALORIMETERS - AN $\triangle B S O L U T E$ DESIGN FOR SHORT REACTOR RUNS (A FEW MINUTES) AND A RATE DESIGN FOF EXTENDED RUNS.

AVAILABILITY - CLEARINGHOUSE FOR FEDERAL SCIENTIFIC AND TECHNICAL INFORMATION, SPRINGFIELD, VA. \& 3. OO COPY, \$0.65 MICROFICHE

* INSTRUMENTATI DN, nUClear + \#instrumentation, temperatupe + gamma + heat generation, internal + MEASUREMENT, TEMPERATURE 
COTEGORY
NUCLEAR INSTRUMFNTATION, CONTHOL, DND SATETY SYSTEMS

9-23355

NEISSEL JP + DAYAL Y

MEASUREMENT OF NEUTREN FLUXES UVDER ADVEFSE CONDITIONS USING CAMPRELLS METHGD

GENERAL FLECTRIC CD., SAN JOSE, CALIF.

ANL-7380 +. 3 PAGES, I FIGURE, 3 REFERENCES, PAGES $165-57$ OF PFOCEEOINGS JF THE SYMPOSIUM ON LIGUID METAL INSTRU:AENTATIDN AND CONTROL, MARCH 2 , ISET

DISCUSSES A METHOD FOR HANDLING THF SIGNAL FEOM A LINFAP NEUTRON DETECTGR IN SLCH A MANNER THAT THE EFFECTS DF GAMMA IRRADIATICN AND CAELE LEAKAGE ACE STOOVGLY SUPPPESSFD.

AVAILABILITY - CLEARIINGHOUSE FOR EEGERAL SCIENTIFIC AND TECHNICAL INFOPMATION. SPRINGFIELD, VA., \$3. OO CDPY, $50.65 \mathrm{MICRDFICHE}$

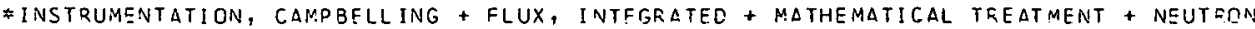

$9-23356$

POPPER GF

SOME LIMITED RESULTS FQOM THE EBR-II TEST OF A COUNTING-CAMPBELLING CHANNEL

ARGONVE NAIIONAL LARGRATORY

ANL-738U +. 2 PAGTS, ? FIGURES, PAGES 168-1ES OF PROLEEOINGS OR THE SYMPTSTHM ON LIQUIC METAL

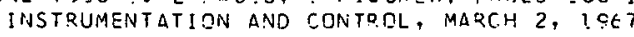

A WIDE-RANGE NEUTF ON-MONITORING CHANNEL SASED ON COUNTING ANO CAMPBELL ING HAS EEEN INSTALLED

IN A J THISBLE OCF THE EBR-II. THE MEASUPEO RESPONSES $\triangle R E$ IN SXCELLENT $\triangle G E E E M E N T$ WITH THE

DREDICTIONS ANO SHOW THAT THE PEREORMANCE OF A CAMPBELLING CHANNEL CAN INESED PE CALCULATED

IF ALL THE ELECTFONIC SYSTCSA PAPAMETERS AFE ADEQUATELY OEFINEO.

AVAILABILITY - CLEARINGHOUSE FOR EECEOAL SCIENTIFIC ANO TECHNICAL INFORMATION, SPRINGFIELD, VA., \$3. OO CPY, \$0.65 MICROFICHE

\# INSTRUMENTATI IN, CAMPBELLING + E3R I ANO 2 IUE) + INSTRUMENTATION, NUCLEAR +

INSTRUMENTATION, RATE CE CHANG + INSTEUMFNTATION, WIDC. RANGE + REACTCR, BREEDER + PEALIUR. FAST

$9-23357$

KNCX $A E+$ POPOER GF

SOME DESIGN $\triangle S P E C T S$ QF THE OROPOSED EPE-II INSTPUMENTED SUBASSEMBLY SYSTEA

$\triangle R G O N N E$ NATIONAL LASOPATTRY

ANL-7390 +. S PAGES, 5 FIGUPES, PASES 174-70 OF OROCEEOINGS OF THF SYMPOSIUM CN LIGUID METAL

INSTRUMENTATION AND CONTROL, MAPCH $2,19 E 7$

PRESENTS A CONCEPTIONAL DESIGN FTR A SURASSEMRLY SYSTEM TO PERMIT IRRADIATION CF INSTFUMENTED FUEL ELEMENIS IN THE ECR-II REACTRF. SIGNAL LEADS ARE TO BE SFGUGUT CUT CF THE FEACTCR ANC PRI HAPY TANK TC APPROPRIATE FFVIEWING INSTEUMENTS.

AVAILABILITY - C.I.EAQINGHOUSE FOR FECEPAL SCIFNTIFIC AND TECHNICAL IN=OFMATION, SPRINCEFIELD, VA., SJ. OO COPY, \$O.65 MICROIFICHE

\#FUEL FIEMENT + \#INSTRUMENTATION, IN CORE + \#IRFAQIATION TESTING + EDF 1 AND 2. IREI + EQUIPMENT DESIGN + REACTDR, BREEDER + EEACTIH, FAST

$9-23358 \quad$ LLSC IN CATEGORY 6

RUUX OP

SUECRITICALITY MEASUREMENTS PY NCUTRON NTISE ANALYSIS

CAK TIDGE VATITNAL LAPOF DTORY

A.VL-7390 +. 3 PLEES, \& REFEQENCES, DAGPS IRO.1E2 OF PROR.FFTINGS OF THE SYMPOSIUM ON LIGUID METAL INSTRUMENTATION AISD CONTREL, MARCH $2, \quad 1,5.7$

EVALUATES THE ABPLICALILIT'G GR USIMC EFACTOC FLUCTUATIONS (NOISE) TU MEASUEE REACTCD

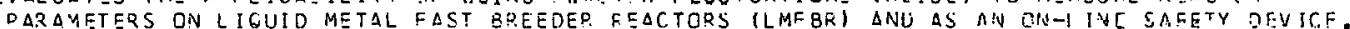
REACTDR SUTRRITICALITY YEASUEE AENT BY NOISE ANALYSIS HAS A FAIC CHANCE TO QR SUCCESSFILLY AUPLIED IF THE MEASUPEMENTS AFL LIMITED TC THCSE OF RNLY SMALL SHUTDCWN YAPGIM. IN THE FARGE UF 1 TO ? DOLLARS SUSCRITICAL: AN ACCURACY UE 1OR CAN RE EXPECTED.

AVAILABILITY - CLEARINGHOUSE COR FEEFGAL SCIENTIFIC AND TECHNICAL INECKMATICN, SPRINGFIELD, VA., S3. OD COPY, \$O.S5 MICP.OFICHE

*NEUTRON + NOISE ANALYSIS + CRITICALITY SAFETY + HEACTOR, LIACR I SHIJTMOQWN MARGIN

$0-23359$

RANDALL P.L + LOGAN D

ADPLICATIUN OF NOISE-LNALYSIS TECHNIQUES TO HYODEULIC MEASUPEMENTS INV LIQUID-METAL SYSTEMS

ATOMICS INTERNAT IONAL, CANOGA PAPK, CALIF.

ANL-7380 + 6 PAGES, 7 FIGURES, 12 REFEPENCES, PAGES $183-88$ JF PROCEEFINGS OF THE SYMPCSIUM ON LIQUID METAL INSTRUMENTATION AND CONTROL, MARCH 2,1967 


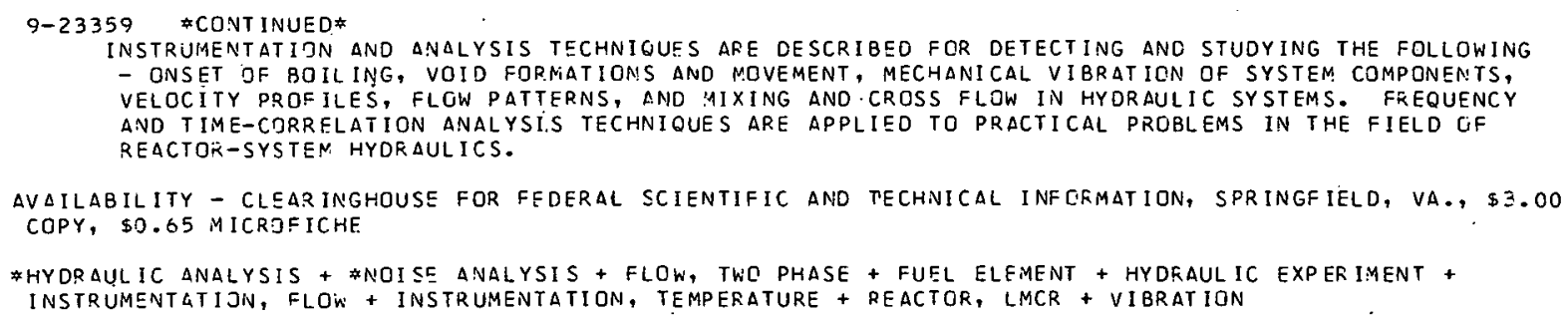


NUCLFAR INSTRUMENTATIDN, CONTROĹ, AND SAFETY SYSTEMS

$9-23398 *$ CONTINUTEO

DESCRIGES A DATA-PROCESSING SYSTEM INCLURING ON-LINE COMPUTING AND USED IN MULTIPARAMETER ANALYSIS EXPERIMENTS WITH THE 12-MEV TANDCM ACCELERATOR. THE MONITOR PROGRAMME IS CAPABLE OF DIRECTING THE VARI IQUS OPERATIONAL ROUTINES WITHOUT INTERRUPTING THE ACQUISITICN IN REAL TIME OF NUCLEAR DATA. THE ROUTINES CAN PROCESS EITHER. CURRENTLY ACQUIRED DATA OR DATA ACQUIRED OURING EARLIER EXPERIMENTS. A CONTRCL CONSOLE FACILLITATES RCUTINED, AND IS EQUIPPED WITH VISUALIZING AND INDICATING FACILITIES FOR THE PRESENTATION OF SEQUENCES IN PROGPESS.

* DATA PR.OCESSINC + ACCELERATOR + COMPUTER, DIGIIAL + FP.ANCE

$5-23399$

GHFSQUIERE GL

ADAPTATIJN CF COMPUTEP. STRUCTURES FOP. THF PRCCESSING OF DATA IN NUCLEAR PHYSICS

COMIAISSARIAT A L ENERGIF ATOMIOUE

5 PAGES, RULLETIN D INFORMATIONS SCIENTIFIQUES FT TECHNIQUES, 120 , PAGES 109-114 (NOVFMBER 1S67) IN FQENCH

ON THE BASIS DF PAPERS PRESENTED EY CTHER DUTHOPS, IT IS SHOWN THAT COMPUTERS USED IN NUCIFAP PHYSICAL FXRTEIMENTS MAY BC CLASSED IN TWO MAIN CATEGOFIES - THOSE EMPLOYED AS INSTRUMENTS PERTAINING TO THE EXPLRIMENT, AND THOSE FMPLOYEO FUK IHE CONTRCL AND DIRECTIDN CIF EXPEF IMENTS. THE PPESENT TENDENCY IS TOWAROS THE INTEGPATICN OF THESE FUNCTIONS IN A SINGLE UNIT. THIS IS FOLLCWED BY A RECAPITULATION OF THE FUNCTIONS.FULFILLED BY COMPUTERS $\triangle N D$ EY TECHNOLOGICAL CONSIOERATIONS REIATING TO THESE VARI OUS FUNCTIONE.

\#CIMP'JTER CONTROL + \#INSTRUMENTATION, CONTROL + COMPUTER, DIGITAL + DATA PROCESSING

$9-23487 \quad$ ALSO IN CATEGORY 18

ARFSICN 2 AND 3 INTEP.MECIATE RANGE TLUX MONITOR SYSTEM (1KM)

COMMCNWEALTH EDISON COMPANY

3 PAGES, PAGES $7.4-6$ THRU 7.4-8 OF DRESDEN 2 AND 3 FINAL SAFETY ANALYSIS REPORT VOLUME II, NOVEMBER 17,

1067 , DOCKET 50-237/24C, TYPE--BWP, MFG.--G.E., $\triangle E--S G T+$ LUNDY

SYSTEM CONSISTS OF TWO LOGIC. CHANNELS, EACH CONNECTED TO FOUR MINATURE FISSION CHAMBERS. THE CHAMRERS OF EACH CHANNEL ARE LOCATED ON A DIAGONAL OF THE CCRE, WITH THE SPACING EETWEEN THE CENTER CHAMBEPS LESS THAN THE SPACING BETWEEN CENTER AND CUTEQ CHAMBERS. WORST

ROD-WITHORAWAL ACCIDENT IS WITH THE REACTOR JUST SUBCRITICAL AND NITH THE IRMS NOT ON SCALE YET. A CONTROL POD NEAR. ONE OF THE OUTEF CHAMBEPS (WHICH IS ASSUYED TO BE PYPASSFO) IS FULLY WITHORAWN. THE MEASUREO P.TLATIVE FLUX IAVERAGE FLUX EQUALS 1 ) AT THE NEAREST DETECTOR IS 0.01 , AND THE FLUX PEAK IS ABOUT 50. RATIO OF PEAK-TO-MEASURED FLUX IS $2.2 \times 10(-4 T H)$. TRIP POINT IS $6 \times 1$ IO(ETH) NV, RESULTING IN A PEAK FLUX AT $2.7 \times 10(12 T H)$. FULL POWER FLUX IS 3.5 $\times 10(13 \mathrm{TH})$.

AVAILABILITY - USAEC PUBLIC DOCUMENT ROOM, WASHINGTON, D. C.

*ACCIDENT, CONTROL RCD HITHDRAWAL + *INSTFUMENTATION, INTERMEDIATE fANGE + DRESDEN 2 (BWFI + REACTUR, BWR + REPQRT, SAQ

$9-23805$

MONTGONERY CE

ALSO IN CATEGORY 17

SAXTGN REPORTS FAILUPF UF CONTRIN. KIJO TO SEAT

SAXTON NUCLEAR EXDERIMENTAL CORPORATION

2 PAGES, FEBPUAZY 73, 1969, ATOMIC ENERCY CLEATING HOUSE 14(10), PAGES 44-4ל (MAPCH 4, 19E9) DOCKET 50-146

(LETTER TO DRL, FEB, 23) DN IAN. 27, THF REACTOP. WAS SCMAMHID ATTER COMFLETION UH IHE UAYS DOERATJR TRAINING. CONTROL-QROD I STCPPED 2.98 IN. $\triangle B O V E$ ZERO (IN.) POSITION. A P.OD-EXERCISC PPDGRAM WAS STLETED, $\triangle N D$ THE RDO STUCK AT ABOUT 3 IN. ON THE IETH ANO 64TH ROD CROPS. AN AODITIONAL 5O CDODS WERE WITHOUT FURTHEP OIFFICULTY. CONCLUSION - PROPARLY A SMAIL PIECE OF FORE IGN MATTER HAS LCOGED IN THE RUO-CRIVE MECHANISM ANO WAS PEMOVED BY THE SELF-FLUSHING ACTION DF THE DASH POT.

\#FAILURE, SCFAM MECHARISM + CONTPOL F.CD DPIVE + REACIOR, PWR + SAXTON (PWR)

$9-230.22$

MOFIN $R$

UTILIZATION OF DIGITAL COMPUTERS EOR STAPTING ANC PUNNING THE EDF-3 ATOMIC POWEP PLANT

$A E C-T Q-6: 13+12$ PAGES, TRANSLATED FPOM NEUE TECH. \&, PAGES $26-32$ (1!C66)

THE COMPLEXITY OF THE EOF-3 ATOMIC POWEF PLANT LED TO THE USE OF CENTRALIYY I OCATED DIGITAL COMPUTERS TO COLLECT ALL IMPORTANT OATA CM THE OPERATING CONOITIONS OF THE PLANT. THE MAIN COMPUTER PPOCESSES 5500 MEASUREMENTS AND SIGNALS, RECOPCS MEASUPED VALUES AND SIGNALS AFTER A OISTURBANCE, MCNITOSS FOR LIAKAGE CONTROL OF THE HUEL CLADOING, CONTROLS STARTUP AND SHUTDCWN OPERATIONS, AND FERFORMS SOME CONTRQLS AND $\triangle D A P T A T I O N S$ OF PRE-SET LIMITS. IF THE MAIN COMPUTER FAILS, ITS MOST IMPORTANT FUNCTICNS ARE TAKEN OVER AUTOMATICALLY BY GN $\triangle U X I L I A R Y$ COMPUTER.

AVAILABILITY - CLEAFINGHOUSE FOR FEDERAL SCIENTIFIC AND TECHNICAL INFOPMATION, SPRINGFIELD, VIRGINIA \$3. OO COPY, \$D.65 MICROFICHF.

* COMPUTER CONTROL + CONPUTER, DIGITAL + DATA DRUCESSING + FFANCE + INSTRUMENTATICN, CQNTROL + 
$9-23932$ *CONTINUED*

INSTRUMENTATION, PRCCESS + INSTRUMENTATION, STARTUP + REACTOR, PCWER

$9-23833$

IMPROVEMENTS RELATING TD NUCLEAR. REACTORS ANO THEIR CONTROL

BABCOCK AND WILCOX COMPANY

FRENCH PATENT $1,395,504+4$ DAGES, MARCH 8,1965, IN FRENCH

THE REACTOR HAS A CONTROL ELEMENT WITH A CLOSED TUBE EXTENDING INTO THE REACTOR CORE. THE. TUBE CONTAINS MATERIAL OF HIGH MICPOSCGPIC THERMAL NEUTRON $\triangle B S O R P T I O N$ CROSS-SECTION I 380 BARNS DR MORE). THE VAPDR DENSITY OF THIS MATEPIAL VARIES IN ACCORCANCE WITH THE TEMPERATURE WITHIN THE COSE TO CONTROL THE REACTIVITY OF THE CORE AND MAINTAIN THE TEMPERATURE OF THE CORE AT A PREDETERMINEO OPERATING VALUE.

AVAILABILITY - U.S. PATENT OFF ICE, DEPARTMENT OF COMMEPCE, WASHINGTON, D. C. (30 CENTS PER PAGE) *REACTOR CONTROL + \#TEMPERATURE REACTIVITY EFFECT + CONTROL ROD + FPANCE + INSTRUMENTATION, TEMPERATURE + PATENT

$9-23835$

FUEL ELFMENT CONTAINING A BURNABLE POI SON

REACTOR CENTRUM NEDERLAND

FRENCH PATENT 1,425,012 +. 4 PAGES, FIGURES, DECEMBER 6, 1965, IN FRENCH

$\triangle$ FUEL ROD IN WHICH BURNABLE POISON DISKS ARE INTERSPERSED BETWEEN THE FUEL PELLETS IS

DESCRIBED. THE OISKS CONSIST OF A DISPEPSICN OF A BURNABLE POISON POWDER IGRAIN SIZE ISC TO 209 MICRONS IN A MATRIX (ZR, SS, C, DL203; SIO2). THE POWDEF DISTRIBUTIDN IN THE MATRIX CAN BE NONUNIFORM ANO/OR THE DISKS CAN BE PERFORATED. IF THE DISKS ARE MADE MAGNETIC, THEIR REMOVAL DUR ING SUBSEQUENT REPROCESSING IS FACILITATEO.

AVAILABILITY - U.S. PATENT DFFICE, DEPARTMENT CF COMMERCE, WASHINGTON, D. C. (3O CENTS PER PAGE)

* FuEl ElEMENT + \#PDISON, Burnable + FRANCE + PATENT

$9-23838$

IMPROVEMENTS IN RADIATION-RESPONSIVE PROPORTIONAL COUNTER TUBES

PHILIPS ELECTRONICS AND PHARMACEUTICAL INDUSTRIES CORP.

BRITISH PATENT $1,082,697+3$ PAGES, I FIGURES, SEPTEMBER 6,1967

DESCRIBES A RARE-GAS-FILLEO CYLINDRICAL PROPORTIONAL COUNTER. S. THE COUNTER CONSISTS OF A HOLLOW CYLINDER HAVING A CONQUCTIVE INNER SURFACF OPERATING AS A CATHODE AND I THIN WIRE AS ON AMODE. SUCH A COUNTER IS USED FOR MEASURING RADIOACTIVE RADIATION.

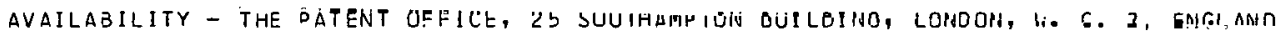

*INSTRUMENTATION, RADIATION MONITORING + MMUNITUR, RADIATION, GENERAL J. COUNTER + PATENT + IINIIEU KINGUOM

$9-23839$

RADIATION MEASURING INSTRUMENT

MECEWA A.G.

BRITISH PATENT $1,073,236+\ldots 4$ PAGES, 1 FIGUFE, REFERENCES, JUNE 21,1967

A RADIATIINN MEASUR ING INSTRUMENT COMPRISING A DETECTION ELEMENT, A PULSE AMPLIFIER, AND $\triangle$ RATEMETER FOR CONTINUOUS INDICATION OF THE MEAN VALUE OF THE RADIATION INTENSITY IS

DESCRIBED. THE PULSE AMPLIFIFR AND THE. RATEMETER HAVE TEMPERATURE-SENSITIVE CHARACTERISTICS ADJUSTED SUCH THAT THEY COMPENSATE EACH OTHER.

AVAILABILITy - The PATENT OFFICE, 25 SOUthampton Builoing, london, W.C. 2, england

*INSTRIJMENTATION, RAOIATION MONITORING + MONITOR, RADIATION, GENERAL + PATENT + UNITEO KINGOOM

$9-23840$

MEANS FOR DETECTING RADIOACTIVE RADIATION

GROUPEMENT ATOMIQUE ALSACIENNE ATLANTIQUE

BRITISH PATENT $1,080,707+4$ PAGES, AUGUST 23,1967

AN IONIZATION CHAMBER IS DESIGNED WHICH CPERATES UNDER HIGH-VOLTAGE ALTERNATING CURRENT. THE IONIZATION CHAMBER CAN BE USED FOR MEASURING GAMMA NEUTRON FLUX. THE CHAMBER IS ALSO

SUITABLE FOR USE IN REACTOR SAFETY SYSTEMS, AND PARTICULARLY IN APPLICATIONS WHICH CALL FOR GAS-CIRCULATION CHAMBERS.

AVAILABILITY - THE PATENT OFFICE, 25 SOUTHAMPTON BUILDING, LONDON, W. C. 2, ENGLAND

\# INSTRUMENTATION, RADIATION MONITORING + CHAMBEF, ION + MONITOR, RADIATION, GENERAL + PATENT + UNITED KINGOOM 
CATEGGRY
NUCLEAR INSTRUMENTATICN, CONTRDL, AND SAFETYY SYSTEMS

$9-2.3941$

HOSEMANN R + WARRIKHOFF H

DETECTDP FOR IONIZIVG RAOIATION

BRITISH PATENT $1,052,144+7$ DAGES, FIGURFS, SEPTFMPFR 6,1067

\begin{abstract}
A RADIATION DETECTOR IS DESCPIRED WHICH INCLUNES TWD ELFCTRODES, DNE OF WHICH HAS MANY LAYERS CF DIFFERENT MATERIALS, LINED UD IN! THE INTENDFD DIRECTION OF THE INCIDENT RADIATION. THE MATEFIALS AND THEIR THICKNESSSS $\triangle P E$ CHOSEN FCF A GIVEN FREQUENCY RANGE OE IONIZING RADIATICN. THE T.HARGE FLOW BETWEEN THE ELECTECOES RESULTS FDOM THE EMISSIONS FROM THE VAEICUS LAYERS AND THE DEGREE OF THEIP ABSORPTICN IN ANY OTHEE LAYEF IN THEIR PATH IS PRCPORTIONAL TC THE TIME INTEGRAL OF THE INTENSITY OF THC PAOIATION.
\end{abstract}

AVAILAGILITY - THE OATENT OFEICE, IS SOUTHAMPTON PUILOING, LONDON, W. C. 2, ENGLAND

* INSTLUMENTATION, RAGIATION MONITCRING + COSIMETFY, GENERAL + INSTFUMENTATION, NUCLEAR + PATEN? + IINTTFO KINGDOM

$9-23842$

FLEXIBLE CAN FOR NUCLSAR FUEL

GENERAL ELECTRIC COMOLNY

FRENCH PATENT 1,383,251 +. \& PAGES, 2 FIGURES, NOVEMEER 16, 1964, IN FRENCH

THE FUEL ROD IS PPOVICED WITH A THIN CAN, WHICH PRESENTS LONGITUOINAL, U-SHADED FOLDS

EQUIOISTANTLY DISTRISUTED ARCUND THE PERIPHERY OF THE ELEMENT. THESE FOLDS ALLCW RADIAL

OEFORMATION DF THE CAN IN RESPONSE TO VARIATIONS IN THE COCLANT PRESSURE OR TO CIFFERENTIAL

DILATIONS NHILE A GOOD CONTACT BETWEEN FUEL AND CAN IS MAINTAINEO. ALL ECLDS MAY BE OIFECTED

SUTWARDLY, OR OUTWARO FOLOS MAY ALTERNATE WITH INWARO FOLDS, THE LATTER DNES THEFFGY

CONTACTING GROOVES IN THE FUEL RODY.

AVAILABILITY - U.S. PATENT OFFICE, [EPPARTMENT OF COMMEFCE, WASHINGTON, D. C. (3O CENTS PES PAGE)

*CONTAINMENT DESIGN + \#FUEL ELEMENT + EDANCE + PATENT

$0-23843$

RARE EARTH PYROHAFNATES - $\triangle$ NEW IDEL ECOO CONTROL ROD MATERIALS

AMAX SPECIALTY METALS, INC., NEW YCOK

16 PAGES, JANUAFY 10 :

A NEN FAMILY OF HAFNIUM-SASC CERANIC PRODUCTS FOR. USE AS CONTFOL-ROD MATERIALS IN COMMERCIAL NUCLEAR POWEP 2EACTURS WAS ANNJUNCEO PY AMAX SDECIALITY METALS, INC. THESE NEW MATEF!ALS, CALLED RARE-EAPTH PYOTHAFNATES AFE COMDOUNOS OF HAFNIUM OXIDE ANO OXIDES OF SELFCTER QAPF EARTHS SUCH $\triangle S$ OYSPROSIUM, FPOIUM, ANO HOLMIUM. THESE COMPCUNDS OFFER A COMBINATION OF EFFICIENT PEQFFICNANCE, AVAILLBILITY, ANIC ECCNOMY. THE DETFAMINFD CDNTFCL RCO WCFTH OF PYRTHAFNATE PELLETS MAS GEEN SHONN TI $\mathrm{SE}$ SUPERIOR. TO THE SILVER-INDIUM-CAEMIUM ALLOY VOW USEO FOR PUWER, REACTUF CUNTKUL.

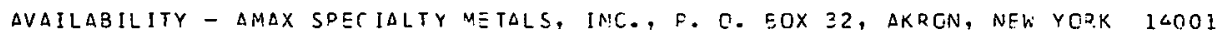

\#CRNTREL ROR + \#MATEPIAL + \#RAES CARTH + GYSPROSIUM + ERBIUM + HAENIUM

$9-23840$

COSTRELL L

STANDARD NUCLEAR INSTSUMENT MODULCS ADODTEO PYY AEC COMMITTEE ON NUCLEAR INSTRUMENT YCDULES. JANUAFY I9G8 NATIDNAL BUREAIJ UE STANLARUS

TID-20893(REV.2) +. 31 PAGES, 7 CIGURTS, I TABLE, JAN. 1968

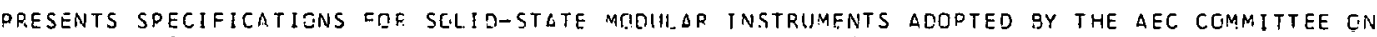
NUCLEAR INSTRUMENT MCDULES GOQ STANDAFD NUCLEAR-INSTRUMENT MOCULES. REPORT INCLUDES ALL CORRECTIONS, ADDITIONS, ANO CHANGES MACE TC OEIGINAL SPECIFICATICNS.

AVAILAGILITY - U.S. GOVERNMENT PRINTING GFFICE, WASHINGTCN, D. C. 20402, \$0.25 PER COPY

* CODES AND STANDARDS + *INSTRUMENTATIOV, NUCLEAR + DESIGN CRITERIA + EQUIPMENT DESIGN +

INSTRUMENTATION, GENERAL + SOLID STATF OEVICE

$0-23850$

INSTRIMEVTATION AND CONTROLS UIVISIUN ANNUAL ORTGEFSS FFDORT FOP OERIOD ENCING SEPTEMBER I, IGE?

DAK RIDGE NATIONAL LAR., TENN.

ORNL-4219+. 134 PAGES, FIGURES, RECERENCES, SEPT. 1, 1957

ONE OF A SERISS OF DROGPESS RFPQRTS (SEE NSIC-12!26). TOPICS CCVFRED INCLUDE - BASIC INSTRUYCNTATICN, ELFCTPONIC SYSTSMS ANO COMPONENTS, RADIATION-MCNITERING SYSTEMS,

RADIATION-DETECTION INSTRUMENTS ANO COMPONENTS, DATA HANDLINE GNC COMPUTATICN, DROCESS

INSTRUMENTATION AND CONTPOL-SYSTEM ENGINCERING, PROCESS-INSTEISENTATIGN DEVELOPMENT, TEST AND 
NATEGORY
NUCLR INSTRUMENTATION, CONTROL; AND SAFETY SYSTEMS

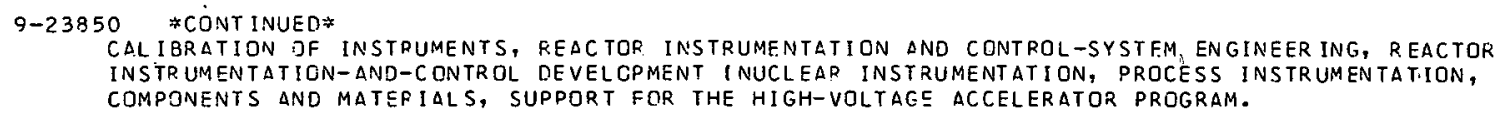


CATEGGRY
NUT, LEAR INSTPUMENTATICN, CONTRDL, AND SAFETY SYSTEMS

O-23911 =CONT INUSO\#

INSTRUMENTATION, CONTROL + INSTRUMENTATION, GENERAL

9-23951 ALSO IN CATEGORIES 18 ANC 10

REVISED RESPONSE TD AEC OUESTIONS

OMAHA PUPL IC POWER DISTR. ICT

10 PAGES, I FIGUPE, SUPPLEMENT 16 (DMENDMENT 16, EXHIBIT FI6) TO FOPT CALHOUN FACILITY DESCPIPTICN AND

SAFETY ANALYSIS REPORT, FEERUARY 2, 1968, DCCKET S0-2̈85, TYPE--PWR, MFG.--C.E., AE--GIBBS + HILL

REVISES ANSWERS TO QUESTIONS $1.1, \varepsilon .4,13.2$, AND A.2. OUESTIDNS DRE RELATED TO OUTSIDE

ELECTRICAL POWER, CONTRDL-QOD-INSEPTION CAPABILITY DURING EARTHQUAKE, AND SCRAM-QUS

SINGLE-FAILURE CFITERICN.

AVAILABILITY - CLEAPINGHOUSE FOR FEDFRAL SCIENTIFIC AND TECHNICAL INFORMATION, SPRINGFIELD, VIPGINIA \$3. OO COPY, \$0.65 MICROFICHE

* ELECTRIE DOWER, GENERAL + AEC QUESTION + FT. CALHOUN (PWR) + OFF SITE + REACTJR, PWP. + REPCPT, PSAR + SINGLE FAILURE CRITERION

$9-24132$

BEINSTEIV DM

RECENT DEVELOPYENTS IN MULTICHANNCL PULSE HEIGHT ANALYSERS

5 PAGES, FIGURES, NUCLEAR ENGINEERING $13(141)$, PAGES $112-116$ (FEBRUARY 1968 )

THE MODERN MULTICHANNEL PULSE HEIGHT ANALYSEP. REPRESENTS A HIGHLY FLEXIBLE, INEXPENSIVE, DIGITAL DATA PROCESSING COMPUTER. THE ACVENT OF SOLIO STATE OETECTORS WITH THEIF EXCEPTIGINAL RESOLUTION HAS PLACED DEMANDS UPDN THE MANUFACTURERS FCF THE DEVELOPMENT OF ANALYSERS WITH AS MANY $\triangle S 40.0$ CHANNELS, AND ANALOGUE TE DIGITAL CONVERTER RATES FROM $20 \mathrm{MC} / \mathrm{S}$ TO $100 \mathrm{MC} / \mathrm{S}$. AT THE SAME TIME GREAT ADVANCES IN USER FLEXIBILITY HAVE FEEN EVTLVEO.

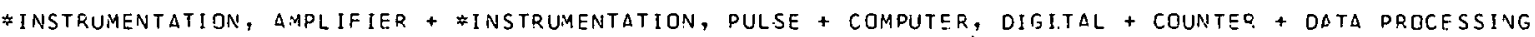

O-24134 ALSO IN CATEGORY 17

SELECTED ELK FIVER DPFRATING EXPSRIENCE

QURAL COOPEPATIVE POWER ASSOCIDTION

NUS-326 +. 54 DAGES, 5 FIGURES, 2 TABLES, ELK RIVER REACTOR OPEP.TIONS SAFETY $\triangle N A L Y S I S$ PROGP.ESS REPDRT TO RURAL CDOPERATIVE PGNER ASSOCIATION, MONTHLY REPORT NO. 16, OCTOBER 1 , TO GCTOBES 31 , 1966

(PD. 5-12) PLATINIZEN HCNEYCOMB CATALYST SHOULD BE SUESTITUTED FOP PELLETS IN THE P.ECOMBINER GECAUSE THE HONEYCOMB TYPE IS INSENSITIVE TO FLCW, TEMPERATURE, AND MOISTURE. (PG 20-2E) VARIATION OF IODINE IN THE COOLANT WITH TIME INDICATES THAT ABDUT 9 G CF U-235 IS GIVING THIS ACTIVITY. (PG 27-29) A LOSS OF IC 2 OF THE CENTRAL-CONTROL-ROD WORTH RESTCICTS ITS LIFETIME TO REGULATING RDD SHOULD BE EXCHANGED FOR A EANKED ROD EVERY 2 FFP YEARS AT THE TECH.-SPEC. CONTRCL-RCD INSPECTION.

AVAILABILITY - CLEAR INGHOUSE FDR FEDERAL SCIENTIFIC AND TECHNICAL INFQFMATION, SPRINGFIELD, VIRELNIA \$3.0O COPY, \$0.65 MICROFICHE

*CONTROL ROD BURNUP + \#RECOMBINER + ACTIVITY BUILDUP + ELK RIVER (BWR) + MAIN COOLING SYSTEM + REACTOR, BWR + REOOPT, OPERATIONS ANALYSIS + STEEL, STAINLESS

S-24138 $\quad \triangle L S O$ IN CATEGOPY 10

SET ON-LINE COMPUTEO FER INUCLEAP GENER.MTOR

1 PAGE, CONTROI. FVFINFFR ING, 1513), FAGF 4G, (MARCH 1968)

AEG-TELEFUNKEN (BEPLIN) RECEIVEO AN ORDER FOR WHICH IS CLAIMED TO SE THE CIRST DN-LINE COMPUTER TQR A INUCLEAR PONER STATION. THE COMPUTER HILL BE USED TO OPTIMILE THE FUEL EFFICIENCY ANC INCPEASE THE ENERGY OENSITY IN THE REACTOF CORE AT THE GUNDREMMINGEN POWEF. STAT ION.

\#COMPUTER CONTROL + \#REACTDR, PONER + GERMANY + INSTRUMENTATION, CONTROL + REACTOR CONTFOL

C-24154 ALSC IN CATEGORIES 17 ANO 11

SCHA SIIUTOQWN ATTRISUTEO TO CORE BAPPEL EOLT FAILURE

I PAGE, NUCLEAR INOUSTRY $15(2)$, PAGE 56, (FEE. 1CEE)

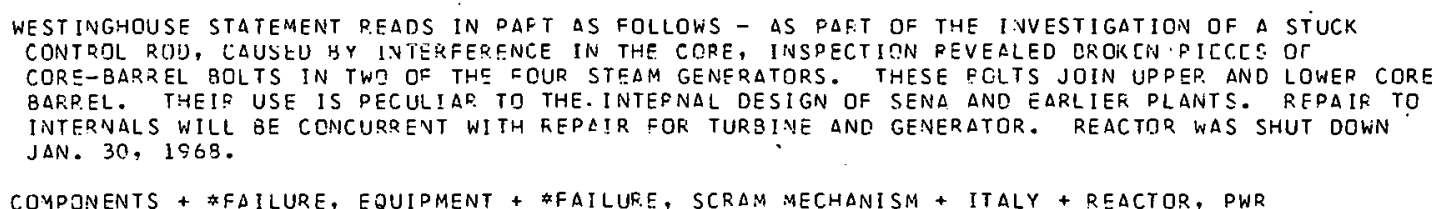

\#CQRE COMPONENTS + \#FILURE, EQUIPMENT + \#FAILUFE, SCRAM MECHANISM + ITALY + REACTOR, PWR 
$9-24196$

HANO I + TAMURA Y

APPL ICATION OF THE MAXIMUM PRINCIPLE TO REACTOR CONTROL

4 PAGES, WESEDA DAIGAKU RIKOGAKU KENKYUSHO HOKOKU, 26 , PAGES $154-7$ (SEPT. 1966) IN JAPANESE

A NEW COMPUTATIONAL APPROACH TO THE MINIMIZATION OF XE POISONING IS PRESENTED. SINCE THIS OPTIMIZING PROBLEM CONSTITUTES A VARIATIGNAL PROQLEM WITH A NUMBER OF COMPLEX RESTRICTIONS IMPOSED ON THE SYSTEM VAR.IABLES, CONVENTICNAL VARIATIONAL TECHNIOUE TURNS OUT TO BE

INEFFECTIVE. THE FORMULATION OF THE PROELEM IS MADE BASED ON THE MAXIMUM PRINCIPLE, AND A

FEW COAMENTS ARE GIVEN TO ITS COMPUTATIONAL $\triangle S P E C T$.

*POISON, BURNABLE + \#REACTOR CONTROL + *XENDN + MATHEMATICAL TREATMENT + THEORETICAL INVESTIGATION

$9-24197$

GORSHKOV SI + GROMOV LF + IONAITIS RR + SHCHEGOLEVA EK

ELECTROHYDRAUL IC CONTROL ROD SAFETY SYSTEM FOR SM-2 REACTOR

2 PAGES, AT. ENERG. (USSR), 22 , PAGES $234-5$ (MARCH 1967) (IN RUSSIAN)

AN ELECTROHYDRAULIC SAFETY ROD IS DESCRIBED. THE ABSORBER ROO IS HELD IN ITS EXTREME UPPER POSITION BY AN ELECTROMAGNET. THE SAFETY ROD IS DRIVEN INTO THE REACTOR BY CUTTING CFF THE ELECTROMAGNET. THE ROD IS REMOVEC FROM THE REACTOR HYDRAULICALLY BY A PISTON WHICH P.ESETS THE CONTROL ROD IN ITS UPPER POSITION.' 'THE CONTROL SYSTEM IS RELIABLE, COMPACT, SIMPLE, AND CHEAP. HENCE, IT IS SUITABLE FOR USE IN OTHER REACTORS.

*CONTROL ROD DRIVE + REACTOR CONTROL + REACTOR, PWR + SM 2 (PWP) + TEST, CONTROL POD DRIVE

\section{$9-24199$}

DEARNALEY G

SOL ID-STATE RADIATION DETECTORS

UNITED KINGDOM ATOMIC ENERGY AUTHORITY, HARWELL

19 PAGES, 10 FIGURES, I TABLE, REFERENCES, CONYEMPORARY PHYSICS 8(6), PAGES G07-t26 (1967)

A

A HISTORICAL SURVEY GF THE DEVELOPMENT OF SOLID-STATE DETECTORS IS GIVEN AND IT IS SHOWN WHY SEMICONDUCTOR DETECTORS ARE SUPERICR TO THE EARLIER CRYSTAL COUNTERS. THE PHYSICAL PROCESSES WHICH OCCUR DUR ING THE DETECTION OF NUCLEAR RADIATION IN A SOLID-STATE DEVICE ARE CONSIDERED IN DETAIL, AND THE. MERITS DF THE REVERSE-BIASED. SEMICONDUCTOP JUNCTION IN SILICGN OR

GERMANIUM ARE'SET OUT. FACTORS WHICH DETERMINE THE ENERGY RESOLUTION OF SUCH A DETECTOR ARE ANALYSED, AND ALSO THE EFFECTS OF RADIATION DAMAGE. THE PREPARATION OF SUCH DETECTORS IS NOT TREATED IN DSTAIL, BUT THE PHYSICAL PEINCIPLES ON WHICH THE IMPORTANT TYPES DF CETECTOR DEPEND ARE DESCRIBED. THE FINAL SECTION SURVEYS THE FIELD OF APPLICATIGNS DF SCLID-STATE DETECTORS IN NUCLEAR PHYSICS, RADICCHEMICAL ANALYSIS, SPACE RESEARCH, MEOICINE, AND BIOLOGY.

*EXAMINATION + \#INSTRUMENTATION, NUCLEAR + \#SOLID STATE DEVICE + COUNTER + FABRICATION + INSTRUMENTATION, COMPONENT + INSTRUMENTATION, CURRENT + INSTRUMENTATION, RADIATION MONITORING + THEORET ICAL INVESTIGATION

$9-24256$

MORITZ U + VIERKE H + WESSER U + WOLF L + ZEISSET W

NOISE ANALYSIS ON ZEP.D-POWER-REACTOR SUR 1 OO BE

UNIVERSITY OF BERLIN

5 PAGES, ATOMKEPNENERGIE, 12, PAGES 415-419 (1967) IN GERMAN

GIVES RESULTS [EF NOISE ANAI,YSIS GF THE ZERD-POWER REACTOR, SUP-IOO-BE. CONTINUOUS CONTROL GF A POWER REACTOR SEEMS PMSSIRIE.

*NOISE ANALYSIS + REACTGR CONTROL + PEACTCR, POWER

$9-24257$

LNFNICKAB + WAGNER K

COMPENSATION OF A HEAVY WATEP REACTOR WI THOUT MECHANICALLY CONTROLLED AESORBING RODS

SKODA WORKS, DEPARTHENT OF NUCLEAR POWER STATIONS

31 PAGES, PAGE 43-73 DF SBORNIK PRACI ZAVODU JADERNE ELEKTRARNY OBOROVEHO POONIKU, SKODA, PLZEN. PLZEN,

CZECHOSLOVAKIA, 1967 , IN CZECH

DESCRIBES A REACTOR SHIM SYSTEM WITHOUT MECHANICALLY CONTROLLED ARSOREING RODS. THIS. SERVEO AS AN AID IN CHOCSING THE COMPFNSATING SYSTEM FOR THE HEAVY-WATER MODERATED, GAS-CODLED, NATURAL-URANIUM FUELED RSACTOR. THE POSSIBILITIES OF USING DEPLETED URANIUM, BURNABLE

POISONS, ABSOREING SHEETS, MODERATOR VOIDS, AND HYORAULICALLY CONTROLLED POOS WERE STUDIED.

*CONTROL ROO, SHIM SAFETY + \#REACTOF. CONTROL + REACTCR, GCR + REACTOR, HWR 
$9-24258$

ZAJICV + VLCEK J+ HIJCECEK M

THE DETECTION OF THE FAILING CF URANIUM fUel ELEMENT at THE NON-ACTIVE TESTS IN THE FLCW 2 F COZ. SKODA WORKS, DEPARTMENT DF NUCLLAR POWED STATIONS

12 PAGES, PAGE 203-14 OF SBORNIK PFACI ZAVROU JADEKNE ELEKTRARNY OPCEOVEHD POONIKU, SKOCA. PLZEN, PLZEN, CZECHOSLOVAKIA, 1957, IN CZECH

A RADIOMETRIC METHOD CF DETECTION CF U IN THE TEST NON-ACTIVE CIRCUIT WITH THE WIPE FUEL ELEMENT AND THE WAY DF $\triangle$ PQACTICAL AOPLICATION IS DESCRIEED. THE GROWTH OF THE U CONCENTRATION IN THE CIDCUIT IS THE EIINR.TINN T.F THE DESTRUCTION OF FUEL ELEMENT, OF THE ESCAPE OF AEROSOL FECM THE CIQCUIT AND OF ITS POSSIBLE GROLND IN PARTS OF TEST LOOO. THE PRACTICAL EXOERIENCES WITH THE APPLICATION OF THE METHOO HAS CEPTIFIED THE PEL IARIL ITY OF THE BEGINNING TESTED EUEL ELEMEVT FAILUFE. THE METHOD OF RADIOMETPIC DETECTICN OF U IN THE TEST CIRCUIT IS EXTRAOREINAPILY SENSITIVE IN COMPARISON TO SCME METHODS OF CHEMICAL ANALYSIS.

* INSTRUMENTATION, DETERTIION FAILEO FUEL ELFMENT + FAILURE, FUEL ELEMENT 
(PG 19) THE JINE 29 POWER OUTAGE FAILED BOTH $480-V O L T$ FEEDS. ONE PHASE OF GNE PFIMARY SIDE OF THE UNGROUNDED DELTA-WOUND $4800 / 480-V$ TRANSFOPMEP HAD SHOWN PREVIOUS SPORADIC GPOUNDING. THIS GROUNDS THE AFFECTED PHASE WITHOUT CURRENT FLOW ANO RAISE THE OTHER PHASES FROM 2770 TO $4900 \mathrm{~V}$. DN JUNE 29, THE RAISED VOLTAGE PROBAELY TRIGGERED A WEAK SPOT IN THE OTHEP FEED, RESULTING IN A PHASE-TO-PHASE SHORT THRRUGH GPOUND, CPENING THE $4800-V$ CIRCUIT EFEAKERS AND DESTROYING THE CABLES. DIESEL CAREIEO THE DIESEL BUS LOADS.

AVAILASILITY - USAEC PUBLIC DOCUMENT ROOM, WASHINGTON, D. C.

ACCIDENT, LOSS OF POWER + EMEPGENCY POWER, ELECTRIC + FAILUPE, SEQUENTIAL + FAILURE, SIMULTANEOUS + REPORT, OPERATIONS SUMMARY

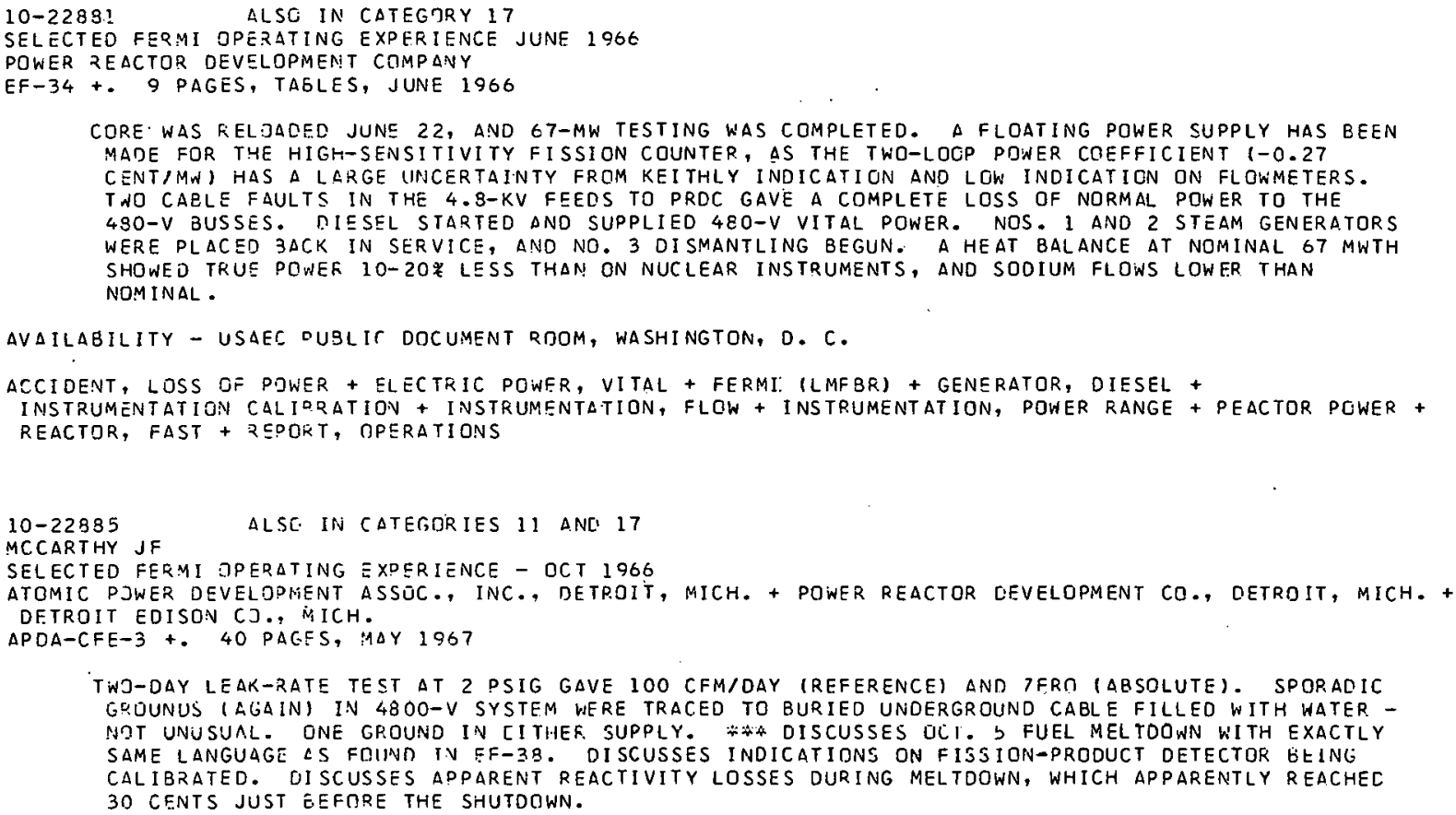

CONFIRMS PHOVE CONVERSATIJN OF JANUARY 17, 1968, THAT ACFS WISHES ADDITIONAL INFORMATION

- Before PPEPARING THFiR REPORT - (1) ADEQUACY OF OFF-SITE POWER, AND GENERAL DES IGN CRITEF. ION $39,(2)$ B BILITY TO INSERT CONTROL RODS IF A PRIMARY COOLANT LINE LARGER THAN I2. JNCHES RUPTURES, AIVD (?) ADEQUACY OF THE FEACTOR PROTECTION SYSTEM, ESPECIALLY THE SCRAM BUS, TO PROVIDE PRUTTECTIEN IF A SINGLE FAILURE WERE TO OCCUR.

USAEC PUBL IC COCUMENT ROOM, WASHINGTON, D. C.

\#EMERGENCY PJWER, ELECTRIC + \#PLANT PROTECTIVE SYSTEN + ACRS + AEC. CESIGN CRITERIA + AEC OUESTIGN + FAILURE, SCRAM MECHANISM + FT. CALHOUN (PWR) + REACTOP, PWR + SINGLE FAILURE CRITERION 
CATEGDRY 10
ELECTRICAL POWER SYSTEMS

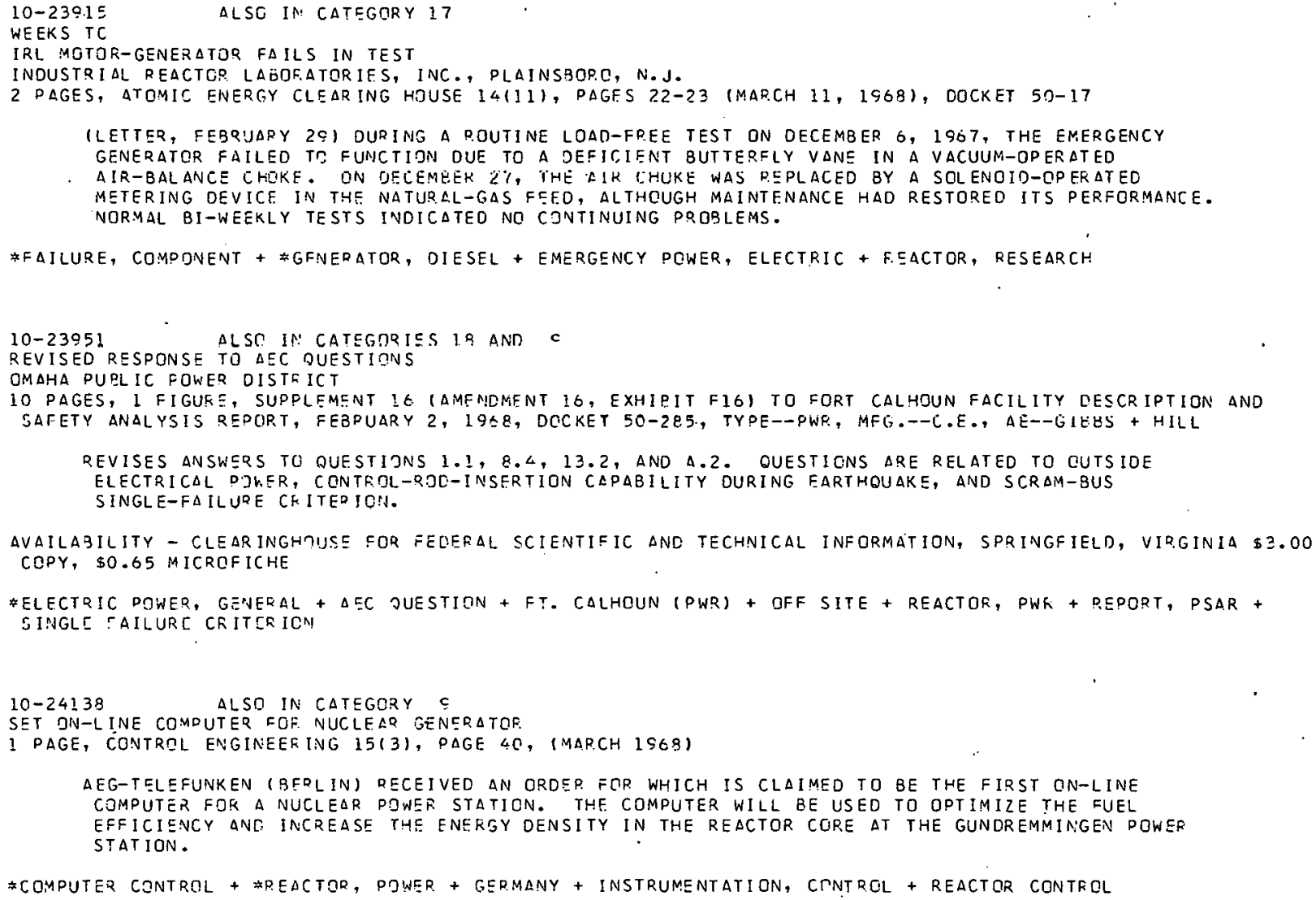


CONTAINMENT OF NUCLEAR FACILITIES

11-20355 ALSE IN CATEGORICS 17 AND I8

SUPPLEMENT TO APPENDIX D--TUREINE GENEP.ATCP FAILURES DUE TO EXCESSIVE, OVERSPEEDING

FLORIDA POWER AND LIGHT COMPANY

4 PAGES, PAGE D1 TO D4 LF SUPPLEMENT 3 TO THE LICENSE APPLICATION AND PRELIMINARY SAFETY ANALYSIS REPORT. SEPTEMBER 1, 1966 , DOCKET $50-250 / 251$

ONLY TWO SUCH FAILIJRES AFE REPORTED, BOTH IN ENGLANO - (1) USKMOUTH - (1) FAILURE AT I7OR OVERSPEED 8 WEEKS $\triangle F T E R$ TOOMMISSONING, (2) BLACK IRON-OXIDE FORMATION IN THE GOVERNOR FRCM BRACKISH-WATER-CONTAMINATED CIL AND LONG SHUTDOWNS. DAMAGE IS DESCRIBED ILOW-PFESSURE WHEEL FDUND 150 YD AWAY). (2) CALDED HALL-B - ONE MONTH AFTER COMMISSIONING, MAIN STEAM-ADMISSION VALVE STUCK FULL-DPEN WHEN LGAD DRQPPED SUDUEMLY. VALVE FAILURE WAS CAUSED BY PARTICLE GF

CHILLED IRON SHOT EMEEDDED IN THE VALVE SPINOLES.

AVAILABILITY - USAEC PUBLIC DOCUMENT POOM, WASHINGTON, O. C.

*FAILURE, EQUIPMENT + \#INCIDENT, cGUIPMENT + \#MISSILE GENERATION AND PRCTECTIQN + \#TURBINE + CONTRCLLER + FAILURE, ADMINISTRATIVF. CONTROL + QUALITY CONTROL + PEACTIOR STARTUP EXPERIENCE + VALVE

$11-21117$

SALKIN RV

THE EFFECT OF LOW CYCLE FATIGUE ANO NEUTRON IRRAOIATION ON THE MECHANICAL PROPERTIES OF LOW ALLOYED STEELS CENTRE NATI DNAL DE RECHERCHES ME TALLURGIQUES

RA-55/67 +. 26 PAGES, 18 FIGURES, 2 TABLES, 6 REFERENCES, JUNE 19E.7, ABSTRACT IN ANS TRANSACTIGNS IOIII PAGE 113, PAPER PRESENTED AT ANS MEETING, SAN DIEGO, CALIF., JUNE 11-15, 1967

DISCUSSES THE RESULTS OF EXPERIMENTS DESIGNEO TO STUDY THE EFFECT OF LOW-CYCLE FATIGUE AND IRRADIATIDN ON THE TRANSITION TSMPERATURE OF PRESSURE-VESSEL STEELS. RESULTS ARE PRESENTED GRAPHICALLY, EUT ONLY PRELIMINARY CONCLUSIONS ARE STATED.

*FAILURE, FATIGUE + ERITTLE FRACTURE + MÉTAL + NOZZLE + PLASTICITY + PRESSURE VESSEL + RAOIATION DAMAGE + STEEL ATRESS

$11-21119$

HILLIER MJ

UL'TIMATE LOAD ANALYSIS OF SIMPLE STRUCTURES

UNIVERSITY OF WATERLOO, WATERLOO, ONTARIO, CANADA

5 PAGES, 2 FIGURES, 1 TABLE, NUCLEAP. ENGINEEPING AND DESIGN 5 11) PAGES 71-75 (JAN-FEB. 1967)

THE ULTIMATE STLTIC-LOAD-CARRYING CAPACITY OF A SIMPLE STRUCTURE OF CUCTILE MATERIAL, SUBJECTED TJ PREDOMINANTLY TENSILE STRESSES, IS DFFINED AS THE LOADING AT WHICH A TENSILE. PLASTIC INSTAEILITY OCCURS, ANALOGOUS TO NECKING IN SIMPLE TENSION. A METHOD OF CALCULATION OF THE CRITICAL LOADING FOP THIN SHELLS SUBJECTED TO A UNIFORM STRESS SYSTEM IS OUTLINED. THE STRENGTH DETERMINED IN THIS WAY ALLOWS FOR THE FULL STRAIN-HAROENING CAPACITY DF THE MATERIAL, AS CONTRASTED WITH METHODS OF ESTIMATING THE YIELD-POINT LOAD.

*PLASTICITY + \#STRESS ANALYSIS + SUPST PRESSURE + CONTAINMENT, HIGH PRESSURE + DEFORMATION + FAILURE, GENERAL + STRESS.

$11-21121$

YALCH JP + MCCONNELEE JE

PLANE STRAIN CREEP ANO PLASTIC DEFORMATION ANALYSIS OF a COMPOSITE TUBE

GENERAL ELECTR IC COMPANY, CINCINNATI, OHIO

11 PAGES, 16 FIGURES, 8 REFERENCES, NUCLEAR ENGINEERING AND DESIGN E(1) PAGES 52-6? (JANUARY-FEERUARY IYG $)$

A METHOO OF ANALYSIS AND ASSOCIATEO COMPUTER PROGRAM IS DESCRIBED FOR THE GENERALIZED PLANE-STRAIN ANALYSIS OF TRANSIENT CREEP AND PLASTIC DEFORMATIONS OF COMPOSITE CYLINOERS.

THE MATER IAL PROPERTIES ARE PERMITTED TO VARY WITH TEMPERATURE, AND THE AXISYMMETRIC LOACING

CONDITIONS MAY VARY WITH TIME. THE LOADING MAY INCLUDE ANY COMBINATION DF INTERNAL PRESSURE,

EXTERNAL PRESSURE, AXIAL LOAD AND KADIAL VARIATION OF THERMAL STRAINS. SEVERAL FORMS OF

CREEP LAW ARE PERMITTED, INCLUDING AN ISO-CURVE PLASTIC-STRAIN LAW FOR USE IN OETAINING

CERTAIN PLASTICITY SCLUTIONS FROM THE CREEP SOLUTIONS.

*CREEP BEHAVIOR + \#CR.三EP PRQPERTY + \#CYLINDER + \#DEFORMATION + \#PLASTICITY + \#STRESS ANALYSIS + COMPUTER PROGRAM + CONCRETE + ELASTICITY + MATHEMATICAL STUDY + STPESS

$11-21122$

TUBA IS + WEI DO

THERMO-ELASTIC-PLASTIC STRESS DISTRIBUTION IN COMPOSITE MEDIA WITH NONUNIFORM TEMPERATURE DISTRIBUTION AND TEMPERATURE DEPENDENT MATERIAL PROPERTIES

WEST INGHOUSE RESEARCH LABOPATORY

9 PAGES, 12 FIGURES, 1 TABLE, 1 REFEP.ENCE, NUCLEAK ENGINEERING ANO DESIGN $5(1)$ PAGES $43=51$

(JANUARY-FEBRUARY $19 E 7$ )

DESCRIBES AN ELASTIC-PLASTIC GENERALIZED PLANE-STRAIN STRESS-ANALYSIS METHOO THAT CAN BE 
CONTAINMENT CAEGOKY LULLAR FACILITIES

$11-21122 \approx \operatorname{CONT} 1 \mathrm{NUCC}: \mathrm{A}$

ADPL TED TO CASES INVOLVING THEPMAL DND PEESSURE LOADING MITH TENPCRATURE-DEPENDENT

PROPERTIES. THE DEFORMATION THEDRY gF PLASTICITY AND THE METHOD JF FINITE DIFFEF ENCES WERE. COMBINEO TJ DETAIN A.SOLUTIDN. AN ANLLYSIS OF A RECTANGULAR CLAD FUEL EL E'AENT IS PRESENTED $\triangle S$ AN EXAMPLE.

*FUEL ELEMENT + \#PLASTICITY + \#STRESS ANALYSIS + \#TEMDERATURE ERAQIENT + CLAC + DEFRFMATION + ELASTICITY + FUEL INTEGRITY + HIGH TEMPERATURE + MATHEMATICAL STUCY + PRESSURE, EXTSRNAL + STSESS + STRESS STF. IN DATA

$11-21185$

TENTATIVE REgULATORY SUPPLEMENTARY CRITERIA FOR ASME CCDE CONSTFUCTIOQN NUCLEAR PFESSURE VESSELS UNITED STATES ATOMIC. ENERGY COMMISSICN, WASHINGTON, D. C.

49 PAGES, AUGUST $23,1 \subseteq E 7$

THIS DOCUMENT CONTAINS TECHNICAL SPECIFICATIONS SUPPLEMENTAPY TO THASF CRNTAINED IN THE ASME CODC SECT IOV Z WHICH ARE CONSIDEGEC NECESSARY TC GUAPANTEF THE ST ZUCTURAL LNTEGEITY OOE A PRESSURE VESSEL FOR THE DURATION OF ITS SERVICE LIFE. VESSELS AF.E CLASSIFIED, AND LOADING CONDITIONS ARE SPECIFIED. REQUIPEMFNTS INCLUDE - 11 . ANALYTICAL OR EXPERIMENTAL VERIFICATIGN OF ALL STRESS DNALYSFS, I I ON INDEPENDENT REVIEW DF THE CCSIGNEKS STRESS REPORT HY THE DWNER, (3) COMPLETE NRITTEN INSOECTION RECOF.OS, 141 CONSIDEP.ATION OF MATERIAL PROPERTY CHANGES IN DESIGN, (5) NONDESTEUCTIVE INSPECTION AFTER FABFICATION ANO HEAT TEEATMENT, (E) A FRACTURE-AAECHANICS FLAN-GROWTH ANALYSIS. FFACTUPE IS SPECIFICALLY RECOGNIZED AS A POSSIELE MODE OF FAILUFE TO BE DESIGVVED AGAINST.

AVAILABILITY - USAEC PUELIC DOCUMENT ROCM, WASHINGTON, D. C.

*BRITTLE FRACTURE + *CODES AND STANOAPDS + \#CONTAINMENT DESIGN + \#CONTAINMENT VESSEL LGADING + *DESIGN CRITEDIA + \#INTFGRITY + \#DHESSUPE VESSEL + \#STRESS + *STRESS ANALYSIS + *WELOS + COMPUTER DROGRAM + CONTAINMENT IVSPECTION AND MAINTENANCE + DEFOEMATICN + EAFTHQUAKE. + ELASTICITY + EMERITTLEMENT + FLAK + FRACTUPE TOUGHNCSS + DLASTICITY + STFEL

11-21663 ALSO IN CATEGORY 18

DRL REQUESTS ADDITIONAL INFORHATION ON ZICN STATION PSAR-STRUCTURAL DESIGN

USAEC DIVISION DF REACTOO LICENSING

$\Leftrightarrow$ PAGES, DOCKET 50-274 AND 50-304, TYPE--PWR, MFG--WEST., AE--SGi + LUNDY, NCVEMBEQ 19E7

DRL ASKS 21 QUESTICNS RELATED TO STPUCTURAL AND COMPONENT DESISN. ZICN PSAR DID NCT MEET THE REQUIREMENTS CE THE $\triangle E C$ GUIDE FRQ THE GEGANIZATION AND CENTENTS CFF SAFETY ANALYSIS RFPRRTS (DESIGN SASES WERE NOT IDENTIFIES CIR EXOLAINED, ETC.). SEISMIC-DSSIGN INFOP:ATION WAS INCOMPIETE, AS WAS CONTAINMENT-DESIGN INFORMATION. INSPECTICIN AND SUEVEILLANCE PROGF. OUALITY CONTRCL, AND TESTING WERE INACEQUATELY CUVERED.

AVAILABILITY - USAEC FUBLIC DOCUMENT FCCH, WASHINGTON, D. C.

HAEL DESIGN CKIIERIA + AEC QUESTION + CONSTRUCTION PERMIT PROCESS + REACTOR, PWR + REDCET, DSAR + · ZION 1 AND 2 (PWP)

11-21923 ALSO IN CATEGORY C

PARRY DL.

NONOESTLUCTIVE FLAW CETECTION IN NUCLEAF, FOWE

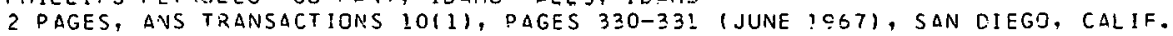

INVESIIGAIIJHS WERE CONOUCTED INTO THE FEASIBILITY OF APPLYING ACOUSTIC PHENOMENA TO FLOW DIAGNOSTICS. THEY WERE DIRECTED AT DEVFLCPING A NONDESTRUCTIVE TECHNIQUE FIRR THE DETECTION AND DEFINITION OF FLAWS IN THC LARGE COMPLEX PRFSSURE VESSELS AND DR.IMARY SYSTEN OF NUICIEAF: POWER INSTALLATICNS. THEY CONSISTTD IN APPLYING THE TECHNIUUE LE UETECTIQN AND INTEPPRETING ACOUSTIC EMISSIONS EMANATING FFOM NATERIALS UNDER APPLIED STRESS.

* TEST, NONDSSTQUCTIVE + \#TFST, PRESSUPE VESSEL + FAILURE, PRESSURE VESSEL + INSTRUMENTLTION, TESTING + PRESSURE VESSEL + STRESS STRAIN DATA

$11-?>108$

REMOTE DISASSEMBLY ANC EXAMINATION CIF THE PM-2A FEACTOR VESSEL

I DAHO NUCLEAR CORP.

1 DAGE; I FICURE, TRANGACTIONS 10(2), DAGE 666, (NUV. 1967), PRESENTED AT THE lag7 WINTEO MEETING GF THE AMERICAN NUCLEAR SDCIETY, CHICAGO, ILLINCIS, NCVEMBER 5- . 19S

ALL THE REACTOF VESSFL INTEQNALS WERF FEMGVFO REMMTELY, AND THE VESSFL WAS ADDF FEADY FOR. REMOTE NONDESTRUCTIVE TESTING. THE VESSEL WAS FIRST TFSTED IN THE AS $\rightarrow$ PECEIVED CONOITION WITH NO FAILUKE. D DEFECT WAS THEN MACHINED INTO ITS WALL. THE CVERALL TEST PRDGCAM CONSISTEC COC EIGHT SEPARATE TEST SFQUENCES. THE DEFECT WAS ENLARGSD BETWEEN EACH TEST. VEW STPAIN GAGES WERE INSTALLEO $\triangle F T E D$ EACH DEFECT ENLAPGEMENT. CN VOVEMBER 18. 1066, THE VESSEL WAS

PRESSURILEO, $\triangle$ IND A BK ITTLE-FFACTURE-TYPC FAILURF, OCCURRTC. AFTED RUPTUP.E OF THE VESSEL, A DUARTER-SECTICN SLAR WAS DFMEVED REMOTELY USING AN OXYGEN-ACETYLEVE CUTTING TORCH. CANE HUNORED SPECIMENTS (TENSILE TEST, DROP-WFIGHT TEAR TEST, CHAPPY V-NOTCH, AND WEDGE-JPENINCLLOADING TRACTURE TMUSHNESS TEST) WERE MACHINED ERCM TIIS SLAE. THE VESSEI WAS PLACED I:S STOPSQF TE ANAIT ALUITILNAL HUNUING FCR FURTHFR SPECIMEN PREPARATIDNS ANO 
11-22108 *CONT INUED*

EXAMINATIUNS.

\#BRITTLE FRACTURE + \#FAILURE, PRESSUPE VESSEL + \#PM 2 A (PWR) + \#FRESSURE VESSEL + \#TEST, DESTRUCTIVE + \#TEST, PRESSURE VESSEL + DOSIMETRY, GENEFAL + STEEL + TEST, NONDESTRUCTIVE

$11-22103$

HAMILTON LJ + NYER R + SCHROCK VE

PRGFAGATIOV OF SHOCK WAVES THRDUGH TWO-PHASE, TWO-COMPGNENT MEDIA

UNIVERSITY OF CAL I FOPNIA, BERKELEY

4 PAGES, 1 FIGURE, 3 FEFERENCES, ABSTRACT IN ANS TRANSACTIONS 10 (2), PAGE 660, (NOV. 1967), ¿PRESENTED AT

THE 1967 WINTER MEETING OF THE AMEPICAN NUCLEAF SOCIETY, CHICAGO, ILLINOIS, NOVEMBER 5-9, I967

A THORDUGH UNDERSTANDING OF HOW PRESSURE WAVES PROPAGATE THRGUGH TWO-PHASE MEDIA IS NECESSARY FOR SAFE REACTOE DESIGN. PREVI OUS EXPERIMENTAL INVESTIGATIONS OF THE PROPAGATIGN QF SHOCK NAVES THROUGH TWO-PHASE MEDIA, USING A SHOCK-TUBE-TYPE APPARATUS, WERE LIMITED TO THE CASE NHERE THE WAVE PASSED THROUGH A MIXTURE THAT WAS ESSENTIALLY AT REST. A LOOP WAS CONSTRUCTED TO INVESTIGATF THE PROPAGATION OF PRESSURE WAVES IN DUCTS CARRYING TWO-PHASE MIXTURES UNDER STEADY FLOW CONDITIONS. THE FIP.ST SERIES. DF EXPERIMENTS WAS LIMITED TO BUBBLY, TWO-COMPONENT FLOW IAIR AND WATER). FOR VOID FRACTIONS GREATER THAN $5 \%$, THE MEASURED VALUES OF THE SHOCK SPEED ARE CONSISTENTLY LARGER THAN THOSE PREDICTED BY THE HOMOGENEOUS MODEL DF CAMPBELL AND PITCHER.

*CONTAINAENT, SHOCK GENERATION AND PROTECTION + \#SHOCK ABSORBER + \#SHOCK WAVE + AIR +

COMPARISON, THFORY AND EXPERIENCE + VOID COEFFICIENT + WATER, GENERAL

$11-22110 \quad$ ALSG IN CATEGORY 17

RITCHIE $\triangle B$

SAFETY EXPERIENCE AND THE CONTROL OF HAZAPDS IN HOT CELL OPERATIONS AT HARWELL

UKAEA, BERKS (HARWELL)

1 PAGE, ANS TRANSACTIONS 10(2), PAGE 679, (NOV. 1967), PRESENTED AT THE 1967 WINTER MEETING OF THE

AMERICAN NUCLEAR STCIETY, CHICAGO, ILLINOIS, NOVEMBER 5-9, 1967

THE ATMIC ENEREY RESEARCH ESTABLISHMENT AT HAR.WELL, FNGLAND; HAS TWO MAJUR ACTIVE-HANDL ING BUILDINGS, OVE TO PROVIDE A GENERAL-PURPOSE SERVICE AND THE OTHER FOR SPECIALIZED

ACTIVE-HANDLING WORK ASSDCIATED WITH THE METALLURGICAL RESEARCH PRDGRAM. THIS PAPER

DESCRISES STHE TF THE INCIDENTS THAT HAVE OCCURRCD SINCE THE BUILDINGS WENT INTO SERVICE IN 1057 AND GIVES EXAMPLES OF SOME OF THE EQUIPMENT AND METHODS THAT HAVE BEEN DEVELOPED TO ENSURE THAT PRCPER CONTROL OF THE HAZARDS IS MAINTAINEO.

*HOT CELL + \#DPERATING EXPERIENCE SLMMARY + ADMINISTRATIVE CONTRQL + CGNTAINMENT ATMOSPHERE, INERT + FIRE + HARWELL + INSPECTIJN AND COMPLIANCE

$11-22117$

HOWFI-L GR + PRINCE K

ENTEY INTO THE WINOSCALE ADVANCED GAS-COOLED REACIUR YKESSURE VESSEL

UKAEA, NINFRITH + UVITED KINGUUM ATOMIC ENERGY AUTHORITY + LANCASHIRF, RISLEY

8 PAGES, 6 FIGURES, JDUFNAL OF THE BRI TISH NUCLEAR ENFRGY SDCIETY 6(3), PAGE 241-248, (JULY 1967)

IN OCTOBER 19SE, THE OPERATGRS DF THE WINDSCALE ADVANCED GAS-COOLED FEACTOR ENTERED THE MAIN PRESSURF VESSEL AND MADE THE FIRST GENERAL INSPECTION OF THE P.EGION WITHIN THE UPPER DOME IN THE VICINITY MF THE HOT 3OX, WI THOUT REMOVAL OF IRRADIATED FUEL FROM THE REACTOP. THIS WAS MADE P.JSSI BLE RY THE UPPER NEUTRON SHIELD, WHICH IS A FEATURE UF IHE AGR DESIGN. IN THIS ARTICLE THE DESIGN OF THIS SHIELD ANO THE INSPECTIONS MADE WITHIN IHE VESSEL ARE DESCRIBED, AND THE MEASURED DOSE RATES ARE COMPAPEO WITH ORIGINAL ESTIMATES. IT IS CONCLUCED THAT THESE MEASURE AENTS HAVE CONFIRMED THE EFFECTIVENESS OF THE SHIELD AND THAT THE ANTICIPATED INCP.EASE IN DOSE RATES WILL BE SUFFICIENTLY SHALL TO PERMIT FURTHER INSPECTIONS OVER THE LIFE OF THE REACTOR.

\#COMPARISON, THEOPY LND EXPERIENCE + \#INSPECTION AND COMPLIANCE + \#PRESSURE VESSEL + *WAGR (GCR) + DOSE MEASUREIANT; INTERNAL + NEUTRCN + SHIELDING

$11-22118 \quad$ ALSO IN CATEGORY 17

NORRISEB + IRELAND DR + LAUTZENHEISEP. CE

THE SECOND INSPECTIIJN OF THE ELK RIVER. REACTOR PRESSURE VESSEL AFTEF. DPERATION

SOUTHWEST RESEARCH INST., SAN ANTONIO, TEX.

SWRI-122399-13+. 5C PAGES, FIGURES, TABLFS, REFERENCES, JULY 21,1967

THE ELK RIVER FEACTOP PFESSURE-VESSEL INSPECTICN WAS AGAIN MAOE EY SOUTHWEST RESEAP.CH INSTITUTE AFTER THE REACTOR HAD BEEN OPERATED FOR NEARLY 2 FULL-POWER YEARS. INSPECTION PROCEDURES, SIMILAR TO THOSE USED DURING THE PREVIUUUS (196E) INSPECTION, ARE DISCUSSED. NO CRACKS NERE FGUND IN NOZZLES IN THE SHELL OR HEAD AND TOP-HEAD OVERLAYS. CRACK ING FOUND IN THE SHELL FLANGE OVERLAY DURING THE 1966 INSPECTION HAS NOT INCREASED, AND AGAIN IT WAS CONCLUDED THAT IT DID NOT DENETRATE INTO THE BASE STEEL. DURING THE POSTOPERATIONAL PERIOD, THE SHELL-FLANGE OVERLAY WAS COATEO WITH AN UNIDENTIFIED SUBSTANCE THAT SIGNIFICANTLY IMPAIRS LIQUID PENETRANT INSPECTION. AN ULTRASONIC INSPECTION GF THE VESSEL FLANGE WAS MAOE TO DETERMINE IF THE CLADOING CRACKS HAD PENETRATED INTO THE BASE STEEL. THE OBSERVATIONS CONFIRMED THE RESULTS DF THE PATCH-GRINOING INSPECTION. 


\section{CONTAINMENT OA OF NUCLEAL 11 HACILITIES}

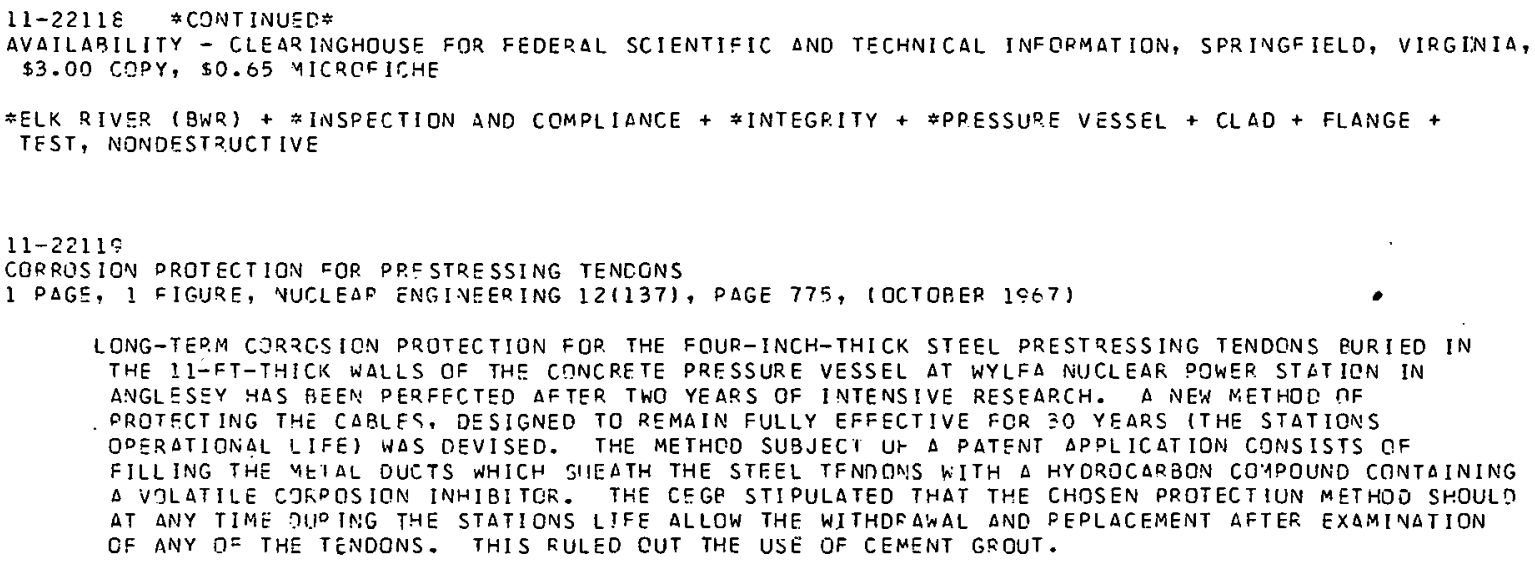

TENSILE SDECIYENS, CHLRPY IMPACT SPECIMENS, ANO MINIATURE IMPACT SPECIMENS COF SIX OIFFER LNT C.JNDITIONS NERE IQDADIATEU TU 2.8 X 10118THI) AND $5.6 \times 10$ IIRTH) NEUTRONS PEP. SQ. CY (GREATER THAN I MEV) AT 160-240 C. THE STFELS INVESTIGATEO WERE SIS 142103, 2103/K3, NO 345 ,

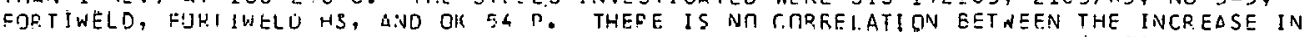

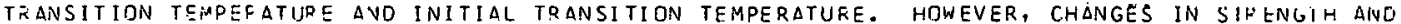
DUCTILITY CAN HE COSRELATED TO THE INITIAL YIELO STRENGTH.

AVAILAGILITY - CLEARINGHOUSE FOR FEDERAL SCIENTIFIC AND TECHNICAL INFORMATION, SPRINGFIELC, VIRGINIA, D3. 20 CODY, \$0.65 HICROF ICHE

\#IPRACIATION TESTING + FNOT DATA + \#STEFL + PRESSURE VESSEL

$11-22122$

GRUHI HH

THE SI IMENS PRESTRESSED CONCRETE PRESSUPE VESSEL, MARCH 1967

SIEMENS-SCHUCK ERTNERKE, GFRMANY

9 PAGES, 3 FIGURES, CRESI MEETING, APRIL 1 I:E7

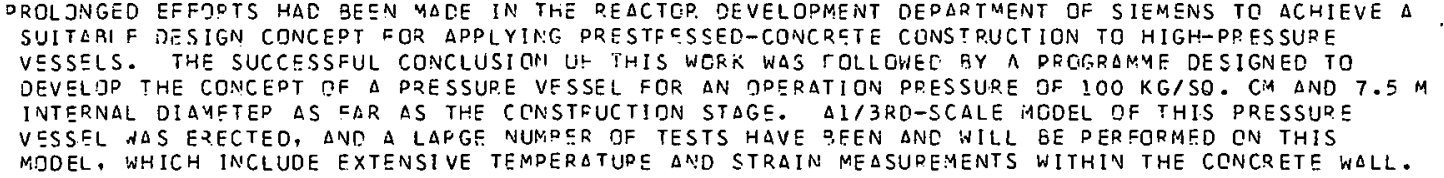

AVAILABILITY - H. H. GRUHL, REACTOR-CEVELOPMENT-DED., SIEMENS AG, EFLANGEN, GERMANY 
$11-22123$

SUMMARY OF BASIC RESEAR.CH AND DEVELOPMENT PROGRAM FCR PRESTRESSEO CONCRETE REACTOR VESSELS QAK RIOGE NATIONAL LAR., TENN.

32 PAGES, 5 FIGURES, 28 PREFERENCE, CPEST MEETING, $\triangle P R I L 1967$

\begin{abstract}
THE PROGRAM DESCRIBED IS AIMED AT INVESTIGATING AND IMPROVING THE BASIC TECHNOLOGY AS IT APPLIES TOO CONCRETE VESSELS FOR ALL DEACTOR TYFES, AND IT IS BEING CODP.DINATED WITH THE PROJECT-SPONSORED RESEARCH ANO DEVELOPMENT WORK TO ENSURF THAT THERE IS NO UNDERSIRABLE DUPLICATION OF EFFORT. ALTHOUGH SOME WORK IN THE BASIC PROGRAM IS BEING CARRIED OUT AT THE CAK RIDGE NATIONAL LABORATORY, THE MAJORITY IS BEING SUBCONTPACTED TO DRAW ON THE EXTENSIVE KNONLEDGE AND PESEARCH CAPABILITIES OF CONCRETE SPECIALISTS AT UNIVERSITIES AND RESEARCH LABORATORIES AND TO ESTABLISH A NUCLEUS OF CONCRETE EXPERTS WHO HAVE CONTFIBUTEO TO, AND ARE FAMILIAR WITH, THE PCRV TECHNGLOGY. THE PROGRAM, AS PRESENTLY CONCEIVED, WILL EXTENO OVER A PERIOD OF FIVE OR SIX YEARS. SINCE IT HAS BEEN IN EXISTENCE FOR LESS THAN ONE YEAR, DNLY THE INITIAL EFFORTS HAVE BEEN IDENTIFIED.
\end{abstract}

- AVAILABILITY - TAK RIDGE NATIONAL LAB., TENN.

*CONCRETE, PRESTRESSED + \#PPESSURE VESSEL + CDNTAINMENT RESEARCH AND DEVELOPMENT + CONTAINMENT VESSEL LOAOING + CREEP REHAVIOR + DEFORMATION + IRRADIATION TESTING + MODEL TESTING + TEST, PRESSURE VESSEL + THERMAL CONSIDERATION

$11-22124$

MILLE KE

MEASUREMENTS ON THE MODEL OF A PRESTRESSED CONCRETE PRESSURE VESSEL

TECHNISCHE UNIVERSITAT BERLIN, INSTITUT FUR BAUKONSTRUKTIONEN UND FESTIGKEIT

5 PAGES, CREST MEETING, APRIL 1967

\begin{abstract}
RFSULTS INDICATE THAT THE AVERAGE STFESS IN THE CONCRETE IS ABOUT EQUAL TO THE AVERAGE STRESS PREDICTEO BY CALCULATION. DUE TO THE LARGE NUMBER OF CHANNELS FOR THE PRESTRESSING REINFORCEMENT AND THE LOCALLY CONCENTRATED APPLICATION OF THE EXTERNAL FORCES, LOCAL DISTURBANCES WERE TO BF EXPECTED. AS A RESULT, A LIMITED NUMBER OF SENSORS DID NOT PRODUCE INTEPPRETABLE PESULTS. A FINAL EVALUATION OF THE RESULTS OF ALL MEASUREMENTS WILL BE COMPLETED SOJN. IT WILL BE POSSIBLE TO MAKE REACTOR PRESSURE VESSELS OUT OF PRECAST CONCRETE ELEMENTS WHICH ARE ASSEMBLED AND PRESTRESSED TOGETHER IN SITU. THEY OFFER THE $\triangle D V A N T A G E$ THAT THE END CAPS CAN BE REMOVED AT A LATER DATE TO GIVE UNHINDERED ACCESS TO THE ENTIRE INTEFNAL CROSS-SECTION DF THE VESSEL, AND THEY WILL BE ABLE TO RESIST THE EXPECTED LOADINGS.
\end{abstract}

AVAILABILITY - K. E. MILLE, INSTITUT FUER BAUKONSTRUKTIONEN UND FESTIGKEIT, TECHNISCHE UNIVERSITAT, BERLIN, WEST GERIMANY

*CONCRETE, PRESTRESSED + \#MOOEL TESTING + \#PRESSURE VESSEL + CONTAINMENT VESSEL LOADING + MEASUREMENT, STRAIN GAGE + MEASUREMENT, TEMPERATURE

$11-22124$

COSTES D

FRENCH SAFETY STUDIES DN PRESTRESSED CONCPETE PPESSURE VESSELS

CENTRE D ETUDES NUCLEA IKES DE SACLAY, FPANCE

5 PAGES, CREST IEETING, APRIL 1967

\begin{abstract}
THE PROGRAM DIO NOT. BRING TO LIGHT ANY NEW HAZARDS FOR PRESTRESSED CONCPETE VESSELS SINCF ALL THE CLEAN RUPTURES WFRE CAUSED EITHER BY CONSIDERABLY INCREASEO PRESSURES OR BY CONSIDERABLE WEAKENING OF THE PRESTRESSING SYSTEM. THEY DO HOWEVER TEND TO SHOW THAT THERE IS A RISK OF RUPTURE WITHDUT PREVIOUS CRACKING IN THE CASE OF VERY HEAVILY CORRODED AND WELL-GROUTED TENDONS. THESE FINDINGS MAY BE THCUGHT SOMEWHAT CONTRADICTDRY. MOREOVER, THIS TYPE OF RUPTURE WOULD HAVE LESS TENDENCY TD APPEAR IN A VESSEL SUBJECTED TO A THERMAL GRAOIENT WHERE CRACKS WOULD IN THE FIRST INSTANCE APPEAR ON THE OUISIDE.
\end{abstract}

avalability - D. COStes, centre D-ETudes nuCleaires de saclay, franee

\#CONCRETS, PRESTRESSED + \#MDDEL TESTING + \#PRESSURE VESSEL + \#TEST, PRESSURE VESSEL + FAILURE, GENERAL + FRANCE + MOCKUP

$11-22128$

COMPLIANT FLANGE VESSEL CLOSURE

U.S. $\triangle$ TOMIC ENERGY COM:1ISSION

FRENCH PATENT NO. 1,457,796 +.6 PAGES, I FIGURE, NCVEMBER 15, 1965, IN FRENCH

THIS INVENTION RELATES TO NUCLEAR RFACTOR PPESSUPE VESSTL COVERS HAVING RLSILIENT SEALS. THE DEVICE OF THIS INVENTION COMFRISES A FIRST FLEXIBLE BELLOWS AFFIXED TO REACTOR VESSEL COVER AND A SECOND FLEXIBLE BELLOWS AFFIXED PROXIMATE THE TOP ACCESS PORT OF NUCLEAR REACTOR PRESSURE VESSEL WHEREGY THE ABUTTING FACES OF FIRST AND SECOND BELLOWS FORM THE PRESSURE RESISTANT SEAL WHEN COVER I'S PLACED OVER THE TOP ACCESS PORT OF PRESSURE VESSEL. UPWARD MOVEMENT OF COVER, DUE TO AN GVEPPRESSURE TRANSIENT, WILL BE TAKEN UP BY THE EXPANSION OF 


\section{CONTAINMENT CAFEGORY NUCLEA '}

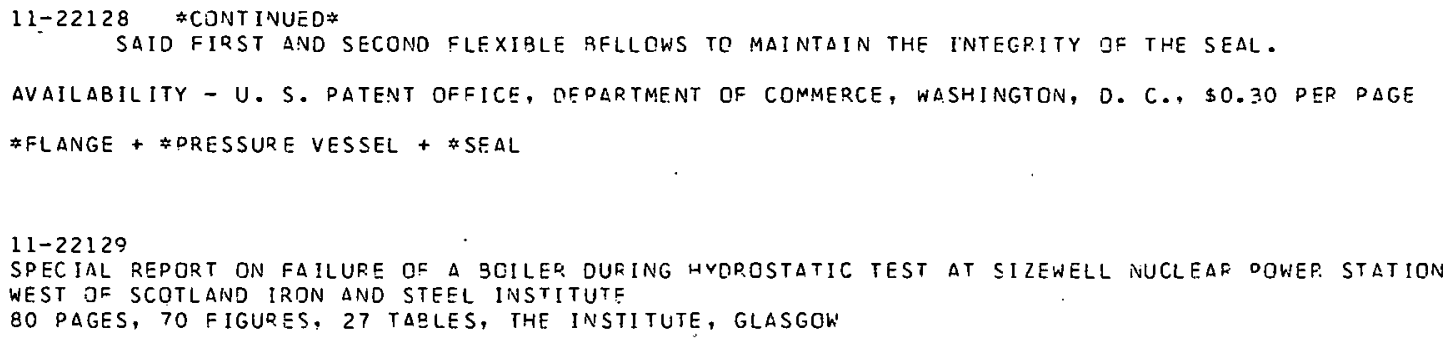

A MECHANICAL TRANSFER PUMD DARTICULARLY $\triangle D A P T E D$ TO THE TFANSFED OF RACIOACTIVE GASES COMPP ISES $\triangle L I Q U I D$ PISTON MOVING IN A COMORESSIGN CHAMBER. THE CHAMEER LIS INTAKE AND DELIVEPY VALVES WHOSE OPENIVGS AND CLOSINGS ARE SYNCHRGNIZED WITH THE MOVEMENT OF THE DISTON, WITH THE INTAKE VALVE LOCATED ON THE AXIS OF THE DFLIVEPY VALVE. THE DELIVEPY VALVE IS MLOE UP OF A FLOATING MEMBER, WHICH IS PAISED DIRECTLY FFOM ITS SEATING AS A RESLLT OF COMPRESSION OF THE VRLUME CF GAS PROOUCEO BY THE MIVEMENT OF THE LIOUIO PISTON. A PORTION OF THE COMPPESSION CHAMBER CONTAINING THE LIOUID DISTON IS FOOMED QY $\triangle$ PAIP. OF BELLCWS THAT ARE CPSRABLE BOTH TO CONTRACT OR BCTH TO EXPAND TGGSTHEF SO $\triangle S$ TO ENSURE MAXIMUM LIQUID DISPLACEMENT IN! THE CHAMBER.

AVAILABILITY - TIIL PATENT DFFICE, 25 SOUTHAHPTON 8LDG., LONDON, W. C. 2, ENGLANO, SO.4L PER COPY \#PATENT + \#PUHD + TOACER, GAS

11-22156 ALSE IN CATEGTRY 3

BAUCIFEER G + ROSSETYIL

DEVICF FRR HANDI. ING IND OBSFRVING ELCNGATED EOOIES WHICH EMIT RADIATION

EUROPEAN ATOMIC ENEREY COMMUNITY

BP.ITISH DATENT 1,$058 ; 140+$ 4 PACES, I TIGUFE, FEBRUARY 9,196 ?

DESCRIBES A DEVICE USED IN HANDL ING AND OBSERVING ELONGATED BCDIES WHICH FMIT RACIATICN, SUCH AS IRZADIATED FUEL RODS FRUM A RFACTOR. THE DEVICE CONSISTS OF A SEALCD ENCLCSURE GF VERTICAL ELONGATED SHAPE SURFDUNDEC EY AN ADEQUATE RADIATION SHIFLD WITH CANE OE MORE VIEHIRIG DJRTS. IN THE ENCLOSUR̈E ARE GUIDES ANO SUPPORT MECHANISMS FOR SUPDORTING AND HANDL ING THE IRRADIATED BDOY CQ RCD.

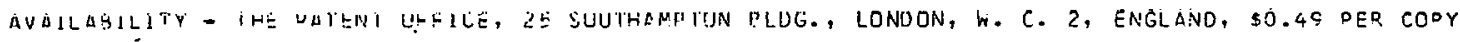
*FUEL HANDLING MACHINE + \#DATENT + CONTAINMENT DESIGN

11-22157 ALSO IN CATEGNQIES 12 $\triangle$ ND 12

CABARET J + GERAPDV + VALENTIN A

LIFTING MECHAMISIM

COMMISSARIAT A L ENEEGIE ATOMIOUE

BRITISH DATENT ?, $354,830^{\circ}+$ SOOAES, 4 FIGUAES. JANUARY 11,1967

DESCRIBES $\triangle$ LIFTING MECHANISM USED IN A REACTOE FACILITY TO.LIFT COVERS OF TANKS OP. LEAK-TIGHT VESSCLS USED TO TRANSTER RADIOACTIVE MATERIALS. THE LIFTING MECHANISM IS DESIGNEC SO THET UPNARD TRAVEL IS IN TNO STAGES. THE COVEP IS LIFTED WHILE REMAINING PARALLEL TO THE PLANE OF THE OPENING. IN THE SECCNO STAGE. THE COVFF IS QEMOVEO SO DS TE FREE THE OPENING. THE FIRST STAGE PERMITS THE NATgPIAL FROM THE LIQUID SEAL TO DRIP INTO THE VESSEL AND NOT EE DISPEFSEC.

AVAILABILIT.Y - THE PLTENT CFEICE, 2 E SOUTHAMPTRN ELOG., LONDON, W.C. 2, ENGLANO, SO.49 PER COPY

* PATENT + CONTAINMENT DESIGN 
BRIEF NONTECHNICAL DISCUSSION OF THE VARIOUS METHODS USED TO PREVENT RELEASE OF RADIOACTIVE FISSION PRODUCTS FROM BWP ANO PWR PCHER PLANTS. SAFEGUARDS OESCRIBED INCLUDE (I) EMERGENCY CORE-CODLING SYSTEM TQ PREVENT HIGH FUEL TEMPERATURE AND (2) CONTAINMENT SYSTEMS, INCLUDING PRESSURE SUPPFESSION, PRESSURE RELIEF, CONTAINMENT COOLING, FILTRATION SYSTEMS, SPRAYS, ICE CONDENSERS, STEAM VENTING, AND SUBATMOSPHERIC CONTAINMENT.

* ENGINEERED SAFETY FEATURE + CONTAINMENT, GENERAL + EMERgENCY COOLING CONSIDERATIONS +

PLANT PQOTFCTIVE SYSTEM + REACTOR, BWR + REACTOR, PWF + SYSTEM DESCRIPTION

11-22463 ALSO IN CATEGORIFS 4 AND 12

HOLCOMB WF

EXPERIENCE NITH GLOVEZOX INERT ATMOSPHERE CONTROL SYSTEM

ARGONNE NATIONAL LAB., IDAHO OIVISION, IDAHO FALLS, IDAHO

4 PAGES, 2 FIGURES, NUCLEAR ENGINEEP ING AND DESIGN 613), PAGE 213-216, (0CT. 1967)

THE HANOLING ANO PDEPARATION OF SODIUM FOK FUEL ELEMENTS AT THE FUEL CYCLE FACILITY FOR THE SECOND EXPERINIENTAL BREEDER REACTOR REQUIRES THE USE OF A GLOVEBOX EQUIPPED WITH A PECIRCULATING INEPT ATMOSPHERE OF HIGH PURITY. THE ARGON GAS PURIFICATION SYSTEM CONSISTS OF A PALLADIUM CATALYST FOR REMOVING OXYGEN, MOLECULAR SIEVE DRYER FOR REMOVING WATER, AND A CANNED 3LDWER FOR CIRCULATING THE GAS. THE PURIFICATION SYSTEM SERVES A 250 CU. FT GLOVEBOX COMPLEX AND WITH CONTINUDUS OPERATION CAN MAINTAIN AN ATMOSPHERE WITH OXYGEN IMPUFITIES OF 2 PPM AND WATER IMPUR ITIES OF 6 PPM AT AN INLEAKAGE RATE OF 0.002 CU. FT/HR OF AIR WHILE OPERATING THE GLEVEBOX COMPLEX AT A NEGATIVE PRESSURE OF I IN. OF WATER.

\#AF.GON + DECONTAMINATION + \#GLGVE BCX + \#SODIUM + OPERATING EXPEFIENCE

11-22895 ALSG IN CATEGDRIES 10 ANC 17

MCCARTHY JF

SELECTED FERMI OPERATING EXPFRIENCE - OCT 1966

ATDMIC PJWER DEVELOPMENT ASSOC., INC., DETROIT, MICH. + POWER REACTGR DEVELOPMENT CO., DETROIT, MICH. + DETROIT EDISON CO., MICH.

APDA-CFE-3 +. 40 PAGES, MAY 1967

TNJ-DAY LEAK-RATE TEST AT 2 PSIG GAVE 100 CFM/DAY (REFERENCE) AND ZERO (ABSOLUTE). SPORALIC GROUNOS (AGAIN) IN 4QOO-V SYSTEM WERE TRACED TO BURISD UNDERGRQUND CABLE FILLED WITH WATER NOT UNUSUAL. ONE GROUND IN EITHER SUPPLY. \# \#ISCUSSES OCT. 5 FUEL MELTDONN WITH EXACTLY SAME LANGUAG: AS FOUND IV EF-38. OISCUSSES INDICATIONS ON FISSION-PRODUCT DETECTOR BEING CAL IBRATED. CISCUSSES APPARENT REACTIVITY LOSSES OURING MELTDOWN, WHICH. APPAEENTLY REACHED 30 CENTS JUST B BEFORE THE SHUTDOWN.

AVAILABILITY - CLEAFINGHOUSE FOR FEOERAL SCIENTIFIC AND TECHNICAL INFOFMATION, SPRINGFIELD, VIRGINIA \$3. OO CUPY, SU.BS MILAOPICHE

*ELECTP.IC POWER, GENERAL + *FUEL MELTOOWN + \#INSTRUMENTATION, OETECTION FAILED FUEL ELEMENT + \#TEST, LEAK RATE + CONTAINMENT, LOW PRESSURE + FERMI (LMFBR) + INCIDENT, GENERAL +

REACTIVITY EFFECT, $\triangle N O M A L O U S$ + REACTOR, FAST + REPORT, OPERATIONS SUMMARY

11-22:38 ALSO IN CATEGORY IE

ISOLATION VALVE SEAL WATER SYSTEM

COMMONWEALTH EDISON COMPANY

4 PAGSS, PAGSS $6.2 .5-1$ THRU $6.2 .5-4$ OF THE ZION STATION 1 AND 2 PRELIMINARY SAFETY ANALYSIS REPORT, VOLUME

II, JUNE 15, 1967, DÜCKETS 50-295/304, IYPE--PWF, MFG.--WEST., AE--SGT + LUNDY

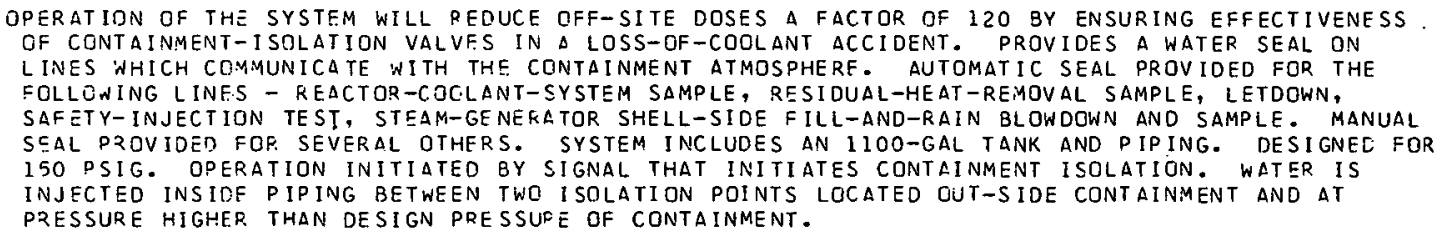
LINES NHICH COMMUNICATE WITH THE CONTAINMENT ATMOSPHERF. AUTOMATIC SEAL PROVIDED FOR THE FOLLONING LINES - REACTOR-COCLANT-SYSTEM SAMPLE, RESIDUAL-HEAT-REMOVAL SAMPLE, LETDOWN, SAFETY-INJECTION TEST, STEAM-GENEKATOR SHELL-SIDE FILL-AND-RAIN BLOWDOWN AND SAMPLE. MANUAL SCAL PRDVIDED FOF. SEVERAL OTHERS. SYSTEM INCLUDES AN IIOO-GAL TANK AND PIPING. DESIGNEE FOR 150 PSIG. OPERATION INITIATED BY SIGNAL THAT INITIATES CONTAINMENT ISOLATION. WATER IS INJECTED INSIDF PIPING BETWEEN TWO ISOLATION POINTS LOCATED GUT-SIDE CONTAINMENT AND AT PRESSURE HIGHER. THAN DESIGN PRESSUFE OF CONTAINMENT.

AVAILABILITY - USAEC DUGLIC DCCUMENT RODM, WASHINGTON, D. C.

*CONTAINIAENT LEAKAGE CONTROL + ACCIDENT, LOSS OF COOLANT + CDNTAINMENT PENETRATION, CLOSURE OF + ENGINEERED SAFETY FEATURE + REACTOR, PWR + KEPORT, PSAR + ZION 1 AND 2 (PWR)

$11-22987 \quad$ ALSG IN CATEGORY 7 
CONTAINMENT OPE NUCLEAR, ${ }^{1}$ FACILITIES

$11-22087 \Rightarrow$ CONTINUSE

ALBAUGH FW + FUQUAY JJ + HARTYH + VOILAND EF + WCRLTON DC

NUCLEAR SAFETY OUAPTEFLY REPRRT APRIL, MAY, JUNE, ICG7 FDR NÜCLEAR SAFETY BRANCH OF USAEC DIVISION OF REACTOR DEVELOPMENT ANU TECHNOLOGY

BATTELLE-NORTHWEST, RICHLAND, WASHINGTON

BNWL $-537+. \quad 33$ PAGES, FIGURES, TABLES, DECEMBER 1967

THE STATUS OF THE FOLLOWING PROJECTS ARE PFPORTED - CDNTAINMENT SYSTEMS EXPERIMENTS (CSE), FISSION-PRDOUCT-AEROSOL CONTROL, CFACK DETECTION IN PRESSUPE PIPING BY ACOUSTICAL EMISSION, COLUMBIA RIVER SEDIMENTATION STUDIES, DISPOSAL DF REACTOR OFF-GAS INTO SOIL SYSTEMS, AND SIMULATION MDOELING OF THERMAL GENERATION IN SELECTED RIVER SYSTEMS.

AVAILABILITY - CLEARINGHOUSE FOR EEDERAL SCIENTIFIC AND TECHNICAL INFGRMATION, SPRINGFIELO, VIRGINIA \$3. OO COPY, \$O.65 MICRDFICHE

* AEROSOL PROOUCT ION + *CONTOINMENT PAINT + \#CSE + \#TEST, NCNDESTRUCTIVE + \#WASTE TPEATMENT, FIXATION + \#WATER POLLUTION + $\triangle E P O S O L+\triangle E R O S O L$ PROPERTIES + CONTAINMENT LEAKAGE CONTROL + C.ONTAINMENT SPRAY + FISSION PROOUCT TRANSPORT + FISSION DROCUCT, IODINE + ORGANIC IODIDE + PIPING + SPRAY, GCNERAL + WASTE DISPOSAL, GAS + VASTE DISPTSAL, LIQUID + WASTE DISPOSAL, TEREESTPIAL

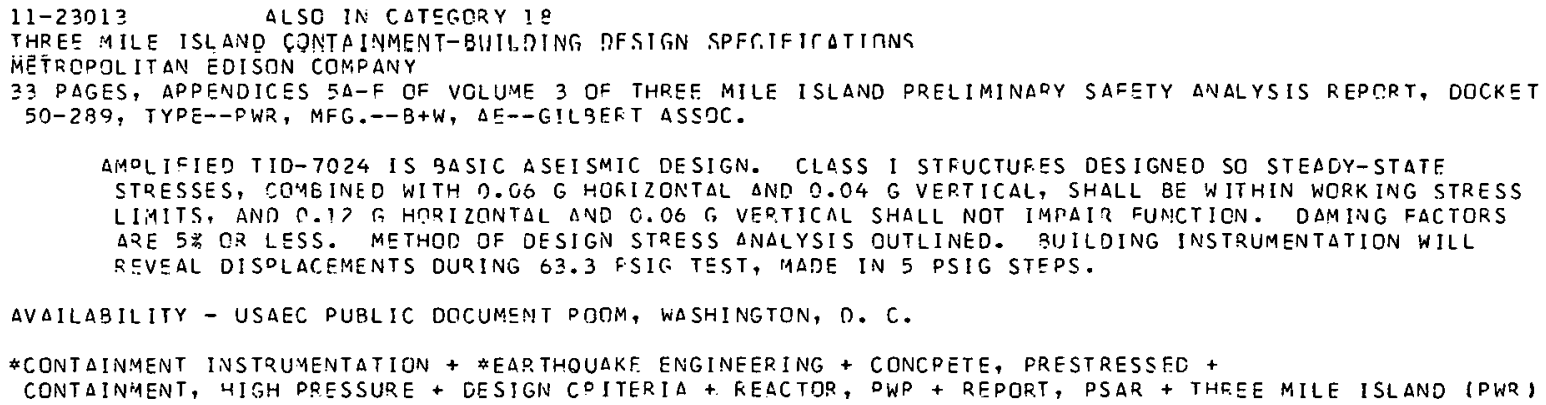

* CONTAINMENT, I CE CONDENSEP + CONTAINMENT FESEAFCH DND DEVELOPMENT + ECONOMICS + MOCKUP + MOOEL TESTING

$11-23304$

CNGEL

CALCULATION METHONS AND P.ESULTS OF LEAK-PATE TESTINGS ON CONTAINMENT VESSELS OF NUCLEAF POWER PLANTS TECHNISCHER UBERWACHUNGS-VEREIN BAYERN F. V., MUCHEN, GFRMANY

O PAGES, FIGUR SS, TAQLES, REFERENCES, $\triangle$ YONKERNENERGIE 12 (7-8) PAGES 240-248 (1CG7) IN GERMAN 
CONTAINMENT OF NUELEAR FACILITIES

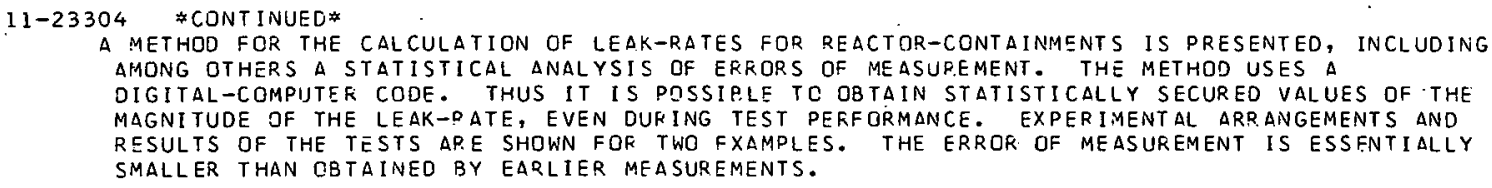

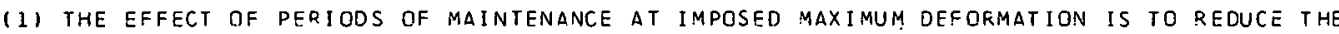
ENDURANCE TO PLASTIC FATIGUE IN BIAXIAL ALTERNATE BENOING. (2) IN THE EXPERIMENTAL CONDITIONS WHICH HAVE BEEN CONSIDERED, STRAIN-HARDENING AT $300 \mathrm{C}$ PRIOR TO THE. ALTER.NATE BENDING FATIGUE TEST $\triangle T$ T $30 \mathrm{C}$ DOES NOT NECESSARILY INVOLVE A REDUCTION OF THE ENOUR.ANCE TD PLASTIC FATIGUE. (3) IF A STEEL IS SUB JECTED TO ALTERNATE PLASTIC DEFORMATIONS, IT IS OBSERVED THAT, DUP.ING THE FIRST DEFORMATION CYCLES, THE MAXIMUM STRESSES ATTAINED AND THE CHARACTER ISTIC PLASTIC DEFDRMATION GF EACH CYCLE ARE UNSTABLE, WHEN DEFINITE TOTAL DEFORMATIONS ARE IMPOSED ON THE MATERIAL.

AVAILABILITY - CLEARINGHOUSE FOR FEDERAL SCIENTIFIC AND TECHNICAL INFGRMATION, SPRINGFIELD, VIRGINIA B3.0O COPY, \$0.65 MICROFICHE

*Embrittlement + *Failure, fatigue + *Steel + deformation + plasticity + pressupe vessel + tensile property

$11-23306$

THF. MULTII-LAYER CPV CONCEPT

3 PAGES, FIGURES, NUCLEAR ENGINEERING, PAGES 926-928 (DECEMBER 1967)

THE NEW CONCEPT CONSISTS OF A VESSEL WITH TWO MULTILAYEK WALLS SEPARATED BY A GAP FILLFO WITH DEMINERAL ISED WATER. THE WATER IS KEPT AT CORE COOLANT PRESSJRE BY A SIMPLE TWO-CHAMRER PRESSURE-EQUALIZATION UNIT, AND A CCOLING SYSTEM IS INCORPORATED IN THE GAP.

\#CONCRETE, DRESTRESSEC + *COQLING, GENERAL + \#PRESSURE VESSEL + \#THER.MAL INSULATION + CGNTAINMENT L.INER

$11-23307$

BELLAEV KI

NUCLEAR REACTOR AND PRESSURE VESSEL THEREFOR

AK. IEBOL $\triangle G F T$ TTOMENERGI

BRITISH PATENT $1,075,476+.3$ PAGES, FIGURES, JULY 12,1067

A NUCLEAR REACTOR, COMLED AND MODERATED BY PRESSURIZED FLUID, COMPRISES AN OUTFR CONCRETE PRESSURE VESSEL AND AN INNER STEEL VESSEL WITH AN INTERVENING SPACE. THE DIMENSION.S OF THE LATTER ARE SO CHOSEN THAT THE PRESSURE OFं FLUID IN THE INNER VESSEL CAUSES IT TO EXPAND AND CONTACT THE OUTER PRESSURE VESSEL WHICH IS BUILT TO HITHSTANC ANY FURTHER INCFEASE IN PRESSURE OF THE. FLUIO IN THE INNEP VFSSFL. SPACE BETWEEN THE INNER AND OUTER VESSELS IS ORIGINALLY CREATED BY HEATING THE STEEL VFSSEL UNDER PRESSURE UNTIL THE YIELD POINT OF THE STEEL VESSEL IS EXCEEDED AND THE VESSEL HAS EXPANDED TO TOUCH THE OUTER VESSEL ALL APBUND.. WHEN TEMPERATURE AND PRESSURE ARE REDUCED THE STEEL VESSEL CONTRACTS UNDER ELASTIC AND THERMAL DEFORMATION LEAVING A WELL DEFINED CLEARANCE BET WEEN THE TWD.

AVAILABILITY - THE PATENT CFFICE, 25 SOUTHAMPTON BUILOING, LGNDON, W. C. 2, ENGLAND (4S CENTS PER COPY) *CONTAINMENT L INER + \#PRESSURE VESSEL + *THERMAL MECHANICAL EFFECT + CCINCRETE + STEEL

11-23308 ALSO IN CATEGRRY 1

NEW CONTAINMENT DESIGN LOWERS NUCLEAR PLANT CAPITAL COSTS

WEST INGHOUSE CORPORATION

2 PAGES, FIGURES, . WESTINGHOUSE ENG., 27, PAGES 82-83 (MAY 1967)

A NEW CONCEPT IS DESCR.IBED WHICH WILL DRASTICALLY REDUCE THE. SIZE OF A NUCLEAR PLANT CONTAINMENT STRUCTURE. IT USES AN ICE BED TO SERVE AS A HEAT ABSORBER IN THE EVENT OF ACC IDENTAL RELEASE OF STEAM WITHIN THE CONTAINMENT STRUCTURE. ITS ADVANTAGES ARE - A SMALLER CONTAINMENT STRUCTURE, DESIGN FOR LOWER PRESSURES, WITH RESULTANT REOUCT ION IN CAPITAL CCSTS, RAPID ABSORPTION OF HEAT,. AND $\triangle$ VIRTUALLY STATIC SYSTEM, WHICH CONTRIBUTES TO RELIABILITY. TESTS HAVE DEMONSTRATED THE EFFECTIVENESS OF THIS NEW CONTAINMENT CONCEPT AND HAVE CONFIFMED ENGINEERING ESTIMATES LF THE PERFORMANCE. THE ICE CONDENSER PERFORMS EQUALLY WELL OVER A WIDE RANGE. OF CONDITIONS, INCLUDING A VARIETY OF ICE CONFIGURATIONS AND STEAM BLOWDOWN TIMES RANGING FROM 10 SEC TO 45 MIN.

\#CONTAINMENT DESIGN + \#CONTAINMENT, ICE CONDENSER + \#MODEL TESTING + ECONOMICS + MOCKUP 
CONTAINMENT OF NUCLEAR FACILITIES

$11-2330^{\circ}$

CAMPBELLLALLEV. D + LOW EW

PRESSURE TESTS ON EVO SLABS FER DRESTRESSED CONCRETE PDESSURE VESSELS

UNIVERSITY OF SYONEY, SYDNEY, N.S. N. , AUSTFALIA

15 PAGES, 3 FIGUPES, 7 FEFERENCES. NUCLEAR ENGINEEPING AND DESIGN 6(4), PAGES $345-350$ (NOVEMRER 1967 )

WITH THE PRESENT TREND TOWARDS CYLINORICAL SHAPES IN THE DESIGN OF PRESTRESSED CGNCRETE PRESSURE VESSELS IT MAY RE PRESUMED THAT THE MAJORITY OF VESSFLS FOO FUTUFE RFACTIRS WILL INVOL VE THE USE OF DEEP END SLABS ANCHORFD TS BARREL WALLS EY AXIAL DRESTRESSING TENDONS. THE IMPORTANCE OF ISOLATING THE END SLABS FOD EXPERIMENTAL STUDY HAS BEEN POINTEU OUT BY VARIOUS REDORTS ON MODEL TESTS OF CCMPLETE VESSELS. THIS AFTICLE SUMMMRISES THE TEST P.ESULTS OF A SERIES OF PRESSURE TESTS INN TWO TYPES OF SLABS. THE TESTS WERE DESIGNED DRIMARILY TO STUDY THE INELUENCE OF SLA3 THICKNESS AND RF PRESTRESS ON THE NATURE CF THE FAILURE MODE AND ON THE MAGNITULE OF THE ULTIMATE PFESSURE. A.PPLICATION QF SGME OF THE CONCLIJSIONS REACHED TO THE DESIGN JF END SLAES FLR C.YLINDRICAL PCPV ARE SUGEFSTED.

*CONCRETE, PRESTRESSED + \#FAILURE, PRESSUPF VESSEL + \#PRESSURE VESSEL + \#SLAR + \#TFST, PROOF + CYLINDER + TEST, DRESSURE VESSEL

$11-23310$

HAMALA K + HAYASHI T + CGUCHI I

STRESS ANALYSIS QE TADEFEO TCANSITION JTINTS IN PEACTOK PRESSURE VESSEL

HITACHI LMTD., JAPAN

ORNL-TR-1769 +. 17 PAGES, TRANSLATED FROM HITACHI HYORON, L9, PAGES P12-16, (19GE)

A COMPUTER CODE, TROIKA, WAS DEVELCPED FOD THE STRESS ANALYSIS OF TAPERFD TRANSITITN JOINTS IN ATOMIC REACTOR PRESSURF VESSELS. THE CALCULATED RESULTS SHOWEO GOON AGREEMENT WITH EXPER IMENTAL FESULTS REDORTED FDOM AMERICA INDICATING THLT THE CODE HAS FEACTICAL VALUE. EXAMPLES OF TADEFED TRANSITION JCINTS SETWEEN TWO CYLINCERS AND BETWEEN CYLINDEE. AVD SPHERE WERE DISCUSSES, AND IT WAS INOICATED THAT THERE IS SOME REASCN TO EXPECT THAT SCME CF THE

ASME SPECIFICATIONS WILL BE MODIFIER. THIS CODE CAN BE USED IN MAVY AGEAS. AND IT IS EXPECTED THAT IT WILL BE USEC FOF VARIDUS TYPES OF STRESS ANALYSIS WHICH WILL BE USED TCGETHER WITH THE NECESSAFY EXPERIMENTAL DATA.

AVAILABILITY - CLEARINGHOUSC FOR FEDERAL SCIENTIFIC ANO TECHNICAL INFQRMATION, SPRINGFIELD, VIRGINIA \$3. OO COPY, \$O.65 MICROFICHE

\#PRESSURE VESSEL \#STREST FLANGE + JAPAN + NOZZLE

11-23311 $A L S O$ IN CATFGIIRITS, $\triangle N$ IS

PATENTS IN THF FIELO OFF CAN-R.UPTURE DETECTION

COMMISSARIAT A L-ENEFGIE ATOMIQUE, SACLAY (FRANCF). CENTRE D-ETUSES NuCleAIRES

CEA-BIB-78 +. I 141 PAGES, FIGURES, DCTORER ISE7, IN FRENCH

THE ABSTRACTS CEF DATENTS ISSUED IN THE PRINCIPAL INDUSTPIAL CCUNTRIIES ARE LISTED ACCORDING TC SEVERAL CHAPTEFS PERTAINING TO THE GENERAL PRINCIPLES OF LFAK GETECTION, CETECTICN ITSELF OF

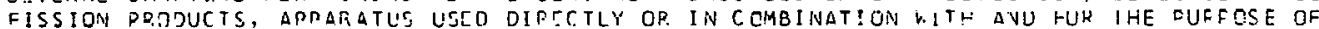
DETECTION, THE INDICATION AND TREATMENT TE THE DATA GIVFN, THE EX AMINATION SEFOEE AND $\triangle$ TTERE USE CF CARTRIDCE JACKETS. A CUMULATION LIST IS APPENDEC, FIVING IN PPOGRESSIVE ORCEP THE PATENT NUMGERS FOP IR COUNTRIES TC FACILITATE THE SEARCH QF THF ABSTRACT IN THE CDPRESOJNOING CHADTER.

AVAILABILITY - MICRQCARQ EUITIUNS, INC. (FCR SALE) ACCCUNT ING AND SHIDDIVG DEPARTMENT, WEST SALEM, WISCONSIN 5466 C

*FUEL ELEMENT + *INSTRUMENTATION, DETECTION FAILED FUEL ELEMENT + \#TSST, LEAK LOCATION + MONITOR, RADIAT ION, GENERAL

11-23312 $\triangle L S O$ IN CATEGURILS 17 AND 10

LE-LEVIER MG

FAILURCS IN PIPES ANO PFESSURE VESSELS CORRELATED TO NUCLEAR PCWEP PLONT SER.VICE
COMMISSARIAT A L-ENERGIE ATOMIQUE, SACLAY (FRANCE). CENTRE D-ETUDES NUCLEAIRES

CEA-319-79+. 32 PAGES, SEPT. 1967 , IN FRENCH

THIS BISLIOGRAPHY DEALS WITH THE PAPERS PUELiSHED CN THE FAILUPES IN PIPES AND PRFSSUP. VESSELS CORRFLATED TO NUCLEAP POWFR PLANT SERVICF. THE REFERENCES WEPE SELECTED FROM BIBLIOGRAPHIG. INDFXFS PIISLISHED FROM ISE3 TO JULY 1 DES INCLUSIVE. AQSTRACTS ARE INCLUDEC.

AVAILABILITY - CLEARINGHQUSE FRR FFDFRAL. SCIENTIFIC ANO TECHNICAL INFGRMATION, SPFINGFIELO, VIPEINIA, $\$ 3.00$ COPY, \$0.65 MICROFICHE

\#FAILURE, GENERAL + \#PIPING + \#PRESSUPE VESSEL + BIBLICIGRAPHY + BRITTLE FRACTURE + STRFSS ANALYSIS + TEST, BENCH + TEST, CESTRUCTIVE + TEST, NONDESTRUCTIVE 
CONTAINMENT CATEGORY I l

$11-233 ! 3$

FRACTURE MECHANICS EVALUATION OF REACTOP VESSEL STEELS. TECHNICAL PROGRESS REPORT FOR THE PERIOO ENDING SEPTEMBER $30,1966$.

WESTINGHOUSE ELECTRIC CCRP., PITTSBURGH, PA. ATOMIC POWER DIVISION

WCAP-3677-1 + EURAEC-1720 +. 21 PAGES, 10 FIGURES, TABLES, OCT. 1966

AN EXPER IMENTAL PROGRAM DIRECTED TCWARDS FURTHER DEVELOPMENT AND EVALUAT ION OF A FRACTURE MECHANICS $\triangle P P R O A C H$ TO THE PROBLEM OF BRITTLE FRACTURE OF REACTOK VESSEL MATERIALS, BASEO UFON THE USE OF MODIFIED WEOGE DPENING LOADING ( WOL) SPECIMENS. EXPERIMENTAL TESTING OF A GROUP OF REACTOR VESSEL STEELS WILL BE PERFORMED TO INVESTIGATE THE APPLICATION OF THE FRACTURE MECHANICS TECHNIQUE TD THESE MATERIALS IN BOTH THE INIRRADIATED AND IRRADIATED CONDITIONS. PROCUREMENT OF THE MATFRIALS WAS INITIATED. INCLUDED ARE TWC DIFFERENT HEATS OF SA533 GRADE B CLASS I 112 IN. AND \&. IN. THICK), THE NOZZLE CUTOUTS FRCM THE NOK VESSEL ANO CORRELATION MONITOR MATERIAL.

AVAILABILITY - CLEARINGHOUSE FOR FEOERAL SCIENTIFIC AND TECHNICAL INFORMATION, SPRINGFIELD, VIRGINIA, $\$ 3.00$ COPY, \$0.65 1 ICROFICHE

*BRITTLE FRACTURE + *STEEL + FRACTURE TOUGHNESS + NDT OATA + PRESSURE VESSEL + R AND D PROGRAM

ZWICKY EE

ALSC IN CATEGORY 5

AN ANALYSIS OF TURBINE MISSILES RESULTING FRCM LAST-STAGE WHEEL FAILURE

GENERAL ELECTRIC CO., SCHENECTAOY, N. Y.

TR-67SL211 +..73 PAGES, 15 FIGURES, 3 TABLES, 7 REFERENCES, OCT. 3, 1967

THE REPJRT DESCF IRES CALCULATIONS MAOE TO EVALUATE THE POTENT IAL OAMAGE WHICH COULD BE DONE BY HYPOTHETICAL TUREINE MISSILES IN THF UNLIKELY EVENT OF THE FAILURE OF THE LAST-STAGE WHEFL GF A NUCLEAR MACHINE. IT IS CONCLUDEO THAT THE MISSILE KINETIC ENERGY AESORBED BY THE TURBINE CASING IS AS LARGE OR LARGER THAN PREVIOUSLY ASSUMED AND THAT $\angle$ I2O-DEG WHEEL FRAGMENT IS PJTENTIALLY MOKE DAMAGING THAN EITHER A SO- OR 180-DEG FRAGMENT. THE POTENTIAL OAMAGE INCREASES SLIGHTLY WITH LAST-STAGE WHEEL SIZE. THE CONCRETE-SLAB THICKNESSES PENETRATED FCR THE 38-, 43-, LND 52-IN. WHEELS ARE IN THE APPROXIMATE FATIOS 1, 1.01, 1.08.

AVAILABILITY - USAEC PUGLIC OOCUMENT ROOM, WASHINGTON, D. C.

\#FAILIJE, EQUIPMENT + \#MISSILE GENEPATION AND PRGTECTION + \#TURBINE + ACCIDENT ANALYSIS + IMPACT PROPERTY

$11-23360 \quad \Delta L S O$ IN CATEGORY 17

COE RN

FAILURE OF CONTA INMENT ELFCTRICAL PENETRATION AT SAN ONOFRE, FEB, 7

SOUTHERN CAL IFDRNIA FDISON COMPANY, LOS ANGELES, CALIF.

5 PAGES, ATOMIC ENERGY CLEARING HQUSE 14(9), PAGES 22-26 (FEBRUARY 26, 1968) DOCKET 50-206

A FIRE JN THE UUTSIDE SE SIDE OF CONTAINMENT SPHERE IN a CAELF TRAY LEADING TJ A SPHERE PENFTRATION CAUSED HIGH PRESSUREITEMPERATURE INSIDE PENETRATION EPC4, FORCING THE OUTER SIJLKHEAD OUT OF THE SHELL ASSEMBLY. NO CAUSE FGR PENETFATION FAILURE FROH DEFECIIVE MATERIAL GR WORKMLNSHIP HAS REEN FOUNC, CAUSE OF FIHE NUT REPQRTED. \#+EPC4 SERVEO PRES SURIZER HEATERS, SAFETY INJECTION AND RESIOUAL HEAT PUMP A, FANS A2 ANO A4, ROO HLIFT COIL, AND AN EMERGENCY LIGHTING PANEL. ELEVEN CABLES IN EPCQ (ABOVE 4 ) WERE DAMAGED BY THE FIRE. DAMAGED EPCO CABLES SERVED FAN AB ANO FOUR CONTROL ROOS. \#\#PLANT SHUTDOWN WAS OROERLY, WITH NO RADIATION RELEASE OR TECH.-SPECS. VIOLATION.

* CINTTINMENT PENETRATION, ELECTRICAL + \#FAILURE, EQUIPMENT + \#FIRE + ENGINEERED SAFETY FEATURE + INDEPFNDFNCE + REACTOR, PWR + SAN ONOFRF (PWR) + SYSTEM OPERABILITY IN ACCIUENI

$11-23484 \quad A L S O$ IN CATEGORY 18

CRESDEN 2 AND 3 DRYWELL EXPANSIDN GAP DESIGN

COMMONWEALTH EDISON COMPANY

3 PAGES, PAGES 5-2.28 THRU 5-2.30 OF DRESDEN 1 AND 2 FINAL SAFETY ANALYSIS REPORT, VOLUME I, NOVEMEER I7, 1967, DOCKETS 50-237/249, TYPE--3WR, MFG.--G.E., $\triangle E--S G T$. + LUNDY

A GAP BETWEEN THE LINCP. AND CONCRETE. ALLOWING FOR EXPANSION IS FILLED WITH POLYURETHANE FOAM. TWO IN. OF THE FGAM IS PJUKED OVER THE STEEL ORYWELL SHELL, THEN COVERED WITH I/4-IN.-THICK PULYESTER FIBEE GLASS SHELL PANELS, WHICH FORM THE INNER SHELL FOR POURING THE CONCRETE. PENETRATICNS ARE SURR JUNOED EY CONCENTRIC SLEEVES. ON-SITE TESTS OF THESE PROCEDURES SHOWED THAT THE FIBER GLASS WAS DISPLACED BY LESS THAN 0.25 IN. BY THE POURING AND CURING OF THE CONCRETE. THE FOAM WILL BE EXPOSFO. TO $2.5 \times 10(7 \mathrm{TH})$. RADS IN 40 YRS. GAMMA DAMAGE THRESHOLD IS BETWEEN $5 \times 10(6 T H)$ AND $4 \times 10(7 T H)$ RAOS FOR POLYURETHANE ELASTOMERS. SAMPLES OF. THE FOAM TO BE USED SHOW NO DETECTABLE CHANGE IN RESILIENCE UP TO 10 (BTHI RADS. THE FOAM IS RATED TG $230 \mathrm{~F} A N D$ IS SELF-EXTINGUISHING.

AVAILABILITY - USAEC PURLIC DOCUMENT ROOM, WASHINGIUN, D. $C$.

*CONTAINMENT LINER + \#EXPANSION + \#FOAM + \#PRESSURE VESSEL + CONTA.I.NMENT CONST.RUCTION + CDNTAINMENT, PRESSUPE SUPPRESSION + DRESOEN 2 (BWR) + IRRADIATION TESTING + PLASTICITY + PRESSURE VESSEL + REACTOR, BWR + REPORT, SAR 
CONTAINMENT CATEG NUCLEAQ 1 FACILITIES

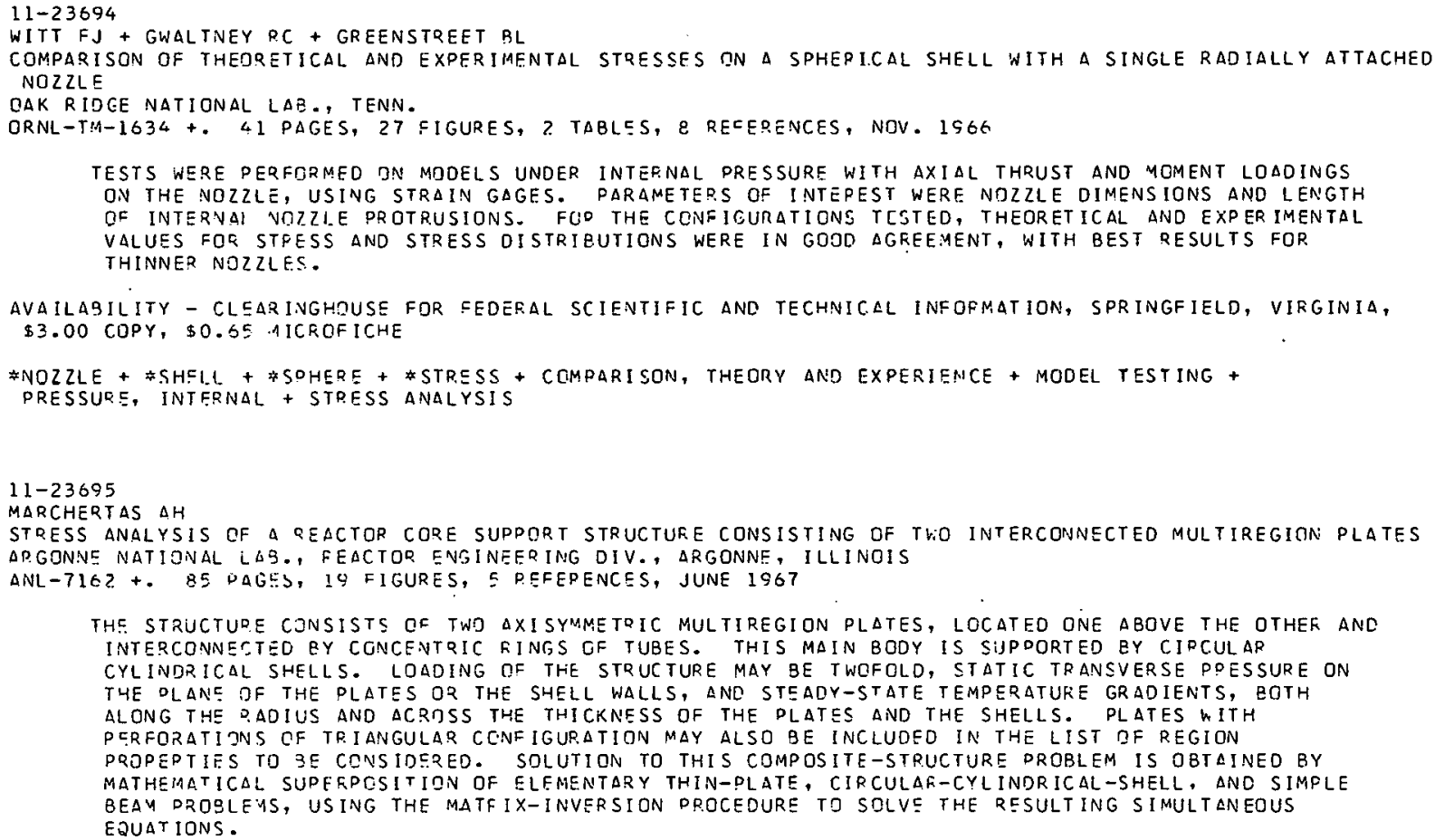

AVAILABILITY - CLEA? INGHOUSE FOR FEDEPAL SCIENTIFIC AND TECHNICAL INFDRMATION, SPRINGFIELD, VIRGINIA, $\$ 3.00$ COPY, \$0.65 MICROFICHE

\#STRESS ANALYSIS + * SUPPRRT STRUCTURE + CGMPUTER. PROGRAM

$11-23696$

KELKAR VS

VIBRATIONS DF A HULLOW ELASTIC CYLINOER RCNDED TO A THIN CASING CFF A TIFFERENT MATERIAL

NASA, AMES RESEARCH CENTEP, MOFFETT FIELC, CALIF.

NASA-IN-U-422I +. IE DACES, 6 FIGUPES, 10 PEFEPENCES, NOV. 1967

EXACT SOLUTIJVS AFE OBTAINED TO DETERMINE THE NATURAL FFEQUENCIFS AND MODE SHAPES CF D THIN CYLINDR ICAL SHELL SUPPTRTEI EY D HULLUW CORE OF A DICFERENT MATEPIAL. MATERIALS FQR BOTH SHELL AND CORE AFF ASSIJMEN TI P.E HOMOGENEOUS, ISOTROPIC, AND LINLARLY ELASTIC. A PERFECT 3OND IS $\triangle S S U M E D A T$ THE JUNCTION CF THE SHELL ANE THE COF.E. THE COMPOSITE CYLINDEF IS FFEE FROM STRESSES AT ITS CURVEO FOUNDARIES AND IS SUPPORTED BY A DIAPHRAGM AT ITS FLAT ENDS. THE SOLUTIONS FOR THE COPF $\triangle$ PE BASED ON THREF-DIMFNSIONAL ELASTICITY THEORY AND COR THE SHELL CEN BENDING THEOPY. CUPVES ARE PLOTTED TO SHOW THE VARIATION OF THE FREOUFNCY WITH THE VARIATION IN CIPCUMECRENTIAL ANO AXIAL WAVE NUMBERS AND IN THE RATIC OF INNEP TO DUTER FADII DF THE CORF.

AVAILABILITY - CLEARINGHOUSE FIR FERERAL SCIENTIFIC AND TECHNICAL INFOFMATION, SPRINGFIELO, VIRGINIA, $\$ 2.00$ COPY, \$0.65 ICQCF ICHE

*CYLINOER + \#VIBFATION ANALYSIS + MATHEMATICAL TREATMENT

$11-23697$

MCDANELS DL + SIGNORELLI DA + WEETON JW

ANALYSIS OF STRESS-QUETUPE ANO CREEP PROPERTIES OF TUNGSTEN-FIBER-EEINFORCED CDPPER COMPCSITES NASA, IFNIS ZFSFQRT.4 TFNTSR, CLEVELANID, OHIO

NASA-TN-D-4173+. 55 PAGES, 35 FIGURES, O TABLES, 24 REFERENCES, SEPT. 1967

EQUATIONS FOR PRECICTIMG THE CRECD D.ATE ANC STPESS-RUPTUUE PRLIPFRTIFS IIF FIRFR-REINFORCED $M E I G L L I C$ CDMPOSITES ARE DEVELOPED. STRESS-EIJPTURE AND CREEP TESTS, CCNDUCTED AT I2OC AND $1500 \mathrm{~F}$ WEPS USED TO VERITY TIIE VALIDITY GF THE EQUATIONS DEVELGPEU IN THE ANALYSIS. A DISCUSSICN 15 DRESENTEO RELATINS THE FESULTS OBTAINEO WITH THE MODEL SYSTEM TC MOPE PDACTICAL FIBER-REJNEDRCF CIMPMSITE SYSTCMS FOP STRESS-P.UPTURE IRPLICATIONG. THE STRESS-RUPTURE STRENGTHS DBTAINED WITH THE TUNGSTFN-COPPEP MODEL SYSTEM COMPARED FAVOFABLY WITH THOSE OF EXISTING SUOEPALLOYS AND DEMONSTRATEN THE POTENTIAL CF FIZER-REINFORCED METALLIC COMPOSITES IV STRESS-RUPTURE APOLICATIONS AT ELEVATED TEMPFRATUE.ES. 
$11-23697$ \#CONTINUED*

AVAILABILITY - CLEARINGHOUSE FOR FEDERAL SCIENTIFIC AND TECHNICAL INFGRMATICN, SPRINGFIELD, VIRGINIA, $\$ 3.00$ COPY, \$0.65 1 ICROFICHE

*COMPOSITE MATERIAL + \#STRESS ANALYSIS + COMFARISON, THEORY AND EXPERIENCE + MATHEMATICAL TREATMENT

$11-23698$

HUNTER AR + SCHWARZ ME

DEVELOPMENT AND APPLICATION OF A PHOTOELASTO-PLASTIC HETHOD TO STUCY STPESS DISTRIBUTIGNS IN VICINITY OF A SIMULATED CRACK

LOCKHEED AIRCRAFT CORP., SUINNYVALE, CALIF.

NG7-16-663+NASA-CR-655 +. 131 PAGES, 104 FIGURES, 1 TABLE, 16 REFEPENCES, DEC. 19E6

THIS METHOD UTILIZES THE IROZEN STRESS AND CREEP CHAPACTERISTICS DF PLASTIC MATERIALS TO SIMULATE THE STRESS-STRAIN BEHAVIOR OF ALUMINUM ALLOYS. TWO POLYMERS WERE SUEJECTED TO THERHAL CYCLES. THE STRAIN AND BIPEERINGENCE DUE TO CREEP WERF THEN FROZEN IN SG THAT THIS MATERIAL COULD BE SLICED WITHOUT REFREEZING THE FROZEN STRAIN. STRESS DISTRIBUTIONS WERE STUDIED IN THO THIN- AND TWO. THICK-PLATE MODELS WITH CENTRAL $1 / 8-I N$. HOLES.

AVAILABILITY - CLEARINGHOUSE FOR FEDEPAL SCIENTIFIC AND TECHNICAL INFORMATION, SPR INGFIELO, VIPGINIA, $\$ 3.00$ COPY, $\$ 0.65$ MICROF ICHE

\#NOZZLE + \#STRESS ANALYSIS + CRCEEP + FAULT + MODEL TESTING + STRESS STRAIN DATA

11-23699 ALSG IN CATEGQPY 1

LIBER T + BARNETT RL

FINAL REPORT. AN EXPFR IMENTAL INVESTIGATION OF FRANGIBLE PLATE FRAGMENTATION

IIT RESEARCH INSTITUTE, TECHNQLOGY CENTER, CHICAGC, ILLINOIS

IITRI-H-6095 +. 99 PAGES, FIGURES, TABLES, 9 REFERENCES, OCT. 1966

OISCUSSES THE EFFECTS OF BLASTS (POSSIBLY FROM NUCLEAR DETONATIONS) ON PLATES. GF CGNCERN ARE STRUCTURAL DEBR IS AND OERSONNEL PROTECTION. EMPHASIS IS ON DYNAMIC LOADING AND TESTING FDR PREDICTABLE CRACK PATTERNS.

AVAILABILITY - DEFENSE DOCUMENTATION CENTEF, CAMERON STATION, ALEXANDRIA, VIRGINIA

CIVIL DEFENSE + MISSILE GENERATION AND PROTECTION + SHIELDING + STRESS ANALYSIS

$11-23801$

MCIVOR IK

THE ELASTIC CYLINDRICAL SHELL UNDER RADIAL IMPULSE

UNIVERSITY OF MICHIGAN, ANN APSOR, MICHIGAN

7 PAGES, 6 FIGURES, 7 REFERENCES, JGURNAL OF APPLIFD MECHANICS 33 (4), PAGES 831-37 (DECEM8EF 19E6)

IN THE MOTINN RF AN ELASTIC CYLINDRICAL SHELL FOLLOWING IMPULSIVE PRESSURE, MARKED OEVIATIONS FROM LINEAR THEQRY MAY OCCUR. THROUGH INTERACTION OF CIRCUMFEP.ENTIAL MEMBRANE FORCE WIIH FLEXURAL CURVATUPE. ENERGY IS TRANSFERREU IU FLEXUKAL MOUES OF PATHER HIGH OROER. TIIC. RESULTING FLEXURAL STRESS IS SIGNIFICANTLY HIGHER THAN THAT GIVEN BY LINEAR THEORY. INCLULES SAMPLE PROBLEM.

\#CYLINDER + \#DYNAMICS, NDNLINEAR + *ELASTICITY + *SHELL + \#STPESS ANALYSIS + SHDCK WAVE

11-23803 ALSO IN CATEGORY 18

INOIAN POINT 2 BUCKLING OF CONTAINMENT LINER AT THE FUEL TRANSFER PENETRATION

CONSDL IDATED EDISON COMPANY OF NEW YORK

2 PAGES, JANUARY 1968 , ATOMIC ENERGY CLEARING HOUSE, $14(10)$, PAGES 38-39 (MARCH 4, 1968), DOCKET 50- 247

(LETTER TO DRL, JAN. 1968 ) THE LINEF DEFORMATION WAS NOTICEO DURING CONSTRUCTION. REPORT

DESCRIBES THE QUALITY-CONTROL PPOCEDURES AND TESTING OF THE LINER WELDS ICHANNELS ARE WELDED

OVER ALL LINER SEAMSI. AFTER RFPAIRING THE BULGE, LEAK TFSTS WERE AGAIN PERFORMED ON THE

WELD CHANNELS IN THE VICINITY. ALL WELD-CHANNEL FILLET WELDS IN THE SAME AREA WERE

MAGNETIC-PARTICLE INSPECTEN. THE WELD-CHANNEL SYSTEM PASSED BGTH TESTS.

*BUCKLING + *CONTAINMENT LINEF + *CONTAINMENT PENETRATION, GENERAL + EXAMINATION + FUEL HANDLING MACHINE + INDIAN POINT 2 (PWR) + QUALITY CONTROL + FEACTOR, PWR + TEST, LEAK RATE + TEST, NONDESTRUCTIVE + WELDS

$11-23806$

SHER BY OD + SHYNE JC

FINAL REPORT. ROLE OF CIFFUSION IN CRFEP AND STRESS-RUPTURE IN SOLIDS

STANFORD UNIVERSITY, MATERIALS SCIENCE DPPT., STANFURU, CALIFURNIA

$A D-657-197+$ SU-DMS-67-35+. 19 PAGES, 26 REFERENCES, DUSUST 1,1967

FINAL REPORT OF RESEARCH PROGRAM. ALSO SUMMARIZES WORK LONE BETWEEN 1961 AND G7. SUPJECTS INCLUDE (1) INFLUENCE OF GRAIN SI ZE ON CREEP BEHAVIOR, 12 ) INFLUENCE OF STACKING FAULT ENERGY ON CREEP BEHAVIOR, (3) INFLUENCE OF SECOND HARD PHASE ON MECHANICAL BEHAVIOR ICOMPOSITE 


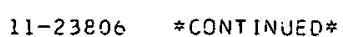

DESCRISES THE SESIGN AND TESTING DF A MIII TI-PIN LEAD CONNECTOR. FER THE SECOR INSTR.UMCNTED FUEL ASSEMPLY AND THE TESTING OE A SOLENCID IOP. THE INSTRUMENTED TUFL ASSEMBLY LIFTING FIXTURF. TESTS IN A STO!UM-VAPOR/ARGON ENVIECNMEITT AT TEMPSRATURES UP TO LOOF DEMCNSTCATED THAT THF OPERATIONAL DEK-LLMANCF DF THE COMORNENTS NOULD MEET OR EXCEEO THE ANTICIPATSE EERUIFEMENTS FOE. THE SEFOP OPERATION.

AVAILABILITY - CLEARIVGHOUSE FOP CELEPLL SCIENTIFIC AND TECHNICAL INFCRMATICN, SPFINGCIELO, VIDGINIA. b. .00 CJPQ, कU.

*INSTRUMENTATIJN, IN COFE + *TESTING + HUEL ELEMENT + EUEL HANOLING + RFACTOR, EAST + REACTOP, LMCF +

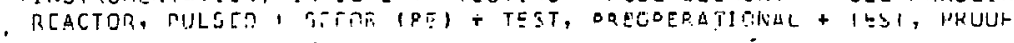

$11-23814$ YOUNGDAHL CK THREE-DIMENSIONAL STRESS CONCFNTRATION AFCUND A CYLINDRICAL HOLE IN A SEMI-INFINITE ELASTIC RODY ARGONNE NATIONAL LAB., ILL.

11 FAGES, 6 FIGURES, I TABLE, 22 DFFEPENCES, J. $\triangle P P L$. MECH., $38(4)$ FLGE 355-865, (DEC. 1CG6)

DEVELCDED A THDEE-OIMENSIJNAL SOLUTION, EXACT WITHIN CLASSICAL ELASTPOSTATICS, FOR THE STRESSES NNJ EEFGRMATIONS ARISING INA IIALT+EPACE, WITH A SEMI-INEIINITE TFANSVEFS. CYLINORICAL HLLL, SUHJELIEU IU AN ARPITPARY UNIFOPM PLANE FISLD OF STPESS DARALLER TO THF RMINOING PLANE. THE SOLUTION IS CEDUCED WITH THE AIC CF THE DAPKOVICH STRESS FUNCTICNS. NUMER ICAL CEESULTS DPE ALSO INCLUOER. THESE RESULTS EXHIEIT TLE THREE-DIMENSIONAL STRESS-SOUNDAFY LAYFG THAT EMFRGES NEAR THE FOGES DF THE HOLE IN THE ANALCGOUS PROBLEM FCP. A PLATE OF FINITE THICKNESS, AS THE RATIO CE THF PLATE THICKNESS TO THE DIAMETED GF THE HOLE GROWS BEYOND ROUNDS.

\#ELASTICITY + \#MATERIAL + \#STPESS + \#STRESS ANALYSIS + LEAK 
$11-23915$

WOODFORO DL + SMITH JP + MOTEFF J

OBSERVATION OF HEL IUM BLBELES IN AN IRRALIATED AND ANNEALED AUSTENITIC STEEL

GENERAL ELECTRIC CO., CINCINNATI, OHIO. NUCLEAR MATERIALS AND PROPULSION OPERATION

GEMF-544 +. 29 PAGES, REFERENCES, AUGUST 25,1967 , PRESENTED AT THE AMERICAN INSTITUTE OF MECHANICAL

ENGINEERS MEETING, CLEVELAND, 3HIO

POSTIFRADIATION TFANSMISSION ELECTRON MICFRSCOPY, PERF TFMEO EN A SPLIT HEAT OF A HIGH TEMP. PRECIPITATION HARDENEO ALLOY (A28E), CONTAINING 0.DC?\% AND $0.010 \%$ NATURAL BORON, SHOWS THAT ALL THREE HEAT TFEATMENTS 1760,845 , ANO 555 C) PROOUCEO VISIRLE HELIUM BUBBLES. ANALYSIS OF THE BUBBLE SIZES AND SIZE DISTP.ISUTION INDICATES THAT THE EUEBLE DIAMETER INCREASES WITH AVNEALING TEMP. AND WITH BORON CONTENT. MEASUREMENTS OF THE HELIUM VOLUMF AGREE OUITE.WELL WITH PREDICTIONS BASED ON THE 3-1.0 CONCENTRATION AND THERMAL FLUXES. RESULTS SHOWED THAT NEARLY ALL THE HELIUM IS ASSOCIATED WITH DISLDCATIONS INDICATING THAT A CUNTRIBUTING FACTOR TO RADIATION NAY BE CAUSED BY BUBBLES PINNING DISLOCATICNS IN AREAS ADJACFNT TO GRAIN BOUNDAR IES.

AVAILABILITY - CLEARINGHDUSE FOR FEDERAL SCIENTIFIC AND TECHNICAL INFORMATION, SPR INGFIELO, VIRGINIA, $\$ 3.00$ COPY, $\$ 0.65$ IICRCFICHE

BOKGN + BR.1TTLE FRACTUEE + HEAT TREATMENT + HELIUM + STEEL

$12-23916$

RIPLING EJ + CROSLEY DQ

DEVELTPYENT OF TEST PFOCEDUPES. FPACTURE TOUGHNESS OF REACTOR PRESSURE VESSEL STEELS. PERIOD COVERED. NOVEMBER I, 1066-JANUAFY 31,1067

MATERIALS R'ESEARCHLAR., INIC., RICHTON PAFK, ILL.

COO-1477-7+. 12 PAGES, MARCH 24,1967

(PART OF DRD ANC $T$ PROJECT) A CONTOURED DOUBLE-CANTILEVER BEAM SPECIMEN IS BEING USED IN A PROGRAM TO .15ASURE K-SUE-IC ANO CRACK-ARREST FRACTUPE TOUGHNESS AS $\triangle$ FUNCTION OF STRAIN RATE AND TESTING, TEMPERATURE FOR CIFFERENT ORIENTATICNS IN THE A3O2B STEEL PLATE. WHEN A MATERIAL WITH A FPACTUPE TOUGHNESS EXCEEDING THE CAPACITY OF THIS SPECIMEN IS TESTED, GROSS PLASTIC BENDING OCCIJRS $\triangle T A$ LOAD $\triangle T$ WHICH FLANE STRAIN CONDITIONS PREVAIL AT THE CRACK TIP. THE LOAD AT THE DNSET C.F PLASTIC BENOING. THEREFORE, CAN BE USEO TO CALCULATE A VALUE OF K-SUB-IC WHICH UNDERESTIMATES THE PLANE STRAIN TOUGHNESS OF THE MATERIAL.

AVAILABILITY - CLEAFINGHOUSE FOR FECFRAL SCIENTIFIC AND TECHNICAL. INFORMATION, SPRINGFIELD, VIRGINIA, $\$ 3.00$ COPY, SO.65 MICRTFICHE

\#PRESSURE VESSEL + \#STEEL + \#TESTING + FAULT

$11-23819$

$\operatorname{COX} T B$

THE RELATIONSHIF OF MITFOGEN CONTENT OF AUSTENITIC STAINLESS STEELS TO STRESS CORROSION. QUARTERLY REPORT NO. II, JANUARY 1-YARCH 31, 1967

VIRGINIA POLYTECHNIC INST., BLACKSBURG. TEPT. OF METALS ANO CERAMIC ENGINEERING

EUPAEC-1938+. 32 PATES, REFERENCES, MARCH 1967

ONE OF A SERIES OF REPORTS ON THF SAME SUBJECT. THE CBJECTIVE CF THIS RESEARCH PROJECT IS TG DETERMINE THE RELATIONSHIP BETWEEN NITROGEN CONTENT OF CERTAIN COMMERCIAL AUSTENITIC

STAINLESS STEELS AND THEIR SUSCEPTIBILITYY TO STRESS CORROSIDN. PREVIOUS WORK INDICATEO THAT. NITROGEN INCRELSES THE SUSCEPTIBILITY. OTHER WORK HAS SHOWN THAT NITROGEN IN SUFFICIENT A:AOUNTS TO PRCOUCE NITRIDES RESULTS IN MAJOR INTERNAL FRICTICN PEAKS AT TEMPERATURES BELGW $200 \mathrm{C}$.

AVAILABILITY - CLEARINGHOUSE FOR FEOERAL SCIENTIFIC AND TECHNICAL INFORMATION, SPRINGFIELO, VIRGINIA, $\$ 3.00$ COPY, \$0.65 1ICRCFICHE

\#NITROGEN + \#STEEL, STDINLESS + \#STRESS COPROSION + F AND D PROGRAM

$11-23820$

STUDY. OF THE BASE METAL INTENDED FOF RESEARCH ON THE BRITTLE FRACTURE OF LARGE WEL DMENTS. TECHNICAL REPORT NO. 2, MAY 1, 1965-APFIL 30, 1966

INSTITUT DE RECHERCHES DE LA SIDERURGIE, ST. GEPMAINE-ENLAYE (FRANCE)

EURAEC- $1669+31$ PAGES, ${ }^{\circ}$ APRIL 30,1966

RESULTS DF. STUDIES CONCERIIING SUPER ELSO NI-CR-MO STEEL REVEALED THAT THE OPTIMAL

STRESS-RELIEF TREATMENT CORRESPONDS TO A RESIDENCE TIME OF 2 HR AT 600 C. ALSO, THE USE OF

FAST HEAT CYCLES DECREASES THE CRITICAL QUENCH RATE $\triangle N D$ HAS A SMALL EFFECT ON TRANSFORMATION.

STUDIES OF MN-NO-V $\triangle M M O$ STEELS $\triangle P E$ PEPORTED ON COMPOSITION, DILATOMETRY, QUENCHING, AND

TENSILE PROPERTIES. TESTS TC DETERMINE BFITTLE FRACTURE STRENGTH ARE REPORTEO ALONG WITH

RESULTS OF STRUCTUPAL TRANSFORMATION STUDIES.

AVAILABILITY - CLEARINGHOUSE FOR FEDERAL SCIENTIFIC DND TECHNICAL INFORMATION, SPRINGFIELD, VIRGINIA, $\$ 3.00$ COPY, $\$ 0.65$ YICRCFICHE 


\section{CONTAINMFNT CATEGORY NUCLEAR I FACILITIES}

11-23820 \#CONTINUFO*

BRITTLE FRACTUPE + FABRICATION + STEEL + WELIING + WELDS

$11-23821$

HACKNEY BO + MCDANIEL CJ + TAGART SH

LOW-CYCLE FATIGUE TESTING OF PARTIAL PENETRATION WELOED REACTGR VESSEL NOZZLE CONNECTICNS. PART I. TESTING TECHN IOUES

GENERAL ELECTRIC CO., SAN JOSE, CALIF. ATOMIC POWER FOUIPMENT DEPT.

APED-4904 + 65-APE-IC +. 33 PAGES, OFIGUPSS, 2 TARLES, REFERENCES, JUNE IS65

FIRST REPORT IN A SERIES ON THE LOW-CYCLE FATIGUE TESTING OF WELDEO REACTOR-VESSEL NOZZLE CONINECTIDNS. DESCRIBES THE TFCHNIQUES EMPLDYED IN TESTING STRAIGHT-THROUGH AND SOCKET TYPES GF NOZZLE CONNECTIONS. TYDE-304 STAINLESS STEEL AND INCONFI-SOO HIUSING MATEPIALS ARE BEINIG TESTEO AT TH2LE LEVELS gF TOTAL STRESS. THE EXPERIMENTAL PRCGRAM IS EXPLAINED, AND THE TEST - EQUIPMENT AND PPFRLTION OF THE TEST FACILITY IS OESCRIBED. FINALLY, A DISCUSSION OF THE ACCURACY TO NHICH TEST VARIAPLES AFE DETERMINEO IS PRESENTED.

AVAILABILITY - CLEAPINGHOUSE FIIK FEQEFAL SCIENTIFIC AND TECHNICAL INEORMATION, SPRINGFIELO, VIRGINIA, $\$ 3.00$ COPY, \$O.C. MICRCE ICHE

*NOZZLE + \#PRESSURE VESSEL + \#TESTING + \#WELDS + EXAMINATION + FAILURF, FATIGUE + WELDING

$11-23823$

LAUTZENHE ISER CE

EVALUATION OF THE SERVICEARILITY OF THE ELK RIVER REACTOR PRESSURE VESSEL. QUARTERLY REPORT, DCTOEER I, $1065-D E C E M B E R \quad 31,196.5$

SOUTHWEST RESCARCH INST., SAN ANTONIG, IEX.

SWRI-1228-4-15+. 18 DAGES. FIGURES, JAN. 20, 1966

THE OBJECT DF THIS TECHNICAL PR.OGRAN IS TO EVALUATE THE SERVICEABILITY OF THE ELK RIVER REACTOR PKCSSURE VESSEL BY DETEPMINING THE EFFECT DF FABRICATION PROCEDURES, IR.RADIATION, DISSIMILAR NELD NETALLURGY AND GECMETPY CN THE FATIGUE LIFE AND NIL OUCTILITY TPANSITION TEMPERATURE OF THE COMPLETED VESSEL. IN ADOITION, A PHASE OF THIS INVESTIGATION IS DIRECTED TOWARD THE DEVELCPMENT DF REMOTE NONDESTRUCTIVE TESTING EQUIPMENT AND TECHNIQUES FOR THE DETECTION $\triangle$ VD MONITOF.ING OF GROSS DEFECTS IN CRITICAL AREAS RF THE VESSEL

AVAILABILITY - CLEAPINGHOUSE FOR FECERAL SCIENTIFIC AND TECHNICAL INFORMATION, SPRINGFIELD, VIRGINIA, $\$ 3.00$ COPY, \$0.65 MICFCIFICHE

\#PRESSURE VESSEL + CONTAINMENT ANALYSIS + ELK RIVER (BWR) + FABRICATION! + RADIATION OAMAGE + REACTOR, BWR + WELDS

$11-23924$

LAUTZFVHE ISER CE + NCFPIS EP

EVALUATION OF THE SEFVIGEABILJTY gF THE FLK. PIVEF REACTOR FRESSURE VESSEL. QUAQIERLY REPORT, JULY I, $10 \angle 6-S E P T \subseteq M B E R \quad 32,1 \subseteq 6 E$

SOUTHWEST RESEARCH INST., SAN $\triangle N T O N I O$, TEX.

SWRI-1228P4-25+. 3E PAGES, FIGURES, TABLES, OCTGRER 25, 1966

THF OBJECT DE THIS TECHNISAL PRQgRAR: IS TO EVALUATE THE SERVIGEAEILITY OF THE ELK RIVFR REACTOR RRESSURC VESSEL BY DFTEOMINING IHE EFFECT OF FABRICATION PROCECURES, IPPADIATION, DISSIMILAP-WELD METALLURGY, ANO GECNETPY CN THE FATIGUE, LIFE AND NIL DUCTILITY TRANSITION TEMPERATUPS NF THE COMRLETED VESSEL. IN LODITION, A HHASE IJ IHIS INVESTIGATION IS DIRECTER TOWARD THE DEVELOPMENT OF REMOTF NCNDESTRIJCTIVE TESTING EQUIPMENT AND TECHNIQUES FOR THE DETFETTIN ANO MONITORING OF CROSS DEFECTS IN CRITICAL AREAS UH THE VESSEL.

AVAILABILIIY - CLEARINGHQUSE FOR FELEFAL SCIENTIEIC AND TECHNICAL INFORMATION, SPRINGFIELD, VIPGINIA, $\$ 3.00$ COPY, \$0.6E भICFOFICHE

\#PRESSURE VESSEL + CUNTLINMENT ANALYSISA+ ELK RIVEP (BWR) + FABRICATION + RADIATION DAMAGE + REACTOR, BWR + WELDS

$11-23425$

SCHWANBECK CA

EFFECT OE NUCLEAR RAQIATION ON MATERIALS LT CRYMGENIC TEMPERATURES. FINAL REPORT

L.DCKHFFC-GEMRGIA CO, MAP IETTA

$N-66-24695+N A S A-C R-E 4821+L \Delta C-E P-9434+.303$ PAGES, FIGURES, TAELES, REFERENCES, JANUARY I SE5

STUDIED OF THE EFFECT OE FAST NEUTPCN AND CRYOGFNIC ENVIRONMENT DN THE STRUICTIIRAL MEMEERS OF A LIQUID-HYDROGEN NUCLEAF: YOLKET'. SINCE THE NEUTPON IRRADIATION EFFECTS ARE SELF-HEALING THFCUGH SPONTANECUS ANNEALING EVEN AT LOW TEMPERATURES, TESTS TC PROVIDE THE DESIP.ED INFORMATIO:N CONCERNING THE COMEINER EFFECT MUST BE CONDUCTEO WITH THE SPECIMENS HELD AT THE TFMPFRATLRE 2F INTEREST DUP. ING THE ENTIPF IRPADIATION AND TESTING PERIOD. THE PF. INCIPAL OBJECTIVE OF THE PR IGGAM WAS TO DFTFRMINE WHICH OF THE SEVERAL ALLOYS WERE LEAST SUSCEPTIBLE TQ DETEPIORATICN OF MECLANICAL PGCPEPTIES IN A COMRINEQ NUCLEAD-CRYOGENIC ENVIRCNMENT. SECONDARY OBJECTIVE WAS TO INVESTIGATE THE POSSIBILITY OF FORMULATING THFORETIR.AL MTRFLS OF

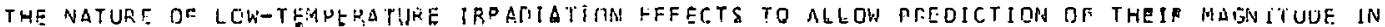
OTHER MATER IALS. 


\title{
CONTAINMENT CATEGORY I l
}

$11-23825^{\circ} *$ CONTTINUED*

AVAILABILITY - CLEARIINGHOUSE FUR FEOERAL SCIENTIFIC ANO TECHVICAL INFORMATION, SPRINGFIELD; VIREINIA, $\$ 3.00$ COPY, \$0.65 YICRQFICHF

CRYDGENICS + MATERIAL + NUCLEAR ROCKET + PADIATICN DAMAGE + RÄDIATION EFFECT

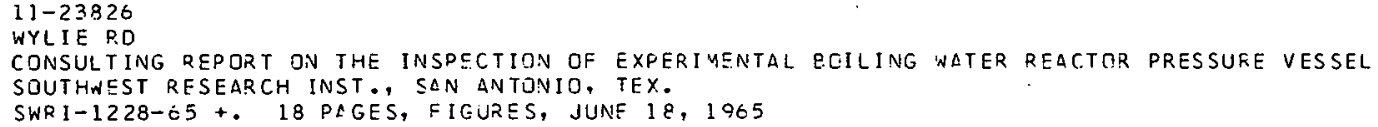

$11-23827$

COC.HRUN LF

FRACTURE MECHANICS EVALUATION OF QEACTOR, VESSEL STEELS. TUARTERLY FROGRESS REPORT FOR THE PERIOD ENDING

MARCH 31,1967

WESTINGHOUSE ELEC.TRIC COPP., PITTSBURGH, FA. ATOMIC POWER DIV.

WCAP-3677-3. + EURAEC-18Z9+. 34 PAGES, FIGUPES, TABLES, APRIL IOGT.

\begin{abstract}
DESCRIBES AN EXPERIMENTAL PROGRAM DIPECTED TONARDS FURTHER DEVELOPMENT AND EVALUATION OF A FRACTURE MECHANICS APPROACH TO THE PRCBLEM QF BRITTLE FRACTURE OF REACTOR-VESSEL MATERIALS, EASED UPON THE USE OF MOOIFIED WECGE OPENING LOADING (WOL) SPECIMENS. A GROUP OF REACTOR-VESSEL STEELS WILL BE TESTED TO INVESTIGATE THE APPLICATION OF THE FRACTUPE MECHANICS

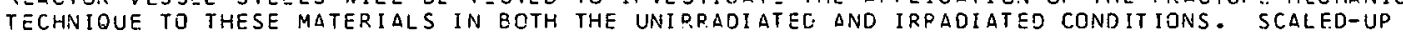
SPECIMENS. WILL BE USED TO OBTAIN PREIRRADIATION DATA. IPRADIATION EFFECTS WILL EE.DETERMINED DV SMALL SPECIMENS. GIVES RESULTS OF CURRENT TESTS AND CALCULATIONS.
\end{abstract}

AVAILABILITY - CLEAR INGHOUSE FOR FI.DERAL SCIENTIFIC AND TECHNICAL INFORMATION, SPRINGFIELD, VIRGINIA, $\$ 3.00$ COPY, \$0.65 YICROFICHE

\#PRESSURE VESSEL + \#RDDIATION DAMAGE + \#STEEL + \#TESTING + RADIATION EFFECT

$11-23826$

WUNDERL ICH JW + BAKER NE

EXPOSURE OF HTGR CANDIDATE CORE PLATE DND THERMAL IN!SULATION MATEPIALS TO IMPURE HEL IUM AT IG5O DEG F TO 1850 DEG F FOR 3000 HGURS

GENERAL OYNAMICS CORP. SAN DIEGO, CALIF. GENERAL ATOMIC DIVISION

GAMD-7377 +. 33 PAGES, DECEMBER 29,1966

THE FOLLOWING MATERIALS WERE EXPOSEC. IN HE CONTAINING 3000 PPM CO AND H2 AT 1650 AND 1850 F RENE 41, INCONEL X, HASIELLOY X, $3 C 4$ STAINLESS STEEL, 130 STAINLESS, $\triangle N O$ INCOLOY ROO.

CHANGES IN MECHANICAL PRUPERIIES AND MICROSTRUCTURT.S WERE EVALUATEO AFTER 5ON- ANR 1.50O-HR EXPOSURES OF THE ABOVE MATERIALS, AND AFTER 3000 HR FOR 430 STAINLESS AND HASTELLCY $X$. THE RESULTS SHON THAT 430 STAINLESS STFEL IS THE BEST CHOICE AS METALLIC THERMAL INSULATION MATERIAL IN AN HTGR, ALTHOUGH HASTELLOY $X$ IS LEAST AFFECTED EY THE ENVIRONMENT.

AVAILABILITY - CLEARINGHOUSE FOR FEDERAL SCIENTIFIC AND TECHNICAL INFORMATION, SPRINGFIELD, VIRGINIA \$3. OO COPY, \$0.65 HICROFICHE

*TESTING + CORE COMPONENTS + DESIGN STUOY + INCONEL + MATERIAL + STESL, STAINLESS + TEST, PRDOF + THERMAL INSULAT ION

$11-23844$

THE PRESTRESSED CONCRETE VESSELS. THE G2-G3 REACTORS GPERATIONAL TESTS

ORNL-YR-1284 +. 15 PAGES, $\triangle P R I L ~ 19 E 6$

THE CONCRETE ITSELF HAS SHOWN NO VISIBLE SIGN OF WEAR AND TEAP WORTHY OF NOTE. NORMAL SURVEILLANCE IS CARRIED OUT, AND THE PEACTOR AS A WHOLE HAS UNCERGONE NO CHANGE. THE FORCE-MEASUR ING SUPPORTING BLOCKS MONITORING THE TENSION IN THE CABLES, INSTALLED IN I962 AND 1963, ARE ALSO KEPT UNDER CONSTANT SUF.VEILLANCE. T.HE CABLES HAVE BEHAVED MOST.

SATISFACTOR ILY. ONLY A FEW OF THE GIRDLING CABLES HAVE RECENTLY SHOWN ARNORMAL BEHAVIOR. THESE SUFFERED SOMF CORROSION WHERE A SECOND LAYSR OF CONCRETE WAS APPLIED TO THE VESSEL AFTER THE CABLES WERE TENSIONED.

AVAILABILITY - CLEARINGHOUSE FOR FEOEPAL SCIENTIFIC AND TECHNICAL INFORHATION, SPRINGFIELO, VIRGINIA \$3. OO COPY, \$0.65 MICROFICHE 


\section{CONTAINMENT CATEGORY NUCLEAR FACILITIFS}

$11-23844$ \#CONTIVUED*

*CONCRETE, PRESTRESSED + FPRESSURE VESSEL + CONTAINMENT, GENERAL + FRANCE + CDERATING EXPERIFNCE + REACTOR, GCR + RSACTOR, GRAPHITE MODERATED + STEFL

$11-23845$

ZIENKIEWICZ OC + WATSON M

SOME CFEEP EFFECTS IN STRESS ANALYSIS WITH PARTICLLAH REFERENCE TO CONCRETE PRESSUDE VESSELS UNIVERSITY OF WALES, SWANSEA, GREAT REITAIN

7 PAGES, 6 FIGURES, S REFERENCSS, NUCLEAR ENGINEERING AND OESIGN, 4(4), PAGES 406-412 (NOVEMBER. ISES)

DESCRIPTION OF L GENEPAL DROCESS OF STFESS ANALYSIS FOR MATERIALS EF LINEAR VISCL-ELASTIC NATURE USING AN INTFGPAL FOPMULATION GF THE VISCO-ELASTIC CFOPERTISS. THE FULL SOLUTION IS ACC CMOL ISHED IN A STEP-BY-STEP MANNED, USING TIME [NTEFVALS CUJPING WHICH THE STRESSES $\triangle D$ TIS TAKEN TO RFYAIN CONSTANT. TIIE CHANGE OF THE CREEP STRAIN TAKING DLACE OURING SUCH A TIME INTESVAL LEADS TO AN INCGMPATIPILITY WHICH IS COORECTSO BY AN ELLSTIC SOLUTIÜN $A T$ THE END OF EACH INTERVAL. THE LLASTIC SOLUTICN AT ANY STAGE IS ACCCMPLISHEO BY THE USE CF THE

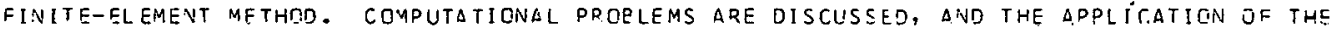
HETHOD TO THE VTSCA-ELASTIC ANALYSIS OF CONCRETE PRESSUP.E VESSELS IS OUTLINED.

CLNCRETE, PREST2ESSED + ELASTICITY + PRESSURE VESSFL + STRESS ANALYSIS

$11-238 / 6$

HARROP J + ASDUL-KARIM RM

STRESSES $\triangle N D$ DEFLECTICNS IN CIRCULAR PLATES WITH SOUARE PITCH PERFGRMATIONS

UNIVEPSITY OF LEEDS, 2 , ENGLAND

- PAGES, 3 EIGUF, 5 , 5 TABLES, \& REFERENCES, NUCLEAT ENGINEEPING AND DESIGN, G(5), PACES $421-439$ (CESE4QER $(067)$

DISCUSSES A METHOD FOR CALCULATING THE DEFLECTICNS AND STRESSES DEVELQPED IN CIRCULAG PLATES WITH SUUARE-DITCH PERFORATIONS WHEN THE PLATES ARE SUBJECTEC TO UNIFORM LATERAL PRFSSURE, ZASEC UDON THE ELENENTAL DISK CONCEPT FOF THE DETERMINATION OF THE EFFFCTIVE ELASTIC MDOULUS O= THE DSRFORATEC ZONF. THS PROPCSED METHDD IS USED TD GIVE OESULTS FOR COMOAFISON WITH EXPER IMENTAL RESULTS DRTAIVED DY OTHEF INVESTIGATDRS ON THOES DLATE MCDELS. THE METHOO GIVES A 5\% OVERESTIMATE OF DEFLECTIONS, POSSIRLY CUE TO NEGLECT OF STIFFENING EFFECT CF THE DVERHANGING PIM PORTIDN OF THE DLATE OUTSIDE THE SUPPORT CIRCLE.

\#DEFORMATION + \#STRESS + COMPARISON, THEGRY ANO EXPERIENCE + MATHEMATICAL TREATMENT + PFESSURE, INTERNAL

$11-23847$

POLLFT H

FOPMATIOV DF VERY HIGH STPENGTH CONCRETES (GFEATER THAN 1000 KG/CM SOUARED)

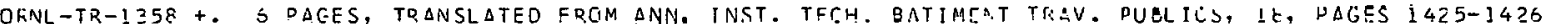
$(1065)$

THREE METHOOS SUGGESTEO BY INTERNATI ONAL DRESTRESSED CONCEFTE EEDERATICIN TGR PROCUCINE

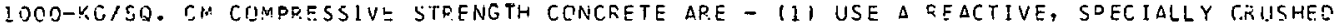
AGGREGATE, (2) USE THF REACTION BETWEEN SILICA (PIOSSIBLY FLYASH) AND LIME, (3) TRIAXIAL SEINEJRCEMENT. THE ICAM LAR AT LILLE HAS TPIED (1) CCNTINUED WORK ON PFSIN EONCINC, (2) FORMATION DF A REACTIVE AGCREGATE USINE NATURAL CEMENT (UNSUCCESSFIJL), (3) USE CF $5 P C X Y$ FESIN (ARALDITE) AS A BINCER (UNSATISFACTORY), (4) ARTIFICIAL $\triangle G G R E G A T E S$. THIS LAST HETHCD GAVF THE BEST RESULTS AND IS DISCUSSED IN THIS REPQRT.

AVAILABILITY - JOUIV CFEFAF LIBRARY, 35 WEST ?3RD. ST. THISACO; ILLIMOIS

*CCNCRETE + \#CONCZETE. FRESTEESSED + F $\triangle N O$ D PRCGRAM

$11-238.55$

JOHNS RH + KAIJPMAN $A$

IN CATEGORY 4

ATLLIC CYLINCRICOL PRESSUPE VESSELS

LEWIS RESEARCH, CENTER, CLEVELAND, OHIO

6 PAGES, 9 FIGURES, 2 TABLES, 8 REEEPENIEES, J. SPACFCRAFT ROCKETS 4(7), DAGE 87?-E77, (JULY I967)

THE INFLUSNCE RE MATER.IAL PROPTRTITE R.F A WEAPREU HRESSURE VESSEL IS DETEOMINEC THECRETICALLY. OVERCEYING THE DIFFERENCE IN YIELD STEAINS OF WRAPDING AND RASE MATERIALS GY WINCING PRETENSION AND PLASTIC ELOW DURING PRESSURIZATICN IS CONSICEFFD. RESILUAL STFESSTS IN THE

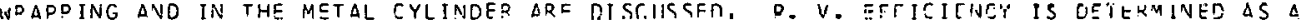
PUPST IO'N OF ALLUWASLE CCMPRESSIVE STRESS IN THE METAL. BUCKLING TESTS INDICATE THAT BUCKLING OF THE SHFLL CUE TO DFETENSICN IN THE WINLING PROBABLY WILL NOT BE A PROPLEM IN SDACE APPLICATIONS. FAILURE OF THE METAL SHELL OFTEN IS DUE TO TENSILE INSTABILITY AT HIGH PRESSURES IN THE 1.1 STRFSS FIELD IMPCSED. A DEFORMATIUN ITERRY ANALYSIS AGREEC WELL WITH THE RESULTS TF 10 OF 20 TESTS GF $5.6-I N$. DIAM AL CYLINGERS WRAPFED WITH GLASS INIPDEGNATFR WITH EPOXY RESIN. THE WRAPPED VESSELS WEFE UP TD $50 \%$ MORE EFFICIENT. FACTQRS C.F SAFETY (BURST PRESSURE) MAY BE $40 \%$ HIGHER THAN THOSE BASED CN STRESS IN THE METAL.

\#MODEL TESTING + \#PRESSURE VESSEL + SPACECRAFT + STRESS ANALYSIS 
CCNTAINMENT OF NUCLEAR FACILITIES

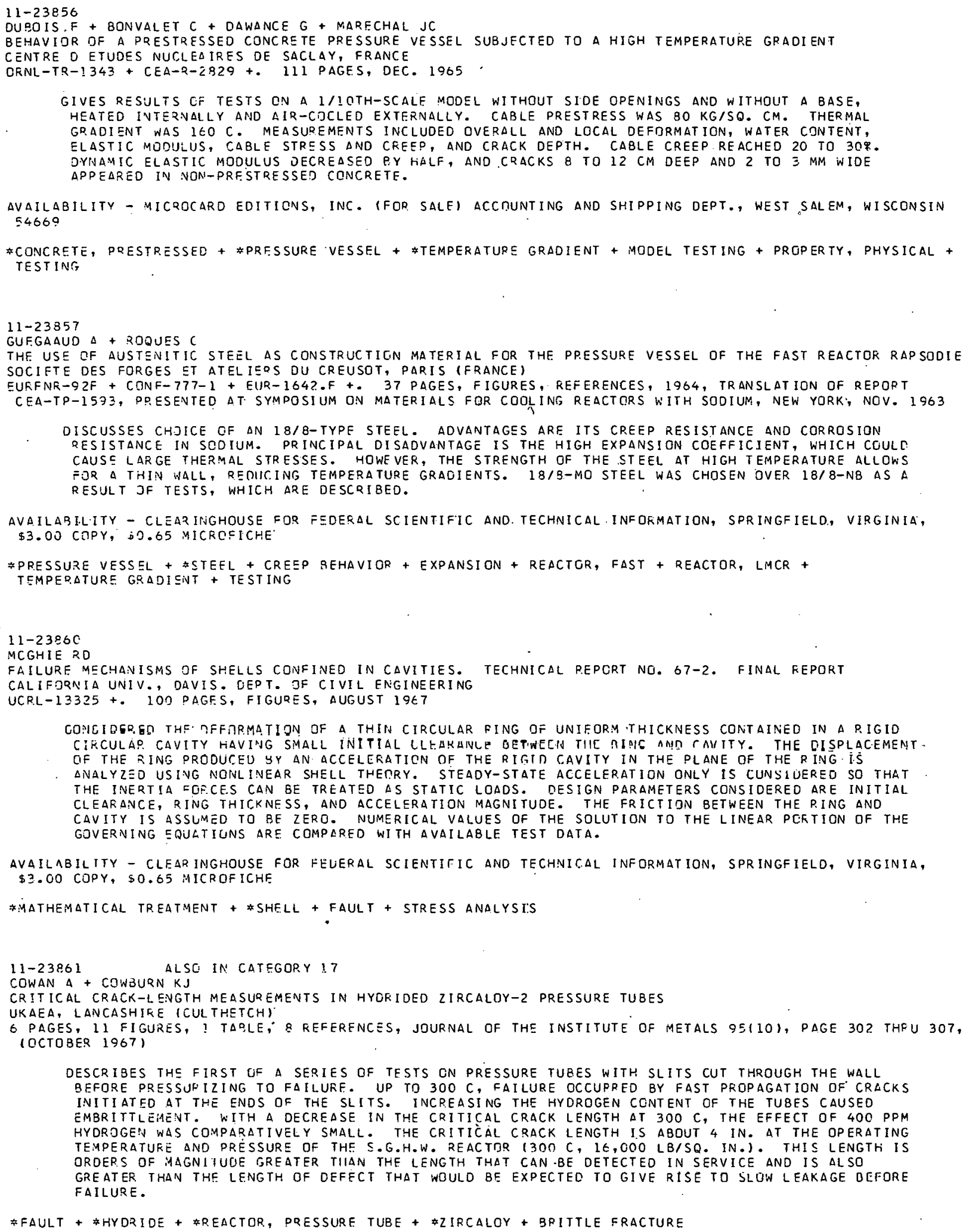


CONTAINMENT OF NUCLEAR 1 FACILITIES

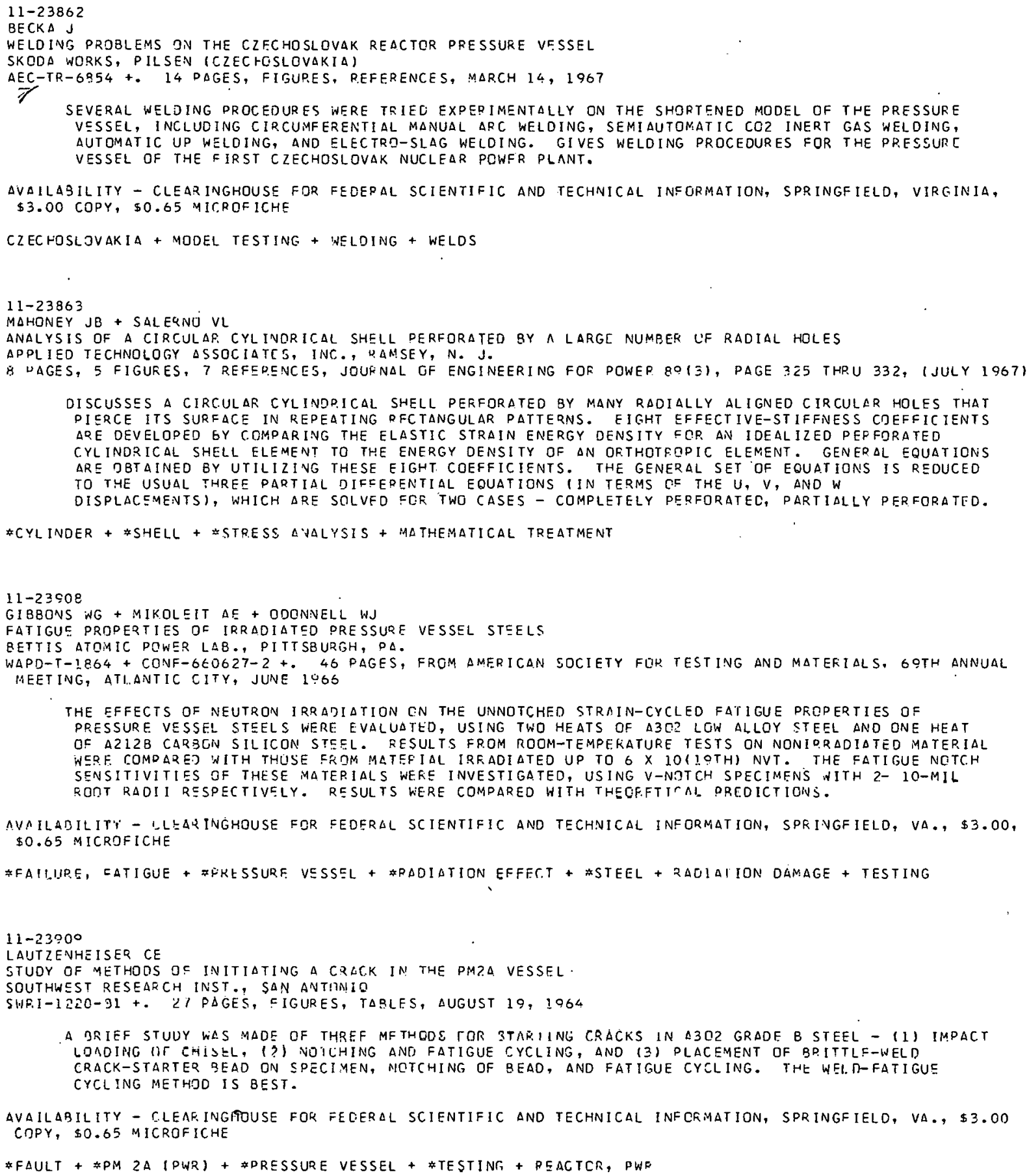


$11-23910$ *ONT INUED*

DISCUSSES INTERNAL CHANGES, DISTRIEUTION OF STRESSES. THE DIFFERENCE BETWEEN THE

TIME-TO-RUPTURE CURVES FOR UNNOTCHED AND NOTCHED BAES CAN PRIMARILY BE EXPLAINED BY THE

INTERACTIDN OF THREE EFFECTS - RELAXATION OF THE STRESS PEAK WITH TIME, FORMATION AND

PROPAGATION OF FISSURES, AND INHIBITION OF PLASTIC DEFGRMATION OWING TO THE FORMATION OF A

TRIDIMENS IONAL STATE OF STRESS.

AVAILABILITY - CLEARINGHOUSE FOR FEDERAL SCIENTIFIC AND TECHNICAL INFCRMATION, SPRINGFIELD, VA., \$3. OO COPY, \$0.65 MICROFICHE

*BRITTLE FRACTURE + \#STEEL + *TESTING + THERMAL MECHANICAL EFFECT

$11-23912$

PRITCHARD P.S + WILDIN MW

TEMPERATURE AND STRESS DISTRIBUTIONS PRDDUCED IN LONG CIRCULAR CYLINDERS COOLED BY EMISSION OF THERMAL RAOIATION. FINAL REPORT

NEW MEXICO UNIVERSITY, ALBUQUERQUE

SC-DC-66-2366+ME-19+. 116 PAGES, FIGURES, REFERENCES, NOVEMBER 1965

PART I CONTAINS EXPERIMENTAL RFSULTS, DESCRIPTION OF EQUIPMENT, AND TECHNIQUES. FOUND

R.ELATIVELY GOOD AGREEMENT BETWEEN THEORY AND EXPERIMENT. PAPT II GIVES A STATEMENT DF THE

PROBLFM, OUTLINES THE LDGIC ANC EVIDENCE LEADING TO AN ANSWER, AND gives the CONCLUSIONS.

AVAILABILITY - CLEARINGHOUSE FOR FEOERAL SCIENTIFIC AND TECHNICAL INFDRMATION, SPRINGFIELD, VA., S3. OO COPY, \$0.65 MICROFICHE

*CYLINDER + \#HEAT TRANSFER, DADIANT + *STRESS + *THERMAL MECHANICAL EFFECT +

COMPARISON, 'THEORY AND FXPERIENCE

$11-23913$

FRASER MC

POSTIRRADIATION EVALUATION OF ZIRCALOY-2 PRTR PRESSURE TUBES. PART III

GENERAL ELECTRIC CO., RICHLAND, WASHINGTON

HW-84540 +. 15 PAGES, REFERENCES, DECEMEER 15,1964

AN ADOITIONAL THREE ZIRCALOY- 2 PRESSURE TUEES WER. DISCHARGED FROM THE PRTR REACTOR, AND SPEC IMENS FROM TWO OF THESE AND FP.OM OTHER TUBES WERE BURST TESTEO. IRRADIATED AND UNIPRADIATED SPFCIMENS OF PRTR ZIRCALOY-2 PRESSURE TUBES WFRE USED FOR RDGM-TEMPERATURE CRACK-PROPAGATION TESTS. THE RESULTS OF VACUUM-FUSION ANALYSIS FOR HYDROGEN CONTENT OF SPECIMENS TAKEN FROM ALL OF THE DISCHARGEO PRTR ZIRCALOY-2 PRESSURE TUBES ARE GIVEN.

AVAILABILITY - CLEARINGHOUSE FOP FECERAL SCIENTIFIC ANO TECHNICAL INFORMATION, SPRINGFIELD, VA., \$3. OO COPY, $\$ 0.65$ MICROFICHE

*EXAMINATION + \#RACTOR, PRESSURE TUBE + *TEST, DESTRUCTIVE + FAULT + HYDRIDE + IRRADIATION TESTINE + TRTR (TR) + REACTOR, TEST + ZIRCALOY

$11-23926$

COTTRELL WB

ALSO IN GATEGRRIES 7 ANO 1

DRNL NUCLEAR SAFETY RESEARCH AND DEVELOPMENT PROGRAM BIMONTHLY REPORT FOR NOVEMBEF-UECEMEER IJ67

OAK RIDGE NATIONAL LAB., TENN.

GRNI.TM-2095 +. 137 PAGES, FIGURES, TABLES, REFERENCES, FEB. 1968

INCLUDED IN THIS PROGRESS REPDRT IS WGRK ON VAHIOUS CHEMICAL REACTIONS, AS WELL AS THE RELEASE, CHARACTERIZATION, AND TRANSPCRT DF FISSION PRCDUCTS. IN CONTAINMENT SYSTEMS UNDER VARIOUS AC.CIDENT CONDITIONS $\triangle N O$ ON PROSLEMS ASSOCIATED WITH THE REMOVAL OF THESE FISSION PRODUCTS FROM GAS STREAMS. ALTHOUGH MOST OF THE WDRK HAS BEEN AND CONT INUES TO BE IN GENERAL SUPPORT OF WATER POWER-REACTOR TECHNOLOGY, INCLUDING SOME IN OIRECT SUPPORT OF THE LOFT ANC CSE PROGRAIAS, SEVERAL PROJECTS WERE STARTED THE FIRST OF THE CALENDER YEAR IN SUPPORT DE THE CSE PROGRAIIS, SEVERAL PROJECTS WERE STARTED THE FIPST OF THE CALENDER YEAR IN SUPPORT DE THE
HIGH-TEMPERATURE GAS-COOLED FEACTOR. (HTGR) PGOGRAM. THESE PROJECTS INCLUDE SOTH IN-PILE AND DUT-PILE STUDIES OF REACTION RATES AND FISSION-PRODUCT FELEASE AND TRANSPORT PHENOMENA RELEVANT TO POTENTIAL HTGR ACCIDENT SITUATIONS. OTHER MAJOR PROJECTS INCLURE FUEL-TRANSPORT SAFETY INVESTIGATIONS, A SERIFS OF DISCUSSION PAPERIS ON VARIGUS ASPECTS OF WATEF-PEACTOR TECHNOLOGY, AND THE STUUISS ON PRT SSUPE-VESSEL TECHNOLOGY. EXPERIMENTAL WORK RELATIVE TO PRESSURE-VESSEL TECHNOLOGY. EXPERIMENTAL WORK RELATIVE TU PRESSURL -VESSEL TFCHNOLOGY INCLUOES INVESTIGATIONS OF THE ATTACHMENT OF NOZZLES TO SHELLS AND THE VARIABILITY OF IMPACT OATA ON LOW-ALLOY STEELS.

AVAILABILITY - CLEARINGHOUSE FOR FEDERAL SCIENTIFIC AND TECHNICAL INFORMATION, SPRINGFIELD, VIRGINIA $22151, \$ 3.00$ COPY, \$0.65 MICROFICHE

*CHEIAICAL KINETICS + \#CONTAINMENT, GENERAL + \#CSE + \#FISSION PRODUCT RETENTION +

\#FISSION PRODUCT TRANSPORT + \#FISSION PRODUCT, $\triangle I R B O R N E+$ \#IMPACT PROPERTY + \#IN PILE EXPERIMENT + \#LOFT (S-RR) + \#NOZZLE + \#OUT OF PILE LOOPS ANJ EXPERIMLNTS + \#REACTOR, HTGR + \#STEEL +

CONT $I N M E N T$ SPRAY + FISSION PRODUCT PELFASF, GENEPAL + PRESSURE VESSEL

$11-23930$

LUKS VH 


\section{CONTAINMENT OFEGOPY NEA T T TACILITIES}

$11-23930$ *CONTINUEC*

PRESTRESSED CONCRETE REACTCR PRESSURE VESSELS

KERNFORSCHUNGSANLAGE, JULICH, GERMANY

6 PAGES, 5 FIGURES, I TABLE, 19 REFERENCES, $\triangle$ TOMWIRTSCHAFT 111111 , FAGE 535 THRU 540 , (NGVEMRER 1CG6) IN GERMAN

GENERAL DISCUSSION DF PCQVS BUILT, REING BUILT, ANO PLANNED, WIITH EMPHAS IS EN THE GERMAN THORIUM HIGH-TEMP. REACTOR (THTR). DISCUSSES GF OMETFY, THERMAL INSULATION, COOLING,

COATINGS, CONSTRUCTIDN PROCEDURES. DESCFIEES EURATCM F ANE. D PRDGRAM FDQ DCRV LEVELCDMENT, INCLUDING WORK BY KRUDP ON LAMINAE VESSFIS, AND THE SIEMENS FIFM DEVELGPMENT CF A 100 ATM., $3 C O$ C VESSEL MODLL.

\#CONCRETE, PRESTRESSED + \#PRESSURE VESSEL + GERMANY + LAYER + REACTGO, GCR + REACTOR, PERBLE BEO

$11-24154 \quad \Delta L S O$ IN CATSGORICS 17 ANOO

SENA SHUTDGAN ATTR. IBUTLO TO CORE EAEPEL FOLT FAILUPE

1 PAGE, NUCLEAR INOUSTRY $15(2)$, DLGE 5\&, (TEE. 1EEC)

WESTINGHOUSE STATEMENT READS IN PAFT AS FOLLOWS - AS PART OF THL IIVVESTIGGTION OF A STUCK CONTPOL P.ID, CAUSED BY INTELFERENCE IN THE CORE, INSPECTION PEVLALED BROKEV PIECES OF CORE-BARFEI. BOLTS IN TWO OF THE FOUR STEAM GENEFATJRS. THESE EOLTS JOIN UPPSF LAO LOWER CGRS BARREL. THEIF USE IS PECULIAE TO THE INTFRMAL DESIGN OF SENA AND EAPLIEP ELANTS. REPAIF TO INTERVALS NILL BE CONCURRENT WITH FEPAIR FCG TURBINE AND GENERATCR. CEEACTOP WAS SHUT DOWN JAN. 30,1968

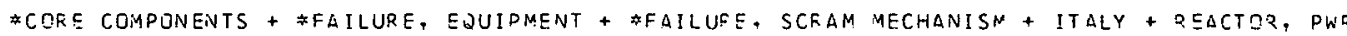

11-24188 ALSE IN CATEGORY 17

ELK RIVER SHITDOWN BFCAUSE JF CJOLANT LEAK

RUPAL COSPERATIVE POWER ASSOCI ITION

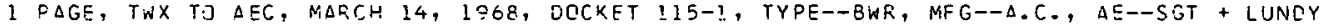

AT 1700 HOURS TIN MARCH 13 , DEFEESSURIZATICN OF THE REACTGR WAS BEGUN, IN CCMPLIANCE WITH TECHNICAL-SPECIFICATION SER.TION 4. C (REACTOR-VESSEL LEAKAGF-MINITIRING SPECIFICLTIUN). A DETAILEO REPJRT ALONG WITH A PHOGQAM FOR REPRESSURIZING ANO FUF.THER TESTING WILL BE SUBMITTED.

\#LEAK + \#PRESSURE VESSEL + ELK RIVEP. (BWF) + FAILURE, PRESSURE VESSEL + INCICENT, EQUIFMENT + MAIN COOLIVG SYSTEM + LPERATING EXFERIENCE SUMMARY + RFACTCR, BWP

$11-24322$

HACKNEY $30+$ MCOANIFL CJ

LOW-CYCLE FATIGUE TESTING OF DARTIAL OENETFATION WELOED REACTOR. VESSEL NDZZLE CCNNECTICNS. PAOT II FABR ICAT ION ASPECTS

GENEPAL ELECTRIC CO., SAN JOSFF. CALIF. ATCMIE HÜEE EQUIPMENT DEOT.

APED-49SD +. ZS PAGES, FIGUQES, TAELES, JULY ICGE

SECIND REPORT IN A SEDIES ON LOW-RYGLE GATIGUE TESIING OF PARTIAL DENETEATIEN WELCFR REACTOP-VESSEL NCZZLE CONNCCTIONS. DEALS WITH FABRICATION $\triangle S P E C T S$ IOF THE PROGRAN. PART I CEF

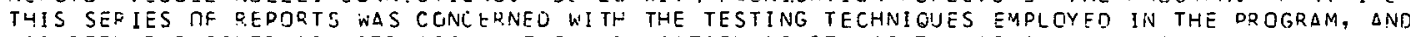
HAS BEEN PUBLISHED AS APSD-4CO4. THE ICQRICATION. OF STRAIGHT-THDOUGH AND SOCKET NOZZLE CONNERTIONS IS DISCUSSED INSCFAT AS SEQUENCE AND AREAS OF DIFFICULTY IN FABRICATION ARE CDNCERVED.

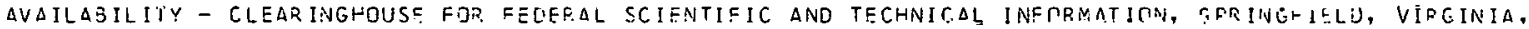
$\$ \equiv .00$ COPY, BC. .5 MICP.CFICHF

\#NOZZLE + \#ORESSURE VESSEL + \#NELDS + FARSICATION + FAILURE, FATIGUE + WEI. PING 
DECONTAMINATION GF SURFACES AND DBJECTS CCNTAMINATED WITH RADIOACTIVE MATERIALS. IV. EXPER IMEATAL PART. USE TF INDIGENDUS LAUNDERING AGENTS FOR THE DECONTAMINATION OF TEXTILE MATERIALS

6 PAGES, 5 FIGURES, 4 REFERENCES, REV. CHIM. (BUCHAREST), 17, PAGES 697-702 (NOV. 1966) IN RUMANIAN

TO PROTECT LATER USERS, CONTAMINATING FADIGACTIVE MATERIALS MUST BE REMDVED FROM SPECIAL PRDTECTIVE EQUIPMENT OR. ORDINARY CLCTHING QY WASHING THEM IN SPECIAL LAUNDERING SOLUTIONS. TESTS, ITH COTTOA SPECIMENS SOAKED IN AQUEOUS SOLUTIONS CONTAINING I-131, BA-131, P-32, CE-141, AND FE-59 REVEALEO THAT BEST RESULTS WEFE OBTAINEO BY WASHING THEM WITH A SOLUTION CONTAINIVG 0.2\% GF A DETERGENT AND $0.3 \Psi$ GF A COMPLEXING AGENT, SUCH AS SODIUM HEXAMET $\triangle P H J S P H A T E$ OF SODIUM FOTA. THFEE WASHING AND RINSING CYCLES OF 5-MIN. DURATION EACH WER SEST. THE DETERGENTS DERO-40, PENETROL, $\triangle N D$ ALBA SUPER, GF RUMANIAN MANUFACTURE, WERE USED IN THE TFSTS, WHICH WEPE CARRIED OUT BY DETERMINING THE COUNT RATE AT VARIOUS STAGES OF THE DECONTAMINATION PROCESS.

* Decontamination + radiation ppotection, chemical

12-20091 ALSG IN CATEGERY I8

IJLTIHATE STRENGTH CRITERIA TC EIVSURE. NO LOSS OF FUNCTION OF PIFING AND VESSELS UNDER EARTHQUAKE LOADING PACIFIC GAS AND ELECTPIC CC.

WCAP-5890 +. 47 PAGSS, 17 FIGURES, 2 TABLES, 9 REFERENCES, JUNE 12, 1967, AMENDMENT 1 TO LICENSE APPL ICATION (FIRST SUPPLEMENT TO DIABLO CANYON PRELIMINARY SAFETY ANALYSIS REPOFT), JULY IO, ISG7, DOCKET 50-?75, TYDE- $P$ WR, MFG.--WEST, $A E--P G+E$

WEST INGHOUSE REPURT DISCUSSES ANO FOPMULATES DESIGN CRITERIA AND COVSRS ANALYTICAL PROCEDURES IN ANALYSIS JF PIPING AND CONTAINERS.

AVAILABILITY - USAEC PUBLIC DOCUMENT ROOM, WASHINGTON, D. C.

\#EARTHZUAKL ENGINEERING + \#PIPING + ANALYTICAL MODEL + CONTAINMENT ANALYSIS + DESIGN CRITERIA + MATHEMATICAL TR.EATMENT

12-21245 ALSO IN CATEGORIES OA AND 7

REPORT UF WTRK IN THE 4TH QUARTER OF 1966

COMMISSAPIAL A L-ENERGIE ATOMIOUE, CAD $\triangle R A C H E$, FRANCE

EURFNR-267 +. 99 PAGES, 1966

THIS REPORT IS TNE OF A SERIES CF REPORTS ON WORK PERFOFMED UNDER THE UNITED STATES-EURATOM

FAST RECCTOR EXCHANGE PROGRAM. TOPICS COVERED ARE - CRITICALITY STUDIES. METALLURGY,

F. $D$ IATION EFFECTS, RADIATION SHIELDING AND PROTECTION, REACTOR CONTROL, REACTOR ENGINEERING,

REACTOR FUELS, AND REACTOR SAFEYY.

AVAILABILITY - AICROCARD EDITIONS, INC., ACCOUNTING AND SHIPPING DEFT., WEST SALEM, WISCONSIN E4EG9

ACCIOTAT, REATTIVITY + CRITICALITY EXPERIMENT + FISSION PRONUCT RETENTION + REACTOR CONTPOL +

RFACTOR DYNAYICS + FEACTOR, LMLK + SODIUH

12-21297 ALSC IN CATEGQRIES 7 AND 17

PIQUA REQUESTS FEMOVAL CIF HIGH EFFICIENCY FILTERS

PIOUA NUCLEAR POWER FACILITY

19 PAGES, DCC. 1, 19E7, DOCKFT NO. 115-2, TYPE--OCR, MFG--A.I., $\triangle E--A . I$.

PIOUA REQUESTS EXEMPTION FROM TECH.-SPEC. REQUIREMENT OF VENTILATION FII.TER.S WHILE THE FUEL IS STORED AND THE REACTOR IS INOPERATIVE. THE FILTERS COST MOFE THAN \$4OOO PER YEAR. PIQUA HAS ALNAYS CONTENDED THAT THE FILTERS hERE UNNECESSARY EVEN UNDEF OPERATING CONDITIONS. ENCLOSED IS A REPORT - HIGH EFFICIENCY PARTICULATE AIR. FILTER EVALUATION FOR PIQUA (I7 PAGES).

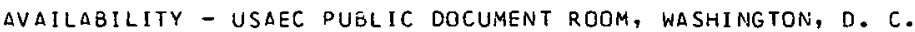

FILTEP, HISH EFFICIENCY + PIQUA (OCR) + REACTOR, ORGANIC COQLED + TECHNICAL SPECIFICATIONS + VENTILATION SYSTEY

$12-213 ? 0 \quad A L S C$ IN CATEGORY 5

EIBERRJ + MAXEY NA + DUFFY AO + ATTERRURY TJ

INVESTIGATION OF THE INITIATION AND EXTENT OF DUCTILE PIPE RUPTURE. QUARTERLY PROGRESS REPORT FOF JULY Y SEPTEMBER, 1967

BATTELLE MEMOR IAL IVSTITUTE

BMI-1817 +. 15 PAGES, 12 FIGURES, 2 TABLES, 3 REFERENCES, OCTOBEP 1,1967

RUPTURES TESTS WERE MADE DN SIX PIPES, 24 IN. OD X 1.5 IN. WALL THICKNESS, MADE OF AIO6B

MATEP I AL ALL TESTS WITH SUECOOLEO WATER SHOWED RILATIVELY SHORT DUCTILE FRACTURE. TESTS

WITH WET VAPOF PROPCGATED AN END-TO-END FRACTURE AT A PROPOGATION SPEED OF 750 FT/ISEC. 
CATEGORY 12
PLANT SAFETY FEATURES

$12-21320$ \#CONTINIEE*

AVAILABILITY - CLEARINGHOUSE FOR FEOERAL SCIENTIFIC AND TECHNICAL INFORMATION, SPFINGFIELD, VA., \$3.00 COPY, \$0.65 MICROFICHE

ACCIDENT, LOSS DF CDCLANT + ACCIDENT, LOSS OF PR.SSSURE + FAILURE, PIPE

12-21929 $\quad \triangle L S C$ IN CATEGORY $1 \&$

MONT ICELLO AMENDMENT 3 TO PSAR--DESCRIPTICN OF HNGINEERED SAFEGUADDS

NCPTHEQN STATES POHER COMPANY, MINNEAPOLIS, MINN.

89 PAGES, FIGURES, TABLES, MONTICELLO NUCLEAP. GENERATING PLANT, THIRD AMENDMENT TO CONSTFUCTION PERMIT

APPLICATION, DOCKET NG. 50-263, TYPE--BVF, MFG--G.E., AE-GECHTEL, OECEYBEP 29,1966

AMENOMENT 3 CONSISTS OF REVISED PAGES TO THE PSAR, DESCRIEING THE REVISED ENGINEEPED

SAFEGUARDS SYSTEMS AND CORRECTING MINOP, EPRCRS.

AVAILABILITY - USAEC PUBLIC DOCUMENT ROOM, WASHINGTON, D. C.

*ENG INEERED SAFETy =EATURE + MONTICELLo (EWR) + REACTOR, BWR + REPIIRT, DSAR.

12-22142 ALSO IN CATEGORIES 17 ANE 5

ST ATUS DF DRESDEN 1 CORE SPRAY SYSTEM

COMMMONIS EMLTII COI JOIN LUMPANY, CHİCAGO, ILL.

1 PAGE, COCKET 50-10, TYPE--BWR, MFG--G.E., $\triangle E--B E C H T E L$, DECEMEER 19,1967

GE RE-EVALUATED THE DESIGN-ZASIS ACCIDENT DND IS DESIGNING AN EMERGENCY COPE-SORAY SYSTEM. DRESDEN REPDRTS THAT THE DESIGN $\triangle M$ D ANALYSIS WORK ON THIS SYSTEM IS $25 \%$ COMPLETE, EXPECTED TO BE COMPLETE SY MARCH 1,1968 .

AVAILADILITY - USAEC PUELIC DCCUMENT ROOM, WASHINGTON, D. C.

\#CORE SPRAY + \#MOOIFICATION, SYSTEM OR EGUIPMENT + ORFSDEN I (BWR) + EMERGENCY COOLING CONSIOERATIONS + REACFOR, BWR

$12-22155$

$\triangle L S C$ IN CATEGORIES 3 AND III

LEFRANCOIS J

MECHANICAL GAP TRANSFER PUMO

COMMISSARIATA L-ENERGIE ATCMIOUE

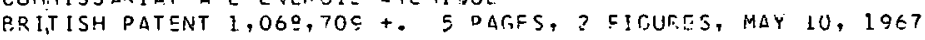

$\triangle$ MECHANICAL TPENSFEP PUMP PARTICULAPLY ADAPTER TO THE TRANSFER OF RADIOACTIVE GASES COMPR ISES $\triangle$ LIQUIN PISTCN MOVING IN A COMPRESSION CHAMBER. THE CHAMEEF HAS INTAKE AND DELIVERY VALVES NHOSF OPENINGS AND CLOSINGS ARE SYNCHRONIZED WITH THE MOVEMENT GF THE PISTRN, WITH TIIT INTAR. VALVE LOCATEO CN THE QXIS DF THE DFI TVERY VALVC. THE ULLIVERY VALVE IS MADE UP GF A FLOATING MEMBER, WIIICH IS HAISED DIRECTLY FFOM ITS SEATING AS A RESULT OF COAPRESSION OF THE VOLUME OF GAS PRIDUCED PY THE YOVEMFINT OF THE LIDUID PISTON. A PORTION OF THE COMPFESSION T.HAMBEP CONTAINING THE LIOUID PISTON IS FOPMCD PY A PAIP. OF BELLOWS THAI ARE DPEDABLE BCTH TO CONTKAC,T OP 3CTII TO CXOANU TCGETHEF SO AS TO ENSURE MAXIMUM IIOUID DISPLACEMENT IN THE CHAMBER .

AVAILABILITY - THE DATFNT OFFICE, 2 E SOUTHAMHTON ELDG., LONDON, W. C, 2, ENGLAND, \$O.4G PER CODY

\#PTENT + \#PUMP + TRACFP, GAS

12-22157 ALSC IN CATEGORIES 13 ANO 11

CABARFT J + GERARDV + VALENTINY

LIFT ING MFRHANISM

COMMISSARIAT A L ENEFGIE. DIUMIQUE

RRITISH PATENT $1,054,239+.5$ PAGES, 4 FIGURES, JANUAFY 11,1967

OESCRIBES A LIFTING MECHANISM USED IN A PEACTQR FACILLITY TO LIFT COVERS OF TANKS QR LEAK-TIGHT VESSELS USED TR TRANSFER RADIOACTIVE MATERIALS. THE LIFTING MECHANISM IS DFSIGNED SO THAT UPNARD TFAVEL IS IN TWO STAGES. THE COVEK IS LIFTED WHILE REMAINING PAPALLEL TO THE PLANE OF THE ODENING. IN THE SECOND STAGE, THE COVEP. IS REMOVED SO AS TO FREE THE OPENING. THE FIRST STAGE PERMITS THE MATERIAL FROM THE LIOUIO SEAL TO DRIP INTO THE VESSEL AND NOT B.E DISPSFSEC.

AVAILAGILITY - THE PATENT CFFICE, 25 SOUTHAMPTON PLDG., LONRON, W.C. 2 , ENGLANU, \$O.4S FER COPY

F PATENT + CONTAINIACNT UESIGN

12.22191 . ALSO IN CATEGORY 11

STRAUSS SD

NUCLEAR POWER PLANT SAFETY

\& PAGES, FIGURES, PNWER, PAGES 150-166 (JANUAQY ISO8)

PRIEF NONTECHNICAL UISCUSSION OF THE VARIOUS METHODS USED TC PREVENT RELEASE DF REDIOACTIVE 
12-22191 *CONTINUED*

FISSION PRODUCTS FROM BWR AND PWR POWER PLANTS. SAFEGUARDS CESCRIBED INCLUDE II) EMERGENCY CORE-COOL ING SYSTEM TO PREVENT HIGH FUEL TEMPERATURE AND (2) CONTAINMENT SYSTEMS, INCLUDING PRESSURE SUPPRESSION, PRESSURE RELIEF, GCNTAINMENT CLOLING, FILTRAT.IGN SYSTEMS, SPRAYS, ICE CONDENSERS, STEAM VENTING, AND SUBATMOSPHERIC CONTAINMENT.

* enginefred safety feature + Containment, general + emergency cooling considerat ions +

PLANT PROTECTIVE SYSTEM + REACTOR, BWR + REACIOR, PWR + SYSTEM DESCRIPTION

$12-22463$

HOL.COMB WF

ALSO IN CATEGORIES 4 AND 11

EXPER IENCE WITH GLQVEBOX INERT AT:AOSPHERE CONTROL SYSTEM

ARGONNE NATIONAL LAB., IDAHO OIVISIGN, IDAHO FALLS, IDAHO

4 PAGES, 2 FIgURES, NUCLEAR ENGINEERING AND DESIGN 613), PAGE 213-216, (OCT. 1967$)$

THE HANDLING AND PREPARATION OF SODIUM FOR FUEL ELEMENTS AT THE FUEL CYCLE FACILITY FOR THE SECOND EXPERIMENTAL BREEDER E.EACTOR REQUIRFS THE USE OF A GLOVEBOX EQUIPPED WITH A P.ECIRCULATING INERT ATMOSPHERE OF HIGH PURITY. THE ARGON GAS PURIFICATION SYSTEM CONSISTS DF A PALLAOIUM CATALYST FOP REMOIVING OXYGEN; MOLECULAR SIEVE DRYER FOR REMOVING WATER, AND A CANNED BLOWER FOR CIRCULATING THE GAS. THE PURIFICATION SYSTEM SERVES A 250 CU. FT GLOVEBOX COMPLEX AND WITH CONTINUDUS OPERATION CAN MAINTAIN AN ATMOSPHEFE WITH OXYGEN IMPUPITIES OF 2 PPM AND WATER IMPURITIES DF 6 PPM AT AN INLEAKAGE RATE OF O.CO2 CU. FT/HR OF AIF. WHILE ODERATING THE GLOVEBOX COMPLEX AT A NEGATIVE PRESSURE OF I IN. OF WATER.

*ARGON + \#DECONTAMINATION + \#GLOVE BOX + \#SODIUM + OPERATING EXPERIENCE

$12-22523$

WOLTER EE

ALSO IN CATEGORY 17

ELK RIVER CITED FOR NON-COMPLIANCE

RURAL COOPERATIVE HOVER ASSOCIATIDN, ELK RIVER, MINN.

1 PAGE, ATOMIC ENERGY CLEARING HOUSE $14(4)$, PAGE 26 i JANUARY 22 , 19681, DOCKET 115-1; TYPE--BWR, MFG--A.C., AE--SGT + LUNDY

(LETTER, DEC. 4.) THREE ITEMS C.ITEL AFTER AN OCT. 2-3 INSPECTION OF JULY 26 ACT IVITY - (1) EMERGENCY CORE-COOL ING AND DEIMARY MAKEUP SYSTEM WERE IN CAPABLE OF INJECTING WATFR INTO THE PRIMARY COOLING SYSTEM DURING 75\% POWER OPERATION. (2) FORESEEABLE PLANT EMERGENCY NOT COVERED BY DETAILED NRITTEN PROCEDURES, ESPECIALLY SINCE THIS TYPE OF SITUATION HAD HAPPENED BEFORE. (3)' TYGON TUBING WAS SUBSTITUTED FOR. CARBON STEEL IN PRESSURE-RELIEF PIPING. \#\# ALSO NOTES POWER RAISED TO 100\% TO RAISE THE APPARENT CORE WATER LEVEL AFTER A LOW-WATER-LEVEL ALARM.

*COOLANT PURIFICATION SYSTEM + \#EMERGENCY PROCEDURE + \#MAINTENANCE AND REPAIR + CORE REFLOODING SYSTEM + FAILURE, ADMINISTRATIVE CONTROL + INSPECTION AND COMPLIANCE + LEAK + PRESSURE P.ELIEF +

TECHNICAL SPECIFICATIONS

12-22529 ALST IN CATEGQRY 7

TECHNICAL SPECIFICATIONS MANUAL

GELMAN INSTRUMENT COMPANY, ANN ARBOR, MICHIGAN

62 PAGES, FIGURES, TAGLES, NOV. 1967

CONTAINS DESCRIPTIONS AND SPECIFICATIONS OF FILTERS, FILTER HCLDERS, AIR SAMPLERS, AND RECORDERS .

AVAILABILITY - GELMAN INSTRIIMENT CO., 6OU SOUTH WAGNER ROND, ANN APEOR, MICHIGAN L8IOG

\#FILTER CHARACTERISTICS + *FILTER, MEMERANE + FILTER + FILTER, HIGH EFFICIENCY + SAMFLING + TESTING

12-23177 ALSO IN CATESORIES 13 AND 17

NUCLEAR FUEL SERVICES, INC. AUTHORIZED TO RESUME OPFRATI ENS

U.S. ATOAIC ENERGY CCMMISSION, WASHING TGN, D. C.

3 PAGES, JANUARY 24,1968 , DOCKET 50-201

LETTER FROM DIVISION OF MATERIAL LICENSING BASES AUTHOR IZATION ON CHANGE 6 IN TECH. SPEC. 7.4, LICENSE CSF-1. \#FOR BASIS OF AEC ACTION, SEF LETTERS NSF TO AEC, DATED JANUARY I3, 15, 1968 .

AVAILABILITY - USAEC PUBLIC DOCUMENT ROOM, WASHINGTDN, D. C.

* ICENS ING STATUS OF NUCLEAR PROJECTS + \#NFS + \#P.ADIATION SAFETY AND CCNTROL +

\# ADIOCHEMICAL PLANT SAFETY + INSPECTION ANE COMPLIANCF + TECHAICAL SPECIFICATICNS

12-23179 ALSO IN. CATEGORY 13

COHENDY G + RIBES C + NIEZBORALA F + LE BOUHELLEC J

DECONTAMINATION OF INSTALLATIONS IN IRRADIATED FUEL PRCCESSING PILOT-PLANT

COMMISSARIAT A L ENERGIE aTOMIQUE, CHUSCLAN, FRANCE 
PLANT SATEGGPY SATY EITURES

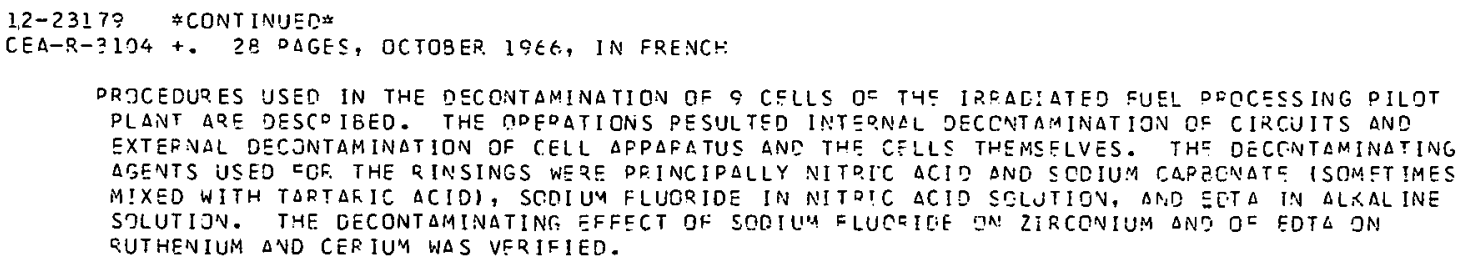

\#DESTRUCTIVE WIND + \#FLCND + \#SITING, REACTOR + \#WEATHEQ, SEVEPF + CQYSTAL PIVER 3 DND \& (PWR) + ENG INEERSD SLFETY FELTURE + HYDRAULIC ANELYSIS + MOOEL TESTINE + CFACTCR, DWP + RED OPT. PSAD.

$12-23485 \quad$ ALSO IN CATEGOPY 18

ORESDEN? AND ? FMERGENCY CORE CODLING SYSTEMS AVAILARILITY ANALYSIS

COMMONWEALTH EOISON COMPANY

5 PAGES, 2 FIGURES, E REFECENCES, DAGES 6-2.45 THRU E-2.47 OF DRESDEN 2 DNE 3 FINAL SAFETY ANAIYSIS

REPQRT, NOVEMBER 1?, 1967, DOCKETS 50-237/249. TYPE--EWP, MTG.--G.E., $4 E--S G T+$ LUNCY

ANALYSES FOR TWO CASES (A SMALL RREAK AND A LEFGE CNE) INCLUDE AVAILASILITY BLCCK DIAGRAMS. LEAST AVAILAGLE SYSTEMS FOP SMALL EPEAKS ARE HPCI (C.Q2C) $\triangle N D$ LPCI 10.CC?5). TCTAL COMPOSITF SYSTEM AVAILABILITY IS 1 AINUS $14 \times 10(7 T H)$, DUE MAINLY TC THE HI BH AVAILABILITY CF FEFOWATER SYSTEM. (IF NOPMAL AUXILIAFY POWER FAILS - HENCE NO FEEDWATED. - AVAILABILITY IS DEDUCED TO I MINUS $12 \times 101-4 T H) .1$ TZR LARGE BPEAKS, LEAST AVAILABLE SYSTEM IS LPCI (O.C925). COMPOSITE

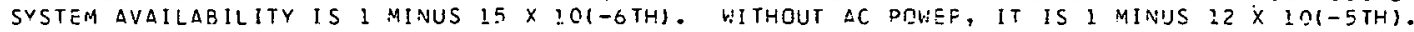


$12-23485$ *CONTINIJER*

AVAILABILITY - USAEC PUPLIC DCCUMENT ROOM, WASHINGTON; D. C.

CORE REFLODOING SYSTEM + CORF SPRAY + DRESUEN 2 (8WR) + ENGINEERED SAFETY FEATURE + FAILURE MODE ANALYSIS + REACTOR, BWR + KELIABILITY ANALYSIS + REPORT, SAP.

12-23871 ALSC IN CATEGORY 13

CLEANSING AGENTS FOR FUR IFYING SUREACES CGNTAMINATED EY RAOIOACTIVE MATERIALS

UNITED KINGDOM ATOMIC ENERGY $\triangle U T H O R I T Y$

FRENCH PATENT 1-303-673 +. 3 PAGES, $\triangle$ UGUST $6,19 E 2$, PATENT (FOREIGN), IN FRENCH

PARTICULATE OR LIQUIO RADIGACTIVE MATERIAL CAN BE REMOVEO FROM A SURFACE EY APPLYING A LIGUID CONTAINING A FILM-FORMING MATER IAL (PREFEFABLY NATURAL INDIA-RUBBER LATEX) AND A DETERGENT, AND SUBSEQUENTLY STRIPPING THE FORMED FLEXIBLE FILM FROM THE SURFACE. SEVERAL COMPOSITIONS $\triangle R E$ GIVEN.

AVAILABILITY - PHOTDCOPIES MAY BE OPTAINER FRDM THE. U.S. PATENT OFFICE, DEPARTMENT OF COMMERCE, WASHINGTON, D. C., (\$O.3O PEF. COPY)

\# DECONTAMINATION + \#SURFACE, GENERAL + FRANCE + PADIATION SAFETY AND CONTROL + RADIOCHEMICAL PLANT SAFETY

$12-23944$

METHOD DF DETERMINING THE CONTAMINABILITY AND DECONTAMINABILITY OF MATERIALS USED IN NUCLEAR ENGINEERING

4 PAGSS, KERNENERGIE, 10 , DAGE ?11 THRU 214, (JULY 1967) IN GERMAN

OESCRIBES A NEW METHOD FOR DETERMINING THE CONTAMINABILITY ANC DECONTAMINABILITY DF PAINTS. REPRODUCIBLE $\triangle N D$ COMPACABLE FESULTS WERE OBTAINED USING THE DROP TECHNIQUE OF DEPOS ITION AND A NEW EOUIPMENT FOR RINSING THE CONTAMINATING SOLUTIONS.

*COATING, SURFACE + \#FADIOCHEMICAL PLANT SAFETY + CQATING + CONTAMINATION + DECONTAMINATION + SURFACE CONTAMINATION:

\section{$12-24058 \quad$ ALSC IN CATEGURISS 5 ANR 8}

LETTER FROM ACRS TO CHAIKMAN $\triangle E C$

$\triangle E C$, DIVISIDN DF DPERATIONAL SAFETY

3 PAGES, FEBRUARY 26, 1968 , FOQY USAEC PRESS RELEASE L-42

SUSJECT - REPOPT OF ADVISORY TASK FORCE ON POWER REACTOR EMERGENCY COOLING (TID- 24226 ). COMMENTS ON TIR-24220, $\triangle D V I S C R Y$ TASK FORCE REPORT, ARE PRESENTED IN THIS LETTER

AVAILABILITY - AEC, OIVISION OE DPERATIONAL SAFETY, WASHINGTON, D. C.

ACCIDENT ANALYSIS + ACCIDENT, LOSS UH LUULUIUT + ACRS I BLOHOTWN + SFIRF MELTDOWN +

EMERGENCY CDOLING LUNSIDEPATIONS I EMERGENCY SYSTEM + REACTOR, BWP + REACTOR, PWR + SAFEIY PKUGKAH

12-24059 ALSO IN CATEGORIES 5 AND 8

REPORT JF ADVISDRY TASK FORCE ON POWEP. REACTOR EMERGENCY COOLING

IJS ATDMIC ENERGY COMMISSICN

TIR-24226 +. 226 PAGES, FIGUPES, TABLES, REFEPENCES, 1968

CONCLUSIONS, DISCUSSIONS, AND TECHNICAL APPENDIES ARE PRESENTED AS THE FOLLUWING ITEMS - I 1 ) PHENOMEVA ASSOCIATEC WITH LOSS OF COOLANT (LOC), (2) STRUCTURAL RESPONSE P.EQUIREMENTS TO BLOWDOWN, (3) REQUIREMENTS OF EMERGENCY CORE-COOLING (ECC) SYSTEM, (4) TECHNDLOGY DF ECC, (5) PRACT ICALITY OF ECC SYSTEM, (6) RELIABILITY ANALYSIS, 17 ) PRIMARY SYSTEM INTEGR ITY, (8) BREAK SIZE FOR EHERGENCY CORE-COOLING DESIGN, (S) SAFEGUARDS ROLE GF CONTAINMENT, (1O) CORE IELTDONN, 111 ) COUNTERMEASURE PRIOR TO LCSS. OF CONTAINMENT INTEGRITY, (12) HANDLING GF LARGE MOLTEN MASSES.

AVAILABILITY - USAEC OIRECTOR JF REGULATION, WASHINGTON, D. C., COPY IS FREE

ACCIDSNT ANALYSIS + ACCIDENT, LOSS OF COOLANT + ACRS + BLOWOOWN + CORE MELTDONN +

EMERGENCY COOLING CONSIDERATIONS + EMERGENCY SYSTEM + REACTOR, BWR + REACTOR, PWR + SAFETY PROGRAM

$12-24192$

ISTOMINA AG + SHTUKKENBERG YM

THE CONTROL OF THE CONTAMINATION GE SURFACES WITH TRITIUM OXIDES AND DEACTIVATIDN MEASURES

7 PAGES, MED. KAUIOL. 12(7), RAGES 61-7 (IIII.Y 1SE7) (IN RUSSIAN)

THE CONTAMINATION OF SIX MATERIALS BY TPITIUM OXIDES IS REPGRTEO. A METHOD IS PFOPOSED EOR THE MEASUREMENT OF THE CONTAMINATION CF SURFACES, AND AN ASSESSMENT IS GIVEN OF DECONTAMINATION METHODS FOR SURFACES. POLLUTEO BY TRITIUM OXIDES.

* CONTAMINATION + \#ECONTAMINATIJN + OXIDE + RADIOCHEMICAL PLANT SAFETY + TRITIUM 


\section{PLANT SATEGOTYY 1 I}

$12-24277$

CALDWELL R

ALSC IN CATEGOPY 17

MILLING MACHINE ACCIDENT

NUCLEAR MATER IALS ANO EQUIP:AENT CGRP., $\triangle P Q L L D, P A$.

2 PAGES, ATOMIC ENFRGY CLEARING HDUSE, 14(14), DAGF 33-24 (APRIL 1, 1968)

(LETTER, FES. 15) ON DEC. 14, 1967, A TER.HNICIAN AMPUTATED HIS HAND IN A GLOVE BOX BY REACHING PAST THE CUTTER TO ADJUST A NITROGEN HOSE, JRDINARILY DONE NITH THE MACHINE OFF. THE HAND

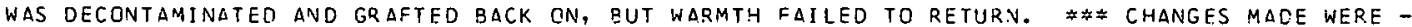
(1) ADD 2 SNITCHES IN MOTOR CIPCUIT SO BOTH HANCS ARE NFFTFD TO OPERATE MACHINE. (2) AN INTEP.LOCK DREVENTS ODERATION WHEN ACCESS TO CUTTING TOOLS IS OPEN. (3-S) SWITCHES RELAPLED AND RELOCATED, LIGHTING IMPROVED, AND INDICATOR, LIGHTS INSTALLED.

*CONTAMINATION + INCIDENT, NONREACTGIP + MODIFICATION, SYSTEM OR EQUIPMENT + PERSONNEL PROTECTIVE DEVICE + RADIATION INJURY, TREATMENT OF + P.EMDTE MANIPULATING AND VIEWING

12-24278 ALSC IN CATCGORIES 15 AND 17

OVER EXPTSURES TO GAMMA RADIATION, LAST HALF 1967

NUCLEAR MATERIALS AVD EQUIPMENT COPF., APOLLO, PA.

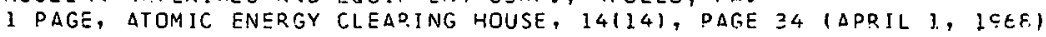

ILE11ER, FEQ. 2\%) (1) THREE 1E-YEAR OLD EMPLOYEES EXCEEDED 1.25 FEMS IN THE QUARTER, DND WERE REMOVED FROY EXPCSURE UNTIL 5(N-!8) ALLOWS RETURN. WE H'ERE $\triangle W \triangle R E$ JF THE AM-24I PEESENT IN ZPPR FUEL BUT NERE NOT AWARE OF THE 18-YEAR-OLDS. PU DUST EMITS MJRE X RAY SECAUSE OF LITTLE SELF-SHIELDI.VG. (2) A 19-YEAR-OLO WAS TAKEN FROM HANDLING 2 PPR. AM-241-CONTAMINATED CRUCIBLES. ( ) A SDURCE TECHNICIAN EXCEEDED LIFETIME LIMITS DURING THE FGURTH GUARTER. HIS JULY 1967 FILM BADGE HAD BCEN DAMAGED, ANO EXPOSURE CMMITTED. ESTIMATION YIELDFD

OVEREXPOSURE. (4) JAN.-MAR. GE FXPOSURE TO SOURCE FOREMAN EXCEEDED 3 REMS.

* AMERICIUM + \#FABRICATION + \#FUFL ELEMENT + \#PERSCNNEL EXPOSURE, PADIATION + PLUTONIIIM + SUUKLL, KAOIATION + X-RAY

12-24270 ALSC IN CATEGORISS 15 AND 17

OVER EXPOSURE TO AIR CONCENTRATIONS AT APQLLO

ATOMIC ENERGY COMMISSION

1 DAGE, ATOMIC ENEQGY CLEADING HOUSF, 14114), PAGE 35 (APRIL 1, 1068)

(LETTFR, MAP. 1$)$ FIVE OPERATOPS WERE EXPOSEO TO MORE THAN 40 MPC-HOURS/WEEK. EACH WAS WEAEING A PESPIPATOD, BUT NASAL CONTAMINATION EXCECCEO LIMITS, SO NO CFECIT WAS TAKEN TOPOSURES WERE DETECTED WITH PERSONAL AIP SAMPLERS. CNE EXPOSURE OCCURRED DURING CLEANUP OF A CP-Z FURNACE. TWO CCCURDED DUFING CRP-3 DISSOLVING OPERATIONS. TWO OCCURRSD DURING FILTER HANDLING. FIITFFS AFE ROUTINELY BAGGED, BUT CCCASSIONALLY A SAG IS PUNCTURED.

\#FABRICATION + \#FUEL FLEMENT + \#INHALATION + MAXIMUM PERMISSIBLE CONCENTRATIGN (MPC) + PERSONNEL EXPOSUPE, RADIATION 
CATEGORY 13
RADIOCHEMICAL PLANT SAFETY

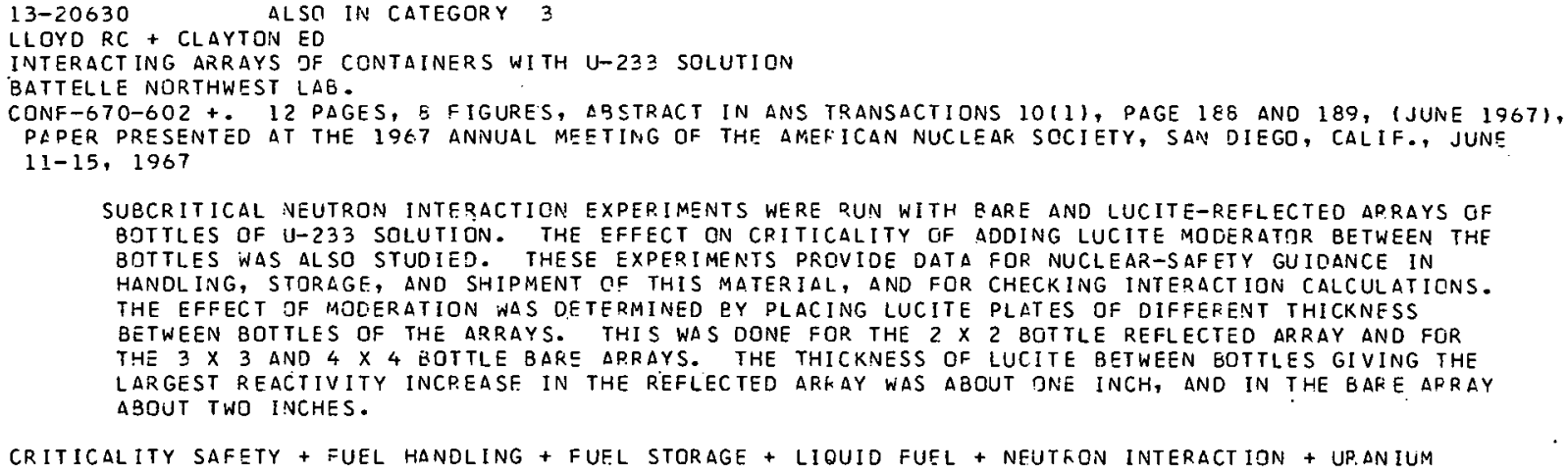

ONE OF THE FOUR EXISTING MULTICURIE BETA-gAMMA CELLS IN THE RADIOACT IVE MATERIALS LAQORATGRY AT THE VALLECITOS NUCLEAR CENTER. WAS CONVERTED INTO AN ALPHA-BETA-GAMMA FACILITY. THE CELL IS NOW CAPABLE OF PERFORMING EXAMINATIONS OF PU-ENRICHED FUELED EXPERIMENTS.

\#BUILDING + \#FUEL REPROCESSING + \#HOT CELL + REACTOR, BWR + VEWR (BWR)

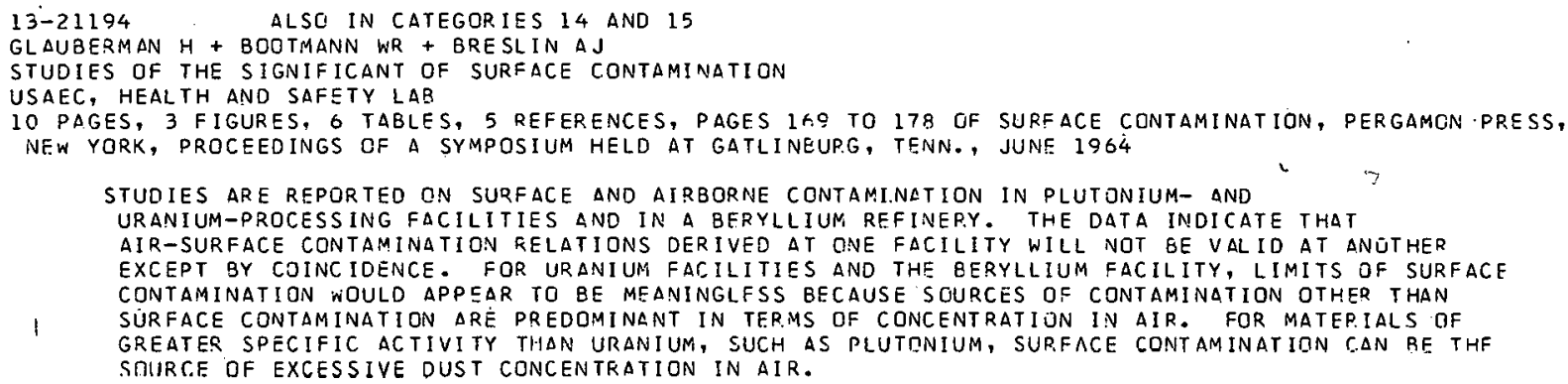

AVAILABILITY - THE PATENT OFFICE, 25 SOUTHAMPTON BLDG., LONDON, W.C. 2, ENGLAND, \$O.49 PER COPY

*PATENT + CONTAINMENT DESIGN

13-22259 ALSO IN CATEGORY 17

RUNION TC

NFS-AEC CORRESPONDENCE REGAROING MANAGEMENT CONTROL

NUCLEAR FUEL SERVICES, INC., NEW YORK

4 PAGES, ATOMIC ENERGY CLEARING HOUSE 14(2), PAGES 23-26 (JANUARY 15, 1968) 


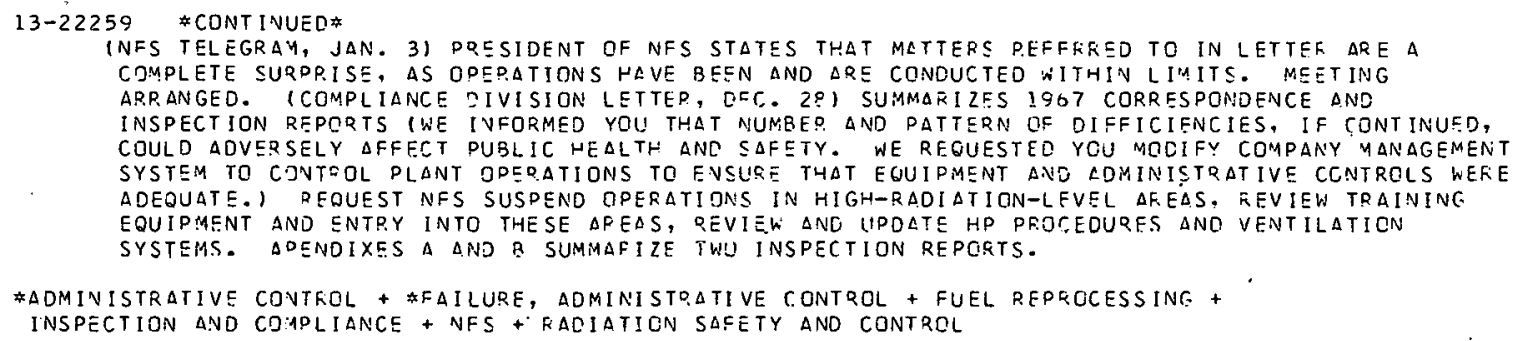

*EXPLOSION + FAILIJRE, ADMINISTPATIVE CONTC.CL + HOT CELL + INCIDENT, GENERAL + INSDECTICN ANO COMPLIANCE + IRIDIUM + PLUTONIUM + SPFC.IAL VULLEAP MATERIAL + STAFFING, TRAINING, DUALIFICATION

13-22437 ALSO IN! CATEGORY 17

NUMEC REPLIES TO COMPLIANCE CITATION OE MAFCH $2 \angle, 19 E 7$

NUCLEAR MATERIALS AVD FQUIPMCNT CERP., APCLLC, PA.

2 PAGES, ATOMIC ENERGY CLEAPING HOUSE l $3(21)$, PAGES 30-3! (MAY $22,3.067$ )

ILETTER, ADR.IL 13) INDICATCS PUZZLEMENT FYY GFNERAL INDICTMENT OF MANAGEMENT SAFETY CGNTPRLS. FACILITY IS VOT STATIC IN VATUDF OF WURK, WHICH IS EXPANDING, ANO DRAET AND FULL EAPLCYMENT CAUSES EMDLOYEE MIGPATION. I WE APE INCREDSING THE HP STAFF, $\triangle N O$ DN INTERNAL RFDCFT FOPM FOR. DEFICIENCY CORESCTION HAS BEEN ESTAELISHED. THE ADOLLO NLANT HLS TWICE LS MANY FMOLEYEES, ANO WE INCFEASED THE STAFF BY IOT IN 1SGE. TO MIINTAIN THIS NIJMESR, WE HIPED ANG TRAINEC SZ4 PEOPLS.

\#STAFFING, TRAINING, QUALIFIGATION + FAILUFE, ACMINISTRATIVE CONTROL + INSPECTIOM ANO CRMELIANCE + RADIATION SAFETY AND CONTROL

\author{
$13-22138$ \\ ALSO IN LAIEGURY 17
}

PUECHL KH

NUMEC REPORTS EXPOSURFS TO AIRRTRNE PLUTONIUM

NUCLEAR MATFR IALS ANO EQUIPACNT CORP. AP(:1.11, PA

2 DAGES, ATUMIC ENERGY CLEARING HOUSE $13(21)$, PAGFS 31-3? (MAY 22, 19E7)

(LETTER, MAY 1(1) THFEE TECHNICIANS WERE EXFCSED [N APRIL 17 (5S.2, 63, $\triangle$ ND EE MPC-HR) BECAUSE OE A PUNCTURED GLOVE-BOX GLOVF, SI!RVFY AT THE TIME TEVEALCD S CEVERALL SLIEVE CCNTAMINATED TO $5 U, U U U$ CHM IN SPẼTS.

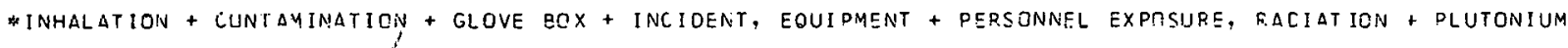

$13-22521$ ALSE IN CATEGORY 17

MALINCKENOT REPLIES TO NEV. 30,1067 NON-COUMLIANCE CITATION

MALL I VCKRODT CHEMICAL WORKS, ST. LOUIS, MO

4 PAGES, $\triangle T O M I C$ ENERGY CLEAP. ING HJUSF 1414), DAGES 22-25 (JANUARY 22,1968 )

METTFR. IFT. 20.1 ACTION TAKEN IN PQUUULIIUN OF I-131 OIAGNLSTIC CAPSULES INCLUCES MOENING YONITDRING DF WORKER THYPOID AND IMMEDIATE INVESTIGATION, USE CF DISPCSAPLE GLOVES, GENEFAL HP OV-THE-JOS TRAINING OF WOFKFRS, A DAILY SURVEY OF REFUSF CONTAIVERS. COMRILATION OE

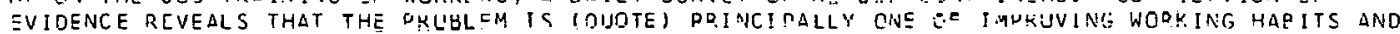
AIIIIUES RATHER THAN EXPOSURES OF PEFSONNEL TO HIGH AIFGOFNE CANIOACTIVITY CONCENTRATION (UNQUOTE).

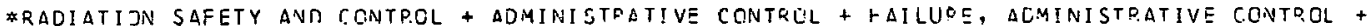
FISSIJN PROOUCT, IOCINE + INHALATION + INSOECTION AND COMPLIANCE + STAFFING, TRAINING, OUAL IFICATION 
CATEGORY 13
PADIOCHEMICAL PLANT SAFETY

13-22526 *CONTINUED*

UNITED NUCLEAR REPORTS CVEREXPOSURE TO AIFRGRNE ACTIVITY

UNITED NIJCLEAR CORP., NEW HAVEN, CONN.

1 PAGE, ATOMIC ENERGY CLEARING HOUSE 1414), PAGE 27 (JANUARY 22,1968 )

(LETTER, DEC. 13.) THREE RECEIVED 1.5 TIMES MAXIMUM ALLDWABLE WEEKLY EXPOSURE, IN FOUR HOURS, TO AIRBORNE ALPHA SMITTER DURING CLEANUP OPFRATIONS. MSA COMFO RESPIRATORS WITH TYPE-II ULTRAFILTERS WERE WORN. NO PROTECTION FACTCR ASSUMED. \#\#\# INCREASED HP COVERAGE AND EXPOSURE CONTFOL DUP.ING NONRGUTINE OPERATIONS WILL BE PROVIDED. APPLICATION WAS MADE FOR USE OF A RESPIRATCOY PROTFCTION FACTOF.

\#DECONTAMINATION + \#INHALATION + \#PERSONNEL CXPCSURE, RADIATION + ALPHA EMITTER + FILTER EFFICIENCY + FILTER, GAS MASK + PERSENNEL PROTECTIVE CEVICE

\author{
$13-22719$ ALSO IN CATEGORY 8
}

COLBY LJ

KINETICS OF 'THE REACTION OF URAVIUM MONOCARBIDE WITH WATER

ATOMICS INTERNATIONAL, NORTH $\triangle M E R I C A N$ AVIATION, INC., CALIF.

7 PAGES, 6 FIGURES, 2 TABLES, 9 REFEPENCES, JOURNAL OF THE LESS-COMMON METALS, $10(6)$, PAGES 425-431 (1966)

THE RATE OF. HYDROLYSIS OF URANIUM CARBIDE FROM 3 C TO 86.2 C WAS MEASURED BY A CONSTANT-VOLUME TECHNIQUE. AN ACTIVATION ENERGY OF $17.6 \mathrm{KCAL/MOLE} \mathrm{OF} \mathrm{UC} \mathrm{WAS} \mathrm{OBTAINED} \mathrm{FROM} \mathrm{AN} \mathrm{ARRHENIUS} \mathrm{PLCT}$ OF THE DATA. THE HYDROLYSIS REACTIGN RATE AT 70 C WAS FOUND TO BE PROPORTIONAL TO THE SQUARE ROOT OF THE WATEF CCNCENTRATION WHEN 2-PRCPANOL WAS USEO AS A DILUENT. IT IS THEREFORE ROOT OF THE WATEF CGNCENTRATION WHEN 2-PRCPANOL WAS USEO AS A DILUENT. IT IS THEREFORE
POSTULATED THAT THE RATE-DETERMINING STEP IN THE HYDROLYSIS OF URANIUM CARBIDE INVOLVES THE BRE AK ING OF AN O-H BOND.

\# ACTIVATIDN ENERGY + *CHEMICAL KINETICS + \#URANIUM CAREIDE + \#WATER, GENERAL + CHEMICAL REACTION

$13-22853 \quad$ ALSO IN CATEGORY 17

AEC-COMPLIANCE AUTHOPIZES NFS CONTINUED OPEPATION UNDER PLAN OF ACTION

UNITED STATES ATOYIC ENERGY COMMISSION, WASHINGTON, D. C.

13 PAGES, DTOMIC ENEPGY CLEARING HDUSE 14(5), PAGE 29-41, (JAN. 30, 196?), DOCKET NO. 5C-201

(TWX, JAN. 19) AGEEES WITH PLAN OF ACTIION ANO SCHEDULE OF EXCEPTIONS OUTLINED IN JAN. $13 / 15$ LETTERS. (NFS LETTER, JAN. 13.) REPLIES IN DETAIL TO CEC. 28 LETTER. NFS BFLIEVES CONTAMINATION-CONTROL PROBLEMS WEFE CAUSED BY VENTILATION SYSTEM SEING MARGINAL FOR UPSET CONDITIONS AND FCR HIGH BURNUP FUEL, AND TO UNEXPECTED FREQUENCY OF MAINTENANCE IN HANDL ING EQUIPMENT - VENT MOOIFICATIONS ANO DECONTAMINATION FACILITY WILL BE COMPLETE GY APRIL G8. MANY PROBLEMS FESULT FROM LACK OF COMMUNICATION - MANY REMEOIAL STEPS BEGAN AFTER YDUR OCT. 67 INSPECTION ANE WE DID NOT FURNISH YOU PROGRESS REPORTS. ADDITIONALLY; AMBIGUITIES IE.G. ADEQIIATE CONTROLS) IN $\triangle E C$ REGULATIONS AND OUR TECH. SPECS. POSE MORE OF $\triangle$ PROBLEM IN THE FIELD.

\# MAINTENANCE AND REPAIR + \#VENTILATION SYSTEM + ADMINISTRATIVE CCNTROL + DECONTAMINATICN +

TULL RERROSESSTRIF + INSOLCTION AND COMPLIANCE + MODIFICATION, SYSTEM OR EQUIPMENT + NFS +

TECHNICAL SPECIFICATIONS

$13-23175$

HUSZAGH DW + KUKACKALE+ STEINBERG M

RADIATION FACILITY FOR USE WITH HAZARDOUS CHEMICAL SYSTEMS

BROOKHAVEN NAT IONAL LAB., LPTON, NEW YORK

BNL-11550 + CONF-671102-7+. 13 PAGES, FIIR PRESENTATION AT 15TH CONFERENCE ON REMOTE SYSTEMS TECHNOLOGY

ANO ATOM FAIR, CHICAGO, ILL.

DESCRIBES FACILITY IN WHICH HIGHLY EXPLOSIVE GAS AND HIGH LEVELS OF RADIATION $\triangle R E$ JOINTLY

PRESENT, FOR EXAMDLE, THE POLYMERIZATION ANO COPOLYMERIZATION OF ETHYLENE THROUGH

RADIATION-INDUCEC. P.EACTIONS.

AVAILABILITY - CLEAPINGHOUSE FOR FELERAL SCIENTIFIC AND TECHNICAL INFORMATION, SPRINGFIELO, VIRGINIA \$?. OO COPY, \$0.55 MICROFICHE

\#RADIOCHEMICAL PLANT SAFETY + DESIGN CPITERIA + EXPLOSION + HGT CELL

$13-23176$

WEST GA + WATSON CD

SAFETY STUDIES OF THE SHEARLEACH PROCESSING OF ZIRCALOY-2-CLAC SPENT NUCLEAR.FUELS

DAK RIDGE NATIUNAL LASORATCRY, DAK RIDGE, TENNESSEE

ORNL-4061 +. 14 DAGES, FIGURES, TABLES, PEFERENCES, OCTOBER 1967

STUDY WAS CONDUCTEU BY MEANS OF A LI TERATURE SEARCH, ISNITION TESTS, SHEARING, AND

ABRASIVE-DISK SAWING. CONCLUDED THAT SHEAR-LEACH PROCESSING CAN BE ACCOMPLISHED SAFELY,

PROVIDED THAT APFROPRIATE PRECAUTIONS ARE TAKEN. BIRLIOGRAPHY INCLUDED.

AVAILABILITY - CLEARINGHOUSE FOR FEDERAL SCIENTIFIC AND TECHNICAL INFGRMATION, SPRINGFIELD, VIRGINIA \$3. OO CGPY, \$0.65 MICROFICHE

\#RADIOCHEMICAL PLANT SAFETY + \#RADICCHEMICAL PROCESSING + FIRE + FUEL REPROCESSING + URANIUM DICXIDE + 
FAOIOCHEMTEGOPY PLANF SAFETY

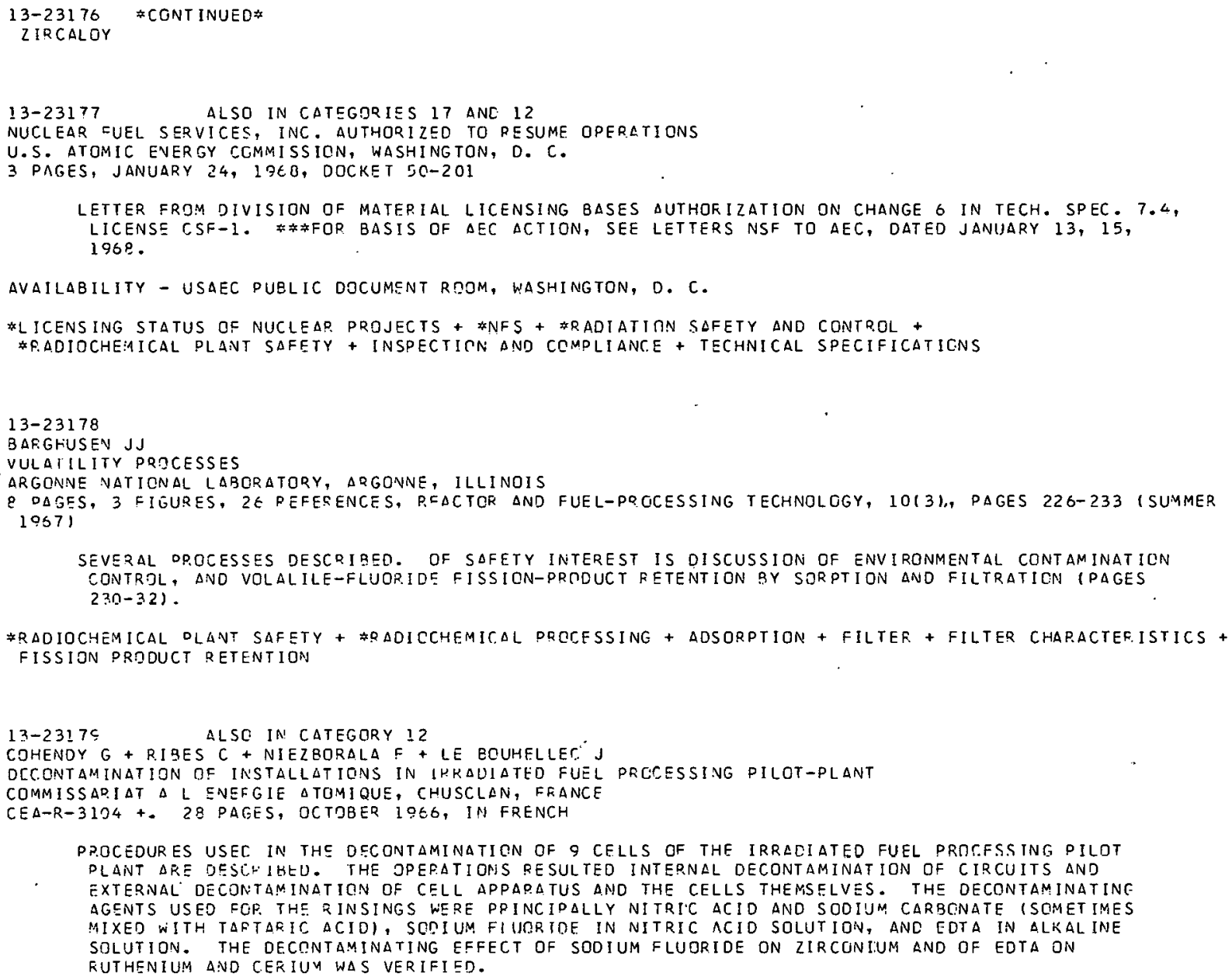

AVAILABILITY - MICROCARD EOITIINS, INC. (FOP SALC), ACCOUNTING ANE SHIPPING DEPARTMENTS, WEST SALEM, WISCONSIN

*RAOIOCHEMICAL PEJCESSING + UFGIINTAMINAIICIN + HOT CELL

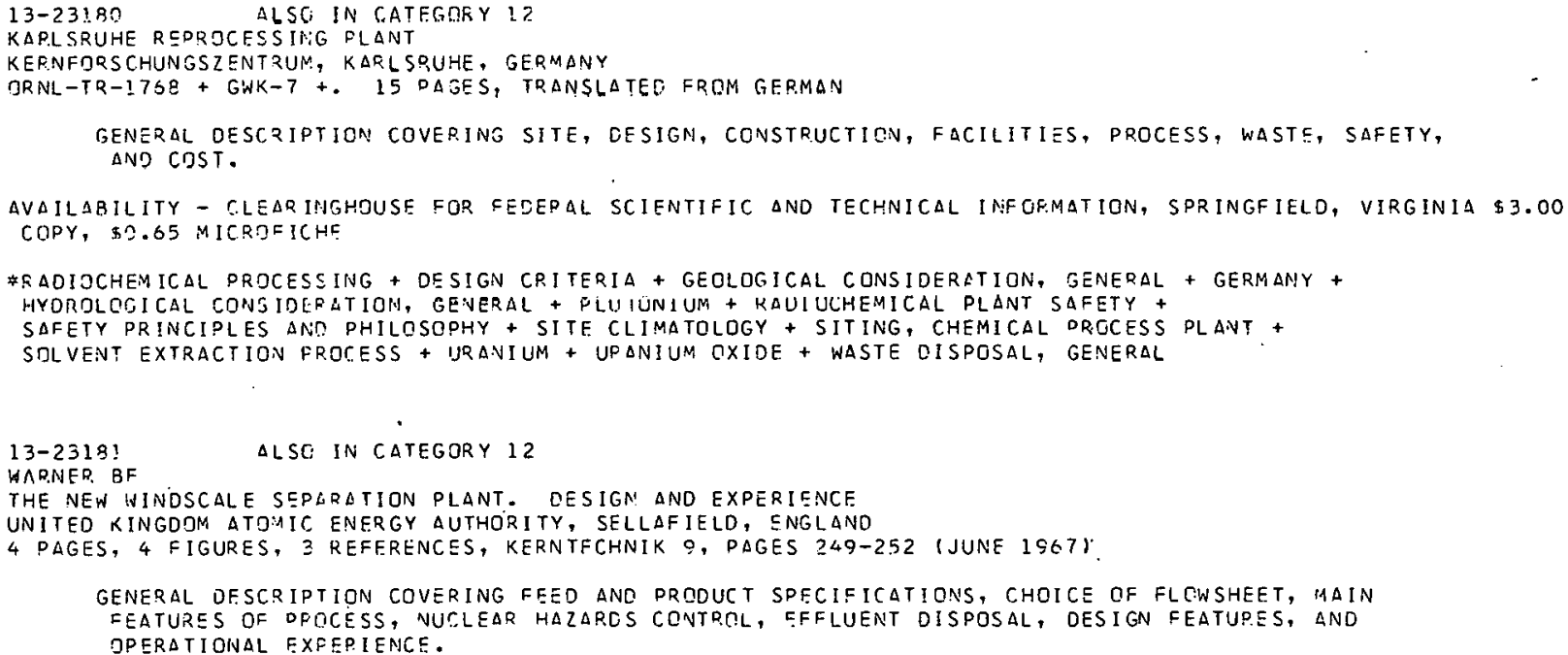


$13-23181$ \#CONTINJED*

1FADIOCHEMICAL PLANT SAFETY + \#RADIOCHEMICAL PROCESSING + \#UNITED KINGDOM + \#WINDSCALE + CRITICALITY SAFETY + DESIGN CRITERIA + PLUTONIUM + SOLVENT EXTRACTION PROCESS + URANIUM DIOXIDE + WASTE DISPOSAL, GENERAL

$13-23315$

FREDR ICKSON RL

ALSO IN CATEGTORY 17

ABBOTT LABS REPORTS HIGH I-13I IN THYROIO

ABBGTT LABORATORIES, CHICAGO, ILL.

2 PAGES, ATOMIC ENERGY CLEÄR ING HOUSE 14(9), DAGES 35-36 (FEBRUARY 19, 1968)

(LETTER, JAN. 3) ROUTINE THYRDIO COUNTING ON NOVEMBER 27 REVEALED ONE PERSON WITH O.34 MICROCURIE (247\% PERMISSISLE) OF I-131. HIS FOURTH-OUARTER THYRDID EXPOSURF WAS 5 . 56 RENS. NO INCIDENTS OCCURPED, NOR DID AIR SAMPLES INDICATE CONCENTRATION TO EXPLAIN THIS. SEVEFAL WORKERS SHOWED ELEVATEO THYROID BURDENS IN 1S67, WITH NO ORVIOUS EXPLANATION. WE ARE RE-EVALUATING AIR FLOW IN FUME HOODS.

\#FISSION PRODUCT, IODINE + \#INHALATION + FPERSONNEL EXPOSURE, RADIATION + RADIOISOTOPE + VENTILATICV SYSTEM

$13-23316$

WILSON SD

ALSO IN CATEGORY 17

RELEASE OF 352 POUNOS OF UFG $\triangle T$ TE-SAN JOSE

GENERAL ELECTRIC, SAN JOSE, CALIF.

1 PAGE, ATOMIC ENERGY CLEAP.ING HOUSE 14(8), PAGE 36 (FEBRUARY 19, 1968)

(LETTER, JAN. 25) THF RELEASE IN PLOG. J ON DEC. 30, 1967, MAY HAVE DAMAGED A \$20,000 FLUORIDE-MEASUR ING INSTRUMENT, SUT NO EXPQSURE OR RELEASE OCCURRED. A MECHANIC TIGHTENEC A LEAK ING CAP ON 1/4-IN. BRASS PIPE NIPPLE, WHICH BROKE OFF BEFOPE HE APPLIED FORCE. HE WES WEARING A FULL-FACE FILTERED-AID MASK. 90\% OF THE MATERIAL HAS GEEN RECOVERED.

AIRBORNE RELEASE + MAINTENANCE AND PEPAIP + URANIUM HEXAFLUORIDE

$13-23364$ ALSO IN CATEGORY 17

NFS DISCUSSES COMPLIANCE CITATION

NFS DISCUSSES COMPLIANC
NUCLEAR FUEL SERVICES

4 PAGES, ATOMIC ENERGY CLEAP ING HOUSE 14(S), PAGES $28-31$ (FEBRUARY 26, 1968) DOCKET 50-201

(LETTER, FES. 2) WITH THE CXCEPTION OF ITEM IA OF THE SEPT. 26-2O CITATION (FAILURE OF AN INDIVIDUAL IO FOLLOW NES PROCEDURE, THE INDIVIDUAL IS NO LONGER EMPLOYED BY NFSI, THE ACTIVITIES CITED WERE IN COMPLIANCE WITH TECHNICAL SPECIFICATIONS ANO 10 CFR 10 AND 55. DETAILED DISCUSSION FQLLOWS.

* INSPECTION AND COMPL IANCE + FAILUR.E, ADMINISTRATIVE CONTROL + NFS + RADIOCHEMICAL PR.OCESSING

13-23365 ALSO IN CATEGORIES 15 SNO 17

BAIN EE

ALS STR

NFS REPORTS EXPOSURE

NUCLEAR FUEL SER VICES, INC.

2 PAGES, ATOMIC ENERGY CLEARING HOUSE, 14(9), PAGES $31-32$ (FEBRUARY 26,1968 )

(LETTER, FEB. 2) THE FOURTH-QUARTER FILM BADGE OF A PLUTONIUM FFODUCT ION PLANT WURKER INDICATED 3.07 REMS EXTERNAL WHOLE-EOCY GAMMA PADIATION. HIS ISE7 TOTAL IS 3.53 REMS AND LIFETIME TOTAL 9.18. \#\#ALL STATIONS WITH SIGNIFICANT PLUTONIUM WILL BF SHIELDED. AND THE CURRENT EXPOSURE RATE WILL BE POSTED DAILY.

\#PERSONINEL EXPOSURE, RADIATION + FUEL REPPOCESSING + PLUTONIUM + RADIATION SAFETY AND CONTROL

$13-23433$

MOSELEY JD + ROBINSON HN

STATIC BED REACTOR FCR STUDIES OF A PLUTONIUM HEXAFLUORIDE VOLATILITY PROCESS

DOW CHEMICAL COMPANY, GOLDEN, COLORADC

RFP-1048 +. 19 PAGES, FIGUPES, DECEMBER 5,1967

STUDIES WERE BEGUN TO FIND IF CHEMICAL SEPARATION AND PURIFICATION OF PLUTCNIUM FROH WASTE MATERIAL COULO BE ACHIEVED WITH FLUORIDE VCLATILITY PROCESSES. EQUIPMENT DESIGNED FOR THE PROJECT AND THE PROCEDURES DEVELOPED FOR USE ARE DESCRIGED. SAFETY DEVICES ARE DISCUSSED CN PAGE 12 .

AVAILABILITY - CLEARINGHOUSE FOR FEDERAL SCIENTIFIC AND TECHNICAL INFORMATION, SPRINGFIELD, VA., \$3. OO COPY, \$0.65 MICROFICHE

\#RAOIOCHEMICAL PLANT SAFETY + *RAOICCHEMICAL PROCESSING + EQUIPMENT, GENERAL +

FLUORIDE VOLATILITY PROCESSES + FLLORINF + PLUTONIUM + PLUTONIUM DIOXIDE + WASTE HANDLING 


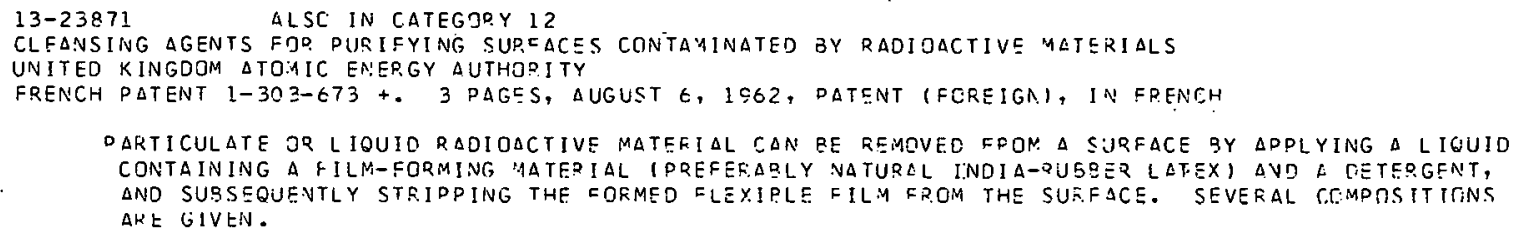


$13-24220$ \#CONTINUEE *

* ECGNOMIC STUDY + FUEL STOPAGE + REACTOR, GCP + STOFAGE CONTAINER + WASTE HANDLING

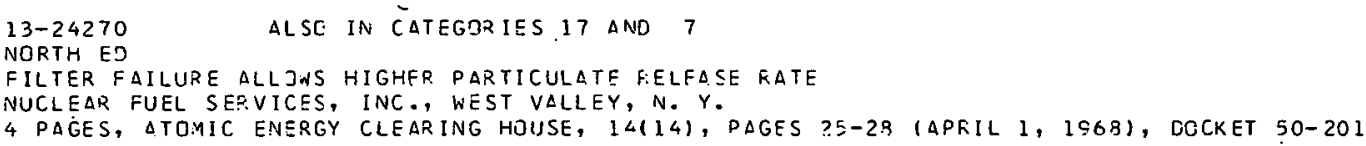

(LETTER, MARCH 24 ) ON MAR. 8-10, THE PAFTICULATE RELEASE FROM THE STACK ALMOST EQUALED THE MONTHLY ALLOWANCE, DUE TO FAILURE OF THE DISSOLVER OFF-GAS FILTER (PLACED IN SERVICE MAR. 7 ). IT HAD BEEN LCADED FQR SEVERAL MONTHS PRIOR, READING 5 R/HR. ALTHJUGH IT MET THE DOP TEST MAR. 7, EITHEF THE MEDIA BECAME PORCUS OR DEVELCPED $\triangle$ CRACK, OR THE SEALANT HARDENED AND FAILED TO SEAL. MOFE PROBABLY, THE ORGANIC BINDER EMBRITTLEL, FREEING THE GLASS FIBERS AND ALLONING THEY TO VIBRATE TO THE POINT OF FAILURE, OR TO PERMIT THEM TO MOVE RELATIVE TO EACH OTHER. FILTEFS WILL BE REPLACED WITHIN A SHORT TIME AFTER REMOVAL FROM SERVICE. FOR HIGH PRESSURE DSOP OK HIGH RADIATION.

*EILTER, DA.MAGED + \#FILTER, FI 9ERGLASS + \#RADIATION DAMAGE + \#RADIOACTIVITY RELEASE + \#STACK + FAILURE, EQUIPMENT + FUEL REPRDCESSING + NFS

13-24274 ALSC IN CATEGORIES 17 AND 15

PEDSONNEL OVEREXPOSURES DURING FOURTH QUARTER 1967

NUCLEAR FUEL SERVICES, INC.

1 PAGE, ATOMIC ENERGY CLEARING HOUSE, 14(14), PAGE 32 (APRIL 1, 196E), DOCKET 50-201

(LITTER, FES. 1C) REPORT DESCFIBES DVEREXPOSURES AND CORRECTIVE ACTIONS. (WHOLE BODY) - 3 EMPLDYEES RFCEIVED 3.1, 3.2, AND 3.4 REMS. (SKIN) - THREE RECEIVED $7.7,8.2,4 N D 9.8$ REMS. (EXTREMITY) - SIX RECEIVEO 10.02, 10.11, 19.41, 19.62, 20.55, ANO 20.56 REMS, ALL DUE TO SPOT SOURCES. CHANGES TO SOP FOR CONTAMINATED WORK AREAS, TO EQUIPMENT TO MINIMIZE CONTACT MAINTENANCE, AND TO IMPROVE VENTILATION ARE BEING UNDERTAKEN. A MANIPULATOR PIEPAIR ANO DECONTAMINATICN FACILITY IS EEING BUILT.

*PERSONNEL EXPOSURE, FAOIATION + CONTAMINATION + FUEL REPROCESSING + MAINTENANCE AND REPAIR + MODIFICATION, SYSTEM OQ EOUIPMENT + NFS

13-24?80 $\triangle L S G$ IN CATEGORY 17

NUMEC 'CITED FOR NON-COMOLIANCE

NUCLEAR MATERIALS AND EQUIPMENT CORF. $\triangle P Q L L O, P A$.

I PAGE, ATOMIC ENERGY CLEARING HOUSE, 14(14), PAGE 35 (APRIL 1, 1968 )

(LETTSR, FE3. 2li CITATIONS AFTER AN INSPECTION WERE FOF THE FOLLOWING REASONS - (1) PERSONNEL HAVE BYPASSED THE CHANGE AREAS BY FREQUENT USE OF REAR DOORS. (2) NUMEC FAILED TO REPORT A 3.76-REM EXPDSUFE DURING THE FIRST QUARTER UF CY 1960. \#\# (QEPLY, MAR. 5 I WE ARE PLEASED NO NTNCQMPLIANCE NOTED TO SNM-14.5 AND 37-4456-3 LICENSES. THIS R.FFLECTS QUR. EFFRRT. IIV EYPASSING IS NOT ROUTINF. WAS USFO ONLY FOR IN-PLANI TRANSFER UF CONSTRUCT ION MATERIAL, ANC

- DODR.S HAVE BEEN PQSTFD. TRAINING CLASS HAS BEEN HELO ON USE OF CHANGE ROGMS. MATERIAL NOW STORED ELSENHERE. (2) THIS WAS AN QVERSIGHT. IN SEPT. 1967 , AN OVERINSPECTION PROCEDURE WAS INST ITUTED.

* INSPECTION AND COMPLIANCE + FAILURE, ADMINISTRATIVE CONTROL + PERSCNNEL Exposure, RADIATION + SPECIAL NUCLEAR MATER IAL 
CATEGORY 14
RAOIONUCLIDE RELSASE AND MOVEMENT IN THE ENVIRONMENT

$14-18834$

GOELDNER RW

CONCENTRATION OF SOLUTIONS CONTAINING; QADIOACTIVE MATERI ALS BY EVAPCRATION

AQUA-CHEM, INC.

BRITISH PATENT 1-063-53इ +. 4 PAGES, I FIGURF, MAPCH 30,1967 , PATENT (BRITISH)

A METHOD COR CONCENTPATING RACIOACTIVE MATERIALS BY EVAPORATION FROM A WASTE SOLUTION SUCH AS $\triangle$ REACTDR COJLANT STREAM IS CEESCRIEED. IN ADDITION TO THE CONCENTRATION OF RADIOACTIVE WASTE, BORON COMPOUNDS MAY BE SEPAFATED FROM THE LIQUID. THF MFTHOO IS USEC TO PPODUCE A LIUUID PRODUCT OF LOWER RADIOACTIVITY EROM A FEED MATEFIAL CF HIGHER RADIGACTIVITY. THE

FORMER MAY BE RETURNED TJ THE DEACTOR COOLANT SYSTEM FCR REUSE ANO THE LATTER DISPOSED OF.

AVAILABILITY - THE PATENT OFFICE, 25 SOUTHAMPTON BUILDING, LONDGN, W. C.2, ENGLAND, (\$O.49 PER CEPY)

*EVAPJRATION + \#PATENT + \#PIACTOR CCOLANT + BORON + CONCRETE + DESIGN CRITERIA + WASTE DISPOSAL, SCLID

$14-20558$

VELTEN OJ

RESOLUIIIUN UF STEONTIUM-8O ANO STRONTIUM-SO IN ENVIRONMENTAL MEDIA BY AN INSTRIJIENTAI TECHNIOUE

ROBERT A. TAFT SAN. ENGH:G. CENTER, CINCINNATI, OHIO

4 PAGES, 4 TASLES, 7 FEFERENCSS, NUCLEAR INSTRUMENTS ANO METHODS, $42(1)$, PAGES $169-72$ (JUNE 1966$)$

THE BETA EMISSIDNS OF SP-8S AND SR-O0 ARE RESOLVED SY QRSERVING THE GROHTH JF THE Y-9O ANO DECAY OF SR-QC. THE PATIO OF COUNT RATE OF SP-9O ANC THE INGRUWV Y-OC TO THAT OF THE PARENT SR-9O AT ANY TIME IS OFEDETERMINEC. TWO MEASUREMENTS OF THE TCTAL RACIOSTRCNTIUM FRACTIONS ARE MADE AT AN INTEPVAL OF 7 TO 14 DAYS. EQUATING THIS RATIO AND THE DECAY FACTOR FOR SF-EO WITH THESE TWO MEASUREMENTS, TWO EQUATICNS CAN BE SET UP ANO SOLVED SIMULTANECUSLY TO EXPRESS THE INOIVIDUAL COUNT PATE GF THE THO STRONTIUM ISOTOPES. THE COUNT RATE OF THE SF-SO IS CORRECTED FOR SELF-

THAT OF Y-GO, AN ENERGGEIIC REIA EMITTER. WITH NO SAMPLE-ABSCRPTION LOSSES AT THE THICKNESS

STUDIED. THIS TECHNIQUE DIFFEPS FPOM CONVENTICNAL METHODS IN THAT NEITHER ADDITIONAL

CHEMISTQY NDR THE USE CF ABSCFBERS IS REQUIRED AS A DIFFERENTIATING TCOL.

* ANALYTICAL TECHNIQUE, genERAL + INSTRUMENTATION, NUCLEAR + INSTRUMENTATION, RADIATION MGNITORING + STRONTIUM + UNITED STATES

14-20574 ALSO IN CATEGTPY 15

TADMOR $J+$ COWSER KE

UNDEFGRDUND DISPOSAL CF KR-Q5 FROM NULLEAP FUEL REPPOCESSING PLANTS

OAK RIDGE NATIONAL LAE., TEVN.

CONF-670602 +. 2 DAGES, 5.REF EOENCES, ANS TPANSACTIONS 10(I) PAGES 159 AND I6O (JUNE 1SE7), PRESENTED AT

THE 1967 ANNUAL MEETING DFF THE AMEKICAN NUCLEAR SOCIETY, SAN DIEGO, CALIFORNIA, JUNE !I-15, I9G7

REPOPT INDICATES THAT, CONSIDERING ACSORPTION AND MOLECULAR DIFFUSION CFF KR-E5, UNCERGROUND

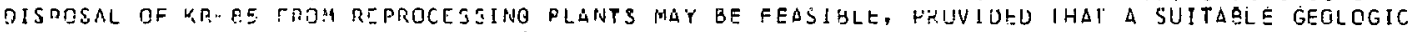
SETTING IS AVAILABLE AT THE PLANT SITE.

\#WASTE DISPOSAL, GAS + KRYPTON + WASTE DISPOSAL, ATMOSTHERIC H WASTE DISPOSAL, TERPESTRIAL

$14-20738$

DEJAEGESE R

ALSG IN CATEGORY 15

RADIOOIOLOGICAL EFFECTS OF TRACERS USEU IN PLANT PHYSIOLOGY

UNIVERSITY LIBRE, BRUSSELS

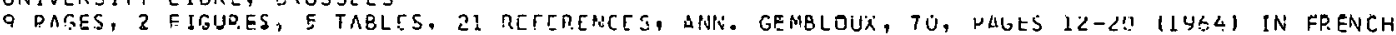

THE USE ÓF RAOIDACTIVE TOACEQS IN QICLOGICAL EXPERIMENTS IS BASED JN THE PREMISE THAT THE TRACERS IN SIOLOGICAL EXPERIMENTS OO NOT INFLUENCE NGRMAL PROCESSES IN THE CELL. EVIOENCE IS PRESENTED THAT THIS CONDITION IS NOT ALWAYS REALIZED AND THAT IN SOME INSTANCES PADIATICN FROM THE RADIOACTIVE TRACER AFFECTS CELLULAR MFTABOLISM. POSSIBLE MECHANISMS WHEREBY A STIMULATING ETICCT MAY OCCUR, JNCLUCING EFFECIS UN THE AUXIN SYSTEM, AP.F DISCISSED. IT IS CUNCLUDED THAT THE BICLOFICAL EEFECTS DF RADIOELEMENTS USED AS TRACERS ADE NOT ALWAYS NEGLIGIBLE AND THAT IT IS NOT ALWAYS POSSIBLE TO PREDICT WHETHER THEY WILL STIMULATE OR INHIBIT.

\#RAOIOBIOLOGY + FRANCE + RADIDTION EFEECT + RADIOISOTOPE

$14-20739$

PIHULEAC I

ALSO IN CATCGORY 12

DECONTAMINATION OF SUFFACES AND OSJECTS CONTAMINATED WITH RADICACTIVE MATERIALS. IV. EXPERIMENTAL PART. USE OF INDIGENGUS LAUNDER ING AGENTS FOR THE DECONTAMINATION CF TEXTILE MATERIALS

6 PAGES, 9 FIGUKES, 4 REFERFNCES, REV. CHIM. (BUCHAREST), 17, PAGES 6G7-702 (NOV. 1966) IN RUMANIAN

TO PRDTECT LATEP USEP.S, CONTAMINATING FADIOACTIVE MATERIALS MUST BE REMOVED FROM SPECIAL PROTECTIVE EQUIPMENT OF ORDINAPY CLOTHING, BY WASHING THEM IN SPECIAL LAUNDERING SOLUTIONS. 
$14-20739$ * CONT INUED*

TESTS WITH COTTON SPECIMENS SOAKED IN AOUEQUS SOLUTIONS CONTAINING I-131, BA-131, P-32, CE-14!, AND FE-5\% REVEALED THAT REST RESULTS WEPE OBTAINED EY WASHING TREM WITH A SOLUTIGN CONTAINING 0.2\% OE A DFTERGENT AND $0.3 \%$ CF A COMPLEXING AGENT, SUCH AS SODIUM

HEXAMETAPHOSPHATE OP SODIUIA EDTA. THREE WASHING AND RINSING CYCLES OF 5-MIN. DURATION EACH WERE BEST. THE DETERGENTS DEFC-40, PENETROL, $\triangle N D$ ALBA SUPER, OF RUMANIAN MAVUFACTURE, WERE USED IN THE TESTS, WHICH WERE CAR.FIED OUT BY DETERMINING THE COUNT RATE AT VARIOUS STAGES OF THE DECONTAMINATION PROCESS.

\# DECONTAMINATION + RADIATION PROTECTION, CHEMICAL

14-21137 ALSO IN CATEGORY 15

GREEN FL

USES ANO SAFETY ASPECTS OF THE LOW-ENERGY SOURCE YR-16S

VISO CORP., BURLINGTON, MASS.

5 PAGES, I TABLE, 3 FIGURES, 6 REFERENCES, AMERICAN INDUSTRIAL HYGIENE ASSOCIATION JOURNAL, 27 , PAGES

444-448 (SEPT. OCT. 19E6)

THE RADIOACTIVE SOURCE YTTERBIUM-IES EMITS A 52-KEV CHARACTERISTIC XRAY AND VARIOUS GAMMA RAYS WITH ENERGIES FROM 65 KEV TO $210 \mathrm{KEV}$. YTTEREIUM SJURCES IN SMALL EXPCSURE UNITS WEIGHING $\triangle B O U T 2 O$ POUNDS ARE USEFUL FRF. RADICGRAPHY OF CASTINGS, WELDMENTS, ASSEMBLIES, AND OTHER FORMS OF VARTOUS MATERIALS, SUCH AS ALUMINUM, MAGNESIUM, IRON, PLASTICS, AND WOOD. RADIOGRAPHY WITH YB-169 PRODUCES NO HAZARD FRCM ELECTRICAL SHOCK OR EXPLOSION. RADIATIGN SCATTERED FROM AIR, THE OBJECT, $\triangle N D$ SURROUNDING MATERIALS IS LESS WITH YB-16\% THAN WITH CONVENTIDNAL X-RAY SOURCES, IP-102, OR CC-60. THEREFORE, PORTABLE RADIOGRAPHIC APPLICATIONS CAN BE MADE WITH LESS DIFFICULTY IN PROTECTION OF PERSONNEL.

*RAOIOGRAPHY + GAMYA + SOURCE, RADIATION + X-RAY + YTTERBIUM

$14-21141$

LITTLE JB

ALSO IN CATEGORY 15

ENVIRONMENTAL HAZARDS - IONIZING RADIATION

HARVARD SCHOOL OF PUBLIC HEALTH, BOSTON, MASS.

10 PAGES, 4 TABLES, 25 REFEPENCES, NEVI ENGLAND JOUKNAL OF MEDICINE, 275, PAGES 929-938 (OCT. 27, 196S)

REVIEWS EVIOENCE POINTING TO FACTS THAT SUPPORT THE THECRIES THAT THE MAJOR BIOLOGIC EFFECTS OF IONIZING RADIATION AT LDW DOSES $\triangle N D$ LOW DOSE RATES ARE CARCINOGENIC AND THAT THE PRODUCTIDN DF GENETIC MUTATICNS IN THE GONAOS IS PASSED ON TO OFFSPRING. THE BIOLOGICAL

EFFECTS OF IONIZING RADIATIONS ON INDIVIDUALS AND POPULATIONS ARE DISCUSSED. CONSIDERATICN WAS GIVEN TO THE MANY POSSIBLE SOURCES OF RADIATION THAT CAN BE HAZARDOUS TO MAN.

*RACIATION DAMAGE + \#RADIOBIDLOGY + RADIATION IN PERSPECTIVE + FADIATION INJURY, TREATMENT OF + RADIOLOGY

$14-21142$

SEIDLER H + NAERT16M

THE REMOVAL OF SR-90 FROM MILK. PART I S SURVEY OF LITERATURE AND EXPERIMENTS ON THE USE OF BONE PREPARATIDNS AS ADSORBENTS.

INSTITUT FUER ERNAEHRUNG, POTSDAM-FEHBRUECKE, GER.MANY

9 PAGES, I FIGURE, REFERENCES, NAHRUNG, $\$$, PAGES 735 43 (1965) IN GERMAN

REVIEWS PREVIOUS REPORTS (55) PRLATING TO HAZARDS OF FALLOUT SR-SO IN DAIRY PRODUCTS AND ITS REMOVAL FROM MILK. DISCUSSES FACTORS THAT MUST BE CONSIDERED RELATIVE TO THE NECESSITY FOF. DECONTAMINATING RESTR ICTCO QUANTITIES OF MILK IN CASE OF A NIJTLEAR OISASTER. ALSO DEALS WITH $\triangle R E$ THE CISTRIBUTION OF SR-90 IN MILK ANO THE REDUCTION OF THE SR-9O ACTIVITY IN MILK ANC. MILK PRODUCTS THAT CAN BE OBTAINEO BY SIMPLE PROCEOURES. $\triangle$ SURVEY IS GIVEN OF THE RESULTS OF INVESTIGATIONS ON THE EFFICIENCY OF BONE PREPARATIONS IN REMOVING SR-SO FROM MILK. SURVEYS PUBL ICATIONS DEALING WITH THE DECCNTAMINITION UF MILK EY MEANS OF RESIN ION EXCHANGERS. TIIC COST OF SR-9O REMOVAL BY VARIOUS METHODS IS ALSO ESTIMATED.

* BIOLOGICAL CONCENTRATION, GENERAL + \#BIOLOGICAL CONCENTRATION, MILK + ADSORPT ION + BIOLOGICAL CONCENTRATION, FOOD + GERMANY + ION EXCHANGE + STRONTIUM

$14-21162$ ALSO IN CATEGORY 15

SAMA:CHSON J + SCHECK J + SPENCER H

RADIOCALCIUM ABSORPTION AT DIFFERENT TIMES OF DAY

VETERANS ADMINISTRATION HOSPITAL, HINES, ILL.

3 PAGES, 1 TABLE, 8 REFERENCES, AMERICAN JOURNAL CLIN. NUTR, 18 , PAGES 449-51 (JUNE 19E6)

TO DETERMINE WHETHER THE ABSORPTION OF CALCIUM DIFFERED AT DIFFERENT TIMES OF THE DAY, TRACEP DOSES OF CA-47 WERE AOMINISTERED WITH THE MORNING AND EVENING MEAL, IN SEPARATE STUDIES, TO PATIENTS WIIO WERS ON A CONSTANT OIETAPY INTAKE IN THE METABOLIC WARD. THE TRACER DOSE WAS GIVEN TO TWO PATIENTS ON A LCW CALCIUM INTAKE, TWO ON A MEDIUM CALCIUM INTAKE, AND TWO ON A HIGH INTAKE. THE VARIABILITY OF ABSORPTION FROM MORNING TO EVENING DOSES WITH ANY LEVEL OF CALCIUH INTAKE WAS $\triangle B O U T$ EQUAL TO THE VARIAEILITY OF REPEATED MORNING DOSES INGESTED ON DIFFERENT DAYS, AND THE ABSORPTION OF CALCIUM WAS NOT CONSISTENTLY GREATER AT EITHER TIME OF DAY. IT THEREFORE APPEARED THAT THE INGESTION OF RADIOCALCIUM WITH A SINGLE MEAL REFLECTED WITH REASONABLE ACCURACY THE ABSORPTION GF CALCIUM OURING THE DAY. 
R DDIONUCLIDE FELEASE ATEG MOVEMILNT IN THE ENVIRONMENT

14-21162 * CONT INUEC*

BIOLOGICAL CONCENTRATION, MAN + BIOMEOICAL + CALCIUN + NIETAOY HAQIT + FADIOEIOLCGY

$14-21186$

FISH $3 R$

SUR,FACE CONTAMINATION

415 PAGES, FIGURES, TAELES, D.EEEFENCES, PERGAMON PEESS, NEW YOPK, IOST DROCEERINES OE L SYMPOSIUM HEI.O DT GATLINBURG, TENNSSSEE, JUNE $19 E 4$

CONTAINS 54 OAPERS AND ABSTRACTS ON SURECCE CONTAMINATION. TCOICS INCLUOF PEOOEETIES NF AEROSOLS, INSTF.UMENTATIOV FOR MEASUREMENT OF ACROSOLS, HEALTH HOZAROS, SUF= ACE OFCOERTIES, ADSORPTION, REOISPEKSILN, DECONTAMINATICN, CLEAN ROOMS, ETC.

AVAILABILITY - PERGAMQN PRESS, 44-CI 2 IST ST., LONG ISLAND CITY, NEW YCRK IIIOI

\#DECONTAMINATION + \#SURFACE CONTAMINATION + ADSORPIION + ADSORPIION SURFACE + AFLOSTL + DISPEPSICN + RADIOISOTOPE

$14-21187$

DAVIS LP

DEPOSITION OH SUBMICGCN-SIZE DARTICLES IN VENTILATION DUCTS

OAK RIDGE NATIONAL LAQOKATORY, OAK FIOGF, TENV.

8 PAGES, E EIGURES, $\angle$ REFEFENCES, PAGFS 121 TI I SE SUPFACE CONT AMINATIEV, PEFGA

PROCEECINGS OF A SYMPOSIUM HELO AT GATLINEUEG, TENN., JUNE 1064

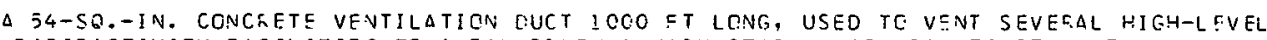

RAOIOACTIVITY FACILITIES TO A FAN EELCN A MAIN STACK, WAS USEO TO STUOY THE JEOCSITIGN

BEHAVIRR DF DAFTICLES CF O.DOI MICECN TO I.O MICRON WITH LIMLENIRATIONS CREA I TR ICCO NG/CU.

HETEP. AN EOUATION WAS DEVELREED THAT PFOVIDES D PLAUSIRLE NECNS JF PFENICTING OFCEFASES IN

CONCENTRATION DUF TO DEPOSITION. THE DREDICTED OECGEASE IN CONCENTOATION CER THE

COVCENTRATION INVSSTIGATED IS RIELIGIELF, BUT THE CONTGMINATIJNi OV THE OUCT NALLS CONNOT BE

OVERLOOKED.

AVAILABILITY - PERGAMON PRESS, 44-0I 2!ST ST., LONG ISLAND CITY, NEW YORK 11101

\#DEPOSITION + AEROSOL + MATHFMATICAL TFEATMENT + VENTILATIGN SYSTEM

$14-21188$

SPANGLER GW + WILLIS CA

PRFMISGIQLE CONTAMINATION LIMITS

UNIVERSITY OF CAL I FTTRNIA, LOS ANGELES + LTOMICS INTERNATIÓNAL, CANOGA PARK, CALIF.

a PAGES, 5 FIGUFES, I TABLE. I 7 REFEFENCES, DAGES 151 TO 159 OF SURFACE COVTAMIVATION, DFRGAMON DFESS, NEW

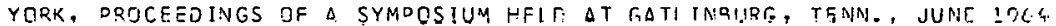

TWE APPROACHES TO THE DETERMINATION CF PCL VALUES BASED ON HAZAPDS WERE CONSIOER SD. EACH

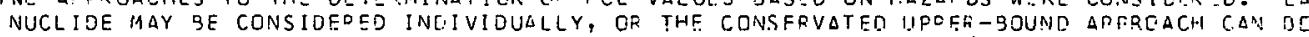
AUPLIEU. THE UPOER-BOUND METHOD WAS CHOSEN. IT WAS CONCLUDED - III SUFFACE CONTAMINATICN

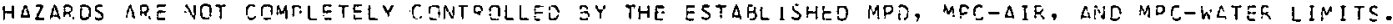
(2) PERMISSIBLE CONTANINATION LIMITS SASSD ON A COVSERVATIVE ASSESSMENT ZF COTFNTIAL

INHALATION ANC DIRECT CAOIATION HALAHC AEE SUFFICIENT TO PFOTECT AGAINST CTHEC SURFACE

CONTAMINATION HAZARDS. (2) CURRENT DETA APPEARS INSUFFICIENT FCR THE ESTADLISHMENT CF

SPECIFIC PCL VAIIIFS FOP INOIVITIJAL ISETCYFS.

AVAILABILITY - DERGANON PRESS, 4L-OT 7!ST ST, LONG ISLAND CITY, NL: YCRK IIIOI

\#CONTAMINATION + DOSE CALCULATION, INTEDNAL. + EDIDISOTOPE

$14-21189$

MORGAN G3 + GALBFAITH EH I GILCREAS FW

THE ADSORPTION OF VARIOUS RADIOISOTOPFS UFEN SELECTFD MATERIALS

U.S. PUSLIC HEALTH SERVICE, CINCINNATI, CLIJ

10 PAGES, 4 FIGURES, \& TASLES, 4 REFSOENCES, PAGES 35 TO 44 OF SUF.FACE CONTAMINATION, PEPGAMON PSESS, NEW

YORK, PROCEEDINGS DF A SYMPOSIUM HELO $\triangle T$ GATLINBURG, TENN., JUNE 1 CG4

THE ADSORPTION OF RAOIOISOTJOFS UPQN COMMON CONSTPUCTION MATEFIALS NAS INVESTIEATEO. RADIOISOTODES WERE CONTAINED IN SOLUTIONS AT PH 6.0, WITH AN IONIR. STRENGTH BF ABOUT O.COOL. MATERIALS IVYESIIISATH WFRS LINE GLASS, PYEEX, PARAFFIN, MYLLR, POLYPROPYLENE, PULYETHYLENE, BUTADIENE RUBBER, $\triangle N D$ NCOPFENE RUPGER, $\triangle O S O F O T I O N$ ON GLASS IS A FUNCTION RE ALKALI JXIDES IN THE GLASS. HIGH-SILICA GLASS DDSCRPS LESS THAN LIME GLASS. ADSORPTION DEGREASES AS PH OECREASES. ZN-65 WAS ADSGOSED TO THE GREATEST EXTENT. POLYETHYLENE AND DOLYPRCOYLENE WEFE LEAST AOSORBENT. NEOFELNE FUGPEF, RECAUSE IIF IIS MULSCULAR CONFIGURATION, ADSDRES TO THE EXT CNT THAT IT SHOULD BE CLOSSIFIFE AS AN I ZN EXCHANGE FESIN.

AVAILABILITY - PERGAMIN PFESS, 4L-01 2.1ST. ST., LING ISLAND CITY, NEW YORK 11101

\#ADSORPTION + MATERIAL + RADIOISOTOPE

ACCESSION NUIAESR $14-? 116 ?$ TO $14-21189$ 
RADIONUCLIDE RELFASE ANEG MOVEMENT IN THE ENVIRONMENT

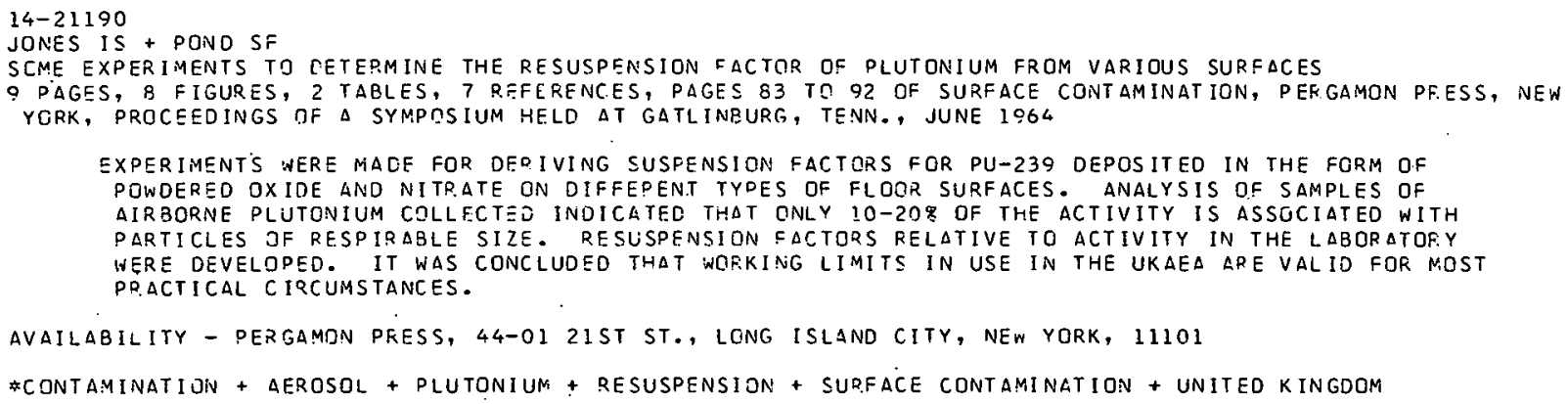

AVAILABILITY - PERGAMON PRESS, 44-01 21 ST. ST., LONG ISLAND CITY, NEW YQRK 11101

* CONTAMINATIGN + oRNL + RADIATION IN PERSPECTIVE + RADIUM + SURFACE conTaMINATION

14-21194 ALSO IN CATFGORIES 15 ANO 13

GLAUBFRMAN H + BOOTMANN WR + RRESLIN AJ

STUDIES OF THE SIGNIFICANT OF SURFACE CONTAMINATION

USAEC, HEALTH AND SAFETY LAB

10 PAGES, 3 FIGURES, 6 TASLES, 5 REFERENCES, PAGES 1 G9 TO 178 OF SURFACE CONTAMINATION, PERGAMON PRESS, 
$14-21194$ \#CONT INUEC*

NEW YORK, PROCEEOINGS OF A SYMPOSIUM HELC AT GATLINBUFG, TENN., JUNE 1964

STUDIES ARE REPORTED ON SURFACE AND AIRBOPNE CONTAMINATION IN PLUTONIUM- AND URANIUM-PROCESSING FACILITIES AND IN A BERYLLIUM REFINERY. THE DATA INDICATE THAT AIR-SURFACE CONTAMINATIIN RELATIONS DERIVED AT ONE FACILITY WILL NOT BE VALID AT ANOTHER EXCEPT BY COINCIDENCE. FOP. URANIUM FACILITIES AND THE BEPYLLIUM FACILITY, LIMITS OF SUPFACE CJNTAMIVATION WOULO APPEAR TO BE MEANINGLESS BECAUSE SOURCES OF CONTAMINATION OTHER THAN SURFACE CONTAMINATION ARE DREDOMINANT IN TERMS OF CONCENTRATION IN AIR. FOR MATEPIALS OF GREATER SPECIFIC ACTIVITY THAN UPANIUM, SUCH AS PLUTCNIUM, SURFACE CONTAMINATION CAN BE THE SOURCE OF EXCESSIVE JUST CONCENTRATIDN IN AIR.

AVAILABILITY - PERGAMON PRESS, 44-01 21ST. ST., LONG ISLAND CITY, NEW YORK 11101

* CONTAMINATION +. AERQSOL + BEPYLLIUM + PLUTONIUM + SURFACF CONTAMINATION + URANIUM

$14-21195$

PRINCE JR + WANG CH

A METHOD FOR EVALUATINGG SURFACE CONTAMINATIDN OF SOFT BETA EMITTERS

OREGON STATE UNIVERSITY

E PAGES, 4 TABLES, 9 REFERENCES, PAGES 179 TO 183 OF SURFACE CONTAMINATION, PERGAMON PPESS, NEW YOFK, PFOCFEDINCS OF I SYMPOSIUM HELD AT GATLINBURG, TENN., JUNE $1 \% 04$

THE PURPOSE OF THIS REPORT IS TO SHOW HOW THE TECHNIQUE OF LIQJID SCINTILLATION CDUNTING CF PAPER STRIDS CAN BF APPLIED TO THC PROBLEM GE EVALUATING SWIPES FROM SURFACES CCNTAMINATED WITH S.FT 3ETA EMITTERS. SACTOF.S TO BE CONSIDERED IN APPLICATION DF THE METHOD ARE - (I) THE COUNTING EFFICIENCY, WHICH CAN BE AFFECTED BY THE TYPE OF FILTER PAPER, THE COMPOSITION CF THE COUNTING SCLUTION, AND THE SOLURILITY OF THE RADIOCONTAMINANT IN THE COUNTING SOLUTICN, AND (2) THE OARAMETFRS WHICH INFLUFNCE THF SWIPE TEST SUCH AS SURFACE PORCSITY, WET OR DFY SWIPE, ETC.

AVAILABILITY - OEOGAMON PRESS, 44-0I 21 ST ST., LONG, ISLAND CITY, NEW YOOK 11101

* Contamination + seta emitter + surface contamination + tritium

14-21196 ALSO IN CATEGORY 15

DUMMER JE

EVALUATION OF SP-90 + Y-90 SURFACE CONTAMINATION USING RADIATION SURVEY INSTRUMENTS

LUS ALAMUS SCIENIIFIL LABURATUMY, NEW MEXICO

11 PAGES, 7 IGURES, E TABLES, 25 REFEPENCES, PAGES 185 TO 195 OF SUPFACE CONTAMINATION, PERGAMCN PRESS, NEW YORK, PRJCEEOINGS OF A SYMPOSIUM HELD AT GATLINBURG, TENN., JUNE 1964

THIS WORK WAS GESIGNED TC PROVIOE (1) A GELATIONSHIP BETWEEN GAMMA-RADIATION SURVEY-METEP READINCS AVD THE QUANTITY DT BETA CMITTLR ON VARIOUS SURFACES, AND (2) A CORRELATION SETVEEN TRUE SURFACE COSE RATE ANO THE INDICATED CONTACT DOSE RATE AS MEASURED WITH SURVEY-TYDE INSTRUMENTS ECQ A BETA-EAITTING ISCTOPE. AN INDICATED O.OS MR/HR WOULO BE MEASURED FROM A 0.0006-!AICROCLRIE POINT SOURCF OR FROM AN EXTENDED SOURCE OF $1.8 \times 10$ (-5TH) MICFDCURIE PER SO. CM. THE SURFACE DOSE RATE FROM SUCH A POINT SOURCE WOULC AE 1.2 MRAD PER HR, AND FROM THE EXTENDED SOURCE, 0.28 MRAD/HR.

AVAILABILITY - PERGAMON PRESS, 44-0I 2IST ST., LONG ISLAND CITY, NEW YORK 11101

\#CONTAMINATION + FOOSE CALCULATION, EXTERNAL + \#SURVEY, RAOIATION, GENERAL + STPONTIUM + SUREACE CONTAMINATION + SURVEY, RADIOTION, ENVIRONMENTAL + YTTRIUM

$14-? 1197$

WILSON R + VIVIAN GA

PERFORMANCE OF SURFACE CONTAMINATION DETECTORS FOR ONTARIO HYDRO MAXIMUM PERMISSIBLE LEVELS OF SURFACE CONT AII INATION

MEDICAL SERVICES DIVISION, DNTARIO HYORO, TDRONTO

4 PAGES, 3 FIGURES, Z TABLES, 3 QEFERENCES, PAGES 107 TO 200 OF SURFACE CONTAMINATION, PERGAMON PRESS, NEW YORK, PROCEEOINGS OF A SYMDOSIUM HELO AT GATLINBUDG, TENN., JUNE 1964

THE RESPJNSE OF A GIVEN DSCONTAMINATION DETECTOP. TO SURFACE CONTAMINAT ION DEPENDS ON THE TECHNIQUE OF THE USER. THIS IS A REPCRT CF THF TECHNIOUE USEO TO DETERMINE THE BEHAVIOP OF THE SURFACE CONTAMINATIOV OETECTORS AT THE NPD AND THE RESPONSE OF THESE INSTPUMENTS FOR MAXIMUM PERMISSIBLE LEVELS OF SUPFACE CONTAMTNATION.

AVAILABILITY - PERGAMCN PRSSS, 44-01 21 ST ST. LDNG ISLAND CITY, NEW YORK 1IIOI

\#CONTAMINATION + CANADA + FISSION PROCUCT ACTIVITY, GROSS + SURFACE CONTAMINATION + SURVEY, YADIAIIUN, GENEKAL

14-21.198

ROYSTER GW I. BIRNEY FF

TECHNIOUES EOR ASSESSING REMOVABLE SURFACF CONTAMINATION

MAK RINCE NATITNAI I $\triangle R A R A T A R Y$

7 PAGES, 7 FIGURES, I TABLF, PAGES 201 TO 207 OF SUFFACE CONTAMINATION, PERGAMON PRESS, NEW YORK, 
$14-21198 \%$ CONT INUED

PROCEEDINGS OF A SYMPOSIUM HELD IN GATLINBURG, TENN., JUNE 1964

THE PURPOSE OF THE STUDY WAS TO EVALUATE THE SMEAR AND ADHESIVE-PAPER METHODS FOR MEASURING SURFACE CONTAMINATION AND TO COMPAPE THESE WITH D NEW METHOD DF SAMPLE COLLECTICN EMPLOYING AIR IMPINGEMENT TO REDISPERSE LOOSE CONTAMINATION ANO COLLECTION DF THE RESULTING AIREORNE MATERIAL ON A FILTER. IT WAS FOUND THAT CONVENTIONAL MEASURING TECHNIQUES FOR EVALUATING THE HAZARD AR ISING FROM DEPOSITEL RADIOACTIVITY AFF. GROSSLY NONQUANTITATIVE. ALL VARIABLES WHICH MATERIALLY AFFECT REDISPERSION SHOULO BE TAKEN INTO CONSICERATION WHEN EVALUATING A SPECIFIC SITUATION.

AVAILABILITY - PERGAMQN PRESS, 44-0] $215 T$ ST., LONG ISLAND CITY, NEW YORK 11101

*CONTAMINATION + SAMPL ING + SURFACE CONTAMINATION + SURVEY, RADIATI.ON, general

$14-21199$

KERRIGAN WJ,

PREPARATION OF STANDARDIZED TEST DUSTS

SAVANNAH RIVER LABJRATORY, AIKEN, SOUTH CAROLINA

8 PAGES, 11 FIGURES, 7 F.EFERENCES, PAGES $21 \%$ TO 226 OF SURFACE CONTAMINATIDN, PEPGAMON PRESS, NFW YORK, PROCEEOINGS OF A SYMPOSIUM HELD IN GATLINBURG, TENN, , JUNE 1 SOS

THE TWO-STEP OPERATION DESCRIPEO PRODUCES A DUST WHOSE FREQUENCY DISTRIBUTION IS GREATER THAN 0.2 MICRON BUT LESS THAN 44.0 MICRONS. THIS DUST CAN RE STURED IN A SEALED VIAL AND RTOISPERSED AS REQUIREO. THE DUST IS SIZED BY THE LESS ELAGCRATE ANDLESS EXPENSIVE METHOOS OF DPTICAL MICROSCOPY.

AVAILABILITY - PERGAMON PRESS, 44-01 21 ST ST., LONG ISLAND CITY, NEW YORK 11101

*AEROSOL + ALUMINUM + UQANIUM

$14-21200$

PUTZIER EA

SOME NEW CEVICES USEO IN PLUTONIUM CONTAMINATION CONTROL

THE DON CHEMICAL COMPANY, GOLDEN, COLORADO

5 PAGES, 5 FIGURES, PAGES 229 TO 233 SURFACE CONTAMINATION, PERGAMUN PRESS, NEW YORK, PROCEEDINGS GF A SYMPOSIUM HELD IN GATLINBURG, TENN., JUNE 1964

THREE SIMPLE DEVICES WERE DEVELOPEO TO DETECT AND CONTROL CONTAMINATION RELEASE. THEY ARE THE ALPHA FLASHER (A TRANSISTOP IZED AIR PROPORTIONAL COUNTER), THE DONNDRAFT GLDVE CHANGE HOCD, AND THE GLOVE CHANGE RING.

AVAILABILITY - PERGAMON PRESS, 44-01 21ST ST., LONG ISLAND CITY, NEW YORK, 11101

\#CONTAMININI ION + \#INSTRUNMENTATION, RADIATION MONITORING + AEROSOL + AIR + PLUTONIUM + RADIOACTIVITY RELEASE

$14-21201$

FRANKE TH

ESTIMATION JF THE DOSE FATE OF FALLOUT DEPOSITION BY X-RAY SPECTROMETRY

MAX PLANCK-INSTITUT FUR BIOPHYSIK, FRANKFUFT, GERMANY

4 PAGES, 4 FIGURES, 7 REFERENCES, PAGES 257 TD 260 OF SURFACE CONTAMINATION, PERGAMON PRESS, NEW YCRK,

PROCEEDINGS OF A. SYMPGSIUM HELD IN GATLINBURG, TENN., JUNE 1964

A MOBILE UNIT FuR DETECTING fallout WAS DEVELOPED. DATA TAKEN WITH THE EQUIPMENT SHOWED THAT IT WAS POSSIBLE TO DETECT DOSE RATES WHICH WERE ONLY $\triangle$ FEW PERCENT OF THE RATE OF THE NATURAL AMBIENT RADIATION.

AVAILABILITY - PFRGMMN PRESS, 44-01 21ST' ST., LONG ISLAND CITY, NER YORK, 11101

*CONTAMINATION + *FALlOUT + *INSTRUMENTATION, RADIATION MONITOPING + gERMANY + SPECTROMETRY, gaMMA + SURFACE CONTAMINATION

14-21202 ALSO IN CATEGORY 15

14-21202 + STODOARTPG + SEVERN FW

PLUTONIU'A MONITOR ING TECHNIQUES FOR ZPR-II

ARGONNE NATIONAL LABORATORY, IDAHD DIVISION

6 PAGES, 3 REFERENCES, PAGES 293 TO 298 SURFACE CONTAMINATION, PEFGAMON PRESS, NEW YORK, PROCECCINGS OF A SYMPOSIUM HELD IN GATLINBURG, TENN., JUNE 1964

OESCRIBES TECHNIQUES AND PROCEDURES FOR MONITORING ANE CONTAMINATION CONTROL FOR THE ZPR III

(PLUTONIUM FUEL LOAOING).

AVAILABILITY - PERGAMON PRESS, 44-01 21 ST ST., LONG ISLAND CITY, NEW YCRK, 11101

*CONTAMINATION + \#,MONITORING SYSTEM, RADIATION + CRITICAL ASSEMBLY FACILITY + PLUTONIUM +

SURFACE CONTAMINATION + ZPR 3 (CAF) 
CATEGCFY 14
PADIONUCLICE PELEASE AND MCVEMENT IN THE ENVIRONMENT

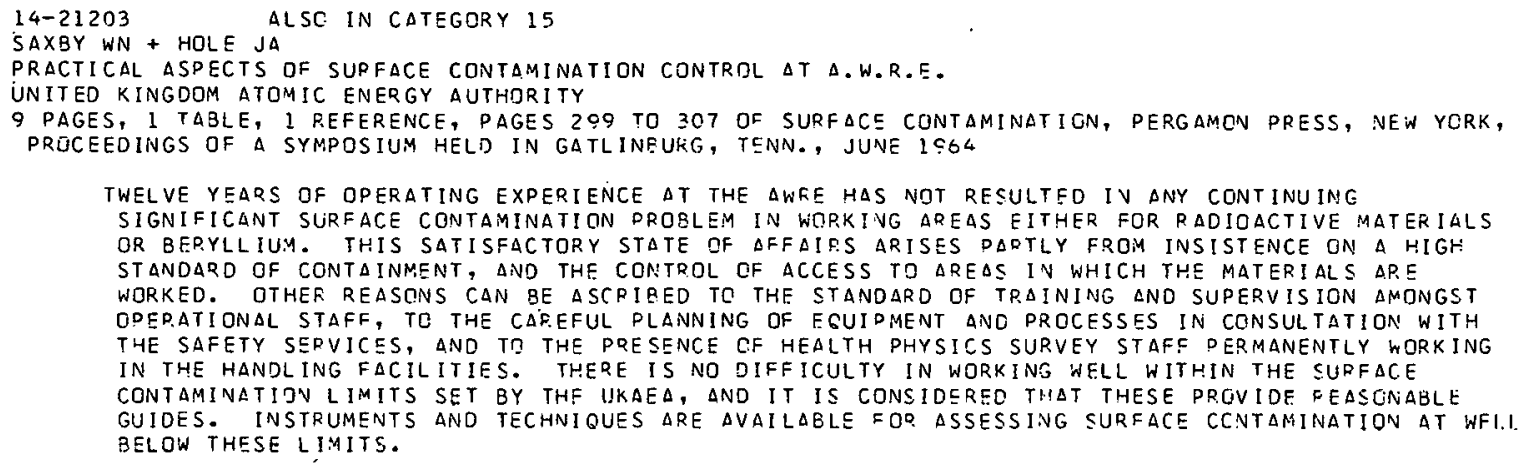


RAOIONUCLICE RELEASE ANDO MOVE IMENT IN THE ENVIRONMENT

14-21207 \#CONTINUEDF

A SYMPOSIUM HELD IN GATLINBURG, TENN., JUNE 1964

DESCRIBES OECONTAMINATIGN PROCECURES ANO FACILITIES. AT HARWELL. INCLUDES DRAWINGS, PHOTOGRAPHS, DNO COPIES OF THE FOFMS USEC IN ATMINISTRATIVE CONTROL.

AVAILABILITY - PERGAMON PRESS, 44-01 21ST ST., LONG ISLAND CITY, NEW YORK, 11101

FDECONTAMINATION + ECCNOMICS + EQUIFMENT, FENERAL + HAFWELL + PROCEDURES AND MANUALS + UNITED KINGDOM

$14-21252$

SHINN $A F$

FRESHIWATER FISHI IN A NUCLEAD DISASTFR

OAK RIDGE VATIONAL LAROK $\triangle T O R Y$

ORNL-D-2954 + CONF-67C208-1+. 12 PAGES, 3 TABLES, 12. REFERENCES, FROM 15T COMMERCIAL FISH FARMING

CONFERENCE, COLLEGE STATICN, TEXAS

FRESH-WATER FISH FAEN.S OFFER RELATIVELY INVULNERABLE SQURCES OF HIGH QUALITY PFOTEIN WHICH INOULD SIGNIFICANTLY CONTRISUTE TO THE MAINTENANCE OF ADEQUATE PRCTEIN INTAKE, AT LEAST IN THEIF, SURROUNOING $\triangle F E \triangle S$ AFTER A NUCLEAR ATTACK. SPORT FISHING COJLD YIELD ABOUT $20 \%$ OF AVAILABLE EDIRLE FISH.

AVAILABILITY - CLEARINGHOUSE FOR FEDERAL SCIENTIFIC AND TECHNICAL INFORMATION, SPRINGFIELD, VA., \$Z. OO COPY, \$0.65 MICROFICHE

* 9IOLOGICAL CONCENTRATIGN, GENERAL + *CIVIL DEFENSE + EI DLOGICAL CONCENTRATION, AQUATIC ORgANISMS + BIOLOTICAL CJNCENTRATION, FOOD + BIOTA + RADIOBIGLOGY

$14 \div 21253$

ALSE IN C.ATERORY LE

DOSE TO THE THYPOID FFOH INTAKE OF TE-13i. INGESTION OR INHALATION OF TRANSPORTAELE CCMPOUNDS

COMITATG NAZIONALE PEP. L ENFRGIA NUCLFAFE, RCIME, ITALY

RT / PROT-166)27 +. 11 PAGES, 2 TASLES, S FEFERENCES, 1966

THF HIGHEST RISK T? THE POPULATION AS THE RESULT OF AN ACCIDENT IU A REACTCR WOULE BE THE IVGESTION AND INHALATION OF FAUIOIGCINE. ONE SOURCE OF IODINE-1?2 WOULD BE THE DECAY DF TFLLURIUM-132. THIS REPORT PPESENTS A CALCULATION OF OOSE TO THE AOULT THYROID DUE TO INHALATION ANO TÜ INGESTION.

AVAILABILITY - MICRICLZD EOITIONS, INC., ACCOUNTING ANO SHIPPING DEFT., WEST SALEM, WISCONSIN S4GE9

\#RADIOZIJLOGY + \#TFLLURIUM + FALLOUT + INGESTION + INHALATIGN + ICOINE + ITALY + RADIATICN DAMAEE

1 1

WILLARE CH

AI SR: IN CATFGRRY 15

INHALATION $\triangle$ ND RETFNTION UF PU-2ZH MICROSPHERES IN BEAGLE DOGS

BATTELLE-NJETHWEST, FICHLAND, WASHINGTON

BNWL-SA-1105+CONF-E70010-4+. 10 pAGES, 4 FIGURES, 2 TABLES, JULY 14, 1967, FFOM 12TH ANNUAL MEET.ING OF THE HEALTH PHYSICS SOCIETY, WASHINGTON, D. C.

IN THE FIRST EXPEPIMENT, 22 DGGS WERE EXPOSED TO AIR IN WHICH PLUTONIUM-23S DIOXIDE PARTICLES 150 MICPONS IN DIAM) WERE OISPERSEU. IN THE SECOND EXPERIMENT, SINGLE OR SEVERAL 5O-, 12O-, UR I50-MICRON PAP.TICLES WERE PLACEC IN THE LUNGS UF 29 UUGS BY INTUBATION WHILE ANESTHETIZED. WHCLE-BODY LONGITUDINAL SCANNING WAS USED TO FOLLOW THE COURSE DF THE PARTICLES IN THE DOGS. INHALED PLUTONIUM PARTICLES WERE CLEARED BY ALL DOGS BY 16 DAYS AFTER EXPOSURE. PARTICLES PLACED IN LUING RY INTUBATION WEP.E CLEARED MORE SLOWLY, BUT ONLY THREE DOGS RETAINED PARTICLES PAST SIX MONTHS. NO BIOLOGICAL EFFECTS HAVE EEEN OBSERVED EXCEPT FOR A POSSIBLE LYMP.HOPENIA IN TNE OOG, WHICH RETAINED A 3OO-MICRON PAKTICLE FOR OVER A YEAR.

AVAILASILITY - CLEARIS:GHDUSE FOA FEDEPAL SCIENTIFIC AND TECHNICAL INFORMATION, SPRINGFIELD, VA., \$?. OO COPY, \$2. 5 MICROFICHE

* RACIOBIOLJGY + AEROSOL + AIRPOP.NE FELEASF + BATTELLE NORTHWEST + INHALATION + PARTICLE SIZE +

PAOTICLE, PADIOACTIVE + PLUTONIUY + PADIATION DAMAGE

$14-21257$

OZISIK MN + HUGHES D

EFFECTS OF NGN-QUIESCENT ATMOSPHERE IN CONTAINMENT VESSELS ON OISPEFSION OF FISSION PRCDUCTS. 'PROGRESS

REPORT NO. 3

NORTH CAROLINA STATE UNTVEFSITY

TID-23969+. IS OAGES, P.EHEKENCES, APRIL 1067

THE DEOOSITION DF AIRBORNE FISSIDN PFODUCTS ON INNER SURFACES OF REACTOR VESSELS AND ON CDUIPMENT SURFACFS WAS EVALUATEO MATHEMATICALLY. THE RESULTS WERE COMPARED WITH SIMULTANEOUS DEPJSITION ANE CONDENSATIGN MEASUREMENTS IN THE NUCLEAR SAFETY PILOT PLANT AT ORNL.

AVAILABILITY - CLEARINGHQUSE FOP. FELEPAL SCIENTIFIC ANG TECHNICAL INFOPMATION, SPRINGFIELD, VA., \$3. OO COPY, \$0.65 MICROFICHE 
RAOIONUCLIDE FELEASE ANEGORY MOVEMENT IN THE ENVIRONMENT

14-21257 *CDNT INUED*

\#FISSION PRODUCT TRANSPOQT + \#MATHEMATICAL STUDY + CONDENSATION + CONTAINMENT, GENERAL + DEPOSITION

$14-21250 \quad \Delta L S C$ IN CATEGQRY 15

ATTILLA H

THE EFFECT CF NUCLEAR PCWER PLANTS CN THEIP ENVIRONMENT

ORNL-TR-1773 +. 17 FAGFS, 1 FIGURE, 4 TARLES, TRANSLATED FROM ENERGIA ES DTOMTECHNIKA 20, PAGES 75-91

$(1967)$

A NUCLEAR POWER PLANT IS CONSIDERED AS A PLANT PFODUCING RADICACTIVE WASTE. SEVERAL OPERATIONAL EXPERIENCES GAINED IN CGNNECTION WITH THE DISPOSAL OF LIQUID RADIOACTIVE WASTES ARE PRESENTED. THE FORMATION AND CCMPOSITION OF GASEOUS RADIDACTIVE WASTES APE DISCUSSED. THE HANDL ING CF F.ADIOACTIVE DUST AND GASES IS CONSIDERED. THE DISCHARG ING INTO THE ATMOSPHERE JF RACIOACTIVE AIR AND THE FACTORS INFLUENCING THE MOVEMENT OF CONTAMINATION ARE DISCUSSED. THE EESULIING CONCENTFATION IS CALCULATED. THE EVALUATION DF THE PLANT LOCATION IN TEF.MS OF SAFETY IS DESCRIP.FN. C.ONSIDERATIONS RELATED TO DETERAIINING THE SIZE QF THE EXCLUSION ZONES TO EE USED AT THE POWER PLANT ARE PRESFNTED.

AVAILADILITY -- CLEARINGHCUSE FOR FEOERAL SLIENIIFIC DND TECHNICAL INFORMATION, SPRINGFIELD, VIFGINIA $22151, \$ 3.00$ COPY, \$O.CD MICPONEGATIVE

* WASTE DISPOSAL, gENEPAL + *WASTE MANAGEMENT + \#WASTE STORAGE + hungaRY + WASTE DISPOSAL, GaS + WASTE DISPOSAL, LIQUID + WASTE DISPOSAL, SOLID

$14-21260 \quad A L S C$ IN CATEGORY 15

PUFRTO RICO NUCLEAR CENTER DNNUAL REPORT 1966

PUERTO RICO UNIVERSITY

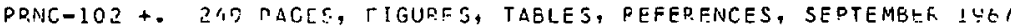

ACTIVITIES ARE IN THE FOLLONING CATEGORIES - EDUCATIGN AND TSAINING IINCLUDING NUCLEAR SCIENCE ANO TECHNOLOGY, NUCLEAR ENGINEERING, RAOIOISOTOPE APPLICATIONS AND OTHERI, BIOL CGICAL ANO MEOICAL P.ESEAPCH OROGRAMS IINCLUDING MARINE EIOLOGY, TERRESTRIAL ECCLOGY, RADIATION

CHEMISTRY, SCHISTOSOURA MANSONI PRCJECT, AND SUGARCANE BORER PPOJECT), PHYSICAL RESEARCH PROGRAMS (NEUTRON DIFFRACTION, SOLID STATE PHYSICS, AND HOT-ATCM CHEMISTRY), ANC PADIATION PRESERVATION OF TDOPICAL FODOSTUFFS.

AVAILABILITY - CLEARINGHÜUSL + UH FEDEPAL SCIENTIFIC AND TECHINICAL INFORMATION, SPRINGFIELD, VA., \$Z. OO COPY, \$O.\$S MICRDEICHE

* PUERTO RICO + SOLID STATE. DEVICE

$14-21264$

KULEBAKINA LG

MAXIMU:M CONCENTRATION FACTORS OE SR-9O FOR BROWN ALGAE

INST. OF BIOLOGY OF STUTH SEAS, ACADEMY OF SC.JFNCFS, HIKRAINIAN SSR

3 PAGES, 3 TABLES, IC REFEFENCES, DOPOV. AKAD. NAUK UKR. RSR, 1C, PAGE 1318-1320, (196E), IN UKFAINIAN

THE MAXIMUM CONCEN!TRATION FACTOF DF SR-9O FOR CYSTOSEIRA BARBATA WAS DETFRMINED. IT IS FGIIAL

TO 55. THE VALUES UF THE CONCENTFATION FACTORS OF SR-90 IN THIS SPECIES POSSIBLY DO NOT DEDEND ON THE SEASON.

*BIOLOGICAL CONCENTRATIUN, GENERAL + PIOLCGICAL CONCENTRATION, AOULTIC ORGANISMS + FALLOUT + STRONTIUM + USSR

14-21205 ALSO IN CATEGUKY lb

PICKARD RC + FRY RM

ADMINISTRATION BF RAOIOLDGICAL HENLTH POGGFAMS WITHIN TIIE STATE GCVERNMENT

KENTUCKY HEALTH DEPT., FPANKFOP.T

5 PAGES, AMER. J. PUEL IC HEALTH, 57, PAGE 29C-294, (FEG. 1967 )

ADMINISTRATIVF ASFECTS OF A PAOIATION SURVEILLANCE DEPARTMENT ARE CONSIDERED, WITH EMPHASIS CN STAFF, EQUIPMENT, EUDGET, METHODS, LEGISLATION AND REGULATIONS, GOALS, AND REPOPTS. A. MULTIDISCIPLINE PRGGQAM IS NTLESSAFY BECAUSE OF THE COMPLEX INTEPRELATIONS RETWEEN RADIOLOGICAL HEALTH, MEOICAL ANO DENTAL PRACTICE, ENGINEERING, TFANSPORTATION, INDUSTRY, LABOR, AGRICULTURE, CIVIL OSFENSE, SPACE EXPLOFATION, AND OTHEP REGULATORY TRGANIZATIONS. FACILITIFS REGIIIRFO FOR A RAOIOLOGICML HEALTH PPCCOAM AND TIIE FEOCUREMENT OF RADIATICIV MONITORING ANC MEASURING EQUIPMENT ARE DISCUSSEC. AN IMPORTANT PDINT IN THE SELECTION DF INS:RUMENIATILIN IS THE EASE GF MAINTENANCE OR THE AVAILAEILITY OF QUALIFIED PERSONNEL TO ENSURE ACCIRATELY FUNCTIONING EQUIPMENT AT ALL TIMES. IT IS IMPORTANT THAT STATE STATUTES EE SOUNDLY [STAOLISHED TO DEVELQP A PROGFAM UNUED PPIJHER LEGISLATIGN.

\#RADIATION PROTECTION, GRGANIZATION + \#PADIATION SAFETY AND CONTROL + AOMINISTRATIVE CONTROL + RADIOLOGICAL ASSISTANCE + REGULATION, STATE 
$14-21266$

IWASHIMA K + YAMAGATA N

ENVIRONMENTAL CONTAMINATION WITH PADICRUTHENIUM 1061-1965

INST. OF PUBLI C HEALTH, TOKYO

21 PAGES, 3.FIGURES, 17 TABLES, 20 f.EFERENCES, J. RAOIAT. RES. (JAP.) 7, PAGE 91-111, (JUNE 1966)

SUMMARIZES THE RESULTS OF MEASUFEMENTS OF MEDIUM-LIVED RU-103 AND RU-106 IN AIRBCRNE PARTICLES, FALLOUT, SUPFACE SCIL, PIVER WATER, SEAWATER, FOGDSTUFFS, COMPLETE DIET, AND HUMAN MUSCLE AND LUNGS DURING $1901-1965$. THE MAIN PASSAGE ROUTE OF RU-103 WAS FOUND THROUGH THE FRESH LEAFY VEGETABLES, WHILE RU-106 WAS SUPPLIED BY DIFFERENT FOUTES, I.E., 77\% BY PLANT MATERIALS RAISEO ON LAND, 6\% BY FCICCSTUFFS OF ANIMAL ORIGIN, $\triangle N D$ THE REMAINDER EY SEAWEED. THE CONCENTRATION WAS HIGHEST IN THF LAST ITEM. THE MAXIMUM PERMISSIBLE CONCENTRATION OF RU-106 IN SEAWATER WAS SUGGESTED AS $3 \times 10(-6 T H)$ MICROCLRIE/ML.

\#EIDLOGICAL CONCENTRATION, FOOD + \#FALLOUT + \#MAXIMUM PERMISSIQLE CONCENTRATION (MPC) +

BIOLOGICAL CONCENTRATION, ARUATIC CRGANISMS + BIOLOGICAL CONCENTRATION, MAN +

BIOLOGICAL CONCENTRATION, VEGETATIGN + JAPAN + OCEAN AND SEA + RUTHENIUM

$14-21269$

JACKSON WB + CARPENTER ML

RADIOISOTOPE CYCLING IN TERRESTRAIL COMMUNITIES AT ENIWETOK ATOLL

BOWLING GREEN STATE UNIV., OHIO

COQ-1485-13+CONF-670503-25+. 13 PAGES, MAY 15, 1S67, PRESENTED AT 2ND NATIONAL SYMPOSIUM ON

RADIOECOLOGY, $\triangle N N$ ARBDP, MICH.

STUDIES IN THE SIMPL IFIED TERRESTRIAL ENVIRONMENT AT ENIKETOK SHOWED A CLOSE CORRELATION BET WEEN THE RADIATION LEVELS OF 137-CESIUM IN SOIL, PLANTS, AND THE ONLY TERRESTRIAL MAMMALS, POLYNESIAN AND ROQF. RATS. BECAUSE OF THE SHORT FODO CHAIN, A CLGSE CORRELATION BETWEEN TESTING ACTIVITY AND THE PRESENCF CF RADIOISOTOPES IN THE ECOSYSTEM EXISTS, AND VARIATICN IN EXPOSURE CUNDITIONS ARE. APDARENT IN ELEMENTS GF THE NATIVE BIOTA. CONT INUED USE OF THESE ISOLATED AND F.ELATIVELY UNDISTURBED MAMMAL POPULATIONS FOR THE STUOY OF LONG-TERM RADIATION EFFECIS IS URGEO.

AVAILABILITY - CLEARIMGHOUSE FOR FEDERAL SCIENTIFIC AND TECHNICAL INFORMATION, SPRINGFIELD, VIRGINIA, $\$ 3.00$ COPY, \$0.65 MICROFICHE

*FALLOUT + *TEST, NEAPONS (HP ASPECTS) + BIOLOGICAL CONCENTRATION, DNIMAL +

BIOLOGICAL CONCENTRATION, GENERAL + CESILIM + ECOLOGICAL CONSIDERATION + RADIOBIOLOGY

$14-21270$

NEUHOLD JIM + SHARMA FK

INTERACTING EFFECTS OF GAMMA RADIATICN AND SODIUM HALIDE CONCENTRATICNS ON RAINBOW TPOUT

UTAH STATE UNIV., LOGAN. DEPT. OF WILDLIFE RESOURCES

COO-1421-4 + CONF-670503-26+. 28 PAGES, MAY 1967, PRESENTED AT 2ND NATIONAL SYMPOSIUM ON RADIOECCLOGY, ANN $\triangle R B O R$, MICH.

MORTALITY OE CS- 137 GAMMA-IRPADIATEO RAINBOW TROUT SUBJECTED TO AQUARIUM-MEDIUM LEVELS OF NAF, NACL, NAER, AND NAI DISPLAYED SIGNIFICANT RESPONSE TO EITHER TIME BY GAMMA DOSE, TIME EY SODIUM HALIDE CONCENTRATION, OP. GAMMA DOSE BY SODIUM HALIOE CONCENTRATION INTERACTIONS. THE INTERACTIONS WERE CONCLUDED TO BE CAUSED BY PADIATION-INDUCED CHANGES IN OXYGEN UPTAKE, SODIUM UPTAKE, $\triangle N D$ EXCRETION.

AVAILABILITY - CLEARINGHOUSE FOR FEDERAL SCIENTIFIC AND TECHNICAL INFORMATION, SPRINGFIELO, VIRGINIA, $\$ 3.00$ COPY, \$0.65 VICRCFICHE

*ECOLOGICAL CONSIOERATION + AQUATIC ORGANISMS + BROMINE + CHLORINE + FLUORINE + IODINE + RARIATION DAMAGE + RACIOBIDLOGY + SODIUM

14-21272 ALSO IN CATEGORY 15

PURLIC HEALTH IMPLICATICNS OF RADON EMITTED FROM URANIUM MILL TAILINGS PILES.

U. S. PUBLIC HEALTH SERVICE, U. S. DEPT. OF HEALTH, EDUCATION, AND WELFARE, NATIONAL CENTER FeR RADIOLOGICAL HEALTH, ROCKVILLE, MARYLAND

HEW-531+. I PAGE, NOVEMBER 3,1967

THE PUBLIC HEALTH SERVICE AND USAEC AGREED ON A JOINT PROSECT TO PROVIDE TECHNICAL ASSISTANCE TO STATES AND INOUSTRY IN EVALUATING PUBLIC-HEALTH IMPLICATIONS OF RADON EMISSION FROM URANIUIA-MILL TAILINGS PILES. WORK TO BE PERFORMED INCLUDES 11 ) THE DEVELOPMENT OF TECHNIQUES FOR SAMPLING AIR FOR RACON CONTENT IN THE VICINITY OF URANIUM TAILINGS, (2) DETERMINATION OF THE EFFECT UDON RADON EMISSIONS WHEN TAILINGS ARE COVEREO WITH EARTH OP. PAVING MATERIAL, ( 3 ) EVALUATION OF ATMOSPHER IC CONCENTRATIONS NEAR TAILING PILES, AND (4) THE PREPARATION, IF NECESSARY, OF RECOMMENDATIONS FOP. THE CONTROL OF RADON EXPOSURE.

AVAILABILITY - PUBLIC HEALTH SERVICE, ROCKVILLE, MARYLANO

*WASTE oISPOSAL, GENERAL + AIR + MILLING + RADIOISOTOPF + RADON + SAMPLING + URANIUM + USAEC 
RAOIONUCLIDE RELEASE CATEGRRY MOVEMENT IN THE ENVIRDNMENT

14-21273 ALSO IN CATEGORY 15

THE OAY H-BOMBS FELL ON PALOMARES

9 PAGES, FIGURES, SATURDAY REVIEW L(4), PAGE 21-27, 39-40, (JAN. 28,1967 )

U.S. STRATEGIC AIF COMMAND BDMEERS CASPYING NUCLEAR WEAPONS ARE IN THE AIR AT ALL TIMES. ONE YEAR AGO-ON JANUAPY 17, 1966, ONE OF THEM, A S-52, COLLIDED WITH A KC-135 JET TANKER DURING A REFUEL ING OPERATION OVER THE MEDI TERRANEAN SEA NEAQ THE SPANISH VILLAGE OF PALOMARES. AMGNG THE RAIN OF DFSRIS WFRE COUR HYDROGEN BOMBS. THF SEAPCH FOR THEM LASTED NEARLY THR.EE MONTHS AND COST AN ESTIMATED \$SO, 000,000. THIS ARTICLE IS THE STORY OF WHAT HAPPENED IN THE VIIIASGF.

*ACCIDENT, GENERAL + *SURVEY, RAOIATION, EMERGENCY + $\triangle$ IRCRAET + PLUTONIUY + SURVEY, RADIATION, ENVIRONMENTAL

$14-21274$

DE LORA SORIA F + DIAZ NOGUE IPA E +. LOPEZ PFQEZ B

TREATMENT OF RADIOACTIVE WASTES RESULTING FPOM THE REPROCESSING OF IRRAOIATED FUELS. SOLUTIONS AOCPTED SY J.E.N. I. LIQUID WASTES OF LOW AND MEOIUM RADIOACTIVITY

16 PAGES, 2 FIGURES, 9 TABLES, 56 SEFEPENCES, ENERG. NUCL. (MADRID), 10, PAGE 2RO-29E, (JULY-AUGUST 19E6) IN SPANISH

VARIOUS WAYS IJH HRUCESSING LIGUID RADIOACTIVE WASTES OF LOW AND MEDIUM RACIDACTIVITY ARE DESCRIBED. YETHCDS DESCRISED INCLUDE HYDROXIOE FLOCCUATION, PHOSPHATE TPEATYFNTS, COPRECIPITATICN OF SULFIDES, ANO FERPOCYANIDE TREATMENTS. IONIC INTERCHANGES, BIDLOGICAL TREATMENTS, AND OTHER METHODS APE ALSC CONSIDEPED. THE METHCDS ADJPTEO BY THE JEN FOR. THE CIES PLANT ARE GIVEN.

*WASTE TREATMENT, GENERAL + ION EXCHANGE + SPAIN + WASTE TRFATMENT, LIOUID

$14-21275$

BOHMAN VR + BL INCOEC + WAQE MA + LESPERANCE AL + FOUNTAINEL

ACCUMULATION OE STRONTIUM IN BOVINE BONES

UNIV. OF NEVADA, D.ENC

3 PAGES, 2 FIGURES, 2 TABLES, 13 REFFRENCES, J. AGR. FODD CHEM. 14, PAGE 413-415, (JULY-AUGUST 196E)

THE SR, SR-GO, AND CA CONTENT OF BGVINE BONE ASH FROM NEVADA FANGE CATTLE AT THREE LOCATIONS WAS STUDIED EFO 1958 TO 1952 , INCLUSIVE. THE LEVEL OF SR-CO WAS INFLUENCED MORE BY WORLD NUCLEAR TESTING THAN BY LOCATIGN GF THE ANIMALS WITHIN THE STATE. PEAK CONCENTRATIONS OCCURRED IN IC59 (1 YEAR $\triangle F T E R$ INITIATION OF THE MORATORIUM) AND IN I962 (I YEAF $\triangle F T E R$ TESTING WAS RESUMEDI. TOTAL SR WAS CHARACTERISTIC OF THE LOCATION OF THE HERD. WHEN A HERC WAS MOVEO FROM AN AREA GH HIGH CUNLENTRATION TO A CORRESPGNOINGLY LOW AREA, THE TOTAL SR IN THE BONE ASH GRADUALLY BECAME SIMILAR TO THAT TN THF NFW FNVIRTNMENT. THE SR-OS CONTSNT OF THE ASH WAS UNRELATED TO EITHER TOTAL SR OR CA. CA LEVEL WAS RELATED TD TOTAL SP, BUT THE C.ORRELATION WAS NOT HIGH (R EQUAL TO 0.5$)$.

FIOLOCICAL CONCENTRATIGN, AAIMAL I TALLOUT + CALCIUM + RAOIOOIOLOGY + STRCINTIUM

$14-21276$

BDNHOTC DA

SOLAR EVAPORATION OF LOW LEVEL RADICACTIVE SLUDGE

AUSTRALIAN ATOMIC ENERGY COMMISSIDN

4 PAGES, 2 FIGUP.ES, REFEFENCES, ATQM. ENERG. AUSTPAL. 9(3), PAGE 14-17, (JULY ISG6)

STUDIED SOLAR EVAPRRATION AS A METHOC OF FURTHER PROCESSING THE SLUDGE 13.5 TO $5.0 \%$ SOLIDS, 0.01 MICRCCIJRIE/MLI PRODUCEN FPOM A SCAVENGING/FLOCCULATION TREATMENT CF LON-LEVEL EFFLUENT AT LUCAS HEIGHTS. PQEL IMINARY EXPEP.IMENTS SHOWEO THAT FILTEPS COULD BE DISPENSFD NITH AND THAT THE SLUDCE COULD BS DRIED IN THC OPEN WITH LITTLE OR NO CONTAMINATION SOEEAL. A FULL-SIZE EVADCRATOE OF 927 SQ. FT APEA WAS DESIGNED TO COPS NITH THE SLUCGE DRTMUICTION RF 15,000 GAL/YR. THE DEYING PEOCECDS UNTIL THE SLUDGE CAN BE CUT INTO BLCCKS, $\triangle V D$, $\triangle T$ THE ENG GF DRYING, THE RLOCKS $\triangle R E$ SHUVELED INTO DRUMS FOR BURIAL. THE PERFDPMANCE IN $1 E$ MONTHS DOERATION IS CESCRIBED. THE VOLUME REDUCTION FACTOR AVERAGES 14, ANO THE MOISTURE GCNTENT CF THE DRIED SLUEGE AVERAGES $27 \%$.

*WASTE TREATMENT, GENERAL + aUSTRALIA + EVAPORATION + WASTE TREATMENT, LIQUID

$14-21279$

TAUTION RECOMMENOED FOR HANDLING AND SHTPPING POLYFTHYIFNF ROTTLES OF PLIJTONIUM NITRATE USAEC OIVISION OF OFCRATIOPIAL SAFETY

2 PAGES, INFORMATION HEALTH AND SAFETY, ISSUE NO, 259, NOVENBER ?0, 1CA7

GROSS LEAKAGE CF PLUTONIUM NITRATE SOLUTION FROM 10-LITER POLYETHYLENE BOTTLES OCCURRED WHILE THEY WERE IV STOFAGE. THE BOTTLES WERE FILLED IN JANUARY 1967 , AND THE LEAKS WEPE FOUNO EARLY IN JULY DUR ING INSPECTICN AND PREPARATION FOR SHIPMENT. THE PLUTONIUM SOLUTION SEEPER THROUGH VERY FINE CFACKS IN THE BOTTOMS OF THE 1O-LITER BOTTLES. MORE THAN IO\% DF THE SOTTLES IN STORAGE HAD DEVELOPFD LEAKS. IN SOME CASES, LEAKAGE WAS SUFFICIENT TO FLOAT THE 
PAGE $=\begin{gathered}: \\ \vdots \\ \vdots \\ \vdots\end{gathered}$

RADIONUCLIDE RELEASE AND MOVEMENT IN THE ENVIRONMENT

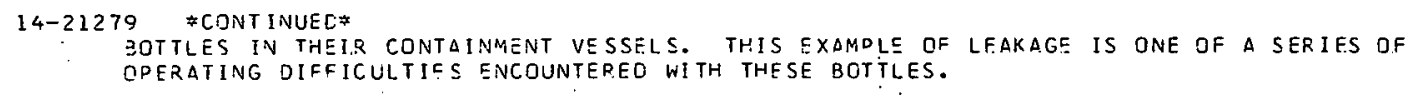

REPORTS WORK IN PHYSICS, CHEMISTRY, BIOLOGICAL STUDIES, PHYSIOLOGY, GENETICS, MEDICAL, STUDIES, AND ENVISONMENTAL STUDIES.

AVAILABILITY - MICROCARD EDITIONS, INC., ACCOUNTING AND SHIPPING. DEPT., WEST SALEM, WISCONSIN 54EG9

* ACCIDENT, CRITICALITY.+ \#COUNTER, WHOLE PCDY + \#DOSE + \#ENVIRONMENTAL CDNDITION + \#RADIATION DAMAGE + \# RADIOBIOLOGY + ALPHA EMITTER + BIOMEDICAL + DOSE CALCULATION, EXTERNAL + GAMMA + JAPAN + STRONTIUM + $X-R A Y$

$14-21284$

LEVI VH

THE TREATMENT DE HIGHLY RADIOACTIVE WASTE SOLUTIONS

6 PAGES, 5 FIGURES, I TABLE, 9 REFEPENCES, $\triangle$ TOMWIRTSCHAFT $12(6)$, PAGES $317-322$ (JUNE 1967 ) IN GEPMAN SURVEYS THE PREBLFMS IN THE DISPOSAL OF RADIOACTIVE WASTES.

* naste disposal, genfaAl + Fuel pepfocessing + germany + waSte dispesal, ocean + waSte oisposal, salt + NASTE OISPOSAL, SOLID + WASTE DISPCSAL, TERFESTRIAL

$14-21289^{\circ} \quad A L S C$ IN CATEGORY 15

VAN MIDOLSSWORTH L

STUDIES IN IODINE METAOLLISM. PROGPESS REPORT, JULY 1966--JULY 1967

UNIVERSITY OF TENNESSEE, MEMPHIS

DRO-1643-071+ 23 PAGES, JULY 21,1067

PRESENTS 1966-67 STUDY OF IODINE MFTAPOLISM AND $\triangle S S O C I A T E D$ EIOLOGICAL STUDIES, THYROID OISEASE, RADIUM IN ANIMAL THYPOIOS, ANO PADIOACTIVE IODINE FALLOUT AS OBSERVED IN ANIMAL THYROIOS.

AVAILABILITY - CLEARINGHOUSF FOR FEDERAL SCIENTIFIC AND TECHNICAL INFORMATION, SPRINGFIELD, VA., \$3. OO COPY, \$O.ES MICROFICHE

*FALLOUT + \#RADIOBIDLQGY + IOOINE + FADIUM 
CATEGORY 14
RAOIONUCLIDE RELEASE AND MOVEMENT IN THE ENVI RONMENT

$14-21290$

ELIASON JR

EARTH SCIENCES WASTE DISPQSAL INVESTIGATIONS, JULY-DECEMBER IC66

BATTELLF-NORTHWEST, RICHLAND, WASHINGTON

BNWL-432 +. 17 PAGES, 2 FIGURES, 2 TABLES, REFERENCES, JUNE 14, 1967

EVALUATES GRDINDNATER CONTAMINATION RESULTING FROM DISPOSAL OF PLANT EFFLUENTS. THE EXTENT OF GROSS BETA ANO TRITIUM CONTAMINATICN IN GROUNO WATER IS PRESENTED.

AVAILABILITY - CLEAR INGHOUSE FOR FEDERAL SCIENTIFIC AND TECHNICAL INFORMATION, SPRINGFIELD, VA., I 3 . OO COPY, \$0.65 MICROFICHE

*GROUND WATER, GENERAL + *WASTE DISPOSAL, GENERAL + BATTELLE NGRTHWEST + CESIUM + GROSS ALPHA + GROSS BETA + GPOUND WATER, NUCLIDE OCCURPENCE + HANFORD SITE + RHCDIUM + RUTHENIUM + STPONTIUM + TRITIUM + WASTE DISPQSAL, LIOUID + WASTE DISPOSAL, TERRESTRIAL

$14-21304$

CASSIDY SH + CROCKER GR

SENSITIVITY ANALYSIS OF THE RADIAL DISTRIEUTION MOOEL. SENSITIVITY TO CARRIER MATERIAL, YIELD LNO TYPE OF FISSION

NAVAL RADIOLOGICAL DEFENSE LAB., SAN FGANCISCO, CNLIF:

USNROL-TR-67-70+. go PAGES, EIGURES, TABLES, 14 REFERENCES, MAY 22,1967

THE U.S. NAVAL RAOIOLOGICAL DEFENSE LAQORATORY DEVELOPED A METHOD FOR CALCULATING THE DISTRIJUTION GF FISSION-PRTOUCT NUCLIDES AMONG FALLOUT PARTICLES AS A FUNCTION CF SIZE. CALCULATIONS FROM THIS PARTICLE ACTIVITY MODULE OF RADIONUCLIDE FRACTIONATION IN LAND-SUPFACE NUCLEAR QURSTS HAVE BEFN TESTED FOP. SENSITIVITY TO THREE KINCS CIF INPUT PARAMETER VARIATION (1) VARIATION IN WEAPON YIELC, (2) VARIATION IN TYPE OF FISSITN AND (3) DIFFEPENCE IN SOL IDIFICATION TEMPERATURE OF THE CARRIER MATERIAL (SILICATE SOIL OQ CORAL). DURING THE CALCULATIONS, A FOURTH INPUT PARAMETER, PARTICLE-SIZE DISTRIRUTION, WAS UNCHANGED. THE CALCULATIONS SHOW THE MODEL TO BE KELATIVELY INSENSITIVE TO VARIATION IN WEAPON YIELD ANO TYPF OF FISSIGN. THE CALCULATIONS AT A SOLIDIFICATION TEMPEPATURE APPROPRIATE TO CORAL I2887. K) INDICATEO THAT PARTICLES SMALLEF. THAN 47 MICRONS IN CIAMETER CONTRIBUTE ABOUT $70 \%$ OF THE TOTAL EXPOSURE RATE, WHILE THE CALCULATIONS DT THE SILICATE SOIL SOLIDIFICATION TEMPERATURE $(1573 \mathrm{KI}$ INDICATE $\triangle B O U T$ 60\%. THE PR.OPORTIONS OF THE I-HR EXFOSURE RATE CONTRIBUTED BY VOL $\triangle T I L$, MIXED, AND RFFRACTORY FISSION-PRODUCT CHAINS ARE CGNSIDERABLY DIFFEPENT FOR THE TWO SOI. IDIFICATIDN TEMPERATURES. THE TEMPERATURE SENSITIVITY DF THE YODEL SHCULD BE INVESTIGATED IN MORE DETAIL SINCE THERE IS F.EA SON TO BELIEVE THAT CHANGES IN FRACT IONATION BEHAVIOR WHICH ARE NOT APPARENT AT I HOUR AFTER GUPST MIGHT RE IMPORTANT AT LATER TIMES.

AVAILABILITY - DEFENSE DOCUMENTATION CENIER, CAMEKUN STATIUN, ALEXANORIA, VIRGINIA

*FALLOUT + \#FISSION PRODUCT TRANSPOFT + CCMPUTER PRCGRAM + COMPUTER, DIGITAL + FISSION PRODUCT, AIFBORNE + TEST, WEAPONS (HP ASPECTS)

$14-21305$

PLATT AM

FIXATION OF RADIOACTIVE RESIDUES. RESFARCH AND OEVELOPMENT ACTIVITIES QUARTERLY PROGRESS PEPOPT, APRIL-JUNE 1967

RATTFI, I. F-NORTHWEST, RICHLAND, WASH. PACIF IC NORTHWEST LAB.

HNWL $-507+39$ PASES, 7 FIGUPES, 11 TABLES, $\triangle$ UGUST 1067

NORK OUR ING THE QUARTER. IS REPOPTED ON POT SOLIDIFICATION, PHOSPHATE GLASS SOLIOIFICATION, ENGINEER ING DEVELOPMENT IOESIGN VEFIFICATION TESTS, SPRAY SOLIDIFICATION, PRODUCT LHAH ALTERISTILS ANO STORAGE, INTERMEDIATE 'OND LOW LEVEL WASTLS.

AVAILABILITY - CLEARINGHOUSE FOR FEOERAL SCIENTIFIC AND TECHNICAL INFORMATION, SPRINGFIELD, VIRGINIA, 19.0O COFY, \$O.C5 HICNORICHIS

* WSTTE TREATMENT, GENERAL + BATTELLE NORTHWEST + GLASS + MATERIAL + WASTE STORAGE +

WASTE TREATMENT, ETUIPMENI + WASTE TREATMENT, FIXATION

$14-21307$

HII 14.1

FEMOVAL TF SLUDGE FRCM HIGH ACTIVITY WASTE TANKS

DU PONT OE NEMIURS (E.I.) AND CO., AIKEN, S. C. SAVANNAH RIVER LAB.

DP-1093+. 27 PAGES, 17 FIGURES, JUIYY IOE. 7

NOUEOUS RAOIOACTIVE WASTFS FRMM THF SFPARATIONS PROCESSES AT THE SAVANNAH PIVEF PLANT ARE STORED UNDERGFOUND IN LARGE, CARBON STEEL TANKS, AND COOLED BY WATER FL OWING THPOUGH $\triangle$ NETWORK OF VEFTICAL AND HORIZONTAL COOLING COILS. TO CONSERVE SPACE, THE SUDEFNATANT SOLUTIDNS ARE PEMOVED PER IODICALLY FRCM THE TANKS, CONCENTRATED BY EVAPORATION, AND TRANSFERP.ED TO OTHER TANKS FGR LONG-TERM STORAGE. DURING STORAGE OF THE WASTES PRIOR TO CONCENTPATION, PEEC IDITATED SLUGGE ACCUMULATES IN THE BOTTOM OF THE TANKS. EQUIPMENT AND TECHNIQUES THAT HAVE BEEN DEVELOPED FOR REMOVAL OF SLUOGE FROM WASTE TANKS ARE DESCRIBED IN THIS REPQRT. HIGH VELOCITY JETS OF WATEP ARE USED TO DISPERSE THE SLUDGE INTO A SLURRY THAT CAN BE REMOVED WITH CENTRIEUGAL PUMPS. THE OEVELOPMENT PROGRAM CULMINATEO IN REMCVAL OF 
CATEGORY 144
RADIONUCLIDE RELEASE AND MOVEMENT IN THE ENVIRONMENT

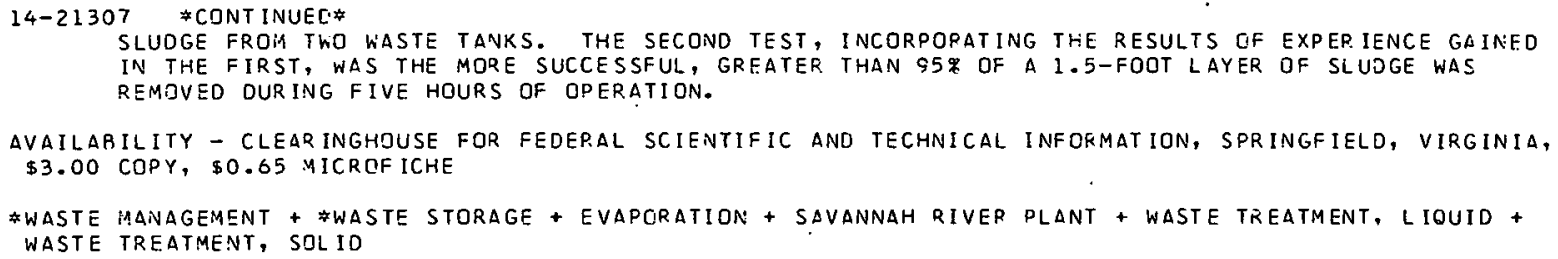


CATEGORY 14
RADIONUCL IDE RELEASE AND MOVEMENT IN THE ENVIRONMENT

$14-21314$ \#CONTINUSD*

TO LEARN THE DISTR IBUTION OF RADIATION ARCUND AN ACCELERATCR CUANTITATIVELY, A PROGRAM FOF MONITORING THE DISTRIBUTION OF INCUCED ACTIVITY AND TOTAL RADIATION DOSE IN THE ZERO GRANDIENT SYNCHP.OTRON PIVG BUILDING WAS STARTED IN 1O65. THIS PAPER IS AN ATTEMPT TO COMPILE THE DATA TO SEE IF DEFINITE PATTERNS EXIST, TO EXTRACT USEFUL CALCULATION CONSTANTS, AND TO EXTRAPOLATE THE TOTAL DOSES RECEIVED GY COMPONENTS SINCE THE STARTUP OF THE $7 G S$. SOME OF THE FELATIONSHIPS EXAMINED ARE - (1) THE DISTRI QUTION OF DOSE RECEIVED BY COMPONENTS OF THE $2 G S$ PER QPERATING HOUR QR PER CIRCULATING PRCTON, (2) THE OISTRIEUTION OF INDUCED ACTIVITY, AND (3) THE RATIO RIF INDUCEO ACTIVITY TC AVERAGE COSE AT THE SAME LOCATION.

\#ACTIVATION + \#DDSE + *COSE MEASUREMENT, EXTERNAL + \#DOSIMETRY, GENERAL + ACTIVATION PRODUCT + ANL + DOSIMETRY, THEPMOLUMINESCENCE + RADIONUCLIDE, INDUCED

$14-21317$

TALENTI H CIGNA

PROBLEM OF RAOIOACTIVE MINEKAL WAIEKS FRIM THE HYGIENIC POINT OF VIEW UNIVERSITY QF ROME

4 PAGES, 6 RFFFRFNRFS. NUOVI ANN. IG. MICROBIOL., 15, PAGES 568-7! (NOV-OEC. IDGA) IN ITALIAN

RACIOACTIVE WATERS ARE DEFINED IN ITALY AS THOSE WHICH CONTAIN MORE THAN 4 NCI/1. MORE EXACTLY, WEAKLY ACTIVE WATERS CDNTLIN $1-3 C$ NCI/1, ACTIVE WATERS CONTAIN $30-150$ NCI/1, STRONGLY ACTIVE WATERS CONTAIN MORE THAN 150 NCI/1. OTHER CLASSIFICATIONS BASED ON RA LUNIENT ARE DISCUSSED. THE EASIS OF DETERMINATIONS ON RN-222 AND RA-22.6 IS OUTLINEO. PREVIOUS MEASL'FEMENTS ON ITALIAN WATERS IN GENERAL HAVE BEEN CARRIED DUT WITH INADEQUATE EOUIPMENT FOR DISTINGUISHING THE CONTRIBUTIONS FROM THESE ISOTOPES. THE SCINTILLATION CHAMBCR $\triangle P P E A R S$ TO BF ADAPTED PARTICULARLY WELL TO THE DETEDMINATION OF PN-222 IN EQUILIERIUM WITH RA-226, $\triangle S$ DISTINQUISHCD FFON EXCFSS RN-222. THE MAX $\triangle$ CAISSIBLE CONCENTEATION CF QA-2ZG IN WATER IS 1 PCI/1, AVOIDANCE OF CONTINUEO USE OF MORE $\triangle C T$ IVE WATERS IS SUGGESTED. THIS VALUE FOR THE GENERAL POPULATION MAY BE ALTEREO BY RECENT STUOISS ON THE FATIC BETINEEN RA CONTENT IN WATEF AND IN THE HUMAN EQDY. CONTRISUTIONS GF FACH NUCLIDE TO TOTAL ACTIVITY OF ITALIAN MINERAL WATERS WILL EE STUEIEN IN THE FUTURE.

*gRQUND WATER, GENERAL + GRQUND WATER, NUCLIDE CCCURRENCE + ITLLY + RADIUM + RADCN

$14-21325$

MOISIOT+MIETTINEN JK

CS-137 AND I-131 IN FINNISH MILK FRCM SEPT. 1SA2 TG $\triangle U G .1943$

BIITCHFIICAI INST.. HFLSINK I

2 DAGES, 1 TABLE, I FFFEPCNCF, SUOMEN KEM., \&, 36. DAGES 175-6 11Ch 1

PEQIOCIC MEASUREMENTS OF. CS-137 ANE: I-131 CONTENT IN MILK WCPE MADE ON SAMPLES TAKEN FDOM THE LARGEST TANKS (5000 TO 15, DOO LITERS) OF THREF CENTRAL DAIPIES IN HELSINKI, JOENSUU, ANO ROVANIEMI. THE SAMPLES DEDRESENTEL ONE DAYS MILK FRCM 50 TO SEVERAL HUNDRED FADMS WITHIN $\triangle B O U T 100$ KA CF EACH DAIRY.

* 9 IOLOGICAL CONCENTRATION, GENERAL + *FALLOUT + BIOLDGICAL CONCENTRATION, FOOD + BIOLOGICAL CONCENTRATIUN, MILK + CESIUM + FINLAND + ICDINE

$14-21327$

BLANC, + FONTAN J + GUEDAILA D

MEASUREMENT OF THE THCR.ON FLUX LEAVING THE SOIL

3 DAGES, 2 FIGURES, 5 F.EFEPENCES, COMPT. RENC., SER. A AND 8,264 , PAGES 491-3 (FER. 6 , 1967 ) IN FFENCH

a COLLECTOR MDUNTED ON AN IONIZATION CHAMBER GIVES DIPECTLY THE VALUE GF THE RELEASE QE THOFCV ON A SURFACE TF APPROXIMATELY I SO. METER IN LESS THAN 10 MIN. THE MINIMUM VALUE MEASURABLE IS $4 \times$ IO(-17TH) CURIE PEP SQ. CM PER SEC. THE RELEASE IS GENERALLY 1OO TIMES GPEATER.

\#INSTRUMENTATIUN, RACIATIGN MONITORING + \#MONITOR, RADIATION, GAS, FRANCE + RADIJISOTOPE + THOFON

$14-2132 \% \quad \Delta L S E$ IN CATEGORY 15

RORERTS IC

EFFLUENT MONITORING AND EVALUATION - $\triangle$ OOWER REACTOR DESIGN GUIDE

FATTFI I E-NRRTHWFST, RTRHI GNI , WA SHINISTOM

BNWL-251(REV) +. 78 PAGES, FIGURES, TABLES, MAY 1067

THIS RERORT IS DIPECTED TOWARD PCHCF-OEACTRR PRACTICES AND, PARTICULARLY, TO CONOITIONS SXISTING DURING INDRMLL OPEOATION OF PCWER REACTCRS. IT DOES NOT INCLUDE EVALUATION OF ACCIDENT CONOITIONS. THE MATERIAL IN THE OOCUMENT WAS SCLECTEO TO MEET THE NEECS OF PEADERS WHO WISH TO UNDERSTAND THE BASIC FFOUIDEMENTS OF MONITCKING. DOES NOT SUPPLY COOKBOOK DROCEDURES.

AVAILABILITY - CLEARINGHOUSE FOR FEDERAL SCIENTIFIC AND TECHNICAL INFORMATION, SPRINGFIELD, VA., \$Z. OO COPY, SO.E5 MICROFICHE

\#MONITORING PROGPAM, ENVIRONMENTAL + \#REACTOR, POWFR + \#WASTE DISPOSAL, GENERAL + BATTELLE NORTHWEST + EFFLUENT + ENVIRBNMENTAL CONDITION + EQUIPMENT, GENERAL + IOCINE + RADIOISOTOPE + REGULATICN, AEC +

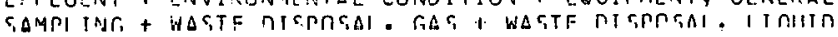




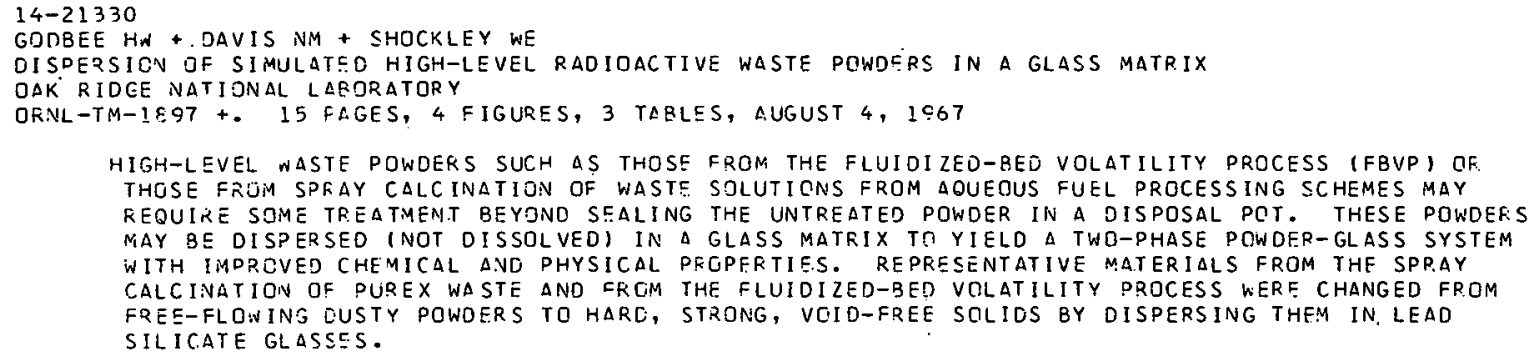

* ION EXCHANGE + CECONTAMINATION + STRONTIUM

$14-21343$

SANT HOL ZFR. $V$

RESULTS OF MEASUREMENTS ANC. ANALYSES OF NUCLEAR FALLOUT UP TJ THE BEGINNING DF $1 S 65$

7 PAGES, 3 FIGURES, 1 TABLE, 26 REFFRENCFS, CZECH. J. PHYS 15, PAGES 506-12 (1965)

AS $\triangle$ RESULT JF THE CESSATION CF NUCLEAR TESTS IN THE ATMOSPHERE, THERE WAS A FURTHER DECREASE IV THE ACTIVITY OF DRY FALLOUT AND FAINOUT, AS WELL AS IN GROUNG-LEVEL DIR, IN IOG4. THE OAILY ACTIVITIES DECREASED TO THE ORDER OF TENTHS OF MCI/SQ. KM. FROM APRIL TO AUGUST AN INCFEASE IN THE ACTIVITY NAS ARAIN SEEN, WHICH WAS CAUSED EY THE DESCENT GF RADIGACTIVE OUST FSOM THE STRATOSPHEP.E TO THE TROPOSFHERE AS A CONSEQUENCE OF METEDROLOGICAL FACTOP.S

SEASONAL VARIATION WAS NOT SO PRONOUNCED IN 1964 AS IN 1963 , NHEN IHE ACTIVITY INCREASEO IN MAY AND JUNE TO 0 OR 7 TIMES THAT GF FEBRUARY ANDMARCH. IN 1964 THE ACTIVITY INCREASED 2 FOLD. THE CONCEPT OF THE EXISTENCE OF A STRATOSPHERIC RESERVOIR OF ART IFICIAL FAOIOACTIVITY, FJPMED AS A RESULT OF NUCLEAR. TESTS, WAS THUS CONFIRMED, AS WAS. THE EXISTENCE OF A CERTAIN R.ESIDENCE TIME OF FADIDACTIVE DUST IN THE STRATOSPHERE.

\#FALLJUT + 'CZECHOSLOVAKIA + MONITORING FRGGRAM, ENVIRONMENTAL + RAINCUT + STRATOSPHERE + TEST, WEAPONS (HP ASPECTS) + TROPOSPHERE

$14-21344 \quad$ ALSE IN CATEGORY 15

MALYKHIN VM + MOISEEV AA + SHAMJV VP

on THE CALCULATION JF THE DOSE LDADS FOR THE BONE TISSUE IN CASE OF DCUTE SR-CO POISONING

2 PAGES, 2 FIGURES, EIG. SANIT 9, PAGES 62-3 ISEPTEMBEF 196E) IN RUSSIAN

A SIOLJGICAL MCREL FOR THE UPTAKE OF STRONTIUM-GO BY HUMANS WAS LSED FCR DETERMINING THE DOSE TT BONE TISSIJE. THE INTEGRAL BONE DOSE WAS COMPUTED CONSIDERING THE AMOUNT DF ACTIVITY INTRODUCED INTO THE ORGANISM DUP.ING ACUTE POISONING WITH STRONTIUM-SO, THE AMOUNT OF ACTIVITY MEASURED IN VIVO AT APBITKARY TIMES DURING THE YEARS FOLLOWING ACUTE POISONING, AND THE AMOUNT OF STPCNTIUM-9O EXCRETED DAILY (IN URINE AND FECES) BY THE PATIENTS FOLLOWING ACUTE POISONING WITH STRONTIUM-90.

\#DOSE + ólOLOGICAL CGNCENTRATION, MAN + DOSE CALCULATIGN, INTERNAL + FAOIOBIOLOGY + STFCNTIUM + USSR

$14-21345$

SANSGM. BF

THE' METABOLISH OF.CS-137 INI DAIRY COWS

AGRI CULTURAL RESEARCH COUNCIL INST. FOR RESEARCH ON ANIMAL DISEASES, COMPTON, ENGLAND 


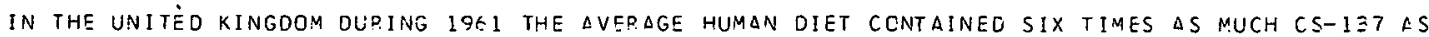
SR-90, AND IN 1962 AND 1963 THIS FETIO HAD INCREASED TO ABCUT 15 . MOST CF THIS, BETWEEN 7O AND 90\%, IS CONTRIBUTED BY DAIRY PRODUCTS AND MEAT. THE METABOLISM OF CS-137 IN DAIPY COWS WAS STUDIED AFTER SINGLE ORAL AND INTRAVENOUS DOSES AND DURING TWICE-DAILY ORAL COS ING FOR 28 DAYS. GASTROINTESTINAL ABSORPTION OF CS-137 WAS ABOUT 70 TO $80 \%$ JF THE ORAL DOSES. AFTER 29 DAYS OF CONTINUOUS FEEOING. THE MEAN CONCENTRATION OF CS-137 IN MILK WAS 0.84F CAILY DOSE/LITER, ANL THE RODY BURDEN OF THE I SOTOPE VARIECO BETWEEN 5.7 ANO 8.2 I IMES THE DAILY INTAKE. WHEV FEEDING OF CS-137 STOPPEO, THE CONCENTRATION OF THE ISOTOPE IN MILK FELL BY A FACTOR DF 5 IN 8 DAYS, BY A FACTOR OF 10 IN 16 DAYS, BY A FACTOF OF 20 IN 32 DAYS, AND THEREAFTER EXPCNENTIALLY WITH A HALF-LIFE OF 30 DAYS. THE CONCENTRATIONS OE THE ISOTOPE IN MUSCLE DECREASED AT FIRST SLONLY BUT FINALLY ALSO EXPONENTIALLY WITH A HALF-LIFE OF ABOUT 20 DAYS. IN ITS SECPETION INTO MILK, CS-137 BEHAVES SIMILARLY TO POTASS IUM, BUT THE RELATIVE I:4PORTANCE OF THE UPINARY AND FECAL, FXCRETORY ROUTES FCR CS-127 ARE REVERSED $\triangle S$ COMPARED WITH POTASSIUM.

*BIOLOGICAL CONCENTRATICN, ANIMAL + *EIOLCGICAL CONCENTRATION, MILK + \#FALLOUT + CESIUM + STRONTIUM + UNITED KINGOOY

$14-21346$

MCCLAIN WC + BRADSHAWPL+ EMPSON FM

DISPOSAL DF HIGH LEVEL SOLIOIFIEU WASTES IN SALT MINES

OAK FIDGE NATIONAL LAPQRATORY

ORNL-P-3053 + CONF-670512-3 +. 22 PAGES, 1967, FRGM JOINT IAEA/ENEA SYMPOSIUM ON THE DISPOSAL DF

R.ACIDACTIVE WASTES INTO THE GROUND, VIENNA, AUSTRIA

PROJECT SALT VEULT, AN EXPERIMENT DEMONSTPATING THE DISPOSAL DF HIGH-LEVEL RADIDACTIVE SOLID WASTES, WAS OPERATED FR,OM NOVEMBER 1965 TO JUNE 1967. IRRADIATED FUEL ASSEMBLIES FROM THE ENGINEERING TEST REACTOR, SUPPLEMENTED WITH ELECTRICAL HEAT WERE USED INSTEAD OF ACTUAL WASTES. THE FEASIQILITY AND SAFETY DF HANOLING RAOIOACTIVE MATERIALS IN AN UNDERGRDUND ENVIRONAENT WAS DEMONSTRATED. THE STABILITY OF THE SALT UNDER THE EFFECTS OF HEAT AND RADIATION WAS SHOWN, $\triangle S$ WELL $\triangle S$ THE CAPABILITY OF SOLVING MINOR STRUCTURAL PROBLEMS RY STANDARD MINING METHODS. THE DATA OBTAINED CN THE CREEP AND PLASTIC FLOW CHAOACTER ISTICS OF THE SALT WILL MAKE IT POSSIBLE TO APRIVE AT A SUITABLE MINE DESIGN FOR A DISPCSAL FACILITY FOR ANY DESIREO DEGREE OF RUCM CLCSURE.

* waste oisposal, genedal + ornl + waSte oisposal, salt + waste disposal, sol id + waste storage

$14-21347$

MCCLAIN WC

HYOR AUL IC FRACTUP IVG AS A WASTE DISPOSAL METHOD

OAK RIOGE NATIONAL LABORATORY

ORNL-D-3054 + CONF-670512-4 +. 20 PAGES, FROM JOINT IAEA/ENEA SYMPOSIUM ON THE CISPOSAI DF PADIONCTIVE WASTES INTD THE GROUND, VIENNA, AUSIRIA, 1967

ORNL DEVELOPED A METHOD OE WASTE DISPOSAL BASED ON THE CIL-FIELD METHOO OF HYDFAULIC FRACTURING. THIS WORK REACHEO FRUIIIUN IN UECEMBER 1966 AND IN $\triangle P R I L 1967$ WHEN TWO INJECTIONS NERE CARRIED DUT TMTAI ING 65,000 AND 80,000 CAL, TESPECTIVELY, OF RESIOUES FKUM A NEW WASTE EVAPORATOR. THIS EVAPORATOR CONCENTRATES THE NORMAL L $\triangle B O R A T O R Y$ WASTES ABOUT IE TC 2C TIMES AND WIII. POQDUTE ABOUT 150,000 TO 200,000 GAL OF WASTE ANNIIAILY, CONTAINING UP TO $0.5 \mathrm{CI} / G A L$. IT IS EXPECTED TO DISPCSE OF THIS CONCENTRATE IN 80,0OD-GAL EATCHES AT L- TC 6-MONTH INTERVALS.

AVAILABILITYY - CLEARINGHOUSE FOR FEDERAL SCIENTIFIC AND TECHNICAL INFORMATION, SPRINGFIEIOO, VA., \$3. OO COPY, \$O.CS MICROFICHE

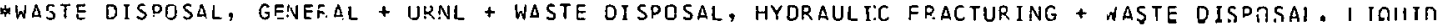

14-21349 ALSC IN CATEGORY 15

RDSENTHAL HL + RIRD .IT + GJLSTER.JE + PINTO RV I ONEILL S

SR-90 CONTENT DF DECIDUCUS TEETH OF CHILDREN

WASHINGTON UNIVERSITY, ST. LOUIS

7 PAGES, 5 FIGURES, 3 TAELES, 17 REFERENCES, J. DENT. RES. 45, PAGES 343-9 (MAP.-APR. 196.6)

TO DETERMINE THF USCFULNESS OF DECIDUOUS TEETH AS A MEASURE OF SR-9O BDDY BURDEN, STUDIES WEFE UNDERTAKEN TO OEFINE THE VARIATION IN THE SR-90 CONTENT OF THE VARIOUS TYPES OF DEC IDUDUS TEETH. THE SF- SO CONTENT OF DECIDUCUS TOOTH CROWNS INCREASED FPMIA 0.15 TH 4.7 PF $5 R-20 / C$ CA BETWEEN 194I ANU 1YLY, RESPECTIVELY, FOR CHILDREN BORN IN THE ST. LOUIS AREA AND WHO WERE ROTTIF-FEO FRCM BIQTH. THE VATIATION CF SF-OO CONTENT IN OLCIIUUUUS INCISORS, CUSPIDS, AND FIRST AND SECONO MDLARS, BETWEEN CARIOUS AND SCUND TEETH OR ESTWEEN TEETH FROM CHILDREN WHO WERE SREAST-FED OR, BOTTLE-FED DIIRTNG THE TIMF OF TOOTH FORMATION WAS LESS THAN $30 \%$.

* BIOLDGICAL CONCENTRATION, MAN + \#FALLOUT + RIOMEDICAL + RADIOEIOLOGY + STRONTIUM + UNITED STATES

$14-21350$

NUITLEAR, SAFETY 


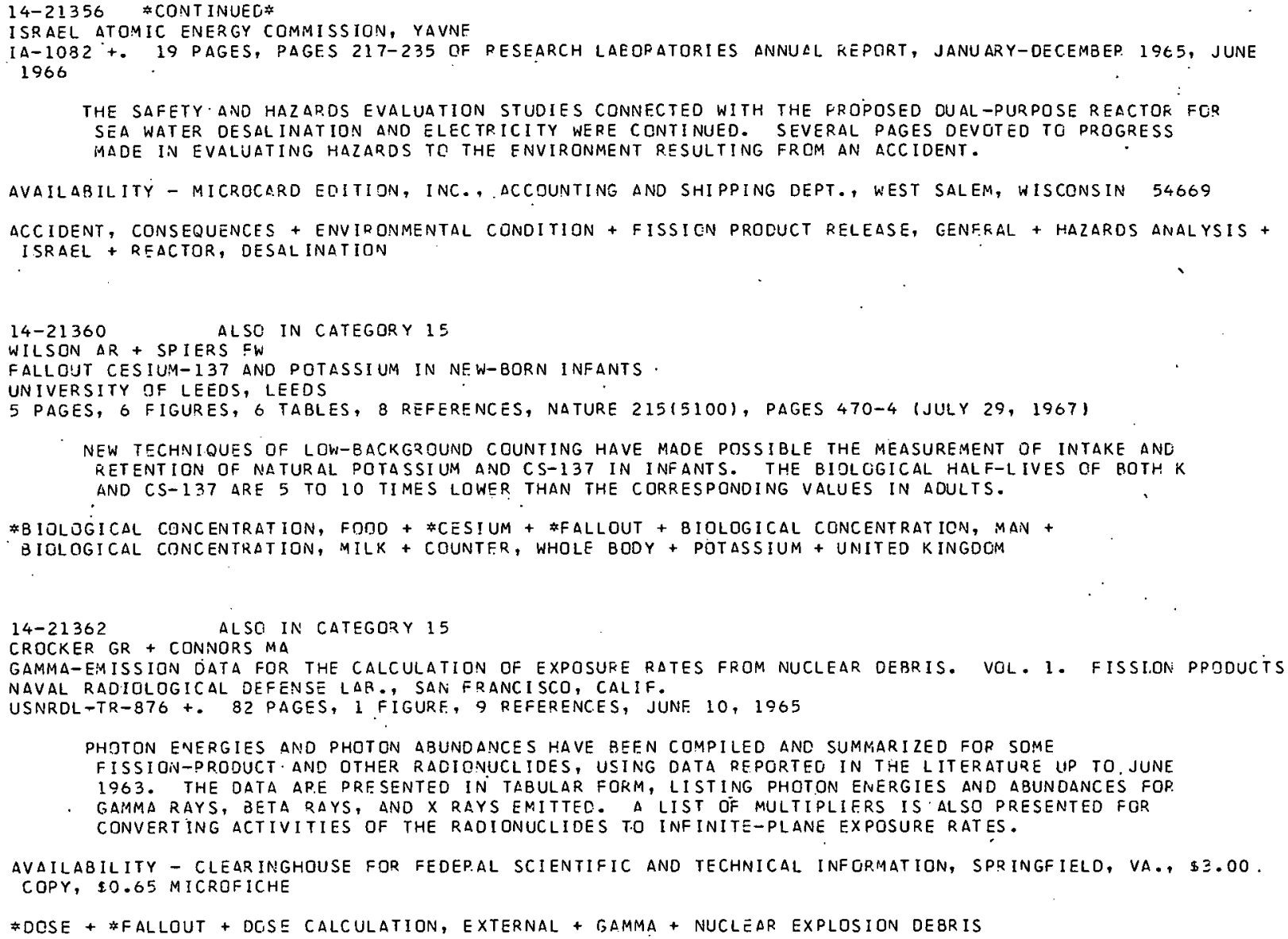

THE HISTORY OF DEVELOPMENT OF WASTE-MANAGEMENT PRACTICES AT CRNL IS CUTLINED. THE POLICY HAS BEEN TO DEVELCP A SYSTEM THAT COULO BE OPERATED SAFELY AT A SITE CLOSE TO A. BUILT-UP AREA AND TO DEMONSTRATE THE CONSTRUCTION AND USE DF FACILITIES THAT CAN GE MADE AND OPERATED AT A REASONABLE COST. THE WASTE FACILITIES ARE DESCRIBED, AND AN ACCOUNT IS GIVEN OF EXPERIMENTS DESIGNED TO TEST THE BEHAVIDUR OF FISSION PRODUCTS MOVING THRDUGH THE GROUNDWATER 2 ONE. OTHER EXPERIMENTS ON DI SPERSION OF PAOIONUCLIDES THROUGH THE ENVIRONMENT ARE OUTLINED. THE 


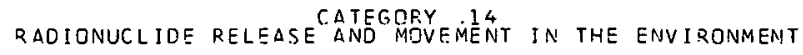

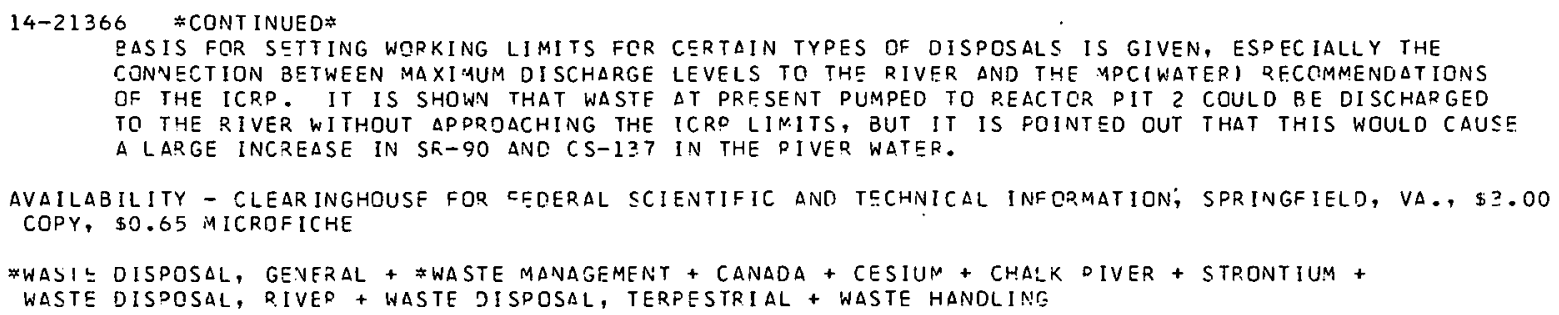

THE YULE UF ROET INTERCEPTION, MASS FLOW, AND DIFFUSICN IN SUPPLYING IDNS TO SOYPEANS GRTV: INE IV A LEACHED SUBSOIL WAS INVESTIGATED. ROOT INTERCEPTION WAS THE MAIN MECHANISM FTR THE SUPPLY DE CU, $\triangle L, \triangle N D$ SP, TO THE SOVBEAN POOTS. MASS FLOW WAS THE MOST IMPORTANT FOR R, ANO DIFFUSION WAS THE MOST IMPORTANT FOR MN, FE, AND ZN. THE MOST SIGNIFICANT MECHANISYS WILL LIKELY VARY WITH THE CROP, CLIMATE, AND SOIL.

*SOIL + IRON + MANGANESE + SOIL, RADIDNUCLIDE MOVEMENT THROUGH + STRONTIUM

$14-21370$

ISHTYAMAT + MATSUMURAT

DECONTAMINATION OF RADIOACTIVE RUTHENIUM BY CELLULOSE DERI:VATIVE-EENTONITE FLCCCULATION RADIATION CENTER OF OSAKA PREFECTURE, JAPAN

6 PAGES, G FIGURES, Z TABLES, OREFERENCES, RAOIOISOTOPES (TOKYO) NO. 15, PAGES $181-6$ (JULY IOGE) IN JAPANESE

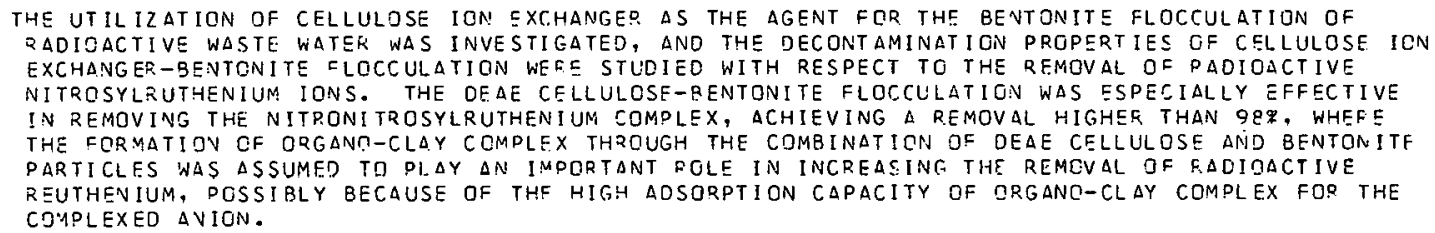
RADIOACTIVE WASTE WATER WAS INVESTIGATED, ANO THE DECONTAMINATION PROPERTIES GF CELLULOSE ION EXCHANGER-SENTONITE LOCCULATION WEFE STUDIED WITH RESPECT TO THE REMOVAL OE PAOIOACTIVE NITROSYLRUTHENIUM IONS. THE OEAE CELLULOSE-RENTONITE FLOCCLLATIGN WAS ESPECIALLY EFFECTIVE IN REMOVING THE NITPONITROSYLRUTHENIUM COMPLEX, ACHIEVING A REMOVAL HIGHER THAN 9R\%, WHEFE THE FORMATIOV CF ORGANR-CLAY COMPLEX THROUGH THE COMBINATION OF DEAE CELLULOSE AND BENTONITF PARTICLES NAS ASSUMED TO PLAY $\triangle N$ IMPORTANT FOLE IN INCREASING THE REMCVAL OF FADIOACTIVE REUTHENIUM, PGSSIBLY BECAUSE OF THF HIGH AOSORPTION CAPACITY OF ORGANC-CLAY COMPLEX FOR THE COMPLEXED AVION.

\#PADIOCHEMICAL ANALVSIS I HHASTE TREATMENT, LIUUIU + ION EXCHANGL + JAPAN + RAOIOCHEMICAL POOCESSING

14-21374 ALSO IN.C.ATEGORY.15

PROCEEDINGS ÜL THE CCNFERENCE ON RAOIATICN BIOLOGY HELC AT THE OAK RIDGE ASSOCIATED UNIVERSITIES, CAK RIDGE, TENN., $\triangle$ UUGUST 2-5, 1965

OAK RIDGE NATIONAL LARORATORY + UT-AEC AGRICULTURAL RESEARCH LAB., CAK RIDGE, TENA. + CAK RIDGE ASSOCIATEO UNIVERSITIES, INC., TENN.

CONF-G50847 +. 63 DAGES, FIGURES, PEFERENCES, JUNE 1967

THE PUROOSE JF THE CONFERENCE WA3 TO ENABLE TEALHERS, HAKI ICULARLY THOSE IN UNDERGRADUATE COLLEGES, TO SECGME FAMILIAR WITH THE FUNDAMENTAL PRINCIPLES OF RADIATIQN BIQLOGY, AND TO DISCUSS HOW INFOR:AATION FROM RADIATION STUDIES CAN BE INCOFPCRATED INTO THE UNDERGRADUATE CURRICUIUM. SIJBJECTS INCLUDE - RADIATIDN RIOLDGY AS A SCIENCE, RAOIATION EHTLCTS AT THE CELLULAR LEVEL, RAOIATION EFFECTS IN MAMMALIAN TISSUES, RAOIATION EFFECTS IN PLANTS, AEC BIOMEOICAL RESEARCH PRCGRAMS, AND REPORTS OF GROUP DISCUSSIONS ON INCLUSION OF RADIATION DIOLOGY IN UNOERGRADUATE COURSES.

AVAILABILITY - CLEARINGHOUSE FOR FEDEFAL SCIENTIFIC AND TECHNICAL INFGRMATION, SPRINGFICLD, VA., \$Z. OO COPY, \$0.65 MICRDFIC.HE

\#RACIATION DAMAGE + \#RADIOEIOLOGY + EIOMEDICAL

$14-21376$

HIMES TL + MANGAROE A

INFLUENCE JF ORGANIC COMPOUNDS ON THE MOVEMENT OF STRONTIUM IN SOILS AND ON THE UPTAKE GY PLANTS OHIO AGR ICULTURAL RESEAKCH AND DEVELOPMFNT CENTER, WOOSTER, DHIO

CONF-O51-114-2 + GMELIN-AED-CONF-65-344-1+. 19 PAGES, \& FIGURES, 2 TABLES, NOVEMBER ISE5, PRESENTEO $\triangle T$ AMERICAN SOCIETY JF AGRONOMY, 1 OS5 ANNUAL MEETING, CCLUMBUS, DHIC, 9CT. 31-NOV. $5,19 E 5$

THE STABILITY CONSTANTS RANGED FPOM 1.4? TO 14.4E. THE SOILS FORMED UNDER NEUTRAL CONDITIONS HAD HIGHER CONSTANTS THAN THOSE FORMED UNCEP VEFY ACIO CONDITIONS. THE STABILITY CONSTANTS INCREASED WHEN THE CLAY MINERALS ANC OTHER HF-SOLUSLE MATEPIALS WERE REMTVEO. THE UPTAKE CF

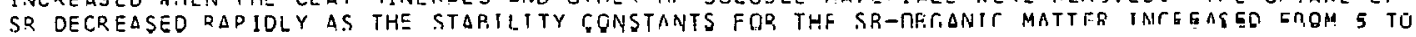


14-21376 \#CONT INUED*

9. THE PHYTIC ACID SOLUTION WAS VFRY EFFECTIVE IN LEACHING SR FROM THE SOIL COLUMNS. NITRILOTRIACETIC ACIO AND EDTA WFFF USUALLY INTERMEDIATE IN EFFICIENCY OF LEACHING AND THE OTHER COMPJUNCS WERE LESS EFFECTIVE. THE WATER EXTRACT OF THE AB-38 SOIL WAS VERY EFFICIENT IN LEACHING SF FROM ANOTHER SAMPLE GF $\triangle B-28$ SOIL.

AVAILABILITY - CLEARIINGHOUSE FOR FECERAL SCIENTIFIC ANO TECHNICAL INFORMATION, SPRINGFIELD, VIRGINIA, $\$ 3.00$ COPY, \$0.65 YICREFICHE

*SOIL, RADIOINUCL IOE MCVEMENT THROUGH + ECGLOGICAL CONSIOERATION + FALLOUT + STRONTIUM

14-21377 ALSO IN CATEGORY 15

BIOENVIRONMENT AL AND RADIOLOGICAL-SAFETY FEASIBILITY STUDIES ATLANTIC-PACIFIC INTEROCEANIC CANAL BATTELLE MEMORIAL IVST. COLUMSUS, OHID

BMI-171-003+. 102 PAGÉS, JANUARY 12,15 C 7

INTERIM REPJRT GF PROGRESS TQN THE STUDIES UNDER MANAGEMENT CF BATTELLE-COLUMBUS. CONCERNED PRIMARILY WITH STUDIES 3EING MADE AND THOSE BEING PLANNED BY BATTELLE-COLUMBUS

SUGCONT ZACTORS. SUBJECTS DISCUSSET: INCLUDE - DOSE ESTIMATION, HUMAN ECOLOGY (PANAMA), $\triangle G R I$ CUL TURAL ECQLGGY, TCRPESTRIAL ECOLOGY, HYDROLOGY AND F. DIONUCLIDE DISTR IBUT ION, FRESHWATER ECOLOGY, OHYSIOCHEMICAL OCEANOGRAPHY, ESTERINE ANO MARINE ECOLOGY, SPECIFIC-ACTIVITY APPROACH, MARIINE ECOLOGY AND RESOUP.CES, DATA EVALUATION PLAN.

AVAILABILITY - CLEARINGHOUSE FOQ FEDERAL SCIENTIFIC AND TECHNICAL INFORMATION, SPRINGFIELD, VIRGINIA, $\$ 3.00$ COPY, \$0.65 MICROFICHE

\#DOSE + \#ECOLOGICAL CONSIDERATION + \#HYOROLOGICAL CONSIDERATION, GENERAL + \#PLOWSHARE PROGRAM + DOSE CALCULATITN, EXTERNAL + DOSE CALCULATION, INTFRNAL + ESTUARY + OCEAN AND SEA +

PLOWSHARE PRDGRAY, ATLANTIC-PACIFIC CANAL + RADIOBIOLOGY

$14-21378$

VOSS GL

BICENVIRONMENTAL AND QADIOLOGICAL-SAFETY FEASIBILITY STUDIES ATLANTIC-PACIFIC INTERDCEANIC CANAL. MARINE RFSDURCES AND ECOLOGY. PHASE I FINAL REPQRT

MIAMI UNIV., FLA. INST, OF MARINE SCIENCE

BMI-171-NOj+. 143 PAGES, FIGURES, MARCHE, 1967

SUDJECTS DISCUSSEC INCLUDE - NICPOEIOLGGY, MARINE INVERTEBRATES OF POTENTIAL USE AS FOOD, MARINE EISHERISS, ECOLOGICAL DESCRIPTION (THE ATLANTIC), ECOLOGICAL DESCRIPTION (THE PACIFIC), IAPCETANT FISHES FROM ATLANTIC AND PACIFIC, AND BIBLIOGRAPHIES OF PERTINENT LITERATURE.

AVAILABILITY - CLSAR IIIGHOUSF FOR FEDEPAL SCIENTIFIC AND TECHNICAL INFORMATION, SPRINGFIELD, VIRGINIA, $\$ 3.00$ CDPY, $\$ 0.65$ MICROF ICHE

*ECGLOGICAL CONSIDERATICIN + \#FLLOUT + \#PLCWSHARE PROGRAM + AGUATIC GRGANISMS + ESTUARY + OCEAN AND SED + PI NWSHARE PROGRAM, ATLANTIC-DACIFIC CANAL

$14-213 \%$

RIC.KARD WH

CESIUM-137 IN LITTER AND UNDERSTORY VEGETATION

BIOLOGY DEPT., GATTELLE MEMORIAL INSTITUTF, PACIFIC NORTHWEST LAB, RICHLAND, WASHTNGTON

BNSA-215 +. S PAGES, I FIGURF, I TABLE, 7 REFERENCES, NORTHWEST SCI., 40(1), PAGE 25-30, (1966)

CESIU:A- 137 DERIVEU FQOM WORLDWIDE FALLCUT WAS MEASURED IN THE UNOERST MRY VEGETAT ION AND LEAF LITTER OF THREE DIFFERENT MATUPE CONIFER STANOS IN THE CASCADE MOUNTAINS OF WASHINGTON IN SEPTFMAFR, 19E4. THE CONCENTRATICN IN UNDERSTORY SHRUBS WAS MORE OR LESS SIMILAR AMONG THE THREE STANDS. HOWEVER, MORE WAS PEESENT IN THE UNUEHSTORY IN THE HEMLOCK ITSUGA EETER OPHYLLA) STAND WHEN EXPRESSER AS CS-137 PER SQUARE METER DF GROUND BECAUSE OF THE MORE LUXUR IANT UNDERSTORY GF. WWTH IN THIS HABITAT. CESIUM-137 IN LEAF LITTEP WAS MOST ABUNDANT IN A FIR IABIES AMAEILISI STAND NEAR THE MOUNTAIN SUMMIT. THE LEAF LITTER OF A HEMLOCK STAND IN A HIGH-PRECIPITATION RFGION WEST OF THE MOUNTAINS HAD HIGHER CONCENTRATIONS THAN DID THE LITTER FRGM A PONCEROSA PINE (PINUS PONDEROSA) STAND FROM A LOWER-PRECIPITATION REGION EAST TF THE MOUNTAINS.

FFALLOIJT + \#RADIOGIOLGGY + BATTELLE NORTHWEST + BIOLGGICAL CONCENTRATION, VEGETATION + CESIUM + PRECIPITATION + PAINGUT

$14-21380$

MCCORMICK JF

EFFECTS OF IONIZING RADIATION ON A PINE FQFEST

NOPTH EARQLINA UNIV., CHAPEL HILL. DEPT. GF BOTANY

ORO-3299-6 + CONF-670503-21+. 2? PAGFS, MAY 1, 19E7, PRESENTED AT 2ND NATIONAL SYMPOSIUM ON RACIOECOLOGY, ANN $\triangle R B D F$, NICHIGAV

A SLASH-LONGLEAF PINE FOPEST WAS EXPOSEO TO A PORTABLE S20O-CURIE CS-137 SOURCE FOP 200 HOURS. THE ECOLOGICAL EFFECTS OF RADILTITN HAVE PEEN INTERPRETED ON THE BASIS OF SIX PARAMETERS -

(1) SPECIES MCRTALITY, (2) INHIBITION DF APICAL AND LATERAL GROWTH, (3) INFLUENCE OF SPECIES 
CATEGORY 14
RADIJNUCLIDE FELEASE AND MOVEMENT IN THE ENVIRONMENT

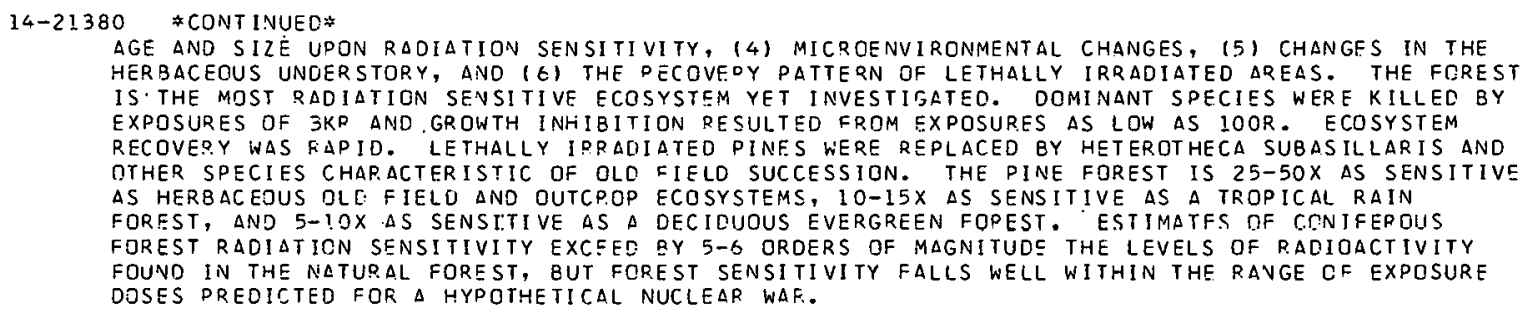

AGE AND SIZE UPON RAOIATION SENSITIVITY, 141 MICROENVIRONMENTAL CHANGES, (5) CHANGFS IN THE HERBACEOUS UNOERSTORY, AND (G) THE PECOVEOY PATTERN OF LETHALLY IRRADIATED AREAS. THE FOREST IS. THE MDST RADIATION SENSITIVE ECOSYSTEM YET INVESTIGATED. DOMINANT SPECIES WERE KILLEC BY EXPOSURES OF 3KP AND. GROWTH INHIBITION RESULTED FROM EXPOSURES AS LOW AS $10 O R$. ECOSYSTEM RECOVEPY WAS FAPID. LETHALLY IPRADIATED PINFS WERE REPLACED EY HETEROTHECA SUBASILLARIS AND OTHER SPECIES CHARACTERISTIC OF OLD FIELD SUCCESSION. THE PINE FOREST IS $25-50 X$ AS SENSITIVE AS HERBACEDUS DLE: FIELO AND OUTCPOP ECOSYSTEMS, 10-15X AS SENSITIVE AS A TROPICAL RAIN FOREST, AND 5-10X AS SENSITIVE AS A DECICUOUS EVERGREEN FOPEST. ESTIMATFS DF CONIFEROUS FOREST RADIATION SENSITIVITY EXCEED EY 5-6 OROERS OF MAGNITUDS THE LEVELS OF RADIOACTIVITY FOUND IN THE NATUPAL FOREST, BUT FOREST SENSITIVITY FALLS WELL WITHIN THE RAVGE CF EXPOSURE DOSES PREOICTED FOR A HYPOTHETICAL NUCLEAR WAF.

AVAILABILITY - CLEARINGHOUSE FOR FEDERAL SCIENTIEIC AND TECHNICAL INFCRMATION, SPRINGFIELD, VIRGINIA, $\$ 3.00$ COPY, \$O. 5 MICROF ICHE

*RAGIATION JAMAGE + FFACIOBIOLOGY + ECOLDGICAL CONSIDERATION

$14-21381$

RURMANVFJ + FKIES GF + ANDERSON MJ + STCDOARD GE

INFL UENCE OF GRAZING INTENSITY ON RADIOSTRONTIUM CONCENTRATIONS IN MILK

U.S. DEPARTMFNT OF HEALTH, EDUCATION, $\triangle N D$ WELFAFE, CINCINNATI, DHIO + U.S. DEPARTMENT CF AGRICULTURF, BELTSVILLE, MARYLAND + DEPARTMENT OF DAIRY INDUSTRY, UTAH STATE UNIVERSITY, LOGAN

5 PAGES, 2 FIGURES, 16 REFERENCES, J. DAIRY SCI., 49, PAGE 1219-1222, (OCTOEFR IOG6)

THE EFFECT OF GPAZING INTENSITY ON RADIOSTRONTIUM CONCENTRATIONS IN MILK WAS STUCIEO BY COMDARING MILK OF TWO GROUPS CF HCLSTEIN COWS GRAZED ROTATIUNALLY. QNE GROUD WAS INCLUDEO IN THE MAIN HER. ON A NOFMAL ROTATIONAL GRAZING SYSTEM, AND THE CTHER GROUP FOLLDWED THE MAIN HERD ONE PLOT BEHIND. MILK SAMPLES FPOM THE GF.GUP FOLLOWING THE MAIN HERD SHOWEQD A SIGNIFICAN! INCREASE AT THE 12 LEVEL IN STRONTIUM-CO UNITS AND STRONTIUM-89 UNITS. A SIGNIFICANT, POSITIVE LINEAR CORRELATION FOR S.U. 90 AND S.U. 8 S IN MILK EETWEEN THE GPOUPS WAS OBTAINED. DURING THE EXPER IMENTAL PERIOD, A HERD OF HOLSTEIN CATTLE WITHCUT ACCESS TC PASTURE, CONSUMINS A WEISHED AMOUNT OF FEED, SECRETED 1.5\% OF THEIR STRONTIUM-GC INTAKE INTC THE MILK.

\# BIGLOGICAL CONCENTRATION, FOOD + \#FALLQUT + PIOLOGICAL CONCENTRATION, ANIMAL FEED + BICLOGICAL CONCENTRATION, MILK + STRONTIUM

14-21382 ALSC IN CATEGORY 15

HEASLIP MS ECOLOGICAL SIGNIFICANCE OF NEUTSON ANR GAMMA RADIATION ON DORMANT AND PHYSIOLOGICALLY ACTIVE SEED AND ECOLOGICAL SIGNIFICANCE OF NEUTSON ANO GAMMA RADIATION ON DORMANT AND PHYSIOLOGICALLY
SEEDLINGS OF TREE SPECISS NATIVE TO THE EASTERN CECIOUOUS FOREST. PROGRESS P.EPCRT MOREHEAD STATE UNIV., KY.

ORC-2066-11 +. 39 PAGES, TABLES, REFERENCES, JUNE $1 \subseteq 67$

TO DETERMINC WHETHER FAST NEUTRONS AND GAMMAS AFE ADOITIVE OF INDEPENDENT IN ACTION, THE PELATIVE RADICSENSITIVITY OF SEED SAMPLES EXPOSED TO IE COMBINATIONS OF FAST NEUTRONS AND GAMMAS WERE INVESTIGATED. THE P.ELATIVE EFFECTS OF HOTER ON FAST NEUTPONS AND GAMMA ACTIVITY WERE DETERMINED EY EXPOSING SOAKED AND NONSOAKED SEED SAMPLES TO VARITIIS IFVFIS DF FAST NEUTRONS OR GLMMAS.

AVAILABILITY - CLEARINGHOUSE FOR FEDERAL SCIENTIFIC AND TECHNICAL INFOFMATION, SPRINGFIELD, VIFGINIA, $\$ 3.00$ COPV, \$0.65 MICPCIFICHE

* RACIATION DAMAGE + FRAJIOBIOLgGY + ECOLOgICAL CONSIDERATION + gamMa + NEUTRON

$14 \div ? 1384$

YAMAGATA N + IWASHIMAK

RAOIOACTIVE CONTAMINATION IN THE HARBOURS CF SASFBO AND YOKOSUKA

DEPT OF RADIOLOGICAL HEALTH, THE INSTITUTE OF HUBLIL HEALTH, TOKYO

10 PAGES, 7 FIGURES, 4 TABLES, 10 REFERENCES, KENKYO HOKOKU 14, PAGE 183-193, 119651 , IN JAPANESE

SURVEYED ENVIRONMENTAL RADIOACTIVITIES IN THE HARBOURS OF SASEBO AND YOKOSUKA AT WHICH UNITEL STATES NUCL EAR-PCWERED SUBMARINES WERE EXPECTED TO CALL. SEAWATER, SEAWEEDS, SHELLFISH, FISH, AND BOTTOM MUD SAMPLES WERE COLLECTED DURING THE PERIOD 30 SEPTEMBER 1964-11 MARCH ISE5 AND $\triangle N A L Y Z E D$ FOR MN-54, ZN-S5 AND P.U-106 BY USING A GAMMA-RAY SPECTROMETRY. THE CONCENTRATION FACTORS FROM SEAWATER TC MARINE ORGANISMS WEPE AROUT O.OI OR HIGHER. NO SIGNIFICANT INDICATION TF THE FFFECT CF CALL OF THE SHIPS HAS BEEN FOUND SO TAR ON THE CONTAMINATION LEVELS. THE LEVFLS WEFE LÜWEK BY FACTUKS OF 10 OR MOPE IN RU-1OG AND 100 OP. MORE IN MN-54 AND ZN-65, COMPAPFR WITH THE MAXIMUM PERMISSIBLE CONCENTRATION IN SEAWATER TOP THE GENEPAL PUBLIC, AS TENTATIVELY ESTARLISHED BY ONF OF THE AUTHORS.

* BIOLOgical CONCENTRation, general + \#ENVIPONMENTAL CONDITION + \#Fallout + SIOLOGICAL CONCENTRATICN, AQUATIC GRGANISMS + JAPAN + MANGANESE + RIJTHENIUM + SPECTROMETRY, GAMMA + ZINC

$14-21307 \quad$ ALSO IN CATEGORY 15

RECHT P

GENERAL STUUIES ON RADILTION ACCIDENTS. PEPORT PRESENTED AT THE SYMPOSIUM ON ACCIDENTAL IRRADIATIONS IN 
THIS SURVEY COMPRISES TWO PARTS. THF FIRST PART IS DEVOTEO TO A LIST OF ACCIDENTAL IRRADIATIONS, AS COMPILED FROM AN ANALYSIS OF CEPTAIN INFORMATION SUPPLIED, ANO TO THE GENERAL LESSONS THAT CAN BE LEARNFD THEPEFROM. WHEREAS THE MOST SERICUS ACCIDENTS HAVE SO FAR DCCURRED IN CPITICAL ASSEMELIES, EXPERIMENTAL REACTORS AND CHEMICAL PLANTS, THE SCATTERED LOCATION OF OTHEF RADIOACTIVITY. SOURCES PRESENTS A NUMBER OF DRGBLEMS AS REGAPDS REGULATIONS AND CONTROL. THE SECOND PART DEALS WITH THE ADMINISTRATIVE AND MEDICO-LEGAL ASPECTS OF ACCIDENTAL IREADIATIONS AND THE AUTHOR R.AISES VAPIOUS PROBLEMS ANO QUESTIONS CONCERNING THE MEANING OF THE TERM ACCIDENTAL IRRADIATION AND ITS MEDICO-LEGAL IMPLICATICNS, BY CONSIDER ING THE IMMEDIATE EFFECTS, THE THFESHOLO OUSES, AND THE DELAYFD EFFECTS.

*ACCIDENT, GENERAL + \#RADIATION PROTECTION, ORGANIZATION + \#RADIOCHEMICAL PLANT SAFETY + ACCIDENT, CRITICALITY + BELGIUM + FAOIATION DAMAGE + RAOIATION SAFETY AND CONTROL + RADIOBIOLOGY

14-21445 ALSO IN CATEGDRY 15

RI EL GK NAVAL ORDNANCE LAB.. WHITE OAK, MD.

AD-648810+. 208 PAGES, DECEMBER 20, 1966

RECENTLY DEVELGPED UNDER NATER GAMMA-PAY SPECTROMETERS WERE USED TO MEASURE THE CONCENTRATIONS DF GAMMA-EMIITING ISOTOPES IN EXTREMELY DILUTE SOLUTIONS CORRESPONDING TO A CONCENTRATION OF ABOUT IO(-14TH) GR.AM PER LITER. THE IDENTIFICATICN OF SPECIFIC ISOTOPES IS POSSIBLE BECAUSE THE UNDERWATER SPECTROMETERS ARE CAPABLE OF. MEASURING THE GAMMA-RAY ENERGIES OF THE SDURCES. GAMMA QADIATION BACKGRGUND SPECTRA WERE MEASURED IN MANY. BCDIES OF WATER. THE SPECTRGMETSRS COUNTING EFFICIENCY WAS MEASURED FOP. 17 RADIOACTIVE ISOTOPES DISSOLVED IN WATER AS STANDARDS.

AVAILABILITY - CLEARINGHOUSE FIR FEDERAL SCIENTIFIC AND TECHNICAL INF ORMATION, SPRINGFIELD, VA., \$3.OU COPY, \$0.65 MICROFICHE

* RFACTOR POWER + * SPECTROMETRY, GAMMA + * hATER POLLUTION + ENVIRONMENTAL CONDITION +

FISSION PRODUCT TRANSPORT + GAIMA EMITTEF + RADIOISOTGPE

14-21446 ALSG IN CATEGORY 15

KIMEL WR + FAW RE + FARAN JA + MINGLE JQ + QUBIN RM

SCATTERING OF FALLDUT RADIATION FROM CEILINGS OF PROTECTIVE STRUCTURERS. SPECIAL REPORT

KANSAS ENGINEERING EXPEF: IMENT STATION, MANHATTAN

$A D-645908+S R-72+.176$ PAGES, JULY $19 \in 6$

MADE A THOROUGH STUDY OF THE CEILING-SHINE PROBLEM. CEILING SHINE IS DEFINED AS THAT

CONTR IBUTION TO THE RADIATION DDSE RATE IN A PRCTECTIVE STP.UCTURE RESULTING FPOM FALLQUT

RADIATION ENTERING THE STRUCTURE THROUGH APERTURES IN VERTICAL WALLS AND SCATTERING DOWNWARD

FROM THE CEILING. A SYSTEMATIC ANALYTICAL ANALYSIS LIF IHIS YKUSLEM, VERIFIEU WAFEKIWEINTALLYI

RESULTED IN A SET OF DESIGN CURVES. THIESE CURVES YIELD THE CEILING SHINE P.EDUCTION FACTGR IN

ANY CONCRETE STRUCTURE AS A FUNCTION OF BUILDING DIMENSIONS, SIZE AND LOCATIUN LF APERTURES, AND DETECTOR LOCATION.

AVAILABILITY - CLEAR INGHOUSE FOR FEDERAL SCIENTIFIC AND TECHNICAL INFORMATION, SPRINGFIELD, VIRGINIA, $\$ 3.00$ COPY, \$0.65 MICRCFICHE

\#DOSIMETQY, GENERAL + \#FALLUUT + \#SAFETY ANALYSIS + *SCATTERING (SKYSHINE) + ENVIRCNMENTAL CONDITION + RADIATION SAFETY AND CONTROL + STRUCTURAL INTEGRITY

14-21665 ALSO IN CATEGORY 15

BAKER RC + DAV IS KA

ENVIRONMENTAL MONITOR ING SUMMARY FOR THE PADUCAH PLANT FOR 1965 AND 1966

PADUCAH GASEOUS DIFFUSICIN PLANT, KY.

KY-543+. 11 PAGES, TABLES, SEPTEMBEP. I, 1967

OUTDOOR MONITJRING OF AIR, WATER, AND VEGETATION IN THE VICINITY OF THE PADUCAH PLANT IS SUMMARIZED FOR 1965-19E6. EFFLUFNTS FP.OM THE PADUCAH GASECUS DIFFUSION PLANT OPEFATIDNS WERE CHANNELED AND CONTROLLED AS NECESSARY FOR THE ENVIRONMENTAL CONCENTRATIONS OF CHEMICALS AND RADIOACTIVITY IN AIP, WATER, AND VEGETATION TO BE AT ACCEPTABLY LOW LEVELS.

AVAILABILITY - CLEARINGHOUSE FOR FEDERAL. SCIENTIFIC AND TECHNICAL INFORMATION, SPRINGFIELO, VA., \&3. OO COPY, \$0.65 MICROFICHE

*GROSS ALPHA + \#GROSS 8ETA + \#GROSS GAMMA + \#MONITOR, PADIATION, ENVIRGNMENTAL + \#SAMPLING + GROUND WATER, NUCLIDE OCCURRENCE + MONITGR, RADIATION, AIR + MONITOR, RADIATION, GROUND SURFACE + MONITOQ, RADIATION, LIOUIO

$14-21667$

ALSC IN CATEGORY $1 E$

PESTANER, JF + LOVE DL

A COMPUTER. PROGRAM FOR IDENTIFYING AND MEASURING COMPONENTS IN A MIXTURE OF GAMMA-EMITTING PADIUNUCLIDES 


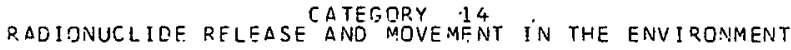

14-21667 \#CONTINUEO*

NAVAL RADIOLOGICAL DEFENSE LAB., SAN FRANCISCO

USNRDL-TR-67-46 +. 48 PAGFS, 15 FIGURES, MARCH 1,1067

PROBLEM - IN A STUDY OF THE PHYSICAL AND CHEMICAL SPECIES OF RAOIOACTIVE OEBRIS RESULTING FROM $\triangle N$ UNDERWATED. NUCLEAR EXPLOSION, COMPLEX MIXTURES OF RADIONUCLIDES, SOMET IMES OF FAIRLY LOW ACTIVITY, ARE TO BE ANALYZED. A COMPUTER PROGRAM FOR. RESOLVING THE GAMMA PULSE-HFIGHT DISTR ISUTION OF A WEAKLY ACTIVE MIXTURE CF GAMMA EMITTEPS INTO ITS COMPONENTS IS OEQUIREO. FINDINGS - $\triangle$ COMPUTER DROGRAM WAS CFVELCPED AND THEN TESTEO SIJCCESSFULLY ON THE GAIMA PULSE-HEIGHT OISTP.IBUTION OF A SYNTHETIC MIXTURE GF 2 RADIONUCLIDES, EACH HAVING SEVERAL PHOTOPEAKS OVER A 2-MEV QANGE. THE PROGRAM IS BASED ON AN ITERATIVE SUBTRACTION TECHNIGUE AND IS PRDMISING BECAUSE ERRORS IN THE ANALYSIS WRE SMALL 10.5 TO $2.0 \%)$, ALTHGUGH :1ANY PJSSIBLE REFINEMENTS IN THE PROGPAM HAVE NOT YET BEEN MADE.

AVAILABILITY - CLEAPINGHOUSE FOR FEDEFAL SCIENTIFIC AND TECHNICAL INFOPMATION, SPRINGFIELD, VA. \$Z. DO COPY, SO.65 YICROFICHE

*COMPUTER PROGRAM + \$GAMMA EMITTER + \#PADIOCHEMICAL ANALYSIS + MEASULEMENI, REACTIVITY + NUCLEAR CETONATION

$14-21668 \quad$ ALSO IN CATEGORY 15

PURTER. SN + SLABACK LA

MEASUR.EMENT OF TFITIUM SUREACF CONTAMINATICM

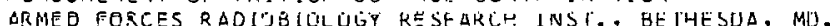

AD-640910 + AFRRI-SP-66-13 + CONF-660L03-4+. 18 PAGES, REEERENCES, JULY ISGE, FROM INTERNATIONAL

SYMPISIU: ON RADIJLCGICAL PROTECTION OF THE WOPKER EY THE DSSIGN AND CONTROL OF HIS ENVIRONYENT, BOURNEMOUTH, ENG.

DESCRIBES SEVERAL METHOCS FOR MEASURING TFITIUM SURFACE CONTAMINATION IN F.EACTOR, ACCELERATCE, $\triangle N D$ TRITIUM OXIDE ENVIRONMENTS. THE PROBLEMS ASSOCIATED WITH THE PRESENTLY UISEN MFTHOR T:F WINDOWLESS FLCW-PROPORTIONAL CCUNTING ARE DISCUSSED. A NEW METHOD OF UTILIZING SPECIAL MEMBRANE SWIPE PADEFS CDUNTED IN A LIGUIC SCINTILLATION SYSTEM IS DESCRISED. THE DATA FFOM SINGLE CHANNEL AND CHANNEL RATIO LIOUID SCINTILLATION COLNTING TECMNIQUES, VARICUS SWIPE PADERS AND VAFICUS TRITIUM ARSOPPTION AGENTS ARE PRESENTED WITH A STATISTICAL ANALYSIS. VARIQUS FACTOFS AFFECTING LIOUIO SCINTILLATING CQUNTING OF INDF.GANIC TF. ITIUM ARE DISCUSSED. THIS METHOD GIVES ABOUT $20 \%$ EFFICIENCY WITH GOOD STATISTICS, VERSUS 1\% EFFICIENCY ANO VEFY POOR COUNTING STATISTICS FDR FLOW-PROPDP.TICNAL COUNTING OF TKITIUM ON SWIPE PAPERS. FROM THE STANDPOINT OF OVERALL COUNTING EFFICIENCY, REPRODUCIBILITY CF COUNTS, EASE OF COUNTING, ANE. PHYSICAL STRENGTH, THE VINYL MEMBRANE VM-1 PAPEK COUNTED IN DIOXANE WAS BEST FOF GENERAL TRITIUM SURFACE-CONTAMINATION MEASUP.EMENTS.

AVAILABILITY - CLCARINGHOUSE FOR FEDFRAL SCIENTIFIC AND TECHNICAL INFORMATION, SPRINGFIELD, VA., \$3. ON COPY, \$0.65 MICROFICHE

\#COUNTER + \#MEASUR CMENT, GENFRAL + \#STATISTICAL ANALYSIS + \#TRITIUM + ACCELERATOR + CONTAMINATICN + OXIDE + REACTOR POWER

14-21712 ALSO IN CATEGORY 15

DAVIS LA F BAKER WL I SUMMERS DL

ANALYSIS OF JADANESE NUCLEAP CASUALTY DATA

DIKEWODD CORP., AL QUQUERQUE, NEW MEXICO

USNRDL-TPC-46 + DC-FP-1C54+.326 PAGES, E9 FIGURES, 15 TABLES, II REFERENCES, $\triangle P R$.IL 1966

SUMMAP.IZES THE QESULTS OF $\triangle$ DETAILED DATA REDUCTION AND CASUALTY STUDY MADE OV OVER $3 E$, OCO PZYSUNS SUHJECIED TO THE NUCLEAR ATTACK ON HIROSHIMA AND NAGASAKI, JAPAN, IN IQLE. GRAPHICAL AND TABULAR ORESENTATICINS ARE MADE OF PERTINENT DATA TO SHCW THAT AN EXCELLENT RASE EXISTS FOR MORE DELIAPLE CONCLUSIONS CF A WIDER VAFIETY THAN HAVE HERETCFORE EEEN AVAILABLE. THE FREE-FIELD WEAPONS EFFECTS $\triangle F E$ PRESENTSD FCR BOTH JAPANESE CITIES TO ALLJW THE ASSOCIATION GF $\triangle$ GIVEV EFFECTS LEVEL WITH A PARTICULAR PERCENTAGE OF MORTALITY OR INJURY. SUCH COMPARISONS INDICATE THAT THE INITIAL NUCLFAR RATIATION FLAYEN O OOMINANT ECLE IN THF DEATHS OF THEFMALLY SHIELDED PESPLE IN BOTH CITIES. OTHER POST-ATTACK DATA ARE GIVEN FOR THOSE PERSONS KILLED IMMEDIATELY, THOSE RESCUED BY CTHERS, THOSE WHO WERE KILLED.

AVAILABILITY - DEFENSE DOCUMENTATION C.FNTEF, C.AMERDN STATION, ALEXANDEIA, VA.

\#DATA PROCESSING + \#JAPAN + \#NUCLEAR DETONATION + \#STATISTICAL ANALYSIS + *SURVEILLANCE PROGPAM + CIVIL DEFENSE + HAZAPDS ANALYSIS + PCDULATION EXPOSURE

$14-2.171 .3$

CRAWFORD TV

LGNG RANGE DIFFUSION IIF THF NRXIFST EP-4A EFFLUENT CLOUD

LAWRENCE RADIATION LAEORATORY, LIVEPMSPE

UCRL $-50,299+.4 \%$ DAGES, 39 FIGURES, 5 TABLES, 23 REFERENCES, JUNE 1967

DISCUSSES THE GENERATION, MOVEMENT, ANO DIFFUSIDN OF THE EFFLUFNT CLOUD PQCDUCED BY THE NRX/EST EP-LA PEACTOR EXDERIMENT OF MARCH 25, 1966. INITIAL SIZE AND TIME-DEOENDENT METEOROLOGICAL PARAMETERS ALUNG THE TRAJECTORY VERE USED AS INPUT INTO A CLOUD-DIFFUSION CALCIJLATION WITH 2BPUFF, A COMPUTFO CODE DEVELOPED GY CPAWFGFD. COMPARISCN DF CALCULATIONS WITH DATA INDICATE AGREEMENT, WITHIN A FACTOR OF T'NO, FOR AIR CCNCENTFATICNS OUT TO TWO CAYS, SURFACE AIR CCNCENTRATION, DRY DEPGSITION, VERTICAL CONCENTRATIGN PROFILE SHAPE, DNO CLOUI SIZE. 
$14-21713 *$ CONTINUED*

AVAILABILITY - CLEARINGHOUSE FOR FEOERAL SCIENTIFIC AND TECHNICAL INFORMATION, SPRINGFIELD, VA., \$3.0O COPY, \$0.6.5 MICROFICHE

\#COMPUTER PROGRA', METEOROLDGICAL + \#DPPOSITION + \#OIFFUSION + \#EXPERIMENT, GENEKAL + \#NUCLEAR ROCKET + ATMOSPHERIC STABILITY + CONCENTRATION, APEA + CONCENTRATION, GRGUNO LEVEL + FALLOUT + MONITOR, RADIATION, AIP + MONITOR, RADIATION, GROUNC SURFACE

14-21715 ALSO IN CATEGORY 17

TRITIUM RELEASE FRDM MIT REACTOR DUE TO HFAT EXCHANGEF LEAK

MASSACHUSETIS INSTITUTE OF TECHNOLOGY, CAMBRIOGE, MASS.

2 PAGES, ATOMIC ENERGY CLEARING HOUSE !3(18), PAGES 14-15 (MAY 1, 1967)

(LETTER, MARCH 24) A TUSE LEAK WAS INOICATED FEB. 21 ANG PROVED GN FEB. 23. 60 LITERS OF DZO, CONTAIIUING 67.9 CUKIES OF TRITIUM, HAD LFAKED INTO THE 20,00C-GAL SECONDARY SYSTEM. URINE SAMPLES FROM THREE REACTOR-OPFRATIONS PERSONNEL WHO SHUT DOWN THE COOLING TOWER WERE 0.2\% TO

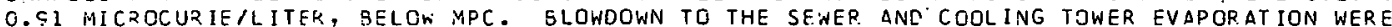
BOTH BELOW MOC.

*FAILURE, TUGING + *HEAT EXCHANGER + *TRITIUM + EFFLUENT + INHALATION + REACTOR, HWR

14-21716 $\quad \triangle L S O$ IN CATEGORY 17

NUCLEAR FUEL SERVICES REPQRTS JN WASTE. EVAPORATOR LEAK OF FEBRUARY 15,1967

NUCLEAR FUEL SERVICES, INC., WEST VALLEY, NEW YOP.K

2 PAGES, ATOMIC ENERGY CLEARING HCUSE 13(18), PAGES 15-16 (MAY 1, 19h7)

(LETTER, MARCH 14) DURING TR.ANSFER IF EVAPGRATOR BOTTOMS TO WASTE STTORAGE, A TECHNICIAN ENTERED THE DUMP ROCM AND DISCOVERED A LEAK IN A PIPING TEE. ABOUT 2100 LITERS WENT TO THE INTERCEPTOR FFGIM FLOOR DRAINS. THE INTERCEPTOR WAS NOT BEING DISCHARGED, CONTAINED 37,000 GALLONS, ANJ WAS 200 ME. /4P. AT THE RAILING. THE INTERCEPTOR CONTENTS WERE P.ETURNED FOR REWOPK, AND THEY WERE PYPASSED FOF ROUTINE GISCHARGES DURING NONOPERATING PERIODS.

*FAILURE, PIPE + \#NASTE TRFATMENT, GENERAL + EVAPORATION + LEAK + NFS + RADICCHEMICAL PROCESSING

$14-21718$

BURTSAVAGE EN

ALSO IN CATEGORY 17

U.S. RADIUM CORP. REPURTS O EXCESSIVË STACK CISCHARGES

U.S. R.ADIUIM COPP., BLOOMSOUFG, PA.

2 PAGES, ATOMIC ENERGY CLEATING hOUSF $13(1 \varepsilon)$, PAGES $21-22$ (MAY 1,1967 )

(LETTER, MARCH 22) OISCHAQGES RURING THE FIPST QUARTER GF 10.7 WERE 18.26, $126.09,63.04$, $201.37,15.44$, ANO 63.7 .4 TI 1 S S MPC PRIMARILY INSTANTANEQUS CONVEPSION CF TRITIUM GAS IN WATER TO HTÚ, SO THAT PEPMISSIBLE CONCENTPATIONS OF H (SUB) IN A FACILITY WITH NORMAL HUMIDITY WILL PROSABLY RESULT IN CONCENTRATIONS CF H(S) ABOVE MPC.

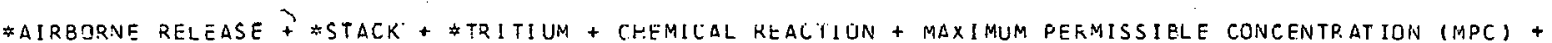
SORPTION

$14-21747$

DUNAWAYPB + LEWIS LL + STORY JO + FAYNE JA + INGLIS JM

RADIATION EFFECTS IN THE SORICIDAE, CHICETIDAE, DND MURIDAE

OAK RIDGE NATIONAL LAF., TENN.

ORNL-P-3212+ CONF-670503-23+. 27 PAGES, REFERENCES, 1967. FREM 2ND NATIONAL SYMPGS IUM ON PADIOECOLOGY, ANN ARBOR, $M I C H$.

EFFECTS DF ACUTE, CO-GO gA MMA IPRAOIATION UNDER CONTRELLED CONOITIONS IN THE LABORATGRY WERE COMPAREO IN SIX SPECIES OF RGOENTS IN THE CRICETIDAE, TWO SPECIES IN THE MURIDAE, ANO TWO SPECIES OF SHPEWS IN THE SORICIDAE. ESTIMATES OF LD(50/30) FOR. THESE TEN SPECIES RANGED FRGM 525 TO 1069 RAGS. THE MOST RERIO-FESISTANT SPECIES (TWO SPECIES OF PEROMYSCUS) AND THE MOST RADIOSENSITIVE SPECIES (JPYZ OMYS PALUSTRIA) WERE CRICETIDS. AVERAGE SURVIVAL TIMES AT HIGHEST RADIATION DOSES (15SC-2CKC FADS) WERE LONGER AMGNG CRICETIDS $(5.6-8.1$ DAYS) THAN IN MURIDS 14.4 - E.1 DAYS) DR SCAICIDS $13.5-4.2$ DAYS), AND INTERSPECIFIC VARIATION WAS MANIFESTEO NITHIN FAMILIES.

AVAILARILITY - CLEARINGHOUSE FIJ? F̈EEFAL SCIENTIFIC AND TECHNICAL INFORMATION, SPRINGFIELD, VIPGINIA, $\$ 3.00$ COPY, \$0.65 4 ICRCFICHE

*ECOLOGICAL CONSIDERETION + FRADIATION DAN:AGF + COBALT + ORNL + RADIOBIOLOGY

$14-21748$

ALSO IN: CATEGORY.15

MCGINNIS JT + GOLLEY FB

BIDENVIRONIAENTAL AND FADIOLOGICAL-SAFETY FEASIEILITY STUDIES ATLANITIC-PACIFIC INTEROCEANIG CANAL.

TERRESTRIAL ECOLOGY. PHASE I . FINAL REFORT

GEORGI $\triangle$ UNIV., $\triangle T H E N S$, INSTITUTE DF RADIATION FCCLOGY

BMI-171-011+. 194 FAGES, FIGURES, $\triangle P R I L 19,1067$ 


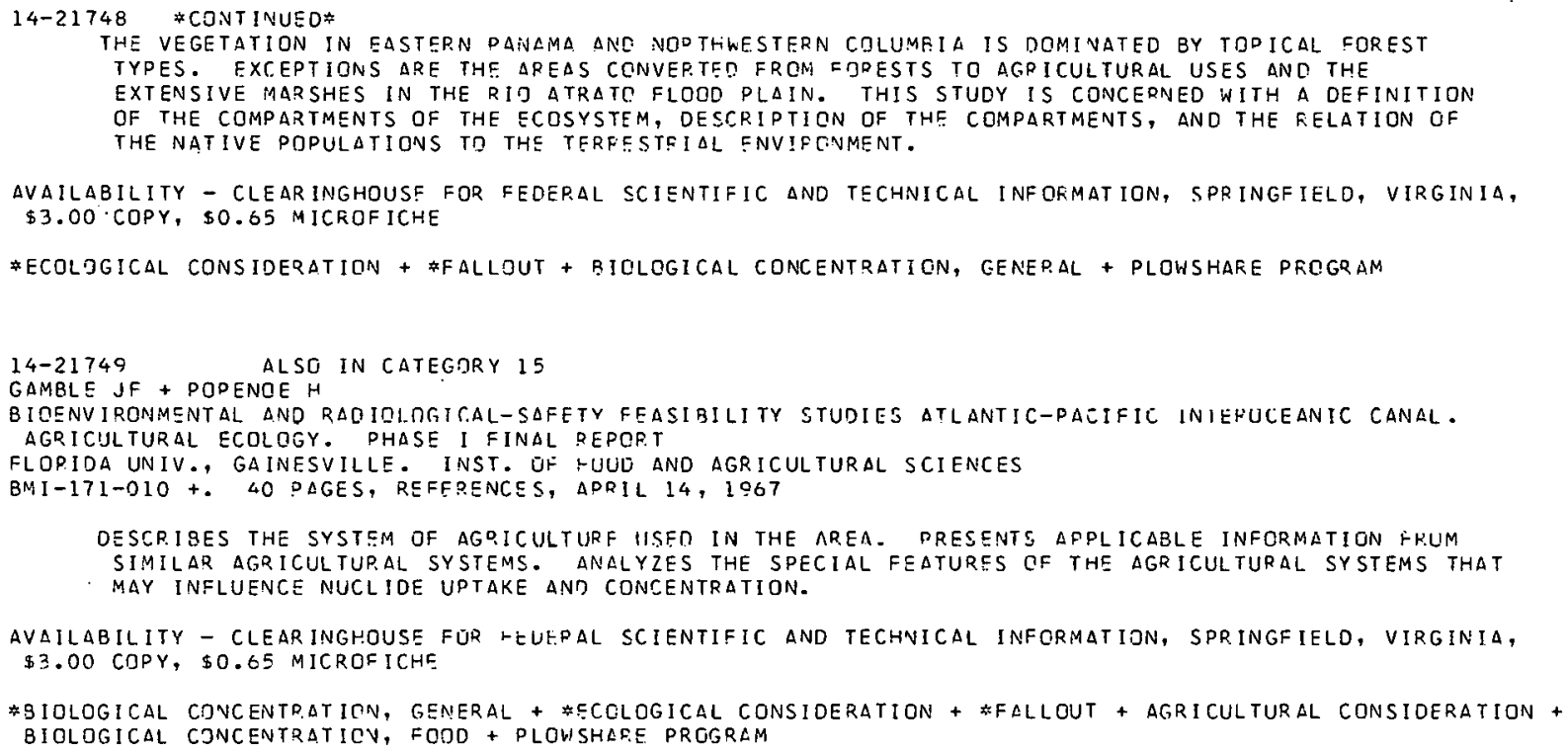

AVAILABILITY - HLARINGHOUSF FOR EEDEPAL SCIENTIFIC AND TECHNICAL INHUHMATION, SPRINGFIELE, VIRGINIA, $\$ 3.00$ COPY, \$0.65 MICROFICHE

* BIOLOgICAl concentration, general + \#EColgigical consideration + \#Fala milt +

DIOLOGICAL CONEENTKHIIUIN, AWUAIIL URGANISMS + BIOLOGICAL CONCENTRATICN, FOOD + PLOWSHAFE PROGRAM + RIVER, GENERAL

$14-21751$

LUWMAN FG

ALSO IN CATEGQRY IE

BIOENVIRONMENTAL ANO RAUIOLDGICAL-SAFETY FEASIBILITY STUDIES ATLANTIC-PACIFIC INTEPDCEANIC CANAL.

ESTUARINE AND MARINE ECOLOGY. PHASE I FINAL REPORT

PUER IJ KLCU NUCLEAR CENTEP, MAYAGUEZ

BMI-171-007+. 86 PAGES, TABLES, FEFEPENCES, MARCH 2\%, 1967

THE PURPOSE OE THE PROGR.A IN ESTULRINE AND MARINE ECOLOGY IS TO DETERMINE THE R.ADIONUCLICES THAT WOULD PQFSENT POTENTIAL HAZAFDS TO MAN IN HIS ASSOCIATION WITH THE ESTIIADINF ANR MARIME [NYIRONHINT OT THE EENTRAL AMEPILAN ISIIIMUS $\triangle N$ H HIS DERIVATIEN UF FUODS THEREFRCM. THE METHOOS TO SE USEO (SPECIFIC-ACTIVITY APPPDACH), TOGETHEF. WITH LIMITED FIELD COLLECTIONS AND METHODS TO BE USEO ISPECI
ANALYSES, ARE REPORTED.

AVAILABII. ITY - CLEARINGHOUSF FOR FECERAL SCILNTIFIC AND TECHNICAL INT URMATIQN, SPRINGFIELD, VIRGINIA, $\$ 3 . D O$ CDPY, $\$ 0.65$ MICRCFICHE

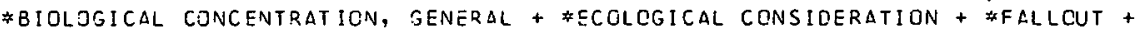

SIOLOGICAL CONCENTRATION, DQUATIC ORGANISMS + BIOLOGICAL CCNCENTRATION, FOOD + OCEAN ANO SEA + PLOWSHARE PROGRAM

14-21755 ALSO IN CATEGORY 15

HABERER K

MEASUREMENTS JF ALPHA ACTIVITY IN THICK TEST LAYERS FOP MONITORING THE SNVIRONMENT

2 PAGES, 1 FIGURE, 3 REFERENCES, $\triangle T O M P R A X I S$ ?3(10), PAGE 443 3 NO 444, (1967) IN GER:AN

BASED ON PREVIGUS WOFK, A NOMOGRAM WAS DESIGNCD FDR RAPID ENERGY AND MATRIX CORRECTION OF ALPHA-ACTIVITY MEASUREMENTS IN THICK-SATUPATION LAYERS. THE ADVANTAGES OF THIS METHOO FCR SAMPLES WITH LOW ALPHA ACTIVITY, SUCH AS CCCUP IN ENVIRONMENTAL MONITLPING, AFE OESCPIBEU.

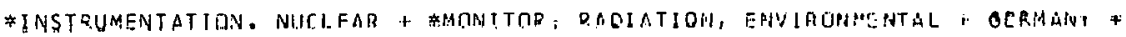




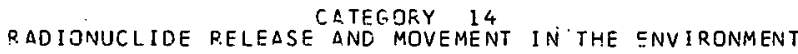

14-21755 *CONTINUED*

INSTRUMENTATION, RAEIATION MONITORING

14-21756 ALSO IN CATEGORY 15

FISCHER HF + PAFFRATH D + PETERS W

MEASUREMENTS OF RADIOACTIVITY AT DIFFFRENT ALTITUDFS OF THE ATMOSPHERE DURING AREIVAL AND PASSAGE OF FRESH

FISSION PRODUCTS

4 PAGES, 4 FIGURES, 19 RSFERENCES, ATOMPRAXIS $13(10)$, PAGE 444-447, $(1967)$ IN GERMAN

AFTER THE THIRO CHINESE NUCLEAR WEAFON.TEST, FLIGHTS AT ALTITUDES UP TO .12,500 M WERE

PERFGRMED FOR COLLECTING AEROSGL ON FIBER FILTERS. THE METHGD OF SAMPLING IS DESCRIBED. THE

FRACTION OF FRESH DEBRIS TO TOTAL $\triangle M$ TUNT OF DESRIS IS DETERMINED BY THE BETA DISINTEGRATION

CURVES OF THE SAMPLES. VERTICAL PFOFILES OF THE SPECIFIC BETA-ACTIVITY OF THE AIR. FOP OLD

AND FRESH FISSION PRODUCTS ARE REPRESENTED BY GRAPHS. THESE RESULTS APE COMPARED WITH GUR

MEASUREMENTS AFTER THE FIRST AND SECOND CHINESE NUCLEAR TEST. IN AODITION TO FISS.ION

PRDOUCTS OF THE NUCLEAP. EXPLCSION, WE I DENTIFIED THE NEUTRON-INOUCED NUCLIDES U-237 AND

INP-239 BY GAMMA-R.AY SPECTROMETRY.

*FALLOUT + \#FILTER; FIBER + \#MONITOFING PFOGRAM, ENVIRONMENTAL + AEFOSCL + AIR + AIRBCRNE RELEASE +

BETA EMITTER + GERMANY + NEPTUNIUM + RADIONUCLIDE, INOUCED + SPECTROMETRY, GAMMA + URANIUM

14-21757 ALSO IN CATEGORY 15

POPTER SW + VERRELLI DM

A QRIEF DESCRIPTION OF THE AFRRI-TRIGA MARK F REACTOR METHOOS FOR CONTROLLING DISCHARGES, ENVIRONMENTAL SURVEILLANCE AND EMERGENCY PLANS

ARMED FORCES RADIOBIQLOGY PES SEARCH INST., PBETHESDA, MD.

AO-645546 + AFRRI-SP-66-17+. 23 PAGES, FIGURES, REFERENCES, JULY 1966

DESCRIBES THE FOLLOWING FEATURES DF THE REACTOR - THE REACTOR AND ASSOCIATED EXPER IMENTAL FACILITIES, REMOTE-ARFA MONITORING SYSTEM, AIR-HANDLING AND MONITORING SYSTEM, PER IMET ER-MONITOR ING SYSTEM, RE ACTOR-ROOM CONFINEMENT, REACTOR-COOLANT MUNITORING SYSTEM, WASTE-DISPOSAL SYSTEM, AND EMERGENCY PRDCEDURES.

* MONITORING PROGRAM, ENVIRONMENTAL + *SURVEILlaNCE PROGRAM + *WASTE DISPOSAL, GeNERAL + RADIATION PROTECTION, ORGANIZATION + RADIATION SAFETY AND CONTROL + REACTOR COOLANT + SHIELDING + TRIGA (RR)

$14-21758$

ENVIRONMENTAL SAMPLING RESULTS (IN CALIFORNIA)

DEPARTMENT OF HEALTH

36 PAGES, 5 FIGURES, 14 TABLES, RADIOLCGICAL HEALTH NEWS 6131, (JULY 1967 )

DATA ARE PRESENTED FOR ANALYSES OF SAMPLES DF VARIOUS MEDIA IAIR, MILK, RAIN, SNOW, DOMESTIC WATER, SEWAGE, AND DIETI. FALLOUT FRO'M THE CHINESE WEAPONS TESTS IN ISGG INCREASED FALLOUT IMI CAI IFIRNIA IMMFNIATELY,

*BIOLOGICAL CONCENTRATIGN, GENERAL + \#FALLOUT. + *MONITORING PROCRAM, ENVIPONMENT ML + BIOLOGICAL CONCENTRATION, FOOD + BIOLOGICAL CONCENTRATION, MILK + PRECIPITATION + RAINOUT + TFST, WEAPONS (HP ASPECTS)

$14-21765$

TTLLES D

EXTRATERRESTRIAL EXCESS AR-36 AND AR-38 CONCENTRATIUNS AS POSSIBLE ACCUMULATIDN-RATE INDICATORS FCP. SEA SEDIMENTS

HARVARD UNIVERSITY, CAMBRIDGE, MASS.

6 PAGES, REFERENCES, ICARUS 7, PAGES 94-9 (JULY 1967)

MEASUREMENTS OF EXCESS AR-36 AND $\triangle R-38$, RELEASED AT HIGH TEMPERATURES FROM MINERAL CONCENTRATES OF FINE-GRAINED SEOIMENT, MAY BE USEFUL FOR DETERMINING AVEPAGE SEDIMENTATION RATES IN MAR INE SFDIMENTS. ASSUMPTIONS ARE PEOUIRED ABOUT LGNG-TERM AVERAGE CONSTANCY OF INFLUX OF INTERPLANETARY DUST TO EARTH, GF RARE-GAS CONCENTRATION IN THIS DUST, AND AENUT MINERAL STABILITY IN THE MARINE ENVIRONMENT. THESE ASSUMPTIONS CAN BE EXAMINED EXPERIMENTALLY BY STUDY OF SAMPLES WHOSE SEDIMENTATIION RATE IS RELIABLY DETERMINEO BY OTHER METHODS. IF THE NECESSARY CONDITIONS ARE FULFILLED, THE GREATEST ATTRACT IONS OF THIS METHCD ARE ITS UNIVERSAL APPLICABILITY, ITS INDEPENDENCE OF LOCAL GEOCHEMICAL ENVIRONMENT OR GFOLOGIC HISTCRY, ANO ITS NONLIMITATION BY HALF-LIFE.

* ARGON + \#ENVIRONMENTAL CONDITION + \#GEOLOGICAL CONSIDERATION, GEQPHYSICAL + \#SEDIMENT + ANALYTICAL TECHNIQUE, AIR + ANALYTICAL TECHNIQUE, SOLID + ANALYTICAL TECHNIQUE, WATER + COSMIC RACIATION

$14-21768$ ALSO IN CATEGORY 15

COWSER KE + BEATTIE JR

CONSFQUENCES OF ACTIVITY RELEASE - FISKS TO THE POPULATION AND THE INDIVIDUAL FROM IODINE RELEASES UNITEO KINGDOA ATOMIC ENERGY AUTHORI TY

16 PAGES, 6 Figures, 4 TABLES, 40 REFERENCES, NUCLEAR SAFETY 8(6), PAGE 573-588, (DECEMBER 1967) 
CATEGOEY $14^{\circ}$
RAOIJNUCLIOE OFLEASE ANO MOVEMENT IN THE ENVIRONMENT

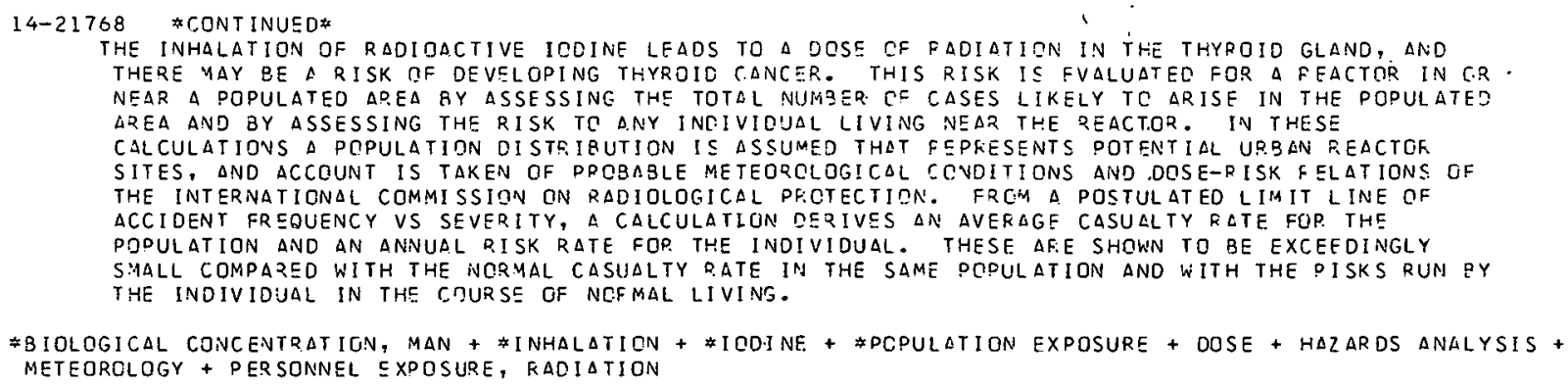

*DOSE + \#FNVIRONMEVTLL CONDITION + \#NUCLFAF DETCNLTION + \#RATIONUCLIDF, INDUCEO + CONTAMINATION + FALLOUT + HAZARD, RELATIVE + NORWAY

14-21770 Q.LSC IN CATEGORY 15

CURT IS GB + PETTY JS

A PROGRAM TO COMPUTE EETA RADIATION DOSAGE. VOLUME I. PROGRAM DESCRIFTION. FINAL REPCRT AMEF. ICAN RESEARCH CDRP., FULLERTON, CLLIF.

TID-24023(VOL.1)+

AMEF ICAN RESEAFCH COPPORATION DEVFLGPEC A COMPUTER PROGRAM TO CALCULATE BETA RADIATION DOSACES TO TISSUE INCURRED FROM SONTACT WITH PADIOACTIVE FALLOUT. PARTICLES CONTAINING MIXEO FISSION PRODUCTS. VEFSIONS OF THE BETA FADINTION OCSAGE PROGQAM WERE PREPARED FOR THE CDC 3600 ANC 13.47094 COMPUTEP.S. VERSATILE INPUT/OUTPUT PFOCEDURES PRCVIOE CGNTROL OVER THE SELECTION ANIT

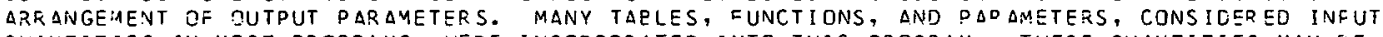
OUANTITIES IV MOST PROGRAMS, WERE INCORPORATED INTO THIS PRCGRAM. THESE QUANTITIES MAY EE TREATED AS OPTIONAL INPUTS. WHEPE CESIRED. VOLUME I OF THIS REPORT DISCUSSES THE TECHNICAL

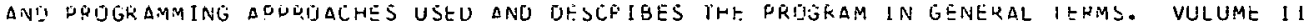
CONTAINS DETAILE INSTRUCTIONS FOF THE USE OF THE PROGRAM AS WELL AS PROGRAM LISTINGS.

- AVAILABILITY - CLEARINGHOUSE FOP. FEDERAL SCIFNTIFIC AND TECHNICAL INFCFMATION, SPRINGFIELO, VIRGINIA, $\$ 3.00$ COOOY, \$0.65. MICRCTICIIC

*BETA EMITTER + \#COMPUTER PQOGRAM + \#DOSIMETOY, GENERAL + \#FALLOUT + FISSION PQDOUCT RELEASF, GENEFAL + NUCLEAR. DETONATIOV

14-21771 ALSC IN CATEGORY 15

JS CURTIS GB

A PPOGRAM TO COMPUTE QETA RODIATION DOSAGE. VOLUME II. USERS MANUAL AND PREGRAM LISTINGS. FINAL PEPCRT AMER ICAN RESEAPCH CORP., FULLERTON, CALIF.

TIC-24033 (VOL.2) + ARC-67-49+. 204 PAGES, AUGUST $1,1.07$

AHERICAN RESEARCH CORPORATION REVELOPED A COMPUTER OROGRAM TO CGLCULATE GETA RADIATION DOSAGES TS TISSUE INCLRRED PROM CONTACT WITH PADIOACTIVE PARTICLES CGNTAINING MIXEO FISSION DPOOUCTS. THE PROGPAIA IS CAPABLE JF EVALUATING EETA DADIATION DOSASES AF. ISIVG FROM CONTACT hITH PAPTICLES ORIGINATING FRTM A NUCLEAR WEAFON DETONATION OS WELL AS PARTICLES QESULTING FFCM THE DESTRUCTION GF A NUCLEAR RRORULSION REACTOR. VERSIONS DF THF RROCRAM TO COMRUTE BETA 2ADIATION DOSAGE WEFE PREPARED FOP THF CDC 3000 ANI $19 \mu 70 C 4$ COMPUTERS. VERSATILE INPUT/OUTPUT PROCFDURES PROVIDE CONTROL CVEF THE SELECTICN AND $\triangle R P A N G E M E N T$ SF OUTPUT PARAMETERS, CONSIDERED INPUT OUANTITIES IN MOST DRDGRAMS, WERE INCORPCRATED INTC THIS YKUGKAM. THESE QUANTITIES MAY RF TREATSO AS OPTIONAL INPUTS NHEPE DESIREO.

AVAILABILITY - CLEAR INGHOUSE FOR FEOERAL SCIENTIFIC ANR TECHIICAL INFCFMATION, SPRINGFIELD, VIRGINIA, $\$ 3.00$ COPY, \$0.65 YICR.CFICHE

* BETA EMITTER + *COMPUTER PROGPAM + \#NUCLEAR DETONATION + DOSIMETRY, gENERAL + FALLDUT 
$14-21780$

ABSTRACTS OF PAPERS, WATER AND DESALINATIEN INFGRMATION MEETING, MARCH 28-29, 1967 OAK RIOGE NATIONAL LAB., TENN.

ORNL-4115+. 77 PAGES, 2 fIGURES, 2 TABLES, 4 REFERENCES, MARCH 1967

PRESENTS FOUR ABSTRACTS WHICH HAVE AS THEIR RASIS VARIOUS PUBLICATIONS IN CONNFCTION WITH THE CLINCH RIVSR STUOY, DPNL-403E. SURJECTS $\triangle P E$ - DILUTIDN, DISPERSIQN, $\triangle N D$ MASS TF.ANSPCRT CF ELEMENTS IN THE CLINCH-TENNESSEE RIVERS, PAOIDACTIVITY IN EOTTOM SEDIMENT OF THE CL INCH RIVER, ELEMENT UPTAKE IN FISH AND CTHFR DQUATIC ANIMALS, AND EVALUATION OF RADIATION COSE TC MAN FROM RADIONUCLIDES RELEASED TO THE CLINCH RIVER.

AVAILASILITY - CLEARINGHOUSE FOR FEDERAL SCIENTIFIC AND TECHNICAL INFORMATION, SPRINGFIELO, VIRGINIA, $\$ 3.00$ CDPY, $\$ 0.65$ HICROFICHE

\#BIOLOGICAL CONCENTRATIC.N, GENERAL + \#DOSE + \#WASTE OISPOSAL, GENEPAL +

BIOLOGICAL CJNCENTRATION, DQUATIC ORGANISMS + FIOTA + DOSE CALCULATION, EXIERNAL +

COSE CALCULATION, INTERNAL + DRNL + RAOICBIGLOGY + RIVER, CLINCH + RIVER, TENNESSEE +

SURFACE, WATER, NUCLIDE OCCURPENCE + WASTE DISPCSAL, LIQUID + WASTE DISPOSAL, RIVER

$14-21781$

STRUXVESS EG + CARRIGAN PH + CHURCHILL MA + COWSEP KE + MORTON RJ + NELSON DJ + PARKER FL COMPREHEVSIVE REPORT OF THE CLIVCH RIVER STUDY

DAK RIDGE NATIONAL LAB., TEVN.

OKNL-4.35 +. 126 DAGES, FIGUPES, TABLES, REFERENCES, APRIL 1967

SUMMARIZES THE STUDY MACE DURING THE PERIOD 1960-1964 OF THE EFFECT OF PELEASE OF FADIOACTIVE MATER IAL TO THE CLINCH RIVER AT OAK RIDGE NATIONAL LASORATCRY REGINNING IN 1943 . THE STUDY WAS A JOINT EFFORT OF THE USAEC, THE U. S. GEOLOGICAL SURVEY, THE U. S. PUBLIC HEALTH SERVICE, THE TENNISSSE VALLEY AUTHORITY, THE TENNESSEE DEPT. OF PUBLIC HEALTH, THE TENNESSEE STREAM PIILUTION CONTROL BOARO, THE TENNESSEE GAME AND FISH COMMISSION, AND THE OAK RIOGE NAT IONAL LABDFATORY.

AVAILABILITY - CLEAPINGHOUSE FOR FEDERAL SCIENTIFIC ANO TECHNICAL INFORMATION, SPRINGFIELD, VIRGINIA, $\$ 3.00$ CÓPY, $\$ 0.65$ MICROF ICHE

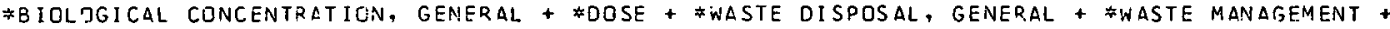

BICLOGICAL CONCENTRATIGN, $\triangle$ QUATIS ORGANISMS + QIDTA + DOSE CALCULATION, EXTERNAL +

DOSE CALCULATION, INTEFNAL + ORNL + PADIOGIOLOGY + RIVER, CLINCH + RIVER, TENNESSEE +

SURFACE HATER, NUCLIDE OCCUPFENCE + WASTE DISPOSAL, RIVEP.

$14-\dot{2} 1782$

FREDRIKSSON L + ERIKSSON A

STUDIES. ON PLANT ACCUMULATION OF FISSION PRODUCTS UNDER. SWEDISH CONOITIONS. VII. PLANT ABSORPTICN OF

SR-SO AND CS-137 FRCM SOIL AS INFLUENCEO BY SOIL ORGANIC MATTER

FDRSVARETS FORSKNINGSANSTALT, STOCKHOLM (SWEDEN)

FOA-C4-4485-4623 +. 26 PAGES, 9 TABLES, 10 REFERENCES, JULY 1966

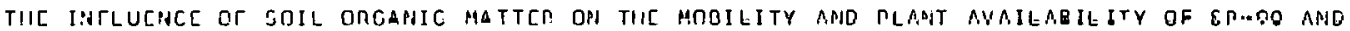
CS- 137 HAS SEEN STUDIED IN LABORATCRY AND POT EXPERIMENTS. A FIELD SURVEY DF THF CONTENT OF CS-137 IN HAY FRGM SOILS DIFFER ING IN CONTENT OR ORGANIC MATTER HAS ALSO BEEN PERFDRMED. THE OVERALL RESULTS OF THE INVESTIGATION SHOW THAT UNDER THE CONCITIONS PREVAILING IN SWEOEN IN THE SUMMER DE 19E3 FROM 3 TO 25 PFF CENT - DEPENDING ON SOIL TYPE - OF THE CS-I37 FOUND IN HAY ORIGINATEO FROM DEPOSITS IN THE SOIL WHILE FROM 75 TO 97 PER CENT WAS COLLECTED BY OIRECT UPTAKE OR AOSERPTION FROM THE ATMOSPHERE.

AVAILAGILITY - USAEC, DIVISION OF TECHNICAL INFORMATION EXTENSION, CAK RIDGE, TENINESSEE

*BIOLUGICAL CONCENTRATION, GFNERAL + \#FALLOUT + BICLOGICAL CONCENTRATIUN, ANIMAL FEED + BIOLOGICAL CONCENTRATION, VEGETATIGN + CESIUM + STRONTIUM + SWEDEN

14-21784 ALSO IN CATEGORY 15

TAMPLIN AR

PEEDICTION OF THE MAXIMUM DOSAGE TJ MAN FROM

MAXIMUM CONTAMINATICN CF AGR ICULTURAL LAND
CALI FORNIA UNIV., LIVERMORF. LAWRENCE RADIATION LAB.

UCP.L-50163 (PT. $11+$ + 28 PAGES, FIGURES, TAELES, REFERENCES, JANUAFY 3, 1967

PART I OF THIS REPORT DRESENTS A SEMIEMPIPICAL APPROACH TOWARD ESTIMATING THE MAXIMUM CONTAMINATION OF AGRICULTURAL LAND BY RADICNUCLIDES PRODUCEO BY NUCLEAR DEVICES. IT IS EASED UPON THE MAXIMUM FALLOUT LEVELS QBSERVED SUBSEQUENT TO ALL PPEVIOUS TESTS OF NUCLEAR DEVICES AND APPLIES TO CLQUD TRAVEL TIMES QP FALLOUT ARRIVAL TIMES RANGING FROM 1 TO 50 HR AND EEYOND.

AVAILABILITY - CLEAR INGHOUSE FOR FEGERAL SCIENTIFIC AND TECHNICAL INFORMATIGN, SPRINGFIELD, VIRGINIA, $\$ 3.00$ COPY, \$0.65 MICRCFICHE

\#DOSE + \#FALLOUT + \#PLOWSHARE PROGRAM + \#SOIL, NUCLIDE OCCURRENCE + " IPIPORNE RELEASE + DIFFUSION + DOSE CALCULATION, EXTEENAL + LRL + RAINOUT + TEST, WEAPONS (HP ASPECTS) 
PAOIONUCLIDE RELEASE CANEGORY MOVEMENT IN THE ENVIRONMENT

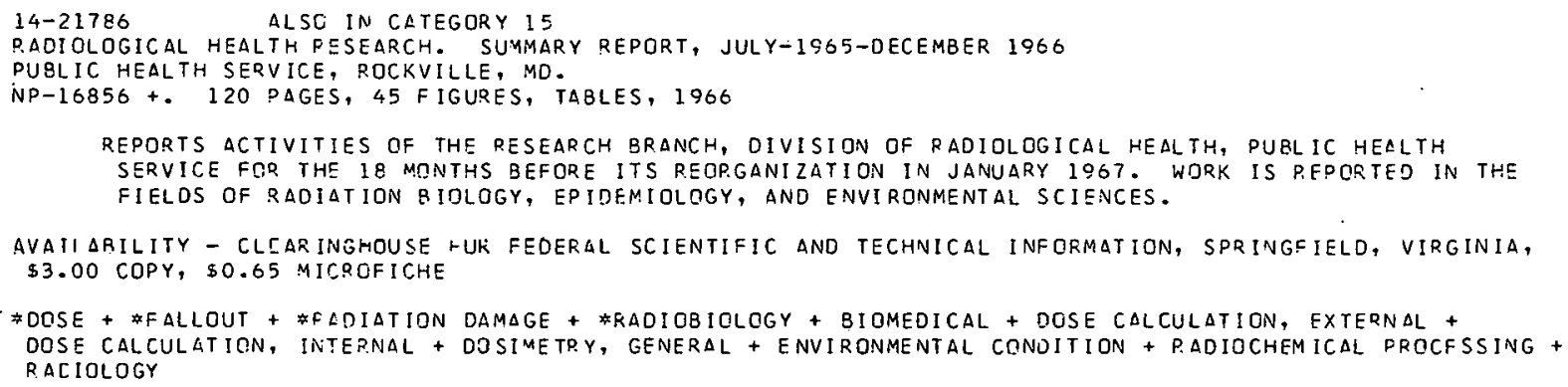


$14-21800$ \#CONT INUED*

THIS IS THE LAST IN A SERIES GF REPORTS ON THE CLINCH RIVER STUDY WHICH WAS SUMMARIZED IN ORNL-4035. THIS REPORT INCLUDES RADIONUCLIDE CORRELATIONS IN WATER SAMPLES FROM THE CLINCH AND TENNESSES RIIVERS, COLLECTION AND ANALYSIS OF FISH AND OTHER AQUATIC ORGANISMS,

HYDROLOGIC, MEASUREMENTS ANO ANALYSES, SAFETY-EVALUATION STUDIES, AND COMPUTER SIMULATION OF THE FATE OF RADICACTIVE WASTES IN STR.EAMS.

AVAILABILITY - CLEARINGHOUSE FOR FECERAL SCIENTIFIC AND TECHNICAL INFORMATION, SPRINGFIELD, VIRGINIA, $\$ 3.00$ COPY, $\$ 0.65$ MICROF ICHE

*RIVER, GENERAL + \#WASTE DISPOSAL, GENEPAL + \#WASTF DISPOSAL, FIVER + ORNL + RIVER, CLINCH + RIVER, TENNESSEE + WASTE DISPOSAL, LIOUID,

$14-21930$

QLANCORE + PARKER FL

WASTE TREATMENT AND DISPOSAL SEMIANNUAL PRDGPESS REPORT, JULY-DECEMEER 1966

OAK RIDGE NATIONAL LAB., TENN.

ORNL-TM-1887 +. 139 PAGES, FIGURES, TABLES, REFERENCES, NOV. 1967

TOPICS COVERED IN THIS REPORT ARE - TREATMENT OF HIGH-LEVEL RADIDACTIVE WASTE, TREATMENT CF LOW- AND INTERMEC IATE-LEVEL RADIOACTIVE WASTE, ENGINEER.ING, ECONOMICS, AND SAFETY EVALUATIGNS. IN CONNECTION WITH POWER-REACTOR WASTE MANAGEMENT, SEPARATION OF NOBLE GASES FROM AIR USING PERMSELECTIVE MEMBRANES, EARTHQUAKES AND REACTOR PLANT DESI'GN, DISPOSAL IN NATUPAL SALT FORMATIONS, DISPOSAL BY HYORAULIC FRACTURING, FATE OF RADICNUCLIDES IN TERRESTRIAL

ENVIPONMENT, APPLICATION OF MINERAL EXCHANGE, SAFETIY EVALUATIONS.

AVAILABILITY - CLEARINGHOUSE FOR FEDERAL SCIENTIFIC ANO TECHNICAL INFORMATION, SPRINGFIELD, VIRGINIA, $\$ 3.00$ COPY, $\$ 0.65$ MICROFICHE

\#EARTHQUAKE, GENERAL + \#SAFETY EVALUATION + \#WASTE DISPOSAL, HYDRAULIC FRACTURING + \#WASTE CISPGSAL, SALT + *WASTE DISPOSAL, TERP.ESTRIAL + \#WASTE MANAGEMENT + W WSTE TPEATMENT, FIXATION + CESIUM + COBALT + DDSE MEASUREMENT, EXTERNAL + ENVIRGNMENTAL CONDITION + GEOLOGICAL CONSIDERATION, GENERAL +

GEOLOGICAL CONSIDERATION, SALT STRUCTURE + KRYPTON + MINERAL EXCHANGE + REACTOR, POWER + RCCK MECHANICS + TRITIUM + WASTE DISPCSAL, GENERAL + WASTE STORAGE + WASTE TREATMENT, LIQUIO + WASTE TREATMENT, SOLID + WATER TREATMENT

14-21931 ALSO IN CATEGORY 15

HEALTH PHYSICS DIVISION ANNUAL PROGRESS REPORT FOR PERIOD ENOING JULY 31 , 1967 . PART VI. HEALTH PHYSICS TECHNOLDGY

OAK RIDEE NATIONAL LAB., TENN

ORNL-4168+. 46 PAGES, 37 FIGURES, 17 TAGLES, 63 REFERENCES, PAGE 185-230, OCT. 1967

STUDIES ARE OIVIDED INTO TWO SECTIONS - 11 ) AEROSOL PHYSICS INCLUDES STUDIES OF BASIC PARTICLE PHYSICS, RETENTION OF PARTICLES ON THE SKIN AND OTHER SURFACES, GENERATION OF AEROSOLS, DND EXPECTED DOSE FRCM PADIDACTIVE PARTICLES DEPOSITEO ON THE SKIN. (2) APPLIED INTERNAL UUS IMETA IIALLUDEC STIDIES WITH THF IN VIVO GAMMA-RAY SPECTROMETRY FACILITY, DETECTION AND MEASUREMENT OF SR-Y-OO INTERNAL CONTAMINATION, ELI'MINAIIUN ÜF INJECTCD IIG-2OR, AASRRPTIMN OF 17-KEV X-RAYS FROM TRANSURANIC ELEMENT, AND A NCH ANALYTICAL PRTCEDURE FOR RADIOSTRONTIUM IN ENVIRONMENTAL SAMPLES.

AVAILABILITY - CLEARINGHOUSE FOQ FEDERAL SCIENTIFIC AND TECHNICAL INFOPMATION, SPRINGFIELD, VIRGINIA, $\$ 3.00$ COPY, \$0.65'

\# $\triangle E R O S O L$ + \#ANALYTICAL TFCHNI.QUE, GENERAL + \#COUNTER, WHOLE BODY + \#DECONTAMINATION +

* UOSE CALCULATION, EXTERNAI. + $\triangle E R O S O L$ PROOUCTION + AEROSOL PROPERTIES + AEROSMI., RADICACTIVE +

ANALYTICAL TECHNIQUE, FOOD + ANALYTICAL TECHNIQUE, SOLIO + ANALYTICAL TECHNIQIJF, VEGETATION +

ANALYTICAL TECHNIQUE, WATEP. + MERCUPY + RADIUM + STRONTIUM + YTTRIUM

$14-21935$

HEALTH PHYSICS DIVISION ANNUAL PROGRESS REPORT FOR PERIOD ENDING JULY 31,1967 . PART I. RAOIOACTIVE WASTE DISPOSAL

OAK RIDGE NATIONAL LAB., TENN.

ORNL-4168 +. 60 PAGES, 33 FIGURES, \& TABLES, 99 REFERENCES, PAGE 1-60, OCT OBER 1967

RESEARCH IS REPORTED ON - (1) FATE OF RADIONUCLIDES IN TERRESTRIAL ENVIRONMENT, (2) DISPOSAL BY HYORAULIC FRACTUR ING, 13 ) DI SPOSAL IN NATURAL SALT FORMAT IONS, (4) APPLICATION OF MINERAL EXCHANGE TO REACTOR TECHNOLOGY, (5) ENGINEERING, ECONOMIC, AND SAFETY EVALUAT IONS, (6) EARTHQUAKES AND REACTDR DESIGN, (7) DOSE-ESTIMATION STUDIES RELATED TO PROPOSED CONSTRUCTICN OF AN ATLANTIC-PACIFIC INTCROCEANIC CANAL WITH NUCLEAR EXPLOSIVES, $\triangle N D$ (8) REL COOPERATIVE PROJECTS.

AVAILASILITY - CLFARINGHOUSE FOR FEDERAL SCIENTIFIC AND TECHNICAL INFORMATION, SPRINGFIELD, VIRGINIA, $\$ 3.00$ COPY, $\$ 0.65$ MICROF ICHE

*EARTHQUAKE ENGINEER ING + \#ECONDMICS + \#MINERAL FXCHANGE + \#SAFETY EVALUATION + \#WASTE DISPOSAL, HYOPAULIC FPACTUPING + \#WASTE DISPOSAL, SALT + \#WASTE DISPOSAL, TERRESTRIAL + BICLOGICAL CONCENTRATION, VEGETATION + CESIUM + CURIUM + DOSE CALCULATION, EXTERNAL + DOSE CALCULATION, INTERNAL + GFOLOGICAL CONSIDERATION, SALT STRUCTURE + KRYPTON + ORNL + PLOWSHARE PROGRAM + ROCK MECHANICS + SOIL, RADICNUCLIDE MOVEMENT THROUGH + SORPTION + TRITIUM + WASTE DISPOSAL, GAS + WASTE MANAGEMENT + WASTE STORAGE 
CATEGORY l 4
RADIONUCLIDE RELEASE AND MOVEMENT IN THE ENVIRONMENT

$14-21936$

ANZAI I + MAEDAK

SIMPLIFIEO METHCD OF URINARY URANIUM ANALYSIS FCR RADIATION DROTECTION MEASURES

TOKYO UNIV.

6 PAGES, 9 FIGURES, 8 REFERFNCES, NIPPON GENSHIPYOKU GAKKAISHI S, PAGE 321-32b, (JUNE ISE7), IN JAPANESE

A METHOD OF URINAFY URANIUM ANALYSIS USING A SODIUM FLUORIDE PELLET WAS DEVELOPED. A DREDETERMINED VQLUME OF URINE NDT PREVIDUSLY SUBJECTSD TO ANY CHEMICAL TREATMENT WAS DRCPPEO ON A PELLET OF SODIUM FLUORIDE (NAF) POWDER, ANS AFTER DRYING, WAS SINTERED IN AN ELECTPIC FURNACE FQR $\triangle$ BOUT 10 MIN AT 95O C. WHEN THE SINTERED PELLET NAS EXPOSED TO ULTREVIOLET LIOHT, IT EMITTEO FLUDRESCFNCE CF $\triangle$ WAVELENGTH CHARACTERISTIC OF URANIUM, AND OF INTENSITY FAIFLY NELL PROPORTIONAL IN A WIDE RANGE TO THE CONCENTRATICN OF JRANIUM IM THE SAMPLE UP. INE. THIS METHOD CAN RE EFFECTIVELY USEC FCR QUANTITATIVE ANALYSIS OF URINARY URANIUM IN FADILTICN PROTECTION MEASURES:

* ANALYTICAL TECHNIOUE, URINE + \#FADICCHEMICAL ANALYSIS + DOSIMETRY, THERMOLUMINESCENCE + JAFAN + uFANIUM

$14-21937$

MARCUS F?

ROLE OF WASTE MANAGEMENT AT EUROCHEMIC

EUROPEAN COMPANY FOR THE CHEMICAL PROCESSING OF IRRADIATED FUELS

4 PAGES, I FIGURE, I TAELE, ATOMPRAXIS 1211 ), PAGE 50-53, (JAN. 1966 )

THE EUROCHEMIC PLANT IS LOCATED IN a DENSELY POPULATED EUROPEAN INLAND AREA WHERE P.ELEASEC CF RADIOACTIVITY TO THE ENVIRINMENT AFF EXTREMELY LIMITED. WASTE MANAGEMENT AT EUFOCHEMIC IS DES IGNED TO (I) REDUCE THE $\triangle M O U N T$ OF WASTE $\triangle S$ FAR AS PRACTICAL, (2) SEGREGATE THE OIFFEPFNT CATFGORIES OF WASTE AT THEIP. ORIGIN, THUS PERMITTING INDIVIDUAL TREATMENT OR UTILIZATION, (3) UESIGN METHŪOS DF TEEATMENI IU UEUUCE THE VDLUMES OF WASTE, (4) DESIGN SAFE STOFAGE INSTALLATIONS, (5) PROVIDE FOR PSRPETUAL CARE OF STORED WASTE, (6) PROMOTE RESEAFCH INTO SCLIDIFICATION METHODS, (7) PREVENT UNDUE ESCAPE OF ACTIVITY IN THE WASTE RELEASED, (8) DESIGN WASTE-HANCLING SYSTEMS AT MINIMUM COST.

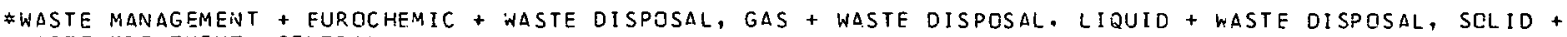
WASTE TREATMENT, GENERAL

$14-21938$

FNVIRDNMENTAL RADIQACTIVITY IN NEW ZEALAND AND RESULTS OF EXTFNDED MONITDRING OF FALLOUT FPOM FPENCH NUCLEAQ TESTS IN THE DACIFIC. QUARTEPLY RFPQRT, APRIL-JUNE ICG6

NATIONAL RADIATION LEF., CHR ISTSHURCH (NEW ZEALAND)

$N P-1641 t+N R L-F-21+.51$ PAGES, TABLES, 1966

REPORTS MONITORING OF ENVIRONMENTAL RADIOACTIVE CONTAMINATION IN NEW ZEALAND AND THE PACIFIC $\triangle R E A S$ WITH WHICH IT IS ASSOCIATEO. DATA $\triangle R E$ INCLUDED ON THE FOLLOWING - BETA ACTIVITY DE AIR SAMPLES NEAQ GFOUND LEVEL, TCTAL AMOUNT OF RETA ACT.IVITY OF FALLOUT DEPOSITED QNA THE GROUNC, SR-30 $\triangle N D$ SR-CO CQNTENT IN QAIN, SR-SO AND CS-127 CONTENT IN MILK, BETA $A C T I V I T Y$ IN $\angle I P A N C$ RAINWATER, ANO I-131 IN MILK $\triangle N D$ CATTLE THYROIDS. AGE ESTIMATION OF FISSION PRCDUCTS IN $\triangle I F$ FILTERS WAS MLDF BY MEASUREMENT OF THE RADIOACTIVE DECAY IN THESE SAMPLES.

AVAILABILITY - MICROCARD ERITIONS, INC. (FOP SALE) ACCOUNTING AND SHIPPIVG DEOT., WCST SALEM, WISCCNSIN 54669

\#BIOLQGICAI CONCENTRATION, MIIK + \#FALLOUT + \$MONITORING PROGRAM, ENVIFONIAENTAL + AIF +

BIOLOGICAL CONCENTRATION, ANIMAL + CESIUM + ENVIRONMENTAL CONOITION + IODINE + NEW ZEALAND + RAINGUT + STRONTIUM + TEST, WEAPONS (HP ASPECTS)

$14-21944$

KHASAWNEH PE + BARBEF: SA

INVESTIGATIONS OF CA-SR ADSORPTION SELECTIVITY IN CLAYS AND SOILS

PURDUE RESEARCH FOUNCATION, LAFAYETTE, IND.

COO-1495-1 + CONF-660820-1 +. 9 PAGES, AUGUST 18, 1966 , PRESENTED $\triangle T$ ANNUAL MEET ING CF SCIL SCIENCE SOCIETY CF AMEDICA. STILLWATER, OKLA.

RESULTS OF STUDIES ON CA AND SR IN E.4 SOILS FP.OM INDIANA LED TO THE FOLLOWING CONCLUSIONS. THE P.MNGE IN SELECTIVITY CF CA-SR EXCHANCE REACTION IN UNTFCATCD SOILS IS WIDER THAN HAS BEEN REPDRTEO SO FAR. A SIXIULU RANGE IS RFPCPTED, 0.36-2.11. THIS RAVGE IS NARRCWED DOWN CONSIDERA BLY EY ELIMINATING THE FFFECT OF OTHER EXCHANGEABLE IONS AND OF DIFFERENT LEVELS CIF SOLUBLE SALTS. THERE IS A NEGATIVE CORRELATION SETWESN SELECTIVITY COEFFICIENT AND ORGANIS MATTFE CINTENT. DESTROYING THE OREANIC MATTEP GF SOIL BY HZO? CESULTED IN A PRONOUNCED INCREASE IN SF SELECTIVITY. SELECTIVITY OF A MUCK SOIL ALSO INOICATED DREFERFNCS FGR CA. THE PREFEFEVCE GIF SOIL ORGANIC IATTTER FOD CA QVEP SR IS IMOORTANT IN MODIFYIVG THE DVEPALL PREFERENCE OF SOIL FOR EITHER DF THESE IONS.

AVAILABILITY - CLFARINGHOUSE FUR FEOSRAL SCIENTIFIC AND TECHNICAL INFOPMATION, SPP INGFIELD, VIRGINIA, $\$ 3.00$ COPY, \$0.65 MICFOFICHE

\#ECOLOGICAL CONSIDERATION + \#FALLDUT + \#MINERAL EXCHANGE + \#SGIL, PADIONUCLIDE MOVEMFNT THROUGH + CALCIUM + STRONTIUM 
14-21945 ALSE: IN CATEGQRY 15

PASTERNACK $3+$ LIUZZI A- BERK HW

STATISTICAL ANALYSIS OF ENVIRCNMENTAL AND TOTAL BODY GAMMA-FAY SCINTILLATION SPECTRA. PROGRESS REPORT, OCTOBER 1, 1965-SEPTEMBER 30, 1966

NEW YORK, N. Y. INST. DF ENVIRENMENTAL MEOICINE

NYO-3136-3 +. 54 DAGES, FIGUPFS, TABLES, FFFERENCES, OCT. 31,1966

DISCUSSES THE USE OF CDMPUTER PFOGHAMS FOR. ANALYZING THE GAMMA SPECTRUM OF RADIONUCL IDES IN ENVIRONMFNTAL SAMPLES INCLUJING VEGETATICN, SCIL MUD, WATER, MILK, FISH, AND HUMAM TISSUE.

AVAILABILITY - CLEARINGHOUSF FOR FEDERAL SCIENTIFIC AND TECHNICAL INFORMATIDN, SPRINGFIELO, VIRGINIA, $\$ 3$. OO COPY, \$0.65 MICKOFICHE

* BIOLOGICAL CONCENTRATIGM, GENERAL + \#COMPUTER PROGRAM + \#CDUNTER, WHOLE BODY + \#RADIOGIOLOGY + * SPECTROIIETRY, GAMMA + PIOL OGICAL CONCENTRATION, AQUATIC ORGANISMS + QIOLOGICAL. CONCENTRATION, MAN + BIOLOGICAL CONCENTRATION, MILK + BIOLOGICAL CONCENTRATION, VEGETATION + BIOMEDICAL + BISIUTH + CESIUM + COBALT + COMPUTER, CIGITAL + GAMMA + IRON + RADIUM

$14-21946$

MADSHUS $K$

LEVELS OF CS-137 IN NORWEGIAN LAMP AND SHEFP, 1C64-1966

NOP.SK RADIUMHOSPITAL, OSLO. NORSK HYDROS INST. FOR CANCER RESEARCH, DSLG. STRUEMME, AKSEL

NYG-3364-28+. 10 PAGES, FIGURES, TABLES, REFERENCES, 1966

DATA ARE PRESENTEC ON THE CONTENT OF CS-137 IN SHEEP IN NORWAY FROM 1964 THRCUGH 1966.

SAMPLES FROM SHEEP AND LAMBS WFRE ANALYZED. A DECREASE IN CS CGNTENT OUP. ING THIS TIME WAS NOTED.

AVAILABILITY - CLEARINGHOUSE FOR FEOERAL SCIENTIFIC ANO TECHNICAL INFORMATION, SPRINGFIELD, VIRGINIA, $\$ 3.00$ COPY, \$O. $\$ 5$ MICROFICHE

* BIOLJGICAL CONCENTRATION, FOOD + \#FALLOUT + *RADIOBIOLOGY + BIDLOGICAL CONCENTRATION, ANIMAL + CESIUA + NORWAY

$14-21947 \quad$ ALSO IN CATEGQRY 15

EDVARDSSON KA + HAGSGARD S + SWENSSON A

DECONTAMINATION EXPEF. IMENTS ON INTACT PIG SKIN CONTAMINATED WITH BETA-GAAMA-EMITTING NUCLIDES

AKT IEBOL AGET ATOMENETGI, STOCKHOLM (SWFOEN)

$\triangle E-255+.35$ PAGES, FIGURES, TASLES, REFEPENCES, NOV. 1966

MOST OF THE EXPERIMENTS USED I- 131 AS NAI IN WATER AS THE CONTAMINATING AGENT BECAUSE IT WIAS

THE MOST DIFFICULT TO P. EMGVF. VARIAELES INVESTIGATED INCLUDED TIME BETWEEN CONTAMINATION AND DECONTAMINATICN, EFFECT IVEVESS OF SDAP AND OTHER CLEANSERS, TEMPERATURE OF WATER, PRESENCE OF DIL ON THE SKIN, AND PFOTECTIVE OINTMENTS.

AVAILABILITY - MICROCARO EOITIONS, INC. (FRR SALE) ACCOUNTING AND SHIPPING DEPARTMENT, WEST SALEM, WISCONS IN $54660^{\circ}$

\#DECONTA?INATION + \#RADIOCHEMICAL PLANT SAFETY + BETA EMITTER + CALCIUM + CESIUM + CONTAMINATION + GAMMA EAITTER + IODINE + PHOSPHORUS + SODIUM + SWEDEN + THALLIUM

$14-21948$

CULLEN TL

ALSC. IN CATEGORY 15

DOSIMETRIC MEASUREMENTS IN BPAZILIAN REGIONS OF HIGH NATURAL RADIOACTIVITY LEADING TO CYTOGENETIC STUDIES PONTIFICIA UNIVERSIDADE CATQLICA DO RIO DE JANEIRO (BRAZILI. INSTITUTC DE FISICA

NYO-2577-8 + CONF-660:20-7 +. 17 PAGES, REFERENCFS, 1966 , PRESENTFD AT IST INTERNATIONAL. CONGRESS OF THE INTERNATIONAL FADIATION PRTTECTION ASSN., ROME, ITTALY

REPORTS DOSIIAETEIC MEASUREMENTS MACE IN GUARAPARI, BRAZIL, A CITY BUILT ON MDNAZITE SANDS. LITHIUM FLUDRIDE DOSIMETERS WERE USEO TO RECONSTRUCT THE LIFETIME DDSE OF SELECTED INDIVIDUALS REPRESENTING VARIOUS SECTIONS OF THE CITY, ALL AGE BRACKETS, AND BOTH SEXES. THE AVERAG DOSE FATF FOR THE 317 PECPLE MEASURED WAS 636 MR/YP. POPULATION MOVEMENT ON A OAILY RASIS NITHIN THE CITY TENDED TO EQLALIZE THE DOSE. ATTEMPTS TO MEASURE INTERNAL

CONTAMINATION WEFE INCONCLUSIVE. HOWEVER, IT IS BELIEVED THAT INTIMATE CENTACT WITH

CONTAMINATEO SURFACES AND DUST IN THE AIR IS THE SDURCE OF BCOY BURDENS THAT MAY HAVE

CYTOLOGICAL SIGNIFICANCE.

AVAILABILITY - CLEARINGHOUSE FOR FEDERAL SCIENTIFIC ANO TECHNICAL INFORMATION, SPRINGFIELD, VIRGINIA, $\$ 3.00$ COPY, \$0.65 YICRCFICHE

*DOSE MEASUREMENT, EXTFFNAL + *DOSE MEASUPFMENT, INTERNAL + *DOSIMETRY, GENERAL + ₹RADIOBIOLOGY + * SURVEY, RADIATION, ENVIPCNMENTAL + 2PAZIL + DOSIMETRY, THERMOLUMINESCENCE + SOIL, NUCLIDE OCCURRENCE + THORIUM 
CATEGORV 14
R ADIONUCLIDE RELEASE AND MOVEMENT IN THF ENVIRONMENT

$14-21949$

FOLSOM $T R$

STUDIES OF BACKGROUNO RADIOACTIVITY LEVELS IN THE MARINE SNVIRONMENT NEAR SOUTHERN CALIFORNIA. REFORT NO. $1 M R-T R-022-66-4$

SCRIPPS INSTITUTION OF OCEANOGRAPHY, LA JGLLA, CALIF. CALIFGRNIA UNIV., LA JOLLA. INST. OF MARINE RESOURCES

TID-23476 +. 43 PAGES, FIgURES, TABLES, REFERENCES, NOV. $1,1966$.

STUOIED PACIFIC COASTAL BACKGROUNO RADIOACTIVITY LEVELS IN THE AREA OF SOUTHERN CALIFGRNIA THAT HAY RE CHANGED SY $\triangle N$ EXPANDING POPULATION AND INCREASEC USE OF RADIDISOTOPES $\triangle N C$ NUCLEAR POWER. SENAGE, SLUOGE, AND DRIFD FERTILIZER FROM THE LOS ANGELES HYPERION PLANT WERE MONITORED COR GAMMA-EMITTING RAOIOISOTOPES. SAMPLES CROM P OTHER CITY SEWAGE PLANTS WERE ALSO MONITOREO. THE MARINE ENVIPONMENTS NEAR POINT ARGUELLO AND THE PACIFIC CCEAN NEAR THE CALIFORNIA COAST WERE MONITORED FOR FALLOUT AND DEBRIS CROM SNAP DEVICES.

AVAILABILITY - CLEARINGHOUSF FOR FFUERAL SCIENTIFIC AND TECHNICAL INFGFMATION, SFRINGFIELD, VIRGINIA, $\$ 3.00$ COPY, \$0.65 MICRQFICHE

\#ENVIRONMENTAL CONDITIONi + \#FLLOUT + \#MONITORING PFOGRAM, ENVIRONMENTAL + \#WASTE DISPRSAL, GENERAL + BIOLOGICAL COVCENTRATION, NOUATIC ORGANISMS + CESIUM + GAMMA EMITTER + OCEAN AND SEA + PLUTONIUM + POLONIUM + SPACECRAFT

$14-21051$

PICKERING DC + ALEKSAKLIN PY

BOCK REVIF'N OF RADIOACTIVE CONTAMINATION OH SOIL AND PLANTS

1 PAGE, NATURE $212(50.66)$, PAGE 1028 , (DEC. 3, 19KA)

THIS HUUK, TRANSLATED FROM THE RUSSI NATURE OF FALLOUT, THE UPTAKE OF FISSION FRAGMENTS (PRINCIPALLY SR AND CS) BY PLANTS, AND MEANS OF RESTRICTING UPTAKE BY.PLANTS.

\#BIOLDGICAL CONCENTRATICN, VEGETATION + \#FLLOUT + \#FISSION PRODUCT TPANSPDRT + CESIUM +

SOIL, RADIONUCL IDE MOIVEMENT THROUGH + STRGNTIUM + USSR

$14-21952$

BARTLETT BJ + RUSSELL RS

PRFCICTION OF TUTUPE LEVELS UE LONG-LIVED FISSION PRCCUCT.S IN MILK

GREAT SRITAIN, AGR ICULTURAL RFSEARCH COUNCIL

4 PAGES, 5 TABLES, 28 P.EFERENCES, NATURE 209(5028), PAGE 1062-1065, (MARCH 12, 1966)

EVALUAILS PROBABLE FUTUPE LEVELS CF SR-COO ANO CS-137 IN MILK F.SSULTING FROM FALLCUT IN THE UNITEO KINGODM. SUGGSSTED THAT $\triangle N$ APPRECIABLY LARGER FFACTION OF THE TOTAL DCSE COMMITMENT IS DUE TO CS-157 AND A SIALLLER FPACTION TO SR-GO THAN HITHEPTD ASSUMED.

* Biological concentration, general + \#Biological concentration, Milk + \#dose + \#Fallout +

GIOLJGICAL CONEENTRATION, GOCO + CESIUM + DOSE CALCULATION, INTEPNAL + STRONTIUM + UNITED KINGCOM

$14-21953$

PLATT AM + COOLEY CQ

WASTE SOLIOIFICATION PROTOTYPF DROGRAM

BATTELLE NORTHWEST LABUKATORY

4 PAGES, 5 FIGURES, 6 REFEOFNCES, ATOMICS 18(4), PAGE 22-25, (JULY 8 , 1066)

DESCRIBES THE WASTE-SOLIDIFICATION-PROTOTYPE DROGRAM INCORPORATING THE DEMONSTPATION OF SPRAY SOL IDIFICATION, FOT CALCINATION, AND PHOSPHATE-GLASS SOIIDIFICATION.

*WASTE DISOOSAL, GENEPAL + WASTE TPEATMENT, FIXATION + *WASTE TPEATMENT, GENERAL +

*WASTE TREATMENT, LIUUID + BATTELLE NORTHWEST + CALCINATIGN + GLASS

14-21954 ALSO IN CATEGORIES 15 ANO 18

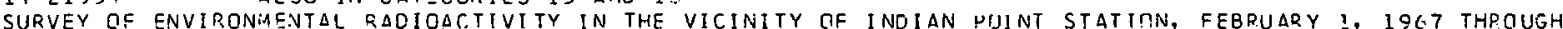
JULY 31,1967

CONSOL ICATED EDISON COMFANY OF NEW YORK

17 PAGES, 4 FIGURES, 8 TARLES, AUGUST 18,1967 , DOCKET NO. 50-3, TYPE--PWR, MFG--B+W, AE--CON ED

REPORTS RESULTS OF MONITORING CF PARTICLES IN AIF, FALLOUT, HUDSON RIVER. MUD, ALGAE, VEGETATION, SOIL, LAKE WATER, HUDSON FIIVER. WATEF, AND BACKGROUND GAMMA PADIATIDN. NC SIGNIFICANT CHANGES IN QACKGRDUND FADIATION WERE FOUNO.

AVAILABILITY - USAEC DUELIC DCCUMENT POMM, WASHINGTON, D. C.

\#MONITORING PROGRAM. ENVIRONMENTAL + \#SURVFY, RAOIATIION, ENVIRENMENTAL + ENVIRLNMENTAL CCNDITICN + FALLOUT + INIJIAN PIINT I (PWR) + REACTOR, PWR + STACK 
14-21957 ALSO IN CATEGORY 15

PETROV RV + PRAVETSKII VN + STEPANOV YS + SHALNEV MI

RADIOACTIVE FALLOUT. PHYSICS, 3 IOLOGICAL EFFECTS ANE PROTECTIVE MEASURES

$A E C-T R-5634+1 P S T-C A T,-1508+$. 140 PAGFS, 1963, ITRANSLATION OF ZASHCHITA OT RADIOAKTIVNYKH OSAOKOV, gOSUDARSTVENNOE IZDATEL STVO, MEOITSINSKOI LITERATURY, MOSCOW, 1963.1

AN ABSTRACT DF THIS MJNOGRAPH WAS PPEPARED ON THE ORIGINAL FIUSSIAN-LANGUAGE PUBL ICATION AND APPEARED IN INSA VDL. IQ AS NUMPER $85 E 7$.

AVAILABILITY - CLEARINGHOUSE FOR FEDERAL SCIENTIFIC.AND TECHNICAL INFORMATION, SFRINGFIELD, VIRGINIA, $\$ 3.00$ COPY, \$0.65 MICROFICHE.

\#DECONTAMINATION + \#DOSIMETRY, GENEPAL + \#FALLOUT + \#INSTRUMENTATIGN, RADIATION MONITORING + DDSE YEASUPEMENT, EXTERNAL + RADIATION PROTECTION, OFGANIZATION + RADIOBIOLOGY + USSR

14-21959 ALSO IN CATEGORY 15

FRANEA EP + RIBEIRE CC + TEITAKOWSKI M + LONDFES H + SANTOS H + AL BUDUERQUE HA

SURVEY OF RADIJACTIVE CONTENT DF FOOD GROWN ON BRAZILIAN AREAS OF HIGH NATURAL RADIOACTIVITY

BRAZIL UNIV., RIO DE JANFIRO. INSTITUTO DE BIOFISICA

NYO-3273-5 + CONF-65052इ-2 +. 15 PAGES, 1965, PR.ESENTED AT SYMPOSIUM ON RADIATION AND TERRESTPIAL

ECOSYSTEMS, RICHLAND, V:ASH.

TWO TYPES OF HIGH-BACKGROUND REgIONS WERE STUDIED IN BRAZIL - THE MONAZITE SANE PEGION ALCNG THE ATLANTIC COAST AND THE ZONE OF VELEANIE INTFUSIVES IN THE INLAND STATE OF MINAS GERAIS. IN BOTH REGIONS, THERE ARE GROUPS OF POPULATION LIVING ON VARIABLE FIELDS OF RADIATICN

RANGING FRJM C..OR TO 1.0 YR/H. THE MOST REPRESENTATIVES TOWNS AND VILLAGES ON THESE $\triangle R E A S$ ARE 8 EING IVTENSIVELY STUDIED TO INVESTIGATE POSSIBLE LONG-TERM CONSEQUENCES TO HUMAN BEINGS DF CONT INUOUS EXPOSURE TO THESF LEVELS OF RADIATION. FOOD PRDOUCED ON THE AREAS HAVE BEEN EXTFNSIVELY SAMPLED AND ASSAYED FOF. THEIR RADIOACTIVE CONTENT. TOTAL ALPHA COUNTING,

FAST-ALPHA-PAIR COINCIDENCE COUNTING, RAOIOCHEMICAL ANALYSIS OF RA-226, RA-228, AND TH+228, AS WELL AS GAMMA AND ALPHA SPECTROMETRY WERE USED.

AVAILABILITY - CLEAPINGHOUSF FOR FEOERAL SCIENTIFIC AND TECHNICAL INFORMATION, SPRINGFIELD, VIRGINIA, $\$ 3.00$ COPY, \$0.65 MICROF ICHE

*3IOLOGICAL CONCENTRATION, FOOD + \#BICLOGICAL CONCENTRATION, GENEPAL + \#SOIL + \#SOIL, NUCLIDE OCCUFREVCE + BIOLOGICAL CONCENTRATION, VEGETATICIN + RIOMEOICAL + BRAZIL + RADIUM + RADON + THORIUM

$14-21964$

FALLOUT IN NEW Z EALAND CONTAMINATSD LEAD

2 PAGES, NATURE $213(5072)$, PAGE IIS ANO 116, (JAN. 14, 1967)

STUDIES BY THE NEW ZEALAND METEOROLOGICAL SERVICE, THE INSTITUTE OF NUCLEAR SCIENCES, AND THE NATIONAL RADIATION LABORATORY SHOW. THAT THE FRENCH NUCLEAR WEAPGNS TEST ING PROGFAM IN THE TUAMOTU ARCHIFELAGO WILL ADO FRACTIONALLY BUT NOT SIGNIFICANTLY TO THE LONG-LIVED RADIOACTIVITY IN NEW ZEALAND. THE GENERAL LEVEL OF RAOIOACTIVE CONTAMINATION IN THE SOUTHEPN HEMISPHERE SHOULD REMAIN BELOW THAT IN THE NORTHERN.

\#F MLLOIIT + \#TEST, WEAPONS (HP ASPECTS) + FRANCE + NËW Z̈EALANU + SIKUINI IUM

$14-21965$

RAJAMA J, NIKKILA DE, MAKELA P

STRONTIU:M-90 IN FINN ISH AND SOME IMPORTEO CEREALS DURING THE HARVEST PERIOD $1963-64$

TIIE STATE INSTITIITE FOR TECHNICAL RESEARCH, LABORATORY FOR FOOD RESEAPCH AND TECHNOLOGY, OTANIEMI, IIELSINKI, FINLANO.

2 PAGES, 1 FIGURE, 1 TAELE, 5 REFFRENCES, NATURE $211(5045)$, PAGE 212 AND 214, (JULY 9 , 1 CS6)

CA AND SR-90 NERE DETERMINEO IN FINNISH AND IN IMPORTED WHEAT ANO RYE, BOTH WHOLE GRAIN AND FLOUR. IMPORTED GRAIN CONTAINS LESS SR-OO. THIS APPEARS TO BE DUE TO A DIFFERENCE IN TIME OF HARVESTING.

\#BIOLOGICAL CGNCENTRATION, GENERAL + \#FALLOUT + \#STRONTIUM + ARTENTINA + BIOLDGICAL CONCENTRATION, FOOD + BIOLOGICAL CONCENTPATIGN, VEGETATION + CANADA + FINLAND + UNITED STATES + USSR

$14-21966$

PALUMBO RF

RADIONUCLIDES IN FODÜS FROM THE CENTRAL PACIFIC, 1962

UNIVERSITY OF WASHINGTON

3 PAGES, I Figure, 3 TABles, 8 REFerenCes, NATURE 209(5029), PAge 1190-1192, (MARCH 19, 1966)

DURING THE ATMOSPHERIC TESTS OF NUCLEAR DEVICES NEAR CHRISTMAS ISLAND IN ISG 2 IOPERATION OOMINTC) A SURVEY WAS CONDUCTED TO DETERMINE THE CONTRIBUTION OF RADIONUCLIDES FROM THESE TESTS TO THE FOODS IN THE CENTRAL PACIFIC. THE RESULTS SHOWED THAT PADIOACTIVE FALLOUT INTC THE CENTRAL PACIFIC FROM THE ATMOSPHERIC DETONATION OF NUCLEAR DEVICES DURING THE DOMINIC 
RADITNUCLIDE RELEASE PATEGORY 14 MCVEMENT IN THE FNVIRONMENT

$14-21966$ \#CONTINUED*

SERIES WAS BAFELY DFTECTABLE. IT WAS MANY THCUSANDFOLD LESS THAN THE LOCAL FALLOUT FEOM

SURFACE AND UNDEFWATEP. DETONATIONS GF NUCLEAP CEVICES AT BIKINI AND ENIWETOK.

\# BIOLOGICAL CONCENTRATIGN, GENERAL + \#FLLLUT + *TEST, WEAPQNS (HP ASPECTS) + BARIUM + BIOLOGICAL CONCENTRATICN, DQUATIS CFGANISMS + BIOLOGICAL CONCFNTRATION, FOOD +

BIOLOGICAL CONCENTRATION, VEGETATION + CESIUM + COBALT + ICDINE + LANTHANUM + NIOBIUM + POTASSIUM + RUTHENIUM + ZINC + ZIRCONIUM

$14-21967$

RICKARD NH

FIELD OBSERVATIONS OF FALLOUT ACCUMULATION BY PLANTS IN NATURAL HABITATS

BIOLOGY DEDT, , SATTELLE-NOPTHWEST, RICHLANC, WASHINGTON

HW-SA-36S2 +. 3 PAGSS, 2 FIGURES, 1 TAPLF, Q REFERENCES, J. RANGE MGT. 13(3), PAGE 3-5, (MAY 1 CE.5)

FALLOUT ACCUMULATION GY AGOVE-GROUND PAPTS WAS PELATED TO THE DIFFERENCES IN LEAF AND TWIG

STRUCTURE AND TIME OFGANS NERE EXPOSED TO ATMOSFHERE. TREES APPFARED TD LESSEN FALLOUT

ACCUMULATION F.Y UNDERSTORY SHRUBS.

*BIOLOGICAL CONCENTRATION, GENERAL + *GIOLGIGICAL CONCENTRATION, VEGETATION + \#FALLOUT +

BATTELLE NOPTHWEST + CEPIUM + CESIUM + MLNGANESE + NIGBIUM + PRASFCDYMIUM + FHCOIUM + RUTHENIUM + ZINC + ZIRCONIUYM

14-21978 ALSO IN CATEGMRY 15

STFTNKAHP RC + CQHLN NL + HUTSON L + KUNKEL H

DIET MODEL FOR MEASIJRING RADIOACTIVITY EXPOSURE THROUGH FOOC-PILOT STUDY

DEPARTMENT GF HEALTH, CALIFORNIA

@ PAGES, 2 FIGJJES, 3 TAQLSS, 5 REFERENCFS, PADIGLOGICAL HEALTH DATA ANC REPORTS E(1O), PAGE 5ES-573,

(OCT. 1967

THIS PAPER REPLIRTS A PILOT STUDY DESIGNED TO TEST THE HYPOTHESIS THAT THE HDUSE CIET OF $\triangle$ HOSPITAL MAY SERVE AS A MODEL FOR THE DIET OF AN ADULT POPULATICN REGIGNALLY SERVED EY THE

HISPITAL IV OFDER TO MEASURE PADID-ACTIVITY EXPCSURE THFDUGH FDOD INTAKE. YEARLY AND

SEASONAL QUANTITIES JF 37 SUBCATEGCRIES GE NINE MAJOR FOCD GROJPS WERE COMPARED FOR $\triangle$

BERK ELEY HOSPITAL HOUSE DIET AND DIETS DF BERKELEY AND OTHER SAN FRANCISCO SAY AREA

RESIDFNTS. RESULTS INDICATE THAT THE HOSPITAL HOUSE DIETS WHILE DIFFERING IN CERTAIN

D.ESPECTS FROY FOQD INTAKE OF THE PCPULATION, MAY PROVIDE. AN ESTIMATE OF NEAR-MAXIMUM INTAKE

OF FOODS SIGNIFICANT FOR RADIOACTIVE CONTENT.

* RIOLJGIGAI CONCEVTRATION, GFNERAL + \#FALLCUT + EIOLOGICAL CONCENIRAIIUN, FOOD +

BIOLOGICAL CONCENTRATION, MILK + DIETAFY HABIT

$14-21979$
LEVINEH + KIRK WD + RECHEN HJ

PLUTCNIUM ANO STRTNTIUM-SO IN DQECIPITATICN, AUGUST I\$G6 THPOUGR MAF.CH I9S7

U.S. DUBLIC HEALTH SFPVICE

3 DAGES, 1 TAQLE, G FEFERENCES, RAOIOLOGICAL HEALTH DATA AND REPORTS 9(10), PAGE 574-576, (OCT. ISE?)

GIVES PII ANT SR-CC IN PRECIPITATION AT TIGITT STATIDINS.

*FALLOUT + *SURVEILl QNCE PRjGRAM + MONITOPING PRGgFAM, ENVIRONMENTAL + PLITCNIUM + DP.ECIPITATION + STRONTIUM + TEST, NEAPUNS IHP ASPECTSI

$14-214 \div 0$

DATA. SECTION I. MILK AND FOOD

43 PAGES, FIGUSES, tARLES, REFERENCES, RACICLOGICAL HEALTH OATA AND REPORTS P(IO), DAGE E7T-6IS, ICETOBEF 10671

IN SECTION I (MILK AND FOOD), DATA ARE REPODTED FOR THE NATIGNAL CANADIAN AND PAN-AMER ICAM MILK-SAYPLING PRCGRAMS AND FOR THE COLORADO, FLODIDA, OKLAHGMA, TENNESSEE, AND TEXAS MILK-SURVEILLANCE NETWORKS. NATICNAL, UNITEU KINGDOM, AND C.ALIFCRVIA DIET-SUDVEILLANCE ACTIVIIIES ARE REPGRTED. IN SECTION II, GROSS RADIOACTIVITY IN SURFACE WATER DF THE UNITEC STATES AND RADIOACTIVITY IN MINNESCTA MUNICIPAL SUPPLIES ARE REPCRTED. IN SECTICN III, RADIOACTIVITY IN AIPBOPNE DARTICLES AND PPECIPITATION IN THE UNITED STATES, CANADA, MEXICG, AND DAN-AMERICAN COUNTRIIS ARE REPCETED. IN SECIIUN IV, ENVIRONMENTAL SURVEILLANCE DI BETTIS AND KNOLLS ATOMIC DOWED LABORATORIES, AND AT SIC PROTOTYPE REACTOR FACILITY IS FEPDRTED.

REPORTS THREE UNDERGQDUND NUCLFAE. DETENATIONS AT THE VEVACA TEST SITE DURING SEPTEMBED ICZT.

* FLLUUT + SUPVEILLANCE PROGRAM + BICLOGICAL CONCENTRATION, FGCP + BIQLOGICAL CGNCENTFATION, GFNEFAL + QIOLJGICAL CONCENTRATICN, MILK + MONITOKING PROGRAN, ENVIRCNMENTAL + PARTICULATE + DRECIPITATILIN

$14-21993 \quad$ ALSO IN CATEGORY 15

FLETCHEQ W + LOUTIT JE + PAPWERTH DG

INTERPEETATION EF LEVELS OF SR-OO IN HUMAN BCNE

UNITED KINGDOY ATOMIC ENERGY $\triangle U T H O R I T Y$, CHESTER, ENG. 
CATEGGRY 14
RAOIONUCLICE RELEASE AND MOVEMENT IN THE ENVIRONMENT

$14-21993$ \#CONT INUED*

6 PAGES, 3 FIGURES, 7 TLELES, 17 REFEPENCES, GRIT. MED. J., 2, PAGE 1225-1230, (NOVEMBER 19, 1966)

NEN DATA ON SR-OO IN SONE, DERIVEO SINCE THE CCNSIDERABLE INCREASE IN FALLGUT FOLLOWING THE 1961-2 NUCLEAF-WEAPON DETONATIONS IN THE ATMOSPHERE, ARE REPLRTED. THE RESULTS FIP. $1962-4$ REFLECTED THE INCPEASE OF CONTAMINATION OF FGDD FDLLCWING THE MASSIVE TESTING OF NUCLEAP. WEAPONS IN 1961-2. MAXIMUM CONCENTRATIONS WITHIN ANY ONE YR CGNTINUED TO OCCUR IN INFANTS AROUND 1 YR OLL, AND THIS MAX WAS REACHED AT ARCUT 4 MONTHS OF AGE. IN CHILDPEN AND ADOLESCENTS, VALUES WERE LOWEF ANO MUCH LESS VARI ABLE RETWEEN INDIVIDUALS AND DOMICILE. IN CONTP.AST WITH ADULTS, MAVY OF WHOSE RONES, FOR EXAMPLE, VERTEBRAE, SHOWED SUBSTANTIALLY HIGHER CONCENTRATIONS THAN DTHERS, THEPE WAS LITTLE VARIATIGN WITHIN THE SKELETON IN CHILDFEN AND EVEN ADOLESCENTS. IT IS THUS POSSIBLE IN JUVENILES TO TAKE THE CONCENTRATIONS OF SR-9O OBSERVED IN JNE SONE AS REPRESENTATIVE JF THF WHDLE SKELETON, AND THUS TO DERIVE BODY BURDENS ACCOROING TO $\triangle G E$ AND YEAR.

* GIOLJgICAL CONCENTRATICN, MAN + \#FALLJUT + PIOMEDICAL + RADIORIGLOGY + STRONTIUM +

TEST, WEAPGNS IHP ASPECTSI + UNITED KINGDUM

$14-21994$

CSBORNE RV

MONITORING FOR TRITIUM AT LOW LEVELS

ATDMIC ENERGY OF CANADA LTD., CHALK FIVER, ONTARIC. CHALK RIVER NUCLEAR LABS.

$\triangle E C L-2700+$ CGNF-6706ก4-6 +. 9 PAGES, 10 FIGURES, 8 REFERENCES, JULY 1967, PRESENTED AT IAEA SYMPCSIUM ON INSTRUMENTS AND TECHNIQUFS FOR THE $\triangle S$ SESSMENT OF $\triangle I R B O R N E$ RADIOACTIVITY IN NUCLEAR OPERATION, VIENNA, AUSTR IA

DIRECT MEASUREMENT OF TF. ITIATED WATEF. VAPOUR (HTO) IN AIR AT LEVELS BELOW I MPC (AIR) IS DIFFICULT WITH EXISTING INSTALLCD OF PORTABLE MONITORS. HOWFVER, AN INDIFECT MEASIJREMENT CAN EE OBTAINED BY MAKING FREQUENT ROUTINE DETERMINATIONS OF THE AMOUNT OF TRITIUM $\triangle B S O R B F D$ BY THE WORKEFS WHO DRE CHPONICALLY EXPQSEO. IN ADDITICN, INDIVIOUAL DOSES MAY BE ESTIMATED DIRECTLY. FQR THIS APPQJACH TO AREA MONITORING TO BE USEFUL TO A HEALTH PHYSICIST, RAPIC, OIRECT MEASIJREMENT OF HTO INTAKE IS NEEDED. IT WILL DETECT BODY BURDENS OF TRITIUM P.ESULTING FROM CHRONIC EXHUSURES TO O.GS (MPC)A. URINE IS VOIDED INTO A URINAI. ATTACHED TC THE ANALYSER, A SAMPLE IS AUTOMATICALLY METERED AND MIXED WITH LIQUID SCINTILLATOP AND THE TRITIUIM ACTIVITY IS THEN MEASUREC. THE ASSAY TAKES LESS THAN 2 MIN. PERFURMANCE OF THE INSTRLMENT IS AUTOMATICALLY CHECKEC BY PROCESSING STANDARD AND BACKGRCUNO SAMPLES.

AVAILABILITY - CLEARINGHDUSE FOR FEOERAL SCIENTIFIC AND TECHNICAL INFOFMATION, SPRIVGFIELD, VIRGINIA, $\$ 3.00$ CDPY, \$0.65 MICROF ICHE

* ANALYTICAL TECHNIQUF, uRINE + \#BIOLGgICAL CONCENTRATICN, MAN + *TRITIUM + aDSORPTION + CANADA + CHALK RIVER + INSTRUMENTATION, RADIATION MDNITCRING

$14-21995$

BUSH WR

REVIEW OF CHALK RIVER EXPERIENCE WITH TRITIATED HEAVY WATER

ATOMIC ENERGY OF CANADA LTD., CHALK RIVER, ONTARIO

AECL-2753 + CUNF-670218-1 +. 17 PAGE3, Q TIGURES, 4 TABLES, 7 REFERENCES, JIILY 1967, PFESENTED AT SYMPJSIUM ON INSTRIIMFNTATION, EXPERIENCE AND PROBLEMS IN HEALTH PHYSICS TRITIUM CONTROL, ALBUOUERGUE, N. MEX.

THE GRONTH OF THE TRITIUA (HTO) HAZARD IN THE NRU REACTCR BUILDING IS REVIEWED, AND THE METHODS AND EXPOSURE GUIDES INTRQDUCED TO KEEP THE HAZARD UNDER CONTROL ARE OUTLINED. HTO INTAKES ARE CLASSIFIED AS REMOVAL, CAUTICN, MINOR, OF NEGLI'GIBLE, DEPENDING ON THE HTO CONCENTRATION IN UEINE. REMOVAL EXPOSURES 120 MICROCURIES/LITERI ARE INVESTIGATED, AND A REPOF.T OF THE EXPOSUKE INCIDFNT IS OISTRIBUTED TO ALL BRANCHES. THE AVERAGE HTD DOSE RECEIVED IN 50 REMOVAL EXPOSUPES IN 1966 WAS 230 MREM, RECEIVED MOSTLY FROM MINCP AND NEGLIGIBLE EXPGSURES. OUR LARGEST HTO FXPOSURE RESULTED IN A DOSE OF 4700 MREM, $\triangle N D$ I9 GITER SINGLE EXPOSURES HAVE EXCESDEO 5 CO MREM. MOST OF THESE RESULTED FROM INTAKE OF HTO VAPOUR THROUGH THE UNWETTLL SKIN DF MEN WEARING AIR-SUFFLIED MASKS ANO COTTON COVERAIIS.

AVAILABILITY - CLEARINGHOUSE FOR FEOERAL SCIENTIFIC AND TECHNICAL INFORMATION, SPRINGFIELD, VIPGINIA, $\$ 3.00$ COPY, \$O.65 IICRGFICHE

* DOSE + \#REACTOR, HIWP + *TEITIUIA + AOSOQPTION + BIOMEOICAL + CANADA + CHALK RIVER + DOSE CALCULATION, INTEFNAL + RADIOBIOLOGY

14-21996 ALSO IN CATEGOPY 15

MATSUOKA O + TANAKA E

GAMMA LABELL ING WITH SR-85 FOP IN VIVO MEASUREMENT OF SR-9O. AN ATTEMPT FOR THE IN VIVC MEASUREMENT OF SR-9 I AND Y-OO IN INTEFNALLY EXPOSED ANIMALS

NATIONAL INST. CF RADIOLOGICAL SCIENCES, CHIOA, JAPAN

8 PAGES, 8 FIGURES, 1 TABLE, 10 REFERENCES, RADIOISOTOPES (TOKYC), 21, PAGE 261-2S8, (SEPTEMPER 1SE6), IN JAPANESE

- IN THE ST.UDY ON THE BIOLOSICAL FFFECT OF INTERNAL EXPOSURE, THE EVALUATION OF ABSORBED DOSE DUE TO DEPUSITED RADIONUCLIDE IN THE ORGAN OF INTEP.EST IS ESSENTIAL. STRONTIUM-9O IS ONE QF THE MOST-STUDIED RADIDNUCLIDES AMONG THE BONE-SEEKING ISOTOPES, PUT ITS BEHAVIOR IN THE LIVING BODY IS NUT CLEARLY UNCERSTOOD. A NEW GAMMA-LABELING METHOD WAS DEVELOPED TO DETERMINE THE $\triangle M O U N T$ OF SR-90 IN VIVD. A MIXTURE OF SR-SO ANO SMALL AMOUNT 12 TO $5 \%$ IN $\triangle C T$ IVITY) DF SR-85 IS ADMINISTEPED TO THE ANIMAL AND THE GAMMA RAYS (0.513.MEV) FROM SR-E5 


\section{CATEGORY 14
14
RACIONUCl IDE PELEASE ANO MOVEMFNT IN THE ENVIRONMENT}

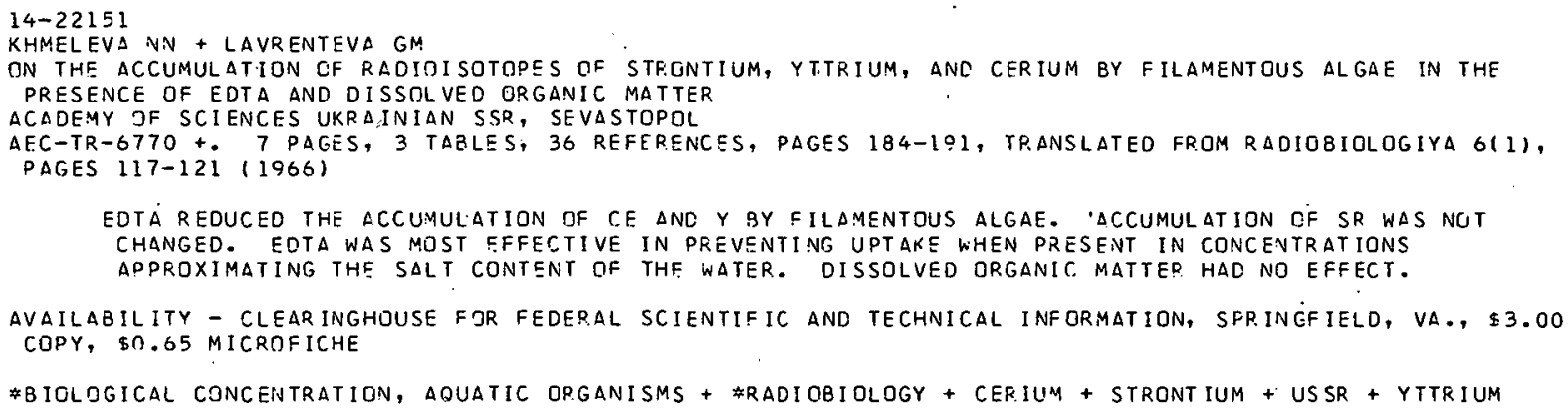


RADIJNUCLIDE RELEASE CANEG MORY MENT IN THE CNVIRONMENT

$14-2224 C$ \#CONTINUED*

GENERAL PRINCIPLES GCVERNING THE PRCQUCTION AND USE DF IFFACIATED FOOD ARE CCASIDERED, ALCNG WITH RECOMAENDATIONS FOR THE ESTAELISHMENT OF LEGISLATION AND CONTROL. RECOAMENDED TECHNICAL PROCEDURES ANC TESTS REQUIRED TO FEFMIT AN EVALUATION GF THE SAFETY FGR CGNSUMPTION OF IRRADIATED FDCD ARE OUTLINES, INCLUDING TESTS FOQ. MICRCBIOLOGICAL SAFETY. IT IS CECOHMENDED THAT DISTRIBUTION OF A SPECIFIED IRFACIATFD FOOD INTENDED FOR GENERAL PUBLIC CONSUMPTION SHOULD BE PCRMITTED DNLY AFTER ACCEPTANCE GY THE APPQQPRIATE GOVERNMENT DUTHORITY CF EVIOENCE THAT THE FODD IS SAFE CDR HUMAN CONSUMPTION.

AVAILABILHY - WORLD IICALTH ORGANIZATION, GENEVA, \$1.OO COPY

IAEA + RADIATION DAMAGE + PADIOBIOLOGY + UNITED NATIONS

$14-22243$

LEFILLATRE G + SCHEIOHAUER J + RODIER J

PROCESS FOR THE PRODUCTIGN OF SOLID DRDDUCTS CONTAINING RADIOACTIVE NASTE MATERIAL AND PRTOUCTS CRTAINED ATCRRDIVG TO SAID RFDCESS

CCMMISSAFIAT A L-CNFFGIE ATOMIQUE

CANADIAN PATENT $754,476+12$ DACFS, MAFCH 14,1967

LOW-ACTIVITY RaDICACTIVE WASTE IN THE FORM OF AN AQUECUS PASTE IS MIXEC WITH SEMIFLUIO BITUMEN BELOW 5 C IN THE PRESENCE OF A WETTING DGENT. MOST OF THE VATEF CAN THEN RE REMOVEC RYY CECONTATIOV OR OTHER MECHANICAL MEANS. FESIRUAL WATER IS DISTII.I EN TFF. ADOITICNAL MIXING WITH MODE PITUMEM AT A ILMPERATURF SUFEICIENT TO ALLOW PDURING IS THE LAST STEP. BLOCKS OF SUITAQLE DLASTICITY APE RPTATNFE FQR PUFIAL IN THE GROUNO.

AVAILABILITY - THE J.S. PATENT OFEICE, DEPADTHFNT OF CCMMERCE, WASHINGTON, D. C., \$O. 3O PER DAGE

*WASTE DISPOSAL, TEREESTPIAL + *WASTE TREATMENT, FIXATIDN + CANADA + PLTENT + WASTE TREATAENT, LIGUID + WASTE TREATHENT, SDL IC

$14-22244$

YOSHINAGA T

LEVELING AND ROTATINE APPAEATUS FIR SOIIITIEYING FAOIOACTIVE LIQUID WASTE

HITACHI LTD.

JAPANESE PATENT 196b-11EBO + . 5 PAGES, fIGUPES, TABLES, MAY 31, 1966, IV JAPANESE

THE APPARATUS PECPOSE IS FOR SCLICIFYING A RADIGACTIVE LIQLIO WASTE BY INIXING WITH CEMENT THE SUPPORT HCLDING $\triangle$ CAN IIN WHICH A LIQUID WASTE ANO CEMENT $\triangle R E$ TO BE PLACED FOR THE SOL IDIFICATION) IS INSTALLED ROTATABLE (FOR LEVELLING THE (LN) ON THE TRUCK. THE TRUCK FUNS BACK AND FORTH IN THE ADPARATUS. THE COTATABLE SUPPORT IS CPERATEO REMDTELY BY MEANS OF A GEAR ATTACHEO TO THE SUPPDPT, AND A F.OD WITH THE DPEGAIING HANCLF, THE THPEADEO END OF WHICH ENGAGES WITH THE SUPPORT GEAP. FUPTHER. THE TRUCK IS PROVIDED WITH ROLLERS FDR ROTATING THE CAN WHEN IT IS LEVELLED (I.F., RRCUGHT DOWN). THE LENGTH OF APRAY OF THF ROLLERS CAN BE ADJUSTED ACCORDING TO THE DIMENSION OF THE CAN.

AVAILABILITY - THE U.S. PATFNT JFEICE, DEPARTMENT OF COMMERCE, WASHINGTON, D.C., \$O.3O PER PAGF * WASTE TREATMENT, FIXATION + JAPAN + PATENT + WASTE TREATMENT, LIGUID

$14-22245$

MIRONOV OG

EFFECT OF EXIRACTED SFAWEEDS ON THE MIGRATION OF SR-SO AND CS-137 FFOM OCEANS AND SEAS TO THE FIRM LAND INST. OF BIOLQGY OF SOIITHFFN SEAS, USSE

1 RAGE, RYON. KHOZLY 11 , DAGE 17 (1965) IN QUSSIAN

THE NUSSIELE SPQEAD QF STRONTIUM-SO AND CESIUM-137 CONTAINED IN EXTRACTED SEANEECS IS REVIEWED ON THE BASIS C.F PUBLISHED SOVIET AND FOREIGN SOURCES. THE LCCUMIJLATION OF P.ACIOACTIVE ISOTOPES PER UNIT WEIGHT IV THE EXTRACTED SEAWEEDS WAS MANY TIMES GREATEF. THAN IN FISH TAKFN FROM THE WATER. IT $\triangle P O R O A C H E D$ THE $\triangle C C U M U L A T I O N S$ OF STRCNTIUM $\triangle N D$ CESIUM IN MCLLUSTS AND CRUSTACEANS. THEREFORE, THE FFFECT OF SEAWEEDS ON THE SFREAD CF RADIDACTIVE SUESTANCES CANNOT BE NEGI ECTTFD.

\#BIOLDGICAL CONCENTRATIEN, AQUATIC GRGANISMS + \#FLLOUT + BIOLOGICAL CQNCENTPATION, VEGETATION + CESIUM + OCEAN AND SEA + STRCNTIUM + USSR

$14-22246$

REISSIG H

EMPIRICAI. FACTOFS FOR EVNLUATIVG THE CONTAMINATION CF AGRICULTURAL FLANTS WITH RADIOACTIVE FISSION

PRODUCTS TAKING INTO ACCDUNT THE WORLD-WIDE FALLOUT OF NUCLEAP. TESTS

TECHNISCHE UNIVEPSITY, DRESDEN

7 PAGES, 7 TABLES, O REFERFNCES, KERENERGIE 10, PAGES 131-7 (APRIL 1967) IN GERMAN

IN PREVIDUS STUDIES, THE SR-SO CONTAMINATION OF AGRICULTURAL FLANTS IN THE TERRITORY OF THE GERMAN DEMOCQATIC REPUBLIC DURING THE PERIOD FRCM 1960 TO 1OEZ WAS STUDIED. FROM THESE ANO OTHER DATA, EMPIFICAL FACTORS FOR FVALUATING THE SR-SO CCNTAMINATION OF THE PLANTS WERE CALCULATED, INCLUDING THE DVEFAGE FELATIENSHIPS BETWESN FALLCUT INTENSITY AND SURFACE

TONTAMINATIDN QD, CROUNO GONTAMINATION ANO UPTEKE SY IHE KULIS. IISING EMPIRICAL FACTORS, THE 
CATEGORY 14
RADIONUCLIDE RELEASE ANO MOVEMENT IN THE ENVIRONMENT

$14-22246$ *CONTINUED

FUtURE CONTAMINATION OF THE AGFiCULTURAL PLANTS MAY RE CALCULATED With SUfFicient aCCURACY WHEN FALLOUT INTENSITY OR GRCUND CENTAMINATION IS KNOWN.

* BIOLOgICAL CONCENTRATICN, VEgeTATICN + \#CLLLOUT + EIOLOGICAL CONCENTRATION, FOOD + CONTAMINATION + GERMANY + SOIL + SOIL, RAOIONUCLIDE MOVEMENT THP.CUGF:

$14-22247$

SAIDL J + RALKOVA J

SOLIDIFICATION OF HIGH-LEVEL RADIOACTIVF WASTES. PART ?. PASALT AS THE FAVOFABLE INCORPDRATION AND FIXATION MEDIUM

INST. OF NUCLEAR RESEARCH, CZECHOSLCVAK ACADEYY GF SCIENCES

4 PAGES, 1 FIGURE, 7 TASLES, \& REFEFENCES, KERNEREGIF 10, PAGES 128-31 (APRIL 1967) IN GERMAN

SILICATE GLASSES SHGHED GOOD PROPERTIES, ESPECIALLY HIGH CHEMICAL RESISTANCE, FOR FIXATION GF HIGH-LEVEL RALIGACTIVE HASTES. FROM DETAILED INVESTIGATIONS ON THE SILIGATE MATERIALS IT WAS FOUVD THAT BASALTS HAVE $\equiv$ SSENTIAL ADVANTAGES COMPARED WIITH CONVENTIONAL GLASS. AFTER THERMAL TREATMENT, THE BASALTS ARE TRAMSFORMEO FROM THE VI.TREOUS STATE INTO THE RECRYSTALLIZED ONE. DUE TO THIS RECRYSTOLLIZATION, PHYSICAL AND CHEMICAL CFANGES DCCURRED, RESULYING IN THE IMPRIVEMENT OF THE C.HEMICAL PESISTIVITY, MECHANICAL STFENGTH, HARONESS, ETC.

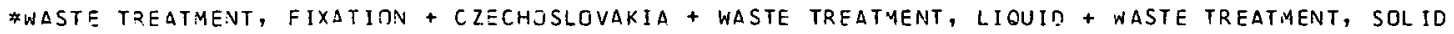

$14-22280$

METHOD OF DISPOSING CF WASTE MATERIALS PAFTICULARLY RADIDACTIVE WASTE

HALL I BURTON COMPANY

BRITISH PATENT $1,054,740+$ + 14 PAGES, I FIGURE, 6 TABLES, JANUARY 11,1967

DESCRIBES A METHOC FUR THF SUETERRANEAN DISPOSAL OF RADIOACTIVE WASTE. THE METHCD CONSISTS IN PRODUCING A NELLSOPE HAVING A CASING WHICH PENETRATES A FRACTURED EARTH FCRMATICN. LON-VISCOSITY SLURKY CONTAINING THE WASTE MATERIAL, WATER, HYDRAULIC CEMENT, CLAYS, AN AGENT WHICH REACTS CHEMICALLY WITH THE CEMENT RETARDING ITS SETTING.) THE SLURRY IS. INJECTFD INTO THE FRACTUZE AND ALLÜWED TO SET, WHICH CONFINES THE RADIDACTIVE WASTE TO THE FOFḾTION.

AVAILABILITY - THF PLTENT OFFICE, 25 STUTHAMPTON BUILDING, W. C. 2, LONDON ENGLAND, SO.49 PER CGPY

wWASTE DISPOSAL, HYDFAUL IC FOACTURING + PATENT + UNITED KINGDOM + WASTE DISPOSAL, LIGUID

14-22329 ALSC IN CATEGORY 1 :

REES DJ

HEALTH DHYSICS. PRINCIPLES OF RADIATION PROTECTION

242 PAGES, FIGUEES, TABLES, REFERENCES, THE M.I.T. PRESS, MASSACHUSETTS INSTITUTE OF TECHVOLOGY, CAMBRIDGE, MASSACHUSETTS, 1967

I HIS MONOGRAPH IS AN ATTEMOT TO PRESENT THE PRINGIPLES OPF RADIATION PROTECTION AND TO MAKE AVAILARIF TN $\triangle$ SINGLE VOLUME THE MERE IMPORTANT NUMERICAL DATA USEO IN RADIATION-PROTECTION ADPLICATIONS. IT IS ASSUMED THAT THE READER HAS. NO PREVIUUS KNUWLEUGE OF THE SUBJECT, AS TAR $\triangle S$ DOSSIBLE, AFGUMENTS ARE. DEVELUPEU FROM FIRST PRI,NCIPLES SO THAT THE BOCK WILL BE DF USE TO THOSF. NITH LIMITED TRAINING IN PHYSICS, CHEMISTRY, BIOLQGY, AND MATHEMATICS. CHAPTERS INCLUDE - (1) FADIATION PROTECTION, (2) MATTER AND RADIATION, (3) RADIOACTIVITY AND X-RAYS, (4) THE INTERACTION OF IONIZING RADIATION WITH MATTER, (5) RAOIATION DOSIMETRY, (E) THE. 3IOLOGICAL EFFECTS OC IONIZING RACIATION, (7) BASIIC STANDARDS CF RADIATION PROTECTION, (E) PROTECTION AGAINST INTERNAL FADIATION, (S) PROTECTION AGAINST EXTERNAL RADIATION, (IO) DESIGN DF RADIOISOTOFE LABORATORIES, AND $(11)$ RADIATION PROTECTI ON MEASUREMENTS.

AVAILARILITY - THE M.I.T. PRESS, MASSACHUSETTS INSTITUTE OF TECHNGLOGY, CAMBRIDGE, MASSACHUSETTS

*RAOIATION PROTECTIJN, CRGANIZZATIJN + \#RAGIOISOTOPE + \#X-RAY + DOSE CALCULATION, EXTERNAL + DOSE CALCULATION, INTERNAL + DOSIMETRY, GENERAL + GAMMA + GAMMA EMITTER + HEALTH PHYSICS TRAINING + ICRP + RACIATION DAMAGE + RADIOBIOLOGY

14-22492 $\quad \triangle L S E$ IN CATEGORY 16

EFFECT UF SOME IONS IN THE ATMOSPHERE ON THE FALLDUT IN 1964 TO 1966

HYGIENISCH-EPIDEMIOLCGISCHE KREISINSTI TUT, ERATISLAVA

5 PAGES, 2 EIGURES, 5 TABLES, 14 REFERENCES, KERNENERGIE 10, PAGES 164-2 (MAY 19E7), IN GERMAN

THE R.ADIOACTIVE FALLOUT ON THE TERRITORY OF WESTERN SLOVAKIA, CSSR, WAS OBSERVED DUR ING 1964 TO 1066. THE TOTAL 3ETA-RAY AC TIVITY, THE SR-90 AND CS-137 CONTENTS, THE AMOUNT [OF STABLE IONS IN THE FALLGUT AS WELL AS THE SALTS DISSOLVFD IN THE AT NOSPHERIC PRECIPITATION WERE DETERMINEO. THE ISOTIPIC CONTENT DECFEASEO CONTINUGUSLY, AND THE VOLUMINDUS ATMOSPHERIC DPEC.IPITATIOVS DURING, 1965 DID NOT RAISE THE FALLOUT RADIOACTIVITY. THE ION CONTENT IN THE FALLDUT WAS INCREASED BY THE INFLUENCE OF THE PRECIPITATIUNS.

*CESIUH + \#PRECIPITATIGN + \#STRONTIUM + BETA EMITTER + FALLGUT + MEASUREMENT ; REACTIVITY + RAINGUT + WASHDUT 
CATEGRRY 14
RADIJNUCLIDF RELEASE ANE MOVEMENT IN THE ENVIRONMENT

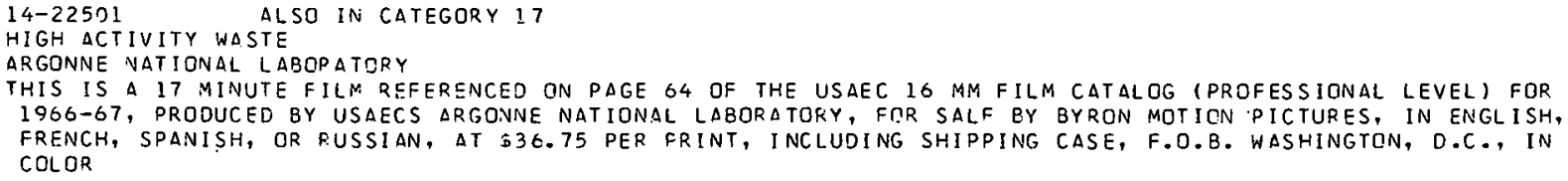

*ACTIVATION + *ECOLOGICAL CONSIDERATION + ANALYTICAL TECHNIQUE, FCOD + $\triangle N A L Y T I C A L$ TECHNIQUE, VEGETATION + ANALYTICAL TECHNIOUE, WATER + CALCIUM + CESIUM + FRANCE + POTASSIUM + SODIUM + STRONTIUM

$14-22803$

MARSHALL RO + SPARLING EM + HF INEMANN BH

KEMOVING RADIONUCLIDES FROM FRESH MILK

PRODUCEPS CREAMERY COIAPANY, SORINGFIELD, NISSOUFI 
$14-22803 \#$ CONT INUED *

PB-175709+. 193 PLGES, FIGURES, TABLES, REFEPENCES, JUNE 1966

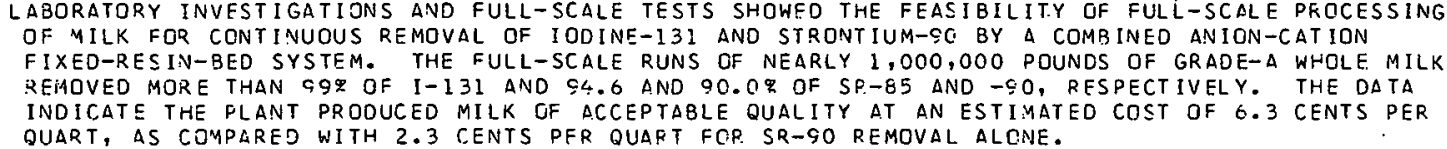

AVAILA马ILITY - CLEARINGHOUSE FOR FEDEPAL SCIENTIFIC AND TECHNICAL INFORMATION, SPRINGFIELD, VIPGINIA S3. OO COPY, SO.65 MICROFICHE

* BIOLOGICAL CONCENTRATIQN, MILK + ION EXCHANGE + \#RADIOCHEMICAL PROCESSING + FALLOUT + IODINE + STRONTIUM

$14-22804$

AARKROG A + LIPPERT J

EU-155 IN DEBR IS FROM NUCLEAR WEAPONS

ATOMIC ENERGY COMMISSIOR:, RISO, DENMARK

3 PAGES, 1 FIGUPE, 2 TABLES, 1 O REFERENCES, SCIENCE, 157, PAGES 425-427 (JULY 28, 1967)

THE LITHIUM-DRIFTEO GFRMANIUM DETECTOR ENABLES DETERMINATION OF EUROPIUM-IS5 ON A ROUTINE BASIS IN ENVIRONMENTAL SAMPLES CONTAMINATED WITH DEBRIS FROM NUCLEAR WEAPCNS. FROM MEASUREMENTS OF EURDDIUM-155, CESIUM-144, AND STRONTIUM-90 IN $\triangle I R$ FILTERS COLLECTED BETWEEN

1961 AND 1960, THE YIELD OC EUROPIUM-155 FROM WEAPONS WAS ESTIMATED AT 1400 ATOMS PER MILLION

FISSIONS, WHICH IS CLOSE TO THE YIELD FROM FAST FISSION OF URANIUM-238.

*FALLOUT + \#NUCLEAR EXPLOSION DEBRIS + CESIUM + DENMARK + EUROPIUM + STRONTIUM + TEST, WEAPONS (HP ASPECTS)

$14-22805$ ALSO IN CATEGORY 15

PFEIFFER EW

13 I FALLOUT IN UTAH

HAZARDS OF IODINE- 131

PRESENTS A BRIEF SUMMARY DF THE PROGRAMS TO BE PRESENTED AT AAS MEETING DECEMBER IOST ON FALLOUT OF IOCINE IN SOUTHERN UTAH RESULTING FROM WEAPONS. TEST ING IN SOUTHERN NEVADA. IT IS SUGGESTED THAT THYROID DOSES DF 50 TO 120 RADS MAY HAVE BEEN RECEIVED BY CHILDREN IN SOUTHERN UTAH WHO WERE 2 TO 5 YEARS OLD DURING 1952-1955.

* DOSE CALCULATION, INTERNAL + \#FLLQUT + \#IODINE + *TEST, WeAPCNS (HP ASPECTS) +

BIOLOGICAL CONCENTRATION; MAN

$14-22806$

MOTQJIMAK + RANMT S + TAMURA N

DETERMINATION OF RADIOACTIVE COBALI IN KEAC PUER COOLANT WATER PY STIVFNT FXTRACTION

JAPAN ATOMIC ENERISY KESEARCH INGTITUTE, TOKAIMIIRA. IBARAKI-KEN, JAPAN

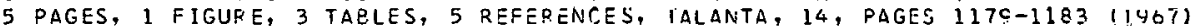

DESCRIBES A RAPID EXTRACTION SEPARATION METHOD FOR THE RADIOCHEMICAL DETERMINATION OF COBALT-58 AND CDEALT-60 IN REAC TOR COOLANT WATER. AFTER ADJUSTMEVT OF THE PH OF THE SAMPLE WATER TO 5.0-5.5, COBALT DIETHYLDITIOCARBAMATE IS EXTRACTED WITH BENZENE. OTHER NUCL IDES, E.G. MANGANESE-54 AND -56, COPPER-64 AND IRON-59, WHICH ARE USUALLY PRESENT IN REACTOR COOLANT WATER, ARE ALSU EXTPACTED TCGETHER. WITH CMRALT. HOWEVER, THEY CAN BE REAOILY REMOVED SY WASHING THE EXTRACT WITH MERCURYIIII CHLORIDE SOIUTION. THE COBALT-58 ANU -6O ACTIVITICS ARE MEASUREO EY GAMMA COUNTING OF AN ALIQUOT OF THE WASHED EXTRACT. TRACE AMUUNTS OF RADIDACTIVE COBAIT IN $500 \mathrm{ML}$ OF SAMPLE WATER CAN BE QUANTITATIVELY EXTRACTED WITHOUT THE USE JF CARRIER. THE SEPARATION COULD BE FINISHEU IN 15 MIN AND AN AVERAGE RECOVERY OF SS.5\% INAS DBTAINED, WITH A RELATIVE STANDARD DEVIATION OF $1.4 \%$ (25 EXPERIMENTS).

* ANALYTICAL TECHNIQUE, HATER + \#RACTOR COCLANT + COBALT + COPPER + IRGN + JAPAN + MANGANESE + , SOLVENT EXTRACTIDN PROCESS

$14-22807$

KAYE SV + NELSON DJ

ANALYSIS OF SPECIFIC-ACTIVITY CONCEPT $\triangle S$ RELATED TO ENVIRONMENTAL CONCENTRATION OF RADIONUCLIDES

6 PAGES, 5 FIGURES, 16 REFERENCES, NUCLEAR SAFETY Q(1), PAGES 53-58 (JAN. FEB. 1968 )

THE SPECIFIC-ACTIVITY TECHNIQUE IS REVIEWED AND EVALUATED FOR ESTIMATING HAZARDS TO MAN FP.OM CONSUMING FOOD OF WATER DERIVED FROM RAOIGACTIVITY-CONTAMINATEO AQUATIC ENVIRONMENTS. PERTINENT LITERATURE ON PAST APPLICATIONS OF THIS TECHNIQUE IS DISCUSSED, AND THE FINDINGS ARE INTERPRETEO. A SPECIIIC-ACTIVITY MOOFI. PROPOSED BY THE NATIONAL ACAOEMY OF SCIENCES-NATIONAL RESEARCH COUNCIL IS EVALUATED WITH AN ANALYSIS OF THE TIME-OEPENDENT PARAMETERS (BIOLGGICAL HALF-TIME, PHYSICAL HALF-LIFE, AND BIGLOGICAL GROWTH) TO DETERMINE THE SENSITIVITY OF THE CALCULATED MAXIMUM ALLOWABLE SPECIFIC ACTIVITY OF RADIOACTIVITY IN AQUATIC ENVIRONMENT TO CHANGES IN THE PARAMETERS. IN ALL CASES THE GUIDANCE GIVEN BY THE

SDECIFIC-ACTIVITY APPRCACH IS CONSERVATIVE. THE MAJOR RESTRICTION ON APPLICATION OF THE SPECIFIC-ACTIVITY MODELS APPEARS TO BE INCOMPLETE MIXING AND DIFFERING BIOLOGICAL 
CATEGCRY 144
RADIONUCLIDE RELEASE AND MCVEMENT IN THE ENVIRONMENT

14-22807 \#CONT INUED*

AVAILABILITY BETWEEN THE RADIOISOTOPE ANO THE STABLE-ISCTOPE ANALOG.

ECOLOGICAL CONSIDERATION + ENVIRONMENTAL CONDITION + EISSION FFODUCT TRANSPORT + ORNL + RADIOISGTOPE

$14-22812$

NEILL RH + SNAVELY DF:

STATE HEALTH OEPAYIMENT SAMPLING' CP.ITFPIA FOR SURVEILLANCE OF RAOIOACTIVITY IN MILK

US PUBLIC HEALTH SERVICE

7 PAGES, 8 TABLES, 3 FIGURES, REFERENCES, RADIOLOGICAL HEALTH DATA AND REPORTS 8 (11), PAGES G21-6i27 (NOVEYBER IOST)

THIS REPQRT SUMMARIZES CRITERIA USED BY THE STATES IN SETTING UP THEIR MILK-SAMPLING PROGRAMS FOR MEASUREMENT OF RAOIOACTIVITY AND THE SAMPLE TYPING, CCLLECTICN POINTS, AND MEASUFEMENTS USED. ALSO INCLUDED ARE THE TIMES REQUIRED BY THE STAIES FR.OA SAMPLE COLLECTION TO THE FINAL RADIOACTIVITY CONCENTRATIONS OF THE VARICUS RADIOISOIOPES FDUND IN MILK.

* fallout + \#urveillahce pfogram + eiological concentration, milk

14. $22013 \quad$ ALSO IN CATEGORY IS

DATA - SECTION IV. OTHER DATA

US PUALIC HEALTH SERVICL

10 PAGES, 7 TABLES, 4 FIGUDFS, RADIOLOGICAL HEALTH DATA AND REPGRTS 8(11), PAGES 664-673 (NOVEMEEP IG67)

THIS SECTION CONTAINS PEPORT ON SR-OO IN HUMAN VERTABRAE COLLFCTED IN 1966 IN NEW YORK CITY AND IN SAN FRANCISCO. REPORTS ENVIP.ONMENTAL SURVEYS FCR THPEE SITES OF THE LAWFENCE P.ADIATION LABORATORY (JULY-DFCEMBER 1966) AND OF MOUND LABORATORY (JULY-DECEMAER AND ANNLAL STJMMARY 1 OSS). THE USAEC RFPORTED UNDERGROUND NUCLEAR TESTS $\triangle T$ THE NEV OCTORER 18, 1067, AND ON OCTOBER 25. IN ADOITION THE AEC PEPGRTED SEISMIC DATA ON OCTOBER IT AND OCTOBER 23, 1067 , INDITATING SCVIET NUCLEAR TESTS IN SIPERIA.

*FALLOUT + \#MONITORING PROGRAM, ENVIRQNMENTAL + \#SURVEILLANCE PFCGRAM + gICLCGICAL CCNCENTEATION, MAN + LRL + MOUND LABORATOPY + STRONTIUM + TRITIUM + WATER, GENERAL

$14-22315$

DATA. SECTION I, MILK AND FOOO, SECTION II, WATER, SECTION III, AIP AND DEPOSITION

US PUBLIC HFALTH SERVICE

21 PAGES, TABLES, FIGURES, REFERENCES, RADIOLOGICAL HEALTH DATA DND PFPORTS E(II), PAGES 628-647 (NOVEMBFR 19671

SECTION I. DATA ARE REPCRTED FOR THF NATIONAL AND INTERNATIONAL MILK-SURVEILLANCE PROGRAMS (UNITED STATES, CANADA, PAN-AMEDICAN), STATE MILK SURVEILLANCE ICONNECTICUT, INCIANA, IOHA, I1 ICHIGAN, IA INNESOTA, VEW YDPK, AND PENNSYLVANIA). FOOD AND DIET SURVEILLANCE (CCNNECTICUT). SECTION II CONTAINS DATA ON GROSS ACTIVITY IN U. S. SURFACE WATERS, NEW YORK TAP WATER, LND COAST-GUARC WATER SUDDLIES IN ALASKA, SECTION III CONTAINS DATA FROM THE RADIATION SURVEILLANCE NETWORK, CANADIAN AIR AND PRECIPITATION MCNITCRING, MEXICAN DIP MONITORING, PAN-AMER. ICAN AIR SAMDLING, AND OLUTONIUM IN $\triangle I R E O R N E$ PAFTICULATES AND PRECIPITATION, $\triangle N D$ STRONTIUM-9O IN PRECIDITATIION.

*FALLOUT + EIULULILAL CUNCENTPATION, FOOD + EIOLOGICAL CONCENTRATICN, MILK + MONITORING PROGRAA, ENVIRONMCNTAL + PARTICULATE + PLUTONIUM + PRECIPITATISN + STRONTIUM + SURVEILLANCE PR.OGRAH + WATFP, DFINKING + WATER, GENERAL

$14-22816$

ZIEGLEK CA + HAHANDJPGIULOS J + SELLERS E

RADIOISOTOPE GAUGE FOQ MONITORING SUSPENCFE SEDIMENT IN RIVERS AND STREAMS

PARAMETRICS, INC, NALTHAM, MASS.

9 PAGES, 6 FIGURES, 3 HEFEFENCES, INT. J. APPL. RADIAT. ISOTOP. 19, OAGES 585-93 (AUGUST 1967)

THE PROBLEM OF GETEPMINING THF AMMUNT DF WATER-CARRIED SUSPENCEC SEDIMENT IS OT INCP.FASING IMPORTANCE IN $\triangle R$ EAS CONCERVEO WITH AGRICULTURE, NAVIGATION, ANO WATER CUNSERVATION. CONVENTIONAL POINT-SAMPLING METHOOS HAVE PRQIVED INADEQUATE TO MEET CUPRENT HYDRCL RGY PLANNING NEEOS SECAUSE SHCRT-TERM CONCENTRATION EXCURSIDNS CANNOT EE MONITDRED. A GAUGE RASED ON THE USE OF RADIATICN FROM A RADIOISDTOPE SOURCE, HAVING THE CAPAEILITY JF CGNTINJOUSLY MEASUFING SEDIMENT CONCENTRATION OVER A RANGE OF 10O0-50, OCO PPM, WAS DESIGVED, DEVFLCPED AND TESTED. THE SYSTEM IS CAPABLE OF OPERATING AND RECORDING DATA UNATTENDED FOE A PERIOD OF $7-1 / 2$ DAYS ON INTERNAL PONER, THUS CONSTITUTING A COMPLETELY AUTOMATIC MONITORING SYSTEM. THE THEOFY OF DPEFATION, ERROR ANALYSIS, GALIREATI UN MEIHUUS, UPERATING PRCCECURES, AND TEST RESULTS, ARE PRESENT LD,

* INSTRUMENTATIDN, GENFRAL + \#RADIDISOTOPE + \#SEDIMENT + RIVFP, GFNERAL + UNITED STATES + WATER, GENERAL

COPENHAGEN RADIDCARBON MEASUREMENTS. VIII. GEOGRAPHIC VARIATIONS IN ATMOSPHERIC C-I4 ACTIVITY 
14-22817 \#CONT INUF.O*

NATIONAL MUSEUM, COPENHAGEN

11 PAGES, 1 FIGURE, FEFERENCES, RADIOCAREON S, PAGES 246-56 (1567)

MEASUREMENTS OF BCMB-PROCUCED C- 14 IN CEREALS AND GGRASSES IN THE NORTHERN HEMISPHERE FROM 1956 THROUGH 1966 ARE PRESENTEO. SAMPLES WERE MEA SURED TC LETERMINIE THE YEARLY ADOITION OF C-I4 AT A SINGLE LGCALITY AND TO DETECT POSSIBLE GEGGRAPHIC VARIATIONS IN THE CISTRIEUTION AND UPTAKE OF BOMB-PRODUCED C- 14 IN TERFESTRIAL PLANT MATERJAL OURING YEARS WITH GREATLY VARYING ADDITIONS OF $\mathrm{C}-14$.

B ICLOGICAL CONCENTRATION, VEGETATION + CAREON + DENMARK + TEST, WEAPONS (HP ASPECTS)

$14-22928^{\circ}$

BLOMEKE JO + HARRINGTON FE

MANAGEMENT OF RADIOACTIVE WASTES AT NUCLEAR POWER STATIONS

OAK RIDGE NATIONAL LAB., TENN.

ORNL-4070 +., 101 PAGES, FIGURES; TABLES, 44 REFERENCES, JAN. 1968

AS A PRELIMINAFY STEP IN ASSESSING WASTE-DISPOSAL DPEPATIONS IN THE EXPANDING NUCLEAR POWER INDUSTRY, THE OPERATING EXPERIENCE IN WASTE MANAGEMENT AT THE DPCSDEN-I, BIG ROCK POINT, HUMBOLDT BAY, ELK-RIVER, INDIAN POINT-I, AND YANKES POWER STATIONS IS REVIEWED. ALL THESE PLANTS HAVE OPERATED WITHIN AUTHORIZED LIMITS AT. COSTS ESTIMLTED TO RANGE BETHEEN 2 AND IOF OF ANNUAL JPEFATING COSTS. GASSDUS RELEASE RATES HAVE F.ANGEC FRO:M AS LOW AS 10 TO THE MINUS 5* TG 30\% JF ALLCWABLE, $\triangle N D$ LIQUID WASTES FROM 0.0002\% TO $9.9 \%$. TRITIUM RELEASES HAVE BEEN BELOW I\% OF ALLOWABLE IN ALL CASES. IT IS CONCLUDED THAT WASTE-MANAGEMENT PRACTICES HAVE BEEN ADEQUATE GNO. THAT NO DRGELEMS ARE ANTICIPATED.

AVAILABILITY - CLEARIVUGHOUSE FOG FELERAL SCIENTIFIC AND TECHVICAL INFORMATION, SPRINGFIELD, VIRGINIA, $\$ 3.00$ COPPY. $\$ 0.65$ MICROF ICHE

*WLSTE DISPOSAL, GAS + *WASTE DISPOSAL, LIQUID + *WASTE DISPOSAL, SOLID + *WASTE MANAGEMENT + RADIJNUCLIDE, INDUCED + FEACT'JR, SWR + REACTOR, POWER + REACTOR, PWR + TRITIUM +

WASTE DISPOSAL; $\triangle T M C S P H E R I C+$ WASTE DISPOSAL, RIVER + WASTE SOURCE AND TYPE

14-2297! ALSO IN CATEGCQY IE

QUARTERLY SUMMARY REPGRT SEPTFMBER 1 THPOUGH DECEMBER I, 1967 APPENDIX TO HEALTH AND SAFETY LABORATORY FALLOUT PROGRAM

USAEC, NEN YORK OPERATICNS OFFICE

HASL-184, APPENDIX +. 200 PAGFS, FIGURES, TABLES, JANUARY 1,1968

TABULAR DATA FÖF (A) SR-OO AND - 89 IN MONTHLY DEPOSITION AT WORLC LANO SITES, (B)

FISSION-PRTOUCT AND ACTIVATITN-PPODUCT RADIONUCLIDES IN MONTHLY DEPOSITION AT SELECTED SITES, (C) RADIOSTRONTIUM OEPGSITION AT ATLANTIC OCEAN WEATHER STATIONS, (D) RACIOSTRONTIUM IN MILK $\triangle V D$ TAP WATER.

AVAILABILITY - CLEARINGHOUSE FOR FEDERAL SCIENTIFIC AND TECHNICAL INFORMATION, SPRINGFIELD, VA., \$3. OO PAPY. \$N. ST MISRAFIS.HE

\#DEPOSITILN + \#MONITGEING PROGRAM, ENVIPGNMENTAL + ANALYTICAL TECHNIQUE, MILK + FALLGUT + RAINOUT + STRONTIUM + WATER, DR INKING

$14-23153 \quad$ ALSO IN CATEGORY IS

RILEY JP + TONGUDAI M

CESIUM AND RUEIDIUM IN SEA WATER

UNIVERSITY OF LIVERPOOL

4 PAGES, REFERENCES, GHEMICAL GEOLOGY 1, PAGES 201-4 (DEC. 1966)

A CATION EXCHANGF SCHEME AAS OEVELCPFO FOP SEPAFATING CS AND PB FRGM SEA WATER. PRIOR TO THEIR SPECTROGRAPUIC OETER:1NATIJN. CONCENTRATIONS OF $11 \%$ PLUS CR MINUS 4 MICROGRAMS RB/1 AND O.55 PLUS OR MINUS 0.06 MICROGRAM CS/I WERE FOUNO FOR IRISH SEA SURFACE WATER AND FOR WATER FROM THE NORTH ATLANTIC.

\#aNALYTICAL TECHNIQUE, LIQUIO + \#CESIUM + \#ION EXCHANGE + \#RUEIDIUM + aCTIVATION

$14-23 ! 54 \quad$ ALSO IN CATEGORY 15

KORANDA JJ

RESIDUAL TRITIUM AT SEDAN CRATER

CALIFJRNIA UNIV., LIVFRMOPE. LAWRENCE RATIATION: LAB

UCRL-70292 + CQNF-67050三-9+. 36 PAGES, APRIL 2, 1C67, PRESFNTED AT 2ND NATIONAL SYMPGSIUM ON

RACIDECOLOGY, $\triangle A N$ SREOR, MICHIGAN

RESIDUAL TRITIUM FRDM THE SEDAN THERMONUCLEAR DETONATION, 6 JULY 1962, WAS SCAVENGEO BY OF ENTRAINED IN THE 5-6 MILLIGN TONS OF SAFTH MATERIALS MOVED BY THE DETONAT IGN. AS A RESULT, THE SEDAN POST-SHOT ENVIRONMENT CONTAINEO A MOST SIGNIFICANT BIOLOGICAL TRACER IN THE FORM OF THO. RESIDUAL TRITIUM (THO) IS FOUNC IN MICRQCURIE CONCENTRATIONS IN THE INTERSTITIAL WATER OF THE SSDAN THROWOUT SOIL, AND IN.THE LCOSE TISSUE WATER OF PLANTS WHICH HAVE FE-INVADED THE NEW SUBSTRATUM. DEPOSITED ON THE LANDSCAPF ADJACENT TO THE CRATER. TRITIUM IS PRESENT NOT DNLY IN THE LOOSE TISSUE WATER OF VASCULAR PLANTS GROWING GN THE SEDAN THROWOUT, BUT A 
$14-23154 *$ CONT INUED*

COMPARABLE LEVEL IS ALSO fOUNO IN THE TISSUE-ROUND HYDROgEN OF THESE PLANTS. Her BIVORES, MAINLY HETERDMYID POODENTS, WHICH HAVE RE-INVACED THE SFDAN POST-SHOT ENVIRONMENT AND RESIDE THERE, ALST HAVE TRITIUM CONCENTRATIONS IN THEIP. QDOY WATER BETWEEN 1 AND 3 MICROCURIEIML. THESE BODY-WATER TRITIUM CONCENTRATIONS ARE CLOSELY RELATED TO THE LEVELS OF TRITIUM IN THE PLANT TISSUE-BOUND HYDROGEN. THE INTERNAL DOSE TO THE RESIDENT MANNAL AT SEOAN CRATER. FROM RESIDUAL TRITIUM IS ESTIMATED TO EE BETWEEN 18 AND 268 RAD, OR ABOUT 10 TIMES THAT FROM EXTERNAL RADIATION SOURCES RESULTING FROM THE DETONATION.

AVAILABILITY - CLEARINGHOUSE FOR FEDERAL SCIENTIFIC ANO TECHNICAL INFORMATION, SPO INGFIELD, VIPGINIA, $\$ 3.00$ COPY, \$0.65 MICROFICHE

* ECological consideqation + \#nUClear detonation + *tritium + biological concentrat iOn, general + DIETARY HABIT + HYDRCGEN

14-23155 ALSO IN CATEGORY 15

NELSON WC + WHICKER FW

CS-137 IN SOME COLODADO GAME FISH, 1965-6E

COLORADO DEPT. CF GAME, FISH, AND PARKS. COLORADO STATE UNIV., FOR COLLINS. OEPT. OF RAOIOLOGY AND P.AOIATIDN BIOLOGY

CON-1156-21 + CONF-670503 1 +. 23 PAGES, JAN. IYG\%, PPESENTED AT 2NO NATIONAL SYMPOSIUM ON RADIOECOLOGY, $\triangle N N$ ARPOP, MICHIGAN

IN 1965 AND 1966 THE CS- 137 CONCENTRATION IN MUSCLE TISSUE CF 132 FISH REPRESENT ING EIGHT GAME FISH SPECISS FROM 23 C.OLORADO WATEFS VARIED FROM NONDETECTABLE (LESS THAN 50 PC/KGM) TO $58 C O$ PC/KGM. WATEFS SAMPLED INCLUDED 3 PLAINS, 2 FOOTHILLS, 5 MONTANE AND 12 ALPINE RESERVOIRS AND LAKES AS WELL $\triangle S$ ONE TROUT STPEAM. ELEVATION OF THESE WATERS VARIED FROM 1 , 538 TO $3,49 E$ METERS. LAKE DEPTHS VARIED FROM 1-L5 METERS, LAKE AREAS FROM 1.4 TO 230 HECTARES AND LAKE WATERSHED AREAS, WHEFE MEASURED, FPCM 53-2; 480 HECTARES. CONDUCTIVITY OF WATERS VARIED FPOM 8 TO 1390 MICROMHOS ANO POTASSIUM CONCENTRATION FROM 0.1 TO 3.1 PPM. EASED ON 6 SAMPLES, CS-137 CONCENTDATIONS WERE 2 TO 7 TIMES GREATER IN 1965 THAN 1966 . BIOLOGICAL CONCENTRATIONS OF CS-137 ARE GIVEN FOR DIEFERENT LOCATIONS.

AVAILABILITY - CLEARINGHOUSE FOR FEOERAL SCIENTIFIC AND TECHNICAL INFORMATION, SPPINGFIELD, VIRGINIA, $\$ 3.00$ CDPY, \$0.65 MICRCFICHE

* BIDLOgICAl CONCENTRATION, a QUATIC GPGANISMS + \#CESIUM + \#SAMPLING, hIGH aLTITUDF + COUNTER +

DIETAPYY HABIT + ECDLDGICAL CONSIDERATION + FALLOUT + RADIOBIOLOGY

$14-23156 \quad A L S O$ IN CATEGORY 15

PAIMEP HE + WOGMAN NA . COOOER JA

I HE DETERMINATIDN DF THE DEPTH ANÜ AMUUNT OF PU-239 IN WOUNDS WITH SIILI) DETECTORS

GATTELLE-NORTHWEST, PICHLAND, NASH. PACIFIC NORTHWEST LAB.

BNWL-SA-1261+CONF-670521-4+CONF-670610-1+. 17 PAGES, MAY 15, 1967, PRESENTED AT THE 12TH ANNUAL MEETING OF THE HEALTH PHYSICS SOCIETY, WASHINGTON, D. C.

A METHOD HAS BEEN DEVELOPEO FOR DEFINING THE AVERAGE DEPTH OF PU-239 IN WOUNDS 8Y X-RAY SPECTROMETPY USING A LITHIUH DRIFTEC SILICON DETECTOR. THE USE OF THIS METHDO ON ACTUAL PU WDUND CASES IS DESCRIBED.

AVAILABILITY CLEAFINGHOUSF FOR FEÜKAL SCIENTIFIC DND TECHNICAL INFOPMATION, SPRINGFIELD, VIRGINIA, $\$ 3.00$ COPY, \$O.6S YICRCFICHE

*COUNTEQ + \#INSTRIJMCATATION: CONTOOL + \#YLUIUNIUM + \#X-RAY

$14-23153$

ALSO IN CATEGORY 15

MORLEY F

ENVIRDNIENTAL MONITOPING ASSOCIATEO WITH OISCHLRGES OF RAOIOACTIVE WASTE DURING 1966 FROM U.K. A.E.A. ESTABL I SHMENTS

UNITED KINGDOM ATOMIC ENERGY $\triangle U T H D R I T Y$, HARWELL (ENGLAND). AUTHORITY HEALTH AND SAFETY BRANCH

$\triangle H S B(2 P) R-79+.20$ PAGFS, 20 TABLES, 6 RFFEPENCFS, $\triangle U$ IUUST 1967

THIS REPORT DESCRIOES THE RESULTS CF THE ENVIRONMENTAL MONITORING UNDERTAKEN TO CONFIRM THAT THE DISCHARGES DF RADIOACTIVE WASTE DURING 1.966 FROM EACH OF THE PRINCIPAL UKAEA

ESTABLISHMENTS PRODUCEO NO HAZARO IN THE ENVIPONMENT. THE RESULTS OF THIS MONITORING ARE SUMMARIZED ANC ARE COMPARED WITH DERIVED WORKING LIMITS TO FACILITATE AN $\triangle P P R E C I A T I O N$ OF THE STANDARDS OF SAFETY ACHIEVED.

AVAIIARII ITY - CLEND INGHOUSE FOR TCOTRAL SCIEINTIEIL ANU IELHNICAL INFORMATION, SPRINGFIELD, VIRGINIA, $\$ 3.00$ COPY, \$0.65 MICROF ICHE

*HAZARDS ANALYSIS + \#MONITORING PROGRAM, ENVIRONMENTAL + \#WASTE TRFATMENT, GENERML + WASTE DISPOSAL. LIQUIO + WASTE DISPOSAL, SOLID

$14-23321 \quad$ ALSC IN CATEGORY 15

FRFKE $\triangle M+$ DOLPHIN SW

A SUMMARY CF RESEARCH AND DEVELOPMENT WORK R.ARRIEQ OUT IN 1 CSG IN HEALTH AND SAFETY OEPAFTMENTS OF THE UNITED KINGOTM ATOMIC FNERGY AIITHORITY 


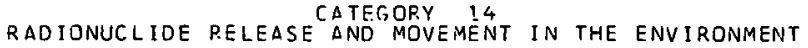

$14-23321 *$ CONTINUED*

UNITED KINGDOM ATOMIC ENERGY AUTHORITY, HARWELL, ENGLAND

AHSB(RP) M-46 +. 54 PAGES, SEPTEMBER 1967

THIS MEMORANDUM LISTS 193 PROJECTS ON WHICH RESEARCH OR DEVELCPMENT WORK HAS BEEN CARP IED OUT IN HEALTH AND SAFETY DEPARTMENTS OF THE UKAEA DURING 1966. THE OBJECT OF THIS MEMORANOUM IS TO PROVIDE INFCRMATION ABOUT CUPRFNT P.ESEARCH ANO DEVELOPMENT WORK WHICH MAY BE HELPFUL TO

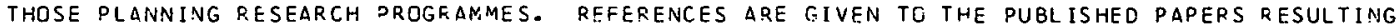
FROM WORK CARKIED OUT ON THE PROJECTS DURING THE YEAR.

AVAILABILITY - CLEARINGHOUSE FOR FEDERAL SCIENTIFIC ANO TECHNICAL INFORMATION, SPRINGFIELD, VIRGINIA \$3. OO COPY, \$0.65 MIICROFICHE

* DOSIMETRY, GENERAL + \#RADIOLOGY + \#SPECTKOMETRY, NEUTRON + \#UNITED KINGDOM + AQUATIC ORgANISMS + FALLOUT + INSTRUMENTATION, RACIATION MONI TORING + NEUTRON

$14-23379$

MURAYAMA N

ALSC IN CATEGORY 16

OBSERVATIONAL EVIDENCE ON TRANSPORT OF RADIOACTIVITY AND OZZONE THROUGH THE TROPOPAUSE

JAPAN METEOROLDGICAL AGENCY, TOKYO

14 PAGES, FIGURES, RFFERENCES, GEOPHYSICAL MAGAZINE (TOKYO), 33, PAGES 149-162 (NGV. 1966)

EXTRAORDINARILY HIGH RAOIOACTIVITY WAS RECORDED BY A GAMMA-ACTIVITY SONDE LAUNCHED AT TATENO, IN THE LAYER EETWEEN 500 AND 300 ME LEVELS IN THE REGION OF STRONG UPDER FRONTS EXTRUDING DOWN FROM THE TROPOPAUSE. THIS IS CISCUSSED IN TERMS OF AN INSTANCE CF THE RADIOACTIVE DUSTS ORIGINATING IN THE STRATOSPHERF EEING TRANSFERRED INTO THE TROPOSPHERE THROUGH THE TROPOPAUSE BREAK BY DISTURBANCES DEVELOPEO IN THE UPPER TROPOSPHERE. THE RESULTS ARE COMPARED WITH VERTICAL-OZONE-DISTRIBUTION FINOINGS.

*FALLOUT + \#JAPAN + \#STRATOSPHERE + \#TRQPOSPHERE + DEROSOL, RADIOACTIVE + ANALYTICAL TECHNIQUE, AIP + ATMOSPHERIC CIR CULATION, GLOBAL + NUCLEAR EXPLOSION DEBRIS

$14-23878 \quad$ ALSO IN CATEGORY 16

KAURANEN P + KULMALA

FISSION PRODUCTS OF UNUSUAL COMPOSITION IN FINLAND

DEPT. OF RADIOCHEMISTRY, UNIVERSITY OF HELSINKI + FINNISH METEQROLOGICAL OFFICE, HELSINKI

4 PAGES, 5 Figures, 2 TAELES, 13 REFERENCES, NATURE $216(5112)$, PAGE 238 THRU 241 , 10CTCBER. 1967 )

A CLOUD OF FRESH, HIGHLY FRACTIONATEC FISSION PRODUCTS WAS CBSERVED IN FINLAND BETWEEN DECEMBER 21 AND 26, 1966. THEY SELMED TO COME FROM CENTRAL ASIA AND WERE PRDBABLY THE PRODUCT OF AN UNDERGRDUND NUCLEAR. TEST. PRESENTS CONCENTRATION DATA DND METEOROLOGICAL CONDITIONS.

\# $\triangle E R O S O L$, RADIDACTIVE + \#FALLOUT + ATMOSPHERIC DIFFUSION + FINLAND

$14-23880$

ALSO IN CATEGORY 16

ALDAZ L

SURFACE AIR RADICACTIVITY AND OZDNE AT AMUNDSEN-SCDTT STATION (OO SI, ANTARCTICA

UNIV. OF N. MEX., ALBUQUERQUE

2 PAGES, 1 FigURE, 4 REFFRENCES, NATURE (LCNDON), 215 , PAGE 722 AND 723 , (AUGUST 1967)

CONTINUMUS MEASUREMENTS OF SURFACE-AIR RADIOACTIVITY LEVELS AT THE SOUTH POLE FROM 1959 TO 1963 HAVE PRFVIOUSLY BEEN REPORTER, AND ADOITIUNAL DATA UP TO 1965 ARE PRESENTEC IN THIS COMMUNICATION. SURFACE-OZONE RFCORDS FOR 1962 TO 1065 ARE ALSO GIVEN. FISSION PFODUCT AND OZONE DATA ARE PEESENTED GRAPHICALLY, AND A YEARLY OSCILLATIGN FOR BOTH SETS OF DATA IS OBSERVED, DPPOSITE IN PHASE, AND WITH A 6-MONTH PHASE DIFFERENCE. IT IS POSSIBLE THAT SEASONAL VARIATIONS IN ATMOSPHERIC EXCHANGE BETWEEN THE MICDLE LATITUDES OF THE NORTHERN HEMISPHERE AND THE POLAR PEGIONS ARE SOMEHOW CONTROLLING THE OBSERVED ANNUAL OSCILLATION OF RADIOACTIVITY AND OZONE. IN THE SURFACE AIR AT THE SOUTH POLE.

* ATMOSPHERIC CIRCULATION, GLOBAL + \#FALLnUT + AFROSOL, RAOIOACTIVE + ATMOSPHERIC DIFFUSION, GLOBAL + OZONE

14-23902 ALSO IN CATEGORY 15

BELLAICHE G + PAUTOT G + $\triangle N G U E N D T F+$ COURTOIS G

NATURAL RADIOACTIVITY OF MARINE SEDIMENTS ALONG THE ESTEREL COASTS

LABORATOIRE DE GEODYNAMIQUE SOURS-MARINE, VILLEFRANCHE-SUR-MER, FRANCE CEA, SACLAY, FRANCE

4 PAGES, 3 FIGURES, 4 REFERENCES, COMPT. RENO., SER. D., 264 , PAGE 2545 THRU.2548, (MAY 29,1967 ), (IN FRENCHI

THE RADIOACTIVITY OF. THE COASTAL MARINE SEOIMENTS PRESENTS WELL-DEFINED CHARACTERISTICS, WHICH CAN BE EXPLAINED BY THE ACTIUN UF CIIFFERENT HYORODYNAMIC ACENTS SUCH AS SEA SWFLLS AND SCME CURRENTS ON THE SEDIMENTARY PARTICLES OF CIFFERENT RADIOACTIVITY.

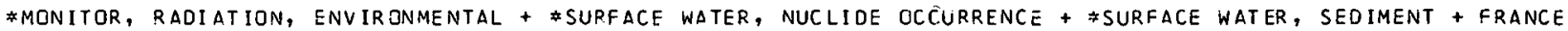




\section{RADIONUCLIDE RELEASE CATEGORY MOVEMENT IN THE ENVIRONMENT}

14-23914 ALSC IN CATEGORY 15

TAGI H + LIM EK

FUNDAMEIVTAL STIJDIES ON BEHAVIOR OF CESIUM IN FIXATION OF RADIDACTIVITY IN CERAMIC SPONCES

TOKYO INSTITUTE OF TECHNOLOGY

86 PAGES, BULL. TOKYO INST. TECHNOL. NO. 71, PAGES 1-86 (MARCH 1966 )

ONE METHOD FOQ OISPOSING OF FISSION-PROOUCT WASTES FROM THE FEPROCESSING. OF THE SPENT URANIUM: FUELS IS THE FIXATION OF THE FISSION PRQOUCTS ON CERAMIC SPONGES, WHICH AFE THEN STRFFD UNDERGPOUND. THE FIXATION OF HIGH-LEVEL RADIOACTIVITY IS DESCDISED. STUDIES WERE MADE ON THE LEACHAB IL ITY FOR LONG-TERM UNDERGROUND STORAGE, MECHANISMS OF THE FIXATION, AND ADSORRABILITY CF THE RADIONUCLIDE CS-137. THE CONCLUSICNS ON THE BSHAVIOP OF CS-I37 IN THE FIXATION OF RADIOACTIVE WASTES IN CERAMIC SPONGES ARE AS FOLLOWS - CERAMIC SDCNGES HAVING SG TD 65\% POFOSITY WERE DPEDARED FROM MATERIALS INCLUDING DIDTOMITE, BENTONITE OR CLAY, AND FELDSPAS. THE COMPOSITIDNS FOUNO TC P.E PROMISING ARE OD TO 7O\% DIATOMITE, 20 TO $20 \%$ BENTINITE, ANE 1O\% FELCSPAR.

*CERAMICS + *CESIUM + \#WASTF OISDOSAL, SOLID + \#WASTE TREATMENT, FIXATION + FUEL ELEMENT + URANIUM

$14-24060 \quad \Delta L S O$ IN CATEGORY 15

MAMUPJT + MATSUNAMIT T FUJITA A

RADIONIICI TOE CRACTIONATION IN FALLOUT PARTICLES FROM AN AIK HUKST

OEPT. DF HEALTH PHYSICS AND INSTRUMENTATION, RACIATION CENTER OF OSAKA PREFECTUPE, SHINKE-CHD TC4, SAKAI-SHI, OSAKA, JAPAN

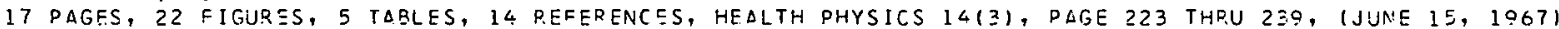

RADIONUCLIOE LF:LIIUNATION IN INOIVIDUAL HOT PARTICLES (HIGHLY RAQIDACTIVE FALLOUT PARTICLES) FCOY THE THIRD CHINESE NUCLEAR EXFLCSION ON O MAY, 1 S. SE, HAS REEN INVESTIGATED RY GAMMA-RAY SPECTROMETRY. ACTIVITIES OF TEN RADIONUCLIDES I2R-95, 2R-97, MO-09, BA-140, CE-141, CE-143, CE-144, NO-147, U-237 AND NP-239) WERF MEASURED, AND THE INITIAL $\triangle T$ OM NUMBFRS MF THESE NUCLIDES CONTAINED IN FACH SAMHLE WESE ESTIMATEO. TO EXPRFSS THE DEGREE GIE FFACTIONATION, THE FRACTIONATION FACTORS DEFINED WITH RESPECT TO ZR-9E VIERE CALCULATED FCR EACH SAMPLE.

\#CHINA + \#FALLOUT + \#ISUTDPIC FRACTIONLTICN + \#PARTICLE, RADICACTIVE + BADIUM + CERIUM + MOLYBDENUM + NEPTUNIUM + NIOBIUM + SPECTROMETRY, GAMMA + URANIUM + ZIP.CONIUM

14-24061 $\quad \triangle L S C$ IN CATEGORY 15

PEQSSOV RB

CS-134/CS-137 ACTIVITY PATIO IN THE BIOSPHERE FROM 1056 UNTIL ICEE

RADIATIUN DHYSICS OEPT., UNIV. TF LUND, LUND, SWEDEN

16 PAGES, 4 FIGUOES, S TAPLES, 30 REFEDENCES, HEALTH PHYSICS, $14(2)$, PAGE 241 THRU 250 , $1 J U N E 26$, 1067

CS-136 AND CS-137 $\triangle C T I V I T I E S$ WEPE MEASUPED IN SANPLES OF LICHEN, MOSS, $\triangle N C$ REIA!CEER MFAT COLLECTEO IN SWFOEN. THE CS-134/CS-137 ACTIVITY RATIOS IN VEGETATION COINCIDE WITHIN THE EXPERIMENTAL UNCEPTAINTY WITH THOSE FOR EEINDEER MEAT. GAMMA-RAY SPECTRA FROM THE ANNUALLY PERFIRMED WHOLE-EODY MEASUREMENTS CN LAPPS WERE ANALYZED. THE TOTAL GLOBAL INJCCTION OF

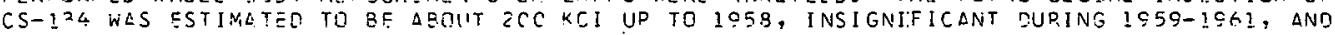
$\triangle B O U T$ T $5 \mathrm{KCI}$ DURINS 19E1-10E2. SINCE 1062, NO SIGNIFICANT INJECTION CF CS-134 HAS BEEN OETECTED. DIFFERENT WAYS OF GENEPATIMG CS-134 HAVE BEEN CONSIDERED.

* ALASKA + *BIDLOGICAL CONCENTRATIJN, GENEFAL + \#CESIUM + \#SPECTRCNETRY, GAMMA + COUNTEP, WHOI.E POBY + MONITOP, GADIATION, ENVIRDNVIVNTAL

14-24063 ALSC IN CATEGORY 15

EINVIRONMENTAL. SAMPI. INI; RFSULTS

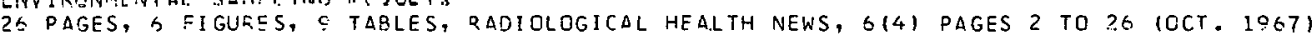

COLLECTING $\triangle N D$ ANALYZING SAMPLES OF VARIOUS MEDIA IS CARRIED ON THROUGHOUT CALIFORNIA WITH THE ASSISTANCE JF SEVERAL CDOPERATING AGENCIES AND QRGANIZATIONS. ALL SAMPLES $\triangle R F$ SENT TO THE SANITATION ANO PADIATICN LABOPATORY OF THE STATE DEPARTMENT CF PUBLIC.HEALTH, WHFPE THEY ARE ASSAYED FOR THFIK RADIMACTIVITY. THE RFSULTS ARE COMPILED, INTERPRETED, DND PUEL ISHED BY THE P.UREAU OF RADIOLOGICAL HEALTH. THE SAMPLING PROGRAM ENC.MMPASSES AIRBODNE RARTICLES,

RAINEALL, DUMFSTIG WATER, SEWAGE, MILK, DIET, AND SNOW, PLUS SPECIAL STUUIES.

\# ANALYTICAL TECHNIJUE, GENERAL + \#MONITOR, RADIATION, ENVIRONMENTAL + \#SAMPLING + RADICLOGY + STATE PROGRAM

$14-24266$

MAMIIRT T

PHYSICO-CHEMICAL DROPERTIES OF FALLOUT PARTICLES IN P.ELATION TC GURST CDNDITIUNS

RADIATION CENTER DF OSAKA PREFECTURE, SHINKCCHO 704 , SAKAI-SHI, OSAKA (JADAN)

6 PAGES, 3 FIGURES, 2 TABLFS, 19 REFEPENCES, ATOMPRAXIS 14(1), DAGE 24 THRU 2R, (.JAN. 1C68)

DHYSICO-CHEMICAL PROPERTIES OF HIGHLY FADIOACTIVE FALLOUT PARTICLES COLLECTED IN JAPAN SHCRTLY AFTER SOVIST C:R CHINESE NUCLEAR EXPLOSICNS ARE DFSCPIBED AND DISCUSSEO BP IEFLY IN PQELATICIN TC EURST CONOITIONS. CONSIDERABLE DIFFERENCES DRE FOUNO BETWEEN FALLOUT PARTICLES FROM AIR 
ENVIRONMENTAL SURVEYS, MATEGORY 15 TORING AND FADIATION EXPOSURE OF MAN

15-20565

SOLDMAN L + HORNBY P

PERSCNNEL PROTECTION FROM HIGH ENERGY LASEPS

CHILDRENS HOSPITAL RESEAPCH FOUNOATION, CINCINNATI

5 PAGES, \& REFERENCES, AMERICAN INOUSTRIAL HYGIENE ASSOCIATION JOUPNAL 25 , PAGES $553-7$ INOVEMBEF-DECEMBER 10651

PREVENTION OF EYE AND SKIN INJURIES IN THE USE OF LASERS IS CONSIDERED FROM THE PCINT OF VIEW OF DERSONNEL CONTROL AND AQEA CONTROL. THE FIRST CONCEFN IN LASER PROTECTION IS THE EYE, NOT ONLY FROM IMPACT OF THE DIRECT SEAM BUT ALSO FROM THE REFLECTION FROM SURFACES. PQOCEDUP.ES FOR EYE PROTECTION ARE DISSUSSED. AREA CONTROL INCLUDES USE OF DARK, OULL, NONREFLECTING SURFACES IN THE LAB, USE OF EXTENSIVE BLACK, HEAVY FELT DRAPES, AND USE DF DEVICES TO ATTEMPT TO FQCUS ON THE TARGET AREA $\triangle N D$ TO OBSERVE THE EFFECTS ON THE TARGET AREA WITHOUT DIRECT DBSERVATION OF THE TARGET. PROTECTION FOR THE EYE REQUIRES A GOGGLE WITH SUFFICIENT PROTECTIVE MATEP IAL ANO SO FITTED THAT STRAY LIGHT CANNOT COME IN FROM ANY ANGLE. IT IS RECOMMENDEO THAT AS A CULE PEDSONNEL NOT WORK IN THE DARK, SINCE THE RATIO OF EYE ACCEPTANCE DREA IN THE DAFK TO THAT IN THE LIGHT IS IS TO 1 .

*LASER + PERSONNEL PP.CTECTIVE DEVICE + RADIATION PROTFCTION, ORgANIZATION + RADIOBIOLOGY

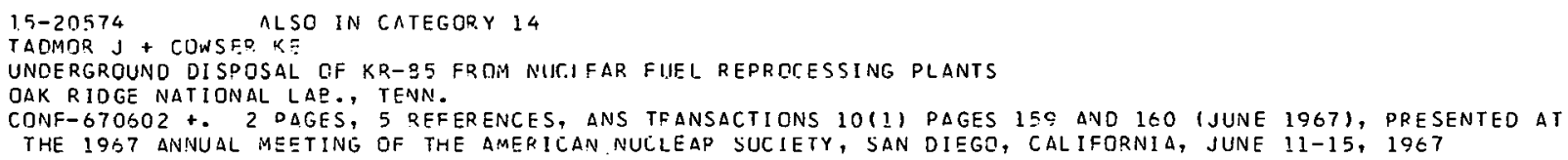

\#WASTE OISPOSAL, GAS + KRYPTON + WASTE DISPOSAL, ATMOSPHERIC + WASTE DISPOSAL, TERRESTFIAL

$15-20736$

KOSSEL F

RADIATION DOSAGE, OTSAGE UNIT, AND COSAGE DETFRMINATION

INSTITUT FUER WASSER-, BODENUND LUF THYGIENE, BERLIN

7 PAGES, I FIGURE, I TAELE, 12 REFERENCES, RCENTGENPRAXIS 18, PAGE 179-184, (AUGUST 1965), IN GERMAN

THE FACTOR EXDEESSING DOSE FOR SOFT TISSUES IS RELATIVELY CONSTANT FOR ALMOST ALL VOLTAGES. IN BONE, THE EFFECTS OF IRRAOIATION ARE MUCH GREATER AND VARY EXTENSIVELY WITH RADIATION ENERGY. WITH INCPEASING VQLTAGE, THE ENERGY ABSORBED ALSO DECPEASES, AND THE DIFFERENCE LN ABSORPTION BETWEEN SOFT TISSUES AND BONE BECOMES LESS. THIS REQUCES THE ABILITY TO

DIFFERENT IATE BETWEFN THESE TISSUES IN X-RAY PHOTOGRAPHY, WHILE TO OBTAIN MORE UNIFORM DOSAGE IN X-RAY THERAPY HIGH VOLTAGES $\triangle P E$ USED. THE RELATIVE BIOLOGICAL EFFECTS OF VAPIOUS TYPES OF RADIATION ARE - FOF $X$, BETA, ANO GAMMA RADIATIONS, 1. FOR FAST NEUTRCNS, PROTONS UP TO IO MEV, AND ALPHA PARTICLES, 10. FOR HEAVY NUCLEI, 20.

\# DOSE + DOSE YEASUPEMENT, EXTEPNAL + GERMANY + RADIATION UNIT + RADIOLGGY

$15-20737$

RACH K.

BASIC CDNCEPTS COR THE USE DF RADIOACTIVITY IN MEDICINE. A REFRESHER COURSE. 3 . DOSE AND EFFICIENCY FRFIF IINIV.. RFRI IN

7 PAGES, 7 FIGUEES, ROSNTGENPRAXIS 19, PAGE 161-167, (JULY 19E5), IN GERMAN

REVIENS THE UNITS USEO TO MEASURE ANO EVALUATE RADIATION DOSE. THESE INCLUDE THE ION DOSE, MEASURED IN TFRMS OF THE R. AS EQUAL TO $2.58 \times 10(-9 T H)$ COULOMB/KG, AND THE ABSORBED OOSE, MEASURET AS THE FAD, WHICH IS EQUAL TO 100 ERG/G. THESE TWO UNITS ARE RELATED TO EACH DTHER BY A FACTOR THAT VAFIES WITH THE TYPE OF MATERIAL IRRADIATED AND THE TYPF OF RADIATION INVOLVED. THE ABSOF.BED DOSE IS MCCIFIED BY THE RELATIVE BIOLOGICAL EFFECT OF THE RADIATION CONCERNEO. GENEHALLY, THE RELATIVE BIOLOGICAL EFFECT AMOUNTS TO I FOR X-RAY, BETA, AND GAMMA RAOIATION, TO IO FOF ALPHA OR PROTON RADIATION, AND TO 20 FOP HEAVY NUCLEI. CALCULATION OF THE GAMMA DOSE FACTOR IS ILLUSTRATED, ANO ITS SIGNIFICANCE IN ESTIMAT ION CF DOSE IS SHOWN. THE CONCEPT OF HALF-VALUE THISKNESS LAYER FOR SEVERAL MATERIALS IS DESCRIBED AND DISCUSSED. IT IS ILLUSTRATEO BY EVALUATIUN Ut RESIDUAL ACTIVITY AS A FUNCTION OF HALF-VALUE THICKNESS.

\#DOSE + BETA EMITTER + GAMMA + GEOMANY + RADIATION INJURY, TREATMENT GF + RADIOL OGY + X-PAY

15-20738 ALSO IN CATEGORY 14

DEJAEGERE R

RADIOBIJLOGICAL EFFECTS OF TPACERS USED IN PLANT PHYSIOLOGY

UNIVERSITY LIBRE, GRUSSELS

9 PAGES, 2 FIgURES, E TABLES, 21 REFERENCES, ANN. GEMBLOUX, 70, PAGES 12-20 (1964) IN FRENCH 
$15-20738$ \#CONTINUED*

THE USE OF RADIOACTIVE TRACERS IN EIOLCGICAL EXPPERIMENTS IS BASED ON THE PFEMISE THAT THE TRACSRS IN $3 I$ IOOGICAL EXPERIMENTS DO NOT INFLUENCE NORMAL PROCESSES IN THE CELL. EVIDENCE IS PRESENTED THAT THIS CONDITION IS NOT ALWAYS REALIZED AND THAT IN SOME INSTANCES RADIATION FROM THE RADICACTIVE TKACER AFFECTS CELLULAR METABDLISM. PCSSIRLE MECHANISMS WHEREBY A STI MULATING EFFECT MAY OCCUR, INCLUDING EFFECTS ON THE AUXIN SYSTEM, ARE DISCUSSED. IT IS CONCLUDED THAT THE BIOLOGICAL EFFECTS OF RADIOELEMENTS USED AS TRACERS ARE NDT ALWAYS NEGLIGIBLE AND THAT IT IS NOT ALWAYS POSSIBLE TO PREDICT WHETHER THEY WILL STIMULATE OR INHIBIT.

FRADIOBIOLOGY' + FPANCE + RADIATION EFFECT + FADIOISOTOPE

$15-20740$

COOPER G + COQPER JB

RADIATION HAZAROS TD MOTHER AND FETUS

UNIVERSITY OF TENNESSEE, MEMPHIS

11 PAGES, 2 TABLES, 24 REFERENCES, CLIN. GBSTET. GYNECOL., O, PAGES 11-21 (MARCH 1066)

IN MAN, EVIDENCE INDICATES THAT THE PERIOD FROM THE SECOND TO 5 IXTH WEEK OF GESTATION IS PROBABLY THE MOST SUSCEPTIBLE TO RADIATION DAMAGE. THIS IS THE PERIOD WHEN PREGNANCY MAY BE UNSUSPECTED. EXPOSURE AT LATEP STAGES IN GESTATION MAY CAUSE LESS DEVIOUS CHANGES. OOSES AS LOW AS 25 RAOS HAVE PRODUCED MALFGRMATIONS IN EXPERIMENTAL ANIMALS IF GIVEN AT CRITICAL PERIODS. THE THFESHOLO LEVELS FOR SOMATIC AND GENETIC EFFECTS TO THE FETUS ANO THE MATERNAL GONAOS HAVE NOT BEEN ESTABLISHED, RUT THE EFFECTS APPEAR TO BE PROPORTIONAL TO THE RADIATION DOSE. IN EHILDHOOD, CANCER AND LEUKEMIA MAY DEVELOP AFTER VERY LOW LEVELS OF IRRADIATION, PERHAPS AS LOW AS 1 R. THUS, INTRAUTERINE RADIATION EVEN FOR MEDICAL DIAGNOSTIC PURPOSES INVOLVES A HAZARD.

\#RAOIOLOGY + RADIOBIOLOGY + UNITEO STATES + X-RAY

$15-20741$

DAVIDANNE $S$

RADIATION - BENEFITS ANO HAZARDS

ST. JOHNS HOSPITAL, TULSA, OKLAHOMA

7 PAGES, 1 FIGURE, 3 PEEFERENES, HOSPITAL PROGRESS 47, PAGES 50-6 (SEPT. 1966)

REVIEWS EFFECTS GF IONIZING RAOIATIONS AND HAZARDS ASSOCIATED WITH THEIR USE, ESPECIALLY WITH REFERENCE TO THEIR USE IN MEDICAL RADIOLOGY. THE PROBLEM OF OETERMINING WHAT DOSES OF RADIATION CAN BE PERMITTED, WITHOUT BIOLOGICAL DAMAGE RESULTING, IS DISCUSSED AS WELL AS PERMISSIBLE DCSES TO WHICH AN INDIVIDUAL MAY BE EXPOSEO WITHOUT SUFFERING APPRECIDBLE BOCILY INJURY OURING HIS LIFETIME. PRELIMINARY TO AN OUTLINE OF THE POSSIBLE DANGERS TO ANYONE WORK ING WITH X-RAYS OR RADIOACTIVE MATERIALS, THE BIOLOGICAL EFFECTS PRODUCED AT VARIOUS DOSE LEVELS ARE CONSIDERED, AND HOW DIAGNOSTIC AND THERAPEUTIC LEVELS OF RADIATION CONTRIBUTE TO THESE. A TABLE GIVES THE APPROXIMATE DOSES. OF RADIATION DELIVERED TO THE SKIN DURING VAPIOUS DIAGNOSTIC PROCEQURES. GENETIC ASPECTS OF MEDICAL IRRADIATION ARE ALSO EXAMINED.

*RADIOLOGY + GAMMA + FADIATION IN PERSPECTIVE + PADIATION INJURY, TREATMENT OF + UNITED STATES + X-RAY

$15-20742$

SCHLUNGBAUM W

TECHNIC AND INDICATION FOR RADIOTHERAPY WITH SEALED BETA IRRADIATORS

STAEDTISCHE KRANKENHAUS, BERLIN-SPANOAU, GERMANY

8 PAGES, 13 FIGURES, 1 TABLE, ROENTGENPRAXIS 18 , PAGES ?01-8 (SEPT. 1965) IN GERMAN

DOSE FALL-OFF FOR VARIOUS Y-9C SEALED BETA IRRADIATIION SOURCES IS REVIEWED. OTHER SOURCES OF BETA RADIATION ARE DISCUSSED, INCLUDING I-131, AU-198, P-32, AND SR-90--Y-SO. THE DETAILS QF TREATMENT FOR THOSE VARIOUS PATHOLCGICAL CONDITIONS ARE PRESENTED, WITH DESCRIPTIONS OF THE APPLICATORS ANO METHODS AVAILABLE. DOSE LEVELS. AT THE SURFACE OF THE APPLICATORS ARE ILLUSTRATED, AND TISSUE I SODOSE CURVES ARE PLOTTED.

*RADIDLOGY + BETA EMITTER + OOSE + GEPMANY + RADIOISOTOPE + YTTRIUM

$15-20743$

RADIATION HYGIENE AND PRACTICE IN DENTISTPY

2 PAGES, 2 REFERENCES, JOURNAL OF THE AMEP.ICAN DENTISTRY ASSOCIATION 74, PAGES $1032-3$ (APRIL I9E7)

THE PROGRAM OF THE AMERICAN DENTAL ASSOCIATION TO PROMOTE RADIATION HYGIENE IS OUTLINEO. THIS PROGR AM IS CONCERNED WITH PROTECTION OF THE PATIENT IINCLUOING RECOMMENDATIONS AS TO FREQUENCY DF RADIOGRAPHIC EXAMINATION AND USE OF PRDTECTIVE COVERINGSI, PROTECTION OF OFFICE PERSONNEL (INCLUOING A OI SCUSSION OF SHIELDING, RADIATION BARRIERS, AND MONITORING SERVICES), GIIIDELIINES FOP MINIMIZING RADIATION EXPOSURE (INCLUOING COLLIMATION; FILTRATION, AND OTHER PERTINENT CACTORS), EXPOSURE-CONTRGL FACTORS (INCLUDING TIMERS, CONVERSION TECHNICS, FILM SPEED, KILOVOLTAGE, AND MILLIAMPERAGE), AND VISUALIZATION FACTORS (INCLUOING DAKKROOM PROCEDURES AND ILLUMINATION TECHNICSI.

\#RADIOLOGY + UNITEO STATES + X-RAY 
ENVIRONMENTAL SUPVEYS, MONEGOPY 15 TORING RADD RADATION EXPOSURE OF MAN

$15-21136$

POOEDINSKII MN + FEOKTISTOV VI + FUNSHTEIN LV

AUTORADIOGPAPHY OF THE NATURAL RADIOACTIVITY IN NORMAL TISSUES OF MEN AND ANIMALS.

CENTRAL SCI ENT IFIC-RESEARCH INST. OF ROENTGEN-RADIOLOGY, LENINGPAD

6 PAGES, 2H. NAUCH. PRIKL. FOTOGR. KINEMATOGP, 11 , PAGES $321-326$ (SEPT. OCT. 1966 ) IN FUSSIAN

THE FOLLOWING PPECAUTIONS ARE STRESSED IN MAKING AUTORADIOGRAPHIC DETERMINATIONS - ABSOLIJTELY CLEAN PHOTOGRAPHIC MATERIAL, FRFEDOM CF THE EMULSION LAYER FFOM RADIDACTIVITY, MINIMUM EXPOSURE TIME TO AVOID ACCIDENTAL IRRADIATION. THE WORK SHOULO BE DCNE AWAY FPCM THE R.ADIOLOGICAL LADORATORY.

* RADIOLOGY + BIOLOGICAL CONEENTRATION, ANIMAL + BIOLOGICAL CONCENTRATIGN, MAN + RADICGRAPHY + USSR

15-21137 ALSO IN CATEGORY 14

GREEN FL

USES AND SAFETY ASPECTS OF THE LOW-ENERGY SOURCE YB-169

VISO CORP., BURL INGTON, MASS.

$\supset$ PAGES, I TABLE, 3 FIGUFES, 6 REFERENCES, AMERICAN INOUSTRIAL HYGIENE $\triangle S S O C I A T I C N$ JCURNAL, 27, PAGES $444-448$ (SEPT. OCT. 1966 )

THE RADICACTIVE SOUPCE YTTERBIUM-1GS EMITS A 52-KEV CHAFACTFRISTIC XRAY ANG VARIOUS GAMMA RAYS WITH ENERGIES FROM E5 KEV TD $310 \mathrm{KEV}$. YTTERBIUM SUURCES IN SMALL EXDOSURE UNITS WE IGHING ABOUT 20 POUNCS $\triangle R E$ USEFUL FOR RADIOGRAPHY OF CASTIINGS, WELDMENTS, ASSEMBLIES, AND OTHER FORMS JF VARIOUS MATERIALS, SUCH AS ALUMINUM, MAGNESIUM, IHUN, PLASTICS, AND WOCR. RADIOGRAPHY WITH YB-169 PRODUCES NO HAZAFD FROM ELECTRICAL SHOCK OR EXPLOSION. RADIATION SCATTERED FROM AIR, THE OBJECT, ANO SUPPOUNOING MATERIALS IS LESS WITH YB-IEQ THAN WITH CONVENTIONAL X-RAY SOUPCES, IR-102, OF. CO-SO. THEREFORE, PIRTABLE RADIOGFAPHIC APPLICATIONS CAN BE MADE WITH LESS DIFFICULTY IN PFOTECTION OF PERSONNEL.

\#RAOIOGRAPHY + GAMMA + SOURCE, RADIATION + X-RAY + YTTERBIUM

\section{5-21138}

EARATTAEJ + FERRI ES

RADIONUCLIDES IN SELECTED HUMAN TISSUES

PUDLIC HEALTH SERVICE, WINCHESTEP., MASS.

6 PAGES, 8 TABLES, 11 REFERENCES, AMERICAN INDUSTRIAL HYGIENE ASSOCIDTION JOURNAL, 27, P.AGES 43E-44?

(SEPT.-OCT. 1966)

THE CONCENTRATIONS OF SP-90, CS-137, AND PO-210 IN VARIQUS HUMAN TISSUES HAVE BEEN MEASURED AT THE NORTHEASTEPN RACIOLOGICAL HEALTH LARORATORY SINCE 1 S6E. THE GREATEST CONCENTRATION CIF CESIUM- 137 WAS COUND IN THE PSOAS MUSCLE. THE SOFT-TISSUE CONCENTRATION CF STRONTIUM-CO NAS HIGHEST IN PSCAS MUSCLE OF MALES; RUT THIS TISSUE CONTAINED THE LONEST CONCENTRATION FOR FEMALES. THE HIGHEST CONCENTRATION OF POLONIUM-2IO WAS OESEFVED IN THE LIVER. IN GENERAL, HIGHER CONCENTRATIONS OF THIS RADICNUCLIDE WERE OBSERVED IN CRGANS FROM SMOKERS THAN IN THOSE FROM NONSMOKEFS. COMPARISON GF THE RELATIVE DISTRIBUTION EF PADIONUCLIDES OBSEFVED IN THIS STUOY TO THE VALUES USED IN COMOUTING MAXIMUM PERMISSIBLE CONCENTRATIONS FOR RADIATION WORKERS FEVEALEO A NUMBER OF OIFFERENCES. ON THIS BASIS IT WOULD APPEAR THAT CONSIDERABLY MORE EFFGRT IS REQUIREO ON THE DETERMINATION OF. THE EODY DISTRIBUTION OF THE MOFE CONMON RADIONUCL IDES BEING INGESTEO BY THE PGPULATION TODAY.

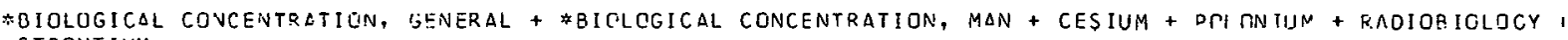
STR.ONTIUM

$15-21140$

Grit CIMAN

PROTECTION OF PERSONNEL GDERATING LASERS

CINCINNATI GENERAL HOSPITAL, CINCINNAII, CHIC

4 PAGES, O REFEREVCES, THE AMERICAN JOUPNAL OF MEDICAL ELECTRONICS, 2, PAGES $335-338$ (OCT.-DEC. ISE3)

EFFECTS OF LASER RADIATION ON ANIMAL TISSUFS ARE REVIEWED, ANE THEFOLLONING MEASURES FOR PROTECTION OE PEPSONNEL OPERATING LASERS ARE RECOMMENOEO - (1) THE LASER BEAM SHDULD NOT BE OSSERVED DIRECTLY WHETHER THE SUBJECT WEARS SR-CALLEO PROTECTIVE GLASSES QR NOT. THE HECD SHOULO BE TIIRNEN AWAY WHEN THE LASER IS FIRED, UNLESS THE LASER UPERATION IS COMPLETELY ENCLOSED DR SUFROUNDED BY SCREENS. (2) PERSONNEL OPERATING LASERS SHOULD HAVE THEIR EYES CHECKED (FUNDUS EXAMINATIONS) AT INTERVALS BY AN OPHTHALMOLOGIST. (3) ANY LASER OPERATOR WHO HAS ANY AFTER IMAGE IMMEDIATELY AFTER A LASER FIRING SHOULD CONSULT THE EYE DOCTCR AT ONCE TC LCOK FOR RETINAL DAMAGE: (4) IT IS ESSENTIAL TO AVOID CONTACT GF THE SKIN WITH THE LASEF BEAM IN ANY TYPE OF FIR ING. (5) IN WCQK IN! HIGH-ENERGY LASEFS, CONTACT OF ANY POPTION OF THE BODY WITH THE DIPECT BEAM SHDULD RE AVOIDED, ANO IF CONTACT CCCURS, A PHYSICIAN SHOULR FXAMINE THE SITE COP. IMMEDIATC OR CELAYET UAMAGL. IE) FOR WORK WITH HIGH-ENERGY LASEPS, PROTECTIVE CREAMS OR CLOTHING THAT $\triangle R E$ PRESENTLY AVAILABLE CANNOT BF RELIED UPON.

* RADIATION DAMAGE + LASER + RADIOBIOLOGY 


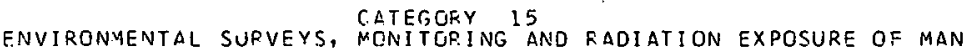

15-21141 ALSO IN CATEGORY 14

LITTLE JB

ENVIRQNMENTAL HAZARDS - ICNIZING RADIATICN

HARVARD SCHOOL OF PUELIC HCALTH, BOSTON, MASS.

10 PAGSS, 4 TABLES, 35 DEFERENCES, NEW ENGLANO JUURNAL OF MEDICINE, 275, PAGES 929-938 (OCT. 27,1966$)$

REVIEWS EVIDENCE POINTING TO FACTS THAT SUPPORT THE THEORIES THAT THE MAJOF. BIOLOGIC EFFECTS GF IONIZING QDOIATION $\triangle T$ LTW DOSES AND LGW DOSE RATES ARE CARCINOGENIC AND THAT THE PRODUCTION OF GENETIC MUTATIONS IN: THE GONALIS IS PASSED ON TO OFFSORING. THE BIOLOGICAL EFFECTS OF IONIZING FACIATIONS ON INDIVIOUALS ANO POPULATIONS AFE DISCUSSED. CONSIDERATIDN WAS GIVEN TO THE MANY POSSIBLE SOURCES OF KADIATION THAT CAN BE HAZARDOUS TO MAN.

* RADIATION DAMAGE + +ODDIOSIOLCGY + RADIATION IN PERSFECTIVE + RADIATICN INJURY, TREATMENT CF + RADIOLOGY

$15-21160$

OHLSEN H + HERRMANV C

ON THE DETERMINATION GF THE POPULATION GUROEN FROM NATURAL EXTERNAL RADIATION ON THE TERPITORIUM OF THE G.D.R.

STAATLICHE ZENTRALE FUER STRAHLENSCHUTZ, DCR, BERLIN

7 PAGES, 7 FIGURES, ZE REFERENCES, KERNENERGIE O, PAGES 3\%0-6 (DECEMBEF 1966) IN GERMAN

REPORTS DOSE RATES MEASURSD BY A 23-1 IONIZATION CHAMBEF IN THE TERRITLRY OF THE GOR. MOREOVER, DOSE. RATES ARE DETERMINED FROM RESULTS OF RADIOGFOLOGICAL IPARTIALLY AIRBORNE AND CARBORNE) MEASUREMENTS. THS TERRESTRIAL COMPONENT OF THE DOSE RATE IN OPEN AIR IS STUDIED UNDER CHARACTEK ISTIC CONOITIGNS IN THE ENVIPONS OF THE POINTS OF MEASUREMENTS IFOREST, FIELD, FOAD, ETC.) AND IN THE GEOLOGICAL UNDERGPOUNO STRUCTURE IGRANITE, CRETACEOUS FOFMATION, ETC.1. A MEAN TERRESTRIAL DOSE RATE GF CO MR/YF FOLLOWS FRCM A METHOD OF AVEFAGING THE RESULTS WITH REGARD TO THE VARINUS FRACTIONS OF THE POPULATIONS AS WEIGHTING FACTDRS. THF $\triangle T T E M P T$ OF ESTIMATING THE MEAN GQNAD DOSE FROM EXTERNAL RAOIATIGN OF TERRESTRIAL DND CDSMIC SOURCES GIVES AN AMOUNT OF 100 MRFM/YR FOF THE WHOLE POPULATION. THIS RESULT IS SATISFACYORY IN ACCORDANCE MITH INTERNATIONAL RESERVATION AS TO FURTHER COSE RATE MEASUREMENTS ON THE INSIDE OF BUILDINGS.

\#DOSE + *ENVIR DNMENTAL CONDITION + DDSE CLLCULATION, EXTERNAL + GERMANY + RADIOISOTOPE

$15-21161$

SNYCER WS

STANDARO MAN IN RELATION TO INTERNAL RADIATION DOSE CONCEPTS

OAK RIOGE NATIONAL LAOJORATORY

7 PAGES, G FIGUPES, 12 REFEPENCES, AMERICAN INDUSTRIAL HYGIENE ASSCCIATION JOURNAL 27, PAGES S3C-45 (NOVEMBER - DECEMBEF)

THE EXTENSION OF THE STANDARD MAN CONCEPT, INSOFAR AS RADIATION PPOTECTION IS CONCER.NED, IS CONSIDEREO TO PROUVIDE A BASIS FOR ESTIMATION OF DOSE WHEN EXPOSURE DF A. POPULATION IS IN QUESTION. DISCUSSIGN IS ORGANIZED ARQUND THREE MAIN CONSICEFATIGNS - PHYSICAL AND CHEMICAL DATA CONCERNING THE PRINCIPAL ORGANS AND TISSUES, METABOLIC LATA CONCERNING BODILY INTAKE AND FXTRFTIMNS, AND F:ANGES OF INCIVIDUAL VARIATION THAT ARE NOT UNCGMMON CND MEANS OF ALLDWING FJR THESE JIFFERENCES.

* dose + dose calculation, external + dose calculation, internal + ornl

15-21162 ALSC IN CATEGOFY 14

SAMACHSON J + SCHECK J + SPCNCER H

RACIOCALCIUM ABSORPTION AT DIFFERENT TIMES OF DAY

VETERANS ADHINISTRATION HOSPITAL, HINES, ILL.

3 PAGES, 1 TABLE, \& FEFERENCES, AMERICAN JOURNAL CLIN. NUTR. 18, PAGFS 449-51 (JUNE 1966)

TO DETERMINE WHETHER THE ARSORPTION QF CALCIUM GIFFERED AT DIFFERENT IIMES OF THE DAY, TRACER DOSES OF CA-47 WERE $\triangle D H I N I S T E R E D$ WITH THE MORNING AND EVENING MEAL,. IN SEPARATE STUDIES, TS PATIENTS WHO WERF ON A CONSTANT DIETAFY INTAKE IN THE METABCLIC WARD. THE TRACER DOSE WAS GIVEN TO TWO PATIENTS ON A LOW CALCIUM INTAKE, TWO ON A MEDIUM CALCIUM INTAKE, AND TWO ON A HIGH TNTAKE. THE VARIARILITY OF APSORPTION FROM MORNING TO EVFNING DOSES WITH $\triangle N Y$ LFVEL OF CALCIUM INTAKE WAS ARCUT EQUAL TO THE VARIALILITY CF REPEATEC MOFNING DJSES INCESTED ON DIFFERENT DAYS, AND THE ABSIRPTION OF CALCIUM WAS NOT CONSISTENTLY GREATER AT EITHER TIME OF DAY. IT THEREFUP.E APPEARED THAT THE INGESTICN CF RADICCALCILM WITH A SINGLE MEAL REFLECTED WITH REASONABLE ACCURACY THE ABSORFTIUN GF CALCIUM DURING THE DAY.

BIOLOGICAL CONCENTRATION, MAN + BIOMEOICAL + CALCIUM + DIETARY HABIT + RADIOEIOLOGY

15-21102 ALSO IN CATEGGRY 14

DUNSTER HJ

THE CONCEPT OF DER IVEO WOKKING LIMITS FOR SURFACE CONTAMINATION

UNITED KINGOOM ATOMIC ENERGY $\triangle U T H O R I T Y$, HARWELL

9 PAGES; 1 FIGURE, 2 TABLES, 4 REFERENCES, PAGES 130 TC 47 OF SURFACE CONTAMINATION, PERGAMON PRESS, NEW 
ENVIRONMENTAL SURVEYS, MATEGORY 15 TOPING AND RADIATION EXPOSURE OE MAN

$15-21192$ *CONT.INUED*

YORK, PPOCEEDINGS OF A SYMPOSIUM HELO AT GATLINBURG, TENN., JUNE 1964

AN OPERATIONAL HEALTH-PHYSICS MEASUREMENT MUST EITHER PROVIDE A BASIS FOR DECISIONS ON CONTREL MEASURES OR MUST CONTRIBUTE TO THE INTERPRETATICIN OF OTHER DATA TO PROVIDE A BASIS FOP SUCH DECISIONS. WITH THE AID OF A NUMEEP OF SIMPLIFYING ASSUMPTIONS, IT IS POSSIRLE TO CALCULATE DERIVEO WORKING LIMITS TYE SKIN CONTAMINATION FROM THE ICP.P RECOMMENOATIONS.

AVAILABILITY - PERGAMON PRESS, 44-01 21ST ST, LONG ISLAND CITY, NEW YORK. 11101

*CONTAMINATION + ALPHA EMITTER + BETA EMITTER + HAPWELL + SURFACE CONTLMINATION + UNITED KINGOOM

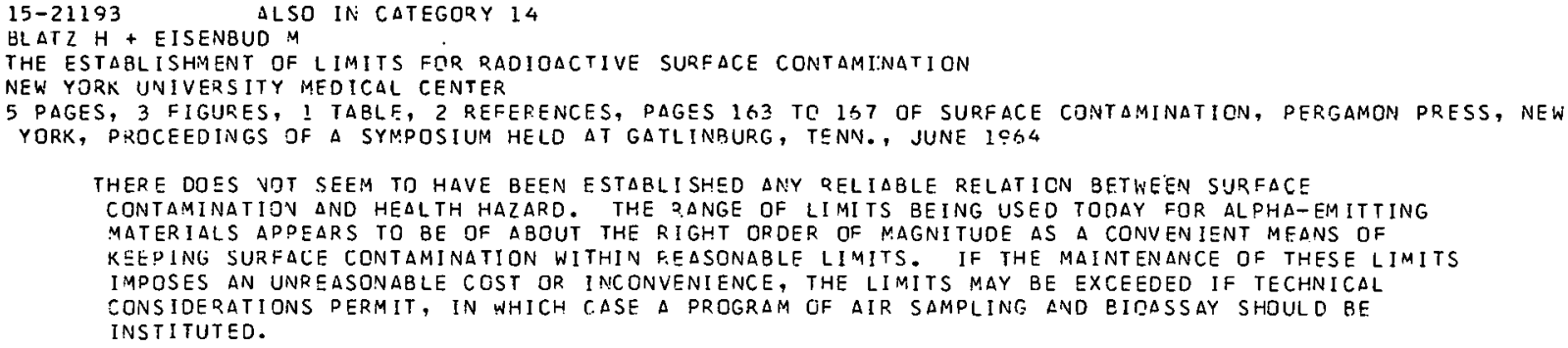

AVAILASILITY - PERGAMON PRESS, 44-01 21 ST. ST., LONG ISLAND CITY, NEN YORK Il!OI

*CONTAMINATION + AEROSOL + BERYLLIUM + PLUTONIUM + SIIRFACF C.ONTAMINATIDN + I,IRANIIIM

15-21196 ALSO IN CATEGORY 14

EUMMER JE

EVALUATIIN OF SR-90+ Y-SO SURFACE CONTAMINATI
LOS ALAMOS SCIENTIFIC LABORATORY, NEW MEXICD

11 PAGES, 7 FIGURES, S TABLES, 25 REFERENCES, PAGES 185 TO 195 OF SURFACE CCNTAMINATION, PERGAMGN FRESS, NEW YORK, PROCEEDIVGS OF A SYMPOSIUM HELD AT GATLINBURG, TENN., JUNE $1 \% 64$

THIS WORK WAS DESIGNED TO PROVIDE (I) A RELATIONSHIP BETWEEN GAMMA-RADIATIGN SURVEY-METER READINGS $\triangle V D$ THE QUANTITY OF EETA EMITTER ON VARIOUS SURFACES. ANO (2) A CORRELATIDN BETWEEN TRUE SUPFACE DOSE RATE ANO THE INDICATCD CONTACT DOSE RATE AS MEASURED WITH SURVEY-TYPE INSTRUMENTS FUP A BEIA-EMITTING ISOTOPE. AN INDICATED 0.05 MR/HR WOULC BE MEASURED FROM A 0.0006-MICQJCURIE POINT SOURCE OR FROM AN EXTENDED SOURCE OF $1.8 \times 10(-5 T H)$ MICROCURIE PER SO. CM. THE SURFACE DOSE RATE FROM SUCH $\triangle$ POINT SOURCE WOULD BE 1.2 MRAD PER HR, $\triangle N D$ FROM THE EXTENDSO SOUFCE, O.2Q MRAD/HR.

AVAILABILITY - PERGAMON PRFSS, 44-01 21 ST ST., LONG ISLAND CITY, NEW YORK 11101

\#CONTAMINATION + \#DOSE CALCULATION, EXTERNAL + \#SURVEY, RADIATION, GENERAL + STRCNTIUM + SURFACE CONTAMINATICN, SURVEY, RACIATIGN, ENVIFONMENTAL + YTTRIUM

$15-21202 \quad$ ALSO IN CATEGORY 14

GRAHAM ED + STODDARTPG + SEVERN EW

PLUTONIUM HONITORING TECHNIQUES FOR ZPR-III

ARGONNE NATIONAL LABORATOPY, IDAHO DIVISION

6 PAGES, 3 REFERENCES, PAGES $2: 3$ TO $2 \%$ S SURFACE CONTAMINATION, PERGAMON PRESS, NEN YCRK, DQOCEEDINGS OF A

SYMFOSIUM IICLD IN GATL INBURG, TENA. , JUNE 1.04 


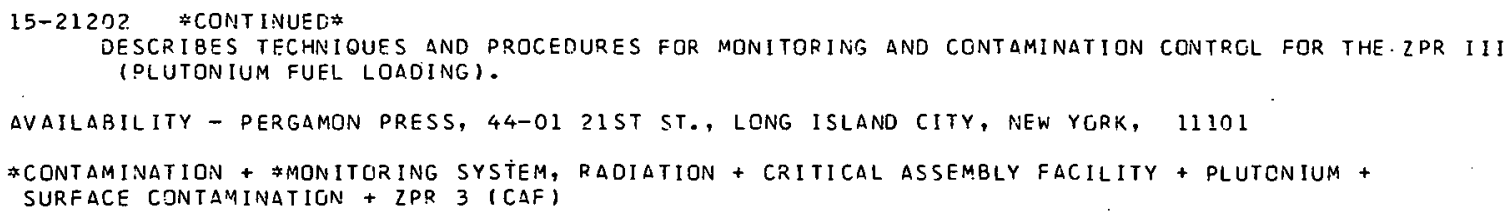

AVAILABILITY - PERGAMON PRESS, 44-0I 21 ST ST., LONG ISLAND CITY, NEW YGRK 11101

* CONTAMINATION + SERYLLIUM + PLUTONIUM + SURFACE CONTAMINATION + THORIUM + URANIUM

$15-21204 \quad$ ALSE IN CATEGORY 14

BURTION LK + COLE JS

ENVIRONMENTAL RADIOACTIVITY AND SODY BURDEN

CENTRAL ELECTRIICITY GENERATING BOARD, BEOKELFY

$\varepsilon$ DAGES, 9 FIGUPES, $\varepsilon$ REFERENCES, PAGES 309 TO 316 OF SURFACE CONTANINATION, PERGAMON PRESS, NEW YGRK,

PROCEEDINGS OF A SYMPOSIUM IN GATLINBURG, TENN., JUNE 1964

DESCRIBES THE PRGGRAM AND EQUIPMENT TO BE USED AT CEGB POWER STATIONS FOR MEASURING ENVIRONMENTAL CONTAMINATION AND BOCY BUREENS.

AVAILABILITY - PERGAMON PFESS, 44-01 21ST ST., LONG ISLAND CITY, NEW YORK 11101

\#CONTAMINATION + \#DJSE MEASUPEMENT, INTERNAL + AIR + ALPHA EMITTER + ANALYTICAL TECHNIQUE, URINE + BIOLOGICAL CONCENTRATIGN, MAN + COUNTER, WHOLE BODY + PLUTONIUM + SAMPLING + UNITEDKINGOOM + URANIUM

$15-212 ? 4 \quad$ ALSG IN CATEGORY 16

TRUNDLE AS + STGRY EJ

AERIAL RADIOLOGICAL MEASURING SYSTEM. PART IV. EQUIPMENT AND PROCEDURES THROUGH FISCAL YEAR IOGG

EDGERTON, GERMESHAUSEN AND GRIER, INC., SANTA BARBARA, CALIF.

CEX-59.4(PT.4) + FGG-1183-2083 +. 57 PAGES, FIGURES, TABLES, II FEFER.ENCES, MAPCH 1966

DESCRIBES THE AERIAL RADIOLOGICAL MEASURING SYSTEM (ARMS-I I:) GPFRATED BY EG+G, INC., FOR THE DIVISION GF SIOLGGY AND MEDICINE, USAEC. DESIGNED TO MEASURE RADIOACTIVITY OVER LARGE AREAS, THE ARISS-II SYSTEM CONSISTS OF SODIUM I DDIDE SCINTILLATION DETECTORS, RADIATION- AND

POSITIONING-MEASUP. ING INSTRUMENTS, AND DATA-READOUT INSTRUMENTS. THE METHOD OF GPERATICN AND DATA INTERPRETATION ARE DISCUSSFD AND EVALUATED, AND RECOMMENDATIONS ARE MADE FOR IMPROVING THE SYSTEM.

AVAILABILITY - CLEARINGHOUSF FOR FEDEPAL SCIENTIFIC AND TECHNICAL INFORMATION, SPRINGFIELD, VIRGINIA, \$3.0O COOY, \$0.65 MICROF ICHE

\#AIRCRAFT + \#INSTRUIAENTATION, RADIATION MCNITORING + \#MONITOR, RADIATIGN, BACKGROUND + MONITOR, RADIATION, ENVIPGNMENTAL + MONITOR, RADIATION, TELEMETRY + SURVEY, RADIATION, AERIAL.

$15-21253$ ALSO IN CATEGDRY 14

OJSE TO THE THYROID FROM INTAKE OE TE-132. INGESTION OR INHALATION OF TRANSPORTABLE CGMPJUNDS COMITATO NAZIONALE DER L ENERGIA NUCLEARE, ROME, ITALY

RT/PROT-(06)27+. 11 PAGES, 3 TABLES, 9 REFERENCES, 1.066

THE HIGHEST RISK TO THE POPULATION AS THE RESULT OF AN ACCIDENT TO A REACTOR. WOULD BE THE INGESTION AND INHALATION OF RADIOICDINE. ONE SOURCE OF IODINE-132 WOULD BE THE DECAY OF TELLURIUM-132. THIS REPIRT PRESENTS A CALCULATICN DF DOSE TO THE ADULT THYROID DUE TO INHALATION AND TO INGESTION.

AVAILABILITY - MICROCARD EDITIONS, INC., ACCOUNTING AND SHIPPING DEPT., WEST SALEM, WISCONSIN 54669 
IN I HE FIPST EXPERIMENT, 22 DOGS WERE FXPOSED TO $\triangle I R$ IN WHICH PLUTONIUM-23O DICXICE DARTICLES (50 MICOONS IN DIAM). WERE DISPERSEC. IN THE SECOND EXPEQIMENT, SINGLE OR SEVERLL 5O-, IZO-, OD. $150-H I C R O N$ PARTIRLES WERE PLACED IN THE LUNGS OF 29 DOGS EY INTUBATION WHILE ANESTHETIZED. WHOLE-3ODY LONGITUDINAL SCANNING WAS USSO TO FOLLOW THE COURSE OF THE PARTICLES IN THE DR:GS. INHALED PLUTONIUM PARTICLES WFPE CLFAFED EY ALL DOSS SY 16 DAYS $\triangle F T E R$ EXOQSURE. PAPTICLES PLACED IN LUNG EY INTUBATION WEPE CLEAREO MORE SLOWLY, EUT ONLY THREE DOGS FETAINEC PAPTICLES PAST SIX MOVTHS. NO BIOLOJICAL EFFECTS HAVE BEEN OBSEPVED EXCEPT FOR A PCSSIBLE LYMPHOPFNIA IN ONE NOG, WHICH PETAINEO A 3LUMMICLUN PARTICLE FOR OVER A YEAF.

AVAILABILITY - CLEARINGHOUSE FOR FEDEFAL SCIENTIFIC AND TECHNICAL INFORMATION, SFRINGFIELO, VA., I . OO COPY, \$C. 65 MICROFICHE

\#QADIJBIOLOGY + $\triangle E R O S O L$ + $\triangle I R B O R N E$ RELEASE + BATTELLE NORTHWEST + INHALATION + PARTICLE SIZE + PARTICLE, RADIOACTIVE + PI.UTTINIIIM + PADIATION DAMAGE

$15-21258$

DUNSTER HJ

THE APPLICATION AND INTERPRETATION CF ICRP RECOMMENDATIONS IN THE UNITEO KINGDOM ATOMIC ENEPGY AUTHORITY (JUNE 1967 )

UNITED KINGDOM $\triangle T O M I C$ ENERGY $\triangle U T H D R I T Y$, HARWELL

AHSEIRP)R-78 +. 20 PAGES, 1 FIGURE, 7 TABLES, 17 REFERENCES, JUNE 1967

THF CUREENT RECOMMENDATIONS OF THE INTERNATIONAL COMMISSION CN RADIOLOGICAL PROTECTION WFEE ENDORSEO FOR USE IN THE UNITED KINGDOM BY THE MEDICAL RESEARCH COUNCIL AND ADOPTED RY THE UNITEO KINGOOM ATOMIC ENERGY AUTHORITY. THIS REPORT SUMMAFIZES THE PRINCIPAL RECOMMENDATIONS AND GIVES GUICANCF ON HOW THEY SHOUID RE INTERPRETED AND, WHERE NECESSARY, EXTENDED FOR USE IN THE AUTHORITY.

AVAILAGILITY - CLEAP INGHOUSE FOR FEDERAL SCIENTIFIC AND TECHNICAL INFCFMATICN, SFRINGFIELD, VA., \$?. OD COPY, $\$ 0.65$ MICROFICHE

\#RACIATION SAFETY ANO CONTROL + ICQP + PAGIATION PROTECTION, CRGANIZATION + UNITED KINGDOM

15-21259 $\triangle L S G$ IN CATEGORY 14

$\triangle T T I L L A H$

THE EFFECT DF NUCL SAR POWER PLANTS ON THFIR FNVIRTNMFNT

ORNL-TR-1773+. 17 DAGES, 1 FIGURF, 4 TAPLES, TRANSLATED FRDM ENERGIA ES ATOMTECHNIKA 20 , PAGES 7E-91 $(1967)$

A INUCLEAR POWER PLANT IS LUIVSIULKEL AS A HLANT PRODUCING RADICACTIVE WASTE. SEVEPAL OPERATIONAL EXPERIENCES GAINED IN CONNECTION WITH THE OISPOSAL OF LIQUID RADICACTIVE WASIES ARE ORESENTED. THE FOFMATIDN AND CCMPCSITION OF GASEOUS RADIJACTIVE WASTES APE DISCUSSEC. THE HANDLING OF PADIOACTIVE CUST ANE GASES IS CONSIDFRFD. THE OISCHAPGING INTO THE ATMOSPHERE OF FADIOACTIVE AIR AND THE FACTORS INFLUEVCING THF MOVEIAENT OF CONTAMINATION ARE OISCUSSED. THE PESULTING CONCENTRATION IS CALCULATED. THE EVALUATION OF THE PLANT LOCATION IN TERMS OE SAFETY IS DESCRIBED. CONSIDERATIONS RELATED TO DETERMINING THE SIZE OF THE EXCLUSION ZONES TO BE USEO AT THE POWER PLANT ARE PRFSENTED.

AVAILABILITY - C CLEARINGHOUSE FOR FEDFRAL SCIENTIFIC AND TECHNICAL INFCR:MATIGN, SPRINGFIELD, VIFIGINIA $22151, \$ 3.00$ C.NPY. SN.A5 MITRTMEGATIVE 
ENVIR.ONIENTAL SURVEYS, MONITORING AND RADI.ATION EXPOSURE OF MAN

$15-21259$ \#CONT INUED*

*WASTE DISPDSAL, GENERAL + *WASTE MANAGEMENT + \#WASTE STORAGE + HUNGARY + WASTE DISPOSAL, GAS + WASTE DISPOSAL, LIQUID + WASTE DISPCISAL, SOLID

$15-21250 \quad$ ALSO IN. CATEGORY 14

PUERTO RICO NUCLEAR CENTER ANNUAL REPCRT 1966

PUERTO RICU UNIVERSITY

PRNC-10z +. 249 PAGES, FIGURES, TABLES, FEFERENCES, SEPTEMBER 1967

ACTIVITIES ARE IN THE FGLLOWING CATEGORISS - EDUCATION AND TRAINING IINCLUDING NUCLEAR SCIENCE AND TICHNOLIGY, NUCLEAP. FNGINEERING, RADIOISOTOPE APPLICATIONS AND DTHERI, BIOLGGICAL AND MEDICAL RESEAFCH PFCGRAMS IINCLUDING MARINE BIOLOGY, TERRESTRIAL ECOLGGY, RADIATION

CHËIISTRY, SCHISTOSOURA MANSONI PROJECT, AND SUGARCANE BORER PROJECT), PHYSICAL RESEARCH PRÓGRAMS INEUTKON DIFFRACTION, SOLIO STATE PHYSICS, AND HOT-ATOM CHEMISTRYI, AND RADIATION PRESERVATION CF TROPICAL FOODSTUFFS.

AVAILABILITY - CLEARINGHOUSE FOR FEDEPAL SCIENTIFIC AND TECHNICAL INFORIATION, SPRINGFIELD, VA., \$3. OO COPY, \$O.65 HICROFICHE

\#RACIATION DAMAGE + \#RAOIOBIOLOEY + RIOMEDICAL + ECOLOGICAL CGNSIDEFATION + HEALTH PHYSICS TRAINING + PUERTO RICG + SOL ID STATE DEVICE

15-21261 ALSC IN CATEGORY 16

RADIOLOGICAL PHYSICS DIVISION ANNUAL PEPODT, JULY 1965 TO JUNE 1966

ARGONNE NATIONAL LAB., ILL.

$A N L-7220+.124$ PAGES, 92 FIGURES, 29 TABLES, REFERENCES, 1966

PROGRAMS COVERED IN THIS REPORT INCLUDE - THOROTRAST DETECTION CHARACTER ISTICS OF NAI CP.YSTALS CF VARIOUS SIZES, THFRMOLUMINESCENT DOSIMETRY OF INTERNAL BETA RAY EMITTEFS, UV LASER EXCITATION FGR ULTRASENSITIVE DHOTOLUMINESCENT DOSIMETRY, THERMGLUMINESCENCE IN BONE, GEOMETRICAL AND PHYSICAL PARAMETERS IN WHOLE-BODY GAMMA-RAY SPECTROMETRY MEASUREMENTS, PQOGDESS IN LCW-FAUIJACTIVITY PHOTGNULITIPLIER TUEES, A STOCHASTIC THEODY OF

RECRYSTALLIZATION AND PONER-CUNCTICIN RETENTION, THE PROLIFERATIVE CAPACITY OF STEM CELLS FREM THE MARROW JF ISOTOPICALLY LABELED RONE (PRELIMINARY EXPERIMENTS), PADIUHA-?26 AND. THE. NATURAL AIRBORNE NUCLIDES LEAD-210 LND POLONIUM-2IO IN ARCTIC-BIOTA, RACON IN COAL MINES, ATMOSPHERIC RADJN MONITJR, CCMPUTER ANALYSIS OF BONE AUTORADIOGRAPHS, EXCHANGEABLE BONE CALCIUM, ANALYSIS OF SMOKE-PLUME PHOTOGRAFHS, CALCULATION CF EFFECTIVE STACK HEIGHT, METEORULOGICAL INSTRUMENTS FOR USE IN THE ATOMIC ENERGY INOUSTRY, DIFFUSION OF A SCALE-MODEL SMOKE PLUME,

THERMOLUMINESCENT DOSIMETPY, AND ENVIRCNMENTAL FADIATION STUEIES.

AVAILABILITY - CLE AO INGHDUSE FOR FEDEPAL SCIENTIFIC AND TECHNICAL INFORMATION, SPR INGFIELD, VIRGINIA, $\$ 3.00$ COPY, $\$ 0.65$ ICEOFICHF

\#BIOLOGICAL CONCENTRATIGIN, GENERAL + \#DOSIMETRY, GENERAL + \#INSTRUMENTATION, METEGROLOGICAL +

7METEOROLOGY + AIRSCRNE RELEASE + ANL + EIOMEDICAL + CALCIUM + DIFFUSION + DOSIMETRY, THERMOLUMINESCENCE + LEAD + POLONIUM + FADIOSIOLOGY + RADIOGRAPHY + PADIUM + SPECTROMETRY, GAMMA + STACK

$15-21262$

CACHOC + GALVAOJP + RAPUSO JS

RADIATION OROTECTION IN PORTUGAL

JUNTA DE ENERGIA NUCLEAR, SACAVEM (POPTUGAL). LABORATORIO DE FISICA E ENGENHARIA NUCLEARES

LFEN-55 + CONF-6.509\%:-? +. 14 PAGFS, 1966, IN PORTUGUESE, PRESENTED AT IOTH BRAZILIAN AND IST PORTUGUESE

CONGRESS ON RAOIOLOGY, RIO DE JANEIRC, RRAZIL

REVIEWS THE JEVELCPMENT IN DORTUGAL OF RADIATION PROTECTION STANCARDS AND THE OPGANIZATION OF OFFICIAL BODIES TO SUPERVISE PADIATION PROTECTION STANDARDS.

AVAILABILITY - MICROCARD EDITIONS, INC. (FOP. SALE) ACCOUNTING AND SHIPPING DEPARTMENT, WEST SALEM, WISCONSIN 54669

PORTUGAL + RAOIATION PROTECTION, ORGANIZLTION + RADIATION SAFETY AND CCNTROL

$15-21263$

SUROVIEC HJ

MICROWAVE DVEIN RADIATION: HAZAPOS IN FOTI-VENDING ESTABLISHMENTS

PENNSYLVANIA DEPT. DF HEALTH, MEADVILLE

4 PAGES, 2 TABLES, ? FEFERENCES, ARCH. ENVIRCN. HEALTH, 14, PAGE 465-472, (MARCH 1967)

PREVENTION OF RADIATION LEAKAGE FROM MICRONAVE OVENS IS OESCRIBED. OF THE UNITS MONITOREO, 71 R RELEASED F.LOIATION IV EXCESS OF I MILLIWATT/SQ.CM, AND IS\% RELEASEO PADIATICN LEVELS OF 10 MILLIWATTS/SG. CM OF. ABOVE. THE. RADIATION INTENSITILS PELEASED APPEARED TO DEPEND ON TIIL DESIGN OF THE COURS, WITH SLIDING DOORS PPOVIDING THE BEST SEAL. MEASURES TO MINIMIZE THE POSSIBILITY OF OVEREXPOSURE INCLUDE - 11 ) THF CONSTRUCTION OF GVENS SHDULD UTILIZE DESIGN FEATURES WHICH PFEVENT THE RELEASF OF MICROWAVE RADIATION, 121 INTERLOCK SYSTEMS SHOULD BE DESIGNED TO PREVENT CIRCUMVENTION EF THEIR USE, (3) UNITS SHOULD BE ADEQUATELY LABELED TC ALERT DWNERS AND DPERATDRS OF THE RISK OF OPERLTING UNITS IN A MANNER OTHER THAN THE

PRESCRI BED PRGCEDURE, (4) OWNERS, CPERATORS, $\triangle N D$ SERVICE PERSONNEL SHOULD BE MADE AWARE OF THE HAZARD JF EXPOSURE TO MICPOWAVE RADIATION, (5) UNITS SHDULD BE MONITORED PERIODICALLY TC 
ENVIRONMENTAL SURVEYS, MONITOFING 15 AND RADIATION EXPOSURE OF MAN

$15-21263 *$ CONT INUED*

DETECT LEAKAGE OP FAULTY OPERATICNAL DEVICES.

\#RACIATION OAMAGE + RIOMEDICAL + RAOIOBIOLOGY

15-21265 ALSO IN CATEGORY 14

PICKARD RC + FRY RM

ADMINISTRATION OF RADIULUGILAL HEAL IH PROGRAMS WITHIN THE STATE GOVERNMENT

KENTUCKY HEALTH DEPT., FRANKFORT

5 PAGES, AMER. J. PUBL IC HEALTH, 57, PAGE 290-204, (FEB. 1967)

ADMINISTRATIVE ASPECTS OF A RAOIATION SURVEILLANCE DEPARTMENT ARE CONSIDERED, WITH EMPHASIS ON STAFF, EQUIPMENT, BUDGET, METHODS, LEGISLATION AND REGLLLATIONS, GOALS, AND REPORTS. A MULTIDISCIPLINE PROGPAM IS NECESSARY BECAUSE OF THE COMPLEX INTERRELATIONS BETWEEN

RADIOLOGICAL HEALTH, MEDICAL ANO DENTAL PRACTICE, ENGINEERING, TRANSPORTATION, INDUSTRY, LABOR, AGRICULTURE, CIVIL DEFENSE, SPACE EXPLORATION, AND OTHER REGULATORY ORGANIZATIONS. FACILITIES REQUIRED FOR $\triangle$ RADIOLOGICAL HEALTH PROGRAM AND THE PROCUPEMENT OF RADIATICN MONITORING AND MEASUP ING EQUIPMENT ARE DISCUSSED. AN IMPORTANT POINT IN THE SELECTION CF INSTRUMENTATICN IS THE EASE OF MAINTENANCE OR. THE AVAILABILITY OF QUALIFIED PERSONNEL TO ENSURE ACCURATELY FUNCTIONING EQUIPMENT AT ALL TIMES. IT IS IMPORTANT THAT STATE STATUTES BE SOUNDLY ESTABLISHED TO DEVELOP A PFOGRAM UNDER PRDPEP LEGISLATICN.

*RADIATION PRJTECTION, QRGANIZATION + \#RADIATION SAFETY ANO CONTROL + ADMINISTRATIVE CONTROL + RADIOLOGICAL. ASSISTANCE + REGULATION, STATE

$15-21257$

FR ENCH RL + TOMPKINS KW + GARFETT CW

CALCULATED GAMMA-RAY DOSE DISTRIBUTIONS INI A PHANTOM EXPOSED TO FALLOUT AND SIMULATED FALLOUT RADIATIDN RESEARCH ASSOCIATES, INC., FORT WORTH, TEX

RRA-T71 +. S9 PAGES, FIGURES, TABLES, REFERENCES, FEBRUARY 1967

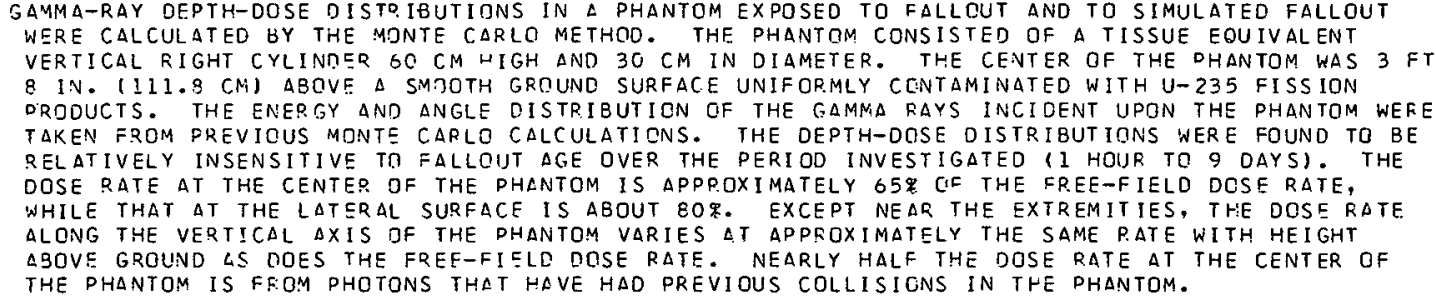

AVAILARILITY - CLEARINGHOUSE FOR FEDEFAL SCIENTIFIC AND TFCHNICAL INFORMATIQN, SPRINGFIELD, VIRGINIA, $\$ 3.00$ COPY, \$0.65 YICREFICHF

*OOSE CALCULATION, EXTEFNAL + \#FLLOUT + COMPUTEP PROGRAM + COMPUTER, DIGITAL +

FISSION PRODUCT ACTIVITY, GRCSS + MONTE CAPLO

$15-21268$

OROULERS Y + MASP + SCIERS P

DEVICE FOR. DETECTIVG AND/OP. MFASURING THE INTENSITY OF MIXED RAUIATION

COMMISSARIAT A 1-EVEPGIE ATOMIQUE, FRANCE

BRITISH PATENT $1,054,708+.4$ PAGES, I FIGURF, NÓV. 1,1967 , PATENT (BRITISH)

A DEVICE FOR MEASURING THE INTENSITY OF MIXED RADIATION. AND WHICH MAY ALSO BE USED TO INDICATE THE TYPE OF RADIATION IN A REFLECTCIR OR MODERATGR FLUID, SUCH AS LIGHT OR HEAVY WATER OR GTHER ORGANIC LIGUIDS OF A NUCLEAR PEACTOF. IS DESCRIBED. THE IINSTRUMENT CONSISTS OF A STAINLESS-STEEL WATERTIGHT CASING, $\triangle$ CORE IN THE CASING, AND A THERMOCOUPLE. THE COLD JUNCTION OF THE THEPMOCOUPLE IS SUR.JECT TO THE AMBIENT TEMPERATURE OF THE REACTOR MEDIUM. THE CORE IN THE CASINC IS HEATED PY DECELEPATING NEUTPCNS ANO ELECTRONS FROM THE REACTOP. MEUIUM. THE COURE IS HEATED IN ACCCRDANCE WITH THE INTENSITY OF THE RADIATION. THE HOT JUNCTION OF THE THERMOCOUPLE IS IN CONTACT WITH THE COPE AND THE TEMPERATURE DIFFERENCE BETWEEN THE THERMOCOUDLF JUNCTIONS FROVIDES A SIGNAL WHICH IS $\triangle N$ INDICATICN DF THE INTENSITY OF THE RADIATION. GRAPHITE CORES ARE SENSITIVE TO ALL KINCS OF PADIATION. LEAD AND BI ARE SENSITIVE TO GAMMA RAYS AND POLYETHYLENE AND POLYSTYRENE ARE SENSITIVE TO THE SUM OF FAST NEUTRONS AND GAMMA RAYS. CONSECUTIVE MEASUREMENTS MADE WITH DIFFERENT CORES AT THE SAME PLACE GIVE AN INEICATION OF THE ENEPGY CORRESPONDING TO EACH KIND JF RADIATION,

AVAILABILITY - THE PATENT CFFICF, 25 SOUTHAMPTON BUILDING, LONDON, W.C. 2, ENGLAND, \$O.4O PER COPY

* INSTRUMENTATION, RAOIATION MONITORING + ELECTRON + FRANCE + GAMMA + INSTRUMENTATION, NUCLEAP. + NEUTRON

15-21271 ALSD IN CATSGORY 1

PROPOSED STANDARD. PRCGRAM FOQ TESTING PIGLGGICAL SHIELOING IN NUCLEAR REACTOR PLANTS

AMER ICAN NUCLEAR SOCIETY

3 PAGES, 7 RETERENCES, NUCLEAF. ENGINEERING BULLETIN, 511 ), (JULY 1067 ) ANS 6.1 
$15-21271$ \#CONTINUED*

THIS STANDARD DESCRIBES AN OPERATIONAL. SHIELO-TESTING PROGRAM TO BE USED IN EVALUATING THE INSTALL SD BIOLCGICAL SHIELOING IN NURLFAR PLANTS. A GENEPAL TESTING PROCEDURE IS OUTLINED, AND THE NEC,ESSARY RADIATIDN MEASUREMENTS AND TYPES OF INSTRUMENTS ARE PRESCR.IBED.

* SHIELDING + CODES AND STANDAFDS + REACTCF SAFETY SYSTEM + TESTING

$15-21272 \quad$ ALSO IN CATEGORY 14

PUELIC HEALTH IMPLICAT IONS OF RADON EMITTEC ER.OM URANIUM MILL TAILINGS PILES

U. S. PUSLIC HEALTH SERVICE, U. S. DEPT. OF HEALTH, EDUCATICN, ANO WELFARE, NATICNAL CENTER FOR RADIQLOGICAL HEALTH, ROCKVILLE, MARYLAND

HEW-S31 +. 1 PAGE, NOVENBER 3, 1967

THE PUBLIC HEALTH SERVICE AND USAEC. AGREED ON L JOINT PRGJECT TO PROVIDF TECHNICAL ASSISTANCE TO STATES AND TNDUSTRY IN EVALUATING PUBLIC-HCALTH IMPLICATIONS OF RADON EMISSION FROM URANIUM-MILL TAILINGS PILES. WORK TO BE PERFORMED INCLUDES 11 THE DEVELCPMENT OF TECHNIQUES FOR SAMPLING AIR FOF RADON CGNTENT IN THE VICINITY OF UR.ANIUM TAILINGS, (2) DETEP.MINATION OF

THE EFFECT UPON RADON EMISSIONS WHEN TAILINGS ARE COVERED WITH EARTH OR PAVING MATERIAL; (3) EVALUATION OF ATMOSPHERIC CONCENTPATIONS NEAR TAILING PILES, AND (4) THE PREPARATION; IF NECESSARY, OF RFCOMMENDATIONS FOR THE CONTROL OF RADCN EXPOSURE.

AVAILABILITY - PUBLIC HEALTH SERVICE, ROCKVILLE, MARYLAND

* WASTE DISPOSAL, GENFPAL + $I I R+$ MILLING + RADIOISOTOPE + RADINN + SAMPLING + URANIUM + USAEC

15-21273 ALSC IN CATEGORY 14

THE DAY H-BOMBS FELL ON PALOMARES

9 PAGES, FIGURES, SATUPCAY REVIEW L(4), PAGE 21-?7, 39-40, (JAN. 28, 1967)

U.S. STRATEGIC AIR COAMANO BOMRERS CARRYING NUCLEAR WEAPONS ARE IN THE AIR AT ALL TIMES. ONE YEAR AGO-ON JANUARY $17,1960^{\circ}$, ONE OF THEM, $\triangle$ B-52, COLLIDED WITH $\triangle$ KC-I35. JET TANKER DURING A REFUEL ING OPERATIJN OVER THE MEDI TERRANEAN SEA NEAR THE SPANISH VILLAGE OF PALOMARES. AMONG THE RAIN OF DERRIS WERE FOUR HYDROGEN BOMES. THE SEARCH FOR THEM LASTED NEARLY THREE MONTHS

AND COST $\triangle N$ ESTIMATED $\$ 90,000,000$. THIS ARTICLE IS THE STORY OF WHAT HAPPENED IN THE VILLAGE.

*ACCIDENT, GENEPAL + *SURVEY, RADIATION, EMERGENCY + AIRCRAFT + PLUTONIUM +

SURVEY, RAOIATIGN, ENVIRONMENTAL

$15-21278$

ROTHE WE + HUYCKE EJ + BUTTERFIELD JL + RLUMENSTOCK JW

IONIZING RADIATION INJURY, PREVENTION AND TREATMENT. ANNUAL PROGRESS REPORT

ARMY MEDICAL RESEARCH UNIT, EURDPE

$A D-626384+A D-475,645+22$ PAGES, OCTOPER 1965

A SLICHT OECREASE IN THE AVEPAGE TOTAL BODY-BUROEN CS-I37 OF NORMAL PERSחNS WAS OBSFRVER FRRM JAN. 1964 THRQUGH MAY 1965 - FROM AQOUT 200 TO 150 PICOCURIES CS-137 PER GRAM DF BODY POTASSIUIA. CLINICAL STUDIES WERE CONTINUED. THESE INCLUDED FOLLOW-UP TESTING UF PEHSUNS NITH CARCINOMA OF THE THYRDID, IRON ABSORPTICN IN ANEMIC PATIENTS, AND VITAMIN E- 12 ABSORPTION IN PATIENTS. CDNTINUEO MEASUREMENTS OF BODY BURDENS DF RADIUM AND THOROTRAST WERE DONE IN SELECTED PERSONS. THE 2-PI LIQUID SCINTILLATION WHOLE BODY COUNTER WAS MODIFIED TU ASSAY WHOLE BODY BURDFNS OF STPONTIUM-OO. THE MINIMUM SENSITIVITY OF SUCH A WHGLE BODY BURDEN ASSAY IS CALCULATED TO BE 70 NANOCURIES SR-9O. MEASUREMENTS OF ENVIRONMENTAL LEVELS OF ALPHA EMITTING RADIOISOTOPES IN WATER, FOOD, SNAILS, AND HUMAN TEETH AND BONE WERE CONTINUSD. DER SONNEL OCCUPATIONALLY EXPOSE'D TO RADIOISOT OPES WERE MONITOKED FOP. POSSIBLE INTERNAL CONTAMINATION. ADENINE WAS TESTED FOR IMPROVING THE IN VIVO VIAEILITY OF REO BLOOD CELLS STORED IN A STANDARD WAY FOR 42 DAYS. LEAN BODY MASS CHANGES OCCURRING DUR ING AIRBORNE TRAINING WERE QUANTITATEO IN TWO MILITARY GROUPS.

AVAILABILITY - DEFENSE DOCUMENTATION CENTER, CAMERON STATION, ALEXANORIA, VIRGINIA

* RADIOBIOLOGY + CESIUM + COUNTER, WHOLE BGOY + PERSONNEL EXPOSURE, RADIATLON + RADIUM + STRONTIUM

$15-21281$

SINCLAIR KF

THE RELATIONSHIP BETWEEN THE RADIOBIOLOGICAL EFFECTS TABLE AND TACTICAL MILITARY RADIATION MEASUREMENT SYSTEM DESIGN

NAVAL RADIOLOGICAL DEFENSE LAR., SAN FRANCISCO

USNRDL-TR-67-67 . 36 PAGES, 3 FIGURES, 5 TABLES, 18 REFERENCES, MAY 29,1967

THE TACTICAL RADIATION MEASUREMENT SYSTEMS ARE USED IN THE. MILITARY PRIMARILY FOR THE ACQUISITION OF RADIATION DATA. FOR ENTRY TO THE RADIOBIOLOGICAL EFFECTS.TABLE (RETI. THE TABLE PROVIDES THE RR IDGE NEEDED TO TRANSLATE A RADIATION MEASUREMENT TO INFORMATION P.EGARDING THE PRESENT AND PROBABLE FUTURE (SHORT TERM) DPERATIONAL EFFECT IVENESS OF A MILITARY GROUP. AT PRESFNT, THE RFT IS STATFD IN TERMS OF EXPOSURE IN ROENTGENS OR ABSORBED DOSE IN RAOS (AIP), AND THE RADIAC INSTRUMENTS ARE CALIBRATED IN EITHER OF THESE UNITS IN A FREE-AIR POINT SCURCE GEOMETRY: THIS RESULTS IN LARGE ERRORS UNDER CERTAIN FIELD CONDITIONS. THE ERRORS IN FALLOUT AND INITIAL RADIATION FIELDS CAN BE GREATLY MINIMIZEO BY COPRELATING THE EFFECTS TABLE WITH MIDLINE DOSF AND RETAINING THE PRESENT CALIBRATION METHOO FOR THE 
ENVIRCNMENTAL SURVEYS, MONITORING AND PADIATION EXPOSURE OF MAN

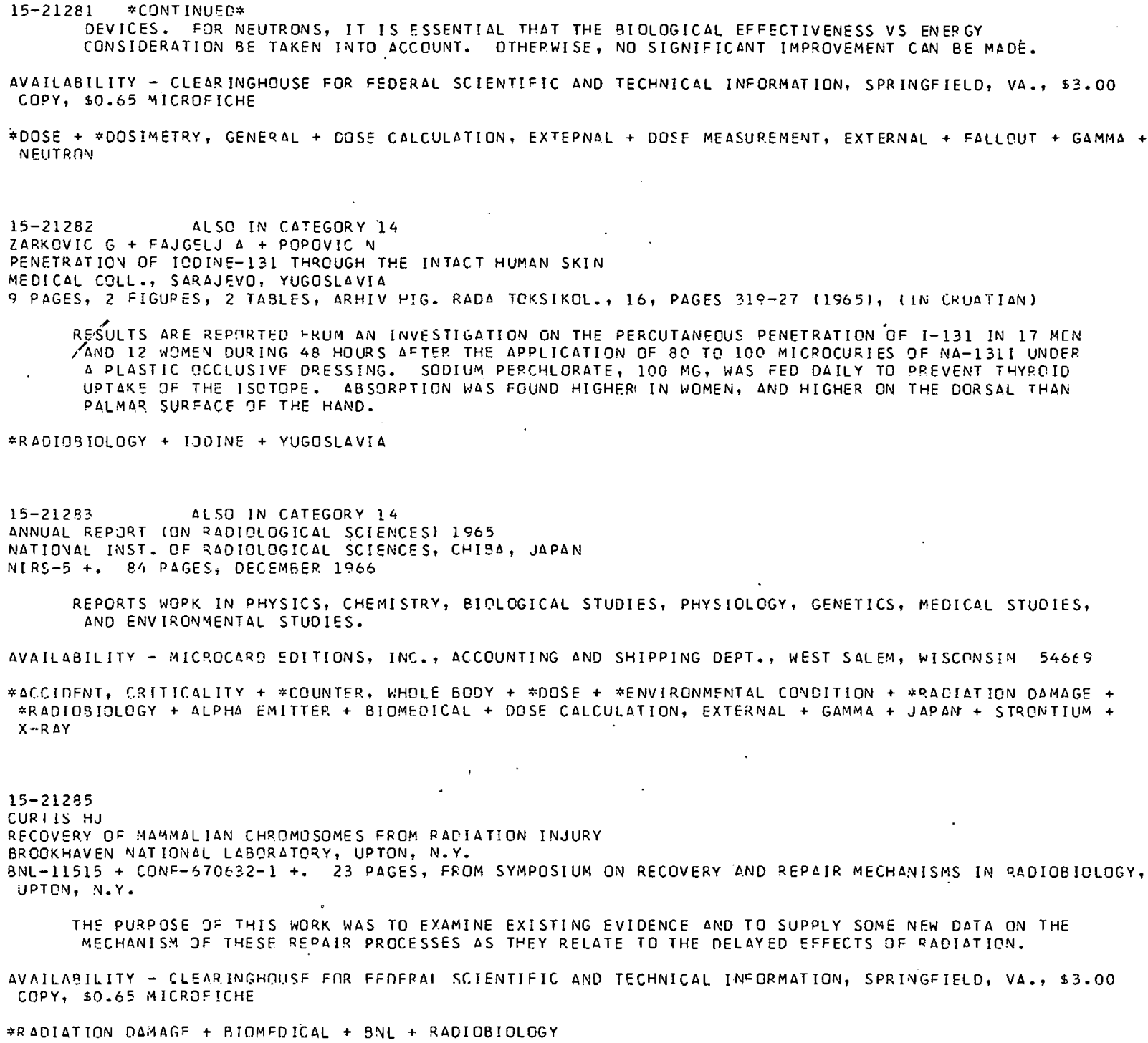




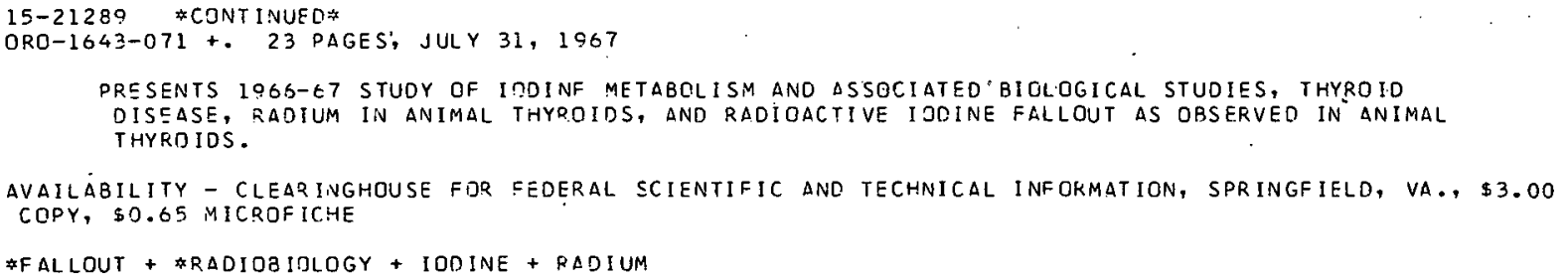

A TOTALLY DEPLETED, SILICON, DE/OX COUNTER (2OC MICRONS THICK) WAS TESTED FOR USE IN GENERAL PURPOSE DOSIMETRY. THE RESPONSE TO ALPHA, BETA, AND GAMMA RAYS AS WELL AS TO FAST NEUTRONS IS PRESENTED, AND THE MEASUREMENTS INDICATE A DETECTOR OF UNUSUAL VERSATILITY.

AVAILABILITY - ATOMIC ENERGY OF CANADA, LTO., CHALK RIVER, ONTARIO, CANADA, \$O.5O COFY

* INSTRUMENTATION, RADIATION MONITORING + \#SOLID. STATE DEVICE + CANADA + CHALK RIVER + DOSE MEASUREMENT; EXTERNAL + DOSIMETKY, GENERAL + GAMMA

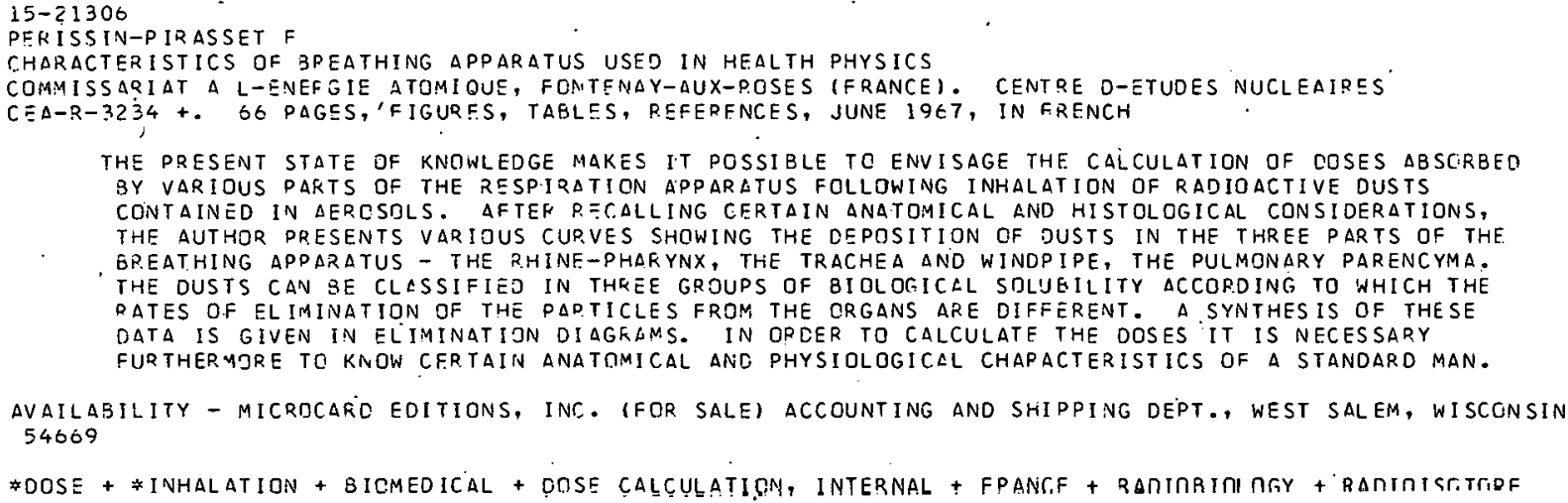

EXPERIENCE IN THE OPERATION OF A PRGTOTYPE SYSTEM FOR THE DETECTION AND ESTIMATION OF IVSOLUSLE PLUTONIUM-?39 IN THE LUNGS IS DESCRIBED. THE SYSTEM CONSISTS OF A LOW BACKGROUNO $X$ ENON-FILLED, MULTIWIRE PRODORTIONAL COUNTER USED IN CONJUNCTION WITH A LARGE AREA, THIN WINDOWED, SDDIUM IODIDE CRYSTAL. A REALISTIC CHEST PHANTOM IS USED TO CALIBRATE THE DETECTORS FOR PLUTONIUM-230 AND ANER ICIUM-241. THE VAFIATIONS IN DETECTOR BACKGRDUNOS CAUSED BY THE PRESENCE DF A HUMAN SUBJECT ARE DESCRIBED, ANO THE SOURCES DF ERROR ANO THEIR MAGNITUDE ARISING BOTH FROM THE DFTFCTION SYSTEM AND THE CALIBRATION PROCEDURE ARE DISCUSSED IN DETAIL. THE USE DF THE EQUIPMENT IN A FEW CASES OF ACCIDENTAL INHALATION DF PLUTONIUMI-239 IS DESCRIBED. THE LIMYT OF DETECTION OF THE PRESENT EQUIPMENT IS GIVEN AS O.OI2 MICROCURIES $P y-239$.

AVAILABILITY - ATOAIC ENEFGY ÉSTABLISHMENT, HINFRITH, DOPCHESTER, DORSET, ENGLAND

\# INSTRUMENTATION, RAOIATION MONITORING + \#RADIOBIOLOGY + AMFRICIUM + COUNTER + COUNTER, WHOLE BODY + PLUTONIUH + UNITED KINGDOM

$15-21311^{\circ} \quad A L S O$ IN.CATEGORY 14

PACIFIC NORTHWEST LABDRATOPY MONTHLY ACTIVITIES REPOPT, SEPT. 1966, ON $\triangle E C$ OIVIS ION OF BIOLOGY AND MEDICINE PROGRAMS

BATTELLE-NOR THWEST, P. ICHLANO, WASHINGTON

BNWL-335(REV.) +. 21 PAGES, OCTOBEP. 1966

WORK PEPPOTTED INCLUDES STUDIES ON RADIATION EFFECTS - GENERAL, TOXICITY OF RADIOELEMENTS, INCLUDING TOXICITY ANO METABQLISM CF RADIONUCLIDES IN AQUATIC ORGANISMS, EFFECT OF 
ENVIRONMENTAL SURVEYS, MONITORING, 15

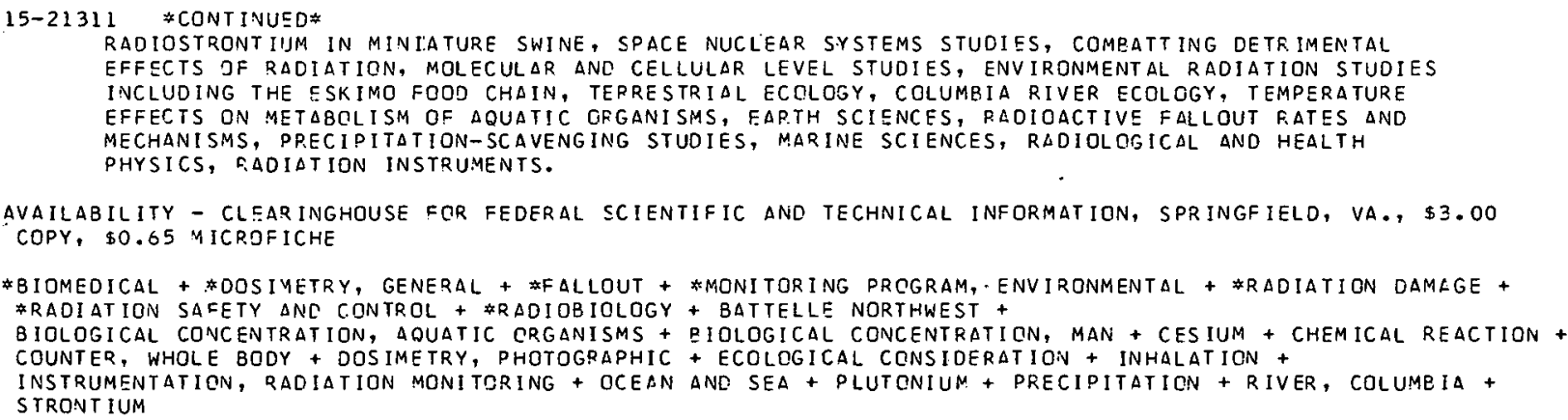

TO LEARN THE DISTRIBUTION OF RADIATION ARQUND AN ACCELERATOF. GUANTITATIVELY, A PFOGRAM FOR MONITORING THE DISTRIBUTION OF INOUCED ACTIVITY AND TOTAL RADIATIDN DOSE IN THE $2 E R O$ GRANDIENT SYNCHROTRON RING 8UILOING WAS STARTED IN 1965 . THIS PAPER IS AN ATTEMPT TO COMPILE THE DATA TO SEE IF DEFINITE PATTFRNS EXIST, TO EXTRACT USEFUL CALCULATION CONSTANTS, ANO TO EXTRAPOLATE THE TOTAL DOSES RECEIVED BY COMPONENTS SINCE THE STARTUP OF THE ZGS. SCME OF THE RELATIONSHIPS EXAMINED ARE - 11 THE DISTRIRUTION OF DOSE RECEIVED BY COMPONENTS OF THE ZGS PER OPERATING HOUR CR PER CIFCULATING PRCTON, (2) THE OISTRIBUTION OF INDUCED ACTIVITY, AND (3) THE RATIO OF INDUCED ACTIVITY TO AVEPAGE DOSE AT THE SAME LOCATION.

\#ACTIVATION + \#DJSE + \#DOSE ME ASUREMENT, EXTERNAL + \#DOSIMETRY, GENERAL + ACGELERATQR + ACT IVATION PRODUCT + ANL + DOSIMETRY, THERMOLUMINESCENCE + RADIONUCLIDE, INCUCED

$15->1315$

WYCKOFF JM

RADIOACTIVITY DROOUCED BY A LINAC

NATI IONAL BUREAU OF STAINDARDS, WASHINGTON, D. C.

2 PAGES, 3 PEFERENCES, IEEE TRANSACTIGNS ON NUCLEAR SCIENCE 14(3), PAGES 990-91 (JUNE 19E7)

MORE THAN 40 MATERIALS WERE IRRADIATED IN THE 100-MEV BREMSSTRAHLUNG BEAM FROM THE NBS LINAC. THE MAJOR CONTRIBUTIONS TO THE GAMMA-RAY SPECTRUM FROM THE RADIOACTIVE PRCDUCTS WWRE MEASURED USING A GE-LI DETECTOR. MEASUREMENTS WERE MADE OF GAMMA RAYS OF CONCERN IN THE $3 U$ UMIN TL. 30-DAY TIME INTERVAL, BUT THIS INCLUDES IN SOME CASES GAMMA RAYS FROM NUCLIOES WITH HALF-LIVES AS LONG AS 30 YSARS. EIGHTEEN OF THE SAMPLES WERE PURE MATERIALS, AND 24 WERE COMIONLY USED STRUCTURAL, SHIELDING, ELECTRICAL AND MECHANICAL COMPDNENTS. IN SEVERAL

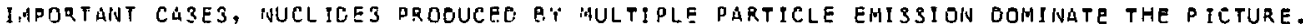

*ACTIVATION + \#ADIDNUCLIDE, INDUCED + ACCELERATOR + ACTIVATION PRODUCT + GAMMA + NBS

$15-21316$

SPOKAS CE

THE NBS LINAC MASTER CONTROL ANO DERSONNEL PROTECTION SYSTEM

NATIONAL BUREAU OF STANIARDS, WASHINGTON, D. C.

6 PAGES, 2 EIGURES, IEEE TRANSACTIONS ON NUCLEAP, SCIENCE 14(3), PAGES 1016-21 (JUNE !O67)

THE OPERATION CF THE NBS LINEAD ACCELERATQR AND ITS BFAM-HANDLING EQUIPMENT WAS INTEGRATEC WITH PERSOVNEL AND EQUIPMENT-PRDTECTION SAFEGUARDS AND WITH THE OCCUPANCY REQUIREMENTS OF THE LINAC COMPLEX. A MODE SWITCH IS USED TO SFLECT BEAM DIRECTION AND EXPERIMENTAL AREA, ANO TO PROGRAM THE REQUIREMENTS FOR PERSONNEL PROTECTION INTERLOCKS, BEAM HANDLING SYSTEM 
15-21316 \#CONTINUEQ*

CONDITIONS, BUILDING MECHANICAL SEPVICES, EXPEPIMENTAL AREA SERVICES, AND LINAC OPERATION. THE SYSTEM INCLUDES VISIBLE AND AUDIBLE DFVICES TO INDICATE DEgREe DF READINESS, hazaRDS, FAULTS, INTERLOCK INFORMATION, ZONE OF OPERATION AND EMERGENCY SITUATIONS - A FORCED INSPECTION OF POTENTIALLY DANGEROUS ZONES, PROGRAMMED CUED TAPED WARNING ANNOUNCEMENTS, KEY INTERLOCKS, AND FLEXIBILITY ARE BUILT-IN FEATURES. IT DFFERS THE CAPABILITY OF PROVIDING MAXIMUM PROTECTION TO PER SONNEL AGAINST ENVIRONMENTAL. PADIATION HAZARDS AND ALLCVS UTILIZATION OF A MAXIMUM OF LABORATGRY SPACE FOR. VARIEO BEAM CONDITIONS.

\# MONITOR, RADIATION, GENERAL + \#RADIATION PROTECTION, ORGANIZATION + \#RADIATION SAFETY AND CONTROL + ACCELERATOR + ENVIRONMENTAL CONOITION + MONITOR, RADIATION, PERSONNEL + NBS

$15-21317$

TALENT I M T CIGNALA

PROBLEM OF RADIOACTIVE MINERAL NATSRS FROM THF HYGIENIC POINT OF VIEW

UNIVERSITY OF ROME

4 PAGES, 6 REFERENCES, NUCVI ANN. IG. MICRCBIOL. , 15, PAGES 56?-71 (NCV-DEC. 1964) IN ITALIAN

RADIOACTIVE WATERS APF DEF INED IN ITALY AS THOSE WHICH CONTAIN MORE THAN 4 NCI/1. MOPE EXACTLY, WEAKLY ACTIVE WATERS CONTAIN 1-30 NCI/1, ACTIVE WATERS CONTAIN 30-150 NCI/1, STRONGLY ACTIVE WATERS CONTAIN MORE THAN 150 NCI/1. OTHER CLASSIFICATIONS EASED ON RA CONTENT ARE DISCUSSED. THE BASIS GF DETFRMINATIONS ON RN-222 AND RA-226 IS OUTLINED. PREVIDUS MEASUREMENTS ON ITALIAN HATERS IN GENERAL HAVE BEEN CARRIED OUT WITH INAOEQUATE EQUIPMENT FOR DISTINGUISHING THE CONTRIEUTIONS FROM THESE ISOTOPES. THE SCINTILLATION CHAMBER APPEARS TO. BE ADAPTEC PAPTICULARLY WELL TD THE DETERMINATION OF RN- 222 IN EQUILIBRIUM WITH RA-22., AS DISTINQUISHED FROM EXCESS RN-222. THS MAX ADMISSIBLE CONCENTRATION OF RA-226 IN WATER IS 1 PCI/1, AVOIDANCE OF CONTINUED USE OF MORE ACTIVE WATERS IS SUGGESTED. THIS VALUF FOR THE GENERAL POPULATION MAY BE ALTERED BY RECENT STUDIES ON THE RATIO BETWEEN RA CONTENT IN WATER AND IN THE HUMAN EODY. CONTRIBUTIONS OF.EACH NUCLIOE TO TOTAL ACTIVITY OF ITALIAN MINERAL WATERS WILL RE STUDIED IN THE FUTURE.

\%GROUNO NATER, GENERAL + GROUND WATER, NUCLIGE OCCURRENCE + ITALY + RACIUM + RADON

$15-21324$

DZANTIEV OG + KGVALEVA EP

CHEMICAL METHODS IN NUCLEAR REACTOR RADIATION DOSIMETRY

INST. DF NUCLEAR ENGINEER ING. MINSK

5 PAGES, 4 TABLES, 1 TASLE, 4 REFERENCES, SER. FIZ. TEKH. NAVUK, NO. 1, PAGES 47-5I 11967 IN RLSSIAN

THE OXIDATION CFF FERFOUS ION TO FFRRIC, AND THE RATE OF CONSUMPTION OF GLUCOSE CAN BE USEC TO MEASURE GAMMA DOSE AND MIXED GAMMA-NEUTRON DOSE IN A REACTOR. THE GLUCOSE LOSS CAN BE MEASURED BY THE CHANGE IN OPTICAL ACTIVITY OF THE SOLUTION OR FROM THE CHANGE IN ABSORPTION SPECTRUM OF THE IRRADIATEO GLUCOSE SOLUTION. THESE VARIOUS MOOIFICATIONS OF CHEMICAL DOSIMETRY GIVE CONCORDANT RESULTS. THE CONTRIBUTION OF FAST NEUTRONS IS 20 TO $30 \%$ OF THF TOTAL DOSE, AS DETERMINED BY GLUCGSE DOSIMETRY. THE DOSE IN THE CENTER OF THE P.EACTOR IS 1260 RADS/SEC RY FERROUS SULFATE DOSIMETRY, WHICH IS IN GOOD AGREEMENT WITH A VALUE OF IZZZO R AOS/SEC AS UETERMINED BY GLUCOSE DOSIMETRY. AN IONIZATION METHOD ALSO GAVE A VALUE IN GCOD AGREEMENT WITH THE TWO VALUES OBTAINED BY CHEMICAL DOSIMEIRY. LIN $\triangle D D I N G$ BORIC ACIO TO THE GLUCOSE SOLUTIUN, A VALIJF OF $1.5 \times 10112 \mathrm{TH})$ IS OBTAINED FOR THE NEUTRON FLUX. THUS, CHEMICAL DOSIMETRY CAN BE USED TO DETERMINE NEUTRON FLUX, ESPECIALLY IF SELF-SHIELDING BY THE BOREN IS TAKEN INTO ACCOUNT.

*DOSIMETRY, GENERAL + GAMMA + NEUTRON + PEACTOR, GENERAL + USSP

$15 \div 21326$

GOLDMAN L + HORNBY D

SAFETY IN THE CHEMICAL LABORATORY. XXV. LASER LABORATORY DESIGN AND PERSONNEL PROTECTION FROM HIGH ENERGY LASERS

CHILDRENS HOSPITAL RESEARCH FOUNDATION, CINCINNATI

12 PAGES, S REFERENCES, J. CHEM. EDUC. 43 , PAGES A335-46 (APRIL 1966)

LASERS OPERATEO IN THE Q-SWITCHED MODE CAN NOW GENERATE POWER OUTPUTS AS HIGH AS GIGAWATTS. WITH THE GEVERATIDN OF SECOND $\triangle N D$ FOUFTH HARMONICS, LASER GENERATION IN THE UV RANGE IS NOW POSSIRLE. WITH SUCH SIGNIFICANT ENERGY AND POWER OUTPUTS, IT IS DBVIOUS THAT PERSONNEL WOPKING WITH LASERS MUST BE PROTECTED. THE PROTECTIDN PROGRAM DESCRI BED CENTERS ABOUT THE FOLLOWING DESIGN AND OPERATIONAL FEATURES - 11 PERSONNEL CONTROL (EYE, EXPOSED SKIN; AND INHALATION), (2) AR.EA CONTROL (AVOIOANCE OF SPECTRAL REFLECTANCE, PROFER VENTILATION, ANC, AVOIDANCE JF ELECTRICAL SHOCKI.

*RADIATION PROTECTION, ORGANIZATION + \#RADIATION SAFETY AND CONTROL + EIOMEDICAL + LASER

$15-21328$

OVERDOSES FROM LINEAR ACCELERATOR

2 PAGES, LANCET 2 , PAGES $212-13$ (JULY 23,1966 )

ON FES. 11, 1966, A FAULT IN THE CONTRQL SYSTEM OF THE 8-MEV LINEAR ACCELEPATOR AT HAMMERSMITH HOSPITAL CAUSED AN DVERDOSE TO BE GIVEN TO THREE PAT IENTS UNOERGOING ELECTRONREAM THERAPY THE EFFECTS ON TWO OF THE PATIENTS WERE SEVERE. IN THE THIRL, SLIGHT. THE COMMITTEE OF 
ENYIRONMENTAL SURVEYS, CMONEGORY 15 IORING AND FADIATION EXPOSURE DF MAN

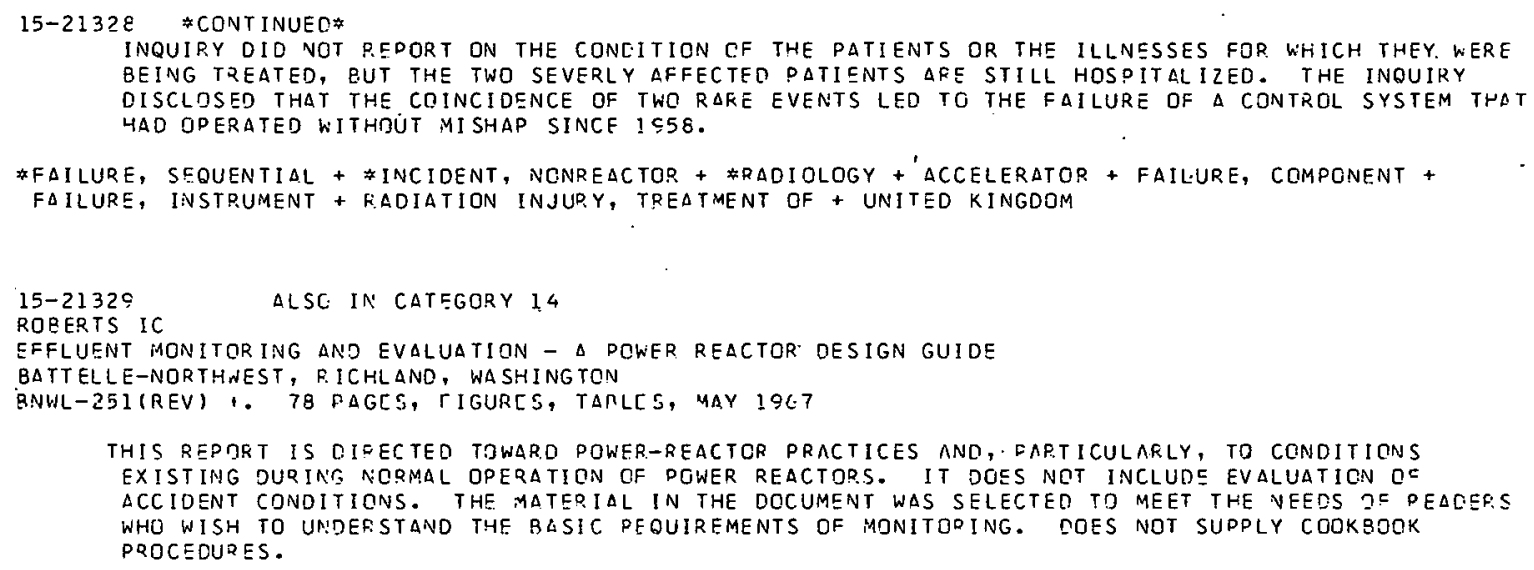

AVAILABILITY - CLEARINGHOUSE FOP FEDERAL SCIENTIFIC AND TECHNICAL INFORMATION, SFRINGEIELD, VA., \$3. OO CUHY, SU.OS MICKULILHE

*DOSIMETRY, GENERAL + DOSE MEASUREMENT, EXTERNAL + DOSIMETRY, THERMOLUMINESCENCE + ITAHO FALLS

$15-21323$

SIUNL GH + IHUKNGAIE JH

EXPER IMENTALLY OET ERMINEO PROTON-RECOIL SPECTRA IN TISSUE-EQUIVALENT MATERIAL FROM 3- ANE IE-MEV NEUTRONS OAK RIOGE NATIONAL LABOFATORY

ORNL-TM-1927+. 85 PAGES, FIGURES, TARLES, CCTCEER $1 \subseteq 67$

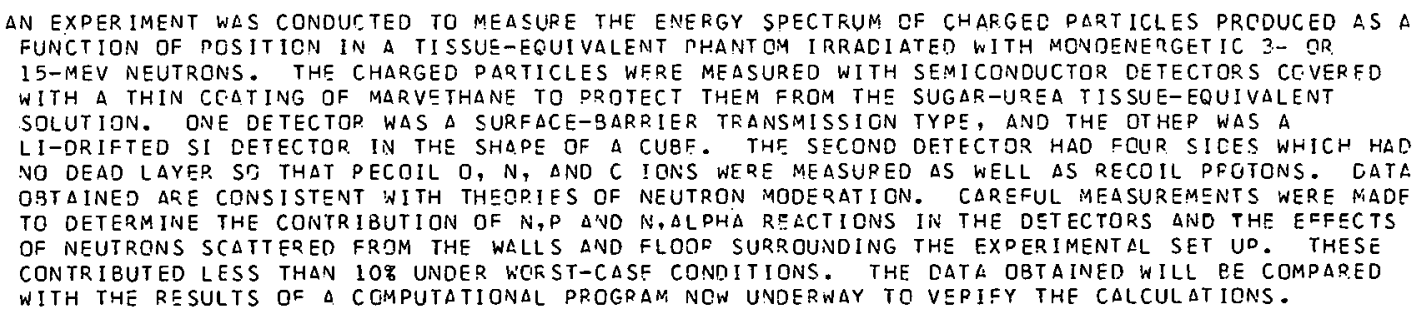


ALSO IN: CATEGORY 14
$15-21344$
MALYKHIN VM + MOISEEV DA + SHAMOV VP

ON THE CALCULATION OF THE DOSE LOADS FDR THE BONE TISSUE IN CASE CIF ACUTE SF-9O POISONING

2 PAGES, 2 FIGURES, GIG. SANIT 9, PAGES E2-3 (SEPTFMBEP 1066) IN PUSSIAN

A BIOLOGICAL MOLEL FOR THE JPTAKE OE STRONTIUM-OO SY HUMANS WAS USED FOR DETERMINING THE LOSE TO BOIVE TISSUE. THE INTEGQAL BDNF. DOSE WISS COMPUTED CONSIDEPING THE AMOUNT OF ACTIVITY INTRODUCED IVTE THE DRGANISM DURING ACUTE PQISONING WITH STRONTIUM-90, THE AMOUNT OF ACTIVITY MEASURED IN VIVO AT APRITRARY TIMES DURING THE YEARS FOLLOWING ACUTE POISCNING, AND THE. AMOUNT OF STRCNTIUM-9O EXCRETED DAILY (IN URINF. AND FECES) BY THE PATIENTS, FOLLOWING ACUTE POISONING WITH STRONTIUM- 90 .

\#DOSE + BIOLOGICAL CONCENTRATION, MAN + DOSE CALCULATION, INTERNAL + RAOIOBIOLOGY + STFONTIUM + USSR

15-21349 ALSO IN CATEGORY 14

ROSENTHAL HL + BIRD JT + GILSTER JE + PINTOPV + ONEILLS

SR-9O CONTENT OF DECIRUCUS TEETH OF CHILDREN

WASHINGTON UNIVERSITY, ST. LOUIS

7 PAGES, 5 FIGURES, 3 TABLES, 17 REFERENCES, J. CENT. RES. 45, PAGES 343-9 (MAR.-APR. 1966)

TG DETERMINE THE USEFULNESS DF DECIDUDUS TEETH AS A MEASUPE OF SR-9O BODY EURDEN, STUDIES WERE UNDERTAKEN TJ OEF INE THE VARIATION IN THE SR-90 CONTENT OF THE VARIOUS TYPES OF DECIDUOUS TEETH. THE SF-SO CONTENT OF DECIDUOUS TOOTH CROWNS INCREASED FF.0M 0.15 TO 4.7 PC SR-90/G CA SETWEEN 1947 AND 1958, RESPECTIVELY, FOR CHILDREN BORN IN THE ST. LOUIS AREA ANO WHO WERE B:JTTLE-FED FRGM EIRTH. THE VARIATION OF SR-9O CONTENT IN CECIDUCUS INCISORS, CUSPIDS, AND FIRST AND SECOND MCLARS, BETVEEN CARIOUS AND SOUND TEETH OR BETWEEN TEETH FROM CHILDKEN WHC WERE BREAST-FED OR P.OTTLE-FED DURING THE TIME OF TOOT 4 FORMATION WAS LESS. THAN $30 \%$.

* B IOLOGICAL CONCENTRATIGN, MAN + \#ALLOUT + EIOMEDICAL + RADIOEIOLOGY + STRONTIUM + UNITED STATES

\section{$15-21358$}

MCLAUGHLIN WL + CHALKLEY L

LOW ATOMIC NUMBER DYE SYSTEMS FOR IONIZING RADIATION MEASUREMENT

NATIONAL BUREAU OF STANDARLS, WASHINGTON

8 PAGES, 11 FIGURES, 4 TABLES, DHOTOGRADHIC SCIENCE AND ENGINEERING 9(3), PAGES 15O-66 (MAY-JUNE 1 SG5)

IN RADIDTHERAOY, RADIATION PROCESSING, AND INTENSE-BEAM DOSIMETPY, THE PROBLEMS OF'ISODOSE MEASURE MENT AND OEPTH-DOSE DISTRIBUTION STUDIES ON A MICROSCGPIC SCALE HAVE NOT BEEN SOLVED SATISFACTORILY BY CONVENTIONAL RAOIATION MEASUREMENT SYSTEMS. ORGANIC DYE SYSTEMS, DLTHGUGH CONSIDERABLY LESS SENSITIVE. THAN MCST SILVER HALIDE EMULSICNS, LEAD TO MUCH SMALLER ERR.ORS IN THE INTERPRETATICN GF THEIR RESPONSE TO INTENSE IONIZING RADIATION BEAMS, DUE TO LOWER SPECTRAL SENSITIVITY VARIATION. COLORLESS DERIVATIVES OF TRIPHENYLMETHANE DYES, SUCH AS STABILIZED FORMS OF DARAROSANILINE NITRILES, SHOW SPECIAL POTENTIAL FOR DOSIMETRY, BECAUSE CF THE HIGH INTENSITY CF. COLDR FORMED UPON IRRADIATION, THE STABILITY OF COLOR AFTER IRRADIATION, THE ABSENCE OF RESPONSE TO WAVELENGTHS LONGER THAN 330 MILLIMICRONS, THE ABSENCE OF RECIPROCITY FAILURE, AND THE CAPABILITY OF BEING INCCRPORATED EASILY INTO A NUMBER OF MEUIA.

*DOSE + \#ODSIMETRY, GENERAL + DOSIMETRY, PHOTOGRAPHIC + GAMMA + NBS + X-RAY

$15-21359$

MCLAUGHL IN WL

MICROSCOPIC VISULIZATION OF DOSE DISTRIBUTIONS

NATIGNAL SUREAU OF STANDARDS, WASHINGTON, D. C.

14 PAGES, 6 FIGURES, 56 REFERENCES, INTERNATIONAL JOURNAL OF APPLIED RADIATION AND ISOTOPES, VOL. I7, PAGES $85-96(1966)$

COLORLESS CYANIDES OF TRIPHENYLMETHANE DYES WHEN SUITABLY ACTIVATED CAN BE MADE INTO FILMS THAT BECOME DEEPLY COLORED UPON IPPADIATION WITH SHORT-WAVE ULTRAVIOLET AND IONIZIVG RADIATIONS BUT ARE NDT SENSITIVF TO NEAR ULTRAVIOLET RADIATICN DR VISIBLELIGHT. THE RESPONSE RANGE FOR X RAYS, GAMMA RAYS, AND ELECTRONS IS ABOUT 1O(5TH) TO 1O(8TH) RADS. EXPER IMENTS SHOW THAT, BECAUSE OF THEIR STABILITY, LOW ENERGY DEPENDENCE, AND HIGH SPATIAL RESOLUTION, THESE SOL IO SYSTEMS HAVE EXCELLENT POTENTIAL FOR VISUAL INSPECTION OF HIGH-LEVEL COSE DISTRIBUTIONS ON A MICROSCOPIC SCALE. SINCE MOLECULAR EXCITAT IONS DUE TO LOW-ENERGY SECONDARIES ARE MOST IMPORTANT TO THE OVERALL RADIATION EFFECTS, THE P.EL $\triangle T I V E L Y$ LARGE SSNSITIVITY JF SUCH DYE SYSTEMS EXPECTED IN THE INTERMEDIATE AND FAR ULTRAVIOLET MAY REPRESENT AN ADVANTAGE IN DOSIMETKY.

*DOSE + \#DOSIMETRY, GENERAL + GAMMA + NBS + X-RAY

$15-21360$

WIISON $A R+S P I E R S$ EW

FALL OUT CESIUM-137 ANE POTASSIUM IN NEW-RORN INFANTS

UNIVERSITY OF LEEDS, LEEDS 
ENVIRONMENTAL SURVEYS, MONEGORY 15 ING AND RADIATION EXPOSURE OF MAN

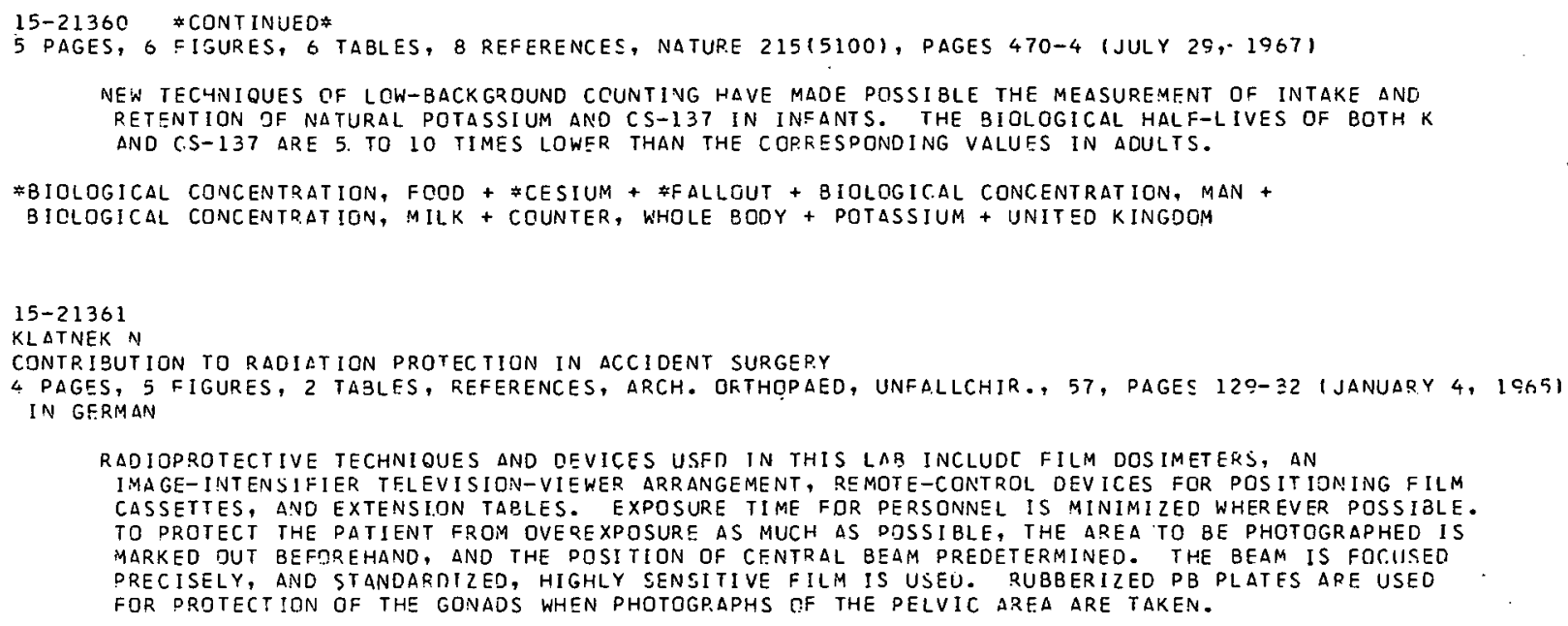


15-21364 \#CONTINUEO *

$\triangle T$ A 5-CM DEOTH, AND THE MAXIMUM DOSE. A SET OF. QUALITY FACTORS WAS $\triangle D O P T E O$ Fof TRANSFORMING RAD DOSE TO REM DOSE, BUT DETAILEO ENERGY DEPOSITION DATA ARE ALSO PRESENTED SO THAT ANY PREFERRED SET OF QUALITY FACTORS CAN BE USED TO OBTAIN ESTIMATES OF THE REM DOSE.

AVAILABILITY - CLEARINGHOUSE FOR FEDERAL SCIENTIFIC AND TECHNICAL INFORMATION, SPRINGFIELD, VA., \$3.00 COPY, \$0.65 MICROFICHE

* OOSE + \# DOSE CALCULATION, EXTERNAL + COMPUTER PROGRAM + COMPUTER, DIGITAL + MONTE CARLO + NEUTPON + ORNL

$15-21365$

THE STANDARDISATION OF PRESSURIZED SUITS

UNITED KINGDOM ATOMIC ENERGY $\triangle U T H O R I T Y$, HARWELL

AHSBIRO)R-76 +. 18 FAGFS, 7 FIGURES, 8 REFERENCES, JUNE 1967

A WDRKING PARTY WAS FORMED TO DRAFT STANDAROS FGR LIGHT-DUTY PRESSURIZED SUITS. THIS REPCRT DESCRIOES THE WORK LEADING TO THE SPECIFICATIONS. FEW DIFFERENT TYPES OF BLOUSES, HDODS, AND OVERSUITS NERE IN USE IN UKAEA, AND PREPAPATION OF STANDARDS PRESENTED LITTLE DIFFICULTY. A NEW AUTHORITY STANDARD WAS ADOP TED FOR PERSONNEL AIR HOSE A SPECIFICATION OF PREFERRED DES IGN CHARACTERISTICS FDR PERSONNEL AIR-HOSE COUPLINGS WAS PREPARED. THE STANOAPD SDECIFICATIONS TAKE ACCOUNT OF THE FEW MINOR CHANGES SHOWN BY USE TO BE NECESSARY:

AVAILABILITY - CLEAFINGHOUSE FOR FECERAL SCIENTIFIC AND TECHNICAL INFCRMATION, SPRINGFIELD, "VA., \$3. OO COPY, \$0.65 4 ICROFICHE

*EQUIPMENT, GENERAL + EQUIPMFNT DESIGN + HARWELL + PERSONNEL PROTECTIVE DEVICE + UNITED KINGDOM

$15-21368$

RACH K

BASIC PRINCIPLES FOR THE USE OF RADIOACTIVITY IN MEDICINE. VII. RAOIATION BURDEN AND RADIATLON DANGER FR IEIE UNIVERSITY, BERL IN

5 PAGES, 2 FIGURES, FOENTGENPRAXIS 19, PAGES 70-4 (MARCH 1966) IN GFRMAN

REVIEWS BRIEFLY THE QUESTION GF RAOIOSENSITIVITY AND THE EFFECTS OF SINGLE ACUTE WHOLE-BODY IRRADIATION. GENETIC RADIATION INJURIES ARE. DEFINED AND COMPARED WITH MANIFESTATIONS OF SOMATIC INJURIES. GONADAL EXPOSURE FROM A THORACIC X RAY AMCUNTS TO 0.04 MREM. IN BERLIN THE NATURALLY OCCURRING RADIATION EXPOSURE OF THE GONADS AMOUNTS TO ABOUT 10 MREM/MCNTH. IN THE SWISS MOUNTAINS, BECAUSE OF THE RADIATION FFOM THE ROCKS, IT IS ABOUT 26 MREM/MONTH. OONE MONTHS GONADAL EXPOSURE TO PADIATION AT THIS RATE IS EOUIVALENT TO 400 THORACIC X RAYS. THE ENVIRINMENTAL GONADAL RADIATION BURDEN IS COMPARED WITH THE EXPOSURES RECEIVED FROM OTHER RADIATION SOURCES. LEGAL REGULATIONS FOR USE GF RADIATION AND R.ADIATION PROTECTION ARE DISCUSSED.

*RACIATION DAMAGE + \#RADIOBIOLJGY + DOSE CALCULATION, FXTERNAL + GERMANY +. RADIATION INJURY, TREATMENT OF + RADIOLOGY

$15-21371$

HISADAK + HIRAKI T

STUDY ON THE MEDICAL UNIVERSAL HUMAN COUNTER. 11I. SIMULTANEOUS PER.FGRMANCE OF ISOSENSITIVE SCANNING AND BILAMINOS CANNING

KANAZAWA UNIVERSITY, JAPAN

5 PAGES, 8 FIGURES, 5 REFERENCES, RADIDISOTOPES (TOKYO) NO. 15, PAGES 354-8 (NOVEMBER 1966) IN JAPANESE

FOR PRACTICAL CONVENIENCE A NEW TECHNIQUE WAS DEVELTPED TO PERFGRM AN ISOSENSITIVE SCAN AND RI-LAMINOSCANS SIMULTANEOUSLY AT ONE SCANNING. THE ESSENTIAL FEATURES ARE THE ADDITION GF TWO OSL IQUE PLACED DETECTORS TO THE TWO OPPCSEC DETECTORS SYSTEM AND THE MODE TO MIX THE SIGNALS ADDITIVELY FROM EACH DETECTCR IN THRFE COMBINATIONS, RECORDING THEM SIMULTANEOUSLY WITH FOUR HEADS OF MECHANICAL MULTIDOT TAPPER, THO SHEETS OF LAMINOSCAN UPPER AND LOWER, ONE ISOSENSITIVE SCAN, AND GNE CONVENTIONAL ANTEPIGR SCAN. THIS SYSTEM CAN $8 E$ A HELP TO DISCLGSE THE SMALLER LESIONS IN THE DIMENSIONALLY THICK ORGAN.

\#COUNTER + COUNTER, WHOLE BODY + JAPAN + RADIATION DAMAGE + RADIDBIOLOGY + RADIOLOGY

$15-21373$

CLIFFORD CE + WAIT GO

AIR-GROUND INTERFACE EFFECTS ON THE EXPOSURE FROM ELEVATSD CS-137 GAMMA SOURCES

DEFENCE RESEARCH BDAPD, OTTAWA, CANADA

3 PAGES, 1 FIGURE, 2 TABLES, 12 REFERENCES, NUCLEAR SCIENCE AND ENGINEERING $27(2)$, PAGES $483-485$ (FEBRUARY $1067)$

THIS NOTE INOICATES THAT INFINITE-MEDIUM CALCULATIONS OF THE EXPOSURE DOSE IN AIR OR AIR-LIKE MATERIALS CAN BE APPL IED TO PROBLEMS INVOLVING ELEVATED, UNIFORMLY DISTRIBUTED GAMMA SOURCES WITHOUT INTRODUCING LARGE ERROKS. FOR INDIVI DUAL ELEVATED SUURCES, THE EFFICTS OF THE AIR-GROUND INTERFACE COULD BE MOST PRONDUNCED. HOWEVER, FOR MANY PROBLEMS IT SHOULD BE POSSIBLE TO APPLY THE BOUNDARY-CORRECTION FACTOFS CALCULATED BY BERGER FOR A SOURCE ON THE GROUND, WITH AN ACCURACY OF PLUS OR MINUS $20 \%$.

*DOSE + AIR + CANADA + CESIUI + DOSE CALCULATION, EXTERNAL + SHIELDING $s$ 
15-21374 ALSO IN CATEGORY 14

PROCEEDINGS OF THE CONFERENCE ON RADIATION BIOLOGY HELC AT THE OAK FIDGE ASSOCIATED UNIVERSITIES, CAK RIDGE, TENN., $\triangle U$ UUST 2-5, 1965

OAK RIDGE NATIONAL LAROPATOPY + UT-AEC AGPICULTUFAL PESFARCH LAB., CAK RIDGE, TENN. + OAK RIDGE ASSOCIATEO UNIVERSITIES, INC., TENN.

CONF- $550947+63$ PAGES, FIGURES, REFERFNCES, JUNE 1967

THE DURPOSE OF THE CONFERENCE WAS TG ENABLE TEACHERS, DARTICULAFLY THOSE IN UNDEPGRADUATE C.OLLEGES, TJ BECUME FAMILIAR. WITH THE FIJNDAMENTAL PRINCIPLES OF QADIATION BIOLOGY, AND TC DISCUSS HOA INFOFMATION FROM RADIATION STUDIES CAN BF INCERPORATED INTO THE UNDERGRADUATE CURRICULUM. SUBJECTS INCLUDE - RACIATION BIOLOGY AS A SCIENCE, RAOIATION ETEECTS AT THE CELLULAR LEVEL, PADIATION EFFECTS IN MAMMALIAN TISSUES, RADIATICN EFFECTS IN PLANTS, AFC. 9IOMEOICAL RESEARCH PROGRAMS, AND REPCQTS OF GROUP DISCUSSIONS ON INCLUSICN OF RADIATION BIOLDGY IN UNDERGR $\triangle D U A T E$ COURSES.

AVAILABILITY - CLEARINGHQUSE FOR FEDEPAL SCIENTIFIC ANC TECHNICAL INFORMATION, SPRINGFIELD, VA., \$Z. OO COPY, \$O.

\#RACIATION DAMAGE + \#RADIOBIOLOGY + BIOMEDICAL

15-21377 ALSO IN CATEGORY 14

BIOENVIRONMENTAL AND PAOIOLOGICAL-SAFETY FFASISILITY STUDIES ATLANTIC-PACIFIC INTEFDCEANIC CANAL BATTELLE MEMORIAL. IVST, COLUMBUS, OHIO

$B M[-171-003+$. 102 FAGES, JANUARY 13,1967

INTERIM REPDRT OF PRDGRESS UN THE STUDIFS UNDER MANAGEMENT OF BATTELLE-COLUMBUS. CONCERNED HKIMAKILY HITH STUDIFS BEING MADE AND THCSE EEING PLANNED EY EATT SLLE-COLUMBUS SUBCONTRACTORS. SUBJECTS DISCUSSEO INCLUCE - DOSE ESTIMATION, HUMAN ECOLOGY (DANAMA), AGR ICULTURAL ECOLOGY, TERRESTPIAL ECOLOGY, HYGRGLOGY AND RADIONLCLIOE DISTRISUTION, FRESHWATER ECOLOGY, PHYSIOCHEMICAL OCEANOGKAPHY, ESTERINE AND MARINE ECOLOGY, SPECICIC-ACTIVITY $\triangle P P P O A C H$, MARINE ECOLOGY AND FESOUPCES, DATA EVALUATION PLAN.

AVAILABILITY - CLEARINGHOUSE FOR FEDERAL SCIENTIFIC AND TECHNICAL INFORMATION, SPRINGFIELD, VIFGINIA, $\$ 3.00$ COPY, \$0.65 MICROFICHE

\#DOSE + \#ECOLOGICAL CONSIDERATION + \#MYORGLOGICAL CONSIOERATION, GENERAL + \#PLOWSHARE OROGRAM + DOSE CALCULATION, EXTEF.NAL + DUSE CALCULATION, INTEFNLL + ESTUARY + CCEAN AND SEA + PLOWSHARE PROGRAY, ATLANTIC-DACIFIC CANAL + RADIOBIOLCGY

15-21382 ALSO IN CA!EGUYY 14

HEASLIP $Y B$

ECOLOGICAL SIGNIFICANCE DF NEUTRON AND GAMMA RADIATION ON DORMANT AND PHYSIULOGICALLY ACTIVF SFFR AVD SEEDLINGS OF TREE SPECIES NATIVE TO THE FASTERN DECIDUOUS FOREST. DROGRESS REPORT. MOREHEAD STATE UNIV., KY.

DRO-2066-11+. 33 DAGES, TABLES, REFEPENCFS, JUNE 1967

TO DETERMINF WHETHER FAST NEUTRONS AND GAMMAS ARE AODITIVE CR INDEPENDENT IN ACTION, THE RELATIVE RADICSENSITIVITY OF SEED SAMPLES EXPOSED TO 16 COMEIVATIONS GF FAST NEUTRONS AND GAMMAS WERE INVESTIGATED. THE RELATIVE EFFECTS OF WATER ON FAST NEUTRONS AND GAMMA ACTIVITY HERE DETER IINED GY EXPOSING SOAKED AND NONSOAKED SEED SAMPLES TO VARIOUS LEVELS CF FAST NEUTRDINS OR GAIAMAS.

AVAILABILITY - CLEAR INGHOUSF. FOR FECERAL SCIENTIFIC AND TECHNICAL INFORMATION, SPRINGFIELO, VIP.GINIA, $\$ 3.00$ COPY, \$0.65 MICROF ICHF

* RACIATION DAIAGE + \#RADIORIOLOGY + ECOLOGICAL CONSIDERATION + GAMMA + NEUTFCN

1 $5-21393$

BENDE? MA

EFFFCTS JF RADIATIJN ON CHROMOSOMES

OAK RIDGE NATIONAL LA

ORNL-P-3201 + CONC-670700-2+. 46 PAGES, 1967 , PRESENTED AT SYMPDSIUM ON PEACEFUL USES CF ATOMIC

RADIATIUN, RIT DE JANEIRO. BRAZIL

THE STUDY OE CHEOMOSOMAL ABERRATIONS IN HUMAN CELLS WAS BEGUN IN 1956 . IT WAS MAOE FOSSIBLE SY THE USE JF TISSUE CULTURES AND CF HYPOTONIC PREF IXATION TREATMENTS. THE START OF HUMAN LYTUGENE! ILS WAY HE UAIEU RUM THE DISCOVERY IN 1956 BY TJIO AND LEVAN THAT THE HUMAN OIPLOID CHROMOSOME NUMEER NAS REALLY 46 INSTEAD OF 48. THE DEVELOPMENT OF A PRACTICAL METHOD FOF OBTAINING CHROMOSOME PREPARATICNS FROM DERIPHERAL BLODO SAMPLES CONTRIBUTED TO FURTHER GFOWTH

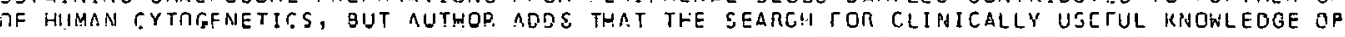
CHROMOSOMAL ABNORMALITIES HAS BEEN OISAOPOINTING, SOMETIMES EVEN DISTRESSING. NANY

TRIVIALITIES APPEAP IN THE LITFRATURE AS IMPORTANT DISCOVERIES. HANDRDLLED NOMENCLATURE ABOUNDS, ADDING TO THE CONFUSION. SOME DATA IS QUESTICNABLE, LEADING TO FALSF CONCLUSIONS.

AVAILABILITY - CLEARINGHOUSE FOR FEDERAL SCIENTIFIC AND TECHNICAL INFORMATION, SPRINGFIELD, VIPGINIA, $\$ 3.00$ COPY, \$0.65 MICROCICHE 
15-21383 *CONTINUEO*

\#R ADIATION DAMAGE + \#RACIOBIOLOGY + ORNL

$15-21385$

LINIECKI J + KARNISWICZ W + SPODENKIEWICZ T

ON THE DOMINANT CAUSE OF INOIVIDUAL VARIATION IN CS-137 BODY CCNTENT

INST. OCCUP. MED., LCEZ, PCLAND

4 PAGES, 1 FIGUR, 2 TABLES, 8 REFEPFNCES, NUKLEONIKA $11(6)$, PAGE 455-458, (1966).

FRDY DATA ON BCDY BURDEN AND EXCRETICN DF CS-137 BY EIGHT YCUNG HEALTHY ADULTS, APPROXIMATE VALUFS OF 9 IJLGGICAL HALF-LIFE OF CAESIUM (LONG-TERM COMPDNEINT) WERE CALCULATED ASSUMING A STATE OF (OR CLOSE TO) METABOLIC EGUILIBRIUM. HIGHLY SIGNIFICANT CORRELATION BETWEEN INOIVIDUAL VALUES GF BODY BURDEN AND HALF-LIFE V:AS OBTAINED, WHEREAS ND CORRELATION WAS ADPARENT CF BQDY LEVELS WITH EXCRETION/INTAKC. IT IS POSTULATED THEREFORE, THAT INOIVIDUAL VARIATION IN TURNOVER RATE OF CAESIUM IS MAINLY PESPGNSIBLE FOF. OBSERVED DISTRIBUTION OF CSS-137 IN URBAN POPULATION, SUBSISTING ON SIMILAR SOURCE ON MARKETED FOOD.

*RLDIO3IOLOGY + 8IOLOGICAL CONCENTPATION, FODD + BIOLOGICAL CONCENTRATION, MAN + CESIUM + DIETARY HABIT + POL AND

$15-21386$

CZOSNDWSKA W

STPONTIUM AND CALCIUM EXCRETIDN IN URINE OIF MAN

DEPT. RAO. DRDTECTION, INST. OCCUP. MED. LGDZ, POLAND

12 PAGES, 3 FIGURES, 6 TABLES, 26 REFEPENCES, NUKLEONIKA $11(6)$, PAGE 450-470, (1966)

THE CA AND SR-COO INTAKE AND EXCRETICN WAS STUDIED UNDER HOSPITAL CONDITIONS IN IO ADULTS OVER A PERIOD OE TWO WEEKS. THE PATIENTS WERE DIVIDED INTO TWO SUBGROUPS ACCORDING TO COMPOSITION DF THE DIET ANC INTAKE DF CALCIUM WHICH ON THE AVERAGE AMOUNTED TO 1.3 AND 0.79 PER OAY, RESPECT IVELY. THE AVERAGE DIETARY INTAKE OF SR-SO IN TWO SUBGROUPS WAS 28.8 AND 16.7 PCI./DAY, RESPECTIVELY. THE EXCRETICN OF SR-90 AND DF CA, WHEN EXPRESSED AS A PERCENTAGE OF INTAKE VARISD IN TWO SUBGPOUPS, HCWEVER THE RATIO SR-9O/CA (URINE) DIVIDED BY SR/CA (FOOD) WAS RELAT IVELY CGNSTANT AT ABOUT 0.75. GN THE OTHER HAND, IN INOIVIOUALS THE RATIO VAP.IED SYSTEMATICALLY WITH CALCIUM EXCRETION RATE IN URINE. ON THE BASIS OF OWN AND OTHER AUTHORS DATA A MORE GENEFAL RELATIONSHIP EETWEEN THE RATIO AND CA EXCRETION IN UP. INE WAS ESTABLISHED.

*RACIOBIOLOGY + ANALYTICAL TECHNIQUE, UPINE + BIGLGGICAL CONCENTRATION, MAN + CALCIUM + POLAND + STRONTIUM

15-21397 ALSO IN CATEGORY 14

RECHT D

GENERAL STUDIES ON RADIATION ACCIDENTS. PEPORT PRESENTED ATTTHE SYMPQSIUM ON ACCIDENTAL IRRADIATIONS IN INDUSTEYY

EUROPEAN ATOMIC ENERGY COMMIJNITY

15 PAGES, 5 TABLES, 25 FEFERENCES, J. BELGF RADICL., 50, PAGE 96-110, (1967) IN FRENCH

THIS SURVEY COMPEISES TWO PARTS. THE FIRST PART IS DEVOTED TO A LIST OF ACCIDENTAL IRRAOLATIDNS, AS COMOILED FROM AN ANALYSIS OF CERTAIN INFORMATION SUPPLIED, AND TO THF GENERAL LESSONS THAT CAN BE LEARNED THEREFROM. WHEREAS THE MOST SERIOUS ACCIDENTS HAVE SO FAR OCCURRED IN CRITICAL ASSEMBLIES, EXPERIMENTAL REACTORS AND CHEMICAL PLANTS, THE SCAIIEREU LOCATION OF OTHER RAOIOACTIVITY SOURCES PRESENTS A NUMBER GF PROBLEMS AS REGARDS REGULATIONS AND CONTROL. THE SECOND PART DEALS WITH THE ADMINISTRATIVE AND MEDICO-LEGAL ASPECTS OF ACCIDENTAL IRRADIATIONS AND THE AUTHOR RAISES VARIOUS PROBLEMS AND QUESTIONS CONCERNING THE MEANING DF THE TEDA ACCIDENTAL IRQADIATION ANC ITS MEOICO-LEGAL IMPLICATIONS, BY CONSIDER ING THE IMAECIATE EFFECTS, THE THRE SHOLD COSES, ANO THE DELAYED EFFECTS.

*ACCIDENT, GENERAL + \#RADIATION PROTECTION, QRGANIZATION + \#RADIOCHEMICAL PLANT SAFETY +

ACCIOENT, CRITICALITY + BELGIUM + RADIATION DAMAGE + RADIATION SAFETY ANO CONTROL + RADIOBIOLOGY

$15-21388$

MALLON 35

CORRELATION OF HEAT CF FUSION AND OPTICAL CENSITY IN PENTON WITH ABSORBEO DOSE USING A PROPOSED SPECTRUM

FOR THE XQD-S X-RAY MACHINE

CALIFORNIA, UNIVERSITY, LAWRENCS RADIATION LAB., LIVERMORE

UCRL-50-203 +. IS PAGES, 13 FIGURES, 3 TABLSS, 16 REFERENCES, MAY 1967

INFCRMATION ON THE SPECTRUM OF COMMEFCIAL X-RAY MACHINES DOES NOT RESOLVE THE RANGE BELOW 10 KEV BECAUSE OF THE DIFFICULTY OF GFTTING ACCURATE SPECTRAL MEASUREMENTS IN THIS REGION. $P \equiv N T O N$ (POLY-3, 3-(BISCHLOROMETHYL)-DXETANE) IS A CANDIDATE FOR THE STUDY OF THIS REGION SINCE IT IS RELATIVELY TRANSPAP.ENT TO RACIATION ABOVE 15 KEV AND RAPIDLY BECDMES INCREASINGLY ABSORBENT BELON THIS ENERGY. STUDIES OF PENTON INDICATE THAT IN RANGE OF $X-R A Y$ ENERGY OF 5 TO $15 \mathrm{KEV}$ AND $\triangle B$ SOREED DDSES OF $O$ TO 400 CAL/G, THE HEATS TF FUSION OF SAMPLES ANNEALED AFTER EXPQSIJRE AND MFI.TING POINTS OF SAMPLES HEATED TO $230 \mathrm{C}$ ANO NATUPALLY COOLED TO ROGM

TEMPERATURE APPEAR TO BE RELIABLE MEASURES OF DOSAGE.

AVAILABILITY - CLEARINGHOUSE FOR. FEDEPAL SCIENTIFIC AND TECHNICAL INFORMATION, SPRINGFIELD, VIRGINIA, $\$ 3.00$ COPY, $\$ 0.65$ MICROFICHE

\#DOSIMETRY, GENERAL + \#RADIATIDN EFFECT + LRL + X-RAY 
ENVIRONMENTAL SURVEYS, MONEGORY 15 ING ANO RADIATION EXPOSURE OF MAN

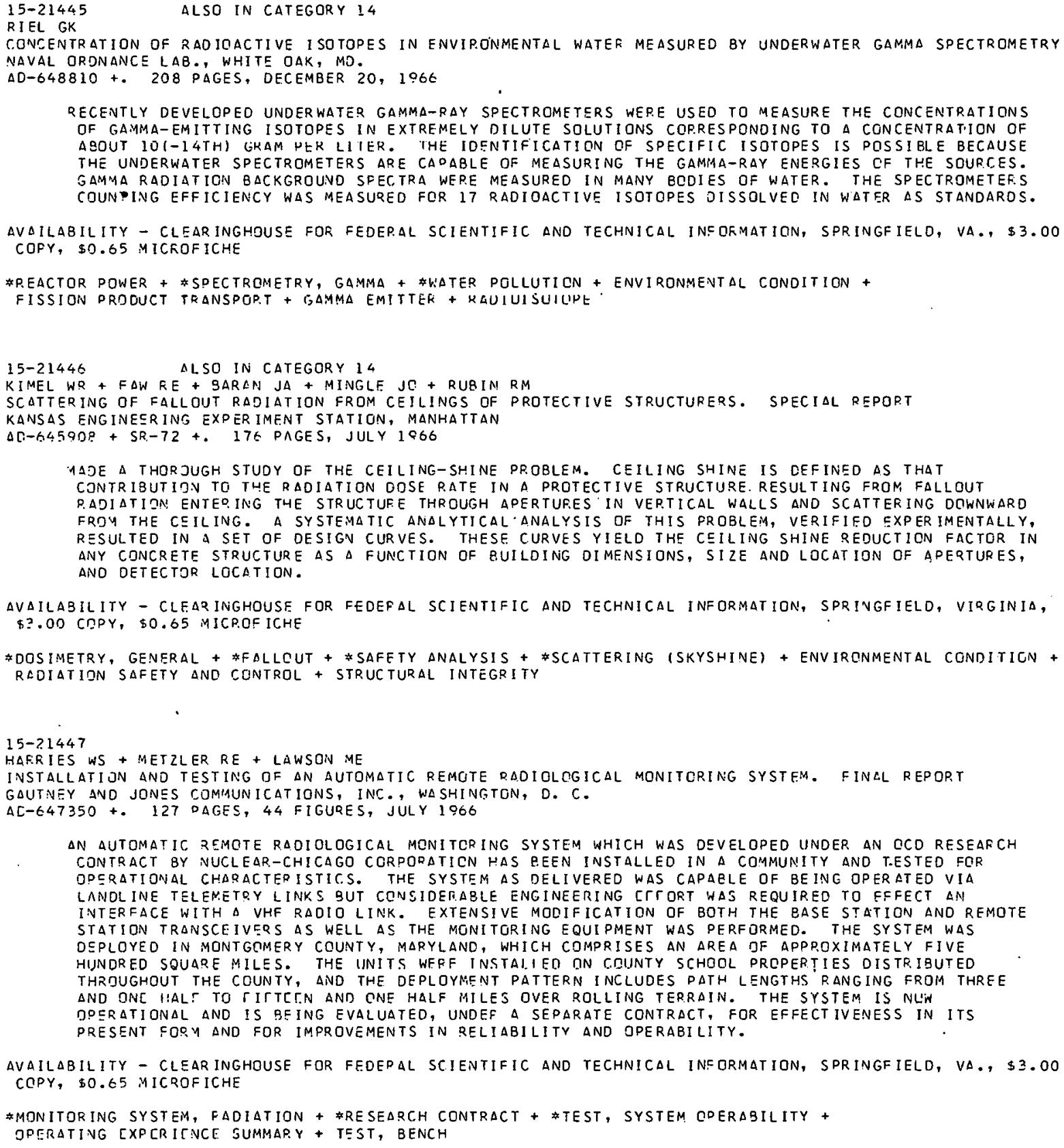

RECENTLY DEVELOPEO UNDERWATER GAMMA-RAY SPECTROMETERS WEPE USEO TO MEASURE THE CONCENTRATIONS OF GAMMA-EMITTING ISOTOPES IN EXTREMELY DILUTE SOLUTIONS COPRESPONOING TO A CONCENTRATION OF AQOUT $10(-14 T H)$ GKAM PLK LIIER. THE IDENTIFICATION OF SPECIFIC ISOTOPES IS POSSIBLE BECAUSE THE UNDERWATER SPECTROMETERS ARE CADABLE OF MEASURING THE GAMMA-RAY ENERGIES CF THE SOURCES. GAMMA RADIATION BACKGROUND SFECTRA WERE MEASURED IN MANY BCDIES OF WATER. THE SPECTROMETEFS COUN ING EFFICIENCY WAS MEASURED FOR 17 RADIOACTIVE ISOTOPES OISSOLVED IN WATER AS STANDAROS.

AVAILABILITY - CLEARINGHOUSE FOR FEDEPAL SCIENTIFIC AND TECHNICAL INEORMATION, SPRINGFIELO, VA., \$3. OO COFY, \$0.65 MICKOFICHE

\#PEACTOR POWER + \#SPECTROMETRY, GAMMA + \#WATER POLLUTICN + ENVIRONMENTAL CONOITION + FISSION PRDOUCT TRANSPGPT + GAMMA EMITTER + RQUIUISUIUPE.

15-21446 ALSO IN CATEGORY 14

KIMEL WR + FAW RE + SARAN JA+ MINGLF JC + RUBIN RM

SCATTERING OF FALLOUT RADIATION FROM CEILINGS OF PROTECTIVE STRUCTURERS. SPECIAL REPOPT KANSAS ENGINESRING EXPER IMENT STATION, MANHATTAN

$\triangle[-64590 ?+S R-72+$ I + PE PAGES, JULY 1966

1ADE A THORJUGH STUDY OF THE CEILING-SHINE PROBLEM. CEILING SHINE IS DEFINED AS THAT CONTRIBUTION TO THE RADIATION DOSE PATE IN A PROTECTIVE STRUCTURE. RESULTING FROM FALLOUT P.ADIATION ENTEO.ING THE STRUCTUFE THROUGH APERTUR.ES IN VEP.TICAL WALLS AND SCATTERING DOWNWARO FROY THE CEILING. A SYSTEMATIC ANALYTICAL ANALYSIS OF THIS PROBLEM, VERIFIFD EXPERIMENTALLY, RESULTED IN A SET OF DESIGN CURVES. THESE CURVES YIELD THE CEILING SHINE REDUCTION FACTOR IN ANY CONCRETE STRUCTURE AS A FUNCTION OF BUILOING OIMENSIONS, SIZE AND LOCATION OF APERTURES, ANO DETECTOR LOCATION.

AVAILABILITY - CLEARINGHOUSF FOR FEDEFAL SCIENTIFIC AND TECHNICAL INFORMATION, SPRINGFIELD, VIRGINIA, $\$ ? .00$ CNPY, $\$ 0.65$ MICP.OF ICHE

\#DOSIMETRY, GENERAL + \#FALLCUT + \#SAFETY ANALYSIS + *SCATTERING (SKYSHINE) + ENVIRCNMENTAL CONDITICN + RLDIATION SAFETY ANO CONTROL + STRUCTURAL INTEGRITY

$15-2.1447$

HARRIES WS + METZLER RE + LAWSON ME

INSTALLATIJN AND TESTING OF AN AUTOMATIC REMOTE RADIOLOGICAL MONITCRING SYSTFM. FINAL REPORT GAUTNEY ANO JONES COMIAUNICATIONS, INC. , WASHINGTON, D. C.

$A C-647350+127$ DAGES, 44 FIGURES, JULY 1966

AN AUTOMATIC REMOTE RADIOLOGICAL MONITCRING SYSTEM WHICH WAS DEVELOPED UNDER AN QCD RESEAFCH CONTRACT BY NUCLEAR-CHICAGO CCRPORATICN HAS REEN INSTALLED IN A COMMUNITY AND T.ESTED FCR OPERATIONAL CHARACTEPISTICS. THE SYSTEM AS DELIVERED WAS CAPAELE OF BEING OPERATED VIA LANOL INE TELEMETQY LINKS SUT CONSIDERABLE ENGINEERING CTTORT WAS REQUIRED TO FFFECT AN INTERFACE WITH A VHF RADIO LINK. EXTENSIVE MODIFICATION OF BOTH THE BASE STATION AND REMOTE STATION TRANSCEIVERS AS WELL AS THE MONITGRING EQUI PMENT WAS PERFORMED. THE SYSTEM WAS DSPLOYED IN MONTGCMERY COUNTY, MARYLAND, WHICH COMPRISES AN AREA DF APPPOXIMATELY FIVE HUNDRED SQUARE MILES. THE INITS WFFF INSTAIIED ON COUNTY SCHOOL PROPERTIES DISTR.IBUTED THRDUGHOUT THE COUNTY, AND THE DEPLOYMENT PATTERN INCLUDES PATH LENGTHS RANGING FROM THREE AND ONE HALS TO TITTECN AND CNE HALF MILES OVER ROLLING TERRAIN. THE SYSTEM IS NLWW DPERATIONAL AND IS REING EVALUATED, UNDEF A SEPARATE CONTRACT, FOR EFFECTIVENESS IN ITS PRESENT FOR Y AND FOR IMPROVEMENTS IN RELIABILITY AND JPERABILITY.

AVAILABILITY - CLEARINGHOUSE FOR FEDEPAL SCIENTIFIC AND TECHNICAL INFORMATION, SPRINGFIELD, VA., \$3. OO COPY, \$0.65 MICROF ICHE

\#MONITORING SYSTEM, FADIATION + \#RESEARCH CONTRACT + \#TEST, SYSTEM QPERABILITY +

OPERATING EXPERILNCE SUMMARY + TSST, BENCH

$15-21664 \quad$ ALSO IN CATEGORY 17

OHIO STATE UNIVERSITY REPORTS NONCOMPLI ANCE WITH RAOIATION MONITOR REQUIREMENTS

OH.IC STATE UNIVERSITY, COLUMRUS, OHIO

6 PAGES, DOCKET 50-150, NDVEMBER 24, 1967

TECHNICAL SPECIFICATIONS REQUIRE A PCRTABLE RETA-GAMMA SURVEY METER WITH D RANGE OF O.OI MR/HR TO 50 R/HR. THE QNLY SUCH INSTRUMENT AT THE FACILITY, A RAD GUN, WAS REPGRTED INOPERATIVE DN AUGUST 29, 1967, AND WAS SHIRPED FOR REPAIRS CN OCT. 30, 1967 . OPERATIONS CONT INUED UNTIL IHE SITUATIJN WAS REALIZED DURING STARTUP ON NOVEMBER 8,1967 . SUPERVISICN BEL IEVES THIS WAS

$\triangle$ TECHNICALITY BFCAUSE TWG DPERABLE INSTRUMENTS $(2.5$ AND 5 R/HR.) WERE AVAILABLE.

AVAILABILITY - USAEC PUELIC DOCUMENT ROOM, WASHINGTON, D. C. 
ENVIRONMENTAL SURVEYS, MONEGCRY 15 TORING AND RADIATION EXPOSURE JF MAN

$15-21664$ \#CONTINUEO*

\#MONITOR, RADIATION, GENERAL + REACTOR, PGOL TYPE + REACTOR, RESEARCH + TECHNICAL SPEC IFICATIONS

$15-21665 \quad$ ALSO IN CATEGORY 14

BAKER RC + DAVIS KA

ENVIRONMENTAL MONITORING SUMMARY FOR THE PADUCAH PLANT FOR 1965 AND 1966

PADUCAH GASEDUS DIFFUSION PLANT, KY.

KY $-54.3+.11$ PAGES, TAELES, SEPTEMEFR 1,1967

OUTDOOR MONITIPING OF AIR, WATEF, ANO VEgETATION IN THE VICINITY OF THE PADUCAH PLANT IS

SUMMARI ZED FOR 1965-1966. EFFLUENTS FROM THE PADUCAH GASEQUS DIFFUSION PLANT OPERATIONS WERE

CHANNELED AND CONTPOLLED AS NECESSAEY FOR THE ENVIRONMENTAL CONCENTRATIONS OF CHEMICALS ANO

FADIOACTIVITY IN AIF, WATER, ANO VEGETATION TO BE AT ACCEPTABLY LON LEVELS.

AVAILABILITY - CLEARINGHOUSE FOR FEDERAL SCIENTIFIC AND TECHNICAL INEORMATION, SPRINGFIELD, VA., \$3.00 COPY, \$0.05 MICROFICHE

*GROSS ALPHA + *GRISS BETA + *GROSS GAMMA + \#MONITOR, RADIATION, ENVIRONMENTAL + \#SAMPLING + GROUND WATER, NUCLIOE OCCURRENCE + MONITOR, RACIATION, AIR + MONITOR, RADIATION, GROUND SURFACE + MONITOR, RADIATION, LIQUID

$15-21666$

MC GUIRE SA

NEUTRON ACTIVATION DROBABILITY FOR SODIUM IN MAN

LOS ALAMOS SCIENTIFIC LAB., N. MEXICO

LA-372I +.. 6 PACES, 2 FIGURES, I TABLE, E REFERENCES, SEPTEMBER 2,1966

KNOWLFOGE OF THE NEUTRON ACTIVATION CF BLCOD SODIUM CAN BE USEO TO CALCULATE AN ACCIDENTAL NEUTRON DOSE IE THE NEUTRON SRECTRUM AND THE NEUTRON CAPTURE TPOEABILITY OF THE MAV AS A CUNCTION OF ENERGY ARE BOTH KNOWN. THIS REPORT OESCRIBES CALCULATIGNS OF. THE NEUTRON CAPTURE PROBABILITY OF A 136-LB MAN, A 200-LB MAN, ANO 30-CM-, 24-CM-, AND 18-CM-DIA BY 6O-CM-HIGH CYLINDERS. THE CAPTURE PROBABILITY OF A MAN WAS FOUND TO BE BELOW THAT DF THE 30-CM-DIA CYLINDER AT ALL ENERGIES AND MUCH CLOSER TO THE CAPTURE PROEABILITY OF THE 18-CM-DIA

CYLINOER. BELOW 0.1 MEV, THE CAPTURE PROBABILITY OF A 136-LE MAN AVERAGES ABCUT $20 \%$ LOWER THAN THAT DF THE 3O-CM-DIA CYLINOER. ABOVE 0.1 MEV, THE GAP WIDENS RAPIDLY UNTIL THE CAPTURE PROBABILITY AT 2 MEV IS TWICE $\triangle S$ GPEAT FOR THE CYLINDER AS FOR THE MAN: THE MANS POSITIQN WITH RESPECT TO THE NEUTRDN EEAM WAS FOUND TO HAVE A CONSIDERABLE EFFECT. THE CAPTURE PRGBABILITY AVERAGES $\triangle E D U T$ ZOZ LOHER FOR A MAN STANDING SIDE-ON TO THE BEAM THAN FOR ONE FAC ING IT.

AVAILABILITY - CLEARINGHOUSF FOR FEDERAL SCIENTIFIC ANO TECHNICAL INFORMATION, SPRINGFIELD, VA., S3. OO COPY, \$0.65 MICRQFICHE

* DOSE CALCULATION, INTERNAL + \#NEUTRON + \#PLASMA + \#SODIUM + aCTIVATION + BIOLOGICAL CONCENTRATION, MAN + MONTF CARLO

15-21667 ALSO IN CATEGORY 14

PESTANER JF + LOVE. DL

A COMPUTER PROGRAM FGR IDENTIFYING AND MEASURING COMPONENTS IN A MIXTURE OF GAMMA-EMITTING RADIDNUCL IDES NAVAL RAOIOLUGICAL OEFENSE LAB., SAN FRANCISCD

USNROL $\rightarrow T R-67-46+4 E$ PACES, 15 FIGUPES, MARCH 1,1967

PROSLEM - IN A STUDY OF THE PHYSICAL AND CHEMICAL SPECIES OF RADIOACTIVE DEBRIS RESULTING FROM AN UNDERWATER NUCLFAR EXPLOSION, COMPLEX MIXTURES DF RADIONUCLIDES, SOMET IMES OF FAIRLY LOW ACTIVITY, ARE TO BE ANALYZED. A COMPUTER PROGRAM FOR RESOLVING THE GAMMA PULSE-HEIGHT OISTRIBUTION DF A WEAKLY ACTIVE MIXTURE OF GAMMA EMITTERS INTO ITS COMPONENTS IS REQUIPED. FINDINGS - A COMPUTER PROGRAM WAS DEVELOPED AND THEN TESTED SUCCESSFULLY GN THE GAMMA PULSE-HEIGHT [EISTR IBUTION OF \& SYNTHETIC MIXTURE OF 3 RADIONUCLIDES, EACH HAVING SEVERAL. PHOTOPEAKS OVFR A 2-MEV RANGE. THE PROGRAM IS BASEO ON AN ITERATIVE SUBTRACTION TECHNIQUE ANO IS PROMISING BECAUSE ERRCRS IN THE ANALYSIS WRE SMALL $(0.5$ TO 2.08$)$, ALTHOUGH MANY PJSSIBLE REFINEMENTS IN THE PROGRAM HAVE NOT YET BEEN MADE.

AVAILABILITY - CLEAP. INGHOUSE FDR FELFRAL SCIENTIFIC AND TECHNICAL INFORMATION, SPRINGFIELD, VA., S3. OO COPY, \$O.S5 MICROFICHE

\#CGMPUTER PROGRAM + \#GAMMA FMITTER + \#RADIOCHEMICAL ANALYSIS + MEASUREMENT, REACTIVITY + NUCLEAR OETONATION

$15-21668$

ALSO IN CATEGDRY 14

PORTER SH' + SLABACKLA

MEASUREMENT OF TRITIUM SURFACE CONTAMINOTION

ARMED FORCES RADIOBIOLOGY RESEARCH INST., BETHESDA, MD

AD-640910 + AFRR I-SP-6.6-13 + CONF-660403-4+. 18 PAGES, REFERENCES, JULY 19E6, FROM INTERNATIONAL SYMPOSIUM JN RADIOLCGICAL PROTCCTIGN OF THE WORKER BY THE OESIGN AND CONTROL OF HIS ENVIRONMENT, BDURNEMOUTH, פNG.

OESCRIBES SEVERAL METHODS FDR MEASURING TRITIUM SURFACE CONTAMINATION IN REACTOR, ACCELERATOR, AND TRITIUM OXIDE ENVIRONMENTS. THE PROBLEMS ASSOCIATED WITH THE PRESENTLY USED METHOD OF WINDOWLESS FLOW-PROPQRTIONAL COUNTING ARE DISCUSSED. A NEW METHOD OF UTILIZING SPECIAL 


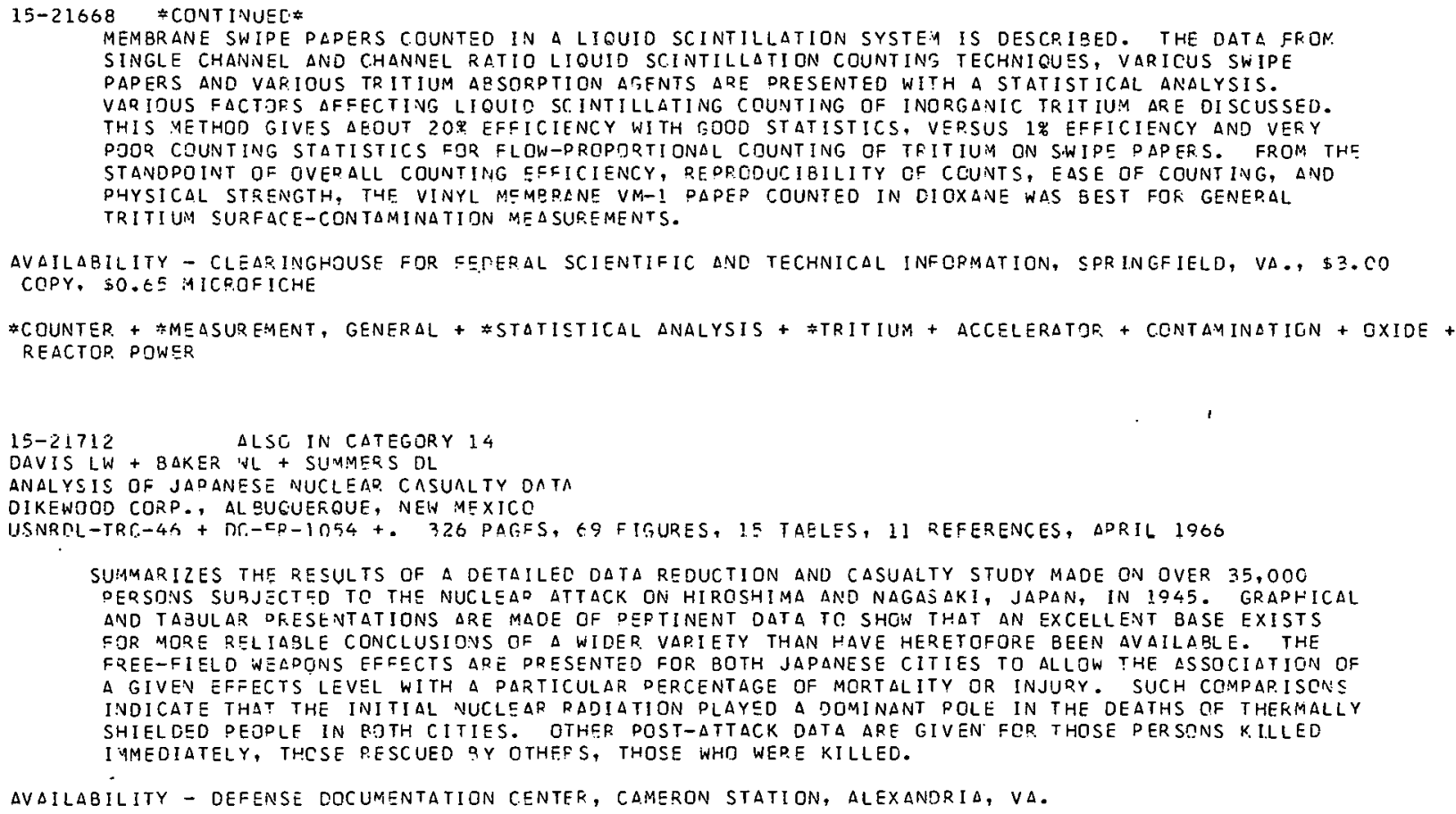

(TWX, APRIL 7) PADIOGRAPHER SUPERVISOR RECFIVED 6 REMS WHEN A 65-CURIE IR-I92 SOURCE STUCK IN THE SOURCE CAELE. THF ODERATOR OII NOT R.FEIVF A DOSE ON DOSIMETCRS.

\#PEF.SONNEL EXPOSURE, RADIATION + \#RADIOGPAPHY + FAILURE, EQUIPMENT + INCIDENT, EGUIPMENT

15-21717 ALSO IN CATEGORY 17

NUCLEAR FUEL SERVICES CITED FOR NON-COMDLIANCE

NUCLEAR FUEL SERVICES, INC.,. WEATON, MD.

5 PAGES, ATOMIC ENERGY CLEARING HOUSE $13(18)$, DAGES 16-20 (MAY 1, 1967)

(LETTER, MARCH 15$)$ CITATION IS FOR INADEQUATE RADIATION MONITOR ING OF STACK AND OF DECONTAMINATICN CPEPATIONS, AND $35 / 27$ MISSING FILM BADGES FOR 2ND/3RD QUAFTER OF 196E. LETTER ALSO REQUESTS DATA ON BETTEP CONTROL OF VENTILATION (SNOW PLUGGING OF MAIN INTAKE, INFLATABLE SEALS DN DUTSIDE DOOR, AND SIMULTANEOUS OPENING OF ROTH AIRLOCK OOORS.) NFS LETTER DF JANUARY 3 ASSERTED IN REPLY TO AEC LETTER OF DECEMBEP. 13 , 1966 THAT ACTION WAS BEING TAKEN ON POINTS NOTED.

*INSPECTION AND COAPLIANCE + WURVEY, RADIATION, GENERAL + \#VENTILAIION SYSTEM + NFS + RADIOCHEYICAL PROCESSING + STACK

15-21719 ALSO IN CATEGORY 17

RR ANTLEY JC

MUCLEAR SCIENCE AND ENGINEERING TORP, REPI.TES TR MARCH IO C.GMFI.TANC.F IFTTFR

NUCLEAR SCIEINCE AND ENG GINEER ING COPPOPATICN, PITTSPUDGH, PA.

2 PAGES, ATOMIC ENERGY CLEARING HOUSE $13(12)$, PAGES 20-2! (4AY 1, 19B\%)

(LETTER, MARCH 27) ACKNOWLEDGES THAT (1) HEALTH PHYSICS PROGRAM WAS INADEQUATE OURING PERIOC, DUE TO LACK OF EQUIPMENT, (2) HP FUNCTIONS WERE NOT CONSCIENTIOUS, AND (3) MANAGEMENT CONTROLS WERE SLOW TO IDENTIFY THIS. BRIEFLY DISCUSSES S ITEMS (AIR SURVEYS, EFFLUENT-AIR SURVEYS, UNRESTRICTED-AREA PADIATION FIELOS, LEAK TESTING CF SEALED SOURCES, RACIOLOGICAL SAFETY INSTRUCTION, RADIATION/CONTAMINATION MONITORING PROGRAM, EXTREMITY DOSES, SURVEY RECOROSI.

* INSPECTION AND COMPLIANCE + MONITJRING SYSTEM, FADIATION + STAFFING, TRAINING, QUALIFICATION + SURVEY, RADIATION, GENERAL 
$15-21720$

STFERMAN JJ

ALSO IN CATEGORY 17

UNIVERSITY OF ILLINDIS REPIRTS SKIN EXPOSURE TO P-32

UNIVERSITY OF ILLINOIS, URBANA, ILL.

3 PAGES, ATOMIC ENERGY CLEARING HDUSE $13(1) 8)$, PAGES 22-24 (MAY 1, 1967)

(LETTER, MARCH 31 ) THE INDIVIOUAL ASSUMED THAT THE FIRST FEW OROPS OF SOLUTION FROM THE ION EXCHANGE COLUMN WOULD NOT BE VERY HGT AND DID NOT CHECK WITH INSTRUMENTS WHEN HE FOUNO HIS GLOVE TORN. FILM SADGE SHOWED 300 MKEM BETA AND. 13 MIR GAMMA (WHOLE BODY). ESTIMATES DF DOSE TO HANDS/THUMB $\triangle R E 7.3 / 147$ RADS. IN THE BACK-CALCULATION OF THE HAND DOSE, DECONTAMINATION FACTORS FRQ THE VARIOUS TREATMENTS WERE. ESTIMATED USING A SIMILAP EXPOSURE AND TREATMENT OF A BABY PIGS SKIN.

\# OECONTAMINATION + \#FAILURE, OPERATOR ERPGF + \#ICN EXCHANGE + BETA EMITTER +

PERSONNEL EXPOSURE, RADIATION + PERSONNEL PRDTECTIVE DEVICE + PHOSPHGRUS

$15-21748$ ALSO IN CATEGORY 14

MCGINNIS JT + GOLLEY FE

BIOENVIRJNMENTAL ANO PADIOLJGICAL-SAFETY FEASIBILITY STUDIES ATLANTIC-PACIFIC INTEROCEANIC CANAL

TERRESTRIAL ECOLOGY. PHASE I . FINAL REPORT

GEORGIA UNIV., ATHENS, INSTITUTE GF RADIATION ECOLOGY

BMI-171-0il $\because$. 114 DAGES, FIGURES, APRIL 19,1967

THE VEGETATIGN IN EASTERN DANAMA ANO NORTHWESTERN COLUMBIA ISS DOMINATED BY TOPICAL FOREST TYPES. EXCEPTIONS ARE THE APEAS CONVERTED FROM FORESTS TO $\triangle G R I C U L T U R A L$ USES AND THE EXTENSIVE MAQSHES IN THE OID ATRATE FLOOD PLAIN. THIS STUOY IS CONCERNED WITH A DEFINITION OF THE COMPARTMENTS OF THE ECOSYSTEM, DESCRIPTION OF THE COMPARTMENTS, AND THE RELATION CF THE NATIVE POPULATIGINS TO THE TFRPESTRIAL ENVIRONMENT.

AVAILABILITY - CLEARINGHQUSE FOR FEDERAL SCIENTIFIC ANO TECHNICAL INFGRMATION, SPRINGFIELD, VIRGINIA, $\$ 3.00$ COPY, \$0.65 4 ICR.OFICHE

* ECOlogical considération + \#Fallout + Piological concentration, general + Plowshare pFogram

$15-21749 \quad$ ALSO IN CATEGORY 14

GAMBLE JF + POPENOE H

BIOENVIRONMENTAL. AND RADIDLOGICAL-SAFETY FEASIBILITY STUDIES ATLANTIC-PACIFIC INTSROCEANIC CANAL.

AGRICULTURAL ECOLJGY. PHASE I FI.VAL REPORT

FLOKIDA UNIV., GAINESVILLF. INST. OF FODD. AND $\triangle G R I C U L T U R A L$ SCIENCES

BMI-171-010+. 40 DAGES, DCFERENCES, APPIL 14, 1967

DESCRIBES THE SYSTEM DF AGRICULTURE USED IN THE AREA. PRESENTS APPLICABLE INFORMATION FROM SIMILAR AGRICULTURAL SYSTEMS. ANALYZES THE SPECIAL FEATURES OF THE AGRICULTURAL SYSTEMS THAT MAY INFLUENCE NUCLIDE UPTAKE AND CONCENTRATION.

AVAILABILITY - CLEARINGHOUSE FOR EEDEFAL SCIENTIFIC AND TECHNICAL INFORMATION, SPRINGFIELD, VIRGINIA, $\$ 3.00$ COPY, \$0.6E YICREFICHE

* BIOLDgICAL CONCENTKATION, GFNERAL + \#ECOLQGICAL CONSIDERATION + \#FALLOUT + AgRICULTURAL CONSIDEPATION + BIOLOGICAL CJNCENTRATION, FOOD + PLOWSHARE PROGRAM

$15-21750 \quad$ ALSC IN CATEGOPY 14

TEMPLETON WL

ALSO IN CATEGORY 14

BIOENVIRONMENTAL AND RADIULOGICAL-SAFETY FEASIBILITY STUDIES ATLANTIC-PACIFIC INTEROCEANIC CANAL.

FRESHWATER ECOLOGY PHASE I FINAL REPORT

BATTELLE-NORTHNEST, RICHLAND, WASH. PACIFIC NGRTHWEST LAB.

QMI-171-008 +. 121 PAGES, MARCH 14,1967

THE PURPOSE DF THIS PROGRAM IS TO PLAN AND MAKE STUDIES IN FRESHWATER ECOLDGY TO ACQUIRE DATA NEEDED TD EVALUATE AND PREDICT THE POTENTIAL RADIATION HAZAROS TO HUMANS. IN THE RFGIONS OF NUCLEAR EXCAVATIONS IN THE DEFINED $\triangle R E A S$ OF CENTRAL AMERICA. PHASE I CONSISTS OF STUDIES QASED ON AVAIL $\triangle B L E$ INFORMATION.

AVAILABILITY - CLEARINGHOUSF FGR FECERAL SCIENTIFIC AND TECHNICAL INFGRMATION, SPRINGFIELD, VIRGINIA, $\$ 3.00$ COPY, \$0.65 MICRGEICHE

*BIOLDGICAL CONCENTRATICN, GENERAL + \#ECCLGgICAL CONSIDERATION + \#FALLOUT +

BIOLOGICAL CONCENTRATION, AQUATIC ORGANISMS + BIOLOGICAL CONCENTRATION, FOOD + PLOWSHARE PROGRAM + RIVER, GENERAL

$15-21751$

LOWMAN'FG

ALSO IN CATEGORY 14

3IOENVIRONMENTAL AND R.ADIOLOGICAL-SAFFTY FEASIBILITY STUDIES ATLANTIC-PACIFIC INTEROCEANIC CANAL

ESTUARINE AND :AAR INE ECOLOGY. PHASE I FINAL FEPORT 
ENVIRDNMENTAL SURVEYS, MONIYORYNG 15 AND RAOIATION EXPOSURE OF MAN

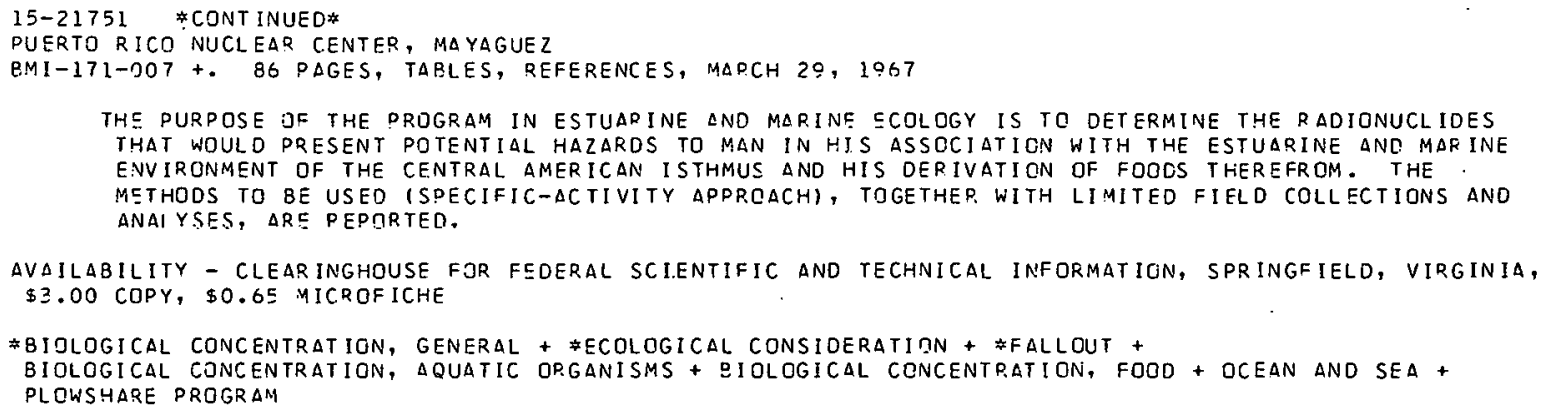

AVAILABILITY - CLEARINGHOUSE FJR FEDERAL SCIENTIFIC AND TECHNICAL INFORMATIGN, SPRINGFIELD, VIRGINIA, $\$ 3.00$ COPY, \$0.65 MICROFICHE

* 8IJlogical concentratign, general + \#ECOLOgICAL CONSIDERATIDN + \#FALLOUT +

BIOLOGICAL CONCENTRATION, AQUATIC OPGANISMS + QIOLOGICAL CONCENTRATION, FOOD + OCEAN AND SEA + PLOWSHARE PROGRAM

$15-21754$

DIETRICHE + KONIG LA

PROBLEMS OF RADIATION PFETER,TION IN CONNECTION WITH TRIT.IUM

KERNFORSCHUNGSZENTRUM, KARLSRUHE, GERMANY

4 PAGES, 5 TABLES, 34 REFEPENCES, ATCMPPAXIS $13(10)$, PAGE 454-457, (NOVEMBER I967) IN GERIMAN

PRESENTS A SURVEY ON PROBLEMS CONNECTED WI TH THE SUPERVISION GF PR.OTECTION MEASUFES CRIOPPING UD NITH THE USE GF TRITIUM. SOLUTICNS AR.E OFFERED. A SHORT P.EPORT DESCRIOING TRITIUM SUPERVISION AT THE TR-2 REACTOR IS ADOCO.

FRADIATION DROTECTION, DRGANIZATION + RADIATION SAFETY ANO CDNTROL + TRITIUM

$15-21755$

HABEREQ K

MEASUREMENTS OF ALPHA ACTIVITY IN.THICK TEST LAYERS FOP MONITORING THE ENVIRONMENT

2 PAGES, 1 FIGURE, 3 REFERENCES, ATOMPRAXIS $13(10)$, PAGE 443 AND 444, (1967) IN GERMAN

BASED ON PREVIOUS WOPK, A NDMOGRAM WAS DESIGNED FOP. RAPID ENERGY AND MATPIX CORRECTION OF ALPHA-ACTIVITY MEASUREMENTS IN THICK-SATURATION LAYERS. THE ADVAVTAGES OF THIS METHOD FOR SAMPLES WITH LOW ALPHA ACTIVITY, SUCH AS OCCUR IN ENVIRONMENTAL MONITORING, ARE DESCRIBED.

+INSTRUMENTATION, NUCLEAR + \$MONITOR, RAOIATION, ENVIRONMENTAL + GERMANY +

INSTRUMENTATION, RADIATION MONITORING

$15-21756 \quad \Delta L S O$ IN CATEGCRY 14

FISCHER HF + PAFFQATHO + PETFRS W

MEASUREMENTS OF RADICACTIVITY AT DIFFERFNT ALTITUDES OF THE ATMOSPHERE DURING ARRIVAL AND PASSAGE OF FRESH FISSION PRCDUCTS

4 PAGES, 4 FIGUPES, IS REFERENCES, ATOMPPAXIS $13(10)$, PAGE 444-447, (1CE7) IN GERMAN

AFTER THE THIRD CHINESE NUCLEAD NEARON TEST, FLIGHTS AT ALTITUDES UP TO 12,500 M WERE PERFORMED FTR COLLECTING AEROSCL CN FIBER FILTEPS. THE METHOD CF SAMPL ING IS OESCRIBEO. THE FRACTION OF FPESH DERRIS TO TOTAL AMOUNT OF DEQPIS IS DETERMINED BY THE BETA DISINTEGRATION CURVES OF THF SAMOLES. VERTICAL PFOFILES OF THE SPECIFIC BETA-ACTIVITY OF THE AIR FIP OLD AND FRESH FISSION PRCDUCTS ARE REPFESENTED GY GRAPHS. THESE PESULT.S APE COMOAP.ED WITH OUP. MEASUR.EMENTS AFTER THE FIP.ST $\triangle N D$ SFCOND CHINESE NUCLEAR TEST. IN ADDITION TO FISSION PRODUCTS OF THE NUCLEAR EXOLOSION, WE IDENTIFIED THE NEUTPON-INOUEEO HUCLIDES U-Z37 ANO ND-239 BY GAMMA-R.AY SPECTROMETRY.

\#FALLOUT + *ILTER, FIBEP + \#MONITORING FPUGRAM, ENVIRONMENTAL + AEROSOL + $\triangle I R$ + $\triangle I R B O R N E$ RELEASE + BETA EMITTER + GERMANY + NEPTUNIUM + RADIONUCLIDE, INDUCED + SPECTROMETRY, GAMMA + URANIUM

$15-21757 \quad \Delta L S O$ IN CATEGORY 14

PORTER SW + VERRELLI DM

$\triangle$ BFIEF DESCRIPTION OF THE $\triangle F R R I-T R I G A$ MAPK F REACTOR METHODS FOR CONTROLLING OISCHARGES, ENVIRONMENTAL SURVEILLANCE AND EMERGENCY DLANS

ARMED FORCES RADIOBIOLOGY RESEARCH IHST., RETHESOA, MD.

$\triangle D-645546+4 F R R I-S P-66-17+23$ OAGES, FIGURES, REFERENCES, JULY 1966

DESCRIBFS THE FOI I NWING FEATURES RF THE REACTDR - THE REACTOR AND ASSOCIATED EXPER IMENTAL FACILITIES, QEMOTE-AREA MONITORING SYSTEM, AIR-HANDLING AND MONITORING SYSTEM, PERIMETER-IAONITORINS SYSTEM, REACTOF-ROCM CONFINEMENT, REACTOR-COOLANT MONITORING SYSTEM, WASTE-DISPOSAL SYSTEM, AND EMCP.GENCY PROCEOUPES.

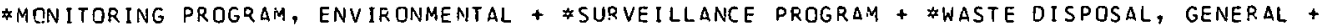
RADIATIDN PROTECTION, CRGANIZATION + RAOIATION SAFETY AND CONTROL + REACTOR COOLANT + SHIELOING + TR. IGA (RR) 
ENVIP.ONMENTAL SURVEYS, MATEGORY IS 5 IORING RADIATION EXPOSURE OF MAN

$15-21759$

$15-21759$
GITLIN JH + LAWRENCE PS

GITLIN JH + LAWRENCE PS U.S. DEPARTMENT CF HEALTH, EDUCATIDN, $\triangle N D$ WELFARE

PHS-PUS- $1519+.217$ PAGES, 32 FIGUPES, 38 TABLES, $19 t 4$

THE PRINCIPAL OEJECTIVE OF IHIS STUDY WIAS TG PROVIDE ESTIMATES OF POPULATICN EXPOSURE, BY TYPE OF EXAMINATION OR PROCEDIJRE, FOR A VARIETY OF DEMOGRAPHIC AND X-R.AY-FACILITY CHARACTERISTICS. THE X-RAY EXPER IENCE OF THE U.S. POPULATION IN 1964 IS EXPRESSED IN TERMS OF THE NUMBER AND RATE OF PERSONS EXPOSED DURING X-RAY VISITS FOR VARIOUS TYPES OF EXAMINATIONS OR PROCEDURES BY SUCH CHARACTERISTICS AS $\triangle G E$, RACE, SEX, AND EY TYPE OF FACILITY AND SPECIALTY OF THE PRACTITIONER.

AVAILABILITY - U.S. GOVERNMENT PRINTING OFFICE, WASHINGTON, D. C. $20402, \$ 1.50$ COPY

\#POPULATION EXPOSURE + DOSE MEASUREMENT, EXTERNAL + RADIATION PROTECTION, ORGANIZATION + RAOIOLCGY + X-RAY

$15-21761$

ISAACKS RE + HAZZARD DG + RARTH J + WALKFR JP

NUTRITIONAL EVALUATION OF MILK PROCESSED FOR REMOVAL OF CATIONIC RADIONUCLIDES. FEEDING STUDIES VETERANS ADMIN ISTRATION HOSPITAL, CORAL GABLES, FLA.

5 PAGES, 7 TABLES, 15 REFERENCES, J. AGR. FOOD CHEM. 15, PAGES 300-4 (MARCH-APRIL 1967)

RATS AND PIGS WERE FEO DRIED WHOLE MILK PROCESSED FOR REMOVAL OF CATIONIC RADIONUCLIDES BY ION EXCHANGE TECHNIQUSS. THE THIAMINE, NIACIN, AND VITAMIN B-6 CONTENTS WERE DECREASED EY 5C, 27. ANO 15\%, RESPECTIVELY, AND K CONTENT INCREASED $80 \%$ COMPARED WITH THE CONTROL MILK. THERE WAS NO SIGNIFICANT DIFFERENCE IN RATE OF GROWTH OR IN BLOOD SERUM CATIONS, IN EITHER RATS OR PIGS, BET WEEN ANIMALS FED PRGCESSEC WHOLE MILK OR FED THE CGNTPOL WHOLE MILK. THERE WAS SIGNIFICANTLY GREATEO URINE K EXCRETION FROM PIGS FED PROCESSED MILK OR CONTROL MILK PLUS K CITKATE AS COMPARED WITH PIGS FED THE CONTPOL WHOLE MILK. ONE EXPERIMENT SHOWED A

SIGNIFICANTLY GREATER EXCRETION OF NA FROM PIGS FED CONTPOL WHOLE MILK PLUS K CITRATE AS

COMPAPED WITH PIGS FED CONTROL WHCLE.MILK. ON THE BASIS OF EARLIER CHEMICAL ANALYSES ANO THESE FEEDING EXPER IMENTS, THE ION EXCHANGE TREATMENT OF MILK FOR REMOVAL OF CATION RADIONUCLIDES DOSS NOT SERIOUSLY AFFECT THE NUTRITIVE QUALITIES.

* DIETARY HABIT + *ECGLOGICAL CONSIDERATION + \#EXPERIMENT, GENERAL + \#RADIATION PROTECTION, CHEMICAL + BIOLOGICAL CONCENTRATICN, ANIMAL + BIOLOGICAL CONCENTRATION, MILK

$15-21762$

ISAACKS RE + HAZZARD DG + BARTH J + FOOKS JH + EDMONDSON LF

NUTRITIONAL EVALUATION OF MILK PROCESSED FOR REMOVAL OF CATIONIC RADIONUCLIDES. CHEMICAL ANALYSIS VETERANS ADMINISTRATION HOSPITAL, CORAL GABLES, FLA.

5 PAGES, 1 FIGURE, 4 TAGLES, 31 REFERENCES, J. AGR. FOOD CHEM. 15, PAGES 295-S (MARCH-APRIL 1967)

STUDIED CHEMICAL CONSTITUENTS OF MILK, WHICH HAD BEEN TREATED WITH AMBERLITE IR-I2O RESIN, IN THE CA MG-K VA CYCLE. CDMPARISONS OF RESULTS ORTAINED ON CONTROL AND RESIN-TREATED MILK SAMPLES SHONED NG SIGNICICANT CHANGE IN TOTAL SOLIDS, BUTTERFAT, PROTEIN, FLAVOR QUALITY, CAROTENE, VITAMIN A, RIBOFLAVIN, PANTOTHENIC ACID, FOLIC ACID, OR VITAMIN B-12. THE ASH, PDTASSIUM, ANO CITRIC ACID CONTENTS OF THE RESIN-TREATED NILK INCREASED NEARLY 14, 80, AND 10O罗, RESPECTIVELY, COMPARED WITH CONTROL MILK. THE THIAMINE, NIACIN, AND VITAMIN B-6 CONTENTS OF THE PROCESSED MILK DECR.EASED 5C, 27 , AND 15\%, RESPECTIVELY. THE DATA INDICATE THAT $86 \%$ OF THE FREE THIAMINE AND $20 \%$ OF THE BOUND THIAMINE $\triangle R E$ REMOVED FROM THE MILK BY THE RESIN TREATMENT. THE COPPER CONTENT OF THE RESIN-TREATED MILK WAS REDUCED ABOUT $23 \%$.

* ANALYTICAL TECHNIQUE, MILK + \#IOLOGICAL CONCENTFATION, MILK + *EXPERIMENT, GENERAL + CALCIUM + HAZARDS ANALYSIS + ION EXCHANGE + MAGNESIUM + POTASSIUM + RAOIATIDN PROTECTION, CHEMICAL + SODIUM

$15-21763$

BARNABY CF + SMITH T

PEFFORMANCE OF A LARGE-AREA WHOLE-BOOY COUNTER

LONOON UNIVERS ITY

7 PAGES, 8 FIGURES, 3 TABLES, REFERENCES, J. SCI. INSTRUM. 44, PAGES 4099-505 (JULY 1967)

DESCRIBES THE DESIGN AND PERFGRMANCE OF A CHEAP BUT SENSITIVE WHOLE-BODY COUNTER WHICH INCORPORATES A LARGE-AREA ORGANIC SCINTILLATOR IN THE FORM OF 4 MOVABLE DETECTOR . THE PERFJRMANCE AND SENSITIVITY GF THE COUNTER ARE SHOWN TO BE AOEQUATE FOR A LARGE NUMBER OF CLINICAL INVEST IGATIDNS USING AMOUNTS OF ADMINISTERED RADIDACTIVITY WELL BELOW THE MAXIMUM RODY SURDENS RECOMMENDED BY THE ICRP. AN INVESTIGATION OF THE SENSITIVITY OF THE COUNTING EFFICIENCY TO THE SOURCE-DETECTOP. GEOMETRY HAS LED TO THE ADCPTION OF A COUNT ING TECHNIQUE WHICH IS RELATIVELY INDEPENDENT OF THE LOCATION OF A POINT SOURCE WITHIN THE TRUNK REGION OF A SUBJECT. USE UF THIS METHOD PERMITS THE MEASUREMENT OF THE NATURAL K-4O CONTENT OF A STANDARD MAN TO $3 \%$ ACCURACY OF COUN!ING STATISTICS IN A COUNTING TIME OF 1000 SEC. FOR CHEAPNESS, A CHALK SHIELD WAS USED, AND THE COST OF MATERIALS FOR A COUNTER BASED ON THIS DESIGN, BUT USING AN EFFICIENT LIQUID SCINTILLATOR, COULD PE AS LOW AS 3OO POUNDS STERLING, EXCLUDING THE COST OF ELECTRONIC UNITS.

*COUNTER, WHOLE BODY + \#EQUIPMENT DESIGN + \#RADIONUCLIDE, INDUCED + GAMMA EMITTER + ICRP + 
ENVIRONMENTAL SUR.VEYS, CATEGORY 15 TORING AND RADIATION EXPOSURE OF MAN

15-2176? FCONT INUED*
MAXIMUM PERMISSIBLE PODY EURDEN + POTASSIUM + SHIELOING + SOURCE, P.ADIATION

$15-21764$

BOOKER DY + CHAMBERLAIN AC + RUNDO J + MUIR DC + THOMPSON ML

ELIMINATION OF E-MICRON PARTICLES FROM THE HUMAN LUNG

AT CMIC ENERGY RESEARCH ESTABLISYHAENT, HARWELL

4 DAGFS, 3 FIGURES, 1 TABLE, 5 REFEEENCES, NATURE 215 , PAGES $30-3$ (JULY 1,1967 )

DESCRIBES AN APPARATUS THAT WILL PROVIOE A CENTINUOUS AND REGULAR AEROSOL OF 5-MICRON

DARTICLES OF POLYSTYRENE LABELLEO WIITH CR-5l. THE ELIMINATICN GF THE LABELLED PARTICLES FRCM

THE LUNGS AFTEP. A SINGLE INHALATION RY HUMAN BEINGS IS FOLLCWED BY EXTERNAL GAMMA-RAY

MEASUREMENTS.

*AEROSOL, RADI JACTIVE + \#CHROMIUM + \#DOSE MEA SUFEMENT, INTERNAL + \#INHALATION + EQUIDMENT DESIGN + GAMMAENITTER + PARTICLE SIZE + PARTICLE, P.ADIOACTIVE

$15-21756$

SPENCER H + LENIN I + SAMACHSON J

EFFECT OF MAGNESIU:A ON RADIOSTRONTIUM EXCFFTIUNN IN MAN

VETERANS ADMINISTRATION HOSDITAL, HINES, ILL.

9 PAGES, I FIGURES, 7 TABLES, 25 REFËRENCES, [NT. J. APPL. RACIAT. ISOTCP., 18, PAGES 407-15 (JUNE 1967)

THE LFFECT OF INTRAVENOIISI Y ADMINISTEREO N.AGNESIUM ON RAUIUSTRONTIUM EXCRETION WAS STUDIEO IJNDER STRICTLY CONTROLLED DIETAPY CONOITIONS IN MAN. THE PESULTS WERE COMPARED WITH THOSE כBTAINED WITH EQUIMOLAR AMOUNTS OF CALCIUM IN THE SAME PATIENTS. A SINGLE TRACEP. DGSE OF SR-35CI2 WAS GIVEN INTRAVENOUSLY IN THE CENTROL, THE MAGNESIUM. ANO THE CALCIUM STUDIES. INFUSIONS JE MAGNESIUM SULFATE OF. CF CALCILM GLUCONATE WFRE GIVEN ON THE DAYY OF THE

INTRAYENOUS INJECTION! UF SR-Z5 AND ON THE SUBSEQUENT TWO DAYS. BOTH MAGNESIUM AND CALCIUM INCREASED THE URINARY EXCRETION OF SR-85, BUT CALCIUM WAS MGRE EFFECTIVE THAN MAGNESIUM IN MOST CASES. THE DIFFEPCNCE IN EFFECT ADPEAREO TO BE DUE TO DIFFERENCES IN URINAPY CALCIUN EXCRETION INOUCEO BY INTRAVENOUS CALCIUM AND MAGNESIUM, THE INFUSIONS OF CALCIUM RESULTING IN HIGHER EXCRETION OF URINARY CALCIUM THAN THE INFUSIONS OF MAGNFSTIJM. THERE HAS NO EFFECT CF SITHER INTPAVENOUS MAGNESIUM OR. INTRAVENOUS CALCIUM ON FECAL SR-8 5 [XCRETION.

\#CALCIUM + \#AGNESIUM + \#RADIONUCLIOE, INDUCED + \#STRONTIUM + BICLOGICAL CONCENTRATION, MAN + COUNTER + DIETARY HASIT + DOSE MEASUREMENT, INTERNAL

$15-21769$

CONSER KE + BFATTIE JG

CONSEQUENEES OL ACTIVITY R.ELEASE - RISK

16 PAGES, 6 FIGURES, 4 TABLES, 40 REFERENCES, NUCLEAR SAFETY 8(6), PAGE 573-588, (DECEMPER 1967)

THE INHALATION TFF RADIOACTIVE IOOINE LEADS TO A DOSE OF RADIATION IN THE THYROID GLAND, AND THERE YAY 3 E A RISK OF DEVELCPING THYFOID CANCER. THIS RISK IS FVALUATED FOR A REACTOR IN OR NEAR A PRPIJLATED ADEA BY $\triangle S S E S S I N G$ THE TDTAL NUMBER OF CASES LIKELY TO AEISE IN THE POPULATED AREA AND BY ASSESSING THE FISK TO ANY INOIVIDUAL LIVING NEAR THE REACTCR. IN THESE

CALCULATIONS A POPULATIUV DISTRIBUTION IS ASSUMED THAT REPRESTNTS POTENTIAL URBAN DEACTOR SITES, AND ACCQUMT IS TAKEN EE UKOBABLE METEOROLOGICAL CONDITIONS AND DOSE-RISK RFLATIONS CF THE INTERNATIONAL CCMMISSION ON PADIOLOGICAL PROTECTION. FROM D POSTULATED LIMIT LINE OF ACCIDENT FR CQUENCY VS SEVERITY, A CALCULATION DERIVES AN AVERAGE C.ASUALTY R.ATE FOR. TIIE POPIILATION $\triangle$ VO AN ANNUAL RISK DATE FUP. THE INDIVIDUAL. THESE DFE SHOWN TS BE EXCEEDINGLY SMALL COMPARED WITH THE NORMAL CASUALTY RATF IN THE SAME POPULATION AND WITH THE OISYS RUN CY THE INDIVTMIAI IN THE GOUNSE OI NCEMAL LIVINIS.

\#BIDI IGICAL CONCENTRATICN, MAN + \#INHALAIION + \#IODINE + \#POPULATION EXPOSURE + DOSE + HAZARDS ANALYSIS + METEOROLOGY + PERSONNEL EXPOSURE, PADIDTION

$15-2175 \% \quad$ ALSO IN CATEGORY 14

DEVIK $F$

RACIOACTIVE CONTAMINATION OF OUR ENVIRONMENT FOLLOWING NUCLEAR RCMB TESTS, AND RADIATION-INDUCED CANCER S.TATENS INSTITUTT FOR STRALFHYGIENE, OSLO

3 PAGES, 5 REFEREVCES, TIDSSKR. NORSKE LAEGFOREN., 85, PAGE 1779-1781, (DECEMBER 1YGל) IN NORWEIGIAN

RADIATION HAZAPDS RESULTING FROM HUMAN INTAKE OF FALLOUT RADICNUCLIDES ARE DISCUSSED IN RELATION TO THE CONCLUSIONS AND RECOMMENDATIONS OF THE THIRD REPORT QF THF IINITEO NATIONS SCIENTIFIC. CIMMITTEE ON TIIE CTFECTS OF ATUMIL H.DIATION (NEW YORK 19G4). THE REPORT GIVES AN ESTIMATE OF ENVIRINMENTAL FADIATION DOSE FROM RADIOACTIVE FALLOUT IN IOG5 AND REVIEWS DATA. PERTINENT TO DOSE-EFFECT RELATIONS WITH PESPECT TO MALIGNANT DISEASES. THE AUTHCF. POINTS OUT THAT THE AVERAGE FALLOUT RADIATION DOSE TO THE POPIILATION IN NORWAY IS NOT LIKELY TO OIFFER BY ANY CONSIDERABLE FACTUR FROM THE AVFPAGE VALUES CALCULATED FOF. THE WORLD POPULATION, EUT LOCAL VARIATIONS MAY BE CNNSIDEPABLE AND MERIT FURTHER INVESTIGATIONS. IN THIS CONNECTICN IT IS MENTIONED THAT COMMON TERMS SUCH AS RAOIATION HAZARD, DANGER, RISK, ETC., WHEN USED IN PUBLIC DISCUSSIONS ARE NOT ALWAYS ADEQUATE. THEY SHCULD BE AVOIDEO UNLESS IT IS MADE CLEAR WHAT THEY ARE INTENDED TO CONVEY, OP. THEY SHOULO BE PEPLACEO BY. UNEQUIVDCDL TERMS.

\#DOSE + \#ENVIRONMENTAL CONOITION + \#NUGLFAR MFTONATION + \#ROICPUCLIDE, INOUCEU + CONTAMINATION + FALLOUT + 
ENVIRONMENTAL SURVEYS, CATEGORY IS 5 TORING AND RADIATION EXPOSURE OF MAN

15-21769 \#CONTINUCD\%

HAZARD, RELATIVE + NORWAY

15-21770 ALSU IN CATEGORY 14

CUPTIS GB + PETTY JS

A PROGRAM TJ CJMPUTE SETA PADIATIJN DOSAGE. VOLUME I. PROGRAM DESCRIPTION. FINAL P.EPCRT

AMER ICAN KESEARCH CDPP., FULLERTON, CALIF.

TID-24033(VOL.1)+

\begin{abstract}
AMERICAN RESEAPEH CORPORATION DEVELOPED A COMPUTER PROGRAM TO CALCULATE BETA RADIATION DOSAGES TO TISSUE INCURRED FROM CONTACT WITH RADIOACTIVE FALLOUT PAPTICLES CONTAINING MIXED FISSION PRODUCTS. VEKSIONS OF THE BETA RADIATION DOSAGE PROGRAM WERE PREPAREO FOR THE COC 3600 AND IBM 7094 COMPUTERS. VERSATILE INPUT/OUTDUTं PROCEDURES PRGVIDE CONTROL OVER THE SFLECTION AND ARRANGE:AENT JF OUTPUT PARAMETFRS. MANY TABLES, FUNCTIONS, AND PARAMETERS, CONSIDERED INPUT QUANTITIES IN MOST PROGRAMS, WERE INCORPORATED INTO THIS PROGRAM. THESE QUANTITIES MAY EE TREATED AS DPTIONAL INPUTS WHERE DESIRED. VOLUME I OF THIS REPORT DISCUSSES THE TECHNICAL AND PROGR A.MMING APPRDACHES USES AND DESCRIBES THE PROGRAN IN GENERAL TERMS. VOLUME II CONTAINS DETAILED INSTRUCTIONS FOR THE USE OF THE PROGRAM AS WELL AS PROGRAM LISTINGS.
\end{abstract}

AVAILABILITY - CLEARINGHOUSE FOR FEDERAL SCIENTIFIC AND TECHNICAL INFORMATION, SPRINGFIELD, VIRGINIA, $\$ 3.00$ COPY, \$0.65 YICRCFICHE

*BETA EMITTER + \#COMPUTER PROGRAM + \#DOSIMETRY, GENERAL + \#FALLCUT + FISSICN PRODUCT RELEASE, GENERAL + NUCLEAR DETONATION

$15-21771$

A PROGRAM TO COMPUTE 3ETA PADIATION DOSAGE. VOLUME II. USERS MANUAL AND PRGGRAM LISTINGS. FINAL REPORT AMERICAN FESEARCH COFP. FULLERTON, CALIF.

$T I O-24033(V O L .2)+$ APC. $-57-49+.204$ PAGES, AUGUST 1,1967

AMERICAN RESEARCH CQRPDRATION DEVELCPED A COMPUTER PROGRAM TO CALCULATE BETA RADIATION DOSAGES TD TISSUE IVCURRED EROM CONTACT WITH RAOIOACTIVE PARTICLES CONTAINING MIXED EISSION PRODUCTS. THE PROGRAM IS CAPABLE OF EVALUATING BETA RADIATION DOSAGES ARISING FPOM CONTACT WITH PARTICLES DRIGINATING ERTM A NUCLEAR WEAPON DETONATION AS WELL AS PARTICLES RESULTING FROM

THE DESTPUCTION CF A NUCLEAR PROPULSION REACTOR. VERSIGNS OF THE PROGRAM TO COMPUTE BETA RAOIATION DOSAGE WERE PREPARED FOR THE CDC 3600 AND IBM 7094 COMPUT.ERS. VERSATILE INPUT/OUTPUT PROCEDUPES PROVIDE CONTPOL OVER THE SELECTION AND ARRANGEMENT OF OUTPUT PARAMETERS, CONSIDERED INPUT QUANTITIES. IN MOST PROGRAMS, WERE INCORPORATED INTO THIS PROGRAM. THESE GUANTITIES MAY BE TREATEO AS OPTIONAL INPUTS WHEFE DESIRED.

AVAILABILITY - CLEARINGHOUSF FOR FEOEPAL SCIENTIFIC AND TECHNICAL INFGRMATION, SPRINGFIELD, VIRGINIA, $\$ 3.00$ COPY, \$0.65: 1 ICROF ICHE

* EETA EAITTER + *COMPUTER PROGRAM + *NUCLEAR DETONATION + DOSIMETRY, genERAL + FAL LOUT

$15-21734$

TAMPLIN AD

NLSO IN LAIEEORY 14

PREDICTION OF THE MAXIMU!A DOSAGE TO MAN FROM THE FALLQUT OF NUCLFAF. DEVICES. I. ESTIMAIIUN OF THE MAXIMUM CONTAMINATION GF AGRICULTURAL LAND

CALI FORNIA UNIV., LIVERMOP.E. LAWRENCF RAOIATION LAE

UCRL-50163 (PT. i) +. 28 PAGES, FIGURES, TABLES, REFERENCES, JANUARY 3,1967

PART I DF THIS REPORT PRESENTS A SEMIEMPIRICAL APPROACH TOWAPD ESTIMATING THE MAXIMUM CONTAMINATIDN DF AGRICULTURAL L LANU BY RAEIONUCLIDES PROOUCED BY NUCLEAR IFVICES. IT ISS BASED UPON THE MAXIMUM FALLOUT LEVELS OESERVED SUBSEQUENT TO ALL PREVIOUS TESTS OF NUCLEAR DEVICES AND APPLIES TG CLOUD TRAVEI TIMES CR FALLOUT ARRIVAL TIMES RANGING FROM 1 TO SO HR AND BEYONO.

AVAILABILITY - CLEAR INGHOUSE FOR FEDERAL SCIENTIFIC AND TECHNICAL INFORMATION, SPRINGFIELD, VIRGINIA, $\$ 3.00$ COPY, \$0.65 MICROFICHE

*DOSF + \#FALLOUT + \#PLOWSHARE PROGRAM. + \#SOIL, NUCLIDE OCCURRENCE + AIRBORNE RELEASE + DIFFUSION + DOSE CALCULATION, EXTERNAL + LRL + RAINOUT + TEST, WEAPONS (HP ASPECTS)

15-21786 ALSO IN CATEGORY 14

RADIOLOGICAL HEALTH RESEAPCH. SUMMARY REPORT, JULY-1965-DECEMBER 1966

PUBLIC HEALTH SERVICE, ROCKVILLE, MD.

NP-16856 +. 120 DAGES, 45 FIGURES, TABLES, 1966

REPORTS ACTIVITIES OF THE RESEARCH BRANCH, DIVISION OF RADIOLOGICAL HEALTH, PUBLIC HEALTH SERVICE FOR THF 18 MONTHS BEFORE ITS REORGANIZATION IN JANUARY 1967. WORK IS REPORTED IN THE FIELOS OF QADIATIUN BIOLOGY, EPIDEMIOLOGY, AND ENVIRONMENTAI. SCIENCES.

AVAILABILITY - CLEARINGHOUSE FOR FEDERAL SCIENTIFIC AND TECHNICAL INFORMATION, SPRINGFIELO, VIRGINIA, $\$ 3.00$ COPY, $\$ 0.65$ MICROFICHE

\#DOSE + \#FALLOUT + \#FAOIATION DAMAGE + \#RADIOBIOLOGY + BIOMEDICAL + DOSE CALCULATION, EXTERNAL +

DOSE CALCULATION, INTERNAL + DOSIMETRY, GENERAL + ENVIRONMENTAL CONDITION + RADIOCHEMICAL PROCESSING + 
ENVIRONMENTAL SURVEYS, MATEGORY IS ISOR RANG AND RADION EXPOSURE OF MAN

$15-21786$ *CONT INUED*
RADIOLOGY

$15-21787$

PACIFIC NORTHNEST LABORATORY ANNUAL REPORT FOR 1966 TO THE USAEC DIVISION OF BIOLOGY ANO MEDICINE. VOL. I.I - PHYSICAL SCIENCES. PART 4. INSTRUMENTATION

BATTELLE-NORTHWEST, FIICHLANR, WASHINGTUN

BNWL-4.1-4 +. 51 PAGES, FIGURES, TABLES, PEFERENCES, AUGUST 1967

REPORTS OEVELOPMENT ON THE FOLLOWING INSTRUMENTATION SYSTEMS - $\triangle Q U A T I C-E N V I R O N M E N T$ DOSE-RATE MONITOR, MINIATUEE DOSE-RATE-MEASUREMENT INSTRUMENT, LIVE-TIME AND HALF-LIFE CONTROL OF SCANNER FQR. WHOLE-BODY-RADIATION COUNTEF, MEASUREMENT OF MIXED-FIELD NEUTRON AND GAMMA DCSE RATES, WOUND CDUNTING WITH SOLID-STATE DETECTOKS, COUNTING OF PLUTONIUM IN THE LUNG, ANIMAL ACTIVITY MONITOR DEVELCPMENT, TIDAL VOLUME AIR MEASUREMENT, ACCELERATOR ION-BEAM-CURRENT REGULATOR, PRCGRESS GN DEVELOPMENT OF ELECTRONICS FOR SOLIC-STATE DIODE DETECTORS, SURFACE-CCNTDURED-DIODF. INVESTIGATIONS, PROCRESS IN X-RAY/ALPHA STUUIES WITH SOLID-STATE DETECTORS, NEUTRON-SENSITIVE CRITICALITY-ALARM SYSTEM, IMPROVEMENTS IN RAINDROP-CHARGE-MEASURING SYSTEMS.

AVAILABILITY - CLEARINGHOUSE FQR FEDERAL SCIENTIFIC AND TECHNICAL INFORMATION, SPRINGFTFI D. VA., \$3. OO COPY, \$O.65 MICROFICHE

*COUNTER + \#INSTRIMMENTAT-ION, PADIATION MONITORING + AMONITUR, RADIATION, ENVIRONMENTAL + *MONITOR, RAOIATION, PERSONNEL + ACCELERATOR + ALPHA EMITTER + BATTELLE NORTHWEST + COUNTER, WHOLE BOOY + GAMMA + INSTRUMENTATION, NUCLEAR + NEUTRON + PLUTONIUM + RADIOGIOLOGY + SOLID STATE DEVICE + X-RAY

$15-21788$

BOND VP

CELLULAR BASIS OF ACUTE RADIATION DEATH IN THE MAMMAL

BROOKHAV EN NAT IONAL LAB., UPTDN, N. Y.

BNL $-50064+$ +. I5 DAGES, 20 FIGURES, I TABLF, \& REFERENCES, FEB. $8,196 ?$

THE EFFECTS DF RADIATION DELIVEREO TO THE ENTIFE BODY ARE DESCRIBED, AND CONDITIONS UNDEF WHICH SUBEXPOSURE OF HUMAN BEINGS MAY BE ENCOUNTERED ARE CUTLINED. IT IS DEMONSTPATED THAT THE COMPLICATEO CLINICAL PICTURE SEEN AS THE RESULT OF SUCH EXPOSURE HAS ITS GENSIS PRIMARILY IN THE DEPLETICN OF CELLULAR ELEMENTS IN THE PERIPHERAL BLODO. IT IS FUTHER SHOWN THAT THE TIME COURSE AND DOSE RELATIONSHIP SEEN CAN BE EXPLAINED SATISFACTORILY ON THE BASIS CF THE KINETICS CE THE CELL POPULATIONS INVOLVED AND THE KNONN CELLULAR RADIOBIOLOGY THAT PERTAINS TO THESE CELLS. THE BODY IS NORMALLY IN A STATE OF OYNAMIC CELLULAR EQUILIBRIUM, AND WHILE

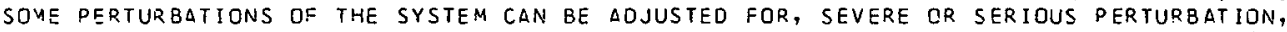
HOWEVER, RESULTS IN DISEASE QR NEATH IF EOUILIBRIUM IS NOT REESTABLISHEO. RADIATION IS BUT ONE OF THE MANY HARMFUL AGENTS THAT CAN UPSET THE CELLULAR ECUILIBRIUM AND LEAD TO SERIOUS ILLNFSS AND DEATH.

AVAILABILITY - CLEARINGHOUSE FOR FEOERAL SCIENTIFIC AND TECHNICAL INFORMATION, SPRINGFIELD, VA., \$3. OO COPY, $\$ 0.65$ MICRDEICHE

* BIOMEOICAL + \#RAOIATION OAMAGE + BNL + RAPIATION IN PERSPECTIVE + PADIOBIOLOGY

$15-21790$

GLDVER JR

ANALYSIS OF RADIATION DEPTH DOSE CATA

ROCHESTER UNIVEP.SITY, N. Y

UR-49-937+. 1.67 PAGES, FIGURES, TABLEJ, 1907

DERTH-DOSE DATA FFOM THE BKITISH JOURNAL OF RADIOLOGY, SUPPLFMENT NO. 10, 1961 , WAS ANALYZEO TD RECTIFY THF FACT THAT IN THE 72 YEAR.S SINCE THE DISCOVEP. OF X RAYS, NC SINGLE ANALYTIC METHOD OF COMPUTING CENTDAL-AXIS PERCENTAGE DEPTH DOSE HAD BEEN PRODUCED WHICH HAO BEEN SHOWN TO BE APPLICABLE CVER ALL DEPTHS FROM THE POINT OF MAXIMUM IONIZATION, ALL SURFACE FIELD AREAS, ANE WHICH WOULD APPLY OVER THE ENTIRE RANGE OF FOCAL-SKIN DISTANCES AND QUALITIES OF INTEREST IN RADILLLOGIC PHYSICS,

AVAILABILITY - CLEARINGHCUSE FOR FEDERAL SCIENTIFIC AND TECHNICAL INFQRMATION, SPRINGFIELD, VA., \$3. OO COPY, \$0.65 MICR.OFICHE

\#OÜSE + DUSE CALCULATIDN, EXTERNAL + RADIOLOGY + X-RAY

$15-21792$

DEWERD LA + CAMERON JP.

A TLD READER FOP MBLE DOSIMETFRS

WISCONSIN UNIVERSITY, MADISON

COO-1105-135+. 7 PAGES, 2 REFERENCES, JULY 15,1967

DESCRISES A READER UNIT FOR THE MBLE THERMOLUMINESCENT DOSIMETEFS. REPRODUCISILITY OF THE READER-OOSIMETEP. COMBINATION WAS THE SAME AS THAT STATED BY MBLE.

AVAILABILITY - CLEARINGHOUSE FOR FFDFRAI. STIENTIFIC AND TECIINICAL INF ORMATION, SUKINGHIELD, VA., \$3. OO COPY, \$0.65 MICROFIC.HF 
ENVIRONMENTAL SURVEYS, MONITORY 15

ENVIRONMENTAL SURVEYS, MONITORING AND RADIATION EXPOSURE DF MAN

15-21792 *CONT INUED*

\#DOSIMETRY, GENERAL + DDSIMETRY, THERMOLUMINESCENCE + GAMMA

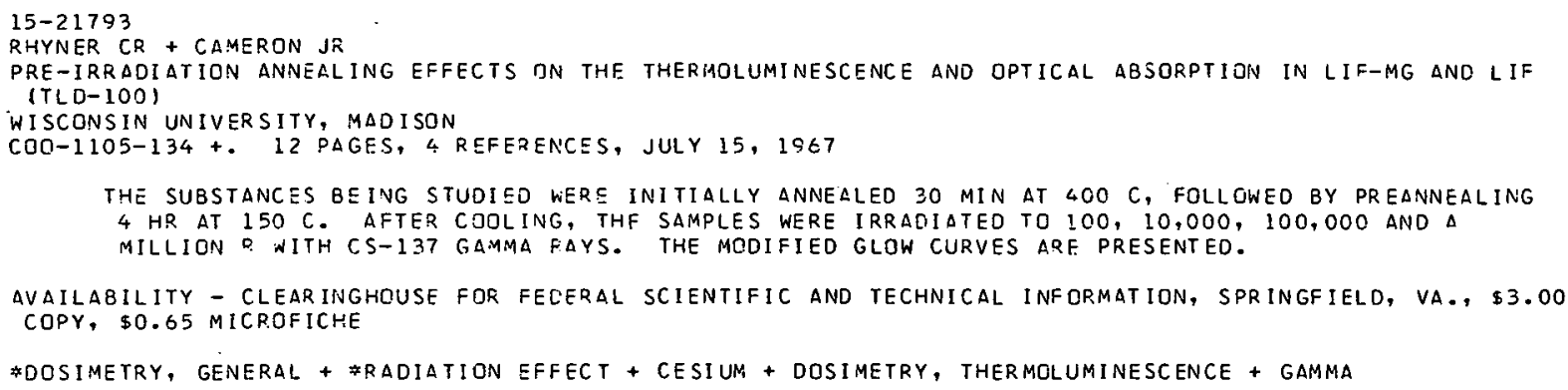


ENVIPONMENTAL SUPVEYS, MATEGORY IS 15 INORING RADIATION EXPOSURE OF MAN

$15-21932$

HEALTH DHYSICS OIVISICN ANNUAL PROGRESS REPORT FOR PERIOD ENDING JULY 31 , ICG7. FART V. INTERNAL UOSIMEYRY TAK RIDGE NATIDNAL LAB., TENN.

ORNL-4163 +. 56 PAGES, 35 FIGURSS, 16 TABLES, 60 REFERENCES, PAGE 233-283, OCTOBER 1067

STUDIES ARE REFGRTED ON CALCULATING EFFECTIVE ENERGY FOF USF IN INTERNAL DOSE CALCULATIONS, DISTRIBUTION CF DOSE IN THE BODY FROM GAMMA DISTRIEUTED UNIFORMLY IN AN DEGAN, DOSE FROM EXPDSURE TC A POINT GAMMA SOURCE, AN AGE-DEPENDENT MODFL FOR BODILY RETENTION DF CESIUM, A OOSIMETRIC STUCY FOR THE ADMINISTRATION GF MERCURY-LABELED NEOHYDRIN, PREDICT ION CF DLUTONIUM BDOY BUPDEN FROM EXCRETIONS DATA. UNDER STAQLE-ELEMENT METABOLISM ARE A LONG-TERM STUDY OF INTAKE ANO EXCKETION OF STABLE ELEMENTS AND A DISCUSSION OF THE TISSUE-ANALYSIS ACTIVITIFS.

AVAILABILITY - CLEARINGHOUSE FOR FEDERAL SCIENTIFIC AND TECHNICAL INFORMATION, SPRINGFIELO, VIRGINIA, $\$ 3.00$ COPY, $\$ 0.65$ MICROF ICHE

*9IOLOGICAL CONCENTRATICN, MAN + \#DUSE + \#DOSE CALCULATION, INTERNAL + CESIUM + GAMMA EMITTER + MAXIMUM PERMISSIBLE RODY BURDEN + MEDCURY + PLUTONIUM + SQURCE, POINT + SOURCE, VOLUME

$15-21933$

HEALTH PHYSICS DIVISION ANNUAL DROGRESS REPORT FOR PERIDD ENOING JULY 21,1967 . PART IV. PADIATIGN DOSIMETRY

OAK RIDGE NATIONAL LAS., TENN.

ORNL-4168+. I 9 PAGFS, I8 FIGIIRFS, 3 TAELES, 4, DEFERENCES, PAGE 291-3!1. OCTOGER 19E7

RESEARCH IS RSPCRTED ON (CHAP. 2!) ICHIRAN STUDIES IDOSF EVALUATION FCP. HIRTSHIMA AND

NAGASAKI), (CHAP. 221 SPLCTRCMETRY AND DOSIMETPY RESEARCH, (CHAP. 23) OOSIMETRY APPLICATIONS, (CHAP. 24) HEALTH PHYSICS RESEARCH QEACTOR ANO DOSAR LOW-ENERGY ACCELERATGR DPERATIONS.

AVAILABILITY - CLEARINGHOUSE FOR FEDERAL SCIENTIFIT AND TECHNICAL INFOFMATION, SPDINGFIELD, VIRGINIA, $\$ 3.00$ COPY, \$0.65 MICROTICHE

* $A C C E L E R A T O Q+\# D O S E+\# D O S E$ CALCULATION, FXTEPNAL + \#DOSIMETRY, FACICPHJTOLUMINESCENCE + \#HPRD (FER) + \# SPFCTR JMETRY, NEUTRCN + GAMMA + INSTRUMENTATION, RADIATION MONITOFING + NEUTRON + FEACTOR, PESEAFCH + SHIELDING

$15-21930$

EISENGUD M + PETSOW HG

RADICACTIVITY STUDISS. ANNUAL PROGRESS REPORT, DECEMBER 1, 1965-NOVEMSER 30. 19FG

NEW YORK UNIV., N. Y. INST. OE ENVIRUNMENTAL MEDICINE

NYO-3086-6 +. I29 RACFS, T.IGURES, OCTOBER I, IOEK

GEPURTS PROGRESS ON (1) ESTIMATES OF TCTAL BODY RADIUM IN THE NFW JERSEY DIAL PAINTERS, (2) STUOY DF THE DISTRI QIJTION OF RA-22E, RA-228, PB-210, AND TH-228 I IN BCNE AND SOFT TISSUE OF RADIUM DIAL PAINTEPS, (3) SPECTRCPHOTCMETRIC DETERMINATIGN OF THDRIUM IN BONE ASH, (4) CETERMINATIJN OF LEAD IN BONE ASH BY ATOMIC ABSORPTION SPECTROPHOTOMETRY, (5) SEQUENTIAL ANALYSIS OF DD-210, TH-228, TH, RA-228, $\triangle N D$ RA-226 IN A SINGLE SAMPLE OF RONE ASH, (G) DISTRIBUTION OF THORON DAUGHTERS IN RATS FOLLOWING INHALATION, (7) DISCUSSION OF POSSIBLE MECHANISMS INVSLLVED IN THE APOARENT CONCENTRATION OF RA-226 AND PB-210 IN AORTA AND THYRCID.

AVAILABILITY - CLEAP INGHOUSE FOR EEOEPAL SCIENTIFIC AND TECHNICAL INFDFMATION, SPRINGFIELD, VIPGINIA. $\$ 3.0 n$ COPV, \$0.65 MICRUT ICIIS

\# ANALYTICAL TECHINIOUE, GENERAL + \#BIOLOGICAL CONCENTRATION, MAN + \#RADIATION DAMAGE + \#RADIOBIOLOGY + BIOLOGICAL. CONCENTRATION. ANIMAL I BIOMEDICAL + LEAD + RAUIUM + THERQN

$1.5-21940$

BERKEHL + VORWALD AJ

THF RESPONSE OF THE RESDIRATQRY TRATT DND LUNG TO INHALED STABLE AND RADIOACTIVE ISITOPES OF CFRTLIN

ELEHENTS. FINAL REFGRT, $\triangle P R I L 15,196 ?-A P R I L \quad 14,1966$

WAYNE STATE UNIV., DETRCIT, MICH. DEPT. GF OCCUPATIONAL AND ENVIRCNMENTAL HEALTH

TIO- $23456+.55$ PAGSS, NOV. 1, 1966

DPDGRESS IS RERCRTED ON STUDIES TIN THE DISTRIRUTION OF INHALED PADIOACTIVE AEROSCLS DF RARE-EARTH FMMPNUNCS IN RATS AND CCGS $\triangle N D$ THE RESPONSES EVOKED BY THE DEDOSITED

PADIOISOTOPES. RESULTS ARE ALSO INCLUDEC FROM A STUDY ON THE EFEECTS OF VAQIOUS DOSES OF $X$

PADIATION ON THE SIZE OF LYMPHOCYTES IN RATS. THE DESIGN CF A DOUBLE-WALLFD INHALATION CHAMBEF ATTACHED TC ANIMAL HCUSING OUARTEPS, THE OESIGN OF AN AEROSOL GENERATCR, AND THE DESIGN JE AN AEROSOL SAMPLE ARE DESCRIBEC. SCHEMATIC SKETCHES ARE INCLUDED.

AVAILABILITY - CLEARINGHOUSE. FOR FEDEPAL SCIENTIFIC ANO TECHNICAL INFORMATION, SPRINGFIELD, VIRGINIA, $\$ 3.00$ COPY, \$O.65 MITROFICHE

*AERIOSOL + \#DUSE + \#INGESTION + *INHALAIILN + \#RACIOBIQLOGY + DOSE CALCULATION, INTERNAL + EUROPIUM + RADITISOTOPE 
ENVIRONMENTAL SURVEYS, CATEGOPY 15 ITING PAND PADIATION EXPOSURE OF MAN

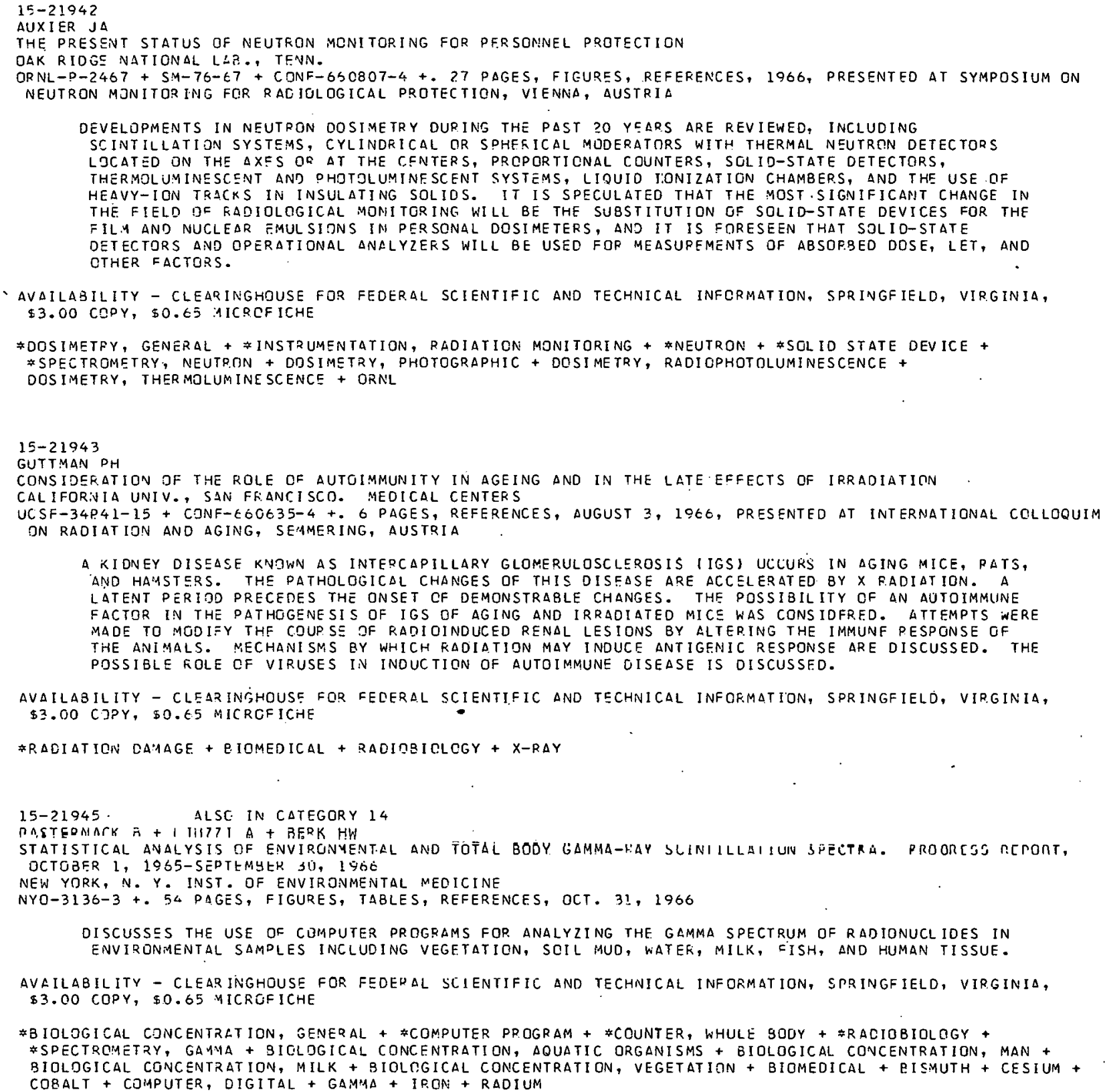

A KIONEY DISEASE KNOWN AS INTEPCAPILLARY GLOMERULOSCLEROSIS (IGS) UCCURS IN AGING MICE, PATS, AND HAMSTSRS. THE PATHOLOGICAL CHANGES OF THIS DISEASE ARE ACCELERATED BY X FADIATION. A LATENT PERIOD PRECEDES THE ONSET CF DEMONSTRABLE CHANGES. THE POSSIBILITY OF AN AUTOIMMUNE FACTOR IN THE PATHOGENESIS OF IGS OF AGING AND IRRAOIATED MICE WAS CONSIDFRFD. $A T T E M P T S$ WERE MADE TO MODIFY THF COUPSS OF RADIOINDUCED RENAL LESIONS BY ALTER.ING THE IMMUNF PESPGNSE GF THE ANIMALS. NECHANISMS BY WHICH RADIATION MAY INDUCE ANTIGENIC RESPONSE ARE DISCUSSED. THE POSSIBLE FOLE OF VIRUSES IN INDUCTION OF AUTOIMMUNE OISEASE IS DISCUSSED. AVAILABILITY - CLEARINGHOUSE FOR FERERAL SCIENTIFIC AND TECHNICAL INFOFMATION, SPRINGFIELD, VIRGINIA,
$\$ 3.00$ CJPY, SO.65 MICRGFICHE

* RAOIATICN CA:AAGE + PIOMEDICAL + RAOINBICLCGY + X-RAY

AVAILABILITY - MICROCARD EDITIONS, INC. (FGR SALE) ACCCUNTING AND SHIPPING DEPARTMENT, WEST SALEM, WISCONSIN $5466^{\circ}$

* DECONTAMINATION + \#RADIOCHEMICAL PLANT SAFETY + BETA EMITTER + CALCIUM + CESIUM + CONTAMINATION + 
ENVIKONMENTAL SURVEYS, MOTEGORY TORING 15 AND RADI.ATION EXPOSURE OF MAN

15-21947 \#CONTINUER*
GAMMA EMITTER + IODINE + PHOSPHORUS + SCOIUM + SWEDEN + THALLIUM

15-21948 ALSO IN CATEGORY 14

CULLEN TL

DOSIMETRIC MEASUREMENTS IN BRAZILIAN REGIONS OF HIGH NATURAL RADIOACTIVITY LEADING TO CYTOGENETIC STUDIES PONTIFICIA UNIVERSIDADE CATOLICA DO RIO DE JANEIRO IBRAZIL). INSTITITTR DE FISICA

NYO-2577-3, CONF-660920-7+. 17 PAGES, REFERENCES, 1:̈S, PRESENTED AT IST INTERNATIONAL CONGRESS OF THE

INTERNATIONAL RADIATION PRDTECTION ASSN., ROME, ITALY

REPORTS DOSIMETRIC MEASUREMENTS MAOE IN GUARAPARI, BRAZIL, a CITY BUILT CN MONAZITE SANDS.

LITHIUIA FLUURIDE DOSIMETERS WERE USED TO R.ECONSTRUCT THE LIFETIME DOSE OF SELECTED

INDIVIDUALS REPRESENTING VARIDUS SECTIONS OF THE CITY, ALL AGE BRACKETS, AND BOTH SEXES. THE

AVERAGE DOSE RATE FOR THE 317 PEOPLE MEASURED WAS 63 E MR/YR. POPULATION MOVEMENT ON A DAILY

BASIS WITHIN THE CITY TENDEO TO SQUALIZE THE DOSE. DTTEMPTS TO MEASURE INTERNAL

CONTAMINATIDN WERE INCONCLUSIVE. HOWEVER, IT IS BELIEVED THAT INTIMATE CONTACT WITH

CONTAMINATED SURFACES AND DUST IN THE AIR IS THE SOURCE CF BODY BURDENS THAT MAY HAVE

CYTOLOGICAL SIGNIFICANCE.

AVAILABILITY - CLEARINGHOUSE FOR FFDERAL SCIENTIFIC AND TECHNICAL INFCRMATION, SPRINGFIELD, VIRGINIA, $\$ 3.00$ C.JPY, \$0.65 MICROEICHE

*OOSE MEASUREMENT, EXTERNAL + \#DOSE MEASUREMENT, INTERNAL + \#DOSINETRY, GENERAL + \#RADIOEIOLDGY + * SURVEY, RADIATION, ENVIRENMFNIAL + BKALIL + DOSIMETRY, THEPMOLUMINESCENCE + SOIL, NUCLIDE DCCURRENCE + THORIUM

15-21954 ALSO IN CATEGORIES 14 ANO 18

SURVEY OF ENVIR.DNMENTAL RADIOACTIVITY IN THE VICINITY OF INDIAN PCINT STATION, FEBRUARY I, I9GT THFOUGH JULY 31,1967

CONSOL IDATED EDISON COMPANY OF NEW YOPK

17 PAGES, 4 FIGURES, 8 TABLES, AUGUST 18, 1967, DOCKET NO. 50-3, TYPE--PWR, MFG--B+W, $\triangle E--C O N$ ED

REPORTS RESULTS OF MONITORING OF PARTICLES IN AIR, FALLOUT, HUDSON RIVER MUD, ALGAE, VEGETATION, SOIL, LAKE WATFR, HIINSON RIVER WATEP, AND BACKGRCUND GAMMA RADIATIDN. NO SIGNIFICANT CHANGES IN BACKGPDUND RADIATION WERE FOUND.

AVAILABILITY - USAEC PUELIC DQCUMENT PQOM, WASHINGTIN, 0.6 .

\#MONITORING PROGRAI, ENVIRQNMFNTAL + \# SURVEY, RAOINTION, ENVIPONMENTAL + ENVIPONMENTAL CONDITION + C $\triangle L L O U T$ + INDIAN POINT I (PWR) + REACTOR, PWR + STACK

$15-21957 \quad \Delta L S E$ IN CATEGORY 14

PETPOV RV + PRAVETSKII VN + STEPANOV YS + SHALNOV MI

RACIOACTIVE FALLOIJT. PHYSICS, BIOLOGICAL EFFECTS AND PROTECTIVE MEASUFES

$\triangle E C-T 2-6634+$ IDST-CAT.-1509+. 140 PAGES, 1063, (TRANSLATION OF ZASHCHITA OT RADIOAKTIVNYKH OSADKOV, GOSUDARSTVENNDE IZJATEL STVQ, MEDITSIENSKOI LITERATURY, MOSCOW, 1963.1

AN ABSTRACT DF THIS MONIGRAPH WAS PREPARED ON THE ORIGINAL RUSS I AN-LANGUAGE FUQL ICATION AND $\triangle P P E \triangle R E D$ IN NSA VOL. 18 AS NUMBEP 8567.

AVAILABILITY - CLEARINGHOUSE FIR FEDEPAL SCIENTIFIC ANO TECHNICAL INFORMATION. SPRINGFIELD, VIPGINIA, $\$ 3.00$ CDPY, \$0.65 MICROF ICHE

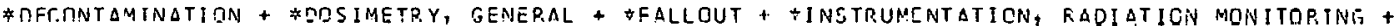
UISE MEASUREMENI, EXIERNAL + RADIATION PROTECTION, .CRGANIZATION + FADIOBIOLCGY + USSR

$15-21958$

GEYHM + LORCH

MEASUREMENT OF THE TEERESTRIAL COMPONENT OF THE NATURAL GAMMA-ENVIRONMENTAL RADIATION IN THE FEDERAL REPUBL IC OE GERMANV

GERMANY. BUINOESINISTEKIUM LUF WISSENSCHFTLTCHE FORSCHUNG

BMWF-FB-K-66-4? +. 65 FAGES, DECEMBER ISEt, IN GERMAN

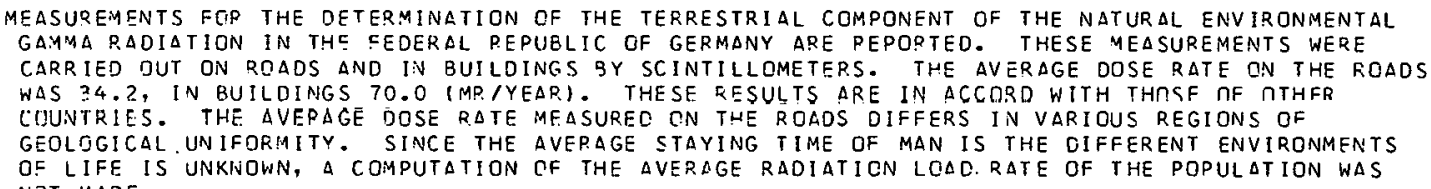

MEASUREMENTS FCP THE DETERMINATION OF THE TERRESTRIAL COMPONENT OF THE NATURAL ENVIRONMENTAL GAMMA RADIATION IN THE CEOERAL PEPUBLIC OF GERMANY ARE PEPOPTED. THESE MEASUREMENTS WERE CARRIED DUT ON ROADS AND IN BUILDINGS SY SCINTILLOMETERS. THE AVERAGE DOSE RATE ON THE ROADS WAS 34.2 , IN BUILDINGS 70.0 (MP. /YEAR). THESE EESULTS ARE IN ACCORD WITH THISF NF ITHFR COUNTRIES. THE AVEPAGE DOSE RATE MFASURED ON THE ROAOS DIFFERS IN VARIOUS REGIONS OF GEOLOGICAL. UNIFORMITY. SINCE THE AVERAGE STAYING TIME OF MAN IS THE OIFFERENT ENVIRONMENTS OF LIFE IS UNKINOWN, A COMPUTATION CF THE AVERAGE RADIATICN LCAD. RATE OF THE POPULATION WAS NDT MADE.

AVAILABILITY - MICROCARC EDITIONS, INC. (FGR SALE) ACCOUNTING AND SHIPPING OEPARTMENT, WEST SALEM, WISCONSIN 54660

*DOSE + \#DOSE MEASUREMENT, EXTERNAL + \#ENVIRONMENTAL CONDITION + gammA + germanY 


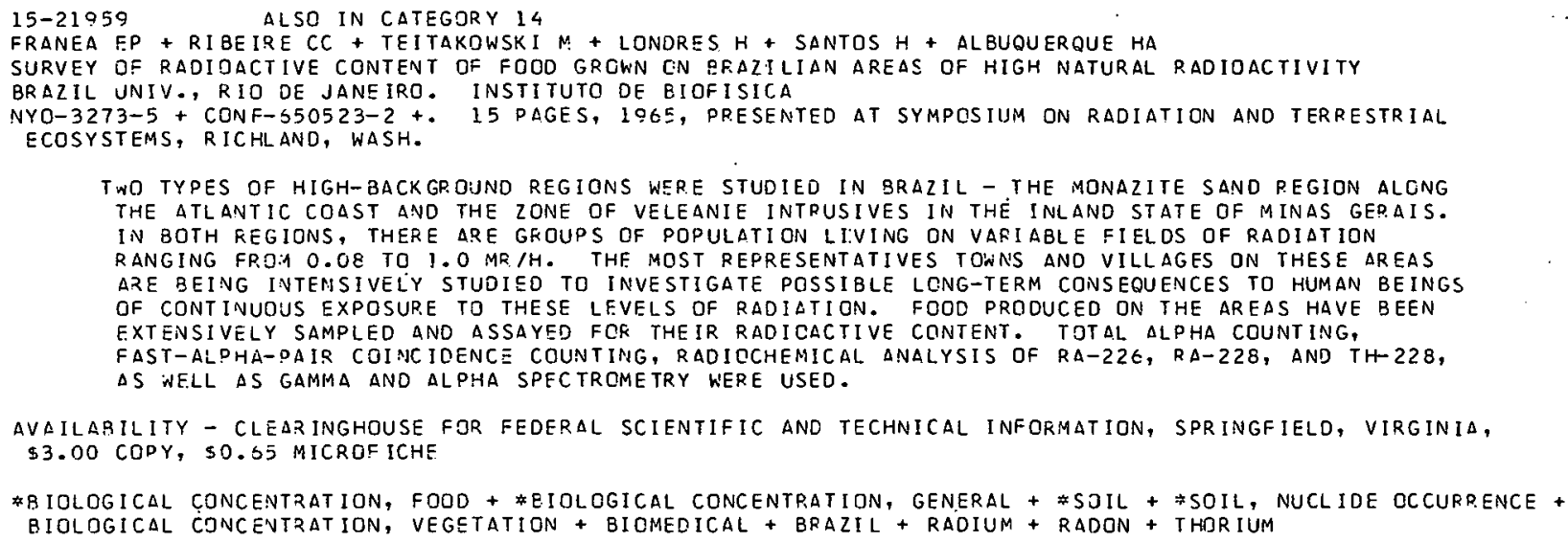


15-21963 \#CONTINUED*

N. HOSPITAL I.Y SCOTLAND PRESENTIY POSSESSES OR HAS EASY ACCESS TO A WHCLE-BODY COUNTER OF HIGH SEVSITIVITY, CESPITE THE WIDESPPEAC INITEREST IN USING SUCH A FACILITY IN MEDICAL PESEAPCH. IN VIEN CF THE LIMITATIONS OFF A CENTRAL FACILITY SITED IN A SINGLE HOSPITAL, OR ELSEWHERE, THE CONCEPT OF A MOEILE WHOLE-BODY COUNTER OF SENSITIVITY EQUAL TO THAT OF A STEEL OR LEAD RJOM INSTALLATICN IS PARTICULARLY ATTPACTIVE. TO FINO A SUITAELE LIGHTHEIGHT SHIELO, PQELIMINARY SHIELDING STUDIES WEPE UNEERTAKEN, AND A PROTOTYPE SHADOW-SHIELDED WHOLE-BOOY COUNTER WAS MADE FROM MATERIALS AND FQUIPMENT OFIGINALLY ACGUIRED FDR OTHER PURPOSES. THE DETECTOR IS $\triangle 3 \times 3$-IN. SODIUM IODIDE CRYSTAL LGCATED IN A CENTRAL SHIELD. STANNING-BEC GEOMETRY IS USED IN WHICH THE SUBJECT PASSES BENEATH THE UEIECTOR.

AVAILABILITY - MICROCARD EDITIONS, INC. (FOR SALE) ACCOUNTING AND SHIFFING DEPT., WEST SALEM, WISCONSIN 54669

*COUNTER, WHOLE goOY + *OOSE + \#INSTRUMENTATION, RADIATION MONITOPING + DOSE MEASUREMENT, INTERNAL + SHIELDING + 'JVITED KINGDOM

$15-2.1969$

ILIC-UTPJVIC J

USE OF POLYVINYL-CHLORILE FILM FOR ELECTRCN BEAM DOSIMETRY

DANISH ATOMIC ENER.GY COHMISSION, RISOE. RESEARCH ESTARLISHMENT

RISO-141 +. 18 PAGES, FIGURES, TABLES, REFEF.ENCES, SEPT. 1966

THE SUITABILITY OF A HOMOPOLYMEP. TYFE OF PVC FILM (QC, -5960, C.015 IN. THICK) $\triangle S$ A HIGHDOSE ELECTRON DOSIMETER (1-5 MEGAPAUS) WAS INVESTIGATED. DIFFERENIT HEAT TREATMENTS WEFE ADPLIEL TO OBTA!N A PEASONABLF. STORAGE STABILITY AND AN APPROXIMATELY LINEAR RELATICNSHIP BETWFEN gPTICAL CENSITY AND DOSE OVEF THE UÜSE DANGE FROM 0.5 TO 5 MEGGARADS. THE SPECTRAL RANGE WAS 390 ก TO 5000 A. THE EFFECT OF THE DOSE RATE ON THE COLORATION OF PVC WAS STUDIED.

AVAILABILITY - HICOOCARD EDITIONS, INC. (FOR SALE) ACCDUNTING ANO SHIPPING CEPT, WFST SALEM, HISCONSIY 54669

* DOS IMETGY, GENERAL + DENMAFK + DJSE + DCSE MEASUREMENT, EXTERNAL + dOSE MEASUREMENT, INTERNAL

$15-21970$

NI R.SCHL JC

SOLID-STATE ELECTROMETEF FOR DORTABLE RADIATION MONITOP.

ARMY ELECTRDNICS COMMAND, FOR.T MONMCUTH, N. J.

$\triangle D-630587+$ ECOM-2736+. 19 PAGES, FIGURES, FEFERENCES, AUGUST 1966

DESCQIBES A. SULID-STATE ELECTROMETER IN WHICH A METAL-OXIDE SEMICONDUCTOR FIELD EFFECT TRANSISTOR (MOS FET) IS USFD IN THE HIGH-IMPEDANCE INPUT STAGE. THE RANGE OT CURRENT MEASUREMENT IS FR IOM 101-12TH) TO 10(-2TH) AMH. THE DESIGN OF THE ELECTROMETER LENDS ITSELF TIJ APPLICATION IN A PORTABLE RADIATION SURVEY METER, AFFOPDING HIGH LINEARITY, FAST RESPLISE, INSTANT WARIAUP, AND LOW PCWER CONSUMPTION.

AVAILASILITY - CLEARINGHDUSE FOR FEDERAL SCIENTIFIC AND TECHNICAL INFORMATICN, SPRINGFIELD, VIRGINIA, $\$ 3.00$ COPY, \$0.55 MICRGFICHE

* INSTRUMENTATION, RAOIATION MONITORING + \#MONI TOP, RADIATI:ON, gENERAL + INSTRUMENTATION, NUCLEAR + MONITOR, RADIATION, GENERAL PRACTICE + SOLID STATE DEVICE

$15-21978 \quad$ ALSC IN CATEGORY 14

STEINKAMP R.C + COHEN NL + HUTSUN E + KUNKEL H

DIET IAODEL FOR MEASUFING RADIOACTIVITY EXPOSURE THFOUGH FUUDI-PILOT STUDY

DEPARTMENT OF HFALTH, CALIFORNIA

9 PAGES, 2 FIGURES, 2 TLGLES, 5 REFERENCES, FAOIOLGGICAL HEALTH DATA AND REPDRTS 8(IC), PAGE 56E-573, (OCT. 1067)

THIS PAPER QEOOFTS A DILOT STUDY DESIGNED TO TEST THE HYPOTHESIS THAT THE HOUSE CIET OF $\triangle$ HOSPITAL MAY SFRVE AS A MODEL FOR THE DIET CF AN ADULT POPULATION REGIONALLY SERVED BY THE HOSPITAL IN ORTER TO MEASURE RAOIO-ACTIVITY EXPOSURE THROUGH FOOD INTAKE. YEARLY AND SEASONAL QUANTITIES TOF 37 SUECATECORILS OF NINE MAJOR FOOD GPOURS WEFE COMPAKED FGR A BERKELEY HISOITAL HOUSE DIET ANO UIETS DF RERKELEY AND OTHER SAN FRANCISCO BAY AREA RESIDENTS. RESULTS INOICATE THAT THE HOSPITAL HOUSE OIETS WHILE DIFFER ING IN CERTAIN RESOECTS FROM FOOD INTAKE OF THE PCPULATION, MIAY PROVIOE AN ESTIMIATE CF NFAR-MAXIMUM INTAKE DF FOODS SIGNIFICANT FOR RADIMACTIVE CONTENT.

\#BIOLOGICAL CONCENTRATION, GENERAL + \#FALLCUT + BIOLOGICAL CONCENTRATION, FOOD + BIOLOGICAL CONCENTRATIUN, MILK + OIETARY HABIT

$15-21992$

R.AUIAT ION ACCIOENT AT HAMMEQSMITH

1 PAGE, BR IT. MEO. J., PAGE 233, (JULY 23, 1S66)

THREE PATIENTS AT THF HAMMERSMITH IICSOITAL (LUNCON) RECEIVED AN CVERDOSE DF ELECTRONS WHILE BEING TREATED FROM THE HOSPITALS Q-MEV LINEAR ACCELERATOR. THE ACCIDENT WAS DUE TO A VERY RARE COMBINATION OF CIRCUMSTANCES - AN IRREGULARITY OF CURRENT THAT OCCURRED ABOUT ONCE A 
$15-21992$ *CDNT INUEC:

YEAR FOR A FEW DAYS, AND A SIMULTANEOUS FAILURE dF THE DOSIMETER, NOT IMMEDIATELY NOTICEABLE.

*ACCELERATOR + \#ACCICENT, GENERAL + \#RAOICLOGY + RADIATICN DAMAGE + RADIATION INJURY, TREATMENT OF + UNITEO KINGDOM + X-RAY

$15-21993$

ALSO IN CATEGORY 14

FLETCHER. W + LOUTIT JF + PAPWCRTH DG

INTERPRETATION OF LEVELS OF SR-9O IN HUMAN BONE

UNITEO KINGDOM ATOMII ENERGY AUTHORITY, CHESTER, ENG.

6 PAGES, 3 FIGURES, 7 TASLES, 77 REFERENCES, ERIT. MED. J., 2, PAGE 1225-1230, (NOVEMBER 19, 1966)

NEN DATA ON SR-OO IN BONE, DERIVED SINCE THE CONSIDERABLE INCREASE IN FALLCLT FOLLONING THE 1961-2 NUCLEAR-WEADON DETONATIONS IN THE ATMOSPHERE, ARE, REPORTED. THE RESULTS FOR 1 OG2-4 REFLECTED THE INCPEASE DF CONTAMINATION OF FODD FOLLOWING THE MASSIVE TESTING OF NUCLEAR WEAPQNS IN 1961-2. MAXIMUM CONCENTKATIONS WITHIN $\triangle N Y$ ONE YR CONTINUED TO OCCUR IN INFANTS AROUND 1 YR OLD, AND THIS MAX WAS FEACHED AT ABDUT 4 MONTHS GF AGE. IN CHILDREN AND ADOLESCENTS, VALUES WEPE. LOWER AND MUCH LESS VARIABLE RETWEEN INDIVIDUALS AND DGMICILE. IA: CONTRAST WITH ADULTS, MANY OF WHOSE BCNES, FOR EXAMPLE, VERTEBRAE, SHOWED SUBSTANTIALLY HIGHER CONCENTRATIONS THAN OTHERS, THERE WAS LITTLE VARIATION WITHIN THE SKELETON IN CHILDREN ANO EVËN ADJLESCENTS. IT IS THUS POSSIBLE IN JUVENILES TO TAKE THE CONCENTRATIONS OF SR-9O OSSERVED IV DNE GDNE AS REPRESENTATIVE OF THE WHDLE SKELETON, AND THUS TO DERIVE BODY.BURDENS ACCOROING TO AGF AND YEAR.

* BIOLOgICAL CONCENTRATION, MAN + \#FALLOUT + BIOMEDICAL + RADIOBIOLOGY + STRONTIUM +

TEST, WEAPONS (HP ASPECTS) + UNITED KINGUOM

15-21996 ALSO IN CATEGORY 14

MATSUOKA O + TANAKAE

GAMMA LAOELL ING IITH SP.-95 FRR IN VIVO MEASUREMENT OF SR-9O. AN ATTEMPT FOR THE IN VIVO MEASUREMENT OF SR-90 ANO Y-90 IN INTER!NALLY EXPOSEO ANIMALS

NATIONAL INST. OF RADIOLOGICAL SCIENCES, CHIBA, JAPAN

8 PAGES, \& FIGURES, I TASLE, 10 PEFERENCES, RADIOISOTOPES (TOKYO), 21, PAGE 261-268, (SEPTEMBER 1.066), IN JAP ANESE

IN THE STUDY ON THE BIOLOGICAL EFFECT OF INTEPNAL EXPOSURE, THE EVALUATION OF ABSORBED DOSE DUE TO DEPOSITED RADIONUCLIDE IN THE ORGAN OF INTEREST IS ESSENTIAL. STRONTIUIA-9O IS ONE OF THE MOST-STUDIED RADIONUCLIDES AMONG THE BONE-SEEKING ISOTOPES, BUT ITS BEHAVJOR. IN THE LIVING BRDY IS NOT CLEARLY UNDERSTOCD. A NEW GAMMA-LABELING METHOD WAS DEVELOPED TO DETERMINE THE AMOUNT OF SR-90 IN VIVO. A MIXTURE DF SR-9O AND SMALL AMOUNT I2 TO $5 \%$ IN $\triangle C T$ IVITY). OF SR-85 IS $\triangle D M I N I S T E R E D$ TO THE ANIMAL ANO THE GAMMA RAYS (0.513 MEV) FROM SR-ES ARE MEASURED hITH A SCINTILLATION COUNTER. THE COUNTING EFFICIENCY SHOULD BE OETERMINED SEFOREHAND WITH THE ORIGINAL MIXTURE SOLUTION. YTTRIUM-OO ACTIVITY EXISTING WITH SR-9O IS MEASUP.ED GY ITS BREMSSTRAMLUNG EFFECT IF NECESSARY.

\#COUNTFR, WHOLE BODY + \#FALL OUT + \#RADIOBICLOGY + BIOLOGICAL CONCENTRATION, ANIMAL + BIOMEDICAL + GAMMA + JAPAIV F RADIOIEDTOPF + STRQNTIUM + YTTRIUM

$15-22111$

GUPTON ED

ALPHA AIR MONITOR FDR PU-239

OAK RIDGE NATIONAL LAR., TENN.

ORNL-TM-2011 +. 15 PAGFS, 4 FIGURES, 2 TARLES, 4 FEFEFENCES, SEPTEMBER 27,1967

AN ALPHA AIR MONITOR WHICH WILL RELIABLY DETECT \& MPC-HR OF PU-239 IN THE PRESENCE DF RADON AND DAUGHTERS, IN CONCENTRATIONS WHICH VARY BY FACTORS OF MCRE THAN IOC, AND IN VARYING, MODERATE LEVELS OF GAMMA RADIATION WAS DEVELOPED AND FIELD TEST.ED. BEGINNING WITH AN EXPER IMENTAL OEVICE IN 1956, MORE REFINEU MODELS HAVE REEN PROGRESSIVELY DESIGNED AND TESTED. THE LATEST MODEL HAS GOOD SENSITIVITY AND RELIABILITY, WITH UNCOMPLICATED DESIGN AND OPERATION. THE PRINCIPAL OF OPERATION IS BASED ON THE ALPHA-TO-BETA PARTICLE EMISSION-RATE RATIO OF THE COLLECTED AIR SAMPLE.

AVAILABILITY - CLEAO INGHOUSE FOR FEOERAL SCIENTIFIC AND TECHNICAL INFORMATION, SPRINGFIELD, VIRGINIA, $\$ 3.00$ COPY, \$0.55 IMICROFICHE

\# ALPHA EMITTER + \#MONITOR, RADIATION, AIR + \#PLUTONIUM + INSTPUMENTATION, RAOIATION MONITORING

$15-22147$

SCHAEFER HJ + SULLIVAN JJ

RAOIATION MONITORING WITH NUCLEAR EMIJLSIONS ON PROJECT GEMINI. I. EXPERIMENTAL DESIGN AND EVALUATION

PROCEDUR SS--PARTIAL RESULTS CN MISSIONS C 'AND 5-

NAVAL SCHOOL OF AVIATION MEDICINE; PENSACOLA; FLA.

$N-66-26692+$ NASA-CR-75036+. 17 PAGES, FEB. 18,1966

SMALL PACKS OF NUCLEAR AND ORDINARY FILM-BADGE EMULSIONS, COMBINED WITH THERMOLUMINESCENT AND OTHER KINOS JF RADIATION SENSORS IN COMPACT, PLIABLE UNITS, WERE WORN BY ASTRONAUTS ON GEMINI MISSIGNS 4 AND 5. THESE FILMS SHOW THAT ON GEMINI ORBITS, THE BULK OF THE TOTAL MISSION DCSE WAS DUE TO TRAPPED PROTONS IN THE SOUTH ATLANTIC ANOMALY. THE LARGE FRACTION OF LOW-ENERGY 
ENVIRONMENTAL SURVEYS, MATEGORY 15 TORING AND RADIATION EXPOSURE OF MAN

$15-22147$ \#CONT INUED*

PARTICLES IN THE TR APPED RADIATION CREATES MARKED DIFFERENCES IN THE FLUX AT DIFFERENT LOCATIONS WITHIN THE VEHICLE DUE TC LQCAL ABSOP.PTION EFFECTS. MARKED VARIATIONS OCCUR ONLY MILLIMETERS ACART.

AVAILABILITY - CLEARINGHOUSE FOR FEDERAL SCIENTIFIC ANO TECHNICAL INFORMATION, SPRINGFIELD, VA., $2 \geq .00$ COPY, \$0.65 MICROFICHE

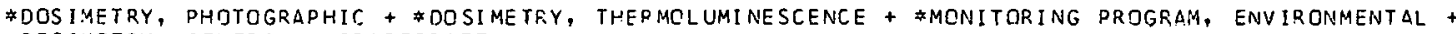
DOSIMETRY, GENERAL + SPACECRAFT

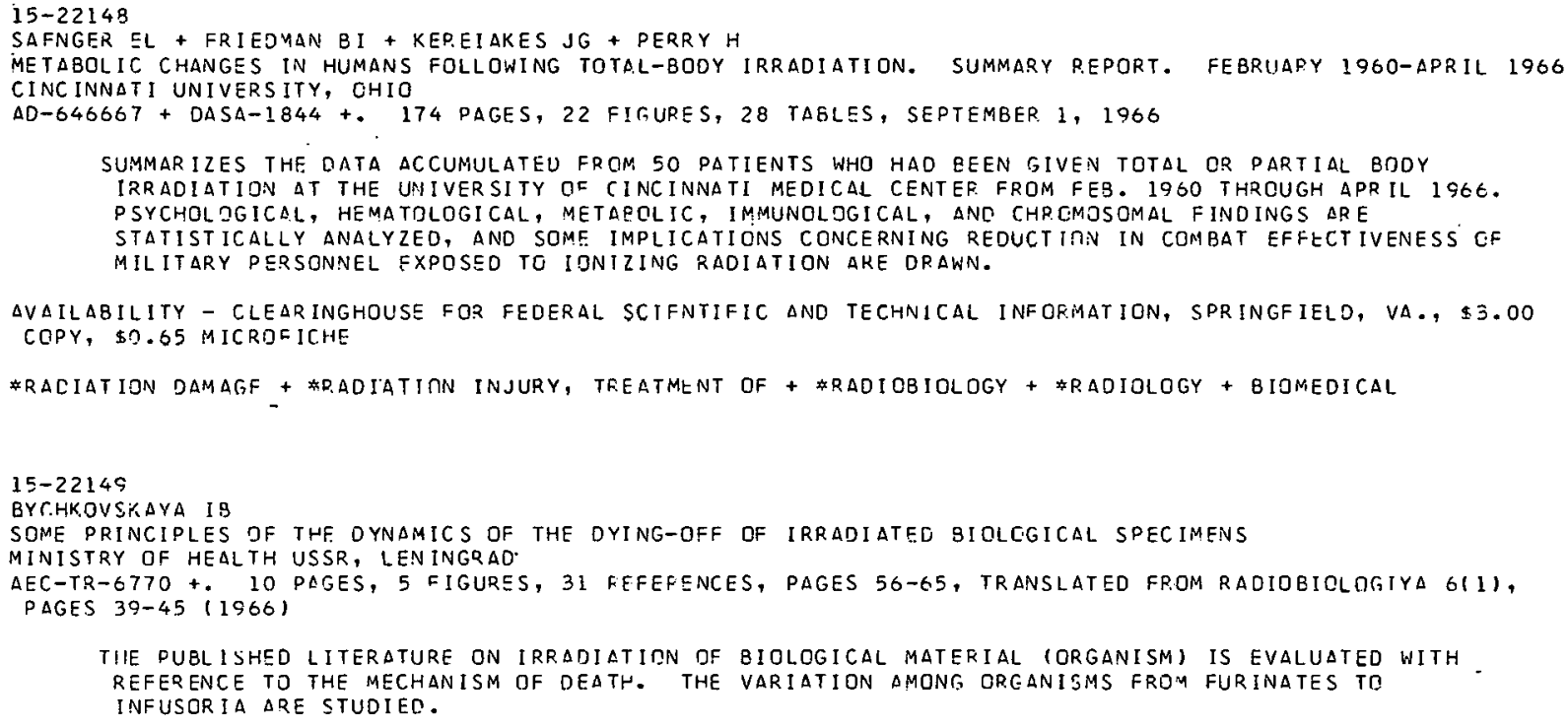


ENVIRONMENTAL SURVEYS, MONEGORY 15 TOR RADIATION EXPOSURE O'F MAN

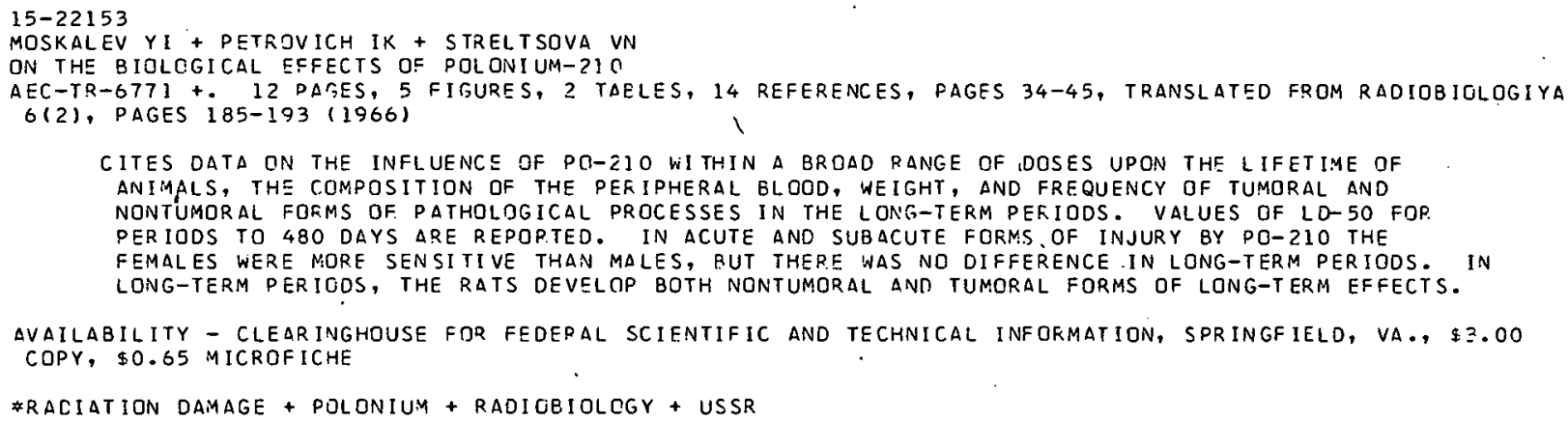


ENVIRON.YENTAL SURVEYS, MATEGORY 15 TORING AND RADIATION EXPOSURE OE MAN

$15-2224 ?$ \#CONT INUED*

DESCRIBES A RADIATION DETECTIGN SYSTEM COMPOSED OF A BETA DETFCTOR AND COSMIC-RAY DETECTOE

CDNNECTEJ WITH AN ANT ICOINCIDENCE CIRCUIT AND SHIELOING SURFCUNOING BCTH DETECTORS.

AVAILABILITY - THE PATENT OFFICE, 25 SOUTHAMPTON PUILOING, LONDCN, W. C. 2, ENGLANO, \$O.4C PER COPY

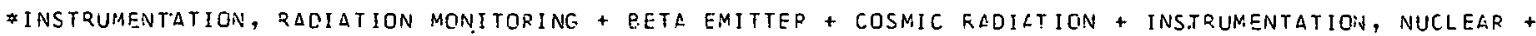
PATFNT + UNITED KINGOOM

$15-72253$

RADIOACTIVE CORDSES

1 PAGE, BRITISH MEDICAL JOURNAL 1, PAGE 331 (MAY 6, 1967 )

HAZARDS ASSOCIATED WITH HANOLING CAMAVFRS REARING CLINICAL PACIOISOTGPES ARE CONSIDERED, PARTI I ULARLY WITH REFERENCE TO A RECENT REPORT PERTINENT TC THIS PRGBLEM ISSUEO BY THE AUSTRAL IAN NATIGNAL HEALTH AND MEDICAL RESEARCH COUNCIL. WHEN D PATIENT DIES IN HOSNITAL, A 2ADIOISTIODE GIVEN TO A PATIENT A FEW DAYS BEFORE DEATH MAY EL FORGUITEN, SO THAT THERE IS A POTENTIALLY SEE ICUS QISK TO THF POST MORTEM ROCM ATTENOANT, PATHCLOGIST, OR EMBOLMER. THF AUSTQALIAN REPGRT SETS OUT A CODE OF FRACTICE FOR THE SAFE HANOLING OF CORDSES CONTAINING RADIOACTIVE SUBSTANCES AND DEALS CONCISELY AND CLEARLY WITH THF MAIN PFORLEMS.

\#R $\triangle C I O L O G Y+$ RADIATICN INJURY, TREATMENT OF + RADIATION PRQTECTION, ERCDNIZATION + RADIATION SAFETY AND CCNTROL

15-22329 ALSO IN CATEGTRY 14

REES DJ

HEALTII PHYSICS. DRINCIPLES TF RADIATION FROTECTION

242 PAGES, FIGURES, TABLES, REFEREVCES, THE M. I. T. PRESS, MASSACHUSETTS INSTITUTL DF TELHVOLOGY, CAMSR IDEE, MASSACHUSETTS, 1967

THIS MONJGPADH IS AN ATTEMPT TO PRESENT THE PPINCIPLES OF RADIATION PROTECTION AND TO MAKF AVAILABL IN A SINGLE VOLUME THE MORE IMPOKTANT NUMERICAL DATA USEO IN PADIATION-PROTFCTION APPLICATIONS. IT IS ASSUMED THAT THF READER HAS NO PREVIOUS KNOWLEDGE OF THE SUEJFT, AS FAR. AS POSSIPLE, ARGUMCNTS ARE DEVELOPED FROM FIRST PRINCIPLES SC. THAT THE BOCK WILL BE OF USE TO THOSE WITH LIMITED TRAINING IN PHYSICS, CHEMISTPY, BIULOGY, AND MATHEMATICS. CHAPTERS INCLUOE - (2) FGDIATION PROTECIION, (2) MATTER ANO RADIATION, (E) RADIOACTIVITY AND X-QAYS, (4) THE INTERACTION OF IONIZING PAOIATION WITH MATTER, (E) F.ADIATIMN ONSIMETRY, (G) THE BIOLDGICAL EFFECTS OF IONIZING FADIATION, (7) BASIC STANDARDS CF RAOIDTION DRCTSCTION, (E) PROTECTION AGAINST INTERVAL RAOIATICN, (G) PROTECTION AGAINST FXTERNAL RQDIDTIUN, (IO) DESIGN GF RADIOISOTJPE LABCRATORIES, AND (1) RATIATION PROTECTION MEASUREMENTS.

AVAILAOILITY - THE M.I.T. PRESS, MASSÁCHUSETTS INSTITUTF OF TECHNCI MGY, CAMERIDGE, MASSACHUSETTS

\#R AOIATION PROTECTTIIN, ORGANIIATION + \#PAOIOISOTOPE + \#X-RAY + COSF CALCULATION, EXTERNAL + DOSE LCLCULATION, INTEFNAL + DOSIMETRY, EENERAL + GAMMA + GAMMA EMITTER + HEALTH PUYSICS TPAINING + ICRP + RACIATION DAMAGE + FADIOBIOLOGY

15-22432 ALSO IN CATEGQRY 1.7

WAP.D WT

GENERAL DYNAMICS REDCRTS RADIATION OVEREXPOSURES

GENERAL DYNAMICS CDRP., FT. WRRTH, TEXAS

1 PASE; $\triangle T$ SMIC ENFRGY CLGARING HOUSE $13(21)$, PAGF 25 (MAY 22, 1967)

(LETTER, APRIL 25) DURING NUTHORIZEO USE OF RY-PRODUCT MATERIAL. TWO CDIFORT WDRTH IMPLUYEES WERE EXPOSEU TO 3.2 ANC 3.1 REMS THE FIRST FOUR WEFKS OF CALEINOAK 1OGE AT CAMP MCCJY, WISC. FILM-BADGE DESIILTS WERE DFIFIVED OLC. Y, 1566. CONTROL OF PERSGNNEL EXPDSURES BY LIMITING BIIKET-DOSIMETEK TOTALS SUEFICIENTLY BELOW LIMITS TO ALLOW FOR DOSIMETSR-RESPONSE VAP.IATION SHOULD PEEVENT FUTURE OVEREXPOSURE.

*MONITOR, R DDIATION, PEG SONNEL + *SAFETY MARGIN + GYPRODUCT MATERIAL + FAILURE, ADMINISTFATIVE CONTROL + INCIDENT, HUAAN ERRCD + PER SONNEL EXPOSURE, RAO!ATION + RADIATION SAFETY AND CONTROL

$15-22433 \quad \Delta L S C$ IN CATEGORY 17

MASSE FX

MIT REDORTS ASSAY EREOR RESULTS IN CLINICAL CIVEREXPOSURE

MASSACHUSETTS INST ITUTE DF TECHNOLUGY, CAMERIDGE, MASS

1 PAGE, AIOMIC ENERGY CLEARINF, HOUSE I $2(21)$, DAGE 26 (MAY 22. 1957)

(LETTER, MARCH 20) AN ADIIIT MALC HAS AUMINISTERED IODINE TO RE EQUIVALENT TO 200 MICRDCUR IES NE ID125, NELL BELOW THAT $\triangle U T H O R I Z F D ~(5$ MICFOCURJES/RG). ANALYSIS OF THF ROUTINE RIO-SAMPIFS IND ICATED ADMINISTRATION IN EXCESS OF 2OR. CHECKING REVEALED THAT A FACTOR-OF-IEN ASSAY ERROR HAD BEEN MADE BY THE PHARMACEUTICAL COMPANY. METHIMAZOLE WAS GIVEN FOR EIGHT DAYS AFTER IODINE TO INCREASE TURNOVER. CALCULATED OOSE IS SO RACS GEFORE METHIMAZOLE AND ICO RADS THEPEAFTEP. TO INFINITY. WE NORMALLY QCURLE-CHECK MATERIAL BUT NOW $h^{\prime} I L L$ PERFORM ROUTINE GROSS ASSAY DN ALL SUCH INCOMING MATERIAL.

FAILURE, ADMINISTRATIVE CONTROL + INCIOENT, HUMAN ERRQR + IGOINE + PERSONNEL EXPOSURE, RADIATIMN + RADIOLOGY 
ENVIRONMENTAL SUFVEY, MATEGORY 15 INORG AND RAOIATION EXPOSURE OF MAN

$15-22434 \quad$ ALSO IN CATEGORY 17

MALSON HA

MONSANTO REPORTS THREE EXPOSED TO AIRBQRNE DU-238

MONSANTO RESEARCH CQFP., LAYTON, OHIO

1 PAGE, ATOMIC ENERGY CLEAF.ING HOUSE 13(21), PAGE 27 (MAY 22, 1967)

ILETTER, APRIL 7) ON FEE. 13, 1967, HIGH CONCENTRATIONS OF AIRGORNE PU-23?.WERE DISCOVEREL IN A GLOVE-BOX AREA. THE INDIVIDUALS. WER. ASSIGNEC MAXIMUM EXPOSURE PERIODS OF 1 HR, 1 HR. AND 15 :IIN; RESPECTIVFLY, TU A MAXIMUM OF $1.01 \times 101-8 T H$ ) MICROCURIEICC. (CAUSE) FAILURE OF GLOVES TO WITHSTAND DELETERIOUS EFFECTS CF PU-238. OIFFERENT TYPE OF GLOVES ANE MORE FREQUENT MONITORING WILL BE CORRECTIVE STFPS. PEDORT IS LATE BECAUSE DF A MATHEMATICAL ERECR IN CONSIDERING EXPOSURE TIME VS WEEKLY MPC FOR INSOLUBLE PU-238 IN AIR.

* FAILURE", COMPONENT + \#GLOVE BOX + INHALATION + PERSONNEL EXPQSURF, RADIATION + PLUTONIUM

15-22435 ALSO IN CAYEGORY 17

NFS CITED FOR NON-COMPLIANCE WITH 10 CFR, 20

NUCLEAR FUEL SERVICES, INC., WHEATON, MD.

2 PAGES, ATOAIC ENERGY CLEAR. ING HOUSE 13121), PAGES 27-28 (MAY 22, 1967)

(LETTER, APRIL 26) BASED ON INSPECTIONS JANUARY-MARCH IOG7, CITATIDN WAS ISSUED. (1) STACK MONITORING WAS INOPERATIVE OURING FIRST HOUR OF DSC. DISSOLUTIONS JPERATICNS. OOCRS TO HIGH RADIATION AREAS NERE NOT LOCKED. (2) MAINTENANCE WOFKEFS WERE NOT SUPPLIED PERSONNEL MONITOR ING TO DETERMINE RADIATION DOSE TO HANDS AND FOREARMS. (3) VARIDUS WDRKERS WERE NOT ADEQUATELY INSTRUC.TED IN RADIATION SAFETY PROBLEMS AND TECHNIQUES. (4) SURVEYS WERE NDT PERFIRMED WHEN IT WAS NCCESSARY TO EVACUATE THE LAUNDRY BECAUSE DF THE FIXED AIR-SAMPLER READING.

FUEL-REPROCESSING + INSPECTION AND COMPLIANCE + MONITOR, RADIATICN, PERSONNEL + MONITOR, RADIATIGN, STIACK + NFS + STAFFING, TRAINING, QUALIFICATION + SURVEY, GENERAL

$15-22489$

MERRIYT WF

MONITORING JF RADIOACTIVE NOBLE GASES IN AIR

AT CIAIC ENERGY OF CANADA. LTD., CHALK. RI VEF, ONTARIO

AECL-2595 +. 10 PAGES, 4 FIGURES, 3 TABLES, 3 PEFERENCES, JUNE 1967

THE RADIOACTIVE NOBLE GAS CONTENT (AP-41, XE-133, XE-135) OF 400-LITEF. AIR SAMPLES COLLECTED IV IMETEOROLDSICAL ¿ALLONS WAS MEASURED BY GAMMA-RAY SPECTROMETRY. PARTICLES AND VOLATILES WERE REMJVEJ BY A FILTER AND A BEC OF ACTIVATED CHARCOAL IN THE SAMPLE LINE. THE BALLOONS WERE PLACED OVER A $7.6 \mathrm{CM} \times 7.6 \mathrm{CM}$ NAIITI) CEYSTAL INSIDE. A LARGE LEAD CASTLE I76 X $76 \times 7$ X CAA NITH 10 CM OF SHIELDING GN ALL SIDES. THE COUNTING EFFICIENCY OF THE CRYSTHL WITH VARYING VULUMES OF GAS IN THE EALLOONS WAS MEASURED AND GPTIMUM CONJITIONS WERE SELECTED.

AVAILASIL.ITY - CLEARINGHOUSF FOR FEUERAL SCIENTIFIC AND TECHNICAL INFORMATION, SFRINGFIELD, VA., \$?. OO COPY, \$O.65 MICROFICHE

*ANALYTICAL TEC.HNIOUE, CAL IGPATIUN + \#IISTTRUMENTATION, RADIATION MONITORING + \#MONITCR, RADIATION, GAS + FNDELE GAS + ARGON + MONIFORING SYSTEM, RADIATION + XENON

15-22518 ALSO IN CATEGORY 17

FREDERICKSON RL

ABBOIT LAB REDORTS EXCESSIVE IODINE AIR CGINCENTRATICNS

ABROTT LASOFATORIES, NOKTH CHILAGO, ILL.

1 PAGE, ATOMIC ENERGY CLEARING HOUSE $14(4)$, PAGE 19 (JANUARY 22,1968 )

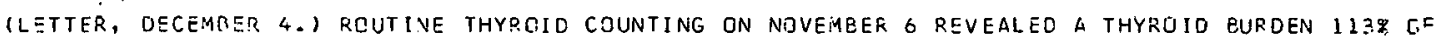
PERMISSIBLE. THE INDIVIDUAL WOP.KS IN THE P.ADIMPHARMACEUTICAL FILLING GPOUP, NOT WHERE VOLATILE I-13]. IS ORDINARILY PRESENT. WE HAVE NO AIR-SAMPLING RESULTS IN HIS AREA FOR THE PERIOD IN OUESTIGN. INVESTIGATION FAILED TO- DISCOVER A REASON FOR THE THYROID ACTIVIIY MEASURED.

- AIREORNE RELEASE + FISSION PRRDIJCT, IDDINE + SURVEILlanCE PROGRAM

15-22519 ALSE IN CATEGORY 17

ATOMICS INTERNATIONAL CITEC FGR NON-COMPLIANCE

ATOMICS INTERNATIONAL, CANOGA PARK, CALIFORNIA

1 PAGE, $\triangle T$ TMIC ENERGY CLEARING HOUSE 14(4), PAGE 20 (JANUARY 22, 1968)

ILETTER, DECEMSER 27.) A SEPT. 23-25, 1967, INVESTIGATION OF 1066 AND 1967 EXPOSURES SHOWED $T$ HE FIILLOWING - SURVEYS WERE INADEQUATE TO DETERMINE AIRBORNE CONCENTRATICNS OF URANIUM. THE U-234 SOLU3LE LIMIIS WERE USED RATHER THAN THE LI:IITS FOR INSOLUBLE U-234. GENERAL ROOM-AIR SAMPLES USED TO EVALUATE EXPOSURFS WERE A FACTOP. OF TEN LESS THAN THE BREATHING-ZONE SAMPLES. TIMELY REPORTS TO AEC WERE NOT FILEO. 
ENVIRONIAENTAL SURVEYS, MONEGORY 15 INORG RADIATION EXPOSURE OF MAN

$15-22519$ *CONTINUEO*

AIPBORNE RELEASE + INSPECTION ANO COMPLIANCE +. MONITCR, RAOIATION, AIR + SAMPLING + SURVEILLANCE PRDGRAM

15-22520 ALSO IN CATEGQRY 17

8IG RDCK POINT NON-COMPLIANCE CITATION

CONSUMERS POWER COMPANY, JACKSON, MICHIGAN

2 PAGES, ATCMIC ENERGY CLEAR ING HOUSE 14(4), PAGES 20-22 (JANUARY 22, 1968), DOCKET 50-155, TYOE--BNR, MFG-G.E., AE-BECHTEL

(LETTER, NOVEMBEQ. 2B.) CI IATION FOF INADEQUATE SURVEY TO EVALUATE RADIATION HAZAF.DS IN THE SEPT. 12, 19S7, TEMPORARY REPAIR OF A RUPTUREO DIAPHRAGM IN THE $\triangle I R-E J E C T O R$ SYSTEM. PROCEDURES DO NOT CONTAIN ADEQUATE INSTRUCTION ON EVALUATION OF RADIATION HAZARDS IN HIGH RADIATION AREAS. (REPLY, DEC. 22.) CASE WAS EXCEPTIDNAL, DLE TO FIRST-TIME DPPEARANCE OF A HIGH BETA/GAMMA RATIO 17 P.ATHEP. THAN 2 OR 3) IN PROCESS STEAM DND TO SPORADIC PUFFING OF THE IFF-GAS LEAK. ** INCIDENT WAS REVIEWED WITH STAFF, SECTION ADDEO TO MANUAL, AND NEW R ADI $\triangle T I O N-S C R E E N I N G$ LEVELS ADDED. A BETA-DETECTING INSTRUMENT WILL BE USED ON $\triangle L L$ WORK IN MORE THAN I REM/HQ. NEW SURVEY INSTRUMENTS ANO CALIBRATION SOURCE WERE OF.DERFD.

*MAINTENANCE ANO REDAIR + \#OEP SONNEL EXPOSURE, RADIATION + \#REACTOR OFFGAS + BETA EMITTER + BIG ROCK DOINT (SWR) + FAILUPE, ADMINISTRATIVE CONTROL + FAILUFE, CPERATOR ERROP + INSPECTION ANO COMPLIANCE + MONITOF, RACIATION, PERSONNEL + PROCEDURCS ANO MANUALS + PEACTOR, BWF + SURVEY, PADIATION, GENERAL

$15-22526 \quad \Delta L S O$ IN CATEGQRISS 13 AND 17

CP.ON IN DF

UNITED NUCLEAP, REPOPTS GVEREXPOSUR. TO AIREURNE ACTIVITY

UNITED NUCLEAR CURP., NEW HAVEN, CONN.

1 PAGE, ATOMIC ENCQGY CLEARING HOUSE 1414), PAGE 27 (JANUARY 22, 1968)

(LETTER, OEC. 13.) THPEE RECEIVED I. 9 TIMES MAXIMUM ALLOWABLE WEEKLY EXPOSURE, IN FOUR HOURS, TO AIRBORNE ILTIIA EMITILY OUPING CLEANUP OPERATIONS. MSA COMFO RESPIRATOPS WITH TYDE-II ULTRAFILTERS VEP.E WORN. NO FPOTECTION FACTOR ASSUMEO. \# INCFEASED HP COVERAGE ANO EXPOSURE CJNTPOL DURING NONROUTINE CPERATICNS WILL BE PROVIDED. APPLICATION WAS MAOE FOF USE OF A RESPIRATORY PROTECTION FACTOP.

\#DECONTAYINATION + \#INHALATICN + FPERSONNEL EXROSURE, RADIATION + ALPHA EMITTER + FILTER EFFICIENCY + FILTER, GAS MASK + PERSONNEL PROTECTIVE DEVICE

$15-22527$ ALSG IN CATEGORY 17

BURTSAVAGE EM

U.S. RADIUY ASKS CLARIFICATION OF BPEATHING ZONE SAMPLES

U.S. RADIUM CORP., BLOOMSBURG, PA

1 DAGE, $\triangle T$ TOMIC ENERGY CLEARING HOUSE 14(4), PAGE 27 (JANUARY 22,1968 )

(LETTER, NOV. 28.$)$ REPCRTS EXCESSIVE CONCENTRATIDNS OF AIPRORNE AMERICIUM DURING WEEK OF SFPT. 4, 1967. THIS WAS NOT REPORTEO ON OCT. 18 BECAUSE WE INTERPRETED 10 CFR 20.103 TO MEAN THAT RDON-AIR. CCNCENTRATIONS APPLY TO ANY PER SONNEL NOT SAMPLFD IN THEIR EREATHING ZONES. HDWEVER, ALL PERSONS WERE BZ SAMPLED SIMULTANEQUSLY, WHICH WAS CONSIDERED MORE VALID THAN FOOM-AIR SAMPLES, ANO THUS 5 PEFSONS WERE NOT REPORTED, WHILE 4 WERE REPOFTED DN THE $3 A S I S$ QF THEIR B-Z SAMPLES. PLEASE CLAFIFY THIS INTERPRETAIION.

* INHALATION + \#PRRSTNNEL PROTECTIVE DEVICE + \#SAMPLING + AMERICIUM + INSPECTION AND COMPLIANCE + PERSINNEL EXPOSURE, FADIATION + RADIATION SAFETY AND CONTROL + REGULATION, AEC

$15-22551$

FURUTAY + KANEMOR I Y

EXPERIMENTAL STUOIES ON GAMMA-RAY DOSE RATES FROM A CO-6O CYLINDRICAL SOURCE

JAPAN ATOMIC ENERGY RESEARCH INSIITUTE + MITSUI SHIPBUILDING ANO ENGINEERING CO., LTD.

7 DAGES, \& FIGURES, I TABLE, NUCLEAF SCIENCE AND ENGINEERING 三0, PAGES 261-267 (1967)

GAMMA-RAY DOSE RATES FREM A CO-GO CYLINDRICAL SOURCE WERE TRTAINED EXPERIMENTALLY IN THE RADIAL OIRECTION AT THE HALF-HFIGHT OF THE SOURCE. THE CONCEDT OF THE DOSE-BUILDUP FACTOR WAS INTRDDUCED FOK A VOLUME SOUPCE. THE FACTOR FOR A CYLINDPICAL SOURCE WHICH IS REPRESENTED AS A FUNG TION OF THE DISTANCE BETWEEN SOURCE AND DETECTION POINT, HAS A VALUE OF ABOUIT FIVE AT THE DOINT NEAREST TO THE SOUPCE SURFACE. THE FACTOF. THFN DECREASES RAPIDLY, PASSES THRDUGH A MINIMUM VALUE, AND APPROACHES A CONSIANT VALUE. THESE FEATURES WERE ANALYZED EXPER IMENTALLV WITH A LINE AND A DISK SOLRCE. AN EMPIFICAL FORMULA FOR THE OCSE-GUILDUP FACTJR IS DROPGSED WHICH AGREES WITH THE EXPSPIMENTAL VALUES TO WITHIN ARMITT RLUS OR MINUS $15 \%$.

\#OOSE MEASURLMENT, EXTERNAL + CORALT + JAPAN

$15-22572$

KHOL G

PERSONAL DJSIMETRY IN THE USE OF RADIATIEN FOR NTMNESTRUCTIVE MATERIALS TESTING 
ENVIRONMENTAL SURVEYS, CATEGORY 15

$15-22572$ \#CONT INUED*

4 PAGES, I Figure, 7 TAELES, JAD. ENERG., 12, PAGES 146-S (APRIL 1966). IN CZECF

THE REQUIREMENTS OF THE CZECHOSL OVAK PEGULATICNS CONCERNING THE FERFORMANCE OF PER SONAL DOSIMETERS WORN BY WORKERS ENGAGED IN THE NONDESTRUCTIVE TESTING OF MATEP.IALS BY RADIOACTIVE METHODS ARE MET EY TWO TYPES OF DOSIMETERS, WHICH ARE, HOVIEVER, UNSUITABLE FOR WORK ON BETATRDNS. FOR PERSONS WORKING WITH X-RAYS, FILM-BAOGE DOSIMETERS AND BL IND CHAMBERS ARE APPROVED, WHEFEAS FILM-8ADGE DOSIMETEPS AND FOCKET IONI ZATION CHAMBERS ARE MANDATORY FOR WCRK WITH RADIOISOTOPES. AN ACCURACY OF PLUS OR MINUS 10 TO $25 \%$ IS REGAROED AS SUFFIC IENT.

\#DOSIMETRY, GENERAL + \#DOSIMETRY, PHOTOGRAPHIC + ACCELERATOR + CZECHOSLCVAKIA + DOSE YEASUREMENT, EXTERNAL + RADIOISOTOPE + X-RAY

$15-22573$

DDBYNA BM

A STUDY DF THE PHYSIOLOGICAL FUNCTION AND HISTOLOGICAL CHANGES IN THYROIDS IRRADIATED WITH RADIOACTIVE

IODINE. ANNUAL REPCFT, JUNE 1,1966 -JUNE 1,1967

NESTERN RESERVE UNIVERSITY, CLEVELAND, OHIO

COO-1243-8 +. 8 PAGES, 6 PEFERENCES, JUNE 28,1967

A BROAD STUDY HAS BEEN MAODE OF PHYSIOLOGICAL AND MORPHOLOGICAL CHANGES PROCUCED BY IODINE-13I IN. THE THYRJIO OF ANIMALS AND MAN. ACTIVITIES COVERED INCLUOE - THE STUDY OF RAOIATION EFFECTS ON THYRDID FUNCTION IN CLINICAL SUBJECTS GIIVEN I-131, NUCLEAR CHANGES IN HUMAN RADIATED THYRQIO TISSUE, A STUDY OF NUCLEAR CHANGES AT THE TIME OF NEOPLASM fORMATION.

FOLLOWING I-13! IN RAT THYROIDS, CHROMOSOMAL ABNORMALITIES IN CIRCULATING LEUKOCYTES OF

PATIENTS TREATED WITH I-131, AND X-RAY RADIATION EFFECT ON THE THYROID.

AVAILABILITY - CLEARINGHOUSE FOR FEDERAL SCIENTIFIC AND TECHNICAL INFGRMATION, SPRINGFIELD, VA., \$3.00 COPY, \$0.65 MICROFICHE

\#RADIATION DAMAGE + \#FADIOBIOLOGY + BIOMEOICAL + IODINE + RADIOLOGY + X-RAY

$15-22802$

KOCHR + SEITER I + MOENIG H

INVESTIGATIGNS ON BIOLOGICAL PADIATION PROTECTION. PART 79. EFCECTS. OF RESERPINE, NARCOTICS, ANO BODY TEMPERATURE ON UTILIZLTION OF RADIOIRON WITH RADIATICN-CONDITIONED INJURIES UNIVERSITY OF FREIBURG

11 PAGES, 4 FIGURES, 5 TABLES, STRAHLENTHERAPIE 133, PAgeS $296-306$ (JUNE I9G7) IN GERMAN

the efFects dF fasting, magaphen, Nembutal, reserpine, and a mixture of atosil, dolantin, and MEGAPHEN ON FE-SS METASOLISM IN WHOLE-BODY X-IRRADI ATED MICE WERE STU.DI EO. RESERPINE DROVOKED A DROP IN EOOY TEMPERATURE AND A DECREASE IN FE-59 UPTAKE. IT ALSO EXERTEO A. STRONG RAOIOPROTECTIVE EFFECT. PROTECTIVE EFFECTS WERE ALSO OBSERVED WITH MEGAPHEN AND THE MIXTURE OF ATOSIL, DOLANTIN, AND MEgAPHEN AT A DOSE OF 75 R. FASTING AND NEMBUTAL DECREASED FE-59 IVCOKPORATION.

\#PAOIATION DAMAGE + \#RADIOBIOLOGY + GERMANY + IRON + RAOIATION INJURY, TREATMENT OF +

RADIATIUN PROTCCTION, THFMICAL + X-RAY

15-22805 ALSO IN CAIEGDRY 14

PFEIFFER EW

HAZARDS OF IODINE-131 FALLOUT IN UTAH

UNIVERSITY OF MONTANA

2 PAGES, SCIENCE $158(3799$ ), PAGES 397-398 (DCTOBER 20, 1967)

PRESENTS A BRIEF SUMMARY JF THE PROGRAMS TO BE PRESENTED AT AAS MFET ING DECEMBER 1967 DN

FALLDUT OF IOCINE IN SOUTHERN UTAH RESULTING FROM WLAPONS TESTING IN SOUTHERN NEVADA. IT IS SUGGESTEU THAT THYROID DOSES OF 50 TO 120 RADS MAY HAVE GEEN RECEIVED BY CHILOKEN IN SOUTHERN UTAH WHO WERE 2 TO 5 YEARS OLD DURING 1952-1955.

* DOSE CALCULATION, INTEENAL + \#FLLQUT + \#IODINE + \#TEST, WeAPONS (HP ASPECTS) + BIOLOGICAL CONCENTRATION, MAN

$15-22808$

SCHNEIDER $C+$ LINDEN WIA

HHOLE-BODY MEASUREMENTS WITH NAI CRYSTALS. SENSITIVITY AND ACCURACY OF MEASUREMENTS WITH VAREOUS DETERTMR ARRANGEMENTS.

UNIVERSITY OF HAMBURG

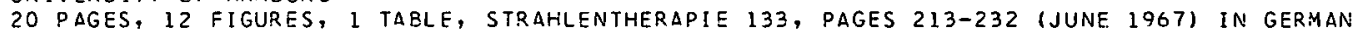

A WHULE-BOOY CGUNTER WITH FQUR NAI CRYSTAL DETECTORS WAS USED AS A REFERENCE IN EVALUATION GF A SINGI E-CRYSTAL DEVICE WITH IILTING CHAIR, LINF ARRANGEMENT DF THE DETECTORS, AND SIMPLE SCAN MEASUREMENTS WITH TWO AND FMUR DETECTORS. HIGHEST SEINSITIVITY FMR GAMMA SOURCES WAS OSTAINED WITH THE TILTING CHAIR. FOUR DETECTURS IN LINE WERE MOST EFFECTIVE IN MEASURING I RREGIJLAR DISTR IBUTED SOURCES. THE LINEAR ARRANGEMENT IS MOST EFFECTIVE FOR RADIOPROTFCTIVE INVESIIGATIONS. FOR CLINICAL USE, THE LINE DEVICE OR THE MODIFIED SCAN MEASUREMENTS ARE BEST SUITED. 
ENVIRONMENTAL SURVEYS, CATEGTORY 15 PONG AND PADIATION EXPOSURE OF MAN

15-22808 *CONTINUED*

COUNTER, WHOLE BODY + GERMANY + INSTRUMENTATION CALIQRATION

15-22813 ALSO IN CATEGORY 14

DATA - SECTIDN IV. OTHER DATA

US PUPLIC HEALTH SERVICE

10 PAGES, 7 TABLES, 4 FIGURES, RADICLOGICAL HEALTH DATA AND REPCRTS $8(11)$, PAGES 664-673 (NDVEMEER 19h7)

THIS SECTIJN CONTAINS REPORT ON SR-90 IN HUMAN VERTAgGAE CQLLECTED IN 1966 IN NEW YORK C.ITY AVO IN SAN FQANCISCD. REPORTS ENVIRONMENTAL SURVEYS FOR THRFE SITES OF THE LAWPENCE

RAOIATION LABORATORY (JULY-DECEMBEF 1966 ) ANO CF MOUND LABORATORY I JULY-DECEMBER DND ANNUAL

SUMMARY 1966). THE USAEC REPORTED UNGERGR.OUND NUCLEAR TESTS AT THE NEVADA TEST SITE IN

CCTOBER 18, 1967, AND ON OCTOBER 25. IN ARDITICN THE AEC REPOPTED SEISMIC DATA ON OCTOBER 17

AND OCTOBER 23, 1967 , INDICATINS SGVIET NUCLEAR TESTS IN SIEERIA.

\#FALLOUT + \#MONITOR ING PROGRAM, ENVIRONMENTAL + \#SURVEILLANCE PRCGRAM + BIOLOGICAL CONCENTRATIJN, MAN + LRL + MJUND LABORATRPY + STRONTIUM + TRITIUM + WATER, CENERAL

$15-22818$

HEPNACI $C$, NAGY $Z$

CHEMICAL RADIATION-PRITECTIVE AGENTS

GYOGYSZEFTANI INTEYZET DEERECEN, HUNGAP.Y

7 PAGES, 3 FIGURES, DPV. HETILAP 106, PAGES 1369-75 (JULY 18, 19E5), IN HUNGARIAN!

A SURVEY OF CHEMICAL RADIOPROTECTORS IS GIVEN WHICH INCLUDES 45 RFFEPENCES. THE BIOLOGICAL EFFECTS OF IONIZING RADIATION ARE DISCUSSED IN RELATION TO THE ACTION OF THE VAPICUS CHEMICAL RADIOPROTECTIVE AGENTS. THERE ARE OIFFFRENT MECHANISMS THPOUGH WHICH THE RADIO-SENSITIVITY OF EACH SYSTEN MAY PF PEDUCEC OY THE USE DI DIFFERENT CHEMICAL AGENTS. VAFIOUS CHEMICAI AGENTS OF DIFFERING STRUCTURES MAY SHCW SIMILAR PROTECTIVE EFEECTS SY THE SAME MECHANISM. AT THE SAME TIME, THE SAME CHEMICAL AGENT MAY ACT BY A DIFFERENT PROTECTIVE MECHANISM, DEPENCING ON THE SYSTEA TO WHICH IT IS APPLIED. IT IS POSSIBLE FOR VARICUS MECHANISMS TO ACT

SIAULTANEOUSLY IN THE SAME SYSTEM. RESEARCH CN THE MECHANISM CF THE EFFECT DF CHEMICAL RADIOPROTECTORS IS LINKED CLOSELY WITH RESEARCH ON THE ANALYSIS OF RADIATION SENSITIVITY CF THE TARGET S'JESTANCE (E.G., DNA).

* RADIATION PROTECTION, CHEMICAL + BIOMEDICAL + HUNGARY + RADIATION DAMAGE +

RADIATION INJURY. TREATMENT OF + RADIOBIOLOGY

15-2282E $\quad$ ALSC IN CATEGORY 17

SLCOND DRL INAORMATICN LETTER ON RACIOTRRAPHIKS IIVEREXPUSURE

USAEC, DIVISION OF STAIE ANU LICENSEE RELATICNS, WASHINGTON, D. C.

6 PAGES, INFORMATIJN LETTER TO ALL RADIOGPAPHY LICENSEES, JUNE 14, 19t5

SUMMAP. IZES 14 INCIOENTS THAT CCCURRED SINCE FIRST LETTEP. (MAR.CH 1963). AGAIN, THE CAUSE FOR MOST OF THEY (DOSES 1 TO 16 PEMS) CAN BE TRACED TO THE FAILUEE GF RADIOGPAPHERS TO PR.QPEFLY USE RADIATION-SURVEY INSTRUMFNTS. ASKS CONTINUED INTERFST OF LICENSEE. MANAGEMENT TD REVIEW OPERATIONS AND EQUIPMENT AND TO STRESS SOUNC PROCEDURES AND ATTENTIDN TO EQUIPMENT.

AVAILABILITY - USAEC, DIVISION OF STATE ANO LICENSEE RELATIONS, WASHINGTON, D. C.

FAILURE, OPERATOP. FRRDR + INCIDENT, HUMAN ERFOR + INFOPMATION RETFIEVAL + PERSONNEL EXFOSURE, PADIATION + RADIATION SAFETY AND CCNTRDL + RADIQGRAPHY

15-22827 ALSO IN CATEGORY 17

DRL INFORMATION LETTER ON PADIOGRAPHERS OVEREXOOSURE

U. S. ATOMIC ENFRGY COMMISSIUN, WASHINGTGN, D. C.

6 PAGES. INGORMATION LETTER TO ALL RACIOGRAPHY LiCENSEes, MARCH 1963

GIVES ONE-PARAGRAPH DESCRIPTIONS TIF 14 CASES (DOSES, 2 TO 6 PEMS) WHERE RACIOGRAPHERS WERE EXPOSED TO UNSHIELDEO SOURCES (OUE TO WARNING-SYSTEM FAILURES OR. HEEDLESS ACTION) WHICII (OULD HAVE BEEN PREVENTED HAD THE OPERATCR USEO SURVEY INSTRUMENTS EACH TIME (AS IN $1 C$ CFR 34.43 ). ASKS THE LICENSEES TO REQUIRE THAT RADIDGF.APHERS REAO LETTEF AND TO STRESS PROPER USE OF SURVEY INSTRUMENTS IN PERIOOIC TRAINING PROGRAMS.

AVAILABILITY - USAEC, DIVISION OF LICENSING ANO REGULATION, WASHINGTON, D. C.

\#INCIOENT, HUMAN ERROR + \#RADIQGRAPHY + FAILUPE, OPERATQR ERROR + INFGPMATION PIETRIEVAL + FLRSONNEL. CXFOSURE, RADIATION + RAOIATION SAFETY ANU LUNIYSLL

$15-22929$

CLOUTIER. RJ + D-FOGHLUOHA F + COMAS FV

CONFERENCE ON DOSIMETPY OF. TDTAL-BODY IPSADIATICNS EY EXTERNAL PHOTCN EEAMS, OAK RIDGE, TENN., FEBRUARY 23-24, 1967

OAK RIDGE ASSOCIATED UNIVERSITIES, INC. TENN.

CONF-67C?19+. 32 DAGES, 2 FIGURES, 4 TABLES, 31 REFERENCES, FEs. 1067 
$15-22929 \quad$ \#CONTINUE[*

SUMMARIZES DISCUSSIONS AT THE CONFEPENCE. THE PURPOSF OF THE CONFERENCE WAS TO REVIEN WORK ON TOTAL-BODY IREADIATION AND, IF POSSIBLE, TO ARRIVE AT A CONSENSUS ON A UNIFORM WAY OF REPORTING THE DOSE DILIVERED. D! SCUSSICIN WAS RESTRICTED TO PHOTON IRRADIATION, WITH EMPHASIS GN THE PHYSICAL RATHER THAN ON THE BIOLOGICAL ASPECTS. IT-W:AS SUGGESTED THAT - (1) THE CHARACTER ISTICS OF THE KADIATION FIELD USED SHOULD BE STATED, (2) THE AVERAGE DCSE IN THE TARGET DRGAN AND THE ME THOO GF TALCULATION GR MEASUREMENT SHCULD BE GIVEN, (3) THE MAXIMUM LNO MINIMUM DOSES IN THE REGION DF INTERTST OR SOME OITHER INDICATION OF THE DEGREE OF NONUNIFORMITY SHOULD BE REPOFTED.

AVAILABILITY - CLEARINGHOUSE FOR FEDERAL SCIENTIFIC ANO TECHNICAL INFORMATION, SPRINGFIELD, VIRGINIA, $\$ 3.00$ COPY, \$0.65 MICROF ICHE

\#DOSE + \#RADIOBIOLOGY + DOSE MEASUREMENT, EXTERNAL + GAMMA + RADIATION INJURY, TEEATMENT OF + RADIOLOGY + $X-R A Y$

$15-22930$

KAKINA VK

CHANGE IN THE SECRETCRY ACTIVITY OE THE THYROID GLAND AFTER TOTAL X-RAY IRRADIATION

AEC-TR-6601 t. 4 DAGES, 2 TLELES, 3 REFERENCES, RADIOPIOLOGY 5(4), PAGE 56-59, (1965)

IMATURE MALE P.ATS WERE SUBJECTED TO SINGLE TOTAL X-RAY IRRADIATION OF 75, 500, AND $200 R$, FOLLOWING WHICH I MILLICURIE OF I-131 WAS GIVEN AT VARIOUS PERIODS AFTER IRP.ADIATION. EVALUATION DF THE RAT THYPOIDS INOICATES THAT SECRETION AND ELIMINATION OF THE THYROXINE WERE DISTURBED.

AVAILABILITY - CLEAPINGHOUSE FOR FECERAL SCIENTIFIC AND TECHNICAL INFOFMATION, SPRINGFIELD, VIRGINIA, $\$ 3.00$ COPY, \$0.65 MICRCIFICHE

* RADIATION DAMAGE + *RADIOBIOLOGY + BIOMEDICAL + IODINE + USSR + X-R.AY

$15-22931$

EIBIKOVA AF + LEREDEV BI

MORPHOL OGICAL CHAVGES IN THE NERVOUS SYSTEM OF OOGS UNDER THE ACTION OF HIGH-ENERGY PROTONS

$\triangle E C-T R-6 S O I+.5$ PAGES, 3 FIGURES, IO REFFRENCES, RACIOBIOLOGY 5(4), PAGE, 116-120, (1965)

WOKK IS REPDRTED GN CHANGES IN THF NERVDUS SYSTEM OF DOGS AS A RESULT OF A SINGLE TOTAL I RRADIATION SY $5 I$ C-MEV PROTONS. THE EFFFCT OF PROTON IRRADIATION IS SIMILAR TO THAT DF GAMMA AND BETA RADIATION.

AVAILABILITY - CLEAR.INGHOUSE FOR FEDERAL SCIENTIFIC AND TECHNICAL INFCRIATIDN, SPRINGFIELD, VIRGINIA, $\$ ? .00$ COPY, $\$ 0.65$ MICFGF ICHE

\#R $\triangle$ CIATION DAMAGE + BETA EMITTER + GAMMA + RADIOBIOLOGY + USSF:

1b-23Ib3 ALSL IN LAIEGUR: 1 L

RILEY JT + TONGUDAI M

CESIUM $\triangle N$ R RUIRTDIIIA IN SEA NATEL

UNIVERSITY DF LIVERPGOL

4 PAGES, REFER ENCES, GHEMICAL GEOLOGY 1, PAGES 291-4 (DEC. 1966 )

A CATION EXCHANGE SCHEME NAS DEVELOFFD FOR SEPARATING CS AND PB FREM SEA WATER PRIOR TO THEIR SPECTRUGRAPHIC DETERMINATION. CONCENTRATIONS OF 119 PLUS GR. MINUS 4 MICROGRAMS RB/1 AND O.55 PLUS OR MINUS 0.06 MICPOCRAM CS/! WERE FOUND FOF IRISH SEA SURFAC.F WATFR AND FOP WATER FROM THE NOSTH ATLANTIC.

\# ANALYTICAL TECHNIQUE, LIQUID + \#CESIUM + *ION EXCHANGE + \#PUBIDIUM + ACTIVATION

$15-23154$

KORANDA JJ

RESIDUAL TRITIUM AT SEDAN CRATER

CALIFDRNIA UNIV., LIVEPMORE. LAWRENCE RALIATION LAB.

UCRL-70292 + CONF-670503-9+. 36 OAGES, DYRIL 2,1467 , PRESENTED AT 2 NO NATIONAL SYMPOSIUM DN

RACIOECOLDGY, ANV ARBOR, MICHIGAN

QESIDUAL TRITIUM FROM THE SEGAN THEPMONUCLEAR DETONATION, 6 JULY I 762 , WAS SCAVENGED BY OR ENTRAINED IN THE 5-6 MILLION TQNS C'F EARTH MATEPIIALS MOVED BY THE DETCNATION. AS A RESULT, THE SEDAN PDST-SHOT ENVIRONMENT C.ONTAINED A MOST SIGNIFICANT BIGLOGICAL TRACER IN THE FORM OF THO. RESIDUAL TRITIUM (THO) IS FOUND IN MICROCURIE CONCENTRATIONS IN THE INTERSTITIAL WATER OC THE SEDAN THROWGUT SOIL, AND IN THE LOGSE TISSUE WATER OF PLANTS WHICH HAVE PE-INVADED THE NEW SUBSTPATUM DEPOSITED ON THE LANDSCAPE ADJACENT TO THF CRATEP. TRITIUM IS PRESENT NOT DNLY IN THE LOOSE TISSUE WATER OF VASCIIIAR PLANTS GROWING ON THE SEDAN THROWOUT, BUT A COMPARABLE LEVEL IS ALSO FOUND IN THE TISSUE-BOUND HYDROGEN OF THESE PLANTS. HERBIVCDES, MAINLY HETEQOMYIC RODENTS, WHICH HAVE RE-INVADEO THE SEOAN PGST-SHOT ENVIRONMENT AND P.ESIDE THERE, ALSJ HAVE TRITIUM CONCENTEATIONS IN THEIR 3OOY WATEP BETWEEN 1 AND 3 . MICROCURIEIML. THESE BODY-WATER TRITIUM CONCENTRATIONS ARE CLOSELY DELATED TO THE LEVELS OF TRITIUM IN THE PLANT TISSUE-EOUND HYDRDGEN. THE INTERNAL DOSF TO THE FESIDENT MANNAL AT SEDAN CPATER FROM RESIDUAL TRITIUN IS ESTIMATEO TO BE BETNEEN 18 ANO 268 RAD, OR ABOUT IO TIMES THAT FFOM 
ENVIRONMENTAL SURVEYS, MONEGORY 15 INOFG FANOIATION EXPOSURE OF MAN

15-23154 \#CONTINUEO*

EXTERNAL RAOIATION SOURCES RESULTING FROM THE. DETONATION.

AVAILAQILITY - CLEARINGHOUSE FOR FEOEPAL SCIENTIFIC AND TECHNICAL INFCRMATION, SPRINGFIELD, VIPGINIA, $\$ 3.00$ COPY, \$0.65 MICROFICHE

* ecological consideration + \#nueleaf detonation + \#tritium + biological concentration, general + DIETARY HABIT + HYOROGEN

15-23155 ALSO IN CATEGDRY 14

NELSON WC + WHICKEQ FW

CS-137 IN SOME COLORADO GAME FISH, 1955-66

COLORADO DEPT. OF GAME, FISH, AND PAPKS. COLOFADO STATE UNIV., FOK COLLINS. DEPT. OF FADIOLOGY ANO RADIATION BIOLOGY

COO-1156-21 + CONF-670503-1 +. 23 FAGES, JAN. 1967, PRESENTED AT 2NO NATIONAL SYMPDSIUM ON RADIOECOLOGY,

ANN $\triangle R B O R$, MICHIGAN

IN 1955 ANO 1966 THE CS- 137 CONCENTRATION IN MUSCLE TISSUE OF 132 FISH REPPESENTING EIGHT GAME FISH SPECIES FPOM 23 COLORADO WATERS VARIED FROM NONDETECTABLE (LESS THAN 50 PC/K.GM) TO $58 C O$ PC/KGM. WATERS SAMPLED [NCLUDED 3 PLAINS, 2 FOOTHILLS, 5 MONT $\triangle N E$ AND 12 ALPINEFESERVOIRS AND LAKES AS WELL AS ONE TROUT STREAM. ELEVATION OF THESE WATERS VARISD FPOM 1,538 TO 3,498 METERS. LAKE DEPTHS VARIED FROM 1-45 METERS, LAKE AREAS FROM 1.4 TO 230 HECTARES AND LAKE WATERSHED ARFAS, WHERE MEASUFED, FFOM 53-2, 480 HECTARES. CONDUCTIVITY UF WATEPS VARIED FFOM 8 TO 1390 MICROMHOS AND DOTASSIUM C.ONCENTRATION FRDM 0.1 TO 3.1 PPM. RASED ON 6 SAMPLES, CS-137 CONCENTRATIONS WERE 2 TO 7 TIMES GREATER IN 1965 THAN 1966 . BIOLOGICAL CONCENTRATIONS OF CS-137 ARE GIVEN FOP DIFEERENT LOCATIONS.

AVAILABILITY - CLEARINGHOUSE FOR FEDEPAL SCIENTIFIC AND TECHNICAL INFCRMATION, SPRINGFIELD, VIRGINIA, $\$ 3.00$ COPY, \$0.55 MICR.CFICHE

* BIOLjgICAL CONCENTRATION, aQUATIS ORgANISMS + *CESIUM + \#SAMPLING, HIGH ALTITUDE + COUNTER + DIETARY HABIT + ECOLOGICAL CONSIDERATION + FALLOUT + RADIOBIOLOGY

$15-23156 \quad \Delta L S E$ IN CAIEGDPY 14

PALMEQ HE + WOGMAN NA + COOPER JA

THE DETERMINATION JF THE DEDTH AND AMOUNT OF PU-230 IN WOUNDS WITH SIILI) DETECTORS

BATTELLE-NDFTHWEST, RICHLANT, WASH. PACIFIC NOPTHWEST LAS.

BNWL-SA-1261 + CONF-670521-4 + CONF-670610-1 +. 17 PAGES, MAY 15, 1967, PRESFNTEO AT THE $12 T H$ ANNUAL MEETING OF THE HEALTH PHYSICS SOCIETY, WASHINGTON, D. C.

A METHOD HAS BEEN DEVELQPED FOR. DEFINING THE AVERAGE DEPTH OF DU-239 IN WOUNDS BY X-RAY SPECTROMETRY USING A LITHIUM DRIFTEL SILICON DETECTOR. THE USE OF THIS METHOD ON ACTUAL PU WOUND CASES IS DESCRIBED.

AVAILABILITY - CLEARINGHOUSE FOR. FEDERAL SCIENTIFIC AND TECHNICAL INFORMATION, SPRINGFIELD, VIRGINIA, $\$ 3.00$ CUPY, \$0.65 MICRCFICHE

\#COUNTER + \#INSTRUMFNTATION, CONTROL + \#DLUTONIUM + \#X-RAY

15-23158 ALSG IN CATEGGRY 14

FNVIRONMENTAL MONITORINC ASSOCIATEO WITH DISCHARGES OF RAUIUACTIVE WASTE DURING 1OGG FROM. U.K.A.E. ESTABL ISHMENTS

UNITEG KINGTIM ATIMIL ENERGY DUTHORITY, HARWCLL (ENGLAND). AUTHORITY HEALTH AND SAFETY RRANCH

AHSBIRP)R-79 +. 20 PAGES, 20 TABLSS, 6 REFERENCES, AUGUST 1967

THIS REPORT DESCEIBES THE RESULTS OF THE ENVIRONMENTAL MONITOFING UNDERTAKEN TO CONFIRM THAT THE DISCHARGES OF RADICACTIVE WASTE DUR ING ICEG FROM EACH OF THE PRINCIPAL UKAEA EST $\triangle B L I S H M E N T S$ PRODUCEO NO HAZARD IN THE ENVIFONMENT. THE RESULTS OF THIS MONITOPING ARE SUMMARIZED ANC ARE COMPARED WITH DERIVED WORKING LIMITS TO FACILITATE AN APPRECIATION OF THE STANDARDS OF SAFETY ACHIEVED.

AVAILABILITY - CLEARINGHOUSE FOR FEDERAL SCIENTIFIC AND TECHNICAL INFORMATICN, SPRINGFIELD, VIRGINIA, $\$ 2.00$ CDPY, $\$ 0.65$ MICROF ICHE

hHAZAROS ANALTSIS + FMONIIUKING PROGRAM, ENVIRONMENTAL + *WASTE TREATMENT, GENERAL + WASTE DISPOSAL, LIQUID + WASTE DISPOSAL, SOLII

$15-23159$

DIGGLE WR + GAUNT AJ + MELHUISH KQ + NEWMAN EE

METHODS IN USE AT D.E.R.E. FOF THE MEASUPEMENT OF BURN-UP OF NUCLEAR FUELS AND NEUTRON DCSE

UNITED KINGOOM ATOMIC ENERGY $\triangle U T H O R I T Y$, DCUNRFAY (SCOTLAND). FEACTOR GROUO

TRG-RSPORT-1494 +. 25 PAGES, 2 FIGURES, TABLES, 22 REFERFNCES, $\triangle P R I L 17,1967$

THE METHODS CUPFENTLY IN USE AT DEPE FOR ROTH BURNUP DND NEUTFON-DOSE MEASUREMENTS ARE DESCRIBED, AND THE CALCULATIONS AND NUCLEAF DATA USED ARE GIVEN. METHCDS INCLUCE MEASUREMENT DF CHANGES IV I SOTOPIC COMPOSITION DF FUFL, MEASUREMENT OF RADIOACT IVE AND STABLE FISSION DLODUCTS, AND THF .USE OF FLUX MONITORS. THE LIMITATION AND ACCURACY OF EACH METHGD 
ENVIRONMENTAL SURVFYS, MATEGORY 15 INORING AND RADIATION EXPOSURE OF MAN

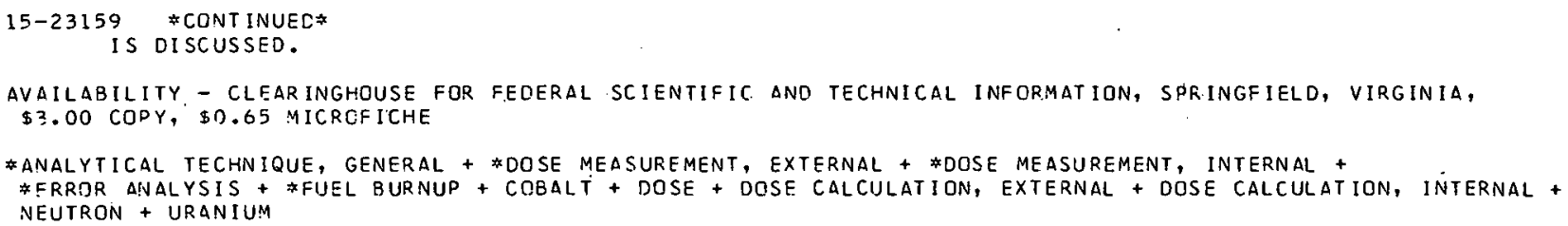

\#MONITOR, RADIATION, AIR + \#PLUTONIUM + \#SPECTRDMETRY, ALPHA + AIRBORNE RELEASE + FILTER + JAPAN

15-23319 ALSO IN CATEGORY 17

SOL AR I AJ

UNIVERSITY OF MICHIGAN REPORTS A POSSIBLE OVEREXPOSURE

UNIVERSITY OF MICHIGAN, ANN ARBOR, MICHIGAN

1 PAGE, ATOMIC ENERGY CLEARING HOUSE 14(8), PAGE 39 (FEBRUARY 26, 1968)

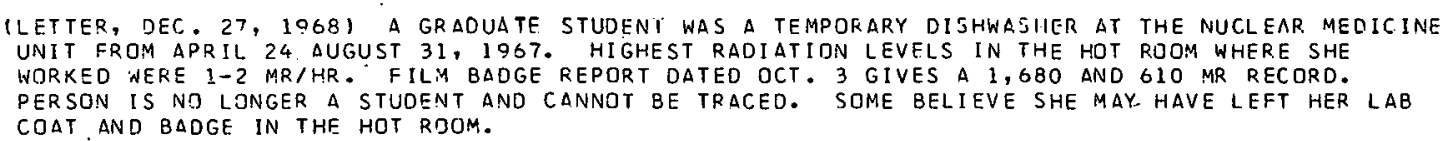

\#PERSONNEL EXPOSURE, RADIATION + INCIDENT, NONREACTOR + RADIATION SAFETY AND CONTROI

$15-23320$

BENES $\triangle$

EXPER IMENTAL CONTR IBUTION ON THE PROBLEM OF THE RESORPTION AND REMOVAL OF RADIOACTIVE SUBSTANCES FROM THE BURNED SURFACE

5 PAGES, 9 FIGURES, PEFERENCES, ZENTRALBL. CHIR., 90, PAGES I121-1125 (1965). IN GERMAN

RURNED SURFACES OF SKIN AND WOUNDS CONTAMINATED WITH RADIOACTIVITY CAN BE OECONTAMINATEO RY

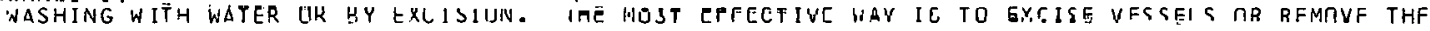
I ISSUES ENTIRELY.

CONTAMINATION + DECONTAMINATION + RADIOACTIVITY RELEASE

$15-23321 \quad$ ALSO IN CATEGORY 14

FREKE AM + DOLPHIN LW

A SUMMARY OF RESEARCH ANU OEVELOPMENT WORK CARRIED OUT IN 1966 IN HEALTH AND SAFETY DEPARTMENTS OF THE UN.ITED KINGDOH ATOMIC ENERGY AUTHORITY

UNITED KINGOOH ATOMIC ENERGY AUTHORITY, HARWELL, ENGLAND

AHSB(RP)M-46 +. 54 PAGES, SEPTEMSER 1967

THIS MEMORANDUM IISTS 193 PRUJECTS GN WHICH RESEARCH OR DEVELOPMENT NORK HAS BEEN CARRIED OUT IN HEALTH AND SAFETY DEPARTMENTS OF THE UKAEA DURING 1966 . THE OBJECT OF THIS MEMORANDUM IS TO PROVIDE INFORMATION ABOUT CURPENT RESEARCH AND DEVELOPMENT WORK WHICH MAY BE HELPFUL TO THOSE PLANN ING RESEARCH PROGRAMMES. REFERENCES ARE GIVEN TO THE PUBLISHED PAPERS RESULTING FROM WORK CARFIED CUT ON THE PROJECTS DURING THE YEAR.

AVAILABILITY - CLEARINGHOUSE FOR FEDERAL SCIENTIFIC AND TECHNICAL INFORMATION, SPRINGFIELD, VIRGINIA S3. OO COPY, $\$ 0.65$ MICROFICHE

* DOSIMETRY, GENERAL + \#RADIOLOGY + \#SPECTROMETRY, NEUTRON + \#UNITED KINGDOM + AQUATIC ORGANISMS + FALLOUT + INSTRUMENTATION, RADIATION MONITORING + NEUTRON

$15-23322$

HANKINS DE

PROCEEDINGS OF THE USAEC FIRST SYMPOSIUM ON ACCELERATOR RADIATION DOSIMETRY AND EXPERIENCE.

DIVISION OF TECHNICAL INFORMATION, U.S. ATOMIC ENERGY COMMISSION

CONF-651109+. 662 PAGES, TABLES, FIGURES, PRIOCEEDINGS OF -THE USAEC FIRST SYMPOSIUM ON ACCELERATOR

RADIATION DOSIMETRY AND EXPER IENCE, HELD AT BROOKHAVEN NATIONAL LABORATORY, UPTON, NEW YORK, NOVEMBER

$3-5, \quad 1965$ 
ENVIRONMENTAL SUPVFY, MONEGORY 15 ING AND RADIATION EXPOSURE OF MAN

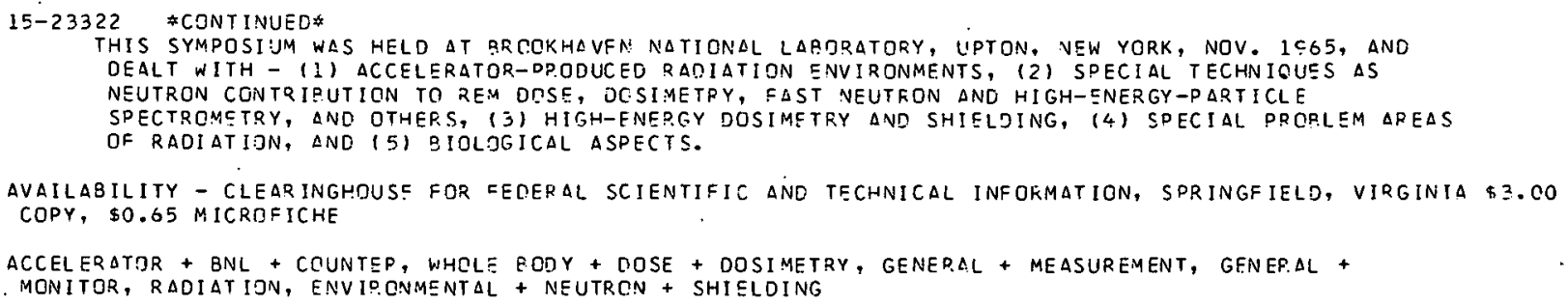

FFERSONINEL EXPIJUUE, RAOIATION + \#R AOICGPAPHY + DOSE CALCULATION, EXTEFNAL + FAILURE, CPERATQR ERTOR

15-23365 $\triangle L S E$ IN CATEGORIES $13 \triangle N O 17$

BAIN EE

NUCLEAR FUEL SERVICES, INC.

2 PAGES, ATGMIC ENERGY CLEARING HDUSF, 141C), PAGES $31-32$ (CEBRUARY 26, 1968)

(LETTFR, FEB. ¿) THE FOURTH-OIIARTEF FILM BACGE OF A PLUIUNIUM PPODUCTION PLANT WOPKEP INUICATED 3.07 REMS EXTERNAL WHOLE-BOCY GAMMA RADIATION. HIS 1967 TOTAL IS 3.52 REMS ANC LIFETIME TOTAL \%.18. \#ALL STATIONS WITH SIGNIFICANT PLUTONIUN, NILI. BE SHIELDED, AND THE CURRENT EXPJSUPF PATE WILL PE POSTED DAILY.

\#PERSONNEL EXPOSURE, FACIATION + FUEL REPROCESSING + PLUTONIUM + RACIATION SAFETY AND CONTFOL

$15-23428$

DUTRANNOIS J + KOELQIO KS

FOPTRAN PROGRAMMES FCF. THE TPEATMENT DE PERSONNEL MONITORING DATA

EUROPEAN ORGANIZATION FGP NUCLEAR RESFARCH, TFFNEVA

CERNM $7-28+.44$ UAGES, 14 FIGURES, REFERENCES, SEPTEMBER 20, 1967

THE PERSONNEL MONITORING AT CERN IS BASFD IN THE INFORMATION FECORDEO UN PERSONAL FILM-BACGES. THE FIEST PROELEM IS TO CALCULATE THE FXTERNAL RADIATICN EXPOSURE DOSE AND THF SFCOND PROELEM CONSISTS DE THE INTER.PRETATIRIN OE THE OPSERVED F:ATA DNO THE COMPUTATICN OF THE. INIEGRATEL UUSES FDR A GIVLN PEP IUY, FUP. MANY PEOPLE, IN A CONVENIENTLY SHCRT TIME. OTHER. ASPECTS OF THE PROGRAMME DEAL WITH SUSH OEQUIFEMENTS AS IOENTIFICATION, DOSE COMPUTATION, ACCUMULATED DATA, AND SOCCIAL INFORMATION. A OSSCRIPTION OF THE MAIN PRGGRAMMES, HEEKLY AND MONTHLY, APE GIVEN ALONG WITH STATISTICAL TDFATMFNT AS A REQUIREMENT FOR THE PROGRAMME.

AVAILABILITY - MICROCARD SOITIONS, INC., DCCOUNTING AND SHIPPING DEPT., WEST SALEM, WISCONSIN 54EG9

\#DOSE CALCULATIJN, EXTERNAI, + \#MONITCP. ING FRQGRLM, ENVIRLINMENTAL + \#STATISTICAL ANALYSIS +

OUSE CALCIH. ATION, INTERNAL + MONITOE, RAUIATION, PERSONNEL + SWITZEPLAND

$15-23429$

THCMAS J

INTERPRETATION OF ABSCLLUTE MEASUREMENTS OF RADIOACTIVE SOURCE STRENGTH BY THE 4 PI BETA-GAMMA-CCINCIOENCE

METHOD

DANISH ATOMIC ENERGY COMMISSION, RISOF

RISO-142+. 85 PAGES, FIGUPES, TABLES, REFEPENCES, OCTOBER IOEG

THE GRESENT RSPGRT DEALS WITH THE INTERPRFTATION gE APSCLUTE MEASUREMENTS OF RADIGACTIVE SOURCE STRENGTH EY THE 4-PI EETA-GAMHA-COINCIDENCE METHCD. AFTER A DESCRIPTION OF THE STATISTICAL BEHAVICUR CF A GENERALIZED MULTISCALTR INSTRUMENT, THE SPECIAL CASE CPF THE 3ET A-GAMMA-COINCIOENCE METHOD IS EVALUATEO. THE THEORY IS CFMONSTRATED BY THE MEASUREMENT CFF AU-193 IN GOLD FOILS, WHERE THE FINAL ACCUFACY IS SHOWN TO BE BETWEEN 0.1 AND O.2\%. SPECIAL ATTENTION IS GIVEN TO THE COUNT-RATE-CEPENDENT CORRECTIONS, WHICH ARF HFRF MFASIIPEO DIRTCTLY PY MEANS OF THF SIIRSTITUTION METHIOD. 
ENVIRONMENTAL SURVEYS, MONITORING 15 AND RADIATION EXPOSURE OF MAN

15-23429 *CDNT INUED*

AVAILABILITY - MICROCARD ERITIONS, INC., ACCOUNTING AND SHIPPING CEPT., WEST SALEM, WISCONSIN 54669

*COUNTEQ + \#MEASUREMENT, GENERAL + \#SOURCE, RADIATION + \#STATISTICAL ANALYSIS + BETA EMITTER + DOSE + GAMMA + GOLD

$15-23430$

GHOSH SK

RPD CRITICAL ITY DOSIMETER

DEPARTMENT OF NATIONAL HEALTH AND WELFARE, CANADA

RPD-52 +. 27 PAGES, 4 FIGURES, 7 TABLFS, DECEMBER 1967

THE RPD CRITICALITY DOSIMETER, DEVELOPED BY THE RADIATION PPOTECTION DIVISION OF CANADA, IS PRESENTED IN THIS ARTICLE, ALONG WITH THE DESIGN AND CONSTRUCTION, FUNCTIONS OF THE DOSIMETER COMPONENTS, AND METHOD OF USE.

AVAILABILITY - DEPARTMENT OF NATIONAL HEALTH AND WELFARE, CANADA, RADIATION PROTECTION DIVISION, BRCOKFIELD ROAD, OTTAWA, CANADA

*DOSE + \#DOSIMETRY, GENERAL + \#UNITED KINGOOM + BETA EMITTER + CQPPER + GAMMA + GOLD + INDIUM + SULFUR + THERMAL NEUTRON + X-R.AY

$15-23431$

PEABOOY CO + PRESTON HE

PLASTIC SACHET DOSIMETER CONTAINING LITHIUM FLUOPIDE POWDER FOR SURFACE AND FINGER-TIP DOSIMETRY UN ITED KINGDOM ATOMIC ENERGY AUTHORITY, WINFRITH

AEEW-R-497 +. 18 PAGES, 6 FIGURES, 8 TABLES, 9 REFERENCES, OCTOBER 1967

A OISIMETER IS DESCRIBED, CONSISTING OF 30 MG OF THERMOLUMINFSCENT LITHIUM FLUORIDE POWDER CONTAINED IN A PLASTIC SACHET. MEASUREMENTS OF ITS SENSITIVITY FRR PHOTONS AND BET R RAYS ARE PRESENTED AND DISCUSSED. IT IS SHCWN TO PROVIDE A CONVENIENT, ACCUPATE AND RELIABLE METHOD OF MEASURING DIRECTLY THE FINGER-TIP RADIATION DOSE OF WORKEFS HANDLING RADIOACTIVE MATERIALS, SURFACE DOSES FROM SUCH MATERIALS AND DOSES IN GENERAL OPERATIONAL AND EXPER IMENTAL WORK.

AVAILABILITY - CLEARINGHOUSE FOR FEDERAL SCIENTIFIC AND TECHNICAL INFORMATION, SPRINGFIELD, VA., \$3. OO COPY, $\$ 0.65$ MICROFICHE

\#DESIGN CRITERIA + \#DOSIMETRY, GENEFAL + \#SOURCE, RADIATION + BETA EMITTER + GAMIAA + X-RAY

15-23368 ALSO IN CATEGORY 17

SELECTED CVTR OPERATING EXPERIENCF.

CAROL INAS VIRGINIA NUCLEAR POWER ASSOCIATES, INC., PARR, S. C.

3? PATFS, MONTHLY OPEKATING REPORT, OCTEBER 1966

(PG 20 ) - EVALUATEO SENSITIVITY OF VARIOUS AIRBORNE-TRITIUM MONITORING INSTRUMENTS TU MIXIURES OF TRITIUM AND FISSION CASSES IN CONTAINAENT FOLLOWING A FUEL FAIIIIRE EARLY IN THE MGNTH. XENON READ HIGHER BY A FACTOR OF IC: OVER THE ACTUAL CUNCENTRATICIN. ACTUAL TRITIUM CONCENTRATION OF THE MIXTURE WAS ONLY 1/5TH THAT INDICATED. (PG 26) - ON STARTUP AFTER THE SECOND REFUEL ING, AFTER $1.5 \mathrm{HP}$ AT OOQ\% POWER, A FUEL FAILURE OC.CURRED. TESTS THE REST OF THE MONTH SHOWED THIS WAS IN U-TUBE B3 (CONTAINING HIGH-POWER-DENS ITY FUEL), AND THE LEAK REPRESENTED LESS THAN $1 \%$ FAILED FUEL, PROBABLY ONE ROD.

AVAILABILITY - CLEARINGHUUSE FOR FEDERAL SCIENTIFIS AND TECHNICAL INFORMATION, SPRINGFIELO, VIRGINIA, $\$ 3.00$ COPY, \$0.65:1ICRCFICHE

*FAILURE, FUEL ELEMENT + *INSTRUMENTATION, ABNÜMAL INDICATION + \#MCNITOR, RADIATIDN, AIR + *TRITIUM + * XENON + CVTR (PWR) + REACTOR, HWR + REACTOR, PRESSURE TUBE + REACTOR, PWR + REPORT, OPERATIONS

$15-23900$

ROGERS EJ

A PORTABLE NEUTRON DOSE EQUIVALENT METER

BROOKHAVEN NATIONAL LAB., UPTON, NEW YDRK

7 PAGES, 4 FIGURES, 1 TABLE, 3 REFERENCES, IEEE TRANS. NUCL. SCI. , 14151, PAGE 8 THRU 14, 10CTOEER 23 , 19671

A PORTABLE, BATTERY-OPERATED FAST-NFUTRON MONITOR WAS DEVELOPED FOR USE AT REACTORS AND ACCELERATORS. THE INSTRUMENT EMPLOYS A POLYETHYLENF LOADED PROPORTIONAL CDUNTER AND READS DIRECTLY IN BIOLOGICALLY EQUIVALENT UNITS FOR NEUTRIONS FRCM 0.1 MEV TO OVER 15 MEV ON EIGHT SCALES RANGING FROM 2 MREM PER HOUR TU 6000 MREM PFR HGUR. ELECTRONIC VOLTAGE REGULATION AND THE USE OF FIELD-EFFECT TRANSISTORS IN THE INTEGPATING AND TIMING CIRCUITS PREVIDE A STABILITY OF CALIBRATION FAR BEYOND THAT NORMALLY ASSOCIATED WITH PORTABLE SURVEY INSTRUMENTS.

\#ACCELERATOR + \#INSTRUMENTATION, RADIATION MONITORING + \#NEUTRON + \#REACTOR POWER + COUNTER + DOSE 
ENVIRONMENTAL SURVEYS, MONEGORY 15 TONG AND PAOIATION EXPOSURE OF MAN

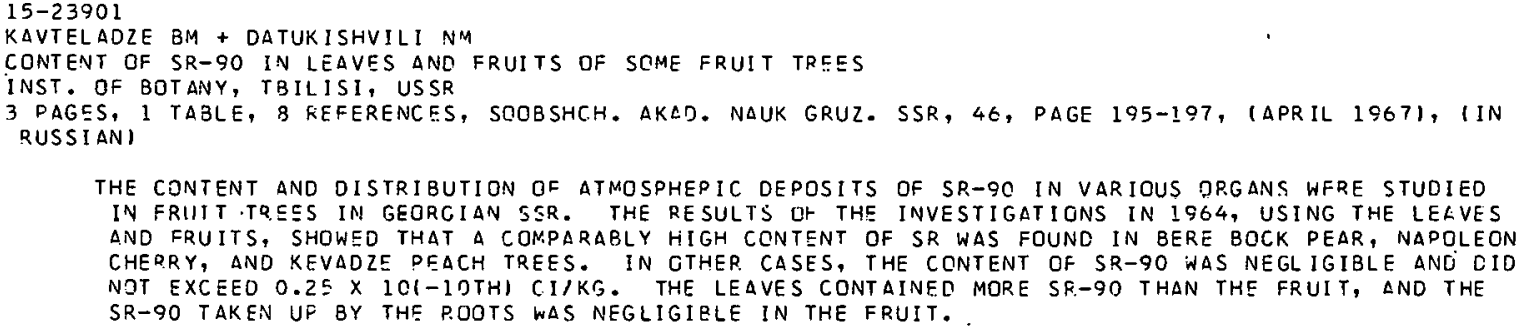

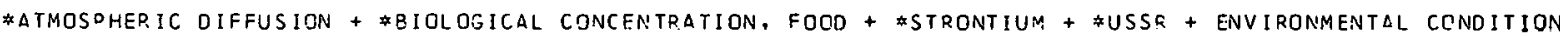

$15-23902 \quad A L S O$ IN CATEGORY 14

BELLAICHE G + PAUTOT G + ANGUENOTF + COURTOIS G

NATURAL RAOIOACTIVITY OF MAPINE SEDIMENTS DLDNG THE ESTEREL COASTS

LABORATOIRE DE GEODYNAMIQUE SOURS-MARINE, VILLEFRANCHE-SUR-MER, FRANCE CEA, SACLAY, FRANCE

4 PAGES, 3 FIGUKES, 4 REFERENCES, COMPT. REND., SER. D., 264 , PAGE 2545 THRU $2548,(M A Y 29,1967),($ IN FREN(H)

THE RADIOACTIVITY DF THF COASTAL MARINE SEDIMENTS PRESENTS WELL-DEFINED CHARACTERIISTICS, hHICH CAN GE EXPLAINED BY THE ACTICN OF CIFFERENT HYDRODYNAMIC AGENTS SUCH DS SEA SWELLLS AND SCME CURRENTS ON THE SEDIMENTARY PARTICLES OF DIFFERENT RADIOACTIVITY.

\#MONITJR, RADIATIJN, ENVIRONMENTAL + \#SUPFACE WATER, NUClide ECCURRENCE + *SURFACE WATER, SEDIMENT + FRANCE

$15-23903$

SPENCER H

EFFECT OF LOW AND HIGH CALCIUM INTAKE ON SP-SO METABOLISM IN ADULT MAN

VETER. ANS ADMINISTRATION HOSDITAL, HINES, ILL.

G PAGES, 2 CIGUFES, G TABLES, 23 REFEFENCES, INT. J. APPL. RAOIAT. ISOTOP., 18, PAGE 6C5-614, (AUGUST 1967)

BALANCES OF SR-ÇD WAS DETERIMINED IN MAN UNDER CONSTANT DIETARY CONOITIONS EURING LOW AND HIGH CALCIUM INTAKF, BUT DUR ING A SIMILAR INTAKE OF SR-9O. TEN PAT IENTS WERE STUDIED DURING LOW CALCIUM INTAKE (AVERAGE 213 MG CAIDAY) AND 10 PATIENTS DURING HIGH CAI.S. IUM INTAKE (AVERAGE 1718 MG (A/DAY), THE LATTER PEING AITAINED BY $\triangle D D I N G$ CALCIUM GLUCONATE TABLCTS TO THE

CDNSTANT LON CALCIUM DIET. THE AVERAGF SR-9O INTAKE WAS SIMILAK JUPING LOW AND HIGH CALCIUM INTAKE, 4.5 PCI/RAY ANO 5.7 PCI /OAY, RESPECTIVELY. THE AVERAGE SR-9C BALANCE WAS SLJGHTLY MIORE NEGATIVE DUR.ING HIGH CALCIUM INTAKE. THERE WAS NO SIGNIFICANT DIFFERENCE EETWEEN THE PERCENT NET AESORPT ICN OF SR-9O DUP.ING THE INTAKE OF THE LOW ANO HIGH CALCIUA DIETS, 12. $2 \%$ VERSUS 6.5\% DF THE SR-90 INTAKE, PESPECTI VELY. THE SR-CN/CA RATIOS OF THE DIET, URINE, AND STDOL NERE TETFRNINEO ANO THE OBSEPVED RATIOS (O.R.) WERE CALCULCTED.

*BIOLOGICAL CONCENTRATION, MAN + *CALCIUN + \#DIETARY HABIT + \#STRONTIUM

$15-23904$

RAY S + DODDCG + MUCHOW GM + NETLSON GE + KAUP DJ

DEPIVATION AND EXPERIMENTAL VERIFICATION OF AN EQUATION FIR EXPOSURE-DOSE RATE DUE TO X-RAY CONTINUA OWENS-ILLINOIS TECHNITAL CENTEQ, TOLEDO, CHIO

5 PAGES, 2 FIGURES, I TABLE, J. APPL. PHYS., 38, PAGE 3122-3126, (.J11., 1967)

AN EQUATION 'NAS DERIVED FOR THE EXPOSURE-DOSE RATE DUE TO RADIATIOV EMITTED RY X-RAY TUBES AND TRANSMITTES THFOUGH MEDIA THAT ARSGR ALL CHARACTERISTIC RADIATION. THE PARAMETEPS INVOL VED ARE THE ODERATING VOLTAGE AND CURRFNT JF THE TUBE AND THE LINEAR. ABSOFPTIGN COEFFIC IENT AND THICKNESS OFF THE DBSOREING MEOIA. EXPERIMENTAL VERIFICATION OF THE EQUAT ION SHOWS THAT EXPTSURE-DCSE RATES CAN BE CALCULATED WITHIN PLUS OR MINUS G\% ON A RELATIVE BASIS.

*CDUNTER + \#DOSE + *X-RAY + FLLCTRON

$15-23905$

SANDERS M

AIR SAMPLING METHOD AND APPARATUS

UNITED STATES ATOMIC TNERGY COMMISSION, WASHINGTON, D. C.

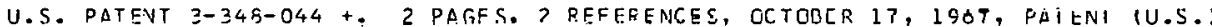

A METHOD AND APPARATUS HUR COF.RELATING THE CQLLECTION DF SAMPLES TAKEN AT DIFFERENT TIMES AND PLACES IN SEPAPATE FILTCR DAPERS WITH THF DISPLAY DF OATA FROM ANALYSIS QF SUCH SAMPLES ARE DESCPI3ED. FILTER PAPERS FOR COLLECTING THE SAMPLSS AFE PLACED IN APFRTURES DROVIDED IN PRECODED DATA DROCESSING CARDS WHICH ARF THEN PLACED IN SPECIAL HOLDERS DERMITTING PASSAGE OF GASEDUS ATMOSPHEPE THRTUGH THE FILTER PADER WHILE HOLDING IT TAUT. THE CARDS ARE REMOVEO FROM THE HOLDERS, THE $\triangle N A L Y S E S$ PERFORMED, THE RESULTS AUTCMATICALLY PUNCHED ONTO THE CARES, 
ENVIRONMENTAL SUPVEYS, MONEGORY 15 GRING ANO RADIATION EXPOSURE DF MAN

15-23905 *ONTINUED*

THE CAROS DUPL ICATED IN UNCONTAMINATED FOFM, aND tHE DUPLiCATE CARDS TABULATED to PROVIDE A DATA DISPLAY.

AVAILABILITY - THE U.S. PATENT OFFICE, DEPARTMENT OF CEMMERCE, WASHINGTON, D. C. (\$O.2E CENTS/COPY)

\#AIR + \#PATENT + \#SAMPLING + DATA PPOCESSING + FILTER

15-23914 ALSO IN CATEGORY 14

TAGI H + LIM EK

FUNDAMENTAL STUDIES ON EEHAVIOR OF CESIUM IN FIXATION OF QADIOACTIVITY IN CERAMIC SPONGES

TOKYO INSTITUTE OF TECHNOLOGY

86 PAGES, BULL. TOKYC INST. TFCHNOL. NO. 71, PAGES 1-8E (MARCH 1966$)$

ONE METHOD FOR OISPOSING OF FISSION-PRODUCT WASTES FROM THE REPROCESSING OF THE SPENT URANIUM FUELS IS THE FIXATION OF THE FISSICN PRODUCTS ON CERAMIC SPONGES, WHICH ARE THEN STORED UNDERGRDUND. THE FIXATION DF HIGH-LEVEL RADIOACTIVITY IS DESCPIBED. STUDIES WERE MADE CIN THE LEACHAB IL ITY FOR LONG-TERM UNDERGROUND STORAGE, MECHANISMS OF THE FIXATION; AND ADSORBABILITY CF THE RADIONUCLIDE CS-137. THE CONCLUSIONS ON THE BEHAVIDR OF CS-137 IN THE FIXATION OF RLDIOACTIVE WASTES IN CERAMIC SPONGES ARE AS FOLLDWS - CERAMIC SPONGES HAVING $5 E$ TO 65\% POROSITY WERE PP.EPARED FROM MATERIALS INCLUDING DIATOMITE, BENTONITE OR CLAY, AND FELDSPAR. THE COMPOSITIONS FOUND TO BE PROMISING ARE 60 TO $70 \%$ DIATOMITE, 20 TC $30 \%$ BENTONITE, AND $10 \%$ FELDSPAR.

*CERAMICS + *CESIUM + *WASTF DISPOSAL, SOLID + \#WASTE TREATMENT, FIXATIDN + FUEL ELEMENT + URANIUM

$15-23037$

LASER RADIATION CAUSES IRREPARABLE EYE DAMAGE

2. PAGES, CHEM. ENG. NEWS, 45(45), PAGE 23 ANO 24, (OCTOBER 23, 1967)

LASER RADIATION MAY DO IRREPARABLE DAMAGE TO THE RETINA, CAUSING LOSS OF VIS ION. Q-SWITCHED LASERS ARE THE MOST DANGEROUS, WHILE SOME CONTINUOUS-WAVE LASERS CAN BE HARMLESS. GECAUSE OF THESE HAZARDS, CONTROLS ARE FAVORED.

* Biological concentration, man + \#LASER + \#RADIATION daMAGe

$15-24060 \quad$ ALSC IN CATEGORY 14

MAMURO T + . MATSUNAMIT + FUJITA A

RADIONUCLIDE FRACTIONATION IN FALLOUT PAFTICLES FROM AN AIR BURST

DEPT. OF HEALTH PHYSICS AND INSTRUMENTATICN, RADIATION CENTER OF OSAKA PREFECTURE, SHINKE-CHO TC4, SAKAI-SHI, JSAKA, JAFAN

17 PAGES, 22 FIGURES, 5 TABLES, 14 REFERENCES, HEALTH PHYSICS 14(3); PAGE 223 THRU 239, (JUNE 15,1967 )

RAOIONUCLIOE FRACTIONATIGN IN INDIVIDUAL HOT PARTICLES (HIGHLY RADIOACTIVE FALLOUT PAQTICLES) FRDM THE THIRL CHINESE NUCLEAR EXFLOSION ON 9 MAY, ISGE, HAS BEEN INVESTIGATED EY GAMMA-PAY SFCCTROMETP.Y. ACTIVITIES OF TEN RADIONUCLIOES (ZR-95, ZR-S7, MO-99, BA-140, CE-141, CE-143, CE-144, ND-147, U-237 $\triangle N D$ NP-239) WERE MEASURED, AND THE INITIAL ATOM NUMBLRS OF THESE NUCLIDES CONTAINED IN. EACH SAMPLE WERE ESTIMATED. TO EXPRESS THE DEGPEE OF FRACTTINNATION, THE FRACTIONATION FACTORS DEFINED WITH RESPECT TO ZR-95 WERE CALCULATED FOR EACH SAMPLE.

\#CHINA + \#FALLOUT + \#ISOTOPIC FRACTIONATION + \#PARTICLE, RADIOACTIVE + BARIUM + CERIUM + MOLYBOENUM + NEPTUNIUM + NIOBIUM + SPECTROMETRY, GAMMA + UPANIUM + ZIRCONIUM

15-24061 ALSO IN CATEGORY 14

PERSSIN RB

CS-134/CS-137 ACTIVITY. RATID IN THE BIOSPHERE FROM 1956 UNTIL 1966

RADI AT ION PHYSICS DEPT., UNIV. OF LUND, LUND, SWEDEN

10 PAGES, 4 FIGURES, 6 TABLES, 39 REFERENCES, HEALTH PHYSICS, 14(3), PAGE 241 THRU 250, (JUNE 26,1967 )

CS-134 AND CS-137 ACTIVITIES WERE MEASUREO IN SAMPLES OF LICHEN, MCSS, AND REINDEEF MEAT COLLECTED IN SWEDEN. THE CS-134/CS-137 ACTIVITY RATIOS IN VEGETATION COINCIDE WITHIN THE EXPER IMENTAL UNCERTAINTY WITH THOSE. FOR REIINDEER MEAT. GAMMA-RAY SPECTRA FROM THE ANNUALLY PERFORMED WHDLE-GODY MEASUREMENTS ON LAPPS WERE ANALYZED. THE TOTAL GLOBAL INJECTIGN OF CS-134 WAS ESTIMATED TO BE AROUT 200 KCI UP TO 1958 , INSIGNIFICANT EURING 1959-1961, AND ABOUT $50 \mathrm{KCI}$ DURING $1961-1962$. SINCE 1962, NO SIGNIFICANT INJECTION OF CS-134 HAS REEN DETECTED. DIFFERENT WAYS OF GENERATING CS-134 HAVE BEEN CONSIDERED.

* ALASKA + *BIOLOGI CAL CONCENTRATION, GENERAL + *CE'SIUM + *SPECTROMETRY, GAMMA + COUNTER, WHOLE BODY + MONITOR, RADIAT ION, ENVIRONMENTAL

$15-24062$

SCHAYESR + BROOKE C + KOZLOWITZ I + LHEUREUX M

NEW DEVELOPMENTS IN THERMDLUMINESCENT DOSIMETRY

MANUFACTURE BELGE DE LAMPES ET DE MATERIEL ELFCTRONIQUE S.A. BO, RUE DES DEUX GARES, BRUXELLES, BELGIQUE

13 PAGES, 17 FIGURES, 13 REFERENCES, HEALTH PHYSICS, $14(3)$, PAGE 251 THRU 263 , (JUNE 16,1967 ) 
ENVIRQNMENTAL SURVEYS, MONITCRY ING 15 AND RADIATION EXPOSURE OF MAN

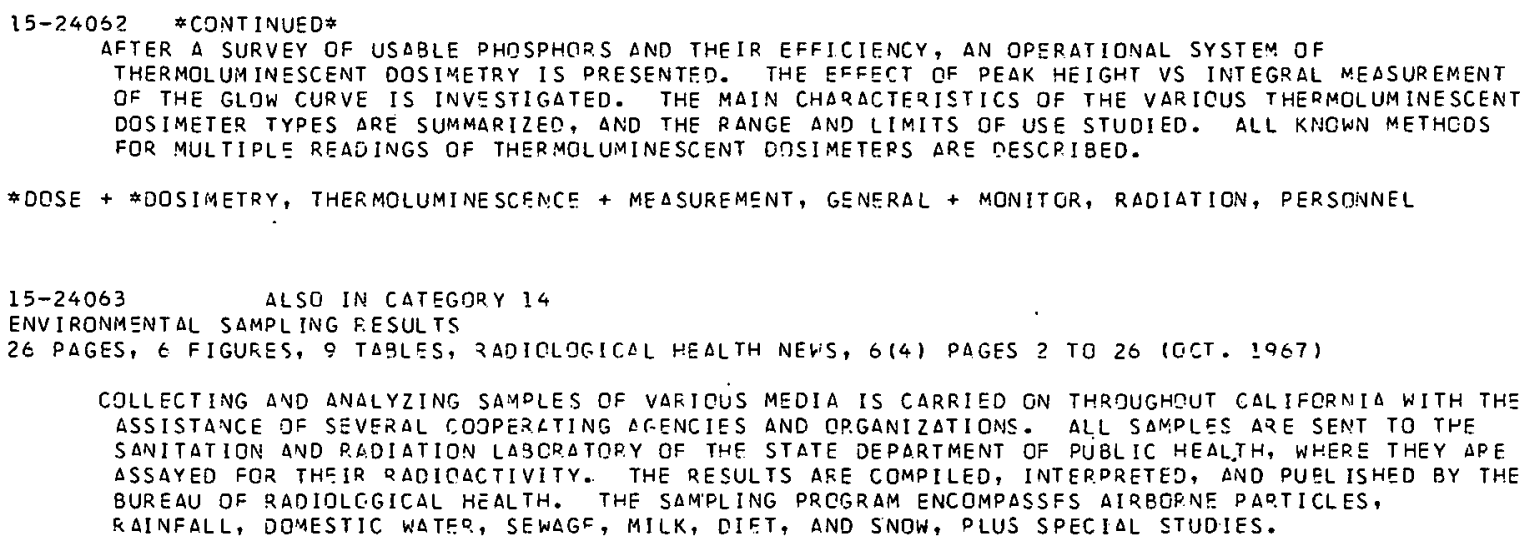

COLLECTING AND ANALYZING SAMPLES OF VARIOUS MEDIA IS CARRIED GN THRDUGHOUT CALIFCRNIA WITH THE ASSISTANCE JF SEVERAL COOJPERLTING AFENCIES AND ORGGANIZATIONS. ALL SAMPLES ARE SENT TO THE SANITATION AND RADIATION LABCRATORY OF THE STATE DEPARTMENT OF PUBLIC HEALTH, WHERE THEY APE ASSAYEO FOR THEIR RADIOACTIVITY. THE RESULTS ARE COMPILED, INTERPRETED, ANO PUEL ISHED BY THE BUREAU OF RADIOLGGICAL HEALTH. THE SAM'PLING PRCGRAM ENCOMPASSFS AIRBORNE PARTICLES, KAINFALL, DOMESTIC WATER, SEWAGF, MILK, DIET, AND SNOW, PLUS SPECIAL STUDIES.

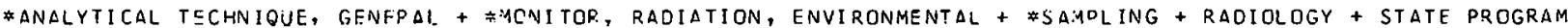

$15-74 ? 24$

DEVRRST Q + LEVYC

ALSG IN CATEGORY 14

30 PAGES, PAGES 775-8OL OF PAOIOBIOLOGIE APPLIQUEE, TOME III. (LOISELEUR, J. (ED)), PAFIS, GAUTHIER-VILLAPS, 1066, IN FRENCH

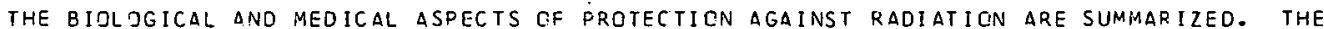
VARI ABLES THAT CONDITION. THE GPAVITY OF RADIOLESIONS ARE OUTLINED. THE LESIONS CAUSED BY ACUTE ANO CHRCNIC IRRAOIATION ARE CESCRIBED. THE LONG-TERM CONSEQUENCES CF IFRAOIATION, I.E., CANCER INDUCTION, SHORTENINF OF THE $\triangle$ VEFAGF LIFE SPAN, AND GENETIC FFFECTS, $\triangle F E$ CONSIOERED IV SOME OETAIL. THE PRE SENT LEVEL OF THE IRRADIATION OF THE GENERAL PRPIILATICN FRGM NATURAL PAOIOACTIVITY, MEDICAL IRPAUIAIION, FALLOUT, DND EVENTUAL IRRADIATIGN AS A RESULT JF A NUCLEAR INOLSTRIAL DEVELODMENT IS CALCULATEO. FPCFESSIONAL EXPOSUPE IS CISCUSSEO AVD EXAMPLES ARE GIVEN. THE LAWS GQVERNING RACIOPROTECTION ARE OUTLINED. THE CLINICAI ANC. PIDLOGICAL MONITORING RLGULATIONS ARE GIVEN.

\#AIOLOGICAL CONCENTRATION, MAN + \#FALLOUT + \#PUPULATION EXPOSURE + MDNTTOR, RADIATIJN, ENVIPJNMENTAL + RADIATION INJUEY, TFEATMENT OE

15-24?15 ALSC IN CATEGORY IL

KRONGAUZ AN + KOLOTILOVA VG + LYADIOEVSKJI VK + PAVLOVA TG + TITOV AA

DOSE IIELDS OF COGO GAMMA RADIATION IN SUEFACE LAYEPS CF TISSUE-EGUIVALENT SUESTANCE

6 PAGSS, MED. RADIOL, 12(7), DAGES O-14 (JULY ISGT) IN RUSSIAN

EXPERIMENTAL STUDIES WERE MADE OF THE DISTRIBUTION OF ABSOREED DOSES OF CO-GO GAMMA RADIATION IN SIJRFACE LAYERS OF A OLEXIOLASS PHANTOM WIIH THE AID OF SCINTILLATION AND TR.ANSISTORIZER DETECTORS. CAI IBRATION JF DETECTOFS WAS PERFOFMED BY THE IONIZATION DOSIMETFE IN IDENTICAL CONDITIONS JF IRPACIATION. THE DISTRIBUTICN GF OEPTH ABSORBED DOSES DEPENOING CEN THE VALUE OF THE IRRADIATICN FIELD IS DESCRIBED.

\#CCBALT + \#DOSE + \#DOSIMETPY, GENERAL + EIOLCGICAL CONCENTRATION, MAN

15-24216 ALSO IN CATEGOPY 14

YOSHIDA Y

MONITORING OF AIR CONTAMINATION AT JPDR (JAPAN POWER DEMONSTRATION REACTDR)

JAPAN $\triangle T$ TMIC ENERGY RESEARCH INST., TOKYO

5 PAGES, GENSHIRYOKU KOGYO, 121101 , PAGES 49-53. (CCT. 1966) IN JAPANESE

IRACES OF RARE GASES AS FISSION PR.DDUCTS ANG I-131 HAVE BEEN DETECTED IN THE DFF-r, REACTOR WATER, RESOECTIVELY, SINCF DIRCCT-CYCLE, BOILING-WATER REACTOR JPQR (THERMAL OUTFUT $45 \mathrm{MW}$, ELECTRICAL OUTDUT $12 \mathrm{MVi}$ ) OPEPATED IN DEC. 1964. THE MONITORING SYSTEM $\triangle T$ JDOR CONSISTS OF NAI COUNTCRS FOR GASES, GM COUNTERS FOR CUST, ANC FIVE SAMPLING DIPINGS IGNE FOP OFF-GAS DUCTS, TWO FOR TUPBINE ROOMS, ANO TWC WITH EMERGENCY DUT-OFF DEVICES FOR FEACTOR VESSELI. AIR CONTAMINATION WHICH OCCURFED FR GM JANUARY TO MARCH 1965 ARE GIVEN. A JESCRIPTION IS ALSTO MADE RF THE LFAKAGE CF FISSION OFODUCT GASES FRUM A CLNNECTCR IN THE OFF-GAS DANEL, ANO AIR CONTAMINATION DURING THE BREAKAGE OF REACTOR INSTRUMENTS.

\#CONTAMINATIOV + \#IDOINE + \#LEAK + \#MONITCRING SYSTEM, RAOIATIGN + \#REACTOR, EWR + COUNTEF + IAPAN + REAT.TOF. POWER + SAMPLING + THERMAL CONSIDERATION

15-24271. ALSO IN CATEGOPY 17

FREDRICKSON RL

EXPOSURE TO EXCESSIVE AIPBORNE IODINE-13] 
CATEGORY 15

ENVIRONMENTAL SURVEYS, MONITORING AND RAOIATION EXPOSURE OF MAN

$15-24271$ \#CONTINUEO*

ABSGIT LABORATCRIES, NORTH CHICAGO, ILL.

1 PAGE, AT JMIC ENERGY CLEARING hOUSE, 14(14), PAGE 30 (APRIL 1,1068 )

ILETTER, FEB. 19) AS INDICATED IN THE FEB. 6 LETTER, RESPIRATORY PROTECT ION IS BEING USED UNTIL HJOD REVISIONS CORRECT THE AIRBORNE-RELEASE PRDBLEM (INADEQUATE AIR VELOCITY). AN EMPLOYEE WAS EXPOSED TO 1-131 IN AIR FOR A TOTAL OF 416 MPC-HOURS (JAN. 23-29) AND FOR 164 MPC-HDURS (FEB. 2-8). HIS AVER AGE THYROID BUROEN IN THIS PERIDD NAS 34\%, WITH A HIGH OF 52\%, INOICATING THAT DDEQUATE RESPIRATORY PROTECTION HAD BEEN PROVIDED.

*FISSION PRODUCT, IOCINE + *PERSONNEL EXPOSURE, RADIATION + \#PERSONNEL PROTECTIVE DEVICE + INCIDENT, GENERAL + INHALATION

$15-24272$ ALSO IN CATEGORY 17

INABILITY JF JUMA HOOD TO PREVENT IODINE PELEASE

ABE.OTT L ABORATJR IES, NORTH CHICAGO, ILL.

1 PAGE, $\triangle T$ TMIC ENERGY CLEARING HOUSE, 14(14), PAGE 30 (APRIL 1, 1968)

(LETTER, FEB. G) A WDRKER. WAS EXPOSED TO EXCESSIVE CONCENTRATION OF I-13I IN AIR, AS HIS THYROID AVEQAGED 373\% PERMISSIBLE I-131 (DEC. 14-20, 1967). AN UNEXPECTED RELEASE OCCIJRRED DUR ING PREPARATICN OF RARIJ-IODO-INSULIN, CONTAMINATING HIS HEAO. HIS QUARTERLY THYROID DOSE IS 5.78 REMS. \#\# ALL FUME HOODS IN THE EUILOING HAVE HAD FACE VELOCITY RE-EVALUATED. DENDING MODIFICATION TO PROVIOE HIGH-VELOCITY AIRFLOW OR BETTER CONTAINMENT, CERTAIN JOBS WILL REQUIRE RESPIRATORY SOUIPMENT ANO BREATHING-ZONE SAMPLERS. ROUTINE THYROID COUNTING WILL BE TWICE PEP. WEEK INSTEAD OF ONCE.

\#FISSION PRODUCT, IJDINE + \#INHALATION + \#PERSONNEL EXPOSURE, RADIATION + DOSE + GLOVE ECX + INCIOENT, GENERAL + PERSONNEL PROTECTIVF DEVICE + VENTILATION SYSTEM

15-24273 ALSE IN CATEGORY 17

LEWIS WH

DUR ING MAINTENANCE

NUCLEAR FUEL SERVICE, INC.

2 PAGES, ATOMIC ENERGY CLEARING HOUSE, 14(14), PAGES 31-32 (APRIL 1, 19E8), COCKET 50-201

(LETTER, JAN: 31) ON DEC. 27, 1967, A MAINTENANCE FOREMAN INSPECTED EQUIPMENT IN THE GP-CELL DRANE RODH FJR 30. MIN. HIS THERMOLUMINESCENT DOSIMETERS (FINGER RINGS) READ 16O RADS. AN HP RESURVEY SHOWED $\triangle$ MAX. DOSE RATE OF 16 RADS/HR. 26 TLD FINGER RINGS ON HIS GLOVE SHOWED AN AVERATE OF 21 RADS/HD, WITH A MAX. OF 90.6 RADS/HR AT THE PALM. THE AVERAGE HAND EXPOSURE IS ESTIMATED AT 44 FADS. THE BETA/GAMMA RATIO USED IN TIME LIMITS IS NOW INCREASED. GLOVES WHICH DECREASE HAND EXPTSURE YET WHICH ARE FLEXIBLE ENOUGH FOR WORK ARE BEING TESTED.

*CONTAMINATION + \#DOSIMETRY, THERMOLUMINESCENCE + \#PERSONNEL PROTECTIVE DEVICE + BETA EMITTER + FUEL REPROCESSING + INCIDENT, GEINERAL + MAINTENANCE AND REPAIR + NFS

$15-24274 \quad$ ALSO IN CATEGORISS 17 AND 13

PERSONNEL' OVEREXPOSURES DUR ING FOURTH QUARTER 1967

NUCLEAR FUEL SERVICES, INC.

1 PAGE, ATOMIC ENERGY CLEAEING HOUSE, 14(14), PAGE 32 (APRIL 1, 1968), DOCKET 50-201

(LETTER, FSB. 19) REPORT DESCPIBES CVEREXPOSURES AND CORRECTIVE ACTIONS. (WHOLE RODY) - 2 EMPLOYEES RECEIVED $3.1,3.2$, AND 3.4 REMS. (SKIN) - THREE P.ECEIVED 7.7, 8.2, AND 9.8 REMS. ( EXTQEMITY) - SIX RFC.FIVED 10.02, 19.11, 19.41, 19.62, 20.55, AND 20.56 REMS, ALL DUE TG SPGT SOURCES. * CHANGES TO SOP FOR CONTAMINATED WORK AREAS, TO EUUIPMENT TO MINIMIZE CONTACT MAINTENANCE, LNO TO IMPROVE VENTILATION ARE BEING UNDERTAKEN. A MANIPULATOR R.EPAIR AND DECONTAMINATICN FACILITY IS EEING BUILT.

*PERSONNEL EXPJSURE, PAOIATION + CONTAMINLTION + FUEL REPROCESSING + MAINTENANCE AND REPAIR + MODICICATION, SYSTIM OF. EQUIPMENT + NFS

$15-24278$ ALSO IN CATEGORIES 12 AND 17

OVER EXPOSURES TO GAMHA RAOIATION, LAST HALF 1967

NUCLEAR MATERIALS AND EQUIPMENT CORP. APOLLO, PA.

1 PAGE, ATOMIC ENERGY CLEARING HOUSE, 14(14), PAGE 34 (APRIL 1, 1968)

(LETTSR, FES. 2S) (1) THREE 1E-YEAP. OLD EMPLOYEES EXCEEDED 1.25 REMS. IN THE QUARTER, ANO WERE REMOVED FROM EXPOSURF UNTIL E(N-1\&) ALLOWS RETURN. WE WERE AWARE OF THE AM-241 PRESENT IN ZPPR FUEL SUT WEFE NOT AWARE OF THE 18-YEAR-OLDS. PU DUST EMITS MORE X RAY BECAUSE OF LITTLE SELF-SHIELDING. (2) A 1S-YEAR-OLO WAS TAKEN FFOM HANDLING ZPPR AM-241-CONTAMINATED

CRUCIBLES. ( $)$; $\triangle$ SOURCE TECHNICIAN EXCEEOED LIFETIME LIMITS DURING THE FOURTH OUARTER. HIS JULY 1967 FILA BADGE HAD BEEN DAMAGED, AND EXPOSURE OMMITTED. ESTIMATION YIELDED

OVEREXPOSURE. (4) JAN.-MAR. 66 EXPOSURE TU SOUFCE FOREMAN EXCEEDED 3 REMS.

\#AMERICIUM + \#ABRICATION + \#FUEL ELEMENT + \#PEKSONNEL EXPOSURE, RACIATION + PLUTONIUM + SOURCE, KADIATION + X-RAY 


\section{ENVIRONMENTAL SURVEYS, MONITOR. ING AND RADIATION.EXPOSURE OF MAN}

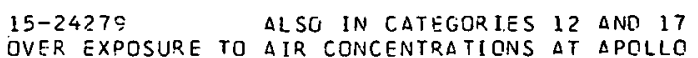

ATOMIC ENERGY COMYISSION

1 PAGE, $\triangle T O M I C$ ENERGY CLEAPING HOUSE, 14(14), PAGE 35 (APRIL 1, 1968)

ILETTER, MAR. 1) FIVE OPERATORS WERE EXPOSED TG MORE THAN $4 C$ MPC-HOURS/WEEK. EACH WAS WEARING A RESPIRATOR, BUT NASAL CONTAMINATION EXCEEDED LIMITS, SO NO CREOIT WAS TAKEN. EXDOSURES WERE DETECTED WITH PERSOVAL AIR SAMPLERS. CNE EXPOSURE OCCUPRED DURING CLEANUP OF A CP-2 FURNACE. TWO DCCURFED DURIVG CRP-3 DISSOLVING EPERATIONS. TWO OCCURRED DURING FILTER HANDLING. FILTERS ARE ROUTINELY PAGGED, BUT OCCASSIONALLY A BAG IS PUNCTUREO.

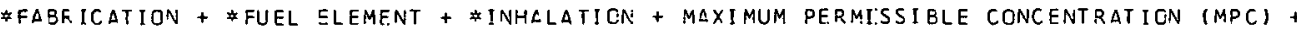
PERSONNEL EXPOSURE, RADIATION 


\section{CATEGQRY 16
METEDROLOG I CAL CONSIDERATIONS}

16-20692

KOGAN RM + FRIDMAN SO

EFFECT OF SOIL MÖISTURE ON THE STRUCTURF CF THE GAMMA FIELD IN THE ATMOSPHERE NEAR THE EARTH

INST. OF APPLIED GEDPHYSICS, MOSCOW

4 PAGES, 2 FIGURES, 1 TABLE, 2 REFERENCES, IZV. AKAD. NAUK SSSR, FIZ. ZEMLI, 3, PAGE 82-88, (MARCH 1967), IN RUSSIAN

ASSUMING A CONSTANT CONCENTRATION OF QADIOACTIVITY'IN THE SOIL, THE INTENSITY OR PPIMARY RADIATION IS A FUNCTION ONLY OF THE SOIL MOISTUPE. IN RAINY P.ERIODS, THE GAMMA FLUX IS SUBSTANTIALLY DECREASED, AND THE ENERGY COMPOSITION CF THE GAMMA QUANTA IS DISTORTED. A WAIT OF 16 TO 30 HR AFTER A RAINFALL IS ADVISABLE, IN TAKING GAMMA-RAY FIELD MEASUREMENTS SO AS TC HAVE NORMAL SOIL MOISTURE.

\#PRECIPITATION + *SOIL, NUCLIDE OCCURPENCE + *STATISTICAL ANALYSIS + CONCENTRATION, GROUND LEVEL + GAMMA + MONITOR, RADIATION, GROUND SUREACE + USSP

$16-21133$

KRUGER P

TRANSPORT OF RADIOACTIVE AEROSOLS ACROSS THE TRADE WIND INVERSION AT HAWAII

STANFORD UNIVERSITY, STANFORD, CALIFIRNIA

12 PAGES, 8 FIGURES, 4 TABLSS, REFERENCES, TELLUS $19(3)$, PAGES 380-3C1 (1957)

RAOIOACTIVITY CONCENTRATION MEASUREMENTS IN AEROSOL AND PRECIPITATION SAMPLES COLLECTEO ALONG THE SLOPES OF MAUNA LOA VOLCANO IN HAWAII WERE EXAMINED IN RELATI DN TO VERTICAL PPOFILES OF TEMPERATURE AND HUMIDITY IN THE ATMOSPHERF ACROSS THE TRADE-WIND INVERS ION. THE GR.ADIENT, OF RADIOACTIVE AEROSOL CONCENTRATION IN THE AIR WITH HEIGHT IS RELATED TO THE HUMIDITY PROFILE AND THE CHARACTER OF THE TRAOF-WIND INVERSION. THE RATIO OF GRCSS EETA CDNCENTFATION IN AIP. AND RAIN GIVES A PARAMETER WITH DIMENSIONS OF MIXING RATIO, WHICH MAY BE OF POTENTIAL USE IN DETERMINING RAINOUT EFFICIENCIES.

* AEROSOL, RADIOACTIVE + \#CONCENTRATION, AREA + ANALYTICAL TECHNIQUE, AIR + ATMOSPHERIC STABILITY + EXPERIMENT, GENERAL + GROSS BETA + STRONTIUM + WIND PROFILE

$16-21134$

MEKHON KO KP

SIMPL IFIED THEORETICAL NOTION OF CONTAMINANT REMOVAL RY PRECIPITATIDN FROM THE ATMOSPHERE

HY DROMETEOROLOGICAL SERVICE OF THE USSR, MOSCOW, RUSSIA

- PAGES, 2 TABLES, 3 FIGURES, 19 REFERENCES, TELLUS, 19 (3), PAGES 467-476 (1967)

PROCESSES OF CONTAMINANT WASHOUT AND RAINOUT FROM THE ATMOSPHERE BY PRECIPITATION ARE CONSIDERED. FORMULAS OF OECREASING CONTAMINANT CONCENTRATION IN PRECIPITATION AND IN THE AIR AS A FUNCTION OF DURATION OF PRECIPITATION ARE DEDUCED. COEFFICIENTS OF CCNTAMINANT WASHOUT (BELOW THE CLOUD) AND RAINOUT. (IN THE CLOUD LAYER DF THE ATMOSPHERE) FOR GASES AND AEROSCLS ARE DETERMINED FROM COMPARISON OF THEGRETICAL CURVES WITH EXPERIMENTAL- DATA. RAINOUT DF ALMOST ALL THE GASES OF THE ATMOSPHERE IS AT LEAST A FACTOR OF IO LESS THAN. THAT OF AEROSOLS.

*CONCENTRATION, GROUNO LEVEL + \#RAINOUT + AEROSOL + ATMOSPHERIC OIFFUSION + FALLGUT +

HATIIEMATIGAL TREATMEMT + PRFT IPITATION +. THEORETICAL INVESTIGATION + WASHOUT

$16-21 ? 22$

SOTOBAYASHI T + SUZUKI T + KOYAMA S

GEOCHEMICAL FRACTIONATION OF NP-239 IN FRESH NUCLEAR DEBRIS THROUGH THE ATMOSPHEPE

NI IGATA UNIV., JAPAN

1 PAGE, I FIGURE, 3 REFERENCES, BULL. CHEM. SOC. JAP., 40, PAGE 1555, (JUNE 1967)

HIGHLY FRACTIONATED FISSION PRODUCTS WERE DETECTED WITHIN $3 G$ HR AFTER THE THIR C CHINESE

NUCLEAR TEST. DATA SUGGEST THAT GRAVITATIONAL AND METEOROLOGICAL FORCES AND OIFFERENCES IN SIZE AND DENSITY CAUSE DARTICIF SEPARATION IN AN ATOMIC CLOUD. OBSERVATIONS SHCW

ERACTIONATION SEHAVIOR OF NP-230 TO BE MODIFIED AND THAT PARTICLE SEPARATION TAKES PLACE IN

1.5 DAYS TRAVEL IN THE CLOUDS.

FAEROSOL, RADIOACTIVE + \#JAPAN + \#SAMPLING + ATMOSPHERIC CIRCULATION, GLOBAL +

ATMOSPHER IC DIFFUSION, GLOBAL + FALLOUT

$16-21223$

BARRY PJ

DISPERSION AND OLFFUSION OF STACK RELEASES

'ATOMIC EN'ERGY OF 'CANADA LIMITED, CHALK RIVER, ONTARIO

AECL-2760 +. 20 PAGES, 6 FIGURES, 2 TABLES, JULY 1967

THIS REPORT IS BASED ON THE REFRESHER COURSE ON DISPERSION AND DIFFUSION OF STACK RELEASES,

GIVEN AT THE HEALTH PHYSICS SOCIETY ANNUAL GENERAL MEET ING IN WASHINGTON, D. C., JUNE 18-22, 1967. IT IS A SIMPLE INTRODUCTION TO THE USE OF DIFFUSINN EQUATIONS FOR PREPARING ESTIMATES OF ENVIRONMENTAL CONCENTRATIONS OF MATERIDLS DISCHARGED INTO THE ATMOSPHERE. THE EQUATIONS 
$16-21223$ *CONT INUED* AQE DERIVED FROM FIP.ST PRINCIPLES WITH A MINIMUM OF MATHEMATICS ANO IN SUCH A WAY AS TO iLLUSTRATE THEIF USES AND LIMITATICNS.

AVAILABILITY - ATOMIC ENERGY OF CANADA, LTD., CHALK PIVER, ONTARIO, CANADA \$1.00 COPY

\#DIFFUSION + \#EQUATICN, GENERAL + \#SQURCE, GROUNO LEVEL + ATMOSPHFRIC STABILITY + CONCENTRATION, GROUND LEVEL + DISPERSION + GAUSSIAN PLUME FOFMULA + SOURCE, ELFVATED + SUTTON DIFFUSION FORMULA

$16-21224$

TRUNDLE AS + STORY E

AERIAL RADIOLOGICAL MEASURING SYSTEM. PAFT IV. EQUIPMENT AND PRCCEDUFES THROUGH FISCAL YEAP ISGE ECGERTON, GERMESHAUSEN AND GRIEQ, INC., SANTA SARBARA, CALIF.

C.EX-59.4(PT.4) + ECC-1183-2083+. 57 PAGES, FIGURES, TABLES, 11 REFERENCES, MARCH 1966

DESCRISES THF $\triangle E R I A L$ PADIOLOSICAL MLASURING SYSTEM (ARMS-II) CPERATEG RY EG+GG, INC., FOR THE DIVISION OF 9IOLOGY AND HEDICINE, USAEC. DESIGNED TO MFASURE RARIOACTIVITY OVER LARGE AREAS, THE ARMS-II SYSTEM CONSISTS CF SODIUM IODIDE SCINTILLATION DETFCTORS, RADIATION- AND POSITIONING-MEASUPING INSTRUMENTS, AND DATA-READOUT INSTCUMENTS. THE METHOD OF OPEPATION AND DATA INTERPRETATION AGE DISCUSSED AND EVALUATED, AND PECOMMENDATITNS. APE MAOE FCOP IMPROVING THE SYSTEM.

AVAILABILITY - CLEARINGHOUSE FOR EEDEDAL SCIENTIFIL AND TECHNICAL INFORMATION, SPRINGFIELD, VIRGINIA, $\$ 3.00$ SODY, \$0.65 MICROFICHE

* AIRCRAFT + \#INSTRUMENTATION, RADIATION MCNITORING + \#MONITOP, RADIATICN, BACKGPCUND + MONITDR, RADIATION, CNVIKONMENTAL + MONITGR, RADIATICN, TELEMETPY + SURVEY. RADIATION, AERIAL

$16-21261 \quad \Delta L S G$ IN CDTEGORY 15

RACIQLOGICAL PHYSICS DIVISION ANNUAL PEPORT, JULY 1965 TO JUNE 1966

ARGONNE NATIONAL LAB., ILL.

$\triangle N L-7220+.124$ DAGES, 92 : IGURES, 29 TAELES, REFERENCES, 1966

PROGRAMS COVERED IN THIS REPORT INCLUDE - THOROTRAST DETECTION CHARACTEP. ISTICS OF NAI CRYSTALS OF VARIOUS SIZES, THEPMOLUMINESCENT DOSIMETRY OF INTERNAL BETA RAY EMITTFRS, UV LASER EXCITATION FOK ULTRASENSITIVE PHOTOLUMINESCFNT DOSIMETRY, THERMOLUMINESCENCE IN EONE, GEUMETRICAL AND PHYSICAL PARAMETEPS IN WHOLE-BODY GAMMA-RAY SPFCTROMETRY MEASUREMENTS, PROGRESS IN LOW-PADIOACTIVITY PHOTOMUI ITIPLIER. TUBES, A STOCHASTIC THEORY OF RECRYSTALLIZATION ANO DOWER-FUNCTION RETENTION, THE PRCLIFERATIVE CAPACITY OF STEM CELLS FRCA THE MARROW OF ISOTOPICALLY LABELEO BONE (PRELIMINARY EXPERIMENTSI, RADIUM-226 AND THE NATUFAL AIR GORNE NUCL ICFS LFAD-2IO AND OOLONIUM - $I O$ IN ARCTIC BIOTA, FADUN IN COAL MINES, ATMOSPHERIC P.ADON MONITOR, COMPUTER ANALYSIS OF BONE AUTORADIOGRADHS, EXCHANGEABLE BONE CALCIUM, ANALYSIS OF SMOKE-PLUME PHOTOGRAPHS, CALCULATION OF EFFECTIVE STACK HEIGHT, MUTEOROLOGICAL INSTRUMENTS FOR USE IN THE ATOMIC ENER.GY INDUSTRY, DIFFUSION OF A SCALE-MODEL SMOKE DLUME,

THERMOLUMINESCENT DOSIMETRY, AND ENVIRONMENTAL PADIATICN STUDIES.

AVAILAPILITY - CLEAPINGHOUSE FOR FEDERAL SCIENTIFIC AND TECHNICAL INFORMATION, SPRINGFIELD, VIRGINIA, $\$ 3.00$ CTOY, \$0.05 MICROFICHE

\#BIOLJGILAL CONCENTRATION, GENERAL + \#DOSIMETRY, GENERAL + FINSTRIIMEVT DTION, METEOPOLOGICAL + - METEDROLOGY + $\triangle$ IQBQUNE RELTASE + ANL + BIOMEDICAL + CALCIUM + DIFFIJSION + DOSIMETRY, THEKMOLUMINESCENCE + LEAD + POLONIUM + RADICPIOLOGY + RAOIOGRAPHY + RADIUM + SPECTRCMFTPY, GAMMA + STACK

16-2147E ALSO IN CATBEORY IT

FLUX OSCILLATION INCIDENT AT RAR IGLIANO DURING ROO I MBALANCE

GENERAL ELECTRIC EIMPANY

2 PAGES, DAGFS 11 ANO 14 DF MEMORANOUM SCER-tO, DOCKET 50-277 AND 278, TYPE--BWR, MFG--G.E., AE--BECHTEL, JULY 1967

BEFORE A SCHEDLLED ROO-OSCILLATION EXPERIMENT, A FLUX OSCILLATICN OF $\triangle B O U T$ 8-ICS $\triangle T$ I/3 HERTZ OCCURRED IN A TEST-LDOP C.HANNEL NENB A CONTROL ROD STUCK AT A PCSITION ABCUT 30 IN. MTRE WITHDRAWN THAN SYMMETRICALLY PLACEO ROOS. CHANNEL OUTLET WAS RESTRICTED EY A FLOW METED. GSCILLATION INOICATED ON IN-CDFE INSTPUMENTATION LASTED FRCM 3 TO 5 MIN ANO INAS TEPMINATED EY INSERTING AN $\triangle$ DJACENT P.OD 15 IN. CTHER CHANNELS ALSO SHOWEC FLUX OSCILLATIONS, WITH THE AMPLITUDE DSCREASING WITH DISTLNCF FROM THE OFIVING CIIANALL.

AVAILAGILITY - USAEC PUBLIC DOCUMENT ROOM, WASHINGTON, D. C.

* FLOH STADILITY + CONTROL ROO pHULKAM + FAILURE, SCRAM MECHAVISM + INCIDENT, GENERAL + INSTRUMENTATION, ABNIRMAI. INOICATION + INSTRUMINTATION, IN COFE + FEACIUR STABILITY + REACTOR, BWR + SENN

16-21713 ALSO IN CATEGORY 14

CRAWFORD TV DIFFUSION OF THE NP.XIEST EP-LA EFFLUENT CLOUD

LAWRENCE RADIATION LAPOFATORY, LIVEPMORE

UCRL-50,299+. 49 DAGES, 39 FIGURES, 5 TABLES, 23 R.EFERENCES, JUNE 1967 
16-21713 *CONTINUED*

DISCUSSES THE GENERATION, MOVEMFNT, ANO DIFFUSION OF THE EFFLUENT CLOUD PRODUCEO BY THE NRX/EST EP-4A REACTOR EXOER IMENT OF MARCH 25, 1966 . INITIAL SI ZE AND T IME-DEPENDENT MSTEDROLOGICAL PARAMETERS ALONG THF TRAJECTORY WERE USED AS INPUT INTO A CLOUD-DIFFUSION CALCULATION WITH 23PUFF, A COMPUTER COOE DEVELOPED BY CRAWFGRD. COMPARISON OF CALCULATIONS WITH DATA INDICATE AGREEMENT, WITHIN $\triangle$ FACTOR. OF TWO, FOR AIR CONCENTRATICNS OUT TO TWO DAYS, SURFACE AIR CONCENTRATIJN, DRY DEPOSITION, VERTICAL CONCENTRATION PROFILE SHAPE, AND CLOUD SIZE.

„VAILABILITY - CLEAR INGHOUSE FOP FEDERAL SCIENTIFIC AND. TECHNICAL INFOFMATION, SPRINGFIELD, VA., \$3. OO COPY, \$0.65 AICROFICHE

\#COMPUTER PROGRAM, METEQROLOGICAL + \#DEPOSITION + \#OIFFUSION + \#EXPERIMENT, GENERAL + \#NUCLEAR ROCKET + ATMOSPHERIC STABILITY + CONCENTRATION, AREA + CONCENTPATION, GROUND LEVEL + FALLOUT + MONITOR, RADIATION, AIR + MONITOR, RADIATION, GROUND SURFACE

$16-21767$

HALITSKY J + KARMIN I + MAGONY G

RESEARCH PROJECT. TRANSVERSE. JET PLUMES. TECHNICAL PROGRESS REPORT, APRIL 1-OCTOBER 31 , I966 NEW YORK UNIV., N. Y. GEOPHYSITAL SCIFNCES LAB.

NYO-3673-1+. 25 PAGES, FIGUPES, TABLES, OCTOBER 1966

TECHNICAL PROGRESS REPORT, $\triangle P R I L$ 1-OCT. 31,1966 . TOPICS ARE - CONSTRUCTION OF TEST

FACILITIES, ASSEMBLY ANO CHECKOUT OF INSTRUMENTS, PERFOFMANCE OF PRELIMINARY TESTS IN BOTH SUBOIVISION 1 (FIELO TESTS) ANC SUBOIVISION 2 (HIGH-TURBULENCE TUNNEL TESTS), AS DESCRIBED IN THE RESEARCH PROPOSAL.

AVAILABILITY - CLEARINGHOUSE FOR FEDERAL SCIENTIFIC AND TECHNICAL INFORMATION, SPRINGFIELD, VIPGINIA, $\$ 3.00$ COPY, \$0.65 MICROF ICHE

*EXPER IMENT, GENERAL + *INSTRUMENTATION CALIBPATION + *TEST, SYSTEM OPERABILITY + INSTRUMENTATIDN, METEOROLGGICAL + TURBULENCE, SHEAR (WIND) + WIND TUNMEL EXPERIMENT

$16-21925$

SINGER IA + BUSCH NE + FRIZZOLA JA

MICROMETEOROLOGY OF THE TUPBULENT FLOW FIELD IN THE ATMOSPHERIC SURFACE BOUNDARY LAYER

BROOKHAVEN NAT IONAL LAB., UPTON, N. Y.

SNL-11800 + CONF-670943-1 +. 50 PAGES, AUGUST 31, 1967, FROM INTERNATIONAL RESEARCH SEMINAR ON WIND

EFFECTS ON BUILDINGS AND STRUCTURES, OTTAWA, CANADA

OUTLINES THE SACKGROUND FOR THE MONIN-OBUKHOV SIMILARITY HYPOTHESES, WHICH DESCRIBES THE HEIGHT DEPENDENCE OF VARIOUS TURBULENT FLOW PARAMETERS IN A THERMALLY STRATIFIED SURFACE BOUNDARY LAYEF. A RECENT ANALYSIS OF SPECTRAL DATA TAKEN AT SROOKHAVEN NATIONAL LABORATORY UNDER THERMALLY NEUTRAL ANO UNSTABLE CONOITIONS IS PRESENTED. AND COMPARED WITH OTHER ANALYSES.

AVAILABILITY - CLEARINGHOUSE FOR FEDFRAL SCIENTIFIC AND TECHNICAL INFORMATION, SPRINGFIELD, VA., \$3. OO COPY, \$\$D.65 MICROFICHE

\# ATMOSPHERIC STABILITY + \#TURBULENCE, STATISTICS + \#WIND PROFILE + EXPERIMENT, GENERAL +

LAPSE RATE, ADIABATIC, NEUTRAL + LAPSE RATE, UNSTABLE + MICROMETEOROLOGY + WIND STATISTICS

$16-21926$

MATSUO S + ERIEDMAN I

DEUTERIUIA CONTENT IN FRACTIONALLY COLLECTED RAINWATER

U.S. GECLUGICAL SURVEY, DENVER, COL CRADO

3 PAGES, 2 FIGURES, 1 TABLE, 9 REFERENCES, JQURNAL OF GEOPHYSICAL RESEARCH 72124), PAGES 6374-76 (DECEMBER 15, $19 \in 71$

PRESENTS THE DEUTERIUM AND CHLORIDE CONTENTS OF TOKYO RAINWATER SERIALLY COLLECTED FROM A VARIETY OF RAIN TYPES. THF COLLECTION WAS MADE FOR EVERY I MM GF RAIN. PRESENTS THE CHANGES IN OCUTER IU:H AND CHLORIDE CONCENTRATIONS AS FUNCTIONS OF RAINEALL INTENSITY.

*AEROSOL, RADIJACTIVE + \#OEUTFRIUM + \#RAINCUT + ANALYTICAL TECHNIQUE, WATER + ATMDSPHERIC DIFFUSION + METEOROLOGY + WASHOUT

$16-21927$

JOHNSON $N B$

A COMPACT PORTABLE TEMPERATURE RECOPOER

INSTITUTSS FOR ENVIRONMENTAL RESEARCH, ATMOSPHERIC TURPULENCE AND OIFFUSION LAB.

ESSA-TR-IERTM-ATOL-S +. 7 PAGES, 3 FIGURES, 1 TABLE, 1 REFERENCE, OCTOBER 19E7

DESIGN OF A COMPACT, PORTABLE, TEMPFRATURE RECOR.CER SUITARLE FOP USE IN A SMALL AIR.PLANE TO TAKE HORIZONTAL AND VERTICAL PROFILES OF AIR TEMPERATURE.

AVAILABILITY - MR. W. E. JOHNSON, JR.- STANFORD RESEARCH INSTITUTE, 333 RAVENSWOCD AVE., MENLO PARK, CALIF.

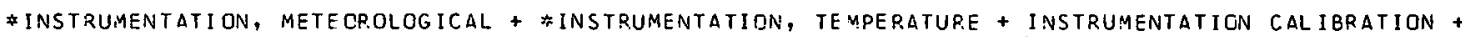

MEASURFMENT, TEMPERATURE 
CATEGORY 16

METEORCL OEICAL CONSIOERATIONS

$16-22196$

LANORY MJ + LOCHNER JR

GB-LIDAR SYSTEM

SANDIA CORP., AL BUQUEFQUE, NEW MEXICO

SC-DC-67-1948+CONF-671015-1+. 21 PAGES, SEPTEMEEP 1OG7, FRGM SEMINAF IN DEPTH ON LASER RANGE INSTRUMENTATION, EL PASO, TEXAS

SANDIA LABCRATOPY DEVELCPED A MOBILE LASER (LIDAF) SYSTEM FOR DETECTING ARTIFICIAL CLOUDS COMDOSED OF ASLATIVE MATERIALS FROM RE-ENTRY VEHICLFS. A STANDARD RADAR SYSTEM CANNOT DETECT SUCH A CLOUN, MUCH LESS THE DESTINATION DF THF PARTICLES, NOE CAN OTHEP. CONVENT IONAL DET ECTING SYSTEMS. THF LIOAF SYSTEM SHOULD NOT DNLY DETECT SUCH A CLOUD BUT SHOULO ALSO GIVE INFORMATION DN ITS DENSITY, ITS TRAJECTOFY, AND THE DISPERSIGN RATES OF ITS CONSTITUENTS.

AVAILAGILITY - CLEARINGHCUSE FOR CEDERAL SCIENTIFIC AND TECHNICAL INFORMATION, SPRINGFIELD, VA., S3. OO COPY, $\$ 0.65$ MICQTEICHE

\# $\triangle B L A T I O N+$ + $A S E R$ + \#MEASUREMENT, GENFPAL + \#REENTRY, ATMOSPHERIC + CIFFUSION + OISPERSION + INSTRUMENTATION, METECROLOGICAL + FEACTOR, SPACE

$16-22450$

MAR.SH KJ + FOSTER MD

AN EXOERIMENTAL STUDY OF THE .DISPERSONN CF THE EMISSIONS FROM CHIMNEYS IN READING--I THE STURY OF LONG-TERM AVERAGE CONCENTRATIONS OF SULPHUR DIOXIDE

THE BRITISH PETPOLEUM CO. LTO., SUNRURYYON-THAMES, MIDDLESEX, ENGLAND

24 PAGES, 11 IGURES, 7 REFERENCES, ATMOSPHERIC ENVIRONMENT 1 (5), PDGES 527-50 (SEPT. 19E7)

THE DISPERSIJN QF SULFUR DIJXIUE IN IHE TOWN OF READING WAS STUDIED FOR 15 MONTHS. IT IS SHOWN THAT, OF VARIDUS IMETSOROL OGICAL VARIABLES EXAMINEC, THE AMEIENT AIR TEMPERATURE HAS THE DREDOMINANT EFFECT ON THE SULFUR DICXIDE CONCENTRATION IN THE AIP. THE ANNUAL AVERAGE CONCENTRATION CF SULFUP. DIOXIDE AT INDIVIOUAL SITES IS STRONGLY CORRELATED WITH LOCAL INSTALLATIONS EMTTTING THFIR FFFLUENTS FROM CHIMNEYS LESS THAN Ż M HIGH. A POLLUTION DOSE FOR THE TRWN AS A WHOLE SHOWS THAT THERE IS AN EXCESS OF SULFUF, DIJXIDE ARRIVING FROM THE EAST, ATTRIBUTED TO POLLUTION FROM LONDON.

* ATMOSDHERIC DOLLUTION + *SOURCE, ELEVATEO + \#STACK + ANALYTICAL MODEL + CONCENTR.ATION, AREA + CONCENTRATIJN, GROUND LEVEL + SULFUR DIOXIDE

$16-22451$

LAWRENCE EN

ATMOSPHERIT. PMIIIITION DURING SPELLS DE LOW-LEVEL AIR TEMPERATURE INVERSION

METEORJLOGICAL JFFICE, RRACKNELL, BERKS., ENGLAND

16 PAGES, 5 FIGURES, 7 TABLES, 5 REFERENCES, ATMOSPHERIC ENVIRONMENT 1(5), PAGES 561-76 (SEPTEMBEF. 1 G67)

AIR-TEMPSRATURE DROFILE DATA FOR CRAWLEY, SUSSEX, AND AIR-POLLUTICN DATA FOR KEW OBSERVATCRY, FOR. THE FIVE WINTER HALF-YEARS FRCM DCTOBER 1O60 TO MARCH $19 E 5$ INCLUSIVE, WERE USED T? SXAMINE THE DEPENDENCS OF THE DAILY MEAN CONCENTRATION OF ATMOSPHERIC SULFUQ OIOXIDE ON THE HEIGHT כF THE LOW-LEVEL AIR TEMPERATURE INVERSION BASE AND TO DEMONSTRATE A TENDENCY FOR A DAILY INCREASE OF AIP PDLLUTICN DLFING SPELLS OF PERSISTENT LOW-LEVEL AIF-TEMPERATURE INVER SIONS.

* ATMOSPHERIC POLIITTITN + \#ATME SPHERIC STAEILITY + \#CONCENTRATION, AP. D + ANALYTICAL TECHNIQUE, AIR + ATMOSPHERIC DIFFUSION + SOURCE, VOLIMME + SIIIFIIR DIOXIDE

$16-22452$

MUNM R.E + COLE AF

SUME STRONE-WIND DONNWASH OIFFUSION MEASUFEMENTS AT DOUGLAS POINT, GNTAFIO, CANADA

METEOROLOGICAL SERVICE OF CANADA, TOPONTG + OCCUPATIONAL HEALTH DIVISI CN, OTTAWA

4 PAGES, 6 FIGIJRES, 1 TABLE, 4 P.EFEFENCES, ATMOSPHERIC ENVIRONMENT 1 (5), PAGES 601-04 (SEPTEMBER 1 S67)

ELEVEN EMISSIONS OF URANINE WEOE MADE FROM THE TOP OF A 46-M STEEL STACK AT THE CANDU NUCLEAR PDWER GENERATING STATION. IN MOST CASES, WINDS WERE LIGHT TO MODERATE, DND THE SAMPLING ARCS WERE 1500 TO $7500 \mathrm{M}$ FROM THE SNURCE. GRAPHS ILLUSTRATE THE CIFFUSION PATTERNS THAT MAY DEVILOP DURING STRONG WINDS. THEY SUGGEST THAT DOWNWASH CONOITIUNS IN A BUILT-UP AREA WITH MANY SHURT CHIMNEYS MUST BE VERY CCMPLICATED.

*CONCENTRATION, GRQUND LEVEL + \#SOUF.CE, ELEVATEO + EFFLUENT + EXPERIMENT, GENERAL +

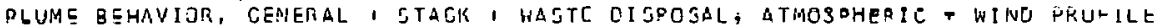

16-22492 ALSE IN CATEGDRY 14

ETICCT DF SOME IONS IN THE ATMOSPHERE ON THE EALLQUT IN 1964101966

HYGIENISCH-EPIDEMIOLOGISCHE KDEI SINSTITUT, BFATISLAVA

5 PAGES, 2 FIGURES, 5 TAGLES, 14 MEFERENCES, KERNENCRGIE 10, PAGES 164-P (MAY 10G7), IN GERMAN

THE RADIOACTIVE FALLOUT DN THE TEPRITQPY OF WFSTERN SLOVAKIA, CSSP, WAS OBSERVED DURING 1964 
16-22492 *CONTINUED*

TO 1966. THE TOTAL 8ETA-RAY ACTIVITY, THE SR-SO AND CS-137 CONTENTS, THE AMDUNT TF STABLE IONS IN THE FALLUUT AS WELL AS THE SALTS DISSOLVED IN THE ATMOSPHERIC PRECIPITATION WERE DETERMINED. THE ISOTOPIC CONTENT DECREASEO CONTINUOUSLY, AND. THE VOLUMINOUS ATMOSPHERIC PRECIPITATIONS DURING 1965 OID NOT RAISE THE FALLOUT RADIOACTIVITY. THE ION CONTENT IN THE FALLOUT WAS INCREASED BY THE INFLUENCE OF THE PRFCIPITATIONS.

*CESIUM + \#PRECIPITATION + \#STRONTIUM + BETA EMITTER + FALLOUT + MEASUREMENT, REACTIVITY + RAINCUT + WASHDUT

$16-22921$

SMITH ME.

REOUCTION OF AMBIENT AIR CONCENTRATIONS OF POLLUTANTS BY DISPERSION FROM HIGH STACKS

BRCOKHAVEN NAT IONAL LAB.

8 PAGES, 5 FIGUFES, 2 TABLES, 10 REFERENCFS, NUCLEAR SAFETY 9(1), PAGE 46-54, (FEB. 1968)

STACKS THAT REACH 500 FT OR. HCRE $\triangle B O V E$ GROUND HAVE BECOME SYMEOLIC. OF GOOD INDUSTRIAL AIR-POLLUTIJN PRACTICE. THIS PAPER SPECIFIES, TO THE BEST OF CURRENT KNOWLEDGE, THE QENEFITS ANO LIMITATIONS ASSOCIATED WITH HIGH STACKS. IT ALSO REVIEWS UNRESOLVEO QUESTIONS ABOUT STACK-GAS BEHAVIOR, INCLUDING PLUME RISE, INVERSI ON BREAKUP FUMIGATIONS, AND THE EFFECTS OF MAJOR TERRAIN FEATURES. THERE IS NOQ QUESTION THAT THE HIGH STACK IS AN EXTREMELY EFFECTIVE DEVICE FOR REUUCING GRQUND-LEVEL CONCENTRATIONS, BUT ADDITIONAL STUDY IS NEEDED TO MAKE SURE THAT STACKS ARE FULLY EXPLOITED.

*CONCENTRATION, GRJUNO LEVEL + \#CONCENTRATION, MAXIMUM + \#SOURCE, ELEVATED + ATMOSPHERIC STABILITY + HEIGHT OF RISE + PLUME BEHAVIJR, GENERAL + STACK

$16-22922$

GATZ DF

LOW-ALTITUDE INPUT JF ARTIFICIAL RADIOACTIVITY TO A SEVERE CONVECTIVE STORM. COMPARISON NITH DEPOSITIDN UNIVERSITY OF MICHICAN, ANN ARBDR

6 PAGES, 7 FIGURES, 3 TABLES, S REFERENCES, J. $\triangle P P L$. METEOROL., 6, PAGE 530-535, (JUNE 1967)

CONCENTRATIONS OF ARTIFICIAL RADIOACTIVITY ANO PLANT POLLENS IN RAIN VARY IN PHASE DUR ING CONVECT IVE STORMS. COMPREHENSIVE MESOMETEOROLOGICAL AND RAOIOCHEMICAL DATA COLLECTED FROM A SEGMENT OF THE SEVERE SQUALL LINE IN CENTRAL OKLAHOMA ON 10 MAY $19 S 4$ WERE USED IN THE ANALYSIS. THE RACIOACTIVITY INFLOW RATE BELOW ESO ME WAS ESTIMATED KINEMATICALLY USING SERIAL SOUNDINGS IN THE STORN: INFLOW AND THE CONCENTRATION OF RADIOACTIVITY IN GROUND-LEVEL AIR. TOTAL INPUT WAS COMPUTED BY MULTIPLYING THE INFLOW RATE BY THE TIME REQUIRED FOR THE STORM TO CROSS A NETWORK OF 10 GPOUNO-LEVEL RAIN SAMPLERS. COMPARISON OF INFLOW AND OEPOSITION OVFR THE SAMPLER NETWORK SHOWS THAT INFLOW OF AIREORNE RAOIOACTIVITY TO THE STDRM AT LOW ALTITUDES CAN ACCOUNT FOP ARTIFICIAL RADIOACTIVITY DEPOSITED IN THE RAIN.

*AEROSOL, RADI JACTIVE + \#PRECIPITATION + *RAINOUT + DEPOSITION + EXPERIMENT, GENER AL + RADIOCHEMICAL ANALYSIS + WATER VAPOR

$16 \div 22924$

LOCKHART LQ + PATTERSON RL + SAUNUERS AW

ATMOSPHERIC RADIDACTIVITY IN ANTARCTICA 1956-1963

U.S. NAVAL RESEARCH LAB., WASH., D. C.

18 PAGES, 7 FIGURES, 5 TABLES, ?3 REFERENCES, NOV. 3, 1965

CONT INUOUS MEASUREMENTS OF THE RADICACTIVE AEROSOL CONTENT OF THE SURFACE AIR IN ANTARCTICA HAVE BEEN MADE SINCE 1056, FIRST AT LITTLE AMERICA AND LATER AT THE AMUNDSEN-SCOTT SOUTH PGLE STATION. BOTH THE RADIOACTIVITY DUE TO BOMB-PRODUCED FISSION PRUUUCTS AND TO THE NATURALLY OCCURRING RADIONUCLIDES OF THE RADON AND THORON SERIES WERE MEASUREU. IHE NATURAL RAOIDACTIVITY WAS LOWER THAN THAT AT ANY OTHER GEOGRAPHICAL LOCATION. THE FISSION-PRODUCT CONCENTRATIDNS WERE EQUAL TO DR GREATER THAN THOSE OBSERVED IN THE SOUTHERNMOST PARTS OF SOUTH AMERICA. WELL-DEFINED SEASONAL VARIATIONS WERE NOTED, WITH MAXIMA IN THE SUMMER.

AVAILABILITY - CLEARINGHOUSE FOR FEDERAL SCIENTIFIC AND TECHNICAL INFORMATION, SPRINGFIELD, VIRGINIA, $\$ 3.00$ COPY, \$0.65 MICRGFICHE

*AFROSOL, RADIOACTIVE + *RADIOCHEMICAL ANALYSIS + ATMOSPHERIC CIRCULATION, GLOBAL + FALLOUT + RADCN + SAMPLING + STRONTIUM + THORON

$16-22925$

CSANADY GT

ON THE PROBLEIA OF THE EFFECTIVE CHIMNEY HEIGHT

WATERLOO UNIV., ONTARIO

NYO-3685-12 + CONF-670931-14+. 25 PAGES, SEPTEMGER 1967, PRESENTED AT USAEC METEQROLOGICAL INFORMATION MEETING, CHALK RIVER, CNTARIO, CANADA

PRESENTS THEORETICAL MODELS OF THE EFFECTIVE CHIMNEY HEIGHT FCR HOT AND COLO PLUMES. IN VERY STRONG WINDS, A HOT BUOYANT PLUME BEHAVES VERY MUCH AS A COLD PLUME. PRESENTS EQUATIONS OF THE CRITICAL WINO SPEEDS FOR MAXIMUM CONCENTRATIONS FOR A CONSTANT WIND SPEED.

AVAILABILITY - CLEARINGHOUSE FOR FEDEPAL SCIENTIFIC AND TECHNICAL INFORMATION, SPRINGFIELD, VIRGINIA, 
METEQPOL OGLIEACERY CONSIOEFRATIONS

$16-22925 *$ CONT INUED*

$\$ 3.00$ CIPY, $\$ 0.65$ YICRCFICHE

\#EUOYANT P.ISE + \#HEIGHT OF RISE + \#STACK + ATMOSPHERIS STABILITY + CONCEVTRATION, GROUND LEVEL + EFFLUENT + SOURCE, ELEVATED + THECRETICAL INVESTIGATICN + WIND PRDFILE

$16-22970$

KEISCH B + KOCH RC + LEVINE AS + RAFSMEF $J+$ WINNCWSKI WS

I-I2C--A NEW ATMOSPHERIIC THACER

NUCLEAR SCIENCE AND ENGINEERING COPP. , PITTSBUPGH, PA.

NSEC-120+NYO-3201-1+. OQ PAGES, FIGURES, TABLES, DUGUST $10 \in 5$

TW] I-129 LABELFD TRACERS, DIIOOOELUGRCSCEIN AND TRIFLUOROMETHYL IODIDE, WERE DEVELOPED FOR USE $\triangle S$ AN ASROSOL $\triangle N D$ A GASEOUS TRACER RESPECTIVELY. DETAILFD DESCRIPTIQNS DF THE METHOCS FDR SYNTHESIS, DISSEMINATION, COLLECTION, AND ANALYSIS OF THESE TRACERS ARE GIVEN. RESULTS, ESSENTIDLLY IN AGREEMENT WITH THEORETICAL PREDICTIONS, WERE GBTAINED TO DISTANCES IFF G4 KM FOR THE AEROSUL TRACER. THE PESULTS FQR THE GASEOUS TRACER WERE INCONCLUSIVE DUE TO THF ACCIDENTAL USE OF CONTAMINATEU CLAFCDAL AS THE GAS-SAMPLING MEDIA. CALCULATIONS SHDW THAT THE I-120 TRACER METHOD CAN BE EFFFCTIVE OVER PANGES UP TO $800 \mathrm{KM}$.

AVAILABILITY - CLEARINGHOUSE FOR FEDERAL SCIENTIFIC ANO TECHNICAL INFORMATION, SPRINGFIELD, VA., \$3. OO COPY, \$0.65 MICRDFICHE

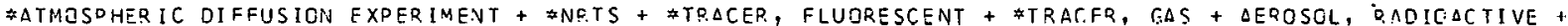
CUNCEVTRATIDN, GRDUND LEVEL + DISPEPSION + INSTRUMENTATION, METEGRGLOGICAL + IOOINE

$16-22971 \quad \Delta L S E$ IN CATEGQRY 14

QUARTERLY SUMMAPY PEPGRT SEOTEMBER 1 THDOUGH DECEMBER 1 , lOE 7 APPFNOIX TO HEALTH AND SAFFTY LABOFATOFY FALLOUT PRQGRAM

USAEC, NEW YORK OPERATICNS DFFICE

HASL-194, $\triangle P$ PENOIX + , 200 PAGES, FIGURES, TABLES, JANUARY 1,1968

TABULAR DATA COR (A) SR-90 ANE - $E$ O IN MONTHLY DEPOSITION AT WORLD LAND SITES, (B)

FISSION-PRODUCT AND ACTIVATION-DQODUCT PADIONUCLIDES IN MONTHLY DEPGSITION AT SELECTED SITES, (C) RADIOSTRONTIUA CFPESITION AT DTLENTIC OCEAN WSATHER STATIONS, IOI RADIOSTSONTIUM IN MILK ANC TAD WATER.

AVAILASILITY - CLEARINGHOUSE FOR FEDERAL SCIENTIFIC AND TECHNICAL INFUK:4ATION, SPRINGFIELD, VA. S3. OO COPY. $\$ 0.65$ MICROFICHE

\#OEFOSITION + \#MONITCRING PROGRAM, ENVIPCNMENTAL + ANALYTICAL TECHNIQUE, MILK + FALLOUT + RAINCUT + STRONTIUM + WATER, DPINKING

$16-22972$

SDMAN SD + $\triangle E R A H A Y P$

ESTIMATION OF DILUTION RATE FACTORS FOR TFITIATED WATER VAPOUR FROM A REACTOR STACK

BHABHA $\triangle T O M I C$ RESEARCH CENTRE, BOMBAY, INCIA

5 PAGES, 1 FIGURE, 2 TAELES, 12 P.EFERENCES, HEALTH PHYSICS PERGAMEN PRESS 1067, VOL. 13, PAGES 11 I 7-112!

TRITIUM IS PRESENT IN THE EFFLUENT AIR FROM NLICLEAR REACTDRS, JSING HEAVY WATER AS MODERATOR DR AS COOLANT OP EOTH, AS TRITIATEC WATER VAPOUF. AS TRITIUM IS LONG-LIVED, THE ESTIMATION OE TRITIUM IN AIR AT DIFEERSNT LOCATICNS CAN PROVIDE A GOCO INDICATION OF THE DILUTION ORTAINED AT THESE POINTS IF THE CONCENTRATION OF TRITIUM IN THE EXHAUST GASES IS ALSO MEASURED SIVULTANEDUSLY. COLD-FINGER SAMPLES FR.OM THE CIR.US EXHAUST SYSTEM. HAVE BEEN ANALYSED FOP TRITIUM CONTENT TO ESTIMETE THE RATE UF KELEASE JH TRITIUM. THE METHOOS AOOPTEO COR THE COLLECTION OF SAMPLES $\triangle T$ DIFFEPENT LOCATIONS IN THE CENTRE, ESTIMATION CF TRITIUM CONCENTRATIONS, $\triangle N D$ THE RESULTS DETAINED ARE PP.ESENTED. A PORTABLE SAMPLER DEVELGPED AT TROMBAY HAS BEEN USED FOR THE COLLEC.TION CF MOISTURE SAMPLES FROM DIFFERENT LDCATIONS.

\#CONCENTRATION, GROUND LEVEL + \#EXPFDIMENT, GENERAL + \#SOJRCE, ELEVATED + DILUTIGN + EFFLUENT + INDIA + SUTTON DIFTUSION FORMULA + TRITIUM + WASTE DISPOSAL, ATMOSPHERIC + WATER VAPRR

16-23197 ALSO IN CATEGCRY 2

COOPER RE + RUSCHE BC

SITE EVALUATION US INC MEASURED MLTLOROLCGY DATA

SAVANNAH RIVER LABORATORY

DP-MS-67-69+ CONF-670931-2 +. 16 PAGES, FP.CM USAEC METEORQLOGICAL INFORMAT ION MEETING, CHALK FIVER, ONTARIC, CANADA, SEPTEMBER 1967

DETAILED MEASUFEMLNTS DF THE bIIND SPEE[, WINO OIRECIILIN, AND TEMPERATURE AT HEIGHTS UP TO IZCO FT AT THE SAVANNAH RIVER PLANT FORM THE BASIS FOR A COMPREHENSIVE ANALYSIS OF THE FREQUENCY OF OCCURR ENCE OE POTFNTIAL UFF-SITE DOSES. THE RESULTS WERE EXPRESSED ON CURVES IN DOSE PER UNIT RELEASE OF ACTIVITY VS OISTANCE FROM THE REACTOF, WITH PQOBABILITY OF OCCURRFNCE AS A PARAMETER. CURVES WERF DEVELOPEO TC SHOW OOSE AS A FUNCTION OF DIRECTION ANO PRORABILITY OF OCCURRENCE.

AVAILABILITY - CLEARINGHOUSE FOR FEQEPAL SCIENTIFIC AND TECHNICAL INF CRMATICN, SPRINGFIELD, VA., \$3. OO COPY, $\$ 0.65$ MICROFICHE 
$10-23197 \#$ CONT INUEC*

\#MFTEOROLOGY + \# SITE CLIMATOLOGY + \#SITING, GENEFAL + .ATMOSPHERIC DIFFUSION + DISPERSION +

MEASUREMENT, GENERAL + STACY

16-23379 ALSO IN CATEGRRY 14

MURAYAMA N

OSSERVATIONAL EVIDENCE ON TRANSPORT OF RAOIDACTIVITY AND OZONE THROUGH THE TROPOPAUSE

JAPAN METEOROLOGICAL AGENCY, TOKYO

14 PAGES, FigURES, REFERENCES, GEOPHYSICAL MAGAZINE (TOKYO), 33, PAGES 149-162 (NOV. 1966)

EXTRAOROINARILY HIGH RADIOACTIVITY WAS.RECCRDEC GY A GAMMA-ACTIVITY SONDE LAUNCHED $\triangle T$ TATENO, IN THE LAYER BETWEEN 500 ANO 300 MB LEVELS IN THE REGION OF STRONG UPPER FRONTS EXTRUOING DOWN FROM THE TROPOPAUSE. THIS IS DISCUSSED IN TERMS OF AN INSTANCE OF THE RADIOACTIVE CUSTS ORIGINATING, IN THE STRATOSPHERE BEING TRANSFERRED INTO THE TROPOSPHERE THROUGH THE TROPOPAUSE BREAK BY DISTURBANCES DEVELOPED IN THE UPPER TROPOSPHERE. THE FESULTS AP.E COMPAREO WITH VERTI ICAL-OZONE-DISTRIBUTION FINDINGS.

\#FALLOUT + \# JAPAN + *STRATOSPHERE + \#TROPOSPHERE + ATMOSPHER IC CIRCULATION, GLOBAL + NUCLEAR EXPLOSION DEBRI'S

$16-23380$

DANIELSEN EF + DIFRCKS JW

STUDY OF THE TROPOPAUSE BASED ON VUMBERICAL INTEGRATION OF THE POTENTIAL VORTICITY EOUATION. FINAL REPOPT PART 1 .

PENNSYLVANIA STATE UNIVERSITY, UNIVERSITY PARK, PENN.

NY0-3317-1 +. 43 DAGES, FEBRUARY 1967

TROPOPAUSE FOLDING WITH ITS DOWNWARO AND SOUTHWARD TRANSPORT OF FADIOACTIVITY PROVIDES A OIRECT LINK BET WEEN THE STRATOSPHERIC RESERVOIR AND THE TROPOSPHERIC MECHANISMS. RESPONSIBLE FOR SURFACE DEPCSITION. A NUMERICAL EXPERIMENT WAS CONDUCTEO TO STUDY THE ADVECTION OF TROPOPAUSE. THE NUMERICAL MODEL ANC THE RELEVANT EOUATIONS DRF DISCISSED. THE INITIAL ANO PRËDICTED DOSITIONS OF THE TROPOPAUSE ARE ILLUSTRATED BY VERTICAL CROSS-SECTION.

AVAILABILITY - CLEARINGHGUSE FOR FEDERAL SCIENTIFIC ANO TECHNICAL INFORMATION, SPRINGFIELD, VIRGINIA \$3.0O COPY, \$0.65 MICROFICHE

* ATMOSPHERIC CIRCULATION, GLOBAL + \#COMPUTER PROGRAM, METEORQLOGICAL + \#FALLOUT +

ATMOSPHERIC DIFFUSION, GLOBAL + MATHEMATICAL TREATMENT + STRATOSPHERE + TROPOSPHERE

$16-23878 \quad$ ALSC IN CATEGORY 14

KAURANEN P + KULMALA A + MATTSSON R

FISSION PRODUCTS OF UNUSUAL COMPOSITION IN FINLAND

DEPT. OF PAOIOCHEMISTRY, UNIVERSITY OF HEL SINKI + FINNISH METEOROLOGICAL OFFICE. HELSINKI

4 PAGES, 5 CIGURES, 2 TABLES, 13 REFERENCES, NATURE $216(51121$, PAGE 238 THRU 241 , (OCTOBER 1967)

A GLQUD QF CDESH, HIGHIY FBATTIMNATFR FISSIMN PROMIICTS WAS CBSERVED IN FINLANO BETWFEN DECEMBER 21 ANE 26, 1966. THEY SEEMED TO COME FROM CENTRAL ASI A AND WERE PROBABLY THE PRODUCT OF AN UNDERGROUND NUCLEAR TEST. PRESENTS CUNCENTRATION DATA AND METEORGLOGICAL CONDITIONS.

*AEROSOL, RADIOACTIVE + FALLOUT + ATMOSPHERIC DIFFUSION + FINLAND

$16-23880$

ALDAZ L

SURFACE AIR RADIDACTIVITY AND OZONE AT AMUNDSEN-SCOTT STATION (9O S), ANTAKCTICA

UNIV. DF IN. MEX.+ AL DUQUERQUE

2 PAGES, 1 FIGURE, 4 REFERENCES, NATURE (LONDON), 215 , PAGE 722 AND.723, (AUGUST 1967)

CONTINUOUS MEASUREMENTS OF SURFACE-AIR RADIOACTIVITY LEVELS AT THE SOUTH POLE FROM I959 TO 1963 HAVE PREVIOUSLY BEEN REPORTED, AND ADDITIONAL DATA UP TO 1965 ARE PRESENTED IN THIS COMMUNICATION. SURFACS-OZONE RECORDS F́OR 1962 TO $19 E 5$ ARE ALSO GIVEN. FISSION PRODUCT ANO OZONE DATA ARE PFESENTEO GRAPHICALLY, AND A YEARLY OSCILLATION FOR BOTH SETS OF DATA IS OBSERVED, OPPOSITE IN PHASE, AND WI TH A 6-MONTH PHASE DIFFERENCE. IT IS POSSIBLE THAT SEASONAL VARIATICNS IN ATMISPHEPIC EXCHANGE BETWEEN THE MIDOLE LATITUDES OF THE NORTHERN HEMISPHERE AND THE POLAR REGIONS ARE SOMEHOW CONTROLLING THE OBSERVEO ANNUAL OSCILLATION OF RAOIOACTIVITY AND OZONE IN THE SURFACE AIR AT THE SOUTH POLE.

\#ATMOSPHERIC CIRCULATION, GLOBAL + \#FALLOUT + AEROSOL, RADIDACTIVE + ATMOSPHERIC DIFFUSION, GLOBAL + OZONE

$16-23833$

SQUIRES AII

AIR POLLUTION. THE CONTROL OF SO-2 FROM POWER STACKS. PART I - THE REMOVAL OF SULFUR FROM FUELS

THE CITY COLLEGE OF THE CITY UNIVERSITY OF NEW YORK

O PAGES, 7 FIGURES, 35 REFERENCES, CHEMICAL ENGINEERING 74(23), PAGE 260-268, (NCV. 1067) 
CATEGORY 16

ME TEOROL OGICAL CONSIDERATIONS

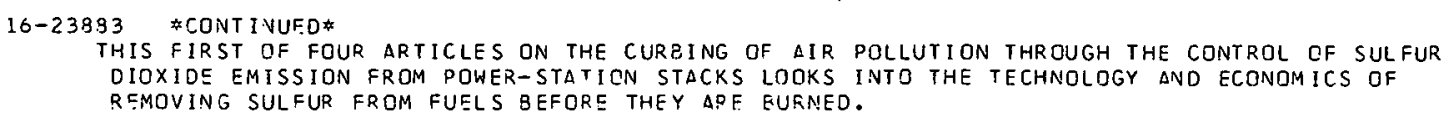

PHYSICO-CHEMICAL PROPERTIES OF HIGHLY RADIOACTIVE FALLOUT PARTICLES COLLECTEO IN JAPAN SHORTLY AFTER. SOVIET OR CHINESE VUCLEAR EXPLOSIONS AFE DESCRIBED AND DISCUSSED BRIEFLY IN RELATICIN. TO GURST CONDITIONS: CONSIDERAFLF DIFFERENCES ARE FOUND BETWEEN FALLOUT PAFTICLES FFUM OIR BUFSTS AND THOSE FFOM SIIRFACF DUPSTS (SHAPE, COLOR, MATRIX MATCPIAL, SFCCIFIC ACTIVITY, RELATION BETWEEN THE INITIAL DTOM NUMBER OF THE RADIONUCLIDE $\triangle N O$ THE PARTICLE VCLUME, RADIONUCLIDE FRACTIONATION, $\triangle N D$ U AND DU CONTENTI.

\#AEROSOL, RADIOACTIVE + \#RADIOCHEAICAL ANALYSIS + FALLOUT + JAPAN

$16-24067$

HENDERSON RW

CHARACTERISTICS OF THE PADITACTIVE POLLUTANT FROM GROUND TESTING OF NUCLEAR PROPULSION REACTORS

LOS ALAMOS SCJENTIFIC LAB., N. 'AEX.

LA-DC-8524+CONF-670704-3+. II DAGES, FIGURES, REFEPENCES, 1967 , PRESENTED AT THE IAEA SYMPISIUM ON INSTRUMENTS AND TECHINIGUES FOR THE ASSESSMENT OF A! KEURNE RADIOACTIVITY IN NUCLEAR OPERATIONS, VIENNA, AUSTRIA

DISCUSSES RESULTS DF ATMOSPHERIC OIFFUSION DURING TESTS OF PRCJECT ROVER. RESULTS SHOW THAT CASCOUS TRACTION SUFFERS MORE LATERAL OIFFUSIUN THAN IHE PARIICULATE FRACTICN, AND THEY DRE NOT DEPLETED FELATIVE TO EACH OTHEF WITH DISTANCE. CONFIRMS THAT THE ASSUMPTION QF THE MAJUR RDLE PLAYED RYY IIAPACTION AND GRAVITATIONAL SETTLING IS EF LITTLE IAPORTANCE IN DEPLETING SMALL PARTICLES.

AVAILABILITY - CLEAQINGHOUSE FOR FELERAL SCIENIIFIC AND TECHNICAL INFOR:AATION, SPRINGFIELD, VIRGINIA $22151, \$ 3.00$ COPY, \$0.65 MICROF ICHE

*ATMOSPHERIC OIFFUSION EXPERIMENT + \#ROVER PROGRAM + COMPARISQN, THEORY ANO EXPERIENCE + DEPOSITION + PARTICL SIZE DISTRIQUTION + PLUME SEHAVICR, GENERAL 
17-16494 ALSO IN CATEGORY 1 E

NS SAVANNAH CHANGE 6 - AUXILIDRY COGLING WHILE IN DRY DOCK

FIRST $\triangle T O M I C$ SHIP TRANSPOPT, INC., HOBOKEN, NEW JERSEY

3 PAGES, DOCKET ND. 50-239, JUNE 26, 1967

DRL APPROVES CHANGE 6 TO ALLOW USE OF A 100-GPM PORTABLE PUMP ANE THE INSTALLED LETDOWN COOLERS AS SUBSTITUTES FOR THE PRIMARY COOLANT PUMP FOR HEAT REMOVAL, WHEN NET POSITIVE SUCTION HEAD CANNOT SE MET.

aVAILABILITY - USAEC PUBLIC DOCUMENT FOOM, WASHINGTON, D. C.

* TECHNICAL SPECIFICATIONS + AUXILIAPY COOLING + NS SAVANNAH (PWR) + REACTOR, MARITIME + REACTOR, PWR + SAFETY EVALUATION + SHUTDOWN CJOLING SYSTEM

$17-17165$

CORDIN RA

FUEL ACCOUNTABILITY EXPERIENCE OF YANKEE ATOMIC ELECTRIC COMPANY

YANKEE ATOMIC ELECTRIC COMPANY

CONF-670-713 +. 9 PAGES, $\triangle$ BSTRACT IN ANS TRANSACTIONS, SUPPLEMENT TO VOLUME 10, PAGE 32 , (JULY 1967), PAPER PRESENTED AT THE CONFERENCE ON PEACTOR OPFRATING EXPERIENCE, REACTOR OPERATIONS DIVISION OF THE AMERICAN NUCLEAR SOCIETY, ATLANTIC CITY, JULY 23-26, 1967

YANKEE HAS GEFN $\triangle B L E$ TO SATISFY $\triangle E C$, IAEA, AND PUBLIC ACCDUNTANT NITHOUT LIFFICULTY AND WITHOUT $\triangle$ DOING A LARGE GROUP DF EMPLDYEES. AUOITS ARE, IN ESSENCE, REDUCED TO TWR OUESTIONS - (1) DOES THE SYSTEM TRUTHFULLY REFLECT BALANCE. OF HIGHLY VALUABLE (AND UNSEEN) MATERIAL, AND (2) ARE PROPER ENTRIES MADE.

REACTOR, PWR + REFUEL ING + YANKEE (PWR)

\section{$17-17458$}

KANTOR ME + MENZEL HF + SCHLICHT RW + WESTLAKE WJ

FNGINEERING TESTS DURING THE INITIAL OPERATION OF THE PEACH BCTTCM HTGR

GENERAL ATOMIC, SAN DIEGO, CALIF.

GA-8040 + CONF-670602 +.27 PASES, 14 FIGURES, JUNE 16, 1967 . ALSO ANS TRANS. 10(1) PAGES 319-320, 1967

ANNUAL MEETING OF THE AMERICAN NUCLEAP SOCIETY, SAN DIEGO, CALIF., JUNE 11-15, 1967

STEAM GENERATORS, PARTICULAQLY TEMPERATURE TRANSIENTS IN THEIR TUEE-SHEETS, ARE THE CONTROLLING EQUIPMENT IN APPROACH-TO-POWER TESTING. COMPUT.EF CODES HEAT IFOR STEAM GENERATORS) AND BLOOST (FOR REACTOR KINETICS) WFRE COMBINED TO YIELD CORE REACTIVITY AND TEMPERATURE DISTRIEUTION FOR ALL PCWERS AND COCLANT FLOWS, AND TRANSIENT STUDIES PERFORMED ON PEACH BOTTOM TRAINER SIMULATOR ANALOG COMPUTER. COOLLNT AND STEAM-GENERATOR DATA AND INSTRUMENT CALIBFATIONS WERE MADE AS POWEP LEVEL ROSE FROM O TO $30 \%$ POWER WITH CONSTANT MASS FLOW RATE. AT 30\%, RESPJNSE TO SCRAM, LOGP I SOLATION, AND SET BACK WERE RECORDED. AS POWER ROSE ABOVE $30 \%$, MASS FLOW INCREASED TO MAINTAIN CONSTANT STEAM CONDITIONS THROUGH FULL POWEF WHILE TESTS CONTINUED. STEAM GENEPATOR NEEDED REBAFFLING AND COCLED P.OOM AIR DIRECTED TO SG HFAT TI! MAINTAIN DESI GN TEMPERATURE.

\#TEST, PLANT RESPONSE + PEACH BOTTOM I (HTGR) + REACTOR, GCR + REACTOR, HTGR + STEAM GENERATOR + TEMPERATURE TRANSIENT

17-17943 ALSO IN CATEGORY 1

NOVICK $S$

QUASI-SCIENTIFIC REPCPTING OF FFPMI FUEL MELTOOWN

9 PAGES, 4 FIGURES, SCIENTISl' AND CITIZEN S(6), PAGE 98 THRU 104, (JUNE-JULY 1367)

WRITER ASSERTS THAT OPERATOR NOTICEO NEUTRON FLUX OSCILLATION AT 20 MW, HAO OBSERVEO IT MANY TIMES BEFORE ANO OFTEN AT 3 PM, SWI TCHEO TO MANUAL CONTKOL AND CONT INUED POWER INCKEASE. POINTS OUT THAT THE ACCIDENT WAS A BIT WORSE THAN THE MCA...WAS NOT ONLY INCREDIBLE BUT MIGHT HAVE. BEEN FAR WORSE. GLOSSARY - EREEDER EXTREMELY SOPHISTICATED IN DESIGN. THOSE WHICH HAVE BEEN BUILT HAVE A HISTDRY OF UNRELIABILITY.

AVAILABILITY - SCIENTISTS INSTITUTE FOR PUBLIC INFOPMATION, 3O EAST 6ETH STREET, NEW YORK, N.Y. IOOZI

\#RADIATION, PUBLIC EDUCATION / ACCEPTANCE + CONTROLLER + FERMI (LMFPR) + FUEL MELTDOWN + INCIDENT, GENERAL + REACTOR POWER + REACTOR, FAST

17-20355 $\triangle L$ SO IN CATEGORIES 11 AND 18

SUPPLEMENT TO APPEND IX D--TURBINE GENERATGR FAILURES OUE TO EXCFSSIVE OVERSPEEDING

FLORIDA POWER ANO LIGHT COMPANY

4 PAGES, PAGE DI TO O4 OF SUPPLEMENT 3 TO THE LICENSE APPLICATION AND PP.ELIMINARY SAFETY ANALYSIS REPORT.

SEPTEMBER 1, 1965, DOCKET 50-2.50/251

ONLY TWO SUCH FAILURES ARE REPOPTEO, gDTH IN ENGLAND - (1) USKHOUTH - (1) FAILURE AT $170 \%$ 
OPERATIONAL CATFGORY 17 TAFETY AND EXPERIENCE

- 17-20355 \#CONT INUED*

OVERSPEED \& WEEKS AFTER C IMMISSONING, (2) BLACK IRON-OXIDE FORMATION IN THE GOVERNOR FRGM BRACKISH-WATEF-CGNTAMINATED OIL AND LONG SHUTDOWNS. DAMAGF IS DESCPIBED ILOW-DRESSURE WHEEL FOUND 150 YD AWAY). (2) CALDER HALL-E - CNE MONTH AFTEP COMMISSIONING, MAIN STEAM-ADMISSICN VALVE STUCK FULL-OPEN WHEN LGAD DPCPPED SUDDENLY. VALVE FAILURE WAS CAUSED BY PARTICLE CF CHILLED IRON SHOT EMBEDDED IN THE VALVE SDINDLES.

AVAILABILITY - USAEC PUELIC DOCUMENT RDOM, WESHINGTON, D. C.

*FAILURE, EOUIDMENT + \#INCIDENT, EQUIPMENT + \#MISSILE GENERATION AND PROTECTION + \#TUREINE + CONTROLLER + FAILURE, ADMINISTRATIVE CONTROL + GUALITY CGNTRDL + REACTOK STAPTUP EXPERIENCE + VALVE

$17-20356$

SUPPLEMENT TO APPENDIX D--TUREINE GENERATGR. FOTOR FAILUPES CAUSED PRIMAPILY BY SEVFRE STRESS CONCENTRATIONS FLORIDA POWER AND LIGHT COMDANY

4 POGES, DAGE D5 TO OF UF SUPPLEMENT 3 TO THE TURKEY POINT 3 ANO 4 LICENSE APPLICATION AND PPELIMINAPY SAFETY ANALYSIS REDQFT. SEPTEMBER 1,1966 , DOCKET NO. 50-250/251

(1) CROMBY STATION - FAILURE AT 5\% CVVERPPED TEST DUE TO HOLES THAT HAD BEEN DRILLEC IN THE ROTOR TO R.EPAIF. FABRICATION DAMASE. (2) ARIZONA P.S. ROTCE AT FACTOKY FAILED AT LESS THAN RATED SDFFO SUE TO INTFPNAL CRACKS (WHICH HAD FEEN PKEVICUSLY DETECTED BY SONIC TESTING)

(3) P. G. AND E. PITTSEURGH STATION - UNIT I POTOR BODY SDLIT IN HALF DUPING A IO\% OVERSPEED TRIP-TEST, DUE TI A SDNIT.ALLY-UNDETECTED INCLUSION (ALSO FOUNU IN UNIT 3 ).

AVAILABILITY MSAEC PUBLIC DOCUMENT UIIIN. HASHINGTON, D. C.

\#INCIDENT, EQUIPMENT + \#MISSILE GENERATION AND PRQTECTION + \#QUALITY CCNTROL + FAILURE, EQUIPMENT + REACTDR, PWR + TEST, NONDESTRUCTIVE + TESTING + TURBINE + TUPKEY POINT 3 AND 4 (PWR)

$17-20357$

SUPPLEMENT TO APPENDIX C--TURBINE WHEEL AND SDINOLF FAILURE

FLORIDA POWER AND LIGHT COMOANY

4 PAGES, PAGE DO THRCUGH $0 ! 2$ OF SUPPLEMENT 3 TO THE LICENSE APPLICATION AND PRELIMINARY SAFETY ANALYSIS REPORT. SEPTEMBEP 1, 1S56, OOCKET 50-250/251

(1) TANNERS CREFK - WHEEL FAILUDE GUE TO POOR HEAT TREATMENT AND A STRESS-RAISCR HOLE WHERE NOTCH BUCKET ATTACHED T? WHEEL. (Z) FIOGELAND - SPINDLE FAILUFE DUE TO FALKCS CR CRACKS CREATED TIURING HFAT TREATYENT, WHICH WERE DETECTED SONICALLY BUT CHNSIDERED HADMLESS.

AVAILABILITY - USAEC PUBLIC DOCUMENT ROOM, WASHINGTON, D. C.

\# INCIOENT, EUUIOMENT + FAILURE. DOMINISTRATIVE CONTROL + FAILURE, EGUIPMENT + MISSILE GENERATION AND PROTECTION + TEST, NCNRESTRUCTIVE + TUREINE + TURBINE BLDOE, VIBRATION

$17-20579$

MCCARTHY JE

ALSO IN CATEGORY 10

SHORT ACROSS BOTH $490 \mathrm{~V}$ FEEDEP.S AT FERMI

ATOMIC ROWER ULVELOOMENT ASSOCIATES, INC. + POWER PEACTOR DEVELOPMENT COMPANY + DETROIT FRISON COMPANY APDA-C.FE-1 +. 1 PAGE, PAGE IS OF COMOILATION OF CURRENT TECHNICAL EXPERIENCE AT ENRICO FERMI ATOMIC, POWER

PLANT, AUGUST $1 \subseteq 6.6$

(DG 1O) THE JUNE 2 ? MOWLR DUTAGE FAILEC CUTH $480-V O L T$ FEEOS. ONE PHASE OF ONE DRIMARY SIDE OE THE UNGROUNDEC DELTA-WOUNO 480ก $1480-V$ TPANSFORMER HAD SHCWN PREVIOUS SPCRADIC GROUNOING.

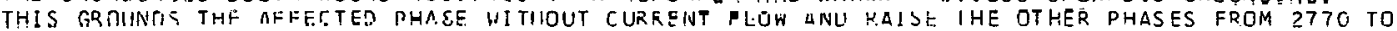
$4800 \mathrm{~V}$. CN JUNE ?9, THE RAISED VOLTAGE PRGBABLY TRIGGERED A WEAK SPDT IN THE OTHER FEED, RESULTING IN A PHASE-TQ-DHASE SHORT THROUGH GRCUND, QPENING THE $48 O \cap-V$. CIRCUIT EREAKERS AND DESTROYING THE CABLES. DIESEL CARRIED THE DIESEL RUS LOADS.

AVAILABILITY - USAEC PUBLIC OOCUMENT ROOM, WASHINGTON, D. C.

ACCIDENT, LOSS OF POWEP + EMERGENCY POWER, ELECTPIC + FAILIIRF, SEOUENTIML + FAILURE, SIMULTANEOUS + REPORT, OPERATIONS SUMMARY

$17-20500$

MCCARTHY JF

COMPILATION OF CURRENT TECHNICAL EXPERIENCE AT ENRICE FERMI ATCMIC POWEP PLANT

ATOMIC PDWER DFVFI TPMENT ISSOCIATES, INC, I FOWEP RFACTOR UEVELUNMHNT COMPANY + DETROIT EDISON CGMPANY

$\triangle P P D A-C F E-1+$. 35 DAGES, TASLFS, FIGURES, $\triangle U G U S T$ I 960

THIS IS ONE DF A SERIES OF MONTHLY PFPORTS WHCSE USUAL CONTENT INCIIIIFFS SUMMARY, DATA AND STATISTICS, NUCLEAR TEST WKUGRAM, PLANT TEST PRQGRAM, OTHER OPFRATING EXPERIENCES, MAINTAINANCE AND ADOITIJNS. USUALLY CONTAINS BRIEF SUMMARIES WITHDUT REDORTING DETAILED ANALYSES OE OCCURRENCES EARLIER THAN THF PEPOPTING PERIOO.

AVAILABILITY - USAEC DUELIC DOCIJMENT ROOM, WASHINGTON,

FERMI (LMEBR) + REACTOR, FAST + REPORT, OPERATIONS SIIMMARY 
CATEGORY I 7 EPERATIONAL SAFETY AND EXPERIENCE
OPERAT

17-20638 ALSO IN CATEGORY S

MCCARTHY WJ + JENS WH

ENRICO FERMI FAST BRFEDER P.EACTOP

POWER REACTOR DEVELOPMENT CO. + $\triangle$ TJMIC PCWER DEVELOPMENT ASSOCIATES, INC.

4 PAGES, NUCLEAK NEWS $10(11$ ), PAGE 54-57, (NOVEMBER 1S6S)

SHDGT DI SCUSSIGN OF CURR S.NT STATUS, MOSTLY WHAT HAS BEEN LEARNED. AN INLET STRAINER, CJRE-PLATE STANDGFF OINS, JR PROVISION FCR CROSS FLOW WOULO HELP ELIMINATE FUTURE MEL TDOWNS. $R=A C T I V I T Y$ QATE-OF-CHANGE INFORMATIGN ANR A FASTER FISSION-PROCUCT MONITOR IDFL AYED NEUTRONS AT CORE EXIT TC SUPPLEMENT PPESENT SENSITIVE COVER-GAS AS DETECTOR WITH I3-HIN TRANSPORT LAGI IS VEFDED. FEW PROVISIONS WERE MADE FOF INCIDENT RECOVFRY, E.G. ' DIFFICULT ACCESS TO WHOLE CŚRE, NO FROVISICN FOR DRAINING VESSEL OR FOR ON-SITE INSPECTION OF IRRADIATED FUEL.

*FLON 3L-3CKAGE + \#FUEL MELTDOHN + \#INCIOENT, GFNERAL + FERMI (LMFBR) + FUEL HANOLING MACHINE + INCIDENT, RECOVERY FROM + INSTRUAENTATION, DETECTION FAILEO FUEL ELEMENT +

INSTRUMENTATIDN, DPERATING REACTIVITY + GPERATING EXPERIENCE SUMMARY + REACTOR, LMCR +

REMOTE MANIPULATING AND VIEWING

$17-20707$

CALIFURNIA STATE PUBLIC OPINION SUPVEY ON ACCEPTABILITY OF NUCLEAF POWER PLANTS

I PAGE, INUCLEONICS WEEK $8(\angle 7)$, DAGS 7, (NCVEMBER 23, 1967)

A STATE-WIDE PUISLIC OPINION SUPVEY BY THE CALIFORNIA OFFICE OF ATOMIC ENERGY DEVELGPMENT AND RAOIATION PROTECTION FCUND A 3-TO-1 RATIO IN FAVOR OF A NUCLEAR PONER PLANT IN THEIR AREA (RANGE WAS 2-1 TO $10-1)$, INCLUNING AREAS WHERE PLANTS HAVE BEEN PROPOSED. SEVERAL POLLSTER CJNCLUSIONS - (1). PEDPLE DO NOT KNOW THAT NUCLEAR PLANTS ARE IN CALIFORNIA, (2) MAJORITY OF THOSE INTERVIFWED FEEL THAT SCARE TACTICS ARE USED BY OPPONENTS OF NUCLEAR POWER PLANTS.

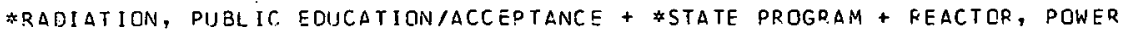

17-20700 $\quad$ LLSE IN CATEGDRY C

CALLEN $Q C+$ + PROUT $\equiv A U L P+$ FRIEDLAND AJ

RESPONSE OF FERMI FIJEL SUBASSEMGLY GUTLET THERMOCOUPLES UNDER NORMAL AND FUEL-FAILURE CONOITIONS ATOMIC POWER DEVELOPMENT ASSOCIATES, INC. + ELECTRICITE DE FRANCE

2 PAGES, $\triangle N S$ TRANSACTIONS $10(2)$, PAGE 637 AND 638 , (NOVEMBER 9,1967 , PRESENTED AT THE 1967 WINTER

MEETING OF THS AMER ICAN NUCLEAR SOCIETY, CHICAGO, ILLINOIS, NOVENIBER 5-9, 1967

HIGH-PGN:E TESTS INCLUDEO MEASUREMENT DF CORE ANO INNER RADIAL. BLANKET LOCAL COOLANT OUTLET TEMDFRATURES TO CETERMINE STATIC THERMAL PESPONSE. RESPONSE DF THE TEMPERATURE

INSTRUMENTATICN WAS EXAMINED IN I SOTHERMAL TESTS. REACTOR POWER AND ELECTROMAGNETIC FLOWMETERS WEFE CALIBRATED DURING HEAT-BALANCE MEASUREMENTS GN THE STEAM-FEEDWATER SIDE CF THE STEAM GENERATORS.

*INSTRUMENTATION CALIBRATION + \#TEST, INSTPUMENT RESPONSE + COMPARISON, THEORY AND EXPEF. IENCE + FERM I (LMFQR) + INSTFUMENTATION, FLOW + INSTRUMENTATION, POWER RANGE + INSTRUMENTATION, TEMPERATURE + OPFFATING EXPERIENCE SUMMARY + RFACTOR, FAST + REACTOR, LMCR

$17-20835$

DRL TERMINATED $\triangle G N-201$, SERIAL ND. IOZM, LICENSE

$\triangle E C$, DIVISION OF REACTOR LICENSING, WASHINCTON, D. C.

6 PAGES, DOCKET NO. $5(1-32$, OCTOSER 26,1967

REACTOR, AT AEFIJET-GENERAL FACILITY IN SAN RAMON, CALIF. HAS BEEN DISMANTLED AND COMPONENT PARTS PLACED IN HLASTIC BAGS AND STORED. PARTS AND FUEL WFRE TRANSFERRED TD IDAHO STATE UNIVERSITY DN AUGUST $8,1967$.

AVAILABILITY - uSAEC PUBLiC DOCUMENT ROCM, WASHINGTUN, D. C.

$\triangle G N$ (TNG) + LICENSING STATUS OF NUCLFAR PROJECTS + REACTOR DECOMMISSIONING + REACTOR, TRAINING

$17-21082$

THE BR-2 ACCIDENT

1 PAGE, NUCLEAR ENGINEERING $12(137)$, PAGE 730 (CCTOBEP 1957)

ALPHA CONTAMINATION (CM-242) WAS SPEEAD THROUGHOUT THE CONTAINMENT BUILOING WHEN RUPTURED CAPSULES OF AM-241 WERE REMOVED AFTER 46 DAYS OF IRRADIATION. DECONTAMINAT ION CF THE PRIMAFY CIRCUIT PRESENTEO TWO PROBLEMS. THE MATERIAL WAS IN THE FORM OF AN INSOLUBLE METALLIC OXIOE, AND ION EXCHANGE COLUMNS HAD NO EFFECT, ALSO, THAT WHICH PLATED GUT ON THE SURFACES WAS VERY TIGHTLY BDUND. LANTHANUM NITRATE WAS ADCED TO THE SYSTEM (PH G), AIDING REMOVAL BY THE ION EXCHANGE CDLUMNS. THE LANTHANUM PLUS A LOW SYSTEM PH HAD SOME SURFACE-STRIPPING EFFECT.

*CONTAMINATION + *CUPIUM + \#DFCONTAMINATION + *INCJDENT, RECOVERY FROM + AMERICIUM + CHEMICAL REACTION I COOLANT PURIFICATION SYSTEM + ION EXCHANGE + LANTHANUM + MAIN COOLING SYSTEM + REACTOR, RESEARCH 


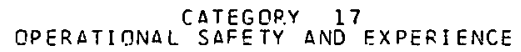

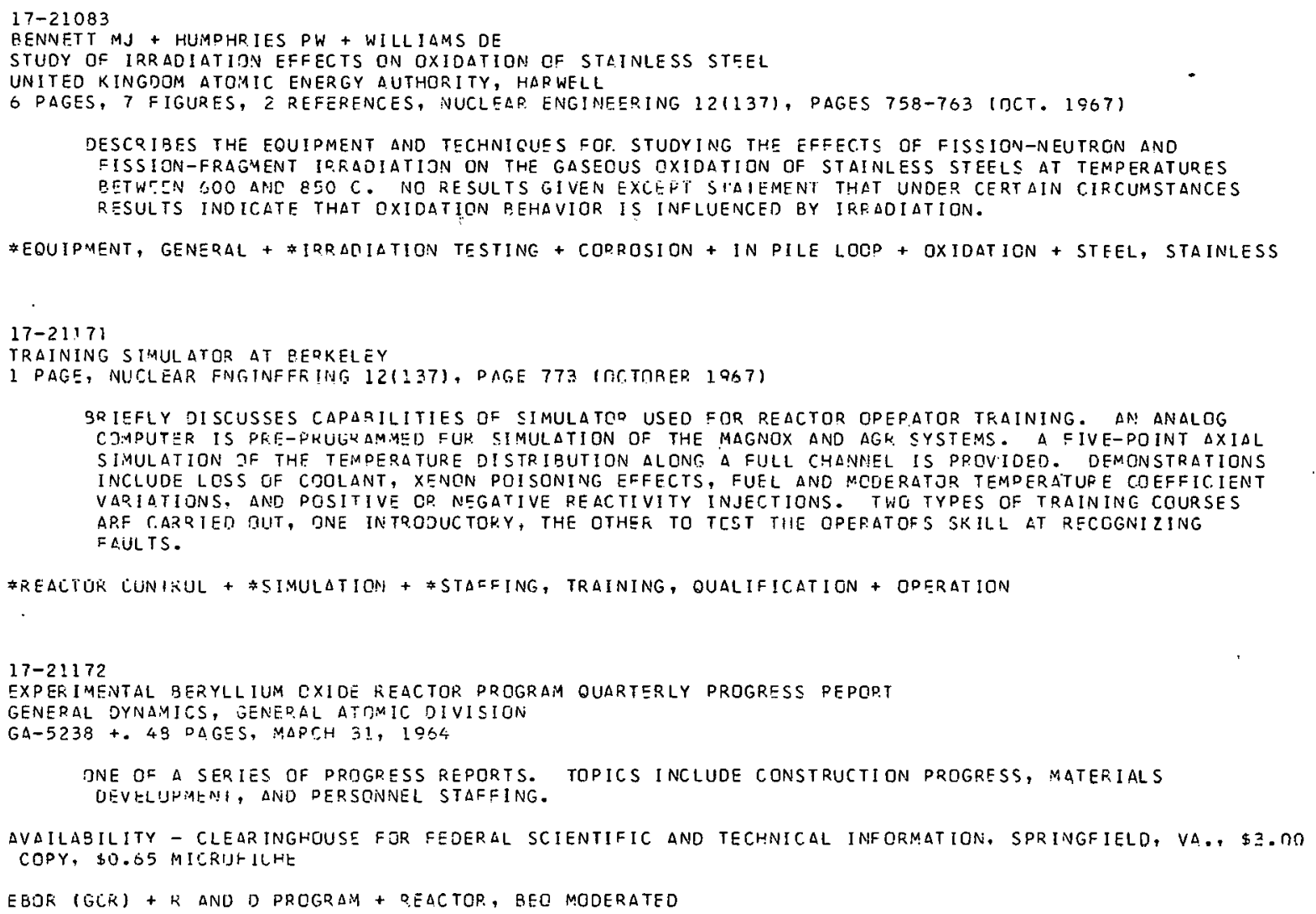

COOLANT CHEMISTRY + FAILURE, INSTRUMENT + FAILUFE, MAINTENANCE EPROR + FAILURE, OPER ATCR ERFOR + FLOW ORIEICE + POWER UPR ATING + REACTOR, PWR + REPORT, OPERATICNS + SCRAM, SPURIOUS + SHIPPINGPGRT (PWR) + SURFACE FILA DEPISSIT 
$17-21177$

INDICENTS RESULTING FROM POOR COMMUNICATICN

DUQUESNE LIGHT CO., SHIPPINGPQRT, PA.

DLCS-5000465 +. I PAGE, PAGE 10 OF GUARTEPLY OPEFATING REPORT (OF SHIPPINGPOPT ATOMIC PCWER. STATICN), FOURTH QUARTER 1965 , DECEMPER 1965

SIPHON DRAINING OF THE REACTOK VESSEL RESULTED FRDM A LACK GF COMMUNICATIDN. THE LEVEL

DRGPPED $S$ IN. PREPARATIONS FOP. FLUSHING WERE SIARTED REFORE THE PROCEDURE WAS APPROVEO AND DISTRIBUTED. HIASTE AND CONFUSIJN DURING A TEST RESULTEO IN 2 CONTROL RODS BEING OROPPEO FROM - THE FULL-OUT POSITION. WHEN RECORDER TROUBLE INTERRUPTED THE TESTING, THE TWO RODS WERE HELD AT THE UPPER LIMIT, AWAITING REPAIRS. DURING THE ENSUING PEFIOD, DERMISSION'WAS GP.ANTED TG A TECHNICIAN (APPARENTLY WI THOUT NOTIFYING THE OPERATING SUPERVISOR) TO DE-ENERGIZE A CONTRGL DRAWER, WHICH RESULTED IN UNLATCHING OF THE RODS.

AVAILABILITY - CLEARINGHOUSE FOR FEDERAL SCIENTIFIC AND TECHNICAL INFORMATIDN, SPRINGFIELD, VIRGINIA, $\$ 3.00$ COPY, \$0.65 iIICROFICHE

*FAILURE, aDMINISTRATIVE CONTROL + \#INCIDENT, HUMAN ERROR + REACTOR, PWR + REPORT, OPERATICNS + SHIPPINGPORT (PWR)

$17-21179$

QUARTERLY OPERATING REPORT (OF SHIPPINGPOPT ATOMIC POWER STATION), THIRD QUARTER IO65

DUQUESNE LIGHT CO., SHIPPINGPORT, PA.

DLCS-5000365 +. 34 DAGES, SFPT. 1965

A SCRAM RESULTED WHEN THE LOW-PRESSURE PROTECTION CUTOUT SWITCH WAS RESET SINCE THE ANNUCCI ATOR HAD CLEARED. THE INSTRUMENT WHICH ACTUATES THE ANNUNCIATOR WAS READING EO PSIG HIGHER THAN THAT WHICH ACTUATES THE SCRAM. ANOTHER SCRAM CCCURRED DUE TO MALFUNCTION OF A COOLANT-LOOP' TH INDICATOR. DESCRIBES TESTS COMPLETED TO VERIFY SATISFACTORY OPERATION AT ISO MW.

AVAILABILITY. - CLEARINGHOUSE FOR FEDERAL SCIENTIFIC ANO TECHNICAL INFURMAIIUN, SPRINGFIELD, VIRGINIA, $\$ 3.00$ COPY, \$0.65 MICROF ICHE

*TEST, PLANT RESPONSE + FAILURE, ADMINISTPATIVE CONTROL + FAILURE, INSTRUMENT + POWER UPRATING + REACTOR, PWR + REPORT, OPERATIONS + SCRAM, SPURIOUS + SHIPPINGPOFT (PWR)

$17-21180$

QUARTERLY OPERATING REPURT (OF SHIPPINGPORT $\triangle T O M I C$ POWER STATION), SECOND QUARTER 1965

DUQUESNE LIGHT CO., SHIPPINGPORT, PL.

DLCE-5000255 +. 46 DAGES, JUNE $1 \subseteq 65$

FDUR SCRAMS OCCUPRED ITWO DUE TO MALFUNCTIONING SWITCHES, TNE DUE TO INAOVERTENT SHORTING OF SIGNAL LEADS FFOM THE NUCLEAR PROTECTION SYSTEM, AND ONE FROM AN ELECTRICAL SPIKE ON THE NUCLEAR INSTRUMENTATION). ONE CONTROL ROD DROPPED TO THE. BOTTOM OF THE CORE WHILE ANOTHER WAS BEING TRANSFERRED TO THE SPARE INVERTER IERRONEOUS SYNCHRONIZATION-INOICATION OF A

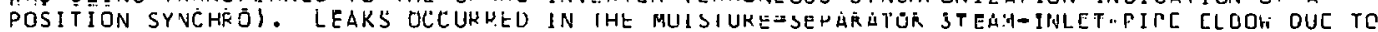
WET STEAIA EROSION. BUILDUP OF EROOED AREAS IS BEING PERFORMED.

AVAILABILITY - CLEARINGHOUSE FOR FEDERAL SCIENTIFIC AND TECHNICAL INFORMATION, SPRINGFIELD, VIPEINIA, $\$ 3.00$ COPY, \$0.65 MICROF ICHE

* SCRAM, SPURIOUS + EPOSION + FAILURE, INSTRUMENT + FAILURE, MAINTENANCE ERROF + FAILURE, OPERATOR ERROR + FAILURE; PIPE + INSTFUMENTATION, SWITCH + REACTOR, PWR + REPORT, OPERATIONS + SHIPPINGPORT (PWR) + STEAM

$17-21181$

QUARTERLY OPERATING REPGRT IOF SHIPPINGPORT ATOMIC POWER STATIUNI, FIRST QUARTER I965

DUQUESNE LIGHT CO., SHIPPINGPORT, PA.

DLCS-5000156+. 43 PAGES, MARCH 1965

DESIGN-PRESSURE TESTS WERE PERFORMED IN PREPARATION FOR CORE-2 POWER OPERATION $\triangle$ FUEL-PORT WELD LEAK WAS DETECTED ON THE VESSEL HEAD. RADIOGRAPHS REVEALED DEFECTS IN ALL 8 MAIN-STEAM ST.OP VAL.VES DUE TO POOR-QUALITY CASTINGS. PITTING OR CRACKS WERE FGUND IN ALL THE TUBES OF. THE MAIN-UNIT CONDENSEP-AIR CFF-TAKE SECTION AND CALLEU FUN COMPLETE RETUBING. ONE SPURIOUS SCRAM RESULTEO FROM A FALSE LEVEL SIGNAL.

AVAILABILITY - CLEAR INGHOUSE FDR FEDERAL SCIENTIFIC AND TECHNICAL INFORMATION, SPRINGFIELD, VIPGINIA, $\$ 3.00$ COPY, \$0.65 MICRCF ICHE

*TEST, PLANT RESPONSE + COPROSION + FAILURE, GENERAL + FAILURE, TURING + POWER UPRATING + REACTOR, PWR + REPORT, OPERATIONS + SCRAM, SPURIOUS + SHIPPINGPORT (PWR) + VALVE 


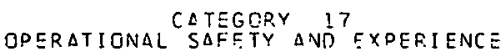

$17-21182$ *CONTINUED*

DUQUESNE LIGHT CO., SHIPPINGPORT, PENNA.

DLCS-5001064 . 35 PAGES, OCTOBER 1964

SHUTOOWN WAS CONTINUED FOR MODIFICATION OF THE FLANT FOF CORE-2. OPERATION, REFUELING OPERATION, ANO OVERHAUL OF THE MAIN TURRINE.

AVAILABILITY - CLEARINGHOUSE FOR FEDERAL SCIENTIFIC ANO TECHNICAL INFORMATION, SPRINGFIELD, VIRGINIA, $\$ 3.00$ COPY, \$0.65 IIICROFICHE

MAINTENANCE AND REPAIF + MODIFICATION, SYSTEM OR EQUIPNENT + POWER UDRATING + PEACTOR, DWR + REFUELING + REPORT, OPERATIONS + SHIPPINGPDRT (PWR.)

$17-21184$

SASTPE C

HFER PHYSICS STARTUP MANUAL

EYUUYK HAVEN NAT IONAL LAB., UPTON, N. 'Y.

$B N L-9591+$. 46 PAGES, CCTTOSER 1965

GIVES PROCEOURES FOR INITIAL PEACTRR, LOADING, CALIRRATIGN OF CONTRDL RODS, AND MEASUREMENT CF REACTIVITY EFFECTS CUE TO DRESSURE, FLOh, TEMPERATIIRF, DINO XENIN.

AVAILABILITY - CLSARINGHOUSE FOR FEOEDAL SCIENTIFIC AND TSCHNICAL INFORMATION, SPRINGFIELD, VIREINIA, $\$ 3.00$ COPY, SO.

*RLACTOR STARTUP TESTING + CENTPUL RUU CALIBRATION + HFBR (RR) + MEASI!REMENT, REACTIVITY +

PROCEDURES AND MAVUALS + REACTOR, HWD + PFACTOR, RESEARCH

$17-21208$

QUARTERLY OPERATING FFPOPT (OF SHIPPINGPORT $\triangle T O M I C$ POWER STATION), THIRD RLARTER IOSG

DUQUESNE LIGHT CO., SHIPPINGPORT, PA.

DLCS-5000366 +. 25 FAGES, SEDTSMPER 1SEt

TESTS CDNTINUEE TO DETERMINE THE MINIMUM PH REQUIREO TO ARREST CCRE PRESSURE DROP RESULTING FROM CRUD DEPOSITION ON CORE SURFACES. SHUTDOWNS WEPE REQUIRED FOR REPAIR OF $\triangle$ HFAT EXCHANGER (TURE) LEAK AND A PIPE RUPTURE ON THE CONDENSATE STOFAGE TANK MAKEUD ANO RETUPN HEDDER .

AVAILABILITY - CLEARINGHOUSE FDR FEDERAL SCIENTIFIC AND TECHNICAL INFORMATION, SPRINGFIELU, VIRGINIA, $\$ 3.00$ COPY, \$O.S5 YICRCFICHE

COOLANT CHEMISTRY + FAILUDE, PIDE + FAILUFE, TUEING + FLOW UKIFICE + HEAT EXCHANGER +

MAINTENANCE AND REOAIR + REACTOR, FINR + FEPCRT, OPERATIONS + SHIDFINGPERT (PWR) + SURFACE FILIA DEPOSIT

$17-21209$

HBWR QUARTERLY, PROGRESS FEPQRT, JULY-SEPTEMEER 19.95

INSTITUTT FOR ATOMENEF,GI, HALDEN (NCPWAY). CECD HALDEN REAKTOF PFOSJEKT

HPR-64 +. 121 PAGES, FIGIIPFS, TAELES, REFERENCES, OCTOSER IOEE

DISCUSSES IN DFTAIL THE LOCATING AND REMCVAL DF A FAILED TEST FUEL ELEMENT. THE LCCATING INVOLVED THE SYSTFMATIR CLUX DEPRESSION OF LOCAL ADEAS OF THE CORE AND MEASUREMENT OF THE CDRRESPONDING CHANGE IN THE FISSION-PFODUIT QELESSE. ONE SCPAM RESULTED TRDM AN ACCIDENTAL SHOET CIRCUIT DURING MAINTENANCE, ANOTHER FROM A POWER FAILURE TO THE GRIP COIL OA! A $R=$ GILATING ROD. THEOPETICAL STUDICS OT IMDROOYNAMICS OF TUBULAK HULL ASSEMBLIES ARS DESCRIBED. PEPORTS PROGRESS CN IRRADIATION TESTS OF FUEL ASSEMBLIES.

AVAILABILITY - MICROCAFO EOITIONS, INC. (FOR SALE) ACCDUNTING AND SHIPPING DEPARTMENT, HEST SALEM, WISCONSIN 54669

*FAILURE, FUSL ELEMENT + FAILURE, INSTQUMENT + FAILURE, OPERATGR ERFOR + FUEL ELEMENT + HBWP (BWR.) + HYORDOYNAMIC ANALYSIS. + IRRADIATION TESTING + NORWAY + REACTOR, BWF + REPORT, QPEPATIONS + SCRAM, SPURIOUS

$17-21210$

HBWR DLIARTERLY DRDGRESS RFPORT, OCTOBER TO DECEMBER 1966

INSTITUTT FOR ATOMENEDGI, HALDEN, NORWAY

HPR-71 +. 34 DAGES, FIGURES, TABLES, REFERENCES, FEBRUARY 1967

UNE UF A SERIES OF POOGRESS REPORTS. TOPICS INCLUDE IRFADIATION TESTING OF FUEL ASSEMBLIES, FUEL BUPNUD EXPERIMENTS, TEST FUFL ELEMENT FAILURES, ANU HYOROCYNAMIC STIJDIES OF TUBULAE FUEL $\triangle S S E M B L$ IES.

AVAILABILITY - MICRTCARD SDITIONS, INC., ACCOUNTING AND SHIPDING OEPT., WEST SALEM, WISCONSIN 54EG9

\#HYDRJDYNAMIC ANALYSIS + \#IPPAOIATICN TESTING + FAILURF, FUFL ELEMENT + FUEL BURNUP + FUEL ELEMENT + HBWR (BWR) + NORWAY + KEACTOP, BWR + REPQGT, OPEPATIONS 


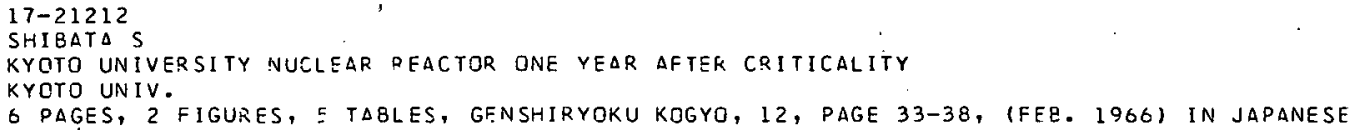

* OPERATING EXPERIENCE SUMMAPY + CONTROL ROO WGRTH + ENVIRONMENTAL CONRITION + FAILURE, DESIGN ERROR + FAILURE, SCRAM MECHANISM + JAPAN + PEACTIR, RESEARCH + SHIELDING

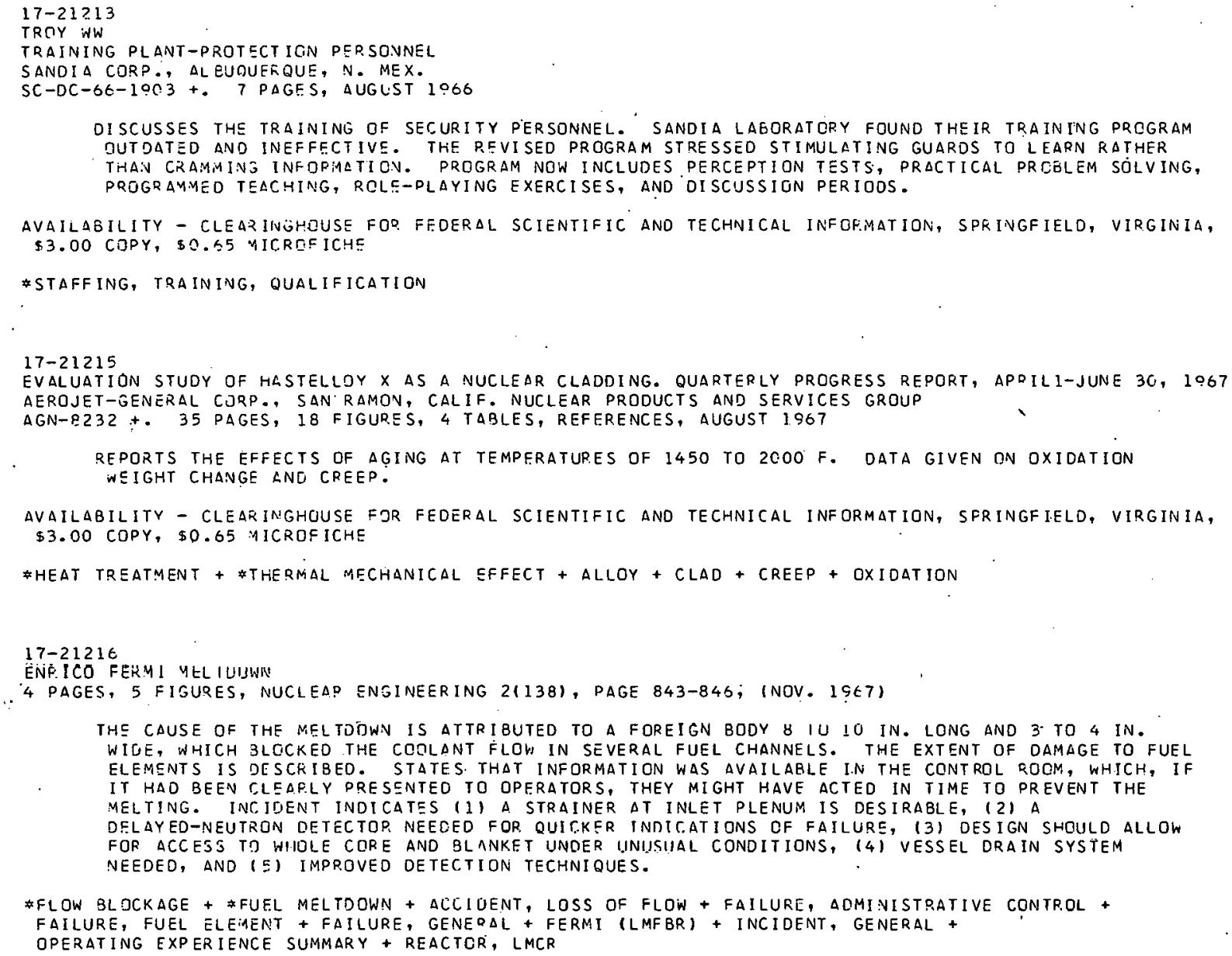

THE CAUSE OF THE MELTOTOWN IS ATTRIBUTED TO A FOREIGN BODY 8 IU 10 IN. LONG AND 3 TO 4 IN. WIOE, WHICH 3LOCKED THE COOLANT FLOW IN SEVERAL FUEL CHANNELS. THE EXTENT OF DAMAGE TO FUEL ELEMENTS IS DESCRIBED. STATES. THAT INFORMATION WAS AVAILABLE I.N THE CONTROL ROCM, WHICH, IF IT HAD BEEN CLEAPLY PRESENTEO TO OPERATORS, THEY MIGHT HAVE ACTED IN TIME TO PREVENT THE MELTING. INCIDENT INDICATES (1) A STRAINER AT INLET PLENUM IS DESIRABLE, (2) A DELAYED-NEUTRON DETECTOP NEECED FOR QUIR.KER INDTCATIONS OF FAILURE, (3) DESIGN SHOULD ALLOW FOR ACCESS TO WIIOLE CORE AND BLANKET UNDER UINIJSUAL CONDITIONS, (4) VESSEL DRAIN SYSTEM NEEDED, AND (E) IMPROVED DETECTION TECHNIQUES.

\#FLOW BLDCKAGE + \#FUEL MELTDOWN + ACLIUENT, LOSS OF FLOW + FAILURE, ADMINISTPATIVE CONTROL + FAILURE, FUEL ELEIAENT + FAILURE, GENEDAL + FERMI (LMFBR) + INCIDENT, GENERAL + OPERATING EXPER IENCE SUMMARY + REACTCR, LMCR

$17-21292$

DRL REQUESTS ADDITICNAL INFORMATION ON HUMEOLDT BAY PROPOSED CHANGE 22 AEC, DIVISION OF REACTÜR LICENSING

5 PAGES, NOV. 20, 1967, DOCKET NO. 50-133, TYPE--8WR, MFG--G.E., $\triangle E-B E C H T E L$

8 QUESTIONS, INCLUDING (I) CLECTRIC-POWER-SYSTEM RELIABILITY, (2) REACTOR-PROTECTION-SYSTEM FAILURE-MODE ANALYSIS, (3) CONTAINMENT ISOLATION, (4) REFUELING INTERLCCK SYSTEM, (5) PRIMARY-SYSTEM INSDECTIION ANE SURVEILLANCE PROGRAM, (7) CONTFOL-ROD INTERLOCKS, AND (8) UPDATING OF TECH. SPECS.

AVAILABILITY - IISAFC PUELIC DOCUMENT P.OOM, WASHINGION, D. C. HUMBOLT BAY (BWR) + REACTOR, RWR + TECHNICAL SPECIFICATIONS 


\section{DPEPATIONAL CATEGORY SAFTY 17 ENDPERIENCE}

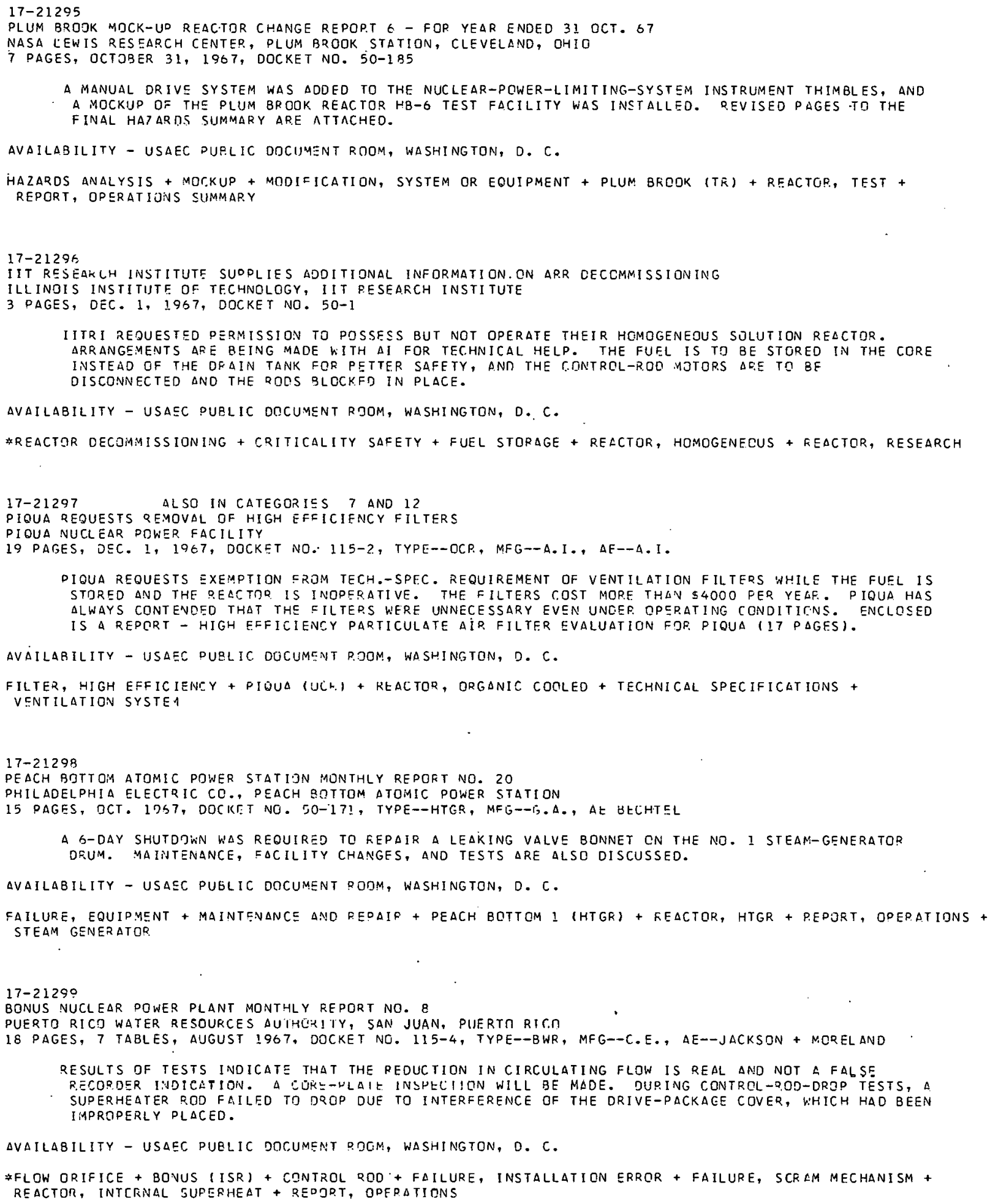


OPERATIONAL SATEGOPYY 17 EXPERIENCE

$17-21300$

BONUS NUCLEAR POWER PLANT MONTHLY REPORT NG. 7

PUERTO RICO WATER RESOURCES AUTHOR ITY

12 PAGES, 1 TABLE, JULY 1967 , DOCKET NO. 115-4, TYPE--BWR, MFG--C.E., AE--JACKSON + MOPELAND

A SHUTOOWN WAS REQUIRED DUE TO EXCESSIVE ARCING AND VIBRATICNS IN THE MOTUR-GENERATOR THAT SUPPLIES THE INSTRUMENT BUS. A SCRAM DCCURREO WHEN A FOWER LEAD TO THE WATER-FLGW

INSTRUMENTATION WAS ERR ONEOUSLY DISCONNECTED. AIPBOFNE ACTIVITY INCREASED IN THE CONTAINMENT BUILDING AFTER TWO SCRAMS DUE TD AN UNIDENTIFIED LEAK. A DECREASE WAS NOTED IN THE RECORDER FOR CIRCULATING-WATER PUMP FLOW BUT HAS NCT SEEN DETERMINED TO BE REAL OP MERELY TROUBLE WITH INDICATOR.

AVAILABILITY - USAEC PUELIC DCCUMENT ROOM, WASHINGTON, D. C.

BONUS (ISR) + ELECTRIC POWER, NORMAL + FAILURE, EQUIPMENT + FAILURE, OPERATOR ERROR + FL OW ORIFICE + RADIOACTIVITY RELEASE + REACTOR, INTERNAL SUPERHEAT + REPORT, OPERATICNS + SCRAM, SPURIOUS

$17-21335$

EREIZY CE

SODIUM-COOLED REACTORS FAST CERAMIC REACTOR DEVELCPMENT PROGRAM. QUARTERLY REPORT NO. IT, NOVEMBER

IO65-J ANUARY 1966

GENERAL ELECTRIC CO., SAN JOSE, CALIF. $\triangle O V A N C E O$ PRODUCTS OPERATION

GEAP-5098 +. 80 PAGES, FIGURES, TABLES, REFERENCES, FEB. 1966

OINE OF A SERISS OF PROGFESS REPQRTS. TOPICS INCLUDE IRRADIATION TESTING OF MIXED PU-U OXIDES, GAP-CONDUCTIVITY EXPERIMENTS, FUEL BURNUP, REACTOP PHYSICS AND CORE ANALYSIS, VENTED-FUEL DEVELOPMENT, AND CLADDING-COMPATIBILITY STUOIES.

AVAILABILITY - CLEARINGHOUSF FOR FEOERAL SCIENTIFIC AND TECHNICAL INFORMATION, SPRINGFIELD, VIRGINIA, $\$ 3.00$ COPY, \$0.65 MICROFICHE

CLAD + FUEL BURNUP + FUEL ELEMENT + HEAT CONOUCTANCE, FUEL TO CLAD + IRRADIATIDN TESTING +

PLUTONIUM OXIDE + R ANO DPROGRAM + REACTOR PHYSICS + REACTOR, LMCR + SODIUM. + URANIUM OXIOE

$17-21336$

RESEARCH PROGRAM FOR THE GARIGLIANO NUCLEAR POWER STATION. QUARTERLY REPORT NO. 13

ENTE NAZIONALE PER L-ENEPGIA ELETTRICA, ROME (ITALY)

EURAEC-1910 + EUR-3355 +. I\& PAGES, JULY $1,10.67$

ONE OF A SERIES OF PROGRESS REPORTS. TOPICS DISCUSSED INCLUDE DATA LOGGING, IRRADIATION TESTING OF PRESSURE-VESSEL SPECIMENS, INSTRUMENTED FLIEL ASSEMBLIES, AND POWER-UPFATING STUDIES.

AVAILABILITY - CLEARINGHOUSE FOR FEDERAL SCIENTIFIC ANO TECHNICAL INEORMATION, SPRINGFIELD, VIRGINIA, $\$ 3.00$ COPY, $\$ 0.65$ MICROF ICHE

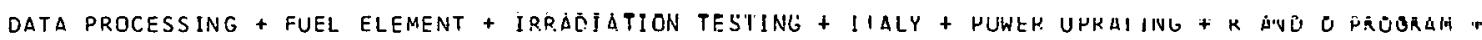

REACHIIR. HWK

$17-21339$

CARVER JG

PLUTONIUM SUBCRITICAL EXPERIMENT DPOGRAM. QUARTERLY REPORT NO. 12, APRIL 1-JUNE 30, 1967

GENERAL ELECTRIC CD., PLEASANTUN, LALIF. NUCLEAF TECHNOLDGY DEPT.

GEAP-5513 + EURAEC-1013 +. 13 PAGES, 2 KEFERENCES, JUNE 30,1907

DISCUSSES THE MEASIIRFMENT OF FISSION RATES AND RESONANCE ABSORPTION RATES OF PU-HZO FUEL LATTICES AT VARIOUS TEMPERATURES AND WATER-FUEL RATIOS.

AVAILABILITY - CLEAD. INGHOUSE FOR FEDERAL SCIENTIFIC AND TECHNICAL INFORMATION, SPRINGFIELD, VIRGINIA, $\$ 3.00$ COPY, \$0.65 MICROF ICHE

* MEASUREMENT, GENERAL + FUEL ELEMENT + PLUTONIUM + P. ANU U HRUGRAM + REACTIOR PHYSICS

$17-21340$

JONES CF

STAFFING NUCLEAR DLANTS

NUS CORPTRATION

4 PAGES, 2 FIgURES, 1 TABLE, POWER ENGINEEFING 7!112), PAGES 54-57 (DECEMBER 1967)

UTILITIES MUST TRAIN THEIR OWN EMPLOYEES SINCE THERE IS ALREADY A SHORTAGE OF NUCLEAR

ENGINEERS. MANPOWER REQUIREMENTS ARI DISCUSSED. A GS-MAN ORGANIZATION IS RECOMMFNDFD AS A MINIMUI FOR A SINGLE NUCLEAR UNIT. THE REQUIPEMENTS FOR PLANTS WITH UP TO 4 UNITS ARE GIVEN. THE POWER OUTPUT IN THE RANGE 500-100C MWE HAS LITTLE EFFECT ON MANPOWER REQUIREMENTS.

SCHEDUL ING FOR GUILDING A PLANT STAFF IS OISCUSSED. THE SUPFRINTENDENT, OPERATIONS 
OPFRATIONAL CATEGGPY 17 SAFETY $\triangle$ ENDPERIFNCE

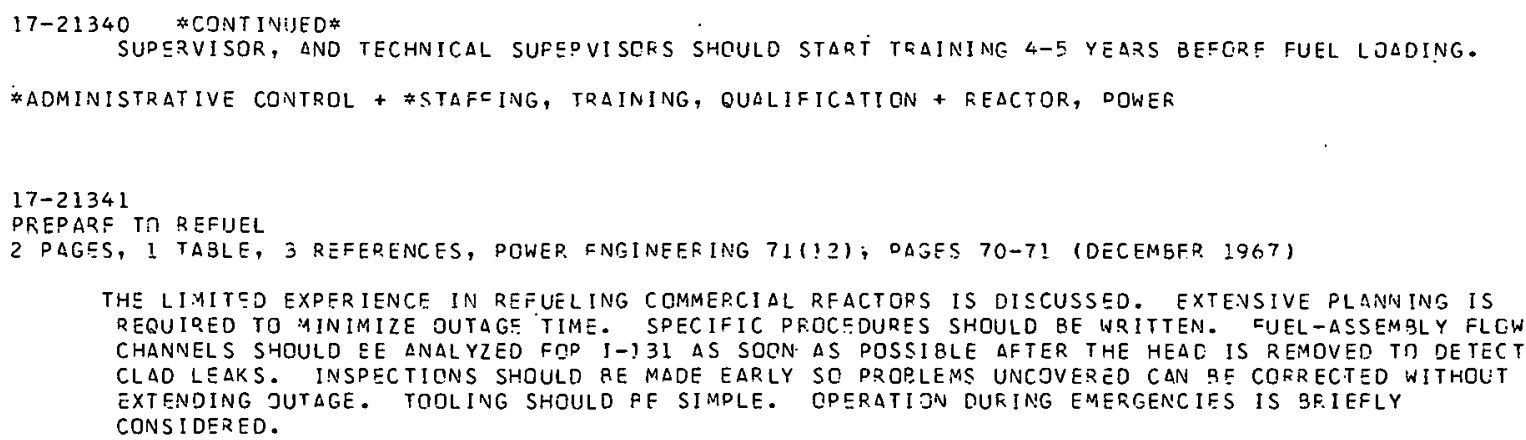

FRANCE + REACTOR DESCPIPTION + REACTQD, PFEECER + PEACTOR, LMCR

$17-21352$

CHAPELOT A L LELITF

SCME ASPECTS RF THE DP.IVE-CONTROL DF P.APSCOIS

COMMISSARIAT A L-ENERGIE ATOMIQUE

1! PAGES, 5 FIGURES, INDUSTRIES ATOMIQUES $11(5 / 6)$, PAGES 60-70 $(1967)$ IN FRENCH

SOME OF THE ASPECTS OF THE CONTEOL SYSTEM AND THE GENERAL PPINCIPLES OF THE DUTOMATION OFSIGN ARE DISCUSSED. THE SAFETY MECHANISMS $\triangle$ PFLIED IN THE CONTRCL OF CQMPQNENTS OF THE PLANT AND IN SAFETY OPERATIONS, HOWEVEP, DEMANC MUCH MORE =I ARTRATE TECHNGLOGICAL STRUCTUFES AND METHODS. THE IMPORTANCE OF CONEVENTIONAL MEASURING AND REGULATION DEV ICES IS STFESSED. SOME SPECIFIC CONTROL ANO MEASURING SYSTEMS OESIGNED E OR OOERATION WITH SODIUM APE DESCRIBED. $\triangle$ DAT A-PRDCESSINF SYSTEM COMPLETES THE CLASSICAL INDICATING UNITS AND ASSUMES THE MERF SUBTLE CONTKOL AND PROC.F.SSING OPER.ATIONS.

\#CONTROL SYSTEM + \#SYSTEM DESCRIPTION + CCNTRCL PGD DFIVE + DATA PRCCESSING + FRANCE +

MEASUREMCNT, GFNFRAI + RFATTRR SAFETY SYSTEM + TEAGTCR, BRCEDCR I FEACTOR, LMCP. 
OPFRATIDNAL CATEGORY 17 SAFETY AND EXPERIENCE

$17-21353$

PONT IER R

THE TESTING AND STARTING UP OF RAPSOOIE

COMMISSARIAT A L-ENERGIE ATOMIQUE

5 FAGES, I FIGURE, INOUSTRIES ATOHIGUES $11(5 / 6)$, PAGES 87-91 (1967) IN FRENCH

DESCRI.BES THE STARTUP OF THE RAPSDOIE. LISTS MAIN PHASES OF THE COURSE OF TESTS, PROBLEMS ENCOUNTERED, $\triangle N O$ RESULTS.

\#REACTOR STARTUP TESTING + FRANCE + REACTOR, BREECER + REACTOR, LMCR + TEST, PHYSICS

$17-21354$

ARDENNES NUCLEAR DJWER PLANT. QUARTERLY FEPOFT NO. 7, JAN. 1--MARCH 31,1964

SOCIETE D ENERGIE NUCLEAIRE FQANCO-BELGE TES ARDENNES, CHOCZ-LEZ-GIVET, FRANCE

TID-20953 +. 31 PAGES, APFIL $24,1 \% 44$

FEPORTS THE CDNSTFUCTION STATUS. VESSEL, PRESSUPIZER, STEAM GENERATORS, FTC., ARE STILL BEING FARR ICATEO.

AVAILABILITY - CLEARINGHOUSE FOR FECERAL SCIENTIFIC AND TECHNICAL INFORMATION, SPRINGFIELO, VA., \$3. OO COPY, $\$ 0.65$ MICROFICEH

FFANCE + REACTOR, PWR

$17-21355$

WESTERMEIR JT + RELSCN JO + SINGLETON JL

PM-1 ANNUAL SUMMAPY REPGRT, NOVEMBCR 1, 1963--OCTOBER 1, 1964

$\triangle I R$ FORCE WEAPONS LAB,, KIPTLANT AFB, N. MEXICO

$A D-618376+W L-T R-65-01+139$ PAGES, JULY 1965

GIVES RESULTS GF CONTROL-2OD-WDP TH TESTS, TEMPERATURE-COEFFICIENT MEASUREMENTS, AND

XENON-EUILOUP DATA. AN EVALUATION OFF THE SUBSYSTEMS IS GIVEN AND PROBLEM AREAS DENOTED.

SCRAMS RESULTED FROM MALFUNCTIONS CIF PRIMARY-PUMP OVERLOAD HEATER, MAIN-GENERATER STATIC

EXCITER, MAIN-STEAM STOP-VALVE SOLENCID, FEEDWATER PUMP, AND SCRAM-BYPASS COUPLER.

MODIFICATIONS ARE DESCRIBED. OTHER TOPICS INCLUDE PERSONNEL AND TRAINING, MAINTENANCE,

SAFETY, AND CEST ANALYSIS.

AVAILABILITY - CLEARINGHOUSE FOR FEDFP.AL SCIENTIFIC AND TECHNICAL INFORMATION, SPRINGFIELD, VA., \$3. OO COPY, \$O.65 MICROFICHE

CONTROL ROD WIRTH + ECCNOMICS + FAILUPE, EQUIPMENT + MAINTENANCE AND FEPAIR +

MODIFICATION, SYSTEM OF EQUIPMENT + OPERATION + PM I (PWR) + REACTIVITY EFFECT + REACTOR, MILITARY + REACTOR, PWR + REDOPT, OPERATIONS + SCPAM, SPURIOUS + STAFFING, TRAINING, QUALIFICATION +

TEMPERATURE COEFFICIENT + XFNON

$17-21394$

MONTHLY JPERATING REPDRT. SEPTEMBEK :966

CAROLINAS VIRGINIA NUCLEAR POWER ASSOCIATES, INC., PARR, S. C.

CVNA-264 +. 29 PAGES, NOVEMBER 1967

PLANT NAS SHUT DOWN DURING SEPT., AND A CONTAINMENT LEAK TEST WAS :MADE (AT 13 PSIG), GIVING AN ACCIDENT LEAK RATE OF $0.184 \%$ /DAY (VS $0.5 \% / D A Y$ ALLOWEO). SECOND REFUELING (I2 ELEMENTS) WAS PERFORMED. REPORT CONTAINS THE USUAL I TEMS (COCLANT CHEMISTRY, HEALTH PHYSICS, ETC).

AVAILABILITY - CLEARINGHOUSE FOR FEDERAL SCIENTIFIC AND TECHNICAL INFORMATION, SPRINGFIELD, VIRGINIA, $\$ 3.00$ COPY, \$O.ES MICROFICHE

\#RFPORT, OPERATIONS + \#TEST, LEAK RATE + CVTR. (PWR) + PEACTOR, HWR + REACTOR, PRESSURE TUBE + REACTOR, PWR

$17-21395$

MONTHLY OPERAT ING REPORT, JULY. ISES

CAROLINAS VIRGINIA NUCLEAR POWER ASSOCIATES, INC., PARR, S. C.

CVNA-262+. 31 PAGES, SEPTEMBER 7,1966

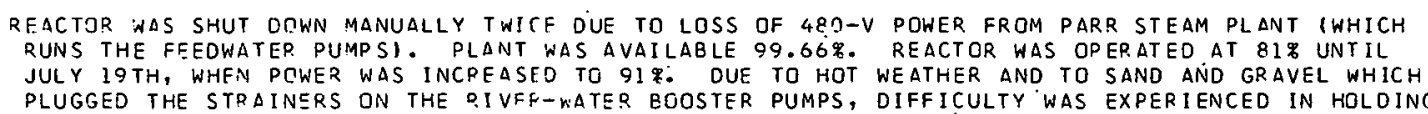
THE VAPOR CONTAINER TEMPERATUPE RELOW THE MAXIMUM $120 \mathrm{~F}$.

AVAILABILITY - CLEARINGHOUSE FOR FEDERAL SCIENTIFIC ANO TECHNICAL INFORMATION, SPRINGFIELD, VIRGINIA, $\$ 2.00$ COPY, $\$ 0.65$ MICRCFICHE

*AUXILIARY COOLING SYSTEM + CVTR (P.WP) + REACTOR, HWF + REACTOR, PRESSURE TUBE + REACTOR, PWR + 
OPEROTIONAL CATEGERY 17 EXPY AND EXPRIENCE

17-21395 \#CONTINUEC*

PEPORT, OPERATIONS

$17-21396$

PIQUA NUCLEAR POWER FACILITY MONTHLY OPERATING REPORT NO. 42 . CCTOBER 1966

PIQUA NUCLEAR POWER FACILITY, OHIO

COO-652-32+. 2O PACES, OCTOEEP 1967

UPON STARTUP OF THE MAIN COOLING SYSTFM A FLOW FATE OF 11,000 GPM WAS CBTAINEO IVS THE IO, OOO EXPECTED). EACH MAIN-PUMP-SUCTIDN STRAINER CONTAINED $\triangle B O U T$ 1/2. GAL OF COKE (PARTICLE SIZE UP TO $3 / 4$ IN.1. RE-STARTUP STILL SHOWED LOSS OF FLOW RATE. 1/2 GAL OF COKE WAS REMOVED FP.CM THE P-IB STRAINEF. 3UT DNLY AEOUT I PINT FROM THE P-1A. 14,300 GPM FLOW RATE WAS REACHED, BUT STRAINERS AGAIN PLUGGED. AFTEF 36 HR, COOLANT-SYSTEM PRESSUFES ANO FLSW HAD STABILIZED.

AVAILABILITY - USAEC PUELIC DOCUMENT RQCM, WASHINGTON, O. 'C.

\#COOLANT QUALITY + \#MIN COOLING SYSTEM + PIQUA (OCR) + REACTCP, ORGANIC COOLED + REPORT, OPERATIGNS

$17-21397$
PEACTOR OPER ATIONS SAFETY ANALYSIS MCNTHLY REPOPT NO. 15, SEPTEMBER $1-30,1066$

NUCLEAR UTILITY SERVICES, INC., WASHINGTON, D. C.

NUS-317+. 138 PAGES, FIGURES, TABLES, REFERENCES, NOV. 7, 1966

SHIELD-COOLING-SYSTEM RAOIATION LEVELS INCREASEO FROM 20 MR/HP TO A3OUT 50 MR/HR IN SEPT. DUE TO USE OF POTASSIUM DICHROMATE AS D CORROSION INHIBITOF, DROBABLY FROM THE CDRMATION OF K- 2 . RAOIATION LEVELS IN GENERAL, HOWEVER, WERE LOW. REPOPT COVERS USUAL SIJ BJECTS ICGOLANT CHEVISTRY, HEALTH PHYSICS, I AND C, ETC.I.

AVAILABILITY - CLEARINGHOUSE FOR FEDERAL SCIENTIFIC ANC TECHNICAL INFOFMATION, SPRINGFIELO, VIRGINIA, $\$ 3.00$ COPY, \$0.65 MICROFICHE

* ADCITIVE + *AUXILIARY COOLING SYSTEM + \#COOLANT CHEMISTRY + \#CORROSION + ACTIVATION PFECUCT +

ELK RIVER (BWR) + POTASSIUM + REACTOF, BWR + REPORT, OPERATICNS

$17-21390$

ANNUAL REPORT OF THE DEPARTMENT OF ATONIC ENERGY, GOVERNMENT CF INDI $4,1765-1966$

DEPARTMENT OF ATOHIC ENERGY. -BOMBAY, INDIA

NP-15950 +. 60 PAGES, 1OE6

ONE OF A SFRIES OF PROGRESS REPQP.TS. TOPICS INCLUDE CONSTRUCTION PROGRESS OF NEW POWER

REACTORS, RADIATION PROTECTION, FUEL REPROCESSING, RADIOBIOLCGY, THEORETICAL NUCLEAR DHYSICS STUDIES, LND SPACE PESEAR.CH.

AVAILABILITY - MICSOCAPD EDITIONS, INC. (FCR SALE) ACCOUNTING AND SHIPPING OEPT., WEST SALEM, WISCONSIN $5<669$

FUEL REPROCESSING + INDIA + RADIATICN SAFETY DNO CONTFCL + RADIOEIOLOGY + QEACTCP, POWER + PFVIFW

$17-21401$

AQUEOUS HOMOGENEOUS SUSPENSION QEACTOR PROJECT. ANNUAL REPORT. PART A, RESEARCH AND TEEVLOPMENT

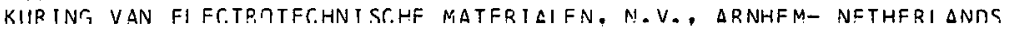

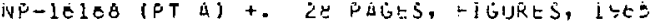

TECHNIQJES WERE DEVELOPED TO PPOOUCE THIN-METAL OR THO? COATINGS ON FUEL DARTICLES TO MINIMIZE OSSERVED IRRADIATION DAMAGE. THE MCST SERIOUS PPOBLEM EXPECT CD, THAT DF HARD C IN THE SYSTEM, HAS NOT OCCURRED. $\triangle$ LSC PEPORTS IRRADIATION TESTING, INSTRUMENT CEVELDOMENT, OPERATICN DE PUMPS AND VALVES, MEASUREMENTS OF P.ADIOLYTIC GAS PRODUCTION, AND HFALTH PHYSICS ASPECTS OF THE FUEL IRPADIATICNS.

AVAILABILITY - MICROCAR.D EDITIONS, INC. (FOR SALE) ACCCUNTING AND SHIPPING DEPARTMENT, iHEST SALEM, WISCONSIN 54669

COATED PARTICLE + INSTRUMENTATIJN, GENFPAL + IRPADIATION TESTING + MEASUREMENT, GENEDAL + NETHERLANDS + R AND D PROGRAM + RADIATION SAFETY AN:D CCNTROL + RADICLYTIC GAS + REACTOR, CIRCULATING FUEL

$17=21403$

RESEARCH LABORATOR IES SEMIANNUAL PEPOPT, JULY-DFCEMREF 1964

ISRAEL ATOHIC ENERCY COMAISSION, YAVNE. SCREO NUCLEAG DESEARCH CENTCR

$1 A-1021+174$ PAGES, DECEMBER 1964

POJL-WATER ACTIVITY AT THE ISFAFL RESEAPCH REACTCR INCREASCD BY A FACTOR CF 20 ON SEPT. 1C. GAIMA ANALYSIS INCICATED A FUEL-ELEMENT LEAK. PROGRESS PEPORTED ON STUDIES DF HAZAPRS EVALUATION ANO SITE SELECTION FOP A DUAL-PURPOSE REACTOR IOESALTING-ELECTRICITYI. FALLOUT MONITOR ING AT THE IRR SITE IS CISCUSSEN. BETA AIR ACTIVITY IS $1 / 10$ BELOW LAST YEARS. 
$17-21403$ \#CONTINUED*

AVAILABILITY - MICRDCARD EOITIONS, INC. (FOR SALE) ACCOUNTING AND SHIPPING DEPAPTMENT, WEST SALEM, WISCONSIN 54669

FAILURE, FUEL ELEMENT + FALLOUT + HAZARDS ANALYSIS + ISRAEL + RADIOACTIVITY RELEASE +

REACTOR, DESALINATION + REACTOR, PGOL TYPE + SITING, GENERAL

$17-21404$

DRAGON HIGH TEMPERATURE REACTOR PROJECT SEVENTTH ANNUAL REPQPT, 1965-1966

ORGANIZATION FOR ECDNOMIC CO-CPERATION AND DEVELCPMENT, PARIS, FRANCE

NP-16272 +. 132 PAGES, REFERENCES, MARCH 31, 1966

THE HOT PRESSURE TEST, APPROACH TO POWER, ANO AN EXTENDED RUN AT 10 MW WERE COMPLETED.

STICKING OF CONTROL ROOS DUE TO BOWING ITEMPERATURE DIFFERENCE BCT WEEN THE INNER AND OUTER FACINGS) WAS CORRECTED BY DESIGNING A NEW ROD SPLIT. INTO 4 SECTIONS. MALFUNCTIONING OF BYPASS VALVES WAS ATTRIBUTEO TO OPEPATING TEMPERATURES ABOVE THE DESIGN VALUE. NEN POSITION INDICATORS AND WATER-COOLED JACKETS WERE INSTALLED. OTHER TOPICS INCLUDE IPRADIATION TESTING OF FUEL PARTICLES, RADIATION EFFECTS ON GRAPHITE CORROSION, ANO REACTOR PHYSICS.

AVAILABILITY - MICROCARD EOITIONS, INC. (FOR SALE) ACCOUNTING AND SHIPPING DEPARTMENT, WFST SALEM, WISCONS IN 54669

COATED PARTICLE + CONTROL ROD + CORROSION + DRAGON (HTGR) + FAILURE, GENERAL + FAILURE, SCRAM MECHANISM + GRAPHITE + IRRADIATION TESTING + MODIFICATION, SYSTEM OR EQUIPMENT + R AND D PROGRAM + RADIATION EFFECT + REACTOR PHYSICS + REACTOR STARTUP EXPEPIENCE + P.EACTOR, HTGR + TEST, SYSTEM OPERABILITY + VALVE

$17-21406$

NERO DEVELOPMENT PROGRAMME. REPORT, COVERING THE PERIOD JUNE 1964-DECFMRER 1965

REACTOR CENTRUA NEDERLAND, PETTEN

EUR-3125.E +. 30 PAGES, FIGURES, TABLES, 1966

REPORTS PROGRESS IN DEVELOPMENT OF A PRESSURIZED-WATER REACTOR FOR MARINE PROPULSICN. TOPICS INCLUDE CRITICAL EXPERIMENTS, INCORPORATION OF BURNABLE POISCN IN UO2, IRRADIATION TESTING, CORROSION AND EROSION, STRESS ANALYSIS, STEAM-GENERATOR PERFGRMANCE, CONTROL ROOS AND ORIVES, SHIELDING, AND AUXILIARY SYSTEMS.

AVAILABILITY - MICROCARD EOITIONS, INC. (FOR SALE) ACCOUNTING ANO SHIPPING DEPARTMENT, WEST SALEM, WISCONSIN 54669

CONTROL ROD + CONTROL ROD ORIVE + CORROSION + CRITICALITY EXPERIMENT + EROSION + IRRADIATION TESTING + NETHERL ANDS + POISON, BURNABLE + R AND D PROGRAM + REACTOR, MARITIME + REACTOR, PWR + SHIELOING + STEAM GENERATOR + STRESS ANALYSIS

$17-21408$

RABIN SA + ATRAZ BG + PADER MB + BUSBOOM HJ + HAZEL VE

EXAMINATION AND EVALUATION DF RUPTURE IN EVESR SUPERHEAT EUEL ROD WITH O.0I2-INCH-THICK INCCLOY-BCO

CLADOING

GENERAL ELECTRIC CO., SUNNYVALE, CALIF. ADVANCED PROOUCTS OPERATION

GEAP $-5416+72$ PAGES, FIGURES, TABLES, REFERENCES, JANUARY 1967

PREMATURE FAILURES WERE GBSERVED IN ONE 0.008-IN.-WALL ROD AND IN ONE O.012-IN.-HALL ROD OF THE MARK-III EXPERIMENTAL FUEL. CLADDING IS INCOLOY-800. FAILURES WERE IN REGION OF MAXIMUY POWER IN PEAK-POWER ROD. MOST REASONABLE EXPLANATION IS LOW-CYCLE FATIGUE, ACCEL ERATED BY HIGHER-THAN-DESIGN CLADDING TEMPERATURES. NO SIGNS OF RAPID CORROSION, SUCH AS HAVE BEEN ASSOCIATED NITH TYPE-304 SS, WERE FOUND.

AVAILABILITY - CLEARINGHOUSE FOR FEDERAL SCIENTIFIC AND TECHNICAL INFORMATION, SPRINGFIELD, VIRGINIA, $\$ 3.00$ COPY, \$0.65 MICRCF ICHE

*FAILURE, FUEL ELEMENT + Clad + FAILURE, FATIGUE + INCONEL. + REACTOR, INTERNAL SUPERHEAT + THERMAL MECHANICAL EFFECT + VESR. (ISR)

$17-21409$

BALFOUR MG + FOSTER ES + FERRARI HM + PAXSON E + KORTHEUER JD + WATLEY LS

DESIGN, FABRICATION, AND OPERATION GF THE CVTS HIGH POWER, HIGH-BURNUP TEST ASSEMBLIES

WESTINGHOUSE ELECTRIC CQRP., PITTSBURGH, PA. ATOMIC POWER DIVISION

CVNA-274 †. 102 PAGES, FIGURES, TABLES, REFERENCES, JUNE 1967

FOUR TEST ASSEMBLIES WERE DESIGNED TO ACHIEVE HIGH POWER LEVELS AND BURNUPS BEYOND THE PRESENT CONSERVATIVE GPERATING LIMITS FOR POWER REACTORS. EACH TEST ASSEMBLY CONSISTED DF SIX UL 2 RODS AND 13 DUMMY (AI 203) RODS, CLAD WITH EITHER FREE-STANDING OR THIN-WALL ZIRCALOY-4 ANO ALTERNATIVELY WITH STAINLESS STEEL. THE UO2 RODS WERE DESIGNED FOR 25.08 AND $20.90 \mathrm{KWIFT} \mathrm{AND}$ PEAK BURNUPS OF 50,000 AND 41,670 MWD/MTU, RESPECTIVELY. AN DPERATION HISTORY FOR THE ASSEMBLISS IS PRESENTED. THREE OF THE FOUR TEST ASSEMBLIES DEVELOPED DEFECTS, ANO IRRADIATION WAS TERMINATEO PREMATURELY. AN ANALYSIS OF CLADDING BEHAVIOR OF THE ASSEMBLIES BASED UPON THEIP. POWER HISTORY WAS PERFORMED.

AVAILABILITY - CLEARINGHOUSF, FOR FEDFPAL SCIENTIFIC AND TECHNICAL INFOPMATION, SPRINGFIELO, VIRGINIA, 
OPERATIONAL SAFGTY AND ${ }^{\text {CATEGOFY EXPERIFNCE }}$

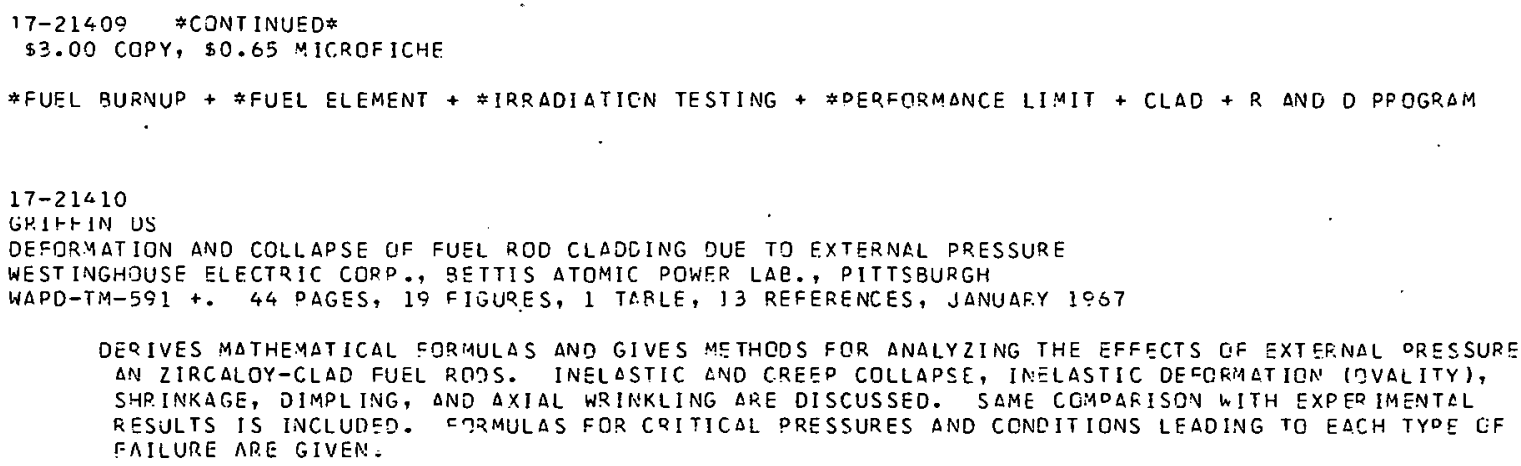


17-21414 *CONT INUED*

NASA WILL USE A MASS-SPECTROMETER-TYPE HELIUM LEAK DETECTOR FGR CHECKING THE WELDS. MINIMUM HEAD-CLAD THICKNESS IS CHANGED TO 0.062 IN. (VS 0.075 ) TO CORRECT AN ERROR IN THE TECH. SPECS.

AVAILABILITY - USAEC PUBLIC DGCUMENT RODM, WASHINGTON, D. C.

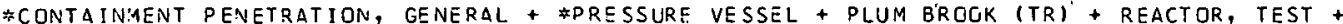
SAFETY EVALUATION + STEEL + TECHNICAL SPECIFICATIONS

$17-21415$

NS SAVANNAH REPORTS FAILURE OF VENT PIPING IN A PRIMARY COOLANT PUMP

FIRST ATJMIC SHID TRANSPORT INC.

2 PAGES, NOV. ??, 1967 , DOCKET NO. 50-238, TYPE--PWR, MFG--B+W, AE--G.G. SHARP

WHILE ANCHORED AT THE PACIFIC ENTRANCE TO THE PANAMA CANAL, A RISE IN THE CONTAINMENT DRAIN-TANK LEVEL LED TO THE DISCOVERY OF THE FAILED PIPING. INITIAL LEAK RATE WAS I2 GPH, INCREASING OVER THE NEXT 5 HR TO $120 \mathrm{GPH}$, AT WHICH TIYE THE PLANT WAS SHUT DOWN. THE

STÁRBOARD LOOP WAS SHUT DOWN, AND THE SHIP HEADED FOR NEW YOPK FOR REPAIRS, USING. ONLY THE PORT LJOP AND AT REDUCEO SPEED. A NEW FITTING WAS INSTALLED AND A. VIBRATION DAMPENER ADCED.

AVAILARILITY - USAEC PUBLIC DOCUMENT ROCM, WASHINGTON, D. C.

\#ACCIOENT, LOSS JE CODLANT + \#FAILURE, PIPE + \#INCIDENT, EQUIFMENT + NS SAVANNAH (PWR) + PUMP + REACTOR, MARITIME + FEACTOR, PWR

$17-21417$

LA CKOSSTE SUPDLIES ADDITIONAL INFORMATION ON COOLANT FLOW CALCULATIONS AND EXPERIMENTS ALLIS-CHALMERS, BETHESDA, MARYLAND

4 PAGES, I FIGURE, I TABLE, NOV. 17, 1967, DOCKET NO. 115-5, TYPE--BWR, MFG--A.C., AE--SGT + LUNOY

- in ANSWER TO AEC QUESTIONS ON PROPOSEO CHANGE IN MINIMUM PUMPGSPEED SETTINGS, LA CROSSE GIVES RESULTS OF COLD-FLOW PRESSURE-DROP EXPERIMENTS TO VERIFY CALCULAT IONS. CALCULATED PRESSURE DRDP IN MAIN CODLANT SYSTEM IS. ABOUT 1O\% MORE THAN EXPERIMENTAL VALUE. PRESSURE CROP ACROSS CORE IS GREATER THAN CALCULATED, RESULTING IN A FLOW. DECREASE OF ONLY O.55\%, HOWEVER.

AVAILABILITY - USAÉC PUSLIC DOCUMENT ROOM, WASHINGTON, D. C.

\#COMPARISON, THEORY ANO EXOERIENCE + \#PRESSURE DPOP + FLOW THEORY AND EXPERIMENTS + LACROSSE (SWR) + MAIN COOLING SYSTSM + MEASUREMENT, GENERAL + REACTOR, BWR + TECHNICAL SPECIFICATIONS

17-21412 $\triangle L S O$ IN CATEGORY

HTGR CRITICAL FACILITY REPORTS COMPONENT FAILURE IN SCRAM CIRCUIT

GULF GENERAL ATOMIC INC.

1 PAGE, DOCKET 50-240, NOVEMBER 22, 1967

ON NOV. 1, 1967, DUEING THE MONTHLY SAFETY EQUIPMENT CHECK, IT WAS OISCOVERED THAT THE OPTICAL METER RELAY IN THE FUEL-ELEMENT TEMPERATURE-GRAOIENT SCRAM CHANNEL WAS INOPERAT IVE. IT WAS REDLACED BY A SPARE, AND A TEST CIRCUIT ALLOWING WEEKLY CHECKS WAS INSTALLED. MALFUNCTION WAS NOTED IV LOG BOOK PUT NOT REPCKTED TO AEC UNTIL NOV. $22,1967$.

AVAILABILITY, - USAEC FUBLIC DOCUMENT RODM, WASHINGTON, D. C.

\#FAILURE, COMPGNENT + \#FAILUEE, SCRAM MECHANISM + CRITICAL ASSEMBLY FACILITY + FUEL ELEMENT + INCIDENT, EQUIPMENT + KEACTOR, HTGR + TEMPERATURE GRADIENT

$17-21426$

PEACH BOTTCM 1 APPLIFS FQR CREDIT FCR BPEATHING APPARATUS

PHILADELPHIA ELECTRIC COMPANY

12 PAGES, I TABLE, DOCKET NO. 50-171, TYPE--HTGP; MFG--G.A., AE--BECHTEL, NOVEMRER 20, 1967

SINCE (IN MAKING MUDIFIGATIONS TJ THE STEAM GENERATOR SO THAT RATED POWER CAN QE REACHED) IIT MAY BE NECESSAFY TO ENTER THE STEAM GENERATOR IWHERE AIRBORNE RADIOACTIVITY LEVELS MAY EXCEED $3 \times 1 C(-10 T H)$ MICROCURIE/CC), PEACH BOTTOM HAS $\triangle P P L I E D$ FOR CREDIT FOR USE OF MASK, ETC. NINE PIECES OF EOUIPMENT (MSA DUSTFOE MASK, FULL-FACE MASK, ETC.) ARE DESCRIBED AND PROTECTION

FACTORS ARE GIVEN. GUIDELINES 12 PAGES) FOR THEIR UȘE ARE GIVEN.

AVAILABILITY - USAEC PUELIC DOCUMENT ROON, WASHINGTON, D. C.

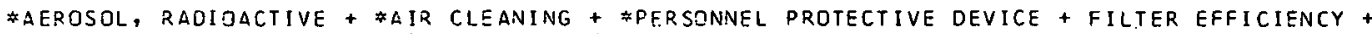
FILTER, GAS MASK + MOOIFICATION, SYSTEM OF EQUIPMENT + PEACH EOTTOM I (HTGR) + REACTOR, HTGR + STEAM GENERAT DR

$17-21427$

IIT RESEARCH INSTIIUTE REQUEST DEACTIVATION OF ARR(L-54) REACTOR

IIT RESEARCH INSTITUTE, CHICAGO, ILL. 


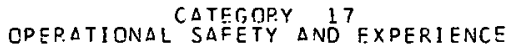

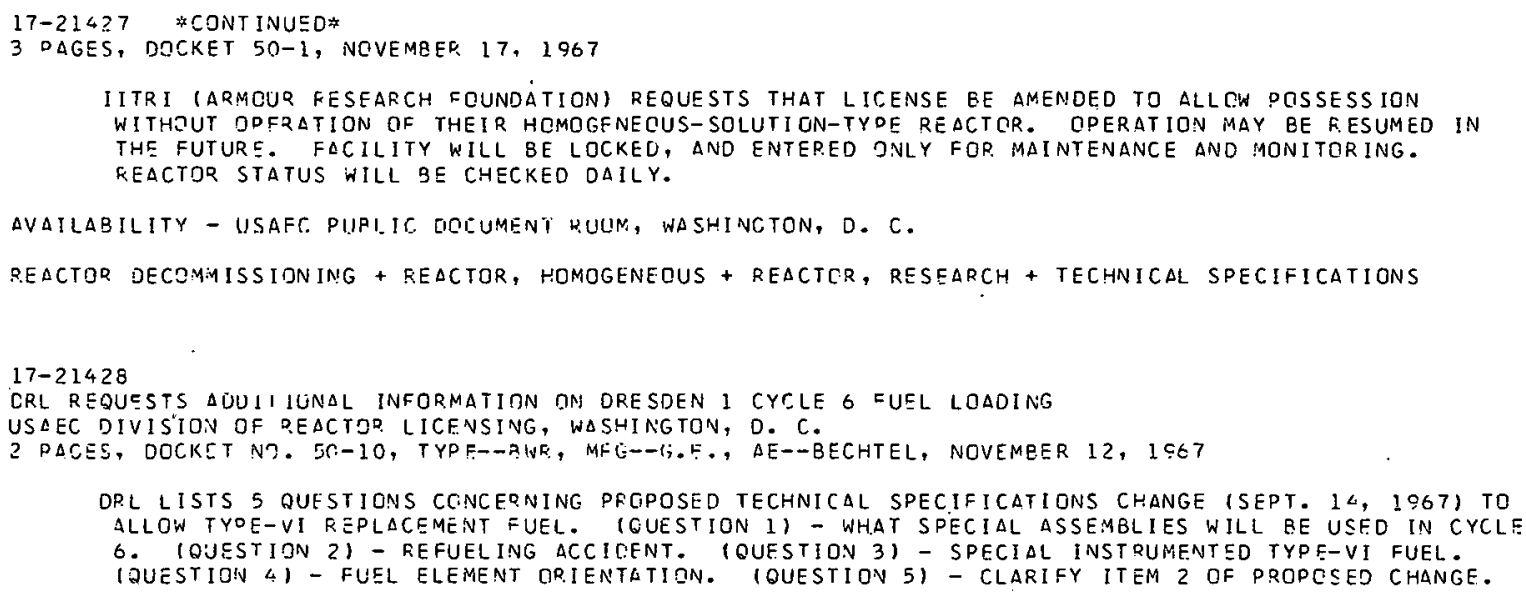


17-21433 \#CONT INUED*

EMERGENCY COOLER. THE CAUSE WAS DUE TO FAILURE TO SEAT OF THE INLET AND EXIT VALVES DN THE EMERGENCY CDOLING SYSTEM, ALLOWING A SMALL AMOUNT OF PRIMARY WATER $\triangle T$ TOB F TO FLOW THROUGH THE NORMALLY ISOLATED SYSTFM. THE HEAT TFANSFER CAUSED WATER IN THE ISOLATED SALT-WATER. COOLING CIRCUIT TO EXPAND, THEPEBY INCREASING THE PRESSURE. PRIOR INCIDENT 2Q IJAN. IE, 1967) HAO SHOWN SIMILAR RESPONSE. (INCIDENT CONSIDERED INSIGNIFICANT BUT REPQRTED BFCAUSE OF WIDESPRSAD INTEREST OF PRESS ANO NEWS MEDIA AND THEIR TENDENCY TO OVERPLAY ANO DISTORT FACTS.)

AVAILABILITY - USAEC PUBLIC DOCUMENT ROOM, WASHINGTCN, D. C.

\#FAILURE, EQUIDMENT + \#VALVE + FAILURE, TUBING + HEAT EXCHANGER + NS SAVANNAH (PWR) + PEACTOR, PWR + SHUTDOWN COOL ING SYSTEM

$17-21448$

CVNPA ASKS FOR DELAY IN SEALING CVTR CONTAINMENT PENETRATIONS

CAROLINAS VIRGINIA NUCLEAR POWER ASSOCIDTES, INC., PARR, SOUTH CAPOLINA

2 PAGES, DOCKET 50-144, T.YPE--PWR, MFG--WEST., AE-STONE + WEBSTER, DECEMBER 8 , 1967

OECOMMISSIONING PROGRAH, SCHEDULED FOR COMPLETION SOON, REQUIRES THAT PENETRATIONS BE WELDED SHUT. CVNPA IS NEGOTIATING A SUBCONTRACT TO MAKE TESTS ON THE CONTAINMENT. CVNPA REQUESTS PERMISSION TO BLGCK THESE PENETPATIONS BUT NOT WELO THEM UNTIL D DECISION IS MADE ON THE TESTS.

AVAILABILITY - USAEC PUBLIC DOCUMENT ROOM, WASHINGTON, D. C.

\#CCNTAINMENT, GENERAL + \#PEACTOR DECOMMISSIONING + \#TESTING + CVTR (PWR) + REACTOR, GRAPHITE MODERATEO + REACTOR, PRESSURE TUBE + REACTOR, PWR

$17-21449$

VA HOSPITAL AMENDMENT 4--AUTHORIZATION FUK USE OF A 2-CURIEE SOURCE

USAEC, DIVISION OF REACTOR LICENSING

5 PAGES, DOCKET 50-121, DECEMBER 12,1967

DRL ALLOWS USE OF A 2-CIJRIE AM-BE NEUTRON STARTUP SOURCE AS AN ALTERNATIVE TO THE PRESENTLY AUTHORIZED PD-BE SOURCE. NEW SOURCE IS A PELLETIZED MIXTURE OF AMO2-BE, DOUBLY ENCAPSULATED IN STAINLESS STEEL.

AVAILABILITY - USAEC PUBLIC DOCUMENT ROOM, WASHINGTON, D. C.

*SOURCE, NEUTRON + DECAY HEAT + REACTOR, RESEARCH + SAFETY EVALUATION + TRIGA (RR)

$17-21450$

NS SAVANNAH REVISED PROPOSED CHANGE IS--ELIMINATIGN OF NUCLEAR ADVISOF POSITIGN

FIRST ATOMIC SHIP.TRANSPORT, INC.

7 PAGES, 1 TABLE, DOCKET 50-238, IYPE--PWR, MFG--B+W, $\triangle E--G . G$. SIRAP

THE POSITION OF NIJCL.FAF ADVISEK WAS ESTABLISHED IN 1 SG4 WHEN THE OPERATING CREW HAD LITTLE EXPERIENCE. FAST BELIEVES THAT THIS POSITION IS NO LONGER REQUIHEU HELAUSE THE CREW ANO SHORE STAFF HAS SUFFICIENT EXPERIENCE AND TRAINING. LETTER DESCRIBES THE TRAINING, TESTING, AND EXPER IENCE FOR ENGINEERING AND DECK OFFICERS. (NOTE - THIS REQUEST WAS WITHORAWN FOR FURTHER STUDY, DECEMBER $11,1967$.

AVAILABILITY - USAEC PUBLIC DOCUMENT ROOM, WASHINGTON, D. C.

NS SAVANNAH (PWR) + REACTOR, PWR + STAFFING, TRAINING, QUALIFICATION + TECHNICAL SPECIFICATIONS

$17-21451$

NS SAVANNAH WITHDRAWS REQUEST FOR ELIMINATION OF POSITION OF NUCLFAR ADVISOR FIRST ATOMIC SHIP TRANSPDRT INC

1 PAGE, DOCKET 50-238, TYPE--PWR, MFG--8+W; $\triangle E--G . G$. SHARP, DECEMBER 11,1967

(PROPOSEO CHANGE 15 OF MAY 15, 1967 , MODIFIED JULY 24, 1967.) FAST $\triangle S K S$ THAT REQUEST AS MODIFIED BE WITHORAWN FOR FUF THEK STUDY AND FUTURE RESURMITTAL.

AVAILABILITY - USAEC PUBLIC DOCUMENT ROOM, WASHINGTON, D. C.

NS SAVANNAH (PWR) + REACTOR, PWR + STAFFING, TRAINING, QUALIFICATION + TECHNICAL SPECIFICATIONS

$17-21454$

OREGON STATE AGN-201 REPORTS FAILURE OF HIGH VOLTAGE CABLE TO MEET SPECIFICATIONS

OREGON STATE UNIVERSITY

2 PAGES, DOCKET 50-106, DECEMBER 6, 1967

ORIGINAL CABLE TO CHANNEL 1 WAS UNCERRATEO AND HAS BEEN REPLACED. PROPORTIONAL BF3 COUNTER HAD BEEN BEHAVING POORLY, AND THE PLATEAU WAS AT 2000-2450 V IVS 1750-1950, ACCGRDING TO 
CLTEROOY 17

CPERATIJNAL SAFETY AND TXPERIENCE

$17-21454 \quad \#$ CONTINUED

MANUFACTUEER). WITH NEW CABLE AND CONNECTOPS, COCPRATION IS MUCH IMPROVEO AND PLATEAU IS IESO.

AVAILABILITY - USAFC DUBLIC DOCUMENT ROON, WASHINGTCN, D. C.

\#FAILURE, COMPONENT + \#INSTRUMENTATICN, NUCLEAF + ELECTRICAL CONDUCTION + PERFCRMANCE LIMIT +

REACTOR, RESEARCH + TRIGA (RP)

17-21475 ALSC IN CATEGORIES 5 AND 6

TECHNOLOGY OF BDILING WATER REACTOR STABILITY ANALYSIS

GENERAL ELECTRIC SOMFANY

75 PAGES, 49 FISUCES, 16 PEFERENCES, 4 TARLES, MEMORANDUM SCEP-6O, DJCKET 50-277 AND 278 , TYPE--BWR, MFG--G.E., $\triangle E--3 E C H T E L$, JULY 1067

(INCORPJPATED IN PEACH BOTTOM DSAE SUPPLEMENT 2.) ASSEFTEO GCZO $\triangle G R E E N E N T$ BETWEEN FARLE-I PRUGRAM AND KEG/GARIGLIANE RGD-OSCILLATOR [ATA. APED HYDFOCYNANIC LCGP ENSUQES SUCCESSEUL USE IN EXAMINING INTERCHANNEL HYDRODYNAMIC STABILITY. MODEL SUMMARIZER, RUT DATA ILC GFAPHSI IS POORLY EISCUSSED TO SUPPOET THE ASSERTION.

AVAILABILITY - USAEC PUELIC DOCUMENT POCM, WASHINGTON, R. C.

\#COMPARISON, THEOPY $\triangle N D$ EXPERIENCE + \#COMPUTER PRCGRAM + \#FLOW STABILITY + PEACH BCTTOM 2 AND ? (BWR) + REACTDR STABILITY + REACTCR, כwR

17-21476 ALSO IN CATEGCKY 16

FLUX JSCILLATION IVCIDENT AT GARIGLIANO DURING RCD IMBALANCE

GENERAL ELECTR. IC COMPANY

2 PAGES, DAGES II AND 14 OF MEMTRSINDUM SCEF-60, DOCKET 50-277 AND 278, TYPE--EWE, MFG--G.E., AE--BECHTEL,

JULY 1957

BEFORE A SCHEDULED RDD-OSCILLATI ON EXPERIMENT, A FLUX OSCILLATION OF ABCUT B-1OF $\triangle T$ I/3 HERTZ DCCURRED IN A TEST-LOCP CHANNEL NEAR A CCNTRQL POD STIJCK AT A PCSITION $\triangle B G U T$ SO IN. MOPE WITHORAWN THAN SYMMETRI ICALLY PLACEO ROOS. CHANNEL DUTLET WAS RESTRICTEO BY A FLUW METER. OSCILLATICN INDICATED ON IV-COPE INSTRUMENTATION LASTEO FROM 2 TO 5 MIN AND WAS TERMINATED BY INSERTING AN ADJACENT ROD IE IN. GTHER CHANNELS ALSO SHOWED FLUX OSCILLATIONS, WITH THE AMOLITUDE JECPEASIIVG WITH DI STANCE FR.QM THE ORIVING C.HANNEL.

AVAILAGILITY - USAEC PUELIS DOCUMENT ROOM, WASHINGTON, D. C.

*FLOW STABILITY + CONTPQL POD DRUTRAM + FAILURE, SCRAM MECHANISM + INCIDENT, GENEPAL + INSTRUMENTATION, AGNORMAL INOICATION + INSTRUMENTATION, IN COPE + REACTOR STABILITY + FEACTOR, OWR + SENN

$17-21661$

AMENCAENT I TO $\triangle D P L I C A T I C N$ FRK LACROSSE LICENSE TRANSFER TO DAIRYLAND PSWER

DARYLAND PONER COODERATIVE, LA CPOSSE, WI SCGNSIN

115 PAGES: DOCKET 115-5, TYPE--3WR, MFG--A.C., AE--SGT + LUNDY

DOCUMENT SETS FORTH (1) DUALIFICATICNS OF UNITER NUCLEAR CCPPORATIDN AS APPL ICABLE TE TECHNICAL-SUODORT SERVICES TO NAIFYLAND PCWER AND (2) SUMMARY FROCEDURES UNDER WHICH DAIRYLAND ANJ UNC WILL WORK IN CBTAINING $\triangle N O$ PEPICORMING SUCH SERVICES. CONSISTS MAINLY OF JINC. DEQSONNEL SUMMARIES

AVAILA3ILITY - USAEC PUBLIC ROCUMENT FOON, WASHINGTON, O. L.

LACROSSE (EWR) + REACTOR, BWR + STAFFING, TRAINING, QUALIFICATION

17-21564 $\quad$ OLSO IN CATSGORY 15

OHIO STATE UNIVERSITY REPORTS NONCOMPLI ANCF WITH RAOILTION MONITOR REQUIREMENTS

OHIO STATE UNIVERSITY, COLUMBUS, DHIO

6 DAGES, DOCKET 50-150, NOVEMSER 24,1967

TECHNICAL SDECIFICATIONS REQUIRE A PGRTABLE BETA-GAMMA SURVEY METER WITH A RANGE OF O.OL MR/HS TO $50 \mathrm{R} / \mathrm{HR}$. THE ONLY SUCH INSTRUNENT AT THE FACILITY, A RAD GUN, WDS REPORTED INODERATIVE ON AUGUST 20, 1067 , LND WAS SHIPPED. FCR REPAIFS ON CCT. 30, 1067. OPERATIONS CONTINUED UNTIL THE SITUATION WAS REALIZED DURING STARTUP ON NOVEMBER 8 , 1067 . SUPERVISION BEL IEVES THIS WAS

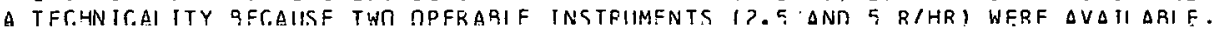

AVAILABILITY - USAEC PUELIC DOCUMENT RUGM, WASHINGTON, D. C.

* MONITOP, RADIATIJN, GENERAL + FEACTOP, POOL TYPE + REATTTR, RESEAPCH + TECHNICAL SPFCIFICATIONS

$17-2167 \mathrm{C}$

FULTONBERG DN

CORROSION DF ALUMINUN IN WATER

WESTINGHOUSE ELECTRIC CORPORATION, PITTSEUPG, PA. 


\section{OPERATIONAL SATEGORY SLFY 17 TNO EXPERIENCE}

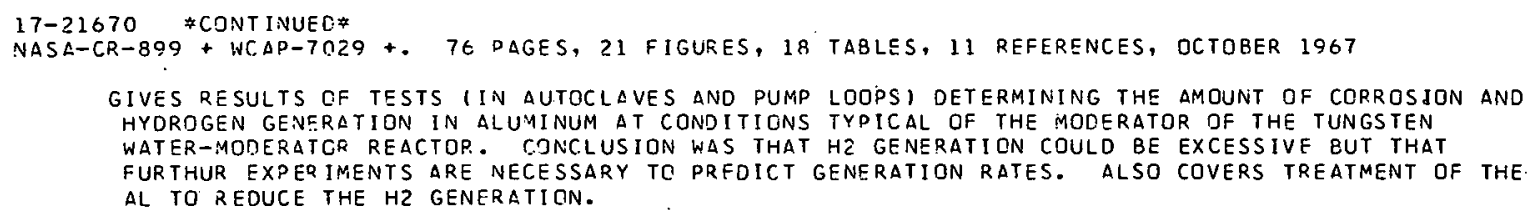

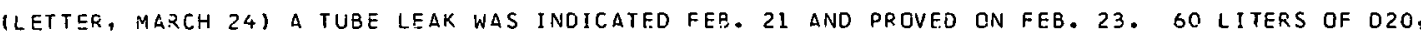
CTINTAINING 67.9 CURIES DF TRITIUM, HAD LEAKED INTO THE 20,000-GAL SECONDARY SYSTEM. URINE SAMPLES FROM THREE REACTOR-OPERATIONS PEFSONNEL WHO SHUT DOWN THE COOLING TOWER WERE 0.:29 TO 0.91 MICROCUR IE/LITER, BSLJW MPC. BLOWDOWN TO THE SFWER AND CCOLING TOWER EVAPOPATION WERE BOTH BELOW MOC.

*FAILURE, TUBING + *HEAT EXCHANGER + *TRITIUM + EFFLUENT + INHALATION + REACTOR, HWR

$17-21716 \quad$ ALSO IN CATEGORY 14

NUTLEAR FUEL SERVICES REPORTS ON WASTE EVAPORATOR LEAK DF FEBRUARY 15,1967

NUCLEAR FUEL SEPVICES, INC., WEST VALLEY, NEW YOPK

2 P.AGES, ATOMIC ENERGY CLEARING HOUSE 13(18), PAGES 15-16 (MAY 1, 1967)

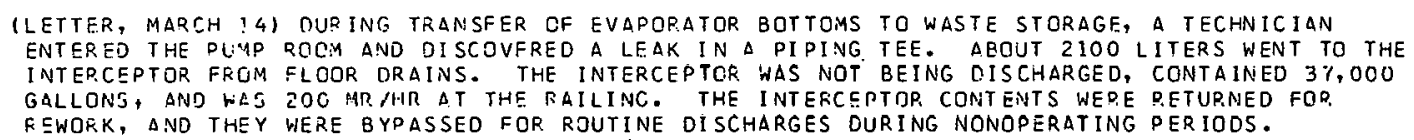
INTEP.CEPTOR FRGM FLOOR DRAINS. THE INTERCEPTCR. WAS NOT BEING DISCHARGED, CONTAINED $3 \%, 0 O O$

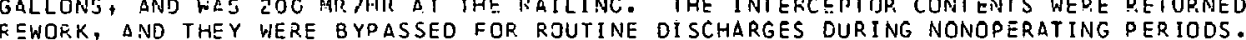

*FAILURE, PIPE + *NASTE TPEATMENT, GENEPAL + EVAPORATION + LEAK + NFS + RACIOCHEMICAL PROCESSING

$17-21717$ ALSC IN CATEGORY 15

NUCLEAR FUEL SERVICES CITED FOR NON-COMPLIANCE

NUCLEAR FUEL SERVICES, INC., WEATON, MO.

5 PAGES, ATOMIC ENERGY CLEAKING HOUSE $13(1 \varepsilon)$, PAGES $16-20$ (MAY 1,1967 )

(LETTER, MARCH :5) CITATION IS FOP. INADEQUATE R.ADIATION MONITGRING OF STACK ANO OF DECONTAMINATION OPERATIONS, AND $35 / 27$ MISSINF, FILM BADGES FOR 2ND/3RD QUARTER OF 1966. LETTER ALSO KEQUESTS DATA ON BETTER CONTROL OF VENTILATION ISNOW PLUGGING OF MAIN INT AKE, INFLATABLE SEAL'S ON DUTSIDE DOOR, AND SIMULTANEOUS OPENING OF BOTH AIRLOCK DOORS.I NFS LETTER OF JANUARY 3 ASSERTED IN REPLY TO AEC LETTER OF DECEMBER 13, 1966 THAT ACTION WAS BEING TAKEN ON'PCINTS NOTEO.

* INSPECTION AND COMPLIANCE + \# SURVEY, RADIATICN, GENERAL + \#VENTILATION SYSTEM + NFS + RADIOCHEYICAL PRICESSING + STACK

17-21718 $\triangle L S O$ IN CATFGORY $: 4$

BURTSAVAGE EM
U.S. RADIUH CORP. REPORTS E EXCESSIVE STACK DISCHARGES

U.S. RADIUM COPP. BLDOMSTURT, D $A$.

2 PAGES, ATOMIC ENERGY CLEARING HOUSE $13(19)$, PAGES 21-22, (MAY 1, 1967 )

(LETTER, MARCH 2Z) DISCHARGES DURING, THE FIRST QUARTER OF 1 TE7 WERE 18.26, $126.09,63.94$, 201.37, 15.44, AND 61.74 TIMES MPC PR IMAP ILY INSTANTANEOUS CONVERSION OF TRITIUM GAS IN WATER TO HTO, SO THAT PERMISSIBLE CONCENTRATIONS OF H (SUB) IN A FACILITY WITH NORMAL HUMIDITY WILL PROBABLY RESULT IN CONCENTRATICNS OF H(S) ABOVE MPC. 
OPFRATIMNAL SATEGRRY 17 TOY EXPERIENCE

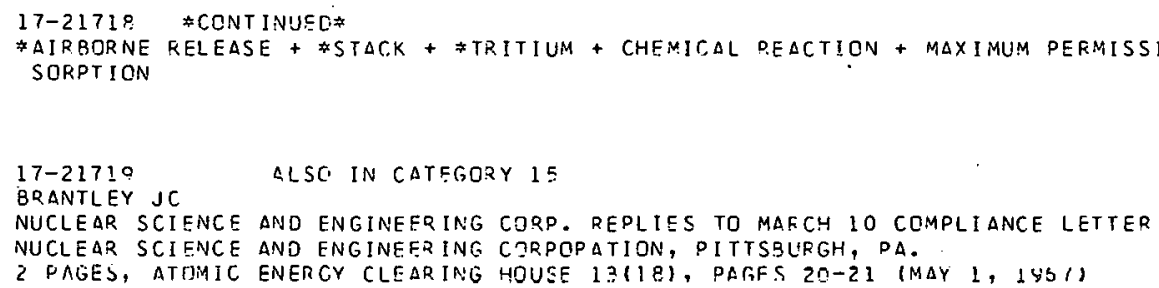

(LETTER, MARCH 27) DCKNOWLEJGES THAT (1) HEALTH PHYSICS PROGPAM WAS INADEQUATE DURING PERIOD, DUE TO LACK DF EQUIPMENT, (2) HP FUNCTIONS WEFE NOT CONSCIENTIOUS, AND (3) MANAGEMENT CONTROLS WERE SLQW TO IDENTIFY THIS. BRIEFLY DISCUSSES 9 ITEMS IAIR SURVEYS, EFFLUENT-AIR SURVEYS, UNRESTRICTED-ADEA RADIATION FIELDS, LEAK TESTING CIF SEALEO SCURCES, FADIOLOGICAL SAFETY INSTRUCTION, RADIATIJN/CONTAMINATION MONITORING PPIOGRA', EXTREMITY DOSES, SURVEY RECORDSI.

*INGPTCTIUN AND CUMDLIANCE + MONITJEING SYSTEM, KAULATION + STAFFING, TRAINING, QUALIFICATION + SURVEY, RADIATION, GENERAL

17-21720 ALSO IN CATEGORY 15

STEERMAN JJ

UNIVERSITY OF ILLINOIS FEEPORTS SKIN FXPUSURE TO P-32

UNIVERSITY OF ILLINOIS, UR BANA, ILL .

3 PAGCS, ATDMIC EVERGY CLEAD.ING HDUSE 13(28), PAGES 22-24 (MAY 1 , 1067)

(LETTER, MARCH 31) THE INDIVICUAL ASSUMED THAT THE FIPST FEI DRGPS OF SOLUTION FROM THE ION EXCHANGE COLUMN WO!JLD NOT BF VERY HOT AND DIO NOT CHECK WITH INSTRUMENTS VIHEN HF FOUND HIS GLOVE TORN. FILN. 8ADGE SHIJWE 300 MRFM RETA AND 13 MR GAMMA (WHOLE BODY). ESTIMATES OF DOSE TO HANOS/THUME AFE 7.3/147 QADS. IN THF BACK-CALCULATION CF THE HAND DOSE, DECONTAMINATION FACTORS FOR THE VARIOUS TREATMENTS WERE ESTIMATED USING A SIMILAR EXPOSURE AND TREATMENT OF A BABY DIGS SKIN.

*DECONTAMINATION + \#FAILUPE, OPERATOP EFPOR + \#ION EXCHANGE + BETA EMITTER + DERSONNEL EXPOSUP., FARIATION + P=F.SINNFL PRDTERTIVE DEVICE + PHOSPHORUS

$17-21752$

GOICANICH G

DISCHARGE ANO SY-PASS SAFETY VALVE FGR HIGH-PRESSURE BCILERS. SCME QATA ON DESIGN OF THE VALUE FOR THERMONUCLEAR PLANT

5 PAGES, 7 FIGUPES, TFRNOTECNICA (MILAN), 20, PAGE $524-528,(1966)$, IN ITALIAN

THE DESIGN JF A OISCHARGE VALVE LND A PRESTARTER EYPASS VALVE FOF USE IN HIGH-PRESSIJRE BCILERS IN THERMOELECTFIC PLANTS ARE GIVEN. THE RIGID REQUIPEMENTS FLACES ON VALVES FOR USE IN NUCLEAR PDNER PLANTS AEE CUTLINED. THE DESIGN OF SOME TYPICAL VALVES IS GIVEN.

* ITALY + VALVE

$17-21753$

ARGONNE NATIONAL LAQQPATORY. REACTGP. DEVELOPMENT PROGPAM PROGRESS FGPGRT. OCTOBER 1967

ARGONNE VATIONAL LA3., AFGOYNE, ILLINOIS

$\triangle N S-7391+.185$ PAGES, FIGURES, TASLES, NOV. 30, 1967

UINE UF A SERIES UH REMOUTS COVERING EOR II, ZDR 3, ZPPR, AAPR, LMFBR, ETC. OVER HALF CONCERNS THE LIQUID-METAL EAST-BREEJER PRTERAM. (EBR. II) AN OSCILLATOR F.OD WAS INSTALLEL IN PLACE OF A CONTROL ROO. INITIAL TESTS INDICATPD OIFFICULTIES (PREVIOUSLY EXPERIENCEO) WITH RUPEING AT LOW FREQUENCIES.

AVAILABILITY - CLEARINGHOUSE FOR EECERAL SCIENTIFIC AND TECHNICAL INEOFMATION, SPRINGFIELO, VIRGINIA, . $\$ 3.09$ COFY, $\$ 0.65$ IICROF ICHE

*CONTROL ROD DRIVE + \#OSCILLATOO, REACTIVITY + REACTOR, BREEOER + REACTOR, FAST + REACTOR, LMCR + REACTJR, RESEARCH + ESPORT, OPERATIONS

$17-21809$

PROPOSFD ISSUANCE DE SAXTDN AMENDMENT Z--PTWER UORATING

USAEL JIVISION OF REACTQR LICENSIVÜ

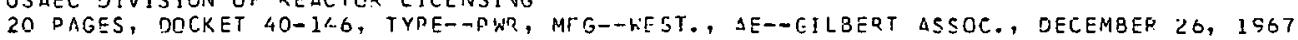

THIS WDULD ALLCW OPFRATION AT 35 MWT EC? AEOUT 3500 MWT DAYS. BEFORE ISSUANCE, ORL WILL VERIFY THAT MOIIFICATIONS OESCOIBEC IN THE ADPLICATION AND SUFDLEMENTS ARE SATISFACTDPILY CDIMPLETEO. HIGHER POWER, $\triangle T$ END CF CORE II, IS TO GAIN INFCRHATION AT OPERATING CONDITICNS SIMILAR TO PLANNED PWRS. PEAK. SPECIFIC PחWFR (10.1 KW/FT) IS 0.6 ABOVE THE HIGHEST YET APPROVED (INDIAN POINT 2). W-3 ONED DUFING NCFMAL OPERATION IS 1.52 VS LATEST FWDS, WHICH ARE 1.32. STATISTICAL ANALYSIS FGR WORST OVER-POWER CASE PREDICTS O.74 RODS MIGHT EXDERIENCE 
$17-21809 *$ CONTINUED*

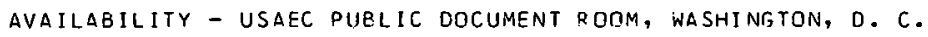

\#DNB + \#PONER UPRATING + \#REACTOR PC.WER + PERFORMANCE LIMI.T + REACTOR, PWR + REACTOR, TEST + SAFETY EVALUATION + SAXTON (PWR) + TECHNICAL SPECIFICATIONS

17-21810 ALSO IN CATEGDRY 5

BIG ROCK POINT SUPPLIES ADOIITION INFORIATION ON PROPOSED CHANGE 13--RESULT OF TWO-PUMP TRIP ANALYSIS

CONSUMERS POWER COMPANY

2 PAGES, DOCKET 50-155, TYPE--BWR, MFG--G.E., AE--BFCHTEL, DECEMBER 14, 1967

ANALYSIS OF 2-PUMP TRIP FOR END OF LIFE AND ${ }^{-B E G I N N I N G ~ O F ~ L I F E, ~} \triangle N D$ FOR $7 \times 7,8 \times 8$, $\triangle$ IND

TYPE-C $(11 \times 11)$ FUEL. TABLE GIVES POWER, CORE FLOW, AND MCHFRS VS TIME O, $1--5$ SEC $A F T E R$

TRIP. MCHFR IN ALL CDSES INCREASES WITH TIME (MINIMUM IS AT T EQUALS ZERO).

AVAILABILITY - USAEC PUBLIC DOCUMENT ROJM, WASHINGTON, D. C.

\#ACCIDENT, LOSS OF FLOW + \#RUF, NOUT HEAT FLUX + \#CENTERLINE MELTING + BIG ROCK POINT (BWR) + REACTOR, BWR + TECHNICAL SPECIFICATIONS

$17-21811$

GULF GENERAL ATOMIC TFIGA MARK F CHANGE O--INTERM QPERATION OF FUELED EXPERIMENTS

USAEC DIVISION OF REACTOR LICENSING

2 PAGES, DOCKET 50-163, DECEMBER 19, 1967

DRL GIVES INTER IM APPROVAL FOR FUEL EXPERIMENTS SO LONG AS THE TOTAL IODINE INVENTORY IN THE

1 EXPER.IMENTS DOES NOT EXCEED 1.5 CUR.IES. GULF/GENERAL ATOMIC ASKED (NOV. 22 , 1967 ) FOR A LIMIT OF $1.7 / F$ CURIES, WHEPE F IS THE RELEASE FACTOR, BUT ASKED FOR INTERIM APPROVAL OF THE 1.5-CURIE LIMIT DUF TO THE IMMEDIATE NEED TO PERFORM CERTAIN EXPERIMENTS.

AVAILABILITY - USAEC PUBLIC DOCUMENT ROOM, WASHINGTON, D. C.

\#FISSION PRODUCT, IODINE + \#IPRADIATION TESTING + FISSION PRODUCT RELEASE, GENERAL + REACTOR, RESEARCH + SAFETY EVALUATION + TECHNICAL SPECIFICATIONS + TRIGA (RR)

$17-21812$

EVESR PROPOSED AMENDMENT 15--UTILIZATION OF DI SMANTLED EVESR COMPONENTS

GENERAL ELECTR IC CUMPANY, SAN JJSE, CALIF.

7 PAGES, DOCKET 50-183, DECEMPER 20, 1967

PROPOSED AMENDMENT 14 REQUESTED LICENSE TFRMINATION. PROPOSED AMENDMENT IS PROPOSES A SECOND COURSE OF ACTICN SINCF LICENSE TFRMINATION DOES NOT APPEAR PUSSIBLE AT THIS TIME. THE REACTOR HAS BEEN DEACTIVATED ANO DEFUELED. GE WISHES TO MAKE NONREACTOR USE OF THE FACILITY, INCLUDING MAKING VARIOUS TESTS AND EXPERIMENTS ON THE COMPONENTS AND SYSTEMS. THE ONLY

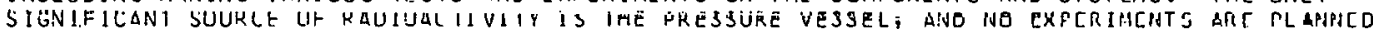
FOR IT. ADMINISTRATIVE CONIROL WILL EE SIMILAR TH THAT FMR AN TPERATING REACTOR.

AVAILABILITY - USAEC PUBLIC DOCUMENT ROOM, WASHINGTON, D. C.

REACTOR DECOMMISSIDNING + REACTOR, BWR + PEACTOR, INTERNAL SUPERHEAT + VESR (ISR)

$11-21813$

DRL REQUESTS THAT DAIRYLAND POHER SUPPLY INFORMATION RETENTION OF RECQRDS

USAEC, DIVISION DF REACTOR LICENSING, WASHINGTON, D. C

2 PAGES, DDCKET 115-5, TYPE--BWR, MFG--A.C., AE--SGT + LUNDY, DECEMBER $26,196 \%$

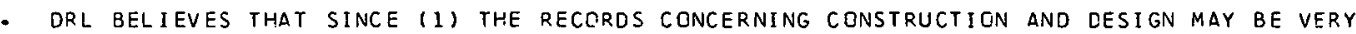
IMPORTANT IN RESOLVING FUTURE PROBLEMS, 12$)$ ALLIS-CHALMERS IS GOING OF THE NUCLEAP BUSINESS, AND (3) THE RECOFOS ARE NOW STORED AT SEVERAL LOCATIONS, THE RECORDS SHOULD BE RETAINED AND ACCESSIBLE TO THE OPERATING AGENCY FOR FUTURE USE.

AVAILABILITY - USAEC PUBLIC DOCUMENT ROOM, WASHINGION, D. C.

ADMINISTRATIVE CONTROL + INFORMATION RETRIEVAL + LACROSSE (BWR) + REACTOR, BWR

17-21814 ALSO IN CATEGORY 1

NUCLEONICS WEEK REPOPTS RESULTS OF SUR VEY COMPARING NUCLEAR AND NONNUCLEAR PLANTS

2 PAGES, NUCLEONICS WEEK, PAGES 4-5 (JUNE 2, 1966 )

(CONSUMERS POWER CD.) COVERS SHIPPINGPORT, DRESDEN, YANKEE, INDIAN POINT, EIG ROCK POINT, HUMBOLDT BAY, HALLAM, PIQUA, CVTR, AND FERMI FROM T.HE START OF OPERATIONS TO PRESENT, AND ALL THE CONVENTIONAL POWER STATIONS OF THE SAME COMPANIES. ACCIDENT RATES PER MILLION MAN-HOURS ARE LOST-TI:AE ACCIDENTS (NUCLEAR-2.96, NONNUCLEAR-4.14), MEDICAL CASES 158.4 VS 61.29), AND 
$17-21814 \quad$ \#CONTINUEC*

SEVERITY PATE IN DAYS LOST PEF MILLION MAN HQURS (917.4 VS 738.9). WALKE SAYS THAT THF NUMBER GF EMPLOYEE RAOIATION CXPOSUPES APCVE THE STATIJTOPY LIMIT CAN BE COUNTED ON ONE, HANC.

* INCIOSNT COMOILATION + INCIDENT, GENEPAL + INCICENT, NONREACTOR + PCACTOR, POWFR

17-21815 ALSO IN CATEGDQY 7

GULF GENERAL ATOMIC PFOPOSED AMENDMENT--FUELED EXDERIMFNTS IN TRIGA MLRK F

GULF GENEPAL ATQMIC, INC..

9 PAGES, 1 ELGUR, 1 TAPLE, DOCKET SO-1EZ, NOVEMBER 22,1967

GULF-G.A. WITHOPAWS MAY 21, 1CE7, APPLICATION DNO REQUESTS DUTHORITY TO PERFORM FUEL EXPERIMENTS WITH THE LIMITATION THAT THE RELEASABLE IODINE INVENTORY NOT EXCEEO $1.7 / F$ CURIES, WHERE F IS THE ACTUAL P.ELEASE FRACTICN OF MATERIAL INIVQLVED EASEO ON EXISTING DATA, OR I.O IF NO DATA IS AVAILABLE. THIS LIMIT WAS DETERMINED FROM REACTOR-POOM SXPOSURES, AND RESULTS IN NO APPRECIASLE OFF-SITE DOSE. ATTLCHMENT I I.S $\triangle$ HAZARDS ANALYSIS - CONSEQUENCES OF $\triangle C T I V I T Y$ RSLEASE FRIA THE TRIGA IMAPK F P.EACTOR. GULF-G. A. ASKS FOR A TEMPORARY AUTHORIZATION TO DPFRATS EXRERIMENTS HITH 1 . T CIIPIES DF IODINE.

AVAILABILITY - USAEC PUELIC DQCUMENT POOM, WASHINGTON, D. C.

\#FISSIJN PRUDUCT, IODINE + \#IRRADIATICN TESTING + HAZARDS ANALYSIS + REACTGR, RESEARCH + TECHNICAL SPECIFICATIDNS + TRIGA 1001

17-21827 $\quad$ LLSC IN CATEGDRY

ANALYSIS OF FAILURE CATA FOR ELECTRONIC EQUIPMENT AT RISO. DERIOD 1960-1965

OANISH ATOMIC ENERGY COMMISSICN, RESELRCH ESTABLISHMENT, RISO

SUPPLEMENT TO RISC REPOCT NO. $38+.13$ FAGES, 12 TABLES, REFERENCES, $\triangle P R I L$ IO67, PRESENTED AT CREST AIEETINS, SEUSSELS

THIS SUDDLEMENTACY DADER SUAMARIZES THE EAULT STATISTICS OF FAILURE CATA FCR ELECTFCNIC EQUIDIAENT AT FISO FRG THE FIVE-YEAR OERIOD 1960-1965. THE OATA ARE PRESENTED FFOM A DRINT CF VIEN DF FELIAEILITY DREDICTIONS. THE EOUIPMENT COVEDED BY THE REPDRTING SYSTEM CONSISTS OF (1) LABTRATORY INSTFUMENTS DESIGNER. IN THE DEPARTMENT AND (2) COMMERCIAL CEACTCF INSTPIIMENTS SLLLINGIVI; TO THE TWC RESEARCH F.EACTORS DF? AND DRZ.

AVAILABILITY - P. TIMMERYANN, DANISH ATOMIC ENERGY COMMISSION, DENMARK

*FAILUPE, INSTRUMENT + \#CPERATING EXPERIENCE SUMMAPY + \#RELIABILITY ANALYSIS + DENMARK + LEACTOR, RESEAR.CH + C.ISO

$17-21828 \quad$ ALSO IN CATEGORY S

JENSEN A + RASMUSSEN + TIMMERMANN P

ANALYSIS OF FAILURE [ATA FGR ELECTRONIC EOUIPMFNT AT RISO

DANISH ATOYIC EINERGY COMMISSION, RESEARCH ESTABLISHMENT, RISO

RISO REPORT NO. $33+2$ ? PAGES, 13 TABLES, REFERENCES, SEPTEMBER, 19E3, PRFSENTED AT CFEST MEETING, BRUSSELS, APQIL 1067

A FAILURE-2CDORT ING SYSTEM FOP. ELECTRONIT EQUIPMENT IS DESCRIBEO, AND FAULT DATA FGR SELECTED ELECTRONIC REACTOR. INSTRUMENTS AND PESEARCH FQUIPMENT ARE PRESENTED. SOME AVERAGE FIGURES ARE SUGGESTED FOR ROUGH DREDICTIONS DF FAILURES IN LARGER INSTRUMENT SYSTEMS.

AVAILABILITY, JUL. GJELLERUP, 87, SOLVGADE, CELENHAGEN K. DENMARK

* EAILURE, INSTRUMENT + \#DREOATINC TKFIRITNCE. SUMMARY + *RELIABILITY ANALYSIS + DENMAKK + R.EACTOF, D.SSEADCH + PISC

$17-21 S 18$

COETNER RA + COAMEQ EN + SCOTT RL

REACTOR OPER ATOF STUEY HANOSDOK--VOLUME II--RADIATION SAFFTY ANO CONTROL OAK. RIDGE NATIONAL LAEOFATOEY

ORNL-TM-P034 +.181 PAGES, FIGURCS, TABLES, JANUARY 1968

DART OF A 5 VILUME SFT OF PRCGRAMMED INSTRUCTION. EACH CHAPTEF INCLUDES $\triangle$ SELF-TEST. CHAOTER HEAOINGS ARE DTOMS (8 PGSI, IONIZATION (IS PGS), RADIATION UNITS (IS PGSI, HEALTH HAZARDS CF P.ADIATION $(\angle 9$ EGSI, RADIATION PROTECTION METHOOS 153 PGSI, ANO RADIOACTIVE CONTAMINATION DRETECTIVS MEASUFES $(34$ OGS). \#\# FOOK INTENCEO COR DPERATORS TRAINING IN UNDERSTANDING THE

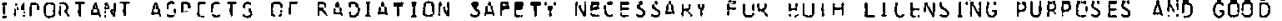

OPEPATION. USEEUL REGAROLESS OF THE REACTMR. TYPF.

AVAILABILITY - CLEAQINGHOUSE FOR CFOERAL SCIENTIEIC AND TECHNICAL INFORMATION, SPRIVGFIFI T. VA., S3. OO COPY, \$0.55 MICROFICHE

\#RADIATION SAFETY A.VD CONTPOL + \#STACFING, TPAINING, OUALIFICATION + HEALTH PHYSICS TRAINING + PROCEDUPES AND MANUALS 
$17-21929$

SURRY AMENDMENT 2 TJ LICENSE APPLICATION REVISED PAGES TO PSAR

VIRGIVIA ELECTRIC ANC POWER CO., RICHMOND, VA.

6 PAGES, DOCKET 50-2EC/281, TYPE--PWR, MFG--WEST, AE--STMNE + WEBSTER, JULY 5,1967

AMENDMENT 2 CONSISTS OF REVISED AND ADDITICNAL PAGES TO THE PSAR, SECTION 14 (SAFETY ANALYSISI. AVAILABILITY - USAEC PUELIC DGCUMENT RDOM, WASHINGTON, D. C.

* ACCIDENT ANALYSIS + *SAFETY ANALYSIS + REACTOR, PWR + REPORT, PSAR + SURRY 1 AND 2 (PWR)

17-21987 ALSO IN COTEGORY 6

SAXTON PLUTONIUM PRDGRAM SFMIANNUAL PROGRESS REPORT FOR THE PERIOO ENDING JUNE 30 , 1 S67

WESTINGHOUSE ELECTRIC CCPP., PITTSBUPGH, FA. ATOMIC POWER DIV.

WCAP-3385 + EURAEC-1877+. 36 PAGES, 20 FIGURES, 3 TABLES, 4 REFERENCES, JUNE 30,1967

REACTOR WAS SHUT [OOWN 5 MONTHS TO INSTALL SUPERCRITICAL LOCP. (PAGES 5-16) THE LAST

JUST-CRITICAL BOPIN CONCENTRATION CALCULATION BEING $1 O \%$ HIGH WAS ATTRIBUTEO TO EITHER (A) NONUNIFORM AXIAL FUEL-BURNUP DEPLETION IN PDQ-XY, WORTH 700 HR OUT OF A PREDICTED O5OO, OR, (B) LEOPARD CROSS SECTIONS INAOEQUATE FOR. PLUTONIUM, WORTH 250 HR. (PAGES 22-35) TWO FUEL RODS WERE GAMML-SCANNED AND METALLOGRAPHIC SPECIMENS PREPARED. VIPAC FUEL HAD MORE CLAD-HYDRIDE (MORE MOISTURE IN FUEL) AND A REACTION LAYER (APPARENTLY FROM REDUCTION OF HYPERSTOICHIMETR IC FUELI.

AVAILASILITY - CLEARINGHOUSE FOR FEOERAL SCIENTIFIC-AND TECHNICAL INFORMATION, SPRINGFIELO, VIRGINIA, $\$ 3.00$ COPY, \$0.65 MICROF ICHE

* FUEL ELEMENT + \#IRRALILTION TESTING + \#PLUTONIUM OIOXIDE + FUEL, POWDER TYPE + HYDRIDE + R AND D PROGRAM + REACTIVITY EFFECT, DIVOMALOUS + REACTOR, PWR + SAXTON (PWR) + STOICHIOMETRY + ZIRCALOY

$17-21991$

PAXSONE + SMALLEY WR

ENGINEERING AND METALLURGICAL EVALUATION GF THE YANKEE CORE I SPENT FUEL

WEST INGHOUSE ELECTRIC CORP., PITTSSURGH, PA. ATOMIC POWER DIV.

WCAP-5084 +. 171 PAGES, 130 FIGURES, 15 TABLES, 36 REFERENCES, JUNE 19E7

CONCLUSION WAS THAT UO2 FUEL AND SS-348 CLAD HAD PERFORMED SATISFACTORILY UP TO 46 , 0OO MWD/MTU AND DOSES OF $8 \times 10(21 S T)$ NELTRONS GREATER THAN 1 MEV. 16 FUEL ASSEMBLIES WERE EXAMINED ANO 71 FUEL RODS DESTPUCTIVELY TESTED. CLAD TUBE-BURSTS WERE MACE, AND UOZ MELTING POINT WAS DETERMINED AS A FUNCTION OF FUFL BURNUP. SURFACE FILM DEPOSITS, SCRATCHES, RUB MARKS FFOM CONTROL RODS, DISCOLORATIONS, EXTENT OF EROSION, ETC., DESCRIBED. 'A 2-IN.-LONG, 0.07-IN.-THICK PIECE DF FOLDED SHEET METAL FOUND IN AN ASSEMBLY CAUSED NO OPERATIGNAL PROBLEMS.

AVAILABILITY - CLEAR. INGHOUSE FOR FEGERAL SCIENTIFIC AND TECHNICAL INFORMATION, SPRINGFIELD, VIRGINIA, $\$ 3.00$ COPY, \$0.65. MICROFICHE

*EXAMINATION + \#FUEL PURNUP + \#FUEL ELEMENT + CLAD + DAMAGE + FLOW BLOCKAGE + MATERIAL +

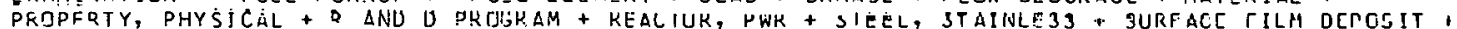
URANIUIA DIOXIGE + YANKEE (FWP)

$17-22107$

NUCLEAR ENERGY - IMPPOVING THE BREEDER

1 PAGE, TIME MAGAZINE, PAGE 64, (JAN. 5, 1968)

A INE-COLUMN AFTICLE BRIECLY UESCRIGES THE OCT. 1966 FERMI INCIDENT, THE SEARCH FOR ITS CAUSE, ANO PLANS FOR FEMOVING THE FORFIGN OBJECT. LESSONS LEARNED ARE - WARNING SYSTEMS SHDULD BE COMPUTERIZED TO GIVE EARLIER INDICATIONS, STRAINERS SHOULD BE INSTALLED IN COOLING SYSTEMS, $\triangle N D$ DESIGN SHCULD ALLOW FASTER DI SMANTLING, INSPECYION, AND RENAIR.

*RADIATION, PUZLIC EC̣UCATION/ACCEPTANCE + FERMI (LMFBR) + FILTER, SCPEEN + FLOW RLOCKAGE + INCIOENT, GEVERAL + MAIN COOLING SYSTEM + MAINTENANCE AND REPAIR + PLANT PROTECTIVE SYSTEM + REACTDR, SREEDER + REACTOR, FAST

\section{7-22110 ALSO IN CATEGORY II}

PITCHIE AS

UKAEA, GERKS (HAP,NELL)

1 PAGF, ANS TRANSACTIONS 10121, PAGE 579, (NOV. 1967), PRESENTED AT THE 1967 WINTER MEETING OF THE AMERICAN NUCLEAR SOCIETY, CHICAGQ, ILLINOIS, NOVEMBER 5-9, 1967

THE ATJMIC ENERGY RESEARCH ESTABLISHMENT AT HARWELL, ENGLANO, HAS THO MAJOR ACTIVE-HANDLING BUILOINSS, ONE TO DPOVIDE A GENERAL-PURPOSE SERVICE AND THE OTHER FOR SPECIALIZED $\triangle C T I V E-H A N D L I N G$ WORK ASSOCIATEO WITH THE METALLURGICAL RESEARCH PROGRAM. THIS PAPER 
OPERATIONAL SATEGOFY I7

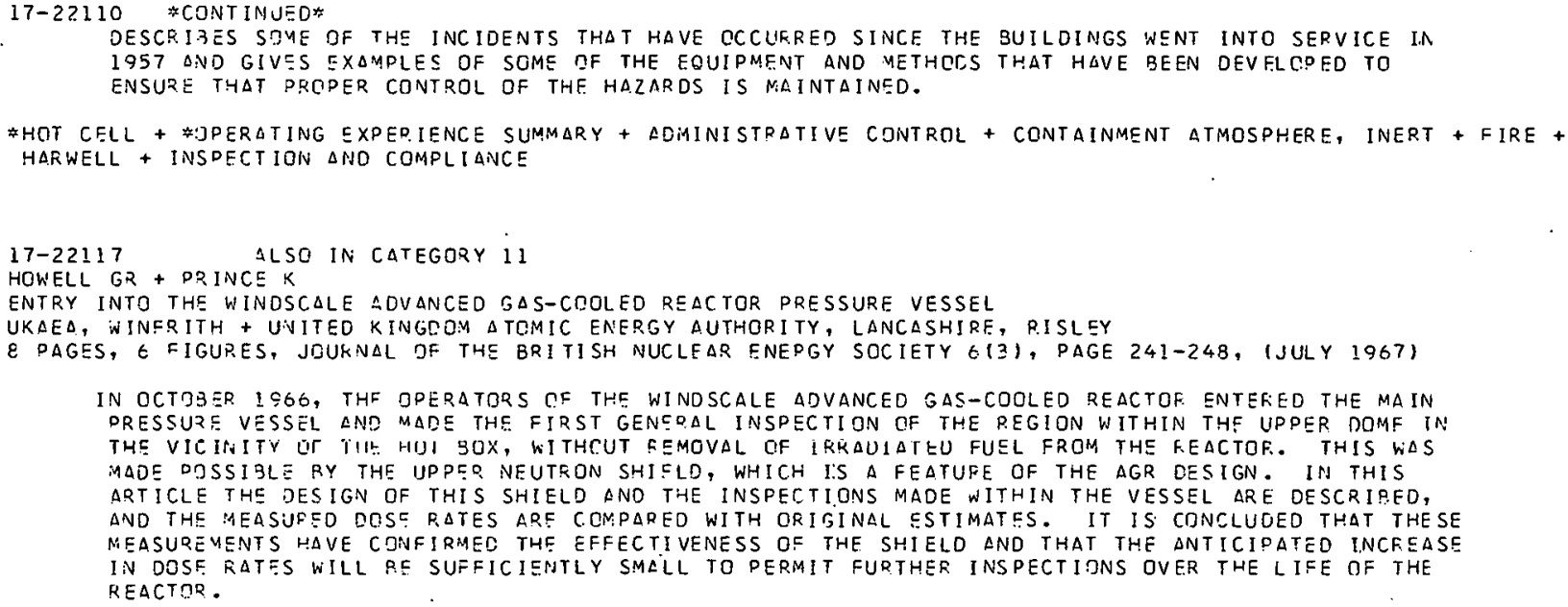

\#HOT CELL + \#:JPERATING EXPEPIENCE SUMMARY + LDIAINISTRATIVE CONTROL + CONTAINMENT ATMOSPHERE, INERT + FIRE + HARWELL + INSPECTION ANO COMPLIANCE

IN OCT 39 ER 1966, THF OPERATORS CF THE WINDSCALE $\triangle D V A N C E O$ GAS-COOLED REACTOF ENTERED THE MAIN PRESSURF VESSEL AND MADE THE FIRST GENEQAL INSPECTION OF THE PEGION WITHIN THF UPPER DOMF IN THE VICINITY UT TIIL HUI SOX, WITHCUT GEMOVAL OF IRKAUIATEU FUEL FROH THE FEACTOF. THIS WAS MADE DOSSI SLE RY THE UPPCQ NEUTRON SHICLD, WHICH IS A FEATUFE OF THE AGR DESIGN. IN THIS ARTICLE THE DESIGN OF THIS SHIELD ANO THE INSPECTIONS MADE WITHIN THE VESSEL ARE DESCRIPED, AND THE AEASUFED DOST RATES ARE COMPARED WITH ORIGINAL SSTIMATES. IT IS CDNCLUOED THAT THESE MEASUREMENTS HAVE CONFIRMED THE EFFECTIVENESS OF THE SHIELD AND THAT THE ANTICIPATED INCFEASE IN DOSF RATES WILL RE SUFFICISNTLY SMALL TO PERMIT FURTHER INSPECTIONS OVER THE LIFE OF THE REACTOR.

*COMPARISON, THEOPY ANC EXPERIENCE + \#INSPECTION AND COMPLIANCE + \#PRESSURE VESSEL + *WAGR (GCR) + DOSE MEASUDEYSNT, INTERNAL + NEUTOON + SHIELDING

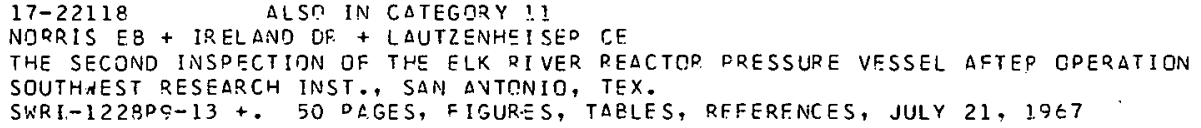

THE ELK RIVER FEEACTDK PRESSURE-VESSEL INSPECTION WAS AGAIN MADE EY SCUTHWEST RESEARCH INSTITUTE AFTEF THE R.ACTOR HAD BEEN OPEPATED FOR NEARLY 2 FULL-POWEP. YEARS. INSOECT ION PROCEDURES, SIMILAF. TO THOSE USEO CURING THE PREVIOUS (1966) INSPECTIGN, ARE DISCUSSEO. NO CRACKS WERE FQUND IN NCZZLES IN THE SHELI. OR HFAD AND TOP-HEAD OVEPLAYS. CRACKING TDUND IIW THE SHELL FLANGE OVERLAY CURING THE 1OE6 INSOECTION HAS NOT INCREASED, AND AGAIN IT WAS CONCLUOED THAT IT UID NOT PFNETRATF INTR THE EASE STEEL DUFING THE POSTGPERATIONAL DERIOD, THE SHELL-FLANCE OVEPLAY WAS CCATED WITH AN UNIDENTIFIED SUEST ANCE THAT SIGNIFICANTLY IMPAIRS LIQUID PENETRANT INSDECTION. AN ULTRASONIC INSPECTION OF THE VESSEL FLANGE WAS MAOE TO DETERHINE IF THE CLNDDING CRACKS HAD PENCTRATED INTO THE BASE STEEL. THE OBSERVAIIUNS CONFIRMED THE EESULTS OF THE PATCH-GPINDING INSDECTICN.

AVAILABILITY - CLEARINGHIUSE FOR FIDERAL SCIENTIFIC AND TECHNICAL INFORMATION, SFRINGFISLD; VIRGINIA, $\$ 3.00$ COPY. \$0.65 MICROFICHE

*ELK RIVER (BNR) + \#INSPECTION AND CDMOLIANCE + \#INTEGRITY + \#PRESSURE VESSEL + CL AD + FLANGE + TEST, NDNDESTPUCT IVE

17-2213! $\triangle L S E$ IN CATEGORY C

WNYNRC PULSTAR PROPCSED CHANGE--INSTPLIMFNT CALIBFATION

HESTERN NEW YORK NUCLEAF. RESEAPCH CENTEP, INC., RUFFALO, NEW YORK

3 PAGES, DJCKET 50-57, DFC.FMAFR 15,1967

\begin{abstract}
STATE UNIVERSITY CF N.Y. ASKS PERMISSION TO CALIBRATE TRANSIENT (DULSING) INSTRUMENTATION BY USE OF NEUTRON-ACTIVATED EDIL INSTEAD OF PY AN INSTRUMENTED FUEL PELLET. IN OLD METHOD, (I) CHANCES IN PELLCT OF IENTATION AND FOSITION RESULTEO IN INACCURATE MEASUREMENTS, (2) PCLLETS FAILED 3Y RADIAL CRACKING, AND (3) THERMAL INSULATION OF THE PELLET WAS A PROBLEM. FCIL METHOD HAS PROVEO RELIABLE. ALSO FEQUESTEO IS A CHANGE IN PULSE-QDD CALIRRATION PROCEOUFE. PREVIOUSLY THE IN-HCUR METHDC WAS USEO, WHICH WAS INACCURATE DUE TO XENON CHANGES. ROD WOULD RF CALL I SPATEO EITHER BY COMPARI SON WITH A STANDARD ROD OR EY TWO OR MOPE CALIBRATION PULSES SEPAFATEO SY ENERGY RELEASES OF NOT LESS THAN 5 MW-SEC.
\end{abstract}

AVAILABILITY - USASC PUELIT. DUCUMENT ROOM, WASHINGTON, D. C.

\#INSTRUMENTATIUN CALIRRATION + \#INSTRUMENTATION, PULSE + INSTRUMENTATIGN, NUCLEAR + PULSTAR (RR) + REACTOR, PULSED + PELCTOR, RESEARCH + TECHNICAL SDECIFICATIONS

$17-2213 ?$

HUMBOLDT BAY ADOENDUM D TO PROPISED CHANGF 2?--ANSWFFS TO AEE DUESTIONS

PACIFIC GAS AND EL CCTEIC COMPANY, SEN FPANCISCO, CALIF.

42 PASES, FIGURES, TABLES, DOCKST NO. 50-13?, TYPE--RWF, MFG--G.E., AE-- SECHTEL, DECEMBER IS, IS67

RESPONSE TJ'E QUESTIONS OF DRL LETTER (NDV. 20, IOE7) REQUESTING ADOITIONAL INFOPMATION ON DQOPDSED CHANEE 22. QUESTIONS COVFR FMERGENCY DOWER SYSTEM, REACTOR PROTECTICN SYSTEY, CONTAINMENT ISOLATICN SYSTEM, REFUELING, SUPVEILLANCE PROGFAM, CONTROL-ROD PROGRAM. 
$17-22132 *$ CONT INUED*

AVAILABILITY - USAEC PUPLIC DOCUMENT ROOM, WASHINGTON, D.C.

* $\triangle E C$ QUESTION + HUMBOLT BAY (BWR) + REACTOP, RWR + TECHNICAL SPECIFICATIJNS

17-22140 ALSO IN CATFGDRIES 5 AND 6

MANHATTAN COLLEGE ZOR MODERATOR COEFFICIENT MEASUREMENTS

MANHATTAN COLLEGE, BKONX, NEW YORK

45 PAGES, 5 TABLES, DOCKET 50-199, DECEMBEF 24,1967

\begin{abstract}
AT DRL DIF.ECTION (NOV. 2, 1SGE) MZPR MEASURED THE EXCESS REACTIVITY AT THE TEHPERATURE AT WHICH THE MOOERATOR COEFFICIENT CHANGES FROM POSITIVE TO NEGATIVE. A HEAT EXCHANGER, A MIXER, ANO 12. THERMISTORS WEPE BOUGHT. THE MIXER CAUSEO VORTEXING AND MOVEMENT OF INSTRUMENTATION AND LIGHTS IN THE CORE AND HAD TO BE MODIFIED. WITH IO THERMISTORS IN THE CORE AND CONTROL RODS FULLY WITHDRAWN, THE REACTOK WAS SUBCRITICAL DUE TO T.HE POISON EFFECT OF THE COPPER LEAD WIPES. RESULTS CF THE EXPER IMENT WERE - TUPNAROUND TEMPERATURE - IIO F, EXCESS REACTIVITY $\triangle T 110 \mathrm{~F}-0.44 \mathrm{Z}$, WORTH OF 5 PAIRS OF THERMISTOR LEADS - O.1OE, LEAST-SQUARES TSMPERATUPE/REACTIVITY RELATIONSHIP - (DELTA K/K)\% IS EQUAL TO - $35.83 \times$ 1O(-2ND) PLUS $100.67 \times 10(-4$ TH) TIMES T MINUS $45.53 \times 10(-6 T H)$ TIMES T SQUARED. PROBABLE SRROR IS $2.1 \times 101-4 T H) \%$. (INCLUDES 25-PAGF TARLE OF THERMOCOUPLE CALIBRATION.)
\end{abstract}

AVAILABILITY - USAEC PUBLIC DOCUMENT P.OOM, WASHINGTON, D. C.

\#MODERATOR COEFFICIENT + \#REACTIVITY, EXCESS + \#TEMPERATURE COEFFICIENT + CRITICAL ASSEMBLY FACILITY + IN CORE MEASUREMENT + MEASUREMENT, GENERAL + REACTIVITY EFFECT, ANCMALOUS + TECHNICAL SPSCIFICATIONS

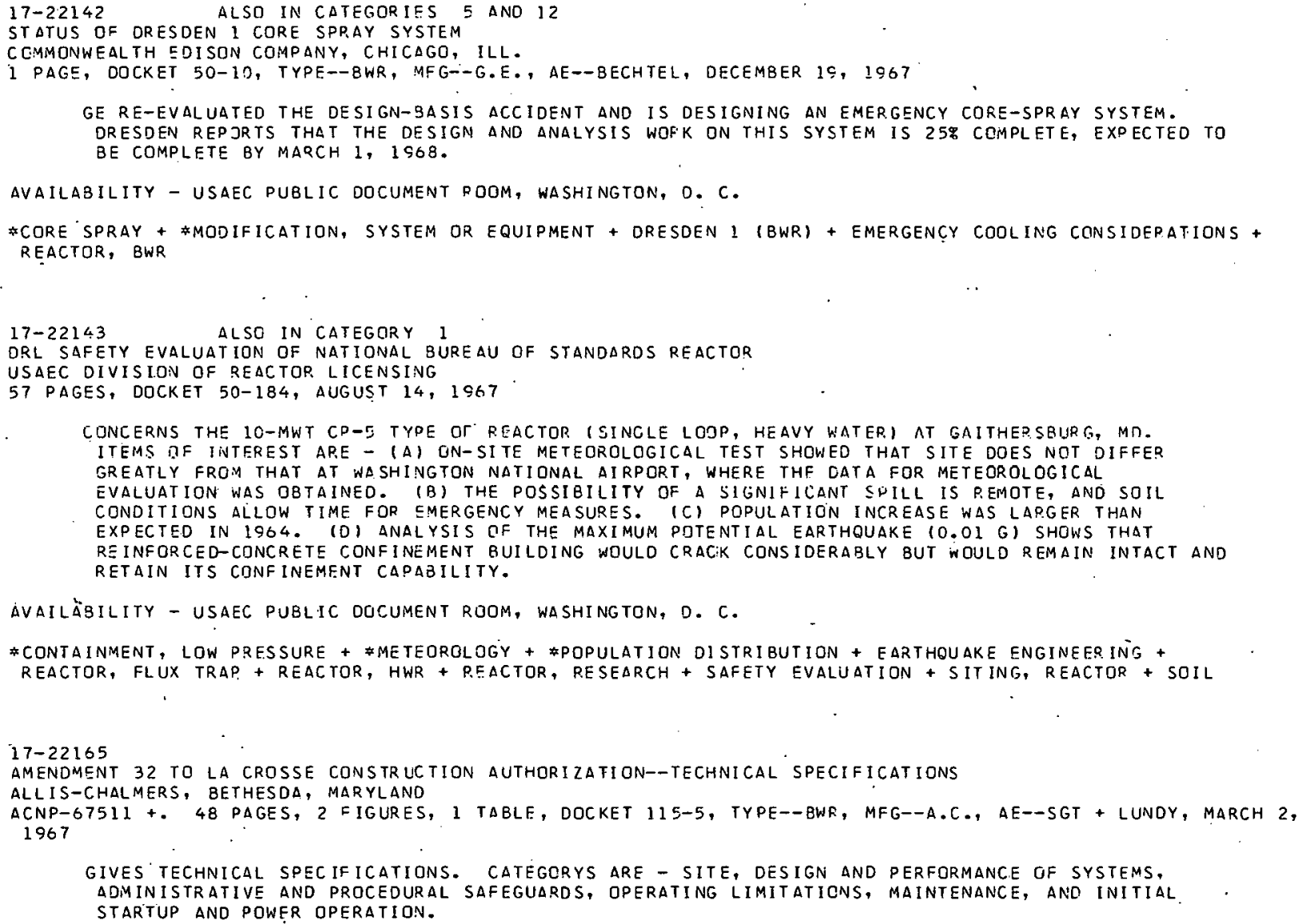


CATEGRRY Ti
OPEPATIONAL SAFETY AND EXPEPIENCE

$17-22192 *$ CONTINUED*

2 PAGES, CHEMICAL AND ENGINEER ING NEWS, PAGES 2S-30 (JANUARY 1, 1968)

BRIEFLY REVIEAS THE EXPANSION OF EDUCATIONAL INSTITUTIONS ANO PROGRAMS TO MEET THE DEMLND FOF NIJCLEAR SCIENTISTS AND ENGINEERS. DI SCUSSED NUCLEAR-SCIENCE-CENTER PROGO AMS AT OREGON STATE UNIVERSITY, NORTH CAROLINA STATE UNIVERSITY, DND LOWELL TECH. ANNUJAL DEMAND UNTIL 1973 IS

3380 B.S. AND 2350 M.S. OR PH.D.S. ICURRENT ANNUAL SUPPLY IS 2500 R.S. .ANO 1500 M.S. OR PH.DS. IN FISCAL 1567 , $\triangle E C$ SPENT \$9.4 MILLION FOR NUCLEAR EDUCATION. \#\#\# RENSSELAEP. POLYTECH AVD PENN STATE HAVE TRAINED PEACTCR OPERATIONS FOR UTILITIES. DIRECTOP DF AEC EDUCATIJN DIVISION SAYS - (1) IMMECIATE PRCBLEM, IS RETRAINING CCMPANY PFRSONNEL, ANC (?) UNTIL NNOW, GREAIESI STRESS HAS BEEN PLACED ON PH.D. -LEVEL EDUCATION (RESEARCH), PUT $\triangle L L$ SCHOOLS SHOULO RE-EXAMINE THEIR ROLES IN RETRAINING CR CONTINUING EOUCATICN IN TERMS DF APPLICATIONS.

* STAFFING, TRAINING, QUAL IFICATION

$17-22193$

JONES CF

STAFFING NUCLEAP. PLANTS

NUS COKP., WASHINGTON, O. $C$.

3 PAGES, 2 TABLES, POWER ENGINEERING 7211), PAGES 47-45 (JANUARY 1962 )

DISCUSSES NEED JF LONG-TERM PLANNING FOR DEVELOPMENT OF TRAINEO PEOPLE FOR BCTH MANAGEMENT AND SIJPPIIRT. TO MAN NUCLEAR. PLANTS NCH ON ORDLR, AN $\triangle V E R \triangle G E$ ADDITION OF 30 TRAINEU OPERATING AND SUPPORT PEOPLE WILL BE NEEDED EVFPY MONTH FOR 6 YEARS. RIEGEST DROBLEM WILL DE DPOVIDING OPERATING EXPER IENCE BECAUSE HIGH COST bF OUTAGE ON EASE-LOAD SECDND-GENERATION FEACTORS WILL EXCLUDE THEIR USE AS TRAINING FACILITIES.

*STAFFING, TRAINING, QUALIFICATION

17-22224 ALSO IN CATEGORY 18

PATHFINDER PROPOSED $\triangle M E N D M E N T$ 42-STORAGE OF COFE II FUEL

ALLIS-CHALMERS, BETHESDA, MAPYLANO

4 PAGES, DOCKET 50-130, TYPE--SWR, MFG--A.C., AE--PI CNFEP SERV., JULY 28,1967

REOUESTS TECHNICAL-SPECIFICATION CHANGES TO PEPMIT RECEIPT ENC STORAGE OF CORE-II TYDE QF FUEL. WHICH IS SLIGHTLY DIFFEDENT FROM COPE-I FUEL. ATTACHED IS ACNP-C7525 \#\# SAFFRIIARTS ANALYSIS FOR SECONO CURE LDAOIMG. \# CHANGES ARE - (1) LOKI-ENRICHMENT SUPERHEATER. CUFL IN PLACE OF CERMET, (2) R4C PELLETS-IM-TUBSS CCNTROL RODS IN ELACE OF RORON-SS T.RUTLIFQRM ROOS, AIVD (3) BOILER FUEL RODS HAVF UNIFORM DIAMETER WITH SOME WATEQ-FILLED PODS IN THE STEAM-VCIDED UPPER REGION IN PLACE CF STEPPED-DIAMETER FUEL RODS.

AVAILABILITY - USAEC PUBLIC DOCUMENT POQM, WASHINGTON, D. C.

*FUEL STORAGE + COVTPOL ROD + FUEL ELEMENT + MOOIFICATION, SYSTEM CP FOUIPMENT + PATHFINCER (ISR) + REACTOA, RINR + REACTOR, INTERNAL SUPFRHEAT + TECHNICAL SPECIFICATIGNS

17-22225 $\triangle L S O$ IN CATEGORY 5

PLTHFINOER ATJMIL POWEK PLANT SAFEGUARDS ANALYSIS FOF SECONO CORE LOAOING

ALLIS-CHALMERS, BETHESDA, MARYLAND

ACND-5752E +. 109 DAGES, 15 FIGURES, 33 TABLES, REFEPENCES, DOCKET 50-130, TYPE--BAR, MFG-- 1 .C.,

$\triangle E--P I O N E C R$ SERV., JUNE 30,1967

DESCribes AND EVALUATES CORE-II COMPCNENT CHANGES - 11) LOW-ENPICHMENT OXIDE SUPEF,HEATEP FUEL (IN PLACE DE EULLY ENTICHED CERMET FUEL) POR LONGER. FUEL LIFEIIME ANU ECUNUMY. (2) GLC PELLET IN INCONEL TUSE IN SAME CRUCIFORM PATTEPN TO REPLACE PRESENT SOL IO BORON-SS EOILEP. CONTROL BLADES. (3) BOILER FUEL ROOS ARE THE SAME DIAMETER. IN THE UPPER AND LOWER CORE HALVES (CORE-I FUEL HAS STEPPED-OIAMETER RCOS), EUT WATER-TUEES WILL REPLACE SOME FUEL IN THE UPPER HALF TO COMDENSATE FDR STEAM VOIDING. COMPLETE CHANGES WILL TAKE FLACE OVEP SEVERAL PEFUELING. \# REACTOR OYNAMICS, THERMAL ANALYSIS, AND ACCIEENT ANALYSIS REPEATEO.

EXPERIMLNTAL JUSTIFICATION MAOE FOF. REVISEO ANALYSIS METHODS.

AVAILABILITY - USAEC PUBLIC DOCUMENT ROOM, WASHINGTON, D. C.

\#REFUELING + CONTROL ROD BURNUP + FUEL ELEMENT + MODIFICATICN, SYSTEM OR EQUIFMENT + PATHFINDER (ISR) + REACTOR, BWR + REACTOR, INTFONAL SUPERHELT + PEPQST, OPERATICNS ANALYSIS + SAFETY ANALYSIS + TECHNICAL SPECIFICATIONS

$17-22226$

ACRS REPORT ON BIG ROCK DOINT PROPJSED EXPERIMENTAL FUEL

U.S. ATOMIC FNERGY COMMISSINN, WASHINGTON, D. C.

3 PAGES, UULKEI $50-155$, TYPE-OWR, MFG-G.E., DE--EECHTEL, OECEMBFE 20,1957

SIX DEVELOD:AEVTAL FUFL ASSE:ABLIES AFE OESIGNED TO TEST OPERATION WITH CENTERLINE MELTING. TWO (WITH 0.57-IN.-DIAM P.OOS) WILL BE $\triangle T$ INCIPIENT MELTING, FOUR (WITH 0.7-IN.-DIAM PCDS) WITH CONSIDERABLE CENTEP. MELTING. AFTEF 30OC-MHO/T, TEST FUEL WILL BE REMGVED FOR EXAMINATION. ACRS RECQMAENCS THAT 0.7-IN. -DIAM ROD FUEL NOT RE REPLACED IN REACTOR UNTIL COMPLFTION AND DRL REVIEW OF DESTPUCTIVE TEST ON 4 FIIFI FOMS. PRDPOSED PLANT MOOIFICATICNS TO IPICREASE 


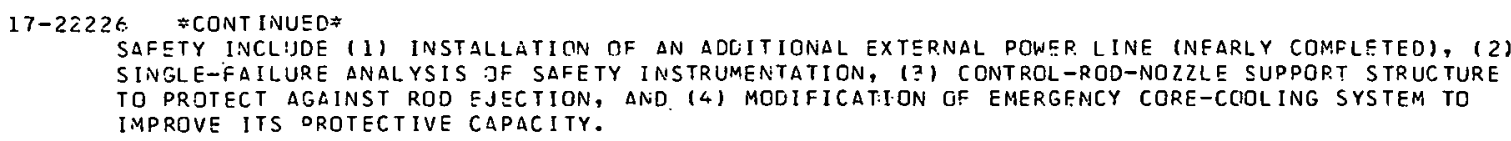

AVAILABILITY - USAEC PUBLIC DOCUMENT ROOM, WASHINGTON, D. C.

*CENTERLINE MELTING + \#IPRADIATION TESTING + ACRS + BIG ROCK POINT (BWR) + FUEL ELEMENT + MODIFICATION, SYSTEM OR EQUIPMANT + REACTOR, BWR + TECHNICAL SPECIFICATIONS

$17-22256$

ERRATIC REHAVIOR OF LA CPOSSE MAIN PUMP DISCHARGE ROTOVALVES

ALLIS-CHALMERS

2 PAGES, ATOMIC ENEQGY CLEARING HOUSE 14(2), PAGES 15-16 (JANUAPY 15, 1968), DDCKET 115-2, TYPe--OCR, $M F G--A . I, \triangle E--A . I$.

(LETTER, DËCEMBER 25, 1CE7) ON DECEMBER 2, CIRCULATION-PUMP IB TRIPPED DUE IO SEAL-INJECTION DIFFICULTIES, AND THE P.OTOVALVE FAILED TO CLOSE AND PREVENT BACKFLOW. PUMP TACHOMETER AND INTERLOCKS WERE ALL RIGHT. GN DECFMBER 5, THE IA VALVE FAILED TO OPEN. LEATHER CUPS ON THE OISTONS WERE HARD $\triangle N O$ STIFF, $\triangle N D$ PISTON CRACKEO. ON DECEMEER 18 , VALVES TESTEO PPOPERLY. ON DECEMBER 27 AND 28 , I A VALVE AGAIN FAILED TO CLOSE, AND THE $1 B$ ALARM UNIT RESPONDED

ERRATICALLY TO THE TACHOMETEP SIGNAL. PLANT IS BFING SHUT DOWN SO CORRECTIONS CAN BE MADE.

\#FAILUZE, EQUIPMENT + \#AIN COOLING SYSTEM + *MAINTENANCE AND REPAIR + \#VALVE + LACROSSE IBWRI + OPERATING EXPERIENCE SUMMARY + PUMP + PRACTOR, BWR + TECHNICAL SPECIFICATIONS

$17-22 ? 57$

ALSO IN CATEGORY 5

MOORE JB

SAN DNOFRE INVESTIGATES HIGH DELTA-T ACPOSS B STEAM GENERATOR

SOUTHERN CALIFDRNIA EDISON CO., LOS ANGELES, CALIF.

3 PAGES, ATOMIC SNERGY CLEARING HOUSE 1413), PAGES 18-20 (JANUARY 15, 1968), DOCKET 50-206, TYPE--PHR, MFG--WEST., AE--BECHTEL

(LETTER, JAVUARY 5) SINCE DDWER TESTING IN JULY, CALOR.IMETRIC MEASUREMENTS OF PRIMARY AND SECONDARY DIFFER BY 4 TO 1O\%. SIX ERRATIC RESISTANCE TEMPERATURE-DETECTORS IN THE REACTOR LODP WERE REPLACEN IN NOVEMBER. IN DECEMBER, AT 405 MWE (90\% LOAD), THE SG DELTA-T WAS $40 / 48 / 44 \mathrm{~F}$ FIR A/B/C STEAM GENERATORS, GIVING THE AVERAGE PREDICTED FOR 450 MWE (IOO\%). ACCORJING TO FÉSULTS OF ANALYSIS SINCE THEN, RTUS ARE ACCURATE, BUT PIPE LOCATION AFFECTS INDICATED TEMPERATURE 5 TO $10 \mathrm{~F}$. PUMP FLOWS ARE OIFFERENT (B PUMP LOWEST), THE RANGE BEING FRUM 112 TD $94 \%$, DEPENDING ON METHGO. UNIT IS BEING HELD AT 3RD-VALVE POINT (4OS MWE), WIIH ALARMS SET ACCCRDINGLY, FOR. FURTHER STUDY.

\$RFACTOR POWEP + COMPAKISON, THEORY AND EXPERIENCE + FLQW ORIFICE + FLGW, GENERAL + INSTRUMENTATION, ABNORMAL INDICATICN + INSTRUMENTATION, TEMPERATURE + CPERATING EXPERIENCE SUMMARY + PUMP + REACTOR, DWR + SAN ONOFRE (PWR) + STEAM GENERATOR

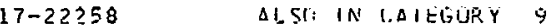

BECK GP

UNIVERSITY OF ILLINOIS REPORTS TRIGA FULSE ROD FAILURE

UNIVERSITY OF ILLINOIS

2 PAGES, ATCMIC SNERGY CLEAR ING HOUSE $14(3)$, PAGES 21-22 (JANUARY 15, 1968), DOCKET 50-151

(LETTER, JANUAFY \&) (A) a GAD RELAY ALLOWED THE PULSE ROD TO BE RAISED WHEN THE SHIM ROO WAS ABOVE FULLY INSER TED WITH MODE SWITCH IN MANUAL. (B) IHE PNEUMATIC SOLENOID VALVE FAILED TO DROP THE PULSE P.OC ON SCRAM. THE FUBBER SEATS ON THE SIX-YEAK-ULD-VALVES WERE WORN ANO OCCASIJNALLY ALLOWED AIR TO LEAK TC THE TOP PORTION OF THE DIAPHRAGM, HOLOING AIR PRESSUPE ON THE PISTON EVEN WHEN THE ELECTRICAL PCRTION WORKED PROPERLY. THE AIR PRESSURE WAS REDUCED FROM 75 TO 40 DSI, WHERE THE ROD DID RELEASE. THE REACTOR DPERATED SATISFACTORILY. A EACKUP SAFETY SYSTEY (RELEASE OF AIR PRESSURE AT A VENT ADJACENT TO CONSOLE) WAS AVAILABLE.

*FAILURE, COMPONENT + \#FILURE, SCRAM MFCHANISM + CONTROL RDD DRIVE + INCIDENT, EQUIPMENT. + INSTRUMENTATION, RELAY + REACFOR, RESEARCH + SHUTDOWN SYSTEM, SECONDARY + TRIGA, (RR) + VALVE

17-22259 ALSO IN CATEGORY 13

RUNION TC

NFS-AEC CORRESPONOENCE PEGARDING MANAGEMENT CONTROL

NUCLEAR FUEL SEKVICES, INC., NEW YORK

4 PAGES, ATOMIC ENERGY CLFARING HOUSE 1413), PAGES 23-26 (JANUARY 15, 19S8)

(NFS TELEGRAM, JAN. 3) PRESIDENT OF MFS STATES THAT MATTEPS REFFRFED TO IN LETTER ARE A COMPLETE SURPFISE, AS OPERATIONS HAVE BEEN AND ARE CONDUCTEE WITHIN LIMITS. MEET ING ARR ANGED. ICCMPLIANCE OIVISIDN LETTER, DEC. 2\%) SUMMARIZES 1967 CORRESPONDENCE AND INSPECTION REPRRTS (WE INFORMED YOU THAT NUMEER AND PATTERN OF CIFFICIENCIES, IF CONTINUED, COULD ADVERSELY AFFECT PUBLIC HEALTH ANO SAFETY. WE REQUESTED YOU MOOIFY COMPANY MANAGEMENT SYSTEM TO CONTROL PLANT OPERATIONS TO ENSURE THAT EQUIPMENT ANO ADMINISTRATIVE CONTROLS WERE ADEQUATE.) REQUEST NFS SUSPFND OPFPATIONS IN HIGH-RADIATION-LEVEL AREAS, REVIEW TRAINING EQUIPMENT AND ENTRY INTO THESE AREAS, REVIEW ANC UPOATE HP PPOCEOURES ANO VENTILATION 
OPERATIONAL SATEGOEYY INT EXPERIENCE

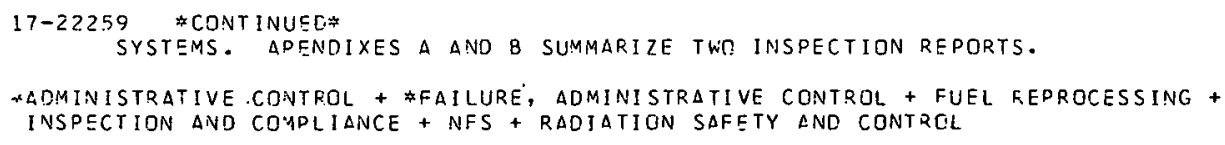




\section{7-22327 \#CONTINUED*}

ANALYSIS OF OPERATING, MAINTENANC, INSPECTIDN, AND TESTING DATA ON COMPCNENTS OF ENGINEERED SAFETY SYSTEMS, AND (2) THE INVESTIGATICN OF TECHNIQUFS FOR THE EVALUATION OF RELIABILITY AND THE APPLICATICN OF THESE TECHIIQUES TO ENGINEERED SAFETY SYSTEMS TYPICAL CF NATER-COOLEO AND -MODERATED POWER REACTOQS. TWO METHOOS WEP.E SELECTED, AUTCMATIC REL IABILITY MATHEMATIC MODEL (A COMPUTER IZEO REL IABILITY ANALYSIS PROGRAM) AND FAULT-TREE ANALYSIS (A LOGICAL ANALYSIS CONCEPT). APPLICATIONS OF SOTH TO SAMPLE PRORLEMS, USING AVAILABLE RELIAEILITY DATA, SHOWEO THAT THEY PROVIDE USEFUL RELIABILITY ESTIMATES. AVAILABILITY - CLEARINGHOUSE FOR FERERAL SCIENTIFIC ANE TECHNICAL INFORMATION, SPRINGFIELD, VA., \$3. OO
COPY, \$0.65 MICROFICHE

*REACTOR. SAFETY SYSTEM + \#RELIABILITY ANALYSIS + CODES AND STANDARDS + COMPUTER PROGRAM + DRESDEN 3 (BWR) + OPERATING EXPERIENCE SUMMARY + REACTOR, RWR + REACTDR, PWR + SAN ONOFRE (PWR) + YANKEE (PWR)

$17-22334$
FURET J G GUYOT C IN CATEGORY S

CONSIDERATIONS ON THE RELIABILITY OF SYSTEMS FOR REACTCR SAFETY (IN FRENCH)

COMMISSARIAT A L ENERGIE ATOMIQUE, SACLAY

40 PAGES, 16 FIGURES, PRESENTED AT ENEA COMMITTEE ON REACTOR SAFETY TECHNOLOGY MEETING OF RELIAE ILITY DF

ELECTRONIC EQUIPMENT ANO SYSTEMS FOP. NUCLEAR REACTOR SAFETY, GRUSSELS, APRIL IC67

GIVES AN OPERATIONAL SKETCH OF THE ELECTRONIC SYSTEMS FCR THE CONTROL AND SURVEILLANCE OF NUCLEAR REACTOFS AT CEA. THE DATA IS EVALUATED TO DETERMINE THE. RELIARILITY AND MAINTENANCE OF THE EQUIPMENT. TWD EXAMPLES APE GIVEN FDR DETERMINING THE EFFECT OF DIFFERENT

TECHNOLOGIES GN RELIABILITY. THE PPOVISIONAL OR. EXPERIMENTAL RELIABILITY HAS A GREAT FFFECT ON THE DEFINITION AND PEALIZATION OF MATERIALS COMPOSING THE SAFETY SYSTEMS. OPERATIONAL

RESULTS ARE NECESSARY FOR THESF. FVALUATICNS. IT IS ALSO FUNDAMENTAL NOT TO NEGLECT THE

CONDITIONS OF INSTALLATION AND OPERATION OF THIS EQUIPMENT.

\#OPERATING EXPERIENCE SUMMARY + *REACTOR SAFETY SYSTEM + *RELIAEILITY aNALYSIS +

COMPARISON, THEORY AND EXPERIENCE + FRANCE

$17-22342$

PLUM BROOK MOCK-UP REACTOR OPERATIONS REPORT FOR YEAR ENDED 31 DCT E7

NATIONAL AERONAUTICS AND SPACE ADMINISTRATION, LEWIS RESEARCH CENTER, PLUM BROOK STATION, SANDUSKY, OHIO

6 PAGES, NOV. 30, 1967 , DOCKET NO. 50-185

REPCRT COVERS POWER HISTORY, SHUTDOWNS 18 UNSCHEDULED - 5 FROM. 1 ANO C NOISE AND 3 FROM PCOR

MAGNET CONTACT), CORE-LOADING CHANGES, AND A LIST OF EXPERIMENTS.

availability - USAEC PUBLic DOCUMENT ROOM, WASHINGTON, D. C.

MOCKUP + PLUM BROOK (TR) + REACTOR, RESEARCH + FEACTOR, TEST + REPORT, OPERATIONS SUMMARY

17-22432 ALSO IN CATEGORY 15

WAK.U WI

GENERAL DYNAMICS REPORTS RADIATION OVEREXPOSURES

GFNFRAL DYNAMICS CURH. HI. WORTH, TEXAS

1 PAGE, ATOMIC ENERGY CLEAPING HOUSE 13(21), PAGE 26 (MAY 22, 1967)

(LETTER, APRIL 25) DURING AUTHORIZED USE OF BY-PRODUCT MATEPIAL, TWO GO/FORT WORTH EMPLOYEES WERE EXPOSED TO 3.2 AND 3.1 REMS THE FIRST FOUR WEEKS OF CALENDAR 1966 AT CAMP MCCOY, WISC. FILM-BADGE RESULTS WERE P.ECEIVED DEC. 9,1966 . CONTROL OF PERSCNNEL EXPOSURES BY LIMITING PDCKLT DOSIMETER TOTALS SUFFICIENTLY BELOW LIMITS TO ALLOW FOR DOSIMETER-PESPMNSF VARIATION SHOUL D PREVENT FUTURE OVEREXPOSUPE.

*MONITOR, RAOIATIJN, PERSONNEL + \#SAFETY MARGIN + BYPRODUCT MATERIAL + FAILURE, ADMINISTPATIVE CONTROL + INCIDENT, HUMAN ERROR + PERSONNEL EXPOSURE, RADIATION + RADIATION SAFETY AND CONTROL

\section{$17-22433$ \\ ALSÜ IN CATEGORY 15}

MASSE FX

MIT REPORTS ASSAY ERROR RESULTS IN CLINICAL OVEPEXPOSURE

MASSACHUSETTS INSTITUTE OF TECHNOLOGY, CAMERIDGE, MASS.

1 PAGE, ATOMIC ENERGY CLEARING HOUSE 13(21), PAGE 26 (MAY 22, 1967)

(LETTER, MAQCH 20) AN AOULT MALE WAS ADMINISTERED I OOINE TO BE EQUIVALENT TO 200 MICROCUF IES OF I-125, WELL BELOW THAT AUTHORIZED (5 MICROCURIES/KG). ANALYSIS OF THE RCUTINE BIO-SAMPLES INOICATED ADMIN ISTRATION IN EXCESS OF 200. CHECKING REVEALEO THAT A FACTOR-OF-TEN ASSAY ERROR HAD BEEN MADE BY THE PHARMACEUTICAL COMPANY. METHIMAZOLE WAS GIVEN FOR EIGHT DAYS AFTER IODINE TO INCREASE TURNOVER, CALCULATEO DOSE IS 50 RADS BEFORE METHIMAZOLE AND IOC RAOS THEREAFTER TO INFINITY. WE NORMALLY DOUBLE-CHECK MATERIAL BUT NOW WILL PERFORM ROUTINE GROSS ASSAY ON AL.I. SUCH INCOMING MATERIAL.

FA ILURE, AOMINISTRATIVE CONTRGL + INCIDENT, HUMAN ERROF + IODINE + PERSONNEL EXPOSURE, RADIATION + RAD IOLOGY 
OPERATIONAL CATEGQRY 17 SAFETY ANO EXPERIENCE

\author{
$17-22434$ \\ MALSON HA \\ ALSO IN CATEGORY 15 \\ MONSANTO REPORTS THREE EXPOSED TO AIRBORNE PU-23\& \\ MONSANTC RESEARCH CORP., DAYTON, OHIO \\ 1 DAGE, ATDMIC ENERGY CLEARING HOUSE $13(21)$, PAGE 27 (MAY 22, 1967)
}

(LETTER, APRIL 7) ON FEB. 13, 1957, HIGH CONCENTFATIONS OF AIFBGRNE PU-239 WẼE QISCOVEPED IN $\triangle$ GLOVE-BOX AFEA. THE INDIVIDUALS WERE ASSIGNED MAXIMUM EXPOSURE PERIOOS DF 1 HF, 1 HR, $\triangle N D$ 15 MIN, RESDECTIVELY, TO A MAXIMUM OF $1.01 \times 101-8 T H$ ) MICRCCURIE/CC. (CAUSE) FAILURE OF GLOVES TO NITHSTAND DELETERIOUS EFFECTS OF PU-238. DIFFERENT TYPE OF GLOVES AND MORE

FQEQUENT MONITORING WILL YL CURHECTIVE STEPS. REPORT IS LATE BECAUSE OF A MATHEMATICAL ERT:OR IN CONSICERING EXPOSURE TIME VS WEEKLY MPC FOR INSOLUBLE PU-23? IN AIR.

\#FAILURE, CCMPONENT + FGLOVE BOX + INHALATION + PERSONNEL EXPOSURE, QADIATION + PLUTCNIUM

1.7-22435 ALSC IN CATEGQPY 15

NFS CITED COR NON-CONDLIANCE WITH IC CER 20

NUCLEAR EUEL SEUVICES, INC., WHEATON, MD.

2 PAGES, ATDMIC EINEDGY CLEARING HOUSE $13 i 21$ ), PAGES 27-2.8 (MAY 22, 1967)

(LETTCR, APRIL 2E) BASFO ON INSPECTIONS JANUAPY-MARCH 19E7, CITATION WAS ISSUED. (1) STACK MONITORING WAS INOPERATIVE DURING FIRST HOUR OF DEC. DISSOLUTICNS DPERATIONS. CCORS TO HIGH RAOIATION AREAS WERE NOT LOCKEO. (12) MAINTENANCE WORKEFS WERF NOT SUPPLIED DERSCENEL MONITORING TO OETERMINE RADIATION DOSE TC HANDS AND FOREARIAS. (3) VAPIOUS WORKSPS WERE INGT DDEQUATELY INSTRUCTEO IN RADIATION SAFETY PROBLEMS AND TECHNIQUES. (4) SURVEYS VEERE NDT PEREDRMED WHEN IT WAS NECESSARY TC FVACUATE THE LAUNDRY BECAUSE GF THE FIXED AIP-SAMPLER PEADING.

FUEL REPROCESSING + INSPECTION AND COMPLIANCE + MONITOR, RADIATION, PEFSONNEL + MONITOR, RAOIATION, STACK + NES + STAFFING, TRAINING, QUALIFICATION + SURVEY, GENERAL

$17-22436 \quad \triangle L S O$ IN CATEGORY 13

NUMEC CITEO FOE NOV-COMELIANCE

NUCLEAR MATERIALS ANC EGUIPMFNT CORE., APQLLO, OA.

3 PAGES, ATDMIC ENERGY CLEAR.ING HOUSE 1?121), PAGES 28-30 (MAY 22, 196.7)

(LETTER, MARCH 24 I LICENSE SNM-L14 (NCV. 30,1966 , EXPLOSION) THE HEAT-KILL OF EXCESS HZO2 HAD NOT BEEV REVIENED EY THE SAFETY COMMITTEE, AND THE PLUTONIUM CONTENT WAS $10 X$

PERMISSIBLF. \#\#LICENSE 37-445s- I JAN. 14, IS67, IR-193 FELEASE) MATERIALS WEFE NOT UNCER THE SPECIEIE? SUPEPVISORS. TECHNICIANS DID NOT SURVEY THEMSLLVIS, NOR WAS THE MCNITORING INSTRUMENTATION R.ORKING PROPERLY. INDIVIDUAL HAO NOT EEEN $\triangle O E O U A T E L Y$ INSTRUCTED IN RADIATIDN-SAFETY ORECATIONS. * *SINCE EARLY 19E6, DEF ICISNCISS HAVE RECURRED, AND THE NUMBED. IS INCREASING. THIS APPEARS TO INDICATE ABSENCE OF EFFECTIVE MANAGEMENT CONTROLS TO ENSURE COMPLIANCE WITH SAFETY PRDCERURES.

* EXPLJSIDN + FAILURE, AUMINISTRATIVE CONTPGL + HOT CELL + INCIDENT, GENERAL + INSPECTIGN ANO COMPLIANCE + IRIOIUM + PLUTONIUM + SPECIAL VUCLEAD MATERIAL + STAFFING, TRAINING, QUALIFICATION

$17-22437 \quad$ ALSO IN CATEGORY IZ

NUMEC REPLIFS TI COMPLIANCE CITATION OF MAFCH 24, 1.967

NUTLEAR MATEP.IALS AVO EDUIPMENT CQRP., ADCLLC, PA.

2 PAGES, ATOMIC EVEQGY CLEARING HDUSE 13(2!), DAGES 30-31. (MAY 22,1967 )

- (LETTFP, APRIL 13) INDICATẼS PUZZLEMENT BY GENEFAL INDICTMENT OF MANAGEMENT SAFETY CQNTECLS. CACILITY IS NOT STATIC IN NATURE OF WRRK, WIIICH IS EXPANDING, AND DRAFT AND FULL EMPLOYMEINT CAUSES EMPLOYEE NIGRATION. WE ARE INCREASING THE HP STAFF, AND AN INTERNAL REPORT FORM FOR DEFICIENCY CDRFECTION HAS SIEN ESTAELISHED. THE APOLLO PLANT HAS TWICE AS MANY EMPLOYEES, ANO WE INCDEASED THE STAFF BY 107 IN 1966. TO MAINTAIN THIS NUMESR, W:E HIRED AND TPDINED E34 PEIPL

\# STAFFING, TFAINING, QUALIFICATION + FAILURF, AOMINISTRATIVE CGNTGOL + INSPECTION AND CCMPLIANCE + RADIATION SAFETY ANO CONTROL

17-2243.9 ALSO IN CATEGOTRY 13

PUECHL KMI

NUCLEAR MATERIALS AND EQUIPMENT COQP., $\triangle P C L L O, P A$.

2 PAGES, ATOMIC ENERGY CLEALING HOUSE 13(2!), halgES 31-32 (NAY 22, 1967)

(LETTER, MAY 1(1) THPEE TECHNICIANS WERE EXPOSED CN APRIL 17 (EB.2, 63 , AND 68 MPC-HR) BFCAUSE OE A PUNCTURED GLDVE-ROX GLQVE. SUFVEY AT THE TIME REVEALED A COVERALL SLEEVE CONTAMINATED TO bi, OOO CHM IN SPOTS.

*INHALATION + CONTAMINATION + GLOVE BRX + INCIDFNT, EQUIPMENT + PERSONNEL CXPGSURE, PAEIATION + PLUTONIUM 
$17-2 ? 447$

RARKLEY HB + ROBIVSON RA + SCHUH RM

GUIDE FOR RAOIATION EFFECTS EXPERIMENTS

LEWIS RFSEARCH CENTEK

2 PAGES, NUCLEAR NEWS 1C(12), PAGES 48-49 (DECEMBER 196.7)

DESCQIBES A GUIOE, GEVELOPED BY THE STAFF $\triangle T$ PLUM BROOK, WHICH DEFINFS THE EXPER IMENT

ENVIRONMENT, AND HIW TO REOORT THE DATA TO ENSUPE AN ADEQUATE DESCRIPTION. THE GUIDE LISTS

SENSORS AND THE RANGE, PRECISION, GESERVED FAILUPES, PECULIARITIES, ANC SHGWS WHICH

ENVIRTNMENTAL PAKAMETEPS AFFECT SELFCTED PROPERTIES OF THE MATERIALS. PURPDSE OF GUIDE IS TO

HELP ENSURE THAT EXPERIYENT INFORMATION SATISFIES EXPEFIMENTERS NEEDS AND IS USEFUL TO OTHERS.

* MEASUREMENT, GENERAL + \#PROCEDURES AND MANUALS + \#RADIATION EFFECT + ENVIRONMENTAL CONDITION +

EXPERIMCNT, GFNESAL + IN PILF LOOP + INSTRUMENTATION, GFNERAL + PLUM EROOK (TRI + REACTOR, TEST

$17-22456$ ALSO IN CATEGOPYY

EBR I I MËASUREMFNTS OF PROMPT PDWER COEFFICIENT FOILED

APGCNNE NATIONAL LAB., LRGONNE, ILL.

ANL-7399+.7 DAGES, E FIGURES, 2 TL3LES, PAGE $48-54$ OF ARGONNE NATIONAL LABORATGRY. REACTOR CEVELOPMENT PROGRAM PRTGRESS REPORT, NOVEMBER 1967

TRANSFER FUNCTIONS WEPE MEASUPED. THE WGRTH OF THE ROD USED IN ROD-DROP EXPER IMENTS CHANGES A3OVE THE O.5-NW CALIBKATION LEVEL. DURING THE DROPPING OF THE ROD, IT SEEMS THAT RCD WORTH. INCREASES ENOUGH TO CANCEL THE EFFECT OF 'FROMPT NEGATIVE FEECBACK FOR O.? SEC. TOTAL

FEEDBACK IS ARDUT O.33 CENT. REACTIVITY DIFFERENCES BETWEEN FULL-POWER FLOW AN:

RERUCED-PUNER FLOW CONDITIONS SEEM TO BE STEADILY INCREASING WITH FUEL BUPNUP.

AVAILABILITY - CLEARINGHOUSE FOR FEDEDAL SCIENTIFIC AND TECHNICAL INFORMATION, SPRINGFIELO, VIRGINIA, $\$ 3.00$ COPY, \$0.65 YICQCEICHE

\#CONTROL ROD NORTH + \#PGWER CDEFFICIFNT + \#TEST, PHYSICS + CONTROL ROD CALIBRATION + EBR I ANO 2 (RE) +

FUEL BURNUP + ₹EACTCR, LMCR + REPORT, OPERATIONS ANALYSIS + RESPONSE TIME + TRANSFER FUNCTION

17-22457 ALSO IN CATEGORY O

EgR 2 STEAM GENERATDF. LEVEL CONTROLLER. MALFUNCTIDN

ARGON:VE NATIONAL LAB., ARGONNE, ILL.

ANL-7359+. 1 PAGE, PAGE S4 OF ARGONNE NATIGNAL LABORATORY. REACTGR OEVELOPMENT PROGRAM PROGRESS REPORT, NOVEMGER ISS7, DECEMSEF. 1 CS?

ON THE NQV. 12, 19E7, STARTUP, AT $20 \mathrm{MW}$ THE PRIMARY BULK-SODIUM TEMPERATURE BEGAN INCREASING AIVD COULD VITT EE CONTROLLED $5 Y$ ADJLSTING SECONDARY FLOW. A MALFUNCTICN OF THE STEAM-DRUM WATER-LEVEL CGNTROLLER/ALARM ALLOWED THE DRUM TO BOIL DRY."

AVAILASILITY - CLEARIMGHOUSE FOR EECERAL SCIENTIFIC AND TECHNICAL INFORMATION, SFRINGFIFLO, VIRGINIA, $\$ 3.00$ COPY, $\$ 0.65$ YICROF ICHE

*CONTROLLER + *FAILUPE, COMPUNENT + \#INSTRUMENTATION, LIOUID LEVEL DETECTION + EBR I AND 2 (RE) + INTIDFNT, EQUIPMENT + INDEPENDCNCE + PFACTOF, LMCR + STEAM GENERATCR

$17-22460$

IZ $\triangle T T \mathrm{~T} A+\mathrm{SCOBIE} J$

CHARACTER ISTICS OF THE UTP $\rightarrow$ I CO REACTOP

THE SCDTTISH RFSEARCH REACTOK CENTRE, EAST KILBRIDE

11 PAGES, 14 FIGURES, 3 TABLES, 7 REFFPENCES, JOURNAL OF THE BRITISH NUCLEAR ENERGY SOCIETY G( 4 ), PAGE 343-353, 1OCTOBE2 1067

102-KW MOCIFIER ARGONALT USING ? PARALLEL FLAT-SIDED TANKS $(58 \times 20 \times 6$ IN.), 18 IN. APART IN $\triangle$ GRAPHITE 3LOCK $(4 \times 4 \times 5$ FT). CRITICAL MASS AT STARTUF WAS LEAST 50 G MORE THAN COULO EE LOJADED, POSSIBLY DUE TO (A) FUEL-CENSITY UNCERTAINITY, (B) USE CF BRITISH GRAPHITE, (C) HIGHCR MAGNESIUM CONTENT IN ALUMINUM STRUCTURE THAN SPECIFIED, (D) LARGER CONTROL RODS IN THE CORE, AND WITHMKAWN.FDD HAS CONSI DERABLE FEACTIVITY EFFECT. DECAY-HEAT EXPERIMENTS - 2 HR AT $100^{\circ} \mathrm{KW}$, FOLLOWED SY SCKAM AND WATEK DUMP SHCWED FUEL ELEMENTS HEATED FROM 30 C TO A PEAK OF $55 C$ IN 50 YIN. PLOT I.S OISCONTINUOUS AT TWO POINTS. P.ADIATION LEVEL AT COOLANT OUMP TANK ( 10 TIMES DERMITTED LEVEL) NAS REDUCED BY USF OF A SHIELDED DELAY TANK, BUT THIS CAUSED QANDOY COOLANT LEVEL PRESSIJRE SURGES. AT LOW POWER LEVELS, SPURIOUS SIGNALS WERE PICKED UP IN THE OO-FT IONIZATION CHAMBER. LEAD.

\#REACTOR STARTUP TESTING + ACCIDENT, LOSS OF COOLANT + ARGONAUT (TNG) + OPERATING EXPERIENCE + REACTOR DESCRIPTION + FEACTOR, RESEARCH + TEST, PROOF

$17-22495 \quad$ ALSO IN CATEGORY 18

PATHFINDER CHANGE IS--STORAGE JF CORE II FUEL

USAEC, DIVISION OF REACTOR LICENSING

5 PAGES, AUGUST 9,1967 , DOCKCT 50-130, TYPE--BWK, MFG--. .C., AE--PIONEER SEPV. 
OPERATIONAL SATEGORY 17 SAFTY AND EXPERIENCE

\section{$17-22495 \Rightarrow$ CONTINUED*}

DRL ALLOWS STORAGE OF THE FUFL FOR CGRE II. SOTH ROILER ANO SUPERHEATEP ELEMENTS DRE

DIFEERENT FPOM PRESENT FUEL. STORAGE ARRAY RFSULTS IN A K-EFF LESS THAN C.E EVEN IF FLOODED.

AVAILABILITY - USAEC, PUBLIC DECUMENT ROCH, WASHINGTON, 5 . C.

*FUEL STORAGE + PATHFINDER (ISF) + REACTCP, RWR + REACTOR, INTSRNAL SUPERHEAT + REFUEL ING + SAFETY EVALUATION + TECHNICAL SPECIFICATICNS

\section{7-22497 ALSO IN CATEGORY 7}

AIP. AND GAS CLEANING FIR NUCLEAR ENERGY

NAK RIDGE NATIJNAL LABORATORY, OAK RIDGS, TENN.

THIS IS A 30 AIVUTE FILM REFERENCED ON PAEF tO OF THE USAEC IE MM FILM CATALOG FOR IS6G-67, PROCUCEO BY OAK RIDGE NATIONAL LABOFATOGY. FOR SALE GY CALVIN PRODUCTIONS, AT \$SE.23 PER PRINT, INCLUDING SHIPOING CASE

DISCUSSCS USE, OEVELCPMENT, AND MANLFACTUFE GF HIGH-EFEICIENCY FILTEPS FOR NUCLEAR $\triangle P D L I C A T I D N S$, INSPECTED BY AEC, $\triangle N D$ CURRCNT R AND D PROGRAMS IAT HARVARD, OR'VL, ANO EOGEWCOO AR SENAL). COVEQS ICDINE-COLLECTION SYSTEMS, AEROSDL REACTIONS ON FILTERS, RAFE-GAS ABSORPTICN STUDIES, ETC.

AVAILABILITY - AVAILABLE FOR LOAN (FREE) FGOM USAEC HEADQUARTERS AND FIELD LIBRARIES. CLEAREO FOR TSLEVISION

*FILTER, HIGH EFFIEIENCY + FILTER INSPECTICN + Fi AND D PROGRAM

$17-22501 \quad$ ALSO IN CATEGORY 14

HIGH ACTIVITY NASTE

ARGONNE VATI.ONAL LABCRATCPY

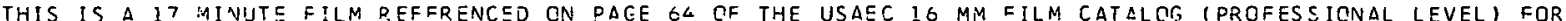
IOE6-57, ORJDUR,ED BY USAECS ARGONNE NATIONAL LLEGRATORY, FCR SALE BY BYRON MOTIGN DICTURES, IN ENGLISH, FRENCH, SPANISH, DQ RUSSIAV, AT \$36.75 PFQ PRINT, INCLUDING SHIPPING CASE, F.O.E. WASHINGTON, D.C., IN COLOR

A 17-MIN COLTR FILM RY ARTCINN NATIONAL LAR. THIS TECHNICAL FILM DESCRIBES METHOCS FOP SOL IDIFVING HIGH-ACTIVITY WASTES AND REDUCING THEIR VTLUME BY A FACTOR OF 1 C. PFOCESS INCLUDES DOT AND SDRAY CALCINATION, DND THE FLUIDIZED-EED CALCINEP WITH A IOO-LITER, HRR CAPACITY. USE T.F SALT MINES FOR WOSTE DISPOSAL IS DISCUSSEO.

AVAILAGILITV - ENGLISH VERSION AVAILABLE FCR LOAN (FPEF) FROM USAEC HEADQUARTERS AND FISLO LIBRARIES, CLEAP EL FOR TELEVISISN

\# NASTE DISPOSAL, SALT + \#WASTE TREATMENT, LIQUIC + WASTE TPEATMENT, SQLID

\section{$17-22504$}

RADIOLOGICAL ASSISTANCE

USAEC, IDAHO DPERATICNS OFFICE

THIS IS A 26.5 MINUTE FILM REFEPENCED ON PAGE 67 OF THE USAEC 16 MM C1LM CATALCG FOR 1SGG-67, PRODUCEO FOR THE USAEC BY J.- L. FEIEPRACHER WITH THE TECHNICAL ASSISTANCE OF THE AECS DIVISION DF CPERATIONAL SAFETY ANO $\triangle E C S$ IDAHO GPERATIONS DFFICE.

$\triangle 26.5-M I N$ AEC-PRQDUCFO MIVIE EXPLAINING THE AEC. RADIOLOGICAL ASSISTANCE PROGRAM. TFAMS STATIONED AROUIND THE COUNTRY ARE AVAILAPLE WHEN THERE IS DANGER TO PUBLIC SAFFTY. TO PRGVIDE TECHNICAL ASSISTANCE, FILM SHOWS THFEE MOCK INCIDENTS ILOSS GF A 5-CUPIE CD RADIOCFAPHIC SOUYCE, PU VAPIJK RLLEASE AT A LAB. AND FIRE $\triangle T$ A URANIUM PROCESSING PLANT AND THE RADIOLOGICAL ASSISTANCE TEAMS ACTIONS. WHILE FILM IS NOT TECHNICALLY PERFECT ISOME MONITORING SLOPOY, ETC.), FILM SEFVES ITS PUPOOSE OF INFORMING OF THE AVAILABILITY OF THE SERVICE.

AVAILABILITY - AVAILARLE FOQ LOAN (FREE) FPOM USAEC HEADQUARTERS AND FIELO LIBPARIES, CLEARED FOR TELEVISIUN

* Fadiological asSistanc.e + STAFFing, train!ng, oualieication

17-22509 $\triangle L S C$ IN CATEGORY 5

SPFRT OESTRUCT IVE TEST, PART-I

PHILLIOS PETROLEUIA COMPANY

THIS IS 15 MINUTE FILM QEFERENCED ON PACE GO CF THE USAEC IE MM FILM CATALOG (PROFESSICNAL LEVEL),

1965-67, PRODUCED 3Y OHILLIDS PETROLEUM COMPANY AS CONTRACTOR THE USAEC AT THE NATIONAL REACTOE TESTING

STATION, IOAHO, FOR SALF BY TELEFILM INOUSTRIES, AT \$75.32 PER PRINT, INCLUDING SHIPPING CASE, F.O.B.

HOLLYWOOD, CALIFONNIA

15-IIIN COLOR MOVIE. TECHNICAL FILM DOCIJMENTS THE DESTRUCTIVE TEST PROGRAM OF A HIGHLY ENFICHEO AI PLATE-TYPE CORE AT NRTS, SHOWING SPECIAL FACILITY MODIFICATIONS, TRANSIENT TESTING HITH LIMITED CORE DAMAFE. SHOWS VIEWS OF EAILED, EOHEC, AND MELTED DLATES. SLJW-MOTION STUDIES SHOW FINAL CORE-DESTPUCTION TEST.

AVAILABILITY - AVAILAGLE FOR LCAN (FREE) FPIN USAEC HEADQUARTERS ANO FIELD LIBRARIES, NCT CLEAREO FOR 
PAGE 310

CATESORY 17
UPERATIONAL SAFETY ANO EXPERIENCE

$17-22509$ *CONTINUED*

TELEVISION

\#ACCIDENT, REACTIVITY + \#CORE, PLATE TYPE + \#TEST, CESTRUCTIVE + EXCURSION, LARGE + FAILURE, CLADDING + FAILURE, FUEL ELEMENT + FUEL ELEMENT BOWING + FUEL MELTDONN + INCIOENT, GENERAL + REACTQR TRANSIENT + REACTOR, SAFETY RESEARCH + SPERT 1 (S-RE)

17-22518 ALSO IN CATEGDRY 15

FREDERICKSON RL

ABEOTT $L A B$ REPORTS EXCESSIVE IODINE AIR CONCENTRATIONS

ABBOTT LABOPATOR IES, NOK TH CHICAGS, ILL.

1 PAGE, ATOMIC ENERGY CLEAFING HOUSE l $4(4)$, PAGE 19 (JANUARY 22,1968 )

(LETTER, DECEMEER 4.1 ROUTINE THYROID CÖUNTING CN NOVEMBER, 6 P.EVEALED A THYROID RURDEN $113 \%$ OF PERMISSIBLE. THE INDIVIDUAL WORKS IN THE FADIOPHARMACEUTICAL FILLING GROUP, NOT WHERE VOLATILE I-131 IS ORDINARILY DRESENT. WE HAVE NO-AIP-SAMPLING RESULTS IN HIS AREA FOR THE PER IOD IN OSJESTION. INVESTIGATION FAILED TO DISCQVER A REASON FOR THE THYROID ACTIVITY MEASURED.

AIRBORNE RELEASE + FISSION PRODUCT, IOOINE + SURVEILLANCE PROGFAM

17-22510. $\quad$ ALSO IN CATEGORY 15

ATOMICS INTERNATIONAL CITED FOR NON-COMPLIANCE

ATOMICS INTERNATIONAL, CANOGA PARK, CALI FORNIA

1 PAGE, ATOMIC ENFRGY CLEARING HOUSE 14(4), PAGE 20 (JANUARY 22,1969 )

(LETTER, DECEMRER 27.) A SEPT. 28-29, 1967, INVESTIGATION OF 1966 AND 1967 EXPOSURES SHOWED THE FOLLOWING - SURVEYS WERE INADEQUATE TC DETERMINE AIRBORNE CONCENTRATICNS OF UFANIUM. THE U-234 SOLUBLE LIMITS WERE USED RATHER THAN THE LIMITS FOR INSOLUBLE U-234. GENERAL POOM-AIR SAMPLES USED TO EVALUATE EXPOSURES WERE A FACTOR OF TEN LESS THAN THE BREATHING-ZONE SAMPLES. TIMELY REPORTS TO AEC WERE NOT FILED.

AIRBORNE RELEASE + INSPECTION ANO COMPLIANCE + MONITOR, RADIATION, AIR + SAMPL ING + SUFVEILLANCE PFOGRAM

17-22520 ALSE IN CATEGORY 15

BIG ROCK POINT NON-COMPLIANCE CITATION

CONSUMERS POWER COMPANY, JACKSDN, MICHIGAN

3 PAGES, $\triangle$ TOMIC ENERGY CLEARING HOUSE 14(4), PAGES 20-22 (JANUARY 22, 1968), 00CKET 50-155, TYPE--8WR,

$M F G--G . E ., A E--B E C H T \subseteq L$

ILETTER, NOVEMEER 28. I CITATION FQR INADEOUATE SUPVEY TO EVALUATE RADIATICN HAZAFDS IN THE SEPT. $12,1.967$, TEMPORARY REPAIR OF A RUPTURED DIAPHRAGM IN THE AIR-EJECTOR SYSTEM. PROCEDURES DO NOT CONTAIN ADEQUATE INSTRUCTION ON EVALUATION OF RADIATION HAZARDS IN HIGH RADIATION AREAS.' (REPLY, DEC. 22.) 'CASE WAS EXCEPTIDNAL, OUE TO FIRST-TIME APPEARANCE OF A HIGH JETA/GAMMA PATIO I RATHER THAN 2 OF 3) IN PROCESS STEAM AND TO SOORADIC PUFFING OF THE

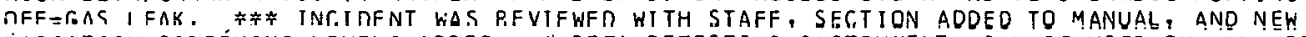
RADIATION-SCREENING LEVELS ADDEO. A BETA-DETECTING INSTRUMENT WILL BE USED ON ALL WOPK IN MORE THAN I REMIHR. NEW SURVEY INSIRUMENTS ANU CILIBKAIION SOURCE WERE ORDERED.

*MAINTENANCE AND REPAIR + \#PEFSONNEL EXPOSURE, RADIATION + \#REACTOR DFFGAS + BETA EMITTER * BIG ROCK POINT (SWR) + FAILURE, ADMINISTKATIVE CONTROL + FAILURE, OPERATOR ERROR \&

INSPECTION AND COMPLIANCE + MONITOR, RODIATION, PERSONNEL + PROCECURES AND MANUALS + REACTOR, BWR + SURVEY, RADIATION, GENERAL

$17-22521 \quad \triangle L S O$ IN CATEGORY 13

MAL INCKRODT REPLIES TO NOV. 30, 1967 NON-COMPLIANCE CITATION

MALL INCKRODT CHEMICAL WORKS, ST. LOUIS, MO.

4 PAGES, ATOMIC ENERGY CLEAR. ING HOUSE 14(4), PAGES 22-25 (JANUARY 22, 1968)

(LETTER, DEC. 20.) ACTION TAKEN IN PRODUCTION OF I-131 OIACNOSTIC CAPSULES INCLUDES MORNING MONITOR ING OF HORKER THYROID AND IMMEOIATE INVESTIGATICN, USE OF OISPOSABLE GLOVES, GENERAL HP ON-THE-JOB TRAINING OF WORKERS, A DAILY SURVEY OF REFUSE CONTAINERS. COMPILATION OF EVIDENCE REVEALS THAT THE PROBLEM IS (QUOTE) PRINCIPALLY ONE OF IMPROVING WORKING HAEITS ANC ATTITUDES RATHER THAN EXPOSURES OF PERSONNEL TO HIGH AIREORNE RADIOACTIVITY CONCENTRATION (UNQUOTE).

* RADIATION SAFETY AND CONTRDL + ADMINISTRATIVE CONTROL + FAILURE, ADMINISTRATIVE CONTRGL +

FISSION PRODUCT, IOCINE + INHALATION + INSPECTION AND COMPLIANCE + STAFFING, TRAINING, QUALIFICATION

$17-22522$

NUMEC REPORTS AMPUTATION IN A GLOVE BOX

NUCLEAR MATERIALS AND EQUIPMENT CORP., APOLLO, PA.

1 PAGE, ATOMIC ENERGY CLEARING HOUSE 1414), PAGE 25 (JANUARY 22, 1968)

(TWX, OEC. 15.) ON DEC. 14, 1967, A TECHNICIAN OPERAT!NG A MILLING MACHINE IN A GLOVE BOX 


\section{CPEPATIONAL COTEGQRY 17 SAFETY}

17-22522 \#CONTINUED*

AMPUTATCD HIS HANO. HE NAS TAKEN TO A PITTSBUFGH HOSPITAL $\triangle N D$ THE HAND GEAFTED BACK CN THE AEM. ESTIMATES INOICATE LESS THAN 10 MICROCURIES OF INSOLUELE AM/PU IN THE NCUNC. RFMOTS MACHINERY JPEPATIONS APE SHUT DOWN PENDING REVIEN.

\#GLOVE BOX + \#INCIDENT, NONREACTOR + AMERICIUM + CCNTAMINATION + PLUTONIUIA + RAOIATION INJUPY, TREATMENT OF

$17-22523 \quad$ LLSO IN CATEGORY 12

WDLTER $=5$

ELK RIVEF CITED FOO NDN-CCMOLIANCE

RURAL COJPERATIVE POHER ASSOCIATION, ELK RIVER, MINN.

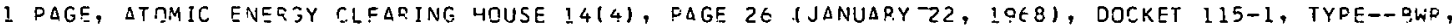
$M F G--A . C ., \triangle E--S G T+$ LUNDY

(LETTER, DEC. 4.) THREE ITEMS CITEO AFTER AN OCT. 2-3 INSPECTICN OF JULY 25 ACTIVITY - (I) E:AFRGENCY CORE-COOL ING AND PRIMARY MAKEUP SYSTEM WERE IN CAPABLE OF INJECTING WATER INTO THE PRIMARY CCOLING 5YSTEM DURING $75 \%$ POWER DPERATIDN. (2) FCRESEEARLE PLANT ÉMEPGENCY NOT COVERER SY OETLILED WRITTEN PROCEDURES, ESPECIALLY SINCE THIS TYPE OF SITUATION HAD HAPPENED GEFOPE. (?) TYGON TUEING INAS SURSTITUTED FOR CAPSON STEEL IN PRESSURE-RELIEF PIPIIVG. \#\# $\triangle L S O$ NOTES DOWER PAISED TO 1 OCF TC DAISE THE APPARENI LIHE WATER LEVEL AFTER A LON-WATER-LEVEL ALARM.

\#CCOLANT OUPIFICATIDN SYSTEM + \#EMEPGENCY PDGCEDURE + \#MAINTENANCE AND REPAIR + CDRE REFLODOINIR SYSTCIA + FAILURE, ADIAINISTRATIVE CONTROL + INSOCCTION AND COMPLIANCE + LEAK + PRESSURE PELIEF +

TECHNICAL SPECIFICATIONS

$17-22524$

NUMEC REPORTS $\triangle I R$ EXPOSURE USING

NUCLEAR MATERIALS ANO EGUIDMENT CORP. APOLLO, PA.

2 DAGES, ATOMIC ENERGY CLEARING HOUSE 14141, PAGES 25-26 IJANUARY 22 , 1063)

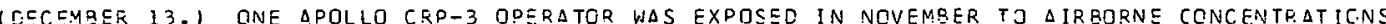
OF ENRICHED JRANIUM EXCEEDIVG 40 MDC-HD/WEEK. THE DISSOLVING OPERATIONS WILL BE REVISED, AND FUME HOODS WILL PE REPLACED WITH GLGVE BMXES.

* INHALATION + *PERSONNEL EXPCSUGE, RADIATION + GLOVE ECX + UP.ANIUM-235

$17-22525$

NUMEC REPOPTS $\triangle$ IRBORNE RADIOACTIVITY

NUCLEAR, MATFR.IALS ANE. EQUIPMENT CORP., APQLLO, PA.

1 PAGE, ATOMIC ENERFY CLEARING HOUSF I 4141 , PAGE 26 (JANUARY 22,1058 )

(LETTER, NOV. 13.) TWO CP-1 OPERATCRS WEPE EXPOSTO TO AIR CONCENTRATIONS EXCEEDING 40 MPC-HR/WEEK NHILE LOADING A LOW-ENRICHMENT HAMMEDIMILL WITHOUT LOEQUATE VENT ILAT ICN. LDCAL EXHAUST IS BEIVG DESIGNED. \# APPARENTLY TWO C:THERS WERE EXOOSED (AS SHCWN EY ROUTINE BIOASSAY) NHILE CLEANING UP AFTER A COOLING-WATER LINE BRGKE IN A CONTAMINATED HOOO AND LEAKED DN THE FLCDR. FIXED AIR SAMPLERS SHOWED NO DETECTASLE ACTIVITY. ANALYTICAL WORKERS WERE FEINSTPUCTED TO CALL HEALTH AND SAFETY REFGRE CLEANING UP SPILLS.

\#DECONTAMINATIQN + \#INHALATION + \#PERSONNEL EXPCSURE, RADIATION + \#VENTILATION SYSTEM + FAILURE, CPERATOP EREOR

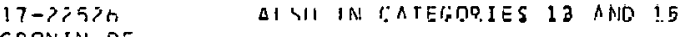

CRONIN DF

UNITED NUCLEAR PREPORTS CVEREXPOSURE TO AIPRORNE DCTIVITY

UNITED NUCLEAR CDPD., NISW HAVEN, CONN.

1 PAGE, ATOMIC ENERĞY CLEARING HOUSE $14(4)$, FAGF 27 (JANUARY 22 , IgG8)

(1ETTER, OFC. 13.) THREF RECEIVED 1.5 TIMES MAXIMUM $\triangle L L O W \triangle P L E$ WEEKLY EXPOSURE, IN COUR HCLRS, TO AIRBORNE ALPHA EMITTER OUKING CLEANUD OPERATIONS. MSA COMFO QESPIFATCPS WITH TYPE-II ULTRAFILTERS WERE WORN. NO PROTECTION FACTOR ASSUMEC. \#\# INCREASER HP COVERAGE $\triangle N O$ EXPOSURE CONTFOL DURING NONROUTINE OPERATIONS WILL BE PROVIDED. APPLICATION WAS MAOE FCF USE OF A RESPIRATDRY DPOTECTION FACTOR.

\#ULCLNIAMINAIIUN + \#INHALAIIUN + *PERSONNEL EXPOSURF, PADIATICN + LLPHA EMITTER + FILTEF EFFICIENCY + FILTER, GAS MASK + DCPSONNEL PROTECTIVE OEVICE

$17-225 ? 7$

BURTSAVAGE EM

ALSO IN CATEGCRY 15

U.S. RADIUM ASKS CLARIFICATION DF BREATHING ZONE SAMHLES

U.S. RADIUH CORD., 3LOOMSBURG, DA.

1 PAGE, ATOMIC ENERGY CLEARING HOUSE 14(4), PAGE 27 (JANUARY 22, 1CE

(LETTER, NOV. 28.$)$ REPORTS EXCESSIVE CONCENTPATIONS OF AIPROPNE AMERICIUM DURING WEEK CF SEPT. 4, 1067. THIS WAS NOT RCPORTED GN OCT. IE BECAUSE WE INTERPRETEO 10 CFR 20.103 TI MEAN 
$17-22527$ \#CONT INUED* THAT RUOM-AIR CCNCENTRATIONS APPLY TO ANY PERSONNEL NOT SAMPLED IN THEIR EREATHING ZGNES. HONEVEP., $\triangle L L$ PERSONS WERE BZ SAMPLED SIMULTANEOUSLY, WHICH WAS CONSIOERED MORE VALID THAN ROOM-AIR SAMPLES, AND THUS 5 PFRSON'S WERE NOT REPORTFO, WHILE 4 WERE REPORTED GN THE BASIS OF THEID. B-Z SAMPLES. PLEASE CLARIFY THIS INTERPRETATION.

* INHALATION + \#PERSONNEL PQOTECTIVE DEVICE + \#SAMPLING + AMERICIUM + INSPECTION AND COMPLIANCE + PERSSONNEL EXPOSURE, RADIATION + RACIATION SAFETY AND CONTROL + REGULATION, AEC

$17-225 ? 8$

A REVIFW OF RECENT CRITICALITY AND FEACTOR. INCIDENTS AT USAEC INSTALLATIONS

DIVISION OF OPERATIONAL SAFETY, USAEC

CONF-660412+. 21 OAGES, 22 REFERENCES, 4 TABLES, PRESENTEE AT SYMPOSIUM OF ACCIDENTAL IRRAOIATION AT PLACE OF WORK, NICE, FRANCE, $\triangle P R I L 25-2 \subseteq, 1966$

TABULATES 60 INCIDENTS $(1961$ THFOUGH 65), MANY NGT AT REACTURS RUT OF MORE IMPDRTANCE. DISCUSSES THE LESSONS TO BE LEARNED FRQM THEIR RECOVERY OPERATIGNS. (SLI) - IF VICTIM SURVIVES THE DOSE, THE RESCUERS WILL. CONVENTIONAL AMBULANCES WITH DUST-TIGHT DRIVERS COMPARTMENTS AND PPRVISION FOR SHIELOING ARE ADEQUATE. HOSPITAL STAFF TRAINED IN HANDLING CONTAMINATED VICTIMS IS IMPORTANT. EMERGENCY-DCSE CRITERIA AND MCNITORS ARE NEECED.

AVAILABILITY - FPED SHON, USAEC, DIVISIDN OF OPERATIONAL SAFETY, WASHINGTON, D. C.

* INCIDENT, RECOVERY FROM + EMERGENCY PROCEDURE + INCIDENT COMPILATION + INCIOENT, SL I + REPORT, CPERATIONS ANALYSIS

$17-22552$

PEACH BOTTOM I MONTHLY OPEPATIONS REPORT NO. 21

PHILADELPHIA ELECTRIC COMPANY

14 PAGES, NOVEMBER 1967 , DOCKET 5D-171, TYFE--HTGR, MFG.--G.4., AE--BECHTEL

A TWO-DAY OUTAGE WAS RFQUIRED TO REPAIR A LEAKING FLANGE ON THE FEEDWATER LINE OUTSIDE THE CGINTAINMENT. BUILDUP OF PQA- 88 ON THE ABSOLUTE FILTERS WAS TPACED TC A LEAKING BELLDWS SEAL ASSEMBLY ON THE B TRANSFER COMPRFSSOR DISCHARGE VALVE. IMPURITIES IN THE HELIUM LEAKING FROM THE SELLOWS INCLUDED KR-8E, WHICH DECAYS TO RB-88. OTHER. MAINTENAINCE REPORTED INCLUDING CLEAVING OF PLASTIC COVERS OF CONSOLE. PERIOO METERS WITH ANTI-STATIC SOLUTION TO FREE INDICATOR NEECLES, WHICH WERE AFFECTED BY STATIC CHARGES ON THE COVERS.

AVAILABILITY - USAEC PUELIC DOCUMENT RCOM, WASHINGTON, D. C.

\#FAILURE, EQUIPMENT + FLANGE + INSTRUMENTATION, ABNORMAL INDICATION + LEAK + MAINTFNANCE AND REPAIR + PFACH SOTTOM - (HTGR) + FERIOD METER + REACTOR, HTGR + REPORT, OPERATIONS + VALVE

$17-22553$

PEACH BUTTOM 1 - DESCFIPTION OF STEAM GENFRATOR SHELL COOLING SYSTEMS

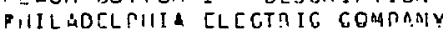

21. PAGES, 5 FIGUFES, DECEMBFR 1967, DOCKET 50-171, TYPE--HTGR, MFG.--G.., AE--BECHTEL

DESCRIBES THE SYSTEM INSTALLEU TO COOL THE LOWER HEAD OF THE STEAM GENCRATOR. SYSTEM CIRCULATES RODM ATMOSPHERE PAST HEAO AND COOLS IT. HIGH CUTLET HELIUM TEMPERATURES WERE DESERVED.AFTER REPLACEMENT OF THE SS SUPERHEATER TUBES WITH INCOLOY-800. SEVERAL BAFFLE MOOIFICATIONS WEPE MADE UNTIL THE TEMPERATURES WERE REOUCED TO DESIGN VALUES, BUT HIGH SHELL TEMPERATURES CIN THE BOTTOM HEAD PERSISTED. THE CAUSE OF THE HIGH TEMPERATURES ON THE LORER HEAD HAS NOT FFEN DETERMINED, AND THIS COOLING SYSTEM IS TEMPORARY:

aVAILABILITY - uSAEC OUBLIC DOCUMENT RCOM, WASHINGTON, D. C.

\#AUXILIARY COOLING SYSTEM + \#MODIFICATION, SYSTEM OR EQUIPMFNT + \#STFAM GENERATOR + FAILURE, DESIGN ERROR + FLOW DISTRIBUTION + HEAT TRANSFER + PEACH BOTTOM I (HTGR) + FEACTOF, HTGR

$17-22579$

IRL REPORTS CORROSIVE FAILURE OF PRIMARY PIPI.NG

INOUSTRI $\triangle L$ REACTOR LAEORATOR IES, INC.

2 PAGES, JANUARY 11 , 1968 , DOCKET 50-17

WATER LEAKAGE GIRING a DECEMBER 28 PRESSURE TEST OF THE HOLOUP TANK LED TO DISCOVERY OF EXTENSIVE PITTING OF THE 10-IN. -DIAM ALUMINUM PPIMARY-COOLANT LINES, AND 3-TO 4-IN. CEM INERALIZER LINES. PIPE WILL RE REPLACED WITH 304 SCHED-1C STAINLESS STEEL, WITH INTERVENING DIELECTPIC DEVICES AT FLANGES TC ALUMINUM.

* ALUMINUM + \#CORROSICIN + \#FAILURF, PIPF + \#MAIN COOLING SYSTEM + MAINTENANCE AND REPAIP + REACTOR, RESEARCH + STEEL, STAINLESS

$17-22580$

RADIDACTIVE INSPECTION OF AGP. 
OPFRATIONAL CATEGORY 177 SAFTY

17-22580 *CONTINUEC*
1 PAGS, ELEC. REVIEW 17\%, PAGE 8Q9 (DECEMBER 9, 1SE6)

ENG INEERS HAVE SAFELY ENTERED THE AGP DURING AN ANNUAL INSPECTION, DEMONSTRATING THAT IT IS SAFE TO CARRY OUT MAINTENANCE AND INSPECTION INSIDE THE PRESSURE VESSEL DESPITE THE PRESENCE OF $\triangle$ FULL CHARGE OF PADIOACTIVE FUEL IN THE CORE. REACTOR WAS BUILT WITH AN INTERNAL SHIELD TO REOUCE NUCLEAR RADIATION TO A LEVEL THAT WOULD ALLOW ENTRY FOR INSPECTION EVEN WITH THE REACTOR FULLY FUELED, ENSURING THAT REGULAR INTERNAL INSPECTION AND MAINTENANCE CAN BE UNDERTAKEN.

\# EXAMINATION + \#PRESSURE VESSEL + OPERATING EXPEPIENCE SUMMARY + RFAC.TMR, GCR + WAGR IGCF)

$17-22582$

ROCERICK C

R AND D FOR NUCLEAR PLANTS DAVED NAY FDR SAN ONOFRE

2 PAGES, 1 FIGURE, PGWEP, $111(8)$, DAGES 1CL-105 (AUGUST 1967 )

VERY RRIEFLY REVIEWS WESTINGHOUSE-AEC JOINT PROGRAM ON CLOSED-CYCLE LARGE-REACTOP DEVELOPMENT. 2)\%-THININER SS-CLADDING OBTAINED BY SPRING CLIPS INSTEAD OF RY BRAZING THE FUEL RODS. ROD-CLUSTER CONTFOL EL.IMINATED POWER PEAKS AND SHORTENED REACTOP VESSEL. ZONED LOADING ANC CHEMICAL SHIM GEDUCED POWER PCAKING. CHECK VALVES ELIMINATED BY PUMP REDESIGN. LARGER PUMPS AND STEAM GENERATORS REDUCEN NUMEEP DF LOOPS.

R AND D PROGRA:A + REACTER, PWR + SAN ONDFPE (PWR)

$17-22621$

PEACH BOTTOM 1 QUARTEPLY PROGPESS REPORT FOR PERIOD ENOING OCTOEER $2:, 1067$

GULF GENERAL ATOMIC INCCP.POP.ATED

GA-8370+. 45 PAGES, 24 FIGURES, 5 TABLES, NOVEMBER 30, 1967

HLANT THERMAL-EFFICIENCY TESTS INDIC ATE THAT PERFORMANCE IS EXCFEDING THE PREDICTEO VALUES AT THE LOWER PQNEF LEVELS $12.5 \%$ AT $40 \%$ FULL POWFRI. OF $\triangle 20 \%$ DISCPEPANCY BETWEEN CALCULATED AND ACTUAL XENTN EQUILIBRIUM REACTIVITY WORTH, $5 \%$ IS ATTPIBUTED TO AXIAL EFFECTS. FURTHER STUOY TO EE MAQE. GEPAIRS INERE MACE TO A LEAK IN THE FEEDWATER PIFING, TO CRACKED WELDS BETWEEN 3AFFLES IN A STEAM GENERATOR, AND TO LEAKING GASKETS ON STEAM-GENERATOF DUMP VALVES. XENON BUILOUP $\triangle N D$ DECAY, TEMPFRATIJEE COEFFICIENT, ROD CALIRRATION, HUWER COEFFICIENT AND FISSION-GAS-DELEASF TESTS REPORTED.

* REACTIVITY EFFECT, aNOMAL DUS + \#TFST, PLANT rESPONSE i COMPARISON, THEORY AND EXPERIENCE + CONTROL ROD CALIBRATION + EISSION GAS RELEASE + MAINTENANCE AND REPAIR + PEACH BOTTOM 1 (HTGR) + POWER COEFFICIENT + REACTOR, HTGR + REPQFT, OPERATIONS + STEAM GENEHATOR + TEMPERATURE COEFFICIENT + THEFMAL CONSIDERATIUN + XENON

17-22775 $\triangle L S C$ INI CATEGORY 5

GRESDEN I SUPPLEMENT A TO PROPOSED CHANGE 14 - CYCLE 6 DESCRIPTIDN AND SAFETY EVALUATION REORRT COMMONWEALTH EDISON COMPANY

6 PAGES, TABLES, FIGURES, JANUAPY 17,1968 , DDCKET 50-10, TYPE--BWR, MFG.--G.E., AE--BECHTEL

ANSWERS 5 QUESTIONS (AEC LETTER OF 22 NDV. 67) ON PROPISED CHANGE 14 . QUESTION 1 COVERS EXPERIMENTAL FUEL ASSFMRLIES. QUESTION 2 - REFUELING ACCIULNT ANALYSIS - DUESTION 3 INSTRUMENTED FUEL-FLEMENT POSITIONS. OUESTION 4 - FUEL-ELEMENT RQIENTATIGN. QUESTION 5 TSC.H. - SPEC. CLAFIFICATION.

AVAILABILITY - USAEC PUBLIC DQCUMSNT ROOM, WASHINGTON, D. C.

\# $\triangle E C$ QUESTION + \#RFFHFI. ING + DQESOEN 1 (BWR) + REACTUR, BWR + TECHNICAL SPECIFICATIONS

17-22781 ALSO IN CATEGORY S

U OF ILLINOIS REPORTS INTERLOCK FAILURE ALLOWING I MPROPEP PULSE-SAFETY RDD OPERATION

NUCLEAR SNGINE ER. ING PROGRAM, UNIVERSITY OF III INOIS

1 PAGE, JAN. 4, 1968 , DOCKET NO. 5O-151

OURING A CHECK OF INTEKLUCKS, A FAILED INTERLOCK WAS DISCOVEREO WHICH ALLOWED THE PULSE-SAFETY RDD TO BE RAISED HITH THE SHIM CONTROL ROD NOT FULLY INSERTEE: AND IN THE MANUAL MODE. THE R.LLYY WAS REPLACFD. INTERLOCK WILL C.ONTINUE TO BE CHECKED ROUTINELY WITHIN TIMFS SPECIFIED BY TECHNICAI. SPECIFICATIONS.

AVAILABILITY - USAEC PUELIC DOCUMENT RIYOM, WASHINGTON, D. C.

W AILURE, COMUUNENI + \#INSTRUMENTATION, INTERLOCK + \#INSTRUMENTATION, PELAY + CONTROL ROD PROGEAM , OPERATING EXPER IENCE SUMAARY + REACTOR, FULSEU + REACTOR, RESEARCH + TECHNICAL SPECIFICATIONS + TFST, CONTROL ROD DRIVE + TRIGA (RP)

17-22782 ALSO IN CATEGJRY 6

II IF AISCONSIN RERORTS ON OPEPATION WITH NEWLY INSTALLED CORE 
$17-22782$ \#CONT INUED*

METROPOL ITAN EDISON CO.

1 PAGE, JAN. 4, 1968, DOCKET NO. 50-156

INITIAL CR ITICALITY WITH THE MODIFIED TRIGA CORE WAS REACHED ON 14 NOV. 67. THE ONLY SIGNIFICANT VARIATION IN PERFORMANCE CONCERNS THE PULSING PERFORMANCE OF THE CORE. CORE IS DIFFERENT FROM PROTOTYPE CORE IN THAT IT IS ALMOST ENTIRELY GRAPHITE REFLECTED, INCREASING THE EFFECTIVE NEUTRON CYCLE TIME FROM $39 \times 10(-6 T H)$ SEC TO $42 \times 10(-6 T H)$. THIS.RESULTS IN LONGER PROMPT PER IOOS FOR A GIVEN REACTIVITY INSERTION. THE POWER COEFFICIENT OF REACTIVITY IS MORE NEGATIVE THAN EXPECTEO.

AVAILABILITY - USAEC PUELIC DOCUMENT ROCM, WASHINGTCN, D. C.

*GRAPHITE + \#PROMPT NFUTRON LIFETIME + \#REFLECTOR + POWER COEFFICIENT + REACTCR KINETICS + REACTOR, PULSED + REPORT, OPERATIONS ANALYSIS + TRIGA (RR)

$17-22783$

YANKEE PROPOSED CHANGE 80 - MODIFICATION CIF CHARGING AND VOLUME CONTROL SYSTEM METROPOLITAN EDISON CO.

2 PAGES, JAN. 4, 195E, DOCKET NO. 50-29, TYPE PWR, MFG--WEST., AE--STONE + WEBSTER

ASKS TO INSTALL A SINGLF CONTKOLLABLE ORIFICE (6-100 GPM) TO A SINGLE BLEFDLINE AND BLDCK, BUT NOT REMOVE THE PARALLEL BLEED LINES FOR ONE OR TWO CORE LIFETIMES IIN CASE OF UNFORESEEN PRQBLEMS). WEAR HAS NECESSITATED THE REPLACEMENT OF THE 2 SMALLER ORIFICES, AND LEAKAGE OF THE BLEED CONTROL VALVES HAS BEFN A PROBLEM. REPAIRS. ARE CIFFICULT. THE REQUESTFO CHANGE WOULD REDUCE SER.VICE REQUIREMENTS.

AVAILABILITY - USAEC PUELIC DOCUMENT ROOM, WASHINGTON, D. C.

\#COOLANT PURIFICATION SYSTEM + \#FLOW ORIFICE + \#VALVE + FAILURE, EQUIPMENT + LEAK + MOD IFICATION, SYSTEM OR EOUIPMENT + OPERATING EXPERIENCE SUMMARY + REACTOR, PWR + TECHNICAL SPECIFICATIONS + YANKEE (PWR)

17-22784 ALSO IN CATEGORY $S$

CATHOL IC U REPORT OF FACILITY MODICICATIONS

THE CATHOL IC UNIVERSITY DF AMERICA, WASHINGTON, D. C.

4 PAGES, JAN. 8, 1968 , DOCKET NO. 50-77

REACTOR SAFETY COMMITTEE AT ITS DEC. MEETING APPROVED A NEW ORGANIZATION CHART AND

MODIFICATION GF THE NO. 2 ION-CHAMEER CIRCUIT SO THAT THE SIGNAL MAY BE FEO TO EITHER THE PRESENT BECKMAN LOG CURRENT METER OR. TO A HONEYWELL LOG-N AND PERIOD $\triangle M P L$ IFIER (MODEL

4639-CA-4). NOT ONLY DOES THE LATTER GIVE A LOG-N READOUT BUT IT ALSO GIVES A PERILD READOUT AND A PERIOD SCRAM SIGNAL. THE BECKMAN UNIT WILL SE RETAINED AS A BACKUP UNIT.

AVAILABILITY - USAEC PUBLIC DOCUMENT RCOM, WASHINGTON, o. C.

*INSTRUMENTATION, POWER RANGE + ADMINISTRATIVE CONTROL + AGN (TNG) + INSTRUMENTATION, PERIOD + MONIFICATIDN, SYSTEM OR EQUIPMENT + REACTOR, TRAINING + SAFETY REVIEW

17-22785 ALSO IN CATEGORY 5

N. CAROLINA STATE (RALEIGH) PROPOSED AMENDMENT $4-R E V I S E D$ MCA ANALYSIS

NORTH CAROLINA STATE UNIVERSITY

8 PAGES, 7 REFERENCES, JAN, 10, $196 \varepsilon$, DOCKET NO. 50-111

MCA IS A STEP-REACTIVITY INSERTION. NEW ANAIYSIS ASSUMES THAT TOTAL EXCESS REACTIVITY (I.5\%) IS HELO DOWN BY A LONG CADMIUM TUBE PLACED IN THE VERTICAL EXPOSURE PORT, THAI THE REACTOR IS 3ROUGHT CRITICAL WITH THE CONTROL PODS FULL OUT, THEN THE TURE IS PULLED FROM THE CORE. BASER ON BORAX AND SPERT DATA, MAXIMUM FUEL-PLATE-SURFACE TEMPFRATURE WOULD BE Z3O C, WITH AN ENERGY RELEASE TO PEAK POWER OF $10 \mathrm{KW}-S E C$ AND. RESULTS TC NO CLAD MELT OR FIIEL-ELEMENT RUFTURE.

AVAILABILITY - USAEC PUELIC DOCUMENT ROOM, WASHINGTON, D.C.

ACCIDENT ANALYSIS + ACCIDENT, MAXIMUM CREDIBLE (MCA) + $\triangle C C I D E N T$, REACTIVITY + REACTOR, POOL TYPE + REACTOR, RESEARCH + REPORT, SAR + TECHNICAL SPECIFICATIONS

$17-22787 \quad A L S O$ IN CATEGORY 6.

POSITIVE GRAPHITE-REFLECTOR TEMP COEFF AT U OF WASHINGTON REACTOR

UNIVERSITY OF WASHINGTON, SEATTLE, WASH.

2 PAGES, JAN. 4, 1966 , DOCKET NO. 50-130

SINCE RAISING THE POWER FROM $10 \mathrm{KW}$ TO 100 , WE OBSERVE THAT THE REG. ROD MUST BE LOWEREO TO MAINTAIN CRITICALITY WITH EXTENDFD 100-KW RUNS. RECOROS SHOW THAT A TYPICAL PUN ADDS O.O4\% OK/K. A TEST SHOWS THE COEFFICIENT TO BE $\triangle B O U T$ PLUS $0.0014 \%$ OK/K PER DEG F, ASSOCIATED WITH THE COOLANT WATER TEMPERATURE. THE EXCESS REACTIVITY IS TO BE COMPUTED HOURLY. IF POWEP IS LESS THAN $10 \mathrm{KW}$, THE $0.585 \%$ LIMIT IS UNCHANGED. IF POWER IS TO EXCEED 10 KW, AND INITIAL REACTIVITY EXCEEDS $0.5 \%$, THE OPERATOR IS NOT TO PROCEEC UNTIL NOT IFYING REACTOR SUPERVISCR. AVAILABILITY - USAEC PUBLIC DOCUMENT ROOM, WASHINGTON, D.'C. 
DDERATIONAL CATEGORY SAFETY 17 ND EXPERIENCE

$17-22787$ \#CONT INUEO*

\#GRAPHITE + \#REACTIVITY EFFECT, DNOMALOUS + \#REFLECTGR + *TEMPERATIIRE COEFFICIENT + POWER UPQATING + PROCEDURES AND MANUALS + REACTOP, GPAPHITF MODEDATED + REACTCR, RESEARCH

17-22788 ALSO IN CATEGORY 5

ASSESSHENT OF LACBIR CLRRY-UNDER SEPARATORS

ALLIS-CHALMERS MANUFACTUREOS

16 PASES, FIGURES, JUN. C, IC68, DOCKET NO. 1I5-5, TYPE--BWR, MFG--A.C., AE--SGT + LUNCY

EVEN THOUGH FXACT CAUSE JF FAILUFE OF THE SIMILIAR PATHFINULP FAILURE HAS NOT BEEN DETERMINEO, DESIGN HAS LARGER MARGIV OE SAFETY $\triangle G A I N S T$ STRUCTURAL FAILURE. OUTLET VELDCITY AND PDESSUPE DIFFERENCE $\triangle$ P.E LESS, GIVING $1 / 4$ THE HYDRAULIC FCRCE, WHILE THE FI 3 STPENGTH IS 3 TIMES, GIVING A FACTCF.-OF-12 AOVANTAGE.

AVEILAQILITY - USAEC FUPLIC DUCUMFNT QOOM, WASHINGTON, D. C.

* SAFETY MARGIN + \$SEFARATOR + \#STRUCTURAL INTEGPITY + HYDRAULIC ANALYSIS + LACROSSE (BWR) + REACTUR, GWR + STPESS AINALYSIS

17-22901 ALSO IN CATEGORY

CONTROL OF XENON INSTABILITIES IN LARGE PHPS. QUARTERLY PROGRESS REPORT FOR THE PERIOD ENDING JUNE 3O, 1967

WESTINGHJUSE ELECTRIC CGRP., PITTSBUFGH, PA.

WCAP-3 SEO-4 + EIJRALC-18S0+.7? PAGES, FIGURFS, JULY 1967

REPORTS RESULTS OF GPOUPS WORKING GN 11 EFFECT GF CORE PARAMETERS JN SPATIAL OSCILLATIONS, (2) DEMEOIAL CONTRQL DPOCEDUSES, AND I I 2-DIMENSIONAL ANALYSIS. A SIMPLF CDFRFLATIOM! ULS DEVELOPEO TO CORFECT FDR THE ERROFS CAUSED BY USING FINITE TIME STEPS IN DIFFUSICN-THEORY CALCULATIONS. AN INOEX OF THE INFLUENCE OF VARIOUS CORE PARAMETERS GN STAEILITY WAS DEVELOPED.

AVAILABILITY - CLEARINGHUUSE FOF FEDEPAL SCIENTIFIC AND TECHNICAL INFCFMATION, SPPINGFIELD, VIPGINIA F3. OC COFY, $\$ 0.65$ MICROFICHE

\# XENON DSCILLATION + ? AND D DEOGRAM + PEACTEE KINETICS + REACTOR STARILITY + PEACTOR, FWR

17-2290C ALSC IN COTEGOPY ?

TTEAP-AWAY SLEEVE

$\triangle E C$, DIVISIUN DF OFFADTIONAL SAFETY

2 DAGES, 2 FIGUR 5 , HE

DESCRI PES A SLEEVT. THAT CAN RE EASILY TULN FROM THE ARM, FITS SNUGLY, AND COES NOT INTERFERE WITH AR.M MOVEMENTS. THE SLEEVE WAS DESIGNEO TO ELIMINATE THE RISK OF $\triangle N$ OPERATCR BEING OULLED INTO ROTATING MACHINERY AND TO OROTECT AGAINST RADIOACTIVE DR GTHER TOXIC MATERIALS. THE SLEEVE IS MADE CF AN ELASTIC. CCTTCN YARN FASTENED GY TKO SEAMS FOPMED BY HGCKK $\triangle N D$ PILE FASTENERS. DETAILS ARE SHOWN IN FIGURES.

AVAILABILITY - US ATOMIC ENERGY COMMTSSION, DIVISION GF OPERATIONAL SLFETY

\#PERSONNEL PROTECTIVF DEVICE + CONTAMINATION

$17-22925$

LICENSES FOR KADIOGRAFHY, AND RADIATION SAFETY REQUIREMENTS FOR RADICGRAPHIC OPERATICNS

U. S. ATIMIT. CNERGY CEMMISSION, WASHINGTDN, O. S.

10 - CFR-14+. 3 PA'GES, JUNE 29,1965

(SUB-PART A) - REVIEWS REQUIREMENTS FCF ISSUANCE OF SEALED-SOURCE LICENSE. ISUB-FART B, RAOIATIDN SAFETY REQUTPEMENTS) - EQUIPMENT CONTROL (LOCKING, STOPING, LEAK TESTING,

LDGBOOKS). DER SONAL SAFETY (TRAINING, WDITTEN PROCEDURES, DCSE MONITGRING). PFECAUTIONARY

PRDCEDURES (DIPECT SURVEILLANCE, PISTINF, SURVEY AFTER USAGE).

AVAII.ASILITY - U. S. ATOMIC ENERGY COMMISSION, WASHINGTON, D. C.

\#RALIOGRAPHY + \#REGULATION, AEC + RLOIATION SAFETY $\triangle N D$ C ONTROL

$17-22: 26 \quad$ ALSC IN CATEGQRY 15

SECOND DRL INFORMATICAN LETTEQ ON RADIULREPHFES RVFRFXPOSUPE

USALL, IIVISICN OF STATE ANO LICENSFE RFLATICNS, WASHINGTON, D. C.

a PAGES, INFORHATION LETTEP TO ALL PADIOGFAPHY LICENSEES, JUNE 14,1965

SUYMARIZFS 14 INCIDENTS THAI OCCURREQ SINCE FIRST LETTEF (MARCH 1OS3). AGAIN, THE CAUSE FQR MOST DF THE:1 (DOSES I TO 16 REMS) CAN BF TRACED TO THE FAILUDC OF RAOICGRAPHEPS TO PFOPEFLY USE RADIATION-SURVEY INSTRUMENTS. ASKS CONTINUED INTEREST OF LICENSEE. MANAGEMENT TO REVIFN OPERATIONS $\triangle$ ND EQUIPMENT AND TO STRESS SOUND PROCEDURES ANC ATTENTION TO FOUIPMENT. 
17-2292S *CONTINUED*

aVAilability - usaec, division of state ane licensee relatiens, hashington, D. C.

FAILURE, OPEKATOR ERKOR + INCIDENT, HUMAN EPROK + INFORMATION PETRIEVAL + PERSONNEL EXPOSURE, RADIATION + RACIATION SAFETY ANO CENTROL + RADIOGPAPHY

$17-22827 \quad \Delta L S O$ IN CATEGORY 15

DRL INFORMATIJN LETTER ON RADIOGRAPHERS OVEPEXPGSURE

U. S. ATTMIC ENERGY COMNISSION, WASHINGTON, D. C.

S PAGES, INFJRMATIOV LETTER TO ALL RAQIOGRAPHY LICENSEES, MARCH 1963

GIVES ONE-PARAGRAPH DESCRIPTIONS OF 14 CASES (DOSES, 2 TO 6 PEESS) WHERF RADIOGRAPHERS WERE EXPOSED. TO UVSHIELCES SOURCES (DUE TO WARNING-SYSTEM FAILURES OR HEEDLESS.ACT ION) WHICH CQULD HAVE PEEN PREVFNTED HAD THE OPERATOR USED SURVEY INSTRUMENTS EACH T.IME (AS IN IC (FR 34.43 ). ASKS THE LICENSEFS TO REQUIRE THAT PADIOGRAPHERS READ LETTER AND TO STRESS PROPER USE OF SURVEY INSTRUMENTS IN PERIODIC TOAINING PROGRAMS.

AVAILABILITY - USAEC, OIVISION OF LiCENSING AND REgULATION, WASHINGTON, D. C.

* INCIOENT, HUMLN ERRQR + \#PADI OGRAPHY + FAILURE, OPERATOR ERROR + INFORMATION RETRIEVAL + PERSONNEL EXPOSURE, PADIATION + RAOIATION SAFETY AND CONTRCL

$17-22329$

BIG ROCK POINT CONTRCL SQD JAMMED

CONSUIMERS PQWER COYDANY, JACKSON, MICHIGAN

2 PAGES, JANUARY 3 , IOSE, DOCKET 50-155, TYPE--BWR, MFG--G.E., $\triangle E-B E C H T E L$

ON DECEMBER 25, 196?, ROUTINE EXIRCISING CF PERIPHERAL ORIVE F5 SHOWED THAT THE ROD WDULO NOT WITHDRAW $\triangle F T E F$ P.E ING INSERTEO ONF NOTCH FROM ITS FULLY WITHDRAWN POSITION. IT WOULD INSERT, BUT $\triangle P P A R E N T L Y$ A COREIGN OBJECT IN THE HOUSING CATCHES ON THE OKIVE-INDEX-TUSE NOTCHES.

SINCE POWF? HAS EEEN REDUC =D TO 60 MWE TO CONSERVE REACTIVITY JUST SEFORE REFUELING, RON HAS AEEN VALVEO DUT OF SERVICE. SHUTDOWN-MARGIN CALCULATIONS SHOW REACTOR SUBCPITICAL AT LEAST $1:$ WITH ALL RODS IN BUT F-5 AND ADJACENT ONE WITHDRAWN.

aVailagility - usaec plBLic document rong, washingtun, D. C.

\#FAILURE, SCRAM MECHANISM + BIG FOCK POINT (BWR) + REACTOR, BWR + SHUTDOWN MARGIN

$17-22929$

UCLA LIMITS COOLAINT TEMPERATUPE

UNIVERSITY OF CALIFORNIA, LOS ANGELES, CALIF.

1 PAGE, JANUARY $8 ; 1968$, DOCKET 50-142

NEW TEMPEP.ATURE LIMITATION FOR THE 500-KW EXPERIMENT IS 212 F MIXED MEAN COOLANT TEMP. MEASURED BY THERMOCOUPLES INSTALLED IN THE DUTLET FLOW CF THE CENTER (HOTTEST) CORE EOXES C.INFIRMS ORAL AGF.F.FENT OF JAN. 4.

AVAIIABILITY - .USAEC PUELIC DOCUMENT ROOM, WASHINGTON, D. C.

\#HIGH TEMDERATURE + \#PERFORMANCE LIMIT + HEAT TRANSFER, BOILING + MAIN COJLING SYSTEM + POWER UFRATINC + REACTOR, RES $\subseteq$ ARCH

17-22930 ALSO IN CAATEGORY 0

WASHINGTDN STATE U REHURTS REACTIVITY EXCESS IN CONVEFIED TRIGA

WASHINGTON STATE UNIVERSITY, PULLMAN, WASHINGTON

3 DAGES, I FIGIIRE, JANUARY 10,1968 , DOCKET $50-57$

THE WORTH OF THE CENTRAL FUEL ELEMENT (4-POD CLUSTEP) WAS PPEDICTED AS \$3.EI (BASEC ON A

CYLINDR ICAL COEE) BUT MEASURED $\triangle S \$ 5.36$ AND \$5.78 IN THE ACTUAL RECTANGULAR CONFIGURATION. QEVISED ACLIDENTAL-FUEL-ADDITION ANALYSIS GIVES 1234 C PEAK FUEL TEMP. (A RISE CF 884 C) INSTEAD OF 853 (LI:AIT I.S SET AT IOOC C). PRESENT ADMINISTRATIVE CONTROL OF LOACINGS WILL PREVENT SUCH ACCIDENT. IN ADOITION WE PLAN TO LIMIT FUEL TEMP. T.O IOO C WHEN A CORE OPENING FXISTS, SO THAT PEAK FUEL TEMP. IN THE ACCIDENT WOULD NOT EXCEED 984 C. THIS WILL ALLOW LON-POWER TESTING.

AVAILABILITY - USAEC PUBLIC DOCUMEN̈T RDOM, WASHINGTON, D. C.

*COMPARISON, THEORY AND EXPERIENCE + \#REACTIVITY EFFECT, ANOMALOUS + \#REACTIVITY, EXCFSS +

ACCIOENT ANALYSIS + ACCIOENT, REFUELING + REACTGR, RESEARCH + TRIGA (FR)

$17-22837$

GENERAL ELECTRIC REQUESTS PERMISSION TO COMPLETE DISMANTLING OF THE THERMAL CRITICAL ASSEMBLY

GENERAL- ELECTRIC COMPANY, SAN JOSE, CALIF.

5 PAGES, JANUARY 8,1968 , DOCKET 50-24 
OPEPATIONAL CATEERRY 17 SAFETY AND EXPERIENCE

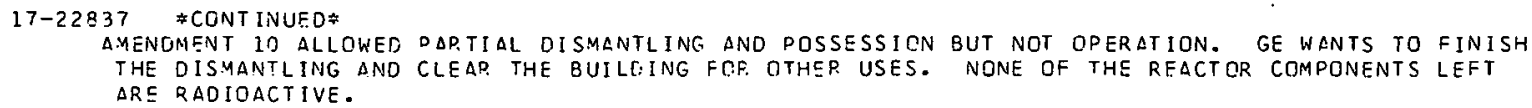

AVAILABILITY - USAEC PUBLIC DOCUMENT RODM, WASHINGTDN, D. C.

CRITICAL ASSEMBLY FACILITY + REACTOR DECCMMISSIONING + TECHNICAL SPECIFICATIONS

$17-22838$

GENERAL ELECTRIC REQUESTS TERMINATION OF MIXED SPECTRUM CRITICAL ASSEMBLY LICENSE

GENERAL ELECTRIC COMPANY, SAN JOSE, CALIF.

4 PAGES, JANUARY 8 , 1968 , DOCKET 50-20?

MSCA HAS BSEN CCMPLETFLY DISMANTLED AND DISPOSED OF. REACTGR COMPONENTS HLO NO CETECTABLE SURFACE CONTAMINATION. SOME PAKIS WITH INOUCED ACTIVITY WERE PACKAGED AS RADIOACTIVE WASTE.

aVAILABILITY - USAEC PUEL IC DOCUMENT ROCM, WASHINGTON, D. C.

CRITICAL ASSEMELY FACILITY + LICENSING STETUS OF NUCLEAD PRCJECTS + REACTOP. GECOMMISSIGNING

$17-22839$

UNIVERSITY DF KANSAS PROPOSED AMENDMENT ALLOWING USE OF PU-Z3C FOILS

THE UVIVERSITY OF KANSAS, LAWRENCE, KANSAS

2 PAGES, DECEMQEK $15,19 E 7$, DOCKET 50-148

THR EE THPESHOLD FOILS (LIKE THOSE USED IN HURST NUCLEAR-ACCIDENT DOSIMETERS) CONSISTING OF $\approx$ G OF PU-230 SEALED IN COPDER CUPS $\triangle R E$ TO SF USED AS IAST-NEUTRGN-THRESHOLD DETECTORS IN EXPERIMENTS JSING THE PNEUMATIC TURE OR VARIOUS BEAM UUKIS SY THE RADIATION BIOPHYSICS DEDATTMENT. THESE FDILS ARE NCW $\triangle T$ ORNL, WHERE THEY ARE USED IN THE HPRE IFAST-BURST REACTOQI.

AVAILABILITY - USAEC PUBLIC DOCUMENT POQN, WASHINGTON, D. C.

-FLUX DISTRIBUTION + \$PLUTONIUM + IN CURE MLASUREMENI + IRRADIATICN TFSTINE + REACTOE, POOL TYPE + REACTOR, RESEARCH + TECHNICAL SPECIFICATICNS

$17-22840$

HADDAM NECK PRQPOSEJ CHANGE 5--MAIN STEAM I SOLATION VALVE CLOSURE TIME

CONNECTICUT YANKEE ATOMIC POWER COMPANY

4 PAGES, JANUARY 9,1968 , DOCKET 50-213, TYPE--PWR, MFG--WEST., AE--STONE + WEBSTER

PEQUESTS THAT SPECIFICATION BE CHANGED TO REQUIRE VERIFICATION OF IO-SSC CLOSUSE TIME IVS ! SECI. VALUSS CANNOT BE TSSTED AT AC.C.IDENT CONDITIONS, AND CLOSURE TIMES OF 1.5 TO $4.6 .5 E C$ (AVG., 2.8) WERE OBTAINED AT APOUT 5O\% DESIGN PPESSURE OROP. STEAM-LINE RUPTURE IS

REANALYZED IN FR̈OPOSFD AMENDMENT 17, ASSUMING A IO-SEC DELAY IN CLOSURE TIME. CFF-SITE THYROID DOSE IS LESS THAN 0.05 REM.

AVAILAGILITY - USAEC DUBLIC ODCUMCNT ROÜ, WASHINGTON, D. C.

* CONTAINMENT PENETRATION, CLOSUPE OF + \#RESPONISF, TIMF + \#TEST, SYSTFM OPERABILITY + FVALVE + ACCIDENT, STSAM LINE RUPTURE + HADCAM NECK (PWR) + REACTOR, PWR + TECHNICAL SPECIFICATIONS + TEST, PROOF

17-2284! $\quad \triangle L S O$ IN CATSGORY I

HADDA!M NECK APPLIES FCR EXEMPTION FPOM IO CFR, 20. 202(C)(2)--FHYSICAL CONTROL OF HIGH RADIATION AREAS CONNECTICUT YANKEE ATOMIC POWER COMPANY

3 PAGES, JANUAKY 3,1968 , DOCKET $50-213$, TYPE--PWR, MFG-WEST., AE--STCNE + WESSTER

REQUESTS SUBSTITUTIDN DF PROCEDUPAL LND PHYSICAL-ACCESS-CONTROL MEASURES AT ENTRANCES TO HIGH RADIATIJN AREAS IN LIEU OF VISIRLE GR AUCIBLE ALARMS. PHYSICAL CONTROLS INCI.URF PARRICACIES ANU SIGNS AT AREAS WITH P.ADIATION LEVELS IN EXCESS OF 0.1 R/HR, AND LGCKED WIFE MESH DOOFS TO AREAS OF 1.O P./HR. DETAILED PROCEDURAL CONTPOLS AR.E LISTED.

AVAILABILITY - USAEC PUBLIC DOCUMENT PDOM, WASHINGTON, D. C.

* ADMINISTRATIVE CONTROL + FRADIATION SAFETY ANO CONTROL + HADDAM NECK (PWR) + HIGH RADIATION + REACTOR, PWR + FEGULATION, $\triangle E C$

17-22844 ALSO IN CATEGORY O

MANHATTAIN COLLEGE SJPPLIES ADOITIUNAL INFURMATION ON SHUTDOWN SYSTEMS

MANHATTAN COLLEGE, GPONX, NFW YJRK

2 PAGES, DECEMSER 29, 1967, DOCKET $50-199$

(1) BDRON EMERGENCY SHUTOOWN SOLUTION (WORTH AT LEAST 2\%) IS FORMEO BY DISSCLVING MJRE THAN $4915 \mathrm{G}$ OF BORIC ACID IN WATER WHICH IS STORED IN 3 LARGE CARROYS ON THE REACTOR PLATFORM 


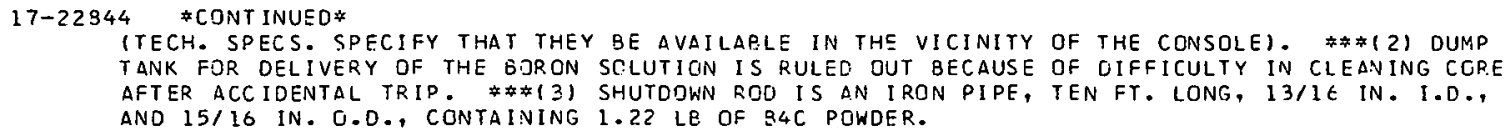

COMPLIANCE INSPECTOR POINTED OUT THESE-DIFFERENCES DUFING INITIAL OPERATION. ISAFETY ANALYSIS REPORT DESCRIPTION FOLLOWS ACTUAL SITUATION.) (1) POISON ROD IS 19 IN. LCNG (NEARLY 20 ). (2) CONCRETE BIOLOGICAL SHIELD IS 3 FT. THICK II FT). (3) VENTILATION FLOW IS 1500 CFM INTAKE AND 1700 EXHAUST 1450 AND 500). (4) TWO SETS OF LOUVRES IN SERIES IN VENT ILATION SYSTEM (1 SET). (5) AREA RACIATION MONITOR IS ON REACTOR ROCM EAST. WALL (CONTRCL-ROD-DRIVE PLATFORY). (6) WATFR-PUR IFI(AATION-SYSTEM PILOT LIGHT IS ON WALL BY CONSOLE (ON CONSOLE), AND (2) WATER RADIOACTIVITY LEVEL MONITOR HAS ONLY AN ALARM BELL (ALARM BELL AND VISIRLE ALARM) ANO THE METER CN THIS MONITOR IS SEPARATE FROM WATER-TEMPERATURE METER ISINGLE METER WITH 2 SENSORS ).

aVAILABILITy - USAEC PUBLic DOCUMENT PODM, WASHINGTON, D. C.

\#MODIFICATION, SYSTEM OR EQUIPMENT + *REPCRT, SAR + INSPECTION AND COMPLIANCE + MONITOF, RADIATION, AREA + REACTOR, RESEARCH + TRIGA (RR)

$17-22846$

LACROSSE ANSWERS ACRS QUESTION CONCERNING CONTROL ROD NOZZLE PKOBLEMS

DAIRYLAND POWER COOPERATIVE, LA CROSSE. WI SCONSIN

2 PAGES, JANUARY 8, 1968, DOCKET 115-5, TYPE--BWP, MFG--A.C., AE--SGT + LUNDY

IN RESPONSE TO AN ACPS QUESTION OF WHAT SIMILARITIES EXIST BETWEEN OYSTER CREEK NOZZLE PROBLEMS AND LACROSSE NOZZLE DESIGN, LACROSSE TRANSMITS TELEGRAM FROM R. WYLIE; SCUTHWEST RESEARCH INSTITUTE. TELEGRAM DESCFIBES WELDING OF NOZZLE IN HEAD AND GIVES QUALITY CONTROL OROCEDURES. NOZZLES ARC OF INCONEL 600 ANO ARE INSTALLED WITH PARTIAL PENETRATION WELDS AT THE SHOP.

AVAILABILITY - USAEC PUBLIC DICUMENTS ROOM, WASHINGTON, D. C.

*CONTROL ROD DRIVE + *NOZZLE + ACRS + FAULT + LACROSSE (BWR) + PRESSURE VESSEL + OUALITY CONTROL + REACTOR, PNR + WELOING + LEELOS

$17-22851$ ALSO IN CATECORY 18

ITEM 4 - REVISED PROCESS FLOW DIAGHAMS ANO A REVISED TABLE LISTING VALVES

SOUTHERN CALIFORNIA EOISON COMPANY + SAN DIEGO GAS AND ELECTRIC COMPANY

17 PAGES, 3 TABLES, 13 FIGURES, PAGES 28 THRU 44 OF SUPPLEMENT 2 TO THE FINAL SAFETY ANALYSIS REPORT FNR

SAN JNIFRE NUCLEAR GENEPATING STATION, MAY 31,1966 , DOCKET 50-206, TYPE--PWR, MFG.--WEST, AE--BECHTEL

LIST $\triangle 1,1$, VAI,VES, INCLUDING CLASS, TYPE, NORMAL POSITION, METHCO GF ACTUATICN, AND FAIL-SAFETY. FLOW OI AGRAMS ARE FOR MISCELLANFOUS WATER SYSTEMS, FEEOWATER AND CONDENSATE SYSTEM, COMPRESSED-AIR SYSTEM, AIR-CLNDITICNING SYSTEM, REACTOR COOLANT SYSTEM, ETC.

AVAILABILITY - USAEC PUBLIC DOCUMENT ROOM, WASHINGTON, D. C.

* SYSTEM DESCRIDTION + \#VALVE + AUXILIADY COOLING SYSTEM + CONTAINMENT PENETRATION, GENERAL + CORE REELOODING SYSTEM + MAIN COOLING SYSTEM + REACTOR, PWR + REPORT, SAR + SAN DNOFRE (PWR) + VENTILATION SYSTEM + WASTE DISPOSAL, GENERAL

$17-22853 \quad$ ALSO IN CATEGORY 13

AEC-COMPLIANCE AUTHORIZES NFS CONTINUED OPERATICN UNDER PLAN CF ACTION

UNITED STATES ATOHIC ENERGY COMMISSIDN, WASHINGTON, D. C.

13 PAGES, ATOMIC ENERGY CLEARING HOUSE 14(5), PAGE 20-41, (JAN. 30, 1968), DOCKET NO. 50-201

(TWX, JAN. 19 ) AGREES WITH PLAN OF ACTION AND SCHEDULE OF EXCEPTIONS OUTLINED IN JAN. 13/15 LETTERS. (NFS LETTER, JAN. 13.) REPLIES IN DETAIL TO DEC. 28 LETTER. NFS BELIEVES CONTAMINATION-CONTROL PROBLEMS WEPE CAUSED QY VENTILATION SYSTEM BEING MARGINAL FOR UPSET CONDITIONS AND FOR HIGH BURNUP FUEL, AND TO UNEXPECTED FREOUENCY OF MAINTENANCE IN HANDLING EQUIPMENT - VENT MOOIFICATIONS AND DECONTAMINAIION FACILITY WILL BE COMPLETE BY APRIL GO. MANY PROBLEMS RESULT FROIA LACK OF COMMUNICATION - MANY REMEDIAL STEPS BEGAN AFTER YOUR OCT. 67 INSPECTION AND WE DID NOT FURNISH YOU PROFRESS REPOPTS. ADDITIONALLY, AMBIGUITIES IE.G. ADEQUATE CONTROLSI IN AEC REgULATIONS AND OUR TECH. SPECS. POSE MORE OF A PROBLEM IN THE FIELD. 
17-22853 *CONTINUED*

\#MAINTENANCE ANO REPAIR + \#VENTILATION SYSTEM + DCMINISTRATIVE CONTROL + DECONTAMINATION + FUEL REPROCESSING + INSPECTIUN AND COMPLIANCE + MODIFICATION, SYSTEM CE EQUIPMENT + NFS + TECHNICAL SPECIFICATIONS

$17-22874$
EXSO IN CATSGORY

EXPERIMENTAL DETERMINATION OF THE DEDARTURE FEQM NQULCATE SOILING IN LARGE ROD BUNOLES $\triangle T$ HIGH FRESSURES WESTINGHOUSE ILECTRIC CORP., ATOMIC PQNER [IIVISION

WCAP-7045 +. 23 UNGES, 7 FICURS S, 11 REFFPENCES, AMENUMENI 6 TO THE LICENSE $\triangle D P L I C A T I C N$, IFIFTH SUPPLEMENT TO DIABLC CANYON PRELIYINARY SAFETY ANALYSIS PEPDFTI, NCVEMAER E, ICE7, DOCKET NO. EO-2T5, TYPE--PWR, MFG--NEST., $\triangle E-O G+5$

(SIJBMITTED AS CIAELD CANYON APPENDIX B TC FIFTH PSAR SUPPLFNENT). TESTS MADE AT IEOC-23OC DSIG ON A $5 \times 5$ ARRAY OFF 7-FT-LTNG. INTERNALLY HEATED ROOS SHCW CD TONGS (W-3) COFF. ELATIJN DERIVED FOP ELQW IVSIDE TUEES (J. NUCL. ENERGY, VOL. 2l) AN $\triangle V$ I RAG E. CONSERVATIVE. THIS IS BELIEVED CUE TO SDECIAL MIXING WAVES IN SPACER GPID. CRUD WHICH TLAKED JFF ELEMENTS AND CAUGHT ON GQID PAISED THE PRESSURF NROP AND DNR FIUXES. CRUD FCULINC DT FCDS INCDEASEO FOU TEMHEKATUR: 1CC-300 F, DQUPLEQ THE PRESSURE DEQP, BUT DIO NCT HAVE L SIGNIFICLNT EFFECT ON ONB HEAT FLUX FOR 3 DOINTS RECHECKED. BUT, AT DNB, THE SLEPE CHANGE OF. HEAT FLUX VS TEMP. WAS NOT SO LARGE. CESOITE OESEQVATION OF TRANSITION FPGM PIJROLY TO SLUG FLON AT $20 \%$ VOID IN CLOSED CHAVNELS, THE OPEN GECMETRY TESTED SHOWED NO FLOW INSTABILITY IAND THUS FREMLTURE DNB), WITH EXIT VOICS (CALCULATED WITH THINC) OF 23-68\%.

AVAILABILITY - USAEC PUBLIC. DGCUMENT PONM, WASHINGTON, D. C.

* COMPARISON, THEDRY AND EXPERIENCE + \#HEAT TRANSFER CORRELATICN + \#HEAT TRANSFFR EXPEPIMENT + DIABLO CANYON (PWR) + DNB + FLOW SLOCKAGE + FLOW STABILITY + FUEL ELEMENT + REACTOR, FWR + REPCRT, PSAR + SURFACE FILM DEPOSIT

17-22981 ALSE IN CGTEGQRY 10

SELECTED FERMI OPERATING EXPERIENCE JUNE IOEA

POWER REACTOR DEVELOPMENT COMPANY

EF-34 +. g PAGES, TABLES, JUNE ISBE

CORE IAS Q.ELDAOFD JUNC 22 , AND 67-MW TESTING WAS CLMPLETED. A FLDATING POWER SUDPLY HAS BEEN MADE FOR THE HIGH-SENSITIVITY FISSION COUNTEP, AS THE TWO-LDOP PCISE COEFFICIENT T-C.27 CENT/MW) HAS A LARGF UNCERTAINTY FFOM KEITHLY INOICATICN AND LOW INDICATION ON FLCWMCTEPS. TWI CABLE FNULTS IN THE 4. Q-KV TEEDS TO PROC GAVE A CUMPLETE LOSS GF NORMAL PCWFO TO THF 4RO-V SUSSES. DIESEL STARTER AND SUPPLIED 48O-V VITAL POWER. NOS. 1 AND 2 STEAM GEN CRATRF.

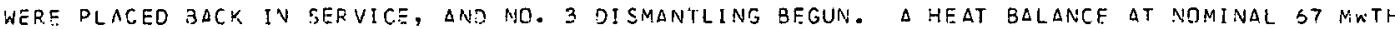
SHOWED TRUE PCIER 1C-2OY LSSS THAN ON NUCLEAF INSTRUMENTS, AND SOOIUM FLCWS LCWER THAN NCP INAL.

AVAILAGILITY - USAEC OURLIC DOCUMENT SOOM, WASHINGTON, D. C.

ACCIDENT, LOSS OF POWER + ELECTRIC POWER, VITAL + FERMI (LMFBP) + GENECATOR, DIESEL + INSTRUMENTATION CALIRAATION + INSTFUMENTATIJN, FLOW + INSTRUMENTATION, PUWER RANGE + FEACTOO POWER + REACTJP, FAST + Q EPOPT, OPEDATIONS

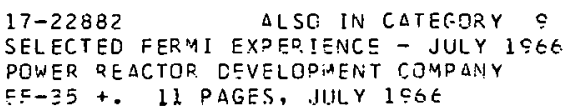

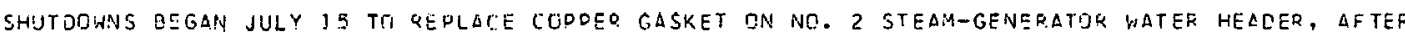
SUME TESTS AT IOC MW WERE COMPLETED. MEASUREO CORE OUTLET TEMPERATUPE DIFFERENCES AND SF GREATER THAV EXOECTEC. \# CURING A PRESSURE RAMP FR.OM O5C TO 60O PSIA WITH KEACTOR $\triangle T$ TT MN, REACTGR INLET SODIUM TEMPERATUPE BEGAN OSCILLATING $\triangle T$ T5O PSIA, REACHING 585 F AND CAUSING A DNE-LOBP SHUTDJWN, WHICH GAVE A LOSS-DF-ELON SCRAM. THERE MAY EE STGNIFICANT HEAT TRANSFEP. IN THE CFNTRAL REGION OF THE STEAM GENERATDR, SO SOILING OCCUPS TOC SOCA IN THE TUBE, CAUSING FI, RIW INSTABILITY. A SECOND SCRAM CAME SIMILARLY, BUI FROM TOO HIGH A TEMPERATURE, DUE T? ERRATIS. TE 301

AVAILABILITY - USAEC DUELIC DOCUMENT RDOM, WASHINGTON, D. C.

\#FLOW STABILITY + \#SCRAM, SPURIQ̣LS + \#STEAM GENERATOR + FERMI (LMFBF) + IMSTRUMCNTATION, ATNORMAL INOICATION + INSIRUMENTATIOM. TEMPERATURE + GDERATING EXPFRIENCE SUMMAKY + REACTOR, FAST + REPORT, OOERATIONS + TEST, PLANT RESPONSF

$17-22383$

MCCARTHY JF

SELECTEO FERHI UPEUATINC EXPERIENCES - $\triangle U G U S T$ ICRE

ATOMIC POWER DEVELODMENT ASSOCIATES, INC. + POWEF RFACTRQ DEVELRFMENT COMPLNY + DETROIT EOISON COMPANY $\triangle P D A-C F E-1+25$ DAGFS, FIGUPES, TABLES, DECEMEER ISEE

FIRST REPSET IF A SERIES Th PECCERD TFSTS $\triangle N O$ OPEPATING EXPERIENCE THAT MAY BE SIGNIFICANT FCR LATER FAST-3P.EEDER P.EACTORS. SUMMAPIZES TSSTS RUN IN JULY AND $\triangle U$ GIJST $\triangle T$ T 7 AND IDO MH THER:AAL. 
OPEQATIONAL CATEGQRY 17 SAFETY AND FXPERIENCE

$17-22888$

MCC.ARTHY J

SELECTED FERMI DPERATING EXDERIENCE - DEC. 1CES

ATOMIC POWER DEVELOPNENT ASSOCIATES, INC., DETPOIT, MICH. + POMER REACTCR DEVELOPMENT CC., DETREIT, MICH. + DETROIT EDISON CO. NICH

APDA-CFE-E +. 32 DAGES, MAY 1967

SIX FUEL ELEMENTS WERE PEMOVEC. ONLY ONF. SHCWED DISTORTION. CALCULATIONS SHOWED THAT FUEL OVERHEATING MAY HAVE EXISTED WI THOUT CAMAGING THE UPPER BLANKET PINS, SO THIS EASY METHOC. CF I.NSDECT ION WAS RULED TUT.

AVAILASILITY - CLEAR INGHOUSE FOQ. FEGEPAL SCIENTIFIC AND TECHINICAL INFGRMATION, SPRINGFIELD, VIRGINIA

\#EXAMINATION + \#FUEL ELEMENT + FERMI (LMFEF) + FUEL HANDLING + FUEL YELTDOWN + REACTOR, FAST +

REPORT, OPEQATIONS SUMMARY

17-22889 $\quad$ ALSE IN CATEGORY

SELSCTED FEPMI DPERATING EXPERISNCE" JAN. 1967

POWER REACTOF DEVELDPMENT COMPANY

EF-41 +. 1 PAGE, DAGF 5 OF ENQICO FERMI ATOMIC POWER PLANT REPORT FOR JANUAF $196 ?$

(PAGE 5) SUURCE-RANGE CDUNTIVG PATF GN CHANNELS $1 / 2$ ROSE BY FACTOP.S OF $2 / 3$ ON JAN. IO, APDAQENTLY =ROM A COMMCNN INDETEPMINATE NOISE SOURCE. CFOSS COUPLING BETWEEN VARIOUS EOUIDMENT RAOIATION MONITOR.S WAS ELIMINATED WITH FILTEF CAPACITORS IN THE COMMON POWER SUPPLIES.

AVAILABILITY - USAEC FUBLIC DOCUMENT ROOM, WASHINGTON, D. C.

* INSTRUMENTATIJN, ABNGRMAL INDICATION + ELECTRIC POWER, VITAL + FERMI (L MFBR) + INDEDENDENCE + INSTRUMENTATION, STLPTUP DANGE + MGNITOE, RADIATION, AREA + REACTOR, FAST + REPORT, DPEFATIONS

17-22890 $\quad \Delta L S C$ IN CATSGQRY.

IACCARTHY JF

SELECTED EERMI OPIRATING EXDERIENCE - JAN. 1067

AT MIC POASR DEVELODMENT ASSOCIATES, INC., DETRCIT, MICH. + PCWER REACTOZ DEVELOPMENT CO., DETPCIT, MICH. + DTTROIT EDISON CO., MICHIGAN

APDA-CEE-6 +. 1 PAGE CF COMPILATION OF CURRENT TECHNICAL EXPERIENCE AT ENRICO EERMI ATOMIC POWER PLANT, IONTHLY REODKT NO. E. JANUARY 1967,30 FAGES, MAY 1967

(DACE 10) A JAN IN OOUBLING COF THE SHUTDCWN COUNTING RATE CN CHANNELS I $\triangle N D 2$, WHICH TOOK PLACF IN 5 MIN $\triangle N$ L LASTSO ABCUT 15 HR, WAS $\triangle P P A R E N T L Y$ NOISE IFPGM AN $\triangle C$ MG SET, STANDBY POWER) ENTERING THE SCALE DF TWO MONULES. DISCRIMINATION CUPVES SHOWED NO CHANEE. (PG 15) OF THE IE ISGE SCRAMS TABULATED, 5 WERE SINGLE ROD DROPS, 3 WERE LOSS OF COCLANT DUE TO HIGH FECDWATER TE:AP., TWO WERE UNKNOWN SAFETY-SYSTEM TRANSIENTS, ONE WAS DUE TC FAULTY DETECTGRS, ANO 4 WER S SCFEDULEC. (PG 24) SURASSEMBLY MO99 SHOWED THAT TWC OF FOUP. PINS HAD 2500 PPM OF HYORIDE IN THE CLAC (VS 150 FOR OTHERS, AND 10,000 AS FAILURE THRESHOLD).

AVAILABILITY - CLEARINGHOUSE FOR FEDEPAL SCIENTIFIC AND TECHNTCAL INFCRMATICN, SPRINGFIELD, VIRGINIA S3. OO COPY, \$0.65 MICROFICHE

*EXAMINATION + \#FUEL ELEMENT + \#INSTRUMENTATION, ABNORMAL INDICATION + \#INSTRUMENTATION, STAFTUF FANGE + \#SCFAM, PEAL + EMERGENCY POWER, ELECTRIC + FERMI (LMFBR) + HYDRIDE + INDEPENDENCE + REACTOR, FAST + RFPORT, OPERATIONS SUMMARY + ZIRCALOY

$17-2289$

MCCARTHY JF

SELECTED FEQMI DPERATING EXPEFIENCE - FEP. 1967

ATCAIC POWER DEVELOPMENT ASSOCIATES, INC., DETROIT, MICH. + PCWER REACTOR DEVELOPMFNT CO., DETROIT, MICH. + DETROIT EDISON CO.. MICHIGAN

APDA-CFE-7 +. I PAGE, PAGE 23 OF COMPILATION OF CURRENT TECHNICAL EXPERIENCE AT ENRICG FERMI ATOMIC POWER

PLANT. MIJNTHIY REPCPT NO 7, FERRUASY ICE.7. MAY 1.967

(PAGE 23 ) RECUEDENT TURE-TC-TUBE-SHEET LEAKAGE IN THE STEAM GENERATOR (SG) WILL PE KEPAIREO

WITH A NEWLY OEVELOPED TIG WELDING PROCESS, WITH A ROYALTY PAID FOR EACH WELD. AFTFP $120 C$

TIJBES OF ND. I SF ARE WELDED, THE UNIT WILL BE THERMALLY SHOCKFD BY VENTING WATEF, AND TESTED.

AVAILABILITY - CLEAP INGHOUSE FOP. FEOERAL SCIENTIFIC AND TECHNICAL INFORMATION, SPRINGFIELO, VIRGINIA \$3. OO COPY, \$0.65 $A$ ICROEICHE

\#FAILURF, TURING + *WELUING + LERYI ILMFELI + MEINIENANCL ANU REPAIF + REACYUR, FASI +

REPORT, OPERATIONS SUMHARY + STEAM GENERATOP

17-22892 $\quad$ OLSE IN CATEGORY Q

MCCARTHY JF + NASH CF 
17-22892 \#CONT INUED*

COMPILATION OF CURRENT TECHNICAL EXPERIENCE AT ENRICO FERMI AT.GMIC POWER. PLANT. MONTHLY REPORT NO. 11 , JUNE 1967

ATOMIC POWER DEVELOPMENT ASSOCIATES, INC., + POWEP. REACTOR DEVELOPMENT CG. + DeiroIt EDISON COMPANY, MICHIGAiN

$\triangle P D A-C F E-11+.31$ DAGES, FIGURES, $\triangle U G U S T$ 19E?

CONTAINS SUBJECT INDEX FOR CFE DEPCRTS l-il. (PAGE 8) DURING VESSEL GPAINING UPERATIONS, THE COUNTING-RATE CHANNELS INCPCASED A FACTOP OF 20 , AND THE INTERMEOIATE-RANGE CHANNELS ROSF A FACTOR OF 10,000. SAFETY CHANNELS WERE NOT AFFECTED. SIGNALS WERE CONTINUOUS AND LASTED $E$

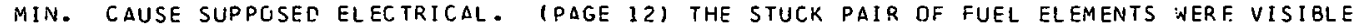
THROUGH BORESCOPES. (PAGE 15) VAPIATION OF PREOICTED FFOM MEASURED SODIUM DELTA T INCKEASES WITH INCKEASING DISTANCE FROM CORE CENTER. TWO MODELS WERE DEVELOPED FOR LOCAL FLOW VARIATIONS. (PAGE 17) VARIOUS CONSTRUCTION MATERIALS WERE IMMERSED IN HOT SOCIUM TO SES IF THEY COULD RETAIN THE TR FORM.

AVAILABILITY - CLEARINGHOUSF FOR FEDERAL SCIENTIFIC AND TECHNICAL INFORMATION, SPRINGFIELD, VA., \$3.OO COPY, \$0.65 MICROFICHE

\#FLOW BLJCKAGE + \#FLOW DISTRIBUTION + \#INSTRUMENTATION, ABNORMAL LANDICATION + FERMI (LMFBR) + INSTRUMENTATION, INTERMEOIATE RANGE + INSTRUMENTATION, STARTUP RANGE + MATERIAL + REACTOR, FAST + REPORT, OPERATIONS SUMMAR.Y

$17-22893$

SELECTED FERMI OPERATING EXPERIENCE--JULY 1967

POWER REACTOR DEVELOPMENT COMPANY

8 PAGES, JULY 1967, DOCKET 50-16, TYPE--LMFBR, MFG--APOA, AE--COMMONWEALTH ASSOC.

(PAGES 1-3) THF. TWO STUCK ELEMENTS WERE SEPARATED, REMOVED, AND SHIPPEC TO BATTELLE. NO ABNOPMALITIES TR OTHER SIGNS OF FLOW QLOCKAGE WERE FOUNC OTHER THAN THE DREAS WHICH HAD MFLTED TOGETHER.

AVAILABILITY - USAEC PUBLIC DOCUMENT RJOM, WASHINGTON, D. C.

\#FUEL MELTOOWN + \#REMOTE MANIPULATING AND VIEWING + FERMI (LMFBR) + FUEL HANDLING MACHINE + REACTOR, FAST + REPORT, OPERATIONS

17-22894 ALSO IN CATEGORY 5

MCCARTHY JF + NASHCR

COMPILATION OF CURRENT TECHNICAL EXPERIENCE AT ENRICO FERMI ATOMIC POWER PLANT. MONTHLY.REPORT NO. 12, JULY 1907

ATOMIC.POWER DEVELOPMENT ASSOCIATES, INC., DETROIT, MICHIGAN + PEWER REACTOR DEVELCPMENT COMPANY + DFTROIT SDISON CO., IMIC.HIGAN

APDA-CFE-12 +33 PAGES, FIGURE S, AUGUST 1967

(PAGES 7-13) SEPAFATION OF THE TWO STUCK ASSEMBLIÉ BY A SPECIAL CHISEL SAVEO ? MONTHS. NO FOREIGN MATERIAL WAS FOUND ON THE SUPPORT PLATC. (PAGE 14) RELEASE OF GAS IN LCADING A FUEL ELEMENT AND TRANSPORT BY BUILDING VENTILATION SYSTEM CONTAMINATED THE AREA WITH ZR-NE-OS AND SR-90. AN ADOITIONAL CHANGE HOUSE WAS CONNECTED TO THE AIRLCCK. (PAGE 1G-25) PICTURES AND EXAMINATION RESULTS DF DAMAGED ELEMENTS MI27 AND MO98 GIVEN. (PAGE $27-22$ ) A COMBINATION FLOW RESTRICTOR AND CHECK VALVE WILL BE INSERTED IN EACH STEAM-GENERATOR TUBE. THIS WILL INCPEASE . THE PART-LDAD ORESSURE DROP (PREVENTING FLOW IMBALANCES AND TUBE-SHEET FAILURES), YET ON A WATER DUMP WILL ALLOW NORMAL BACKFLOW.

AVAILABILITY - PUBLIC OOCUMENT ROOM, WASHINGTON, D. C.

*FISSION GAS RELEASE + \#FLOW ORIFICE + \#REMOTE MANIPULATING AND VIEWING + CONTAMINATION + FERMI (LMFBR) +
FLOW DISTRIBUTION + FLOW STABILITY + FUEL MELTDOWN + REACTOR, FAST + REPORT, OPERATIGNS SUMMARY + STEAM GENERATOR. + VENTILATION SYSTEM

$17-22895$

MCCARTHY JF

COMPILATION OF CURRENT TECHNICAL EXPERIENCE AT ENRICD FERMI ATOMIC POWER PLANT. MONTHLY PEPCRT NC. 13, AUGUST 1967

ATCMIC POWER DEVELOPMENT ASSOCIATES, INC., DETROIT, MICHIGAN + POWER PEACTOR DEVFLOPMENT COMPANY + DFTROIT EDISON COMPANY

APDA-CFE-13 +. 2E. PAGES, OCTOBER 1967

(PAGES 16-20) BFIEF DISCUSSION AND PICTURES OF SUBASSEMBLIES MDO8 AND MI27, CUT APART IN BMI HOT CELL.

AVAILABILITY - CLEARINGHOUSE FOR FEDEPAL SCIENTIFIC AND TECHNICAL INFORMATION, SPRINGFIELD, VA., \$3. OO COPY, \$0.65 MICRQFICHE

*EXAMINATION + FFUCL MELTDOWN + FERMI (LMFBR) + HOT CELL + REACTOR, FAST + REPORT, OPERATIONS SUMMARY

$17-22896$

SELECTED FERMI OPERATION EXPERIENCE--NOVEMBER 1967. 
OPERATIONAL CATEGQRRY IT 17 EXPFRIENCE

$17-22906$ *CONTINUED*

POWER REACTOR DFVELIPMENT COMPANY

PROC-EF-51 +. 7 OAGES, NOVEMGE? 1967 , DCCKET 50-16, TYPE--LMFEF, MFG-APDA, AE--COMMONHEALTH $\triangle S S C C$.

PHOTOGRADHS JE THF FOREIGN OZJECT WHICH BLOCKED FLEW WERE GIVEN TO A PHCTC INTERDSETER FOF DIMENSIONAL DFAWINGS ANO STEROSTOPIC VIEVING. CBJECT IS SLIGHTLY MAGNETIC. SEVEN FUEL FINS DF MI22 WERE SWDLLEN, NTTICEABLY AT. THE END CAPS. CAUSE NOT YET UNDERSTDOD.

AVAILABILITY - USAEC DUELIC DDCUMENT ROON, WASHINGTON, D. C.

EXPANSION + FERMI (I. NFRF) + FLON GLOCKAGE + FUEL ELEMENT + REACTCR, TAST +

REMOTE MANIPULAIINF AND VIEWING + REPORT, OPSRATIONS

\section{$17-22897$}

MCC.ARTHY JF

COMPILATION OF CURRENT TECHNICAL EXPEEICNCE AT ENFICO FERMI ATOMIC POWEP PLANT. CUREENT EXPERIENCE SERIES ATOMIC POWER DEVEL JPMENT ASSCCIATES, INC., DETPOIT, MICHIGAN + POWER PEACTDR DEVELDPMENT CO., DETECIT, MICHIGAN + DETRITIT EDISON COM., MICHIGAN

$A D D A-C E E-8+32$ PAGES, FIGURES, MARCH 1967

THIS IS A MONTHLY PRTGRESS REPOPT WHICH CONTAINS INFOPMATION CN (I) CUPPENT EXPEEIENCF, (II) DATA AND STATISTICS, (III) NUCLEAO TEST PPOGRAM (IV) PLANT TEST DRJGPAM (V) OTHES JPESATINE EXPEPIENCE, ANS (VI) MAINTENANCF AND $\triangle$ IOITIONS.

AVAILABILITY - USAEC DUBLIC DOCUMCNT DOQON, HESIIINGTON, D. C.

\#GPERATING =XPEFIENCF + \#REPOPT, OPEPATIONS ANALYSIS + FERMI (LMFBP.) + MAINTENANCE AND FEPAIO +

REACTDR, BREEDEF + FEACTOR, FAST + IS Di, - LANT QESHCNSE

IT-2Zs;is

MCCARTHY JF

COMPILATION OF CURRENT TECHNICAL EXPERIENCE AT ENRICO FERMI ATOMIC POWER PLANT. MONIHLY REPORT NO. Q,

APRIL 1967

ATOMIC POWER DEVELUPMENT ASSOCIATES, INC., DETROIT, MICH + POWER REACTOR DEVELOPMENT COMPANY + DETROIT

EDISON T.MMPANY, MICHTRAN

APUA-CFE-9 +. 31 PAGES, JUNE $19 \bar{E} 7$

(PAGE 23) A LOW-FREQUENCY COIL TO NONNDESTRUCTI V̈ELY'TEST' FUEL PINS HAS A THRESHOL D OF IOOO PPM HYDR IDE, TESTED ON DELIBERATELY HYORIDED (250-5000 PPM) PINS. (PAGE 24) BYPASS FLOW ANALYSIS

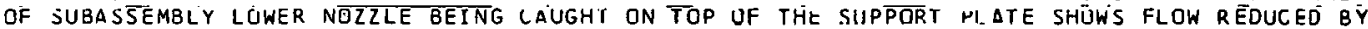
$7 \%$, INSUFFICIENT TO CAUSE FUEL DAMAGE. (PAGE 27 ) FAILURE OF A SOLENRIN VALVE ALLOWFN PRIAARY-SHIELE-TARK PKLSSURE TO TAKE FOSITIY DKESSURE SUINGS. FAILUOE QLEH A. FUSE IN THE TDMMON POWFR SUPPLY. PREVFNTINF SWTTRHOVER TO AN ALTEPNATE SENSING LINE. MANUAL VALVES REPLALE THE SQLENOIO VALVES IIN A LESS COMPLICATED AKKAYI.

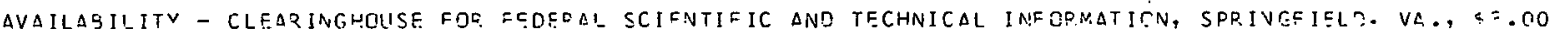
COPY, \$O. 65 MICROFICHE

* FILURE, COMPONENT + *FAILURE, SEQUENTIAL + \#FLOW DIST2IBUTION + \#TFST, NONDESTFUCTIVE + CLAD + ELECTRIC PONEQ, NDOMAL + FERMI (LMERP) + FUEL ELEMENT + HYDRIDE + HYGEEDYNAMIC $\triangle N A L V S I S$ + INDEFENCENCE + REACTOR, FAST + REOCOT, QPEDATIOVS SUMMASY + VALVE

\section{$17-22899$}

MCCARTHY JF

COMPILATION OF CURRENT TECHNICAL EXPCEIENCF AT ENFICR FEPIMI ATEMIC PDWFF PIANT

ATIMIC POWER gEVELODIANT ASSTCIATES, INC., DETPOIT, MICHIGAN + POWER REA LT JP. DEVELCPAENT CO. DETFCIT, MICHIGAN + DETROIT EDISON CO., MICHIGAN

$\triangle P C A-C F E-10+. \quad 30$ PACES, JULY ISST

MONTHLY PQCGRESS REPCOT. CONTAINS INFORMATION ON II) CURRENT EXPERIENCE, (II) CATE $\triangle N D$

STATISTICS, (III) NUCLEAR TEST PROGRAM (IV) PLANT TEST PROGRAM, (V) OTHFR OIPECATING

EXPERIENCE, AND (VI) MAINTENANCE ONO AJOITICNS.

AVATLARILITY - USAEC DUBLIC DCCUMENT PONM, WASHINGTCN, D. C.

\#OPEFATING EXPERIENCE + FERMI (LMFBF) + MAINTENANCE ANO REPAIR + FEACTCF, GREEDEF + FEACTOR. FAST + TEST, PLANT RESPONSE

$17-22000$

SELECTEO FERMI OPERATING EXOEPIENCE - $\triangle$ UGUST 1966

POWER REACTOR DEVELOPNENT COMPANY

PRDC-EF-36 +. 11 DAGES, DOCKFT 50-1E, $\triangle U E$ UST ICE6

THIS P.EPORT IS ONE CF A SEPIES. SEEMS ADFQUATE IN DEPTH. COVERS JPERATICNS, HEALTH PHYSICS, MAINTENANCE AND MOCIFICATIONS, NONNUCLSAF TEST PROGRAM, AND FACILITY CHANGE.

AVAILABILITY - USAEC PUELIC DECUMENT ROCM, WASHINGTON. D. C. 


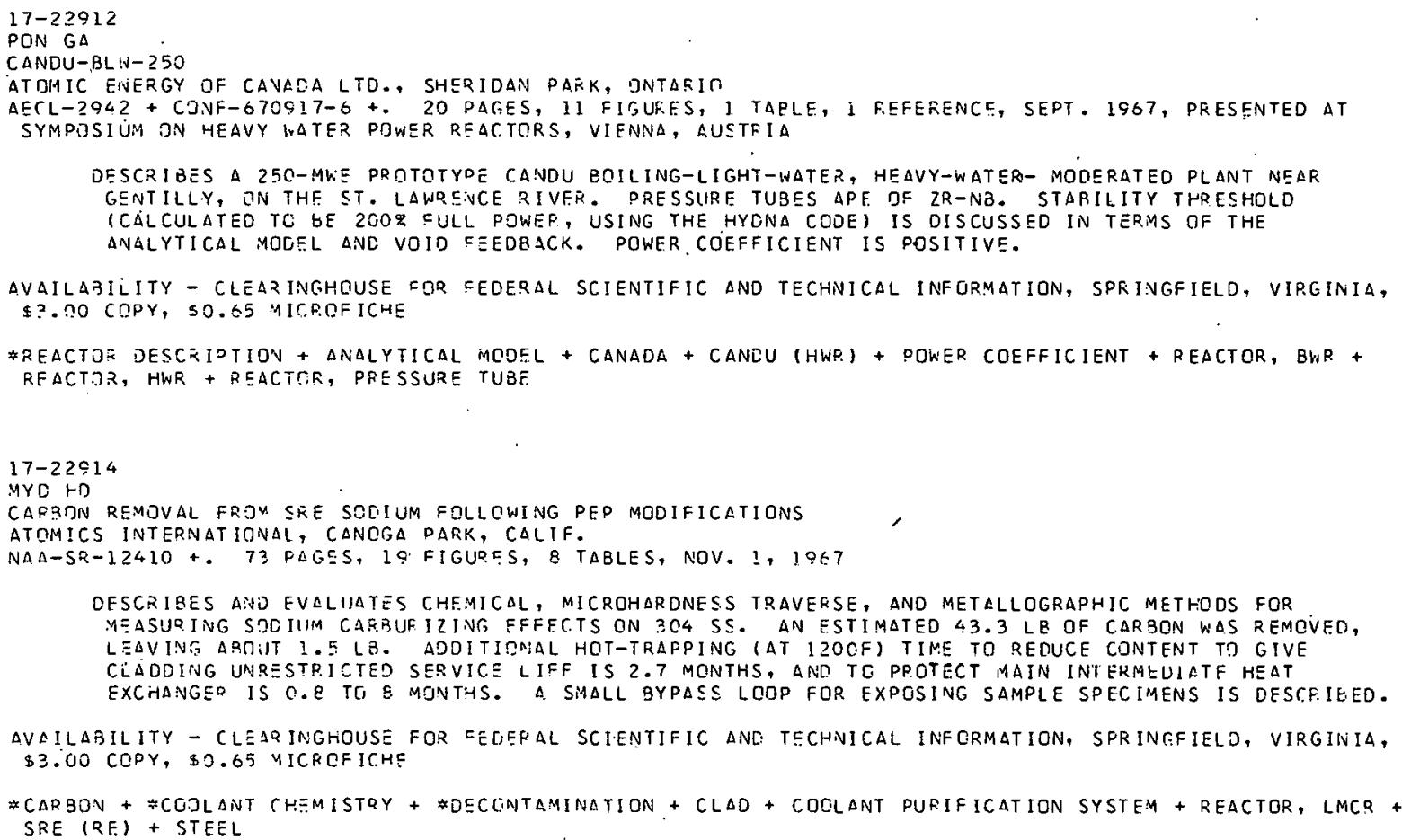

AVAILABILITY - CLEARINGHOUSE FQR FEDERAL SCIENTIFIC ANO TECHNICAL INFORMATION, SPRINGFIELD, VIRGINIA, $\$ 3.00$ COPY, \$0.65 MICROFICHE

*REACTIVITY EFFECT, ANOMALOUS + MSRE (RE) + REACTCR, MGLTEN SALT + REPQRT, OPERATIONS ANALYSIS + VOID CBEFFICIENT 
17-22941 $\triangle L S O$ IN CATEGOPIES 3 AND 1 BAGCOCK AND WILCDX REPORTS PLUTONIUM VITRATE LFAKEGE FKOM POLYETHYLENE BOTTLES BAECOX ANO WILCOX COMFANV

1 PAGE, ATOMIC ENERGY CLEAPING HOUSE 14(6), PAGE F, (FEB. 5,1968 )

(LETTER, JAV. 17) ALTHOIGH NOT REPORTAELE UNDEF IO CFR 20, THIS IS AN EXAMPLE OF LEAKAGE $\triangle S$ IV YDUR. HEALTH AND SAFETY BULLETIN? 5C, DEC. 21, IS67. ON JAN. R, 1968, RCUTINE INSF5CTIDN REVEALED A LEAK FDOM A SMALL CRACK IN A I-GAL PCLYETHYLENE BCTTLE THAT PENETRATED THPDUGH THPEE 4-MIL-THICK POL YE THYLENE BAGS (TWO WITH PGOR HEAT SEALSI, DISSOLVED A 3-IN.-CIAM HGLE IN THE CARBON-STEEL SHELF, AND DRIFPED THRCUGH TWO OTHER STEFL SHELVES. THE EOTTLE KAS GUITE STIFF, AVD CQACK MAY HAVE BEEN CAUSED BY PADIOLYTIC GAS PPESSURE, RADIATION DAMAGE, OR OXIDATION. STAINLESS-STEEL SHELVING AND ACIC-RESISTANT DRIP PANS ARE BEING CDNSICERED.

*LEAK + \#STDRAGE CINTAINER + I NCIDENT, EGUIPMENT + NITPATE + PLASTICS + PLUTONIUM

17-22042 $\quad \triangle L S C$ IN CATERORY 1

RIINYTN 0

COULD WASHINGTJN SURVIVE AN ATOMIC PLANT ELOWUP

2 PAGES, FIGURES, THF WASHINGTON D.C. EXAMINER 1 (14), DAGE 1 DND 16, (DECEMBEF. 7-ID, 1GE7)

(FIRST PART.) REIEF DISCUSSION CF THE OCT. GE FERMI-PLANT FUEL MELTDOWN, THEN A FFMINDER THAT THE DLAVT CONTAINED ENOUGH U-235 TO MAKE LO HIPCSHIMA-SIZE ATOM BOMBS. R.EFERENCFS TO LEC GOODMAN AND SCIFNTISTS INSTITUTE FOR PUBLIC INFORMATION STATEMENTS - A 1OS7 AEC FFPGPT GUISSCD THAT THE WDPST RESULT OF A CPITICAL ACCIUEN, WUULD BE THOUSANDS KILLED AND INJUPEO 45

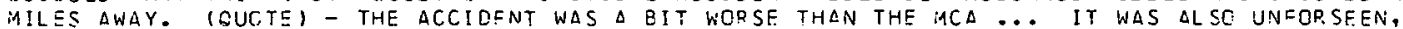
UESPITE ALL THE AECS HIGHLY TOUTED STUDIFS GN THE PROBABILITY OF SUCH ACCIDENTS. OFFICIALS HAVE SINCE DUT OUT A STORY THAT THE FERMI PLANT WENT HAYWIRE - DESPITE ALL THE AUTOMATIC CONTROLS AVD EF.AKES - BFCAUSF. A WORKER DROPPED A BEEF CAN IN THE NORKS (JNOUOTE).

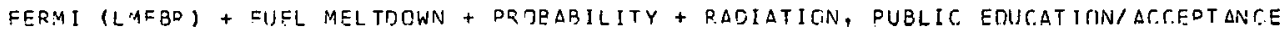

$17-22043 \quad$ ILSU IN CATEGORY I

RUNYONO

INVISIBLE DEATH - PTLLUTION OF THE ATDMIC AGE

2 PAGSS, FIGURES, THE WASHINGTOV D. C. CXAMINER 1(15), PAGES 1 AND E (OECEMBER 1L-17, 19G7)

(SECOND OF THDEF PAFTS,) (QUOTE) ATOMIC POWER PLANTS GENERATE MORE CONTROVERSY THAN ELECTRICITY. THE DISDUTE OVEP SAFETY IN ITSELF IS A MAEASURE DF THE LACK CF KNOHLEDGE AECUUT THE INHERENT PANGERS (UNQUOTE), ARTICIE DISCUSSES FFPMI AND WINCSCALE INCIDSAITS, SHDWS DICTURE DF IEFADIATER AND UNIRRADIATED CHICKEN EMBPOYOS. (OUOTE) THE FCOERAL GCVFRNMENT QUICKLY WASHES ITS HANDS OF RESDONSIBILITY. FOF. INSTANCE, RESPONSIPILITY FOR KECOING NUCLEAR GAQRAGE "IAS =EISTED ON THE STATE OF NEW YORK (UNOUOTC). LEO EOCOMAN HAS COAOILED A WEALTH UF ACTIJAL AATEFILL - ATOMIC PEACTOE ACCIDENTS 1210I, ATGMIC FATALITIES (12SI, AND $\triangle C C I D E N T S$ INVOLVING XंDILTION (OSB).

INTICENT CGMPILATIJN + RADIATION, PURLIC EOUCATICN/ACCEPTANCE

17-22044 LLSC IN CDTEGORY 1

RUNYON D

$\triangle T$ IMIC ENERGY - IS IT WORTH IT

2 PAGES, FISURSS, THE WASHINGTON D.C. EXAMINER 1 (15), PAGES 8 DND 18, (DECEMEER 21-24, 1967)

(THIRD JE 3 DARTS,) ASSERTS THAT A NATIONAL FCPTUNE RF BILLICNS WAS SPENT FOR IE PLANTS THAT ARE SHAKY AT EFST OP TCTAL FAILUPES. $\triangle$ \$120 MILLION PLANT PROOUCED ONLY \$330, COO WOPTH TEF ELECTRICITY HEFTRE A MINIJR ACCIUCNT SHUT IT DCWN COMPLETELY. PI QUA CONTRACT WAS ENDEO LAST WEDNESIAY AFTEE TWO YEARS OF SHUTOOWN DUE TO TECHNICAL OIFFICULTIES IN THE REACTOF CORE. GOVERNMEINT LOSS - \$24 MILLIGN. UMW ATTRIPUTED WIRTZ URANIUM-MINER LUNG-CANCEF $\triangle C T I O N$ TC THIS SERIES IN THE EXAMINER. ILLUSTRATES FFFECTS OF RADIOACTIVITY WITH AFC PHCTO OF BDNE DAMAGE TJ DADIUIA-NATCH-OIAL PAINTER, WHO TOUCHED BRUSH TO TIP OF TONGUE.

RALIATION, PUBLIC EDUCATIONIACSEPTANCE + RADIUM

$17-22046$

UNIVERSITY OF WYOMING YEARLY DPERATIONS SUMMAPY FOR AEC

THF UNIVERSITY OF WYOMING, LAFAMIE, WYOMING

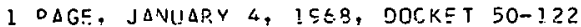

UUH ING IHË YZ̈AR, NO CHANGES JCCURRED THAT AFFECT LICENSF R-E5. SUBMITTED IN DCCOFDANCE WITH 10 C.F. 50.59 .

AVAILABILITY - USASE PURLIC DOCUMENT RONA, WASHINGTMN, O. C:

REACTOR, RESEARCH + EEDOFT, DPERATIONS SUMMAFY 
17-22947 ALSO IN CATEGDRY

DRESDEN I DRDPOSED CHANGE 15-REFUELING WITHCUT CCCKED RODS

COMMONNEALTH EDISON COMPANY, CHICAGO, ILLINOIS

4 PAGES, JANUARY 17,1968 , DOCKEY 50-10, TYPE--8WR, MFE--G.F., AE--BECHTEL

DRESDEN ASKS TO ELIMINATE REQUIREMENT THAT SOME CONTROL ROOS BE COCKED DURING REFUEL ING. SHUTDOWN MARGIN AT ALL STAGES, WITH ONE RCD STUCK DUT OF CORE, WOULD HAVE TO BE AT LEAST 1\%. A CONTROL RDD IN THE VICINITY DOF THE REFUELING ACTIVITY WOULD EE HITHDRAWN AND FEINSERTED BSFOKEE AND AFTER EACH FUEL ADDIYION. ONE-STUCK-ROD REFUELING ACCIDENT RESULTS IN NO CLAD OR FUEL MELTING.

AVAILABILITY - USAEC PUBLIC DOCUMENT ROOM, WASHINGTON, $\therefore$.

*REFUEL ING + *SHUTDOWN MARGIN + ACCIDENT, REFUELING + LDMINISTR ATIVE CONTROL + CONTROL ROD + DPESDEN 1 (BNR) + REACTDR, BWR + TECHNICAL SPECIFICATIONS

17-22948 ALSC IN: CATEGORY :

PLUM BROOK SUPPLIES ADDITIONAL INFORMATION ON CHANGE REPORI 32--CONTROL RODS NATIONAL AERONAUTICS ANC SPACE ADMINISTRATION, LEWIS RESEARCH CENTER.

3 PAGES, JANUARY 12 , 1.9E8, COCKET $50-30$

TESTS WITH CONTROL-ROD-BEARING MATERIALS IZIRCALOY 32, 17-7PH STAINLESS, EO61-T6 ALUMINUM, TI-16 ALUMINUM, AND WAUKESHA METAL 88) SHOVEO WAUKESHA E\& TO HAVE THE ECST COMB INATICN OF PRDPERTIES, WITH 6061-T6 AI $\triangle N$ ACCFPTAELE SECONC. BEARING PLATE IN ALL CASES WAS 304 STAINLESS. TEST CONDITIONS WERE - (1) VELCCITY, 1? FT/SEC (POO DROP VELGCITY), (?) LATFFAL LOADING OF 55 PSI (GREATER THAN THAT EXPECTED), AND (3) 10-MIN RUN, EQUIVALENT TO 3 , OOORCID DROPS. WEAR GF BFARING MATERIAL, DAMAGE TO STAINLESS-STEEL SURFACE, AND THE INITIAL AND FINAL CDEFFICIENT OF FRICTION WEPE DETERMINED. \#\#ROD-DROP TIMES FOR THE REFLECTOR RODS WILL GE CHECKED AFTER INSTALLATION: OF THF ROLLERLESS GUIDES (BEFORE OPERATION) AND RODS 6, 7 , ANO 8 WILL BE CHECKEC MONTHLY FOK 6 MONTHS.

AVAILABILITY - USAEC PURLIC DOCUMFNT ROOM, WASHINGTON, D. C.

\#CONTROL ROD SCR AM MECHANISH + \#TEST, DRQOF + $\triangle E C$ QUFSTION + CONTROL ROD DPIVE + PLUM RRODK (TR) + REACTOF, TEST + RESPONSE TIME + TECHNICAL SPECIFICATIONS

17-22949 ALSO IN CATEGORY 9

UNIVERSITY OF ILLINOIS REPORTS SOLENOIO FAILURE CAUSES PULSE-SAFETY ROD TO FAIL TO DROP UNIVERSITY OF ILLINJIS, UP. RANA, ILLINOIS

2 PAGES, JANUARY 4, 196?, DOCKET 50-151

DURING STARTUP CHECKOUT, THE PULSE-SAFETY ROO FAILED TO DROF. RGD WAS THEN OROPPED BY VENTINO AIR PRESSURE. ROD THEN! OPEQATED PEUPERLY IN REFEATED CHECKS. AFTER $\triangle$ SFCOND FAILUPE TO DRCP OCCURRED DURING THE CHECKOUT, THE SOLENOID VALVE CONTROLLING THE AIR PRESSURE WAS TESTEO AND. FDUNR TO SE THE SOURCE DF TKOUBLE. SINCE NO REPLACEMENT WAS AVAILABLE, THE DIR PPESSURE HAS REDUCEO =RJiA 75 PSI TO 40 , AT WHICH THE VALVE OPERATEO PROPERLY IA REPLACEMENT VALVE WAS OBTAINED). THE PURRER SEATS IN THE G-YEAR-OLD VALVE WEPE WOFN, ALLOWING LEAKAGE. \#\#\#A BACRUF SATCTY SVETSH (ICLENSE OF MIO PRFSSIIRF WITH THF VFNT NFAR THE CDNSOLE) WAS AVAILAELE IN EVFNT OF FAILURE DUR ING RGUTINE SHUTDOWN.

AVAILABILITY - USAEC, PUBL IC DOCUMENT ROUM, WASHINGTGN, D. C.

\#FAILURE, SCRAM MECHANISM + \#INCIDENT, EQUIPMENT + \#VALVE + FAILUFE, EQUIPMENT + OPERATING EXPERIENCE + PRESSUFE, INTERNAL + REACTOR, PULSED + SHUTDOWN SYSTEM, SECONDARY + TRIGA (RR)

17-22950 ALSC IN CATEGORY S

UNIVERSITY OF ILLINOIS FEPOP.TS FAILUPE IN PULSE ROD SOLENOID VALVE UNIVERSIIY UF ILLINOIS

2 PAGES, JANUARY 15,1968 , DOCKET 50-151

THF PULSE RDD FAILED TO DROP RUPING A ROUTINE SHUTOOWN, OROPPED WHEN MANUAL VENT CPENED, PUT WITHDREN WHEN VENY CLOSED. MASTFR-KEY SWITCH OROPPED ROD, AND OPERATION THEREAFTER WAS NORMAL. CAJSE APPEARS TO BE IN A NUMEER OF MICPOSWITCHES, AND MECHANICAL MOVEMENT OF IAND A HOL OING CONTACT IN) THE UP-ZUTTON. (TWO YEARS AGO SIMILAR DIFFICULTY WAS P.EL IEVED EY LUBRICATIGN ANO SIZF REDUCTICN OF THE BUTTON SLIDE.) SINGLE OCCURRENCE DGES NOT ALLGW THE FINDING THAT A COMPONENT FAILFD.

AVAILABILITY - USAEC OURLIC DOCUMENT ROOM, WASHINGTON, D. C.

* FaILURE, SCRAM MECHANISH + CONTROL ROD DRIVE + FAILUPE, COMPGNENT + INCIDFNT, EQUIOMENT + REACTOR, PULSEO + TRIGA $(P R)$ + VALVE

$17-22951$

G.G.A. ADFA-III PQOPOSEC CHANGES TS TECHNICAL SPFCIFICATIONS 
CATEGRPY 17
ODEDATICNAL SAFETY AND EXFERIENCE

$17-22051$ *CONTINUER:

GUL GENERAL $\triangle T O M I C$ INC CRPNRATED

4 PAGES, JANUARY 3 , 1C6?, DOCKET 50-25?

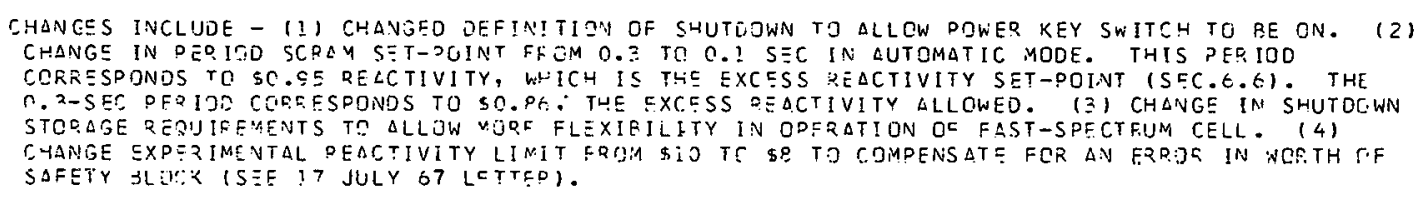

AVAILARILITY - USAEC PIJELIC DOCUMEVT ROCM, WASHINGTON, D. C.

ADMIVISTRATIVE COVTREL + COITICAL ASSFMRLY FACILITY + INSTCUMENTATICN, PERIOC +

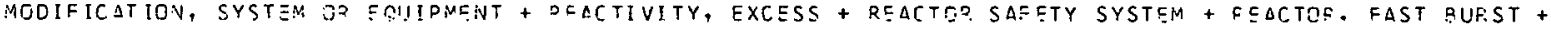
TECHNICAL SDECIFICATIGNS

\section{$17-22952$}

GGA TQIGA YAQK III CHAVGE E--CETCR MINUATION OF SHUTDOWN MAQGIN

USAEC, DIVISIOV OFF REATOO LICEVSIVC, WASHIINGTON, D. C.

3 PAGES, JANUARY 23, ICE3, DOCKET 50-7?7

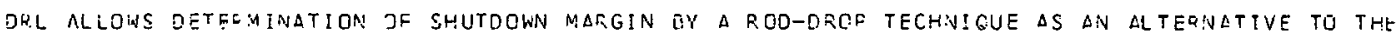
PRESENT NEGATIVE-OEGIDD METHCD. SHUTCOWN MAREIN MUST RE AT LEAST \$0.10 NITH THE MOST

FEATTIVE ZO2 STUCK CUT. DLO METHOR IS TIME-CONSUMING.

AVAILABILITY - USA C EUELIC DOCUMENT ROCM, WASHINGTON, D. C.

4MEAS:JRFACVT, QEATTIVITY + \#SHUTDOWN MARGIN + CONTROL P.OD WORTH + FEACTGR, PESEAFCH + SAFETY EVALUATIOV +

TECHVICAL JUELIr!:AII!IS + TUIGA (OD)

$17-22052$

U OF VIRGINIA REOCET IF TESTS AND FACILITY MOOIFICATIONS

UNIVEESITY OF VIZSIYIA

3 PAGES, JANUAZY :S, : CE.8, JOCKET 50-A2

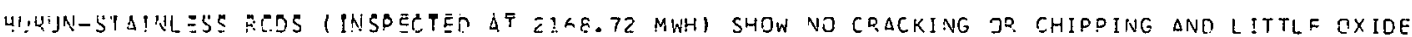

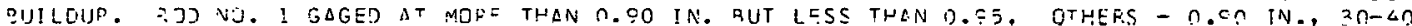
R/4R AT I I THER WERE NO SIGNIFICANT CHANGFS TN DROP TIMES. TNC LIOUID-NASTE TANKS ISCCO GAL FSC4 VIEZE INSTALLF'). A NEW DFLTA-TEMP. MEASURING SYSTEM ILSIVG PLATINUA RESTSTANCE BULBS) ALS IVSTALLED. A DTOL SKIMMMFR WAS INSTALLER.

AVAILABILITY - USAEC DUFLIC DRCUMENT ROON, WASHINGTON, D. C.

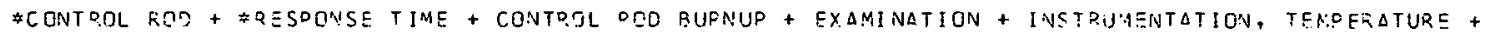

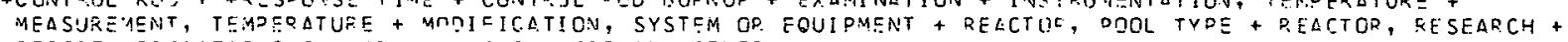
REPTRT, OPERATIONS SUMMARY + WASTE DISPZSAL, GLNERAL

$17-22954$

NORTHROP REPORTS FAILUEE OF TFISA MARK-F FUEL ELCMENT

NORTHROP CORPQRATION, QEVERLY HILLS, CALIFRFNIA

1 PAGE, JANUAZY IO, ISË, COCKST 5O-1BI

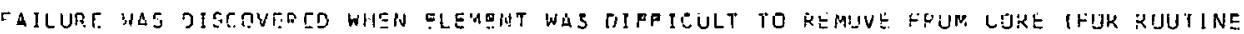

YEASUPE AEVT). A SMALL BLISTER IN THF CLACOING AT THE MIOSLE JF THE ELEMENT WAS ABOUT O.I IN. IN JIAU/ANO 0.05 IN. HIGU, APPADFNTLY DUE TE CLAD WEAKNESS. ELEMENT WAS FROM C-FIVG ANO HAD

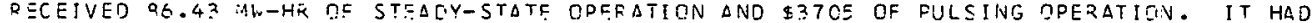
ELONGATES 2.02 IN. SINCE PUJECHASF, DUT NO FOWING WAS $\triangle P P A R S N T$. NO MEASURFABLF

EISSIONTODDUCT FFLEASE.

AVAILARILITY - USAEC CUELIC DOCUMEVT ONGM WASHINGTON, D. R.

FFAILURE, CLADDIYG + EXAMINATION + INCIRERT, GENEPAL + PEACTOF, DILSED + TRIGA (FR)

$17-22955$

LACROSSE KEPORTS ELININLTITN RF RATRIVALVE FPCBLENS

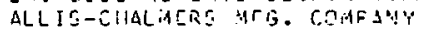

2 PAGES, JANUARY 22, , OGg, DOCKET $115-5$, TYPF--EWR, NFG.--A.C., AE--SGT + LUNOY

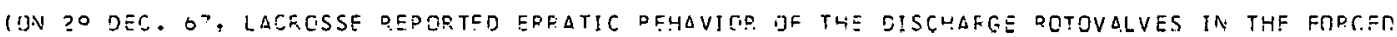
CIP.CULATION LOOPS). THF VALVES AEE COUELE-ACTUATING - THE PLJG IS ORIVEN INTC ITS SFAT AT THE LIMITS RE TRLVEL. IN EETWEEN WHITH IT MOVES EDESLY WITH NO CONTACT OF SEATING CACES. A MAVUEACTUEERS REDAESTNTATIVZ DETFFMINES THAT THE VALVES NEFE SEJNG WECGEO TOJ FAR IN THE SECT WHEN COLO. THE PLUG LEADS THE SEAT DURING HEATUP, CAUSING BINDING DURING MOVEMENT. $\triangle F T E R$ READJUSTHENT, THE VALVFS WDFKED DRCPERLY, \#\# CLOSUAE TIMES, AT VARIOUS TEMPERATURES DNO FLOW, WERE BETWFEN 13.2 AND 14.5 SEC AVD SHCWFD A SLIGHT DECFEASE WITH INCREASED FLOH. 
CATEGCRY 17

CPERATIONAL SAFETY AND EXPERIENCE

$\because 7-22955 \quad$ *CONT I VUEC:*

AVAILABILITY - USAEC PURLIC DCICUMENT RQRM, WASHINGTON, D. C.

\#RESPONSE TIME + WVALVE + FLOW, RECIFCULATICN + LACFOSSE (BVR) + MAIN COOLING SYSTEM + PEACTOR, BWR + TFSTIVS

$17-22057$

DOW CHEMICAL PROPOSEC AMEVDMENT 2 - USE CF $\triangle N$ AM-3E SOURCE

DOW CHE.AICAL COMPANY, MIDLAND, MICHIGAN

4 PAGES, JANUARY 12,1968 , DOCKET 50-26.4

PE:JUESTS USE JF AN LN-BE SOURCE IN DLACE CF PFESENT PO-RE SOURCE. JRIGINAL PLAN TO SUGSTITUTE AN ANTJMONY SUURCE FOR THE POC-PE SFURCE IRFCAUSE THE FORMEK GREW IV STRENGTH DND THE LATTEK DIMINISHED CRCIM IPRADIATISUI IS NRT PRACTICAL SECAUSE OF LESS FULL-POWER CIPCRATION THAN PLANNED AND SECAUSE SRURCE CONTAINEF IS LONG AND THIN, FAVORING AN ALPHA RFACTION BUT MITIGATING AGAINST AN EFFIRIIENT GAMMA REACTION. CALCULATIONS SHOW FISSION RATE OF 6 WATTS I4 NATTS/GRAM, GCIAPAREG WITH TRIGL FUEL VALUE OF IC. iN/GRAM AT I MH).

AVAILABILITV - USAEC DUELIC DOCIJAENT ROOM, WASHINGTON, O. C.

* AMERICIUM + MATHE 1ATICAL TREATMENT + \#SOUUPCE, NEUTRON + \#THERMAL ANALYSIS + MODIFICATION, SYSTEN OP EQUIPMENT + 2. $\triangle C T C R$, RESEARCH + TRIGA (RR)

\section{$17-2 \geq 958$}

U CF NYJAIVG YEAPLY TOEPATITN SUMMARY FRR $\triangle E C$

UNIVERSITY JF NYJAIVE, LARABIE, WYYCMIING

1 FAGE, JAVUARY 15 , 1968 , DUTKET 50-1?2

2EPRRTS I NCW MEMMGCR TO TAKF TH= DLACE CF ONE LEAVING THE REACTOF HAZARDS COMMITTEE

AVAILABILITY - USAEC PUELIC DICJMENT ROQN, WASHINGTON, D. C.

REACTOR, RESEARCH + REPORT, UPERATICNS SUMMAFY + SAFETY REVIEW

$17-2295^{\circ}$

PEACH BOTTCM CHANGE EZQUEST $=5$ - FT. ST. VRAIN PROOF TEST FUEL ELEMFNTS

PHILADELDHIA ELECTRIC COMPANY

4 PAGES, OCTORER ?6, 1967, ODCKET 50-171, TYPE--HTGR, MFG--G.A., $\triangle E--B E C H T E L$

RERIJESTS AODITIIN OF TECH.-SPEC. SECTION 7 - TEST ELEMENTS. SECTION 7-1 GIVES RFVISED FUEL ELEMENT TESCQIPTION. TWT EUEL ELEMENTS ARE TO BE IRRAOIATEO FOR 3ON FPD, AFTER WHICH $\triangle T$ LEAST ONE ELEMENT HILL BE REMGVEO. THE REMAINING ELEMFNT WILL BE IRRADIATEO $\triangle T$ MOST UNTIL THE NEXT RECUELING.

AVAILABILITY - USAEC PUSLIC ONCUMENT OGOM, WASHINGTON, D. C.

\#FUEL ELEMCNT + FIRRAOIATICTH TFSTING + \#TEST, PROOF + PEACH 3OTTCM I (HTGR) + REACTOF, HTGR + TECHVILAL SPECIFICATIONS

$17-2 \geq 9 \leqslant 0$

PEACH BCTTCIM I CHA.NGF REQUEST S. SAEETY ANALYSIS REPORT - FUEL ELEMENT PROOF TEST FHILADELPHIA ELECTPIC COUPANY

3S P AGES, 15 FIGIJRES, 4 TAELES, I S PEEERENIFF, OCTOBER ?6, 19S7, NOCKET 50-171, TYPE--HTGR, MFG.--G.A., $\triangle E-D E C H T E L$

DEPORT COVESS TWC FT. ST. VPAIN PROLF-TFST FUEL ELEMENTS TC EE IRRAOIATED DT PEACH BOTTOM. THESE HAVE A HIGHCR IIOANIUY/LOWEP THOFI UN, CONTENT AND NO BURNAPLE POISONS BUT WILL HAVE LITTLE EFFECT IN CGFE FEACTIVITY (INCEEASE PER ELEMENT IS $0.012 \%$ ). TOLERANCE INE URANIUM LOADING IS 3R, BUT THOF. IUM TCLERANCF IS R.ROD II5\% TO ALLOW FOR VARIATION IN FUEL-PARTICLE LVVD FUEL-ROT DAFAYET:R.S.

AVAILARILITY - USAEC JUELIS DFCUMENT ROOM, WASHINGTON, D. C.

* FUEL SLEMENT + *IRZADIATIDN TESTING + \#TEST, PROOF + PEACH BOTTCM I (hTGR) + REACTOR, HTGR + SLFETY ANALYSIS + TECHAICAL SPECIFICATIONS

$17-22965$ ILSO Il: CATEGORY 1

TOMS J

NEW D. C. DAPER CRUSADES AGAINST NUCLFAK SCOUFGE

2 OAGES, I FIGUSE, THE OAK RIOGER.20(12), PAGES I AND 4 (FEBRUARY G, 1968)

(MEDILL WEWS SEDVICE) DISTUSSES DEC. 7, 14, AND 21 , 1057, ARTICLES IN D. C. EXAMINER 8Y DAMON RIJVYDN, JP... WUO ASSERTS THAT 200 U. S. REACTORS ARE POTENTIAL EOMBS. CITES WINOSCALS AND FERMI ACCINENTS, $\triangle N O$ CITES LEO GOGEMAN AS COMPILING MUCH OF THE INFORMATICN FP.OM $\triangle E C$ SOUR.CES. * \#ISCUSSES LEC REDLY CITING THAT PUPLISHERS IGNORFD FACTUAL ERRDRS POINTED OUT AFTER FIRST 


\section{- OPERATIDNAL CATEGORY 17 TATY AND EXPERIENCE}

$17-22990$ \#CONTINUIED*

BOFHNE EN

SOME RELATED FAILURES DF MEN AND EQUIPMENT

I-I-E CIRCUIT BP.FAKEF COMFANY, PHILADELPHIL, PC.

P PAGES, 8. F.IGURES, PAGES 642 TO 650 OF PROCFEDINGS OF THE AMERICAN POWER CONFERENCE, VGLUME XXIX, APQIL $25,1967^{\circ}$

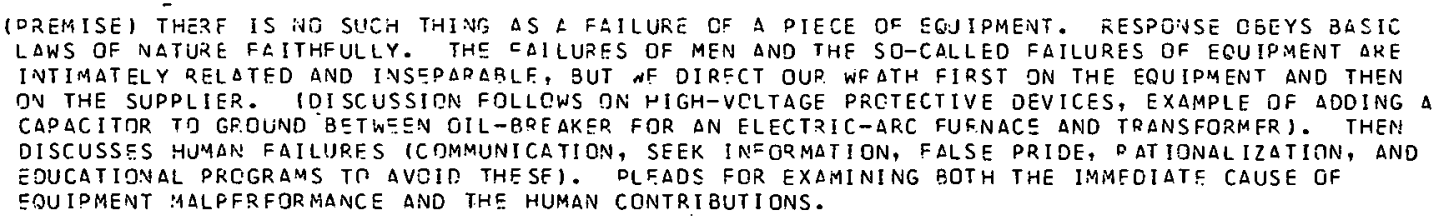

AVAILASILITY - AMFRICAN POWER CONFERCNCF, ILLINOIS INSTITUTE OF TECHNOLGGY, TECHNOLOGY CENTER, CHICAGO, ILLINDIS 60616

*FAILURE, DESIGN ERRDR + \#INCIDENT, EOUIPMENT + FAILURE, EQUIPMENT + INFORMATION RETRIFVAL

$17-22991$

AMES WC + LUX JA

AN EXPFR IMENTAL INVESTIGATION OF HYEROGEN DAMAGE IN BOILER TUBING

PUELIC SERVICE ELECTPIC AND GAS COMFANY, LINOEN, N.J. + BABCOCK AND WILCOX, OHIO

15 PAGES, 14 FIGURES, 3 TABLES, 4 REFEQENCES, PDGES 76 ? TO 777 OF FRTCEEDINGS CF THE ANEPICAN OCWER CONFERENCE, VOLUME XXIX, $\triangle P Q I L 25,1967$

DISCUSSES RESIJLTS OF 6-YEAR STURY CN INDUCING HYDROGEN INTO CARGON STEEL, WHERE LAFGER VOLUME DF METHANE FORMFD RURSTS GRAINS. DAMAGE IS A SECOVDARY FOPM OF CORROSION, WHEN HYDPOGEN RELEASED IN PRIMARY CORROSION CANNOT FSCAPE A HARD, BRITTLE OVERL AY. A CORRDSIVE CONTAMINANT IS REQUIRED FCR DAMAGE IV LESS THAN SEVFFAL THOUSAND HOURS. STEAM QUAL ITY IS NCT IMPORTANT. TUBES WITH DSPOSITS $\triangle R E$ MRRE SUSTEPTAELE THAN CLEAN TUBES. CONTAMINATION NEEDES IS RELOW THRESHOLO OF SPECIFIC CONDUCTIVITY MEASUREMENTS, AND HYDPOGEN EVALUAT ION IS NOT A REL IAPLE INDICATION THAT DAMAGF IS IN PPDCESS.

AVAILABILITY - AMERICAN POWER CONFERFNCE, ILLINOIS INSTITUTE OF TECHNOLOGY, TECHNOLOGY CENTER, CHICAGO, ILLINDIS SOS16

\#HYDRIDE + \#OUT OF DILE LOODS AND EXPERIMENTS + COOLANT CHEMISTRY + CGRRDSION + EMBRITTLEIAENT + FAILIJRE, CLADDING + FAILURE, TURING + STEEL + SURFACE FILM DEPOSIT

17-2209? ALSO IN CATESORYY 9

MCCORO RV + CORBETT PL

HIGH FLUX ISOTOPE REACTOD, QUAPTERLY PFPORT, JULY-SEPTEMAER OF 1967

OAK RIDGE NATIONAL LABORATOPY

ORNL-TM-2073+. 26 PAGES, ? FIGUPES, 22 TABLES, NOVEMEER 13.1967

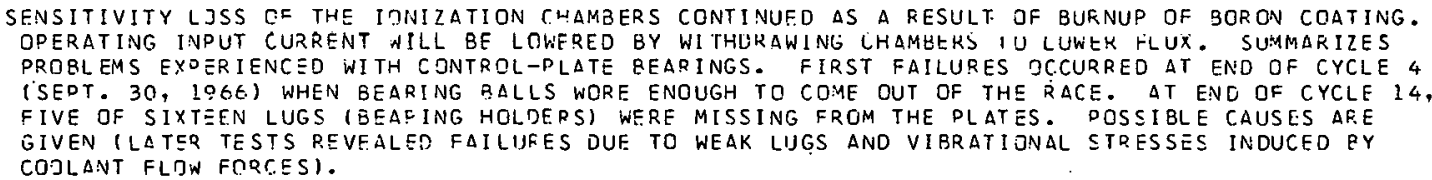
COOLANT FLDW FORCESI.

AVAILABILITY - CLEARINGHOUSE FOR FÉDEPAL SCIENTIFIC ANO TFCHNICAL INFORMATICN, SPRINGFIELD, VA., \$3. OO COPY. $\$ 0.65$ MICROFICHE

\#CCNTRJL RUD + \#FAILUFE, SCRAM MFCHANISM + FAILURE, INSTRUMENT + HFIR (FTR) + HYDRAULIC EFFECT +

INSTRUMENTATION, DOWER RANGE + REACTOR, FLUX TRAP + REPORT, OPERATICNS + STRESS + VIBRATION

$17-22093$

MCCORD RV + CORBETT RL

CURIUM DECONTAMINATION OF PRIMARY CODLANT SYSTEM

OAK RIOGE NATIONAL LALORATORY

ORNL-TM-?078+. 4 P $\triangle G E S, 1$ TAPLE, 1 FIGURE, PAGES 17-20 JF HIGH FLUX ISOTOPE REACTOR QUARTERLY REPORT, JULY-SEPTEMBER OF 1967

CONTAMIVATIJN RY TRANSPLUTOMI UM ISOTOPES OCCURPED DUE TO SUCCESSIVE RUPTURE OF IE TARGET PODS. MAIN CONTAMIVANT WSS CURIUHA-244, AN ALPHA EMITTER. DEMINERALIZERS AND FILTERS WEPE NDT EFFECTIVE IV REMGVING CONTAMINANTS FROM SYSTFM. LANTHANUM NITRATE WAS INTROUDCED TO GIVE A SYSTEM CONCENTRATION OF I POM LA. THE LA SEEMED TO IONIZE THE CM AND ENABLED THE DSMINERALIZERS TO STRIP IT FROM THE SYSTEM.

AVAILABILITY - CLEARINGHDUSE FOR FEDEPAL SCIENTIFIC AND TECHNICAL INFORMATION, SPRINGFIELD, VA., \$3. ON COPY, \$0.65 MICROFICHE

\#DECONTAMINATION + COOLANT CHEMISTRY + CURIUM + HFIR (FTR) + LANTHANUM + MAIN COOLING SYSTEM +

REACTOR, FLUX TRAO + REDORT, OPEFATIONS 
17-23143 ALSC IN CATEGOPY C

ANALYSIS OF INOPERATIVF CNIVTROL POD AT SAM ONOEDE

SOUTHERN CAL IFOPNIA EOISTN COMPANY

6 PAGSS, JANUARY ?Ó, I 9EB, DOCKCT 50-2ŁO, TYPS--PNE, MFG--WEST., AE--RECHTEL

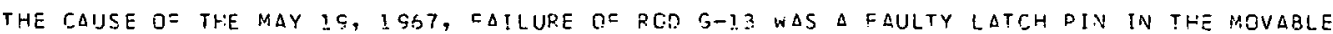

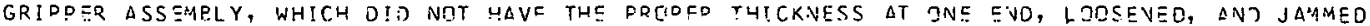
THE MECHANISM AT SOF WITHDRAWN. THE DIN FAILEO WHERE IT WAS FLAPCD ITJ WCLO IT IN DLACE) TC 0.000 IV. IVSTEAD OF 0.25 . QUALI TY-C, QNTROL CHCCKS REVELLED THAT THIS STEP HAD PEEV IDOT INSPECTED AND THAT TWD PELPLE HAD INITIALEO THE SHCET. THIS IS DTTPIBUTED TO RANCOM OCCURRENCE. \# CSULD BE SHJT IOOWN RY OTHER RDOS IF ANOTHEF ACCIDENT IS NGT COMPOUNOEG.

AVAILABILITY - USAEC FURLIC DOCUMENT RDON, WASHINGTSN, D. C.

\#COIVTROL OND ORIVF + \#FAILURE, SCZAM MECHANISM + \#QUALITV CONTREL + CQNTRIJL RED FAERICATION. + EXAMINATION + REACTDP, DWR + SAV GNOFRE (PWP)

$17-2 ? ! 44$

INDIAN PJINT I ANALYSTS CF EFFECTS GF LOST MLTEPIAL IN VESSEL

CONSEL IDATED EDIS?Y CRMPANY DF VEW YOPK

5 PAGES, FEQRUAEY S, ¿QES, DTS,KET 50-?, TYPE--PWE, MFG--P+W, $\triangle E--C C N$ ED

(FFB. 6, TWX) LETTER gE NOV. 2, ICE7, GEPTRTED FINDING EXTRANEOUS MATEOIAL JV TOP RE COPE.

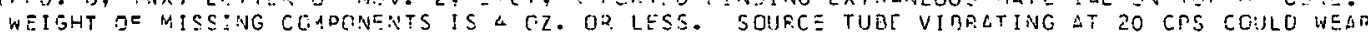
THROUS4 2.1 OO-IN.-THICK STAIVLESS-STEEL CLADDING IN $\angle O$ YEAOS BUT YIICLLY IMPR:THAELE. FOFTTING WOUEO NOT IVCREASE IRON TONTENT CF WATER FNOUGH TO MONITOR. SCRAM TIMES AND NEUTPOV TFACES LCTED SCRAM SHCIN NO INTICATICIN OE STICKING RODS. \#\# IF ALL S SCURCE CADSULES WFPE TO PFLEASF THE OO ZF RE, NORMAL DILUTION TAKCS IT RELDW MOC. ANALYSIS OF DP. INAQY CEGLANT SHOWEZ I PICOC:JP IE/LITFF, ABOUT AS IA OFCINADY TAP WATER. ROUTINE NEUTRON SURVFYS TF PIPINE WILL LOCATE ANY INTACT CAOSUL:.

AVAILARILITY - USAEC DUELIC ORCIJMENT RONMM, NASHINGTON, D. C.

CLAD + FAILURE, SCRAM MECHENISM + UAZAOOS ANALYSIS + INOIAN POINT I (PWR) + FFESSUFE VESSEL + REACTOR, PWR + SDURCF. NEUTRON

$17-23345$ ALST: IN: C.ATFGRZY ?

ELK RIVER QUERIFS AFC ON ITS FESPOVSIRILITY FDP NUCLEAF SAFETY

RIIPALI. GOTPEF,ATIVE POWER AS\$OCI $\triangle T I O N$

3 DAGES, FEBKUAFY E, IS68, DOSKET 115-!. TYPF--BWF, MEG--A.C., $\triangle E--S G T+$ LUNGY

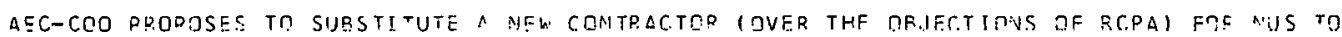
PERFTPM TECHVICAL-SUPPQRT CONSULTLTION SUPVEILLANCE IN THE AREA OE NUCLEAR REACTCA SAFETY. RCPA ASKS AEC TWO QUESTIONS - (I) GCES RCPA HAVE CDMPLETE AND UNRFSTRICTED FESDCNSIEILITY TC CAREY CIJT THE LICENSING AGEVCYS GFGUIPEMCNTS FOD NUCLEAR DEACTOR JPEQATING SAFETY. IZI IF YCU

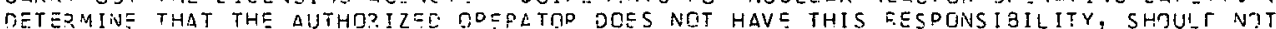

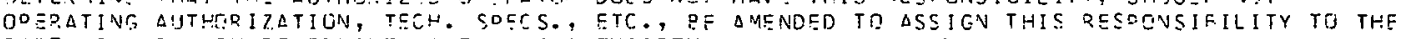

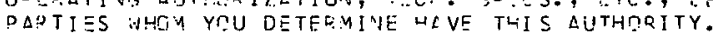

AVAILABILITY - USAEC DUELIC DOCUMENT DDOM, WASHINGTON, D. C.

AOMINISTRATIVE CONTRGL + ELK RIVER (RWR) + REACTCP, GWF + SAFETY REVIEW + TECHNICAL SPECIFICATICNS

17-23167 $\quad \Delta L S \cap$ IN CATFGORY F

GERNANUER G

IAESSUREMENTS OF THE EEACTIVITY DROPERTIES RC THF AGESTA NUCLEAR POWER REACTOR. AT ZERC PCWER $\triangle K T$ I SQLL $\triangle G E T$ DTOMEVFFGI, STOCKHOLM

$A E-20 A+$ L 3 OAGES, FEFERENCES, JULY IOC 7

FOR THE $\triangle G E S T A$ EEACTOR, MDDERATCR LEVEL $\triangle N O$ TEMPERATURE COEFFICIENTS OF REACTIVITY $\triangle N O$ CONTROL-ROD DIFFERENTIAL REACTIVITY WORTHS WERE DETERMINED EY PERIOD MEASUIREMENTS. C.PITICAL

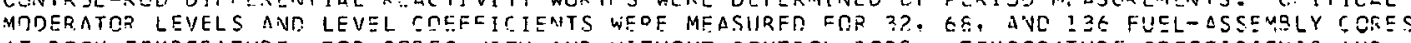

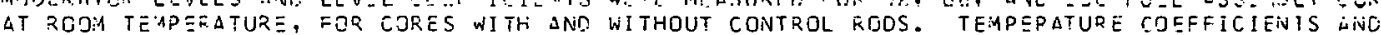
DIFEERENT IAL WE.THS WERE DETEFMINER ECF. THE FULLY LOADED CDRE WITH FULL TANK BETWEEN 30 AND $210 \mathrm{C}$. CRITICAL DOSITIONS FCD RCD COMAINATIONS WERE MEASURED AS A FUNCTION OF TEMPERATUPE. COMDARISCN OF CALCULATIONS WITH EXPFRIMENTAL RFSIIITS IS DISCUSSED.

AVAILABILITY - MICROCARO EOITIONS, INC., ACCOUNTING AND SHIDPING OEPT., WEST SALEM, WISCRVSIN S4EEQ

*AGESTA (PWE) + \#HEASUREMENT, RFACTIVITY + TGMPSRISON, THEORY ANJ EXPERIENCE + CONTZOL FGO WORTH + NDOERATOR COEFEICIENT + Q.FACTOP., DWR

$17-23174 \quad$ ALSC IN CATECTRY \& 
DPEFATIONAL SAFETY AND 17 EXPEPIENCE

$17-? 3174$ *CONTIVIJEC *

EXPLOSIVES ACEITEVT/INCIOENT ARSTPACTS, SEPTEMGFP $1 ? E !-J U N E$ IOGT

ARMED SERVICES EXPLOSIVES SAFETY BOARD, WISHINGTON, D. C.

$A D-660,020+300$ DAGES, CCTORER 1907

TD GIVE GUIJANCF TO THE IVTFPAGENCY CHEMICAL ROCKFT PPOPULSION GROUP IN SOLVING PROBLEMS ON THE SENSITIVITY TF NEW PROOELLFNT MATEZIALS IINITALLV N-F COMPOUNOSI. ALL INCIOENTS INVOLVING RAPID SPTINTA UECUS DECOMPOSITION, PFFSSUQF EXPLOSION, OR DETONATION WILL BE RECORGEO,

SEPOCTED, LND COMPILES. THIS IS APPAKENTLY THE SECOND C.OMPILATION.

AVAILABILITY - CLEARINGHDUSF F:JR FEOERAL SCIENTIFIC AND TFCHNICAL INFORMATION, SPRINGFIELD, VA., I3. OO COPY, \$0.65 MIT,2BCICHE

*EXPLOSIVE, CONVENTIGNAL + \#INCIDCNT COMFILATION + EXPLOSI:ON + INCIDENT, NONNUCLEAR

17-23177. $\quad$ LLST IN CATEGOKIES 13 AND 12

NUCLEAG FUEL SEFVICES, IINC. AUTHCIRIZED TO RESUME OPERATIONS

U. S. $\triangle T$ TMIC ENERGY CCIMMISSIDN, WLSHINGTON, D. C.

3 PAGES, JANUARY 24, 1968, nOCK $=T$ 50-20?

LETTER FROM JIVISION TF MATERIAL LICENSING BASES AUTHORIZATION ON CHANGE 6 IN TETH. SPEC. 7.4 , LICENSE C.SF-1. \#\#FCR. BASIS OF $\triangle E C$ ACTION, SEE LETTERS NSF TO AEC, DATED JANIJARY 13, 15, 1768 .

AVAILABILITY - USAEC DUELIC DUEUMENT KJOM, WASHINGTON, D. C.

\#LICFNSING STATUS JF NUCLEAE DROJECTS + \#NFS + \#RADIATION SAFETY AND CONTRDL +

\#PADIUCHEYICAL PLANT SAFETY + INSDECTION AND COMPLIANCE + TECHNICAL SPECIFICATIUNS

17-23312 ALSC IN CATEGORIES II ANO 19

FAILURES IN PIPES ANE PFESSURE VESSELS CORRELATED TO NUCLEAR POWER PLANT SERVICF

COMMISSARIAT A L-ENERGIE ATRMI QUF, SACLAY (FRANCE). CENTRE D-ETUDES NUCLEAIRES

CEA-BIB-79 +. 32 ? AGES, SEDT. 19E7, IN FP.ENCH

THIS 3 IBLIGGRAPHY DEALS WITH THE PAPERS PUBLISHEO ON THE FAILURES IN PIPES AND PFESSURF

VESSELS COPRELATED TO NUCLEAR POWER PLANT SEQVICE. THE REFERENCES WERE SELECTED FROM

BIBLIJGRAPHIC INDEXES PURLISHED FPCIM 1963 TO JULY 1966 INCLUSIVE. ABSTRACTS ARE INCLUDED.

AVAILABILITY - CLFAR INGHDUSE FOR FECERAL SCIENTIFIC AND TECHNICAL INFORMATION, SPRINGFIELD, VIPGINIA, $\$ 3.00$ C.PYY, \$0.65 MICRRIFICHE

\#FAILIRE, GENERAL + \#PIPING + \#DPESSUPE VESSEL + BIBLIOGRAPHY + BRITTLE FRACTURE + STRESS ANALYSIS +

TEST, BEVCH + TEST, DESTRUCTIVE + TEST, NONDESTRUCTIVE

$17-23315 \quad$ ILSO IN CATEGOPY 13

FQREDKILKSUN LL

ABBOTT LABS REFORTS HIGH I-I3I IN THYROID

ABBOTT LARORATJR IES, CHICAGG, ILL.

2 PAGES, ATOMIC E:S EPGY CLEARING HOUSE 14(E), PAGES 35-36 (FEBRUARY 19, 1963)

(LETTER, JAN. 3) ROUTINE THYFOID COUNTING ON NOVEMBER 27 RFVEALED ONE PERSON WITH O.34 AICRTCURIF. I $247 \%$ PERMISSIQLE) $\mathrm{O}=1-131$. HIS FOUPTH-OUAP.TER THYROID EXPOSURE WAS 5 . 56 P.EMS. NO INCIOENTS GCCURRED, NOR OIO AIR SAMPLES INDICATE CONCENTRATIGN TO EXPLAIN THIS. SEVEFAL WIRKERS SHDNED FLEVATEO THYKOID RIJFDENS IN 1SE7, WITH NC OBVIOUS EXPLANATION. WE $\triangle P E$ RE-EVALUATINA DIF FLOW IN FUME HOROS.

\#FISSIJN PROOUCT, IOCINE + \#INHALATIUN! + \#PERSONNEL EXPOSURE, RADIATION + RADIDISOTOPE + VENTILATION SYSTEM

$17-23316$

WILSON BD

ALSE. IN CATEGORY 13

RELTESE JF 352 POUNDS OF UFS $\triangle T$ TE-SAN JOSE

GENERAL ELECTRIC, SAN JGSE, CALIF.

1 DAGE, AT D:AIC ENERGY CLEARING HOUSE 14(E), PAGE 26 (FFBRUARY 19, 1968 )

(LETTER, JAV. 25) THE PELCASE IN QLDG. J ON DEC. 30, I9E7, MAY HAVE CAMAGED A \$20, 0OO

FLUTR IDE-MEASUR ING INSTRUMENT, SUT NA EXPOSURE OR RELEASE OCCURRED. A MECHANIC TIGHTENED A

LEAKING CAP TN 1/4-IN. SRASS PIPF AIPPLE, WHICH BROKE GFF BEFORE HE APPLIFD FORCE. HE WAS

WF ARING A FULL-FACE FILTERED-AIF MESK. ON\& OF THE MATERIAL HAS BEEN RECOVERED.

AIRBORVE REL EASE + MAINTENANCE AND REPAIP. + URANIUM HEXAFLUCRIDE

$17-23317$

PR INCETD: UN IVECSITY CITED FOR NONCOMPLIANCE

PRINCETON UNIVEK SITY, PR INCETON, 'NEW JEPSEY 
CATEGOPY 17
OPERATIONAL SAFETY ANO EXPERIENCE

$17-23317 * C \cdot 3 N T I N U \equiv D *$

2 DAGES, ATOMIC ENE?GY CLEARING HOUSE 14(E), PAGES 36-3.7 (FEBRUARY 10, 1068)

(LETTER, DEC. 15) FOLLOWING A CF-25: RELEASE DURING GLOVE-BOX DPERATIONS SEPT. IC, 1967 , DRIVCET JN CITED FRP. INADEQUATE SURVEYS, CELAYED NOTICE, ANE NOT FOLLOWING RADIATION SAFETY GUIDE IN N.JT USING A GLOVE 9OX. (PEPLY, JAN. 3) a COMPLETE PEVIEW OF CF-252 HANDLING DRCCEOURES HAS RESULTED IN INTENSIFIED SUPVE ILLANCE.

*CALIFOR.NIUM + \#CONTAMINATION + \#FAILUPE, AOMINISTRATIVE CONTPOL + INSPECTION AND COMPLIDNCE + RADIATION SAFETY ANO COONTORL

$17-23318$

U. S. R $\triangle O I U M$ COPP. CITEO FDR NONCOMPLIANCE

U.S. RADIUM CORPORATION

2 PAGES, ATOMIT, ENERGY CLEARING HOUSE 14(8), DAGES 37-58 (FESRUAPY 19, 1968)

(LETTCE, JAN. E) CITATION FOP NOT INFRRMING EMPLOYEFS OF POSSIBLE PRESENCE OF 3 CUR IFS OF LOST AM-241. (REDLY, JAN. 12) IMAJQR (HANGFS IN ORGANIZATION SINCE JAN. I INCLUCF DNE MAN TAK ING FULL FESPONSISILITY FOP LAE CPERATIONS, CHANGES IN PROCEDURES, AND A NEW PLANT IN 1968. CORRECTIVE STCOS ARE - 1L) LCCFSS TO LAB LIMITED TD OPERATORS ENGAGED IN PPJCESS, WHC $\triangle R E$ ALSO RESPCNSIBLE FOR CLEANUP, 121 NE RULK DSDERS PLACED, SFDAPATE VIALS JFDEPED FOR EACH CDAPACT, (3) MEKE OPERATORS TO BE HIRED.

- AMESICIUM + HINGDECTION ANO COMPLIANCE + FSQURCE, RADIATION, LOST + OECONTAMINATION + GLOVE ROX + RACIATION SAFETY AND CONTROL + SOURCE, NEUTFON

17-23310 ALSG IN CATGGTRY 15

SOLARI AJ

UNIVERSITY OF MICHIGAN FCDORTS A OOSSIQLE OVEREXPOSURE

UNIVERSITY JE VICHIGAN, ANN ARBOR, MICHIGAN

I PAGE, AFOMIC ENERGY CLEARINF HOUSF, 1418 , PAGE 39 (FESRUAPY 26, 1958)

(LETTER, DEC. 27, 1968) A GRADUATE STUDENT WAS A TEMPURARY DISHWASHER AT THE NUCLEAR MEDICINE UVIT FROM APRIL 24 AUGUST 31 , IOS7. HIGHEST RODIATION LEVELS IN THE HOT RODM WHERE SHE W'JRKED WTRE 1-2 MR/HR. EILM EAOCF PEFDRT DATED OCT. 3 GIVES A 1, 69O AN!O SIO MR FECQRD. DERSON IS ivJ LONGEQ A STUDENT AND TANNOT RE TRACED. SOME BELIEVE SHE MAY HAVE LEFT HER LAB Ci) AT AND BADGE IN THC HOT ROOM.

\#PFRSTNNEL EXPOSJPE, FIADIATION + INCIOCNT, NCNREACTOP + RADIATION SAFETY AND CONTROL

17-2Z330 ALSO IN CATEGORY C

MOP I ARTY KJ

EBF-II INSTF UNENTATION EXPERIFNCES

ARGONNE NATIONAL LABOFATORY

ANL-7390 +. 7 DAGES, 3 FIGURES, PASES 22-28 OC PROCEEDINGS OF THE SYMPOSIUM ON LIOUID HETAL

INSTRUIMENTATION $\triangle N D$ CONTRDL: MARCH ?, ICF7

EXPERIENCES WITH THE FBR-II PRESSUPE INSTRUMENTATIGN, SOTH STATIC ANC DIFFERENTIAL, THE TEMPERATURE-MEASURING OEVICES, ANO WITH THE LEVEL INDICATIONS ARE PRESENTEO. THE PRTELFMS ENCOUNTERED ARE RIUTLINED, AND THE CORRECTIVE ACTION TAKEN TO PECTIEY A POCBLEM IS GIVEN WHEPE DOSSIRLE. THE IMPOETANCE OF FF.E-INSTALLATION CATA IS STRESSED. CALIBRATIJN AIND REFAIR PROCCDUPES USFO FOR FILLED SYSTEMS $\triangle R F$ INCLUDEC FOR GENERAL INFORMATION AND TO PCINT DUT THE TYPE DF INFORMATIIJN IHAI MUS'I HE INLLUULL' IN IHE PRE-INSIALLATIUN CALIHKATIUN CHECK UNA COMPONFNT.

AVAILABILITY - CLEARINGHOUSE FOR FEDERAL SCIENTIFIC AND TECHNICAL INFORMATION, SPRINGFIELO, VA., S. OO CODY, \$O.S5 MICEDFICHE

\#INSTRUMENTATION, PQCTESS + EBR 1 AND 2 (DE) + INSTRUMENTATION, LIGUID LEVEL DETECTION + INSTRUMENTATIJIA, PRESSURE + INSTRUNENTATION, TEMPERATURF + DPFPATING EXPERIENCE SUMMAFY + REALIUH, HKEEUEK + KCACTUL, LMCR

$17-23331 \quad$ ALSO IN CATEGORY 5

SCITT CS

FERMI DRACESS INSTRUMENTATION

ATCMIC DOWER DEVELIDMENT ASSOCIATES, INC., DETRCIT, MICHIGAN

ANL-73PO +. 8 PAGES, 12 FIGUFES, PAGES $29-36$ OF PROCEEDINGS OF THE SYMPOSIUM ON LIOUIO METAL

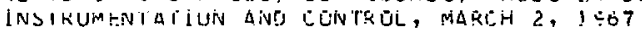

TPERATING EXDED IENCE AND EOUIPMENT DESIGN ARE RFVIEWER FOP. THPEE KINDS OF PROCESS INSTRUMENTS UEN THE EERMI PEACTOR. PRORLEMS ASSOCI $\triangle T E O$ WITH PLUGGFD PROCESS LINES, IN-PLACE CALIBPATION, AND THE DIFEICULTY OF REMOVING UNITS FOR MAINTFNANCE ARE DISCUSSED COMPONENTS.

AVAILARILITY - CLEARINGHOUSE FOR PEDERAL SCIENTIEIC AND TECHNICAL INEOPMATION, SPR INGFIELD, VA., \$3.OO COOY, $\$ 0.65$ MICOOFICHE

*INSTRU:AENTATI JN, PROCESS + \#OPERATING, EXPERIENCE SUMMAPY + EQUIPMENT CESIGN + FERMI (LMFBR) + INSTRUMENTATION CALIBRATION + INSTR,LMENTATION. FLOW + INSTRIIMENTATIDN, DRESSURE + 
$17-23331$ \#CONT INUED*

INSTRUAAENTATION, TEMPERATURE + REACTOP, RREEDER + REACTOR, LMCR

$17-23332$

ILSO IN CATEGORIES 4 AN:D 9

STPAHL H

SNAP SYSTEM INSTRUMENTATION

ATOMICS INTERNATIENAL, CANOGA DARK, CALIF.

ANL-7380+. 3 YAGES, 2 TABLES, I REFERENCE, PAGFS 37-39 OF PRCREEOINGS OF THE SYMPOSIUM ON LIQUID METAL INSTRUMENTATION ANN CONTROL, MARCH $2,1 \subseteq 87$

THE EXPER.IENCE GAINFD DURING OPEPATION OF SNAP PEACTORS WITH LIOUID-METAL PRDCESS INSTRUMENTATIUN IS PRESENTEO. THIS EXPERIENCE IS QASFO ON THE OPERATION OF SEVEPAL SNAP REACTOR SYSTEMS AT TEMPERATURES UP TO $1300 \mathrm{~F}$ FOR PERIODS OF UP TO 10, OOO HR. SEVERAL TYFES O= TEMDEPATURE AND ORESSURE DEVISES WERE INSTALLFD IN. A LOOP, AND THEIR PERFORMANCES WERE COMPARED AND EVALUATFO PRIJR TO SELECTION OF INSTRUMENTATION FOR THE SEDR TESTS.

AVAILASILITY - CLEARINGHOUSE FDR FEOERAL SCIENTIFIC AND TECHNICAL INFORMATION, SDRINGFIELD, VA., \$3. OO COPY, \$0.55 MICROEICHE

* INSTRUMCNTATION, DROCESS + \#OPEFATING EXPERIENCE SUMMARY + \#SNAP, GENERAL (SR) + HIGH TEMPERATURE + INSTRUMENTATION, FLOW + INSTRUMENTATION, LIOUID LEVEL DETECTION + INSTRUMENTATION, PRESSURE + INSTRUMCNTATION, TEMPSRATURE + INSTRUMENTATION, TESTING + RTACTOR, LMCR + REACTOR, SPACE

$17-23333$

TUPNER GE

ALSO IN CATEGORY 9

SCTI SODIUM INST ZUMENT RPERATING EXPEPIENCE

ATOMICS INTERNAT IDNAL, CANOGA PARK, CALIF.

ANL $-7380+.3$ PAGES, FAGES $40-42$ DF PROCEEDINGS OF THE SYMPOSIUM ON LIQUID METAL INSTRUMENTATION AND CONTROL, MARCH 2, 1 C 67

SODIUM PRESSIJRES ARE MEASUREO RY NAK-FILLED PRESSURE TRANSMITTERS. SODIUM LEVELS ARF. MEASUREO IN FOUK DIFFEFENT NAYS - INDUCTION COIL GLGES, $\triangle$ BIJEBLF GAGE, RADIATION GAGFS, $\triangle N D A$ DISPLACER-FLDAT GAGE. OPEKATION CF THE FLOWMETFPS AND PRESSURE TRANSMITTERS HAS REEN QUITE SATISFACTGRY, WITH NO PARTICULAR DIFFICULTIES ENCDUNTERED. EXPERIENCE WITH THE FOUR DIFFERENT LEVEL GAGES HAS PJINTEO OUT SOME PRGELEM AFEAS WITH EURBLES AND RADIATIGN-TYPE GAGFS, NHEPEAS JPERATION OF THE INDUCTION-COIL DND DISPLACER-FLOAT TYPES HAS BEEN GENERALLY SATISFACTDRY.

AVAILABILITY - CLEAR INGHOUSE FOR CECERAL SCIENTIFIC ANO TECHINICAL INFCRMATION, SPRINGFIELD, VA., S 3. OO COPY, \$O.65 YICR.JFICHE

* INSTRUMENTATION, PROCFSS + \#OPERATING EXPERIENCE SUMMARY + HIGH TEMPERATURE + INSTRUMENTATION, FLGW + INSTRUMENTATIOIN, LIOUIO LEVEL DETECTION + INSTRUMENTATION, PRESSUF.E

$17-23360$

ALSO IN CATEGCRY 11

$\cos$ nat

FAILURE DF CDNTAINIENT ELECTRICAL PENETRATION AT SAN ONOFRE, FEB. 7

SOUTHERN CAL IFIRNIA EDISON CDMPANY, LOS ANGELES, CALIF.

5 PAGFS, ATDMIC ENERGY CLEARING HOUSE 14(9), PAGES 22-26 (FEBRUARY 26, 1968) DOCKET 50-206

$\triangle F I R E$ ON THE OUTSIDE SE SIDE OF CCNTAINMENT SPHERE IN A CAELE TRAY LEADING TO A SPHERE PENETRATION CAUSED HIGH DRESSURE /TEMPERATURE INSIDE PENETRATION EPC4, FORCING THE OUTEP. EULKHEAD DUT OF THE SHELL ASSEMSLY. NO CAUSE FOR. PFNETRATION FAILIJRE FROM DEFECTIVE MATERIAL JR WIRKMANSHIP HAS BEEN FOUND, CAUSE OF FIRE NDT REPORTED. \#\#\#EPC4 SEPIVED PRESSUFIZER HEATERS, SAFETY INJECTION AND RESIQUAL HEAT PUMP A, FANS A2 AND A4, ROD H LIFT CEIL, ANC $\triangle N$ EAERGENCY LIGHTING PANEL. ELEVFN CASLES IN EDCG (ABCVE $\angle$ ) WERF DAIAAGD BY THE FIEE. DAMAGED EPCO CABLES SEF,VED FAN AS AND. FOUF CONTROL RODS. \#\#PLANT SHUTDOWN WAS OPDERLY, WITH NO RADIATION RELEASE OR TECH.-SPECS. VIOLATION.

* CONTAINMENT PENETRATION, ELECTRICAL + \#FGILURE, EQUIPMENT + \#FIRE + ENGINEERED SAFETY FEATURE + INDEOENDENCE + REACTOR, PWR + SAN GNOFRF (PWR) + SYSTEM OPERABILITY IN ACCIDENT

$17-23361$

ONEIL RW

EXPOSURE DUR ING WELDING AT WATERTOWN ARSENAL REACTOR

ARMY MATERIALS AND MECHANICS PESEAPCH CENTER, WATERTOWN, MASS.

I PAGE, ATOMIC ENERGY CLEAPING HOUSE 14(9), PAGE 27 (FEBRUARY 26, 1968) DOCKET $50-47$

(LETTER DEC. 15) A WELDEP. RECEIVED 1.1 TO 1.3 REMS AUG.-SEPT. 1967 WHILE WELDING IN A GAMMA FIELD (PRODUCED BY MATERIALS AC TIVATED BY UTILIZATION OF REACTOR LICENSE R-65) DF $25-200$ MR/HR. SINCE THIS WAS RECEIVED UNCER CONTRQLLED CONCITIONS, ANO SINCE WELDER HAD ND PRIGRDCCUPATIONAL EXPOSURE, NO FUF.THER ACTION IS CONTEMPLATED.

+PERSONNEL EXPOSURE, PACIATIDN + DQWER UPRATING + REACTOR, POOL TYPE + WELDING 


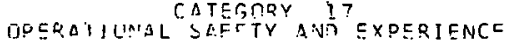

\section{$17-232352$}

ALSO IN CATEGORY IE

CLIFFORD FL

RADIOGRAPHY OVEREXPOSURE AT ROSTON NAVAL SH!PYAFES, I! DEC. 1CS?

BOSTON NAVAL SHIOYARD, BOSTON, MASS

2 PAGES, ATOMIC ENERGY CLEARING HOUSF 1410). OAGES 27-29 (FEQRUAPY 2S, 19SE)

ILETTER, JAN. O) THE RADIOGRAPHEO IN CHAOGE FAILEO TI SUPVEY THE RETURN OF THE SCUPCE AFTER EACH EXPOSURE AND UPON COMPLETION CF THE WOKK. HIS CSSISTANT WORE DOSIMETER ANO FILM BADGE (800 MR, GAYMA), SUT THIS WAS THOUEHT THE LCOST EXPJSIJRE. A HELDER CARQIED THE CGILED TURE BACK TO THE STCREPDOM. \#\# \#ANOTHEP RACIOGPAPHEE SUPPVYYEO THE CONCRETE STORAGE DROM, ANO DBSERVCD HIGH FEADINGS. \#\#ARE-ENACTMENT LEL TU SSTIMATE OF 2.2 REMS, D.R REM IAS INOICATEC 3Y FILM BADGE), ANO 4.2 TO 230 RENS FOR THE THIRO YAN. THE LATTER DOSE WOIJLO RESIHLT IF THE SOUPCE IN THE COILED TUBE WEFE $\triangle T$ T MEXIMUM PPCXIMITY TO THE BODY WHILE HANC-CARRICD. * * CORRECTIVE STFPS INCLJOE - ALL NOT LAS FMPLCYEES REOUIRED TO WEAR FILM EADSE, A COITIGUE HFLD FOD RADIOGRAPHERS, PLANS TO DE-EXAMINE RADIOGRAPUERS YEARLY, AND PROCUREMENT GF AUOIBLE MONITORING DEVICES.

\#PERSONNSL EXPOSURE, FALIATION + \#RAZIOGFLPHY + COSE CALCULATION, EXTERNAL + FAILUFE. CDERLTOR ERFOR

\section{$17-23353$}

CLIFFOR FL

RADIOGRADHY EXOCSURE AT ELECTRIC RDAT, JAN. ZC, 1968

GENERAL DYNAMICS CORP.. GROTON, COUN.

1 PAGE. ATOMIC ENERGY CLEAFING HOUSF 14191 . DAGE 28 (FERRUARY ?6, 1SER)

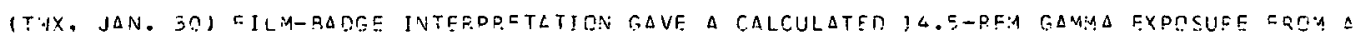

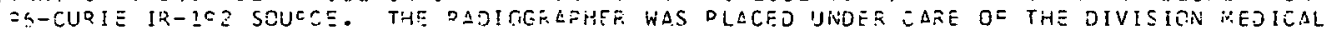
OIVECTOR.

INGIOENT, GENERAL + DTRSONNEL EXPOSURE, DARILTINN + RADIOGRAPHY

17-23364 ALSE IH: CATEGORY 13

RUNION TC

ALsc in Category 13

NUCL DISCUSSES CONEL SERVICES

4 PAGES, ATDMIC EVERGY CLEARING HOUSE 14(9), DAGES 28-3! (FEBRUARY 26, 1968 ) DOCKET 5C-2O!!

(LETTER, TER. 2) WITH THE EXCEPTION OF ITEM IA OH THE SEPI. 26-2C CITATION (FAILUPE OF AH INDIVIDUAL TJ FOLLOW NES POOCEOUDE, THE INDIVIDUAL IS NO LONGEP EMPLOYEO BY VFSI, THE ACTIVITIES CITED WEOEIN COAPLIANCE WITH IECHNICAL SPECIFICATIONS ANO IO CFR 10 AND E5. DETAILED DISCUSSIDN TOLLONS.

* INSHECTION ANJ COMDLIANCE + FAILURE, AEMINISTPATIVE CONTROL + NFS + RADIOCHE!AICAL DQOCESSING

$17-23365 \quad \triangle L S C$ IN CATEGORIES I2 $\triangle N D$ 15

$B \triangle \mathrm{IN} F$

NFS REOTRTS EXPJSURF

NUCLEAR =UEL SERVICES, INC.

2 PAGES, ATDMIC ENERGY CLEAP.INE HIUSE, 1.4(9), DELESS 3:-3? (FEBFUAEY 26, 1968)

(LETTER, FEP. () THE FOURTH-QUARTEF EILM OADGE OF A PLUTONIUM PRCDUCT ION PLANT WTEKKE

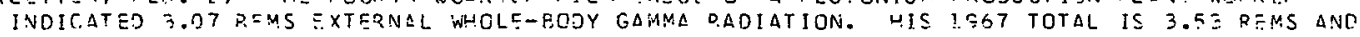
LIFETIME TJTAL Q.19. \#\#ALL STATICNS HITH SIGNIFICANT PLUTONIUN, WILL EE SHIELUEO, AND THE CURRENT EXOJSUPF RATE WILL BE POSTEG OAILY.

\#PERSJNVEL EXOOSIRE, RACIATION + FUEL REPECCESSING + PLUTONIUM + RAOIATION SAEETY LIO CONTREL

$17-23366$

UI RF MARYLANO CITED FOP. NONCOMOLIANCE

UNIVERSITY OF MARYLAND, COLLEGE PARK, MD.

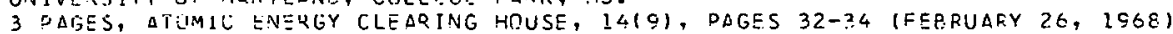

(LETTER, JAV. IS) A DEC. 5-7 INSPECTIJN FEVFALEO (1) INC NNERATOF. ASH RESIDUES WFEE NET SIJRVEYED, (2) SEALED SOURCES WERE NOT LEAK-CHECKED, (7-5) RECDRDS NERE NDT KEDT. THE ? $\triangle D I A T I D N$ SAFETY OFFICER MADE ONLY 2 SURVEYS IN 30 MENTHS. (REPLY, JAN. ZO) RLCIATION SAFETY COMAITTEE INVESTIGATION SHOWS A UNIOUE SET OF CIRCUMSTANCFS. ONE PADIATION SAFETY OFFICER NAS SEPIOUSLY ILL DURING I $9 E 6$ ANO HAS UNABLF TO FULLFIL ALL HIS RESPONSIPILITIES. FOLLDWINE HIS DENTH, THE SECOND RSO, HIRED JAN. 1967, HAD TC TRAIN A NEW SECRETAMY AI A IIME WHEN HE HIMSELC WAS NEW TO THE CAMPUS. CDERATIONAL CONTINUITY WAS THEP.EFCRE LRST. HE LEFT IHE UNIVERSITY LT THE ENO OF DEC. 1967, QUT HIS INTERIM REPLACEMEINT HAS BESN D LICENSSS

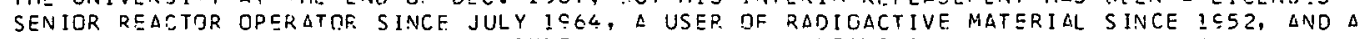
MEHBER OF THE PEACTOR SAEETY COMMJTIEL. WHILE HF IS LEAVING JIJNF 3D, ISEZ, THE NEW F. SO WILL OVERLAD A MOVTH. THE SECRETARY IS OUE FCE PRGMETION AND TRANSFER BUT HAS BEEN CIPECTED TO REMAIN UNTIL A NEW SECRETARY IS FULLY TFAINED. 
$17-23366 \quad \#$ CONTINUEC*

*INSPCCTIJN AND COMPLIANCE + RYORODUCT MATERIAL + FAILURE, ADMINISTRATIVE CONTRDL +

FALIATIJY SAFETY AND CONTROL

$17-23367$

U OF YAEYLAND REPLY EN SFO AVAILABILITY

UN IVEQSITY OF AARYLAND, COLLFGF PARK, MT.

2 PAGES, ATIMIC EN ERGY CLEARING HOUSE. 1410), PAGES 34-35 (FEBPUARY 26, 1968) OUCKET 50-165

(LCTTER, JAV. C) REPLY TO DEC. 22, 10E7, $4 E C$ LETTER. (1) IF AT ANY TIME THE OPERATOR OR REACTOR DIRECTRR FIND THE SENIDR OPERATOR NOT AVAILABLE, HE WILL SHUT THE REACTCP. DOWN. (2) ON SEPT. 25 ANC NOV. 14, WE ASKED FGR SFO EXAMS FCP. THE NEW FEACTOR DIR.ECTOR IDR. AKINI AND,

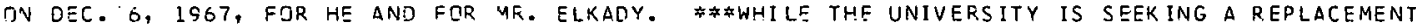
FOR THE RADIATION SAFETY OFFICER, DR. AKIN IS CARPYING OUT HIS REACTOR DUTIES.

* STAFFIVG, tRAINING, GUALIFICATION + inSPECTION AND COMPLIANCE + REACTOR, RESEARCH

$17-2 \geq 368$

CRAMER F:V

SECONDARY PEASGNS FTF INCOROORATING NUCLFAF SAFETY IN NUCLEAR ENGINEERING CURRICULA

6 PAGES, 4 FIGUKES, REFERENCES, NUCLEAR, SAFETY, Q11), PAGES 5S-6.4 (JAN. F5B. 1968 )

TWD UIS:USSIJMS GIVEN. EIRST, SOCIAL PERSFECTIVE - MAJOP PCRTIJN OF DISCUSSION LEVOTED TO EMPHASIZING THAT PUBLIC ACCEPTANCE OF THE SAFETY RECORD IS FGOR AND THERE IS A NEET FOR REALISM. SECEND, SYSTEMS CNGINFCRING APPROACH - NIICLEAR-SAFETY ENGINEERING IS NOT A PRIFESSICIN GIJT A SPECIALIZOTIGN WITHIN NUCLEAR ENGINFERING, AND A SEPARATE COURSE IN NUCLEAR. SAFETY IS DESIRARLE TO INCREASE THE ENGINFERS AWARENESS OF SAFETY PROBLEMS.

* STAFCIVG, TZAINIMG, DUALIFICATION + RADIATION, PUELIC EDUCATIGN/ACCEPTANCE + SAFETY PRINRIPLES AMD PHILOSOPHY

$17-23370$

PSACH BOTTOM ATOMIC PRWER STATIJIN MONTHLY CPERATIONS REPORT NO. 22 PHILADELPHIA ELECTRIC CLIAPANY

14 PAGES, DECEMBER 1967, DOCKET 50-171, TYPE--HTGR, MFG--S.A., AE--BECHTEL

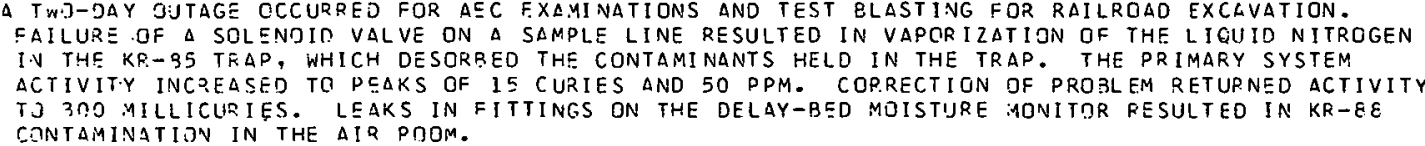

AVAILABILITY - USAEC PUBLIC DOCUMENT PODM, WASHINGTON, D. C.

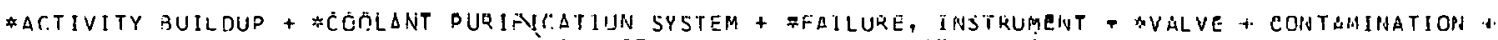
KRYPTJN + MAIN COOLLING SYSTEM + PEACH BOTTOM I (HTSR) + REACTOR, GCR + REACTOR, GR.APHITE MODERATED + REACTUR, HTGR + REPORT, OPERATIONS

$17-23375$

MODIFICATION OF PLUY RROOK CONTROL ROD GUIDES

NASA, LENIS KEESSARLH CENTER

6 PAGES, FESRUAKY 5 , ISEB, DOCKET 50-30

TECHVICAL-SPECIFICATION CHANGE AUTHCRIZES REPLACEMENT OF THE UPPEP ROLLFR. GUIDFS FCR FIVE P.EFLECTOP CONTROL RONS WITH GOLLERLESS GUIDE BEARINGS. THE MAIEPIALS TESTED WHICH EXHIBITED THE REST FRICTION WFAF DROPERTIES APE WAUKESHA METAL Q? AND 6O61-TG ALUMINUM. CHANGE ALLOWS LISE OF THESE CQ COMPARABLE MATSPIALS. PUPPOSF OF CHANGE IS TO FACILITATS OESIGN OF A NEW 2-DIECE UPPE? GRID TO ELIMTNATE THE NEED TO REMOVE EXPERIMENTS WITH ELECTRICAL LEADS FROM THE LATTICE REFLECTOR LGCATIONS FACH TIME THE CORE IS RELOADEO.

AVAILABILITY - USAEC PUBLIC DOCUMENT ROOM, WASHINGTON, D. C.

\#MODIFICDTION, SYSTEN OR. EQUTPMENT + \#TECHNICAL SPECIFICATIONS + CONTROL ROD DRIVE + CORE COMPONENTS + FPICTION + PLIIM BROOK (TR) + REACTOR, TEST

17-23390 ALSO IN! CATEGQRY 5

HADDAH NECK AMENOMENT 17. RE-ANALYSIS OF STEAM LINE PUPTURE CONNECTICUT YANKEE ATOMIC POWER COMPANY

7 PAGES, JANUARY 9,1968 . DOCKET 50-213, TYPE--PWR, MEG.--WEST., $\triangle E--S T O N E$ + WERSTER

REANALYSIS USCS 10-SEC VALVE-CLOSUFE TINE I.VSTEAD OF I SEC (SEE PROPOSED CHANGE 5, 1/ON68) 36-IN. DOUSLE STEAM-HFADER BEFAK RESULTS IN AN OFF-SITE THYRCID DOSE CF 0.05 REM. MAXIMUM REACTIVITY GAINS LESS THAN 1\%. 24-IN. DOUSLF BREAK UPSTREAM FRGM THE ISOLATION VALVES RESULTS IN A MAXIMUM REACTIVITY GAIN GF 1.0!\%. SHUTOOWN MARGIN IN BOTH CASES IS $3.4 \%$, WITH 
OPEP.ATIONAL CATEGORY SOFY 17 ENDERIENCE

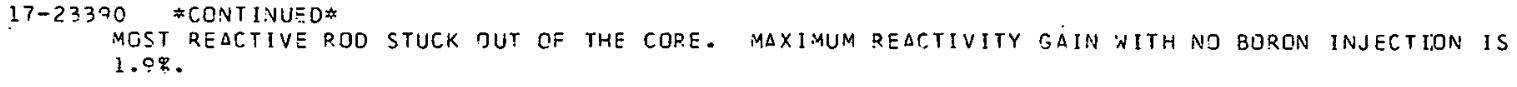

(LETTER, FEZ: 7) IN A P.ECENTLY CONVERTED TRIGA, THERMOC QUDLE LEADS FROM A SINGLE UNCLAMPED CUEL ROD AZE IN A STAINLESS-STEEL CONDUIT, WHICH HAS A PIGHT $\triangle N G L E$ IN. ABDVE THE ROO IAGGETS WHEN THEY AP.E IN THE DOWN POSITION. INSERTION OF ANOTHER EXPEPIMENT PUSHED THE ANGLE OVER N.J. 3 HAGNET. ROD ? POSITION WAS 15.2 IN. AT CRITICALITY. AND THEN VISS RAISED TO 19 IN. REFORE DULSING, WHICH GAVE GNLY A 70 C READING. CORE CHECK SHOWED THE BEND NOT OVER THE WAGNET, BUT EXPERIMENTS SHOWED THAT FUEL ROD LIFTSO 12 IN. (REMOVEO \$1.80 P.EACTIVITY). FOO IS NOW CLAMDED.

\#ACCIDENT, REACTIVITY + *EAILURE, ADMINISTRATIVE CONTROL + FUEL HANCLING + INSTRUMENTATION, IN CORE + RFAC.TRF, PIILSED + TRITGA $\mid R Q\}$

$17-23904$

WOLTFR 5

AEC-RCPA CORRESDONDENCE TN RESPONSIRLF CONSULTANTS

RURAL COOPEPATIVE POWER ASSOCIATION + DIVISION OF REACTOR LIEENSINC

3 DASES, FEPRUARY 12, 19S8, ATOMIC FNEP.GY CLEARING HOUSE $14(10)$, PAGES 4?-44 (MARCH L, 19C8) DOCKET 115-1

(TWX DND LETTERS, FE9. 12, 15, ET SEQ.) AN EXCHANGE OF CORRESPCNCENCE ESTAELISHEC THAT (I) DRL REGAODS CHOICE OF CONSULTANT $\triangle S$ RETWEEN P.CPA AND AEC-COQ, ALTHOUGH P.CPA HAS RFSFGNSIRILITY CF MAINTAININS STAFF AND C.ONSULTANTS. (2) RCPA FEELS THE SITUATION AND ISSUES HAVF BECDME DISTIRTED, AND PROGRESS TO EXTEND THE NUS CORP. CONTRACT TIL JAN. 31, 1960, TO COVER DPERATIJNAL SAFETY ANE SURVEILLAVCE, (3) AEC-COO ACCEPTS THE TECHNICAL COMPETENCF OF NUS, BUT AEC DREFEFS THAT CERTAIN SERVICES BE PEPFORMED BY UNC, AN? WILL DIRECTLY REIMRURSE UNC. DCPA MAY REIYLUESE N'US FOR SEPVICES PERFORMED FOR RCPA. THE AEC WILL NUT. RFDUESTS RCEA ODERATE ELK RIVER TO FULF ILL CONTRACT.

\#ADMINISTRATIVS CONTRCL + \#SAFETY REVISW + ELK FIVER (BWR) + FFACTOP, BWR + TECHNICAL SPECIFICATIONS

17-23905 DLSE: IN CATEGQRY O

MONT GOMERY CR

SAXTCV PREPCPTS FAILUTRE OE CONTRDL POOD TO SEAT

SAXTON NUCLEAR EXOER. IMENTAL CORDORATION

2 PAGES, FERRUARY 23, 19O8, ATOMIC ENFRGY CLEARING HOUSE 14(10), PAGES 44-45 (MAFCH 4, 1SG9) DCCKET 50-146

ILETILK IU UKL, +EH. 23) JN JAN. ?2, THE REACTOR WAS SCRAMMEO AFTER COMPLETION DF THE DAYS CDERATJR TRAINING. CONTROL-RDD I STODPED 2.98 IN. AROVE ZEGIO (IN.) POSITION. A P.OD-EYERCISE PROGRAM WAS STARTED, AND THE RCD STUCK $\triangle T$ ABOUT ? IN. ON THE $16 T H A N D$ G4TH ROD DROPS. $\triangle N$ ADOITIONAL 50 DROPS WERE WITHOUT FUPTHER DIFFICULTY. CONCLUSION - PROPAPLYASMALL PIECE OF FOREIGN MATTER HAS LOOGEO IN THE RCD-DRIVE MECHANISM AND WAS REMOVEO EY THE SELF-FLUSHING $\triangle C T I C N$ DF THE DASH POT.

\#FAILIJRE, SCRAM IMEC,HANISIM + CONTROL ROD DPIVE + REACTCR, PWR + SAXTCN (PWR)

$17-23861 \quad$ ALSO IN CATEGTRY 11

COWAN A + COWDURN KJ

CRITICAL CRACK-LENGTH MEASURFMENTS IN HYORIDED ZIRCALOY-2 PRESSURE TUBES

UKAEA, LANCASHIRE (CLLTHETCH)

6 PAGFS, 1 I FIGURFS, I TASLF, 8 PEFERENCES, JOURNAL CF THE INSTITUTE OF YETALS 951IO), PAGF 302 THRU 307, (OCTDBER 1967$)$

DESCPIPES THE FIRST OF O SERIES DF TESTS CN PRFSSURE TURFS WITH SLITS CUT THROUGH THE WALL BEFORE PRESSURIZING TO FAILUPE. UD TO 700 C, FAILURE OCCUPRED BY FAST PROPAGATION OF CRACKS INITIATED AT THE ENDS OF THE SLITS. IMCREASING THE HYCECGEN CCNTENT OE THE TUBES CAUSED T.MORITTLEMENT. WITH S DECREASE IN THE CRITICAL CRACK LENGTH DT 300 C, THE EFFECT OF 40O PPM HYORDGEN WAS COMPARATIVELY SMALL. THE CRITICAL CRACK LENGTH IS $\angle 3 O U T$ L IN. AT THE OPERATING TEIPERLTURE AND PRESSURE O= THE S.G.H.W. REACTOF. $1300 \mathrm{C}, 16,0$ OO L3/SO. IN.). THIS LENGTH IS GRDERS DF MAGNITUDE GREATER. THAN THE LENGTH THAT CAN BE DETECTED IN SERVICE AND IS $\triangle L S O$ GREATER THAN THE LENGTH JF DEFECT THAT WOULO BE EXPECTFO TG GIVE RISE TO SLON LEAKAGE BEFORE CAILURE.

*FAULT + \# HYDRICE + \#FEACTMR, PRESSURE TUEE + \#ZIFCALOY + ARITTLE FRACTURE 
17-23368 ALSU IN CATESTPY IE

SELECTED CVTR DPERATING EXPERIENCE

CAROLINAS VIRGINIA NUCLEAR POWER ASSOC.IATFS, INC., PARR, S. C.

32 PAGES, MONTHLY OPERATING REPORT, OCTORER 1966

(PG 20) - EVALUATED SENSITIVITY OF VARIOUS AIPBQRNE-TRITIUM MONITORING INSTRUMENTS TO MIXTURES OE TRITIUM AND FISSION GASES IN CONTAINMENT FRLLOWING A FUEL FAILURE EARLY IN THE MONTH. XENON READ HIGHER BY A EACTOR OF 10 OVER THE $\triangle C T U A L$ CONCENTRATIGN. ACTUAL TRITIUM CONCENTRATION OF THE MIXTURE WAS ONLY 1/STH THAT INCICATEO. (PG 26) - ON STARTUP AFTEF THE SECOND REFUEL ING, AFTER 1.5 HR $\triangle T$ TO: POWEP, A FUEL FAILURE GCCUPRED. TFSTS THE PEST OF THE MONTH SHOWED THIS WAS IN LLTURE BZ (CONTLINING HIGH-POWER-DENSITY FUEL), AND THE LEAK F $\equiv$ PRESENTED LESS THAN IT FAILED CUEL, PROBABLY JNE ROD.

AVAILABILITY - CLEARINGHOUSE FOR FEDFRAL SCIENTIFIC AND TECHNICAL INFDRMATION, SPRINGFIFLD, VIRGINIA, $\$ 3.00$ CDPY, \$0.65 MICRCFICHE

\#FAILUPE, FUEL FLEYENT + \#INSTRUIAENTATION, ARNDRMAL INDICATION + \#MONITOR, RADIATICN, AIR + \#TRITFIUM + * XENJN + CVTR (PWR) + REACTDR, HNR + REACTOR, PRFSSURE TUBE + REAGTOR, PWR + REPQRT, OPEFATIONS

$17-23860$

PIQUA MUNTHLY OPERATING REPORT VIC. 43

PIQUA VUCLEAR POWER FACILITY, QHIO

COO-6:2-33+. I9 DAGES, NOV. 1900

PRDGRESS REPOPT. THE USUAL CONTENTS $\triangle R E$ DIVIDED BETWFEN HIGH-LIGHTS, PLDNT PERFCRMANCF DETA, ATMINISTRATION, TESTING AND ANALYSIS, HEALTH AND SAFETY, MAINTENANCE, aND MODIFICATION.

AVAILABILITY - CLEARINGHOUSE FOR FSCERAL SCIENTIFIC ANO TECHNICAL INFORMATION, SPRINGFIELO, VIRGINIA, $\$ 2.00$ COPY, $\$ 0.65$ MICROF ICHE

* MAINTENANCE AND REPAIR + \#RADIATION SAFETY AND CONTRQL + \#TESTING + PIQUA (OCR) +

REACTOR, ORGANIC COOLED + REPORT, OPERATIONS

$17-23874$

MIKESELL FE

TRIGA EXPERIMENTAL ANO IRRADIATION FACILITIES FOR RESEARCH AND DEVELODMENT

GENERAL DYNAMICS CORP., SAN DIEGO, CALIF. GENERAL ATOMIC DIV.

GA-1995(REV.5) +. 67 PAGES, FIGURES, NDV. 1, 1966

RRIFF DESCRIPTION OF THREE TRIGA REACTORS, EXPERIMENTAL FACILITIES AVAILABLE FOR RENT AT GA-SAN DIEGT CALIF. APTR FLUXES RANGE FROM (FAST) $3.3 \times 10(13 T H),(T H E R M A L) 4.4 \times 10(13 T H)$, IGAMIAA RADS/SEC, $9.9 \times 10(4$ TH), ALL $\triangle T 1.5 \mathrm{MW}$ STEADY STATE. FLUX/DOSE AVAILABLE WITH B4OO-MW PULSES ARE - (FAST) $1.4 \times 10(17 T H)$ AND $9.5 \times 10(14 T H)$, (THERMAL) $1.9 \times 10(17 T H$ ) AND $1.2 \times$ 10(15TH), (GAMMA) $4.2 \times 10($ ITH) AND $2.8 \times 10(6 T H)$. PULSE CHARACTERISTICS, FLUX

DISTRIJUTIONS, AND SUPPLEMENTARY SERVICES DESCRIBED.

AVAILABILITY - CLEARINGHOUSF, FOR FEDERAL SCIENTIFIC AND TECHNICAL INFORMATION, SPRINGFIELD, VIPGINIA, $\$ 3.00$ COPY, \$0.65 MICRCFICHE

\#IRRAOI ATION FACILITY + \#SYSTEM DESCQIPTION + FLUX DISTRIBUTION + IRRADIATION TESTING + REACTOP, RESEARCH + TPIGA (RP)

$17-23911 \quad$ ALSO IN CATEGTRIES $\subseteq \triangle N O 7$

SIDDALL E + SMITH JE

COMPUTER CONTROL IN THE DOUGLAS POINT NUCLEAR POWER STATION

ATOMIC ENERGY OF CAVADA LIMITEO, SHERIDAN PARK, ONTARIO

AECL-2943+SM-\$9/38+. IS PAGES, SEPTEMRER 1967 , PAPER PRESENTEO AT THE IAEA SYMP.JSIUM JN HEAVY WATER POWER REACTOR S, VIENNA, SEPTEMBER 11-15, 1967

BY USING TIME MULTIPLEXING TECHNIQUES, THF HIGH DATA PROCESSING CAPABILITIES DF D SINGLE DIGITAL COMOUTER CAN QE USED TO REPLACE A MULTIPLE ANALOGUE CONTROL SYSTEM WITH A CONSEQUENT SAVING IN COSTS ANO SOMEWHAT RETTER OPERATION. TO TEST THIS PREMISE, AND TO GAIN AN INSIGHT INTO THE PROSLEIAS, A DIGITAL COMPUTER CONTROLLER WAS INCORPORATEO IN THE CONTSOL SYSTEM FOR THE DOUGLAS POINT NIUCLEAR DOWER PLANT. MUCH USEFUL EXPERIENCE IN THE DESIGN PHASE HAS BEEN GAINED, AND OPERATING EXPERIENCE WHILE STILL LIMITED HAS BEEN ENCOUJAGING.

AVAILABILITY - CLEARINGHOUSE FOR FEOERAL SCIENTIFIC AND TECHNICAL INFORMATION, SFRINGFIELO, VA., \$3. OO COPY, \$?.65 MICROFICHE

\#COMPUTER CONTRGL + \#CPERATING EXPERIENCE + \#REACTOR, HWR + CHALK RIVER + COMPUTER PRCGPAIA + IAEA + INSTRUMENTATION, CONTROL + INSTRUMENTATICN, GENERAL

17-23915 ALSC IN CATEGỌRY 10

WEEKS TC 
OPERATIONAL SATETYRY SNO ${ }^{7}$ EXPERIENCE

$17-23915=$ CONTINUEC*

IRL MJTOR-GENERATTOR FAILS IN TEST

INDUSTRIAL P.EACTOR LAEDRATCRIFS. INC., PLAINSBOFR, M.J.

2 PAGES, ATOMIC ENERCY CLEARING HOUSE 1411.1), PAGES 22-?? (4ACCH 11, 10:P), COCKET 5C-?7

ILETTER, FEBRUAZY 201 OUPING A ROUTINE LOAD-FREE TEST ON DECEMBEP. 6, 1SG7. THE ENEF.GFNCY GENERATIR FAILED TO EUNCTION DUE TS D DEFICIFNT QUTTERELY VANE IN A VACUINM-OOERLTEO

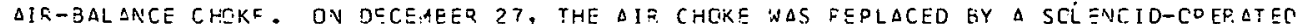
METSRING DEVICE IN THE NATURAL-GAS FEED, ALTHCUGH VAINTENANCE HAO RESTODEO ITS PEFEROMANCE. NORMAL BI-WEEKLY TESTS INDICATSD NO CONTINUING PROOLLES.

\#FAILURE, COMPONCAT + *GENERATOR, DIESEL + EMEQEENCY PÜLK, EleCIGIC + REACTOR, aESEARCH

17-24134 ALSC IN CATEGORY C

SFL ECTED ELK RIVER JPERATING EXOERIENCE

RURAL COOPERATIVE PTWER ASSOCIATION

NUS-? ?S +. E.4 FAGES. 5 FISURES, 2 TARLES, ELK DIVER REACTOR OPERATIONS SAFETY DNALYSIS DRCGEFSS REPORT TO

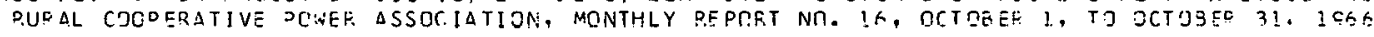

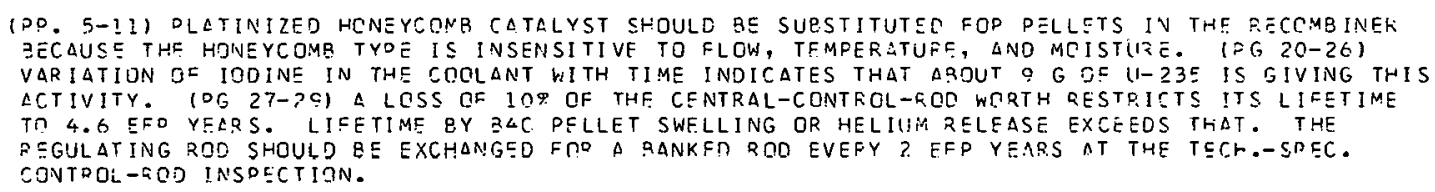

AVAILABILITY - CLEARINGHOUSF FOR EECERAL SCIENTIFIC AND TECHNICAL INEORMATIOIN, SPEINGFIELD, VIOEINIA \$3.OC COPY, $\$ 0.55$ MICRDEICHE

*CONTROL ROC BURNUD + \#PECOMBINER + ACTIVITY BUILDUP + ELK P.IVEF ( QWE) + MAIN COCLINE SYSTEM + D.EACTOO, SWR + REDOFT, DPFADTIONG ANALYSIS + STEEL, STAINLESS

17-24154 $\triangle L S G$ IN CATEGOPIFS 11 ANC C

SENA SHUTDOWN ATTRIRUTED TO CORE RAPREL DCLT FAILURE

I PAGF, NUCLEAZ INOUSTEY $15(2)$, PAGE 5A. (FFE. IOEE)

WEST INGHOUSE STATEUENT FEADS IN DAFT AS FCLLOWS - DS DAPT OF THF INVESTIGATIRIV OE A STUCK CONTREL GOD, CAUSED BY INTERFEPENCE IN THE CORE, INSPECTICN KEVEALED BDDKEN OIECES OF COPS-EARPEL BCLTS IN TWO OF THE COUR STEAM GENERATORS. THFSE ECLTS JCIN UPPER ANR LONER CORE QARREL. THEIF USE IS DECULIAP. TO THE INTERNDL DESIGN UF SENA AND EARLIEF ELANTS. PFOAIR TO IVTERNALS WILL BE CONCURRENT WITH CEPAIS FOR TURBINE AND GENERATCR. PRACTRS WAS SHUT DCWN JAN: 39,1968 .

*CORE SOMPONENTS + \#FILURE, EQUIDMENT + \#FILURE, SCRAM MECHANISM + ITALY + ?EDCTOP, PWE

17-24190 DLSO IN CATEGOQY 11

ELK FIVEG SHIIT DOWN 3 SCAUSE JF COOLANT LEAK

PURAL COGPERATIVE POWER ASSOCIATION

? PAGE, TWX TO $\triangle E C$, MARCH 14, 1062, COCKET 1.15-1., IYPE--UWR. MFG--A.C., AE--SGT + LUNDY

AT 1700 HOURS CN MAOCH 13, DEPOESSUFIZATION OF THE REACTOR WAS PEGUN, IN CO:APL IAREE WITH TECHNICAL-SDECIFICATION SECTION 4. G (FEACTOR-VESSEL LEAKAGE-MCNITORINC SPECIFICATION). A DETAIL $=0$ RFOORT LLGNG WITH A OROGRAM FOR PEPRESSUPIZIVG ANG FURTHER TESTING NILL BE SUBMITTED.

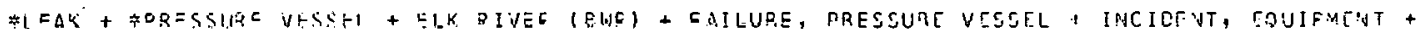
MAIN COOLING SYSTEM + OPEPATING EXPEPIENTE SUMMARY + REACTOP, BKP

$17-24 ? 20$

SEDEN WH

HTGR LONG-TFRY SPEVT FUEL STORASE COSTS

GENERAL ATOHIC DIVISION, GFIVEALL TYNAMICS CCRP., SAN DIEGO, CALIF.

GAMO-7004 +. 27 PAGES, FIGURES, TABLES, SEDTEMOER 1, 1.667

PRELIMINARY DESIGNS HAVE BEEN PPEPAFED, ANR PFESENT-DAY COSTS HAVE 3EEN ESTIMATEC FCZ SPENT FUEL STORAES VAULTS CONSTRUCTED AS A PART DE D IONO MNIEI HIGH-TSAPEPATUEE GAS CCOLEO REACTCR (HTGR) PLANT. TWU SPENT FULL STOFAGS CONCEPTS WFFE DEVELOPEC. I'N CNE CONCEDT, THE FUEL

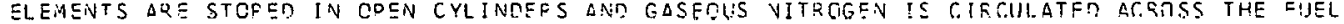

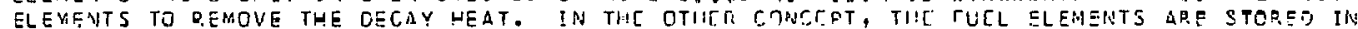
SEALFO CONTAINERS FROM INHICH NO CONTAMINATEO GFADHITS OUST COU ESCAPE. THEPEFORF, A ONCE-THRGUGH AIR COOLING SYSTCM IS USED IN WHITH THE AIP IS FASSEO ARQUND THE DUTSIDE WALLS GF THF CONTAINERS. THE FUEL STOPAGE VAULTS FC' BOTH CUNCEPTS HAVE THE SAME CAOACITY - THE AYOUNT OF FUEL OISCHARGET ERUM A IUUO MWIL) KLACTOD OVEP A 5-YR PERIOD. AIAORTIZING VAULT CAPITAL COSTS OVER A 5-YR PERIOD, THF TOTAL LNNUAL COST OE STORING THE FUEL ELENENTS WDULD BE APPROXIMATELY SGO DER KILOSRAM OF HEAVY METALS STORED FCF 9OTH THS OPEN CYLINDEF CONCEPT (UNCANNED) AND THE SEALED CONTAINER CONCEPT (CONNED).

AVAILABILITY - CLEAPINGHIUSC FRR FEQEOAL SCIENTIFIC AND TSCHNICAL INFORMATION, SPFINGFIELO, VIFGINIA SZ. CO 
OPFPATIONAL SATEGTY ANOS 17 EXPERIENCE

$17-242.20$ \#CONTINUED*

COPY, \$3.65 MICATFICHE

\#ECONOMIC. STUDY + EUFL STORAGE + REACTOPP, GCF + STORAGE CONTAINEF + WASTE HANDLING

17-24:73 ALSO IN CATCGORISS $13 \cdot \Delta$ ANT 7

NORTH $\equiv$ D

FILTER FDILURE ALLIWS HIGHER PAPTICULATE FFLEASF RATE

NUR,LEAR FUEL SERVICES, INC., WEST VALLEY, N. Y.

4 PAGES, LTTMIC EVERTYY CLELPING HJUSE, 14(1.4), DAGES 25-28 (APFIL 1, 1968), COCKET 50-201

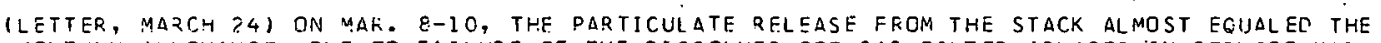
MONTHLY ALLONANSCE, LUE TS FAILIJPE OF THE DISSCLVER OFE-GAS FILTER (DLACED IN SERVICE MAR. 7). IT HAD 3EEV LEADSD FOF. SEVERAL MONTHS PRIOR, FEADING 5 R/HR. ALTHOUGH IT MET THE DOP TEST

AAR. 7, EITHEF THE MEDIA GECAME PGFOUIS OR DEVELOPEO A CRACK, DF THE SEALANT HARDENED AND

FAILED TO SEAL. MORF. DROBABLY, THE ORGANIC BINCEP EMBRITTLEO, FPEEING THE GLASS FIBERS AND

ALLOWIVG THE TE VIBRATE TO THE PEINT OF FAILURE, OR TO PEKMIT THEM TO MOVE RELATIVE TO EACH

OTHER. FILTEKS WILL B.E REPLACED WITHIN A SHDRT TIME AFTER REMGVAL FROM SERVICE FOR HIGH

PRESSURE QR.OP GR HIGH KADIATION.

\#FILTER, DAMAGED + \#FILTED, FIRERTLLASS + \#RADIATION CAMAGË + \#RADIOACTIVITY RELEASE + \#STACK + FAILURE, EGUITHENT + FUEL RTPRDCESSING + NFS

$17-24271$

ALSG IN 'CATERTORY IE:

FREDRICKSTN RL

EXPOSURE TJ EXCESSIVL ATRRDRNE IDOINE-I3!

AQROTT LABTRATTR IFS, NUT.TH CHICAG?, ILL.

1 PAGE, LTOYIC ENERGY CLEARING YOUSE, 14(14), PAGE ?0 (APRIL 1, 1:68)

(LETTER, FE3. 1S) AS INDITATED IN THE FEB. G LETTFE, P.FSFIRATORY PRITECTION IS BEING USED U.VT.IL HOOO QEVISIONS CORRECT THE AIRPORNE-FELEASE PRCBLEM (INADEQUATE AIR VELOCITY). AN EMPL.JYE WAS EXDOSEC TD I-1?1 IN AIP. FOR A TOTAL DF 416 MPC-HOURS (JAN. ?3-29) ANO FUR IE4 MOC-HOURS (FEB. 2-E). HIS AVFPAGE THYROID RUPOEN IN THIS PEFIOD NAS 34 , NITH $A$ HIGH OF $52 \%$, INDICATING THAT DOFGUATE RESPIFATORY PROTECTION HAD BEEN PROVIDED.

* ISSIDN PFDDUCT, IOOINE + \#PFPSONNEL EXfGSURE, RADIATION + \#PERSONNFl pROTECTIVE device + INCIDENT, GEVERAL + INHALATION

$17-24272 \quad$ ALSC. IN CATEGORY 15

INABILITY JF JUMA HOOD TO PREVENT IOOINE FELEASE

ABROTT LAEORATOOIFS, NORTH CHICAGO, ILL.

1 DAGE, ATOMIC ENERGY CLEAPING HOISE, 141]4), PAGE 30 (APRIL 1, 1968)

(LETTER, FE3. $\Leftrightarrow$ ) A WMRKER WAS EXPOSFO TO EXCESSIVE CONCENTRATION OF I-131 IN AIR, AS HIS THYROID AVEZAGEO 373 \% DERMISSIRLF I-131 (DFC 14-20, 10E7). AN UNEXPECTED RELEASE OCCIURREO nIJP ING PREPAZATICN DF RADIJ-IUDO-IMSULIN, CONTAMINATING HIS HEAD. HIS QUARTERLY THYROIO DOSE IS 5.09 REYS. * ALL FUME HOOOS IN THE BUILOING HAVE HAD FACE VELOCITY RE-EVALUATED.

PENDI VA 'AOJI=ICATIOM TO PRCVIDE HIGH-VELOCITY AIRFLOW UR SETTER CONTAINMENT, CERTAIN JOBS

WILL REDUIRE FESFIRATORY EOUIPMENT AND BREATHING-ZONE SAMPLERS. QOUTINE THYROID COUNT.ING

WILL RE TWICE PE? WEEK INSTEAD OF ONCE.

*FISSION PROOUCT, IODINE + \#INHALATION + \#PSRSONNEL EXPOSURE, RADIATION + DOSE + GLOVE COX +

INCIDENT, GENEPAL + PER SONNEL DROTECTIVF DEVICE + VENTILATION SYSTEM

17-24273 ALSC IN CATEGQRY 15

LEWIS WH

HAND JVEREXPOSURE JUP. ING MAINTENANCE

NUCLEAR FUEL SERVICE, INIC.

? PAG:S, ATOMIC ENERGY (LFARING HOUSE, 14(14), PAGES 31-32 (APPIL 1, !968), COCKET 50- ¿CI

(LETTFR, JAN. 31) ON JEC: 27, 10E7, A MAINTENANCE FOREMAN INSFECTED EQUIPMENT IN THE GP-CELL

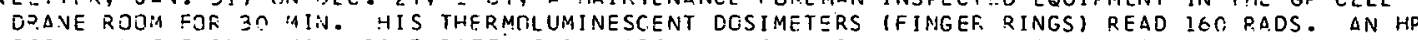
PESURVEY SHJWED $\triangle$ MLX. DTSE FATE GF lE RADS/HR. 26 TLO FINGER RINGS ON HIS GLUVE SHDWED AN $\triangle V E R A G E$ OF 21 DAOS/HR, WITH A MAX. GF 90.6 RADS/HR AT THE PALM. THE AVERAGE HAND EXPOSURE IS ESTIMATED AT 44 TDDS. \#\# THE RFT /GAMMA RATIO USED IN TIME LIMITS IS NOW INCREASED. GLOVES WHICH DECREASE HANO EXPOSUP.: YET WHICH ARE FLEXIBLE ENOUGH FCR WORK ARE BEING TESTEO.

* CONTAMINATION + * JOSIMETPY, THFRMOLUMINESCENCE + \#PERSONNEL PRETECTIVE DEVICE +. BETA EMITTER + FUEL REDROCESSING + INCIDENT, GFNERAL + MAINTENANCF LND REPAIR + NFS

17-24?74. ALSC IN CATSGORIES $15 \triangle M D 1^{2}$

PEP.SOINEL OVEREXPOSURES TUFING.FDURTH DUAPTER ICE7

NUCLEAR CUEL SEP.VICES, INC.

1 PAGE, ATOMIC ENERGY CLEARING HOUSE, 14114), PAGE 32 (APRIL 1, 1968), DOCKET 50-201 
OPEFATIONAL SATEGCRY 177

$17-24274 \quad$ \#CONTINUED*

(LETTER, FEB. IS) REPORT TJESCFIBES OVEREXPOSURES ANO COFFECTIVE ACTIONS. (WHOLE EOOY) ESPLOYEES R.ECEIVED $3.1,3.2$, ANO 3.4 REME. (SKIN) - THREE RECEIVED 7.7, 8.2, AND O.8 REMS. (EXTREMITY) - SIX R.ECEIVED 1C.02, 1 $5.11,10.41,10.62,20.55$, AND 20.56 REMS, DLL DUE TO SPOT SOURCES. \# \# CHANGES TO SOP FOR CONTAMINATED WORK AREAS, TO GOUIPMENT TO MINIMIZE CONTACT MAIVTENANCF, AND TO IMPRTVE VENTILATION ARE REING UNDERTAKEN. A MANIPULATOF REFAIR AND DECONTAMINATION FACILITY IS BEING BUILT.

*PERSONNEL EXDOSURE, PADIATION + CONTAMINATION + FUFL FEPROCESSING + MAINTENANCE AND PEPAIR + MOOIFICATION, SYSTEM OR FOUIPMENT + NFS

$17-24 ? .75$

SPENCER CW

LQST RADIATION SOURCES

SROWN UNIVERSITY, DRQVILENCE, R. I.

2 PLGES, ATRMIC ENELGY LLEASINI; HOUSE, 14(14), PAGES 32-33 (APRIL 1, 1968)

(LETTER, DEC, 2, 1957) THE SEVEN: SCUIRCES (CO-57, THREE (S-137, EA-173, ND-22 AND CC-EO) W!ERE PURCHASED AIJG. 27, 1965, LISTED $\triangle S$ 5-10 MICROCUF.IES EACH. ALL ADE GENEQDLLY LICENSED, SEALEO IN DLASTIC, STEFE? IN THD WJOREN COSES. BUILOINGS ARE BEING SELECHEO, ANE PEPSONNEL DUSST IONEO.

\#SOUPCE, RADIATIDN, LOST + OPERATINE EXPERIENCE SUMMARY

$17-24275$

LEFOY GM

LOS.S JE SODIUM IODINE DURING SHIDMENT

METRODOLITAN HOSPITAL, DETDOIT, MICH.

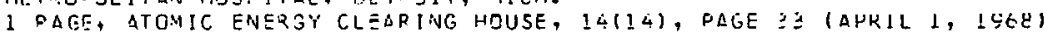

(LETTER, FE3. ?2) ON CE3. 20, TWENTY IOC-MICROCURIE CAPSULES OF NAI-12E WEFE RECEIVEC AT METPOPOLITAV AIFPRRT AND PLACER IN A TRUCK. LETFP. $\triangle$ DELIVERY AT GREENFIELD, THE DPIVER OISCTVERED THE ZLCK ONOR OPEN AND THE I SOTCPES GTNE. THIS WAS FEPORTED TC POLICE. A SIAILIAS PACKLGE WAS SHJWN ON TV, HAZAROS DESCRIBED REALISTICALLY, ANORETURN REQUESTED. IT UAS NCT $\triangle P D E A R E O$ AS OF FEM. 22.

*SCUPCS, P. $\triangle 0 I 4 T I O N$, LOST

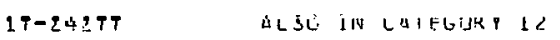

CALDWELL D.

MILLING MACHINE ACCIDENT

NUCLEAR MATERIALS INC EQUIPMENT COFP., ADCLLC, PA.

2. PAGES, ATOAI ENERGY CLEARING HOUSE, 14(14), PAGE 33-24 (AORIL 1, !968)

(LETTER, FEZ. 10) ON DEC. 14, 1967, A TECHNICIAN AMPUTATED HIS HAND IN A GLJVE ECX BY REACHING PAST THE CITTEF TO ADJUST A NITPCGEN HOSE, DPDINARILY CONE WITH THE MACHINE JFF. THE HANO WAS DECONTAYINATFD LND GEAETED PACK ON, BUT HARMTH FAILFD TO EETURN. \#\# CHANGFS MADE WERE (1) AOD 2 SNITCHES IN MOTOE CIPCUIT SO SOTH HANOS ARE NFEDED TO ODERATE MACHINE. (2) DN: INTEELOEK OREVENIS IULPATIIN WHEN ACCESS TO CUTTING TOCLS IS OPEN. (3-6) SWITCHES RELABLED AND $P$ ELOCATSO, LIGHTING IMPRCVED, AND INCICATOP. LIGHTS INSTALLED.

*CONTAMIVATIJIN + INCICENT, NONQTACTGR + MOCIFICATIGN, SYSTEM OR EQUIDMENT + PEPSGNNEL PRCTECTIVE DEVICE + RACIATION INJURY, TREATMENT CF + REMETE MANIPULATING ANO VIEWINE

17-24279 ALSO IN CATEGDRIES 1.2. AND IE

DVER EXPJSURES TO GANFA RAOIATION, IAST HALF 196.7

NUCLEAR :AATERIALS ANT EQUJIFMENT CORP., ALCLLC, PA.

1 PAGE, ATMMIC ENERGY CLEARING HOUSE, 141!41, PAGE 34 (APRIL 1, 10EE)

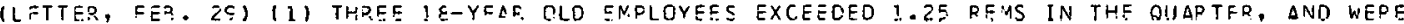

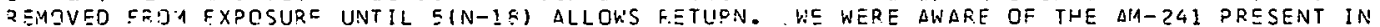

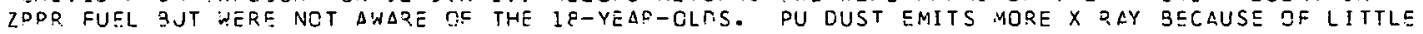
SELF-SHISLOING. (2) A IC-YEAR-OLD WAS TAKEN FFOM HANDLING ZPPF AM-241-CONTAMINATED CFUCIBLES. (Z) A SOURCE TECHNICIAN EXCEFDEQ LIFETIME LIMITS DURING THE FOURTH QUARTEP. HIS JJLY 1767 = ILM SADGE. HAD REEN DAMAGEN, AHD EYOOSURE OMMITTEC. ESTIMATION YIELDED OVEREXPJSURE. (4) JAN.-YAR. ES EYPQSUPF TO SOURCE FOREMAN EXCEEDEO 3 REMS.

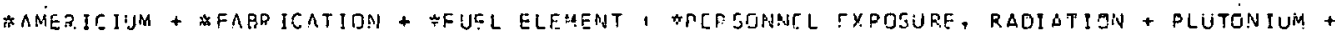
SCUP.CE, RAIIATION + X-RAY

$17-24 ? 70 \quad \Delta L S O$ IN CATCGDRIES 12 AND :5 OVFF. EXPCSURE TI AIR CONCFINTRATIONS $\triangle T$ T $\triangle$ PGLLLC

AT RMIC FNERSY COMIA ISSION

1 PAGE, ATOMIC ENERGY CLEAPING HOUSE, 14(14), PLGE $35(\triangle D P 1 L 1,1068)$ 
$17-24279 \quad$ *CONTINUE[1* (LETTEP, MAR. 1) FIVE OPERATOPS WFRE EXPOSFO TC MOPE THAN 40 MPC-HOURS/WEEK. EACH WAS WEARING,
A RSSPIRATOR, EUT NASAL CONTAMINATICN EXCEEDFD LIMITS, SO NO CREOIT NAS TAKEN. EXPOSURES WERE DETECTED WITH PERSOVAL $\triangle I P$. SAMPLFRS. ONE FXPOSURE OCCURRED DUPING CLSANUP OF A CP-2 FURNACE. TAJ GCCURRED DIJRTNE CPP-? DISSOLVING CPERATIONS. TWO OCCURREO OURING FILTER HANDLING. FILTERS ARE RJUTINELY BAGGED, BUT OCCASSIONALLY A BAG IS PUNCTURED.

*FASRICATION + *FUEL ELEMENT + \#INHALATION + MAXIMUM PERMISSIBLE CONCENTRATICN (MPC) + DERSONNEL EXPOSURE, RADIATION

17-24280 ALSO IN! CATEGORY LE

NUMEC CITED FOR NON-CCMFL IANCE

NUCL SAR MATER I ALS AND SQUIDMENT CORO. APRLLO, PA.

I PAGE, ATOMIC ENERGY CLEARING HOUSE, 14114), PAGE 35 (APRIL 1, 1C68)

(LETTER, FES. 21 ) CITATIONS AFTEP AN INSPFCTION VEERE FOR THF FOLLOWING PEASONS - (I) PFRSONNEL HAVE GYPASSED THE CHANGE AREAS EY FREQUFNT USE OF REAR DOORS. ( 2 ) NUMEC FAILED TO REPORT A 3.75-REY EXPOSURE DURING THE FIRST GUARTER CF CY 1066. \# (REPLY, MAR. 5 ) WE ARE PLEASED NJ NONCOMPLIANCE NOTED TO SNM-145 $\triangle N O \quad 37-445 t-2$ LICENSES. THIS REFLECTS OUP EFFORT. (I) BYPASSING IS NOT ROUTINE. WAS USEO ONLY FOR IN-PLANT TRANSFER OF CONSTRUCTION MATERIAL, AND DOJRS HAVE GEEN POSTED. TRAINING CLASS HAS BEEN HFLD ON USE. OF CHANGE ROOMS. MATER IAL NOW STJRED ELSFWHERE. (2) THIS WAS AN CVERSIGHT. IN SEPT. 19ET, AN OVERINSPECTION PPDCEDURE WAS INST ITUTEO.

*INSPECTIJN ANO COMPLIANCE + FAILUzE, AMMINISTRATIVE CONTROL + PEPSCNNEL EXPOSURE, 2ADIATION + SPECIAL NUCLEAE MATER.IAL 


\section{SACETY MNALYSISSARY DESIGN EEPOPTS}

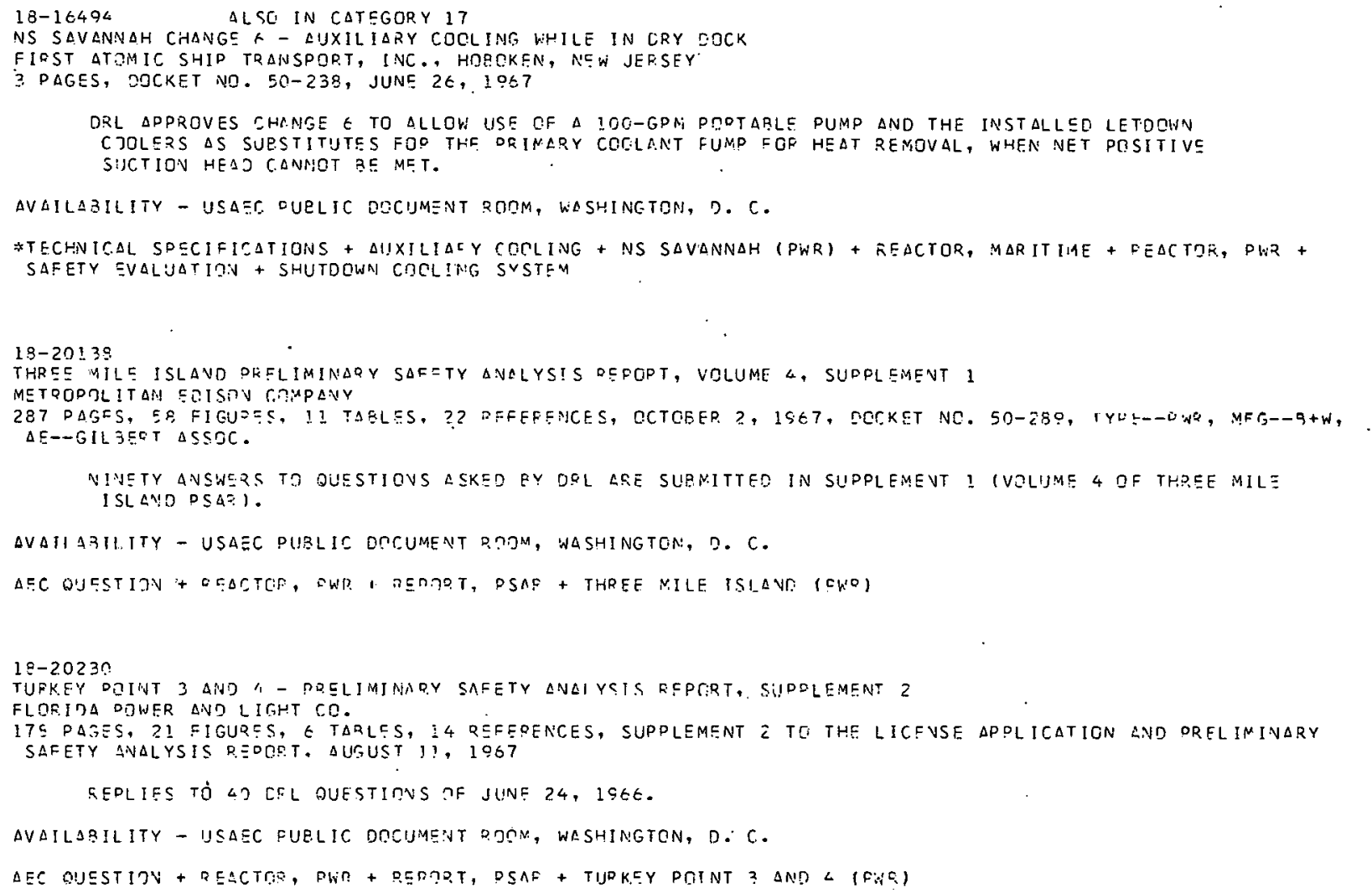




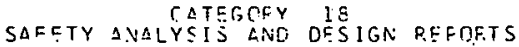

$19-20355 \quad$ *CONTINUED*

4 DAGES, PAGE 01 TO 04 OF SUPPLEMENT 2 TG THE LICENSE APPLICATION $\triangle N D$ PRELIMINARY SAFETY ANALYSIS REPORT. SEPTCHEEF 1, 1966, EחC.KET 50-250/251

JNLY TWO SUCH FAILURES ARE QEPGRTEC, EOTH IN ENGLAND - 11 U USKMCUTH - 11 FAILURE AT $170 \%$ OVERSPEED \& WESKS AFTER COMMISSONIHE, I?) BLACK IRON-CXIDE FOKMATION IN THE GOVERNOR FROM SR.ACK ISH-NATER-CONTAMINATE) 'OIL ANE LRNG SHUTDOWNS. GAMAFE IS DESCRIBED (LOW-PRESSURE WHEEL FJUAN 150 Y S AWAY). (2) CALDEP. HALL-Z - TNE MONTH AFTEF COMMISSIONING, MAIN STEAM-ADMISSION VALVE STUCK FULL-ODEN WHEN LCAD DPCPPED SUEREMLY. VALVE FAILURE WAS CAUSED BY PADTICLE GF CHILLED TRON SHOT EMBEDDFO IN THE VALVE SPINDLES.

AVAILABILITY - USAEC PULLIC DOCUMENT POOM, WASHINGTIN, D. C.

FFAILIJRE, EQUIPMENT + \#INCIOSNT, EQUIDMEAT + \#MISSILE GENERATION ANI PFOTECTION + \#TURRINE + CONTRGLLER + FAILUPE, ADMINISTRATIVE CONTPOL + DUALITY COIVTRCL + REACTOR STARTUP EXPERIENCE + VALVE

$18-30355$

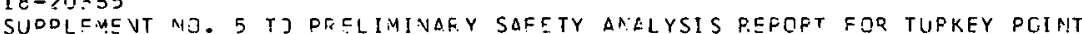

FLCRIOA POTWER ANO LIGHT ROEIAPAMYY

13? PASES, 25 EIGURES, ? TABLES, 91 PEFFFENCES, OCTOBFF 7, 15E6, ROCKET NO. 50-250 AND 50-251.

AMSWELS TO 17 QUESTIGNS FZLIM OLP, SEOTEMBER 23, 1966, ARE GIVEN. INCLUDED ARE PESULTS OF INVESTIGATION I!NTO CHAPACTES ISTICS CF WAVES THAT. COULD REACH THE PLANT (APPENDIX A). ALSO INCLUDED APE REVISEO ANSWE?S TD QUESTIONS 10.0. THROUGH 10.6 FREM SUPPLEMENT 2.125 RUESTIONS $\triangle G E$ AVSWEZED IN SUPPLLIAEVT T.

AVAILABILITY - JSAEC PUPLIC OUTUMENT ROTM, WASHINGICN, 9. C.

AEC QIJESTION + ZEACTCP, PH? + PEP.JET, DSAP + TUEKEY POINT a ANC 4 (PWF)

10-20537. ALST, IN: CATEGTRY I

SHCUPD NE

NIICL EAP STANOAPES

UNITED STATES ATOAIC ENEZGY COMAISSIUN

23 PAGES, NUCLEAF NEWS $10(11)$, DAGE $25-47$, (NOVEMBEF 1966 )

JISCUSSIUVS DF NUCLEAR-STAM!DAFOS ACTIVITIES CROM THE VIEWPCINTS OF SEVERAL ORGANIZATICNS. (I) ANS - N. E. SHIJUFD, 2. G. SHALKFR, $\triangle N D$ ANN SAVOLAINEN, 12 FG. 12) USASI - F. K. MCCUNE AND VAFY ELLIS, 3 DG. (3) 1 GE - J. T. FAINEY, M. SHAW. AND E. G. CASE, 8 PG. AEC STANDARLS AFE FEGULATORY INE INCLUDE THGSE NOT NFCESSARILY ASSOCIATEO WITH NUCLEAR SAFETY BUT MORE WITH GJALITY CONTRCL CR WITH IN-STPEAM TIVAE.

\#CODES AND STANDAODS + GPFRATIMIE EXPEFIFNCE SUMMARY + FEGULATION, AEC

L

$18-2036=$

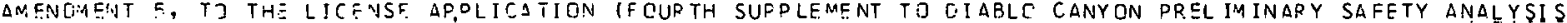
FiERGT

DATIFIC GAS AND ELTCTEIC CrMPANY

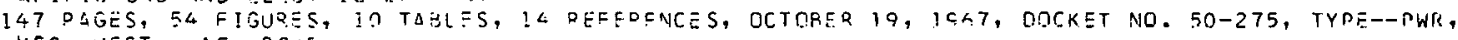
$M F G-N E S T$, A AE- D $3+E$

SUPPLFAENT 4 CONTLINS - 121 ADEITIGNAL TSUNAMI INFORMATICN, (2) REVISICN I TF WCAP-58GO, ULTIUATE STR=NGTH CFITESID TG ENSUFE NO LOSS OF FUNCTION OF PIPING AND VESSELS UNDER

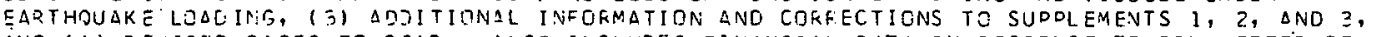
ÁND (4) P.EVISED CAGES TO OSAF. ALSO INCLUDES EINANCIAL DATA IN RESPONSE TO DRL LETTER OF II IIIIY 57 AND THE $196 \%$ NNNUAL REPTJPT.

AVAILABILITY - ISAEC, OULLIC DOCUMENT ROCS, WASHINGTON, D. C.

DIABLO CANYJN (DWR) + EADTHOUAKE ENGINFEFING + PEACTOR, PWR + REPORT, PSAR + TSUNAMI

$10-20 P E 3 \quad$ ALSO IN CATEGORY 2

SECTION T. ADOITIJNAL INFIORMATION ON TSLNAMIS

PACIFIC GAS AVD ELECTPIC CODIPANY

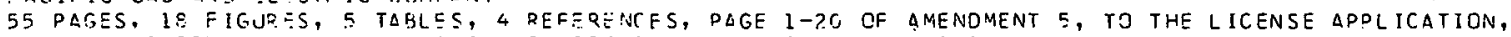
(FDURTH SIJPPL EMENT TO DIASLJ CANYON DOFLIMINARY SAFETY ANALYSIS REPORTI, S.ECTION 4, OCTOBER IO, 1SG7, SICKET NÜ. 50-Z75, TYPF-DWE, MFG--WEST., $\triangle F--P G+E$

SECTION I INCLUOSS - (A) SUOPLEMCNTAFY REPOFT CN TSUNGWI STUEIES, BY MARINE AOVISERS, INC. GIVES RESULTS CF A STUDY IIN FE SPCINSE TO AEC QUESTIONS.) AN TSUNAMIS RECENTLY RECOPDED IN THE PACIFIC, AND OISC,USSES POSSIEILTTY GF $\triangle$ LAFGE TSUNAMI ANO WAVE RUNUP.AT DIABLQ CANYON. (B) 2 PULLETINS ( $\triangle$ DFEP OFE THE COAST TF MEXICE AND CENTDAL ANERICA, AND, SEISMIC ACTIVITY IN MEXICO DURIVG JUNE 193?). (C) PEFCPT RY R. F, HOUTZ DN THE 195: SUVA TSUNAMI. (D) FEPOFT CN IOIE RUSSIAN TSUNAMI. IEI ZND SUPPLFMENT TO OEPORT ON TSUNAMI POTENTIAL AT DIABLO CANYON (REFRACTION OF $\triangle P P P C A C H I N G$ TSUNAMI).

AVAILABILITY - USAER FUSLIC, DOCUMENT DOOM, WASHINGTEN, D. C. 


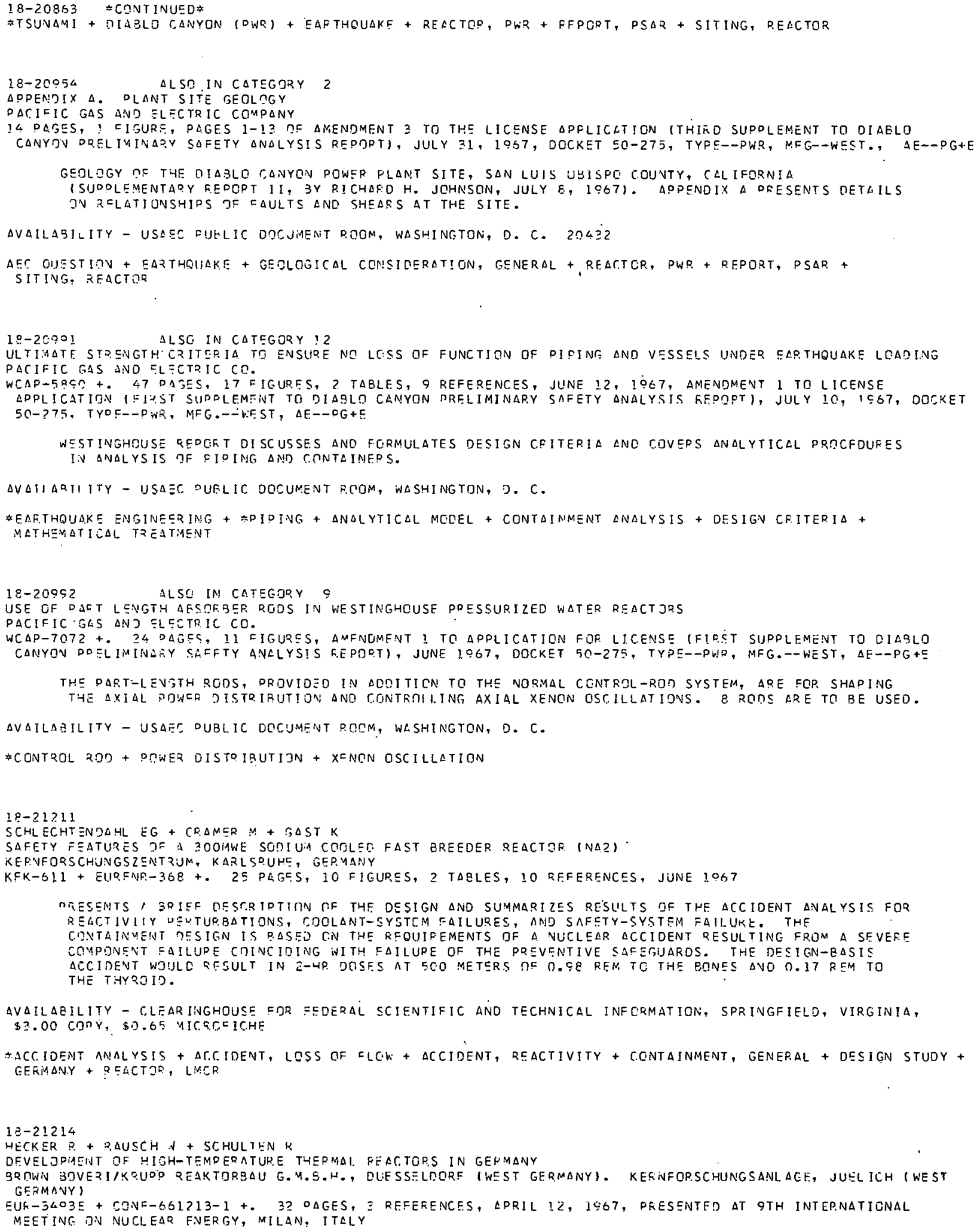




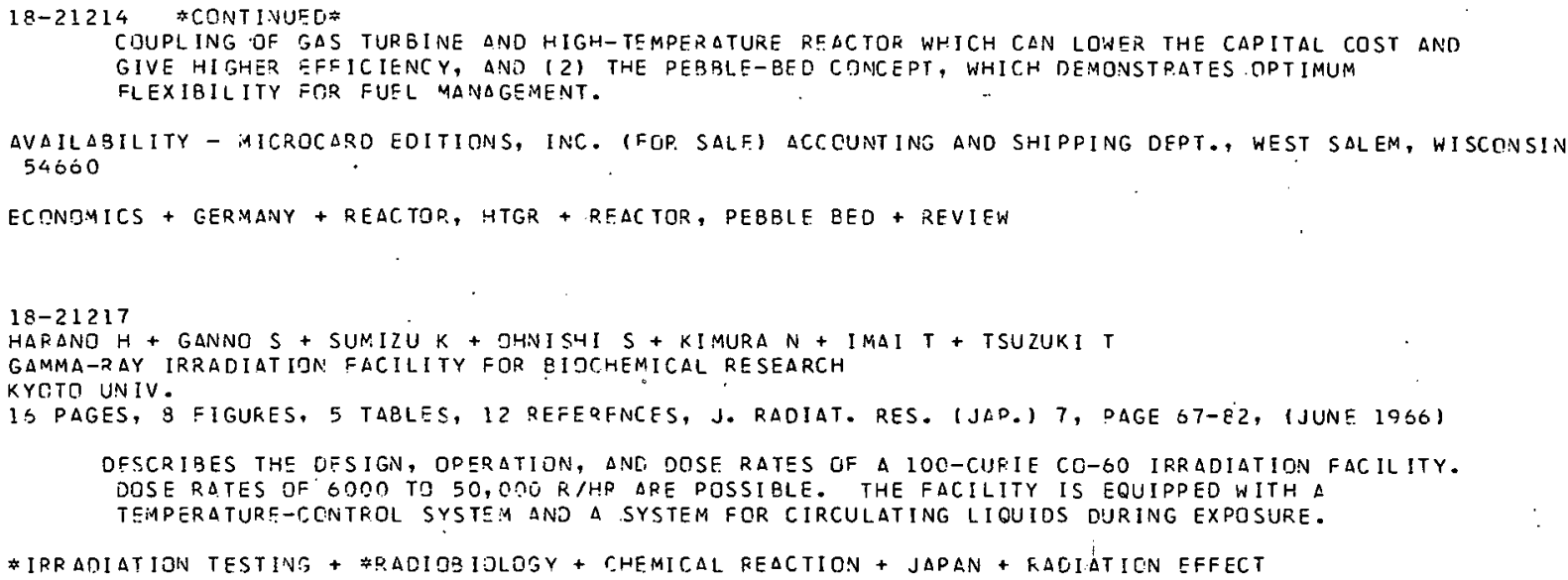

AVAILABILITY - CLEARINGHOUSE FOR FEOEPAL SCIENTIFIC AND TECHNICAL INFGFMATION; SFRINGFIELD, VIREINIA, $\$ 3.00$ COPY, \$0.65 MICPCF ICHE

*CLAD + \#FUEL ELEMENT + \#IRRADIATION TESTING + BATTELLE NORTHWEST + R AND D PROGRAM + THORIUM + URANIUM + ZIRCALOY + ZIRCONIIJM

$18-21220$

PLUMLEE KE + CRAIG DS + DATES LR + JULI $\triangle N O J O+K E L B E R ~ C N+L E N N O X ~ D H$ ADOENOA TO THE HAZARDS SUMMAFY RFPORT ON THE OXIDE CRITICAL EXPERIMENTS $\triangle R G O N N E$ NATIONAL L 18 ., ILL.

ANL-5715(ADO.) +. SS PAGSS, 5 FISURES, 3 TABLES, MARCH 1967

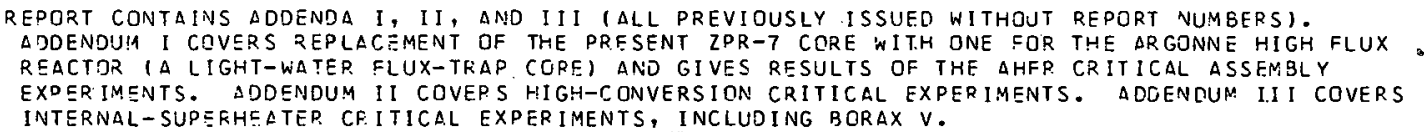

AVAILABILITY - CLEARINGHDUSE FOR FEDERAL SCIENTIFIC AND TECHNICAL INFORMATION, SPRINGFIELD, VIRGINIA, $\$ 3.00$ COPY, \$0.65 4 ICRDF ICHE

\#HAZARDS ANALYSIS + CPITICAL ASSEMELY FACILITY + P. DNO D PROGFAM + PEPORT, SAR

$18-21221$

HEAVY WATER ORGANIC COOLED REACTOR. QUARTERLY TECHNICAL PRGGRESS REPORT, APRIL-JUNE ISEG 
SAFETY ANALYSISS DNY DOS DISN FEPORTS

$18-21221$ \#CONTINUED*

ATOMICS INTERNATIONAL, CANOGA DARK, CALIF. COMBUSTION ENGINEERING, INC., WINOSTR, CDNN.

$\triangle I-C E-54+214$ PAGES, 68 FIGURES, 44 TAELES, OCTGQER 1,1057

ONE OF A SERIES OF REPORTS COVERINE RESEARCH AND DEVELOPMENT IN HWOCR PROSKAM. FEPORT INCLUDES RESULTS DF TESTING GE VARIOUS STPUCTURAL MATERIALS IFSPECIALLY THE SAP-STEEL JOINTSI $\triangle N D$ SN SVALUATION DF THE MCA.

AVAILABILITY - CLEARINGHOUSE FOP FEDERAL SCIFNTIFFC AND TECHNICLL INEDPMATION. SPRINGFIELC, VIFGINIA, $\$ 3.00$ COPY, SO. 5 S MICRLF ICHE

CORE COMPONENTS + R. LVD D OROGRAM + REACTOR, HWI + REACTOP, OPGAN!C COLLEO

18-21291 ALSO IN CATSGTRY I

DI AELO CANYQIN CONETRMANCF WITH DEOOCSFD GENERAL DESIGN CRITERIA

PACIFIC GAS AND ELECTRIC COMDANY, SAN FRANCISCT, CALIF.

2 PAGES, SEPTELAER 9, IC67, DCCKST NO. 50-275, TYPE--PWR, MFG--WEST., $\triangle E--P G+Z$

LISTS SIGVIEICANT PSAR (AND SUOPLFMENTS) CHOPTERS WHICH DEAL WITH EACH CRITEFITN GE JULY ISGT.

AVAILABILITY - USAEC PURLIC DOCUMENT RCOM, WASHINGTCN, D. C.

* AEC dESIGN CRITE? I + CIABLO CANYON (PWQ) + REACTCR, fWR + REPOET, DSAR

$16-21 \geq 23$

COLUMSIA U. (N.Y.) ASKS FTR CONSTRUCTION PFRMIT FXTENTIDN

COLUMBIA UNIVERSITY, C. ITY CF NE:N YDPK

I PAGE, veV. 3?, I 2G.7, DCrKFT No. 50-208

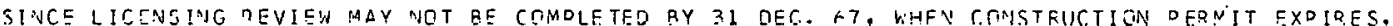
AN EXTENTION TO 20 JUNE $\leq 8$ IS REQUFSTEO. FEACTOQ IS A TRIGA MK II.

AVAILASILITY - USAEC PUSLIC DOCUMENT POOM, WASHINGTON, D. C.

CONSTRUCTION DERMIT PRQCESS + REACTCR, DESEACCH + TPIGA (RD)

$18-21334$

HOCK I:VG JE

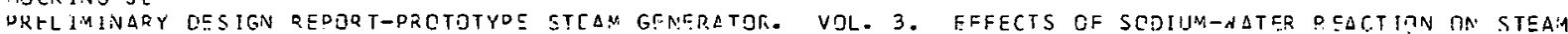

GENESATOP. SODIJMAIEATEO STEAM GENEDATGR DEVELOPMENT

BABCCCK $\triangle V D$ WILCOX CO., BARGCRTON, OHID. BOILFR OIV.

SAW-1280-2S(VIL.3) +. 140 PAGES, ILELSS, NOVEMPEF 15,1935

SIJWMAQIZES THF EESULTS CE DN ANALYSIS OF A SINGLE-TUBE-WALL STEAM GENERATOF TO DETERNINE THE

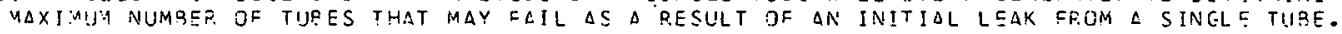
CONSIDEES THE FFFECTS DF STCAIN HASCENING, CORRCSION, SUPPOET VIERATION, LCCALIZED BULGE

EALUFE, STRUCTURAL FAILURES, ANC THE CPESIPILITY OF OVERHEATING THE SHELL AND LINEE.

AVAILABILITY - CLEAR INGHOUSF FQR FEOSRAL SCIENTIEIC AND TECHNICAL INGCPMATICN, SPR INGFIELO, VIFGINIA,

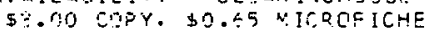

\# METAL WATEP. CEACTION + FSTEAM GENEEATOP + CORP.OSICN + DESIGN STUOY + FAILUPE, TUSING + SCOIUM + STR.UCTURAL INTEGRITY + VIRRATION

$18-21338$

HOCKING JE

PRFI. JHINARY OESIGN REOORT-PZOTOTYPE STEAM GENERATQR. VOL. 2. STFFSS ANALYSIS. SODIUM-HCATEO STEAM

GENERATTR DEVELOP.AENT

BAPCOCK AND WILCOX CO., TARBERTON, CHIC. EOILER OIV.

$B A W-1220-2 O(V O L .2)+184$ OAGSS, VGVCMPCR 15,1065

SUMMARIZES THE ANALYTICAL DESULTS, ASSUMETIONS, AND METHOOS OF SOLUTION TOF STRLSS DROOLENS TO ENSURE STRUCTURAL INTEGRITY UNDEO RETH STEAOY-STATE AND TRANSIENT CONOITICNS.

AVAILABILITY - CLEARINGHDUSE FOR =EOECAL SCIENTIFIC AND TECHNICAL INCTIMATION. SPRIVGFIELC, VIFGINIA, S3.0O SOPY, \$O.ST MICRCFICHE

* STEAM GENERATOR + *STQESS aNALYSIS + OFSIGN STUDY + SODIJM + STRUCTURLL INTEgRITY

$1 \varepsilon-21400$

AQUEOUS HOMOGENEOUS SUSPENSION REACTOR PPCJECT. PART B, KSTP. DESIGN $\triangle N D$ CONSTRLCTION, ANNUAL PEPGRT KEURING VON ELECTRDTER. HNISCHE MATCRIALEN, N.V., NETHEPLAMOS

$N P-16168$ (PT. 3 ) 27 PAGES, 1965

RFPORTS ONLY THE OESIGN AND CONSTRUCTICN FEUGLTSS TIE THE KEMA SUSFEINSION TEST REACTOR. 
AVAILASILITY - USAEC PUELIC DOCUYENT ROOM, WASHINGTON, D. C.

AGN (TNG) + LICENSING STATUS OF NUCLEAP PPOJECTS + REACTOR, TFAINING

$15-21442$

PM-3A TYOE? COOE SAFCGUARDS ANALYSES

HITTMAN ASSICIATES, INC., BALTIMORE, MO.

HIT-3616-4+. SE DAGES;'FIGUPES, TABLES, JANUARY 14,1066

PRESENTS RESULTS OF ANALYSIS OF ACCIDENTS WHICH INCLUDE CQLC STARTUP, REACTIVITY INSERTIGN, COLD WATER, LOSS OF COOLANT, SFCONDARY SYSTEM TRANSIFNTS, ANO A PEEUELING ACCIDENT. A GUIDE-RAIL SYSTEM WAS RECD:AMENDED TO PREVENT THE CORE FROM TURNING OVER IN REFUEL.ING. THE

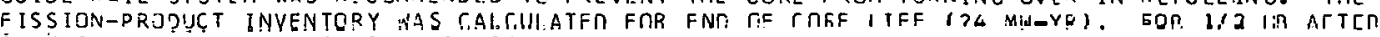
SHUTDOWN, THE TOTAL IS 13.1 M.ILLION CURIES.

AVAILAOILITY - CLEAZINGHOUSE FTR FECEPAL SCIENTIFIC ANC TECHNICAL INFORMATION, SPPINGFIELC, VA., \$3. DO COPY, \$. .55 MICFOFICHE

* ACCIDENT $\triangle$ VALYSIS + ACCIDENT, COLD COQLANT + ACCIDENT, LOSS OF COOLANT + ACCIDSNT, RELCTIVITY + FUEL HANULING + MOOIFICATION, SYSTEM CR ERUIPMENT + PN $3 A$ (PWE) + REACTOR, MILITARY + REACTOR, PWR

$19-21444$

HENORIE JM + SHEEHAN TV

REPORT ON HFER YODIFICATIONS LND TESTS PREPARATORY TO OPERATING AUTHORIZATION

BP.COKHAVEN NATIJNAL LARCIPATORY, UOTEN, N.Y.

SNL $-9308+.75$ PAGES, AUSUST I. 965

DESCRIBES MUDIFICATIONS, TESTS, DND SAFETY PROCEOURES NHICH WERE COMPLETED AS REGUIREO BY ACRS DQIIR TJ OPERATION BYY OESCRIEING THE AS-IS SITUATION NITHOUT INOICATING THE CHANGES I2O

PAGES). ODERATINS LIMITS ANO EMEPGENCY PROCEDURES APE INCLUDED IN THE APPENDIXES (45 PAGES).

AVAILABILITY - CLEMRINGHEUSE FOR FECEFAL SCIENTIFIC AND TECHNICAL INFORMATION, SPRINGFIELD, VA., \$3. OO COFY, \&O.55 MICROFICHE

EMER GENCY PROCEDURE + HFBR (PO) + MUDIFICATION, SYSTEM OR EQUIPMENT + REACTOR, HWR + REACTOR, PESEARCH + TECHVICAL SPECIFICATIONS + TEST, PFEODERATIONAL

$18-21452$

WISCONSIN ELECTRIC POWER GECOME HALF OWNER OF POINT EFACH I

USAEC, DIVISION OF PEACTOR LICENSING

5 PAGES, POINT EEACH !, AMENDMENT I TO CONSTRUCTICN! PEPMIT, DOCKET 5O-266, TYPE-PWR, MFG--WEST., 
CATEGORY 12
SAFETY ANALYSTS AND DESIGN RTPORTS

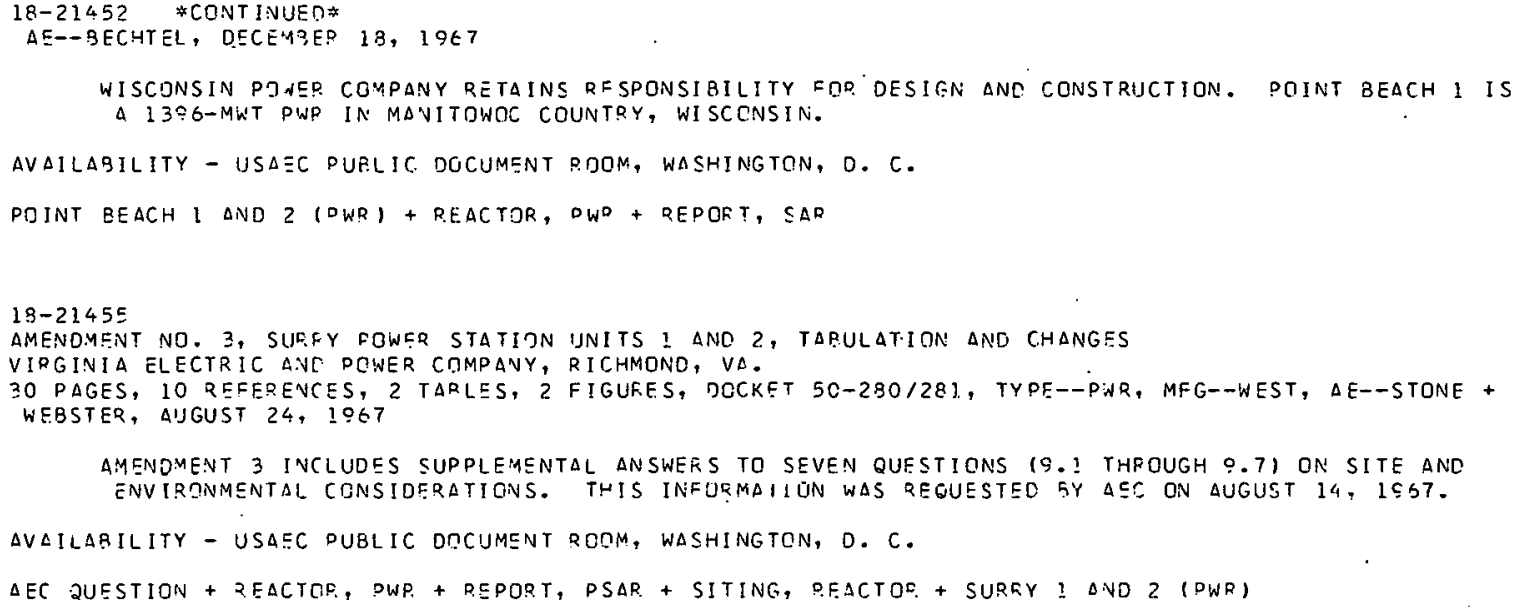


$18-21633 \#$ CONTIN.JED*

REQUIREMENTS CF THE AEC GUIDE COR THE DRGANIZATION AND CONTENTS OF SAFETY ANALYSIS RFPORTS IOESIGN ZASES WFFE NOT IDENTIFIEO CRR EXPLAINED, ETC.). SEISMIC-DES IGN INFORMATION WAS INCOMPLETE, AS WAS CONTAINMENT-OESIGN INFOFMATION. INSPECTION AND SURVEILLANCE PROGRAMS, QUALITY CONTRGL, AND TESTING WERE INADEQUATELY COVERED.

AVAILABILITY - USAEC FUELIC DOCU:AENT FOOM, AASH!NGTON, D. C.

*AEC DESIGN CFITERIA + $\triangle E C$ QUESTION + CONSTPUCTION PEPMIT PROCESS + REACTOR, PWR + REPORT, PSAR + ZION I AND 2 (PWD)

18-216ES ALSC IN CATEGORY 1

PURLIC ATt ITUDES AFFECTING THE GPOWTH JF a TOMIC POWER FLANTS IN CALIFGRNia

OFFICE TF ATOMIC FNERGY DEVELODIAENT AND RADIATION PROTECTION, STATE OF CALIF., SACRAMENTC

14 PAGES, DECEMBER 1CE

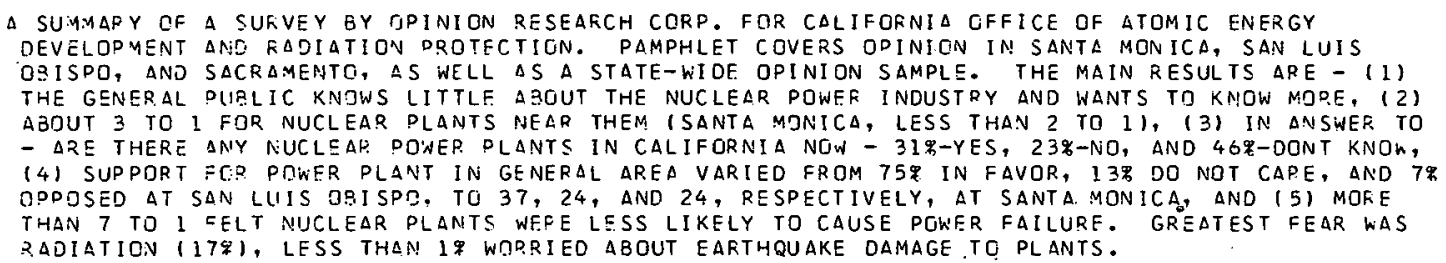

AVAILABILITY - DFFICE OF ATOMIC ENERGY DEVELOPMENT ANO PADIATION PROTECTION, SACRAMENTG, CALIFGRNIA

RAOIATION, PURLIC EDUCATION/ACCEPTANCF + PEACTOR, POWER

$18-21721$

SECONO SUPOLEMENT TO PRELIMINARY SAFETY ANALYSIS REPORT. INDIAN POINT NUCLEAR GENERATING UNIT NO. 2 CONSOL IDATER EDIS?IV COMPANY OF NEN YORK, INC.

157 PAGES, 54 FIGURES, 27 REFERENCES, 8 TAPLES, COCKET 50-247, TYPE--PWR, IMFG--WEST., AE--UNIJD ENGR, MAY 1966

IHIS EXHIBIT ANSWERS 13 QUESTIONS RAISED BY AFC REGULATOPY STAFF IN LETTER DATED MAY 11, 1966, REGARDING CONTAINMENT DESIGN, LOSS-CF-COOLANT ACCIDENT DETAILS, AVO EMERGENCY CGOLING.

AVAILABILITY - USAEC CUBLIT DOCUMENT PCOM, WASHINGTON, D. C.

AEC QUESTION + INDIAN! PCINT 2 (PNR) + REACTOR, PWF + REPORT, PSAR

$18-21735 \quad$ ALSO IN CATEGORISS $E$ AND 8

FRENCHRJ + GALLAGHER JM + MOOPE JS + SALVATORI R

INDIAN DDINT UNIT NO. 2 ROD EJECTION ANALYSIS

WESTINGHOUSE ELECTOIC CORP., DITTSBURGH. PA.

WCAP-? $940+$ +. 108 DAGES, 45 FIGURES, 7 TABLES, 25 REFERENCES, OF SFT SND SUPPLEMENT TO INDIAN POINT 2

PRELIMINARY SAFETY ANALYSIS REPORT (FXHIEIT 3-2), MAY 1966 , DOCKET 50-247, TYPE-PWR, MFG-- WEST,

AF--UNITD ENGR

IINCLUDED IN DSAR SUPPLEMENT 2.) ANALYSIS USES CHIC-KIN FOR KINETICS, AND HAS 1.E OF 1.0 REACTIVITY \& FOR EJECTED RDO iO OR ID2\% POWER) AND 1.5* FOP POSITIVE MOOERATOR FFFECT WITH A SCRAM AFTER 1.5 SEC. AI,THM SOME FUEL MELTINC WOULD OCCUR, PEAK SYSTEM PRESSURE IS LESS. THAN GOOO PSIA. A SHICK-WAVE ANALYSIS FOR. REACTOR VESSEL INDICATES THAT 1/3 OF COJHE MUST BECOME MDLTEN ANO DISPEKSED TO DILATE VESSEL WALL UP TO $50 \%$ ULTIMATE ELOVGATION IPASED CN TNT EXPER IMENTS AT NRL-WISEI.

AVAILABILITY - USAEC PUBLIT, DOCUMENT ROOM, WASHINGTON, D. C.

\#ACCIDENT ANALYSIS + *ACCIDENT, CONTROL ROD EJECTION + EXPLOSION + FUEL IMELTDOWN + INTEGRITY + PRESSURE VESSEL

$18-21797$

FRISCH A + HELLER F + HUEBSCHMANN W + MALANG S + MUELLER A + SCHIKARSKI HA + SMIDT D + WOITE F, SAFETY ASPECTS DF STEAM CQOLED FAST BREEDER P.EACTORS

KERNFORSCHUNGSZENTQUM, KARLSRUHE

KFK-613 +. 29 PAGES, 18 FIGURES, 8 REFERENCES, JUNE 1967

DRESFNTS SOME RESULTS OF THE DYNAMIC AND SAFETY ANALYSIS OF THE FIRST GERMAN $10 O C-M W E$ STEAM-COOLED FAST-BREEDER REACTOR DESIGN. CONCLUSIONS $\triangle R E$ - $(1)$ ALTHOUGH CONTROL SYSTEM IS NESDED, NO OSCILLATIONS WILL OCCUR WITHOUT ONF. (?) OYNAMIC BEHAVIOR COULD BE IMPROVED PY MOVING REHEATERS. (3) THE LOSS-OF-COOLANT ACCIDENT REQLIRES A RELI ABLE EMERGENCY COOLING SYSTEM AND ISGLATING VALVES. (4) SOME CONDITIONS REQUIRE THAT THE REACTOR NOT RE SCP.AMMED ACTER FAILURE CE A BLOWER OR STEAM GENERATOF, 151 BEHAVIOR DURING TURBINE-LOAD CHANGES IS STRONGLY DEPENDENT ON THE DENSITY COEFFICIENT. 
$19-21707 *$ CONT INUEC

AVAILASILITY - MICROCARC EOITION, INC., ACCOUNTING ANO SHIPPING DECT., WEST SALEM, WISCGNSIN 5LEGG

*PEACTOR DYNAMICS + \#SAFETY DNALYSIS + ACCIDENT, LOSS OF COOLANT + ACCIDENT, LCSS OC FLOW + GERMANY + REACTOR STABILITY + RFACTOR, BREEDEF + FEACTOE, FAST + RCACTQR, GCR + STEAM

$18-21808$

PEACH SDTTOM 1 CHAVGE 5--IPRADIATION CF TEST FUEL ELEMENTS

USAEC DIVISIQN OF REACTOR. LICENSING

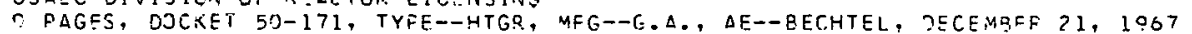

AUTHOFIZES JDEPATION WITH UP TO E FT. ST. VRAIN PROTOTYPE POOCF-TEST ELEMENTS, CONTAINING BOTH PYROLYTIC-CARQRN-COATED AND SILICCN-CARBIOE-COATED FUEL PLETICLES. THE TFST ELEMFNT DOFS NCT HAVE A PURGE STPEAM TO REMOVE FISSIGN DRODUCTS ANO COVTAINS 447 GRAMS OF FULLY ENRICHED U, COAPARED WITH 33.2 FOR A STANEAPD FLEMENT. CORE IRRADIATICN LOCATICNS $\triangle N D A$ LIMIT OF 5 TEST ELEMENTS $\triangle R E$ SPECIFIED.

AVAILABILITY - USAEC FUELIC OÜUUMENT ROOM, WASHINGTON, D. C.

* SAFETY EVALUATION + \#TECHNICAL SPECIFICATIONS + COATEO PARTICLE + FUEL ELEMENT + IRDAOIATION TESTING + PEDCH BOTTOY I (HTGP) + DEACTOR, HTGR + SILICON

$18-21916$

15 TELEGFAMS TO THE PFESICENT PQOTESTING CONSTOUCTION OF VEQMONT YANKEF

1 PAGE, AT THIC ENERGY CLEARING HCUSE 14(2), PAGE 32 (JANUARY Q, ICEE) COCKET 5O-271, TYPF-RIR, NIFG--G.E., $\triangle F=-S B \triangle S C D$

FIPTEEN TEL FGRAMS FFOM IVDIVIDUALS TO THE PPESIDENT DROTSSTING CONSTRUCT ION DF THE DLANT WERE

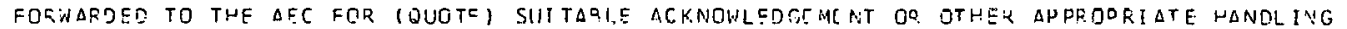
luvougtis.

\#CONSTRUCTICN PERMIT DQQCESS + \#RADIATION, PUSLIC EDUCATION/ACCEDTANCE + REACTOR, BHQ + VERMDNT Y ANKEE (BNQ)

$16-219 ! 7 \quad A L S O$ IN CATEGORY 2

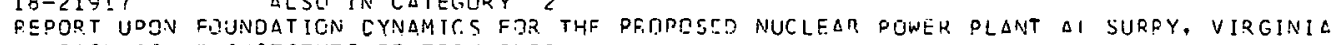
MASSACHUSEIIS INST ITUTE OF TECHNCLCGY

52 PAGES, 23 FIGURES, 6 REFERENCES, AMENCMENT 4 (SUPPLCMENT VOLUME II OE THE $\triangle D O L I C A T I B N$ ECR LICENSE FOQ

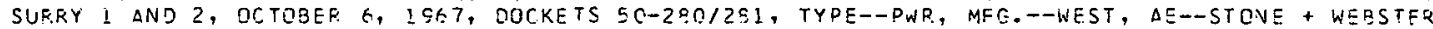

(INCOPPORATED IN SIRRY I ANO ? PSAE, AMENDMENT 4.) ANALYTICAL MCOSL AND CALCULATIONS GF EARTHOUAKE RESPCNSE GIVEN IN DETAIL FOS SURRY DND CGR NIGATA. ALTHOUGH WATER TAELE IS DT ELEVATIGN ?ERC, WATER STOOD IN DRILL HOLE FROM E TO 20 FT ELFV. DUE TO DEFCHED AND SEASONAL WATEP TABLSS. RELATIVE DISPLACEMENT OF STRUCTURES IS LESS THAN 3 IN. FO? MAXIMUM

HYPOTHETICAL EAFTHOUAKE. SIILS UNDER CONTAINMENT BUILOING APE MORE FAVCRABLE ICETAILEO

COMDAQISON UADE) THAV AT NIGATA, JAFAN, WHERF A SET OF SEVFPE FARTHOUAK SS IN IOEL DCODUCEO NIJ LIOUEFACT IOV OR SETTLEMENT. SITE ALSC CCMPAPED WITH THAT AT MALI 3I. * * VERY CCNSEPVATIVE ESTIMATES IVDICATED THAT LIQUEEACTIGN MIGLT OCCUR IN THE SANO UNDER THE CUEL BUILOIAGG. PEPORT SUGGESTS THAT PLANNED IISE OF DILES EF REVIEWED, ANO, 1F FILES ADE USED, STEDS QE TAKEN 10 OREVENT LIOUEFACTION.

AVAILABILITY - USAEC FUELIC DOCUMENT RQCM, WASHINGTON, O.C.

FFOUNDATION ENGINEERING + \#LIQUEFACTION + ANALYTICAL MOOFL + COMPAFISON, THEORY AND FXPEFIENCE + EARTHQUAKE ENGINECQING + RFACTDR, DWD + SAFCTY MARGIN + SITINIF FEACTOR H SOIL MECHLNICS + SUROY I ANC ? (FWR)

$18-2 ! 924$

NINE MILE DOINT AMENRMENT 3 TO ESAR-REVISED PAGES ANG TECH SPECS.

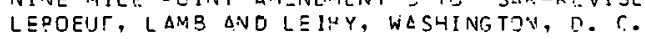

164 OAGES, EIGURGS, TABIES, NINE-YILF TIINT UNIT 1, THIRD AMENOMENT TO THE FINAL SLEETY ANLLYSIS FEPORT;

JULY 17,2067 , DOCKFT NO. 50-220, TYPE- -P, MR, MEG--G.E., $\triangle E--N I A G A P \triangle M C H \triangle W K$

AMENDMENT 3 CONSISTS OF RCVISED PAGES TC VOLS. I DND II OF THE FSAR, AND VIL. III - TECHNICAL STECIFICATIONS.

AVAILAgILITY - PUBLIC DCCUMENT ROJM, WASHINGTON, D. C.

NINF 4ILE OOINT (BNC) + YLACTCR, BWR + PEPCIRT, PSAR + TECHNICAL SPECIFICATIONS

$1 Y-\angle 1 O 20 \quad \Delta L S G$ IN CATEGORY 12

MONTICFLLI AMHVDMEVT a TO PSAR-ODESCRIPTIGN OF CNGINEEPCO SAEEGUACDS

NORTHEQN STATES PONER COMPANY, MINNEAPRLIS, MINN.

83 PAGES, FIGURFS, TAELES, MONTICELLO NUCLEAR GENLPATING PLANT, THIRO AMENCMENT TO CONSTPUCTIMN PESMIT

APPLICATION, DOCKET NO. 50-263, TYPE--PWF, MEG--G. F., $\triangle$ E--GECHTEL, DECEMBER 2O, 1CSS 
SAFETY CATESORY 1 S

SOFETY ANALYSIS AND DESIGN REPORTS

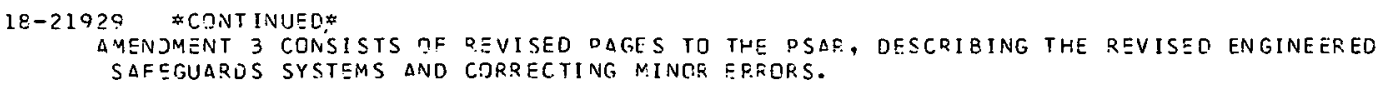


SAFETY ANALYSTEGOOYY DE̊ OPIGN FEFOFTS

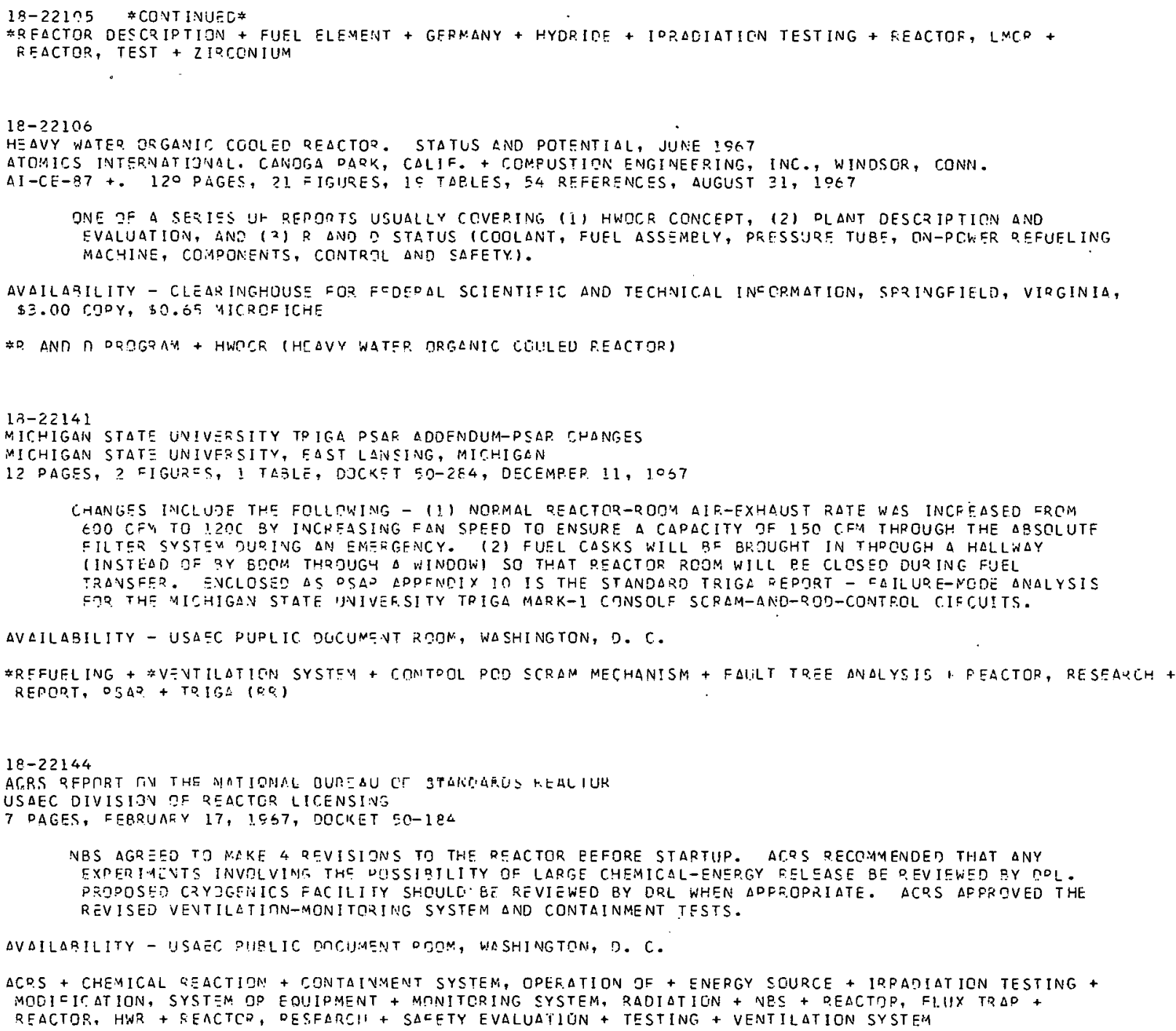


18-22223*CONTIN.J:C*

AVAILAPILITY - USAEC PURLIC DOCUMENT KONM, WASHINGTON, D. C.

*FOUNDATION FNGINEERING + MILGRIM STATION (BWD) + REACTOR, 3NR + FEPDRT, PSAF

19-22224 ALSO IN CATEGORY 17
PATHFINDEQ DQODOSES AMENDMENT 42-STOEACE OF COPE II FUEL

PATHF INDEQ DQODOSED AMENDMENT 4 ? - S
ALLIS-CHALMEZS, EETHESDA, MARYLAND

4 PAGES, DOCKET SJ-130, TYDE--BWR, MEF--A.C., DF--PIONFEF. SEKV., JULY $28,1 C E T$

P.FOUESTS TECHVIT, AL-SPECIFICATION CHLNGES TG FERMIT RECEIPT ANC STORAEE TFF CORE-II TYPE OF FUEL, NHICH IS SLIGHTLY DIFFERENT FEOM CCRE-I FUFL. ATTACHED IS $\triangle C N P-67525$ \#\# SAFEGUARDS ANALYSIS FTIR SECGNR CORE LOADING. \# CHANGES ARE - 111 LOn-ENFICHMENT SUPERHEATEP FUEL IN PLACE OF CERAFT. 12 , B $4 C$ PELLETS-IN-TUSFS CONTROL RODS IN PLACE OF BOPON-SS CRUCIFORM RODS, AND (3) FOILEP. FUEL RODS HAVE (INIFCRM DIAMETER WITH SOME WATES-FILLED RDOS IN THE STEAM-VIIDFD UPOEP. OEGIJN IN PLATE GIF STEPPED-DIAMETER FUEL RODS.

AVAILABILITY - USLEC DIJBLIC DGCUM=NT POOM, WASHINGTON, D. C.

*FUEL STORAGE + CONTPQL PDO + FUEL ELEMENT + MOOIFICATION, SYSTEM OR EQUIPMENT + PATHFINDER (ISF) + REACTOR, BWR + REACTORR. INTERNAL SUPERHEAT + TECHNICAL SPECIFICATIONS

13-2723E ALSO IN CATEGORIES 5 ANC $S$

$\triangle C E S$ REOJRT ON DIABLC CANYGN

U.S. ATOMIC ENEREY COMMISSION, WASHINGTEIN, D. C.

5 PAGES, 11 FEFERE UEES, DOCKFT 5C-275, TYDE--PWR, MFG--WEST, AE--FG+E, DECEMGER 20, 19E7

ACRS PELIEVES THAT THF FOLLOWING $t$ ITEMS PERTAIN TO ALL LARGE WATER-COGLED POWER REACTORS -

(1) THER:AAL SHACK. EEFECT OF COL W WATER INJECTION IN LOSS-OF-COCLANT ACCIDENT, (2) EFFECT OF

OLTWDONN FORCES ON COPE ANO PRIMAPY SYSTEM COMPONENTS, (3) EFFECT JF FUEL FAILUPES ON

EMERGENCY COOLING ABILITY. (4) INIEPENDENCE RF CONTPBL ANC PROTCCTION

INSTRUMENTATION--PPESENT DESIGN INADEGUAIE, (5) PR.OMPT DETCCTION JF GPOSS FUEL FAIIURE. (O)

PQI:AARY-SYSTEM DUALITY C.ONTROL AND IN-SERVICE INSPECTION. \#\# FIXED POISON IBOROSILICATE

GLASS) JURING EIRST CYCLE TJ ENSUFE NEGATIVE MODERATOR COEFFICIENT NEEDS MORE PERFOPMANCE

DATA.

AVAILABILITY - USAEE PUZLIC DOCUMENT OORM, WASHINGTON, D. C.

* BLOWDONA + TREESSIJZE VESSEL + \#THEF:MAL MECHANICAL EFFECT + ACCIDFNT, LUSS OF COOLANT + ACFS + CONTROL ROD PRIIGRAA + CORE REFL OTOING SYSTEM + DIARLO CANYON (PNR) + EMCRGENCY COOLING CONSIDERATIONS + FAILURE, FUEL ELE IENT + FAILUPE, FUEL FLFMENT + INDEPENDENCE +

INSTRUYENTATION, JETECTION FAILEO EUEL ELEMENT + MODERATOR COEFFICIFNT + PLANT PROTECTIVE SYSTEM + POISON, FIXEO+ ZEACTOF, PWR

$18-22279 \quad \Delta L S O$ IN CATEGORY $: 7$

I IRTTNFSS RI.

NUCLEAR POWEP PLANTS. DESIGN, JHERAIING EAUNÁIEIJCE, AND ECONGMICE

ATOMICS INTERNATIJVAL

548 PAGES, FIGURES, TAPLES, REFERENCFS, O. VAN NOSTPAND COMPANY, INC., PRINCETDN, NEW IELSEY, TORGNTO, NEH

YORK, LIJNOUN, 1954

AFTER 30 PAGES OF ENGINEERING DRIMCIPLFS AND REACTOR FUELS AND MATERIALS, BOOK BECOMES A SET DF 3-PAGE DESCFIPTIONS OF 121 FFACTORS, SUBDIVIDED INTQ VARIOUS TYPES. \#\#\#ADEQUATE AS A CJMP ILATION OF OUTSTANDING FEATUPES OF VARIOUS PLANTS BUILT BEFGRE 1904.

AVAILABILITY - D. VAN NGSTRANO CO., INC., 24 WEST 40 ST., NFW YORK 19, N. Y., \$12.00 CEPY

\#REACTOR DESCR.IPTIJN + FEACTOR, PDWER

$18-22339$

CRL REQUESTS ADOITIJNAL INFTRMATION ON PRAIRIE ISLAND PSAR

USAEC DIVISION OF REACTOR LICENSING, WASHINGTON, D. C.

3 PAGES, DOCKET 50-282 AND 50-30E, TYPE--PWR, MFG--WEST., AE--PIONEER. SERV., DFC. 29, 19E7

DRL ACKNOWLEDGES RECEIPT OF AMENDMENT 2 TO PSAR AND $\triangle S K S$ FOF ADDITIONAL INFORMATION IN! CFF TAIN $\triangle R=A S$, INCLUIING INFORMATION REQUESTED NOV. 15 ANO 21,1967 I I AND C DESIGN, POSTACCIDENT INSTRUMENTATION, RESULTS DF SMALL CCOLANT BREAKS - 0.55 SQ. FT OR LESS, AND INFOFMATIDN ON PART-LENGTH CONTROL RODS). GUESTIONS ON CONTAINMENT DESIGN (SIMILAR TO INDIAN POINT I) D.ESULT SINCE THIS IS FIRST TIME THIS DESIGN HAS BEEN USEO IN A BIG PWR. AVERAGE POWER OENSITY IS IRT HIGHFR THAN FGR PREVIOUSLY APPROVFD PWRS.

AVAILABILITY - USAEC PUBLIC DOCUMENT POOM, WASHINGTON, D. C.

* AEC DUESTION + CONTAINMENT DESIGN + CONTPCL POD + INSTRUMENTAT.ION, GENERAL +

PRAIRIE ISLAND I AND 2 (PWR) + REACTOR, PWR + REPQRT, PSAR 


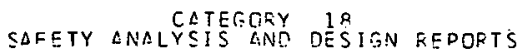

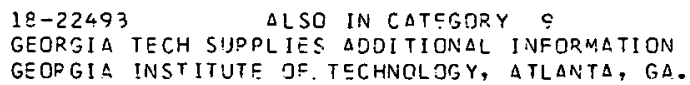

IOESDINSE TO $\triangle E C$ QUESTIONS JF 27 APRIL IOE?. NCTE - EFACTCP HAD BEEN CRIGINALLY AT UNIVEPSITY DF $\triangle K K O N)$ - (1) O-D INGS WILL QE REPLACEN ANO TESTED TO IS FSI TC CHECK. TANK LEAKTIGHTNESS. (2) SCRAM C.IRCUIT MCDIFIEO IN ACCOF DANCE WITH $\triangle G N$ ORINT 2-ONC-7LI-H. (2) ALL CICCUITS $\triangle N$ IO

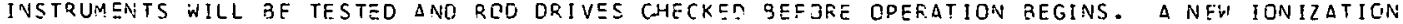
CHAMBER WAS TJTAINCE, LNJ THE LINCAP AND LOG-N MCTERS, WERE OVSFHAULEO DT THE FACTOFY.

DVAILABILITY - USAEC PUBLIC DCCUMENT ROCM, WESHINGTON, D.C.

\#INSTRUMENTATION, GENERAL + \#TEST, LEAK FATF + $\triangle E C$ QUESTION + $\triangle G A:(T N G)+$ MOOIFICATIQN, SYSTSM UO EOUIONENT + REACTCP, RESEARCH + REACTOR, TOLINIVO + EEPCRT, PSAD + SEAL

$18-224 \div 4$

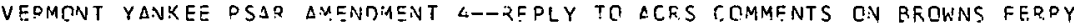

VERMAVT YANKEF NUILLA? DOWEQ COMGANY, RUTLAMO, VEOMONT

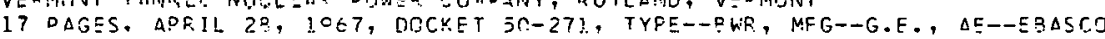

SUSHITS VEF. 1JNT YANKEES OOSITIOU CONCEFNING DCPS CCMMENTS (I4 MARCF ST) ON BROWNS FEDPY $D=C A U S E$ OF THE SIMILADITICS FFT AFEN THE TWC. ITEMS COVFRCD ARE (1) ECFECT OF FLIEL CLACDING CAILURE RN EMERGENCY COZLING 121 COFE-SPRAY EFFECTIVFNESS, 1 I) ENERGENCY-PJWER-CENTCOL SYSTCMS, (L) INSTOUMENTATION INDRQVEMENTS, (S) ISOLATION-VALVETFSTINF, (S) FUCL

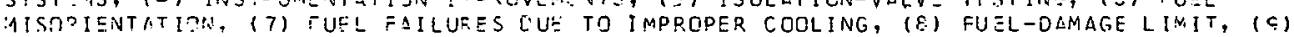
F.OD-BLOCK-VIOVITOR, SYSTEM OESIGN, (10) OIESEL-GENERATOR TESTING, (1I) DUALITY $\triangle S S U=\triangle N C E ~ A N D$ INSPECTION JE THE POIMAEY SYSTEM, (12) IN-SERVICE INSPECT1GN, (12) STAFTISE PDCGOAM $\triangle N D$ (] 4) INCPEASED SAFETY MAF.GINS.

AVAILABILITY - USAEC FUELIC OTCUMENT ROMM, WASHINGTCN, D. C.

\#CONTAIPMENT PEIVETRAIIUN, CLOSURE OFF + \#CCPE SPRAY + \#EMERGENCY CCOLING CONSIOCOAT IONS + *FAILURE, CLADDING + \#INSTRUMEVTATION, GENEPAL + $\triangle C C I D E N T$, REFUELING + $A C R S+\triangle F C$ QUSSTIUN + CONTROL QOD DRIVE + ENEOGENCY POWER, ELECTRIC + EXAMINATION + FLCW BLOCKACE + FUEL ELFMFNT + GENEPATR?, DIESEL + DERFOPMANCE LIMIT + QUALITY CONTROL + REACTOR, BWR + REPORT, DSAR + SAFCTY MAFGIN + SUPVEILLANCE PPOGRAW + TEST, PZOOF + VALVE + VERMONT YANKEE (BWR)

$18-\overline{2} 2405$ ALST IN CATEGTRY 1 ?

FLPHPIVUER CHANGE IJ--STOTSAGE OF COFE II FUEL

USASC, DIVISIZN OF RFACTRR LICENSING

5 PAGES, AUGUST $S, 1 C S 7$, DOCKET 5C-13ח, TYPE--3WR, MFG--A.C., AE--PIONEFR SEPV.

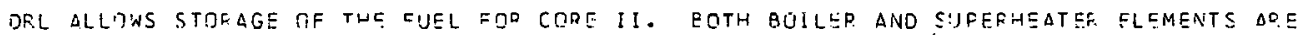

OIFFEREVT SO JM DFESENT FUEL. STOEAGE ARPAY RESULTS IN A K-EFE LESS THAN O.E EVEN IE FLOCDEC.

AVAILABILITY - USAEC, DUBLIC DOCUMENT POOON, WASHINGTON, D. C.

FFLEL STOKAGE + PATHFINOCR (ISQ) + PEACTOF, PWR + REACTOR, INTERNAL SUPERHEAT + FEFUFLING + SAFETY EVALUATION + TECHNISAL SPECIFICATIONS

$18-2.2511$

DRL REDUESTS ADCITIONAL INFTRMATION ON DILCDIM STATION

USAEC DIVISION OF REACTCQ LICENSIVG, WASHINGTON, D. 6 .

14 PACE5, JECEMBER 12, IU67, DOCKCT 50-29इ, TYPE-OBWF, MFG--G.E., AE-DECHTEL

IN ADOITION TO 50 OETAIL= JUESIIONS, ORL $\triangle S K S$ FOR GENERAL INFOPMATION ON ERINCICAL DFSIGN SRITERIA, DCEANOGEAPHIC AND METEGPLGGICAL PROGRAMS, SUGSURFACE INVESTIGATIOH, ANO A SEISNIC AINALYSIS.

AVAILAOILITY - USAEC PUELIC DOCUMENT DOOM, NASHINGTON, D. C.

\#AEC QUESTION + PILGEIM SIAIICN (QWF) + R.EACTOP, BWR + REPORT, PSAR

$18-22531$

GIMSTEDT J + SANOSTRCM S

THF NIJCLEAR DOWEP STATIGN AT ISKARSHAMN

AKTI ISOLAGET ATCMENTRGI, STOCKHOLU

I PAGE, I FIGURE, ENFQF. NUCLEAIRE G(S), PAGE ?OG (SEPIEMGFR 1O67)

BR.IEF DESCRIOTION (IN FFCNCH) OF SWEDISH CSKACSHAMN 4CO-MWE GHP, TO BE IN DPERATION IN IGTO.

REACTER DESGRTPTION + FEACTOR, BHE + SWFMEN 
$18-22593$
EPEL LG+ LEVINE $11+$ NUGENT G + PAPSICKKFJ

THE. DRDERED-GEO EAST EEACTUR CONCSPT (IOOC-MW(E) REACTOR DESIGN)

BRDOKHAVEN NAT IONAL LABCRATORY, INC.

BNL $-50027+.37$ PAGES, 15 FIGURFS, 19 TAELES, 20 RECERENCES, JUNE 1966

10ON-MWE PLANT YILL HAVE L DOUBLING TIME OF II YEARS, TCTAL EAERGY COST 3.28 MILLS/KWE-HR US:5 URANIUA CARRIDE SPHEPES CROLED OY LIOUIN SONIUM. \# BRIEF REVIEW OF REACTOP PHYSICS ANO ENGIVEERING ASFFCTS, ECONOMIC ANALYSIS.

AVAILASILITY - CLSARINGHGUSE FOR CECEFAL SCIENTIFIC AND TECHNICAL INFORMATION, SPRINGFIELD, VIRGINIA \$3. OO COPY, $\$ 2.55$ YICRJ $=$ ICHE

\# OESIGN STUDY + FR EACTOF DESCDIOTION + PEACTOR, FAST + REACTOR, LMCF + REACTOR, CIROEREC EED, FAST

18-2277? ALSG IN CATEGORY Z

PILE FDUNDATIDN DESIGN

MMAHA PUBLIS POWEP DISTFICT

5 PAGES OF SIJP?L UENT 4, EXHIPIT F4, TO FT. CALHOUN 1 - FACILITY DESCFIPTION AND SAFETY ANALYSIS REPORT, DOCKET 5O-205, TYPE--Phiz, MFE--C.E., $\triangle E--G I B B S+$ HILL

EXTENOS INFORALTICN FELATIVE TQ FOUNDATIONS AS COVERED IN SECTION V-2.5.3 CF THE PSAR AND P.ECLCCTS SJBSEOUEVT DEVEL TOMFNTS RESULTING FROM SITE EXFLORATION. CAVITIES IN THE BEOROCK SENEATH THE PLANT SITE WEPE DISCLOSEO BY BORINGS. DESCRIBES THE PILES TD SUPPORT THE CLASS-I STRUCTUOES. YFTHCO CIE INSTALLATION, AND TEST PROGRAM.

AVAILABILITY - USAEE PLELIC DOCUHENT ROOM, WASHINGTON, D. C.

*FOUIVATION EVIINEzRING + FT. CALHOUN (PWR) + REACTOR, PWP. + REPCRT, PSAR + SOIL PROPEFTY, IN SITU

10-22796 ALSO IN CATFGORY 2

NS SAVANINAH REVISED FCRT DPEPATING PLAN FL:K EOSTON

FIRST ATJMIC SHID TZANSPRQT INC., NEW YOFK, NEW YORK

FAST-112+. 41 PAGES, $t$ FIGURES, DEC. 22, 1967, DOCKET NO. 30-238, TYPE--PWR, MFG--B+W, AE--G.G. SHARP

PLAN HAS 3EEN PEVISEO TO INCLUDE ACOITIONAL BERTHS AT CASTLE ISLANO TEFMINAL AND TO MODIFY SLIGLTLY THE STISTON HAFBOR TKANSIT. PLAN ALSO FEELECTS CHANGE IN CAPE COD CANAL PILOTAGE. L TW-D ?PULATION-ZUNE RAGIUS IS 1 EQC FT AT MYSTIC.TERMINAL AND 2400 FT AT CASTLE ISLAND T ER Y IVVAL.

AVAILABILITY - USACC FUELIC DCICUMENT DOON, WASHINGTON, D. C.

NS SAVAVNAH (PWR) + FEACTOR, IALITIME + REACTOR, PWF. + SITING, REACTOR

$19-22800$

DALIF IONNE $M+$ PALLFELZ J + KUCHLE M

SOME ASPFCTS OF THE FEASISILIIY UL A IUIEOFLUK REACTOR

KERNFORSCHUNGSZLNTRUN, NARLSRUHE (WEST GEEMANY)

KFK-575 +. 35 PAGES, \& FIGURFS, 5 TAELFS, 26 REFERENCES, JUNE 1967

DISCUSSES NEED FOF A HIRHER-FLUX PFACTOR; THE POSSIRLE EXPERIMENTAL USAGE, AND CORE MATERIALS TO RE USED IN SUCH A P.FACTDR. RFSICE DECREASING THE TIME TO DO AN EXPERIMENT, IT WOULD ALSO INCRELSF THE SIGNAL-TQ-NOISE RATIG CF. THE RESOLUTION. 3 COOLANTS (HZC, NA, HZ) WERE ANALYZED, WITH SLPERCRITICAL WATEF HAVING THE REST PRIDPETIES. PRESSURE DROP ACROSS THE CORE WCULJ BE 49 TUT 'LEO PSI DIJE TC HICH VELOCITY $\triangle N D$ SMALL CHANNELS. INCONEL 625. WAS CHOSEN FOR

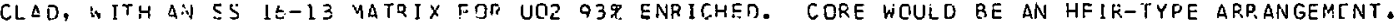

AVAILABILITY - AICRORAFO ËITIONS, INE. (FCR SALE) ACCOUNTIAG ANO SHIPPING DEPARTMENT, WEST SALEM, WISCONSIN 54659

DESIGN STUJY + PERESFHANCE LIMIT + FEACTCF, FLUX TRAP + REACTOR, RESEARCH

$15-22936$

ACRS REPDRT TN SAN ONOFRE

U. S. $\triangle T$ OMIC ENERGY COMFISSION, WASHINZGTON, C. C.

3 PAEES, OCTOSEF 8, 1960, DOCKET 50-2CS. TYPE--PWR, MFG--WEST., AE--SECHTEL

KEACTOR-VESSEL SUFVEILLANCE PROGPAM USES 8 CAPSULES, CONTAINING VESSEL MATERIALS, BETWEEN THE THE RMAL SHIELO AND THE VESSEL. SEPARATE CAEINETS WILL BE PRCVIDED FOR THE PRESSURIZED LEVEL AND DRESSURE CONTROL TFANSMITTEFS TO REDUCE THE LIKELIHOOD OF SIMULTANEOUS FAILURE.

E:AERGENCY PDNER WILL SE SUPPLIED PY ? DIESFL GENERATORS.

AVAILABILITY - USAEC PUBLIC DOCUMENT PCOBM, WASHINGTCN, D. C. 
CATEGORY 18
SAFFTY ANALYSIS ANO DESIGN FEPORTS

$18-2.2836$ \#CONTINUEO*

\#PRESSUFE VESSEL + † SUP.VEILLANCE DRQGPAM + ACRS + EMERGENCY POWER, ELECTRIC + INCEPENDENCE + REACTCR, PWP + REPORT, SAD + SAN ONOFOE (PWP)

$18-22342$

GEORGIA TECH PR.CPOSED AMENDMENT--INITIAL STARTUF PRCCEDURE

GEORGIA INSTITUTE DF TECHNOLOGY

3 PAGES, JANUARY $15, \quad$ ! 968 , DNCKET $5 C-776$

PRDCEDURE TO 3 F FCLLOWEO IN PERFOPMING INITIAL EXPERIMENT IS THAT GIVEN IN EIEHL ET AL.

(ELEMENTARY REACTOR EXPERIMENTATICN). EXCEPT II) PU-BE SOURCE IN AN ACCESS PCRT INSTEAD OF OD-BE IN THE GLOKY HOLE, 12 ) MNLY Z AUXILIDRY NFUTRON DETECTCRS WILL BC USEO, DND (3) INITIAL

LIADING WILL DE WITH LCWER HALE OE CDRE FUELED BUT WITH POLYETHYLENE IN THE UPPER HALF:

AVAILARILITY - USAEC PUELIC DOCUMENT FJCM, WASHINGTON, D. C.

\#REACTJP STARTUP TESTINE + AGN (TNG) + INSTRUMENTATION, NUCLEAR I. PEACICR, TRAINING + SOUPCE, NEUTPON + TECHNICAL SRECICIEATIIINS

$18-22843 \quad \Delta L S C$ IN CATEGORY S

MICHIGAN STATE TEISA OEQUESTS PERMISSION TO REASSEMBLE 4 FUEL ELEMENTS

MICHIGAN STATE UNIVIRSITY

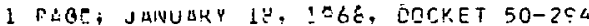

IT IS NECESSAPY TC DISASSEMBLF \&. INSTRUMENTED ELEMENTS FOR TRANSFER FROM U OF ILLINOIS. THESE ARE TO RE QEASSFMRLET IN THE STORAGE APEA OF THE POOL OF IN 2 FUEL CASK SUSPENDED DVER THE POCLL. THEY WILL THEN FE TESTSD FOF ELECTFICAL CONTINUITY. GNLY OVE ASSEMBLY WILL BE TESTED

IN THE CORE $\triangle T$ A TIMF, THEN FETUONER TO STORARE.

AVAILABILITY - USAEC OUELIC DORUMENT EJOM, WASHINGTON, D. C.

*FUEL HANDL ING + FIJI SLEMENT + INSTFUMENTATION, IN COFE + INSTRUMENTATIDN, TEMPERATURE +

DEACTQP. RESLARCH I TECHNICAL SPECJHICATICNS + TPIGA (RR)

$18-2.2847$

SAN ONOERE AMFNOMEVT'1! - SUOFLE HFNT? TO FSAK.

SOUTHERN CAL IFOPIVIA EDISTN COMDANY + SAN OICGJ GAS AND ELCCTRIC COMFANY

50 PAGES, TARLES, FIFIRES, DEFEOENCES, MAY 31, 1OE, UOCKET 50-206, TYPE-DWR, MFG--WFST, AE--BECHTEL

SUDPL. ? ANSWERS L ZUESTITNS ON SIJPVEILLANCE PROGRAM, STARTHP ACCIDENT, MAXIMUM CONTROL-PUD WIRTH, ANO HVOROGIN =IRE. ALSE INCLUDFO IS THE FSAR REFERENCE-CRANING LIST, LIST JF VALVES, AND REVISED FLOW OIAGR.AYS.

AVAILABILITY - USAFC PUELIC LOCUMENT FOMN, WASHINGTON, D. C.

AEC QUESTION + REACTCR, DWF + CEDORT, SAF + SAN ONOFRE (PWR)

18-2?:51 ALSC IN CATSGOPY 17

ITEM 4 - REVISED DRTCESS FLFW DIAGRAMS AND A REVISED TABLE LISTING VALVES

SOUTHERN CALIFORNIA EEISTN COMOANY + SAN DIFGO GAS AND ELECTRIC CCMPANY

17 PAGFS, 2 TABLES, I? EIGIIEES. DAGES 28 THEU LS OF SUOPLEMENT 2 TO THE FINAL SAFETY LNALYSIS REPORT FOR

SAN UNDFRE VUCLEAR GENEPATING STATICN, MAY 21, 196E, COCKET 50-2CE, TYPE--PWR, MFF, N-WFST, AF--BFIHTEL

LISI ALL VALVES, INCLIIDING CLASS, TYPC; NOOMAL DOSITION, METHGO OF ACTUATION, DNO FAIL-SAFETY. FLON JIAGRAMS APE FOR MISCELLONEOUS WATEF. SYSTEMS, FEEDWATER AND CONOENSATE SYSTEM, CJADRESSED-AIP. SYSTEIA, DIR-CANOITICINING SYSTFM, REACTOR COOLANT SYSTEM, ETC.

AVAILABILITY - USAEC DUELIC DOCUMENT POCM, WASHINGTON, D. C.

\#SYSTEM DESCRIOTIOV + \#VALVE + AUXILIAQY CCOLING SYSTEM + CONTAINMFNT PENETPATION, GENEPAL + CORF REELONDIUG SYSTEM + MAIN COOLINE SYSTEM + FEACTOP, PWR + PEFGFT, SAR + SAN OHOFPE (OWP) + VENTILATION SYSTEA + VISTS OISPOSAL, GENEPAL

$18-? 2954$

ACRS REOTRT DN THREE MILE ISLAND

IINITED STATES LTOMIC SNERGV CEMAIISSION

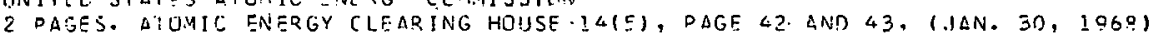

(JAN. 17) FAVOFAPLE REPORT INCLUOES PECOMMENDATIOHS - 11 1 CIFFERENT DRTNCIPLE FOP 4 SFCONO SENSOC TO IVITIATC ECCS ACTION, (2) EEVISF SCEAM BISS SE THAT ALL OROP IF EITHER D-C FEEDFR IS DE-ENERGIZET, (3) CULLEST SEPADATJCEN EETWEEN CCNTRDL AND PEOTECTION SYSTEMS, (L) OEVELOPMENT OF DROAPT DETECTION FOP GPISS FUEL FAILUPE. ADVISES REGULATCRY STAFF TO REVIFW BLOWDOWN EFFECTS DN COP.F INTERNALS, THERMAL SHOCK OF ECCS OPCEATION JN REACTOR VESSEL. SUEGESTS EXOEOIMENTAL VEP.IF ICATION IHAT NORIALL VIRFATION WILL NOT UNSEAT CORE-EARPEL CHECK VALVES BET WFC'N HOT $\triangle N$ COLD LEG. 
CLTEGORY 18
SAFETY ANALYSIS ANU DESIGN REPOFTS

$18-22954 \quad$ \#CONT INUE[:

$\triangle C R S$ + CONSTRUCTION PERMIT PROCESS + REACTOR, DHP. + SAFETY PEEVIEW + THREE MILE ISLAND (PWR)

$18-22910$

RUSSELVILLE RSSPQNSE TO THE 70 CONSTRUCTICN PFEMIT CRITERIA

ARKANSAS POWFR ANO LIGHT CO.

29 PAGES, JAN. 22, 1968, DOCKFT NO. 50-313

RESPONDS TO THE JULY 11, 1967 , CRITEFIL WITH $\triangle$ SHORT SIMMMAFY PARAGRAPH AND DETAILED PSAR REFERENCES EOR EACHISEPARATE CEITFQION.

AVAILABILITY - USACC PURLIC DOCUMENT RJOM, WASHINGTON, D. C.

AEC DESIGN CRITERIA + REACTGR, PWP + REPGRT, DSAR + RUSSELLVILLE (PWR)

18-22911 ALSO IN CATEGORY .2

SALEM AMENDMENT 3 TO LICENSE ADOLICATION-SITE ANE NAMF CHANGE ANO PSAO

PUBLIC SERVICE ELECTPIC AND GAS CTMPANYY

6 PAGES, JAN. 22, 19tE, DDCKFT NO. 50-?7?/311, TYPE--PWP, MFG--WEST., $\triangle F--P U B L I C$ SERVICE GF N. J.

UNITS WERE FDRMEFLY CALLED RUFLINGTON 1 MAND 2 AND LOCATED AT FURLINGTON,'N. J. NEW SITE' IS $\triangle T$

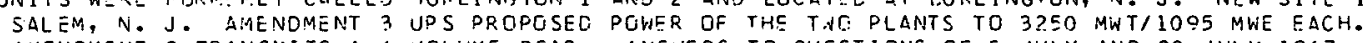

AMENDMENT 3 TPANSMITS A 4-VOLUME PSAR. ANSWERS TO OUESTIONS OF 3 JULY AND? JULY 1967

$\triangle P P \subseteq A R$ IN THE P.ACK CF VOL 3 . VOL L CCNSISTS OF SALEM ANSWERS TE DIABLO CANYIN GUESTIONS FROA

$\triangle E C$ OF 5 AND, 19 MAY, 30 JUNË, Z1 LUG., 20 OCT., AND I NCV., 19O7. SOME QUESTIONS ARE

ANSWERED BY GIVING A REEERENCE TO THE DSAF.

AVAILABILITY - USAEC FUELIC DOCIMENT ROOM, WASHINGTCN, D. C.

AEC QIIESTIJN + REACTCR, DWP + REPJRT, SAP + SALEM I DNO 2 (P.NF) + SITING, REACTOR.

$18-2291 ?$

HUNTERSTON B

2 PAGES, 2 FIGURES, NUCLEAP. EMGINEEPING 121139$)$, PAGE $9 ? 4 \triangle N D 925$, (DEC. 1967)

T.WO 1250-MW(E) AGF.S (IN SCOTLAND), VEF.Y SIMILAR TO HINKLEY POINT B. GAS CIRCULATORS ARE ENCAPSULATEO TO PROVIDE DOUSLE CONTAINMENT. THERE APF 12 ONCE-THROUGH BCILER UNITS TO FACH PEACTOR, 3 TO A QUARRANT. ME THANF IS ADDFC TO THE CODLANT TO REDUCS GRAPHITE CCRROSION. DRYERS KEEP WATEF DRODUCEO IN CORE (FRGM METHANE) AT ARCUNO 25C PPM. THERE AFE NO VACANCIES IN THE FUEL LATTICE, AS IN EARLIFF $\triangle G R S$, $\triangle N D$ THE GPAPHITE IS MUCH MORE STARLE. THE REACTOR FOLLOWS TURSINE LTAL DEMAND AUTOMATICALLY.

REACTOR DESCRIDTIJV + REACTOR, GCR + FEACTCR, GPAPHITF MOOEFATED + UNITED KINGDOM

$18-22917 \quad$ ALSO INI CATFGORY 7

SMALL NC

CONTINUUM DILATATION MOOEL FOP CRECP SNELLING OF CEGAMIC NUCLEAP FIJELS NITH APPLICATIONS ILWB-LSBR

DEVELOPMENT DROGRAM )

BETTIS ATOMIC POWFR LAB., PITTSSURGH, PA.

WAPD-TM-649+. 44 PAGFS, 13 FIGURSS, ? TAELFS, 11 FEFERFNCES, SEFTEMBER 1967

DRESENTS A CREEP MODEL FOR THF CPEEF SWELLING OF CERAMIC FUELS, INCLUDING THE EFFECTS OF FABRICATEO PORCSITY, EISSITHAINOUCEU PJPOSITY, ANO SURFACE TENSION, USING AS A MACROSCOPIC DILATATIONAL ELEMENT A HOLLOW SFHEPE WITH THE CENTRAL CAVITY PLAYING TIIE ROLE OF THE

FABRICATEO POFE, WITH FISSION GAS PORES IN THE ANNULUS REPRESENTED BY ANALOGJUS MICROSCOFIC MOLLOW SPHERFS. APPENOIX DESCRIDES THE COMPUTEP PROGRAM FUEL SWELL III FOR FORTRAN III.

AVAILABILITY - CLEARINGHOUSE FOR FEDFRAL SCIENTIFIC AND TECHNICAL INFORMATION, SPRINGFIFLO, VIRGINIA \$3. OD COPY, \$O.S5 MICROFICHE

* ANALYTICAL MODEL + \#CRECD. + CEqAMICS + CCMPUTER PFügRAM + FUEL ELEMENT + R AND D PRLIGRAM +

REACTOR, BREEDER + FEACTOR, PWR

$18-22935$

ZION 1 AND 2 AMENDMENT 3 - RESPONSE TO NGV. 20, 1 SS7 DRL QUFSTIONS

COMMONWEALTH EDISON COMPANY

3O PAGES, FIGURES, REFERENCES, DECEMBER 20, 1967 , COCKETS 50-2S5/304, TYPE--PWR, MFG.--WEST, AE--SGT + LUNDY

REGPONDS TO QIJESTIINS ON (I) SEISMIC CRITEFIA AND ENGINEERING, (II) CONT AINMENT DESIGN, (III) QUAL ITY ASSURANCE, AND (IV) OTHERS. SOME ANSWERED BY REFERENC.E TO $\triangle M E N D M E N T 2$. ALSO INCLUDES REVISED PSAR PAGES.

AVAILABILITY - USAFC FUELIC DOCUMENT ROOM, NASHINGTON, D. C. 
SAFETY ANALYSTSSORY JUS USISN OEPORTS

$18-22935$ * CONT INUEC:

AEC QUESTION + REACTCE, PWS + PEPQRT, PSAP + ZICN I AND 2 (D:NF)

$19-22936$

ZION 1 AND 2 DRELIMINAEY SAFETY ANALYSIS FEPOET, VOL.

COMMONWEALTH COISOV CCMPANY

400 DAGES, TARLES, FISURCS, REFEOENCES, JUNE 15, 19E7, DOCKET 50-205/3C4, TYPE--PWR, MFG.--WEST., AE--SGT + LUNDY

DESCRIBES THE TWO 4-COSLANT-LQDD DVES, CACH FATED AT 2250 MWT/IOES MWE, IVITH STFETCH TO 2391/1129. SIMILAD, TO INGI $\triangle N$ Og!NT 2 BUT WITH $\triangle N$ IE\& INCFEASE IN AVERAGE HEAT FLUX. FUFL IS

UO? PELLETS IN ZP TUBES. CENTPOL BY CLUSTERS. OF AG-CD-IN IN SS CLADDING FLUS BGROW CHEMICAL

SHIM. CONTAINER QY A STEFL-LIVED PRESTRESSEO-CONCRETE STRUCTUFE WITH DESIGN PRESSURE OQF 47

PSIG AND LEAK CATE LESS TUAN O.I\&. ADJITIONAL SAFEGUAKOS INCLUDE SAFETY INJECTION,

CONTAINHENT VEHTILATION AND SORAY SYSTEMS. THREE DIESFL GENERATORS SUPPLY POWEF. FOR

DPERATING OISTLCCIDFNT EOUIONENT. VESSEL PENCTRATI ON HEVE D DOUBLE CONTAINMENT WHICH IS

CDVTINIJJUSLY PE ESSUEIZED ASTVE DESIGN DRESSURE. LINFR WFLDS APE ALSO COVERED SY STEEL

CHANNELS AND ALE SIMILAOLY ORESSUF IZLC.

AVAILAGILITY - USAEC PUTLIC OOSUAENT PCON, WASHINGTON, O. C.

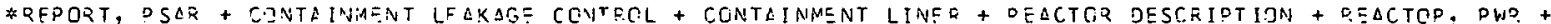
WELOS + ZION I AND ? (DUN)

18-22030 ULSE IN CATFGORY II

ISCLATION VALVE SEIL IAATTP SYSTEM.

COMMONWEALTH EDISON COHEANY

4 PAGES, PAGES E.2.5-1 THPU 5.2. E-L OF THE ZION STATICN 1 AND 2 DPELIMINARY SAFETY INALYSIS PFPRIT, VOLUME

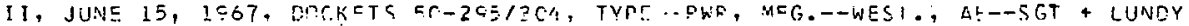

JPFRATION DF THE SYSTIY WILL REOUCE CFF-SITE DCSES A FACTOD OF 120 BY ENSUEINEG ECFECTIVENESS gF CONTAINYCNT-ISDLATIOY VALVES IN: A LRSS-OF-COOLANT ACCIDENT. PRDVIOES A WATED SELL CN

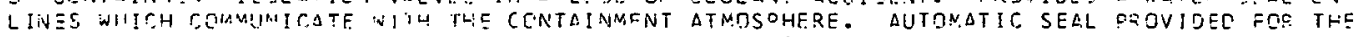

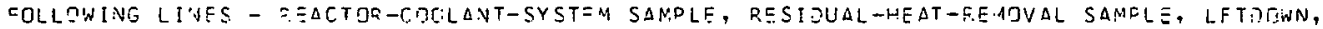
SAEETY-IV.JFETION TEST, STEAY-GRNEPATQD SHELL-SIOE - ILL-ANO-FAIN ELOWDOWN LNO SAMPLE . MANUAL SEAL DROVIDED ECE SEVFFAL OTHESS SYSTFM INCLUEES AN I IOO-GAL TANK ANO PIPING. RESIGNER FCR 150 PSIF. JOESATIUN INITIATEO OY SIGNAL THAT INITIATES CONTAENMEVT ISOLATION. WLTFD. IS INJECTED IUSIRE FIPING OETASEN TNG ISCLATION POINTS LUCATEO GUT-SIDE CONTAINMENT AVC AT DRESSURE HIGHEF TH: IN DESIG.Y PHESSLPE CF CONTLINMENT.

AVAILABILITY - USACG OUELIC, MOCUMENT DOCM, hASHINGTON, O. C.

\#CONTAIVAENT LEAKAGE TONTPCL + ACCIUENT, LOSS RF CGOLANT + CONTAINMENT PENFTPATIEN, CLESUPE OF + ENGINEERED SAFETY ECATLPE + PEACTIR, PWD + DEPROT, PSAR+ZION 1 AND 2 (PWR)

$18-22939$

ZION! CNO 2 ORELIAINAEY SAFFTY AVALYSIS EERERT - VCLIJME 3

COMMONWEALTH ENISTN STMEANY

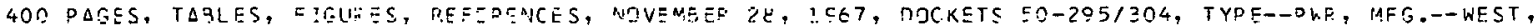
$A E-S S T+L U N D Y$

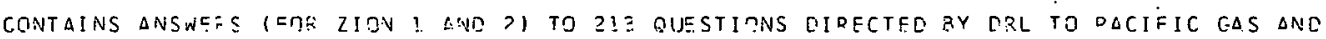
FLECTRIC NITH "ESOECT TO OIAFLC CAMYON CONCTONING DLANT LAYGUI, CINTAINMENT, INSTRUNENTATICN AND COHTOTLS, EVGINCEOEN SAFETY FEATUFSS, ANID ACCIDENT ANALYSIS.

AUVILABJLIIY - USAEC EIJELIC OOCJMENT DOON, WASHINGTON, D. C.

* AEC DUESTION + \#REPCFT, DSAP + REACTMF, FWR + ZION I ANO 2 (OWF

$18-22940$

ZION 1 ANO?; PRELIMINAFY SACETY ANALYSIS PFPOOT - VRLUME IV

COMMONWEALTH $=1 B I S O N$ COMPANY

350 OAGES, TABLES, EIGUEES, CEFERENCES, MEVENGEF. 2Q, ISG7, DOCKETS SD-295/304. TYOE-DWF, MEG.- WEST, $A E--S G T$. + LUVDY

CONTAINS $(1)$ AN EVALUATION OF COITEPIA TO ENSUEE NO LOSS OF EUNCTION CF PIFING AND VESSELS

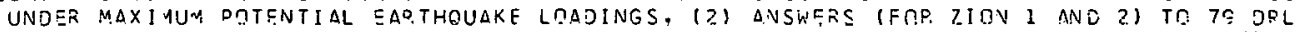

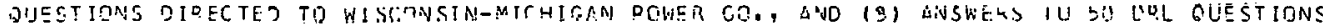
DIRECTED TO CEMMENIWEALTH EOISCN.

AVAILASILITY - USAEC EUELIC MICUMENT ODOM, NASHINGTON, T. C.

\# AEC QUESTION + \#REPCPT, DSAR + REACTOR, FWQ + 2ION 1 ANG? IOWRI

18-22@45 ALSC IN T.ATEGOOY 7 
$19-22945 *$ CONTINUED*

CALCULATION OF SPRAY IODINE REMOVAL FACTOE ECP WESTINGHOUSE 2-, 3-, ANO 4-LOOP PWR

PUPLIC SERVICE ELECTFIC ANOD GAS COMPANY

7 PAGES, 7 REFEREINEES, PAGES $6.3-14$ THQU $6.3-20$, VOLUHE 2 . OF SALEM I ANO 2 . PRELIMINARY SAFETY ANALYSIS

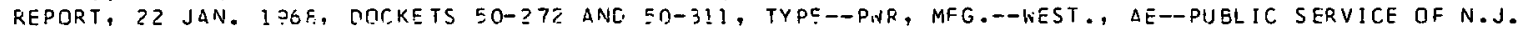

GIVES THE TECHNICAL OASIS FOR, THE CALCULATION OF, AND THE EXPERIMENTAL VERIFICATICN OF THE IODIVE-REMOVIL AND DOSE-REDUCTION FACTOES, USING NAOH $\triangle S$ SPRAY ADOITIVE. THE REOUCTION IN THE ?-HR DFE-SITE DOSE IS $5 \$(2$ LDOP, SOPSIG, 286 F), $22(3,42,264), 4 N D 6414,47,270)$. DISCUSSES RTMOVAL OF HI, CHBI, AVE DARTICLES.

AVAILAGILITY - USAEC DUFLIC DOCUMENT ROON, WASHINGTON, D. C.

\# ADOITIVE + \#CJNTAINMENT SPPAY + \#FISSION PRCOUCT, IODINE + MATHEMATICAL IREATMENT + REACTOR, PWR + REDUCTIJN + SODIUY

$18-2255$

DROPOSED ISSUAVCE JF MICHIGAN STATE TOIGA CONSTRUCTION PERMIT

DIVISITN OF REACT.JR LICENSING, USAEC

12 PAGFS, JANUARY 2E, IS68, DOCKET EC: 204

REACTOR IS GCING MQVEJ FROM THE UJ OF ILLINGIS. THE TRIGA MARK-I WILL BE NPERATED AT 250 KW STEADY STAT AND PULSEO TO $1.5 \%$, PESULTING IN AN \& MW-SEC RELEASE. MAXIMUIA EXCESS REACTIVITY IS $2.25 \%$. TESTS AT THE SITE INDICATE THAT, IN COMPLETE LOSS OF POOL WATER, THE SURROUNDING NATSR TAELE IS SUCH THAT DSOUT 1 ? FT GF WATER REMAINSS ABOVF THE CORE.

AVAILABILITY - USAEC PUELIS ONCUMENT FODM, WASHINGTON, D. C.

* SAFETY eVALjATION + LCCIDENT, LOSS OF CCOLANT, + CONSTRUCTION PERMIT PF.CCESS + REACTOR, PULSED + TRIGA (RR)

$18-22961$

SAN DNOFRE AMENDMENT $2 \geq$ - SUPPLEMENT Z TO PSAR - ANSWEFS TO AEC QUESTIGNS

SOUTHCRN CALIFOPNIA FTISON COMPANY + SAN DIEGO GAS AND ELECTRIC COMPANY

14 PAGES, TASLES, FIGURES, SEPTEM3EF 2.1, 1966 , COCKET 50-2.06, TYPE-DWF, MFG.--WEST, AE--3ECHTEL

SUDPLFMEINT 3 CENTAINS ANSNERS TC 7 QUESTICNS ON CONTROL-ROD-PATTERN REFUEL ING ACCIDENT,

THER̃MAL DESIGN, FEACTIVITY, SAFETY INJECTION SYSTEM, PUMPS, ANO POSSIBLE EVACUATION OF SAN

CLEMENTE. THE APDENDIX CONTAINS INFERMATION ON PRIMARY ANC SECONDARY SOURCE, MENITOR LNG OF

NEW FUEL, D.ND ROD-POSITION INOICATION. ROD-POSITION MGNITOPING SYSTEM HAS BEEN AODED TO

CDNT INUUOUSLY MONITOF. ALL CONTPOL RTDS.

AV ILABILITY - USAEC PUELIC DOCUMENT PODM, WASHINGTON, D. C.

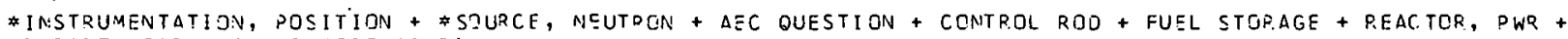
REPCRT., SAQ + SAV ONOFRE (PWR)

$18-729 \% 4 \quad A L S C$ IN CATEGORIES O $\triangle N$ IN 10

DRL REQUESTS ADOITIONAL OISCLISSIIIN UN FOFT CALHGUN

U. S. ATOMIC ENERGY COMMISSICN, WASHINGTCN, D. C.

I PAGE, JANUADY 27, 3.968, DOCKET 5n-?०5, TYPE--PWR, MFG--C.F., AE--GISBS + HILL

CONFIRMS PHIN CONVERSATIOH OF JANUAFY 17, 1968 , THAT ACRS WISHES AEOITIONAL INFCRMATIDN REFORE DREPAPING THEIP QEPTFT - (1). ADEQUACY OF OFF-SITE POWER. AND GENERAL DESIGN CRITERION $3 c,(2)$ AQILITY Tก INIIRT CONTOML OONS IF A PRIMARY COOLANT LINE LARGER THAN I? INCHES RIJPTUYES, AVD (B) ADEQUSCY OF THE PEACTOP PROTECTION SYSTEM, ESPECIALLY THE SCRAM BUS, TC PRDVIDE PPDTECTIEN IF A SINGLE FAILURE WERE TO OCCUP.

USAER PURLIC DOCUMENT RCJM, WASHINGTUN, O. C:

* EMERGENCY POWER, ELECTFIC + APLANT PROTECTIVE SYSTEM + ACRE +

FAILURE, SCRA1 MECHANISH + FT. CALHOUN (FWR) + REACTOR, PWR + SINGLE FAILURE CRITERION

$18-22075$

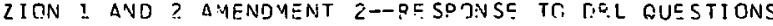

U.S. $\triangle T O M I C$ EVERGY COMMISSION, WASHINGTON, D. C.

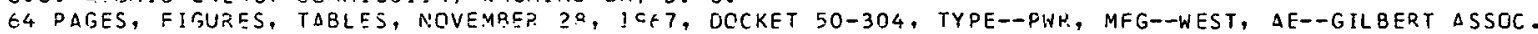

CONTAINS DEVISEC PLGES TO PSAF FOP VOLUMES I AND II, DNO VOLUMES III AND IV. WHICH ARE AOOITIDNS TJ THE PSAR. VOLUNE III CONTAINS ANSWERS (ON ZION I AND 2 ) TO 213 QUESTIONS

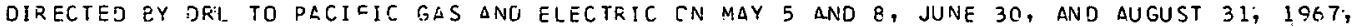
WITH RESPECT TO IILBLO CANYON CONCERNING PLANT LAYOUT, CONTAINMENT, INSTRUMENTATION AND CONTFOLS, EYCINEEP.ED SAFFTY FFATUPES, ANC DCCICENT DNALYSIS. VOLUME IV CONTAINS (I) AN EVALUATIGN JF CRITFRIA TO ENSUPF NO LCSS OF FUNCTION OF PIPING AND VESSELS UNDER MAXIMUM DOTENTIAL CARTHQUAKE LOAOIVGS, 121 ANSWFPS TC 70 DRL QUESTIONS CIRECTED TU WISCONSIN-MICHIGAN PJWEP CO., VOVEYZER 1, 19KS, $\triangle N D$ (3) ANSWERS TO 50 DRL QUESTIONS DIRECTED TO COMMONWEALTH EDISON TN AJGUST 31 AND TCTOBER $18,1 \% 57$.

AVAILABILITY - USAEC FUELIC DOCUMENT P.ONM, WASHINGTON, D. C. 
SAFETY ANOLYSISSORY DESISN REPORTS

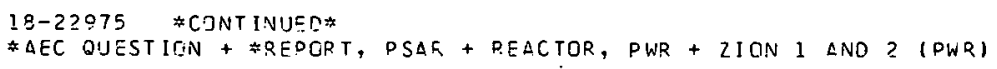

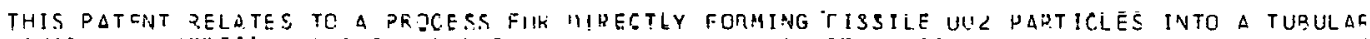
SHAPLU UISULLSICN HAVING A FETAINING MATPIX IN WHICH STAINLESS-STEEL-COATED SPHEPICAL UOZ DARTICLES $\triangle A F$ EXTPUDED AT LOW TEMPEPATURE WITH A SINDER DIRECTLY TO FCFM D TUBE, AND THE RINDER IS R MOVED FOR FURTHFF PEICCESSING IN WHTSH A STAINLFSS=STEEL CLADOING IS INTIMATELY BONDED TO THE TUEF HYY HOT ISCSTATIC PRESSING.

AVAILABILITY - THE U. S. PATENT OCFICE, DEPAPTMENT OF COMMERCE, WASHINGTON, D. C. (25 CENTS PER COFY) \#CCATFD DARTICLE + \#EUEL ELEMFINT + FAQRICATIJN + PATENT + STEEL, STAINLFSS + URANIUM DIOXIDE

$18-22789$

SUPPLEMENT 14 TO THE ET CALHCUV EACILITY OESCDIPTION AND SAEETY ANALYSIS DPPORT OMAHA DUSL IC DJWER OISTPICT

GO PASES, AMENOMENT lL TR FT, CALHMINN I LICENISE APFLICATION (SUPULEMENT IL TO FOSAR) 2 JANUARY ISEE, EXHIUI1 HL OF DOCKET ED-285, TYDE--PWF, MFG.-C.E., AE--GT QPS + HILL

THE PUFDOSE JF THIS SUPPLEMENT IS TO PEVISF, TREPECT, ANO UROATE THE PFELIMTNAOY SATETY ANALYSIS RFOORT ANU TO BE A GUIDE TO THL APPLICATION AS AMENOED. FOR EACH SFCTION OF THE PSAR THER IS A CRRPESPOVDING SECTION TN THIS SUPHLEMENT WHICH II) CUTL, INES THE SIGNIFICANT CHANGES WHICH HAVE OCCURRED SINCF. THE OOITINAL FILING WHICH AFFECT THAT SECTION, (2) DEFERS THE REAIFR TD THOSE POPTICVS OF LATER AMENDMENTS WHJCH CONTAIN FURTHER INFORMATIUN RELATING TO THAT SECTION $\triangle N O$, II LISTS FACH PEVISION IN IFF COPPECTION TC THE SECTICN. THIS 


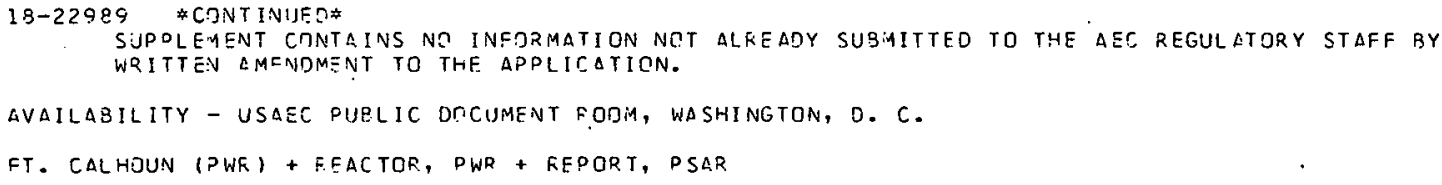




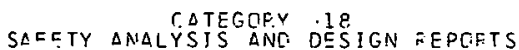

$18-23014$ \#CONTINJER*

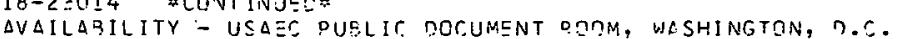

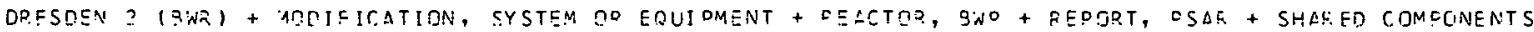

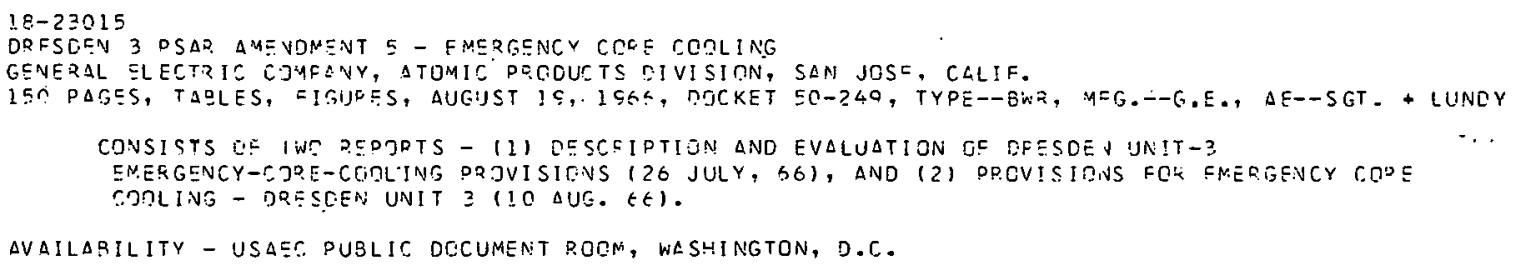


SAFFTY DNALYSISG ANOO DES IGN FEFORTS

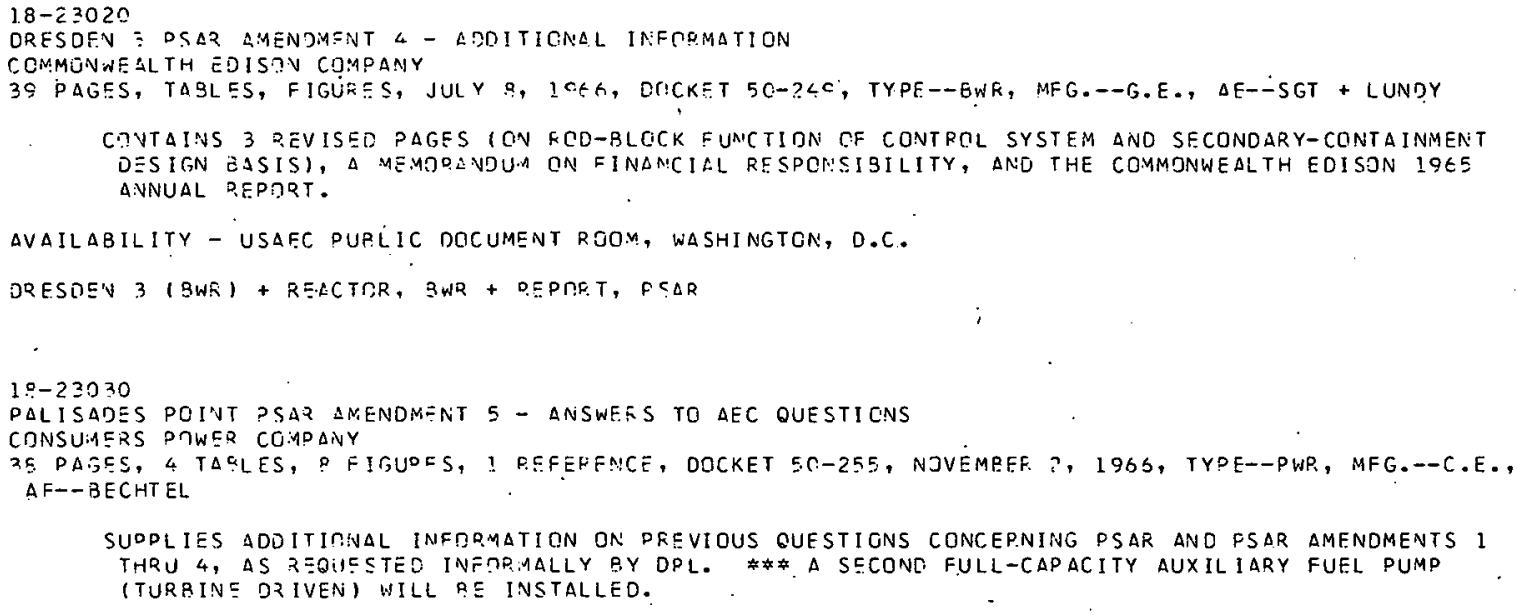

AVAILABILITY - USAEC PUBLIIC DOCUMENT ROOM, WASHINGTON, D. C.

* ACRS + \#PEVIEN + CONSTRUCTION PERMIT PRGCESS + REACTOF, PWP + 'THFEE MILE ISLAND (PWR) 
CATEGGFY IE
SALETY ANALYSIS AND DESIGN REPCRTS

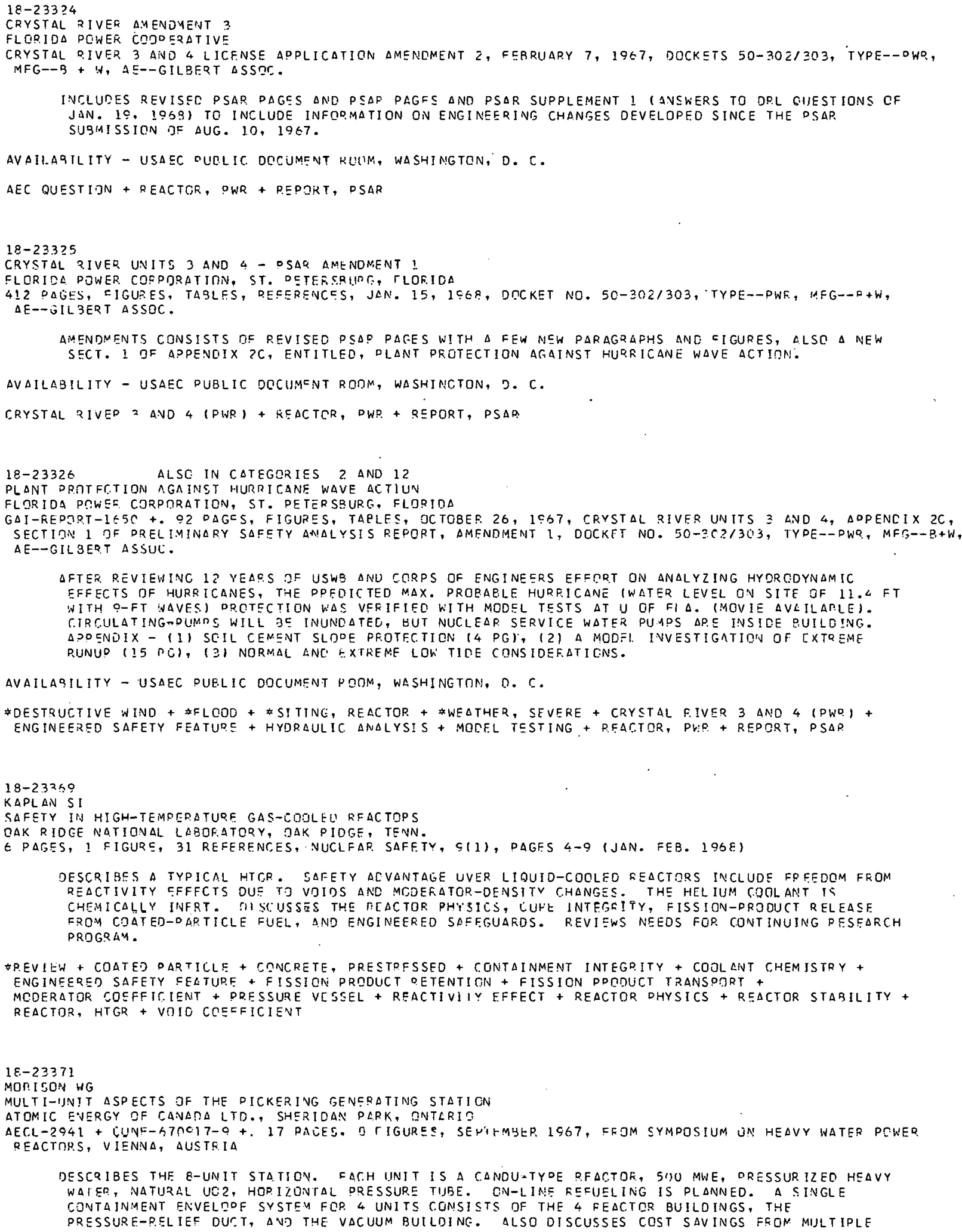


18-23371 *CONT INUEO* UNIT CCNSTRUCTIDN, DESIGN, CONSTRUCTION, EQUIPMENT PR.SCUREMENT, AND SAFETY CONSIOERATIONS. AVAILABILITY - CLEARINGHOUSE FOR FECEFAL SCIENTIFIC ANO TECHNICAL INFGRMATICN, SPRIVGFIELO, VIRGINIA S3. OO
COPY: \$O.65 MICROFICHE

*REACTDR DESCEIPTIIJN + \#SYSTEM JESCRIPTION + CANADA + CANDIJ (HWR) + CGNTAINMENT, LON PFESSURE + REACTOK, HWF + REACTOR, PRESSURE TUBE

18-23446 $\triangle L S E$ IN CATEGORY 6

ENGELMANV P + BICKEL W + DAFUNERT U + HABERMANN FW + VAN VELZE PL + WLAZE H + WITTEK G CONSTRUCTION LND EXPERIMENTAL EQUIPNENT OF THE KARLSFUHE FAST CRITICAL FACILITY, SNEAK KERNFORSCHUNGSZENTRUM, KARLSRUHE, WEST GERMANY

KFK-471 +. 33 PAGES, 7 FIGURES, 13 REFERENCES, OCTOEEP, 1966

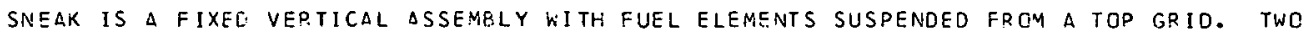
HOR I ZONTAL CHANNELS WILL BE USED FOR A MATERIAL REPLACEMENT ORAWER WITH AUTOMATIC SAMPLE CHANGER, A DETECTOR OR MATERIAL TRAVERSE DEVICE, AND A PULSED NEUTRON SOURCE. FUUR VERTICAL CHANNELS CLOSE TO THE CORE CENTER ARE AVAILABLE FER INSTALLATION JF A PILE-OSCILLATCR. A GAS-HEATED LOOP IS BEING BUILT FOR DOPPLER EXPERIMENTS. FOUP METHODS USED IN SNEAK FOR PRECISE FEACTIVITY MEASUREMENTS ARE COMPAREC - THE ASYMPTOTIC PERIOD METHOD, THE PILE OSCILLATOR METHOD, THE INVEOSE KINETICS METHDO, AND THE AUTOROD YETHOD.

AVAILABILITY - MICRCCARE FDITIONS, INC., ACCOUNTING ANC SHIPDING DEPT., WEST SALFM, WISCCNSIN E4EG9 \#CRITICAL ASSEMBLY FACILITY + \#EASUREMENT, REACTIVITY + \#DEACTOR, FAST + CCNTROL ROD + COPPLER EFFECT + OSCILLATOR, REACTIVITY + PLUTONIUM OXIDE + REACTOR CONTROL

$18-23470 \quad \triangle L S C$ IN CATEGDRY 5

DRESDEN 3 SUMIA AOY MEMDRANDUM ON FXCUK.SION ON ANALYSIS UNCERTAINTIES

COMMONWEALTH EDISON CO., CHICAGD, ILLINOIS

38 PAGES, FIGURES, TASLES, 17 RECERENCES, MAY 23, 1966, DOCKET NO. 50-249, IYPE--BWR, MFG--G.E., AE--SGT + LUNOY

COVERS (1) WNCERTAINTY IN CALCULATION OF PEAK ENTHALPY, (2) SFCCNDARY REACTIVITY EFFECTS, AND (3) UNCERTAINTY OF DAMAGF-THPESHOLC ENTHALPY LIMIT. ERRORS IN (1) ARE EITHER STATISTICAL (CALCULATIONAL UNCERTAINTIES ERPORS IN EXPERIMENTAL DATA, ETC.) OR PREBABIL ISTIC ARISING FRGM THE STATE VARIASLES OF THE CLIE. STATISTICAL ERROR IS ABCUT $10 \%$. BEST PRESENT FSTIMATE JF THRESHOLD AT WHICH RAPID CONVERSION OF FI SSION ENFRGY TO MECHANICAL ENERGY COULC TAKE PLACE DUE TO FUEL DAMAGE IS $425 \mathrm{CAL/GM.} \mathrm{FOR} \mathrm{CONSERVATISM,} \mathrm{ENTHALPY} \mathrm{LIMIT} \mathrm{IS} \mathrm{TAKEN} \mathrm{AS} \mathrm{THE} \mathrm{MELTING}$ POINT $(220-280$ CAL/GM).

AVAILABILITY - USAEC PUBLIC DOCUMENT POOM, WASHINGTON, D. C.

* ACCIDENT, REACTIVITY + \#FPRDF. ANALYSIS + AEC QUESTION + EXCURSION, LARGE + FUCL ELCMENT + PERFORM ANCE LIMIT + PEPORT, PSAR

$18-23471$

DRESDEN 3 PSAR AMENDMENT 2 - PEVISEO PAGES AND ADDITIONAL INFFRMATIGN

COMMONWEALTH EDISON CO., CHICAGO, ILLINOIS

38 PAGES, FIGURES, TAELES, 17 REFFRFNCES, MAY 23,1966 , DOCKET NG. 50-249, TYPE--BWR, MFG--G.E., AF--SGT + LUNDY

AMENDMENT 3 SUEMTTS PEVISED DAGES V-2-24 ANO XI-2-7 TO INDICATE CHANGES IN CDRE SPFAY CMOLING SYSTEM. IT ALSO CONTAINS A SUMMARY MEMORANDUM UN EXCURSION-LNALYSIS UNCERT DINT IFS, PREPARED IN RESPONSE TO VARIOUS QUESTIONS BY $\triangle F C$ DRL ANU ACRS, SPECIFICALLY TC QUESTION? RY DIRECTCR, DRL, IN LETTEF DATED MAY $13,1966$.

AVAILABILITY - USAEC PUBLIC DOCUMENT ROCM, WASHINGTON, O.C.

$\triangle E C$ QUESTION + DRESDEN Z (RWR) + REACTOR, RWP + FEPOPT, PSAF

$18-23472$

DRESDEN 3 PSAR AMENDMENT 2 - $\triangle N S W E R S$ TO $\triangle E C$ QUESTIONS

COMMONWEALTH EDISON CO. , CHICAGO, ILLINOIS

18 PAGES, I FIGUPE, PEFERENCES, MAY 1966 , DOCKET NO. 50-249, TYPE--BWR, MFG--G.F., AE--SGT + LUNDY

AMENDMENT 2 CONTAINS 9 ANSWERS TO BUFSTIONS RAISED BY AEC IN LETTER DATED $\triangle P R I L .12,1966$. QUESTIONS PERTAIN TO INFORMATION SUBMITTED IN AMENDMENT 1.

AVAILABILITY - USAEC PUBLIC. DOCUMENT ROOM, WASHINGTON, D. C.

AEC QUESTION + ORESDEN 2 (BWR) + REACTISR, EWR + REPORT, PSAD 


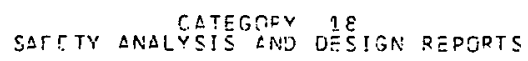

$19-23482 \quad *$ CONTINUED*

DRESDEN? AND 3 FIVAL SACETY ANALYSIS QEPGPT

COMMONNEALTH EOISON COMPANY

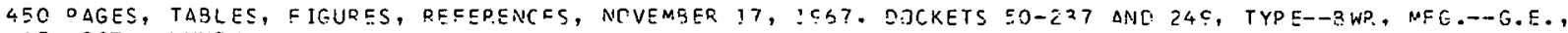
$\triangle S--S G T+$ LUNOY

SAR IS FOR OPERATION OF 2 RINS (25:T MWTIRCO MWE). PLANT DESION QUND ANALYSIS REFORTS WETEF FER

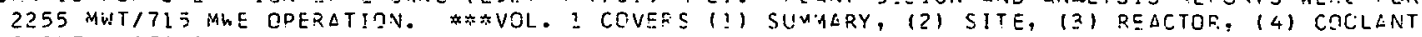

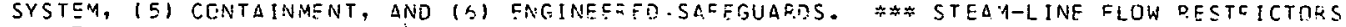

LIMIT FLCW TO 175\%. INSTALLED DPYWELL INEFT ATNOYSDHER.F EQUIPMENT WIIL NOT RE USEC, AS

EMERTENCY GIRF CEOLING DLLOWS ONLY A NEGLIGILLE VGLUME OF HYCOOGEN COFAED FROM METAL-WATER

REACTIONS. EXCLUSION FAJIUS IS ABCUT O.S MILE. NEAREST POPULATION CENTEF. IS JCLIET, ILL. 114 MILSS).

AVAILABILITY - USACC FUPLIC DOCUMCNT POחM, WASHINGTON, ?. C.

CONTAIVMENT ATMOSPHERF, INERT + DRESPENI ? (FWR) + POWER UPRATING + REACTOR, PWR + REPDRT, SLP

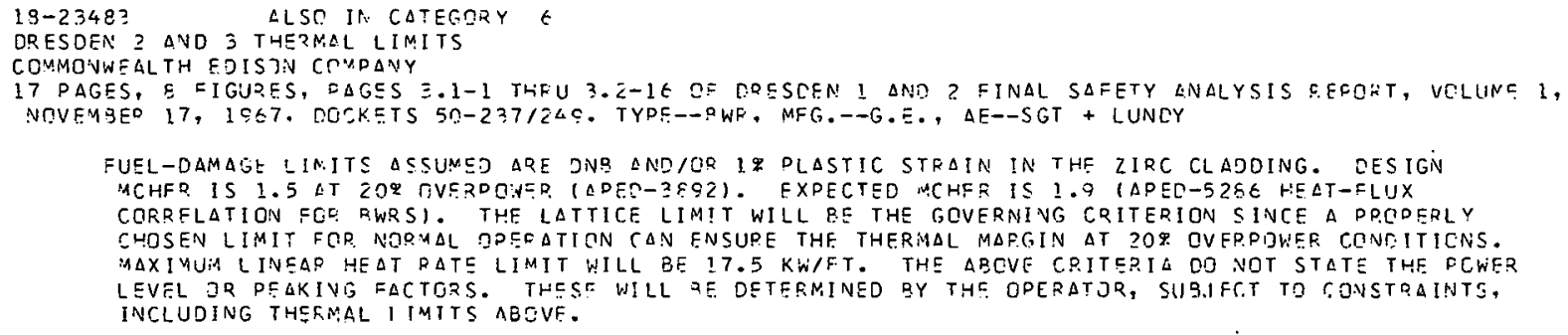

AVAILABILITY - USAEC DUPLIC DOCIJMENT DOOCM, WASHINGTON, D. C.

BURNOUT HEAT FLUX I [DESOEN 2 (BWR) + PERFCEMANCE LIMIT + REACTUE, BAR + QEPQRT, SAR + THERYAL CONSIDERATION

$18-23484 \quad$ AIST IA TOTECTRY II

ORESDEN? AND E DPYWELL EXPANSION GAD DFSIGN

COMMONAEALTH EDISTIV CEMPANY

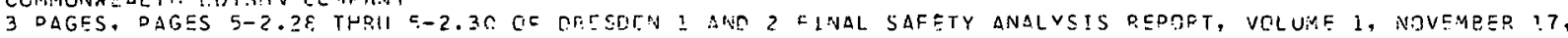

1OE7. DOCKETS $\equiv 0-237 / 240$, TYPS- - QWR, MEG.--G.S., AE--SGT, + I.UNCY

A GQO QETWEEN THE LINTR AND CENR OFTE ALLOWING FOS EXPANSION IS EILLED WITH DOLYUFETHANE FCAPI. TAO IN. OF THF FOAM IS FQUPEO NVFE TUE STEEL DRYWELL SHELL, THEN COVEOED WITH $1 / 4-I N .-T H I C K$ POLYESTER FIDEF GLASS SHELL PANELS, WHICH FCOM THE INNER SHELL FOR PUURINE THF CGNCPETE.

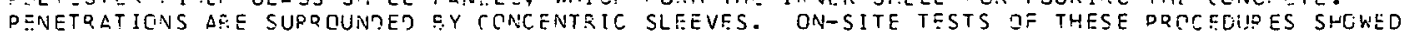
THAT THE FIBER GLASS HAS DISFLACED EY LESS THAN 0.25 IN. BY THE EJUPING AND CUPING CE THE CONCRETE. THE FCAY WILL BE EXPOSED TO 2.5 X 1O(TTH) RADS IN 4 ? YZS. GAMMA DAMAGF THPESHOLD

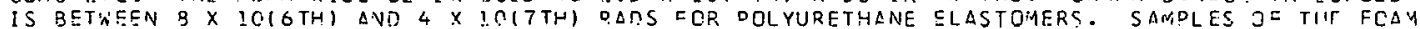
TO BE USED SHTW ND CFTECTAPLC CHANGE IN AESILIENCE UP TO IOIETHI RADS. THE GOAM IS RATED TE 2 SO F AND IS SELF-EXTINGUISHING.

AVAILAPILITY - IJSAEC PUBLIC DOCUMENT POOM, WASHINGTON, D. C.

\# CONIAINMENT LINFO + \#EXOANSION + \#FAM + \#PESSURE VESSEL + CONTAINMFNT CENSTRUCTION +

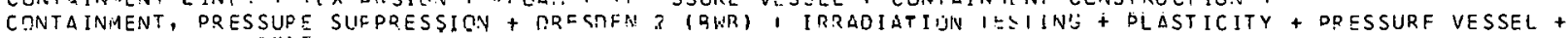
REACTOA, HWK + HEPOPF, SAR

19-23495 $\triangle L S E$ IN CATEGDRY 12

DPFSDEN 2 AND 3 EAERGENCY CQRE COTILING SYSTSMS AVAILARILITY ANALYSIS

COMMONWEALTH EDISON CONPANY

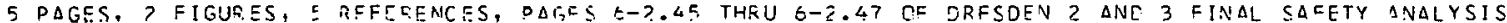

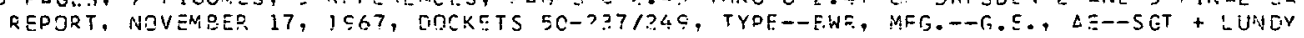

ANALYSES FCR ThC CASES (A SMALL gREAK AND A LARGE OVE) INCLLDF AVAII.ABILITY RLOCK CIAGQAMS. IFAST AUAILABLF SVSTCMS FOO. SMALL LKLAKS ARE HDCI (O.S2C) AND LPCI (O.SO2E). TETAL COMPCSITE SYSTEM AVAILARILITY IS I MIVUS $14 X 1 \mathrm{X}$ I $(7 T H)$, DUT MAINLY TO THE HIGH AVAILASILITY OFE FEEOWATER. SYSTE!A. II NCRMAL AUXILIAOY PCWCF FAILS - HFVCE NO EEEOWATEO - AVAILABILITY IS KFRIICFR TS I

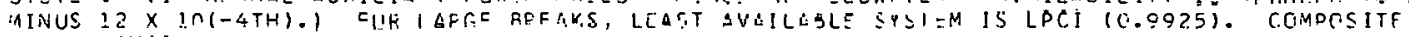

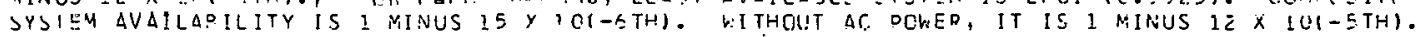

AVAILABILITY - USAEC, DUELIC DOCUMENT C.OOM, WASHINFTON, 7. C.

CORE REFLOODING SYSTEN + CORE SORAY + DFESTEN ?. (ENE) + FNGINEEREQ SAFETY FELTUEE + FAILUPE HOCE CNALYSIS + REACTOP, BWR + RELILEILITY AMALYSIS + EEFRQT, SAC 
SAEETY DNALYSIEGOAFY DESIGN REPORTS

18-23486 \#CONTINUEC*

CRESDEN 2 AND 3 SAFCTY ANALYSIS REPQRT. VOLUME II COMMONWEALTH EDISON COMPANY

$500^{\circ}$ PAGES, TABLES, FIGUP.ES, REEERENCES, NOVEMBER 17, 1057; DOCKET 50-237/249, TYPE--BWR, MFG:-G.E., $A E--S G T+$ LUNDY

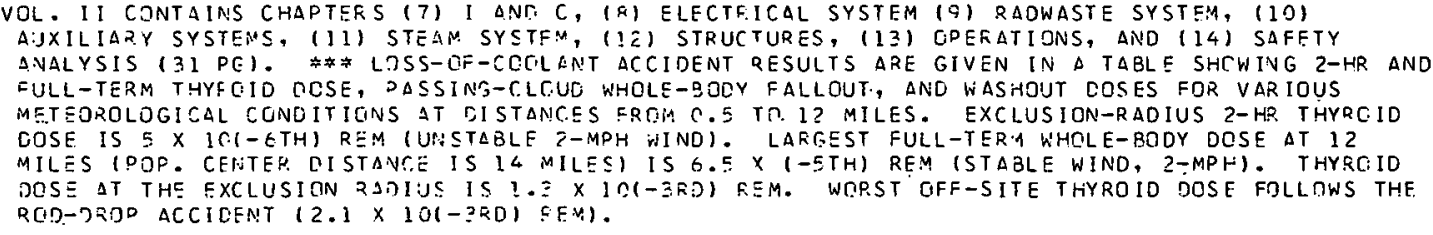

AVAILABILITY - USAEC DUBLIC DOCUMENT QOON, WASHINGTON, . C.

* REPJET, SAR + ACCIDENT ANALYSIS + ACCIOENT, LOSS OF CDOLANT + aCCIDENT, STEAM LINE FUPTURE +

AIR BDRNE RELEASE + DC.SE + DRSSDEN Z (?WF) + REACTOR, 3 WR.

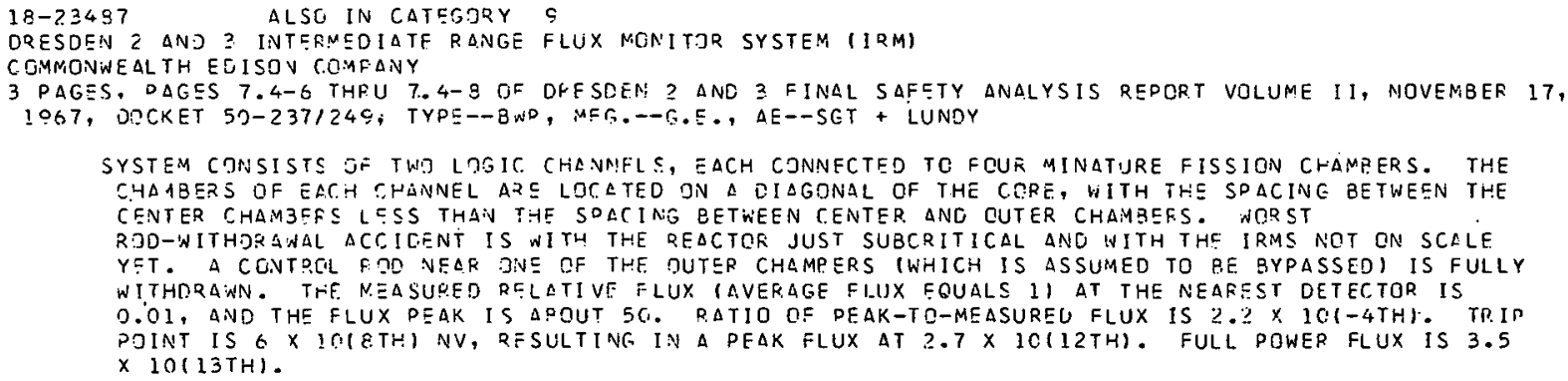

AVAILASILITY - USAEC PUBLIC DOCUMENT ROOM, WASHINGTON, D. C.

\# ACCIDENT, CONTROL REE WITHDRAWAL + \#INSTFUMENTATION, INTERMEDIATE PANGE + DRESDEN 2 (EWF) + REACTOR, BWR + RFPDRT, SAR

$18-23488$ ALSC IN CATEGORY 7

DRESDEN? DND 3 SAEETY ANALYSIS INVCLVING FISSION PRODUCT RELEASE FROM FUEL

COMMONWEALTH EOISON COMFANY

5 DAGFS, 3 TASLES, OAGSS 14.2-13 THFU 14.2-17 OF DRESOEN-2 $\triangle N O 3$ FINAL SAFETY $\triangle N A L Y S I S$ REPGRT, NOVEMBER

17, 1967 , DUCKETS 5C2- $09 / 247$, TYDS--B.WR, MFG.--G.E., AE--SGT + LUNDY

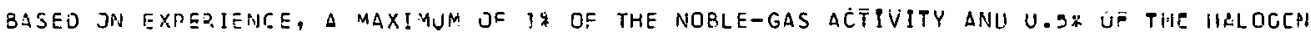

ACTIVITY IS ASSUMES RELEASED FROM A FUTL FOU WITH A CLAO FCRFORATION. ORFSIFN-I EXPERIEMCE HAS SHOWN THE ECLLOWING - (1) SOME FISSICN GASES LEAK FPOM THE FIIEL LATTICE TO THE PLENUMS.

MJST JF THE ?AOIUACTIVF GASES HAVE SHOPT HALF-LIVES, LEAVING MOSTLY NONRADIACTIVE GASES IN

THE PLENUMS. (2) RELEASE RLTE JF NCBLE GASES CAN BE ESTIMATED BY MEASURING THE PELLESES FROM

$\triangle$ DEFECTIVE RCD. THIS GIVES AN GVEFESTIMATIDN BECAUSE WATER AND STEAM SNTER THE BREAK,

CAUSING LEAKING ANI DETERITPATION CF THE UO2. \#\# ASSUMING CLAODING FAILURE IN 330 RODS, 4.4

$x$ ID $(4 T H)$ CURIES OF NORI GASES AND $2.3 \times 10(4 T H)$ CURIES OF HALOGENS ARE RELEASFO.

AVAILABILITY - USAEC PUELIC DOCUMENT ROOM, WASHINGTON, D. C.

\#FISSION GAS RELEASE + *LISSION PROCUCT PELEASE, GENERAI, + DRESDEN 2 (BWR) + OPEFATING EXPERIENCE SUMMARY + REACTDR, SWR + REPOPT, SAR.

$18-2348 \%$

QUAC CITIES 1 AND 2 PSAR $\triangle M E N O M E N T Z$ - $\triangle N S W E E S$ TO $\triangle E C$ QUJESTIONS

COMMONWEALTH EOISON CUMPANY

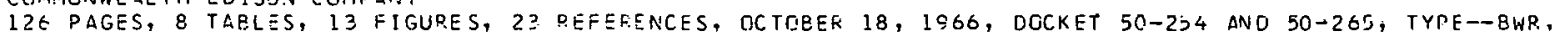

IMFG- G, E., $\triangle E--E B A S C O$

ANSWERS ARE GIVEN TO 19 QUESTIONS FC SED BY AEC IN A LETTER DATED OCTOBER 12, 196E. ADOITIONAL INFORMATION REOUESTED BY TELEPHONE CCTOEER 14, 1966 , IS ALSO SUBMITTED.

AVAILABILITY - USAEC PUELIS. ODCUMENT RUOM, WASHINGTON, D. C.

$\triangle E C$ QUESTION + QIION CITIES I AND 2. (EWP) + QEMCTRF, BWR + REPGRT, PSAR

$18-23600$

FORT CALHOUN STATION-UNIT NO. 1. FACILITY DESERIPTION ANO SAFETY ANALYSIS REPORT, SUDPLEMENT NO. 2, EXHIBIT F 
CATEGORY II
SAFETY ANALYSIS AND DESIGN REPORTS

$18-23600$ \#CDNT INUTO

OMAHA PUBLIC POWEQ DISTP ICT

220 PAGSS, 46 FIGURES, 6 TARLES, 10 REFERENCES, SEPT. 16,1557 , DOCKET NO. 50-285, TYPE--OWF, MFG--C.F., $\triangle E-G I E Q S+H I L L$

CONTAINS ANSWERS TO Sa QUESTIONS FAISEC GY DPL IN LETTTERS CF JINE 14 AND JULY PQ, 1967 .

USAEC PUßLIC DOCUMENT RGOM, WASHINGTON, G. C.

* AFC QUEST ION + FT. CALHOUN (PWR) + PEACTCR, PWP + REPORT, OSAR

18-2380? DLSC IN CATEGORY II.

INDIAN POINT 2 BUCKLING OF CONTAINMENT LINER AT THE FUEL TRGNSFER FENCTTRATION

CONSOL IDATED EOISTV COMPANY OF NEW YGRK

? PAGES, JANUARY I9SE, ATUMIC ENERGY CLEAFIMG HCUSE, I4(10), DAGES 39-3C (MARCH 4, 196E), DOCKET EC-247

(LFTTER TO JRL, JAN. 19EZ) THE LIMER DEFORMATION WAS NJTICED DURING CCNSTRUCTION. REPTRT

DESCPIBES THE DUALITY-CONTRJL DEORF MUESS AND TESTING OFF THE LINER NEL CIS ICHANNELS ARF WELDED

JVER, ALL LINEF SEMMSI. AFTEP DFDLIRING THE BULGE, LEAK TESTS WERE AGAIN PERFGRNED ON THE

INELD CHANNELS IN THE VICINITY. ALL WELD-CHANNFL FILLLT WFLDS IN THE SAME AREA hEPE

VAGISTIC-PAPTICLE INSPECTED. THF WELD-CHANNEL SYSTEM PASSFD SOTH TESTS.

\#BUCKLING + \#CONTA INNENT LINER + \#CONTAINMFNT PENETRATION, GENERAL + EXAMINATICN + FUEL HANDLING MACHINE + INDIAN PJINT \& (PIR) + OULLITY CONTRIL + FEACTOP, PWF + TEST, LEAK RATE + TEST, IVDNDESTEUCTIVE + WELDS

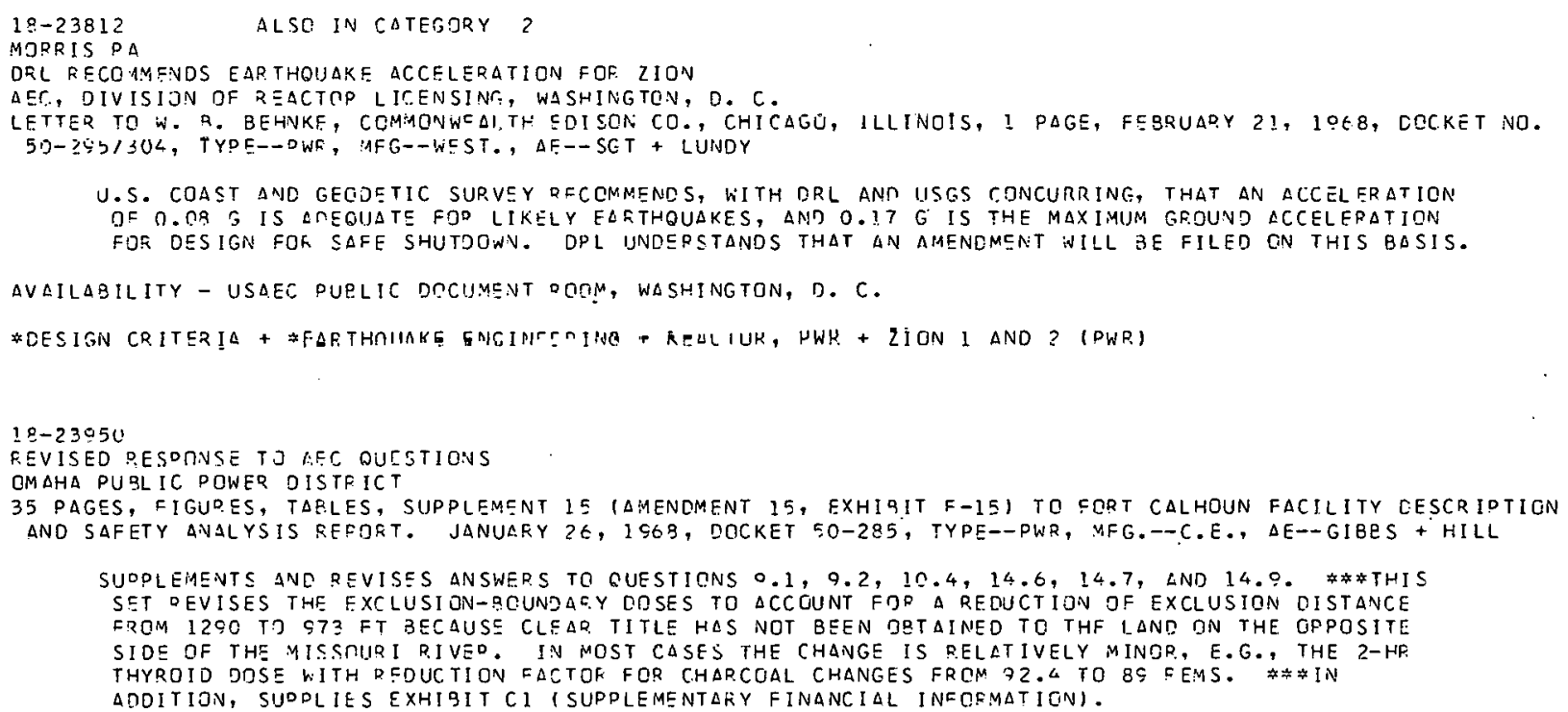




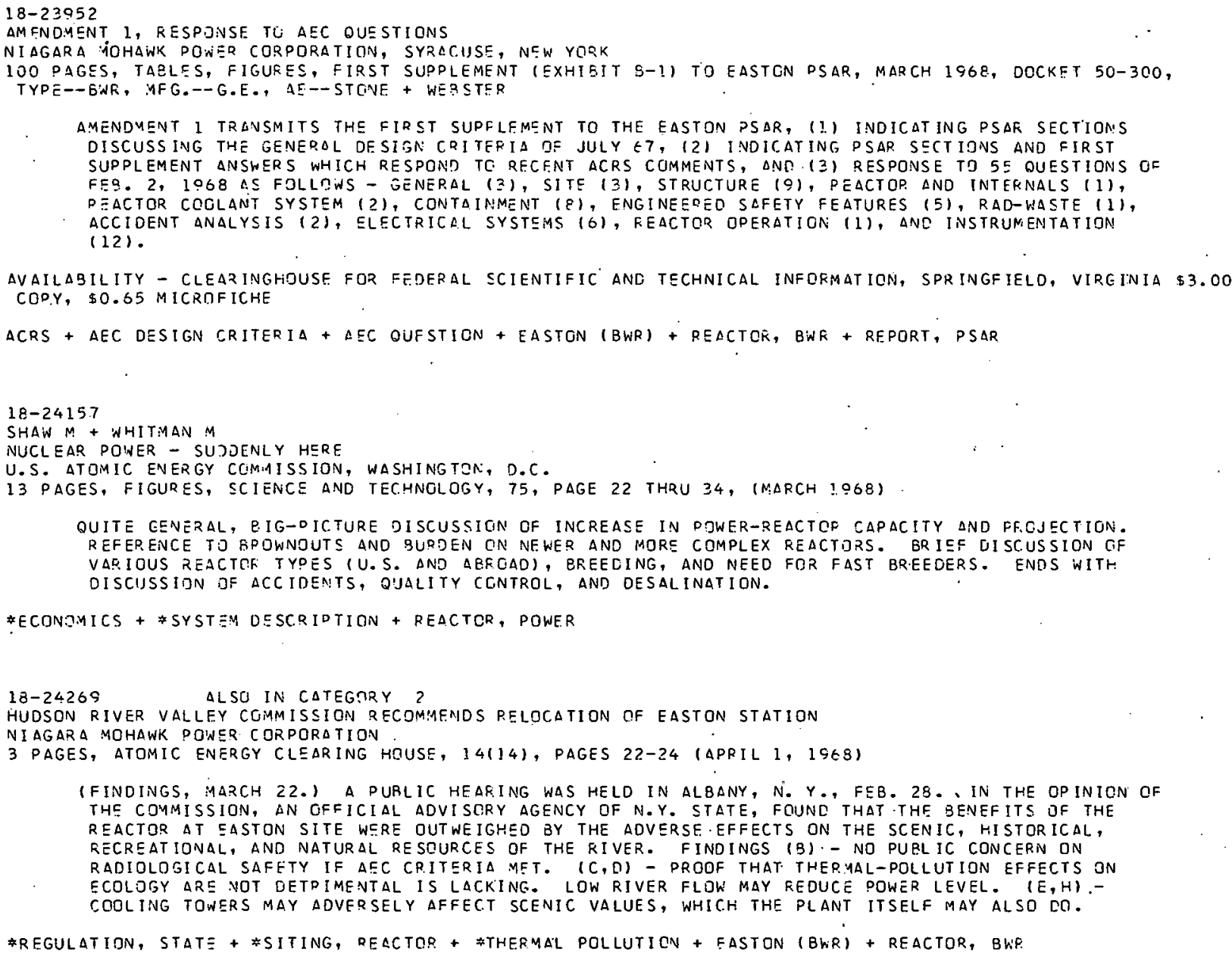

*ECONOMICS + \#SYSTEM DESCRIDTION + REACTCR, POWER

18-24269 ALSO IN CATEGRRY 2

HUDSON RIVER VALLEY CGMMISSION RECOMIAENIDS PELOCATION OF EASTON STATION

NI AGARA MOHAWK PONER CORPORATION

3 PAGES, ATOMIC ENERGY CLEARING HOUSE, 14(14), PAGES 22-24 (APRIL 1, 19E8)

(FINDINGS, MARCH 22.) A PURLIC HEARING WAS HELD IN ALBANY, N. Y., FEB. 28 . IN THE OPINION OF THE COMMISSION, AN OFFICIAL ADVISCRY AGENCY OF N.Y. STATE, FOUNC THAT THE BENEFITS OF THE REACTOR AT EASTON SITE WERE OUTWEIGHEO BY THE ADVERSE.EFFECTS ON THE SCENIC, HISTORICAL, RECREATIONAL, AND NATURAL RESOURCES OF THE RIVER. FINOINGS (B) - NO PURL IC CONCERN ON RADIOLOGICAL SAFETY IF AEC CRITERIA MFT. (C,O) - PROOF THAT THERMAL-POLLUTION EFFECTS ON ECOLOSY ARE VOT DETPIMENTAL IS LACKING. LOW RIVER FLOW MAY REDUCE POWER LEVEL. (E, H).COOLING TOWERS MAY ADVERSELY AFFECT SCENIC VALUES, WHICH THE PLANT ITSELF MAY ALSO CO.

\#REGULATION, STATE + \#SITING, REACTOR + \#THERMAL POLLUTICN + FASTON (BWR) + REACTOR, BW' 


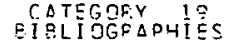

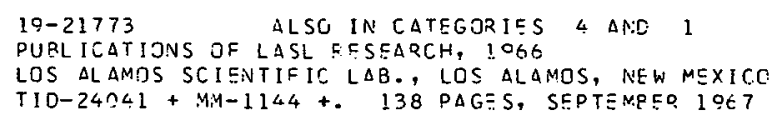

BIEL IOGQAPHY + STAFFING, TRAINIVS. OIJALIFICATION

19:23BI! - $\triangle L S E$ IN CATEETRISS 7 AND 11

PATENTS IN THE FIELD OE CAN-FUPTUIFE DETFCTION

COMMISSAFI ITT L LENEEGIC ATOZMIOUE, SACLAY (FRANCE). CCNTRE D-ETURES NUCLEAIPES

CEA-BIS-79+. L4I PAGES, FIGUEES, OCTCBED ISKT, IN FRENCH

THE ABSTRACTS OF PATENTS ISSUEO IN THE PEINCIPAL INDUSTRIAL CCJNTFIES LFE LISTFD ACCOROING TO SEVERAL CHAOTERS DEPTAINING TU THE GENIEDAL DRINCIPLES CF LEAK DETFCTITN, DCTECTION ITSELF CF FISSINN PQDDUCTS, APOARATUS USER CIRECTLY GR IN COMBINATION WITH ANC FGR THE PUFFOSE OF DETECTION, THF INDICATION AND TRFATMENT CF THE DATA GIVEN, THE FXAYINLTION RCEQCE ANR AFTEF USR TE CADTPIOCE JACKETS. A CUMULATICN LIST IS AOPENDED, GIVING TN OFOGRSSSIVE OZJER THE DATEVT NUUE ZOS ECR 18 COUNTFIES TC FACILITATE THE SEARCH OE THE A3STRACT IN THE CORRESPONOIA:S CHAOTER.

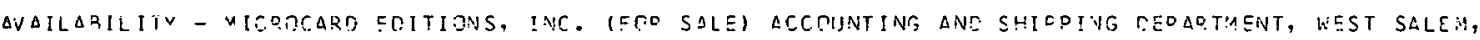
WISCJNS IN $546 \leqslant$ ?

\#FUEL ELEMENT + \#IVSTRUMENTATION, DETECTION FAILEO FUEL ELEMENT + \#TEST, LEAK LOCATION + MONITOZ, SADIATION, GENERAL

$19-23312 \quad$ ALSO IN CATEGTRIES 11 ANE 17

LE-LEVIER. MS

HAILURES IN CIDES ANC PKESSURE VESSELS COFRELATFD TO NUCLEAR DOWEF FLANT SERVICE

COMMISSAKIAT A L-FINEFGIE ATOMIQUE, SAT.LAY (FRANT.E). "CENTRE D-ETUDES NUCLLAIFES

CEA-BIB-79+. 32. PAGES, SEFT. 1967, I F.: FENCH

THIS PIQLIOGRAPHY DEALS WIIH THE DAPERS DURLISHED ON THF FAILURES IN PIDES AND PEESSUIOE VESSELS CORRELATED TO NUCLEAF COWFF PLANT SERVICE. THE REFEFCNCES WEPE SELECTED FQDM

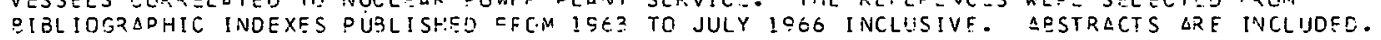

AVAILAQILITY - CLEAR INGHOUSE FIR CECERAL SCICNTICIC AND TECHNICAL INFOFMATION, SPRIVGEIELD, VIRGINIA, $\$ 3.00$ COPY, \$O.65 1ICROF ICHE

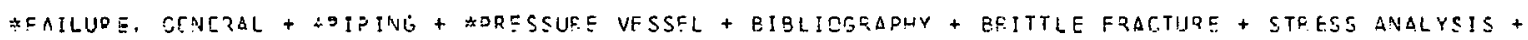
TEST, BENCH + TSST, TESTRUCTIVE + TLST, NONGESTOUCTIVE 
PAGE 372

$$
\begin{aligned}
& \text { CATFGORY } 1 \stackrel{0}{\circ} \\
& \text { BIPLICGRAPHIES }
\end{aligned}
$$

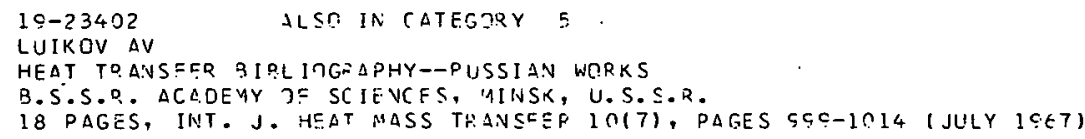


INFORMATION AT NSIC IS OIVIDED INTC IS CATEGORIES. AN ITEM OF INFCRMATION MAY BE KEYED TO AS MANY AS THREE OF THESF. A CCLLECTION OF SELECTORS OR KEYWOFDS IS USED TO CENOTE THE MAIN SAFETY FIFLATED POINTS COVERED IN $\triangle N$ APTICLE. THE FDLLDNING INDEX IS AN ALPHASETIR,AL LISTING OF SELECTORS GIVING REFEF ENCES TO $\triangle C$ CH $\triangle Q T I C L E$ WHICH WAS KEYED TO IT. THE CATEGORY NUMBER IS GIVEN FIFST, FOLLOWEO BY THE ACCESSICN NIIMPEP. THE DCCESSION NUMBERS ARE USED TC LOCATE 3IBLIOGRAPHIC ITEMS WI THIN A CATEGQRY.

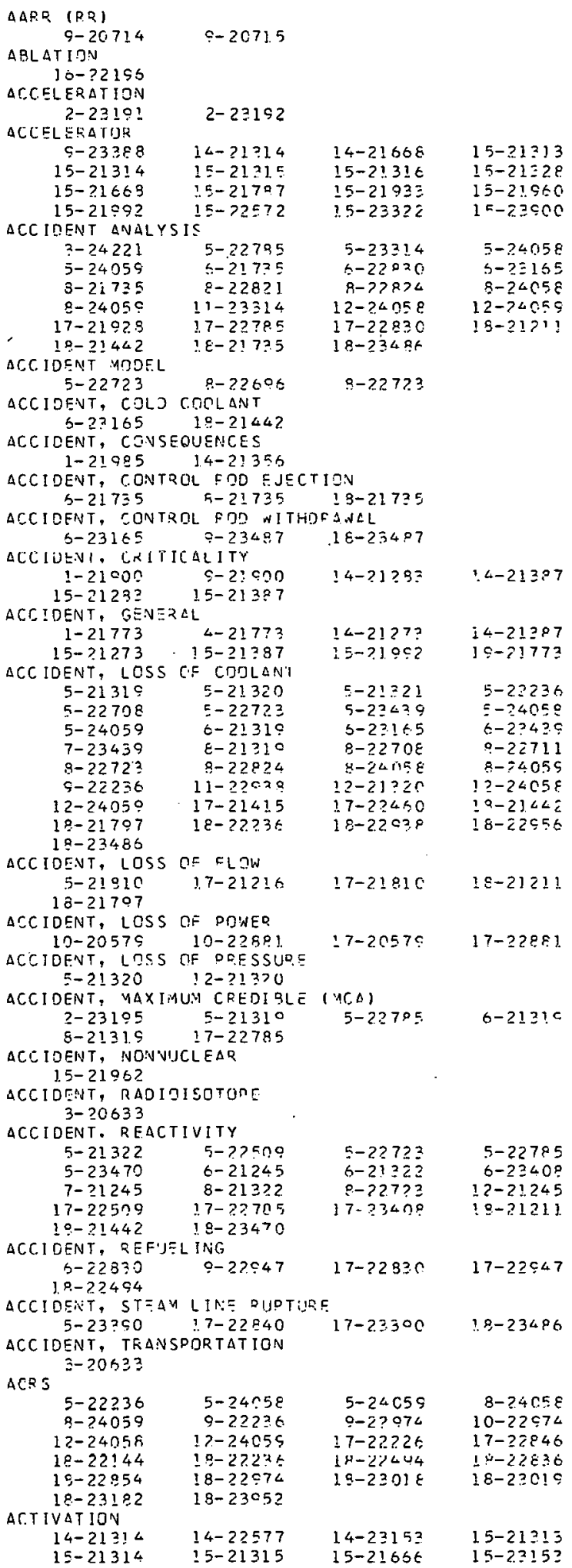

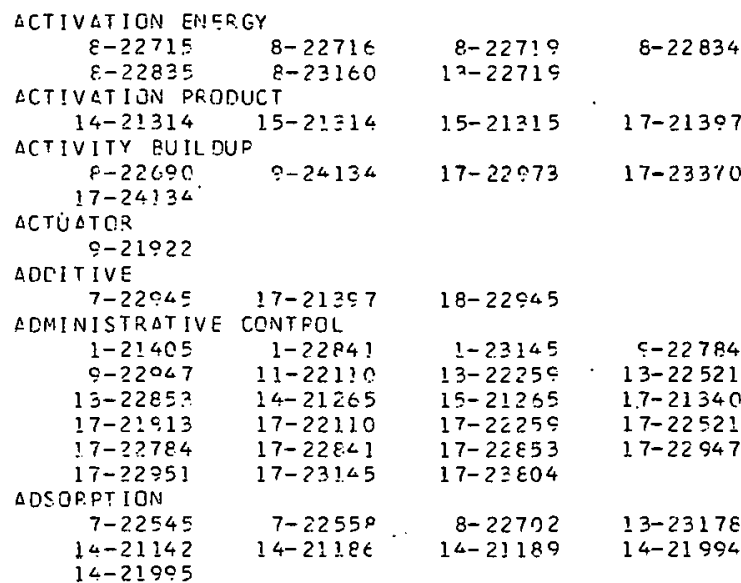

ADSORPTION SURFACE

$14-21186$

AEC DESIGN CPITFPIA

$\begin{array}{cccc}1-21291 & 9-22974 & 10-22974 & 11-21663 \\ 19-21291 & 18-21602 & 19-22910 & 18-22974 \\ 18.2395 ? & & & \end{array}$

$\triangle E C$ QU

\begin{tabular}{|c|c|c|c|}
\hline $2-20054$ & $2-2.2911$ & $5-22775$ & $5-234$ \\
\hline$-2249 ?$ & $9-22844$ & $9-2.2 \div 48$ & -22 \\
\hline-23051 & $10-22 \subseteq 74$ & $10-2 \geq \leq 51$ & $11-216$ \\
\hline $142 \%$ & $17-221.3 ?$ & $17-22775$ & $17-228$ \\
\hline 4t: & $17-22: 48$ & $18-20138$ & \\
\hline 05 & $18-20 \leq 52$ & $18-20 \equiv 65$ & 1 \\
\hline-21455 & $18-7.1464$ & $19-21662$ & $18-21$ \\
\hline-21721 & $18-22339$ & $19-22493$ & $18-224$ \\
\hline-22511 & $19-228<7$ & $18-229 ! 1$ & $18-229$ \\
\hline$-229 \equiv 0$ & $19-22940$ & $18-22961$ & -229 \\
\hline 2975 & $18-22 c c 4$ & $15-22010$ & -2 \\
\hline 3017 & $19-2302 n$ & $18-23037$ & $3-23$ \\
\hline 224 & $13-2 \geq 270$ & $18-23471$ & -2 \\
\hline & $i \varepsilon-23600$ & $18-23 \div 50$ & $8-23$ \\
\hline
\end{tabular}

$\triangle E F O S O L$

$18-23952$

$18-23550$

$4-22476 \quad 4-22480 \quad 7-22472 \quad 7-22479$

$7-22496 \quad 7-22531 \quad 7-22532 \quad 7-22533$

$7-22543 \quad 7-22544 \quad 7-2254 \varepsilon \quad 7-22707$

$\begin{array}{llll}7-22987 & 1 ?-22987 & 13-21194 & 14-21186\end{array}$

$14-21187 \quad 14-21190 \quad 14-21191 \quad 14-21154$

1.4-21195 $14-21200 \quad 14-21256 \quad 14-21756$

$14-21031 \quad 15-21194 \quad 15-21256 \quad 15-21756$

AERDSEL POODUCT IGN

4-224BE 4-22514 7-22472.7-22486

$\begin{array}{llll}7-7.7514 & 7-2.7548 & 7-22587 & 12-26987\end{array}$

$\triangle E R O S O L$ PRCPERTIES

$\begin{array}{rrrr}4-22490 & 4-22514 & 7-22472 & 7-22486 \\ 7-22514 & 7-22533 & 7-22534 & 7-22543 \\ 7-22544 & 7-22548 & 7-22597 & 11-22987 \\ 14-2193 ! & 15-21631 & & \end{array}$

$\triangle E R O S C L$, PACIOACTIVE

$14-21921 \quad 14-23: 10 \quad 14-23878 \quad 14-23880$

$14-24065 \quad 15-21764 \quad 15-21931 \quad 16-21123$

$16-21 ? 27 \quad 16-21526 \quad 16-220 ? 2 \quad 16-22924$

$16-22970 \quad 16-2337 \mathrm{c} \quad 16-23878 \quad 16-23880$

$16-24065 \quad 16-24066 \quad 17-21426$

$\triangle E$ EOSPACE SLFETY

$\begin{array}{llll}1-21773 & 1-23301 & 4-21398 & 4-21773\end{array}$

$4-22547 \quad 4-77+98 \quad 4-22700 \quad 4-2334$

LGESTA (OWR)

6-23167 $17-23167$

$A G N$ (TNG)

$9-22453 \quad 0-22794 \quad 9-22844 \quad 17-20835$

$17-27784 \quad 17-72644 \quad 1 \varepsilon-21430 \quad 1 \varepsilon-22493$

$18-22842$

$\triangle G F$ ( $\triangle O V A N C E D$ GASCOOLED PEACTOR, WINDSCALE, UK) $6-21247$ 
AGRICULTURAL CONSIOCDATION

14-21749 15-?1749

$\triangle I R$

$5-2272$

8- 22720

$\Xi-23377$

14- 21204

$15-21204$

15-21756

$7-22707$

AIP RORNE RELEASE

$13-23316$.

$\begin{array}{ll}13-233 ! 6 & 14-2 ! 25 \\ 14-21784.15-2 ! 256\end{array}$

$15-21784 \quad 15-22518$

$16-21261$

$17-23316$

! 7-21718

1 $8-23486$

15-?1??4

$15-2<061$

14

14-21?73

1 4-24061

$1-21392$

$4-22515$
$8-22719$

$4-? 256$

17-21215

ALPHD EMITTER

$7-1.3345$

13-2252

14-21192

$15-21204$

$14-21283$

$15-22.111$

$15-2252 \epsilon$

ALUMIVUM

$1-2139 ?$
$4-21199$

$\triangle M E R I C I U M$

$12-24278 \quad 14-21709 \quad 15-21308 \quad 15-22527$

$15-24278 \quad 17-21082 \quad 17-22522 \quad 17-22527$

ANALOG SIMULATICN

$9-23385$

ANALYTICAL :AJDEL

$$
2-21917
$$

$6-21247$

$7-22487$

$8-22720$

$0-23385$

5- 22723

$8-22723$

$17-27579$

$17-24 ? 78$

17-22912

$4-22480$
$7-22477$
$7-22217$

$8-22723$

18-20001

ANALYTICAL TEC,HNIQUE, AIR

$7-22531$ T $7-22986$

16-21133 16-22451 $16-23379$

A.VALYTICAL TECHNIOUE, CALIBRATION

$$
7-22534 \text {. 7-22548 }
$$
$15-2248$

ANALYTICAL TECHNIQUE, FחODO 14-21931 14-22577

$15-2193$

ANALYTICAL TECHNIQUE, GAS $7-22554 \quad 7-22561$

ANALYTICAL TECHNI IQUF, GENERAL

$14-20558$ 14-21931 14-2406? 15-21939 $15-23150 \quad 15-240 \mathrm{~K} 3$

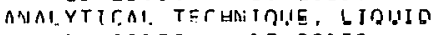
14-23153 1.5-23?.53

NNALYTICAL TECHNIQUE, IAIL $14-22471 \quad 15-21762$

$16-2 ? 971$

ANALYTICAL TEC:HNIQUE, SOLID 14-21765 14-21931 15-21031

ANALYTICAL TECHNIQUE, URINE $\begin{array}{lll}14-21204 & 14-21336 & 14-21994 \\ 15-21287 & 1.5-21396 & 15-21952\end{array}$

ANALYTICAL TECHNIQUE, VEGETATION 14-21931 14-22577 15-21931

ANALYTICAL TSCHNIQUE, WATER $\begin{array}{lll}14-21755 & 14-21931 & 14-22577\end{array}$ $15-21931 \quad 16-21926$

AiNL

5- $22723 \quad 8-2271^{\circ} \quad 9-2272$ $8-22822 \quad 9-22823 \quad 8-22824$ $15-21261 \quad 15-21314 \quad 16-2126$

ANT IMONY 4-22458 7-22468

$\triangle Q U A T$ IC ORGANISMS

14-21270 14-21378 14-23321 15-23321

$\triangle R G E N T$ INA 14-?1965

$\triangle R G O N$

$$
\text { 4- } 22463 \quad 4-22486 \quad 7-22486 \quad 11-22463
$$

ARGONAUT ITNG

$\triangle S L B$ $17-22460$

$19-22 \% 8$

ATMOSPHER IC CIRCULATION, GLOBAL $14-23379 \quad 14-23890 \quad 16-212 ? 2$ $16-23370$
$5-22708$

$7-22480$

$7-227 ? 4$

$8-23435$

$6-22450$

$14-21755$

$5-22723$

$7-2248$

c-21832

17-21410

$18-22917$

$14-22379$

$7-22982$

$15-21204$

$14-22806$

8-?2821

$14-21 \geq 14$

$15-22488$

$16-22024$
$16-24065$

$\triangle T M O S P F E R I C$ CIFFUSION

$2-23197 \quad 14-23 \varepsilon 78 \quad 15-23001 \quad 16-21134$ $16-21926 \quad 16-22451 \quad 16-23197 \quad 16-23878$ $16-24064$

ATMOSPHERIC DIFFUS IDN EXPFR IMENT

$16-22970 \quad 16-24067$

$\triangle T M O S P H E R I C$ DIFFUSION, GLOEAL

14-23980 16-21<2? 16-23380 16-23880

$\triangle T M O S P H E R I C$ FOLLUT ION

16-22450 16-22451

ATMOSPHER IC STABILITY

$14-21713 \quad 16-21133 \quad 16-21223 \quad 16-21713$

AUSTRALIA

$1<-2127 t$

AUXILI IRY CODLING

$17-10494 \quad 18-16404$

$\triangle U X I L I A R Y$ COOLING SYSTEM

$\begin{array}{llll}17-21395 & 17-21 ? 97 & 17-22553 & 17-22851\end{array}$

E.ARIUIM

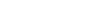

$7-22542$

$4-22468$

$7-22468$

$7-22472$

$14-240.60$

$15-24060$

$1-22459$

$\begin{array}{ll}1-22330 & 1-22458\end{array}$

$1-22706 \quad 1-22 \% 19$

$14-2129 \mathrm{C} \quad 14-21305$

14-21379 i 4-21798

$14-21967 \quad 15-21256$

15-21787 18-21?15

$9-2192$

14-2131

$14-21799$

15-21311

$14-21256$

$14-21329$

$15-21320$

BELGIUM

$14-21387 \quad 15-21397$

EEPYLLIUM

$6-23 \fallingdotseq 17 \quad c-20713 \quad 13-21194 \quad 14-21194$

$14-2120 ?$

14- 21205

$15-21194$

1. $5-2) 203$

EMITTFR

$14-21192$
$14-21771$

$14-211 \div 5$

$14-21756$

$14-21770$

$15-20742 \quad 15-2116 ?$

$15-? 1770 \quad 15-21771$

$15-22242 \quad 15-22520$

$15-23430 \quad 15-23431$

4- 22492

$15-21720$

$20-15-21756$

$15-21547 \quad 15-22238$

$15-22931 \quad 15-23429$

$15-24273 \quad 16-22492$

BIPLI OGRAPHY

$1-21773$

$17-23312$

$17-22520$

$17-24273$

4-21773

$5-23402$

$11-23312$

1S-23?12 19-2340?

$19-21772$

$19-224 \% 6$

EIG R.CK DOINT (3WR)

5-21\&1C 15-22520

$17-21810$

$17-22226$

PIOLOGICAL CONCENTRATION, ANIMAL

$14-21269 \quad 14-21275 \quad 14-21345$

$14-21946 \quad 14-21 \% 96 \quad 14-22237$

$15-21254 \quad 15-21761$ 15-21939

BICLOGICAL CONCENTRATION, ANIMAL FEED

$14-21381 \quad 1<-21792 \quad 14-22237$

BIOL OGICAL CONCENTRAT ICN, DOUATIC ORGANISMS

$14=1258 \quad 14-21264$ I4-21205 14- 21311

$14-21384 \quad 14-71750 \quad 14-21751 \quad 14-2178 \mathrm{C}$

14-2178! $14-21945 \quad 14-21949 \quad 14-2196 \mathrm{~A}$

14-22150 14-2215! 14-22154 14-22245

$14-23155 \quad 15-213110$

$15-21945 \quad 15-22150 \quad 15-23155$

EIOLOGICAL CONCENTRAT ION, FOCO

$14-? 1360 \quad 14-21363$

$14-21750 \quad 14-21751$

$14-21952 \quad 14-21559$

14-21978 $\quad 14-21980$

$15-21254 \quad 15-21360$

15-21745 15-21750

$15-21978 \quad 15-23901$

PIOLOGICAL CONCENTRATION,

$14-21142$

$14-21325 \quad 14-21384 \quad 14-21748$

$14-21750 \quad 14-2175 ! \quad 14-21758$

$14-21781 \quad 14-21782 \quad 14-21799$

$14-21952 \quad 14-21959 \quad 14-21965$

$14-21967$

$14-23154 \quad 14-24061$

$15-21748 \quad 15-21749$

$15-21945 \quad 15-21950$

$15-24061 \quad 16-21261$

EIOLOGICAL CONCENTRAT ION, MAN

$14-21162 \quad 14-21204$

$14-21344$

$14-21204$
$14-21349$

$14-21980$

$15-21138$

$15-21750$

$15-21978$

$15-21751$

$14-22813 \quad 14-24214$

$15-21138 \quad 15-21162$

15-21311 15-21344

$15-21385$

$15-21 \geq 86$
14-21266

$14-71360$

$14-21594$

$14-24215$

$15-21204$

$15-21349$

$15-21666$
$14-21325$

14-21749

$1<-21946$

$14-21966$

14-22815

$15-21385$

14-21269

14-21749

14-21780

$14-21945$

14-21966

1 4-22 112

$15-\overline{1} 1261$

15-2i 751

14-21311

$14-21768$

1 4- 22805 


\begin{tabular}{|c|c|c|c|}
\hline $\begin{array}{l}15-21768 \\
15-21953 \\
15-23937\end{array}$ & $\begin{array}{l}15-21932 \\
15-22805 \\
15-24216\end{array}$ & $\begin{array}{l}15-21930 \\
15-22915 \\
15-24215\end{array}$ & $\begin{array}{l}15-21.95 \\
15-23005\end{array}$ \\
\hline \multicolumn{2}{|c|}{ BIOLOGICAL CDNEEVTRATION, } & is I LK & \\
\hline $14-21242$ & $14-? 1379$ & $14-21325$ & $14-21345$ \\
\hline $14-21360$ & $14->1281$ & $14-21758$ & $14-21 \div ? \%$ \\
\hline $14-21045$ & $14-21552$ & $14-21978$ & $14-? i \subsetneq 80$ \\
\hline $14-21907$ & $14-? 28 ? 3$ & $14-22: 12$ & $14-228 ! 5$ \\
\hline $\begin{array}{l}15-21260 \\
15-21078\end{array}$ & $15-? 176 !$ & $! 5-2 ! 7 \in 2$ & $15-21.45$ \\
\hline \multicolumn{2}{|c|}{ BIOLOGICAL CDVCENTRATION, } & VEGETATION & \\
\hline $14-21265$ & $14-21379$ & $14-21782$ & 1. $4-21799$ \\
\hline $1.4-21.935$ & $14-2 ? .55$ & $14-21951$ & $14-21959$ \\
\hline $14-2 \div 505$ & $14-21$ Cot & $14-21067$ & $14-22112$ \\
\hline $14-22245$ & $14-22246$ & $14-2257 t$ & $! 4-225 ! 7$ \\
\hline $15-2.1245$ & $15-21950$ & & \\
\hline \multicolumn{4}{|l|}{ BICMEDICAL } \\
\hline $1-21773$ & $4-21773$ & $4-22700$ & $14-21162$ \\
\hline $14-21250$ & $14-21283$ & $14-21311$ & $14-21349$ \\
\hline $14-21374$ & $14-21786$ & $14-2 !<45$ & $.4-22950$ \\
\hline $14-21953$ & $1<-21505$ & $24-21096$ & $15-2.1152$ \\
\hline $15-21254$ & $15-? 1260$ & $15-21261$ & $15-21263$ \\
\hline $15-21 ? 93$ & $15-2 ! 235$ & $15-2130 \mathrm{t}$ & $15-2 ! 3 ! ?$ \\
\hline $1.5-21326$ & $15-21=\angle c$ & $i 5-21374$ & $1.5-2.1705$ \\
\hline $15-2172 t$ & $15-217 \div 5$ & $15-2 ! 535$ & $15-21943$ \\
\hline $15-21945$ & $25-2 ! 959$ & $15-21093$ & $15-21996$ \\
\hline $15-22 ! 48$ & $15-22152$ & i $5-22573$ & $15-\pi 28.8$ \\
\hline $15-22930$ & $16-21251$ & $19-2177 ?$ & \\
\hline \multicolumn{4}{|l|}{ B10TA } \\
\hline $14-21252$ & $1<-2.1780$ & $! 4-2 ! 76 !$ & \\
\hline BISIAUTH & & & \\
\hline $14-21=45$ & $? 5-? ! 943$ & & \\
\hline BLOWDOWN & & & \\
\hline $5-2 ? 226$ & $5-2 \equiv ! 50$ & $5-23<18$ & $5-?<r .58$ \\
\hline $5-2405 \div$ & $t-23160$ & $8-2<050$ & $8-2<059$ \\
\hline $0-22236$ & $12-? 4259$ & $12-24055$ & $19-? 2236$ \\
\hline $3 M I$ & & & \\
\hline $1-2.3 \div ? !$ & & · & \\
\hline $15-21285$ & & & \\
\hline $\begin{array}{l}15-21255 \\
\text { 8ONUS (ISQ) }\end{array}$ & $15-21798$ & $15-2 ? 3 ? 2$ & \\
\hline $17-? 1 ? 99$ & $17-21300$ & $17-21411$ & \\
\hline SOR'T & & & \\
\hline $6-23440$ & $7-22065$ & $9-2.2 .277$ & $9-20714$ \\
\hline$c-22344$ & $9-23196$ & $11-239 ! 5$ & $14-16824$ \\
\hline $17-22044$ & & & \\
\hline DOUNDAPY I $\triangle Y F ?$ & & & \\
\hline $5-23 ? 79$ & $5-? 33 \div \div$ & $5-23<0 ?$ & \\
\hline $\begin{array}{c}\text { BOUNDARY LAYEA, } \\
Q-23435\end{array}$ & $E E \angle C T I N G$ & & \\
\hline$B R \triangle 71 L$ & & & \\
\hline $14-21045$ & $1<-2 ! ? 59$ & $15-21048$ & $15-21859$ \\
\hline BRITTLE FP.ACTIJP & & & \\
\hline $11-21117$ & $11-21135$ & $11-22108$ & $11-2.212 c$ \\
\hline $11-23312$ & $11-2331 ?$ & $\therefore 1-22 \times 15$ & $11-2 \leq 8 ? 0$ \\
\hline $11-2386 ?$ & $11-23910$ & $17-23312$ & $17-7386 ?$ \\
\hline $18-214 t 3$ & $10-23 ? 1.2$ & & \\
\hline BRQAI VE & & & \\
\hline $1<-21270$ & & & \\
\hline RUSBLE & & & \\
\hline $5-23400$ & & . & \\
\hline BUCKL INS & & & \\
\hline $11-2=003$ & $1=-23 \leq 0 ;$ & & \\
\hline SUILDING & & & \\
\hline $13-20710$ & & & \\
\hline BUSYANT Q ISE & & & \\
\hline $16-72025$ & & & \\
\hline BUS.VOUT HEAT FL & & & \\
\hline $5-21810$ & $5-22607$ & $5-23410$ & $\leqslant-234 \varepsilon 3$ \\
\hline $17-21: 3 \geq 0$ & $122: 435$ & & \\
\hline 3URST FRESSUSE & & & \\
\hline $11-2111 \mathrm{c}$ & & & \\
\hline BYOROOUET YATER & $I \& L$ & & \\
\hline $15-22432$ & $17-22422$ & $17-23366$ & \\
\hline CALCINATIOA: & & & \\
\hline $14-21 \geq 30$ & $: 4-7.1553$ & & \\
\hline CALCIUM & & & \\
\hline $14-21162$ & $2<-2 ! 20 t$ & $14-2 ! 275$ & $14-21799$ \\
\hline $14-21944$ & $14-21947$ & $14-22112$ & $14-22576$ \\
\hline $14-22577$ & $1 \leq-21: \in 2$ & $: 5-21261$ & $15-213.96$ \\
\hline $15-\geqq 1762$ & $15-2.1756$ & $15-21047$ & $15-23503$ \\
\hline $1 E-21261$ & & & \\
\hline CAL IFDP:NIUM & & & \\
\hline $17-23^{2} 17$ & & & \\
\hline CANADA & & & \\
\hline $1-21399$ & $7-23372$ & $0-22932$ & $14-21197$ \\
\hline $14-21366$ & $14-21965$ & $1<-2190<$ & $14-215 ? 5$ \\
\hline $14-22243$ & $15-21303$ & $15-2 ! 273$ & $17-229 ! 2$ \\
\hline $18-23371$ & & & \\
\hline CANOU (HWR) & & & \\
\hline $17-22912$ & $3=7$ & & \\
\hline
\end{tabular}

CAFBICF

CAFEON

$4-2254 c$

$4-22465$

$4-22549$

$7-22516$

c- -2.3344

CARSON IIDXIOS

$\varepsilon-2271 \%$

CAPBON MONOXIDE

$\varepsilon-22716$

CENTEFILINF MELTING $5-21910$
$17-22226$

CEFAMICS $4-22549$
$7-22927$

$5-22078$
$17-2207$

$17-21342$

$\varepsilon-23377$

$4-22483$

$7-205.5 n$

$7-225 ? 0$

$14-22 \neq 1$

$7-22 \equiv 40$

$17-225 ! 4$

$8-227 ! ?$

C.ERIUM

$4-22480$

$4-22556$

$14-23 \div 14$

$14-3.2574$

$7-2248^{\circ}$

$14-24060$

$4-22468$ ?

$4-2.246$

$7-22469$

$4-31245$

1 $4-\overline{2} 12 \mathrm{cr}$

$14-21325$

$1<-215<5$

$14-21325$

$14-21792$

!4-2193E 14-21 545

$14-21949 \quad 14-21951$

$14-21967$

$1<-22150$

$14-22<92$

$14-2224$

$1<-2215$

$14-2 ? 304$

$15-21138$

14-2400!

15-2!13

$15-210<5$

$15-? 19 ?$

$15-2325$

$15-? 3152$

(-

CHALK FIVER

$7-23011$
$14-21005$

c- $23 \div 11$ $\operatorname{lon}^{1}$

$0-23.299$

CUAMQEF, ION

$C-23353$
EF, NFUTCON

$e-22500$

CHARCOAL

$7-27556 \quad 7-226:$ ? $8-26473$

CH $\triangle Q C C \angle L \quad \triangle D S \cap F B E$

$7-22556$

$7-22564 \quad 7-22810$

CHENICAL $\triangle N A L Y S$ IS $8-22 \leqslant 51$

CHEMICAL KIVETICS

$1-23025$

$7-2258 t$

$5-22708$

$\begin{array}{ll}9-22708 & 0-727 ! 4 \\ 0-22717 & 0-22710\end{array}$

$8-220 \div 4 \quad 6-22034$

$0-23425 \quad 11-23526$

CHEWICAL REACTION

$4-3246 C$

$7-2246 \mathrm{C}$

ON

$2-22696$

$-7 ? 47$

$7-2.2<8 ?$

8- 22702

$8-22715$

s- 22736

$8-22790$
$9-22934$

$8 .-23435$

$15-21 \leq 1:$

$\varepsilon-22720$

$8-22$ e 25

$13-777 !$

1. 1- 1. 1.62 ? 8-21217

$12-221<4$

CHFXISORPTION

CHINA E-?2702.

CHLORINE

$14-21270$

CHF.OMAT OGRAFHY

15-2!28.7

CHROMIUM

$$
4-22483
$$

CIVIL DEFENSE $1-23690$
$15-21712$

$7-22<8$

$15-21.764$

$C L \Delta D$ $15-21 ?-2$

$11-23 \in c c$

$14-21252$

$14-21712$

$17-8,919$
$7-23037$

$5-22898$

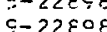

:7-?!? 1 $\mathrm{C}-22 \mathrm{2}$
$17-21=0$

7-22CR2

$11-21122$

$11-21122$
$17-21408$

$17-22898$ 7-2 214

17-22118

$18-21453$

$7-23826$

$11-22118$

$17-21402$

COATEO DAFTICLE

C- 22510

$17-21401$

$7-22 \leq 42$

$17-21404$

$7-22540$

$18-21808$

$7-22585$

$: \varepsilon-22988$ 
COAT ING

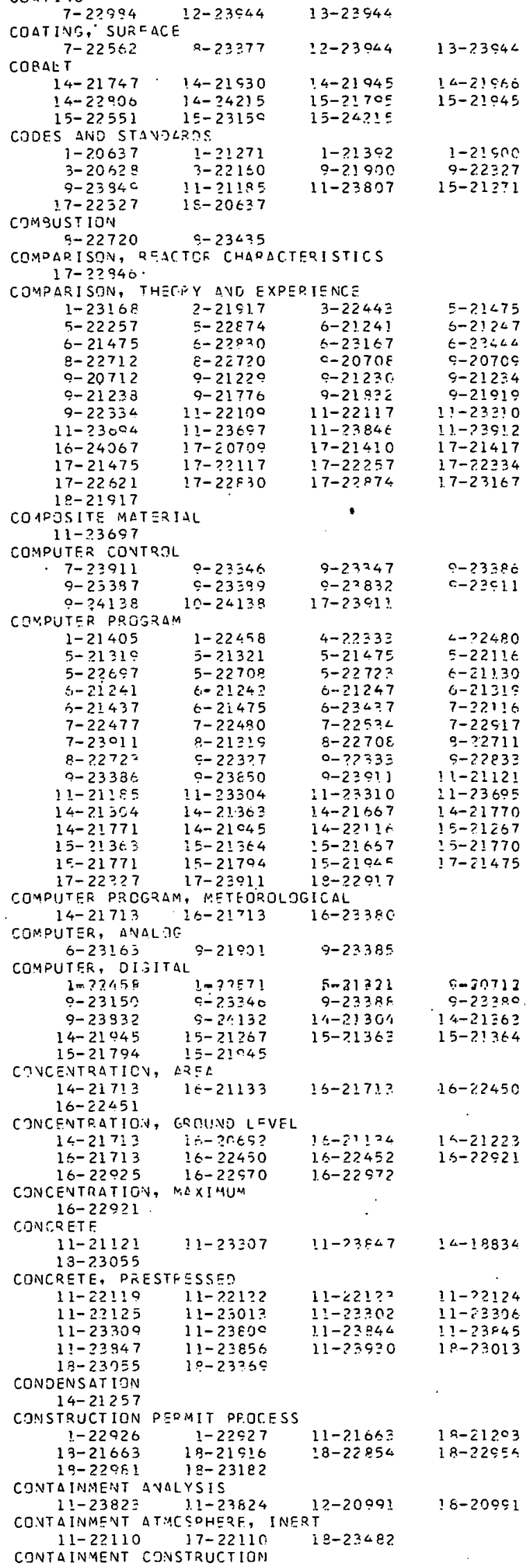

$11-? 3484 \quad 18-20252 \quad 18-23484$

CONT AINMENT DESIGN

$\begin{array}{rrrr}1-23308 & 3-22156 & 5-23439 & 6-23439 \\ 7-23439 & 0-23842 & 11-21185 & 11-22156 \\ 11-22157 & 11-23308 & 12-22157 & 13-22157\end{array}$

$18-25330$

$12-22157$

$13-22157$

CCNT AINMENT INSPECTIIN AND MAINTENANCE $11-2118=$

CONTAIMMENT INSTRUMENTATION

$11-23013 \quad 18-23013$

CONT $\triangle$ INMENT INTEGR ITY

$3-24221 \quad 18-23369$

CONTA INMENT LEAKAGE CONTROL
$7-22987$
$11-22 \div 38$
$11-22587$
$18-22936$ $18-22938$

CONT AINMENT LINEF

$\begin{array}{llll}11-23306 & 11-23307 & 11-22484 & 11-23803\end{array}$

$11-23826$

CONT $\triangle$ INMENT PAINT

$\begin{array}{lll}7-22984 & 7-22587 & 11-22987\end{array}$

CCNT AINMENT PENETRATION, CLOSURE DE

5-23396 $11-22638 \quad 17-22840 \quad 17-23390$

$19-22494 \quad 18-22038$

CONT AINMENT PENETPATION, ELECTF ICAL $11-23360 \quad 17-23360$

CONTAINMENT PENETPATION, GENERAL

$\begin{array}{llll}11-23903 & 17-21414 & 17-22 E 51 & 18-22851\end{array}$

$18-23903$

CONT $\triangle$ INMENT RESEARCH ANO OEVELOPMENT $11-22122 \quad 11-22123 \quad 11-23303$ CONT AINMENT SPRAY

$\begin{array}{lrrr}1-23925 & 7-22545 & 7-22983 & 7-22926 \\ 7-22987 & 7-22926 & 11-22987 & 11-23926\end{array}$
$18-32045$

CONTAINMENT SYSTEM, GFERATION DF $19-221.44$

CCNTAINMENT VESSEL LOARING 1.1-21185 11-22123 11-22124

CCNTT A IN:AENT, COERCSION PPOTECTIÜN $11-22110$

CENTATNIAENT, GENEEAL

$$
\begin{array}{rrrr}
1-23926 & 7-22477 & 7-23926 & 11-22191 \\
11-23304 & 11-23844 & 11-23926 & 12-22191
\end{array}
$$

$11-23304 \quad 11-23844 \quad 11-23926 \quad 12-22191$

$14-21257 \quad 17-21448 \quad 18-21211$

CONT AINMENT, HIGH PDESSURE

11-21119 $11-23013 \quad 11-23304 \quad 18-23013$

CONT A INMENT, ICE CONDENSEP

$1-23309$ I $1-23303 \quad 11-23308$

CONTAINMENT, LOW PRESSURE

$1-22143 \quad 1 C-22885 \quad 11-22885 \quad 17-22143$

$17-22885$ IP-23?71

CONT AINMENT, PRESSUSE SUPPRESSION

$11-23484 \quad 18-23484$

CONT AINMENT, SHOCK GFNEPATION AND PRJTECTION $11-22109$

CONT AMINATICN

$\begin{array}{rrrr}3-20633 & 3-22909 & 4-22483 & 5-22894 \\ 7-33193 & 0-2339 ? & 9 \cdots 233 i & 7-23345 \\ 12-23944 & 12-24192 & 12-24277 & 13-21194 \\ 13-22438 & 13-23944 & 13-24274 & 14-21188 \\ 14-21100 & 14-21191 & 14-21192 & 14-21193 \\ 14-21194 & 14-21195 & 14-21196 & 14-21157 \\ 14-21198 & 14-21200 & 14-21201 & 14-21202 \\ 14-21203 & 14-21204 & 14-21235 & 14-21206 \\ 14-21668 & 14-21769 & 14-21947 & 14-22246 \\ 14-24216 & 15-21102 & 15-71102 & 15-21164 \\ 15-21195 & 15-2176 ? & 15-21279 & 15-21204 \\ 15-21668 & 15-21769 & 15-21947 & 15-23320 \\ 15-24216 & 15-24273 & 15-24274 & 17-21082 \\ 17-22438 & 17-22522 & 17-22809 & 17-22894 \\ 17-23317 & 17-23370 & 17-24273 & 17-24274 \\ 17-24277 & & & \end{array}$

$17-24 ? 77$

$17-22522$

$17-24273$

$7-24274$

CONTRCL ROD

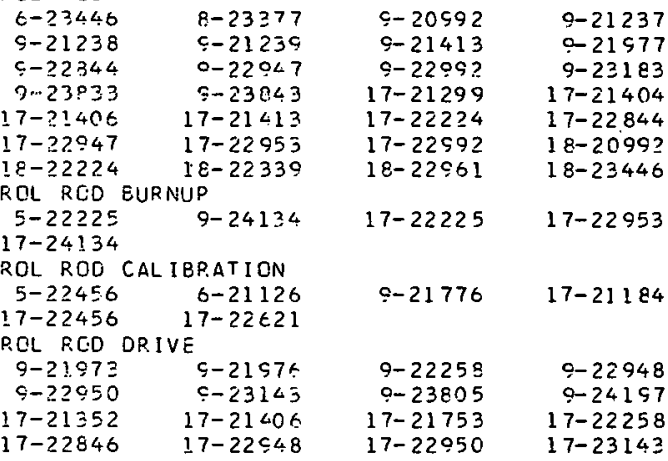




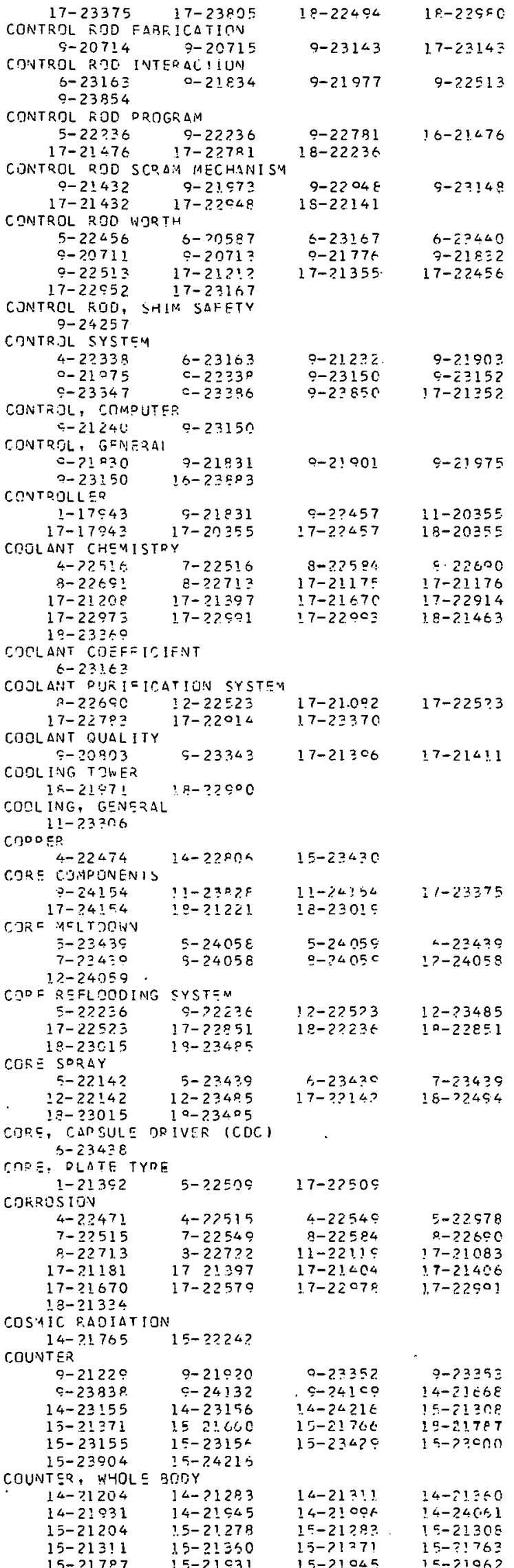

\begin{tabular}{|c|c|c|c|}
\hline \multicolumn{4}{|l|}{$\begin{array}{c}15-210 \% 3 \\
15-240 E 1 \\
\text { COUPLED CORES } \\
\text { S-2316? } \\
\text { CRESP }\end{array}$} \\
\hline $\begin{array}{r}7-22017 \\
10-22017\end{array}$ & $11-23 \leqslant 58$ & $11-23806$ & $17-21215$ \\
\hline CREEP BEHOVIOP. & & & \\
\hline $\begin{array}{c}11-2 ? 12 ? \\
\text { CFEEF PRDPEPTY }\end{array}$ & $11-22123$ & $11-22857$ & \\
\hline $\begin{array}{c}11-21121 \\
\text { CRITICAL } \triangle S S E M P\end{array}$ & LY $=\Delta C I L I T Y$ & & \\
\hline $1-23 ! 66$ & $5-221.40$ & $5-221140$ & $6-23446$ \\
\hline $5-20>11$ & $9-2141 \%$ & - 22291 & $c-22513$ \\
\hline $14-21202$ & $15-21202$ & $17-21412$ & $17-21418$ \\
\hline $17-2 ? ? 40$ & $17-22.25 !$ & $17-22837$ & $17-2283 \varepsilon$ \\
\hline $17-22 \div 5 !$ & $18-2122 n$ & $18-21416$ & $16-23116$ \\
\hline $\begin{array}{c}\text { CPITICAL MASS } \\
\text { E-23917 } \\
\text { CEITICALITY FXD }\end{array}$ & ER IMENT & & \\
\hline $\begin{array}{c}1-23168 \\
1-38\end{array}$ & $6-2 C \leq \varepsilon 7$ & $6-21241$ & $6-21245$ \\
\hline $6-212<c$ & $t-21250$ & $6-2143 P$ & $6-23434$ \\
\hline$t-23440$ & $\dot{t}-23442$ & $7-21245$ & $c-22513$ \\
\hline $\begin{array}{c}12-2: 2 \angle 5 \\
\text { CRITICALITY SDF }\end{array}$ & $\begin{array}{l}! 7-81<n E \\
\text { ETY }\end{array}$ & & \\
\hline $\begin{array}{c}C R I T I C \Delta L I T Y S \Delta F \\
1-21 O \cap 0\end{array}$ & $\begin{array}{l}\text { ETY } \\
1-2 \geq 442\end{array}$ & & \\
\hline $\begin{array}{l}1-21000 \\
0-23258\end{array}$ & $\begin{array}{l}1-23442 \\
6-23<43\end{array}$ & $\begin{array}{l}2-20630 \\
0-23517\end{array}$ & $\begin{array}{l}3-22160 \\
0-21900\end{array}$ \\
\hline $\begin{array}{l}0-23258 \\
9-33350\end{array}$ & $\begin{array}{r}6-23<43 \\
12-231 \varepsilon !\end{array}$ & $13-20630$ & $13-231 \varepsilon 1$ \\
\hline $17-21205$ & & & \\
\hline CPOSS SECTICM & & & \\
\hline $\begin{array}{l}\text { E-21130 } \\
\text { CRYOEENICS }\end{array}$ & $6-21244$ & $t-? 244 ?$ & \\
\hline $\begin{array}{r}4-22547 \\
11-23525\end{array}$ & $4-22 \leq t 7$ & $5-19543$ & $5-23<24$ \\
\hline $\begin{array}{l}11-23525 \\
\text { CPYSTAL RIVER ? }\end{array}$ & $\triangle N O \&$ (OWR) & & \\
\hline $2-23=26$ & $12-23 \geq 26$ & $18-23225$ & $18-23326$ \\
\hline $\begin{array}{l}1-23 c 26 \\
1-230 ? 6\end{array}$ & $7-2.2 \subseteq 87$ & $7-23036$ & $11-22987$ \\
\hline CUFIUM & & & \\
\hline CVTP $14-3.10325$ & $17-21 C^{\circ} ?$ & $17-22993$ & \\
\hline CVTR $\begin{array}{l}(P W R) \\
t-? 3 ! \leqslant 5\end{array}$ & $15-235 \in E$ & $17-21294$ & \\
\hline CYLI $17-21448$ & $17-23 \varepsilon \in \rho$ & & 1.7-2! \\
\hline $11-211 ? 1$ & $11-2330^{\circ}$ & $11-2 \equiv t 96$ & $11-25901$ \\
\hline $\begin{array}{c}11-23863 \\
\text { CZECHOSLOVAK IA }\end{array}$ & $11-23<\div 2$ & & \\
\hline $11-23 \div 62$ & $14-21 \equiv 4 ?$ & $14-22239$ & $14-22247$ \\
\hline $15-22572$ & & & \\
\hline $\begin{array}{l}D \triangle M A G E \\
17-2 ! 99 !\end{array}$ & & & \\
\hline DATA PF.JT,FSSING & & & \\
\hline $1-22571$ & $0-20712$ & $0-21240$ & $c-23347$ \\
\hline$s-233 \varepsilon \varepsilon$ & $c-23200$ & $9-23832$ & $c-2<132$ \\
\hline $14-2171 ?$ & $15-21712$ & $15-23505$ & $17-21336$ \\
\hline $17-21352$ & & & \\
\hline $\begin{array}{c}\text { DECAY HEAT } \\
17-? 1440\end{array}$ & & & \\
\hline DECONTA YINATION & & & \\
\hline $1-? 1773$ & $4-? 177 ?$ & $4-22463$ & $4-2248 ?$ \\
\hline $4-2.2516$ & $7-22<83$ & $7-22516$ & $11-22463$ \\
\hline $12-20739$ & $12-? 2463$ & $12-23179$ & $12-23871$ \\
\hline$: 2-23344$ & $1 z-241 \div \bar{z}$ & $13-2<<5 ? 6$ & $13-2285 ?$ \\
\hline $12-23 ! 70$ & $13-2327 !$ & $13-23944$ & $14-20739$ \\
\hline $1<-21186$ & $1 \angle-2120 t$ & $14-21207$ & $14-21332$ \\
\hline $14-2 ! \div 3 !$ & $14-21<47$ & $1<-21957$ & $15-217 ? 0$ \\
\hline $15-2 i \div+1$ & $: 5-21 c 47$ & $15-21957$ & $15-22526$ \\
\hline $15-23 ? 20$ & $17-21682$ & $17-21720$ & $17-22525$ \\
\hline $17-22525$ & $17-22953$ & $17-22914$ & $17-22093$ \\
\hline $37-23518$ & $19-21773$ & & \\
\hline OECONTAMINATION & FACTRK & & \\
\hline $\begin{array}{r}7-22.5 .64 \\
\text { DEFOPMATION }\end{array}$ & $7-22707$ & - & \\
\hline $11-21: 19$ & $11-21121$ & $11-21122$ & $11-21185$ \\
\hline $11-22123$ & $11-23 \geq 05$ & $11-23846$ & \\
\hline DELAYED NEUTFON & & & \\
\hline$t-20587$ & $9-23385$ & & \\
\hline TIFNMARK & & & \\
\hline$\varsigma-21827$ & $9-21528$ & $14-22804$ & $14-22217$ \\
\hline $\begin{array}{l}15-21960 \\
\text { CEDOSITION }\end{array}$ & $17-218$ & $17-218 ; 28$ & \\
\hline $4-22480$ & $5-2211 t$ & $7-22116$ & $7-22.477$ \\
\hline $7-224.78$ & $7-2240 ?$ & & $7-22533$ \\
\hline $7-22539$ & $7-22952$ & $14-21187$ & $14-21257$ \\
\hline $14-21713$ & $14-22116$ & & $16-21713$ \\
\hline $1 k-2 \geq 922$ & $16-22571$ & $16-24057$ & \\
\hline DESISNN CRIITEPIA & & & \\
\hline $1-23443$ & $2-23188$ & $2-23190$ & $2-23812$ \\
\hline $3-22<44$ & $4-22464$ & $4-22484$ & $t-2=443$ \\
\hline $7-22484$ & $7-22558$ & $0-225 ! 2$ & $9-23151$ \\
\hline
\end{tabular}




\begin{tabular}{|c|c|c|c|}
\hline $\begin{array}{r}9-23327 \\
12-20991 \\
13-23180 \\
13-20991\end{array}$ & $\begin{array}{r}9-23940 \\
12-23190 \\
13-23181 \\
18-23913\end{array}$ & $\begin{array}{l}11-21185 \\
12-23181 \\
14-18934 \\
18-23912\end{array}$ & $\begin{array}{l}11-23013 \\
13-23175 \\
15-23431\end{array}$ \\
\hline \multicolumn{4}{|l|}{ DESIGN STUDY } \\
\hline $1-213 \subseteq 0$ & $6-231 \leqslant 2$ & $3-22584$ & $\varphi-? ? 512$ \\
\hline $9-23147$ & $11-23809$ & $11-23828$ & $17-21342$ \\
\hline $18-z ! 2 ! 1$ & $18-21218$ & $18-21334$ & $18-21339$ \\
\hline $18-21400$ & $18-21972$ & $18-22583$ & $18-22800$ \\
\hline \multicolumn{4}{|c|}{ OESTRUCTIVE WIND } \\
\hline \multicolumn{4}{|l|}{ DEUTER IUA } \\
\hline $9-22651$ & $16-21 \div 26$ & & \\
\hline \multicolumn{4}{|l|}{ DIABLO CANYON } \\
\hline $1-2 ! 201$ & $2-20563$ & $5-22236$ & $5-278 ? 4$ \\
\hline $\begin{array}{r}0-22236 \\
19-21291 \\
\text { OIETARY HASIT }\end{array}$ & $\begin{array}{l}17-22574 \\
18-22236\end{array}$ & $18-20962$ & $19-208 \leq 3$ \\
\hline $1<-2 ! ! \in 2$ & $14-21978$ & $14-23154$ & $14-23155$ \\
\hline $15-21162$ & $15-21385$ & $15-21761$ & $15-21766$ \\
\hline $15-21978$ & $15-23154$ & $15-23155$ & $15-23003$ \\
\hline \multicolumn{4}{|l|}{ DIFFUSION } \\
\hline $7-20550$ & $7-22495$ & $7-22537$ & $7-? 2538$ \\
\hline $7-225<2$ & $7-22543$ & $7-22563$ & $7-22984$ \\
\hline $7-22985$ & $7-23936$ & $11-23806$ & $14-21713$ \\
\hline $14-21784$ & $1<-22239$ & $15-21261$ & $15-21794$ \\
\hline $15-21223$ & $16-21261$ & $16-21713$ & $16-22106$ \\
\hline \multicolumn{4}{|c|}{ DIFFUSION COSFFICIENT } \\
\hline $4-22466$ & $7-22.466$ & $9-23435$ & \\
\hline $\begin{array}{c}\text { DILUTION } \\
\text { 16-22972 } \\
\text { DISPERSION }\end{array}$ & & -. & \\
\hline $\begin{array}{r}2-23197 \\
16-22970\end{array}$ & $\begin{array}{l}14-21196 \\
16-23197\end{array}$ & $15-21223$ & $15-2 ? 196$ \\
\hline $\begin{array}{r}\text { DISPLAC } \\
2-2319 N, \\
2-23197\end{array}$ & GENERAL & & • \\
\hline DNB & & & \\
\hline $\begin{array}{r}5-22874 \\
17-22874\end{array}$ & $\begin{array}{r}5-22576 \\
17-22576\end{array}$ & $5-2342 \bar{z}$ & $17-21809$ \\
\hline DOPPLER CJEFEI & ICIENT & & \\
\hline $1-23168$ & $6-2316 ?$ & & \\
\hline DOPPLER EFFECT & & & \\
\hline $6-23446$ & $18-23446$ & & \\
\hline DOSE & & & \\
\hline $4-21398$ & $14-21283$ & $14-21314$ & $14-21344$ \\
\hline $14-21362$ & $14-21363$ & $14-21377$ & $14-21768$ \\
\hline $14-21769$ & $14-21780$ & $14-21781$ & $14-21784$ \\
\hline $14-2 ! 786$ & $14-21952$ & $14-21955$ & $14-24215$ \\
\hline $15-20736$ & $15-20737$ & $15-20742$ & $15-21160$ \\
\hline $15-21161$ & $1.5-21281$ & $15-212 P \equiv$ & $15-21306$ \\
\hline $15-21314$ & $15-21333$ & $15-21344$ & $15-21358$ \\
\hline $15-21359$ & $15-21361$ & $15-21362$ & $15-2136 ?$ \\
\hline $15-21364$ & $15-21373$ & $15-21377$ & $15-21768$ \\
\hline $15-21769$ & $15-21734$ & $15-2 ! 78 E$ & $15-21790$ \\
\hline $15-2 ! 794$ & $15-21032$ & $15-2193 ?$ & $15-21940$ \\
\hline $15-21958$ & $1.5-21960$ & $15-21963$ & $15-21069$ \\
\hline $15-22929$ & $15-23159$ & $15-23322$ & $15-23<29$ \\
\hline $15-23430$ & $15-239 ? 0$ & $15-23904$ & $15-24062$ \\
\hline $15-24215$ & $15-24272$ & $17-24272$ & $13-23486$ \\
\hline $18-23950$ & $\cdot$ & & \\
\hline DOSE CALCULATI & ION, EXTERNAL & & \\
\hline $14-21196$ & $14-21203$ & $14-2 ! 352$ & $14-21277$ \\
\hline $14-21780$ & $14-21791$ & $14-2 ! 794$ & $14-21786$ \\
\hline $14-21931$ & $14-21<35$ & $1<-2.232 \%$ & $15-21160$ \\
\hline $15-21161$ & $15-21.196$ & $15-21267$ & $15-21281$ \\
\hline $15-21283$ & $15-21362$ & $15-213 \epsilon 4$ & $15-2] \geq 68$ \\
\hline $15-21273$ & $15-21377$ & $15-21784$ & $15-? 1786$ \\
\hline $15-21790$ & $15-21794$ & $15-2 ! 9 ? 1$ & $15-21933$ \\
\hline $15-22329$ & $15-23150$ & $15-23362$ & $15-23428$ \\
\hline $17-? 3362$ & & & \\
\hline DOSE CALCULAT I & ION, INTERNAL & & \\
\hline $14-21188$ & $1.4-21.344$ & $14-21 ? 6 ?$ & $14-21377$ \\
\hline $14-21780$ & $14-21791$ & $14-2178 t$ & $14-21035$ \\
\hline $14-21952$ & $14-21995$ & $14-2.2320$ & $14-22805$ \\
\hline $15-21161$ & $15-21306$ & $15-2 ! 344$ & $15-21363$ \\
\hline $15-21377$ & $15-21<66$ & $15-21786$ & $15-21932$ \\
\hline $\begin{array}{l}15-21940 \\
15-23424\end{array}$ & $15-22329$ & $15-22805$ & $15-23159$ \\
\hline OOSE MEASUREYE & ENT, EXTERNAL & & \\
\hline $14-21314$ & $14-21030$ & $14-21 \div 4 E$ & $14-21 \subseteq 57$ \\
\hline $15-20736$ & $15-21281$ & $15-21 \times 03$ & $15-21314$ \\
\hline $15-21331$ & $15-21333$ & $15-21755$ & $15-21948$ \\
\hline $15-21957$ & $15-21<58$ & $15-21560$ & $15-21969$ \\
\hline $15-22551$ & $15-22572$ & $15-2292 \mathrm{c}$ & $15-22159$ \\
\hline DOSE MEASUEE YE & ENT, INTERNAL & & \\
\hline $11-22117$ & $14-21204$ & $14-21048$ & $15-21204$ \\
\hline $15-21764$ & $15-21766$ & $15-21948$ & $15-21003$ \\
\hline $15-21969$ & $15-23159$ & $17-22117$ & - \\
\hline SIMETRY, GES & JERAL & & \\
\hline $\begin{array}{l}1-21773 \\
0-23941\end{array}$ & $4-21773$ & $5-23348$ & $9-23348$ \\
\hline
\end{tabular}

\begin{tabular}{|c|c|c|c|}
\hline & & & \\
\hline $\begin{array}{l}14-21446 \\
14-21948\end{array}$ & $\begin{array}{l}14-2177 n \\
14-21957\end{array}$ & $\begin{array}{l}14-21771 \\
14-22329\end{array}$ & $\begin{array}{l}14-21786 \\
14-22321\end{array}$ \\
\hline $14-24215$ & $15-2126.1$ & $15-21281$ & $15-21303$ \\
\hline $15-? 1211$ & $15-213 ! 4$ & $15-21324$ & $15-21331$ \\
\hline $15-21333$ & $15-21358$ & $15-21359$ & $15-21361$ \\
\hline $15-2138 \varepsilon$ & $15-21446$ & $1 E-2 i 770$ & $15-21771$ \\
\hline $15-21786$ & $15-2170 ?$ & $15-21793$ & $15-21942$ \\
\hline $15-21949$ & $15-21 c 57$ & $15-21060$ & $15-21969$ \\
\hline $15-22147$ & $15-22238$ & $15-22329$ & $15-22572$ \\
\hline $15-23321$ & $15-23322$ & $15-23430$ & $15-23431$ \\
\hline $15-24215$ & $16-21261$ & $19-21773$ & \\
\hline DCSIMETRY, PHOTS & OGRAPHIC & & \\
\hline $14-21311$ & $15-21311$ & $15-21358$ & $15-21942$ \\
\hline $15-22147$ & $15-22572$ & & \\
\hline DOSIMETRY, RADIS & ГP HOTOLUMI & NESCENCE & \\
\hline $\begin{array}{c}\text { 1E-21933 } \\
\text { OOSIMETPY, THERN }\end{array}$ & $15-21942$ & & \\
\hline $\begin{array}{l}\text { UOSIMETPY, THERM THE } \\
14-? 1314\end{array}$ & $\begin{array}{l}\text { MOLUM INESC } \\
14-21036\end{array}$ & $\begin{array}{l}\text { ENCE } \\
\qquad 14-21948\end{array}$ & $15-21261$ \\
\hline $15-21314$ & $15-21 \geq 31$ & $15-21792$ & $15-21793$ \\
\hline $15-21942$ & $15-21948$ & $15-22147$ & $15-22238$ \\
\hline $15-24062$ & $15-24273$ & $16-21261$ & $17-24273$ \\
\hline DQUNREAY' (TR) & & & \\
\hline $5-23147$ & & & \\
\hline DRAGGN (HTGR) & & & \\
\hline $17-21404$ & & & \\
\hline DRESDEN I (SWR) & & & \\
\hline $5-22142$ & $5-22775$ & $9-22947$ & $12-22142$ \\
\hline $17-21428$ & $17-22142$ & $17-22775$ & $17-22947$ \\
\hline DRESDEN 2 (BWR) & & & \\
\hline $6-23483$ & $7-2348 \varepsilon$ & $0-23487$ & $11-23484$ \\
\hline $12-23485$ & $19-2301<$ & $18-23016$ & $18-23017$ \\
\hline $18-23018$ & $18-2301 \%$ & $18-23471$ & $18-23472$ \\
\hline $18-23482$ & $18-23483$ & $18-22484$ & $18-22485$ \\
\hline $1 \varepsilon-234 \varepsilon 6$ & $18-23487$ & $18-23438$ & \\
\hline RESDEN 3 (SWR) & & & \\
\hline $9-22327$ & $17-223.27$ & $18-23015$ & $18-23020$ \\
\hline DROPLET & & & \\
\hline $5-23395$ & $5-23421$ & $5-23426$ & $5-23427$ \\
\hline DYNAMICS, NONLIN & NEAR & & \\
\hline $\begin{array}{l}6-21125 \\
t-23171\end{array}$ & $6-21436$ & $t-21437$ & $6-23161$ \\
\hline $\begin{array}{l}t-23171 \\
\text { DYSPPOS [U]M }\end{array}$ & $11-23201$ & & \\
\hline $\begin{array}{r}s-23843 \\
S-238\end{array}$ & . & & \\
\hline $\begin{array}{c}\text { EARTH MATERIAL, } \\
2-23189\end{array}$ & DYNAMIC $F$ & ROPERTY & \\
\hline EARTHQU $\triangle K E$ & & & \\
\hline $\begin{array}{r}\text { EARTHQU } \triangle K E \\
2-20263\end{array}$ & & & \\
\hline $\begin{array}{r}2-20863 \\
18-20554\end{array}$ & $.2-20054$ & $11-21185$ & $18-20863$ \\
\hline FARTHQUAKE ENGIN & NEEP.ING & & \\
\hline $1-22143$ & $c-21 \subseteq 17$ & $2-23188$ & $2-23190$ \\
\hline $2-23191$ & $2-23108$ & $2-23812$ & $11-23013$ \\
\hline $12-20091$ & $14-21935$ & $17-2214 ?$ & $18-2086 \bar{c}$ \\
\hline $18-20091$ & $18-21017$ & $18-23013$ & $18-23812$ \\
\hline EARTHQU AKE PRED & ICT ION & & \\
\hline $\begin{array}{l}2-20527 \\
2-20729\end{array}$ & $2-20 \in 34$ & $2-20635$ & $2-20636$ \\
\hline EAPTHOU AKE RECOR & ROS & & \\
\hline $2-20527$ & $2-20661$ & $2-23190$ & $2-23192$ \\
\hline EARTHDUAKE, GENE & ERAL & & \\
\hline $2-20 \in 27$ & $2-20634$ & $2-20635$ & $2-2063 t$ \\
\hline $2-.00661$ & $2-20729$ & $2-23187$ & $2-23188$ \\
\hline $2-2318^{\circ}$ & $2-? 3190$ & $2-23191$ & $2-23192$ \\
\hline $14-21.90$ & & & \\
\hline EASTON (BWR). & & & \\
\hline $2-24269$ & $18-23952$ & $18-2<269$ & \\
\hline EBOR (GCR) & & & \\
\hline $17-21172$ & & & \\
\hline EBR I. AND 2 (R.E) & & & \\
\hline $5-22456$ & $9-20 \div 12$ & $9-22457$ & $0-23330$ \\
\hline $9-23356$ & $9-23357$ & $17-22456$ & $17-22457$ \\
\hline $17-233 \geq 0$ & & & \\
\hline EBWR (BWR) & & & \\
\hline $11-23926$ & & & \\
\hline ECOLOGICAL CONS I & IOER $\triangle T$ ION & & \\
\hline $1-22330$ & $1-22571$ & $1-22706$ & $14-21260$ \\
\hline $14-21260$ & $1<-21270$ & $14-21311$ & $14-21312$ \\
\hline $34-21376$ & $14-21377$ & $14-213$ & $14-21380$ \\
\hline $14-21382$ & $14-21747$ & $14-217$ & $14-21749$ \\
\hline $14-21750$ & $14-21751$ & $14-219$ & $14-22237$ \\
\hline $14-22574$ & $14-22576$ & $14-225$ & $14-22807$ \\
\hline $14-23154$ & $14-23155$ & $15-21260$ & $15-21311$ \\
\hline & $15-21382$ & $15-21748$ & $15-21749$ \\
\hline $15-21750$ & $15-21751$ & $15-21761$ & $15-23154$ \\
\hline $15-2.3155$ & & & \\
\hline ECONOMIC STUDY & & & \\
\hline $1-21380$ & $1-21390$ & $1-2337 t$ & $3-22441$ \\
\hline $3-22442$ & $2-22445$ & $3-24219$ & $3-24220$ \\
\hline $13-24220$ & $10-2306 \equiv$ & $17-2,1220$ & \\
\hline ECONOMICS & & & \\
\hline $\begin{array}{l}1-21391 \\
3-20628\end{array}$ & & $1-23308$ & $2-23195$ \\
\hline $3-20628$ & 302 & $11-23308$ & $14-21205$ \\
\hline
\end{tabular}




\begin{tabular}{|c|c|c|c|}
\hline $\begin{array}{l}14-21207 \\
18-21218\end{array}$ & $\begin{array}{l}14-21 \subseteq 35 \\
18-? 2157\end{array}$ & $17-21355$ & $18-21214$ \\
\hline \multicolumn{4}{|l|}{ EFFLUSNT } \\
\hline $\begin{array}{l}14-21329 \\
16-229 ? 5\end{array}$ & $\begin{array}{l}14-21715 \\
16-22572\end{array}$ & $\begin{array}{l}15-21325 \\
.6-23893\end{array}$ & $\begin{array}{l}16-2.2452 \\
17-217 ! 5\end{array}$ \\
\hline \multicolumn{4}{|l|}{ ELASTICITY } \\
\hline $\begin{array}{l}11-21121 \\
11-23014\end{array}$ & $\begin{array}{l}11-211 ? 2 \\
11-23845\end{array}$ & $11-21 ! \& 5$ & $11-23501$ \\
\hline ELECTFIC FOWCQ, & GENERAL & & \\
\hline $\begin{array}{r}9-23>51 \\
17-22885\end{array}$ & $\begin{array}{l}10-22885 \\
10-2305 ?\end{array}$ & $10-2295 !$ & $11-22005$ \\
\hline ELECTPIC POWER, & MJENAL & & \\
\hline $5-22095$ & $9-2 ? .978$ & $17-? ! 200$ & $17-27998$ \\
\hline ELESTRIC POWEF, & VITAL & & \\
\hline \multirow{2}{*}{\multicolumn{4}{|c|}{ FLECTFICAL CJNDUCTION }} \\
\hline & & & \\
\hline \multicolumn{4}{|c|}{ 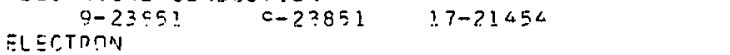 } \\
\hline $15-212.58$ & $15-? .30 .24$ & & \\
\hline \multicolumn{4}{|c|}{ ELK RIVER (BNR) } \\
\hline $1-2 \vdots 34 \vdots$ & $9-241 ? 4$ & $11-2211=$ & $1,-238>3$ \\
\hline $1 !-? 39 ? 24$ & $11-24189$ & $17-21307$ & $17-22 ! \geq 8$ \\
\hline $17-22292$ & $17-22293$ & $17-23 ! 45$ & $17-23804$ \\
\hline $17-24 ! \geq 4$ & $17-24 ! 99$ & & \\
\hline \multicolumn{4}{|l|}{ EYEFITTLEMENT } \\
\hline \multirow{2}{*}{\multicolumn{4}{|c|}{ FMERGENCY COOLLING CONSIDERATIUNS }} \\
\hline & & & \\
\hline $5-2 \geq 1<7$ & $5-72230$ & $5-2405 \varepsilon$ & $5-24050$ \\
\hline $0-24058$ & $5-2405=$ & $a-2 z 2 a t$ & $1 !-22.19 !$ \\
\hline $12-2 ? 142$ & 12-??19! & $12-2<05 \varepsilon$ & $? ?-3405 \mathrm{~s}$ \\
\hline $17-22142$ & $12-22236$ & $19-? 2<04$ & $1.9-230 ! 5$ \\
\hline $18-23 c ! 9$ & & & \\
\hline EMEQGEVCY DOWER, & DLLCTOIC & & \\
\hline $4-2239 ?$ & $\varphi-22974$ & $10-2057 c$ & $10-\bar{z} 2 \uparrow 74$ \\
\hline $10-23 c \leq 5$ & $17-2057 c$ & $17-22000$ & $17-234 ? 5$ \\
\hline $19-22.494$ & $10-229 \times 6$ & $18-22974$ & \\
\hline AERGENCY POWER, & NCNELECT & & \\
\hline $19-2.3036$ & & & \\
\hline$E: A \equiv D G \equiv N C Y$ DKDCED & CURE & & \\
\hline $12 \cdot 22523$ & $17-32523$ & $17-29528$ & $1 \varepsilon-2 l \dot{\alpha} \dot{\Delta} \dot{\Delta}$ \\
\hline$F A=F G \equiv N C Y \quad S Y S T=N$ & & & \\
\hline $5-?<050$ & $5-74055$ & $8-24058$ & $9-24059$ \\
\hline $12-2405=$ & $12-24059$ & & \\
\hline ENEA & & & \\
\hline $1-31.405$ & & & \\
\hline ENERGY LEVEL. & & & \\
\hline $2-2072 \varsigma$ & & & \\
\hline ENEAGY SOUECE & & & \\
\hline $\begin{array}{l}19-22 ! 4 \Delta \\
\text { FNGIVEC }\end{array}$ & & & \\
\hline $\begin{array}{c}1-21900 \\
1-21901\end{array}$ & $2-23326$ & & \\
\hline $11-22<3 ?$ & $11-2.33 \leq 2$ & $12-2192 \div$ & $12-22101$ \\
\hline $12-23326$ & $12-23495$ & $77-23 j \leq 0$ & $9-21929$ \\
\hline $12-23930$ & $18-232>3$ & $: 5-?>2.56$ & $\therefore c-33,495$ \\
\hline 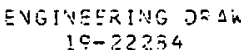 & INE LIST & & \\
\hline $\begin{array}{c}19-22354 \\
\text { ENVIRJVMEVTAL CO }\end{array}$ & ROITIOY & & \\
\hline $14-21 \geq 9 ?$ & $24-212 \geq c$ & $14-21356$ & $24-21304$ \\
\hline $1<-2 ! 445$ & $1<-312<46$ & $14-217+5$ & $24-2 ! 7 \in c$ \\
\hline $14-21796$ & $14-\geqslant 1 c=0$ & $14-21029$ & $1<-21 \subseteq 4 \mathrm{c}$ \\
\hline $14-21954$ & $14-22897$ & $15-21] \leqslant C$ & $25-? 1292$ \\
\hline $15-21 \equiv 1 t$ & $15-21230$ & i $3-21446$ & $15-\div 14 a t$ \\
\hline $15-21.750$ & $15-? 17^{\circ} 6$ & $15-21954$ & $15-21058$ \\
\hline $15-23001$ & $17-21212$ & $17-22.447$ & $19-21054$ \\
\hline EOUSTION, GENTRA & & & \\
\hline $16-21223$ & & & \\
\hline EQUATINN, IN HOU & & & \\
\hline$n-7 i>4 i$ & & & \\
\hline EQUIDYEVT DESISN & & & \\
\hline $3-20+2 c$ & $9-21225$ & $9-21230$ & $0-21770$ \\
\hline $9-21 \subseteq 0 ?$ & $9-2 ! 921$ & $9-231<7$ & $9-23^{2} ! 4 E$ \\
\hline $9-23140$ & $c-23152$ & $0-223.27$ & $c-23328$ \\
\hline $9-23329$ & $c-2322 !$ & $c-22235$ & $0-233 \equiv 7$ \\
\hline $9-2332.8$ & $4-2324 ?$ & $9-2 ? ? 44$ & $6-2.3357$ \\
\hline $5-230.4 \mathrm{c}$ & $: 5-213<5$ & $15-217 \leq 2$ & $: 5-21754$ \\
\hline $17-23 \geq 3 !$ & & & \\
\hline FQUIPAENT, SEVEF & & & \\
\hline $13-23423$ & $: 4-21>207$ & $: 4-2: \geq 2 c$ & $15-213>0$ \\
\hline $15-21355$ & $17-21$ ㅇ? & & \\
\hline EQBIUH & & & \\
\hline $5-2341 ?$ & $0-2394 ?$ & & \\
\hline EROSION & & & \\
\hline $8-225=6$ & $17=31 ! 90$ & $17-25406$ & \\
\hline FRROD $\begin{array}{c}A V \Delta L Y S I S \\
5-23<70\end{array}$ & $11-22304$ & $15-2215$ & $18-23470$ \\
\hline $\begin{array}{l}5-23<70 \\
\text { ESTUARY }\end{array}$ & $11-2 x=14$ & $2=-2=13$ & \\
\hline $\begin{array}{r}1-2 ? 310 \\
15-21 ? 77\end{array}$ & $1-22820$ & $14-21377$ & $14-2137 \%$ \\
\hline EURATOH & & & \\
\hline $1-2 ! 301$ & $c-21>>R$ & & \\
\hline
\end{tabular}

\begin{tabular}{|c|c|c|c|}
\hline \\
\hline & \multicolumn{3}{|c|}{ EIJPOPIU'A } \\
\hline \multicolumn{4}{|l|}{ EVAPOPATION } \\
\hline $4-22464$ & $4-2247 t$ & $4-22496$ & $7-22486$ \\
\hline $14-1 \sum 8 \equiv 4$ & $14-2127 t$ & $14-21307$ & $14-21716$ \\
\hline $17-21716$ & & & \\
\hline \multicolumn{4}{|l|}{ EXAMINATION } \\
\hline $9-22990$ & $9-231<2$ & $5-2419 \%$ & $11-23803$ \\
\hline $11-23921$ & $11-23826$ & $11-23 \div 13$ & $17-21001$ \\
\hline $17-2258 \mathrm{C}$ & $17-728=9$ & $17-22890$ & $17-22895$ \\
\hline $17-22553$ & $1 ?-22 c \equiv 4$ & $7-2214 \equiv$ & $18-2035 ?$ \\
\hline $38-2 \geq<04$ & $18-23803$ & & \\
\hline \multicolumn{4}{|c|}{ FXRAVLTION, NUCLETLR } \\
\hline \multirow{2}{*}{\multicolumn{4}{|c|}{$\begin{array}{c}14-21312 \\
E X C Y=5 I D Y\end{array}$}} \\
\hline & & & \\
\hline 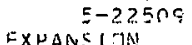 & $5-2 \geq<70$ & $17-2.2509$ & $18-2 \equiv 470$ \\
\hline \multicolumn{4}{|l|}{ EXMANEIJN } \\
\hline $\begin{aligned} 11-23494 \\
\text { EXFSQ }\end{aligned}$ & $11-23857$ & $17-22896$ & $18-23484$ \\
\hline \multicolumn{4}{|c|}{ EXFERIMENT, GENEFAL } \\
\hline $4-22700$ & $t-22348$ & $7-22.478$ & $7-2 \approx 982$ \\
\hline$c-23348$ & $14-21713$ & $15-21761$ & $15-21762$ \\
\hline $1 \leq-211 \geq 3$ & $16-21713$ & $16-21767$ & $16-21 \$ 25$ \\
\hline $15-22452$ & $1+-2 z<2 ?$ & $16-22 \subseteq 72$ & $17-22.447$ \\
\hline
\end{tabular}

EXPLCSION

CSION

$$
\begin{array}{rr}
5-21222 & 5-21322 \\
2-2173 E & 8-23174 \\
17-22436 & 17-23174 \\
\text { EXPLCSIVE, CONVEVTIONAL } \\
5-23174 & 17-23174 \\
\text { FABFICAIION } & 0-24199 \\
3-22445 & 0-2419 \\
11-23924 & 11-24922 \\
15-74279 & 15-24 ? 79 \\
17-24272 & 17-24279
\end{array}
$$$$
\text { FAILURE MCOE ANALYYSIS }
$$$$
12-23485 \text { 18-23485 }
$$$$
\text { FAILIJFE, ADMINISTRATIVE CONTROL }
$$$$
6-234 C E \quad 11-20=55 \quad 12-22523
$$$$
1 \equiv-2<280 \quad 15-324 ? 2 \quad 15-22433 \quad 13-2 ? 364
$$$$
17-20355 \quad 17-2 C 357 \quad 17-21177 \quad 37-21179
$$$$
\begin{array}{llll}
17-261215 & 17-22650 & 17-77422 & 17-22433
\end{array}
$$

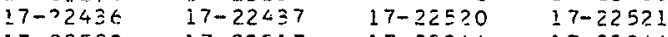$$
\begin{array}{llll}
17-22523 & 17-23 \equiv 17 & 17-23254 & 17-2 \pm 366
\end{array}
$$$$
\text { FAILUCE. CLAOOING }
$$$$
5-22509 \text { 5-22 } 979 \text { 7-2द } 992 \quad 17-21410
$$$$
\begin{array}{llll}
17-22505 & 1 \%-22 \div 54 & 17-22<78 & 17-22591
\end{array}
$$$$
\text { 18-21462 } 18-22404
$$$$
\text { FAILLIFE, COMPCNENT }
$$$$
5-328 \% \text { Q } \quad-21418 \quad 9-2225 \% \quad 9-22457
$$$$
\text { c-2.2781 c-22800 } 0-27050 \text { } 5-23852
$$$$
\text { 10-22c15 } 11-22120 \quad 15-21378 \quad 15-22424
$$$$
\begin{array}{llll}
17-214 ? \mathrm{c} & 17-21454 & 17-22.25 \varepsilon & 17-22434
\end{array}
$$$$
17-22457 \quad 17-227 \varepsilon 1 \quad 17-22808 \quad 17-22950
$$$$
\text { FAILUKE, CESICN EPROR }
$$$$
\text { j7-71212 } 17-2 \hat{2} \equiv 53 \quad 17-22590
$$$$
\text { FAILUPE, EQUIPMENT }
$$$$
5-23214 \quad 7-2427
$$$$
11-20355 \quad 11-23314
$$$$
15-21714
$$$$
\begin{array}{ll}
17-20357 & 17-21208 \\
17-21433 & 17-21714
\end{array}
$$$$
\begin{array}{ll}
1.7-22783 & 17-22840 \\
17-24154 & 17-24270
\end{array}
$$$$
17-24154 \quad 17-24270
$$$$
\text { FAILURE, TATICUE }
$$$$
\text { 11-21117 11-23305 11-23.821 11-23908 }
$$$$
\text { FAILUIPE, FIIFI EIEEMENT }
$$$$
\text { 5-22236 } 5-22536 \quad 5-22509 \quad 7-22982
$$$$
\begin{array}{llll}
5-22336 & 0-22236 & 5-24258 & 15-23868
\end{array}
$$$$
17-2120^{\circ} \quad 17-21210 \quad 17-21216 \quad 17-21403
$$$$
17-?=409 \quad 17-2141 ? \quad 17-22282 \quad 17-22509
$$$$
17-23968 \quad 12-22 \geq 36 \quad 19-22236
$$$$
\text { FAILUFE, GENERAL }
$$$$
\text { 11-21119 11-22125 11-2321? 17-21181 }
$$$$
\begin{array}{llll}
1.7-21216 & 17-214 C 4 & 17-23312 & 19-23312
\end{array}
$$$$
\text { FAILUEE, INSTALLATION FDODR }
$$$$
17-21.29 ?
$$$$
\text { FAILUFE, INSTRUMENT }
$$

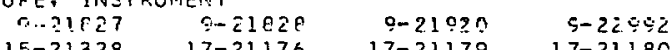$$
17-21175 \quad 17-21179 \quad 17-71180
$$$$
\begin{array}{llll}
17-21205 & 17-31827 & 17-21829 & 17-22902
\end{array}
$$

FAILISFF, MAINTENANCE EER.OP 17-21176 17-21180

FAILUPF, OPEKATOR EKKCER

$\begin{array}{llll}15-21720 & 15-22520 & 15-22876 & 15-22827 \\ 15-23362 & 17-21175 & 17-21176 & 17-21180\end{array}$

$\begin{array}{rr}c-22540 & c-24154 \\ 11-23360 & 11-24154\end{array}$

$17-20355 \quad 1.7-20356$

$17-21300 \quad 17-21355$

$17-28000 \quad 11-22360$

$18-20355$

$19-23312$

$7-22992$

EUP JCHEMIC 


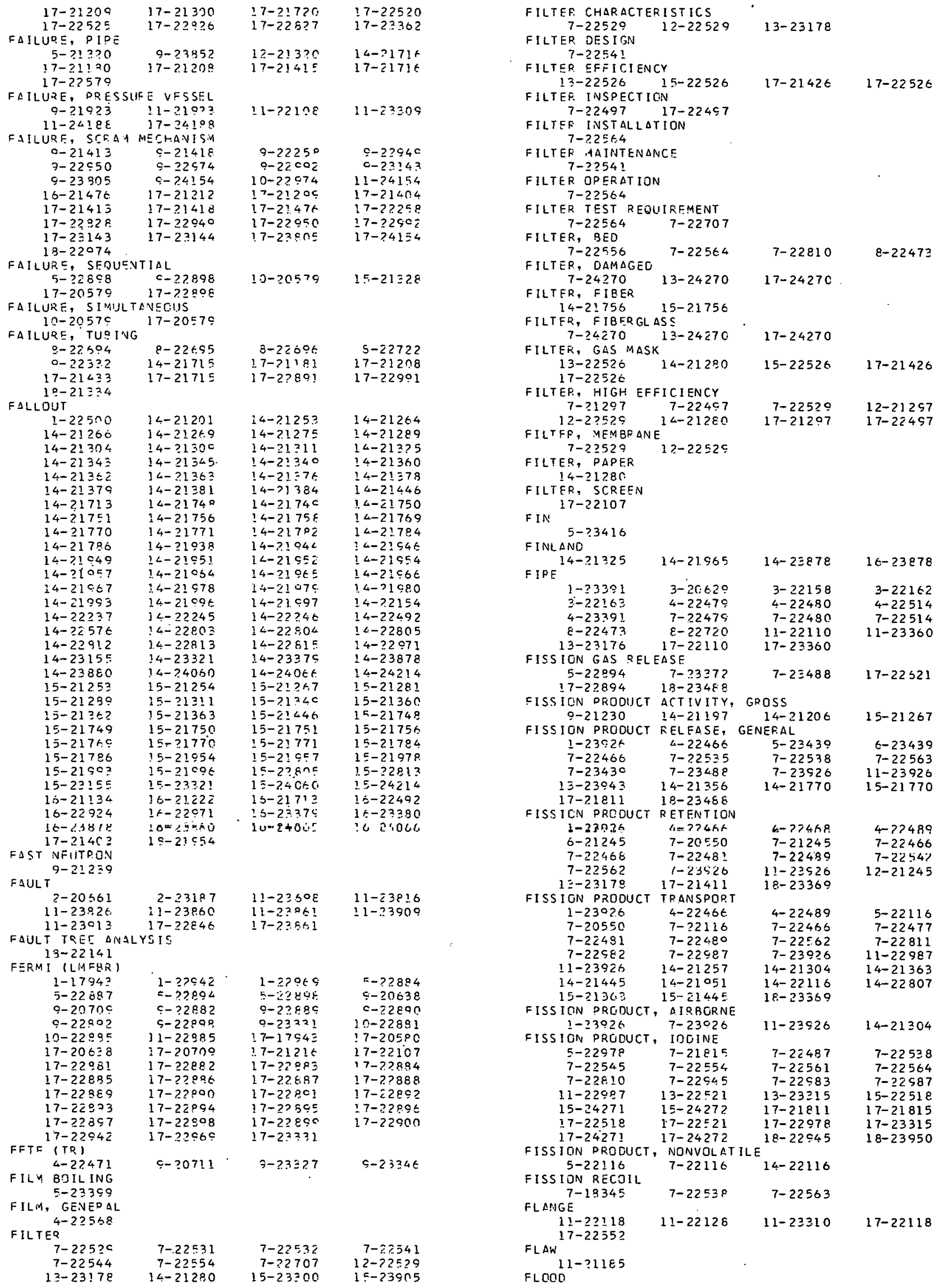




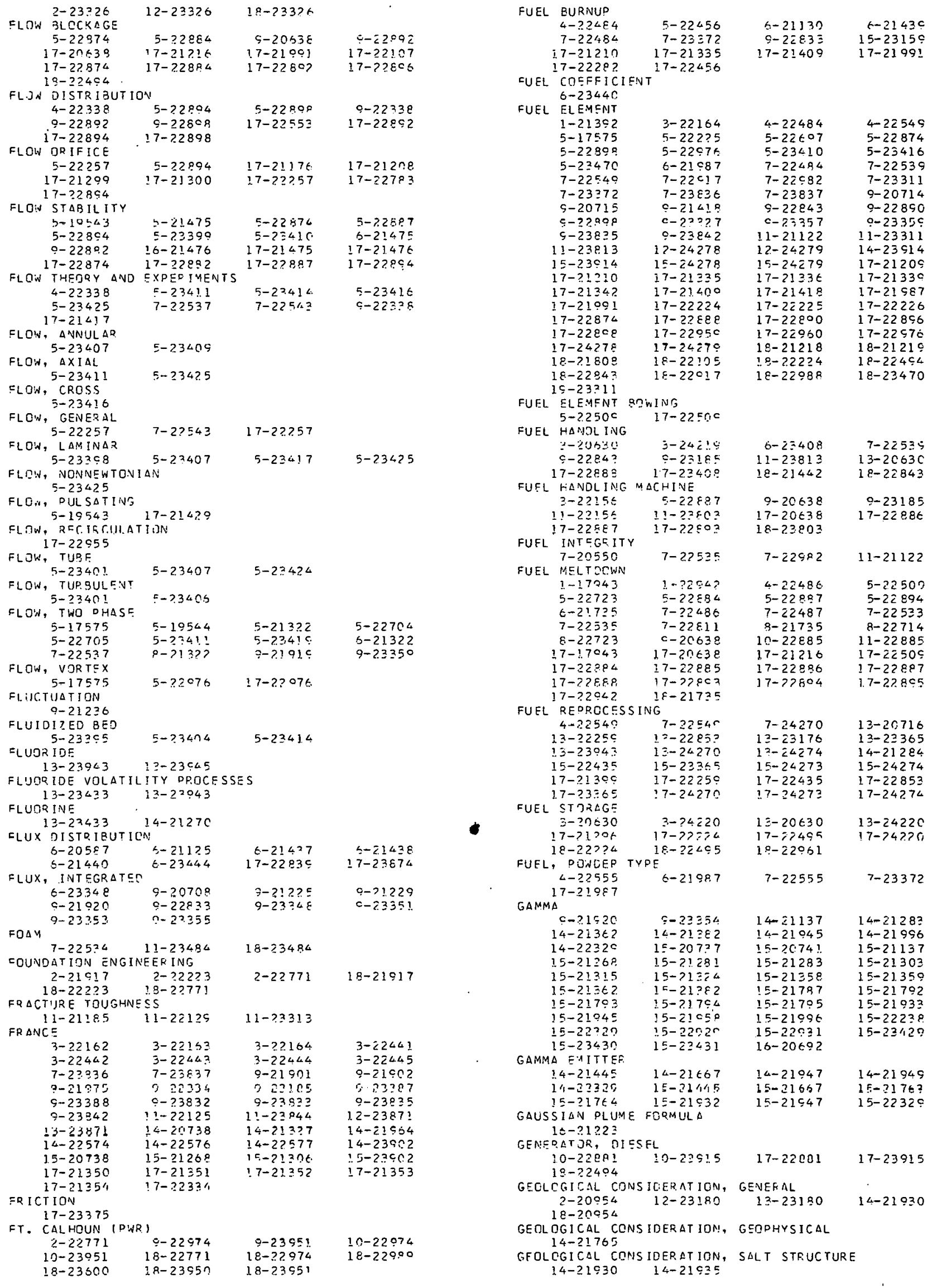


GEGIA

$1-23023$

$8-22835$

$10-24138$

$13-23180$

14-21755

15-20737

15- 21368

$15-21061$

$18-21211$

GETR (TR)

GLASS

5-22978 17-2?578

$14-21305$

i $4-21953$

GLOVE BDX

$$
\begin{array}{r}
4-22463 \\
15-22434
\end{array}
$$

$17-22522$

GOLD

$15-23420$

GR APHITE

15-23430

$7-20550$

8-22717

$17-22787$

GROSS ALPHA

ROSS 3 ETA

$14-21290$

11-22453

$15-24272$

$17-22524$

$12-22463$

$17-2331 \mathrm{E} \quad 17-24272$

4- ?2:549

7-2246\%

$\varepsilon-22712$

a $-23<35$

$6-22.78$

$7-2254 c$

9-22715

$17-2: 404$

$6-2.2787$

$7-22095$

$17-22782$

$14-21665 \quad 15-21655$

$14-21 \leqslant 6.5$

$15-21645$

$16-21133$

14-21665 15-2!.665

GROUNO WATER, GENERAL

14-21290 14-21317 14-21798 15-21इ17

GROUNC NATEF, NUCLIDE OCCURRENCE

14-21290 14-21317 14-21665 14-2!798

15-21317 I5-21665

HACOAM NECK (PWR)

$$
\begin{array}{llll}
1-22841 & 5-23390 & 17-22840 & 17-22841
\end{array}
$$

HACNIUM

$$
\text { 9-23843 }
$$

HANFORD SITE

$$
\begin{array}{r}
1-22320 \\
14-21795
\end{array}
$$

$1-22571$

$1-22706$

$14-21250$

HARWELL

$11-22110 \quad 14-21192$

$14-21207$

$15-21192$

$15-21365$
14 , RELATIVE 14-217E9 15-21769

HAZ ARDS ANALYSIS

7-21815 $\quad 14-21356$

14-23158 15-21712

15-23158 17-21295

$17-23144 \quad 18-21220$

$15-21762$

$17-21403$

14-21768

$15-2 ! 768$

. $17-21815$

$17-21210$ 8-22691 17-2120 TII rIVISICS TIAIMIHC 14-21260 14-22329

$15-21260$ 17-21918

HEAT CONDUCTANCE, FUEL TO CLAD 17-21335

HEAT EXCHANGER

$4-22464$
$0-22695$

$8-22695 \quad 8-22696$

17-21208 17-2!433

HEAT FLUX, CRITICAL

5-23422

HEAT FLUX, DRYOUT

5-22976 5-2342?

HEAT GENERATIJN, INTERNAL

9-23354

HEST PIPE

4-22567

HEAT SINK

HEAT TRANSFER

$3-20629$

$5-22703$

$5-23396$

$5-23400$

5- 23404

$5-23409$

$5-23417$

$5-23422$

$5-23426$

$18-22194$

$1-22819$

$1-22: 26$

$14-217=1$

$3-221 \in 2$

3-22163

$5-22705$

$5-23398$

$5-23402$

23397

$5-23401$

$5-23405$

5- 23411

$5-23414$
$5-23420$

$5-22424$

$9-22 \div 33$

$5-234 ? 7$

$10-23402$

HEAT TRANSFEP. ANALYSIS

$\begin{array}{lr}5-19544 & 5-22 \notin 97 \\ 5-23403 & 5-23414\end{array}$

$5-22723$

HEAT TRANSFER AUGMENTLTION

5-17575 5-22C7t

TRANSFER CGRRELATION

$5-22874$ CORRELATION

$5-23416 \quad 17-22976$

$17-22874$

HEAT TRANSFER EXPER IMENT T $\angle-22547 \quad 4-22567$

$5-23<26$

5- 23427

$8-23723,17-22874$

HEAT TRANSFER, BOILING

$\begin{array}{ll}\text { TRANSFER, } & \text { BOILING } \\ 5-17575 & 5-1954 \\ 5-22733 & 5-23309\end{array}$ $\begin{array}{rr}5-22723 & 5-23299 \\ 8-22723 & 17-22820\end{array}$

$5-22723$

$5-22874$ TRAMSFER, CONDUCTION

$5-22704 \quad 5-22705$ 4-225E7, CONDUCTION

$5-23400 \quad 5-23401$

HEAT TRANSFER, CONVECTION $5-19543 \quad 5-23357$

HEAT TRANSFER, RADIANT

$E-22703,5-23405$

HEAT TREATMENT

$\varepsilon-22712$

$11-23215$

5- 23403

$5-2 \geqslant 400$

$5-23401$

HF $\triangle V Y$ WATEF. $\varepsilon-220 \% 1$

HEIGHT JF P.ISE

$16-22 \div 21 \quad 16-22925$

HELIUM

$11-23 \leqq 15$

$H F B R$ (RR)

HEIR (FTR)

$18-21444$

$5-2.2607$
$17-32002$

IGH FADIATION

$1-22841$

17-22953

$9-22 \div 92$

$9-23148$

HIGH TEMPERATUP.E

$3-22163$.

$3-22163$
$\varepsilon-22835$

c- 23332

$22 \div 4$

$0-23223$

$c-23 ? 42$

$17-22829$

HOT CELL

$11-22110 \quad 12-23174 \quad 13-20716 \quad 13-22436$

$13-23175$ $17-22895$

HOT CHANNEL FACTOR

$18-22: 94$

HOT SPDT FACTOR ANALYSIS

$$
5-226 \div 7
$$

HPPR (FBR)

$15-? .1033$

HUMBOLT $3 \triangle Y$ (EWR)

$17-21292$. 17-22132

HUNGAFY

$14-21259 \quad 15-21250 \quad 15-22818$

HWOCR (HEAVY WATER ORGANIC COOLEC REACTOR) $18-22106$

HY [RRUULIC ANALYSIS

$$
\begin{array}{lrrr}
2-23326 & 5-22788 & 9-23350 & 12-23326
\end{array}
$$

HYDRALIL IC EFFFET

$S-22905 \quad 17-22502$

HYDE $L L I L I C$ EXPER IMENT $c-23359$

HYOPIDE

$$
\begin{array}{rrr}
5-22808 & 6-210 \varepsilon 7 \quad 9-22890 \quad 9-2289 \varepsilon
\end{array}
$$

$11-23961 \quad 11-23513 \quad 17-21997 \quad 17-22890$

$17-22998$ 17-22091 17-2385! 18-21463

HYCREDYNAIA IC ANALYSIS

$\begin{array}{llll}5-22808 & 9-2.2898 & 17-21200 & 17-21210\end{array}$

$17-22893$

$\begin{array}{rccc}8-22702 & 14-23154 & 15-23154 & 17-21670 \\ \text { HYDROLOGICAL } & \text { CONSIDERATION, GENERAL } & \\ 2-23195 & 12-231 E 0 & 13-23190 & 14-21377 \\ 15-21377 & & & \end{array}$

I $\triangle E A$ A.

$7-23011 \quad 9-23911 \quad 14-22240$

ICRP

$\begin{array}{rrr}2-23196 & 7-23411 \\ 15-22 ? 40 & 17-23511\end{array} \quad 9-23911 \quad 14-22240$

14-22329 $15-21258 \quad 15-21763 \quad 15-22329$

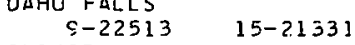

IGNITION

$1-23391 \quad 4-23391 \quad 8-22473 \quad 8-22718$

IGNITION TEMPERATURE

8-22473

IMPACT PROPERTY

$1-23926$
$11-23926$

IMPACT SHOCK

7-23526

$11-23314$ $3-24221$ 
IMPUR ITY$$
\text { 8- } 22715
$$

IN CORE HEASUREMFNT$$
5-221 \angle 0 \text {. }
$$

IN PILE EXPSQ I MENT

IN OILE L'OOP

$$
\text { 5-22978 17-21083 }
$$

INCIDENT COMPILATION

$$
\begin{array}{rr}
1-21814 & 1-22043 \\
17-22528 & 17-22943
\end{array}
$$

INC INENT, EOUIDMENT

$$
\begin{array}{rr}
1-22941 & 3-22941 \\
9-22259 & c-2 ? 457 \\
11-20355 & 11-24199 \\
17-20355 & 17-20356 \\
17-21415 & 17-21418 \\
17-22439 & 17-22457 \\
17-22950 & 17-22990
\end{array}
$$

INCIDENT, GENERAL c- $20538 . \quad 10-22895$

$15-24271 \quad 15-24272$

17-17043 $\quad 17-20630$ $17-21914 \quad 17-22107$ $\begin{array}{ll}17-22904 & 17-22895 \\ 17-24271 & 17-24272\end{array}$ $17-24271 \quad 17-?<27$

IVC IDENT, HUMAV EPEOR

$$
\begin{array}{ll}
15-22432 & 15-22433 \\
17-21177 & 17-22432
\end{array}
$$

$17-? 1177$

$17-22927$

INCISENT. NONNUCLEAR Q-23174 $17-23174$

IVRITENT, VINREATTHS

$$
1-21014 \quad 12-24277
$$

$17-21314 \quad 17-22522$

INCIDENT, DECJVERY EROW o-20638 I7-20038

INC IDENT, SL

I. $7-22528$

INEIDENT, WINDSCALE

INCONEL

INDEPENDFNCE

$0-2580 \mathrm{P} \quad \mathrm{Q}-2 \geq 890$

$17-2 ? 457 \quad 17-27.900$

INOIA

$17-23360 \quad 18-2.2234$

$17-27447 \quad 17-22 \$ 78$

$8-23174 \quad 17-21514$

$17-23174$

ร-21412 $9-21418$

9-2204 $\quad 9-22950$

$15-2243 \mathrm{~g} \quad 15-21714$

$17-? 0357 \quad 17-21413$

$17-2 ! 7 ! 1 \quad 17-22259$

$17-22941 \quad 17-22540$

$5-22500 \quad 5-? 2894$

11-20255 $\quad 13-22436$

$15-2427 ? \quad 15-21476$

17-21?!6 17-2!476

$17-2 ? 436 \quad 17-? 2500$

1.7-?? 454 17-7336?

$15-22926 \quad 15-22827$

$17-274 ? 2 \quad 17-2 \geq 826$

$15-21328 \quad 15-27319$

17-23?19. 17-44277

1 7-21082 :7-2?:28

16-22972 17-?2399

INDIAN POINT 1 (DWF)

$c-2141 ?$
$17-23144$

$$
\text { 1]-23903 IE-2172! }
$$

INDIUM

I $5-23430$

INFTRMATION RCTSIEVAL

$$
\begin{array}{ll}
1-21<25 & 15-22826 \\
17-22826 & 17-22927
\end{array}
$$

INGESTICV

$1.4-21253 \quad 15-2 ! 253$

I VHALATIOV

$1 ?-24279 \quad 12-22438$

$13-33315$

$13-23315$
$14-217 ! 5$

1. $5-2 \geq 396$

$15-21940$

$15-24271$

$17-2 ? 434$

$17-22525$

$14-21253$

$14-2175 \%$

$15-21311$
$15-2 ? 434$

$15-2427$ ?

$17-22439$

INGSECTION AND COMFLIAVCE

11-2?110 11-22117

$12-23177 \quad 13-22250$

$13-22521 \quad 13-22953$

$13-24280 \quad 15-21717$

$15-2251$ ? $15-22920$

17-21719 17-22110

$\begin{array}{ll}17-22350 & 17-22435\end{array}$

$17-22527 \quad 17-22.845$

$17-23317 \quad 17-23218$

17-23:t7 I7-?<?90

$9-22 ? \equiv$

$0-25$ न

$17-2>004$
$18-27826$

$9-22457$

$11-233 \in 0$

$: \subseteq-2 ! \subseteq 54$

$17-216 ? 3$

1. $9-235 n 3$

1. 5-22 977

$17-2181=$

$: 7-22990$

$1.5-2 ! \div 40$

$13-7 ? 25 ?$ ?

$14-2 ! 25 t$

$15-2 ! ? 5 ?$

$15-217 t<$

$15-2252 t$
$15-24276$

$17-22521$

1 7-22527

$17-24>70$

$11-22118$

$13-22426$

$13-23177$

$15-21719$

$15-22527$

17-2?117

1 7-224?

$7-72=7$

17-72 75 ?

$17-22 x \leq 4$

$13-22526$

$14-? 1 \geq 11$

$15-71256$

$15-21768$
$15-22577$

$17-217 ! 5$

? 7-??5? 4

1. 7-23315

12.-20523

$13-22427$

$33-23: 3 \pm 4$

$15-22<35$

$17-21717$

$17-22118$

$17-2: 52 ?$

$17-73177$
$17-23366$
T- 21775 O-22332

$\begin{array}{rrrr}1-23926 & 5-22773 & 5-22976 & 5-23438 \\ 7-23926 & 8-22723 & 5-21027 & 11-23926 \\ 17-22976 & & & \end{array}$

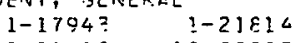
$1-22969$, $7-22669$

$11-2382 \varepsilon \quad 17-? 1408$

$$
\text { L- } 223 ? 6 \quad 5-23.9 \% 8
$$

$17-23144,18-21$
110 )

$17-24271 \quad 17-22526$

INSTPUMENTATISN CAL IORATICA!

$\begin{array}{rrrr}9-20700 & c-20710 & c-21 c 19 & 9-22131 \\ 5-233 ? ! & c-22242 & 5-23245 & 9-23850 \\ 10-2299 ! & 15-22808 & 16-21757 & 16-21927 \\ 17-2070 c & 17-22131 & 17-22891 & 17-23331\end{array}$

INSTPUMENTATIGN, DENCRMAL INDICATIJN

$5-22257 \quad c-21 \subseteq 20 \quad c-22882 \quad C-2288 c$

o-??PCC . $9-22892$ 15-23858

1.7-31476 17-22257 17-2255?

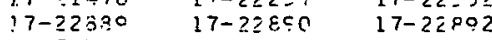

INSTRUMENTATION, LMPL IFIFR

C.?3?48, $\subseteq-24132$

INSTRUMCNTATION, CAMDEELL ING

$\begin{array}{cl}S-2122 \mathrm{C} & \text { C-23:5E } \\ \text { SUMCNTATION, } & \text { COINCIDENT }\end{array}$

$0-2 \equiv 356$

$1 \mathrm{t}-21476$

$17-22882$

$17-23868$ $0-21778$

INSTR UHANTATIRN, COMP NAFNT

$c-21325$

$\mathrm{C}-2 ! z$
$\mathrm{c}-21 \mathrm{l}=0$

$c-21779$

c- 21.22

$\begin{array}{ll}0-2332 E & C-23 E 51 \\ = & \text { CNCNTATION, CONTCEIL }\end{array}$

c. $2419 \%$

$7-23 \subseteq 1 ! \quad c-21<3$

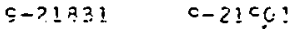

$0-2314^{\circ}$

c-?3j:=

$0-23300$

$c-21<0:$
$0-231<\mathrm{c}$

$c-23 \equiv 34$

$c-2383 \bar{z}$

$2-24128$

$10-241=8$

c- 21232

c- $21<22$

c- 23150

c- $2 \geq 2 \geq 46$

c- 23250

$14-23156$

TELIMENTATICN, COGL GNT OIIALITY

$$
\begin{array}{lll}
C-30708 & c-? 0 \varepsilon C 2 & 0-21230 \\
C-2318 \% & C-23243 & 0-23344
\end{array}
$$

IHST EUMMENT $\triangle T$ ION, CURP FAT

$=-24209$

INSTRUMENTATIGN, RETECT ITN FAILEC FUEL ELEMENT

$\begin{array}{cccr}5-22236 & 7-22692 & 7-23311 & 5-20638 \\ c-21230 & 0-22236 & 0-23228 & 5-23394 \\ 9-24250 & 1 C-22985 & 11-22895 & 11-23311\end{array}$

$11-23311$

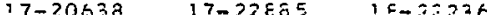

$15-23311$ UMEVT $\triangle T$ I CIN, FAETHGUAKKE

2-206?4 2-20t35: 2-20t36

$2-2 \equiv 152$

INSTRUMCNTATION, FLOV.

4-\%34+2 $9-21 \% 5 \quad$ C- 21231

C.-23:32 $9-23 \equiv 33$

$17-2070 \mathrm{C} \quad 17-228 \% 1$

$c-23359$

$1 \cdot 7-2 \geq 3 \geq 1$

$0-23931$

$10-22881$

$17-23332$

INSTRUMENTATION, FLUICICS C-2123?

INSTRUMENT LTICN, GENERAL

$1-? 1773,4-21773$

$7-73<11 \quad 0-21 \geq 40$

$0-21074 \quad c-2240$

$c-23327 \quad 9-23 \% 4 c$

14-22015 $\quad 17-21401$

$18-25=30$

$17-214 r$

NSTRUMENTATION, IN CIC.

$0-23408$ Q 2070 ह

$c-? .1240$

c -22833

$\because-23 \div 2 \%$

$\mathrm{c}-2>051$

$\because-21775$

- 2250.

$17-23208$

C. 22350

$18-228<2$

$7-1 \& 345$

$7-2253 !$

c- 21778

$4-323 \geq 2$

$0-23 \varepsilon 50$

$17-\overline{2} 2<47$

$15-2.2404$

- गु 150

$5-25911$

$17-2.3911$

$19-21775$

INSTRUMENTATION, JNTECLOCK

INSTRUMCNT $\triangle T$ ION, INTFFM TATE PANGE

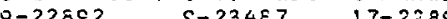

Q-2?RC2.
FIUMENT $L T$ ION, LINEAE

ç- ¿l<? 5

c-21233

$0-22332$
$0-23237$

$16-21<76$

C- 22.832

c- 23257

$17-21476$ $c-1.7<40$

IVSTARILITY
$6-2.28=1 \quad c-22831$

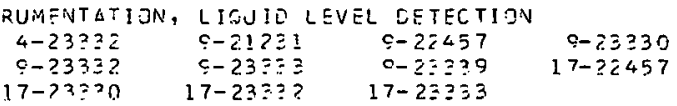

INSTRUMENT $\triangle$ TION, LOGACITHMIC $S-17045$

INST RUMENT $\triangle T$ I ON, METERRCL OG ICAL

$\begin{array}{llll}15-? 126 ! & 16-? ! 261 & 16-21757 & 16-21927\end{array}$ $16-22196 \quad 16-22970$

INETRUMENTATION, NULLEAO 
INSTRUMENTATION, POWFR RANGE $\begin{array}{rr}9-21709 & 9-22794 \\ 10-22821 & 17-20700 .\end{array}$ $10-22851$ c-?.?09? $c-2314 \mathrm{c}$

$17-22881$

INSTRUMENTATIJN, PFESSURE

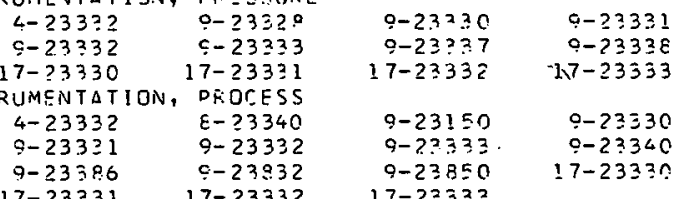

9-23386 $\quad 9-23832 \quad 9-23850 \quad 17-23330$

IVSTRUMENTATION, PFDTECTIVE

$$
5-231 \leq 1,9-23334
$$

INSTRUMENTATION, PULSE$$
5-17949,5-2213
$$

$0-2<132$

INSTRIJYETATION, PADIATION MJNITOEING. $7-19345 \quad \mathrm{C}-21230 \quad \mathrm{C}-2124 \mathrm{C}$ C- 25830 $5-23841$ $14-21200$ $14-21755$ $c-23838$ $9-24199$ $15-21224$ $14-21721$ $15-21311 \quad 15-21755 \quad 15-21787$ $15-21042 \quad 15-21557 \quad 15-2106 ?$ $15-22111 \quad 15-2224$ ? $15-22<8.8$ $15-2390$ ? $16-21274$

IVSTRU:MENTATION, FATE OF CHANGE $0-17949, \quad c-23356$

INSTRIJMENTATINN, RELAY $0-21779$ C- $\quad 218=0$ $0-2 ? 78$ $9-21830 \quad 0-21973$ $: 7-2 ? 7.91$

IVSTTIJMENTATIJN, STAKTUD $=-21233 \quad 9-2363 ?$

INSTEIIYENTATIJN, STARTUD RANGE

$3-22800$ ग C- 25890 $9-22.92$ $17-22000$ ! 7-22:9?

INSTRUMFVTATION. SURVFILLANCE c-209? $9-21340 \quad 9-21 \subseteq 21 \quad 9-22332$

INETRUYEVTATION, SUITCH $=-2177 \mathrm{C} \quad S-? 3140 \quad 17-2118 \mathrm{C}$

INSTRUYEVTATIDN, TEMFERTURE $4-2332 ?$

$4-? 2 \div 69$

$9-22245$

i:-23.3?c

$3-233 \div 4$

$0-230.94$

$17-22257$

$17-33230$

$\overline{3}-22257$

c- 20710

S- $228 \% ?$

$c-23330$

$c-23335$

$\mathrm{c}-23.933$

$7-2$
$7-2$
$7-233$

INSTRUMENTATION, TESTING 4-?333? $\quad 9-210 ? 3$ $9-23341 \quad 9-23343$ $17-233 \div ?$

INSTEUMENTATIJN, WIDE RANGE

- $-1 ! 114 \quad y=19190$

INSUanic $3-2244$ ?

INT $E G Z I T Y$ $5-217 ? \equiv$ $17-? ? 11 \mathrm{c}$

I GJ INE

$=-2063$

$7-2 ? 479$

$7-22<00$

$7-225: 54$

$7-229234$

$14-? 1 ? 70$

$14-? 1329$

$14-21=\angle 7$

$1<-2 \geq 305$

$15-21 \geq 52$

$15-21762$

$15-22805$

$17-22433$

$\equiv-22.54$

$5-2 ! 240$

$9-23327$

9-233.31

c-23354

$16-? 1927$

$17-20709$
$17-22952$
$19-2284 ?$

$c-20708$

9- 21775

$2332 \varepsilon$

c. 2333 ?

$c-23359$
$7-20709$

$0-23322$ $0-23850 \quad 1 !-21923$

I J' EXCHANG

$\begin{array}{llll}7-22554 & 14-21142 & 14-21274 & 14-21332 \\ 14-21370 & 14-21007 & 14-22303 & 14-23152 \\ 15-21730 & 15-2176 ? & 15-22153 & 17-21092\end{array}$

I0I 101 $17-21720$

$$
\begin{array}{r}
8-21735 \\
18-21735
\end{array}
$$

$11-2118=$

$11-221 ! 8$

4- 22479

$4-2248^{\circ}$

$7-2249.2$

$7-22538$

$7-22810$

$14-212 ? \mathrm{C}$

$14-21768$
$14-22237$

$15-2 ! 253$

$15-21 \times 2 c$

$15-2 ? 433$

-

$15-22930$

$15-24216$

$7-2.2472$

$7-2248.5$

7- 22545

$7-2 \geq 98 ?$

$14-21253$

14-21325

1. 4-21938

$14-22903$

$15-21254$

$15-22573$

$16-22970$

$13-22436 \quad 17-2 ? 4.36$

IRON

I RRATIATI TV FAC IL ITY

$17-23874$

IR? ADIATIOVI TESTING

$\begin{array}{llll}6-21097 & 7-21915 & 7-23372 & 0-20710\end{array}$

$\because-20715$

S- 22550

$11-22120$

$11-22121$

$11-23913$

$17-21335$

$17-21404$

$17-21811$

$17-2 \geq 8 ? 9$

$17-21 \mathrm{C} 23$

$17-2133 t$

$17-21.06$

$17-21815$

$17-22955$

$18-21219$

$18-22144 \quad 18-2348$

ISOTCEFIC ERACTIONATION

14-24060 15-24060

ISOTOPIC GENERATOR

$4-21398$

ISRAEL

ITALY

$14-21356 \quad 17-2140 ?$

9-21232 9-22za1

$17-21336$

$15-21253$

11-24154

$17-21752$

17-22281

$17-24154$

JAPAN

$2-23190$

$\mathrm{c}-2123$

$11-23310$

$14-21370$

$14-21996$

$14-24066$

$15-21712$

$15-24 ? 16$

$8-22+\div 0$

$9-21574$

$14-2126.6$

$14-22244$

$1<-24216$

$15-21096$

$16-21222$

c- 21236

c- 21577

14-21266

14- 21712

$14-22806$

$15-21283$

$15-22551$

$16-23379$

$$
17-
$$

$18-21217$

$7-22556 \quad 14-20574$

$14-20574$
$17-23 \geq 70$

$14-21930$

$17-21<17$

17-21651

$17-22798$

$5-22780$
$17-22165$

$17-22955$

LANTHANUM

$14-21966 \quad 17-21082 \quad 17-22993$

LAFSE RATE, ADIAEATIC, NEUTRAL

$16-21925$

LAPSE RATE, UNSTABLE

$L \triangle S E P$. $1 t-21925$

LAW

$15-20565$

$15-21140$

$15-2132.6$

$15-23937$

$L \triangle Y \subseteq R$

$1-21985$

LEAO

$11-2.3930$

LEAK

$3-22158$

$15-21261$

$15-21939$

$16-21261$

$1-22: 41$

$9-23340$
$14-21270$

$17-21716$

$3-22 \div 4$

$11-23214$
$14-21716$

$17-2252 ?$

$7-22564$

$1]-24198$

$14-24.216$

$170 \div 2 \div 41$

$17 * 241 \leqslant 0$

$17-22552$

$8-23340$

$12-22523$

$15-24216$

LEAK. RLTE

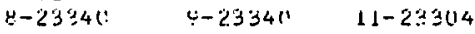

LIABILITY $1-21085$

LICENSINVS STATUS OF NUCLEAR PROJECTS $\begin{array}{lll}12-2.31 .77 & 13-23177 & 17-26.835\end{array}$ $17-33177 \quad 10-214 \equiv 0$

LIGUEFACTION $2-21517$

100021517

LIOUIO FUEL $3-20630 \quad 3.3-20 \epsilon 30$

LITHIUM

$1 \varepsilon-21463$

LOFT $(S-R R)$

$1-23926$

$-23439$

$7-? 3926$

LP.L

$14-2136$

$15-21363$

MAGNES IU:M

$13-23943 \quad 15-21762$

5-21321

$6-23160$

5-22708

$t-23439$

$5-23169$

$7-23439$ 


\begin{tabular}{|c|c|c|c|c|c|c|c|}
\hline $17-21355$ & 7 & $17-22256$ & בר & $7=2077$ & 322000 & $7=2001$ & $7-22087$ \\
\hline $\begin{array}{l}17-21355 \\
17-22522\end{array}$ & $\begin{array}{l}17-22107 \\
17-22552\end{array}$ & $\begin{array}{l}17-2225 t \\
17-22575\end{array}$ & $\begin{array}{l}17-2252 C \\
17-2252 ?\end{array}$ & $\begin{array}{r}7-22477 \\
11-22122\end{array}$ & $\begin{array}{r}7-22480 \\
11-2212=\end{array}$ & $\begin{array}{r}7-22481 \\
1 . ?-22124\end{array}$ & $\begin{array}{r}7-22487 \\
11-22125\end{array}$ \\
\hline $17-22853$ & $17-22891$ & $17-22897$ & $17-228 \div c$ & $11-23302$ & $11-23 \equiv 03$ & $11-23308$ & $11-23 \leqslant 54$ \\
\hline $17-22000$ & $27-23216$ & $17-2386 c$ & $17-24273$ & $11-23 \in 98$ & $11-23855$ & $11-238.56$ & $11-23862$ \\
\hline $17-24274$ & & & & $12-23326$ & $18-23 \geq 26$ & & \\
\hline \multicolumn{4}{|c|}{ MAIVTENANCE, REMRTE } & MOOFFATOR & & & \\
\hline $9-23852$ & & & & $9-2123 \circ$ & & & \\
\hline MANGANESE & & & & MODERATOR COE & FFIC IENT & & \\
\hline $14-21369$ & $14-? 1384$ & $14-21967$ & $14-22806$ & $5-22140$ & $5-22236$ & $A-22140$ & $6-23167$ \\
\hline HASS TRANSFER & & & & $9-22336$ & $17-22140$ & $17-23167$ & $18-22236$ \\
\hline $4-22455$ & $4-2247 !$ & $4-22515$ & $5-2270,8$ & $18-? 3360$ & & & \\
\hline $5-23395$ & $5-23396$ & $5-23 \geq 0 \%$ & $5-23404$ & MOOIFICATICN, & SYSTEM OR EQU & IPMENT & \\
\hline $5-23410$ & $5-23423$ & $7-22515$ & $9-22708$ & $5-22142$ & $5-22<25$ & $0-22403$ & $9-22.784$ \\
\hline $8-23435$ & & & & $12-22: 42$ & $12-24277$ & $13-22853$ & $13-24 ? 74$ \\
\hline MOTER I $\triangle L$ & & & & $15-24274$ & $17-21182$ & $17-21275$ & $17-21355$ \\
\hline $9-228 \div 2$ & $c-23843$ & $11-23814$ & $11-23825$ & $17-21404$ & $17-21426$ & $17-21<20$ & $17-21431$ \\
\hline $11-238>8$ & $14-21180$ & $14-21305$ & $17-21991$ & $17-2214 ?$ & $17-722224$ & $17-21225$ & $17-22226$ \\
\hline $11-22992$ & & & & $17-22553$ & $17-2278: 3$ & $17-22784$ & $17-22845$ \\
\hline MATHEYATICAL & STUOY & & & $17-22853$ & $17-2 z 500$ & $17-22 \subseteq 51$ & $17-22953$ \\
\hline $2-2072 ?$ & $2-23191$ & $5-21244$ & $8-23435$ & $17-22057$ & $17-23 \div 75$ & $17-24274$ & $17-24277$ \\
\hline $9-23385$ & $11-21121$ & $11-21122$ & $14-? 1257$ & $18-21218$ & $18-21442$ & $18-21444$ & $18-22144$ \\
\hline MATHEMATICAL & TREATMFNT & & & $18-27224$ & $18-2245 ?$ & $18-230.14$ & \\
\hline $4-22333$ & $5-2123 E$ & $6-2 ! 247$ & $6-21833$ & MOLYRDENUM & & & \\
\hline $5-23170$ & $7-22945$ & $5-2071 \bar{a}$ & -21235 & $1 \geq-23043$ & $1.4-24060$ & $15-2: 060$ & \\
\hline $0-21829$ & $9-21932$ & $9-21832$ & $9-21834$ & MONIT TR, PADI & OT ION, AIR & 4. & \\
\hline $9-21976$ & $9-22333$ & $9-72 x=1$ & $9-23951$ & $14-21665$ & $14-21 \div 23$ & $15-21655$ & $15-22111$ \\
\hline $0-24195$ & $11-23606$ & $11-2 \geqq 697$ & $11-23846$ & $1 E-2251 \%$ & $1 E-23 \geq 00$ & $15-23858$ & $16-21>13$ \\
\hline $11-23850$ & $11-23963$ & $12-2099$ & $14-21187$ & $17-22516$ & $17-2386 ?$ & & \\
\hline $15-21.134$ & $15-23380$ & $16-24064$ & $17-21410$ & MONITOR, RACI & ATION, AFED & & \\
\hline $17-22957$ & $18-20591$ & $18-22945$ & & $9-2 \geq 889$ & $17-22845$ & $17-22889$ & \\
\hline MAXIMUM PERMI & SSIFLE BODY & BUPDEN & & MONITOR, QAOI & $A T I \cap N, E A C K G R O$ & UND & \\
\hline $15-217 t 3$ & $15-2193 ?$ & & & $15-21224$ & $16-21224$ & & \\
\hline MAXIAUM DEYMI & SSIPLE CONCR & CNTRATICN (MDC, & & MONITOE, RAUI & AT ION, ENVIRON & YENTAL & \\
\hline $12-24279$ & $14-2125 t$ & $14-2 ! ? 1 \varepsilon$ & $15-24279$ & $14-216.55$ & $14-21755$ & $14-2.3 \div 02$ & $14-24061$ \\
\hline $17-2: 71 \%$ & $17-24279$ & $27-20.6$ & 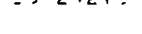 & $14-24063$ & $14-24214$ & $15-21224$ & $15-21665$ \\
\hline MEA SUREMENT, & GENERAL & & & $15-21755$ & $15-7.1787$ & $15-23322$ & i5-23902 \\
\hline $2-22197$ & $5-221<0$ & $s-221<0$ & $7-23372$ & $15-24061$ & $15-2<r \in 3$ & $15-24=14$ & $l \epsilon-21224$ \\
\hline $9-21002$ & $14-21648$ & $15-21658$ & $15-23322$ & MONITOR, RADI & ATION, GLS. & & \\
\hline $15-23429$ & $15-24062$ & $16-22196$ & $16-23197$ & $14-21327$ & $15-22488$ & & \\
\hline $16-24065$ & $17-21330$ & $17-21352$ & $17-21401$ & MONITCR, QAOI & DT ION, GENCE.AL & & \\
\hline $17-21417$ & $17-221.40$ & $17-22.447$ & & $7-23 \equiv 11$ & $c-23838$ & $9-2383 \%$ & $9-23840$ \\
\hline MEASUREMENT, & NDISE & & & $11-23311$ & $15-21316$ & $15-21664$ & $15-21970$ \\
\hline $0-2 ! 236$ & & & & $17-2142.4$ & $10-23211$ & & \\
\hline YEA SUJE YEVT, & PCAC,TIVITY & & & MONITOF, FAOI & AT ION, GENED $\triangle L$ & PQ.ACTICE & \\
\hline $1-23165$ & $1-23168$ & $t-? 2167$ & $6-2334 ?$ & $1 \equiv->1570$ & & & \\
\hline $6-23446$ & $0-212 ? 4$ & $9-2334 \varepsilon$ & $14-21667$ & MONITOR, PADI & ATION, GKCUND & SURFACE & \\
\hline $14-2 ? 4 \div 2$ & $15-21<67$ & $\therefore 5-224 \times 2$ & $17-2 ? 184$ & $14-21665$ & $14-21713$ & $15-21665$ & $16-20692$ \\
\hline $17-22952$ & $17-23167$ & $19-2.3446$ & & $15-21713$ & $+7=2+10$ & & $10-2000$ \\
\hline 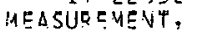 & STEAIN GDGE & & & MGNITIR, PAEI & $\triangle T$ ION, LIQUID & & \\
\hline $9-23341$ & $0-23342$ & $11-221 ? ?$ & $11-22124$ & $: \angle->1,6 h 5$ & $15-2) \in 65$ & & \\
\hline ME ASUR EMENT, & TEMPERATURE & 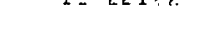 & $-4+2<-2 \pi$ & MQNITQR, PACI & $\triangle T$ IDN, PER SONN & & \\
\hline $7-20708$ & $9-21775$ & $c-22335$ & $9-23354$ & $4-22595$ & $15-21 \equiv 16$ & $15-21787$ & $15-22241$ \\
\hline$a-2 \equiv 354$ & $9-23306$ & $11-? \geqslant 1, ? ?$ & $11-22126$ & $1 E-22432$ & $15-22<35$ & $35-22520$ & $15-23428$ \\
\hline $16-2 ! 527$ & $17-22953$ & & & $15-24062$ & $17-22<32$ & $17-22435$ & $17-22520$ \\
\hline MERCURY & & & & MENITOR, RAOI & $\triangle T$ ION, STACK & & \\
\hline $5-23421$ & $14-21 \subseteq 3 !$ & $15-2 ! 02 !$ & $15-21932$ & $15-22435$ & $17-2.2<\equiv 5$ & & \\
\hline METAL & & & & MONITGR, $P \triangle O I$ & AT ION!, TELEMET & & \\
\hline $7-22^{2} 33$ & $8-22>15$ & $11-21117$ & & $0-22322$ & $15-21224$ & $16-21 \leqslant 24$ & \\
\hline METAL WATER R & $\equiv A C T I O N$ & & & MONITCRING PRR & OGRAM, FNVIFON & MENTAL & \\
\hline $5-22708$ & $-4 \quad 8-22694$ & $3-22695$ & $8-22696$ & $14-21311$ & $1<-2132 c$ & $14-21 \geq 43$ & $14-21756$ \\
\hline $8-2 ? 708$ & $9-227 ! ?$ & $3-2 ? 71.4$ & $8-22722$. & $14-21757$ & $16-21758$ & $14-21 \subseteq 38$ & $14-21549$ \\
\hline $8-22821$ & $8-22922$ & $8-2232 \equiv$ & $9-22824$ & $1<-21<54$ & $1<-21<70$ & $14-21090$ & $14-22813$ \\
\hline $8-23150$ & c- $23 \geq<0$ & $0-232340$ & $18-21334$ & $1<-22915$ & $1<-22<7 !$ & $14-2 \geq 150$ & $15-21311$ \\
\hline HETAL, LIJIID & & & & $15-21329$ & $15-21756$ & $15-21757$ & $15-21954$ \\
\hline $4-22514$ & $4-22515$ & $4-225 ! 6$ & $5-23417$ & $15-221.47$ & $1=-22 \varepsilon]^{2}$ & $15-72158$ & $1.5-23428$ \\
\hline $5-23420$ & $=-11421$ & $7-2 ? 514$ & $7-22515$ & $1 \epsilon-22971$ & $18-21054$ & & \\
\hline $7-22516$ & $2-23604$ & $8-22595$ & $8->>606$ & MONITCPING SY & STEM, RACIATIO & & \\
\hline 3.23720 & $0-22722$ & $g=2332$ & & $4-22608$ & $14-21202$ & $1<-24216$ & $15-21202$ \\
\hline METAL, Q ERRAC & TDFY $2<1<2$ & & & $15-21447$ & $15-2171 c$ & $15-22488$ & $15-24216$ \\
\hline $8-22: 24$ & & & & $17-2171^{\circ}$ & $18-22.144$ & & \\
\hline METERROL JGY & & & & MONTE CARLO & & & \\
\hline $1-221<3$ & $2-23105$ & $2-23107$ & $14-217 k .8$ & $5-23,05$ & $15-2.1257$ & $15-21364$ & $15-21666$ \\
\hline $1 \div-21 ? \in 1$ & $15-21750$ & $\therefore 5-212 \in 1$ & $16-21.926$ & MONTICFLLO IB: & $(W R)^{-1}$ & & \\
\hline $10-23197$ & $17-22142$ & & & $12-21929$ & $18-21929$ & & \\
\hline MICRTMET $\cong O Q O L$ & JรY & & & MOUNO LABOSITE & onv & & \\
\hline $1 t-210 \geq 5$ & & & & $14-22813$ & $15-22813$ & & \\
\hline MILLIVG & & & & MSFR (RE) & & & \\
\hline $14-21272$ & $15-21272$ & & & $t-2143 c$ & & & \\
\hline MINERAL EXCHA & NGE & & & MSRE (FE) & & & \\
\hline $14-21030$ & $14-2 ? 925$ & $14-21044$ & & $t-22920$ & $17-22520$ & & \\
\hline MINIVS & & & & NAS & & & \\
\hline $1-21995$ & AT Igiv aly & wotei jun & & $\begin{array}{l}15-21^{2} 15 \\
18-22144\end{array}$ & $15-21 \geq 16$ & $15-21358$ & $15-71359$ \\
\hline MISSILE GEVER & (1) $5-23314$ & $11-20355$ & $11-23314$ & NDT DATA & & & \\
\hline $11-23609$ & $17-22 \geq 55$ & $17-20356$ & $17-20357$ & $11-22: 20$ & $11-22121$ & $11-22120$ & $11-23313$ \\
\hline $1.8-20355$ & $18-23018$ & & & NFPTINA TUM & & & \\
\hline CKUP $1-23308$ & $11-? 2125$ & $11-2330 ?$ & $11-23308$ & $\begin{array}{l}12-23543 \\
15-240 \in 0\end{array}$ & $14-2175 t$ & $14-24 C 60$ & $15-21756$ \\
\hline $\begin{array}{l}17-21255 \\
\end{array}$ & $17-3.2342$ & & & $\begin{array}{l}\text { NEFVA PROGRAM } \\
9-23253\end{array}$ & & & \\
\hline $\begin{array}{l}\text { MONFL TESTING } \\
1-23308\end{array}$ & $2-23326$ & $4-2 ? 48 \mathrm{C}$ & $4-23855$ & $\begin{array}{r}9-23253 \\
\text { NFTHERL ANDS }\end{array}$ & & & \\
\hline
\end{tabular}




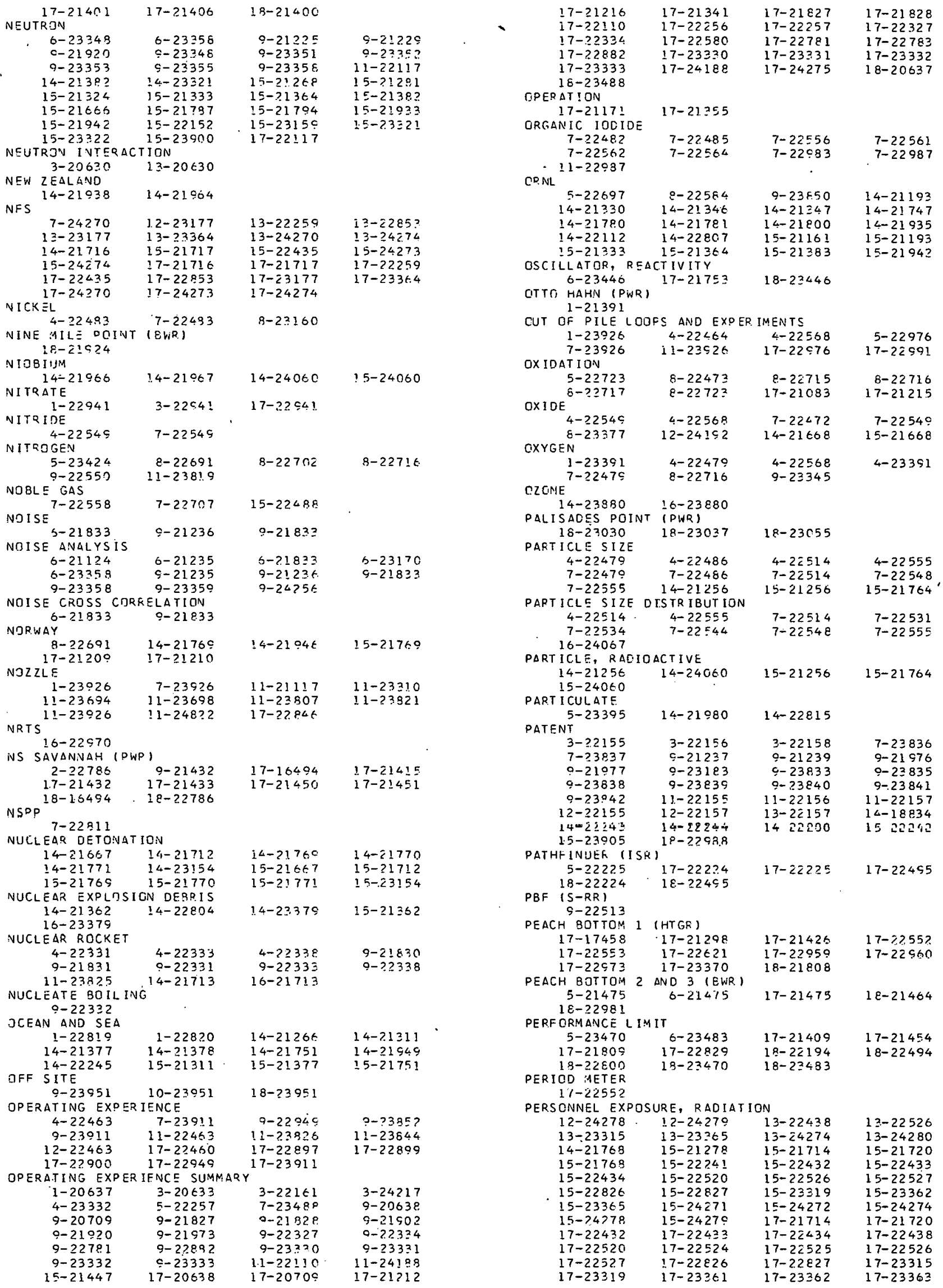




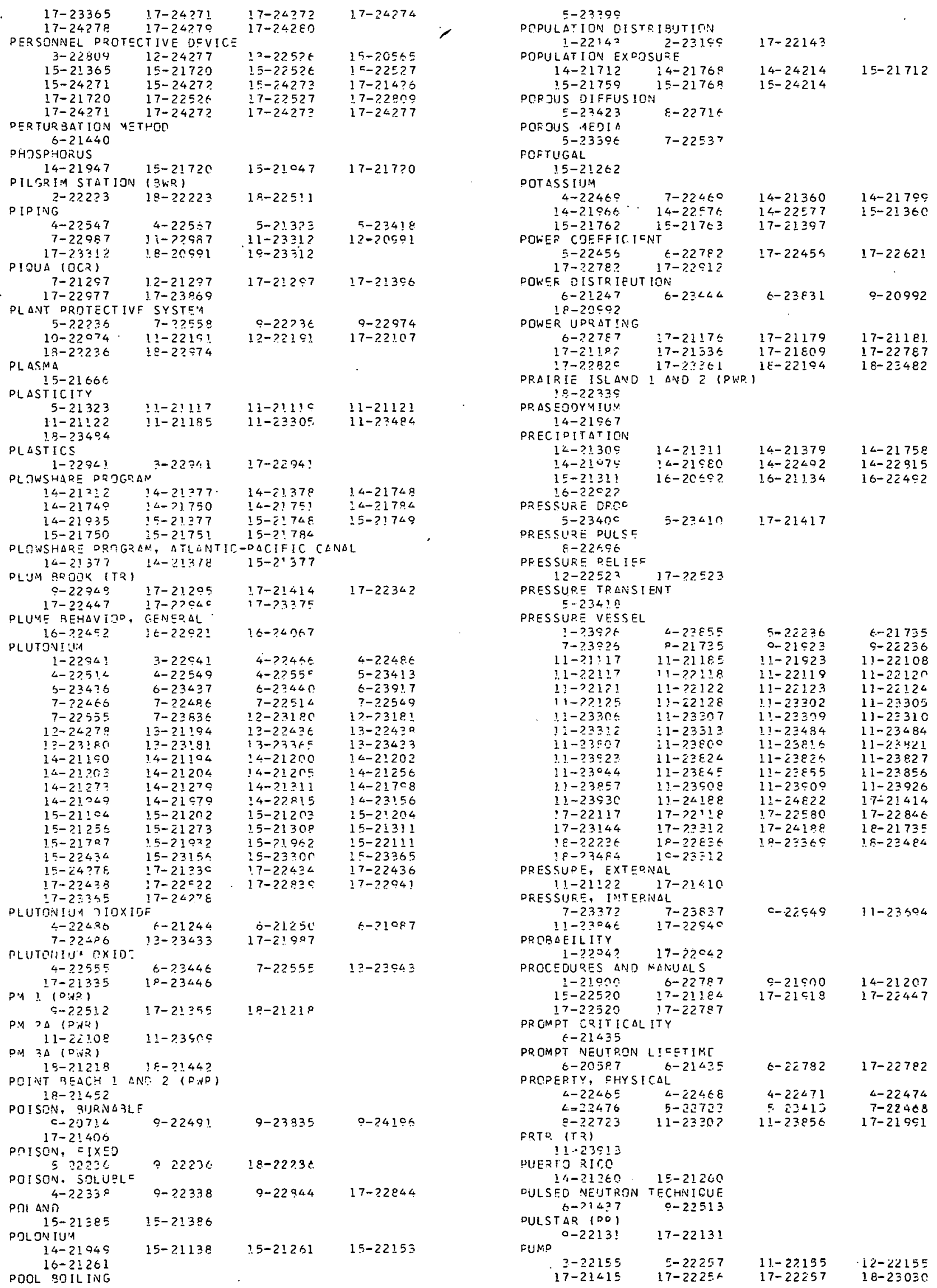


PYROLYTIC $7-20550$

$7-22955$

$8-2 \geq 717$

QUAD CITIES 1 ANO 2 (PWR)

$1 \varepsilon-21982 \quad 1 \varepsilon-23499$

DUALITY CONTRJL

$1-21392$. $c-23512$

$11-23803 \quad, 7-20255$

$17-23143 \quad 18-? 0352$

$18-23903$

R $\triangle V D D P R Z G \bar{R} \triangle A$

$3-20628 \quad 6-21 c 8$

7-22917

$11-23919$

$6-21 \div 97$
$11-23 \div 13$

$11-23313$
$11-23847$
$17-21339$

$17-21336 \quad 17-21339$

$17-21404$ 17-21406

$17-21937 \quad 17-21991$

$17-22301 \quad 18-? 1219$

RADIATION TAAAAGE

$4-\geq \geq 700$

$18-21453$

$11-23924$

$7-24270$

$11-23825$

$13-242.70$

$14-21260$

$1.4-21.141$

$14-21270$

$14-21270$
$14-21290$

$1.4-21374$

$14-21747$
$14-22329$

$15-21256$

$15-2 \mathrm{i} 205$

$14-21794$

$15-21140$

$15-21250$

$15-? .287$

$1=-21271$

$15-213.74$

$15-21327$

$15-21030$

$15-22148$

$5-21786$

$15-21943$

$15-22149$

$15-223 ? 9$.

$15-22318 \quad 15-22930$

$17-24270$

ECT

RADIATION CFEECT
$4-22515$

$7-22985$

$11-238 ? 7$

4-22700

9- $227 ! 2$ $19-2 i z i 7$

RADIATION IN DERSPECTIVE

14-21141 14-2119?

$15-2110 \equiv$ $15-21738$

$9-23 ! 4 ?$

$13-20355$

$11-202=5$

$17-22846$

$18-22494$

$3-2 ? 801$

$1-2390 \mathrm{CE}$

$17-21172$

$17-21342$

$17-21409$

$17-22407$

18-2!?20

$19-22106$

$7-224 c 7$

$11-23 a n s$

$17-21325$

$17-21401$

$17-21410$

$17-22582$

$18-? 1221$

$11-21117 . \quad 11-23823$

$11-23827 \quad 11-23008$

$14-21253 \quad 14-21256$

14-2128? 14-21311

$14-71382 \quad 14-21387$

$14-22154 \quad 1<-22240$

15-21141 15-21253

$15-21263 \quad 15-21283$

$15-21311 \quad \square 5-21368$

$15-31302 \quad 15-21383$

$15-21788 \quad 15-21795$

15-21961 15-21992

$15-22.152 \quad 15-22153$

$15-22573 \quad 15-22802$

$15-22031 \quad 15-23537$

$7-22515$

$9-207 C 8$

$4-20738$

$17-2 ! 404$

$15-? 074 !$

CF

RADIATIDN INJURY, TREATMENT OE

$\begin{array}{lll}12-24 ? 77 & 14-21 ! 4 ! & 14-24 ? 14\end{array}$

$15-20741 \quad 15-21141 \quad 15-2132 \varepsilon$

$\begin{array}{lll}15-21358 & 15-21951 & 15-21902 \\ 15-22353 & 15-22802 & 15-22818\end{array}$

15-24214 17-32522 17-24?77

RADIATION PROTCCTION. CHFMICAL

$12-20739 \quad 14-20729 \quad 15-217 \leq 1$

15-?1962 15-2?802 15-22818

RADIATION DRTTECTION, TRGANIZATION

$14-21265 \quad 14-21387 \quad 14-2175$

$14-22329 \quad 15-20565 \quad 15-2135$

$15-21205 \quad 15-21313 \quad$.5-21316

$\begin{array}{lll}150 ? 1397 & 15-21754 & 15-21.757 \\ 15-21057 & 15-21950 & 15-? 2253\end{array}$

PACIATIONS SAFETY DEND CONTRIII.

$\begin{array}{lll}1-21405 & 1-21900 \quad 1-229.4\end{array}$

$13-22521 \quad 13-23177 \quad 13-23365$

14-21265 14-7131! 14-2!387

14-21757 15-21253 15-21262

i $5-2131$ i

$15-21313$

$15-21216$

$15-31754$

$15-724 ? 2$

$15-21397$

$15-22826$

: $7-21396$

$17-22432$

$!=-21445$

$15-22253$

$15-2 ? 8 . ? 7$

$15-23319$

$1.7-21918$

$17-22521$

$17-22437$

$17-? 2807$

$17-23177 \quad 17-22826$

$17-23318$

$17-23365$

$17-23266$

$17-23856$

RAOIATION UNIT

$15-20736$

RAOIATION, PUBLIC FDIHCATION/ACCEPTANCE

$\begin{array}{lll}1-17043 & 1-21669 & 1-220 ? 6\end{array}$

$1-22944$

$17-22107$
$17-22965$

$17-17943$

$1-22943$
$17-30707$

$1.7-2 ? .944$

$1 \varepsilon-216 \in 9 \quad 10-21016$

RADIOACTIVITY RELFASE

$$
7-24 ? 70
$$

$17-21300$

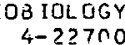

$14-2125$ ?

$14-21269$

$14-21283$

$17-2140.3$

14-21200:

$17-24370$

14-20738

$14-2.1141$

$14-21270$

$14-21256$

$14-21275$

$14-213.11$
$14-21.377$
$1-22927$

$7-22561$

$11-23825$

$17-22447$

$15-21141$

$15-20737$

$15-21361$

$15-22148$

$15-2176 ?$

14-21957

! $5-211252$

$15-21326$

1 $\overline{2}-21755$

$15-22329$

r.w21900

$1=-22437$

1? -23871

$14-21446$

$15-21265$

1. $5-21326$

? -21751

드 522527

$19-23365$

$17-22259$

$17-22527$

$17-22942$

$17-23368$

$15-233.20$

$14-21162$

$14-21260$

$14-2128 ?$

$14-21344$

14-21379

$14-21360$

1380

$14-21780$
$14-21>46$

$14-21995$

$14-22154$

$14-23155$

$\mid 5-21\} \geq 8$

$15-21253$

15-2126]

$15-21283$

15-21349

15-21377

$15-21386$

$15-21788$
$15-21943$

$15-21961$

$15-22148$

15-22153

15-22573

$15-22030$

$17-21399$

RADIOCHEMICAL

$14-21370$
$15-21667$

$14-2] 657$ IOCHEMICAL PLANT SAFETY

12-23177 12-2318C

$12-23944$

$13-23177$

$13-23433$

$14-213.87$
$17-33177$

12- -2419 ?

$1 \geq-23178$

$13-23671$

$14-21947$

OCHEMICAL PPOCESSING

$12-23170 \quad 12-23180$

13-23178 $13-23179$

$13-23364 \quad 13-23433$

$14-21370 \quad 14-21716$

$15-21717$

$15-21786$

$17-23364$

RACIOGR $\triangle D H Y$

14-21137 15-2113t

$15-21714$

$16-21261$

$17-22827$

$15-22826$

$17-21714$

RADIOISOTOPE

3-20631

$14-21186$

$14-21309$

$14-21996$

14-22807

$15-21160$

$15-21445$

$15-22572$

RACIOLOGICAL
$14-21265$

$14-2126$

$5-23169$

14-?3321

$15-30740$

$15-21136$

$15-21368$

$15-21790$

15-22253

15-23321

$17-2 \geq 362$

$3-22444$

$14-21188$

14-21327

14-22112

$14-22816$

$15-? 1272$

$15-21940$

$17-23315$

SISTANCE 


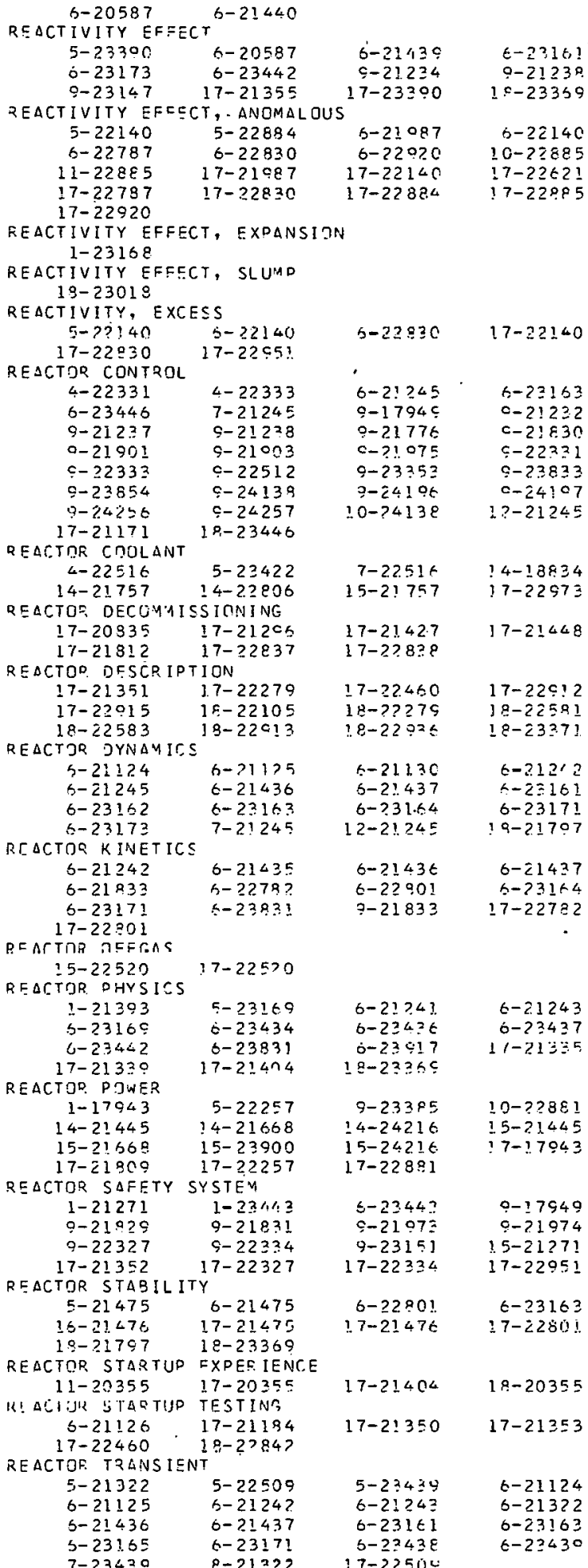

REACTOR, $\triangle$ IRCRAFT S-23353

REATTDF, BEU MUULRATFD $17-21172$

REACTOR, gOEEOEO

\begin{tabular}{|c|c|c|c|}
\hline $1-21300$ & $1-23168$ & $1-2337 t$ & $2-23105$ \\
\hline & $6-23434$ & $3-23430$ & $7-22517$ \\
\hline 12 & $9-2.3330$ & $0-23 \geq 31$ & $9-23356$ \\
\hline 23357 & $17-21 \geq 50$ & $17-21351$ & $17-21.352$ \\
\hline 21353 & $17-21753$ & $17-22 ! 07$ & $17-2289$ \\
\hline بوبن & $17-2.3330$ & $17-2.3331$ & $18-2175$ \\
\hline
\end{tabular}

REACTOR, PWR $2-? .2223$

$5-22142$

$5-22788$

$=-23410$

$5-24059$

$\epsilon-23483$

$8-22601$

$c-22327$

$11-22191$

$11-23824$

$12-22142$

$15-22520$

$17-2121.0$

$17-7.1413$

$17-21476$

$1.7-21913$

$17-22224$

$17-22282$

$7-22520$

$17-22846$

$17-22976$

$1.7-24134$

$18-21924$

$18-22223$

$18-22511$

$1 \varepsilon-23 n 15$

$1 \varepsilon-2301$ \%

$18-23482$

$18-2348 \%$

$18-23552$

$2-24260$

$5-22225$

$5-22976$

$5-23418$

$6-21<75$

$7-23488$

$8-2405 E$

c- 22947

1) $1-23<84$

$11-23826$

$12-2219$

13-20716

$15-24216$

$17-21 ? \div ?$

$17-2141 ?$

$17-216 \dot{1}$

$17-2213 z$

$17-22225$

$17-2228 \Xi$

$17-22775$

$17-22912$
$17-22978$

$17-24108$

$18-21929$

$18-22224$

$18-2258$ ?

$18-23016$

$1 F-23020$

$19-23483$

$10-23<97$

REACTOR, CIDCULATING FUEL

$17-21401$

$1 \varepsilon-21400$

REACTCF, DESALINATION

$14-21256$

$1 ?-21<03$

REACTOR, FAST

$1-17943$

$1-21290$
$4-22480$

$5-32387$

$4-22480$

$c-21240$

$\epsilon-2 \geq 1 \leqslant$ ?

$6-23446$

$5-20711$

$7-22489$

$9-21776$

$9-21234$

9-2289?

$0-22 \varepsilon a 2$

s- 233.46

$1 U-2 \pi .6:$

$-228 \div 8$

$11-23257$

$9-23 ? 48$

$17-2175$

1 u-2<ry

1. $1-22107$

$17-228 \varepsilon$

$17-228 \varepsilon$

$17-22991 \quad 17-2.2892$

$17-22805 \quad 17-228 \mathrm{CG}$

$17-22899 \quad 17-22000$

$18-21972$

$18-22583$

REACTOR, FAST BURST

17-2295I

REACTOR, FLUX TRAP $1-22143$

$-2314$

$5-22+c 7$

$17-2214$ ?

$17-22993$

$18-22144$

$1-23370$

$5-23409$

$7-22538$

$13-?<220$

$3-24219$
$0-21247$

9-24257

$17-24220$

$17-17 \angle 58$

$1 \varepsilon-21797$

REACTOR, GENEPAL

5-21310 A-2124?

$15-21324$

PEACTOF, GRAPHITE MDDEP.ATED $t=22797 \quad t-23437$

$17-21448 \quad 17-22281$

$17-23370 \quad 18-22 \div 13$

REACTOR, HOMOGENENUS

$17-21296 \quad 17-21<27$

REACTGR, HTGR

$1-23,926$

$17-17458$

$17-21<27$

$17-21426$

$17-21298$
$17-2755 ?$

$17 \quad 22359$

$17-22060$

$8-21214$

12-?1808

$1-71380$

$0-22281$

$1-22143$

$0-22833$

$14-2171.5$

$17-21305$

$17-21394$

$17-2129$
$17-2701$

$\begin{array}{ll}17-22291 & 17-27 \div 1.2 \\ 18-21221 & 18-21444\end{array}$

REACTOR, INTERNAL SUPEPHEAT
$1-23376$

$5-21475$

22704

$5-22 \% 78$

$5-2 \lesssim 422$

$t-22164$

$8-22584$

$-24059$

o- 23487

$11-23809$

$11-24128$

$12-22495$

-1
-12

$17-21336$

$17-211428$

$17-218 ! 0$

$17-22142$

$17-22226$

$17-22327$

$17-22798$

$17-22 \div 47$

$17-231<5$

$18-21<54$

$18-21571$

$19-22494$

$18-22981$

$13-23017$

$19-22<71$

$18-23494$

$1 ;-23<98$

$4-2 \div 514$

3-23 248

$7-22514$

9-21235

c-22899

$9-23147$

a- 23356

$11-2 \angle E B 5$

$17-20530$

17-228?

$7-22825$

$17-22890$

$17-22893$

$17-22907$

$18-21<16$

$18-23446$

c- 22281

$17-2 \overline{2} 281$

$18-22800$

$3-24220$

$6-23444$

$11-23844$

$17-22580$

$18-22 \div 13$

$\leq-2 ! 3 ! ?$

0-22281 $11-23844$ 17-22787 17-77915

$c-21418$

$17-21404$

$17-22553$

$17-22 \div 13$

$11-23926$

$17-21418$

$7-22621$

$7-22911$

$0-21231$

$\begin{array}{ll}22858 & 17-21184\end{array}$

$17-21715 \quad 17-22143$

$17-23868 \quad 17-23911$

$18-22144$ 18-23371 


\begin{tabular}{|c|c|c|c|}
\hline $\begin{array}{r}5-222 ? 5 \\
17-21411 \\
17-22495\end{array}$ & $\begin{array}{l}17-21290 \\
17-21812 \\
17-22915\end{array}$ & $\begin{array}{l}17-21300 \\
17-22 ? ? 24 \\
18-22 ? 24\end{array}$ & $\begin{array}{l}17-21408 \\
17-22225 \\
18-22495\end{array}$ \\
\hline \multicolumn{4}{|l|}{$R \subseteq A C T O R, L M C R$} \\
\hline $1-21350$ & $1-23168$ & $4-22471$ & $4-2247 t$ \\
\hline $4-22479$ & $4-2 ? 489$ & $4-? ? 514^{\circ}$ & $4-22569$ \\
\hline $4-23332$ & $5-22456$ & $6-21244$ & $6-21245$ \\
\hline $6-23162$ & $6-23358$ & $7-21245$ & $7-22470$ \\
\hline $7-22489$ & $7-22514^{\circ}$ & $0-20632$ & $0-20709$ \\
\hline $9-22457$ & $0-23227$ & $9-23328$ & $0-2332 \%$ \\
\hline $9-2.3330$ & $9-2333 ?$ & $9-23332$ & $9-23334$ \\
\hline $9-23335$ & $9-23347$ & $9-23350$ & $9-233=1$ \\
\hline $9-23358$ & $9-23359$ & $1 !-23812$ & $11-23857$ \\
\hline $12-21245$ & $.17-20632$ & $17-20709$ & $17-21216$ \\
\hline $17-21335$ & $17-21350$ & $17-21351$ & $17-21352$ \\
\hline $17-21353$ & $17-21753$ & $17-2.2<56$ & $17-224.57$ \\
\hline $17-22900$ & $17-22914$ & $17-23330$ & $17-23331$ \\
\hline $17-23332$ & $18-21211$ & $18-22105$ & $18-22583$ \\
\hline \multicolumn{4}{|c|}{ REACTOR, MARITIME } \\
\hline $1-21391$ & $2-2 ? 786$ & $17-16404$ & $17-21406$ \\
\hline $17-2 i 415$ & $16-10494$ & $18-2278 t$ & \\
\hline \multicolumn{4}{|c|}{ REACTOR, MILITARY } \\
\hline & $9-27512$ & $17-21355$ & $18-21218$ \\
\hline $\begin{array}{c}18-21442 \\
\text { REACTOR, MOLTE }\end{array}$ & & & \\
\hline & $\begin{array}{ll}\text { NN } & \text { SALT } \\
& 17-22920\end{array}$ & & \\
\hline \multirow{2}{*}{\multicolumn{4}{|c|}{$\begin{array}{l}\text { REACT JR, DR DEREC BED, FAST } \\
13-22592\end{array}$}} \\
\hline & & & \\
\hline $\begin{array}{c}\text { REACTOR, } C R G A ! \\
1-21380\end{array}$ & COOLED & & \\
\hline $\begin{array}{r}1-21380 \\
17-21297\end{array}$ & $5-2342 ?$ & $7-21297$ & $12-21297$ \\
\hline $\begin{array}{l}17-21297 \\
19-21221\end{array}$ & $17-21396$ & $17-22977$ & $17-23869$ \\
\hline RE $\triangle C T O^{2}, D E B B L$ & ZEO & & \\
\hline $5-21126$ & $11-23930$ & $18-21214$ & \\
\hline QEACTOR, POOL & TYPE & & \\
\hline $5-22785$ & $9-23397$ & $9-2,3854$ & 1. 5-21664 \\
\hline $17-21405$ & $17-21431$ & $17-23 \cdot 5+4$ & $17-22785$ \\
\hline $17-23830$ & $17-22953$ & $17-23361$ & \\
\hline$R \equiv A C T Q R, P \cap W E F$ & & & \\
\hline $1-2 ! 069$ & $1-21791$ & $1-21814$ & $1-22919$ \\
\hline $1-23376$ & $4-? ? 515$ & $7-22515$ & $9-21973$ \\
\hline $0-22512$ & $9-23832$ & $9-2 \geq 852$ & $9-24138$ \\
\hline $9-24256$ & $1.0-24138$ & $14-21329$ & $14-21791$ \\
\hline $14-21930$ & $14-229 ? 8$ & $15-21220$ & $17-20707$ \\
\hline $17-21340$ & $17-21341$ & $17-213 c c$ & $17-? 1814$ \\
\hline $17-22 ? .70$ & $18-2 ! 669$ & $18-2227 c$ & $16-24157$ \\
\hline RE $\triangle C T O R, D R E S$ & SURE TURE & & \\
\hline $7-2.2982$ & $11-23861$ & $11-23012$ & $15-23868$ \\
\hline $17-21394$ & $17-21305$ & $17-21448$ & $17-22912$ \\
\hline $17-22915$ & $17-23861$ & $17-23868$ & $18-23371$ \\
\hline REACTOR, PROD & JCTION : & & \\
\hline $1-22330$ & $1-22705$ & & \\
\hline REACTOR, PULSE & & & \\
\hline $6-22.792$ & $6-23408$ & $8-2.2^{\circ} 2.1$ & $9-22131$ \\
\hline $0-22781$ & $9-22949$ & $0-22950$ & $1 !-23813$ \\
\hline $17-22131$ & $17-22781$ & $17-22782$ & $17-22949$ \\
\hline $17-22950$ & $17-22954$ & $17-23408$ & $18-22956$ \\
\hline RF ArTTR, DWP & & & \\
\hline $1-21291$ & $1-22841$ & $1-23396$ & $1-23921$ \\
\hline $2-20963$ & $2-20954$ & $2-21917$ & $2-22771$ \\
\hline $2-22786$ & $2-22011$ & $2-2332 \epsilon$ & $2-238 ! 2$ \\
\hline $5-19544$ & $5-21321$ & $5-2223 \epsilon$ & $5-22257$ \\
\hline $5-22874$ & $5-23390$ & $5-2 \geq 422$ & $5-24058$ \\
\hline $5-24059$ & $6-21987$ & $5-22801$ & $6-22831$ \\
\hline $6-23165$ & $6-23157$ & $7-22917$ & $7-22945$ \\
\hline $8-22584$ & $\varepsilon-24058$ & $8-24055$ & $0-2123.3$ \\
\hline $9-? 1432$ & $c-22236$ & $9-22227$ & $9-22831$ \\
\hline $9-22974$ & $c-23143$ & $9-23905$ & $0-23951$ \\
\hline $9-24154$ & Q- 24107 & $10-22974$ & $10-23951$ \\
\hline $11-21663$ & $11-22191$ & $11-22938$ & $11-23013$ \\
\hline $11-23360$ & $11-23803$ & $11-23900$ & $11-241 \leq 4$ \\
\hline $12-22191$ & $12-23326$ & $12-24058$ & $12-24059$ \\
\hline $14-21954$ & $14-22528$ & $15-21954$ & $15-23868$ \\
\hline $17-16404$ & $17-17165$ & $17-20356$ & $17-21175$ \\
\hline $17-21176$ & $17-21177$ & $17-21179$ & $17-21180$ \\
\hline $17-21181$ & $17-21 ! 82$ & $17-212 \mathrm{c} z$ & $17-21.354$ \\
\hline $17-21355$ & $17-21394$ & $17-21395$ & $17-21406$ \\
\hline $17-21415$ & $17-214 ? 29$ & $17-21422$ & $17-21433$ \\
\hline $17-21448$ & $17-21450$ & $17-21451$ & $17-21809$ \\
\hline $17-21928$ & $17-21987$ & $17-21901$ & $17-22257$ \\
\hline $17-22327$ & $17-22582$ & $17-22783$ & $17-22801$ \\
\hline $17-22840$ & $17-22841$ & $17-2285 !$ & $17-22874$ \\
\hline $17-23143$ & $17-23144$ & $17-23167$ & $17-23,360$ \\
\hline $17-23390$ & $17-23805$ & $17-23868$ & 1. $7-24154$ \\
\hline $18-16494$ & $18-20138$ & $18-20230$ & $19-20295$ \\
\hline $18-20352$ & $18-20365$ & $15-2086 \overline{4}$ & $18-20863$ \\
\hline $19-20 \div 54$ & $18-21218$ & $18-2.12 \% 1$ & $18-21<42$ \\
\hline $18-21452$ & $18-21455$ & $18-21662$ & $19-216.63$ \\
\hline $13-21721$ & $18-21917$ & $18-21954$ & $18-22194$ \\
\hline $18-22236$ & $18-22339$ & $18-22771$ & $19-22786$ \\
\hline $18-22936$ & $18-22847$ & $18-22851$ & $18-22854$ \\
\hline
\end{tabular}

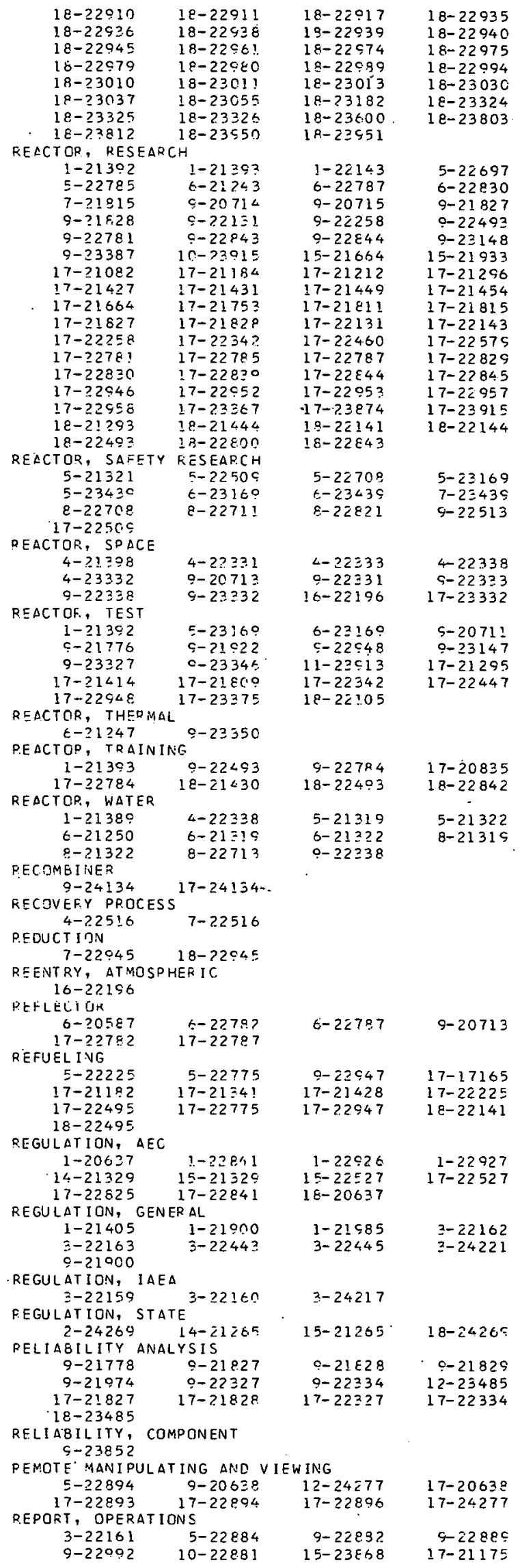




\section{$17-21176 \quad 17-21177$ \\ $\begin{array}{ll}17-21181 & 17-21192 \\ 17-21210 & 17-21298\end{array}$ \\ i $7-213 \equiv 5 \quad 17-21394$ \\ 17-21397 17-21753 \\ $17-22881$ 17-2289? \\ 17-22895 17-2289? \\ $17-22992$ \\ $17-238 \% 9$ \\ REPORT, EDERATIONS ANALYSIS}

$5-222 \overline{2} 5$ 5-22456

c- $24134 \quad 17-22225$

$\begin{array}{ll}17-22456 & 17-22528 \\ 17-22200 & 17-23077\end{array}$

REP TPT, JOERATICNS SUMUARY

$\begin{array}{ll}5-22887 & 5-22094 \\ 9-22892 & 5-22809 \\ 1-22985 & 17-29599\end{array}$

\begin{tabular}{rr}
$9-22892$ & \multicolumn{2}{c}{-22809} \\
$11-22365$ & $17-20579$ \\
$17-22438$ & $17-25392$
\end{tabular}

$17-21432 \quad 77-22342$

$17-22687 \quad 17-22 \varepsilon 09$

$17-22892 \quad 17-22894$

17-22000 i7-22945

REPQRT, PSAR

$1-21291 \quad 2-20.63$

2-2277!

$0-2249$ ?

$11-2 ? 938$

$17-21029$

$18-202 ? 0$

1.8-20962

$18-21455$

$18-21721$

$19-22 ! 41$

$18-22494$

$18-22935$

$1.9-22040$

$19-22009$

$19-23013$

$19-23011$

$19-23055$

$10-73600$

$2-23236$

$0-23051$

$11-230 ! 3$

$17-22105$

$18-20295$

$18-20853$

$18-21464$

$18-21024$

$18-222 ? 3$

$19-22511$

18-?2936

$18-22975$

$18-23074$

$19-23014$

$1,4-230 \% 0$

$18-23324$

$1 \varepsilon-23471$

$19-? 3950$

REDORT. SAD.

2-22011 5-227:5

$7-23408$

$12-23485 \quad: 7-2228$.

$17-22851 \quad 17-23300$

$18-33336 \quad 18-23041$

$19-22051 \quad 10-23492$

$13-23485$ ! $12-23430$

RESEARCH CONTRACT

$15-? ! 447$

PESTNANCE RVERLAP

c-2315?

RESPONSE SJECTPLUA $2-23 ! 31$

RESOTNSE TIME

$5-22454$

$9-23054$

$17-229<8$

RESUSPENSION

$14-2 ! 190$

REVIEN

IN

$8-2 \div 21$

$8-231 \leqslant 0$

$10-230 \div 9$

QนTOIUM

10.2301?

$5-23390$

1.7-21432

$17-2205$ ?

2-231.95

- -2.222

$10 . \cdots 23010$

$17-21175$

$17-21208$

$17-21 ? 05$

17-21305

$17-22552$

$17-22894$

$17-228^{\circ} \mathrm{E}$

$17-2 ? 270$

6-72782

$17-22282$

$17-22782$

$17-24 ! 34$

5-2? 208

$10-20280$
$10-2057$

$17-2058 \mathrm{C}$

17-228?2

$17-22890$

$17-22805$

1 $7-2295 \equiv$

$2-20004$

$5-220,74$

$10-23951$

12-21.925

$17-22.874$

13-?035?

$18-70954$

$18-? 1$ की?

$19-22330$

$18-22771$

18-?203?

$13-22070$

$10-22010$

$19-23015$

$19-230 \times 0$

18-73325

$18-22472$

$18-23051$

5-23200

$4-? 3407$

$17-2 ? 785$

$18-21220$

$1 \mathrm{y}-1145$

$18-23483$

$16-13447$

$17-21900$

$17-2120$ ?

$17-21300$

$17-213=6$

$17-22621$

$17-22886$

$: 7-72500$

$17-23268$

$5-22020$

$17-27283$

$17-22967$

c- $225=0$

$10-22805$

$17-? ! 295$

17-2?095

$17-22891$

$17-22508$

$17-22.958$

$2-22223$

$11-2164$

$12-23326$

$10-20138$
$18-203 \leqslant 5$

$18-21 ? 20$ ?

$19-216 t 3$

$18-21002$

1. $8-2.2493$

$19-22510$

$18-22 c>0$

$19-23900$

$18-23011$

$13-23016$

$18-73037$

$15-22326$

$19-23952$

$\leq-23483$

$11-2340,4$

1 $7-22245$

$18-21.452$

$\therefore \theta=224.1$

$10-234.04$

$18-23499$

$9-21422$

$17-2 ? 456$

$17-22955$

与- 22048

$17-22840$

$17-23200$

5-22711

$2-23825$

$17-2: 30$

$1 \pi \cdots 23183$

$8-2271.4$

n-22824

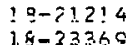

14-2!.957

RIST

$0-22350 \quad \leq 4-21290$

$17-2.1827$

17-218?9

$14-21800$

$1-2 ? 57$

$1-22700$

RIVFD, COLUMBIA $1-22320 \quad 1-22458$ $14-213 ! 1$

P.IV $\equiv D, G=V E P . A L$

$1-21791 \quad 1-22450$

$1-2703 n \quad 1-22510$

$14-219$ प- ?2016

P. IVER, TENIVESSEF $14-21700 \quad 14-21791$

R.JCK ITECHAN! ICS $2-23107$

2-2319\%

$1-2245$

$14-21750$

$15-2 ! 750$

$1-2281$

14.21800

$14-21030$

$14-\overline{2} 1935$

ROCKY ELATS

$15-2106 ?$

O.OSEI ALDHA $6-205$ ह 7

$6-? ! 225$

$7-2 ! 235$

$15-? 4067$

QUEIDIU⿴囗十

$4-22468$ $4-22468$
$14-23153$

$4-22469$ $15-23153$

$7-22468$

$7-22469$

F.UMANI

$c-21003$

FUSSELLVILLE (PWR)

$18-22910$

RUTHENIJM

$4-22489$

$1<-21290$

$7-22472$
$14-21384$

$7-22489$
$14-21566$

$14-21266$
$14-21967$

SAFETY ANALYSIS

$\begin{array}{lrrr}1-23443 & 1-22921 & 5-22225 & 5-23390 \\ t-22443 & 14-21<46 & 15-21446 & 17-21928\end{array}$

$\begin{array}{llll}17-222.25 & 17-32560 & 17-23200 & 17-217907\end{array}$

SAFETY EVALUATIGN

$1-22143 \quad 0-21432 \quad 14-21930$

$17-16494 \quad 17-21411 \quad 17-21414$

$17-21440 \quad 17-2180 \circ \quad 17-2181 !$

$17-22455 \quad 17-22552 \quad 15-16434$

16-?1808

$18-22144 \quad 18-22405$

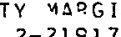

$2-21917$
$17-22788$

$5-22788 \quad 15-22432$

i. $9-21017$

$19-22494$

$\triangle F E T Y$ PRINCIPLES $\triangle N$ O FHILOSORHY

$\begin{array}{llll}1-71900 & 1-7392 ! & 1-22523 & 2-22190 \\ 3-20628 & 3-22 ! 60 & 4-21390 & 9-21900\end{array}$

$3-23628 \quad 3-22 ! 60 \quad 4-21=09$

SAFETY PROGRAM

$1-3.1300$

$1-23 \div 2$

$12-23150$

$17-2236$ ?

$8-24059$

$5-24050$

$?-23196$

$5-24050$

$3-221 \in 1$
$8-24058$

SAFETY REVIES

$1-231<5$

$12-24 C 5$

$12-24059$

$17-2314$

$1-2.3923$

$17-22283$
$17-23894$

$3-22150$

17-22784

$19-22854$

$5-22784$

17-22 958

SALEM I AND 2 (PNE)

$2-22011$ 1\&-22ऽ1

S $\triangle M D L I N G$

$7-22529 \quad 7-3253$

$7-22554$

$14-21 ? 73$

$14-2421$

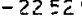

$14-21220$

$15-21202$ 


\begin{tabular}{|c|c|c|c|}
\hline & $1-32500$ & $1-3360 \mathrm{c}$ & $3-23158$ \\
\hline $11-23117$ & $j 1-23<09$ & $14-217557$ & $15-21.271$ \\
\hline $15-21313$ & $: 5-21.73$ & $15-21757$ & $15-2 ! 76 ?$ \\
\hline $15-21033$ & $15-215 \leq 3$ & $15-23322$ & $17-21212$ \\
\hline $17-21406$ & $17-22117$ & & \\
\hline SHIDOING A.VAL & YSIS & & \\
\hline${ }^{2}-24210$ & & & \\
\hline SHIOPING CONT & TAINEP & & \\
\hline $3-2062 \circ$ & $3-22156$ & $3-2215 c$ & $3-22 ! 60$ \\
\hline$z-221 \in z$ & $3-22164$ & $3-22444$ & $3-22445$ \\
\hline $3-24221$ & $1<-21279$ & & \\
\hline SHIPD INGPDET & (OWF. $)$ & & \\
\hline $17-21175$ & $17-21176$ & $17-21 ! 77$ & $17-2117^{\circ}$ \\
\hline $17-21: 0^{\circ} 0$ & $17-21191$ & $17-71198$ & $17-21208$ \\
\hline SHCCK $\triangle \mathrm{ESSTRB}$ & & & \\
\hline $\begin{array}{l}11-23105 \\
\text { SHOCK WAVE }\end{array}$ & & & \\
\hline $\begin{array}{r}\text { SHJCK WAVE } \\
\text { I. } 1-22109\end{array}$ & $11-23901$ & & \\
\hline SHUTOOWN CNOL & ING SYSTEM & & \\
\hline $17-16464$ & $17-21433$ & $18-1 \leqslant 494$. & \\
\hline SHUTDOWN MASG & & & \\
\hline$b-21126$ & $t-23358$ & $9-2 ? 947$ & $9-23358$ \\
\hline $\begin{array}{l}17-2232 \varepsilon \\
\end{array}$ & $17-2<\div<7$ & $17-22952$ & \\
\hline SHUTDONN MECH & HAVISM, SFLF & & \\
\hline $19-21416$ & (1) & & \\
\hline SHUTDOWV SYST & $T E Y, \quad S E C C N J \triangle R Y$ & & \\
\hline $9-22 ? 58$ & $\stackrel{c}{-} ? 2844$ & $9-229<9$ & $17-22258$ \\
\hline $17-22344$ & $17-22949$ & & \\
\hline SILICON & & & \\
\hline $9-23377$ & $1 F-21808$ & & \\
\hline SIMUL ATIOV & & & \\
\hline $1-2257 !$ & $7-22554$ & $9-2.0712$ & $9-21231$ \\
\hline $9-21 \geq<0$ & $c-21.001$ & $9-21003$ & $9-23385$ \\
\hline $17-21171$ & & & \\
\hline SINGL $\equiv F A I L U R$ & RE CRITERION & & \\
\hline $9-22374$ & $c-23051$ & $10-22974$ & $10-23951$ \\
\hline $19-22974$ & $18-23951$ & & - \\
\hline SITE CLIAATJLL & LBOY & & $\therefore \cdot$ \\
\hline $2-2 \geq 107$ & $12-23100$ & $13-23180$ & $16-23197$ \\
\hline SITINS, CHFUI & ICAL DFDEESS P & PL ANT & \\
\hline & $2 \Delta L \quad 12-23130$ & & \\
\hline $\begin{array}{r}\text { ITIVG, GFUE? } \\
2-231.97\end{array}$ & $2 \Delta L_{16-23 ! 07}$ & $17-2.1<03$ & . \\
\hline SITING, ZEACT & & & • \\
\hline $1-22 ! 4 ?$ & $1-22790$ & $1-229 ? t$ & $1-229 ? 7$ \\
\hline $2-20053$ & $2-20554$ & $2-2 ! 017$ & $2-? 2780$ \\
\hline $2-22911$ & $2-2.3195$ & $2-2 \geq 196$ & $2-23108$ \\
\hline $2-23199$ & $2-23326$ & $2-24.26 ?$ & $12-23326$ \\
\hline $17-22143$ & $18-20863$ & $13-20 \div 54$ & $10-21455$ \\
\hline $1.9-21.93 .7$ & $1 \varepsilon-22736$ & $18-22 \circ 11$ & $18-23326$ \\
\hline $19-24 ? 69$ & & & \\
\hline SITIVG, JRBAN & & & \\
\hline $1-21 \geq 03$ & & & \\
\hline SLAS & & & \\
\hline 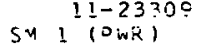 & & & \\
\hline $\begin{array}{l}5 x+(0 w k) \\
3-21 \geqslant 20\end{array}$ & & & \\
\hline $\operatorname{Sin} 2(O W R)$ & & & \\
\hline $0-24 ! \square^{\prime \prime}$ & & & \\
\hline SVAD, GFNFOAL & $L\left(S^{D}\right)$ & & \\
\hline $4-333 \div ?$ & $4-? 3 \div 32$ & $17-23332$ & \\
\hline $\begin{array}{l}570104 \\
4-224 \leqslant 3\end{array}$ & $4-22464$ & $4-22465$ & $4-22466$ \\
\hline $4-224 t 8$ & $4-22460$ & $4-224 ? 1$ & $4-22.474$ \\
\hline $4-22476$ & $4-22479$ & $4-2248 C$ & $4-? 2483$ \\
\hline $4-2 \geq 4 \div 4$ & $4-22486$ & $4-22490$ & $4-? 2514$ \\
\hline $4-? 2516$ & $4-2256 \%$ & $5-2 ? 7 ? ?$ & $5-234 ? 0$ \\
\hline $5-2 ! \geq 44$ & $5-21245$ & $5-2124 \div$ & $7-2 ! 2<5$ \\
\hline $7-224 \leq 5$ & $7-22459$ & $7-2 \geq 465$ & $7-22479$ \\
\hline $7-22430$ & $7-2248 ?$ & $7-224 A \angle$ & $7-22486$ \\
\hline $7-22<00$ & $7-22514$ & $7-22516$ & $7-? .2707$ \\
\hline $7-22945$ & $8-22694$ & $9-22.6 \div 5$ & $9-22695$ \\
\hline $9-2 ? 72 ?$ & $a-22722$ & $8-22723$ & $9-23343$ \\
\hline$\therefore-2.3344$ & $9-23345$ & $11-22402$ & $1 ?-21245$ \\
\hline $12-22462$ & $13-23943$ & $14-21270$ & $14-21799$ \\
\hline $14-21<47$ & $14-22577$ & $15-2166 t$ & $15-21762$ \\
\hline $15-21 \div 47$ & $17-21335$ & $18-2 ! 3 ? 4$ & $18-21328$ \\
\hline $19-2 ? 745$ & & & \\
\hline SOOIUM COJEFFI & IC, IENT & & \\
\hline $1-2316 a$ & $6-21240$ & & \\
\hline SOIL & & & \\
\hline $\begin{array}{l}1-22143 \\
15-21750\end{array}$ & $\begin{array}{l}14-21269 \\
17-22142\end{array}$ & $14-2.195^{\circ}$ & $14-? 2246$ \\
\hline SOIL AECHANIC & & & \\
\hline $2-21917$ & $19-21 \div 17$ & & \\
\hline S.JIL PQOPEPTY & $Y$, IN SITII & & \\
\hline $2-22771$ & $18-22771$ & & \\
\hline IL, NUCL IDE & OCR URRENCE & & \\
\hline $14-21784$ & $14-2 ! \subseteq 49$ & $14-2195 c$ & $1.5-21784$ \\
\hline $15-21945$ & $15-21050$ & $16-70092$ & \\
\hline
\end{tabular}

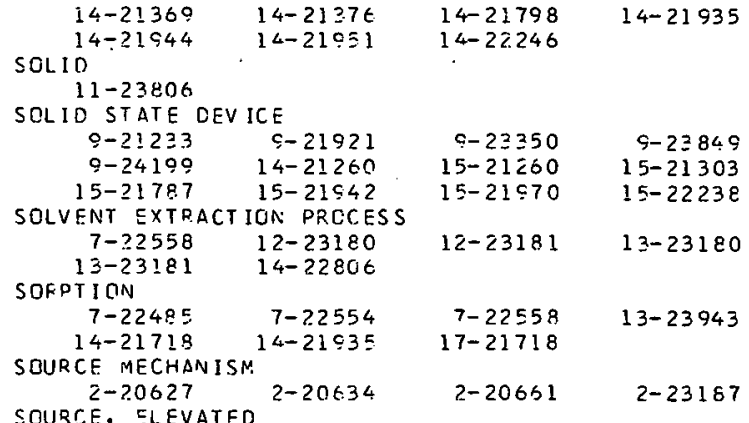

SOURCE, ELEVATED

$16-22921$

$\begin{array}{ll}16-21223 & 16-22450 \\ 16-22925 & 16-2297 ?\end{array}$

$16-24064$

$16-21223 \quad 16-24 C E 4$

SOURCE, NEUTKON

$\begin{array}{lll}17-21449 & 17-? 2957\end{array}$ $18-2 ? 842 \quad 18-22 \div 6$ ?

$17-23144$

$17-23318$

SOURCE, POINT $15-21 \subseteq 32$

SOURCE, RADIATION

$12-24278 \quad 14-21137 \quad 15-21137 \quad 15-21763$

SOURCE, DAOIDTION, LOST $15-23431 \quad 15-24278 \quad 17-24278$

$17-23318$ 17-24275
SOURCE, VOLUME

$15-21932 \quad 16-26451$

SPACE DEPENDENT DYNAMICS

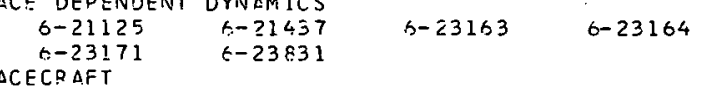

SPACECRAFT

$\begin{array}{rrrr}1-23391 & 4-22698 & 4-22700 & 4-22391 \\ 4-23955 & c-21232 & 11-23855 & 14-21949\end{array}$

SPAIN

$4-23955$
$15-22147$

I-21985 14-21274

SPECIAL NUCLEAP. MATER. IAL

SPECTR-22436 13-2428

SPECTROMETPY, ALPHA

$15-23300$

SPECTROMETRY, GAMMA

$\begin{array}{rrrr}14-21201 & 14-21384 & 14-21445 & 14-21756 \\ 14-21945 & 14-24060 & 14-24061 & 15-21261 \\ 15-21445 & 15-21756 & 15-21945 & 15-24060 \\ 15-24061 & 16-21261 & & \\ \text { ECTROMTTRY, NEUTRON } & & \end{array}$

SPECTROMETRY, NEUTRON

$\begin{array}{cccc}14-23321 & 15-21 \subseteq 33 & 15-21942 & 15-23321 \\ \text { SPERT } 1(S-P . R) & & & \\ 5-22509 & 17-22509 & & \\ \text { SPERT } 3 \text { (S-RR) } & & & \\ 5-23438 & & & \\ \text { SPEPT } 4(S-R T) & & & \\ 6-23438 & & & \\ \text { SPHERE } & & & \\ 5-23397 & 5-23404 & 5-23406 & 5-23417 \\ 1-23694 & & & \\ \text { SPRAY, GENERAL } & & & \\ 5-23419 & 5-23426 & 5-23427 & 7-22482 \\ 7-22485 & 7-22583 & 7-22586 & 7-22987 \\ 11-22987 & & & \end{array}$

SRE (RE)

SRE $17-22914$

STACK

2-23197 7-24270 13-24270 14-21718

$14-21354 \quad 15-2126 ! \quad 15-21717 \quad 15-21954$

$16-21261 \quad 16-22450 \quad 16-22452 \quad 16-22921$

$16-22925 \quad 16-23197 \quad 16-23883 \quad 17-21717$

STAFFING, TRAINING, QUALIFICATION

$1 \equiv-22436 \quad 13-224 \equiv 7 \quad 13-22521 \quad 15-21719$

$\begin{array}{llll}15-22435 & 17-21171 & 17-21213 & 17-21340\end{array}$

$\begin{array}{llll}17-21355 & 17-21450 & 17-21451 & 17-21661\end{array}$

$\begin{array}{llll}17-21719 & 17-21518 & 17-22192 & 17-22193\end{array}$

$\begin{array}{llll}17-22435 & 17-22436 & 17-22437 & 17-22504\end{array}$

$\begin{array}{llll}17-22425 & 17-22436 & 17-22437 & 17-22504 \\ 17-22521 & 17-23267 & 17-23368 & 19-22496\end{array}$

STATE PROGRAM $15-24063 \quad 17-20707$

STAT ISTICAL ANALYSIS

$\begin{array}{cccc}6-23170 & 11-23304 & 14-21658 & 14-21712 \\ 15-21668 & 15-21712 & 15-23428 & 15-23429\end{array}$ $15-21712$

STATISTICAL CORRELATICN

STEAM $3-22442$

4-22476 5-22704

$5-2 \check{2} 708$

$5-22723$ 


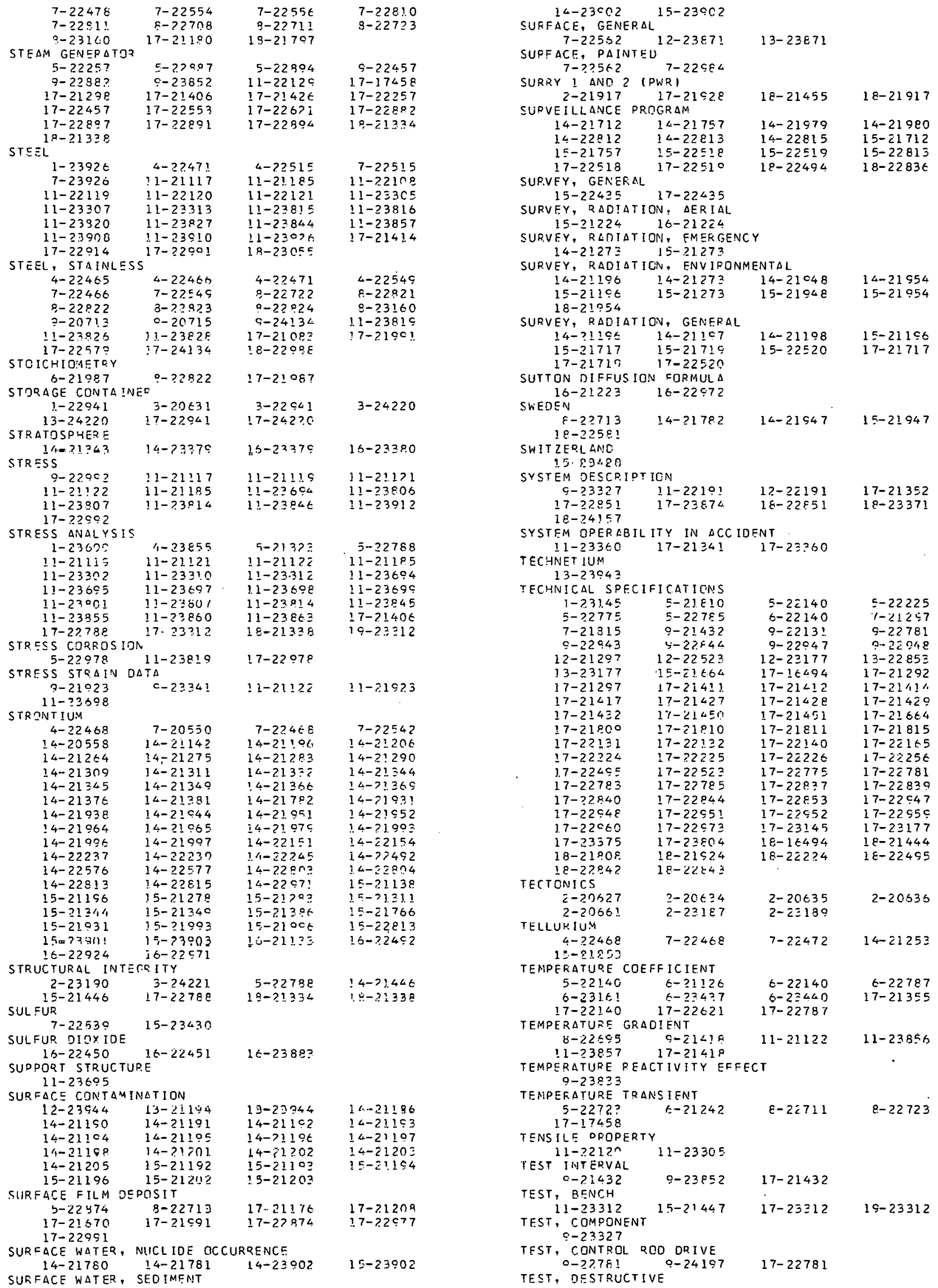




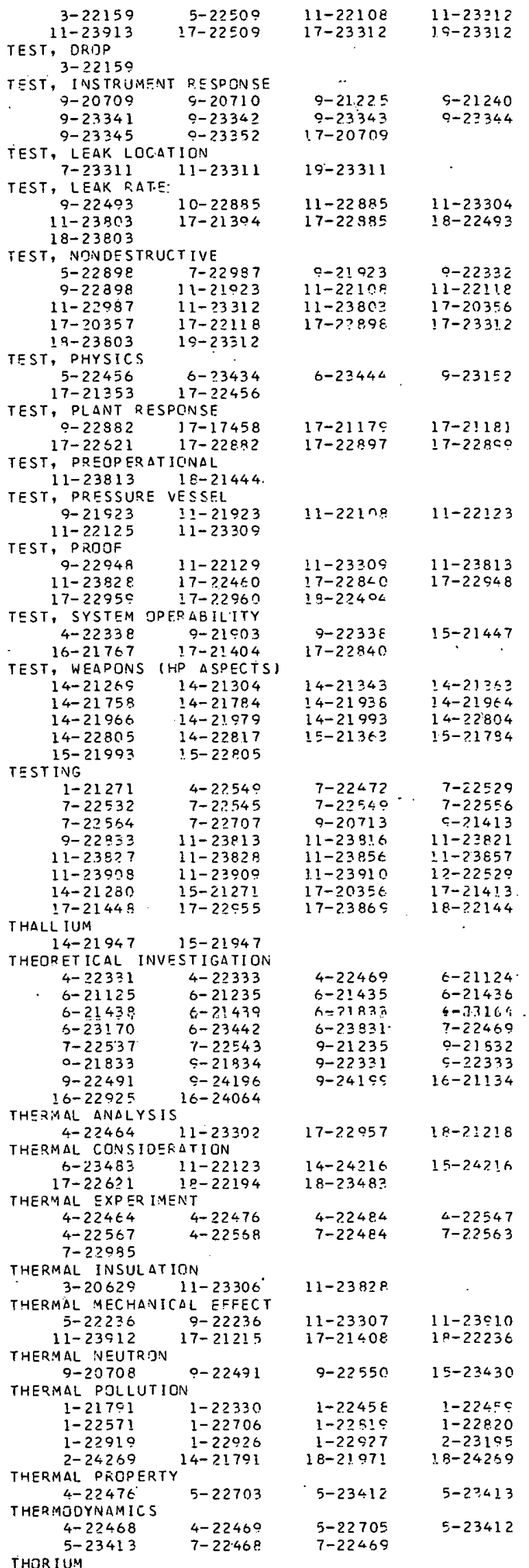

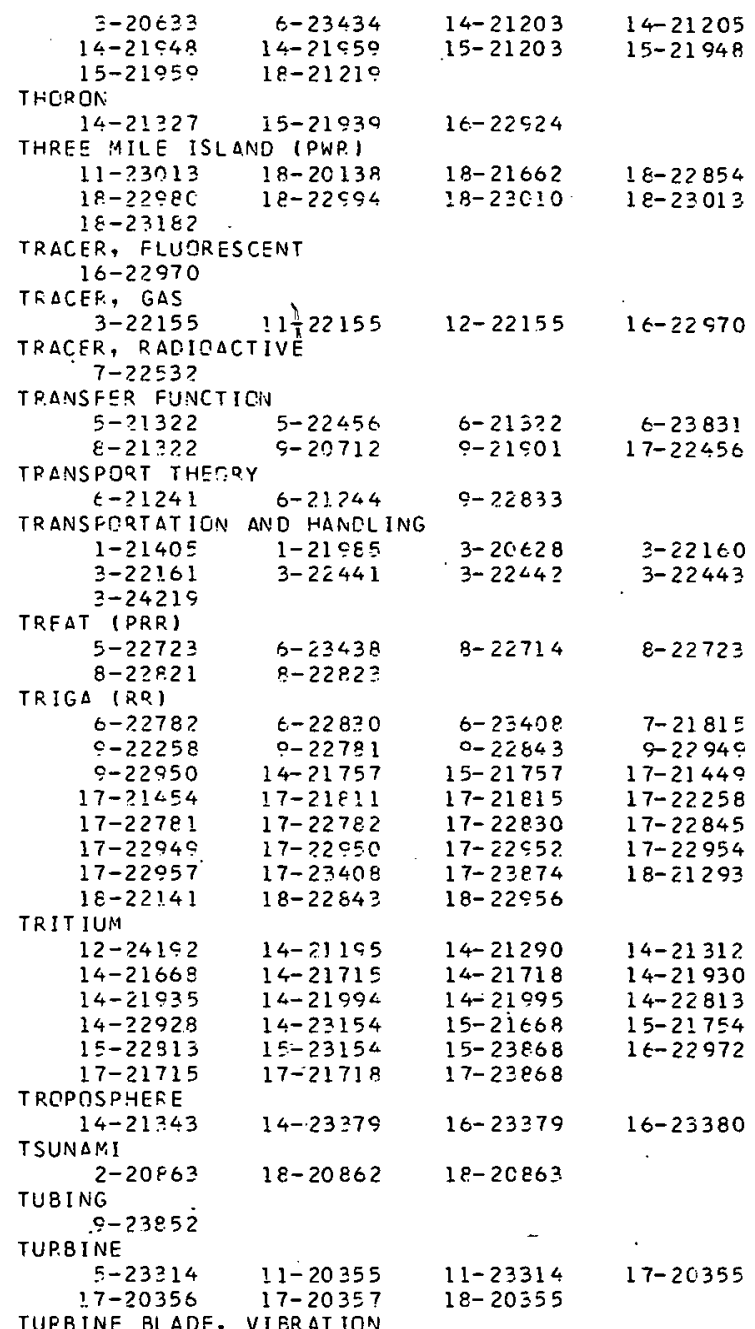

TUPBINE BLADE, VIERATION 17-20357

TURBULENCE; SHEAR (WIND) $16-21767$

TURBULENCE, STATISTICS 16-21925

TURKE'T PIIINI ANU 4 (HWR) $17-20356 \cdot 18-20230 \quad 18-20205 \quad 18-20352$

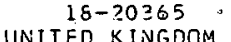

UNITEO KINGOOM

$\begin{array}{lrrr} & \\ 1-21392 & 3-20631 & 3-24217 & 6-21247 \\ 8-22712 & 5-21230 & 9-21778 & 5-21976 \\ 9-23147 & 9-22183 & 0-23838 & 9-23839 \\ 9-23840 & 9-23841 & 12-2319 ! & 13-23 ! 81 \\ 14-21190 & 14-21191 & 14-21142 & 14-21204 \\ 14-21207 & 14-21349 & 14-21360 & 14-21952 \\ 14-21093 & 14-22280 & 14-23321 & 15-21192 \\ 15-21204 & 15-21258 & 15-21308 & 15-2132 \varepsilon \\ 15-21360 & 15-21365 & 15-21963 & 15-21992 \\ 15-21993 & 15-22242 & 15-23321 & 15-23430\end{array}$

$18-22913$

UNITED NATIONS $14-22240 \quad 15-22240$ UNITED STATES

$\begin{array}{rrrr}9-22833 & 9-23852 & 14-20558 & 14-21349 \\ 14-21965 & 14-22816 & 15-20740 & 15-20741\end{array}$

URANIUM $15-20743 \quad 15-21349$

$15-20740 \quad 15-20741$

$\begin{array}{lrrr}1-21392 & 3-20630 & 4-22549 & 6-23437 \\ 7-22487 & 7-22549 & 8-22718 & 8-22834 \\ 8-22835 & 12-23180 & 13-20630 & 13-21194 \\ 13-23180 & 13-23645 & 14-21194 & 14-21109 \\ 14-21203 & 14-21204 & 14-21205 & 14-21272 \\ 14-21756 & 14-21936 & 14-23914 & 14-24060 \\ 15-21194 & 15-21203 & 15-21204 & 15-21272 \\ 15-21756 & 15-23159 & 15-23914 & 15-24060 \\ 18-21219 & & & \\ \text { 5-23412 } & 8-22719 & 8-22834 & 8-22835\end{array}$


$13-22719$

URANIUM DIOX IDE

$4-22468$

$6-23438$

$7-22555$

$4-22485$

$7-22446$

$7-228 ! 1$

$8-22823$

$12-23181 \quad 12-23175$

$12-2 ? 181$
$18-2298 E$

ANIUMM HEXAFLUOF IOE

13-23316

UR DIVIUM OXIDE

IIDE

$17-21335$

$12-23180$

$13-23 !$

$4-?>55$

$7-22486$

$0-32036$

$13-2 \geq 101$

$-22723$

$7-22538$

$\therefore-72723$

$8-228 \div 5$

$$
5-23434 \quad 6-23917
$$

IJP. A:VIUM-235

US $\triangle E C$

USSR

$$
6-23 \div 17 \quad 17-22524
$$

$14-21272 \quad 14-21279$

$14-21290$

$15-21 \div 2$

$14-21264$

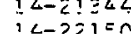

$14-2 ? 245 \quad 15-21136$

$15-21957 \quad 15-22145$

$15-22241 \quad 15-229=0$

$16-20 \% 02 \quad 17-22915$

VALVE

$15-21 \geqslant>4$

$15-220: 1$

$15-? 1344$

$15-22153$

: $-23 \sin 1$

5- 23390

$5-22803$

$3-2 ? 045$

$17-2119 !$

$17-21752$

$17-22783$

$17-2 ? 949$

$17-23390$

$0-53250$

$17-21404$

i $7-22256$

$17-2 ? ? 40$

$17-22050$

$15-20355$

$13-20716$

VENTILATION SYSTEM

$$
\begin{array}{rr}
5-27204 & 7-21207 \\
13-22315 & 14-21197 \\
17-21297 & 17-21717 \\
17-22853 & 17-22004 \\
18-22141 & 18-2 ? 144
\end{array}
$$

VERMONT YANKEE (FWR)

$1-217 \subsetneq 1$ 1 $4-2179 !$

18-??404

VESR (ISR)

17-21408 17-2!E!?

VI RRATITN

2-2319! $\varsigma-22992$

$17-22992 \quad 18-2 ! \equiv 34$

VIBRATION ANALYSIS

$$
\text { 2-23186 il-?3696 }
$$

VOID COEFFICI INT

$$
\begin{array}{lr}
5-19544 & 6-21240
\end{array}
$$

ㄷ? $2 \geq 58$

$11-20355$

$17-2 ! 425$

$17-22258$

$17-2 ? 851$

$17-22055$

$12-22494$

c- -25 F

$17-20 ? 55$

$17-21<53$

$17-22552$

17-22\&C8

$17-2.37 \%$

$28-\overline{2} 285 ?$

$12-21297 \quad 12-22553$

$15-2 ! 7 ! 7 \quad 15-24272$

$11-225 \div 3 \quad 17-223 \div$

$17-2^{2} 315 \quad 77-24272$

$18-22851$

$18-2: 916 \quad 19-21971$

$5-22342 . \quad 9-2 \div 25$

$W A G R$ (GCR)

11-221.17 17-22117 17-2?500

WASHDUT

14-22492 :6-2!134

WASTE IISPOSAL, ATMOSPHERIT 14-20574 $24-22574$

$1.4-22 \% 2$

$1 \in-21926$

$15-20574$ $16-22972$

WASTE OISPOSAL, GAS

$\begin{array}{ll}7-22987 & 1 !-2 ? 98\end{array}$

$14-2132 \% \quad 14-21 \subseteq 35$

$15-20574 \quad I 5-21254$

WASTE DISOOSAL, GENEQAL $1-2141,5 \quad 1-21779$ $4-21773$

$13-27101$

$12-23190$

ㅇ $1<-? 1259$

$14-21200 \quad 1 / 213 ? 0$

$14-2136 t \quad 1<-2175$ ?

$14-21701$

$14-21949$

$14-21700$

$14-21553$

$15-21329 \quad 15-21757$

$10-22851 \quad 1 C-21772$

14-2.0574, $4-21250$

$14-21937 \quad 14-22028$

$: 5->12 ? 0$

1. $-2: 701$

?2-2318?

$14-2:>72$

$14-? 1346$

$14-21780$
$14-21900$

$15-21250$

17-22851

WASTE OISDOSAL, HYDRAULIC, ERACTURINE

14-21347 :4-219?0 14-21035

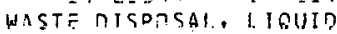

$7-22097 \quad 11-22 \div 97$

$14-21325 \quad 14-21347$

$14-21900 \quad 14-? 1937$

1.4-22150 is-? 1259

WASTE DISPESAL, DCEAN $14-21 ? ? 4$

WASTE CISFJSAL, PIVE?

$\begin{array}{ll}1-21>C 1 & 14-21006\end{array}$

$14-21791 \quad 14-21990$

NASTS DISOOSAL, SALT

$14 \cdots 21284 \quad 14-21346$

1. 4-2?5ก!

1. $7-22501$
$14-2 ! 250$

$14-21790$

14- ?.2 200

15-?1 329

$14-21780$

14-22 9? 8

$14-2 ! 0 ? 0$ $t-2316 \hat{\epsilon}$

$1 \leq-224 \div 2$

$1 \leqslant-224=2$

$3-23198$
$3-23180$

$23-23180$

$14-21284$

$14-21347$

14-2!791

$14-2193 \mathrm{C}$

$15-21272$

$17-22053$

$14-22280$

$1<-31200$

$14-217$ 됴

$14-22528$

? 5.23159

WAST DISOOSAL, SOL 10

$14-10834$

$14-21937 \quad 14-22 \% 28$

$15-21250 \quad 15-23158$

WASTE DISPOSAL. TERPESTEIAL

$\begin{array}{llll}7-22587 & 11-22927 & 14-20574 & 14-21284\end{array}$

14-21290 $\quad 14-2136 t \quad 14-21798 \quad 14-21930$

$14-21035 \quad 14-22<30 \quad 14-22<43 \quad 15-20574$

WASTE HANDL ING $3-24220 \quad 13-23<3 ? \quad 12-24220$

$1<-21366$

$17-24 ? 20$

WASTE MANAGEMENT

$\begin{array}{llll}14-21259 & 14-21307 & 14-21360 & 14-21781 \\ 14-21930 & 14-21935 & 14-21537 & 14-22928\end{array}$

$15-21250$

WASTE SDURCE $\triangle N D$ TYPF $14-2292 \mathrm{E}$

WASTE STIDAGE

$14-2125 C^{\circ} \quad 14-21005 \quad 14-21307 \quad 14-21345$

WAST F TREATMENT, EQUICMENT $14-? 12 C \equiv$

WASTE TREATMENT, FIYATION $7-22$ \% $11-22087$ $14-21<30 \quad 14-21 \subseteq 5 ?$ $14-22 ? 44$ TLNT, $14-22$ $7-22559$ 7-22707

WASTE TRSATME:NT, GENEFAL $1<-? ! 274 \quad 14-21 ? 76$ $14-317 \geq 6 \quad 1<-2152 ?$ $15-23158 \quad 17-21716$

WASTF TREATMENT, LIGUIO 14-21.274 14-21276 $1<-21930 \quad 14-21<5$ ? $14-22247 \quad 14-2250$

WASTF TREATMENT, SDLIO $14-21307 \quad 14-2133 n$ $14-22247 \quad 14-2250 !$

WATEI POLLUTION $7-2$ ?98?

$11-? 2 \div 87$ $14-2 ! 930$

WATEF $V A P O R$ $7-22810$

14-21305

$14-2 \equiv 514 \quad 14-22914$

$14-21305$

14- $21.3 \geq 0$

$14-21553 \quad 14-2315$

14-21307 14-21370

$14-22243 \quad 14-22244$

$17-22501$

$14-21 \div 30$

$17-2<50 !$

$14-2 \angle 243$

$14-? 1<45$

$15-2]<45$

$Q-22835$

$16-22922$

$16-22072$

WATEF, OSINIK ING

$1-22450 \quad 14-22 \varepsilon 1=$

WAIER, 'GLNEOAL

$1-32459 \quad 5-23400$

$11-22100 \quad 13-22710$ $14-22815$ 1 $4-22 E 16$ TEE, SEVEC

ELDING

$11-23820$

WELDS $17-22 ? 46 \quad 17-22901$

$11-21185$

$11-23 ? 10$

$11-23821 \quad 11-2382$

$11-24222 \quad 17-22846$

$18-2380 ?$

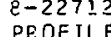

W $16-21133$

WIND STATISTICS 1 H.? 1.925

WIND TUNNCL SXPED IMENT

$1 \in-? 1767$

WINDSCALS

$X-R \Delta \stackrel{?}{?}$ $12-23181$

$13-231: 1$

$1,-24278$

1.4-21137

$14-23156 \quad 15-20737$

$15-20743 \quad 15-211=7$

$15-21350 \quad 15-21380$

$15-21790 \quad 15-2154 ?$

15-22572 $15-22573$

$15-2202010-29100$

$X E N O N$

$15-24272$

$14-22 \div 71$

16-22971

$5->34 ? 7$ 
YTTERBIUM

$14-21137 \quad 15-21137$

YTTRIUM

$7-22542$

1.42151

$\begin{array}{ll}1.4-22151 & 14-22154 \\ 15-21 \uparrow 31 & 15-21096\end{array}$

YUGTSLAVIA

ZINC $2-2310$

$14-2138.4$

IINN 1 AND 2 2- 23812

$18-2$ ? ? 35

$15-22040$

$19-23912$
$14-? 1 \div 31 \quad 14-219 \% 6$

$14-21282 \quad 15-212 \varepsilon z$

14-?1966 14-21067

$11-21$ cs 3

$18-22036$

$18-22975$

$11-22$ 9?

$18-22070$

$18-2297 \mathrm{c} \quad 18-23011$
ZIRCALCY

$5-2270$ ?

$8-22708$

$8-22821$

c- -22890

$7-21410$

$17-23861$

ZIREONIUM

$4-22480$

$7-2251.5$

$14-21967$

$18-22105$

ZPP. 3 (CAF)

$1-23168$
$-22978,6-21987$

$8-22714 \quad 8-22723$

$8-22824 \quad 8-23160$

$\begin{array}{rrr}8-22823 & 8-22824 & 8-23160 \\ 11-23861 & 11-23012 & 13-23176 \\ 17-21987 & 17-22890 & 17-22978\end{array}$

$\begin{array}{ll}17-21987 & 17-22890 \\ 18-21219 & 18-21463\end{array}$

4- $22515^{\circ} \quad 4-22568 \quad 7-22489$

7-22811 8-23160 14-21966

$14-2<060 \quad 15-24060 \quad 18-21210$

$9-20711 \quad 14-21202 \quad 15-21202$

1. 
FCLLCWING IS A LIST CF AUTHORS WHOSE DOCUMENTS

HAVE EFFN ABSTRACTED IN THIS DUELICATICN

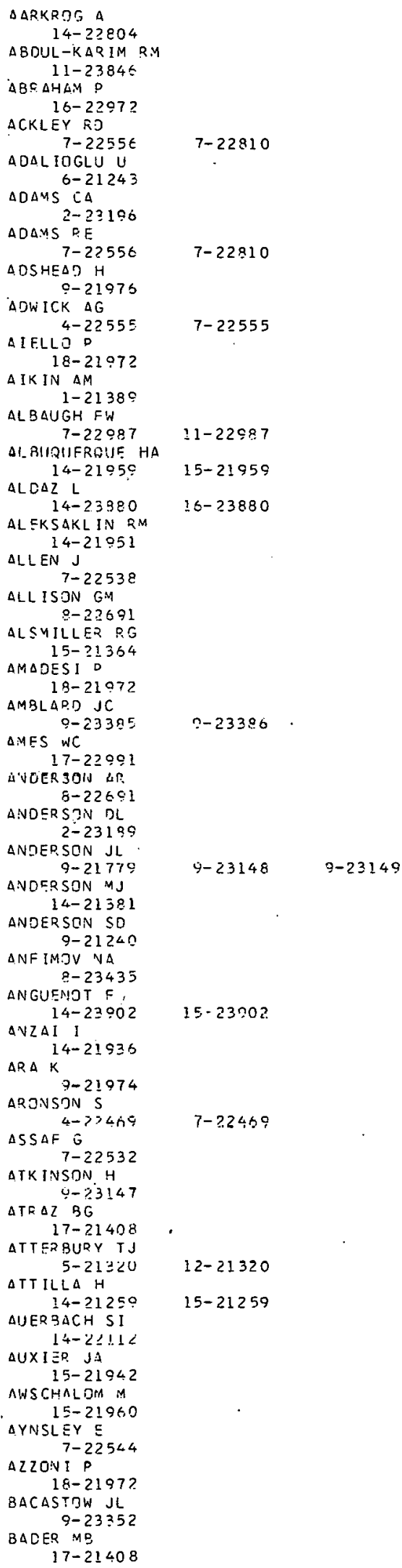

BAIN EE

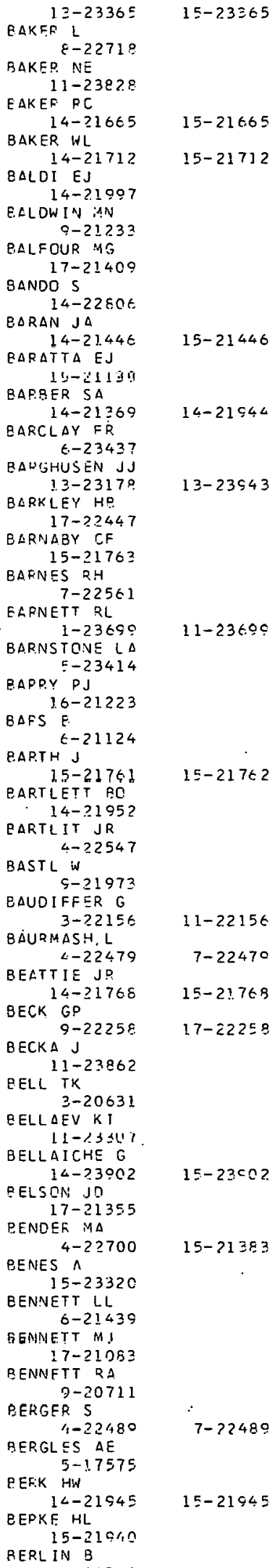




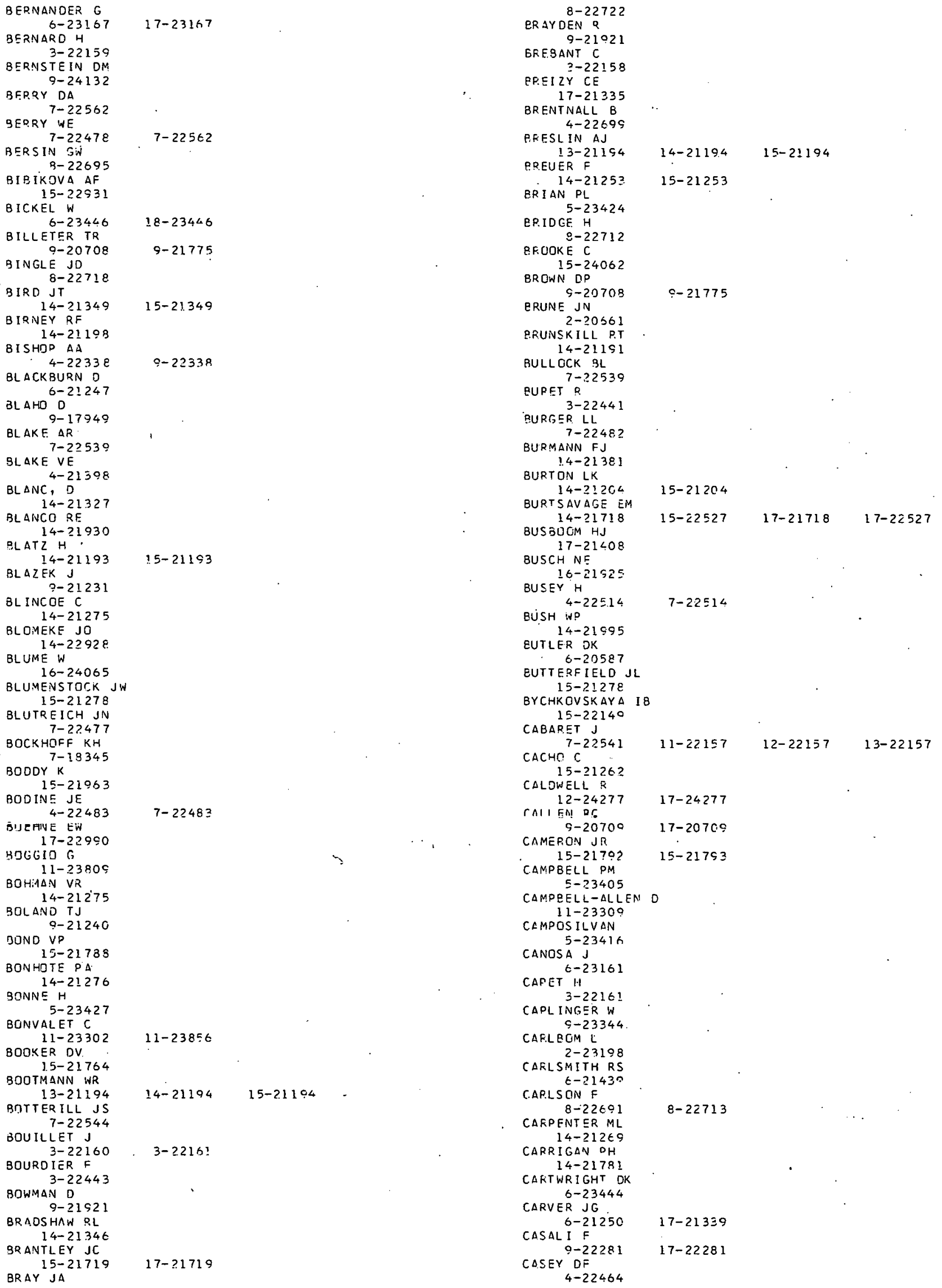



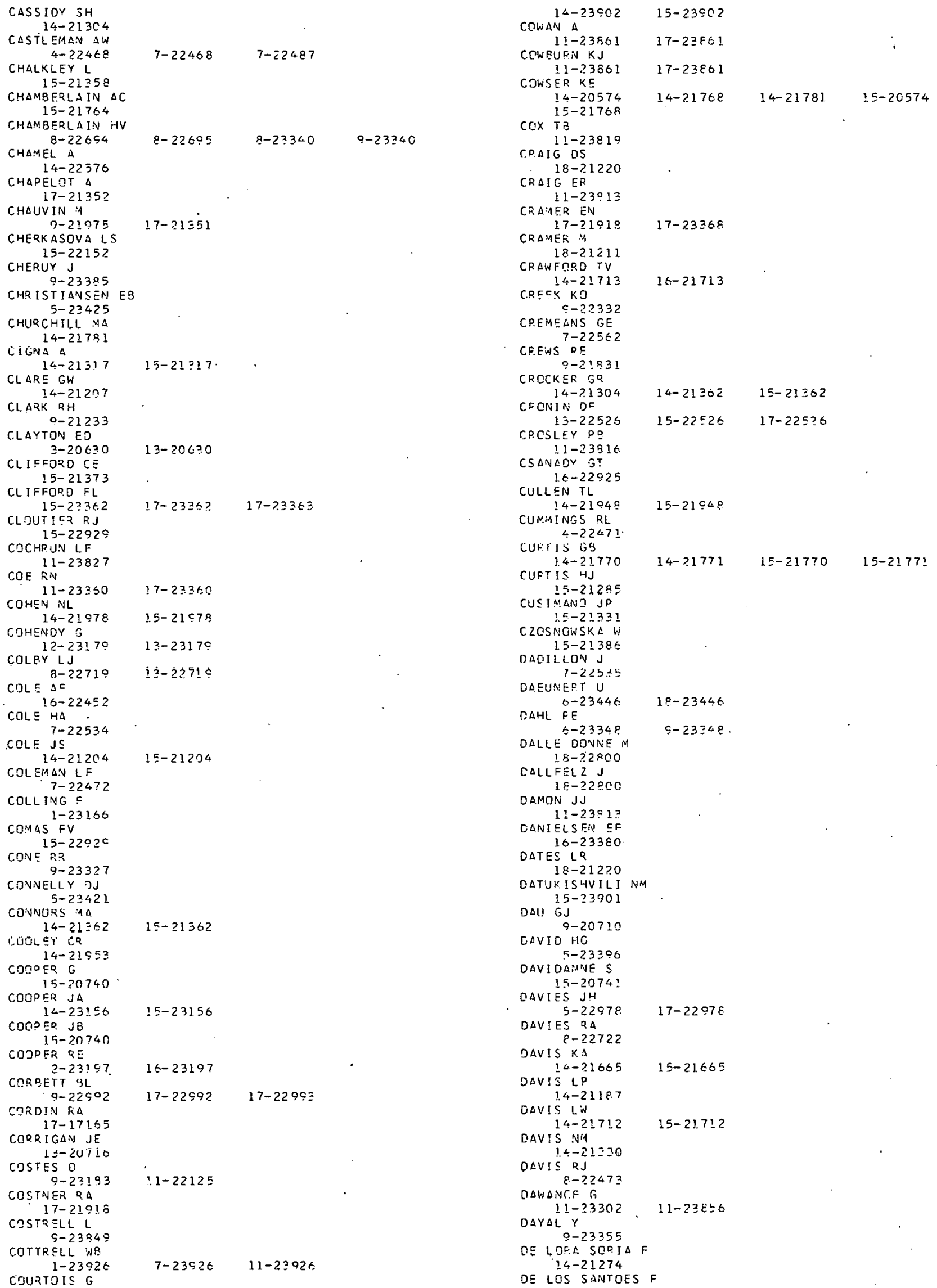


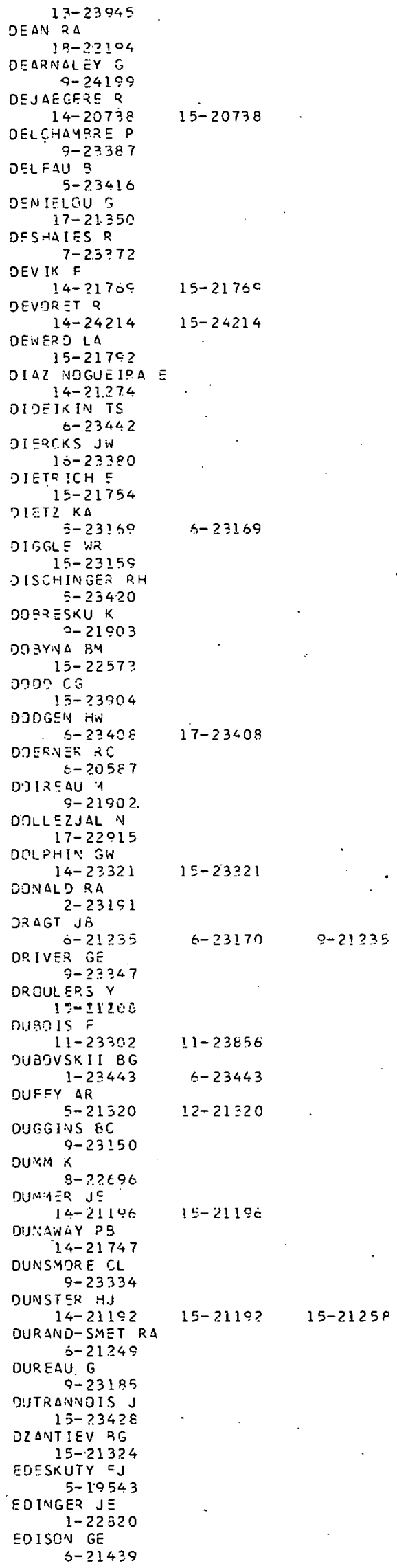

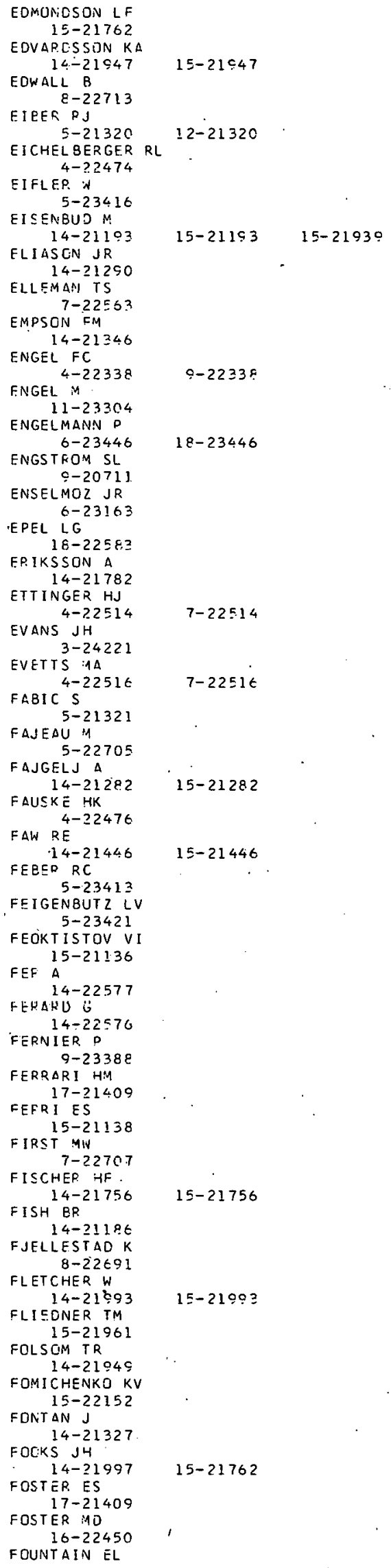




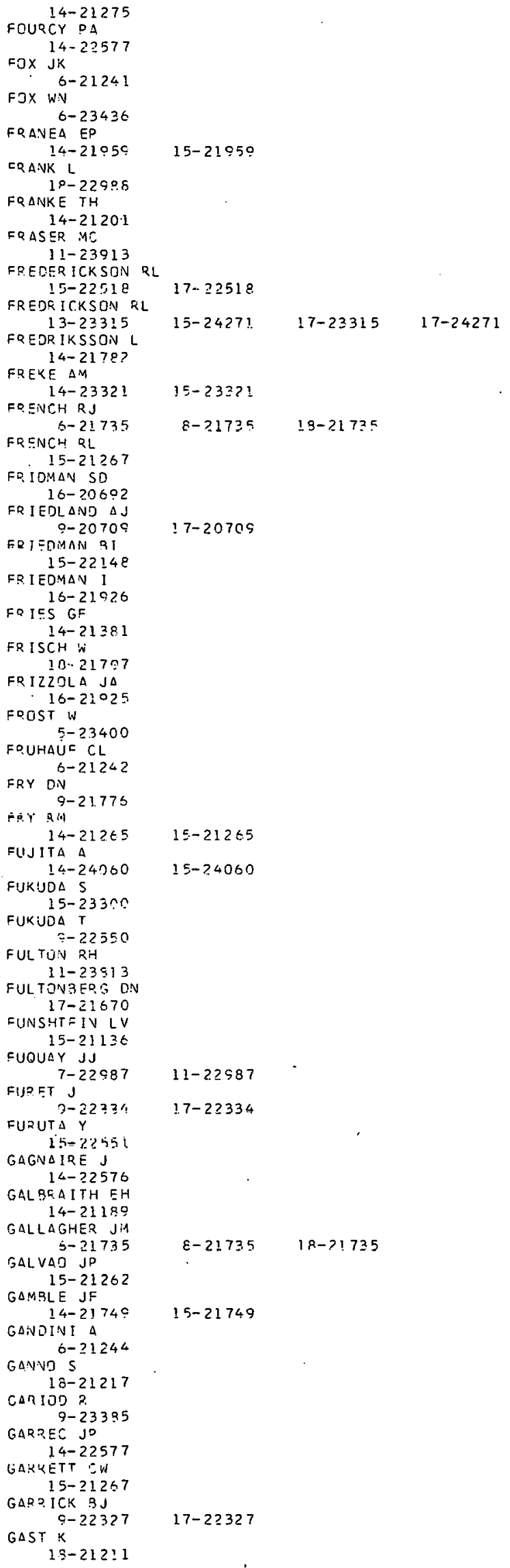

GDT JR

GATE LF

7-22564

GATZ DF

$16-22922$

GAUNT AJ

15-23159

GEFTS J:4

G-23!65

GEKL $5 R$ WC S-22327

GENCO JM

$5-21319$
$7-22562$

$7-22562$
$8-22714$

GEPAPO V

I. $1-22157$

GETHAFC PE

GEYER JC

I-22820

15-21958

GHESQUIERE GL $5 . .232 .289$

GUCSH $\leq K$

$15-23<30$

GIANNINI $G$

$S-21238$

GI BRON'S NG

$11-23908$

Glus UN GW

O-20715

GIESCN JA 8-22716

EIESEKE JA $7-22477$

GIESELER H

9-218?

GIFT FH

$6-21430$

GILSERT WS $15-21 \equiv 13$

GILCREAS FW

$14-2118$ ?

GILMOUR GA $9-23354$

GILSTER JC

14-? 1349

GIMSTEDT $\square$

19-2.258

GITLIN JH

15-21750

GITTUS JH

$4-22515$
GLAUPERMAN H 13-211 4

GLCUC.HKJV LK $5-? 3307$

GLOVER JR

15-? 1790

GCDQEE HW

14-2!3 30

GCDFREY TG

$5-23412$

GOEBEL IR

$1-2<10 E$

GCELDNER QW 1. $4-13834$

GCFFARD JW

$18-2121 c$

GCIDANICH G

I 7-21752

GOLDF ISHER, L $S-22327$

GOLDMAN L

15-20565

GCLOMANN $\mathrm{K}$

$O-23345$

GCLLEY FB

1 4. 21748

CGOCH PC

GORSHKOV 51 $\div-24197$

GOSLEE DW

$18-22988$

GRABER AJ

$s-20715$
$17-22327$

$15-21140$

$15-2132 \%$

$\begin{array}{lll}17-22227 & & \\ 5-22709 & 6-213 ! 9 & 7-22478 \\ 8-21219 & 8-22708 & 8-22711 \\ 8-22 \varepsilon 21 & & \end{array}$

12-22157 13-22157

$15-21540$

$7-22515$

$14-21194 \quad 15-21194$

$15-21748$

GRAHAM ED 


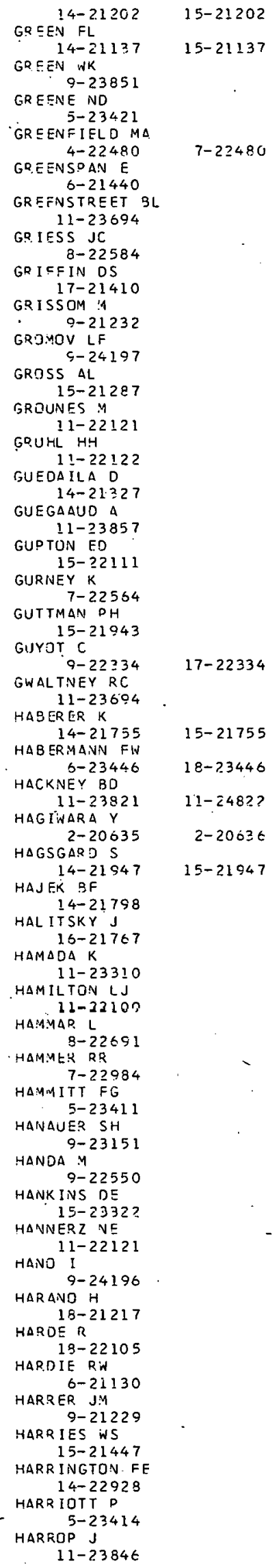

HARTH ?

$$
\begin{aligned}
& \text { 5-23400 } \\
& \begin{array}{r}
\text { HAPTLEY } \\
\qquad-231 \in 3
\end{array} \\
& \text { HAPTY H } \\
& \text { 7-22987 11-22587 } \\
& \text { HASKIN NL } \\
& \text { 4-2256.7 } \\
& \text { HASTY RA } \\
& 7-22432 \\
& \text { HAUSKNECHT DF } \\
& \text { 4-?2480.7-22480 } \\
& \text { HAWTHORNE JR } \\
& \text { 11-22120 } \\
& \text { HAWT IN O } \\
& 8-2 \geq 716 \\
& \text { HAYASHI T } \\
& \text { I1-233io } \\
& \text { HAYWOCD LR } \\
& \text { H-213E? } \\
& \text { HAZEL VE } \\
& 17-21408 \\
& \text { HAZZARD DG, } \\
& \text { 15-21761 } \\
& \text { 15-21761 15-2176? } \\
& \text { HEAD HN } \\
& \text { 5-23426 } \\
& \text { HEASL I P MB } \\
& 14-21382
\end{aligned}
$$$$
\text { HECKER R }
$$$$
18-21214
$$$$
\text { HEINEMANN } B
$$$$
\text { 14-21997 }
$$$$
\text { HEINEMANN BH }
$$$$
\text { 14-22803 }
$$$$
\text { HEINT } Z \text { EA }
$$$$
\text { E-22715 }
$$$$
\text { HELLER F }
$$$$
\text { 18-21797 }
$$$$
\text { HELLUMS } J 0
$$$$
\text { 5-23426 }
$$$$
\text { HENDEPSON R'N }
$$$$
\text { 16-24067 }
$$$$
\text { HENER IE J:4 }
$$$$
1 \varepsilon-21444
$$$$
\text { HENZEL } N
$$$$
8-22835
$$$$
\text { HERNADI } F
$$$$
15-22 \varepsilon 18
$$$$
\text { HERR [ CK CC }
$$$$
\text { . } 5-23413
$$$$
\text { HERRMANN D }
$$$$
15-21160
$$$$
\text { HILBOFN HS }
$$$$
\text { Q-22833 }
$$$$
\text { HILO }
$$$$
7-2.2545
$$$$
\text { HILL AJ }
$$$$
14-2130 ?
$$$$
\text { HILLÄRY Jj }
$$$$
\text { 7-22564 }
$$$$
\text { HILL I AFD RK }
$$$$
7-22472
$$$$
\text { HILLIER MJ }
$$$$
11-21119
$$$$
\text { HILTCN DA }
$$$$
\text { 7-22539 }
$$$$
\text { HIMES } F L
$$$$
\text { 14-21376 }
$$$$
\text { HINES DP }
$$$$
\text { HIRAK I T }
$$$$
15-21371
$$$$
\text { HIRATSUKA Y }
$$$$
\text { 9-21977 }
$$$$
\text { HISADA K }
$$$$
\text { 15-21371 }
$$$$
\text { HOCHSCHILDS }
$$$$
\text { HOCKING JE }
$$$$
18-21334 \quad 18-21338
$$$$
\text { HOGERT ON JF }
$$$$
1-23376
$$$$
\text { HOHMANN CL }
$$$$
\bigcirc-21 \varepsilon 30^{\circ}
$$$$
\text { HOHMANN GL }
$$$$
9-21 \varepsilon 31
$$$$
\begin{gathered}
\text { HOLCGME WF } \\
4-22463
\end{gathered}
$$$$
\text { HOLE JA }
$$$$
\text { 4-224t3 4-22465 }
$$

$11-22463$

$12-22463$ 


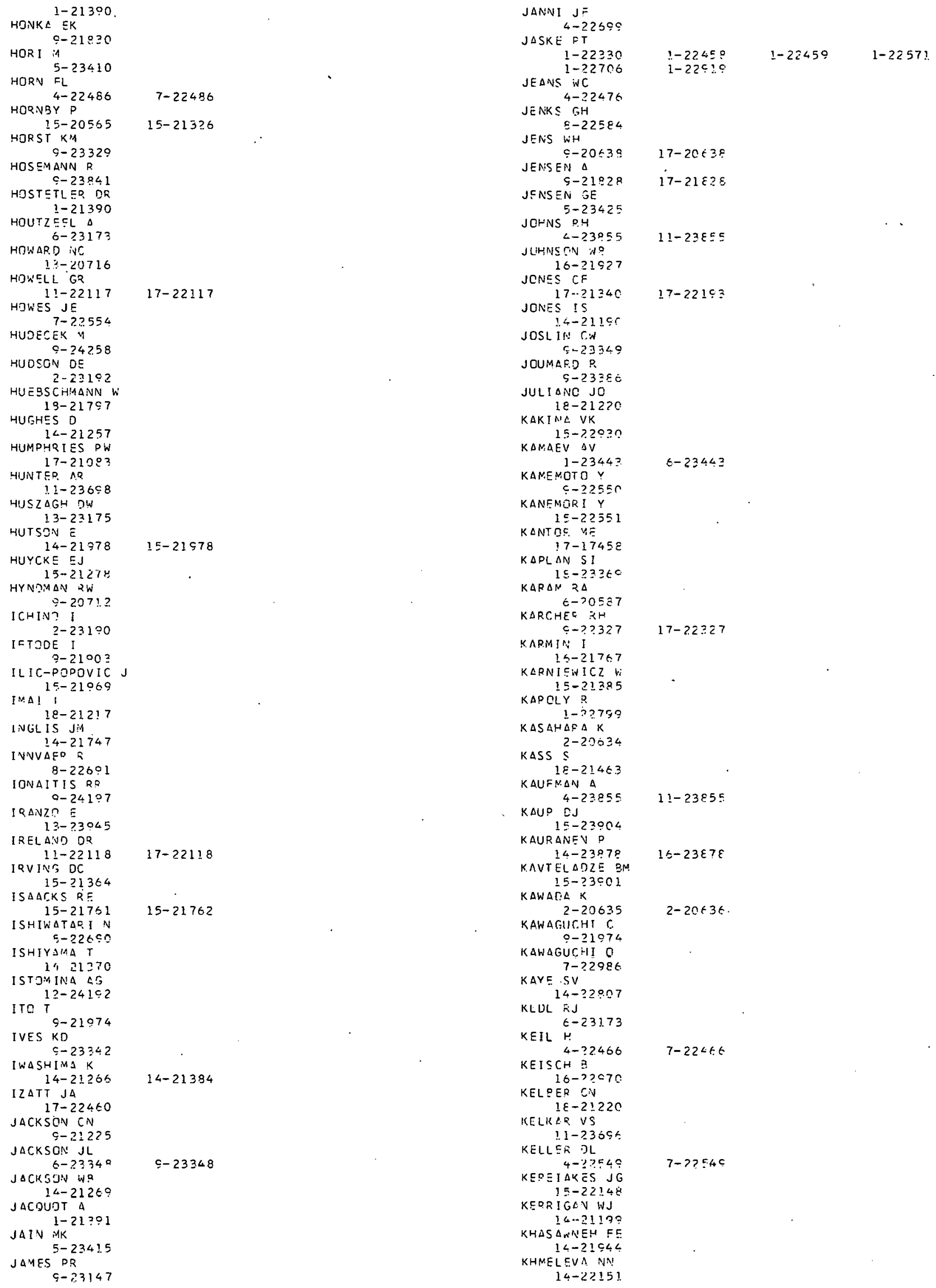




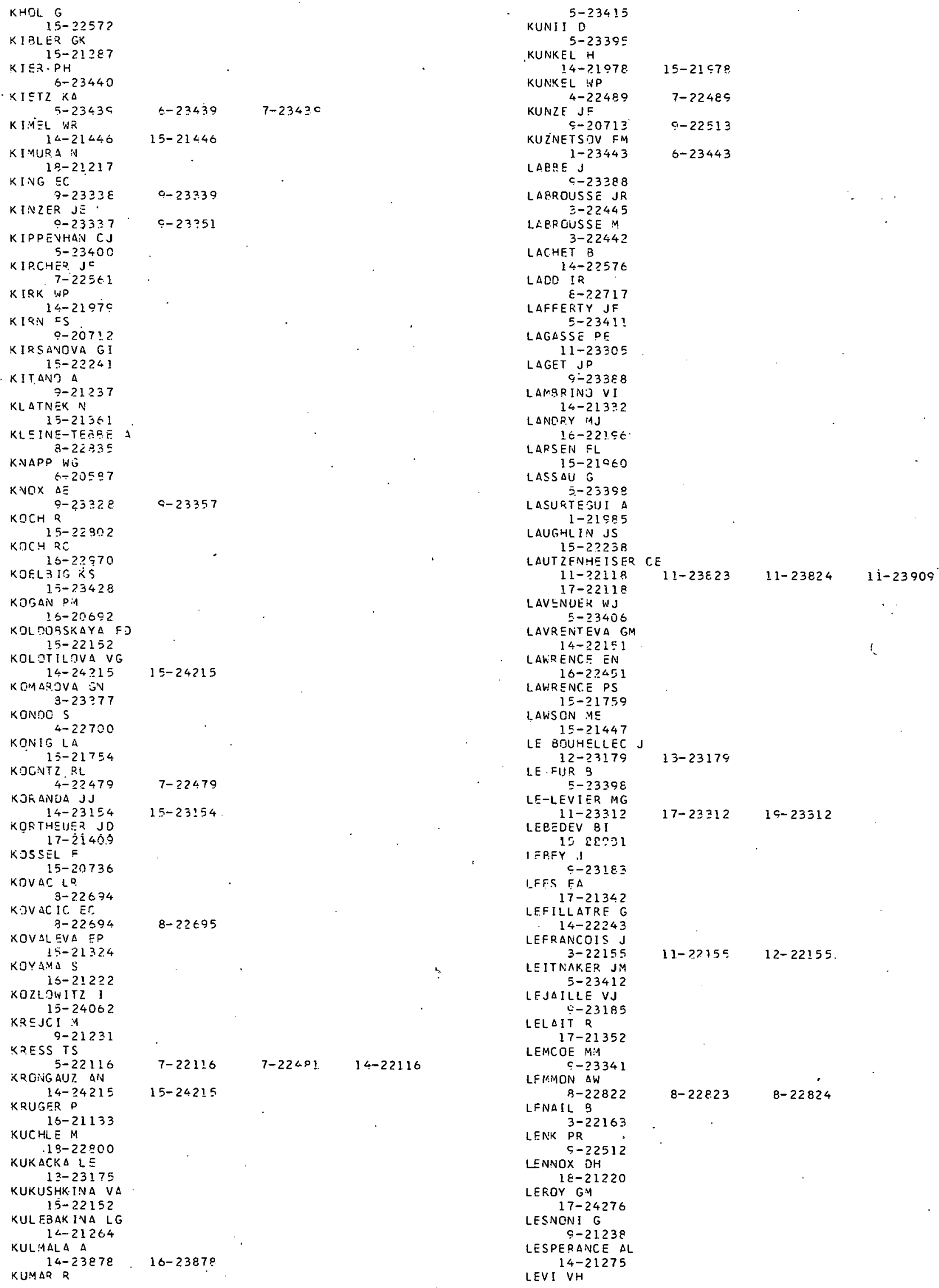


$14-21284$

INE AS

16-2?970

LEV INE $H$

14-21979

LEV INE IAM

18-22583

LEVY $C$

$14-24214$

LEVY $S$

5-234חI

LEN IN I

15-2176t.

LENIS LL

1 4-21747

LEWIS RH

?- $2.3350^{\circ}$

LEWIS WH

$15-24273$

LHEUR EUX i

15-24002

$L I B E R \quad T$

$1-23699$

LIESE $\mathrm{KH}$

LIV 5 K

1 4-23914

LINDEN WA

1 5-22308

LINDHE $S$

8-22713.

$17-24273$

$11-236 \% 9$

$15-23914$

$15-213 \& 5$

LIPINSKI WC

$$
\text { O-21?29 }
$$

LIPPERT J

$$
14-22304
$$

LIPSETT J J

$$
\text { 7-22@82 }
$$

LITILE JJ

$14-2 ! 141$

LITTLE W:N

$6-211.30$

LIUZZI A

14-21945

LLOYD $2 \mathrm{C}$.

$3-205 \geq 0$

LNENICKA $P$

G-24257

LOCHNED JQ

$16-22196$

LOCKHART LS
$16-22924$

LOFTNESS RL

$$
\text { 17-22279 18-?2270. }
$$

L. $\mathrm{G} \Delta \mathrm{N} D$

$0-23353$

LONORES $H$ 14-21959

LOPEZ PEREZ B

14- 21274

LUPINA PF

$$
\text { 5- } 17575
$$

$\mathrm{LORCH} S$

15-21958

LDUTIT JF

14-21993

$25-21903$

LOVE DL

$14-21667 \quad 15-21 \in 67$

LOW EW

$11-23309$

LOWMAN $F G$

14-21751

OYSEN P

14-21205

LUJCAS H

$$
\text { 3-22163 }
$$

LUCKS $\mathrm{H}$

14-21314 15-21314

LUIKOV AV

$$
\text { 5-23402 19-23402 }
$$

LUKS VH

$$
11-23030
$$

LUPICA LA

$$
\text { 9-23353 }
$$

$111 \times \mathrm{J}$

17-229:1

LYAPIDEVSKII VK

14-24215 15-24215

LYONS JH

$8-2272 ?$
MAAZ

$2-20720$ AN Ji

MADSHUS $K$

$14-21946$

MAEDA K

$14-21936$

MAEKAWA T

MAGEE P.S

$1-2330$

NY $G$

16-21767

MAHONEY JB

$11-23863$

MALANG 5

$$
1 \varepsilon-21797
$$

MALL ING GF

5-23404

MALLON $9 \mathrm{~J}$

15-21288

MALSGN HA

$15-22434$

MALYKHIN VM

14-2124

MAMUFO T

14-2406C

MANG $\triangle R O E \triangle$ 14-21376

MAPCHERTAS AH $11-23605$

MAPCILLAT G

$$
\text { 9-21901 }
$$

MAFCOWITZ SM

14-21314

MAPCUS FR

14-21537

MARECHA! JC

$11-23202$

MARSH KJ

16-22450

MARSHALL RK

$18-21219$

MAFSHALL RO

$14-21997$

MAFT IN R

$0-23183$

MAS P

$15-2126 \varepsilon$

MASSE FX

15-22433

MATSIJMUKA I

$14-21370$

MATSUNAMI T

$14-24060$

MATSUO 5

$16-21926$

MATSUDKA

$14-21996 \quad 15-21996$

MATTSSON $D$

$14-2387:$

MAUSBECK H.

$8-22696$

MAWSON T.A

$14-21366$

MAXEY WW

5-21320

MCALEVY RF $1-2.339$

MCCARTHY J

1 7-22885

MCCAPTHY IF

5-22887

$9-22892$

$11-22885$

$17-22885$

$17-22892$

$17-22809$

MC,CARTHY WJ $9-20630$

MCCLAIN WC

$14-21346$

MCCONNELEE J: $11-21121$

MCCORD RV

C-22902

MCCOPMACK JD 7-22472

MCCURMICK JF

$14-21380$

$17-2063 \varepsilon$

14-21347

$17-22 \div 92$
$4-23391$

$17-22434$

$15-212<4$

$14-24066$

$15-24050$

$16-24066$

$15-21314$

$11-23 \varepsilon 56$

$14-22 \varepsilon C 3$

$17-224 ? 3$

$15-24060$

$16-23 \varepsilon 78$

$12-21320$

$4-23301$

$5-22894$

$\div-22898$

17-20579

$17-22887$

$17-22894$

$17-22 \varepsilon \circ 9$

5- 22 $9 \varphi 8$

$10-20579$

$17-20580$

$17-22890$

17-22\&0 5

9- 22890

$10-22885$

$17-22883$

$17-2 \div 8 \% 1$

17-22857

$17-22903$ 
MCCREARY JC 9-225!2 MCDANELS DL 11-236:7

MCICANIEL CJ 11-23921

MCFARLING JL 7-2256.1

MCGHIE RD

$$
11-23860
$$

MCGINN IS JT 14-21748 MCEUIRE SA 15-2165s MC IVOR IK

$$
\text { 11-23801 }
$$

MCKEE J

$$
s-23344
$$$$
\text { MCKEE JM }
$$$$
\text { 4-22568 }
$$

MCKISSON RL 4-22474

HCK ITTR ICK N 3-20631

MCKNIGHT JA S-23444

MCL.AIN HA 5-2.2597

MCLAUGHL IN WL 15-21358

MCNALLY JK

$9-21920$

MCSHERRY 9- 21921 MEARS LD $7-22563$ MEKHON KO KP 16- 21134 MEL HUISH KR 15-23159 MENZEL HF $17-1.7458$ 7-22558 MCP.RITT WF 15-22488 METZLER RE 15-21447 MILLKI VN 1- 23923 $\checkmark$ ICHEL C 3-22164 MIETT INEN JK 14-21325 MIGNECO 7-18345 MIRESELL RE 17-23374 MIKHAILOV MD 5-23397 MIKULEIT AE $11-23908$

MIL ANI S

$$
6-23434
$$

MILLE KE

1 1-22124

MILLS CB

MILLS WJ

$$
\text { 5-23417 }
$$

M INAM I K

15-23300

MINGLE JO

$$
\text { 1 4- } 21446
$$

$M I R O N E M$

$$
\text { 1-23166 }
$$

MIRONOV DG

$$
\text { 14-22245 }
$$

MIRONOVA TM

15-22152

MISHIMA J

$7-22482$

MISHIMAT J $7-2 \geq 983$

MIXON $\mathrm{FO}$

$$
\text { 5-23419 }
$$

MOELLER DW

7-22707

MOENIG H
$11-24822$

$15-21748$

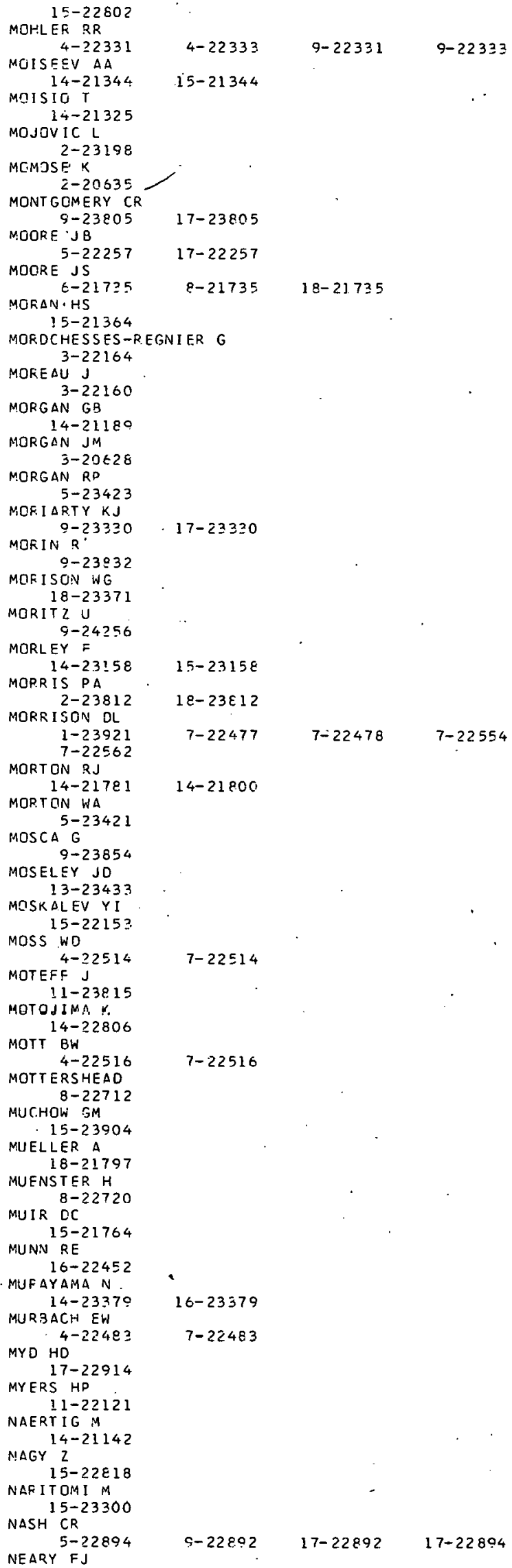




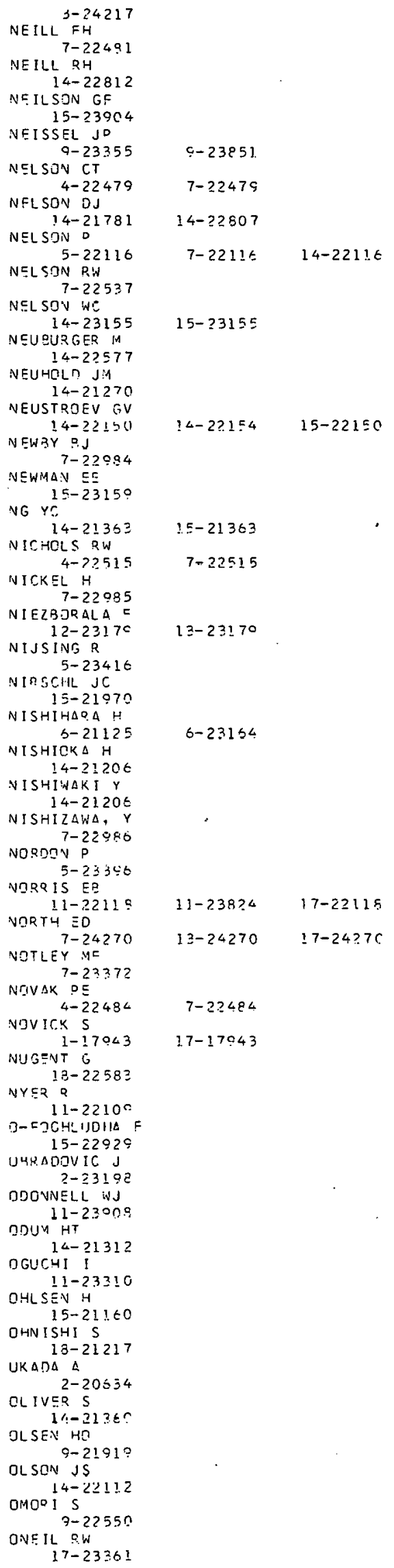

CNEILL 5

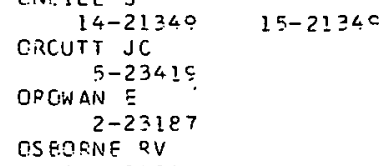




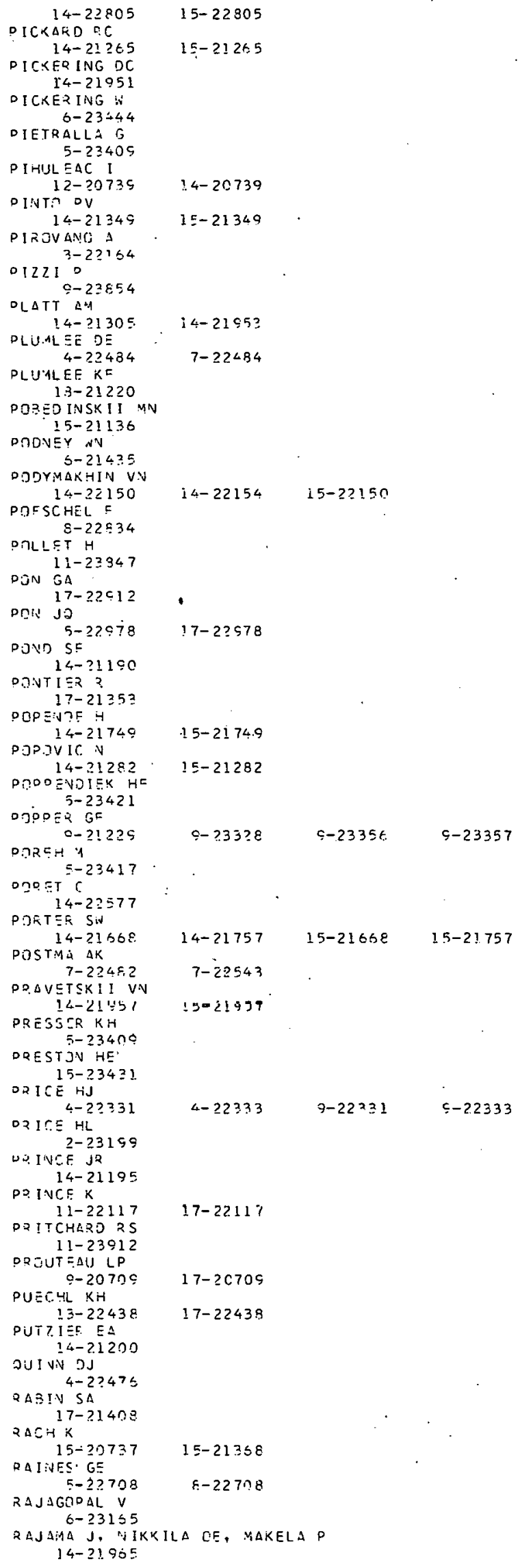

RALKOVA J

$14-2 ? 239$

RAMS DEN D

$15-21308$

RANDALL RL S-23359

RAPOSO JS

$15-2126$

RASMUSSEN

c -21828

$17-21828$

PAUSCTI

RAY $S$

$8-21214$

$15-23504$

RSCHEN HJ

$1<-21570$

RECHT $P$

$1<-21387$

REES DJ

14-22329

REICKS GH

REID FC $E-23424$

REID RF

c -20712

R.EIDEL HJ

7-2254?

REISS $16 \mathrm{H}$

$14-22246$

REIST $P C$

7-?2707

P.EMSERGER VG 15-22152

RENN CE

P $\quad 1-22819$

REYNOLUS AE

1-23168

RHYNER CR

$15-21793$

RIBEIRE CC

$$
\text { 14-21950 15-21559 }
$$

RI PES C

$12-23179$

$13-23175$

RICHMOND R $6-23436$

R. I CKARD WH $14-21379$

RIEL GK $1<-2 !<45$

RIKITAKE T

2-20635

i 5-21387

$15-2232^{\circ}$

$8-22695$

$14-21799$

$14-21967$

15-21445

$2-20 t 36$

$15-23153$

$14-23153$

RIPLING EJ 11-23816

RITCHIE $\triangle B$ $1]-22110$

$17-22110$

RITZMAN RL 7-2247 14-? 1329

$7-22554$

15-21329

ROBINSGN HN

ROEINSON MJ

5-23411

ROEINSON RA $17-2244^{7}$ RODERICK C 17-?258?

RODIFR J

$$
\text { 14-22243 }
$$

ROESMER J

16-22070

ROGERS EJ

15-2.3900

ROGERS JT

$5-23+22$

E $K$

$7-22984$

ROJAHN N $1-21391$

ROGUES $C$

ROSE $R$ E-22691 R.OSENBAUM HS 5-22970 RQSENBERG HS 7-2? 47 e

$17-22 \varsigma 79$ RESENHCLC M 

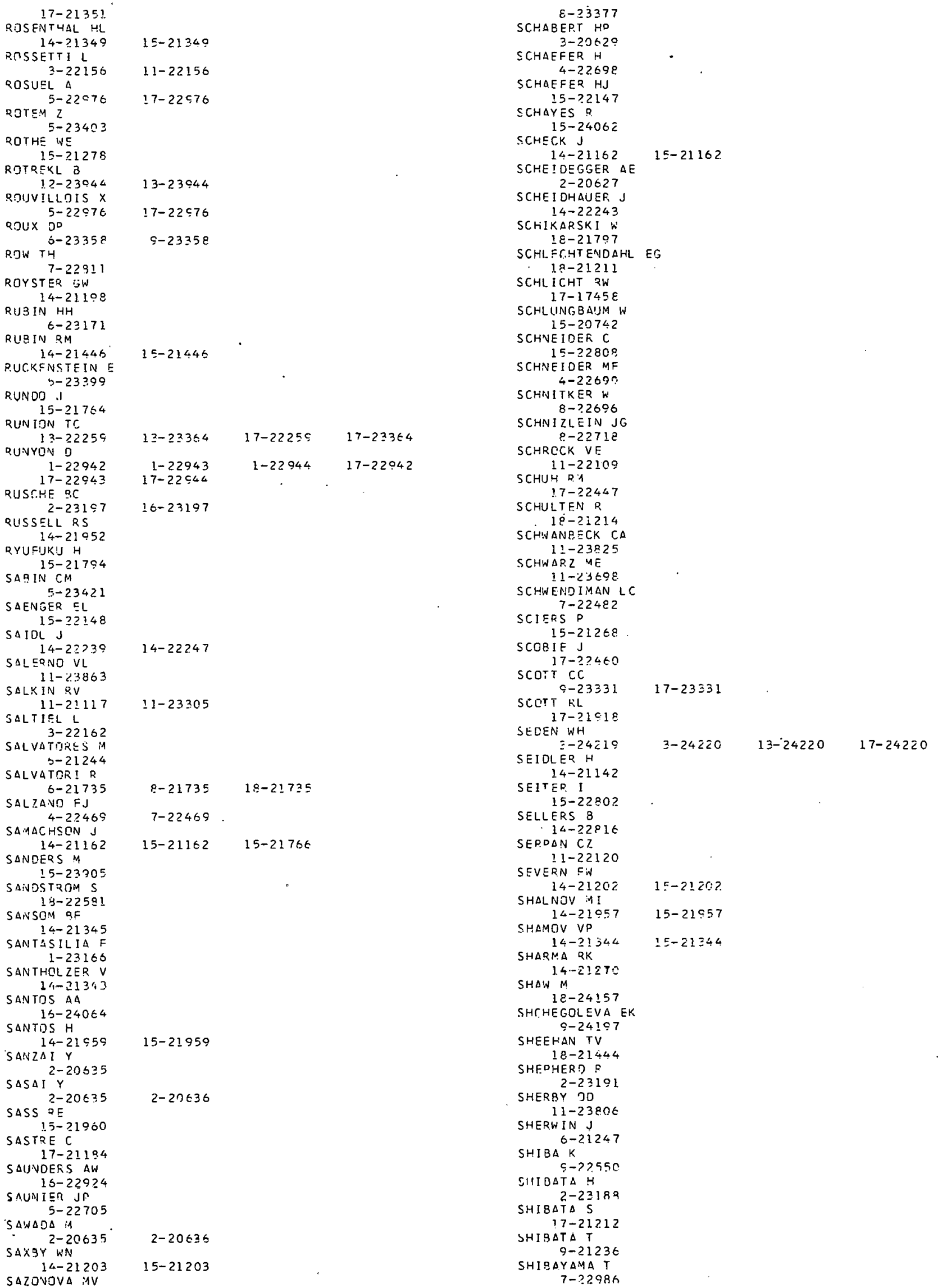


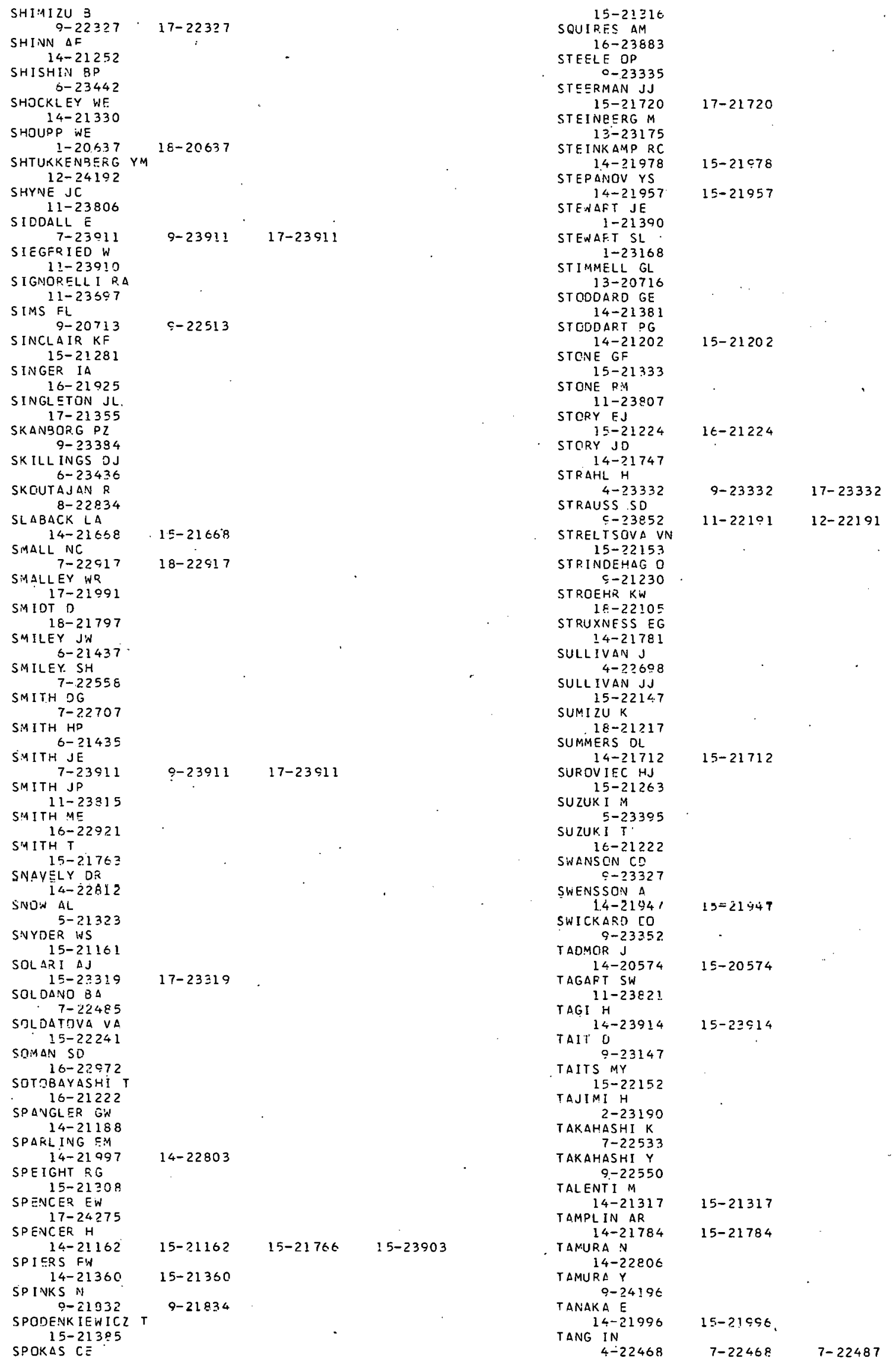




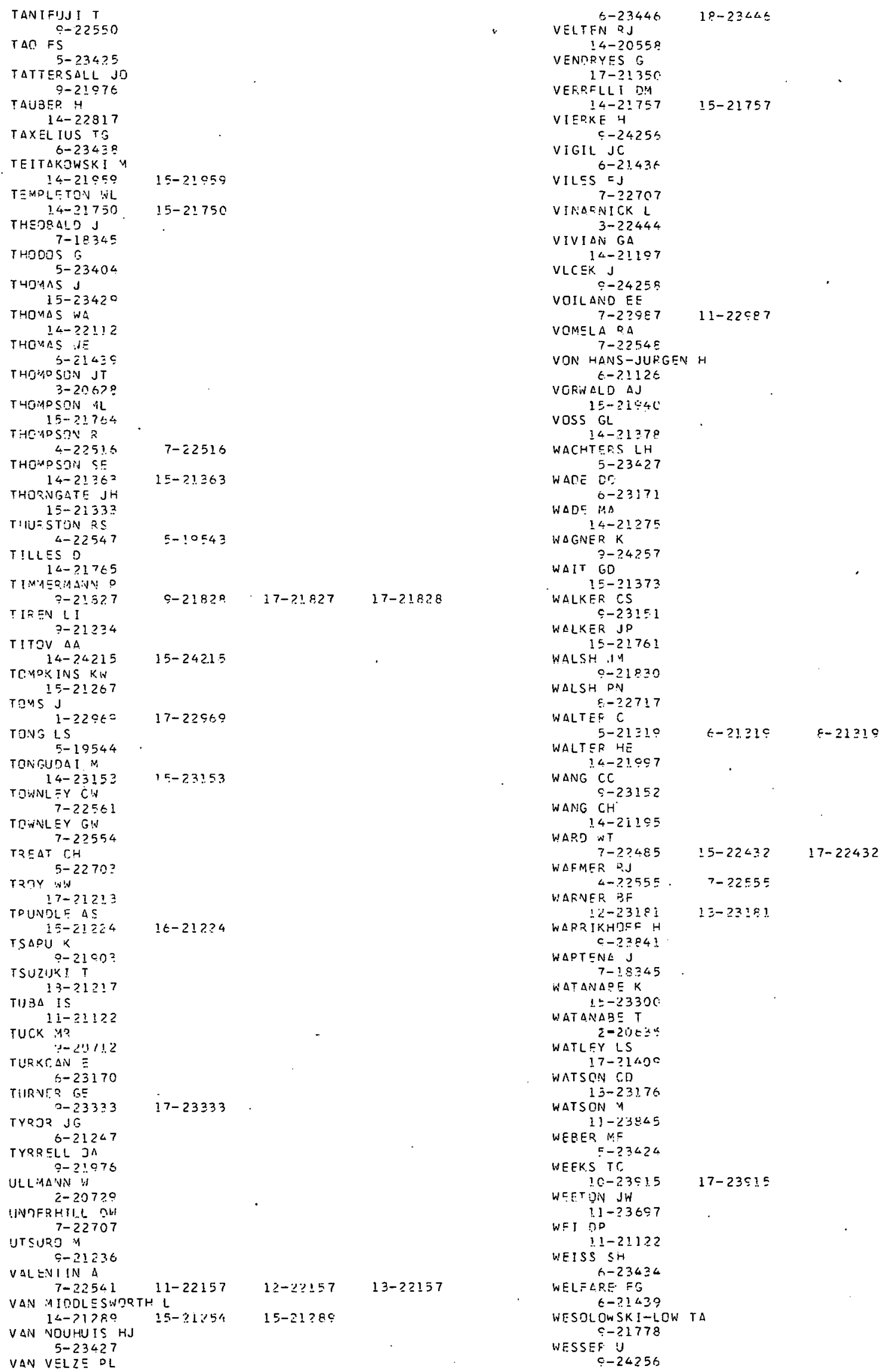




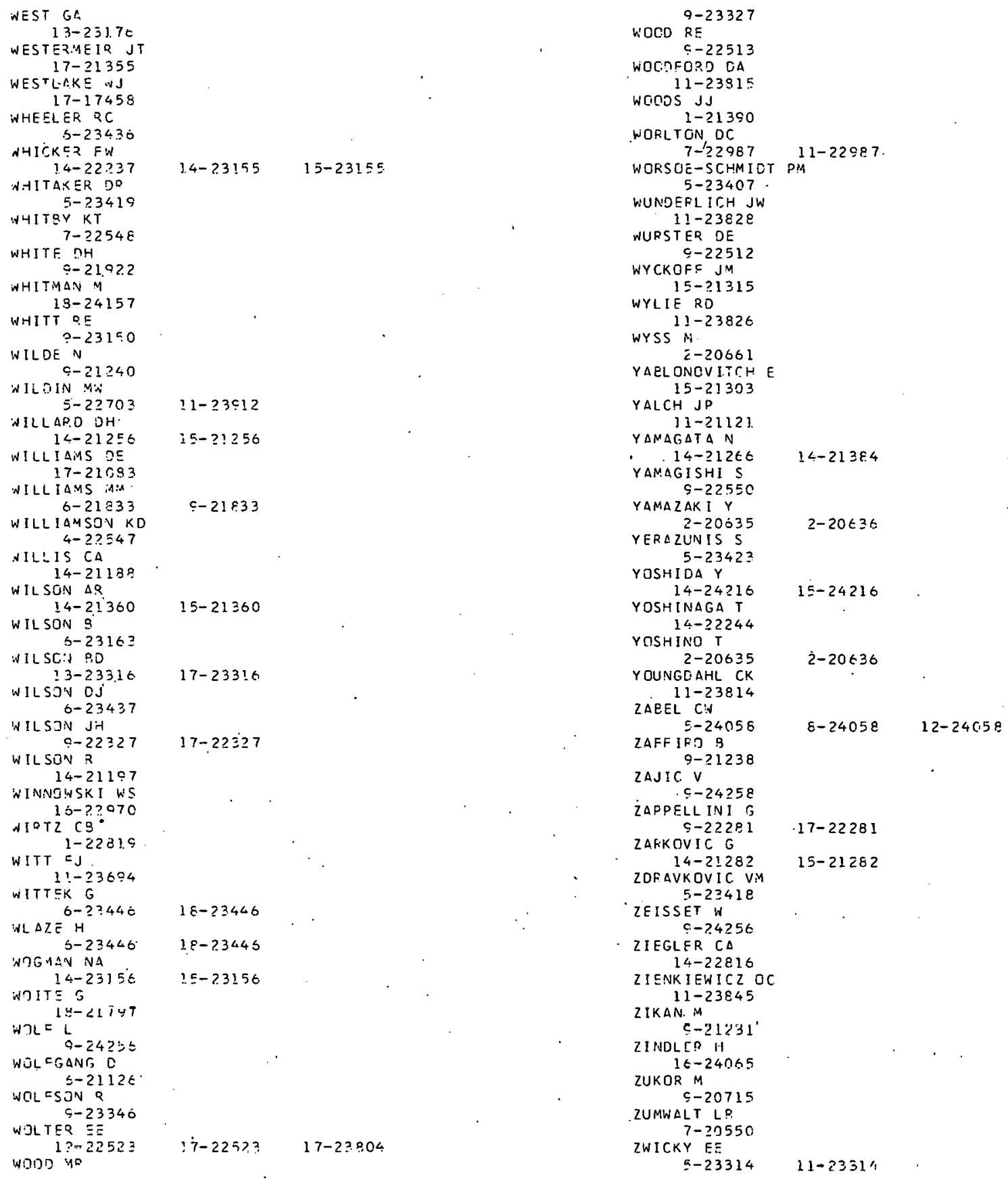


APPENDIX

REFERENCE SOURCES

THE ONLY REPORTS DISTRIBUTED BY NSIC ARE THOSE GENERATED BY THE CENTER, I.E., THOSE WITH ORNL-NSIC NUMBERS. UNDER NO CIRCUMSTANCES ARE COPIES OF THE OTHER REPORTS REFERENCED IN THIS BIBLIOGRAPHY FURNISHED, ALTHOUGH ALL AVAILABLE DOCUMENTS MAY BE EXAMINED AT THE CENTER BY QUALIFIED PERSONNEL.

NSIC HAS INITIATED A NEW FORMAT FOR DOCUMENT AVAILABILITY AND PRICE. THIS INFORMATION IS NOW PRESENTED, WHERE APPLICABLE AND AVAILABLE, IN A LINE TO ITSELF FOLLOWING THE DOCUMENT ABSTRACT. WHERE PREVIOUSLY THE NAME OF THE SOURCE ORGANIZATION APPEARED AT THE END OF THE LINE PRECEEOING THE ABSTRACT AND WAS ABBREVIATED, IT IS NOW SPELLED OUT IN THE NEW LOCATION. SINCE IT WILL TAKE SOME TIME TO CONVERT COMPLETELY TO THE NEW SYSTEM, NSIC WILL CONTINUE TO FURNISH A KEY TO THE ABBREVIATIONS. THIS KEY ALONG WITH THE ADDRESSES OF THE SOURCE DRGANIZATIDNS FULLOWS.

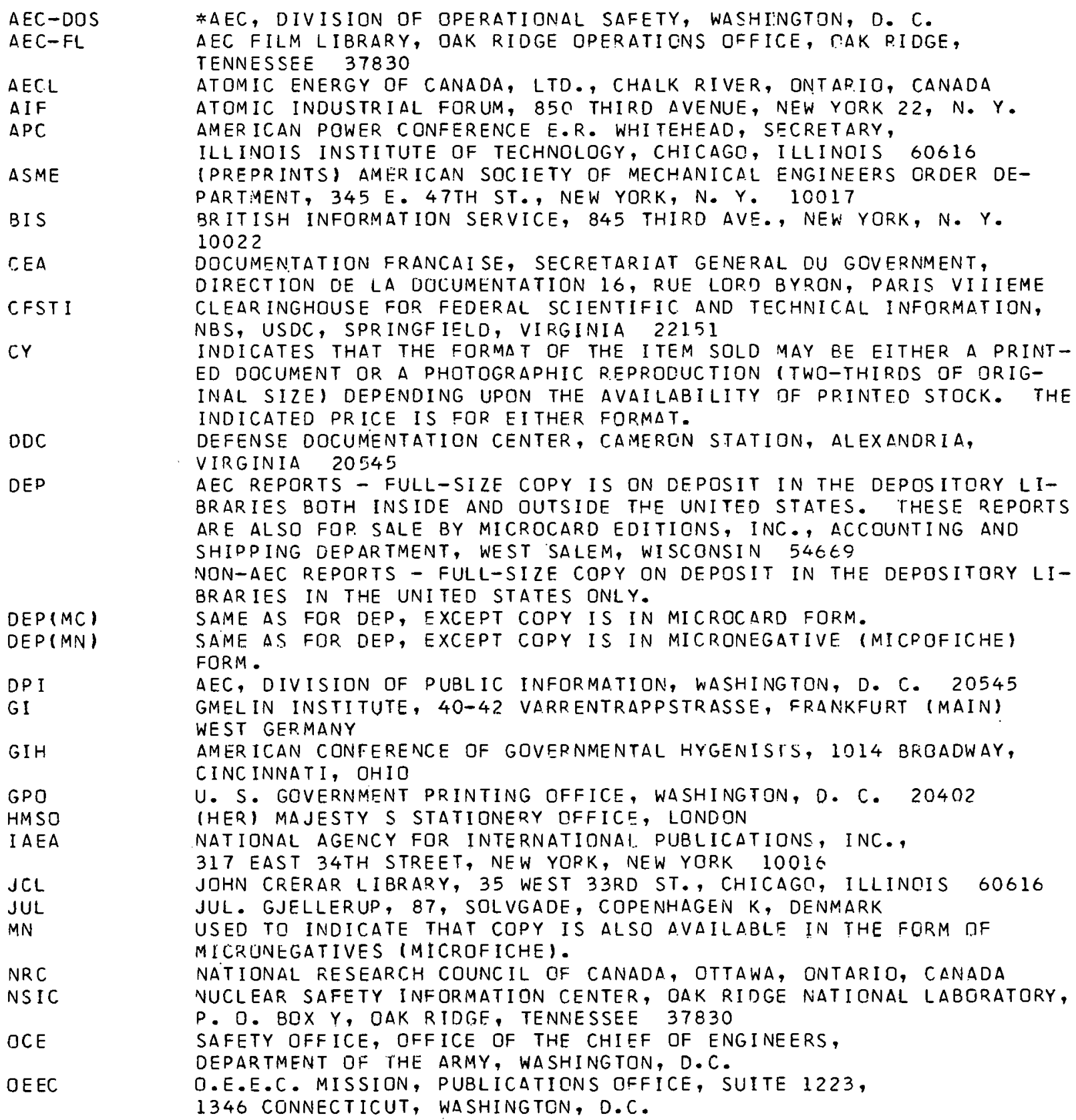


ORAU

PATENTS

(BRIT ISH)

PATENTS

(FOREIGN)

PATENTS

IU. S.)

PDR

SOURCE

UKAEA,

(LONDON)

USGS
AVAILABLE ON INTERLIBRARY LOAN FROM THE LIBRARY, OAK IRIDGE ASSOCIATED UNIVERSITIES, POST OFFICE BOX 117, OAK RIOGE, TENNESSEE 37830 .

THE PATENT OFFICE, 25 SOUTHAMPTON BUILDING, LQNDON, $W . C .2$, ENGLANE ( 49 CENTS PER COPY)

(OTHER THAN BRITISH) IT IS OUR UNDERSTANDING THAT FOREIGN PATENTS MAY BE OBTAINED IN PHOTOCOPY FROM THE U. S. PATENT OFFICE, DEPARTMENT OF COMMERCE, WASHINGTCN, D. C. (30 CENTS PER PAGE)

THE U. S. PATENT OFFICE, DEPARTMENT OF COMMERCE, WASHINGTON, D. C. $(25$ CENTS PER COPY $)$

* * USAEC PUBLIC DOCUMENT ROOM, WASHINGTCN, D. C. OR IGINATOR OF DOCUMENT (AUTHOR, CORPORATE AUTHOR, OR PUBLISHER) UNITED KINGDOM ATOMIC ENERGY AUTHORITY, 1 I CHARLES II STREET, LONDON, S. W. 1

U. S. GEOLOGICAL SURVEY; WASHINGTON, D. C. 20242

* PREPARED by usaec diVISION of operational safety, aVAILABLE from dos if THE SUPPLY OF A PARTICULAR ISSUE IS NOT EXHAUSTEO.

* USUALLY DOCUMENTS MAY BE EXAMINED ONLY AT THE PUBLIC DCCUMENT ROOM. OCCASIONALLY EXTRA COPIES ARE AVAILABLE FCR DISTRIBUTION. 